TESIS DOCTORAL

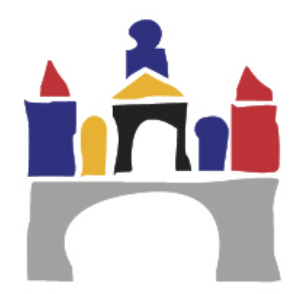

UNIVERSIDAD DE BURGOS

FACULTAd de HUMANIDAdes y COMUNiCACIÓN

CONTENIDOS MEDIÁTICOS EN FUNCIÓN DEL GÉNERO: DE LA PRENSA SEGREGADA A LOS CANALES DE TELEVISIÓN ESPECIALIZADOS

Programa de Doctorado en Humanidades y ComuniCaCión

AutorA: Paula Illera Miguel

Directora DE Tesis: Dra. María Isabel Menéndez Menéndez

Burgos, 2019 
A mi madre, por ser mujer, sobrevivir y cuidarme tanto.

Gracias.

A mi hermana pequeña, que me hace grande con cada uno de sus pensamientos.

A la abuela Silvia, mi luna de enero, las flores de mi campo.

Y a mi abuelo, por haber desafiado, de algún modo, los mandatos del género. 


\section{AGRADECIMIENTOS}

La primera vez que escuché hablar a la doctora Isabel Menéndez Menéndez me quedé fascinada. Fue mi profesora durante el postgrado de Especialista Universitario en Enfoque de Género que tuve la grandísima suerte de cursar en la Universidad de Burgos. Puedo asegurar que esos meses cambiaron mi vida. Si hoy estoy aquí, cerrando esta tesis, es porque Isabel, no solo me ha guiado durante el proceso sino que, en su día y antes de que todo esto empezara, me brindó las herramientas necesarias para despegar.

Tengo muchas cosas que agradecerle. Han pasado seis años desde que cursara el postgrado y sigo rescatando, llegado el caso, todo lo que aprendí. A medida que maduro, las ideas, los argumentos adquieren nuevas dimensiones. Forjarme una visión crítica está siendo un camino largo pero disfruto, sin duda, de la mejor compañía y mentora que pudiera imaginar.

Ha sido un honor que Isabel dirigiera mi trabajo de investigación. Querría darle las gracias por su disponibilidad absoluta, sus correcciones, el saber que me tendería una mano en cualquier momento. Por toda la confianza que ha depositado en mí, por las oportunidades brindadas y el camino abierto. No me voy solo con la tesis doctoral, me llevo un libro editado, horas de docencia, participación en jornadas... y una visión violeta del mundo.

Gracias, de verdad.

La etapa que más disfruté del periodo de elaboración de la tesis fue la estancia de investigación en Dublin City University. Se trataron de tres meses de absoluto aprendizaje, ya no solo académico, sino que también personal. Debo darle las gracias a la doctora Alicia Castillo Iglesias, por su calurosa acogida, por abrirme las puertas de DCU y del despachito que se convirtió en mi casa. Gracias por escucharme y brindarme tanta ayuda en aquella sala común.

La tesis doctoral puede resultar, a veces, un proceso frío. A mí Dublín me arropó, me mostró la mejor cara de cuantas tenga la investigación. Me llevó hasta Sweta, mi compañera de oficina y de bailes (en la oficina), Liridona, que sabía un poquito (mucho) de español y con quien compartí charlas maravillosas, Arpita y Cristian, quienes me cocinaron tortilla de patata nada más llegar, Hassan que, siempre pendiente, me hizo sentir parte del grupo, Tahir, con quien, si lo tuviera cerca, pasaría tantas y tantas horas 
y, por supuesto, Hari, que me recordó que los sitios son especiales por las personas que hay en ellos. Con todo, no podría olvidarme de mi prima Diana, de ese gran punto de apoyo con el que tuve la suerte de contar siempre que lo necesité.

A mi familia debo agradecerles la infinita confianza y preocupación. Sé que mi hermana ha sufrido esta tesis. En cierto modo, ella también forma parte de la misma, al igual que forma parte del resto de las áreas de mi vida. Es la mayor suerte que tengo a mi lado. Luego está mi madre, a quien le dedico en primer lugar mi trabajo de investigación. Simplemente, jamás ha dejado de cuidarme: si mi madre para, se para mi mundo. Le debo todas y cada una de estas líneas. Además, no puedo cerrar este párrafo sin mencionar a mi abuela: mi abuela y su risa, mi abuela y sus cantares, pero, también, mi abuela y su generosidad, porque ella siempre quiso que yo estudiara y si yo estudié fue, en parte, gracias a ella.

Me siento afortunadísima de contar con mi burbuja feminista, con mis amigas que me proporcionan ese espacio en el que sentirme comprendida: Eva, Raquel, Isa y Amparo, sois luz. Gracias, por supuesto, a Olaya, que me acompaña desde el primer desvelo en Madrid y que me sostiene cuando la realidad golpea. Gracias, también, a Natalia, por su inestimable ayuda académica. A Moncho, que es lo más bonito que me ha dado de vuelta un congreso y que lleva cuidándome desde el momento en el que lo conocí. A Alejandra, Anaclara y Andrea, por luchar, porque me hacen creer en el cambio a escala internacional. Gracias, en general, a todas las mujeres valientes, a todas las que pelearon antes que nosotras, porque sin ellas ninguna seríamos nada.

Y gracias a Iván, el que, un día, cuando le estaba hablando de este u otro tema feminista, se me quedó mirando y me dijo la cosa más preciosa que haya podido escuchar: "por favor, Paula, no te calles nunca". 


\section{RESUMEN}

Los medios de comunicación utilizan distintas estrategias para fidelizar a su audiencia: fijan intereses en función de la edad, el área regional o los gustos e inquietudes. Desde que, a principios del siglo XXI, la oferta de canales se multiplicara en el medio televisivo español, observamos que, además de las anteriores fórmulas, se produce una segmentación del público en base al sexo. Esto es, nacen canales dirigidos en exclusiva o bien a las mujeres o bien a los hombres.

Dicha tendencia, aunque novedosa en el medio televisivo, no lo es tanto para la prensa que, desde el siglo XVIII, especializó sus contenidos, ofreciendo un producto concreto a las mujeres. La trayectoria de la prensa femenina es, por tanto, extensa y ha ido evolucionando a lo largo del tiempo. Pues bien, en las dos últimas décadas del siglo pasado, los grupos editoriales apostaron por la creación de una publicación paralela para los hombres, surgiendo, de este modo, las revistas de estilo de vida masculino.

En esta tesis doctoral, buscamos construir un diálogo, establecer una relación entre los mensajes emitidos por la prensa segregada en función del género y los nuevos canales de televisión especializados. Para ello, se acudirá a los propios medios, tanto escritos como audiovisuales, recabando una muestra que nos permita, finalmente, enfrentar ambos soportes. De forma paralela, se explorará tanto la teoría feminista como mediática, con el fin de crear una red que contextualice y dé sentido, en última instancia, a los resultados de la muestra. Nuestro análisis permitirá, pues, cuestionar las representaciones de la feminidad y la masculinidad, reflexionar sobre la retroalimentación y evolución del discurso mediático y abordar las consecuencias sociales del mismo.

Palabras Clave: Prensa femenina y masculina, Revistas de estilo de vida, Canales de televisión especializados, Estudios feministas, Feminismo. 


\section{ABSTRACT}

The media use various strategies to retain their audience: interests set according to age, regional area or tastes and queries. Since, at the beginning of the 21 st century, the channel offer multiplied in the Spanish television medium, we observe, in addition to the previous formulas, we produce a segmentation of the public based on sex. That is, channels directed exclusively to women or to men are born.

This trend, although novel in the television medium is not so much for the press that, since the 18th century, it specialized in its contents, it had a specific product for women. The trajectory of the female press is, therefore, extensive and has evolved over time. Well, in the last two decades of the last century, the editorial groups opted for the creation of a parallel publication for men, thus emerging the magazines of male lifestyle.

In this doctoral thesis, we seek to build a dialogue, establish a relationship between the messages issued by the segregated press according to gender and the new specialized television channels. For this, we will go to the media, both written and audio-visual, collecting a sample that allows us, finally, will face both media. In parallel, he will explore both feminist and medical theory, in order to create a network that contextualizes and ultimately makes sense of the results of the sample. Our analysis evaluated, then, to question the representations of femininity and masculinity, to reflect on the feedback and evolution of media discourse and to address the social consequences of it.

KEY WORDS: Female and male press, Lifestyle magazines, Specialized television channels, Feminist studies, Feminism. 


\section{ÍNDICE}

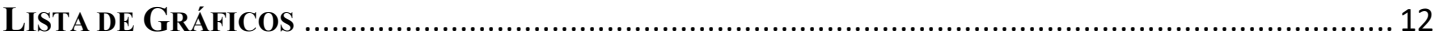

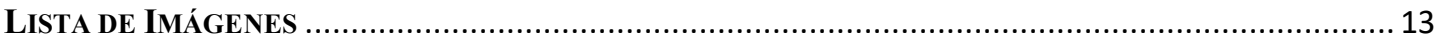

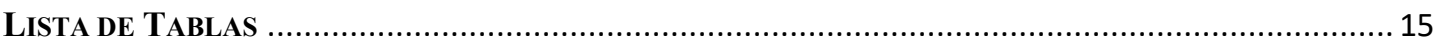

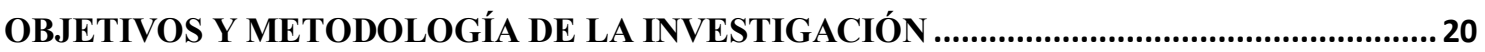

1. OBJETO, FINALIDAD Y METODOLOGÍA DE LA INVESTIGACIÓN ............................... 20

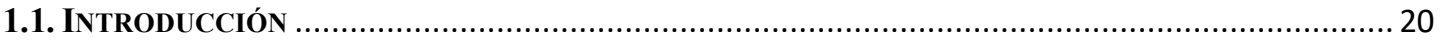

1.2. OBJETIVOS E HIPÓTESIS DE LA INVESTIGACIÓN............................................................ 22

1.3. ESTRUCTURA DEL TEXTO Y METODOLOGÍA............................................................. 26

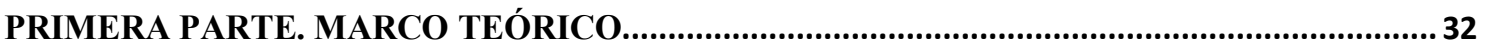

CAPÍTULO PRIMERO. PRODUCTOS MEDIÁTICOS ESPECIALIZADOS Y COMPORTAMIENTOS DEL PÚBLICO: LOS NUEVOS CANALES DE TELEVISIÓN TEMÁTICOS 34

1. SEGMENTACIÓN DE LA AUDIENCIA Y NUEVAS FORMAS DE CONSUMO......................... 34

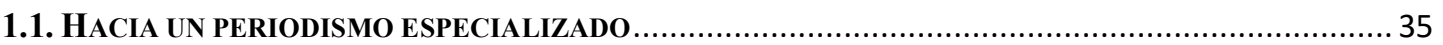

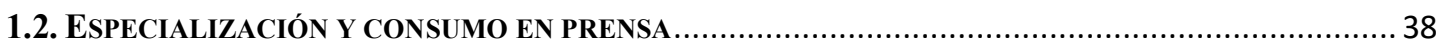

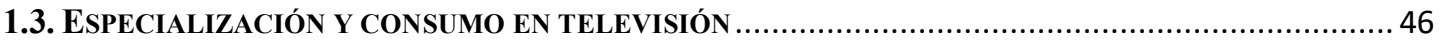

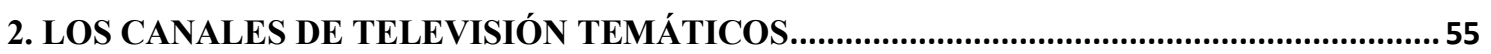

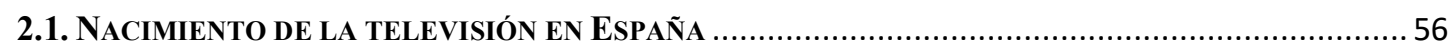

2.2. LA TELEVISIÓN DIGITAL TERRESTRE Y LA FRAGMENTACIÓN DE LA AUDIENCIA ........................66

2.3. CANALES DE TELEVISIÓN TEMÁTICOS SEGREGAdOS POR GÉNERO ....................................... 75

CAPÍTULO SEGUNDO. REPRESENTACIONES MEDIÁTICAS DE LA FEMINIDAD: LAS REVISTAS DE ESTILO DE VIDA DIRIGIDAS A MUJERES......................................................... 90

1. CONSTRUCCIÓN MEDIÁTICA Y SOCIAL DE LA FEMINIDAD..............................................90

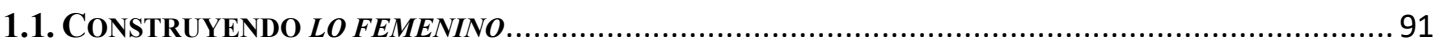

1.2. REPRESENTACIONES FEMENINAS EN EL DISCURSO MEDIÁTICO ….......................................... 107

2. HISTORIA Y ESTADO ACTUAL DE LAS REVISTAS DIRIGIDAS A MUJERES................. 119

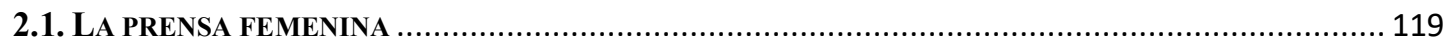

2.2. EVOLUCIÓN DE LA PRENSA DIRIGIDA A LAS MUJERES EN ESPAÑA ....................................... 124

2.3. REVISTAS ESPECIALIZADAS EN ESTILO DE VIDA FEMENINO ............................................. 136

CAPÍTULO TERCERO. REPRESENTACIONES MEDIÁTICAS DE LA MASCULINIDAD: LAS REVISTAS DE ESTILO DE VIDA DIRIGIDAS A HOMBRES.................................................. 146

1. CONSTRUCCIÓN MEDIÁTICA Y SOCIAL DE LA MASCULINIDAD.................................... 146

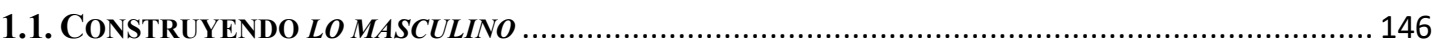

1.2. REPRESENTACIONES MASCULINAS EN EL DISCURSO MEDIÁTICO ........................................ 164

2. HISTORIA Y ESTADO ACTUAL DE LAS REVISTAS DIRIGIDAS A HOMBRES ............... 175

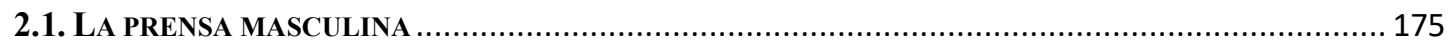

2.2. EVOLUCIÓN DE LAS REVISTAS MASCULINAS A LO LARGO DE LA HISTORIA ............................ 180

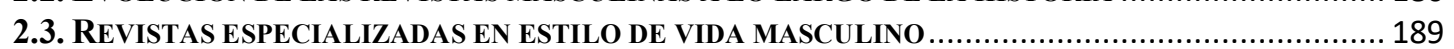

SEGUNDA PARTE. ESTUDIO EMPÍRICO ..................................................................... 200

CAPÍTULO CUARTO. ANÁLISIS DE LA MUESTRA: LAS REVISTAS ESPECIALIZADAS EN ESTILO DE VIDA FEMENINO Y MASCULINO ............................................................. 202

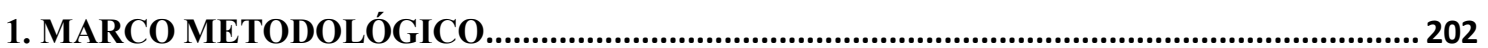


1.1. DELIMITACIÓN DEL CORPUS DE ESTUDIO................................................................... 202

1.2. Propuesta METOdológICA .................................................................................... 204

2. REVISTAS ESPECIALIZADAS EN ESTILO DE VIDA FEMENINO ................................... 207

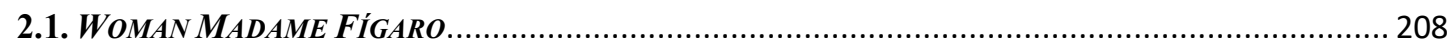

2.2. TELVA

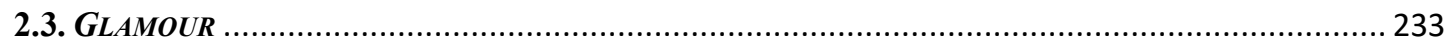

3. REVISTAS ESPECIALIZADAS EN ESTILO DE VIDA MASCULINO ................................ 245

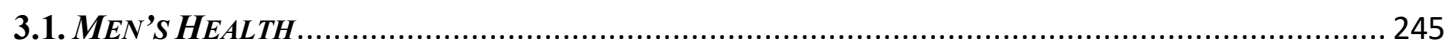

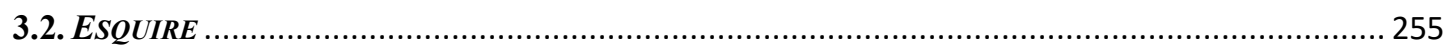

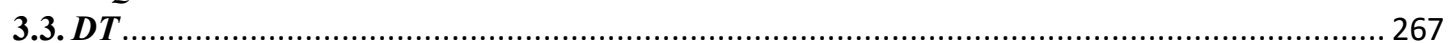

4. LAS REVISTAS DE ESTILO DE VIDA Y SUS REPRESENTACIONES DE LA FEMINIDAD

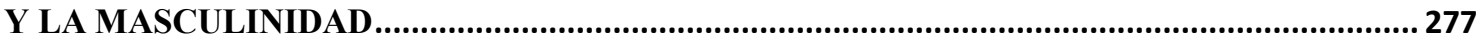

4.1. LA TECNOLOGÍA, LA DECORACIÓN Y EL HOGAR COMO CATEGORÍAS DIFERENCIADORAS....... 278

4.2. EL MITO DE LA BELLEZA EN LAS REVISTAS DE ESTILO DE VIDA .............................................. 282

4.3. EL MUNDO LABORAL PARA LAS MUJERES Y PARA LOS HOMBRES ....................................... 291

4.4. LAS CONTRADICCIONES DEL DISCURSO FEMINISTA EN LAS REVISTAS DE ESTILO DE VIDA ...... 303

CAPÍTULO QUINTO. ANÁLISIS DE LA MUESTRA: LOS CANALES DE TELEVISIÓN ESPECIALIZADOS SEGREGADOS POR GÉNERO........................................................... 308

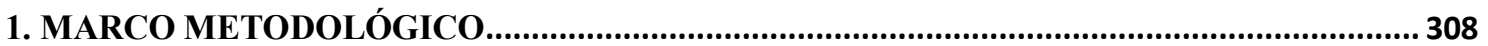

1.1. DELIMITACIÓN DEL CORPUS DE ESTUdIO......................................................................... 308

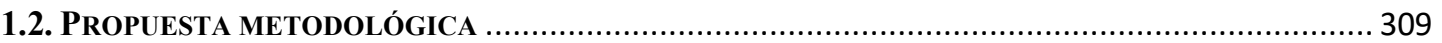

2. CANALES DE TELEVISIÓN ESPECIALIZADOS ORIENTADOS A UN PÚBLICO

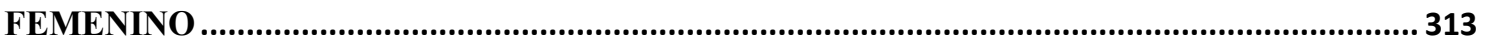

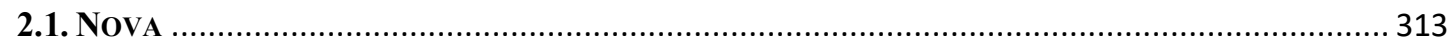

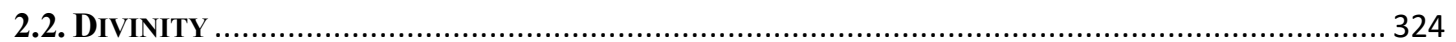

3. CANALES DE TELEVISIÓN ESPECIALIZADOS ORIENTADOS A UN PÚBLICO

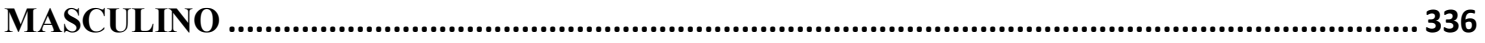

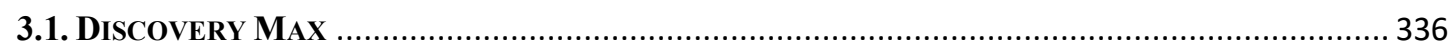

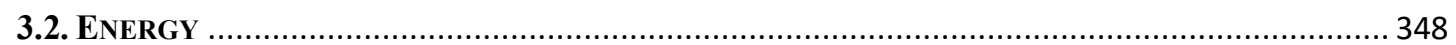

4. LOS CANALES DE TELEVISIÓN SEGREGADOS POR GÉNERO Y SU CONSTRUCCIÓN

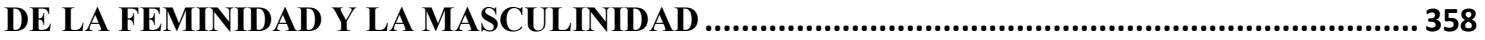

4.1. CATEGORÍAS QUE COMPARTEN LOS CANALES FEMENINOS Y MASCULINOS........................... 359

4.2. CATEGORÍAS QUE COMPARTEN LOS CANALES FEMENINOS ................................................ 366

4.3. CATEGORÍAS QUE COMPARTEN LOS CANALES MASCULINOS .............................................. 368

4.4. CONTENIDOS DE FICCIÓN EN LOS CANALES FEMENINOS Y MASCULINOS............................... 377

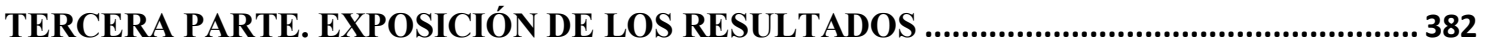

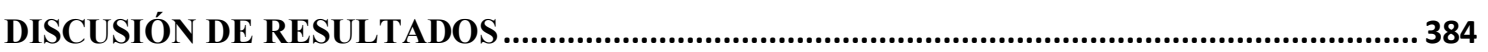

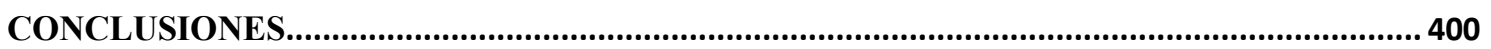

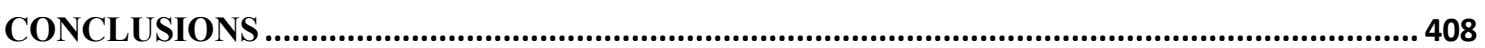

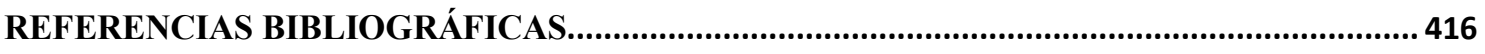

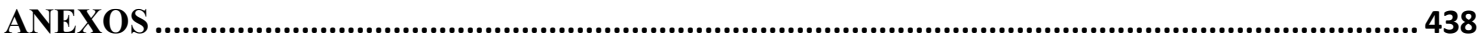




\section{LiSTA DE GRÁFICOS}

Gráfico 1 Evolución de la audiencia de revistas, diarios y suplementos Pág. 42 en papel en España (2008-2018).

Gráfico 2 Evolución de la audiencia de revistas teniendo en cuenta el Pág. 43 soporte (papel, internet o ambos) durante los años 2008-2018.

Gráfico 3 Evolución de la audiencia de diarios teniendo en cuenta el Pág. 44 soporte (papel, internet o ambos) durante los años 20082018).

Gráfico 4 Perfil de la audiencia de revistas, diarios y suplementos en Pág. 45 2018 por sexo y edad.

Gráfico 5 Evolución anual de minutos diarios de televisión consumidos Pág. 54 por persona (2000-2018).

Gráfico 6 Consumo diario de televisión en España por sexo y edad en el Pág. 55 año 2018.

Gráfico 7 Cuota de pantalla de los canales generalistas que emitían en Pág. 69 analógico en 2005 y 2006

Gráfico 8 Evolución de la cuota de pantalla de los canales televisivos Pág. 86 femeninos entre los años 2009 y 2010.

Gráfico 9 Evolución de la cuota de pantalla de los canales televisivos Pág. 87 masculinos entre los años 2009 y 2010.

Gráfico 10 Perfil de la audiencia, por sexo, de los canales masculinos y Pág. 88 femeninos (mayo de 2019).

Gráfico 11 Contenidos de la revista Woman en marzo, junio, septiembre Pág. 219 y diciembre de 2015.

Gráfico 12 Contenidos de la revista Telva en marzo, junio, septiembre y Pág. 232 diciembre de 2015.

Gráfico 13 Contenidos de la revista Glamour en marzo, junio, septiembre Pág. 245 y diciembre de 2015.

Gráfico 14 Contenidos de la revista Men's Health en marzo, junio, Pág. 255 septiembre y diciembre de 2015.

Gráfico 15 Contenidos de la revista Esquire en marzo, junio, septiembre Pág. 266 y diciembre de 2015.

Gráfico 16 Contenidos de la revista $D T$ en marzo, junio, septiembre y Pág. 276 diciembre de 2015.

Gráfico 17 Distribución de las cuatro categorías que comparten las seis Pág. 278 revistas de estilo de vida (muestra año 2015)

Gráfico 18 Número de unidades redaccionales dedicadas a tecnología Pág. 279 (muestra año 2015).

Gráfico 19 Funciones de las personas en las revistas de estilo de vida Pág. 291 femenino y masculino.

Gráfico 20 Función de los y las protagonistas en las revistas de estilo de Pág. 296 vida (muestra año 2015). 
Gráfico 21 Presencia de hombres y mujeres en las publicaciones de estilo Pág. 299 de vida femenino y masculino

Gráfico 22 Tipo de programación en Nova y número de repeticiones Pág. 315 (muestra año 2015).

Gráfico 23 Ficción seriada en Nova y número de repeticiones (muestra Pág. 318 año 2015).

Gráfico 24 Largometrajes en Nova (muestra año 2015).

Pág. 321

Gráfico 25 Espacios de no ficción en Nova y número de repeticiones

Pág. 324 (muestra año 2015).

Gráfico 26 Tipo de programación en Divinity y número de repeticiones

Pág. 326 (muestra año 2015).

Gráfico 27 Ficción seriada en Divinity y número de repeticiones (muestra año 2015).

Gráfico 28 Largometrajes en Divinity (muestra año 2015).

Pág. 329

Gráfico 29 Espacios de no ficción en Divinity y número de repeticiones

Pág. 331 (muestra año 2015).

Gráfico 30 Tipo de programación en Discovery Max y número de repeticiones (muestra año 2015).

Gráfico 31 Tipo de programación en Energy y número de repeticiones (muestra año 2015).

Gráfico 32 Ficción seriada en Energy y número de repeticiones (muestra año 2015).

Gráfico 33 Largometrajes en Energy (muestra año 2015).

Gráfico 34 Espacios de no ficción de Energy y número de repeticiones (muestra año 2015).

\section{LISTA DE IMÁGENES}

Imagen 1 Logotipo del canal femenino Divinity y del masculino Pág. 79 Energy, ambos de Mediaset.

Imagen 2 Sí, quiero ese vestido del canal femenino Dkiss y Locos por Pág. 80 los coches de Mega.

Imagen 3 Folletos católicos de la editorial Sal Terrae: A nadie (después de dios) debe amar más la mujer que a su marido (1965) y Diez cosas que una mujer casada no debe hacer (1967).

Imagen 4 Publicidad de la marca de moda masculina Suit Supply del Pág. 116 año 2010.

Imagen 5 Portada de diciembre de 2015 de la revista Elle y portada del Pág. 120 suplemento del grupo Vocento, Mujerhoy, de noviembre de 2018.

Imagen 6 Portada del primer número en papel, año 2013, de la revista feminista Pikara Magazine y portada de febrero de 2018 de la revista Harper's Bazaar España. 
Imagen 7 Portada número 70 de la revista Dunia y portada número 376 Pág. 130 de la revistas Telva.

Imagen 8 Portada de septiembre de 2017 de Yo dona, suplemento Pág. 141 semanal de El Mundo, y portada de abril de 2017 de la revista Mía.

Imagen 9 Carteles publicitarios de la marca Marlboro.

Pág. 154

Imagen 10 "The spanish brute, adds mutilation to murder" (El bruto

Pág. 157 español, añade mutilación al asesinato), portada de Grant Hamilton, Judge, 9 de julio de 1989.

Imagen 11 Anuncio de Emporio Armani de la campaña otoño-invierno de 2008 protagonizado por David Beckham.

Imagen 12 Anuncio de Nespresso de la campaña de 2007 protagonizado por George Clooney y anuncio de H\&M de la campaña de 2012 protagonizado por David Beckham.

Imagen 13 Portada de la revista The Gentleman's Magazine de mayo de 1759.

Imagen 14 Portada del primer número de la revista Man de noviembre de 1987 y portada del último número de la misma revista en verano de 2012.

Imagen 15 Mensaje de la cuenta oficial de Twitter de la revista FHM en el que se anuncia el fin de la publicación.

Imagen 16 Portada de la revista Esquire de diciembre de 2007 y portada de la revista Código Único nacida en 2013.

Imagen 17 Portada número 59 (enero de 2019) y portada número 62 Pág. 193 (abril de 2019) del suplemento Icon.

Imagen 18 La modelo Charlotte McKinney en la revista Men's Health (núm. 162, 2015) y la actriz Emilia Clarke en la revista Esquire (núm. 91, 2015).

Imagen 19 Logotipo de la revista Woman Madame Figaro.

Pág. 208

Imagen 20 Salma Hayek en la portada de la revista Woman de junio de

Pág. 210 2015.

Imagen 21 Logotipo de la revista Telva.

Pág. 220

Imagen 22 Portada de la revista Telva de junio de 2015.

Pág. 223

Imagen 23 Logotipo de la revista Glamour.

Pág. 233

Imagen 24 Portada de la revista Glamour de marzo de 2015.

Pág. 235

Imagen 25 Logotipo de la revista Men's Health.

Pág. 246

Imagen 26 Portada de la revista Men's Health de diciembre de 2015.

Pág. 248

Imagen 27 Logotipo de la revista Esquire.

Pág. 256

Imagen 28 El actor Steve Carrell en la portada de septiembre de 2015 de

Pág. 258 Esquire.

Imagen 29 Logotipo de la revista $D T$.

Pág. 267

Imagen 30 Las dos portadas de la revista $D T$ de junio de 2015.

Pág. 269

Imagen 31 Las dos portadas de la revista $D T$ de marzo de 2015.

Pág. 270 
Imagen 32 Portada de la revista Esquire de diciembre de 2015 y de la Pág. 299 revista Woman de septiembre de 2015.

Imagen 33 El modelo Marlon Teixiera posa para Glamour. Pág. 300

Imagen 34 La modelo Charlotte McKinney en la revista Men's Health. Pág. 300

Imagen 35 Algunas de las fotografías que podemos encontrar en el Pág. 301 reportaje de Esquire sobre la actriz Evangeline Lilly.

Imagen 36 DT dedica un reportaje en el mes de junio a la modelo Sara Pág. 302 Sampaio por su campaña de trajes de baño.

Imagen 37 Las modelos Emma Stone y Eva Doll en DT

Pág. 303

Imagen 38 Logotipo del canal televisivo Nova.

Pág. 313

Imagen 39 Logotipo del canal televisivo Divinity.

Pág. 325

Imagen 40 Logotipo del canal televisivo Discovery Max.

Pág. 337

Imagen 41 Logotipo del canal televisivo Energy.

Pág. 348

\section{LiSTA DE TABLAS}

Tabla 1 Categorización de publicaciones en el año 2019 según la OJD. Pág. 40

Tabla 2 Evolución anual de las audiencias (2009-2018) en los canales Pág. 48 que emiten a nivel nacional en España.

Tabla 3 Clasificación de las diferentes plataformas de pago para ver Pág. 50 contenidos audiovisuales online.

Tabla 4 Consumo de contenidos audiovisuales online al menos una vez Pág. 53 por semana.

Tabla 5 Televisión en abierto en España durante la primera década del Pág. 70 siglo XXI.

Tabla 6 Televisión en abierto en España durante la segunda década del Pág. 73 siglo XXI.

Tabla 7 Tipología de los canales televisivos en abierto en España Pág. 75 (1956-2019).

Tabla 8 Tipología de los canales televisivos en abierto en España Pág. 78 (2019)

Tabla 9 Prototipos de mujeres en publicidad.

Pág. 114

Tabla 10 Tipología de la prensa dirigida a mujeres en España en el siglo Pág. 139 XXI.

Tabla 11 Revistas especializadas en estilo de vida femenino, año 2019. Pág. 142

Tabla 12 Centralidad de las mujeres en las noticias por tema principal Pág. 177 (2000-2015).

Tabla 13 Temas con mayor y menor presencia de mujeres en las noticias Pág. 178 en el año 2015.

Tabla 14 Tipología de la prensa dirigida a hombres en España en el siglo Pág. 191 XXI.

Tabla 15 Cabeceras de prensa masculina en España en el año 2019. Pág. 192 
Tabla 16 Revistas especializadas en estilo de vida femenino que Pág. 203 componen la muestra.

Tabla 17 Revistas especializadas en estilo de vida masculino que Pág. 204 componen la muestra.

Tabla 18 Número de ejemplar de cada revista que compone la muestra. Pág. 205

Tabla 19 Ficha morfológica de la revista Woman Madame Figaro. Pág. 208

Tabla 20 Estructura de la revista Woman en 2015 (ejemplares de marzo, Pág. 211 junio, septiembre y diciembre).

Tabla 21 Función de las personas en la revista Woman (muestra año Pág. 218 2015)

Tabla 22 Ficha morfológica de la revista Telva.

Pág. 220

Tabla 23 Estructura de la revista Telva en 2015 (ejemplares de marzo, Pág. 224 junio, septiembre y diciembre).

Tabla 24 Función de las personas en la revista Telva (muestra año 2015). Pág. 230

Tabla 25 Ficha morfológica de la revista Glamour. Pág. 233

Tabla 26 Estructura de la revista Glamour en 2015 (ejemplares de marzo, Pág. 236 junio, septiembre y diciembre).

Tabla 27 Función de las personas en Glamour (muestra año 2015). Pág. 243

Tabla 28 Ficha morfológica de la revista Men's Health. Pág. 246

Tabla 29 Estructura de la revista Men's Health en 2015 (ejemplares de Pág. 249 marzo, junio, septiembre y diciembre).

Tabla 30 Función de las personas en Men's Health (muestra año 2015). Pág. 254

Tabla 31 Ficha morfológica de la revista Esquire. Pág. 257

Tabla 32 Estructura de la revista Esquire en 2015 (ejemplares de marzo, Pág. 259 junio, septiembre y diciembre).

Tabla 33 Función de las personas en Esquire (muestra año 2015).

Pág. 265

Tabla 34 Ficha morfológica de la revista $D T$.

Pág. 267

Tabla 35 Estructura de la revista $D T$ en 2015 (ejemplares de marzo, Pág. 271 junio, septiembre y diciembre).

Tabla 36 Función de las personas en DT (muestra año 2015). Pág. 275

Tabla 37 Contenidos de las principales revistas especializadas en estilo Pág. 277 de vida en España (muestra año 2015).

Tabla 38 Semanas de seguimiento de cada canal que compone la Pág. 309 muestra.

Tabla 39 Ficha morfológica del canal televisivo Nova.

Pág. 313

Tabla 40 Ficha morfológica del canal televisivo Divinity.

Pág. 325

Tabla 41 Ficha morfológica del canal televisivo Discovery Max.

Pág. 337

Tabla 42 Ficha morfológica del canal televisivo Energy.

Pág. 348

Tabla 43 Categorías de los contenidos de no ficción en Nova, Divinity, Pág. 358 Discovery Max y Energy en 2015.

Tabla 44 Programación de belleza y moda en Divinity, Nova, Energy y Pág. 361 Discovery Max en 2015.

Tabla 45 Programación de cocina y restauración en Nova, Divinity y Pág. 362 Energy en 2015. 
Tabla 46 Programación de ocio y cultura en Nova, Divinity y Energy en Pág. 363 2015.

Tabla 47 Programación de sociedad en Nova, Divinity y Energy en 2015. Pág. 364

Tabla 48 Programación de relaciones sentimentales de Nova, Divinity y Pág. 365 Energy en 2015.

Tabla 49 Contenido del programa Decogarden en Nova, año 2015. Pág. 366

Tabla 50 Contenido del programa La casa de mis sueños en Divinity, año Pág. 367 2015.

Tabla 51 Contenido del programa Mudanzas imposibles en Energy, año Pág. 368 2015.

Tabla 52 Contenido del programa ¿Cómo lo hacen? en Discovery Max, Pág. 369 año 2015.

Tabla 53 Contenido del programa Ciencia para torpes en Energy, año Pág. 370 2015.

Tabla 54 Contenido del programa Fast n’Loud en Discovery Max, año Pág. 370 2015.

Tabla 55 Contenido del programa Más que motos en Energy, año 2015. Pág. 371

Tabla 56 Contenido del programa Cazasubastas en Discovery Max, año Pág. 372 2015.

Tabla 57 Contenido del programa Transportes imposibles en Energy, Pág. 373 año 2015.

Tabla 58 Contenido del programa El último superviviente en Discovery Pág. 374 Max, año 2015.

Tabla 59 Contenido del programa Veterinario al rescate en Energy, año Pág. 375 2015.

Tabla 60 Contenido del programa Control de aduanas, Canadá en Pág. 376 Discovery Max, año 2015.

Tabla 61 Contenido del programa Los Timadores en Energy, año 2015. Pág. 377

Tabla 62 Contenidos de ficción seriada en Nova, Divinity y Energy, año Pág. 378 2015.

Tabla 63 Tipos de largometrajes en Nova, Divinity y Energy, año 2015. Pág. 379

Tabla 64 Temáticas de las seis principales revistas de estilo de vida de Pág. 385 España (muestra año 2015). 
INTRODUCCIÓN, OBJETIVOS Y METODOLOGÍA DE LA INVESTIGACIÓN 


\title{
OBJETIVOS Y METODOLOGÍA DE LA INVESTIGACIÓN
}

\author{
Comencé con la convicción, compartida por la mayoría de las \\ pensadoras feministas, de que el patriarcado es un sistema \\ histórico, es decir, tiene un inicio en la historia. Si es así, podrá \\ acabarse gracias al proceso histórico.
}

Gerda Lener

\section{OBJETO, FINALIDAD Y METODOLOGÍA DE LA INVESTIGACIÓN}

\subsection{Introducción}

Desde el año 1975 hasta el año 1995, Las Naciones Unidas organizaron cuatro conferencias mundiales orientadas a analizar la situación de las mujeres en el mundo y a establecer una serie de medidas que favorecieran el avance hacia sociedades igualitarias. La cuarta y última tuvo lugar en Beijing (Pekín), en septiembre de 1995 y en ella se establecieron toda una batería de propuestas y objetivos estratégicos encaminados a lograr la igualdad entre hombres y mujeres. Se delimitaron hasta 12 esferas de actuación, que abarcaban desde educación, salud, economía o medio ambiente. Una de las esferas, concretamente la $\mathrm{J}$, comprendía los medios de comunicación e instaba a los mismos a contribuir de una manera más decidida en el avance de las mujeres (ONU, 1995: 223). La propia organización aseguraba:

Hay que suprimir la proyección constante de imágenes negativas y degradantes de las mujeres en los medios de comunicación, ya sean electrónicos, impresos, visuales o sonoros. Los medios impresos y audiovisuales de la mayoría de los países no ofrecen una imagen equilibrada de los diversos estilos de vida de las mujeres y de su aportación a la sociedad en un mundo en evolución. Además, los productos violentos y degradantes o pornográficos de estos medios también perjudican a las mujeres y su participación en la sociedad. Los programas que insisten en presentar a las mujeres en sus papeles tradicionales son igualmente restrictivos. La tendencia mundial al consumo ha creado un clima en el que los anuncios y mensajes comerciales presentan a las mujeres como meras consumidoras, dirigiéndose a las niñas y a las mujeres de todas las edades de forma inapropiada (ONU, 1995: 223-224). 
Así, los objetivos estratégicos J.1. — “aumentar el grado de participación y de acceso a las mujeres a los espacios de toma de decisiones, de debate y exposición de ideas de los medios de comunicación" (ONU, 1995: 224)—y los objetivos estratégicos J.2. — "fomentar una imagen de las mujeres equilibrada y sin estereotipos en los medios de comunicación" (ONU, 1995: 228) — pasan por pedir a gobiernos, organismos internacionales, medios y agentes de comunicación, agencias publicitarias, organizaciones no gubernamentales, asociaciones y sector privado que cooperen en la promoción de las mujeres mediante programas de formación y sensibilización en asuntos de género, creación de legislación pertinente y de grupos de control que supervisen los medios de comunicación o supresión de mensajes negativos que insistan en "presentar a las mujeres como seres inferiores y de explotarlas como objeto sexual y bien de consumo" (ONU, 1995: 228).

Entre las medidas concretas, se requería "fomentar la idea de que los estereotipos sexistas que se presentan en los medios de comunicación son discriminatorios, degradantes y ofensivos para las mujeres" (ONU, 1995: 228). Podríamos determinar que este punto refleja de una manera muy viva el sentir de nuestra investigación. Como veremos más adelante, el recorrido histórico de los medios de comunicación nos hace partícipes de la desequilibrada representación de las mujeres en la narrativa mediática. Además, cuando estas han protagonizado algún tipo de soporte, lo han hecho desde la otredad —desligándose de la norma, lo masculino - y evidenciando de esta forma el carácter androcentrista que impregna a los medios de masas.

Como hemos señalado, la conferencia de Beijing se celebró en 1995 y alertaba del peligro de fomentar los estereotipos sexistas, además, recogía, expresamente, que los medios impresos y audiovisuales no ofrecían "una imagen equilibrada de los diversos estilos de vida de las mujeres y de su aportación a la sociedad" (ONU, 1995: 224). Efectivamente, los medios de comunicación de masas construían un discurso unidireccional sobre cómo debían vivir las mujeres y, en contraposición, otro de cómo debían hacerlo los hombres. Un ejemplo de ello, y que ocupa parte de nuestra investigación, es la prensa que sectoriza su audiencia y busca ser leída, o bien por un público masculino, o bien por un público femenino.

Han pasado casi 25 años desde que tuviera lugar la IV (y última) conferencia mundial sobre las mujeres. A lo largo de este tiempo, los medios de comunicación han sufrido diversas transformaciones: internet se ha consolidado como un medio más, 
mientras que los tradicionales han diversificado su oferta. Entre las nuevas propuestas, encontramos canales de televisión que guardan cierta relación con la prensa segregada en función del género: se trata de formatos que construyen dos esferas sociales y que, muy posiblemente, cimienten su programación sobre estereotipos sexistas, hecho que se aleja de las directrices requeridas por la plataforma de Beijing para el avance social de las mujeres. Así, este trabajo pretende, entre otros objetivos, conocer a fondo el mensaje de los nuevos canales de televisión. Parte de la hipótesis, como veremos en detalle más adelante, de que su discurso es estereotipado, lo que, a pesar de los aires de modernidad con los que dichos canales hayan podido aterrizar en nuestras pantallas, sigue perpetuando una visión del mundo tradicional.

Decidimos abrir la investigación con una cita de la autora Gerda Lener pues, consideramos, constituye un excelente punto de partida y justifica, en parte, la intencionalidad de nuestro trabajo. La historiadora contextualiza el patriarcado: sistema histórico que, como tal, cuenta con un inicio determinado. Del mismo modo, afirma, tendrá algún tipo de fin. El movimiento feminista lleva más de tres siglos luchando por lograrlo, por derribar la estructura que oprime a las mujeres por el simple hecho de serlo. Así, y siendo conscientes de que esto es solo un pequeñísimo grano de arena, queremos formar parte de un movimiento que cree en un mundo más justo. Lo hacemos desde la academia, pues entendemos que el conocimiento se convierte en educación y la educación en motor de los cambios sociales.

Inspirándonos en Gerda Lener, comenzamos nuestro trabajo con la convicción de que llegará el momento en que estas investigaciones ya no serán necesarias, pues el patriarcado, simplemente, habrá desaparecido. Sin embargo, aquí y ahora, hemos decidido formar parte activa del proceso histórico.

\subsection{Objetivos e hipótesis de la investigación}

El objetivo general de esta investigación es el de establecer una relación entre los mensajes de la prensa escrita segregada por género y los canales de televisión temáticos orientados a un público, por un lado femenino y, por el otro, masculino. Para alcanzar dicho propósito, será necesario estudiar la agenda temática de las revistas dirigidas a mujeres y a hombres y, también, la programación televisiva de las cadenas que segmentan sus audiencias en función del sexo. Por ello, a lo largo del estudio, se explorarán los 
estándares de la feminidad y la masculinidad que operan en nuestros días en la cultura occidental para comprender, así, de qué manera los recogen los medios de comunicación. En este sentido, nos interesa destacar el papel que juegan los medios de masas en la promoción y reproducción de una cultura dual — diferenciada para hombres y para mujeres-, mediante, precisamente, la sectorización de su público y la identificación con el mismo a través de la explotación discursiva de la masculinidad y la feminidad.

Así, concretamente, nos proponemos conocer la forma en que el mensaje televisivo ha bebido del periodístico en la creación de los nuevos canales segregados por sexos. Debemos tener en cuenta que la prensa dirigida a mujeres existe, en nuestro país, desde el siglo XVIII. Esta fue evolucionando, ofreciendo distintas vertientes y una de ellas, la de estilo de vida, llegó a consolidarse en el mercado como un producto muy específico que generaba grandes cifras de audiencia. En las últimas décadas del siglo pasado, los grupos editoriales apostaron por la creación de una publicación paralela para los hombres, surgiendo, de este modo, las revistas de estilo de vida masculino. ${ }^{1}$ Como ya han estudiado numerosas autoras y autores, las publicaciones de estilo de vida segregadas cimientan su narrativa en la socialización diferencial de los sexos, fomentando un discurso enfrentado y proyectando, por tanto, una sociedad jerarquizada entre hombres y mujeres.

Ahora, hace menos de dos décadas, cuando la televisión española ha contado con la posibilidad de multiplicar sus emisoras, los conglomerados comunicacionales han apostado, también, por la elaboración de canales, primero orientados a un público femenino y, posteriormente, a un público masculino. Este último fenómeno motiva el objetivo general de nuestra tesis, que es, como vinimos adelantando, el de conocer la relación entre los mensajes de ambos soportes, la prensa y la televisión, pudiendo establecer conexiones y paralelismos entre las narrativas de los más antiguos - los periodísticos — con los más recientes - los televisivos-.

Teniendo en cuenta lo anterior, nuestra hipótesis principal sostiene que los nuevos soportes de comunicación que segmentan sus audiencias en función del género - ciertos canales de televisión temáticos-, buscan la identificación con su público mediante la elaboración de un discurso sexista y estereotipado como ya lo hizo, anteriormente, la

\footnotetext{
${ }^{1}$ La prensa dirigida a mujeres es un concepto muy amplio y que, a día de hoy y según la clasificación elaborada por Isabel Menéndez (2010: 225), comprende varias tipologías de revistas: revistas especializadas de hogar, prácticas, del corazón, feministas y de estilo de vida. Serán estas últimas las que sirvan como espejo en la elaboración del producto masculino.
} 
prensa. Una vez establecida dicha hipótesis, la investigación estará guiada por tres objetivos específicos:

1. Conocer el medio televisivo español, su nacimiento y recorrido histórico, hasta alcanzar la irrupción de los canales temáticos en abierto y sus estrategias de sectorización de la audiencia.

2. Ahondar en la construcción social y cultural de la feminidad y comprender de qué manera los medios de comunicación recogen estas construcciones, profundizando en la prensa femenina como soporte tradicional que ha cimentado su narrativa en los valores de la feminidad.

3. De igual modo, analizar la construcción social y cultural de la masculinidad y estudiar la forma en que los medios incluyen estas construcciones, deteniéndonos en las revistas masculinas, ya que se tratan de soportes que erigen su narrativa sobre los valores de la masculinidad.

Con estos tres objetivos, pretendemos dibujar una panorámica que contextualice, precisamente, los medios de comunicación que componen nuestro corpus de estudio y, del mismo modo, nos ayude a comprender su mensaje. Es decir, buscamos reflejar si la prensa es tanto receptora como generadora de unos discursos sexistas y estereotipados y, por tanto, limitantes para con la construcción identitaria de su audiencia. Además, estos mensajes se pondrán en relación con los de los canales de televisión orientados a un publico femenino y masculino, con el fin último de que podamos determinar las conexiones entre la narrativa de ambos medios de comunicación.

Para lograr resolver nuestra hipótesis principal, es preciso formular una serie de hipótesis secundarias que hagan más sencillo y operativo el proceso de análisis e investigación. Estas serían las siguientes:

1. La feminidad y la masculinidad son construcciones culturales que conforman el género, herramienta de la que se sirve el patriarcado para sustentar la jerarquización de los sexos.

2. La feminidad y la masculinidad son construcciones culturales y, como tal, evolucionan en el tiempo. La modernización de ambos ordenes simbólicos no implica el fin de la jerarquía sexual imperante. 
3. Los medios de comunicación en general recogen los discursos de la feminidad y la masculinidad, alentando la continuidad del orden social existente.

4. Los medios de comunicación orientados a uno u otro sexo explotan, explícitamente, los valores, o bien de la feminidad, cuando se dirigen a las mujeres, o bien de la masculinidad, cuando se dirigen a los hombres.

5. La pluralidad de los medios de comunicación de masas es, por tanto, aparente y, como agentes socializadores, imposibilitan la identificación con formas de ser que transciendan las establecidas por el sistema sexogénero. $^{2}$

6. La sectorización de las audiencias en función del sexo ha superado los tradicionales soportes de papel y se está asentando fuertemente en el medio televisivo, con la proliferación de varios canales orientados a públicos masculinos y femeninos.

7. La fragmentación de la audiencia en función del sexo lleva a comprender el mundo de una manera dual y enfrentada donde, cabe señalar, lo considerado masculino siempre tendrá más valor que lo femenino. Así, además de difundir un discurso insuficiente y paralizante para con la construcción de la propia identidad, los medios de comunicación alimentan la dominación masculina.

Hay que destacar que uno de los desafíos de esta investigación radica en que se situarán a un mismo nivel de análisis los mensajes emitidos por el medio televisivo y los generados por la prensa escrita. Esto supone un reto a la hora de categorizar la muestra y de enfrentar los resultados. Se trataría, por su carácter inédito y novedoso, de la principal aportación de la tesis, pues todavía no contamos con un estudio que haya reflexionado dichos soportes de manera conjunta. Además, debemos precisar que la investigación académica en estos campos, aun por separado, es todavía escasa, siendo la más numerosa la referente a la prensa dirigida a las mujeres. Sin embargo, no cuentan con el mismo volumen de investigación ni las revistas destinadas a los varones ni los canales temáticos

\footnotetext{
${ }^{2}$ El sistema sexo-género, expresión que acuñó Gayle Rubin en el año 1975, hace referencia a las expectativas sociales que se tienen de una persona por pertenecer a uno de los dos sexos. Así, de las mujeres se espera que se comporten según los cánones de la feminidad y de los hombres, que hagan lo propio con la masculinidad.
} 
orientados a públicos masculinos y femeninos. Estos últimos, de tan recientes que son, apenas reúnen bibliografía específica. Es por esto, por su cercana irrupción, que debemos situarnos en el contexto actual español, ofreciendo una perspectiva contemporánea sobre dichos medios de comunicación, sus mensajes y su papel como agentes socializadores de género.

El trabajo irá abordando las diferentes hipótesis planteadas de una manera no lineal, construyendo un marco teórico que permita, finalmente, interpretar el objeto de estudio. Dado el carácter multidisciplinar de la investigación, este trabajo se nutre de teoría de los medios de comunicación, pero también feminista, sociológica o antropológica. La pretensión final es la de ofrecer un análisis que posibilite la lectura del discurso mediático desde una perspectiva feminista y poder contribuir, así, a la creación y construcción de una mirada más crítica.

\subsection{Estructura del texto y metodología}

La tesis doctoral se articula en torno a tres partes fundamentales, un primer bloque teórico, otro empírico y, en último lugar, la exposición de los resultados. Estos bloques, a su vez, se subdividen en diferentes apartados.

El bloque teórico cuenta con tres grandes capítulos. En el primero de ellos se aborda la especialización de contenidos en prensa y televisión y los comportamientos actuales del público ante la multiplicidad de la oferta mediática. Si nos situamos en el contexto actual español, el medio de comunicación tradicional que ha sufrido una mayor especialización en las dos últimas décadas ha sido el de la televisión, que ha pasado de ofrecer, en el año 2000 y a nivel nacional, cuatro canales generalistas en abierto - las dos cadenas públicas (La 1 y La 2) y las dos privadas (Antena 3 y Telecinco)—, a 26 canales en 2019 —entre los cuales encontramos tanto ofertas generalistas como temáticas-. Es por eso que, una vez estudiados los modos que tiene el público de relacionarse con la prensa y televisión, analizaremos la situación actual de esta última.

Desde que internet se popularizara y llegara a las vidas de millones de personas, el medio ha saltado de los ordenadores, a los teléfonos móviles y a los aparatos de televisión. Vivimos en un contexto multipantalla, el cual nos permite acceder a los contenidos mediáticos tradicionales, esta vez, desde nuevos soportes y en cualquier momento. Los canales de transmisión clásicos se encuentran, por tanto, ante un desafío 
considerable. El público consume televisión y prensa de forma distinta, lo que obliga a revisar las estrategias de alcance de una audiencia cada vez más familiarizada con las nuevas tecnologías.

Aunque la especialización de los contenidos puede ser un modo de atraer a nichos de audiencias fieles, lo cierto es que la prensa lleva décadas —más de dos siglos en el caso concreto de la prensa dirigida a mujeres_-, ofreciendo temáticas acotadas según intereses o perfiles del público. Sin embargo, como hemos avanzado unas líneas más arriba, la televisión nacional en abierto comenzó hace apenas quince años a tematizar sus contenidos. Es por esto que analizaremos profundamente este fenómeno, —proporcionando un análisis histórico del medio con autores como Manuel Palacio o Gustavo Bueno-y, también, porque dentro de la nueva oferta temática se han sucedido una serie de canales orientados a un público femenino y, paralelamente, otros a un público masculino. De ellos, rescataremos sus contenidos, pues el objetivo principal de esta tesis es, como dijimos, el de establecer un diálogo entre los mensajes proporcionados por la prensa segregada por género y los que encontramos en la televisión.

En el segundo capítulo, profundizaremos en los soportes de prensa dirigidos a las mujeres y en el tipo de mensajes que ofrecen. Para ello, primeramente, realizaremos un análisis sobre el concepto de la feminidad, exponiendo de qué manera esta se ha configurado cultural y socialmente y atendiendo a las voces feministas que se han mostrado críticas con el discurso hegemónico que aúna naturalmente la noción biológica de ser mujer con la construcción cultural de la feminidad. Partiremos de las reflexiones de Simone de Beauvoir, recogidas en su obra El segundo sexo (1949), pues se considera texto fundacional del feminismo contemporáneo, y las complementaremos tanto con otras voces anteriores - Olympe de Gouges, Mary Wollstonecraft_ - como posteriores - Kate Millet o Gayle Rubin-. Una vez introducido el tema, procederemos a exponer los distintos modelos históricos de la feminidad que se han sucedido desde el siglo XIX hasta nuestros días - el discurso de la domesticidad (trabajado por teóricas como Mary Nash), la mística de la feminidad (Friedan, 1963) o el mito de la belleza (Wolf, 1991) Además, tras esta visión social, aportaremos otra mediática que, del mismo modo, indagará en las distintas maneras posibles y aceptadas de ser mujer, atendiendo a roles, representaciones y estereotipos dentro de los medios de comunicación de masas.

Finalmente, en la segunda parte de este capítulo, nos centraremos en la prensa femenina, tratando de acotar su definición y ofreciendo un repaso sobre la evolución 
histórica de la misma para, en último lugar, desembocar en el estado actual de las revistas femeninas, más concretamente, en las de estilo de vida femenino. Llegar hasta estas últimas será posible gracias al trabajo que previamente han elaborado numerosas autoras y autores, sin embargo, son destacables, por un lado, la conceptualización de Juana Gallego de la prensa femenina como prensa de lo privado y, por el otro, la tipología que Isabel Menéndez ofrece sobre la prensa de masas dirigida a mujeres, en la cual encontramos perfectamente diferenciadas las revistas especializadas en estilo de vida femenino frente a otras revistas, también orientadas a un público femenino, como son las del hogar o del corazón.

El último capítulo del marco teórico indaga, paralelo al anterior, en los soportes de prensa dirigidos a los hombres y en los mensajes que estos lanzan. Comienza, del mismo modo, cuestionando el carácter natural de la masculinidad y exponiendo las características del modelo hegemónico, basándose, principalmente, en la voz y los trabajos de Connell, aunque también encontramos, entre otros, al autor Luis Bonino o a la autora Nerea Aresti. Posteriormente, un recorrido histórico nos permitirá comprender de qué manera el modelo ha evolucionado a lo largo de estos dos últimos siglos, para culminar en lo que hoy se denominan las nuevas masculinidades, término no exento de polémica y del que rescataremos las reflexiones de Miguel Lorente, autor que también nos introducirá en el concepto del postmachismo.

Al igual que hicimos en el anterior capítulo, tras el recorrido histórico, situaremos a la masculinidad dentro del contexto mediático. Haremos especial hincapié en las representaciones del hombre bello - muy presente en la publicidad y conceptualizado, bajo diferentes etiquetas, como la de metrosexual o spornosexual, primeramente por el periodista Mark Simpson y más adelante por autores y autoras de la academia-. El hombre bello nos interesa dado su auge y su supuesto paralelismo con la mujer objeto. Además, expondremos los modelos que encontramos en el cine y la televisión. Este apartado nos servirá, precisamente, de antesala para introducir los soportes de prensa dirigidos a los hombres.

El último bloque de este capítulo está dedicado, por completo, a la prensa masculina. Trataremos de acotar su definición y ofreceremos un repaso sobre la evolución histórica de la misma, para, finalmente, concluir con una exposición del estado actual de las revistas masculinas, no sin antes centrarnos en su tipología. Para ello, nos serviremos del esquema elaborado previamente por Isabel Menéndez (2010: 225), que clasificaba la 
prensa femenina, y haremos lo propio con la masculina. De este modo, llegaremos a las revistas especializadas en estilo de vida masculino y a sus características formales y discursivas, basándonos en las investigaciones recientes elaboradas por autoras como Teresa Iriarte (2016) o Felipe Viero Kolinski (2019).

La segunda parte de esta tesis, dedicada al estudio empírico, está dividida en dos capítulos, centrados en exponer y describir el corpus de estudio. El primero de ellos analiza la muestra de prensa y el segundo, de televisión. Ambos capítulos cuentan con un epígrafe inicial que delimita el área de estudio y nos sitúa en la metodología utilizada. Se ha escogido el análisis de contenido, recogido por autores como Roger Wimmer y Joseph Dominick, por ser una metodología pensada para la investigación de los medios de comunicación. En cuanto a la muestra, la componen, por un lado, las revistas y los canales televisivos dirigidos a audiencias femeninas y, por el otro, las revistas y los canales televisivos dirigidos a audiencias masculinas en España. El periodo comprendido es el año 2015, habiendo grabado la programación y recopilado las revistas durante los meses de marzo, junio, septiembre y diciembre. Esta simultaneidad nos permitirá establecer un análisis paralelo y poner en consonancia el mensaje de ambos formatos sin que existan desfases temporales. Además, la cata comprende cada uno de los trimestres del año 2015, procurando así que los resultados sean lo más representativos posibles.

Tras la exposición del trabajo de campo, llegamos al último bloque de nuestra investigación. Este, a su vez, cuenta con dos epígrafes: la discusión de resultados — que analiza e interpreta los datos de nuestra muestra concreta - y las conclusiones generales de la tesis doctoral — que extrapola los resultados contextualizándolos en el ámbito social actual, ofreciendo, así, una perspectiva más amplia de los mismos- Después de estos dos apartados, se mostrará, primero, la bibliografía citada y, finalmente, los anexos que acompañan a la investigación. Dichos anexos están formados por las fichas de análisis de cada una de las revistas que conforman la muestra y por la parrilla de los distintos canales televisivos durante las semanas que se procedió a la grabación de los mismos.

En último lugar, señalar que para redactar las referencias bibliográficas de nuestra investigación, se ha privilegiado la normativa más común y más utilizada en las ciencias sociales. De este modo, nos hemos servido de las reglas de estilo APA —creadas por la American Psychological Association-, más concretamente, de la adaptación para trabajos académicos y científicos realizada por Ángel Forner y Luis Carro (1997: 271285). Mientras, la bibliografía consultada pertenece, en mayor medida, a la publicada en 
el ámbito español y latinoamericano, así como la disponible en castellano. Finalmente, destacar que en las ocasiones en las que se ha utilizado algún documento redactado en otras lenguas la traducción que se podrá leer es propia. 


\section{PRIMERA PARTE. MARCO TEÓRICO}




\title{
CAPÍTULO PRIMERO. PRODUCTOS MEDIÁTICOS ESPECIALIZADOS Y COMPORTAMIENTOS DEL PÚBLICO: LOS NUEVOS CANALES DE TELEVISIÓN TEMÁTICOS
}

\begin{abstract}
Ahora bien, trátese de un discurso, de un libro o de un mensaje televisivo, el problema principal de la comunicación consiste en saber si se han cumplido las condiciones de recepción: ¿tiene quién escucha el código para descodificar lo que estoy diciendo?
\end{abstract}

Pierre Bourdieu

\section{SEGMENTACIÓN DE LA AUDIENCIA Y NUEVAS FORMAS DE CONSUMO}

A lo largo de la historia, los distintos cambios políticos, económicos, sociales y tecnológicos han ido alterando el modo en que transmitimos la información, de esta manera, sabemos, por ejemplo, que la prensa escrita del siglo XIX y principios del siglo XX hubo de adaptarse a la aparición de la radio y la televisión para convivir con ellas. Además, la irrupción de nuevos medios de comunicación conllevó cambios en las rutinas informativas, un ejemplo directo de ello sería la espectacularización que ha ido sufriendo la información, que se mezcla con el entretenimiento en los distintos soportes mediáticos con el fin de atraer a más público (Martínez, 2005: 294-295).

Ya en el siglo XXI, el gran desarrollo tecnológico propició lo que conocemos como la revolución digital, que se caracteriza por un internet móvil, software cada vez más potente y pequeño, el aprendizaje de la máquina y el avance de la inteligencia artificial. Sin embargo, dicha revolución lleva gestándose, gracias al desarrollo de la computación, desde el inicio de la década de 1960, siguió afianzándose en los años setenta y ochenta con la informática personal, y se consolidó en la década de los noventa mediante internet (Schwab, 2016: 20).

Así, la revolución digital "marcará los procesos productivos y comunicacionales de nuestra era a nivel mundial" (Jódar, 2010: 2). Es decir, la llegada de internet supone un nuevo paradigma para los medios de comunicación clásicos, como ya le sucedió anteriormente a la prensa escrita con la irrupción de la radio o la televisión. Sin embargo, no estamos hablando de la desaparición de los modelos de comunicación tradicionales, 
sino que, con esta era digital, encuentran nuevos canales y soportes comunicativos: "los interfaces actúan a modo de representaciones de los viejos medios y formas culturales, privilegiando uno de ellos a expensas de los demás" (Manovich, 2005: 60). En este sentido, internet nos permite leer la prensa, ver la televisión o escuchar la radio, siendo el canal y la relación con la masa receptora — mucho más implicada— los que han cambiado.

Precisamente, con esta nueva era, los canales de flujo de la información se han visto multiplicados, logrando transmitir aun más datos, lo que conlleva una especialización de contenidos dada la inevitable fragmentación o segmentación de la audiencia y la presencia de una masa receptora más activa que demanda temas acordes a sus gustos y necesidades (Jódar, 2010: 3). En las siguientes páginas, se procederá a analizar de qué manera afecta dicha realidad a dos de los medios históricos que forman el objeto de estudio de esta investigación — la prensa y a la televisión—y, además, qué cambios se han producido en la relación entre el medio y la audiencia. También, abordaremos en profundidad el caso concreto de la televisión en España pues ha vivido, en esta última década, una verdadera revolución temática.

\subsection{Hacia un periodismo especializado}

Actualmente, existe mucha más información de la que jamás nunca podríamos llegar a consumir, a menos a nivel individual. La comunidad académica nos habla de que vivimos en la sociedad de la información. Este término evoluciona directamente de la sociedadpostindustrial, la cual Daniel Bell explicó en su obra del año 1973 - El advenimiento de la sociedad post-industrial—. Según el sociólogo, el descenso en el número de empleos relacionados con la manufactura y el incremento del sector servicios, implicaban una reducción del trabajo manual a favor de una nueva materia prima, esta es, la información (citado en Webster, 2006: 36).

Así, entendemos que es la actual una sociedad donde la información ocupa un lugar primordial: pasa a ser fuente de riqueza y es transversal al resto de actividades, que se adaptan a este modo de ser comunicacional - la industria, el entretenimiento, la educación, el comercio...-. Esta sociedad es posible gracias al desarrollo de las tecnologías de información y comunicación, TICs (Crovi, 2002: 16). 
Tanto la sociedad de la información, que pone en alza el valor del conocimiento e incrementa la producción comunicacional, como la revolución digital, mencionada en el anterior epígrafe, obligan a los medios a adaptarse a una realidad sobresaturada de información y que cuenta con más canales que nunca para la transmisión de la misma. Por ello, cabe esperar que la especialización periodística sea un fenómeno esencial a la hora de abordar una realidad de otro modo inabarcable.

Los lectores y las lectoras de prensa, al igual que la audiencia en televisión, se han convertido en demandantes selectivos de la información, lo que exige que la industria mediática genere unos contenidos especializados que hagan, ya no solo más sencillo el proceso de asimilación de la información, sino que este se adecue a los gustos y preferencias personales de quién lo vaya a consumir. En este sentido, la prensa y la televisión cuentan con una oferta muy variada: podremos encontrar múltiples cabeceras y canales que nos acerquen a diversos temas y que vayan dirigidos a un público concreto, esto es, canales juveniles, cabeceras culturales, de economía, tecnología, moda, decoración, salud...

Diversos autores y autoras han estudiado dicha tematización de la información. El investigador Francisco Esteve nos cuenta que "la especialización periodística da respuesta a la necesidad de contextualizar la información en una sociedad inmersa en una visión global de la realidad" (citado en Menéndez, 2009: 280). En este sentido, los y las periodistas se convierten en expertos dentro de una temática, lo que aporta credibilidad y fiabilidad al mensaje que vayan a transmitir. Montserrat Quesada, por su lado, considera que el periodismo especializado "resulta de la aplicación minuciosa de la metodología periodística a los múltiples ámbitos temáticos que conforman la realidad social condicionada siempre por el medio de comunicación que se utilice como canal" (Quesada, 1998: 23).

A la hora de afrontar esta disciplina, una de las premisas que se tienen en cuenta es que se trata de un periodismo en profundidad, el cual aporta "aquellos elementos documentales y de investigación que puedan ser de mayor utilidad para su mejor comprensión" (Esteve, 2014: 13). Por otro lado, y asociado a esta labor de profundizar, se puede discernir que el periodismo especializado no siempre responde a criterios de noticiabilidad, dado que la profundidad que requiere muchas veces no puede ir acorde con la agenda que marca la rigurosa actualidad. 
Desde los estudios académicos, se ha probado que existen distintos niveles de especialización en el quehacer periodístico. El primer grado es aquel que va dirigido a una audiencia general y contaría con un nivel de especialización muy bajo (Esteve, 2014: 12). Es el que encontramos en los medios generalistas, como pueden ser las cabeceras de $A B C$ o El País, las cuales incluyen distintas secciones entre sus páginas: política, economía, sociedad, deportes, cultura... También, dentro de la televisión, tenemos los llamados canales generalistas - La 1, Antena 3, La Sexta...-que ofrecen informativos, entretenimiento, documentales, cine, series de ficción, etc.

El segundo nivel de especialización lo asociaríamos a los suplementos que acompañan a la prensa escrita y, también, a los programas especiales emitidos en los medios audiovisuales generalistas (Esteve, 2014: 12). Los suplementos se nos pueden ofrecer de dos maneras. Por un lado, como una publicación aparte de la propia cabecera - El País Semanal del grupo Prisa - o insertos en forma de cuadernillo dentro del mismo diario — puede ser el caso de Motor en el periódico El Mundo-. Estas publicaciones cuentan con un nivel de especialización mayor que el producto al que acompañan y buscan una audiencia mucho más sectorial.

Finalmente, el tercer nivel comprende, tanto en la prensa escrita como en la información audiovisual, a aquellos medios "que ofrecen con determinada periodicidad contenidos monográficos relativos a una determinada área temática y que van dirigidos a un sector de la población especialmente interesado en estos temas y con conocimientos suficientes sobre los mismos" (Esteve, 2014: 12). Aquí es donde encontramos tanto los canales de televisión temáticos - Clan, FDF, Paramount Channel...- que se especializan en series, largometrajes, deportes, estilo de vida...; como las publicaciones de información especializada, las cuales tratan sobre ciencia, fotografía, historia, decoración, viajes, etc.

La autora Diezhandino coincide en el anterior análisis al asegurar que "el actual es un periodismo con distintos niveles de especialización, pero casi por definición podría decirse que es especializado" (Diezhandino, 1997: 86). Es este sentido, explica que los y las periodistas no pueden contentarse con describir un hecho noticioso, sino que deben ofrecer una interpretación del mismo "hay que indicar porqué son importantes, en qué contexto hay que situarlos, adónde nos conducen" (Diezhandino, 1997: 87). 
Teniendo en cuenta el panorama mediático actual, el periodismo especializado debe dar respuesta, según Quesada, a una triple especialización: por contenidos, por sectores de audiencia y por medios de comunicación (Quesada, 1998: 18). Aunque esta triple especialización aparezca, a priori, bien diferenciada, cabe decir que en muchos casos puede retroalimentarse ofreciendo fórmulas mixtas. Por tanto, conviene pararse a analizar en qué consiste exactamente pues será importante a la hora de llevar a cabo nuestra investigación.

En primer lugar, la especialización por contenidos es aquella que aborda de una manera precisa y con profundidad una temática y que ofrece a un público interesado información acerca de la misma (esté o no de actualidad). Esta especialización por contenidos la podemos encontrar, o bien conformando un medio de comunicación en sí - la revista Saber Vivir de salud_-, o bien ocupando un espacio dentro de los medios generalistas —el programa Saber Vivir, de salud, que se emite en el canal generalista La 1 de RTVE-.

Por otro lado, la especialización por sectores de audiencia implica entender al público antes que al contenido. Es decir, si en el caso anterior pensábamos en ofrecer un tema de salud a la audiencia que estuviera interesada, ahora, nos enfocaremos primero en el público y, a partir de ahí, elaboramos el discurso que mejor vaya a llegarle. Entonces, si buscamos que nuestro público sea infantil, ofreceremos dibujos animados, como haría el canal temático Clan de RTVE.

Finalmente, la especialización por medios de comunicación nos habla de todos aquellos medios que han tematizado o especializado sus contenidos. La revista mencionada anteriormente, Saber Vivir, es, en sí misma, un medio de comunicación especializado. Lo mismo ocurre con el canal infantil Clan que ha sectorizado su audiencia y tematizado sus contenidos ofreciendo las 24 horas del día un contenido especializado.

\subsection{Especialización y consumo en prensa}

Las fuentes que hemos ido mencionando hablan del periodismo especializado como respuesta lógica ante la sociedad de la información y la revolución digital, fenómenos ambos desarrollados tras la Segunda Guerra Mundial. Sin embargo, aunque estos dos hechos propicien en mayor medida la tematización de contenidos, sí es cierto que la prensa de papel especializada cuenta con una amplia trayectoria histórica. El auge de estas 
publicaciones data del siglo XX, pero, al menos en España, debemos retrotraernos hasta el siglo XVIII para situarnos en los inicios mismos de la especialización periodística: la publicación Discursos Mercuriales Económicos-Políticos de Enrique de Graef (1752) será el primer periódico especializado en economía de España (Mercado, 2006: 2) y La Pensadora Gaditana (1768) primera publicación, de periodicidad semanal, que fragmentó su audiencia y se dirigió a un público femenino (Menéndez y Figueras, 2013: $35)$.

En el siglo XIX, encontramos títulos como El Cazador, que empezó a editarse en Barcelona en 1856 y se considera la primera publicación deportiva. Era de periodicidad quinquenal destinada a defender los derechos de los cazadores y a reclamar la observancia de las leyes de caza. Otras publicaciones deportivas de ese mismo periodo son El Pedal (1869) o El Deporte Velocipédico: Revista Ciclista Ilustrada (1895) (Sainz de Baranda, 2013:10). También, en este mismo siglo proliferan las revistas femeninas, en especial las enfocadas en la moda, como es El Periódico de las Damas que en 1822 es ya una revista especializada (González y Pérez, 2009: 56).

Aunque, como vemos, el periodismo especializado irrumpe en el siglo XVIII y sigue desarrollándose en el XIX, es a mediados de los años 50 del siglo XX cuando desde las redacciones de los grandes periódicos advierten que deben apostar en mayor medida por una fórmula especializada de sus contenidos. Esto es así debido a que se suceden varias crisis: "crisis de la función de servicio, al tambalearse la eficacia del periodismo informativo como simple relato de noticias; crisis de contenidos, ante la competencia de la radio y la televisión; y crisis de identidad, ante la pérdida de lectores que no encuentran en la prensa la respuesta a sus expectativas" (Mercado, 2006: 3).

A día de hoy en España, contamos con múltiples cabeceras nacidas a raíz de la especialización de los contenidos: ya sean diarios, revistas, suplementos o publicaciones. Los temas son muy variados: desde divulgación científica, hasta turismo, educación, música, religión, arquitectura o educación. Esta prensa, de mayor grado de especialización, convive con la prensa de menor grado de especialización o prensa general. La Oficina de Justificación de la Difusión, OJD, nos ofrece una recopilación de todas ellas en su portal web: ${ }^{3}$

\footnotetext{
${ }^{3}$ Véase información publicada en la página web de la Oficina de Justificación de la Difusión. Recuperado el 19 de mayo de 2019 de https://www.ojd.es/medios-controlados/
} 


\begin{tabular}{|c|c|c|}
\hline \multicolumn{3}{|c|}{ MEDIOS CONTROLADOS (2019) - OJD } \\
\hline \multirow[t]{3}{*}{ DIARIOS } & \multicolumn{2}{|c|}{ Información general } \\
\hline & \multicolumn{2}{|c|}{ Información deportiva } \\
\hline & \multicolumn{2}{|c|}{ Información económica } \\
\hline $\begin{array}{l}\text { DIARIOS DE } \\
\text { DISTRIBUCIÓN } \\
\text { GRATUITA }\end{array}$ & \multicolumn{2}{|c|}{ Información general } \\
\hline \multirow[t]{2}{*}{ REVISTAS } & $\begin{array}{l}\text { Información } \\
\text { general }\end{array}$ & Nacional; regional; comarcal. \\
\hline & $\begin{array}{l}\text { Información } \\
\text { especializada }\end{array}$ & $\begin{array}{l}\text { Cine, vídeo y fotografía; decoración; deportivas y ocio; } \\
\text { divulgación; economía, empresas y negocios; estilo de vida; } \\
\text { femeninas; gastronomía y cocina; historia y arte; infantiles; } \\
\text { literatura, cultura y pensamiento; motor: aeronáutica; } \\
\text { motor: automovilismo; motor ciclismo; religiosas; satíricas; } \\
\text { salud; viajes; vídeo - fotografía. }\end{array}$ \\
\hline \multirow[t]{2}{*}{ SUPLEMENTOS } & $\begin{array}{l}\text { Suplementos de } \\
\text { diarios }\end{array}$ & Información general; información económica. \\
\hline & $\begin{array}{l}\text { Suplementos } \\
\text { temáticos }\end{array}$ & nformación de estilo de vida; información femenina. \\
\hline $\begin{array}{l}\text { PUBLICACIONES } \\
\text { TÉCNICAS Y } \\
\text { PROFESIONALES }\end{array}$ & \multicolumn{2}{|c|}{$\begin{array}{l}\text { Alimentación y bebidas (comercio); animales y compañía; arquitectura y } \\
\text { construcción; comercio; derecho y ciencias sociales; economía, empresas y } \\
\text { negocios; farmacia; medicina; motor para profesionales; educación enseñanza; } \\
\text { inmobiliarias; ópticas; puericultura; musicales; transporte, logística y } \\
\text { distribución; turismo y hostelería; vegetariana. }\end{array}$} \\
\hline \multirow{2}{*}{$\begin{array}{l}\text { PUBLICACIONES } \\
\text { GRATUITAS NO } \\
\text { PROFESIONALES }\end{array}$} & Interés general & General; local \\
\hline & Interés temático & $\begin{array}{l}\text { Deportes de invierno; deportivas y ocio; economía, } \\
\text { empresas y negocio; estilo de vida; familiares; hogar y } \\
\text { entretenimiento; motor. }\end{array}$ \\
\hline \multirow[t]{4}{*}{$\begin{array}{l}\text { PUBLICACIONES DE } \\
\text { DISTRIBUCIÓN } \\
\text { GRATUITA }\end{array}$} & Interés local & $\begin{array}{l}\text { Albacete; Alicante; Ávila; Barcelona; Cádiz; Castellón; } \\
\text { Ciudad Real; Galicia; Girona; León; Lleida; Madrid; } \\
\text { Palencia; Canarias; Cantabria; Tarragona; Valencia; } \\
\text { Catalunya. }\end{array}$ \\
\hline & Interés general & Interés general; interés general en lengua extranjera. \\
\hline & Interés temático & $\begin{array}{l}\text { Cine, teatro y vídeo; deportivas y ocio; inmigrantes; estilo } \\
\text { de vida; familiares; femeninas; gastronómicas; marketing } \\
\text { profesional; ocio, cultura y turismo; turismo y hostelería; } \\
\text { salud; viajes. }\end{array}$ \\
\hline & $\begin{array}{l}\text { Técnicas y } \\
\text { profesionales }\end{array}$ & $\begin{array}{l}\text { Ganadería y pesca; derecho y ciencias sociales; economía, } \\
\text { empresas y negocios; electrodomésticos (comercio); } \\
\text { medicina. }\end{array}$ \\
\hline
\end{tabular}

TABla 1. Categorización de publicaciones en el año 2019 según la OJD.

FUENTE: Elaboración propia con datos de la OJD.

Esta clasificación es, como hemos dicho, la que propone la OJD. Acudiremos a ella a lo largo de nuestro trabajo pues nos sirve de punto de partida para delimitar parte del objeto de estudio de la investigación. En ella encontramos tres grandes grupos: el 
primer grupo, que está compuesto por los diarios y sus suplementos, el segundo grupo, de las revistas y sus suplementos y, finalmente, el tercer grupo, que recoge el resto de publicaciones —que son las publicaciones técnicas y profesionales, las publicaciones no profesionales y las de distribución gratuita—.

Una vez acotados estos tres grandes grupos, comprobamos que dentro de cada uno existe tanto periodismo de interés general, como temático o especializado. En este sentido, vemos diarios de información general —abeceras nacionales como $A B C, E l$ País, La Razón y otras regionales como Diario de Burgos o El Norte de Castilla- que conviven con diarios especializados - los deportivos Marca y Sport o los económicos Cinco Días y Expansión- Esto mismo ocurre en el caso de las revistas, que se nos ofrecen tanto de información general - la nacional Tinta Libre, la regional El Iris o la comarcal Hora Nova - como especializada o temática. Las revistas temáticas reúnen hasta 19 categorías: cine, decoración, deportivas, motor, fotografía, cocina, historia, infantiles... Así, cada una de estas publicaciones se especializa en un campo y busca ser consumida por un grupo de población muy concreto.

Por su lado, las publicaciones no profesionales y las de distribución gratuita también responden a esta doble vertiente periodística. Las de distribución gratuita cuentan con publicaciones de interés general —Nuestro Tiempo o Perfiles — y de interés temático —publicaciones deportivas, de economía, estilo de vida, familiares, hogar y motor-. Mientras, las publicaciones de distribución gratuita de nuevo ofrecen información general, tanto nacional — Ling, Local Xpress...- como regional —Gente, La Voz de Cantabria... - En cuanto a los contenidos especializados, seguimos viendo teatro, deportes, familia, gastronomía, etc. Finalmente, las publicaciones técnicas y profesionales ofrecen solamente contenidos temáticos: comercio, arquitectura, derecho, economía, farmacia, educación, turismo... Son en su mayoría publicaciones gratuitas —salvo Transporte XXI y El Croquis—, y están especializadas en el mundo laboral.

En cuanto a la audiencia, la evolución de los soportes y de los flujos de información ha colocado a la prensa escrita en una posición delicada. Esta se está viendo forzada a rediseñar sus estrategias para proyectarse en el modelo actual de consumo debido, básicamente, a la pérdida de lectores y lectoras, al descenso de los ingresos publicitarios y al auge de los nuevos soportes para la recepción de la información. Durante los últimos años, los grupos comunicacionales buscan fórmulas de viabilidad que 
permitan que el papel resista (Túñez, 2009: 504). En España, podemos comprobar un progresivo descenso en la penetración de diarios, suplementos y revistas en papel durante la última década.

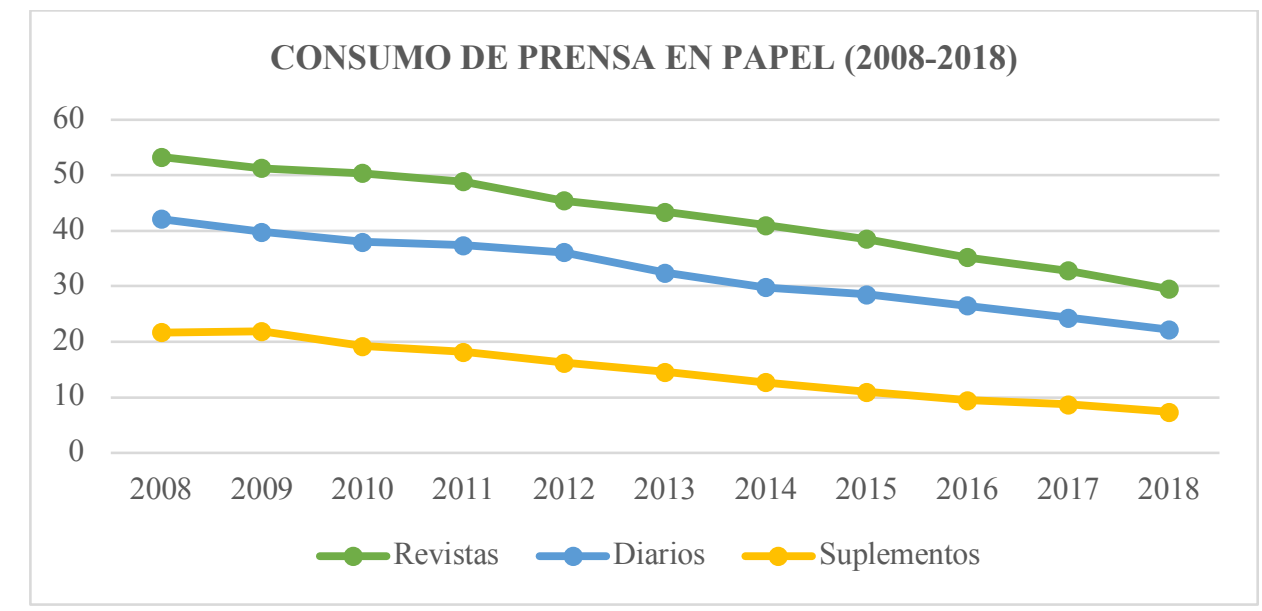

GRÁFICo 1. Evolución de la audiencia de revistas, diarios y suplementos en papel en España (2008-2018). FuenTE: Elaboración propia a partir de datos de AIMC (2019: 11).

Los datos del gráfico 1 están tomados sobre el universo de población española de más de 14 años lo que, en 2018, suma un total de 39.852.000 de personas (AIMC, 2019: 11). En cuanto a la medición, se tiene en cuenta la lectura durante el periodo de publicación del ejemplar, es decir, si se trata de un diario, la audiencia acumulada se calculará considerando los lectores y lectoras del día de su publicación, en un suplemento semanal se contabilizará la lectura de toda la semana, en una revista mensual el periodo será de todo el mes, etc.

Vemos un claro descenso en el consumo de los tres tipos de publicaciones. Mientras que la penetración en 2008 era de un 53,3\% en las revistas (20.393.000 personas sobre un universo de 38.261.000), es decir, más de la mitad de la población mayor de 14 años consumía este tipo de producto, en 2018 bajó hasta el 29,5\%, lo que deja a una audiencia fiel que roza el tercio de la población (11.756.000 de personas sobre un universo de 39.852.000). Las revistas obtuvieron su mejor dato en 1991 con un 58,2\% de penetración que, teniendo en cuenta la población de la época (32.000.000), supuso hasta 18.624.000 de lectores y lectoras (AIMC, 2019: 11).

Como se ha mencionado, la prensa está pasando por un proceso de digitalización y las revistas no son ajenas a ello. De esta manera, existe un porcentaje de la población 
que está privilegiando la lectura online frente al papel. Este porcentaje crece tímidamente cada año, habiendo pasado de un $1,4 \%$ a un 5,6\% en los últimos 10 años. Si a esto se le suma el consumo de la audiencia que usa tanto papel como Internet, el flujo de audiencia online para las revistas en 2018 es de 10,4\% frente al 29,5\% del total del papel. Aun así, se observa un descenso en el hábito de lectura de revistas, independientemente de su soporte (AIMC, 2019: 52).

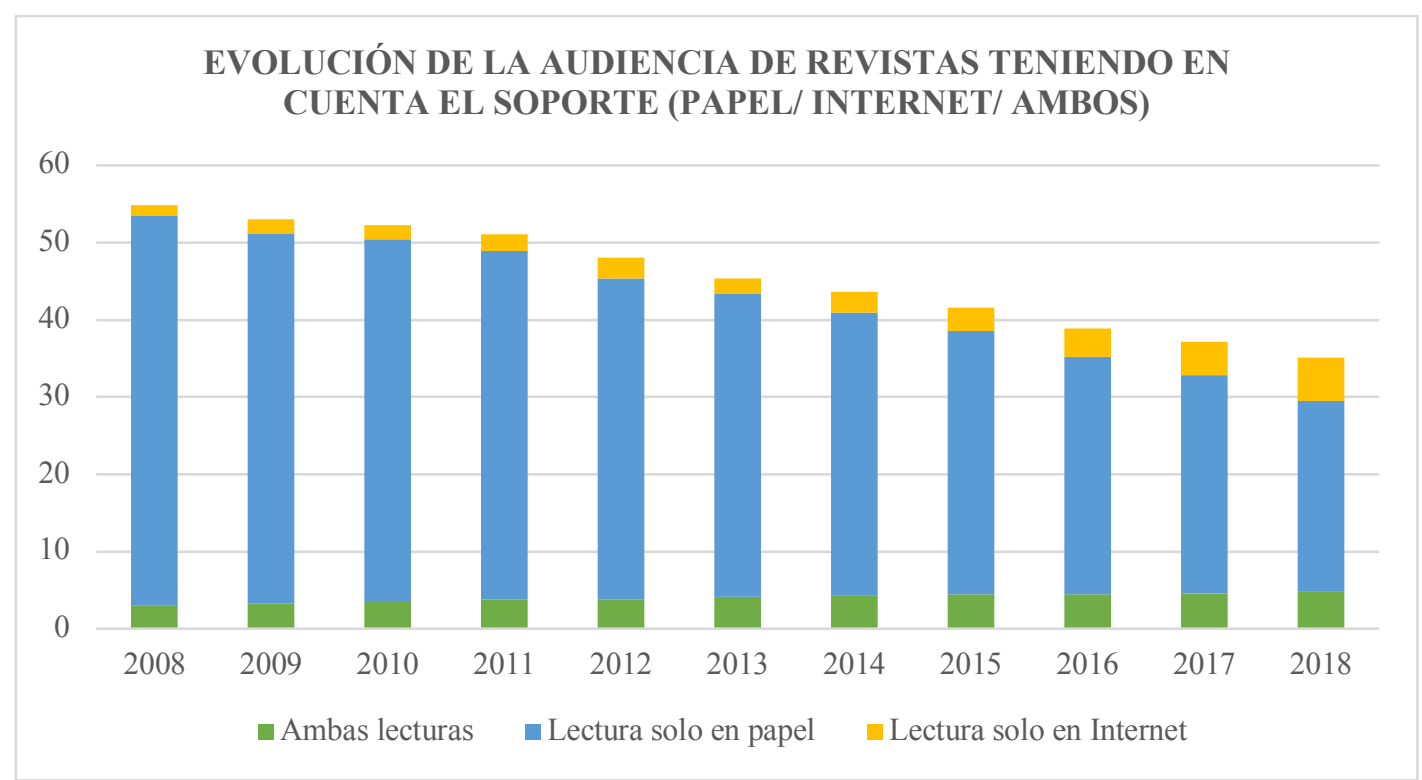

GráFICo 2. Evolución de la audiencia de revistas teniendo en cuenta el soporte (papel, internet o ambos) durante los años 2008-2018.

FuENTE: Elaboración propia a partir de datos de AIMC (2019: 52).

Por su lado, el consumo de diarios en papel se ha reducido casi a la mitad. En 2008, el 42,1\% de la población leía la prensa diaria en papel (16.107.000 de personas sobre un universo de 38.261.000), dato que ha ido descendiendo progresivamente hasta situarse en el 22,2\% actual (8.847.144 de personas sobre un universo de 39.852.000). Cabe destacar que la cifra de 2008 fue la más alta desde el año 1980, que es la primera fecha que nos ofrece la Asociación para la Investigación de Medios de Comunicación, AIMC, en su informe. En cuanto a los suplementos, han descendido desde el 21,7\% (8.302.637 de personas) al 7,4\%, dejando una pequeña muestra de lectores y de lectoras (2.949.000 de personas) (AIMC: 2019: 11).

Teniendo en cuenta el tipo de canal que se privilegia, en el caso de los diarios, la lectura digital ha desbancado al papel. En el año 2018, un 20,6\% de la población se 
informa exclusivamente a través de internet, cuando en 2008 lo hacía tan solo el 3,4\%. Si a esto se le suma el consumo de la audiencia que usa tanto papel como internet, el flujo de audiencia online para los diarios es, actualmente, de $28,7 \%$ frente al $22,2 \%$ del total del papel. Al contrario de lo que ocurría con las revistas, el porcentaje de personas que ha leído el diario durante estos últimos 10 años, independientemente del soporte, ha mantenido una mayor estabilidad, habiendo registrado su cifra más alta en 2012 (46,4\% considerando el total de papel e internet) y la más baja en 2015 (42\% considerando, de nuevo, el total de papel e internet) (AIMC, 2019: 47).

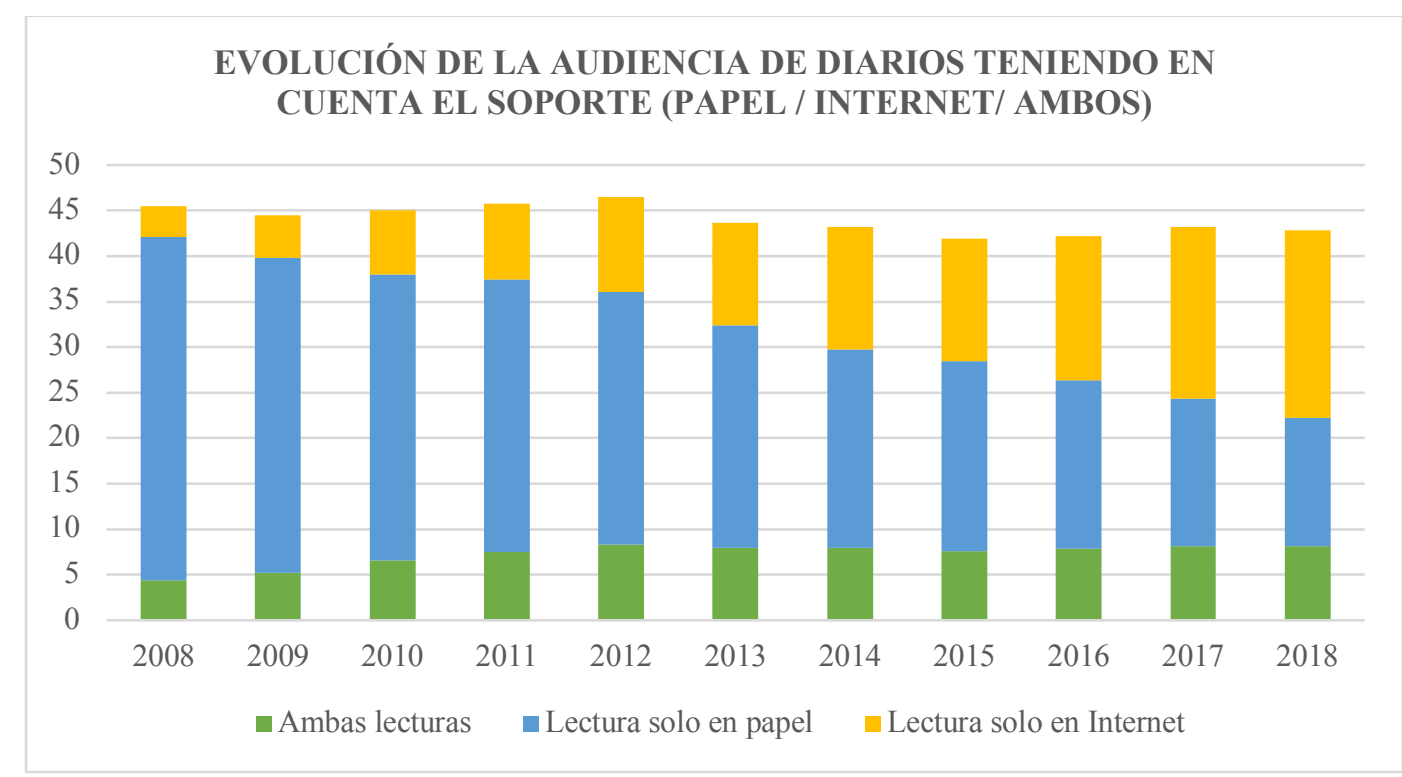

GrÁFICO 3. Evolución de la audiencia de diarios teniendo en cuenta el soporte (papel, internet o ambos) durante los años 2008-2018).

FUENTE: Elaboración propia a partir de datos de AIMC (2019: 47).

Los hábitos de lectura difieren entre sexos y edades. Las mujeres consumen más revistas y suplementos y los hombres prefieren los diarios. Concretamente, las revistas son leídas por un 59\% de mujeres frente a un $41 \%$ de hombres, los suplementos por un $56,4 \%$ de mujeres frente a un $43,6 \%$ de hombres y los diarios por un $40,3 \%$ de mujeres frente a un 59,7\% de hombres (AIMC, 2019: 14).

Mientras, el grupo de edad que más prensa consume es el de 65 años en adelante. Así, del total de las revistas, este grupo lee un $19,7 \%$, de los diarios un $22,5 \%$ y de los suplementos un 25,2\%. Dicha situación contrasta con las franjas poblacionales más jóvenes, de entre 14 y 19 años, donde apenas se consume el 6,5\% de las revistas, el 4,1\% 
de los suplementos y el 3,7\% del total de los diarios. Tampoco la franja que comprende de los 20 a los 24 años es gran asidua de la prensa en papel: 5,5\% en las revistas, 3,9\% en los diarios y $4,1 \%$ en los suplementos. El grupo que mantiene porcentajes similares al de 65 en adelante es el de 45 a 54 años que es responsable de la lectura del 19,9\% de las revistas, del 21,6\% de los diarios y del 20\% de los suplementos (AIMC, 2019: 14).

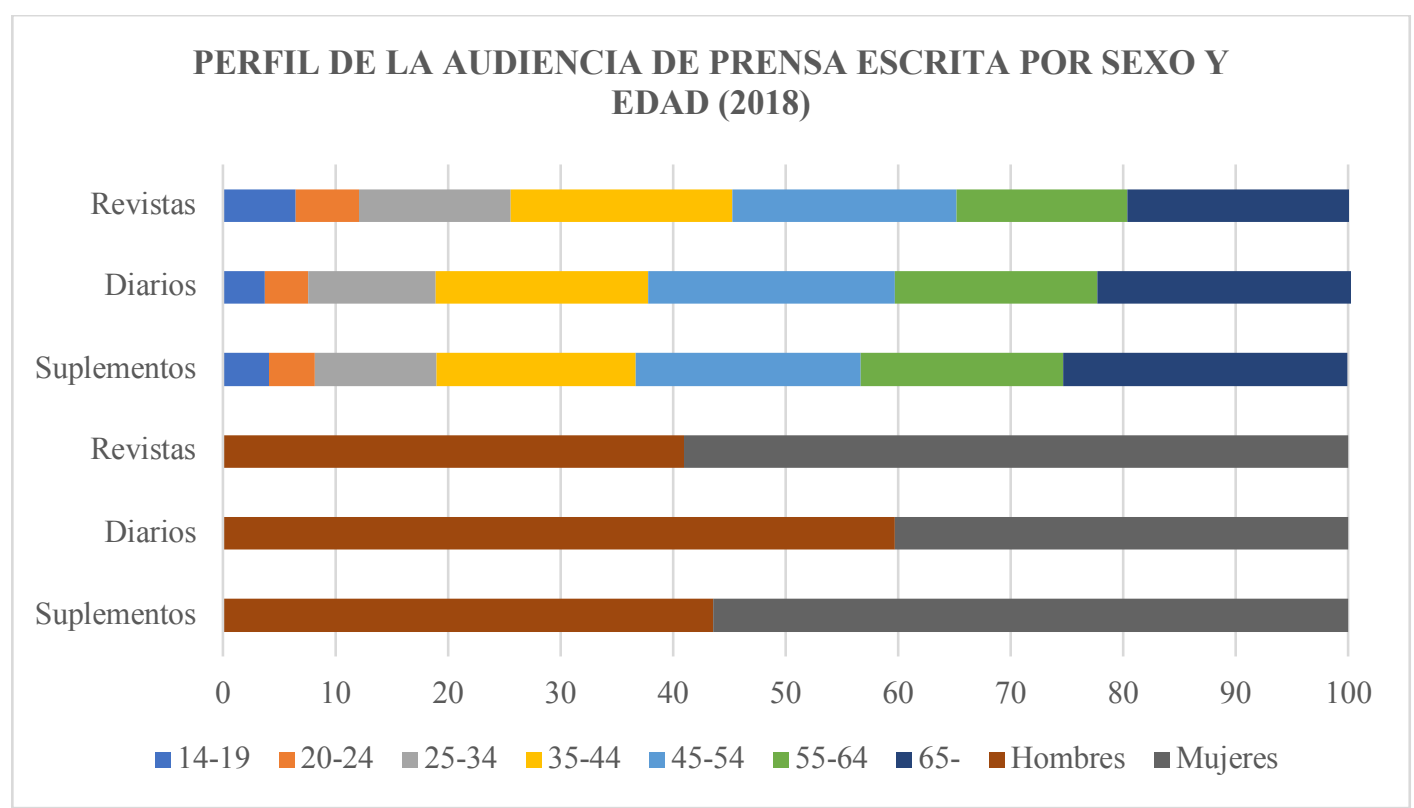

Gráfico 4. Perfil de la audiencia de revistas, diarios y suplementos en 2018 por sexo y edad. FueNTE: Elaboración propia a partir de datos de AIMC (2019: 14).

Estos datos solo recogen los hábitos de consumo en papel. Recordemos que el consumo online era relevante para los diarios, pero no tanto para las revistas. Así, teniendo en cuenta esta última variable, existe una descompensación en el consumo de revistas entre la población joven, que apenas usa este medio y la población adulta o mayor, más propensa a acudir a ellas.

En cuanto a la relación de los diarios y el consumo juvenil, una investigación realizada por el Pew Reserach Center for the People and the Press, PRCPP, con población estadounidense, detectó que desde el año 1994 hasta el año 2000, la población dedicaba menos tiempo a informarse vía televisión, prensa y radio, sin embargo, en cuanto en 2004 se incorporaron las variables de la prensa online, se produjo un crecimiento significativo, sobre todo entre la población de 18 a 29 años que podría deberse, precisamente, a la aparición de internet como variable (citado en Parratt, 2010: 
135). En España, en el año 2012, un estudio de caso en el que participaron 262 alumnas y alumnos del Grado de Publicidad y Relaciones Públicas de la Universidad de Alicante evidenciaba la caída de la lectura de prensa en papel entre este sector de la población. Mientras que el 2,7\% usaba la prensa escrita para informarse todos los días, el porcentaje ascendía al 15\% en la prensa online (Iglesias, 2012: 107-108).

Otras investigaciones concluyen que lo que hoy parece que elige la población joven para estar al tanto de la actualidad son las redes sociales. Estas sirven de intermediarias para acceder a la información, ya sea de manera consiente o casual (Ortega, 2017: 11). Así, es especialmente significativo el papel que asumen estas plataformas como soporte de consumo de noticias entre el público joven, de hecho, Facebook o Tuenti (red social que fue muy popular en España a finales de la primera década de este siglo), ocupaban la primera posición entre los soportes informativos y eran usados por un 77,4\% de la población joven, según un estudio realizado en 2011 (CaseroRipollés, 2012, 154).

\subsection{Especialización y consumo en televisión}

La televisión es el medio de comunicación con mayor penetración en España: 85\% de personas, 33.874.000 millones de espectadores y espectadoras consumen televisión a diario — sobre una población de 39.852.000 millones-(AIMC, 2019: 13). La televisión, como explica Villagrasa, "ha creado una forma diferente de socialización y de formación social. Se establece una cohesión de grupo gracias a los contenidos de los programas, que se convierten en fuentes de información cotidiana y referente de opiniones y modos de vida" (citado en Quintas-Froufe y Díaz-González, 2014: 711).

Existen diversos factores que condicionan la programación, entre ellos la legislación, los hábitos de consumo televisivo y la imagen de la emisora. Por un lado, la actividad televisiva está sometida a diversas normativas europeas, estatales y autonómicas de obligatorio cumplimiento. Mientras, los hábitos de consumo, es decir, de que manera la ciudadanía se organiza en torno al televisor, influyen directamente en la programación, pues esta se configura en base a estudios del tiempo social. Así, dicha organización determina el contenido de los programas, el ritmo narrativo e incluso características de personajes de los contenidos de ficción. En cuanto a la imagen de la emisora, cada cadena cuenta con un tipo de proyecto editorial que establece un proceso 
comunicativo entre la audiencia y ella. En este sentido, las distintas emisoras trabajan por crear un producto diferenciador (Cabrera y Gómez, 2008: 637-638).

Tampoco podemos olvidar la publicidad como factor clave a la hora de fijar los contenidos. En España, al inicio del proceso democrático, la legislación permitió una apertura a nuevos canales, lo que provocó un reparto de la audiencia en base a las televisiones nacionales públicas y privadas - a las dos emisoras de RTVE hubo que añadir Antena 3 y Telecinco- a la fragmentación territorial — gracias al nacimiento de las televisiones regionales — y a la aparición de las cadenas de pago —como Canal+ y las plataformas que emitían por satélite-. Sin embargo, en los nuevos canales generalistas, la dependencia de la publicidad provocó la homogeneidad en los contenidos, pues todas las cadenas buscaban los mismos públicos masivos para atraer a las empresas anunciadoras. Como consecuencia de esta dependencia publicitaria, no se logró, por aquel entonces, un reparto de la audiencia en clave a la distinción de los contenidos (Callejo, 2007: 202-207).

Actualmente, hemos entrado en una etapa que se caracteriza por tres procesos que aumentan la fragmentación del público: establecimiento de vínculos más intensos con los segmentos de la audiencia, reducido papel de las televisiones públicas y multiplicación de la oferta de canales (Callejo, 2007: 210). Además, existen nuevos hábitos de consumo, propiciados por el entorno multipantalla, que permiten el acceso inmediato a los contenidos a través de internet y dispositivos móviles. También, la situación heredada de la crisis económica ha mermado los ingresos por publicidad. Con todo ello, la televisión hubo de adaptarse y reestructurar su oferta, especializándose con el fin de fidelizar a la audiencia y desarrollando formatos de bajo coste que, además, atraigan importantes audiencias (Martínez, 2014: 281).

Finalmente, la implantación de la televisión digital terrestre, TDT, ha consolidado el proceso de fragmentación televisiva iniciado en España con la creación de las cadenas privadas. Sin embargo, aunque la oferta de nuevos canales temáticos amplíe la libertad de decisión del público, gran parte de estos contenidos no son nuevos para la audiencia, ya que se tratan de reposiciones emitidas anteriormente en los canales generalistas. Con todo, las emisoras que mejor funcionaron en los primeros cuatro años de vida de la TDT fueron las infantiles, que obtuvieron un gran respaldo por parte del público de menor edad (Quintas-Froufe y Díaz-González, 2014: 727). 
$\begin{array}{llllllllll}2009 & 2010 & 2011 & 2012 & 2013 & 2014 & 2015 & 2016 & 2017 & 2018\end{array}$

\begin{tabular}{|c|c|c|c|c|c|c|c|c|c|c|}
\hline LA 1 & 16,4 & 16,0 & 14,5 & 12,2 & 10,2 & 10,0 & 9,8 & 10,1 & 10,4 & 10,5 \\
\hline LA 2 & 3,8 & 3,1 & 2,6 & 2,5 & 2,4 & 2,8 & 2,7 & 2,6 & 2,6 & 2,7 \\
\hline ANTENA 3 & 14,7 & 11,7 & 11,5 & 12,5 & 13,4 & 13,6 & 13,4 & 12,8 & 12,3 & 12,3 \\
\hline CUATRO & 8,2 & 7,0 & 6,1 & 6,0 & 6,0 & 6,7 & 7,2 & 6,5 & 6,1 & 6,0 \\
\hline TELECINCO & 15,1 & 14,6 & 14,2 & 13,9 & 13,5 & 14,5 & 14,8 & 14,4 & 13,3 & 14,1 \\
\hline LA SEXTA & 6,8 & 6,6 & 5,7 & 4,9 & 6,0 & 7,2 & 7,4 & 7,1 & 6,7 & 6,9 \\
\hline $13 \mathrm{TV}$ & & & 0,4 & 1,0 & 1,3 & 1,6 & 2,0 & 2,1 & 2,1 & 2,0 \\
\hline $24 \mathrm{H}$ & 0,4 & 0,7 & 0,9 & 0,9 & 0,8 & 0,8 & 0,9 & 0,9 & 1,0 & 0,9 \\
\hline ATRES SERIES & & & & & & & & 0,8 & 1,1 & 1,2 \\
\hline BE MAD & & & & & & & & 0,4 & 0,6 & 0,6 \\
\hline BOING & & 0,2 & 1,1 & 1,7 & 1,7 & 1,7 & 1,6 & 1,5 & 1,4 & 1,3 \\
\hline CLAN & 1,4 & 3,2 & 3,2 & 2,5 & 2,4 & 2,3 & 2,3 & 2,2 & 2,0 & 1,8 \\
\hline $\mathrm{CNN}+$ & 0,3 & 0,6 & & & & & & 0,0 & & \\
\hline $\begin{array}{l}\text { DISNNEY } \\
\text { CHANNEL }\end{array}$ & 1,4 & 2,1 & 1,7 & 1,6 & 1,5 & 1,5 & 1,4 & 1,1 & 1,2 & 1,2 \\
\hline DIVINITY & & & 0,7 & 1,4 & 1,7 & 2,1 & 2,3 & 2,3 & 2,2 & 2,0 \\
\hline DKISS & & & & & & & & 0,4 & 0,9 & 0,8 \\
\hline DMAX & & & & 1,2 & 1,6 & 2,1 & 2,1 & 1,9 & 1,7 & 1,6 \\
\hline ENERGY & & & & 0,9 & 1,2 & 1,5 & 1,5 & 1,9 & 2,0 & 1,9 \\
\hline FDF & 0,5 & 1,5 & 2,6 & 2,9 & 2,9 & 3,5 & 3,5 & 3,2 & 3,1 & 2,9 \\
\hline GOL & & & & & & & & 0,2 & 1,0 & 1,0 \\
\hline INTERECONOMÍA & 0,5 & 1,1 & 1,4 & 1,2 & 0,9 & 0,1 & & & & \\
\hline LA SEXTA 2 & & 0,1 & 0,6 & 0,2 & & & & & & \\
\hline LA SEXTA 3 & & 0,1 & 1,4 & 1,6 & 1,6 & 0,6 & & & & \\
\hline LA SIETE & 0,6 & 1,4 & 1,5 & 1,4 & & & & & & \\
\hline MARCA TV & & 0,2 & 0,8 & 1,0 & 0,6 & & & & & \\
\hline MEGA & & & & & & & 0,9 & 1,8 & 1,7 & 1,6 \\
\hline MTV & & 0,1 & 0,5 & 0,7 & 0,6 & 0,1 & & & & \\
\hline NEOX & 1,2 & 2,2 & 2,7 & 2,6 & 2,3 & 2,6 & 2,6 & 2,5 & 2,5 & 2,4 \\
\hline NITRO & & 0,4 & 1,4 & 1,6 & 1,7 & 0,6 & & & & \\
\hline NOVA & 0,7 & 1,5 & 1,5 & 1,6 & 2,1 & 2,5 & 2,4 & 2,2 & 2,2 & 2,4 \\
\hline NUEVE & & & & & 0,7 & 0,3 & & & & \\
\hline $\begin{array}{l}\text { PARAMOUNT } \\
\text { CHANNEL }\end{array}$ & & & & 0.8 & 1,4 & 1,9 & 2,0 & 1,8 & 1,9 & 1,8 \\
\hline REAL MADRID TV & & & & & & & & 0,2 & 0,4 & 0,3 \\
\hline TELEDEPORTE & 0,6 & 1,1 & 1,0 & 0,8 & 0,9 & 0,9 & 0,9 & 0,9 & 0,7 & 0,6 \\
\hline TEN & & & & & & & & 0,3 & 0,4 & 0,3 \\
\hline XPLORA & & & & 0,9 & 1,7 & 0,6 & & & & \\
\hline
\end{tabular}

TABLA 2. Evolución anual de las audiencias (2009-2018) en los canales que emiten a nivel nacional en España.

Fuente: Barlovento Comunicación (2019a: 45).

Cuando sucedió el apagón analógico, el 3 de abril de 2010, había más de una veintena de nuevos canales en la televisión española, aunque poco a poco la oferta fue creciendo, se fueron incorporando algunos nuevos y otros dejaron de emitir. Actualmente, 
existen un total de 20 canales que conviven con los 6 de más veteranía — La 1, La 2, Antena 3, Cuatro, Telecinco y La Sexta—. En la tabla 2 podemos ver una recopilación de la mayoría de ellos y de su audiencia.

Nos dicen las autoras Natalia Quintas-Froufe y Díaz-González —en un estudio que comprende la oferta de canales desde 2010 hasta 2014 - que la escasa aceptación de las cadenas temáticas puede deberse a que la mayoría de ellas están orientadas a un público joven. En este sentido, los estudios de consumo corroboran que la audiencia que ve televisión tiene cada vez más edad. Mientras, la gente joven está influenciada por la incorporación de los dispositivos móviles, que desplazan al televisor en el consumo audiovisual, el aumento de contenidos a la carta, la recepción asincrónica o el consumo personalizado (Quintas-Froufe y Díaz-González, 2014: 728).

En este sentido, no es que la población joven no vea la televisión, es que simplemente accede desde otro dispositivo, es decir, en palabras de David Bolter y Richard Grusin vivimos "la representación de un medio en otro medio" (2011: 51). García, Tur-Viñes y Pastor, basándose en una recopilación de estudios elaborados sobre jóvenes y adolescentes en los últimos años en España, nos explican que existe un factor clave de espacios: lo digital se desarrolla en el espacio privado, mientras que la televisión pertenece al espacio común, un lugar compartido con más personas con las que habría que negociar los distintos visionados y contenidos (García et al., 2018: 32). Así, existe un traspaso de consumo desde la televisión al espacio digital por temas de acceso, control de los contenidos, ubicuidad, inmediatez y gestión del tiempo de consumo (García et al., 2018: 38).

Tanto para jóvenes como adolescentes, la ficción y el entretenimiento son los contenidos más demandados, siendo las series y el cine sus formatos preferidos, e internet el canal mejor valorado, pues permite consumir de acuerdo a las necesidades individuales (García et al., 2018: 32). Cabe destacar que estos rituales de consumo, individualizados y elegidos, contrastan drásticamente con el concepto television flow desarrollado por Raymond Williams, pionero de los estudios académicos sobre televisión.

Williams nos dice que la televisión se organiza en torno a una sucesión de distintos programas y sus pausas publicitarias, creando una corriente de comunicación que arrastra a la audiencia de un programa hasta el siguiente. Además, indica que la publicidad no solo aparece cuando se corta el programa, sino que también lo hace dentro de él. Así, los 
distintos espacios de ficción, entretenimiento, informativos, los contenidos publicitarios y las estrategias de autopromoción dentro de la cadena forman una sola trama. Para Williams, esta corriente de contenidos conformaría la experiencia de ver la televisión, experiencia que va más allá de sentarse a visionar un programa en concreto (Williams, 1992: 86-94).

A día de hoy, la teoría del flow está siendo desafiada por el consumo privado y fuera de contexto que nos ofrecen las nuevas plataformas digitales. Incluso las propias televisiones inteligentes, más cercanas ya a un ordenador, permiten una ruptura con el tiempo real de visionado al reunir entre sus características el rebobinado de los contenidos o la grabación de los mismos. Pero, sin duda, son las grandes empresas del audiovisual como Movistar+, Netflix, HBO, Amazon Prime Vídeo, etc. las que han materializado los nuevos hábitos de consumo demandados por la generación nativa digital. En España, uno de cada tres hogares conectados a internet usan plataformas de pago para ver contenidos audiovisuales (Barlovento, 2019a: 25).

\begin{tabular}{|c|c|}
\hline \multicolumn{2}{|c|}{$\begin{array}{l}\text { PLATAFORMAS DE PAGO AUDIOVISUALES MÁS POPULARES EN } \\
\text { ESPAÑA (2018) }\end{array}$} \\
\hline MOVISTAR+ & 2.200 .000 hogares y el $13,4 \%$ del total \\
\hline NETFLIX & 2.052 .000 hogares y el $12,5 \%$ del total \\
\hline VODAFONE & 954.000 hogares y el 5,8\% del total \\
\hline ORANGE & 744.000 hogares y el $4,5 \%$ del total \\
\hline $\mathrm{HBO}$ & 478.000 hogares y el $2,9 \%$ del total \\
\hline RAKUTEN-WUAKI & 144.000 hogares y el $0.9 \%$ del total \\
\hline SKY & 115.000 hogares y el $0,7 \%$ del total \\
\hline
\end{tabular}

TABLA 3. Clasificación de las diferentes plataformas de pago para ver contenidos audiovisuales online. Fuente: Barlovento Comunicación (2019a: 25).

Según Amanda Lotz, vivimos lo que ella denominaría la post-network era, en la que gracias a los avances tecnológicos se puede ver lo que se quiera, cuando se quiera, en la pantalla que se quiera (citado en Costas, 2014: 247). Dicho fenómeno actúa en detrimento de las cadenas y beneficia a la audiencia, quien tiene un mayor control en el consumo de los contenidos y puede huir de la rigidez de las parrillas televisivas. Así, actualmente contamos con canales de distribución adaptables a la disponibilidad del público (Costas, 2014: 247). 
Este consumo ha roto con la experiencia lineal de ver la televisión y ha creado una serie de nuevos comportamientos delimitados dentro del término binge-watching que hace referencia, principalmente, al "visionado de capítulos consecutivos de material fílmico basado en series de ficción” (Hernández y Martínez, 2016: 204). Ya habíamos mencionado anteriormente que los productos audiovisuales favoritos entre la gente joven son las series de ficción y los largometrajes. Pues bien, si el soporte había cambiado y ahora el ocio audiovisual se consume a través de internet, también los usos del tiempo son distintos, pues la red destruye esos tiempos de espera, generalmente semanales, que nos imponía la parrilla televisiva.

Nos dice Jaime Costas que esto tiene sus consecuencias y que el fenómeno bingewatching está rompiendo con el factor social que resultaba de los estrenos semanales. Es decir, ese momento en el cual se reunía simultáneamente todo el público en torno al mismo producto y los siguientes siete días de espera donde la legión de fans lanzaba sus teorías (Costas, 2014: 250). Sin embargo, cabe destacar que, aunque esto sea totalmente cierto y se trate de una consecuencia directa del binge-watching, las distintas plataformas están optando por maneras diferentes de distribuir sus ficciones seriadas.

Mientras que Netflix ofrece las temporadas en una sola vez, subiendo todos los capítulos que la conforman el mismo día y propiciando el binge-watching, HBO sigue distribuyendo sus episodios semanalmente, lo que nos ha permitido vivir fenómenos como el sucedido con la serie Perdidos (Lost, J.J. Abrams y Damon Lindelof, ABC, 20042011) unos años atrás. Perdidos fue una serie emitida por la televisión de Estados Unidos. La legión de fans era tal, que el presidente, Barack Obama, llegó a adelantar su discurso sobre el Estado de la Unión, pues coincidía con la retransmisión del primer episodio de la temporada final de la serie. ${ }^{4}$ Debemos tener en cuenta que el Discurso del Estado de la Unión es un acontecimiento anual por el cual las cadenas de televisión reestructuran toda su programación con el fin de retransmitirlo. Pues bien, en enero de 2010, fue el presidente de los Estados Unidos quien hubo de adaptarse a la programación y no al revés. Recientemente, la última temporada de Juego de Tronos (Game of Thrones, David Benioff y D.B. Weiss, HBO, 2011-2019) también ha tenido en vilo a su audiencia. Los últimos 6 capítulos de la serie, emitidos entre abril y mayo de 2019 por la plataforma digital $\mathrm{HBO}$, que, recordemos, distribuye semanalmente, han generado la misma

\footnotetext{
${ }^{4}$ Véase información publicada el 9 de enero de 2010 en el periódico El Mundo: "Obama cede ante Perdidos". Recuperado el 29 de mayo de 2019 de https://www.elmundo.es
} 
expectación, los mismos tiempos de espera y las mismas teorías semanales que si esta hubiera sido emitida a través del soporte tradicional.

Aun así, el binge-watching es un fenómeno a tener muy en cuenta. Tomando los resultados de un estudio de caso elaborado sobre jóvenes universitarios en 2016 en España, más de una cuarta parte de los estudiantes (29\%) afirmaba visionar al menos tres capítulos de forma consecutiva y al menos dos veces por semana (Hernández y Martínez, 2016: 219). Estos datos son superiores en países como Estados Unidos, donde siete de cada diez espectadores practican el fenómeno, según un estudio del 2014 de Ciramella y Biscutiti (citado en Hernández y Martínez, 2016: 207).

Evidentemente, los grandes grupos que distribuyen sus contenidos a través de los canales de televisión no son ajenos a estos crecientes hábitos de consumo. En el contexto del vídeo bajo demanda y los dispositivos móviles, las normas que rigen la relación entre la audiencia y la televisión ya no son válidas. Como hemos mencionado, han aparecido nuevos actores que se ajustan mejor a las preferencias de los segmentos poblacionales más jóvenes (Netflix, HBO, Amazon Prime Video...) y que han adquirido mayor protagonismo en el control de las redes de difusión, lo que está obligando a los operadores televisivos a proponer sus propios proyectos (Izquierdo-Castillo, 2014: 743).

En nuestro país, Atresmedia ha lanzado Atresplayer, RTVE sube sus contenidos a RTVE.es y Mediaset ha hecho lo propio con Mitele. Las tres son plataformas digitales donde podemos encontrar la programación emitida anteriormente en los canales generalistas y temáticos de cada grupo comunicacional. Atresmedia, a parte, creó en 2015 su marca de contenidos audiovisuales Floxeer, accesible desde Atresplayer y donde genera contenido exclusivo para internet. Series como la popular Paquita Salas (Javier Calvo y Javier Ambrosi, Netflix, 2016-), que posteriormente compró Netflix, han nacido de esta plataforma enfocada a un público joven. También Mediaset España cuenta con Mtmad, plataforma online de vídeos exclusivos pensando para los y las nativas digitales y lanzada en 2016. Sin embargo, cabe decir que, todavía, "ninguna de estas iniciativas están asentadas en un modelo de negocio sostenible, ya que su introducción en internet está motivada por una necesidad y no una estrategia de expansión de negocio" (IzquierdoCastillo, 2014: 742).

Este trasvase de audiencia de la televisión a internet resulta importante a la hora de ser conscientes del visionado real de un contenido. En este sentido, Jorge GallardoCamacho y Javier Sierra nos informan de que "es muy destacable el caso de cadenas 
temáticas que obtienen una cuota de mercado tradicional muy escasa, pero que posteriormente acumulan miles de espectadores en diferido" (2017: 185). Apuntan, también, que son los contenidos infantiles, juveniles y, sobre todo, los de ficción los que más audiencia de este tipo reciben. Así, por ejemplo, la película Carlitos y Snoopy que durante la emisión lineal consiguió 3.000 espectadores, a los siete días de estar en diferido acumulaba 74.000 reproducciones (Gallardo-Camacho y Sierra, 2017: 185).

\begin{tabular}{|c|c|}
\hline CONSUMO & $\begin{array}{l}\text { TENIDOS AUDIOVISUALES ONLINE EN ESPAÑA } \\
\text { (2018) }\end{array}$ \\
\hline YouTube & 9,0 millones de hogares y el $55 \%$ sobre el total \\
\hline Atresplayer & 5,8 millones de hogares y el $35 \%$ sobre el total \\
\hline RTVE & 4,9 millones de hogares y el $30 \%$ sobre el total \\
\hline Mitele & 4,3 millones de hogares y el $26 \%$ sobre el total \\
\hline Movistar+ & 3,2 millones de hogares y el $19 \%$ sobre el total \\
\hline Bein Channel & 0,5 millones de hogares y el $3 \%$ sobre el total \\
\hline
\end{tabular}

TABla 4. Consumo de contenidos audiovisuales online al menos una vez por semana. Fuente: Barlovento Comunicación (2019a: 27).

Sin embargo, cabe destacar que el incremento de la audiencia en diferido es muy superior en la televisión temática de pago $(303,9 \%)$ que en la temática en abierto $(69,3 \%)$. Ello puede deberse a los contenidos premium que ofrecen los canales de pago o los servicios de grabación y vídeo bajo demanda para la clientela, que motivan el consumo posterior del producto. Por otro lado, este trasvase de audiencia no es tan notable en las cadenas generalistas, posiblemente porque ofrecen contenidos de un carácter más efímero, como pueden ser los informativos o los magazines en directo (GallardoCamacho y Sierra, 2017: 185-186).

Los últimos estudios de audiencia en España ya tienen en cuenta tres variables a la hora de contabilizar las audiencias: el consumo lineal, en diferido e invitados (esto último recoge el hábito de ver la televisión en compañía de gente externa al propio hogar, como puede ser un grupo de amigos y amigas reunidas para ver una película). El consumo lineal, es decir, el tradicional, desciende desde 2012 (Barlovento, 2019a: 43). Así, el consumo promedio diario de televisión en 2018 es de 234 minutos por persona y día sobre el universo consumo (44,6 millones de ciudadanía de España de 4 o más años de edad). Estos 234 minutos se desglosan de la siguiente manera: 228 minutos es audiencia lineal $(216+12$ minutos de invitados) y 6 minutos en diferido (contenidos televisivos vistos 
durante los siete días siguientes de la emisión original). Este último presenta el 2,6\% del total y ha experimentado un ligero crecimiento frente al año anterior (Barlovento, 2019a: $11)$.

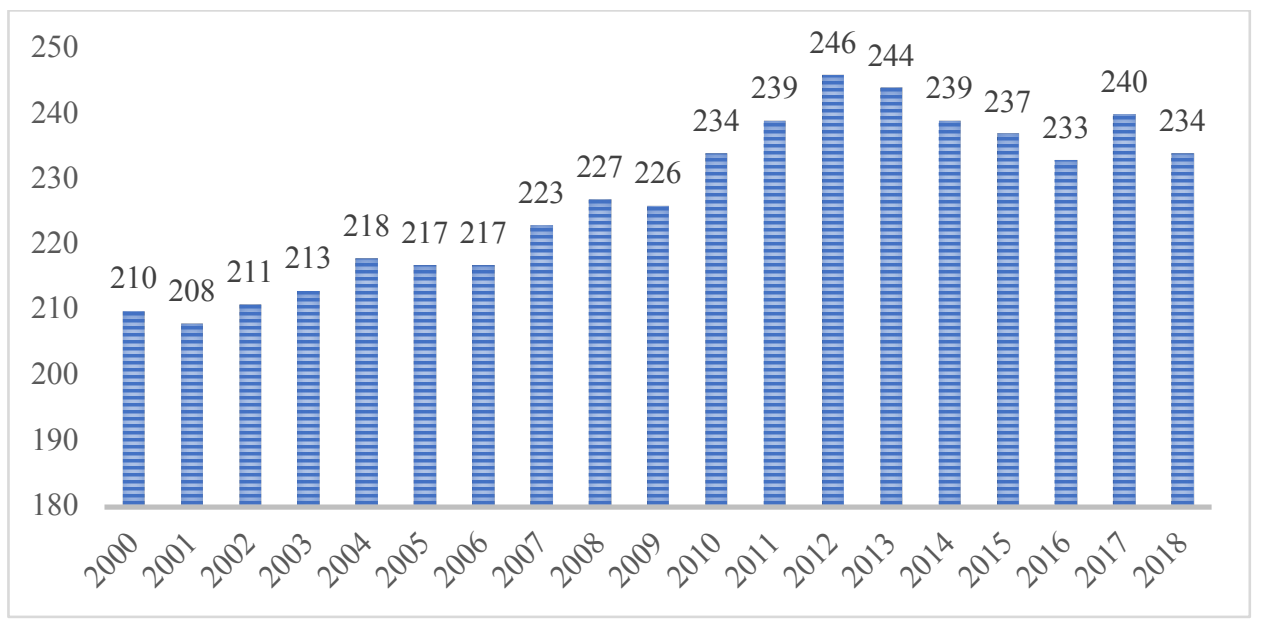

Gráfico 5. Evolución anual de minutos diarios de televisión consumidos por persona (2000-2018). FueNTE: Barlovento Comunicación (2019a: 43).

Sin embargo, cabe destacar que de los 44,6 millones de potenciales consumidores y consumidoras, 31.433 .000 ven a diario la televisión, lo que logra un promedio de 5 horas y 15 minutos de consumo, es decir 316 minutos por día como media en 2018 (Barlovento, 2019a: 43).

En cuanto al consumo por franjas de edades, el grupo infantil (4 a 12 años) ve la televisión (lineal y diferido) 2 horas y 12 minutos, los y las jóvenes (13 a 24 años) 1 hora y 50 minutos, adultos jóvenes ( 25 a 44 años), 2 horas y 58 minutos, maduros (45 a 64 años), 4 horas y 44 minutos, mayores (65 años en adelante), 6 horas y 4 minutos. Los grupos de edad infantil, jóvenes y adultos jóvenes cuentan con los registros mínimos históricos desde que se mide el consumo en España. Por otro lado, las mujeres consumen más televisión que los hombres, con un promedio de 4:09 horas frente a los 3:37 horas de los hombres (Barlovento, 2019a: 44).

La televisión como medio tradicional se enfrenta, pues, al desafío que supone internet. Si bien es cierto que las capas de población de más edad consumen varias horas de televisión al día, no sucede lo mismo con las nuevas generaciones, que encuentran en la red un medio más personalizable y cercano. 


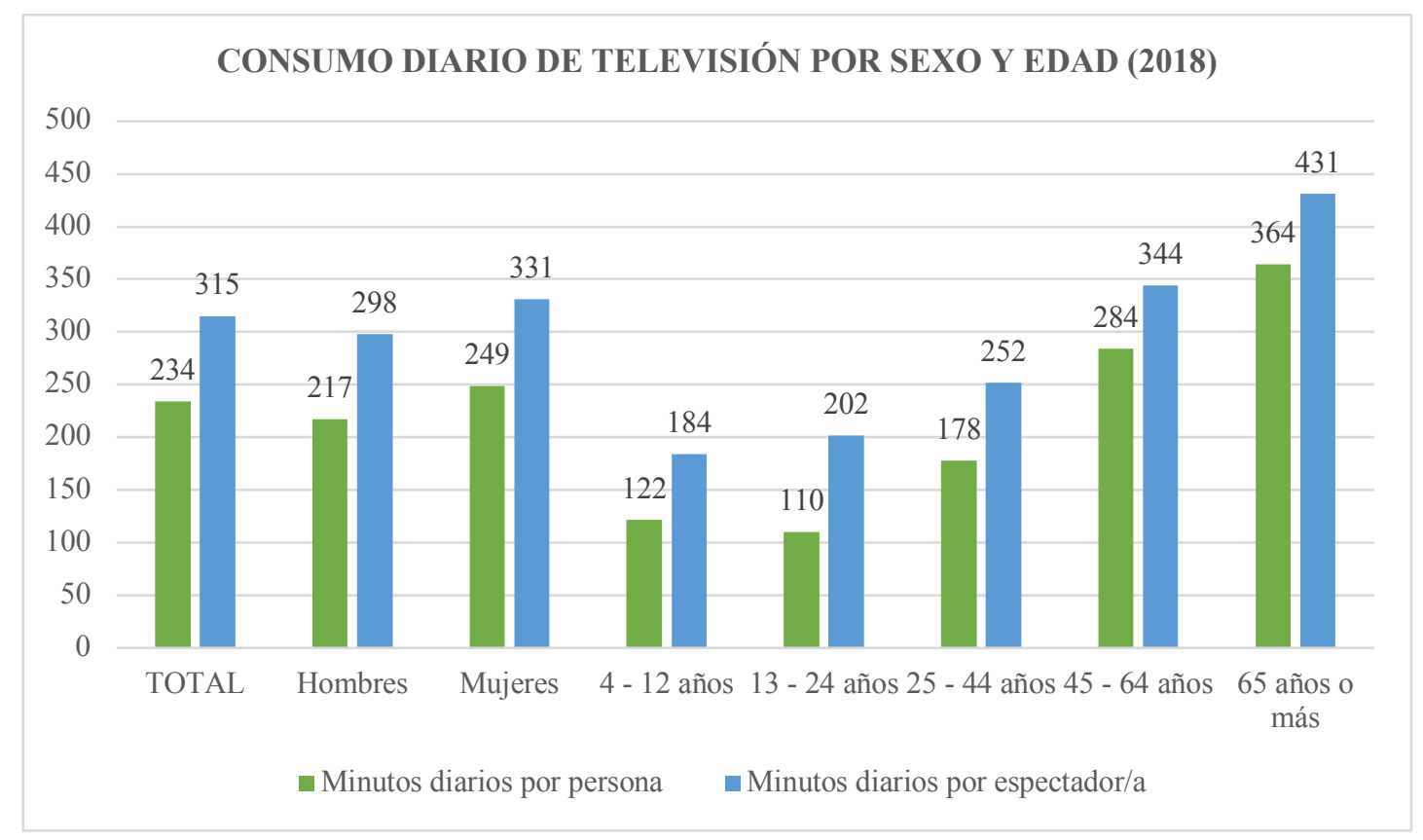

GrÁFico 6. Consumo diario de televisión en España por sexo y edad en el año 2018. FUENTE: Elaboración propia a partir de datos de Barlovento Comunicación (2019a: 44).

Como veremos en el siguiente epígrafe, la oferta de canales es mayor que nunca, sin embargo, queda por comprobar de qué manera se adaptan las distintas cadenas a los incipientes hábitos de consumo.

\section{LOS CANALES DE TELEVISIÓN TEMÁTICOS}

Mientras que la prensa, como hemos mencionado, lleva algunos cientos de años produciendo contenidos especializados, la televisión empieza ahora a abandonar su carácter generalista y a sectorizar audiencias a gran escala. Si bien tradicionalmente los canales de televisión han reservado franjas horarias a ciertos públicos - la hora de la merienda para las niñas y niños que salían del colegio, por ejemplo-, actualmente encontramos cadenas enteras volcadas en un único tipo de audiencia.

En el siguiente apartado analizaremos el fenómeno de la especialización de los contenidos y la fragmentación de las audiencias en la televisión en España. Para ello, haremos un recorrido desde el nacimiento del primer canal, TVE, hasta la súbita irrupción de las cadenas temáticas en el nuevo milenio. De esta manera, llegaremos a los canales segregados por género, que forman parte del objeto de estudio de nuestra investigación. 
Así, constataremos cuántos ha habido, cuáles sobreviven, qué contenidos ofrecen o la acogida por parte del público.

\subsection{Nacimiento de la televisión en España}

Los primeros experimentos televisivos debemos atribuírselos, en la década de los años veinte del siglo pasado, al británico John Logie Baird, al ruso Vladimir Kosma Zworykin y al norteamericano Charles F.Jenkins (Campos, 2015: 38). Así, la primera emisión televisiva digna de mención fue en Estados Unidos el 7 de abril de 1927. Charles Francis Jenkins, en colaboración con Bell Telephone y American Telephone and Telegraph, envió, primero imágenes por cable desde Washington a Nueva York y, en una segunda fase, imágenes por ondas hercianas desde Nueva Jersey a Nueva York. En esta segunda ocasión, Herbert Clark Hoover, que un año más tarde sería nombrado presidente de los Estados Unidos, saludaba a las y los espectadores (Melgar, 2003: 28).

Mientras, en España en los años veinte, la prensa diaria y las revistas especializadas en temas de radio - Orbe, Antena, Radio Universal o Radio Sportcubrían los experimentos y progresos del nuevo medio de comunicación que ya sorprendía con sus primeros pasos (Melgar, 2003: 73). Fue una década más tarde, en 1938 y en plena Guerra Civil, cuando se produjo la primera exhibición televisiva en España. El Reichpost alemán obsequió al bando nacional con un servicio de televisión bidireccional conocido como Fonovisión (Palacio, 2003: 23).

Así, el General Francisco Franco y el Comandante Martínez Maza lanzaron las primeras señales el 25 de noviembre de 1938 en Burgos, bajo la atenta mirada alemana. El Diario de Burgos recogió la siguiente nota "los asistentes al acto pudieron contemplar la imagen de S.E. y su ayudante durante la conversación que ambos sostuvieron" (Palacio, 2003: 23). Sin embargo, cabe destacar que no se conoce auténticamente sus resultados y que estos ensayos no tuvieron continuidad. Fonovisión acabó, en la segunda mitad de los años cuarenta, en el Paseo de la Habana, primera sede de Televisión Española, TVE (Palacio: 2002: 75).

Las emisiones regulares televisivas se iniciaron el 28 de octubre de 1956. Al mando quedaba la Dirección General de Radiodifusión, un organismo adscrito al Ministerio de Información y Turismo. Al nacer la televisión en un contexto de dictadura, se convirtió esta en un instrumento de transmisión de valores, pautas ideológicas y control 
informativo del propio régimen franquista (Rueda y Chicharro, 2006: 40-41). El discurso de inauguración del ministro de Información y Turismo, Gabriel Arias Salgado, que tuvo lugar en el centro emisor de TVE donde se celebró, también, una misa en honor al nuevo medio, recoge muy bien la fundamentación ideológica y doctrinal que conformó la política informativa de la primera cadena (Melgar, 2003: 76):

Hoy, día 28 de octubre, domingo, día de Cristo Rey, a quien ha sido dado todo el poder en los Cielos y la Tierra, se inauguran los nuevos equipos y estudios de televisión española. Mañana, 29 de octubre, fecha del vigésimo tercer aniversario de la fundación de Falange Española, darán comienzo, de manera regular y periódica, los programas diarios de televisión. Hemos elegido estas dos fechas para proclamar así los dos principios básicos, fundamentales, que han de presidir, sostener y enmarcar todo desarrollo futuro de la televisión en España: la ortodoxia y rigor desde el punto de vista religioso y moral, con obediencia a las normas que, en tal materia, dicte la Iglesia Católica, y la intención de servicio y el servicio mismo a los grandes ideales del Movimiento Nacional (citado en Melgar, 2003: 76-77).

Sin embargo, aunque se tratara de una televisión controlada por un régimen político totalitarista y en un sistema de monopolio, en estos primeros años lo que se percibió fue un gran interés por agradar a la audiencia. Así, si bien es cierto que los mensajes eran de lo más tradicionales, no se saturó al medio con propaganda política, sino que la programación se articuló en torno a espacios culturales, infantiles, deportivos, y, también, de información (Montero y Antona, 2018: 32). Para llenar el primer programa de la historia de TVE se escogieron varias actuaciones: la de un grupo de coros y danzas de la Sección Femenina de Falange, la del pianista Enrique Cubiles y la de la orquesta de Roberto Inglez con Monna Bell como solista (Melgar, 2003: 77).

La primera señal de este medio apenas alcanzó los 70 kilómetros de distancia y fue seguida por 600 personas (Melgar, 2003: 77). En 1957, y, aunque no existía ningún censo oficial de aparatos, TVE calculaba que había unos 25.000 televisores en Madrid y, un año más tarde, la cifra ascendía a 50.000 unidades teniendo en cuenta, también, el área de Barcelona (Palacio, 2005: 42). En abril de 1958 se amplió el horario de emisión hasta las 5 horas diarias, dejando agosto sin programación para que el personal pudiera tener vacaciones (Melgar, 2003: 79).

De los primeros años, nos quedan, entre otros, los programas Cita con la música y Gran Parada, ambos musicales, Cotilleo al aire libre, El tranvía del humor, 
Universidad $T V$, que versaba sobre cultura, y Teresita y Marianín, un programa dramatizado para el público infantil. También, los informativos de TVE, las retransmisiones de fútbol y las corridas de toros (Melgar, 2003: 79-86). Así, en su primera etapa de desarrollo, que discurrió entre 1956 y 1962, la televisión se percibió, ante todo, como un instrumento para la evasión en el que "tendía a extirparse cualquier reflexión crítica acerca de la realidad social y, aun más, cualquier ejercicio público de disidencia política" (Rueda y Chicharro, 2006: 42-43).

En 1963, que fue cuando la señal de televisión abarcaba ya un porcentaje considerable del territorio español, comienza, en nuestro país, la difusión mayoritaria del medio televisivo. Dos años antes, en 1961, se había anulado el impuesto de artículo de lujo que acompañaba a la compra de los televisores y, en 1962, se había favorecido legalmente el pago a plazos de los mismos, hechos que repercutieron en una mayor penetración del medio audiovisual en los hogares españoles (Palacio, 2005: 56). En 1963, puede hablarse de una programación estable, del estilo a la que presentaban otras televisiones públicas europeas. En aquellas fechas, se emitieron un total de 3.500 horas anuales (Rueda, 2005: 50).

En 1964, TVE organizó una encuesta para conocer sus niveles de audiencia y, en ella, reunieron su programación bajo cinco macrogéneros: dramático, cultural, films, telefilms, música ligera y variedades infantiles. Los programas más destacados resultaron ser el dramático Primera fila (43,4\% de votos), los culturales La familia por dentro $(35,54 \%)$ y Tengo un libro en las manos $(24,41 \%)$, los telefilmes estadounidenses Bonanza (36,8\%) y Rompeolas (22\%), los musicales y de variedades Amigos de los lunes (46,5\%) y Gran Parada (22,3\%) y, finalmente, los infantiles Dibujos animados (46,2\%) y Fiesta con vosotros (21,5\%) (Palacio, 2005: 62-63).

El 10 de febrero de ese mismo año, se inauguró el primer teleclub en la España rural. Esta iniciativa, inspirada en los Fernsehstuben alemanes, vino de la mano de Manuel Fraga, ministro de Información y Turismo, y fue clave en la modernización de España. Aunque en 1963 el 80\% del territorio español se hallaba ya cubierto por las hondas hercianas que portaban la señal de TVE, lo cierto es que los receptores eran demasiado costosos, así, se pusieron en marcha una red de locales públicos en los que la población rural podía ver el televisor. De esta forma, en 1974, eran ya 4.500 los teleclubs que se mantenían en funcionamiento donde los vecinos y vecinas veían corridas de toros, los teatros de Estudio 1, las imágenes de $A$ toda plana y Datos para un informe, la música 
de Galas de sábado, los telefilmes norteamericanos, los documentales de Félix Rodríguez de la Fuente y los informativos del Telediario (Melgar, 2003: 90-91).

Durante esta misma década, podemos percibir los esfuerzos por segmentar la audiencia y lograr, de esta manera, una permeabilidad de la parrilla más efectiva. Así, la programación comienza a agruparse en bloques. Los primeros en aparecer fueron el bloque cultural en la franja de tarde y el bloque infantil, los jueves y sábados por la tarde. También, los contenidos tienden a organizarse en torno a formatos que se dirigen a un mismo público, es el caso de los programas informativos, que se emiten alrededor de los telediarios. Estos recursos profesionales, más propios de sistemas de televisión competitivos, evidencian, tanto la profesionalidad de la plantilla de TVE, como los esfuerzos por llegar a un público que aún no se consideraba cautivo (Montero y Antona, 2018: 32).

Si bien es cierto que el régimen de Franco mantuvo un férreo control sobre el mensaje televisivo, a mediados de los sesenta observamos que su actuación se centra más en el control de la información y no tanto en la transmisión de pautas de comportamiento. También, se destapa el deseo político por crear una emisora dedicada a programas divulgativos, hecho que se materializó en 1966 con el nacimiento de la Segunda Cadena de TVE, UHF. ${ }^{5}$ Durante los primeros años, esta cadena solo podía sintonizarse en algunas ciudades, sin embargo, servía para materializar la aspiración de una televisión impregnada de cultura sin descuidar los objetivos prioritarios de la evasión y el entretenimiento masivos. Dichas realidades —evasión mayoritaria frente a televisión cultural minoritaria-, cobran sentido si tenemos en cuenta la realidad de la época: el limitado aperturismo político del régimen franquista y la cristalización de la sociedad de consumo en España (Rueda, 2005 :52).

Por estas mismas fechas, aparecieron algunas denuncias sobre las limitaciones de TVE en materia de información. Concretamente, en marzo de 1968, un artículo publicado por Sopena en La Vanguardia puso de relieve que la imagen que estaba difundiendo el Telediario sobre la realidad española parecía la propia de "un país equivalente al mejor de los mundos pensados" (citado en Rueda y Chicharro, 2006: 107). A inicios de los setenta, se juntaron más voces críticas, las cuales llamaban la atención acerca de aspectos como el "tono triunfalista", la "parcialidad", el "conservadurismo" y la "mediocridad

\footnotetext{
${ }^{5}$ En 1983 UHF pasará a llamarse TVE2 y en 1991, La 2.
} 
intelectual" que emanaba TVE y que, por el contrario, no se veía en la prensa, medio relativamente cada vez más plural (Rueda y Chicharro, 2006: 107).

En 1970, Patxi Aguinaga escribió un artículo en la revista Familia Nueva acerca de TVE que provocó la cancelación de la publicación. En él, se podía leer que la televisión estatal se centraba en mostrar que España era un lugar de libertad, paz y orden y que instrumentalizaba los conflictos de otros países, usándolos cual propaganda para elevar la realidad del país. Además, trataba los movimientos sociales y políticos —manifestaciones, huelgas o paros—, como fenómenos minoritarios, organizados por agentes subversivos que recibían financiación extranjera. Finalmente, denunciaba que se promovía el fascismo, engrandeciendo figuras políticas y elevándolas a mitos mediante la presencia constante de las mismas en los programas televisivos (citado en Palacio, 2005: 81-82). Así, se produjo un paulatino desencanto de aquellos que, en los primeros años, confiaban en que la televisión se convirtiera en un servicio cultural y se revelaron los intereses políticos e ideológicos que nutrían el mensaje televisivo (Palacio, 2005: 81).

En la década de los setenta, la extensión en audiencia y horarios determinó que la televisión se enfrentase a públicos cada vez más amplios y heterogéneos, incluyendo a los turistas extranjeros que comenzaban a llegar a España masivamente. La audiencia se fragmenta en torno a la oferta del momento: se amplían los concursos donde participa el público en general, como Un millón para el mejor, de Joaquín Prat, también vemos Estudio abierto de José María Íñigo, series de teatro clásico y de zarzuela, los conciertos de la Orquesta de RTVE o los documentales de Félix Rodríguez de la Fuente, como Fauna, los cuales encuentran su mejor acogida en 1970 y 1971. En 1972 la audiencia alcanza sus máximos picos con el programa Un, dos, tres... responda otra vez, de Narciso Ibáñez Serrador y, en 1973, La cabina, de Antonio Mercero obtiene el Premio Montecarlo (Bueno, 2002: 216-217).

Entre 1970 y 1975 la parrilla está muy ordenada y responde a una estructura vertical, la cual permite combinar espacios más costosos, como son los de producción propia, con otros que requieren menor presupuesto o menor esfuerzo técnico. La franja de la noche es el horario estrella y, cada día, se proyecta un programa diferente dirigido a una audiencia variada, generalista, que alberga gustos diversos. No faltan, a esa hora, los programas de ficción. Por su lado, los martes y jueves se emite, al comienzo de la programación principal, un documental. Para los sábados se reserva el espectáculo, tras 
el cual se proyecta siempre una película, un telefilm seriado extranjero o una serie de producción propia (Montero y Antona, 2018: 32).

En 1974, en la etapa terminal del franquismo, Jesús Sancho Rof fue nombrado director general. Se mantuvo 13 meses al cargo y hubo de lidiar, por un lado, con las tensiones provocadas por las voces aperturistas y, por el otro, con los intentos de control de los viejos prohombres del régimen. Le sustituyó Gabriel Peña Aranda, quien nombró a Alberto Miguel Arruti director de los informativos, y que, finalmente, cubrió la muerte del dictador. Con la caída del régimen franquista, llego el presidente Adolfo Suárez, lo que marcó el inicio de la transición a la democracia, ya no solo de España, sino también de TVE. Así, el presidente situó a Sotillos, Azcona, Macía y Gozalo al frente de las cuatro ediciones de Telediario, potenció los centros regionales —especialmente los de Cataluña y País Vasco-, sacó adelante una ordenanza laboral para RTVE y asentó las bases del Estatuto Jurídico de la Radio y la Televisión que se aprobó en enero de 1980 (Melgar, 2003: 101-102).

En 1976, existían unos ocho millones de televisores, de los cuales, el 10\% eran en color. La audiencia diaria estaba fijada en 20 millones de espectadores. También, en ese mismo año, TVE publica un índice de aceptación de sus programas, que nos puede servir como referencia para conocer los gustos televisivos en plena transición. La lista, por orden de puntuación, quedó configurada de la siguiente manera: Heidi —dibujos animados que se emitían los sábados a las 15:30—, Vivir para ver — presentado y dirigido por Alfredo Amestoy_, La casa de la pradera — telefilme estadounidense—, Un, dos, tres... responda otra vez — concurso-, El hombre y la Tierra — programa divulgativo de Félix Rodríguez de la Fuente—, En ruta — telefilme estadounidense-, El circo de TVE — programa infantil—, Shaft — telefilme estadounidense-, Pollyana — telefilmey, finalmente, Nacida libre — telefilme infantil—. Unos años más tarde, se observan cambios en los gustos de la audiencia: los programas juveniles vienen a sustituir al contenido infantil (el hartazgo de la serie de dibujos animados Marco fue tal - llegaron incluso a verse grafitis en tono jocoso "si la madre de Marco no aparece, mañana huelga general"-, que el Telediario anunció que emitirían los capítulos de dos en dos para finalizar antes) y, también, encontramos más producción propia (Palacio, 2005: 94).

Entre 1975 y 1982 se producen y emiten algunos de los productos más valorados en la memoria colectiva, tales como Informe semanal (1976) que, a día de hoy, lleva 
cuatro décadas de emisión ininterrumpida, La clave (1976), El hombre y la tierra (1976), Los gozos y las sombras (1982), La barraca (1979), Verano azul (1981), A fondo (1976), Encuentros con las artes y las letras (1976), Popgrama (1977), Dos por dos (1980), La España de los Botejara (1976), Vivir cada día (1979) o Su turno (1981) (Palacio, 2005: 96). A lo largo de estos años, la televisión fue, progresivamente, perdiendo las connotaciones de instrumento de modernización del país para convertirse en un medio de entretenimiento y fuente de distracción. Durante los setenta y ochenta, el consumo televisivo es una de las actividades diarias y casi obligadas de la población española que buscan en el medio, básicamente, esparcimiento y evasión (Rueda y Chicharro, 2006: 243).

En los años 80, con el nacimiento de las cadenas autonómicas, asistimos al fin del monopolio de TVE. Estas aparecieron, primero, en las denominadas nacionalidades históricas, para, después, esparcirse por otras regiones del país: ETB, que comienza su andadura en 1982, será el canal televisivo para la región vasca; TVE3, que emitirá por primera vez en septiembre de 1983 en versiones de prueba hasta que se asiente en enero de 1984, será la cadena autonómica catalana y TVG, fundada en 1985, abastecerá la región gallega. Posteriormente, en 1989, llegaron Telemadrid —Madrid—, Canal Sur —Andalucía— y Canal 9 -Valencia—. A excepción de la televisión catalana, las audiencias eran muy reducidas y apenas rivalizaban con TVE (Roel y Grandío, 2018: 780).

El 25 de agosto de ese mismo año, 1989, se otorgan finalmente las concesiones a Antena 3 TV — grupo Vanguardia y Antena 3 Radio—, Telecinco — Gestavisión, ONCE y Berlusconi- y Canal+ - grupo PRISA y Canal+ Francia- Las primeras peticiones de permisos para establecer cadenas privadas habían sido ya en 1976, aunque hubo que esperar hasta 1981 para que se formalizaran las solicitudes de la SER, Radio 80, La Vanguardia, Europa Press y el Grupo Z, sin embargo, no será hasta que el Partido Socialista apruebe la Ley de Ordenación de las Telecomunicaciones, en abril de 1988, que se confirma que serían tres las concesiones de televisión privada (Melgar, 2003: 103).

Por tanto, la ruptura del monopolio de las televisiones públicas a nivel nacional se produjo en 1990, con el inicio de las emisiones privadas de Antena 3, Telecinco y, posteriormente, Canal + . Los datos de audiencia de ese año dejan entrever, aunque tímidamente, el final del dominio de TVE: nace, así, la etapa de coexistencia de los modelos de televisión públicos y privados, donde la televisión estatal irá, 
progresivamente, perdiendo su dominio. En el primer año de vida del modelo mixto, los datos de audiencia son los siguientes: las cadenas públicas reúnen el $72,6 \%$ de la audiencia - TVE1, 52,4\% y TVE2, 20,2\%—, el conjunto de las autonómicas el 16,4\%, la televisión privada en abierto el 10,2\% —-Telecinco, 6,5\% y Antena 3, 3,27\%—y la televisión privada de pago el $0,3 \%$ - Canal + - (existe un $0,5 \%$ restante queda reservado para la categoría “otras”) (Roel y Grandío, 2018: 780-781).

Conviene hablar brevemente del caso de Canal+, pues supone una innovación importante en la economía televisiva. En este modelo de negocio, solo quien paga el abono tiene derecho de acceso a los programas, lo que crea una sensación de distinción frente a la mayor parte de la audiencia, que no tendrá acceso a los mismos. En cuanto al tipo de programación, Canal+ se sitúa a medio camino entre los canales de pago temáticos y los generalistas en abierto. En este sentido, su programación es orientada: trata de crear una oferta que cumpla las expectativas de la demanda insatisfecha con los contenidos de la televisión gratuita. Por último, su objetivo no es el de maximizar la audiencia de cada programa, sino el de lograr altos índices de audiencia acumulada: lo importante será el porcentaje de renovación de los abonos (Richeri, 1994: 117-119).

En menos de siete años, el universo televisivo español pasó de 2 a 13 opciones en su oferta. Además, a ello hay que añadirle las televisiones locales que, a falta de legislación específica, fueron surgiendo espontáneamente y sin ningún tipo de control (Mateos-Pérez y Rebollo, 2018: 805). Poco a poco, se fue instaurando el modelo comercial —el de Estados Unidos— y la televisión pública se vio arrastrada por la competitividad. Esta perdió su carácter de servicio público para identificarse con las televisiones privadas, ejerciendo, al igual que ellas, la técnica de "la caza del espectador". Dicha lucha desencadenó prácticas como la contraprogramación y la desprogramación (a última hora y sin previo aviso). A estas alturas, la fragmentación de la audiencia era ya una realidad y, en 1996, TVE perdió definitivamente el liderazgo (Mateos-Pérez y Rebollo, 2018: 807).

Entre 1989 y 1996, se registró un crecimiento considerable en el tiempo de visionado de la televisión. Si en 1989 la audiencia dedicaba una media de tres horas diarias, en 1996 ese tiempo se había incrementado hasta situarse por encima de las cuatro horas. Esto se debió a la apertura de la oferta televisiva, que incrementó el deseo por ver la televisión durante el tiempo libre, sin embargo, en 1996, se llegó a una especie de 
estado de saturación o de fatiga tras ocho años consecutivos de crecimiento y los indicadores comenzaron a descender (Rueda y Chicharro, 2006: 329).

La programación televisiva en España se articuló en torno a una oferta dominada por el entretenimiento y el ocio, que estaba muy por encima de la información o la divulgación. Así, por ejemplo, el cine de autor empezó a proyectarse en las franjas de baja audiencia y, en prime time, apareció el comercial. La programación infantil se colocó a primera hora de la mañana y algo, poco, por la tarde, además, desaparecieron los espacios culturales y proliferaron los de variedades. En este sentido, salía más rentable, en términos económicos, fomentar las emociones, mediante la espectacularidad, que la reflexión y el análisis de los informativos y los programas de formación (Mateos-Pérez y Rebollo, 2018: 808).

Así, empezamos a ver espacios fácilmente digeribles, que alternan lo serio con lo entretenido o que muestran los contenidos en clave ligera, de diversión. Nace la neotelevisión, donde el discurso televisivo deja de ser ventana del mundo para ser un espejo del sujeto social. La televisión documental y referencial se convierte en una televisión especular, con un fuerte componente narcisista. La imagen moderna pasa a ser un bien efímero, de consumo inmediato, desechable y no un saber acumulable. El discurso televisivo socializa ahora desde lo emotivo, en lugar de desde lo racional, desde los relatos, en lugar de desde los discursos (Imbert, 2003: 42-45). Pensadores como Umberto Eco, nos dicen que la neotelevisión deja de ser un vehículo de los hechos y se convierte en un aparato para la producción de los mismos (Eco, 1983: 135).

Se consolidó en esta década lo que conocemos como la telebasura, esto es, rumorología como esencia de la información, filtración interesada, desinformación... se implantaron espacios dedicados a la polémica, al periodismo rosa o a los sucesos. En el caso de la información rosa, este tipo de programas fue creciendo progresivamente hasta los más de 42 que se emitían en otoño de 2003, la mayoría inspirados en una falta de respeto hacia los personajes y en una búsqueda desesperada de audiencia (Menéndez, 2006: 121). Además, los canales emitieron programas, muchos de ellos en franjas de máxima audiencia, que construían su guion a raíz de casos escabrosos y hasta punibles que llegaron a provocar la intervención de la justicia o de asociaciones. También, surgieron espacios dedicados a la parapsicología y a la crónica social que dieron pie a que nuevos personajes estrafalarios, controvertidos, iluminados irrumpieran en las parrillas (Mateos-Pérez y Rebollo, 2018: 808-809). Los programas con mejores índices de 
audiencia iban a ser "aquellos que son explícitos y generosos a la hora de tratar los temas más morbosos, escandalosos o escabrosos” (López y López, 2001: 190).

Así, en los años noventa, vemos los programas Quién sabe dónde —que se emitió primero en La 2 para pasar luego a TVE1-, Misterios sin resolver, de Telecinco, Al filo de la ley, de Antena 3 y Código Uno, de TVE1. Estos espacios, que intentaban resolver toda clase de sucesos — desapariciones, secuestros, asesinatos o violaciones...-, se presentaron a la audiencia como ejemplos de investigación periodística de servicio público en lugar de como programas de telerrealidad. Otros ejemplos fueron De tú a tú y Cita con la vida, de Antena 3, que mostraban un escenario cada vez más polémico y espectacular. También, La máquina de la verdad, de Telecinco, buceaba en las vidas de los y las personajes populares generando entretenimiento con sus asuntos privados (Mateos-Pérez y Rebollo, 2018: 812).

Lo que necesitas es amor, en Antena 3, Perdóname, en TVE1 o Contacto... con tacto y Vivan los novios, en Telecinco, fueron espacios donde personas anónimas buscaban pareja o trataban de resolver conflictos sentimentales. Proliferaron también los programas de divulgación médica: Al hilo de la vida, de TVE1, o En buenas manos, de Antena 3, se colaron en quirófanos, mostraron operaciones en directo y dieron voz al sufrimiento, siempre espectacularizado de personas enfermas, arrastrando a las pantallas una epidemia de morbo (Mateos-Pérez y Rebollo, 2018: 813).

Esta evolución en los contenidos refleja una crisis de la representación televisiva: "cuando ya cansa la realidad misma, lo último que queda es reinventarla, crearla desde y dentro del propio medio (como ocurre con los reality shows y los docudramas)" (Imbert, 2003: 47). El máximo exponente de esta nueva narrativa lo encontraríamos en el programa Gran Hermano, nacido en el año 2000 en Telecinco. Gran Hermano se mueve en la lógica de las relaciones humanas desde la cotidianidad más descarnada, ejemplificada en la convivencia de un grupo de desconocidos y desconocidas (Rueda y Chicharro, 2006: 361). Nos cuenta Gerard Imbert que este espacio reúne todos los mitos instituidos por la neotelevisión: la transparencia, la cercanía y la participación/integración de la audiencia en la construcción de la realidad (Imbert, 2001:201).

Paralelamente al fenómeno de la telerrealidad, afloró una nueva industria de la fícción televisiva en España. Los buenos índices de audiencia, trajeron consigo un incremento en la inversión publicitaria que permitió reforzar la producción propia, la cual 
pasó a suponer el $57 \%$ de la oferta global de las televisiones. Esta se distribuyó principalmente entre Antena 3 y Telecinco. Las series empezaron a reunir grandes cuotas de audiencia y se convirtieron en elementos clave de la imagen de marca de las distintas cadenas. La emisión de Farmacia de Guardia, serie de Antena 3, obtiene espectaculares resultados de popularidad en la temporada 93-94 y puso el germen de lo que estaba por venir. Le siguieron, en la temporada 95-96, éxitos como Hostal Royal Manzanares de TVE y Médico de Familia en Telecinco (García de Castro, 2002: 132).

Así, la temporada 98-99 supuso la consolidación de las series de producción propia - llegaron a surgir hasta una veintena de ellas-, las cuales nos muestran, generalmente, un escenario costumbrista, con clara inclinación hacia la comedia -aunque se puedan advertir tintes dramáticos-, y con vocación familiar o intergeneracional. En 1999, las series estadounidenses habían desaparecido, casi completamente, de la franja de máxima audiencia y habían sido sustituidas por el producto nacional que, aunque tenía un mayor coste de producción que las series enlatadas o importadas, obtenía mejores resultados económicos. En estos años, podemos ver las series Tío Willy o A las once en casa, de La Primera, ${ }^{6}$ La casa de los líos, Manos a la obra o Compañeros, de Antena 3 y Médico de Familia, Periodistas, 7 vidas o Todos los hombres de Telecinco (García de Castro, 2002: 133-136).

\subsection{La televisión digital terrestre y la fragmentación de la audiencia}

Con la llegada del nuevo milenio, aparecieron, también, nuevos actores. En el año 2000, el gobierno concedió dos licencias para dos cadenas de emisión digital terrestre: Net TV —de Globomedia, Telson y Cartel—y Veo TV — de Unedisa y Recoletos—. Ambas empezaron a retransmitir en 2002, sin embargo, no lograron penetrar en la audiencia ya que "se lanzaron a un mercado muy competitivo para el que carecían de experiencia y de oferta atractiva, con escasa capacidad de programas interactivos y con la práctica ausencia de descodificadores o receptores digitales accesibles" (Videla y Costa, 2912: 41).

Mientras, ese mismo año, las televisiones privadas renovaron su licencia por otra década y, a parte, se les implantó la obligatoriedad de simultanear la emisión con la de la señal digital terrestre en un plazo de dos años. Así, se daban los primeros pasos hacia la

\footnotetext{
${ }^{6}$ En 1995 TVE1 se convirtió en La primera, nombre que mantuvo hasta finales de 2007, cuando pasa a ser La 1.
} 
televisión digital terrestre, TDT. Sin embargo, no fue hasta 2005 que las televisiones analógicas se repartieron definitivamente los canales, formado por un multiplex (4 canales) para cada televisión privada y dos multiplex completos (8 canales) para RTVE (Izquierdo-Castillo, 2016: 739-740).

En el año 2005, se aprobó la Ley de medidas urgentes para el impulso de la televisión digital terrestre, de liberalización de la televisión por cable y de fomento del pluralismo. Esta ley otorgó una nueva licencia de televisión privada y extendió el periodo de compatibilidad de posesión de canales analógicos y digitales para todo el periodo de transición entre un tipo de señal y otro. Además, ese mismo año, 2005, el Consejo de Ministros autorizó a Canal +, propiedad de Sogecable, emitir en abierto las 24 horas del día, permitiendo así la aparición de la cadena televisiva Cuatro (Barriga, 2013: 76).

El concurso para el nuevo canal de televisión analógico de alcance estatal se adjudicó, justo antes de finalizar 2005, a la compañía Gestora de Inversiones Audiovisuales La Sexta: nació, así, La Sexta. Esta cadena, que empezó a emitir regularmente el 27 de marzo de 2006, apostó por una programación con grandes dosis de deporte —principalmente retransmisión de todo tipo de competiciones de fútbol, baloncesto y Fórmula 1-, programas de humor y entretenimiento, a veces mezclado con actualidad —Sé lo que hicisteis..., El Intermedio, Buenafuente- - y series de producción norteamericana —Prison Break y El Mentalista-. Políticamente hablando, sus informativos tomaron un cariz progresista (García, 2009: 532).

Cuatro, por su lado, también se construyó como una cadena generalista. Sus retransmisiones comenzaron el 7 de noviembre de 2005 con una pieza del periodista Iñaki Gabilondo. Cuatro ofrecía el mismo contenido que el resto de canales, sin embargo, innovó más en su tratamiento. Un ejemplo de ello serían los informativos, donde predominaba la personalidad del comunicador sobre la imagen de la cadena. El informativo de las 9 de la noche, presentado por Iñaki Gabilondo, era un espacio pausado, analítico y narrativo, el de las tres de la tarde, conducido por Marta Reyero y Marta Fernández, más dinámico y rápido. Apostó por series extranjeras como House o Anatomía de Grey, por programas de humor y actualidad como Noche Hache o Las noticias del Guiñol, también produjo el programa de sucesos paranormales Cuarto Milenio, retransmitió el Mundial de fútbol del año 2006 e incorporó el género del reality show (González, 2006: 591-595). 
Tanto Cuatro como La Sexta se caracterizaron por ofrecer un contenido, que si bien es cierto que habíamos visto con anterioridad, ambas lo explotaron en mayor medida. Se trata del periodismo satírico: género basado en el entretenimiento y el espectáculo y que se caracteriza por la ironía, el descaro y la acidez con la que se plantean los asuntos de actualidad. En los años 90, Las noticias del guiñol en Canal+ y Caiga quien caiga en Telecinco fueron dos espacios que ya articularon su narrativa en base a este género. Años más tarde, no solo Cuatro incorporó Las noticias del Guiñol a su parrilla, sino que ambas cadenas apostaron por multiplicar los espacios de este género, con programas como $\mathrm{El}$ intermedio en La Sexta y Noche Hache de Cuatro (Salgado, 2010: 63-66).

Tal y como se muestra en el gráfico 7, la aparición de estos dos canales generalistas provocó una mayor fragmentación de la audiencia. Todas las cadenas históricas nacionales perdieron cuota de pantalla: Antena 3 registró una caída de 1,9 puntos, La Primera de 1,3, Telecinco de 1,1 y La 2 de un punto. Cabe destacar que es reseñable que con solo un año de emisión a sus espaldas, Cuatro consiguiese un 6,4\% de audiencia. Mientras, La Sexta acumuló 1,8 puntos anuales, aunque si tomamos como punto de partida abril, que es cuando empezó a emitir y, por tanto a contabilizarse, promedia un 2,4\% (Barlovento, 2007: 6). En cuanto a los hábitos de consumo, se vio la televisión 217 minutos al día, siendo las mujeres (236 minutos) y la franja de más de 64 años (306 minutos) quienes más vieron la misma (Barlovento, 2007: 4).

En la transición a la TDT se establecieron dos procesos diferenciados: un periodo en el cual convivían las emisiones analógicas con las digitales terrestres y la fase posterior, a partir de 2010, en la que solo se emitiría en digital. Al final de la transición, cada emisora privada tendría un multiplex, es decir, 4 canales. La oferta que se desarrolló quedó constituida por alrededor de una veintena de canales nacionales - generalistas y temáticos-, cuatro canales autonómicos y una cantidad variable de emisoras de ámbito local (Videla y Carmen, 2012: 42-43).

Durante la primera etapa de relanzamiento de la TDT, es decir, de 2005 a 2010, la tendencia que se observa es la de una especialización por sexos — como pueden ser los canales Nova y Hogar 10 enfocados a un público femenino-y por edades - 40 Latino, Flymusic y Neox estaban pensados para un público joven y Clan para uno infantil—, mientras que y, en cuanto a los contenidos, se apuesta por el entretenimiento. Aun así, 
muchos de los canales ofrecen una oferta generalista que cabe atribuir a la escasa audiencia de la TDT (Videla y Carmen, 2012: 45).

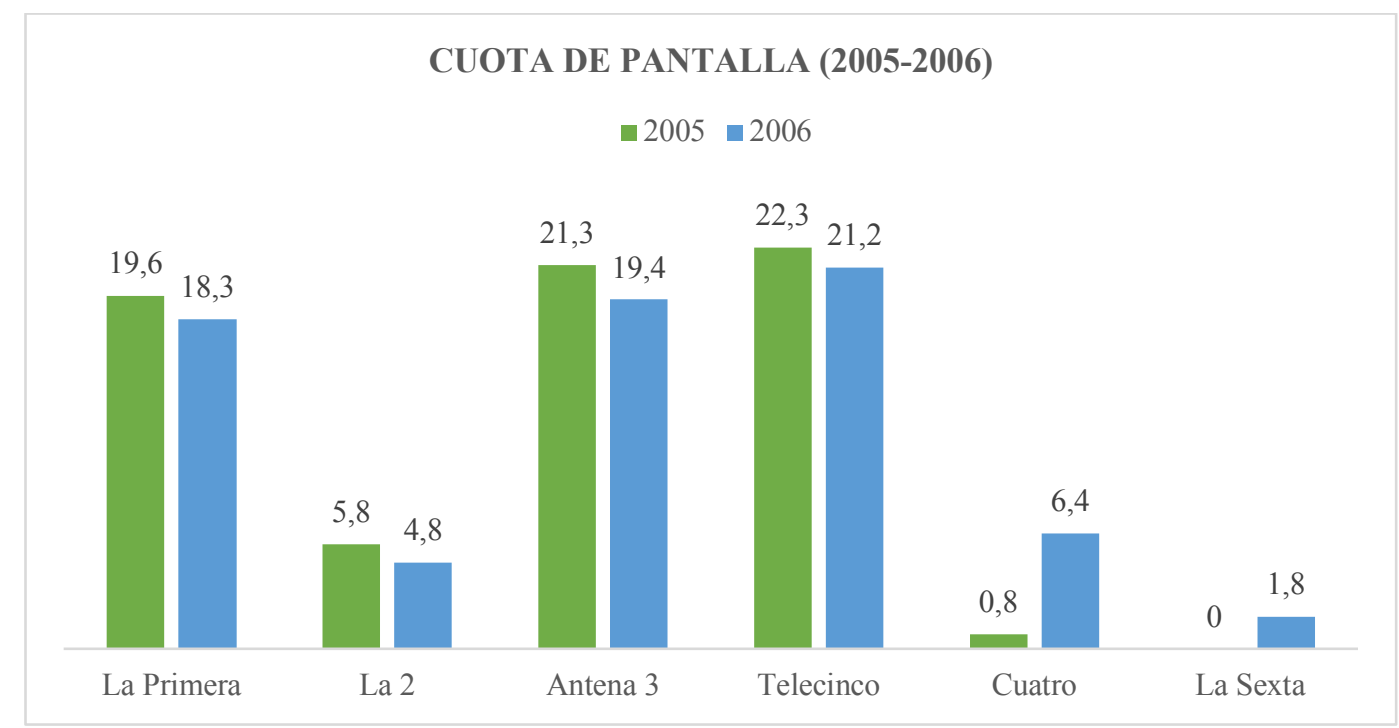

GrÁFICo 7. Cuota de pantalla de los canales generalistas que emitían en analógico en 2005 y 2006. FuENTE: Elaboración propia con datos de Barlovento Comunicación (2007: 6).

Se puede decir que, durante la primera década del 2000, el ámbito político potenció la multiplicación del sector televisivo. El mapa de cadenas resulta abrumador para un mercado español de tamaño tan reducido: la audiencia podía elegir, no solo entre las cadenas generalistas y sus extensiones temáticas, tal y como aparece desarrollado en la tabla 5, sino que también entre las corporaciones autonómicas y sus cuatro canales digitales concedidos, las locales, y la televisión por satélite (Izquierdo Castillo, 2016: 740).

El 23 de febrero de 2009, se aprobó el Real Decreto Ley de medidas urgentes en materias de telecomunicaciones. Esta normativa permitía una mayor concentración del poder mediático, dejando de lado los intereses del pluralismo informático y atendiendo, únicamente, a los deseos económicos de la industria audiovisual. Como consecuencia de ello, en diciembre de 2009, se anunció la fusión de Cuatro y Telecinco por un lado y Antena 3 y La Sexta por el otro. Esta operación acabó con el 80\% de los anunciantes concentrados en los dos grandes grupos comunicacionales, estos son, Atresmedia Televisión y Mediaset España (Barriga, 2013: 76-84). 


\begin{tabular}{|c|c|c|c|c|c|c|c|c|c|}
\hline \multicolumn{10}{|c|}{$\begin{array}{l}\text { TELEVISIÓN EN ABIERTO EN ESPAÑA DURANTE LA PRIMERA DÉCADA DEL SIGLO } \\
\text { XXI }\end{array}$} \\
\hline \multicolumn{10}{|c|}{ CORPORACIÓN RTVE } \\
\hline 2000 & 2001 & 2002 & 2003 & 2004 & 2005 & 2006 & 2007 & 2008 & 2009 \\
\hline \multicolumn{10}{|c|}{ La Primera / La 1} \\
\hline \multicolumn{10}{|c|}{$\mathrm{La} 2$} \\
\hline & & & & & \multicolumn{5}{|c|}{$24 \mathrm{~h}$} \\
\hline & & & & & \multicolumn{5}{|c|}{ Clan } \\
\hline & & & & & \multicolumn{5}{|c|}{ Teledeporte } \\
\hline \multicolumn{10}{|c|}{ ANTENA 3 TELEVISIÓN } \\
\hline 2000 & 2001 & 2002 & 2003 & 2004 & 2005 & 2006 & 2007 & 2008 & 2009 \\
\hline \multicolumn{10}{|c|}{ Antena 3} \\
\hline & & & & & \multicolumn{5}{|c|}{ Antena.Neox } \\
\hline & & & & & \multicolumn{5}{|c|}{ Antena.Nova } \\
\hline \multicolumn{10}{|c|}{ SOGECUATRO } \\
\hline 2000 & 2001 & 2002 & 2003 & 2004 & 2005 & 2006 & 2007 & 2008 & 2009 \\
\hline & & & & & \multicolumn{5}{|c|}{ Cuatro } \\
\hline & & & & & & & & \multicolumn{2}{|c|}{$\mathrm{CNN}+$} \\
\hline & & & & & \multicolumn{5}{|c|}{40 Latino } \\
\hline & & & & & & & & $\begin{array}{c}\text { Promo } \\
\text { TV }\end{array}$ & $\begin{array}{l}\text { Canal } \\
\text { Club }\end{array}$ \\
\hline \multicolumn{10}{|c|}{ GESTELEVISIÓN TELECINCO } \\
\hline 2000 & 2001 & 2002 & 2003 & 2004 & 2005 & 2006 & 2007 & 2008 & 2009 \\
\hline \multicolumn{10}{|c|}{ Telecinco } \\
\hline & & & & & \multicolumn{3}{|c|}{ Telecinco Estrellas } & \multicolumn{2}{|c|}{ FDF } \\
\hline & & & & & \multicolumn{3}{|c|}{ Telecinco Sport } & T5 2 & $\begin{array}{c}\text { La } \\
\text { Siete }\end{array}$ \\
\hline & & & & & & & & Cincosho & \\
\hline \multicolumn{10}{|c|}{ GESTORA DE INVERSIONES AUDIOVISUALES LA SEXTA } \\
\hline 2000 & 2001 & 2002 & 2003 & 2004 & 2005 & 2006 & 2007 & 2008 & 2009 \\
\hline & & & & & \multicolumn{5}{|c|}{ La Sexta } \\
\hline & & & & & & Telehit & \multicolumn{2}{|c|}{ Hogar 10} & $\begin{array}{l}\text { Gol } \\
\mathrm{TV}^{7}\end{array}$ \\
\hline \multicolumn{10}{|c|}{ NET TV } \\
\hline 2000 & 2001 & 2002 & 2003 & 2004 & 2005 & 2006 & 2007 & 2008 & 2009 \\
\hline & & \multicolumn{6}{|c|}{ Net TV } & Intereco & mía TV \\
\hline & & & & & & ly Music & & Disney & hannel \\
\hline & & & & EO TH & LVISIÓ & & & & \\
\hline 2000 & 2001 & 2002 & 2003 & 2004 & 2005 & 2006 & 2007 & 2008 & 2009 \\
\hline & & & & & Veo T & Veo $7^{8}$ & & & \\
\hline & & & ansión & & Interec & mía TV & Set en & $\mathrm{o} /$ Sony & en Veo \\
\hline & & & & & & & Tiend & $n$ VEO & \\
\hline
\end{tabular}

TABlA 5. Televisión en abierto en España durante la primera década del siglo XXI.

FuENTE: Elaboración propia a partir de diversas fuentes.

\footnotetext{
${ }^{7}$ Hogar 10 fue sustituido por Gol TV que fue un canal de pago.

${ }^{8}$ El 12 de enero de 2009, Veo TV cambia su nombre por Veo7.
} 
E1 31 de marzo de 2010, entra en vigor la Ley 7/2010 General de la Comunicación Audiovisual. Posteriormente, el 16 de julio, se entregaron canales adicionales a Atresmedia, Mediaset, Net TV y Veo Televisión sin la previa realización de concurso público, lo que atentaba con el punto 2 del artículo 27.9 Así, el Gobierno desarrolló previsiones reglamentarias que se correspondían a una regulación anterior, por lo que Infraestructuras y Gestión 2002, empresa de señales televisivas, inició una demanda que desembocó en una sentencia del Tribunal Supremo, la cual exigió el cierre de 9 cadenas el 6 de mayo de 2014. Por tanto, ese mismo día, dejaron de emitirse Nitro, Xplora y La Sexta 3 -de Atresmedia—, La Siete y Nueve —de Mediaset España—, La Tienda en Casa y MTV España — de Net TV—y AXN y Tienda — de Veo televisión—. Cabe destacar que MTV y AXN habían dejado de emitir poco antes de que se resolviera la sentencia, en febrero y abril de ese año respectivamente, debido la inseguridad jurídica provocada en el sector. ${ }^{10}$

El 17 de abril de 2015 se publicó, mediante Resolución de la Secretaría de Estado de Telecomunicaciones y para la Sociedad de la Información, el pliego de bases de la adjudicación de seis nuevas licencias de TDT en abierto. Este concurso se resolvió, por Acuerdo del Consejo de Ministros, del siguiente modo: Atresmedia, Mediaset y Real Madrid TV resultaron adjudicatarias de las tres licencias destinadas a difundirse en alta definición, mientras Radio Blanca Kiss, Central Broadcaster Media (Grupo Secuoya) y 13 Televisión consiguieron las señales restantes que permitían emitir en calidad estándar (Bustamante y García, 2017: 29).

Nacen, por tanto, en 2016, Atreseries, de Atresmedia —conformada por ficción seriada —, Be Mad, de Mediaset — presentado como un canal de divulgación orientado a un público masculino y que emite muchos de los contenidos de Energy_- Dkiss, de Radio Blanca — pensada para una audiencia femenina y con espacios de proveedores como Discovery Networks International—, Real Madrid TV, de Real Madrid Televisión —con

\footnotetext{
9 “Todas las licencias disponibles de la misma naturaleza e idéntico ámbito de cobertura deberán ofrecerse de forma simultánea, y previa confirmación de existencia de espacio radioeléctrico suficiente. No obstante, en el marco de los dispuesto, en su caso, por el Plan técnico Nacional de oferta de licencias, a desarrollar reglamentariamente, cuando haya quedado liberada una única licencia, la Administración competente deberá proceder a convocar el concurso para su adjudicación en un plazo máximo de tres meses sin esperar a que queden liberados más títulos habilitantes" Ley 7/2010. General de Comunicación Audiovisual, 2010, art. 27. Recuperado el 25 de junio de 2019 de: https://www.boe.es/boe/dias/2010/04/01/pdfs/BOE-A-20105292.pdf

${ }^{10}$ Véase información publicada en El Mundo el 5 de mayo de 2014: "La TDT se despide de nueve canales". Recuperado el 8 de junio de 2019 de https://www.elmundo.es
} 
contenidos del Club de Fútbol Real Madrid—, Ten, del Grupo Secuoya —que ofrece una propuesta familiar basada en el entretenimiento-y 13TV, de 13 Televisión — vinculada a la Conferencia Episcopal y que ya emitía a través de una de las frecuencias que alquilaba a Veo Televisión, sin embargo, esta vez para a tener su propia adjudicación(Bustamante y García, 2017: 29).

Por primera vez, vemos hasta nueve grupos comunicacionales operando en las parrillas televisivas. Sin embargo, cabe destacar que sigue siendo Mediaset, Atresmedia $\mathrm{y}$, en menor medida, RTVE quienes aglutinan la mayor parte de la audiencia: Mediaset, con sus 7 canales, se lleva el 28,8\% del público, Atresmedia, que cuenta con 6 canales, el $26,8 \%$ y, RTVE, con 5 canales, reúne un 16,5\% de cuota de pantalla en el año 2018 (Barlovento, 2019a: 38). Además, tal y como publica El Español, 13TV, Dkiss y Ten, que no están bajo el paraguas de un gran grupo, registran pérdidas de al menos 44 millones de euros: DKiss, 10,5 millones, 13tv, 22 millones y Ten, 12 millones. De Real Madrid TV no hay cifras oficiales, sin embargo la audiencia es de un 0,3\% en 2018, la más baja de todos los canales junto a Ten, por lo que se deduce que tampoco esté logrando ningún tipo de beneficio. ${ }^{11}$

Esta segunda década del siglo XXI, se ha caracterizado por ser una etapa muy convulsa para la televisión. Se han sucedido un total de 50 espacios, empezando por 31 en el 2010 y acabando con 26 en 2019. Como hemos visto, no siempre se ha cumplido con la legalidad vigente, lo que provocó, primero el cierre de 3 canales en 2010 - Cincoshop, Tienda en VEO y Canal Club (aunque la señal de Canal Club no desapareció y fue sustituida por La Tienda en Casa)— y, posteriormente, los 9 mencionados en 2014. Además, han aparecido nuevos actores, como 13 televisión, Radio Blanca Kiss, Real Madrid TV y el Grupo Secuoya. Las audiencias no han sido muy halagüeñas y continúan concentradas en los grandes grupos comunicacionales, concretamente, en sus cadenas generalistas (véase tabla 2 para más información).

Aun con todo, las empresas han procurado diversificar su oferta y especializar sus contenidos. A lo largo de esta segunda década, los mejores resultados los han conseguido FDF, especializada en series y que llegó a tener una cuota de pantalla de 3,5 en 2014 y 2015, Clan, de dibujos animados, que obtuvo un 3,2 en 2010 y, finalmente, Neox, también

\footnotetext{
${ }^{11}$ Véase información publicada el 28 de abril de 2018 en El Español: "El fracaso de los nuevos canales de TDT: flojas audiencias y pérdidas millonarias". Recuperado el 9 de junio de 2018 de https://www.elespanol.com/bluper/noticias/fracaso-nuevos-canales-tdt-ten-dkiss-real-madrid-trece
} 
especializada en series, registró un 2,7 en 2011. Por su lado, en 2018, las más vistas fueron las ya mencionadas FDF con un 2,9, Neox con un 2,4 y Nova, canal especializado en el público femenino que obtuvo, también, 2,4 de cuota de pantalla (Barlovento, 2019a: 45).

En cuanto a como quedan repartidos los canales en 2019, RTVE que mantiene su oferta estable desde 2005, ofrece cinco cadenas en calidad estándar y en alta definición, de las cuales dos son generalistas y tres temáticas. El grupo Atresmedia cuenta con seis canales, dos generalistas que también tienen su frecuencia en alta definición, y cuatro temáticos. Mediaset es el grupo comunicacional que más canales posee, un total de siete: dos generalistas, con su versión en alta definición, y cinco temáticos. Mientras, Net TV y Veo Televisión reúnen dos canales cada una. Finalmente, Radio Blanca, Grupo Secuoya, 13 Televisión y Real Madrid televisión ofrecen un único canal por grupo.

\begin{tabular}{|c|c|c|c|c|c|c|c|c|c|}
\hline \multicolumn{10}{|c|}{$\begin{array}{l}\text { TELEVISIÓN EN ABIERTO EN ESPAÑA DURANTE LA SEGUNDA DÉCADA DEL SIGLO } \\
\text { XXI }\end{array}$} \\
\hline \multicolumn{10}{|c|}{ CORPORACIÓN RTVE } \\
\hline 2010 & 2011 & 2012 & 2013 & 2014 & 2015 & 2016 & 2017 & 2018 & 2019 \\
\hline \multicolumn{10}{|c|}{$\mathrm{La} 1 / \mathrm{La} 1 \mathrm{HD}$} \\
\hline \multicolumn{10}{|c|}{$\mathrm{La} 2 / \mathrm{La} 2 \mathrm{HD}$} \\
\hline \multicolumn{10}{|c|}{ 24h / 24h HD } \\
\hline \multicolumn{10}{|c|}{ Clan / Clan HD } \\
\hline \multicolumn{10}{|c|}{ Teledeporte / Teledeporte HD } \\
\hline \multicolumn{10}{|c|}{ ATRESMEDIA TELEVISIÓN } \\
\hline 2010 & 2011 & 2012 & 2013 & 2014 & 2015 & 2016 & 2017 & 2018 & 2019 \\
\hline \multicolumn{10}{|c|}{ Antena 3 / Antena 3 HD } \\
\hline \multicolumn{10}{|c|}{ La Sexta / La Sexta HD } \\
\hline \multicolumn{10}{|c|}{ Antena.Neox / Neox ${ }^{12}$} \\
\hline \multicolumn{10}{|c|}{ Antena.Nova / Nova ${ }^{13}$} \\
\hline \multicolumn{10}{|c|}{ Nitro } \\
\hline \multicolumn{5}{|c|}{ Gol TV $^{14}$} & \multicolumn{5}{|c|}{ Mega } \\
\hline & a Sexta 2 & & & & & & & & \\
\hline \multicolumn{10}{|c|}{ La Sexta 3 / La Sexta 3 Todo Cine ${ }^{15}$} \\
\hline \multirow{2}{*}{\multicolumn{10}{|c|}{ MEDIASET ESPAÑA }} \\
\hline & & & & & & & & & \\
\hline 2010 & 2011 & 2012 & 2013 & 2014 & 2015 & 2016 & 2017 & 2018 & 2019 \\
\hline \multicolumn{10}{|c|}{ Telecinco / Telecinco HD } \\
\hline \multicolumn{10}{|c|}{ Cuatro / Cuatro HD } \\
\hline \multicolumn{10}{|c|}{ FDF } \\
\hline & & La Siet & & & & & & & \\
\hline
\end{tabular}

\footnotetext{
${ }^{12}$ El 6 de agosto de 2010, Antena.Neox cambia su nombre por Neox.

${ }^{13}$ El 6 de agosto de 2010, Antena.Nova cambia su nombre por Nova.

${ }^{14} \mathrm{Gol} \mathrm{TV}$, que sustituyó a Hogar 10, fue un canal de pago.

${ }^{15}$ El 28 de febrero de 2011, La Sexta 3 cambia su nombre por la Sexta 3 Todo Cine.
} 


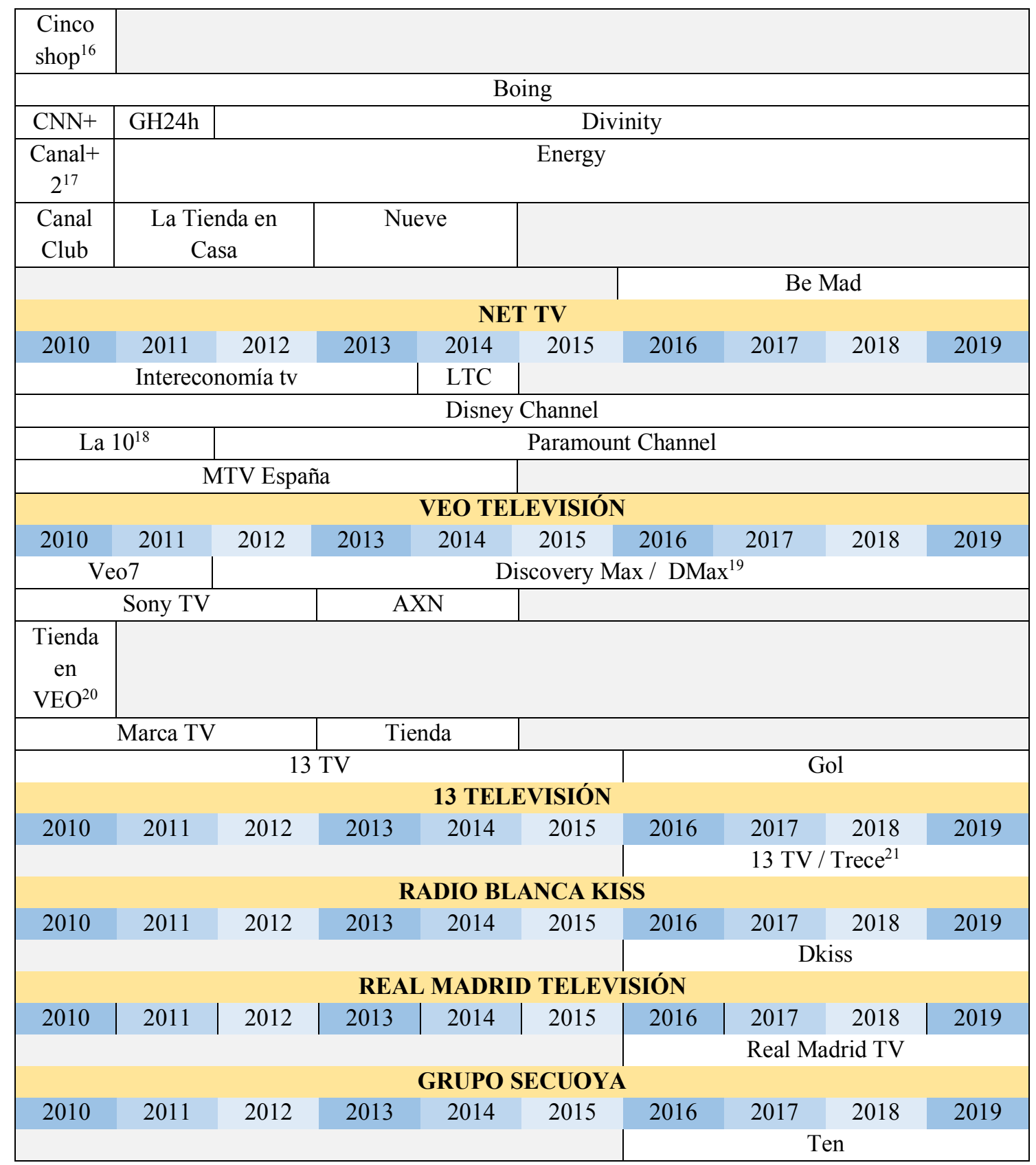

TABLA 6. Televisión en abierto en España durante la segunda década del siglo XXI.

FUENTE: Elaboración propia a partir de diversas fuentes.

${ }^{16}$ El canal de teletienda Cincoshop dejó de emitirse el 30 de septiembre de 2010 debido a que la aparición de Boing (1 de septiembre de 2010) provocó que Telecinco reuniera 5 canales (Telecinco, FDF, La Siete, Cincoshop y Boing), uno más del permitido, por lo que el Ministerio de Industria, Turismo y Comercio pidió su retirada.

${ }^{17}$ Canal+2 fue un canal de pago que sustituyó en 2010 a 40 latino (véase tabla 5).

${ }^{18}$ Del 1 de enero de 2012 al 22 de marzo de 2012, entre La 10 y Paramount Channel, se emitió La Tienda en Casa.

${ }^{19}$ El 12 de septiembre de 2016, Discovery Max cambia su nombre por DMax.

${ }^{20}$ El canal de teletienda Tienda en VEO dejó de emitirse el 21 de diciembre de 2010 debido a que la aparición de Marca TV y 13 TV hacía que Veo Televisión tuviera, a fecha de 2010, 5 canales, uno más del permitido, por lo que el Ministerio de Industria, Turismo y Comercio pidió su retirada.

${ }^{21}$ El 11 de septiembre de 2017, 13 TV cambia su nombre por Trece. 


\subsection{Canales de televisión temáticos segregados por género}

La implantación de la TDT ha traído consigo la presencia de los canales temáticos especializados en la televisión en abierto en España. A la hora de diseñar la oferta temática, los grupos comunicacionales pretendieron completar la programación generalista de los canales principales. Así, orientaron sus contenidos para llegar a públicos segmentados en función de la edad — canales infantiles como Boing y Clan-, del sexo - hay quienes se enfocan en un target femenino, es el caso de Nova, o masculino, Energy_ o de los diferentes intereses mediáticos de consumo —informativos, el canal 24h, deportivos, la cadena Teledeporte, etc._- (Quintas y DíazGonzález, 2014: 723).

Lo cierto es que desde el nacimiento de la televisión, en 1956, hasta prácticamente medio siglo después, 2005, no encontramos ningún canal temático en abierto. Cuando a cada grupo comunicacional se le adjudica un multiplex (compuesto por cuatro frecuencias) y comienza a configurar su oferta, la televisión sufre un proceso de especialización a gran escala. La siguiente tabla recoge los canales que han ido sucediéndose a lo largo de la historia televisiva española y la naturaleza de los mismos.

\begin{tabular}{|l|cl|}
\hline \multicolumn{3}{|c|}{ TIPOLOGÍA DE LOS CANALES TELEVISIVOS EN ABIERTO EN ESPAÑA (1956-2019) } \\
\hline Generalistas $^{22}$ & $1956-$ & TVE / TVE1 / La 1 \\
$1966-$ & UHF / TVE2 / La 2 \\
$1990-$ & Antena 3 \\
$1990-$ & Telecinco \\
& $2002-2008$ & Net TV \\
$2002-2012$ & Veo TV / Veo 7 \\
$2005-$ & Cuatro \\
$2005-$ & La Sexta \\
& $2005-2014$ & Intereconomía (especializado en contenidos económicos, \\
& & políticos, sociales y deportivos. Dejo de emitirse durante el 2007 \\
& y luego apareció de nuevo hasta el 2014) \\
& $2010-2012$ & La 10 \\
& $2010-$ & 13 TV \\
& $2016-$ & Ten (enfocado a un público familiar, apuesta por los contenidos \\
& & de entretenimiento) \\
\hline Ficción seriada & $2005-$ & Antena.Neox / Neox (enfocado a un público juvenil, también \\
& incluye programas de entretenimiento) \\
& $2008-$ & FDF \\
& $2016-$ & Atreseries \\
\hline
\end{tabular}

22 Entre su programación destacan los informativos, magazines, el cine, las series de ficción, el humor, entretenimiento, los documentales y la telerrealidad. 


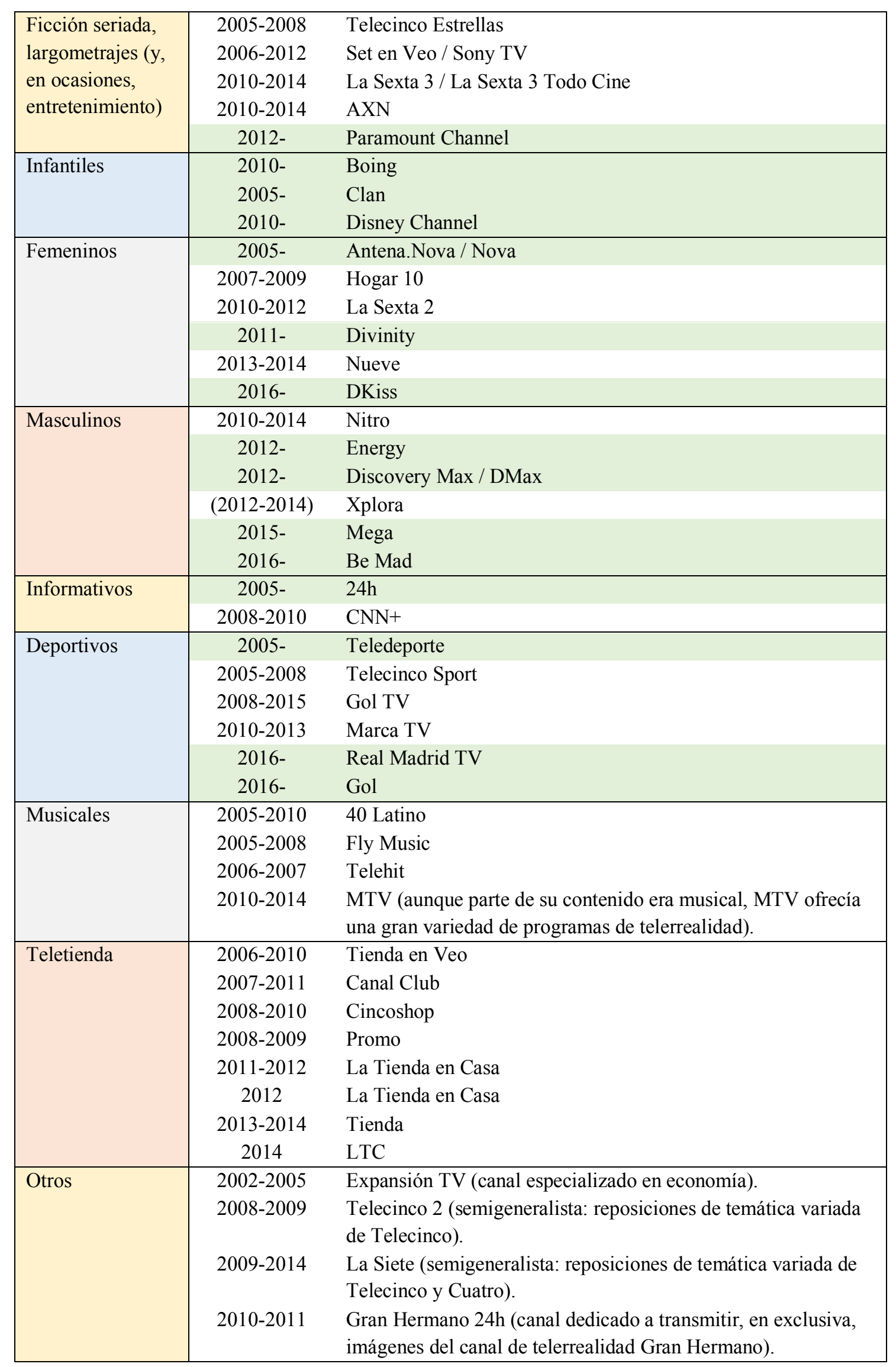

Tabla 7. Tipología de los canales televisivos en abierto en España (1956-2019).

FUENTE: Elaboración propia a partir de diversas fuentes. 
En la tabla, se han marcado en verde las cadenas que podemos ver en la actualidad. Así, comprobamos que algunos de los primeros canales temáticos que surgieron todavía existen a día de hoy. Del 2005 sobreviven, de RTVE, 24h —proporciona contenidos informativos-, Teledeporte —especializado en deportes — y Clan —enfocado en un público infantil—. Atresmedia mantiene Neox —especializado en series y dirigido a una audiencia joven—y Nova — que busca llegar a un público femenino-. También, de 2008, se mantiene FDF, de Mediaset España, que ofrece series y que ha conseguido las mejores cuotas de pantalla de los canales temáticos, con un 3,5 tanto en 2014 como en 2015.

El resto de canales que aparecieron en aquella primera etapa han desparecido. No han triunfado ni los musicales, como 40 latino (Sogecuatro), o Fly Music, (Net TV), ambos del 2005, y, aunque ha habido hasta 2 intentos más por parte de los distintos grupos mediáticos — Telehit (La Sexta) y Mtv (Net TV)—, a día de hoy ya no vemos ningún canal de este tipo en nuestra pantalla. Tampoco los especializados en la televenta han corrido mejor suerte. Han sido ocho canales repartidos entre Sogecuatro, Gestelevisión —posteriormente Mediaset—, Net TV y Veo Televisión. Actualmente, encontramos venta en distintos espacios y franjas horarias, pero ya no existen canales completos dedicados a ello.

De los canales que surgieron desde 2010, que ocurrió el apagón analógico hasta que en 2014 se pronunciara la sentencia del Tribunal Supremo que obligara a cerrar 9 frecuencias por irregularidades en la concesión, todavía permanecen: $13 \mathrm{TV} \longrightarrow$ canal generalista de la Conferencia Episcopal, que primero emitía alquilando la frecuencia en Veo Televisión hasta que, en 2016, pudo hacerlo a través de su propia frecuencia-, Paramount Channel, de Net TV, —especializado en películas, aunque también ofrece series - Boing, de Mediaset, y Disney Channel, de Net TV — ambos dirigidos a un público infantil—, Divinity, de Mediaset — pensado para ser consumido por mujeres—, y, por último, Energy, de Mediaset, y DMax, de Veo Televisión, que están enfocados a un público masculino.

Finalmente, en la última etapa de la TDT, aparecen ocho canales que todavía hoy se encuentran en antena: Real Madrid TV, de Real Madrid Televisión, y Gol, de Veo Televisión, son dos canales que refuerzan la oferta deportiva; Atreseries, de Atresmedia, está especializado en la ficción seriada; Ten, del Grupo Secuoya, se considera generalista 
y nace con la intención de ofrecer contenidos de entretenimiento a todos los tipos de público; DKiss, de Radio Blanca, es un canal pensado para una audiencia femenina y Mega, de Atresmedia, y Be Mad, de Mediaset, son canales orientados a un público masculino.

\begin{tabular}{|c|c|c|c|c|}
\hline \multicolumn{5}{|c|}{ CANALES TELEVISIVOS EN ABIERTO EN ESPAÑA (2019) } \\
\hline Temática & $\begin{array}{c}\text { Año de } \\
\text { fundación }\end{array}$ & Nombre & $\begin{array}{l}\text { Grupo } \\
\text { comunicacional }\end{array}$ & $\begin{array}{c}\text { Audiencia } \\
2018\end{array}$ \\
\hline \multirow{8}{*}{ Generalistas } & $1956-$ & $\mathrm{La} 1 / \mathrm{La} 1 \mathrm{HD}$ & RTVE & 10,5 \\
\hline & 1966- & $\mathrm{La} 2 / \mathrm{La} 2 \mathrm{HD}$ & RTVE & 2,7 \\
\hline & $1990-$ & Antena 3 / Antena $3 \mathrm{HD}$ & Atresmedia & 12,3 \\
\hline & $1990-$ & Telecinco / Telecinco HD & Mediaset & 14,1 \\
\hline & $2005-$ & Cuatro / Cuatro HD & Mediaset & 6,0 \\
\hline & 2005- & La Sexta / La Sexta HD & Atresmedia & 6,9 \\
\hline & 2016- & $13 \mathrm{TV}$ & 13 Televisión & 2,0 \\
\hline & 2016- & Ten & Secuoya & 0,3 \\
\hline \multirow{4}{*}{$\begin{array}{l}\text { Ficción (series, } \\
\text { en algunos casos } \\
\text { largometrajes y } \\
\text { algo de } \\
\text { entretenimiento) }\end{array}$} & 2005- & Neox & Atresmedia & 2,4 \\
\hline & $2008-$ & FDF & Mediaset & 2,9 \\
\hline & 2012- & Paramount Channel & Net TV & 1,2 \\
\hline & 2016- & Atreseries & Atresmedia & 1,8 \\
\hline \multirow[t]{3}{*}{ Infantiles } & $2010-$ & Boing & Mediaset & 1,3 \\
\hline & 2005- & Clan / Clan HD & RTVE & 1,8 \\
\hline & $2010-$ & Disney Channel & Net TV & 1,2 \\
\hline \multirow[t]{3}{*}{ Femeninos } & 2005- & Nova & Atresmedia & 2,4 \\
\hline & $2011-$ & Divinity & Mediaset & 2,0 \\
\hline & 2016- & DKiss & Radio Blanca & 0,8 \\
\hline \multirow[t]{4}{*}{ Masculinos } & $2012-$ & Energy & Mediaset & 1,9 \\
\hline & 2012- & DMax & Veo Televisión & 1,6 \\
\hline & 2015- & Mega & Atresmedia & 1,6 \\
\hline & 2016- & Be Mad & Mediaset & 0,6 \\
\hline Informativos & $2005-$ & $24 \mathrm{~h}$ & RTVE & 0,9 \\
\hline \multirow[t]{3}{*}{ Deportivos } & $2005-$ & Teledeporte / Teledeporte HD & RTVE & 0,6 \\
\hline & $2016-$ & Real Madrid TV & Real Madrid TV & 0,3 \\
\hline & 2016- & Gol & Veo Televisión & 1,0 \\
\hline
\end{tabular}

TABLA 8. Tipología de los canales televisivos en abierto en España (2019).

FUENTE: Elaboración propia a partir de diversas fuentes.

A día de hoy, los grupos comunicacionales han especializado su oferta en función de la edad — vemos los canales infantiles Boing, Clan y Disney Channel—; del género, —encontramos los femeninos Nova, Divinity y Dkiss y los masculinos Energy, DMax, Mega y Be Mad—; y de los distintos intereses mediáticos: canales de ficción —Neox, 
FDF, Paramount Channel y Atreseries_- deportivos - Teledeporte, Real Madrid TV y Gol— e informativos —-24h—. De entre las cadenas más vistas destacan FDF $(2,9)$ y Neox $(2,4)$, ambas producen ficción, y Nova $(2,4)$, femenina. En cuanto al bloque de contenidos completo, la clasificación por audiencia quedaría de la siguiente manera: ficción $(2,07)$, femeninos $(1,73)$, infantiles $(1,43)$, masculinos $(1,42)$, informativos $(0,9)$ $\mathrm{y}$, finalmente, deportivos $(0,63)$.

Como esta investigación centra sus esfuerzos en analizar los productos mediáticos segregados en función del género, es imprescindible que hablemos, con un poco más de detenimiento, de los canales femeninos y masculinos. A la hora de configurar la oferta televisiva y especializar sus contenidos, los grupos comunicacionales acotan, entre otras, el sector poblacional al que quieren dirigirse. En el caso concreto de los canales segregados por género, existe una intencionalidad, por parte de las cadenas, de apelar a uno de los dos sexos. Así, se crean imágenes corporativas que se ajustan a los estándares de la feminidad y la masculinidad, a través, por ejemplo, del uso de los colores (véase imagen 1), además, los propios grupos mediáticos incluyen una llamada a las mujeres o a los hombres en las descripciones que elaboran de sus cadenas y/o encontramos declaraciones de las esferas directivas haciendo mención al target.
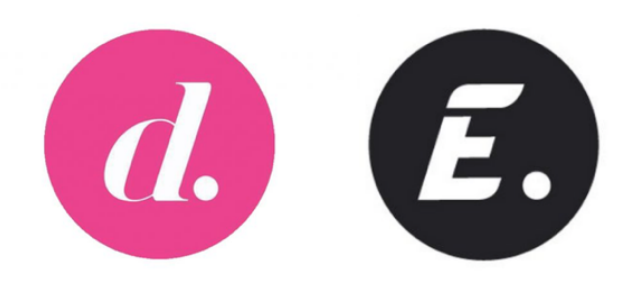

IMAGEN 1. Logotipo del canal femenino Divinity y del masculino Energy, ambos de Mediaset. FuENTE: Mediaset España.

Cuando nació Nitro, la primera cadena intencionalmente masculina, Bernd Reichart, director de canales digitales del grupo Antena 3 Televisión, aseguraba querer "reducir un poco el desnivel que existe a favor de las mujeres [pues las mujeres contaban con el canal de Nova]. No funcionamos por estereotipos, así que esta nueva parrilla no va a estar dominada por las artes marciales, los deportes de contacto en directo ni la noche 
Playboy". ${ }^{23}$ Por su lado, el cierre de Nitro y Xplora, en 2014, dejó un hueco que Atresmedia quiso cubrir con Mega: "la realidad es que ciertos contenidos perfilan más a un público masculino [...] los factual de negocios tienden a perfilar audiencia más masculina y los de decoración, más femenina”, ${ }^{24}$ aseguraba José Antonio Antón, director de Programación y Canales Temáticos de Atresmedia, al referirse a la programación que ofrecería Mega.

Mientras, en la fundación de Divinity, Mediaset declaró dirigirse a las "mujeres de 16 a 44 años que viven en las ciudades y que gozan de un nivel socio-económico alto o medio-alto". ${ }^{25}$ Lo mismo escuchamos durante la presentación de uno de los últimos canales que aterrizó en nuestras pantallas, DKiss: "nuestro objetivo es buscar huecos. Hicimos un análisis de mercado y detectamos que el modelo de programación femenino era el menos utilizado", ${ }^{26}$ aseguró Susana Ortega, directora de programación.

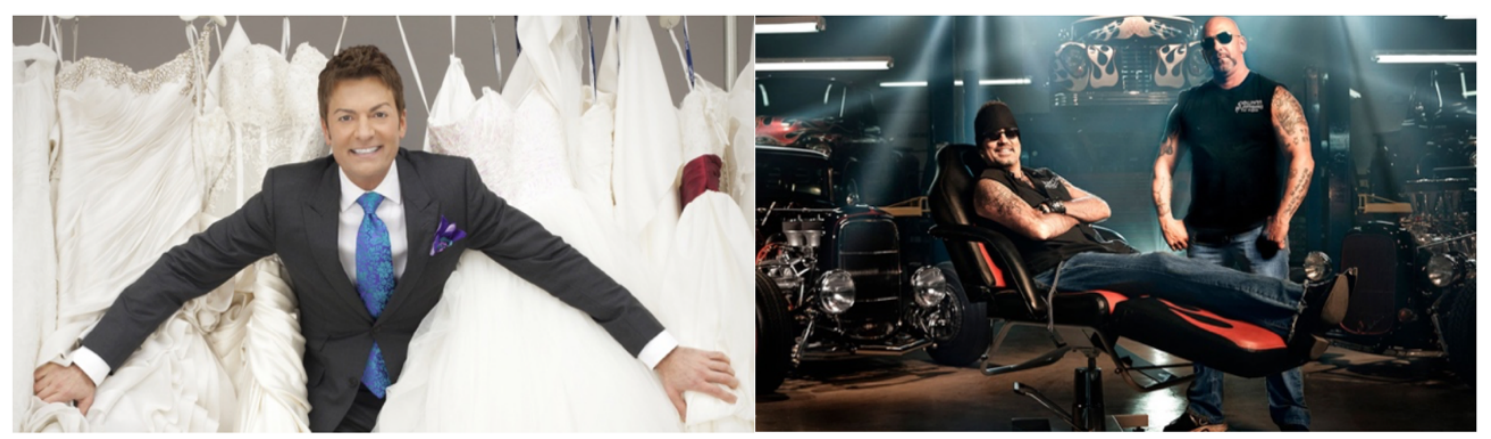

IMAGEN 2. A la izquierda, programa Sí, quiero ese vestido del canal femenino DKiss y, a la derecha, Locos por los coches del canal masculino Mega.

Fuente: Grupo Radio Blanca y Atresmedia.

En cuanto a sus contenidos, estos productos van a recoger los gustos, intereses, preferencias derivadas de la socialización diferencial entre hombres y mujeres. A través de su programación, van a retratar el universo simbólico femenino y el universo simbólico masculino, con el fin de que la asimilación y decodificación del mensaje por parte de uno

\footnotetext{
${ }^{23}$ Véase información publicada el 16 de julio de 2010 en La Vanguardia: "Las teles insisten en la audiencia femenina". Recuperado el 11 de junio de 2019 de https://www.lavanguardia.com

${ }^{24}$ Véase información publicada el 11 de julio de 2016 en El Mundo: "Canales de mujeres, hombres y viceversa". Recuperado el 13 de junio de 2019 de https://www.elmundo.es

${ }^{25}$ Véase información publicada el 31 de marzo de 2011 en 20 minutos: "Telecinco arranca Divinity su nuevo canal para mujeres". Recuperado el 13 de junio de 2019 de https://www.20minutos.es

26 Véase información publicada el 11 de julio de 2016 en El Mundo: "Canales de mujeres, hombres y viceversa". Recuperado el 13 de junio de 2019 de https://www.elmundo.es
} 
u otro sexo sea sencilla y agradable. Lo veremos en las siguientes páginas y a lo largo de nuestra investigación, pero en los canales femeninos encontraremos hogar, moda, belleza, drama, romance, relaciones, etc. y en los masculinos aventura, riesgo, naturaleza, supervivencia, deportes, acción, misterio, violencia...

Aunque hoy existan tres canales femeninos y cuatro masculinos, lo cierto es que, en total, se han sucedido 6 canales enfocados a atraer a las mujeres y 6 enfocados a atraer a los hombres. El nacimiento de Nova (Atresmedia, 2005-) marcó el inicio de los femeninos y, a partir de ahí, se sucedieron Hogar 10 (La Sexta, 2007-2009), La Sexta 2 (Atresmedia, 2010-2012), Divinity (Mediaset, 2011-), Nueve (Mediaset, 2012-2014) y Dkiss (Radio Blanca, 2016-). En cuanto a los masculinos, el primero fue Nitro (Atresmedia, 2010-2014), posteriormente aparecieron Energy (Mediaset, 2012-), DMax (Veo Televisión, 2012-), Xplora (Atresmedia, 2012-2014), Mega (Atresmedia, 2015-) y Be Mad (Mediaset, 2016-).

Nova supuso el comienzo de los canales femeninos. Antena 3 Televisión, en su página web, contaba que atendía, principalmente, a un target compuesto por mujeres. Un estudio publicado en el año 2011 nos explica que en su contenido predominan las series de ficción, esencialmente telenovelas - las cuales ocupaban 48,5 horas de emisión semanales, siendo estas el contenido de más peso del canal—. También, vemos programas de cocina — Cocina con Bruno, Karlos Arguiñano en tu cocina—, espacios de cuidado y mantenimiento de la casa —Bricomanía, Hogar, sucio hogar-, de moda y belleza-Yo dona, el armario de Josie y Fiona — o de tarot —aunque estos se sitúan a horas de baja audiencia- En menor medida se emiten largometrajes, programas de viaje, salud, contenidos informativos y culturales (González de Garay y Alfeo, 2011: 400-402).

Hubo que esperar cinco años hasta que apareciese el primer canal masculino y lo hizo de nuevo Atresmedia lanzando, el 23 de agosto de 2010, Nitro. Dentro de su programación, y siguiendo el mismo estudio del año 2011, vemos que predominan las series policiacas, con más de 60 horas semanales; los programas tipo zapping, que están elaborados a raíz de fragmentos de otros programas y tienen el objetivo de entretener mediante la risa, el asombro, etc. —aunque se emitían a horas de baja audiencia, con lo cual su importancia para la cadena no es tal—; las series de ciencia ficción, con más de veinte horas semanales; el cine — principalmente de acción—; los programas de desastres o de violencia —Impacto total, 100 manera de morir-; los animales —Zoorprendete-; 
y los deportes completan la programación del canal (González de Garay y Alfeo, 2011: 403-405).

A la hora de diseñar la programación, existen diferencias básicas. El producto estrella de Nova son las telenovelas, mientras que el género predominante en Nitro son las series policiacas. Tampoco ninguno de los programas o películas que se emiten en uno de los canales se repite en el otro. La programación se construye por una especie de oposición donde predomina, por un lado la dimensión interior, el mundo de los sentimientos y la esfera privada en los canales femeninos y, por el otro, la acción y el mundo exterior en los canales masculinos (González de Garay y Alfeo, 2011: 406-407).

Esta división refleja también las trayectorias que tomaron el resto de canales especializados por sexos. Los primeros en aparecer fueron los femeninos. Nova, como bien hemos mencionado, lo hizo en 2005. Posteriormente, en 2007 y hasta 2009, permaneció en antena el canal Hogar 10, de Gestora de Inversiones Audiovisuales La Sexta. Hogar 10 contaba con una programación que ofertaba telenovelas, telecomedias, concursos, cocina, salud y belleza, entre otros (Videla y Costa, 2012: 44). Un año después de que este cesara, en 2010, el mismo grupo comunicacional lo intentó con La Sexta 2. Como sucesora de Hogar 10, en su parrilla abundaban los programas de estilo de vida, entre los que destacaban los de cocina — Hoy cocinas tú, Salud a la carta-. El docureality, mezcla de documental y espectáculo, era la otra gran apuesta de la Sexta 2 (Videla y Costa, 2012: 60). Este cesó sus emisiones en 2012 y fue sustituido por el canal Xplora.

Mediaset, que todavía no había probado suerte con los canales segregados por género, lanzó Divinity el 1 de marzo de 2011. La base de la programación de este canal, que se diseñó para la audiencia femenina, ${ }^{27}$ era la fícción — series y cine- y los programas de telerrealidad (Albújar, 2014: 81). Buscaba llegar a un público más joven que el de Nova, su competidora directa, por ello, incluye espacios de temática fresca: presenta una programación marcadamente centrada en la crónica social, con el programa Cazamariposas como ejemplo paradigmático, además, incluye resúmenes de reality shows en emisión en esos momentos en Cuatro y en Telecinco y la reposición constante de series norteamericanas (Alonso, 2017: 162). Un año más tarde, el 31 de diciembre de 2012, comenzaron las emisiones de Nueve, también del grupo Mediaset, en este caso

\footnotetext{
27 Véase información de la página web de Mediaset España. Recuperado el 11 de junio de 2019 de https://www.mediaset.es/Conocenos_0_2463300660.html
} 
centrado en las telenovelas y en la ficción en general (Albújar, 2014: 81). Nueve fue una de las frecuencias que desapareció a raíz de la Sentencia del Tribunal Supremo en 2014.

Finalmente, el 28 de abril de 2016 aparece Dkiss, la apuesta televisiva de Radio Blanca. Su programación está destinada principalmente al público femenino joven-adulto (Guillán, 2017: 23). Su oferta se centra en los contenidos de telerrealidad —reality show y docu-reality —, algunos de conocido éxito fuera de nuestras fronteras (Fuenfría, 2017: 27). Dentro de su página web, ordena los contenidos en las siguientes categorías: belleza, cocina, familia, hogar, investigación, relaciones, salud y otros. ${ }^{28}$ Cada una de las pestañas está compuesta por programas de telerrealidad como Entre pasteles, Belleza en crisis, Embarazada a los 16, La reforma de tus sueños o Mi vida con 300 kilos.

En cuanto a los masculinos, después de la aparición de Nitro en 2010, llegó Energy, de Mediaset España, el 9 de enero de 2012. Mediaset, que ya contaba con el canal femenino Divinity, decidió apostar por uno masculino e incluyó entre sus espacios cine, deportes y docu-realities, aunque en esta última etapa ha virado hacia una parrilla basada en los productos de ficción, dejando de lado la telerrealidad tan característica de sus primeros años (Alonso, 2017: 162). En 2013, recoge su programación bajo una serie de etiquetas: Wildlife, Extreme, Speed, Food, Auction, Attitude, Travel, Sport, Series de élite, Cinergetic... Dentro de cada grupo, podemos ver, entre otros, contenidos de riesgo, aventura, naturaleza, motor, gastronomía, subastas, viajes, deportes y ficción. $^{29}$ Actualmente, ha centrado su contenido en la ficción, siendo su eslogan Las series nos hacen grandes y ofreciendo series de acción, ciencia ficción y terror, junto a largometrajes de acción. Su target sigue siendo el público masculino. ${ }^{30}$

Ese mismo año, tan solo tres días más tarde, el 12 de enero de 2012, Discovery Max, empezó a emitir en una de las frecuencias operadas por Veo Televisión. Nace como un canal masculino, centrado en un segmento de edad entre 25 y 44 años. Este canal se especializó en telerrealidad, dejando de lado por completo la ficción. Sus programas mostraban deportes extremos, motor, desastres naturales, cocina, construcción, ciencia, naturaleza, historia (Videla y Costa, 2012: 59; Albújar, 2014: 110). En septiembre de

\footnotetext{
${ }^{28}$ Véase información publicada en la página web de Dkiss. Recuperado el 19 de junio de 2019 de http://www.dkiss.es

${ }^{29}$ Véase información publicada en Mundoplus.TV en noviembre de 2013: "Energy presenta su nueva imagen on air y una batería de estrenos en su parrilla de programación”. Recuperado el 19 de junio de 2019 de https://www.mundoplus.tv/noticias/?seccion=tv_digital\&id=10387

${ }^{30}$ Véase información publicada en la página web de Mediaset. Recuperado el 19 de junio de 2019 de https://www.mediaset.es/Conocenos_0_2463300660.html
} 
2016 Discovery Max pasó a llamarse DMax, además, empezó a incluir en su parrilla contenidos de ficción, series y largometrajes. ${ }^{31}$ También, en ocasiones puntuales, su programación ha incluido retransmisiones deportivas (Alonso, 2017: 163).

Xplora, del grupo Atresmedia, vino a sustituir, el 1 de mayo de 2012, a La Sexta 2 y se mantuvo en antena dos años hasta que la citada sentencia del Tribunal Supremo de 2014 obligó al cese de nueve frecuencias. Este canal, del grupo Atresmedia, ofertaba un contenido basado en documentales y cine documental (Guillán, 2017: 21) y estaba dirigido a un target masculino de entre 24 y 44 años (Videla y Costa, 2012: 59). Su eslogan era El canal para gente curiosa. Así, se especializó en los docu-realities que mostraban situaciones límite — como Carreteras del infierno — la vida extrema en la naturaleza, -Desafio bajo cero-, construcciones, - los programas Megaedificios o Ax men leñadores -, subastas, - La casa de empeños-, etc. Lo cierto es que la programación y el tipo de canal era bastante similar al de Discovery Max. ${ }^{32}$

Mega empezó a emitir el 1 de julio de 2015 en la frecuencia que el grupo Atresmedia tenía reservada, hasta un día antes, para el canal de Gol Televisión. A día de hoy, sigue en antena y su parrilla está compuesta por series y miniseries históricas, de acción, de misterio o de ciencia-ficción, telerrealidad, documentales, deporte, redifusiones y cine tanto nacional como internacional (Guillán, 2017: 23). Según José Antonio Antón, director de programación y canales temáticos de Atresmedia, la cadena está enfocada "a un hombre actual, moderno, con inquietudes y con ganas de divertirse". ${ }^{33}$ El canal presenta contenidos como los ya elegidos anteriormente por Atresmedia para completar la parrilla de Nitro y de Xplora.

Finalmente, el 21 de abril de 2016, comenzaron las emisiones de Be Mad del grupo Mediaset. Be Mad fue presentado como un canal de divulgación orientado a un público masculino. Gran parte de sus contenidos ya los emitía su canal hermano Energy (Bustamante y García, 2017: 29). La programación está compuesta por programas de

\footnotetext{
${ }^{31}$ Véase información publicada en El País el 9 de septiembre de 2016: "Discovery Max se transforma en Dmax". Recuperado el 19 de junio de 2019 de https://elpais.com

${ }^{32}$ Véase información publicada el 25 de abril de 2012 en ADSLZONE.TV: "Xplora: así es la programación del nuevo canal temático de documentales". Recuperado el 11 de junio de 2019 de https://www.adslzone.tv/2012/04/25/xplora-asi-es-la-programacion-del-nuevo-canal-tematico-dedocumentales/

${ }^{33}$ Véase información publicada el 1 de julio de 2015 en El País: "Mega, el nuevo canal masculino de Atresmedia Televisión". Recuperado el 11 de junio de 2019 de https://elpais.com
} 
telerrealidad del tipo factual, entretenimiento basado en hechos reales, y docu-realities, ${ }^{34}$ además de por eventos deportivos, tal y como vemos en su página web. Según explicó Paolo Vasile, consejero delegado de Mediaset España, el canal recoge "aventura, ciencia, historia, gastronomía, naturaleza y misterio". ${ }^{35}$ Algunos de sus programas son Veterinario al rescate, Construcciones imposibles, Chapuzas estéticas o El xef.

Así, tal y como adelantaban ya las conclusiones del estudio comparado entre la programación de Nova y de Nitro, los contenidos que ofrecen los canales femeninos y los canales masculinos dista de ser similar. Aunque los formatos explotados sean los mismos —docu-reality, factual, reality show, ficción seriada y largometrajes—, en los canales femeninos encontramos moda, belleza, estética, hogar, relaciones y, dentro de la ficción, las telenovelas o el drama tienen un peso muy relevante. Para los canales masculinos, sin embargo, vemos naturaleza, historia, misterio, deportes, situaciones extremas, gastronomía... en cuanto a la ficción, se explota la ciencia ficción o la acción. ${ }^{36}$

Si consideramos la recepción del público, obtienen mejores resultados los canales femeninos, aunque es una diferencia leve: la media de los canales orientados a las mujeres durante estos últimos diez años (2009-2018) presenta una cuota de pantalla de 1,33, mientras que los masculinos, de 1,25. Como ya hemos mencionado, los canales temáticos reúnen una audiencia baja, siendo los generalistas tradicionales los que siguen presentando las mejores cifras. Dentro de estas limitaciones, Nova consiguió una buena cuota de pantalla en el $2018(2,4)$, solo superada por FDF $(2,9)$ e igual que la de Neox. El siguiente mejor dato es para Divinity, con un 2,0, seguido de Energy, que presenta un 1,9 (véase tabla 2). Por tanto, dentro de la oferta temática, estos canales gozan de una cierta popularidad.

Los canales femeninos cuentan, por tanto, con Nova y Divinity, que ofrecen, dentro de las limitaciones temáticas, buenos resultados de audiencia. El más popular es Nova, solo superado en 2016 por Divinity (2,2 Nova frente a 2,3 Divinity), por otro lado, La Sexta 2 y Dkiss no han obtenido muy buenos resultados. La Sexta 2, que estuvo en pantalla entre 2010 y 2012, consiguió 0,1 el primer año, remontó algo en 2011 con un

\footnotetext{
${ }^{34}$ Véase información publicada en la página web de Mediaset. Recuperado el 11 de junio de 2019 de https://www.mediaset.es/Conocenos_0_2463300660.html

${ }^{35}$ Véase información publicada el 13 de abril de 2016 en Telemanía: "Be Mad, el canal de Mediaset España 360 grados, nace el 21 de abril”. Recuperado el 11 de junio de 2019 de https://www.mediaset.es

${ }^{36}$ En el trabajo de campo de esta investigación habrá un análisis más detallado de la programación de los canales que componen nuestra muestra.
} 
0,6, pero volvió a caer al año siguiente hasta el 0,2. Por su lado, Dkiss, el más nuevo de todos, se mueve en cifras inferiores a un punto: en 2016, el año de su fundación, apenas llegó al 0,4, subió a 0,9 el siguiente año y, en 2018, obtuvo un 0,8.

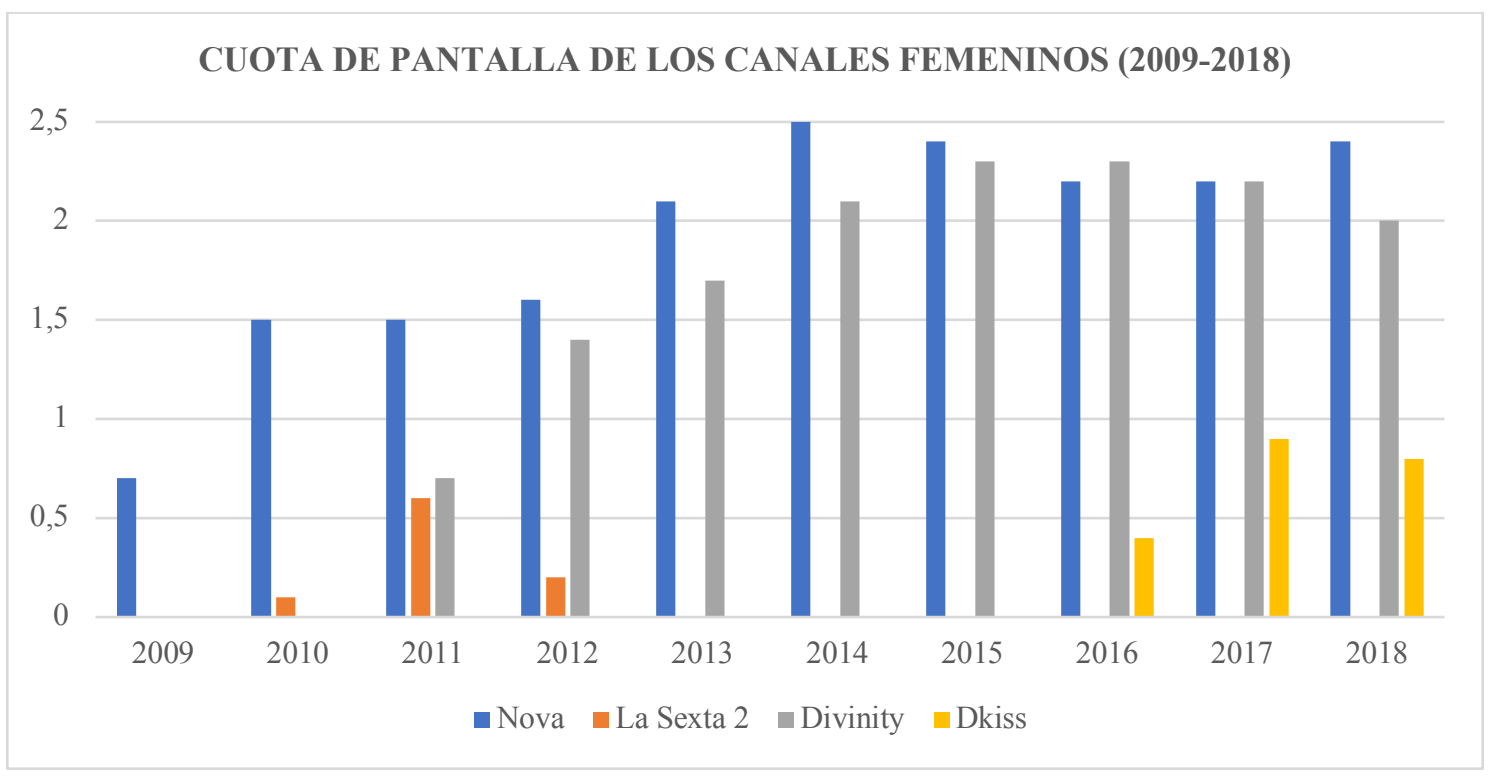

GrÁfiCo 8. Evolución de la cuota de pantalla de los canales televisivos femeninos entre los años 2009 y 2018. FuENTE: Elaboración propia a partir de datos de Barlovento Comunicación (2019a: 45).

Mientras, los canales masculinos han obtenido sus mejores resultados con DMax, que en 2014 y en 2015 llegó al 2,1 de cuota de pantalla. Nitro, hasta el momento de su desaparición, en 2014, estaba siendo líder, puntuando en 1,7 el año antes de su cierre. También Xplora consiguió un 1,7 ese mismo año, sin embargo, ambas frecuencias desaparecieron tras la sentencia del Tribunal Supremo de 2014. Por su lado, Energy igualó a DMax en 2016 y ha sido el más visto tanto en 2017 como en 2018.

Es reseñable que en 2016, justo cuando DMax y Energy igualaron audiencias, ambos habían reformulado su apuesta de contenidos. DMax, que hasta el momento no incluía ficción, pasó a ofrecer series y largometrajes, lo mismo que ocurrió con Energy, quién apostó, en mayor medida por los contenidos de ficción - aunque este, al contrario que DMax, sí los incluía anteriormente- Energy reformuló su imagen y empezó a denominarse "el canal de las series de verdad". ${ }^{37}$ También DMax dejó atrás su vieja

\footnotetext{
37 Véase información publicada el 18 de marzo de 2016 en El Español: "Energy renueva por completo su imagen: El canal de las series de verdad". Recuperado el 12 de junio de 2019 de https://www.elespanol.com/bluper/noticias/energy-renueva-imagen-canal-series-verdad
} 
imagen y transformó su nombre — hasta el momento Discovery Max-. Esta apuesta por los contenidos de ficción no fue bien recibida por la audiencia de DMax, que ha registrado un descenso de resultados desde 2016, sin embargo, no ha ocurrido lo mismo con Energy, el cual ha conseguido aumentar su audiencia siendo ahora el canal líder masculino.

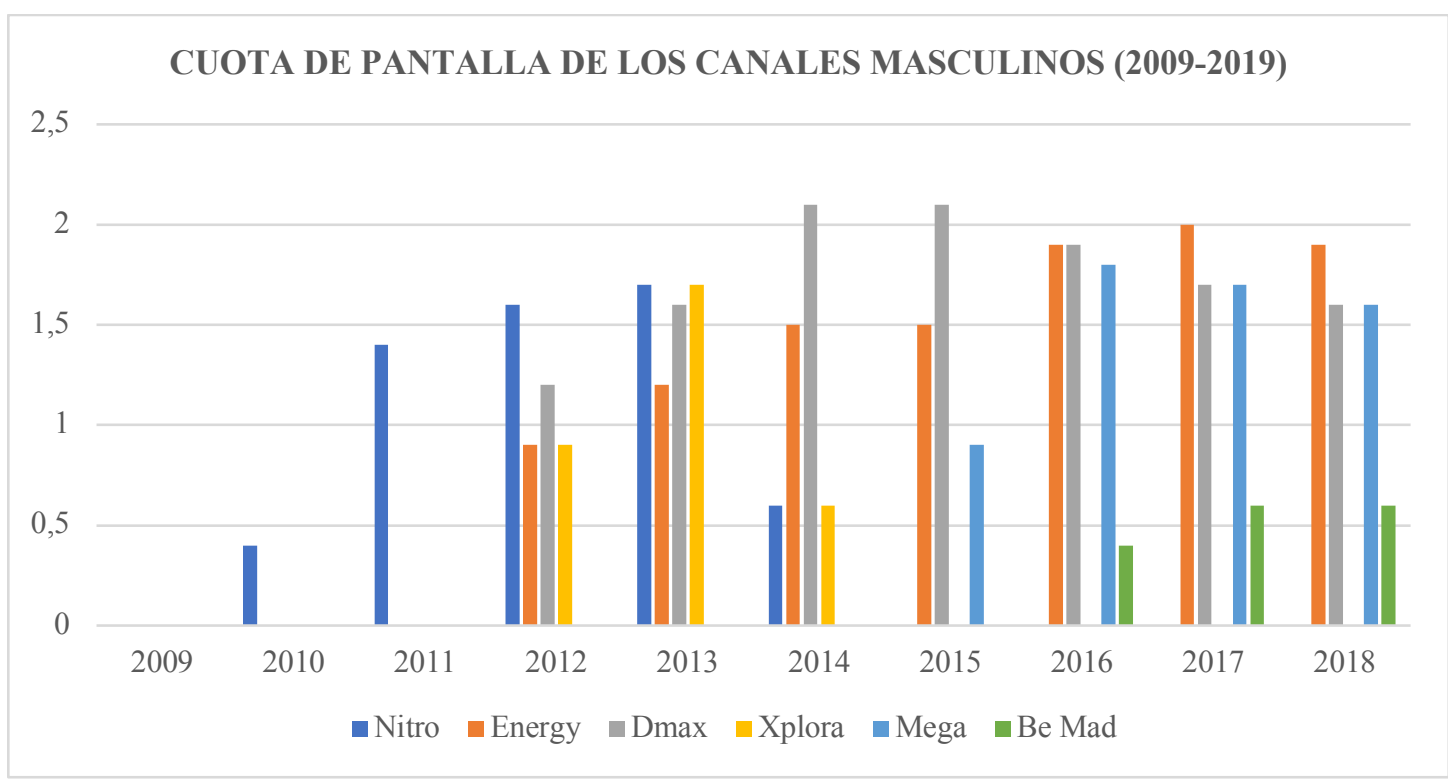

GrÁFiCo 9. Evolución de la cuota de pantalla de los canales televisivos masculinos entre los años 2009 y 2018. FuenTE: Elaboración propia a partir de datos de Barlovento Comunicación (2019a: 45).

Mega apareció en 2015 y, ya en su segundo año, registró cifras similares a las de DMax —ambos canales han conseguido 1,7 en 2017 y 1,6 en 2018- No corrió la misma suerte Be Mad, el cual se estrenó con un tímido 0,4 en 2016, y, en 2017 y en 2018 se ha mantenido con un 0,6. Por tanto, a excepción de Mega, que sí parece estar desafiando a sus competidores, los canales masculinos y femeninos que mejores resultados obtienen, están siendo, por ahora, los más veteranos.

Si nos centramos en el consumo por sexos, los últimos datos a los que tenemos acceso — informe de mayo de 2019 de Barlovento Comunicación—, revelan lo siguiente: Nova y Divinity registran un $73 \%$ de audiencia femenina, frente a un $27 \%$ de audiencia masculina, mientras, DKiss contempla un $62 \%$ de público femenino y un $38 \%$ de público masculino. Por su lado, DMax es visto en un $71 \%$ por hombres y en un $29 \%$ por mujeres y Mega en un $68 \%$ por hombres y en un $32 \%$ por mujeres. Be Mad es consumido al $50 \%$ por cada uno de los sexos y Energy, contrariamente a lo que pudiera pensarse, registra 
una audiencia en mayor medida femenina: 59\% de mujeres frente a $41 \%$ de hombres. Hemos consultado las audiencias de febrero, marzo y abril para ver si esta tendencia se repetía y, en los meses de febrero y abril, Energy fue visto en un $61 \%$ por mujeres y en un $39 \%$ por hombres, mientras que en marzo la cifra fue similar: $60 \%$ de mujeres, $40 \%$ de hombres. ${ }^{38}$

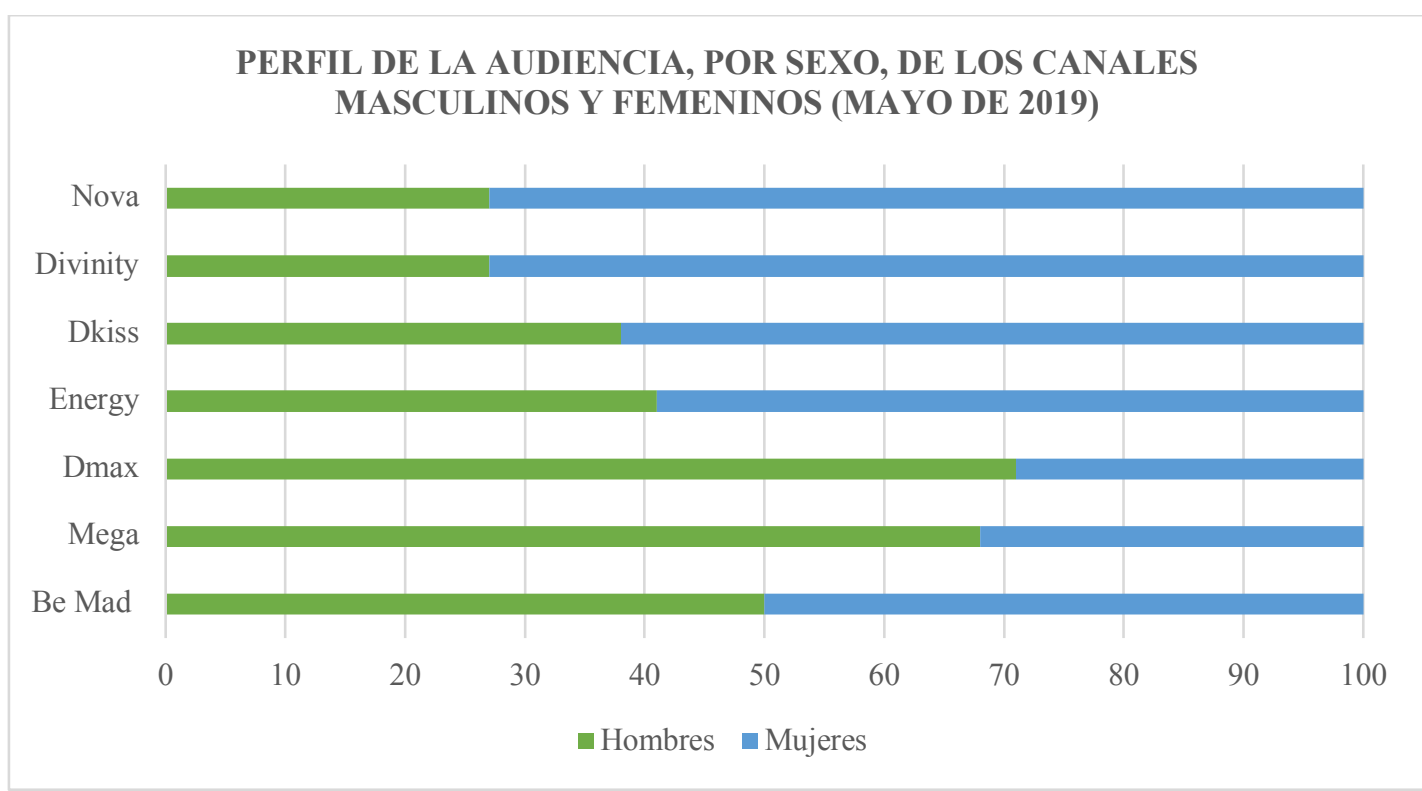

Gráfico 10. Perfil de la audiencia, por sexo, de los canales masculinos y femeninos (mayo de 2019). FueNTE: Elaboración propia a partir de datos de Barlovento Comunicación (2019b: 14).

En el caso de Divinity, Nova, Dkiss, DMax y Mega, el comportamiento de la audiencia es el esperado según su segmentación, sin embargo, no ocurre lo mismo con Be Mad y Energy. Aun con todo, ambos canales mantienen su intencionalidad masculina y así lo recoge el Ministerio de Economía y Empresa en su página web, que los describe de manera casi similar. De Energy dice ser "un canal destinado a un público principalmente masculino, joven y urbano" y, de Be Mad, un "canal dirigido a un público joven, masculino y urbano". ${ }^{39}$ Pese a ello, lo cierto es que este desequilibrio entre la intencionalidad y la audiencia resulta interesante y puede servir para futuras líneas de investigación.

\footnotetext{
${ }^{38}$ Véase información publicada en la página web de Barlovento Comunicación: "Audiencias mensuales". Recuperado el 26 de junio de 2019 de https://www.barloventocomunicacion.es/audiencias-mensuales/ 39 Véase información publicada en 2019 en la página web del Ministerio de Economía y Empresa. Recuperado el 13 de junio de 2019 de https:/www.televisiondigital.gob.es/tdt/paginas/canales-tdt.aspx
} 


\section{CAPÍTULO SEGUNDO. REPRESENTACIONES MEDIÁTICAS DE LA FEMINIDAD: LAS REVISTAS DE ESTILO DE VIDA DIRIGIDAS A MUJERES}

La nueva mujer dispuesta a hacer valer sus derechos es "anormal" precisamente porque los defiende. Una mujer "normal" abandona pasivamente en manos de un hombre la definición de su experiencia, para bien o para mal.

Susan Faludi

\section{CONSTRUCCIÓN MEDIÁTICA Y SOCIAL DE LA FEMINIDAD}

La feminidad normativa forma parte del esquema de percepciones de un orden simbólico, que, aunque construido bajo criterios patriarcales, se percibe socialmente desde la objetividad y se asume como un estándar natural (Mateos, 2013: 300). En este capítulo, veremos, precisamente, de qué manera las instituciones expanden un ideal femenino el cual, aunque en muchas ocasiones se encuentre alejado de la realidad cotidiana de millones de mujeres, es aceptado, socialmente, como lo que deber ser.

Estado y medios de comunicación han funcionado y funcionan de agentes reguladores en la construcción identitaria de las mujeres, por ello, en las siguientes páginas, se pondrán en consonancia los discursos de la feminidad históricos con los mediáticos, evidenciando de qué forma el segundo ha ido recogiendo los modelos del primero. Así, encontraremos que los medios de comunicación son instrumentos patriarcales que legitiman las representaciones femeninas válidas. Finalmente, este recorrido histórico-social y mediático desembocará en un análisis de la prensa femenina.

La prensa femenina lleva, desde que despegara en el siglo XIX, siendo uno de los soportes tradicionales de la feminidad. Ha reflejado las evoluciones del modelo normativo y, también, sus resistencias, dando cabida no solo a los discursos patriarcales, sino que ha servido de medio para extender, además, el pensamiento feminista. Sin embargo, como veremos a lo largo de las siguientes páginas, la producción que se repliega a los mandatos patriarcales ha sido infinitamente mayor que la crítica. A día de hoy, el modelo más representativo de prensa dirigida a mujeres es el de las revistas especializadas 
en estilo de vida femenino, que es con el que cerraremos este capítulo ya que, además, forma parte de nuestro trabajo de campo.

\subsection{Construyendo lo femenino}

En 1949, Simone de Beauvoir escribe su famosa obra El Segundo Sexo. En ella, teoriza sobre conceptos como el de mujer, hembra o feminidad. Al inicio del ensayo, realiza una reflexión muy interesante que permite, precisamente, cuestionarnos el alcance de esos tres términos:

Para empezar: ¿qué es una mujer? "Tota mulier in utero: es una matriz", dicen unos. Sin embargo, cuando hablan de algunas mujeres, los entendidos decretan: "No son mujeres", aunque tengan un útero como todas las demás. Todo el mundo está de acuerdo en reconocer que en la especie humana hay hembras; constituyen, ahora como siempre aproximadamente la mitad de la humanidad; sin embargo, se nos dice que "la feminidad está en peligro"; nos exhortan: "Sed mujeres, siempre mujeres, más mujeres". Por lo tanto, no todo ser humano hembra es necesariamente una mujer; necesita participar de esta realidad misteriosa y amenazada que es la feminidad. ¿Se trata de algo que segregan los ovarios? ¿Está colgada del cielo de Platón? ¿Bastarán unas enaguas susurrantes para que baje a la tierra? Aunque algunas mujeres se afanen en encarnarlo, el modelo nunca ha sido patentado (Beauvoir, 2008: 47-48).

La autora, pues, se pregunta porqué no todas las hembras son consideradas de igual modo mujeres y revela que la feminidad es clave a la hora de, socialmente, percibir a una mujer como tal. Es decir, para que una hembra humana sea digna de ser nombrada mujer deberá incorporar una serie de actitudes femeninas. Quizá su frase más famosa resuma mejor esto que intentamos decir: "no se nace mujer: se llega a serlo". En este sentido, argumenta "ningún destino biológico, psíquico, económico, define la imagen que reviste en el seno de la sociedad la hembra humana; el conjunto de la civilización elabora ese producto intermedio entre el macho y el castrado que se suele calificar de femenino" (Beauvoir, 2008: 371).

Lo cierto es que esta idea, lanzada en 1949, no es nueva para el feminismo. Distintas teóricas como Wollstonecraft o Harriet Taylor ya habían hecho hincapié en que no existían factores biológicos que justificaran la discriminación que sufrían las mujeres y diferenciaban entre el sexo y las construcciones culturales atribuidas al mismo (Varela, 2013: 86). Incluso antes, en 1640, Aphra Behn escribió varios ensayos y obras de teatro 
con las que denunciaba que los hombres se burlaran de la inferioridad intelectual de las mujeres, cuando eran ellos mismos quienes les prohibían estudiar. Olympe de Gouges, en 1768 —Declaración de los derechos de la mujer y la ciudadana-, o Mary Wollstonecraft, en 1792 —Vindicación de los derechos de la mujer-, también exponían que era la sociedad, y no la biología, la que incapacitaba a las mujeres física e intelectualmente (Facio y Fries, 2005: 269). Sin embargo, puede que el éxito de Beauvoir radique en que, como concluye Nuria Varela, le sirvió una sola frase para contextualizar, de manera profunda, sencilla y resumida, la realidad de las mujeres en el mundo, separando, así, la naturaleza de la cultura y profundizando en la idea de que el género es una construcción social (Varela, 2013: 86).

Cabe destacar que, aunque la filósofa Simone de Beauvoir ya hablara y diferenciara entre lo que hoy día conocemos como sexo y género, en ningún momento utilizó este último a lo largo de los cientos de páginas que componen su obra. Esto se debe a que la acepción actual de género es posterior a la autora: hasta mediados de los años 50 del siglo XX “el término género era patrimonio de la gramática y los estudios lingüísticos" (García-Mina, 2003: 15). Es más, todavía en 1986 el Diccionario de usos del inglés moderno recogía la siguiente definición: “género. Sólo un término gramatical. Referirse a personas o criaturas como de género femenino o masculino, es o bien un uso jocoso, o un error" (citado en Scott, 2011: 95).

A lo largo de la historia, son pocas las ocasiones en que esta palabra había sido usada como sinónimo de sexo. La cita más antigua la encontramos en una carta que M.W. Montagu envió a la señora Wortlye en el año 1709 donde decía "del bello sexo... mi único consuelo por ser de ese género ha sido la seguridad que me ha dado de que no me casaré nunca con alguien de él" (citado en García-Mina, 2003: 25). Obviando las pocas excepciones, y como ya recogían los diccionarios, el género era una categoría gramatical referida a sustantivos, artículos, adjetivos o pronombres. Fue John Money quien, en 1955 lo incluyó por vez primera en el lenguaje científico para hacer referencia a los comportamientos humanos. El psicólogo participaba de una visión progresista de la ciencia constituida después de la segunda guerra mundial y afirmaba, siguiendo la misma línea de Beauvoir, que la educación es la que hace al hombre o a la mujer (Fassin, 2011: 12).

John Money, en lugar de utilizar el término contemporáneo roles de sexo, hizo alusión a los roles de género para referirse a los modos de comportamiento, gustos, 
preferencias, formas de expresarse, de actuar, etc. que caracterizaban a la identidad masculina y femenina. Resignificó dicho término después de realizar unos estudios sobre la intersexualidad —en aquellos momentos conocida como hermafroditismo-, estudios que le revelaron la importancia del medio en los casos genitalmente dudosos: una hembra genética, gonadal y hormonal se experimentará a sí misma como varón si el entorno le trata como tal, es decir, si le visten, peinan y educan de acuerdo a los estándares de masculinidad de su cultura (Puleo, 2007: 16).

La nueva acepción que John Money había otorgado a la palabra género comenzó a extenderse de las ciencias médicas a las ciencias sociales e, incluso, al lenguaje de la calle. En 1968, el psiquiatra Robert Stoller formuló el concepto de identidad de género (Fernández y García-Vega, 2012: 556) y en la década de los setenta, el feminismo académico agregó dicho término a sus estudios, facilitando a las teóricas la denuncia del discurso naturalista que justificaba la discriminación de las mujeres. Sin embargo, como hemos mencionado, esta idea no era nueva. El feminismo ya repudiaba el hecho de que existieran dichos destinos biológicos que subordinaban a las mujeres y, al mismo tiempo, ponía en alza la idea de que la feminidad era un constructo social. Lo defendieron las distintas teóricas desde la Revolución Francesa hasta que, a mediados del siglo XX, Simone de Beauvoir sentenciara que "la civilización elabora ese producto intermedio entre el macho y el castrado" (2008: 371).

Respecto a la irrupción del género en la teoría feminista, la autora Ana GarcíaMina nos explica que para que las voces de los años setenta fueran escuchadas sin prejuicios ni descalificaciones, convinieron que era necesario disponer de un lenguaje legitimado desde el mismo seno de la ciencia el cual, además, no se encontrara marcado por el sesgo del androcentrismo (García-Mina, 2003: 50). Resulta del mismo modo interesante la reflexión que lanza la filósofa Fina Birules (1992) acerca de la aparición de del término en la teoría feminista: "ha constituido la vía a través de la cual los estudios sobre la mujer han entrado en la academia sin el molesto aguijón de la lucha feminista. De este modo, el término parece indicar seriedad, rigor..." (citado en Jayme y Sau, 2004: 55).

Así, fueron varias las autoras que desde finales de los años sesenta y durante la década de los setenta teorizaran acerca del género. Lo hizo Kate Millett con la obra Política Sexual (1969), Ann Oakley en su tratado Sexo, Género y Sociedad (1972), Gayle Rubin a través del ensayo El tráfico de mujeres: notas sobre la economía política del 
sexo (1975) o Natalie Davis en Women's history in transition: the European Case (1975) (García-Mina, 2003: 50-51). Además, el trabajo de estas y otras autoras consolidarán lo que conocemos como feminismo académico, esto es, corriente de pensamiento que, desde la academia, se propone explicar los factores que causan las opresiones de las mujeres (Estrada, 2009: 110).

Asistimos, pues, a través del trabajo de estas académicas, a la ruta teórica que trata de analizar cómo se construye la diferencia femenina y de qué manera esta construcción se superpone a la frontera puramente biológica entre los sexos. La aportación de Kate Millett, en 1969, defiende que la vida social está dividida en dos géneros —aunque ella aún los llamara categorías sexuales_- y que, en tanto son construidos, es necesario cuestionar la estratificación política y económica, la división sexual del trabajo, el reparto de roles y, en general, las categorías que habían articulado el pensamiento social y político tradicional (Posada, 2015: 30). Por su lado, Ann Oakley, en 1972, nos explica que "cada sociedad emplea el sexo biológico como un criterio para la adscripción del género [...] cree que sus propias definiciones de género corresponden a la dualidad de sexo biológico" (citado en Díaz-Andreu, 2015:15).

A Gayle Rubin (1975) se le atribuye la expresión del sistema sexo-género que es el conjunto de disposiciones por las cuales una cultura transforma la sexualidad biológica en productos humanos (Cobo, 2005: 252). En este sentido, Rubin evidencia que la sociedad acepta como realidades biológicas lo que son productos de la actividad humana y que existe una organización estructural en la que la subordinación de las mujeres es clave. Así, la cultura transforma la biología en unas prácticas determinadas: machos y hembras se convierten en hombres y mujeres, además, siempre bajo relaciones jerárquicas (Osborne y Molina, 2008: 151-153). Finalmente, cabe destacar la aportación de Natalie Davis (1975) quien toma el género como categoría de análisis que afecta y modifica las variables clase social y raza (García-Mina, 2003: 52).

Por lo tanto, el feminismo propone una transformación conceptual y metodológica del estudio de las relaciones sexuales, cuestionando la supuesta naturalidad que articula los comportamientos de hombres y mujeres y denunciando, además, las estrategias que legitiman la subordinación de las últimas. Separa la realidad material de la subjetiva y revisa los conceptos de feminidad y masculinidad. "Las estrategias discursivas de la alteridad de género, que reiteran visiones negativas, pueden favorecer no sólo la negación 
o la anulación y erosión cultural de las mujeres, sino también justificar prácticas discriminatorias" (Nash, 2006: 41).

Los estudios antropológicos desvelan que no existe un solo modelo de masculinidad y feminidad, que el desarrollo del mismo depende de la cultura y el momento histórico al que nos enfrentemos, sin embargo, tal y como apunta Kate Millett, encontramos una constante que se repite en todos ellos, y es que el estándar de masculinidad será altamente valorado frente al de feminidad, al cual no se le asocia ningún tipo de reconocimiento:

La antropología ha demostrado que existe una variabilidad casi infinita en el ámbito de la división de las funciones y del trabajo. A este respecto resulta muy revelador analizar el tipo de posición que suele asociarse con determinada ocupación. Tanto en una sociedad en la que el hombre teja y la mujer pesque, como en otra en la que el hombre pesque y la mujer teja, la actividad del varón gozará, de modo axiomático, de mayor prestigio y recibirá mayor remuneración, por hallarse ligada a un poder y a una posición sociales superiores (Millett, 2010: 394).

En este sentido, en la cultura occidental, en el siglo XIX, al sexo femenino se le exigía pasividad, recato y sumisión. Rousseau, un siglo antes, había definido a la mujer como una criatura viciosa y con defectos que "debe aprender a ser sumisa ante la injusticia y sufrir sin quejarse los males que su marido le inflija [...]. La amargura y la obstinación no hacen más que multiplicar los sufrimientos de la esposa y los malos tratos del marido" (citado en Bosch et al. 1999: 34). Rousseau no fue el único pensador, ni mucho menos, que escribió sobre la condición e inferioridad de las mujeres. Es más, la construcción cultural del modelo de feminidad del siglo XIX partía del propio Aristóteles que, entre otras, recomendaba la reclusión femenina de las mujeres en los hogares (Espigado, 2018: 197).

El discurso de esta época se basará en el de la complementariedad de los sexos. Los pensadores del momento defenderán que las diferencias primarias sexuales afectan a cada fibra del cuerpo y que esto conlleva profundas diferencias psíquicas y mentales: los hombres serán, por naturaleza, racionales, objetivos, creativos, agresivos y ambiciosos, mientras que las mujeres se presentarán sensibles, sentimentales, poco racionales, emocionales y compasivas: "el primero es excepcionalmente apto para la vida pública, para la vida de relación, para el comercio social; la segunda es, por esencia, el ángel del hogar" (citado en Jagoe, 1998: 30). 
El término ángel de hogar se relaciona directamente con el poema homónimo, The Angel in the House, del autor Coventry Patmore publicado en 1854 en Inglaterra, si bien su inspiración arranca de más atrás y se retrotrae hasta la creación del personaje femenino principal de la novela que Samuel Richardson, Pamela o la virtud recompensada, publicó en 1740. Sea como fuere, gozó de una rápida expansión y acompañó a los procesos culturales, sociales y políticos relacionados con el ascenso de la burguesía y la entrada a la nueva era moderna. Supuso, además, el anclaje necesario para la construcción del discurso de las esferas — pública y privada—, que, unido al pensamiento científico de la complementariedad de los sexos, ordenarían a hombres y mujeres y, al mismo tiempo, dinamitaría cualquier pretensión de igualdad entre los sexos, enmascarando el dominio de los varones y la falta de derechos y subordinación de las mujeres (Espigado, 2018: 196-197).

En este sentido, se desechó la creencia de que las mujeres fueran las imitaciones defectuosas de los hombres para asumirse que conformaban su complemento, articulando siempre el discurso en torno al sujeto dominante, varón, y convirtiéndose el sexo femenino en lo otro — concepto trabajado por la teórica Simone de Beauvoir (2008: 5051) - Dicha dualidad, que transciende lo meramente psicológico y llega a definir incluso el uso de espacios físicos, responde a cuestiones sociales que tienen que ver con el sistema de clases emergente, la definición de la burguesía como grupo o el incremento de la urbanización $\mathrm{y}$, aunque primeramente se esperara que fueran las mujeres burguesas quienes encarnaran al perfecto ángel del hogar —en oposición a las mujeres de la aristocracia y de las clases bajas — (Jagoe, 1994: 21), pronto este modelo traspasó las fronteras impuestas por los distintos estratos e impregnó, al menos idealmente, a toda una sociedad (Nash, 2008: 118).

El modelo de feminidad del siglo XIX lo encarnó, pues, la mujer que se recluía en el hogar cumpliendo con las ficciones del discurso de la domesticidad: "pura, angelical, inocente, asexuada y abnegada, esposa, madre y ama de casa" (Nash, 2004: 39). Este discurso, que en los países mediterráneos incorporó más rasgos de continuidad que de renovación, se vio reforzado por la iglesia católica, la cual dictaba códigos de conducta y normas, dibujaba retratos de familia e imágenes de la vida cotidiana con los que se servía para perfilar a la mujer virtuosa y hogareña, siempre centrada en la educación religiosa (Ramos, 2014: 24). Algunos de los textos de la época-como Lady's own book: a manual of intellectual improvement and moral deportment (El libro propio de una joven dama: 
un manual de mejora intelectual y de conducta moral), que se publicó en Filadelfia en 1836 - recogen la síntesis que de lo que se les exigía a las mujeres "una mujer debe ser doméstica. Su corazón debe estar en casa. Ella no debe buscar ningún tipo de emociones, pero debe encontrar su placer igual que su ocupación en la esfera que le es asignada" (citado en Belmonte, 2016: 46).

La base y fundamento de la educación que recibían las mujeres pasaba por el entrenamiento como esposas y madres futuras, responsables últimas del bienestar y la moralidad privada, así, la maternidad se alzaba, no ya sólo como un deber, sino como una sagrada misión (Palacios, 2007: 119). Precisamente, la autora Luz Sanfeliu nos explica que incluso la misma educación femenina reglada por el Estado era moral más que literaria y doméstica y privada más que pública y así fue durante el siglo XIX, a pesar de las reformas pertinentes, como la Ley de Instrucción Pública de 1857 —más conocida como Ley Moyano-, que seguía evidenciando que no existía el derecho de las mujeres a ser educadas, sino que sus obligaciones las encorsetaban en ámbitos privados y su destino era el de la maternidad (Sanfeliu, 2010: 88-89).

En el siglo XIX, asistimos, por tanto, a un juego de compensaciones, aunque se enarbola una narrativa de complementariedad de los sexos, el discurso de la domesticidad implica, para las mujeres, la imposibilidad de construirse a ellas mismas sino es en función del resto: al ser sus misiones las de esposa y madre, una mujer estará completa al lado de un hombre y durante la crianza. Además, las características relativas al modelo de masculinidad gozarán de un mayor prestigio, por lo que el mensaje social enaltecerá el destino de las mujeres con el fin de encubrir la opresión que sufren las mismas. En 1900, Mercedes Tella, ante la Sociedad Española de Higiene, aseguraba: "la mujer, regenerada por el Cristianismo... constituyese en ángel del hogar, como la llama, no sólo los poetas, sino todos aquellos que, penetrados de la altísima misión que Dios ha confiado a la llamada mitad más débil de la humanidad, creen ver en ella algo superior a lo humano" (citado en Palacios, 2007: 119).

En el siglo XX, el modelo femenino sufrió diversas variaciones, fruto de la alteración de las estructuras económicas, sociales y demográficas. Durante la Primera Guerra Mundial, las mujeres presentaron grandes aptitudes en el trabajo, la producción, las industrias de guerra y la resistencia en la retaguardia, aspectos que desplazaron el viejo discurso de la inferioridad natural de las capacidades femeninas. En muchos países, por tanto, la guerra significó un giro en el tipo de representación: la nueva mujer moderna 
sirvió como prototipo para un modelo femenino que ponía en entredicho la definición tradicional de la feminidad y los límites convencionales a los patrones de género (Nash, 2004: 54-55). Se vivió, por tanto, un distanciamiento gradual del modelo doméstico que había irrumpido en el siglo XIX. Durante la postguerra mundial, y desde las voces de mujeres feministas, se reivindicaron derechos políticos y civiles, espacios culturales propios, el ejercicio de nuevos oficios y el acceso a carreras universitarias, exigiendo a los varones la aceptación de estos cambios, hecho que conllevaría una reestructuración de los modelos de masculinidad y feminidad (Ramos, 2014: 33).

En España, esta ruptura con el modelo tradicional preocupaba a las voces más conservadoras. Desde las ciencias médicas, en 1928, el ginecólogo Vital Aza escribía:

La mujer, que va conquistando todos los derechos del hombre y escapando a los deberes que este no tiene, lo hace olvidando su feminidad, tratando de ahogar lo que de hembra tiene, y pretendiendo extirpar de su espíritu y disimular de su cuerpo cuanto de mujer, de femenino, puso Natura en ella (citado en Aresti, 2001: 91).

Puede que lo más significativo de este texto no sea tanto su mensaje, hijo de la época, como sí el título del escrito: Feminismo. El médico se dirigía a lectoras feministas y les proponía una especie de trueque: la posibilidad de obtener determinados derechos a cambio del cumplimiento de su destino natural, el cual se vería dignificado y protegido socialmente. En este sentido, instaba a las mujeres a seguir la ruta del feminismo "sin hacer el sacrificio de sus más hermosas aspiraciones y deberes [...] y sin temer que su unión, al fructificar en fecunda semilla de risas infantiles, obstaculizará su marcha social" (citado en Aresti, 2001: 92).

En el periodo de entreguerras, nace, como la describiera Carmen de Burgos, la nueva mujer. Así, el ángel del hogar no desaparecerá, pero se verá abocado a reinventarse y compartir espacios con nuevos iconos (Espigado, 2018: 212). La génesis cultural de la nueva mujer o mujer moderna suele situarse en la novela La Garçone (1922) de Victor Margueritte, publicada en Francia pero que pronto traspasó la frontera de los Pirineos y que proponía un orden sexual hasta cierto punto innovador. Los cambios ideológicos y culturales postulaban el amor libre, el control de la natalidad, la eugenesia y la tolerancia de las prácticas lésbicas. Sin embargo, frente a la irrupción de estas activistas políticas, feministas y reformadoras sociales, se situaban, también, las esposas de los burgueses de vida cómoda, las mujeres rurales, segadoras, vendimiadoras, recogedoras de aceitunas o 
las obreras atrapadas en insufribles jornadas laborales. Así con todo, el espacio público siguió siendo masculino por definición y las mujeres que lo conquistaron fueron excepciones (Ramos, 2014: 33-35).

A esto último, cabe añadir que la aparente modernización se vio truncada por la persistencia de uno de los ejes fundamentales del discurso tradicional de la domesticidad: la maternidad como base esencial de la identidad cultural de la mujer (Nash, 2004: 59). Además, tras la Segunda Guerra Mundial, los viejos discursos volvieron a rearmarse. Como ya pasara en la Primera Guerra Mundial, los códigos femeninos se habían roto y las mujeres se habían implicado en actividades que de otra manera hubieran desempañado los hombres. Por tanto, después del conflicto y con el fin de asegurarse la vuelta pacífica de las mujeres a sus esquemas identitarios de madres y esposas, aparecieron teorías que hablaban de la feminidad, las cuales "eran supuestamente tan complejas que no estaban al alcance de todo el mundo, sólo de unos pocos iniciados, y por consiguiente eran irrefutables" (Friedan, 2016: 80).

Nos dice Betty Friedan, tras un análisis de los años de postguerra en Estados Unidos, que las mujeres sufrían un malestar generalizado, consecuencia de la vuelta a un modelo de feminidad que se había visto alterado durante el periodo de guerra. El sexo femenino experimentaba, así, el problema que no tiene nombre - las mujeres acudían a especialistas y eran tratadas con psicofármacos- Surgió, entonces, la mística de la feminidad, una serie de discursos y narrativas sociales que ensalzaban la feminidad en sí misma y defendían que el gran error de la cultura occidental había sido, precisamente, minusvalorar el modelo femenino. Desde esta perspectiva, se instaba a las mujeres a aceptar su propia naturaleza y a que cesaran en sus intentos de ser como los varones, puesto que la plenitud del sexo femenino se hallaba a través de la pasividad sexual, la dominación masculina y el amor maternal. En este sentido, la nueva mística convertía a las mujeres-amas de casa en referente para todas las mujeres, asegurando que la historia había alcanzado una cúspide final y gloriosa (Friedan, 2016: 81).

En España, los postulados que habían empezado a cuestionarse desde los sectores feministas en el primer tercio del siglo XX, se vieron totalmente reprimidos durante los casi cuarenta años que duró la dictadura del régimen franquista (1939-1975). Los avances femeninos fueron dinamitados y la funcionalidad de la mujer como madre y esposa, ángel del hogar, se vio refrendada, enaltecida y perpetuada en el marco ideológico y conductual del nacional-catolicismo (Peinado, 2012: 29). El modelo educativo que impuso a las 
mujeres la dictadura franquista actualizaba y reformulaba los mecanismos tradicionales de subordinación. La Iglesia y la Falange crearon un prototipo de mujer que conectaba con el esquema burgués-católico decimonónico, negando la autonomía femenina y confinándola a la esfera doméstica. Así, los estamentos culturales, políticos y educativos establecieron que la misión de las mujeres se hallaba única y exclusivamente en el hogar (González, 2009:95).

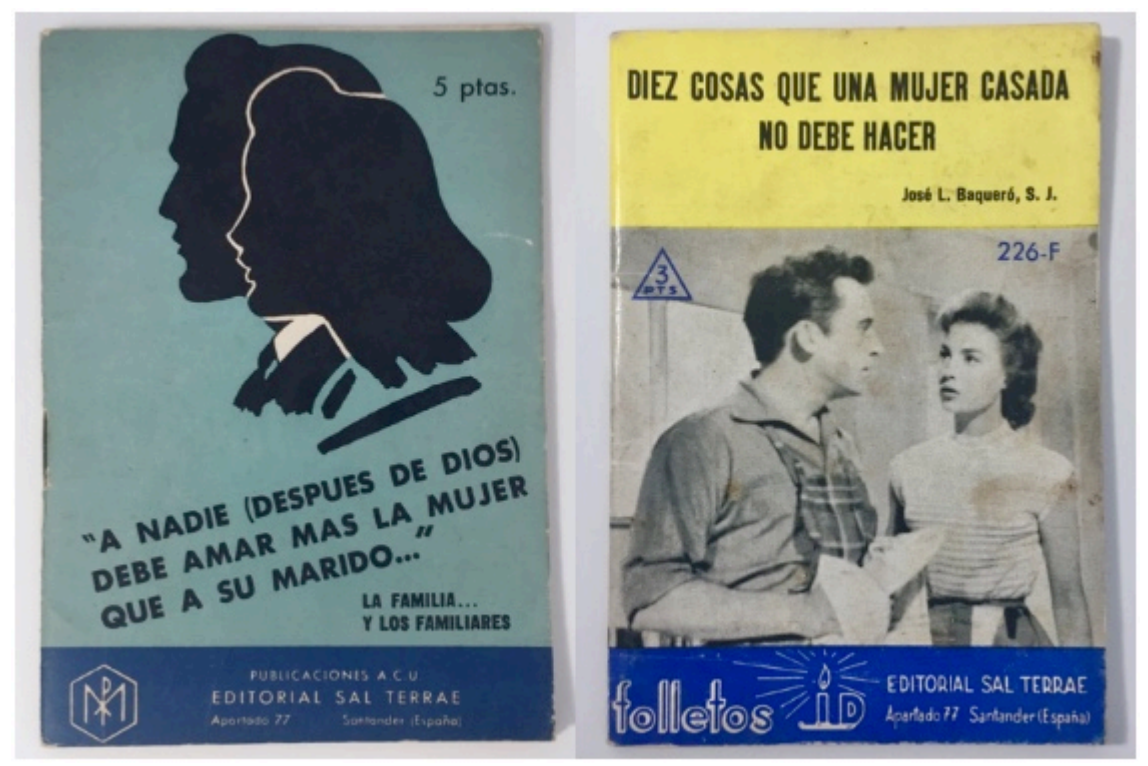

IMAGEN 3. Folletos católicos de la editorial Sal Terrae: A nadie (después de dios) debe amar más la mujer que su marido... (1965) y Diez cosas que una mujer casada no debe hacer (1967).

FuENTE: Material propio.

La educación y los centros escolares eran segregados y las asignaturas del currículum femenino, recogidas por la Ley de 17 de julio de 1945 sobre Educación Primaria, establecían, para las niñas, las materias de formación político social, educación física, iniciación para el hogar, canto y música (Ballarín, 2001: 123). El inspector Agustín Serrano de Haro, en su ejemplar La escuela rural de 1946, dictaminaba, "nada de conocimientos científicos para estas niñas. La cocina — isí, la cocina! — debe ser un gran laboratorio" (citado en Costa, 1990: 115). Las declaraciones de Serrano de Haro no representan, ni mucho menos, un caso aislado. Pilar Primo de Rivera, en 1942, en una intervención del I Consejo Nacional del SEM (Servicio Español de Magisterio), sentenciaba: "las mujeres nunca descubren nada; les falta, desde luego, el talento creador reservado por Dios para inteligencias varoniles; nosotras no podemos hacer nada más que 
interpretar, mejor o peor, lo que los hombres nos dan hecho" (citado en Ballarín, 2001: 116). Dos décadas más tarde, en 1960 en un libro de la asignatura formación políticosocial de primer curso de bachillerato, leemos:

A través de toda la vida, la misión de la mujer es servir. Cuando Dios hizo al primer hombre pensó: no es bueno que el hombre esté solo. Y formó a la mujer, para ayuda y compañía, para que sirviera de madre. Su primera idea fue el hombre. Pensó en la mujer después, como un complemento, como algo útil (citado en Ballarín, 2001: 124).

El modelo de feminidad se ha creado a los márgenes del trabajo extradoméstico, a pesar de que son muchas las investigaciones que han demostrado que las mujeres, no solo han trabajado siempre, sino que la subsistencia de la inmensa mayoría de las familias españolas en los dos últimos siglos ha dependido, en gran medida, del sexo femenino (Peinado, 2012: 44). Aunque si bien las mujeres de las clases acomodadas no estuvieran empleadas fuera del hogar, lo cierto es que en el siglo XIX, el trabajo asalariado de estas era una realidad generalizada. Sin embargo, debido a que el discurso de la domesticidad reforzaba la idea del empleo femenino como una ayuda puntual y complementaria frente al masculino (Nash, 2004: 45-48), se dificultó enormemente el asentamiento de una identidad que incorporara el perfil de trabajadora y profesional, unido al de madre y esposa, hasta la segunda mitad del siglo XX (Nash, 2008: 119).

Precisamente, en la España de mitad del siglo XX, encontramos una doble realidad. Por un lado, el discurso oficial recuerda a las mujeres cuál es su lugar $-\mathrm{y}$ así lo recoge, por ejemplo, la revista falangista $Y$ en el año 1941, "la verdadera carrera de la mujer es la de madre de familia" (citado en Ruiz, 2008: 157)—, pero, por el otro, los campos de las zonas rurales eran trabajados por manos femeninas en completa paridad con los varones. Además, estas mujeres debían compaginar las duras jornadas laborales con la crianza de los hijos e hijas. Mientras, en las ciudades, se hacía más difícil que las mujeres trabajaran fuera del hogar, ya que existían duras leyes que lo restringían o incluso prohibían, aunque vemos como en el caso del trabajo doméstico remunerando las chicas de servicio aumentaron de forma notable a la vez que lo hacía la industrialización española (Díaz, 2008: 169-173).

Según las estadísticas laborales, el porcentaje de población femenina activa al inicio de la dictadura franquista, en 1940, era de un 12\% y, al final, en 1975, era de un $21,3 \%$. Cabe destacar que, por supuesto, esta cifra se encontraba sustancialmente por 
debajo de la real, puesto que, en muchos casos y como se ha mencionado, el empleo de las mujeres no era reconocido oficialmente (Valiente, 2003: 146). Aun con todo, encontramos que se van incorporando progresivamente al mundo laboral $\mathrm{y}$, lo que es de especial importancia, su trabajo empieza a ser visible socialmente. Dicho fenómeno consolida la identidad de trabajadora asalariada, que reconfigurará el modelo de feminidad, sin embargo, este nuevo rol social funcionará como un aditivo, puesto que las mujeres seguirán manteniendo sus anteriores papeles — esposa, madre, ama de casa-y los hombres no asumirán las tareas de cuidados ni del hogar (Escartí et al., 1988: 218).

Frente a las imágenes patriarcales, el discurso feminista se mostró, en todo momento, crítico y combativo. Ya hemos mencionado que las voces de mujeres denunciando los mecanismos de opresión femeninos - lo que hoy conocemos como género-, se retrotraen a siglos atrás, siendo especialmente relevantes, por ser de las que tenemos constancia, las surgidas a partir de la Revolución Francesa. Sin embargo, no fue hasta el siglo XX, y gracias a la obra de Simone de Beauvoir —escrita en 1949 pero popularizada en los años setenta-, que el feminismo tomó un cariz internacional (Nash, 2004: 168). Si recordamos, en esa década varias autoras adoptaron para sus escritos la variable género y el feminismo entró en el discurso científico.

Fuera de la academia, surgen nuevas prácticas feministas que permiten que las mujeres comiencen a leerse desde la colectividad, hecho que modificará las formas políticas y de organización del movimiento y, posteriormente, a la propia sociedad. A finales de los años 60, aparecen los consciousness-raising, los grupos de autoconciencia. En ellos, gracias a los relatos personales —que incluían la familia, el trabajo doméstico, la maternidad, la sexualidad, la discriminación laboral... - las integrantes del grupo tomaron conciencia de las situaciones a las que eran inducidas socialmente (Campillo, 2016: 67). En este sentido, se forjó el lema lo personal es político que identificaba como centros de dominación esferas de la vida que, hasta el momento, se habían considerado privadas (Verdugo, 2010: 264). Es decir, las mujeres descubrieron que sus vivencias intimas y personales eran compartidas por el resto del grupo, destapando así el carácter estructural de realidades que se creían individuales.

A partir de las elaboraciones de los feminismos de los años setenta, surgieron conceptos como opresión, sexismo, género o patriarcado. Este último, según el 
diccionario ideológico feminista, escrito por la autora Victoria Sau en el año 1981, hace referencia a:

Una toma de poder histórica por parte de los hombres sobre las mujeres cuyo agente ocasional fue de orden biológico, si bien elevado éste a la categoría política y económica. Dicha toma de poder pasa forzosamente por el sometimiento de las mujeres a la maternidad, la represión de la sexualidad femenina, y la apropiación de la fuerza de trabajo total del grupo dominado, del cual su primer, pero no único producto, son los hijos (Sau, 2000: 238).

En el sistema patriarcal, los hombres ostentan el poder económico, político y social. Además, se alzan dueños y señores de las mujeres, disciplinando, controlando y legislando sobre aspectos tan personales como son el propio cuerpo femenino. Es por esto, que una de las demandas de los nuevos discursos feministas pasaba por reclamar los derechos sexuales y reproductivos de las mujeres. Así, el movimiento feminista rompe con el tabú de la sexualidad exigiendo el control del placer, del propio cuerpo y de la maternidad (Verdugo, 2010: 264), luchando por una desvinculación entre la procreación y la práctica sexual.

A este respecto, en España, en el año 1985, se despenaliza el aborto, y aunque la ley recogerá restricciones en los tres supuestos legales que permiten ejercer dicho derecho, la despenalización será considerada como una de las grandes victorias del movimiento feminista. Además, en esa década ocurrieron otras reformas legales que, al menos formalmente, hicieron tambalear los cimientos del modelo femenino tradicional: la igualdad de salario en 1980 — seguido del primer Plan de Oportunidades PIOM 198890 que fomentaba el empleo de las mujeres_-, y el divorcio por consentimiento mutuo en 1981, significaron fuertes logros a nivel legislativo (Lombardo y León, 2014: 17).

Vemos que el modelo femenino occidental se ha transformado. Las mujeres empiezan a tener el control sobre sus cuerpos, a conquistar la esfera pública, a acceder a estudios superiores. Se visibiliza y expande el trabajo extradoméstico, lo que se traduce en una autonomía económica. Desde el feminismo, la obligada maternidad es cuestionada y se evidencia que el destino natural de las mujeres no era sino un discurso creado por el patriarcado con el fin de someterlas. Se pone en jaque el sistema de género y los mitos de sumisión clásicos. Sin embargo, como ya sucediera en los años 50 con el problema que no tiene nombre, un nuevo malestar aqueja a las mujeres. Se trata del último de los mitos, el que vienen a destronar al discurso de la domesticidad, el mito de la belleza, reflejado 
en realidades como que "33.000 mujeres norteamericanas manifestaron en las encuestas que preferían rebajar de cinco a siete kilos de peso antes que alcanzar cualquier otra meta" (Wolf, 1991: 14).

Naomi Wolf, en su obra El mito de la belleza (1991), denuncia que, aunque un mayor número de mujeres posean más dinero, más campo de acción y más derechos legales que nunca, en lo referente al físico están más sometidas que las generaciones anteriores (Wolf, 1991: 14).

Estamos en medio de una violenta reacción contra el feminismo, que utiliza imágenes de belleza femenina como arma política para frenar el progreso de la mujer: es el mito de la belleza. Se trata de la versión moderna de una actitud social vigente desde la Revolución Industrial. Al liberarse las mujeres de la mística femenina de la domesticidad, el mito de la belleza vino a ocupar su lugar y se expandió para llevar a cabo su labor de control social (Wolf, 1991: 14-15).

En este sentido, el orden patriarcal precisaba de un nuevo mecanismo de control, pues las mujeres en occidente habían conquistado tantos campos, que amenazaban con destruir las instituciones clásicas de poder masculino. Por ello, cuando la identidad femenina dejo de regirse por la ficción de la domesticidad, se creó un nuevo discurso que articularía la vida de todas ellas. Dicho modelo es tremendamente tramposo, ya que se muestra imposible de encarnar: mientras que las mujeres crecen, evolucionan y expresan su individualidad la belleza es, por definición, inerte y eterna (Wolf, 1991: 22-23). Así, este modelo poco tiene que ver con las mujeres y mucho con los hombres y con perpetuar su poder.

La imposición de cierto físico femenino sirve como mecanismo de control, ya no solo porque las mujeres invertirán su tiempo y dinero en perseguir esa belleza virtuosa - hasta tal punto que se convertirá en un potente sedante que amenazará incluso a la salud femenina-, sino porque, además, cortará los lazos entre las generaciones, al ser la juventud una amenaza para las más maduras y la vejez una característica rechazable para las más jóvenes. También, nos señala la autora que este mito crea un estado permanente de vulnerabilidad, pues la aprobación de una misma deja de ser algo autoconstruido y controlable y pasa a depender de las apreciaciones, críticas y modelos exteriores (Wolf, 1991: 17-18). Es preciso señalar, además, que, como parte del mito, resurge la figura de la feminista fea, imagen ya vista en el siglo XIX, prototipo que se acuña siempre para 
ridiculizar al movimiento y pretende mantener alejadas a las mujeres del feminismo (Wolf, 1991: 23).

El modelo de feminidad se encuentra lleno de involuciones. Cada vez que las mujeres han subido un escalón, el patriarcado ha lanzado un nuevo ataque. El trabajo extradoméstico femenino de las dos guerras mundiales, el cual configuró modelos de mujeres nuevas con planes de vida emancipadores, provocó que se reforzara el discurso de la domesticidad. Posteriormente, el movimiento liberador feminista de finales de los sesenta y la década de los setenta, se encuentra debilitado, entre otros, por el mito de la belleza.

Además de este último ataque, el feminismo se enfrenta, también, al fantasma del postfeminismo. El postfeminismo es hijo de la postmodernidad, movimiento que surge durante la segunda mitad del siglo XX y se refiere, inicialmente, al ámbito de la literatura, las artes plásticas y la arquitectura. Posteriormente, se expandirá a otras áreas sociales y del conocimiento. El elemento común compartido por todas las corrientes es la idea de que el proyecto modernista no ha sido útil en la renovación radical de las formas tradicionales del arte y la cultura, pero, también, del pensamiento y la vida social: existe una sensación generalizada de fracaso y las críticas se dirigen hacia el origen del modernismo y contra la Ilustración (Lorente, 2019: 32). En este sentido, el pensamiento postmoderno pone en tela de juicio la validez de la ciencia, la misma que representa el saber, y se muestra escéptico respecto a las nociones de racionalidad y verdad (Carvallo, 2006: 90).

Las circunstancias de la postmodernidad propician actitudes que elevan la idea de vivir el presente, buscando y revalorizando la inmediatez y el individualismo. Se rompe con la noción de colectividad, encaminándose el pensamiento hacia las teorías relativistas y de subjetividad. Así, el individuo pasa a ser el gran referente en un momento en el que, paradójicamente, la personalidad individual queda diluida en el grupo (Lorente, 2019: 33). Para el sociólogo Zygmunt Bauman, la globalización, presenta, precisamente, un gran desafío actual: "el mundo es un lugar en el que por una vez, el desiderátum de la responsabilidad moral y los intereses de la supervivencia coinciden y se funden. La globalización es, entre otras cosas (y quizás, más que nunca), un desafío ético" (citado en Carvallo 2006: 99). Mientras, Ellen Meiksins, relacionando la teoría postmoderna con el socialismo nos anuncia: "en vez de las aspiraciones universalistas del socialismo y la política integradora de la lucha contra la explotación de clases, tenemos una pluralidad 
de luchas particulares, desconectadas que concluyen en una sumisión al capitalismo" (citado en en Kohan, 2006: 1).

En este sentido, y repitiendo la lógica de la postmodernidad, el discurso postfeminista sería una reacción al discurso feminista en sí. Surgió paralelo al desarrollo de la ola de los años setenta y fue adoptado, con gran vehemencia, por mujeres jóvenes en los años 90 que no se reconocían en las luchas que consideraban propias de la generación de sus madres. Reivindicaban poder sentirse felices dentro de discursos femeninos tradicionales como el de la maternidad. Precisamente, en 1991, Susan Faludi, escritora y periodista estadounidense, publica Reacción: la guerra no declarada contra la mujer moderna, donde describe la misoginia hacia las mujeres con trabajado asalariado presente en medios de comunicación y productos audiovisuales. Esta autora comenzó a estudiar cómo, al mismo tiempo que el capitalismo se endurecía en occidente con las posturas neoliberales, surgía una reacción muy fuerte en contra del movimiento feminista (Bernárdez, 2015: 39).

La crítica Angela McRobbie nos dice que, dentro de la lógica postfeminsta, el feminismo se entiende como un discurso obsoleto que restringe y reduce las opciones de las mujeres: se trataría de una teoría la cual, al ya haber conseguido sus logros — cosa que no es en absoluto cierta— se encontraría totalmente desfasada y debería relegarse al pasado (Tortajada y Araüna, 2014: 26). Como señalaba Susan Faludi, el postfeminismo es visible especialmente en la producción audiovisual, donde los personajes femeninos asumen roles de independencia personal e individual, sin cuestionarse conceptos tales como la opresión, el patriarcado o el sometimiento. Estos caracteres, que buscan la satisfacción personal o crear una identidad propia, han abandonado totalmente el discurso político de lo colectivo (Bernárdez, 2015: 40-41).

Así, la narrativa postfeminista infunde un sentimiento de autosuficiencia: alimenta la idea del empoderamiento femenino a través de los valores de la juventud, el éxito profesional y el control de la sexualidad y las emociones. En este sentido, invita a disfrutar a las mujeres de los logros feministas en un marco consumista y de privilegios neoliberales. Una de las consecuencias directas es que despolitiza la realidad, al presentar una visión individualizada donde todo vale y cualquier estilo de vida es lícito (Mateo, 2013: 118-119). 


\subsection{Representaciones femeninas en el discurso mediático}

Los medios de comunicación son generadores tanto de subjetividad, ya que contribuyen a la formación de las ideas que tenemos sobre el entorno, como de inter-subjetividad, es decir a través de ellos comprendemos lo que somos, cómo nos valoramos o incluso qué cuerpo debemos tener. Por poner un ejemplo, antes de las representaciones mediáticas, la idea de belleza se formaba en un contexto interpersonal, a partir de la observación del entorno cercano. Ahora, debido a los medios de producción en masa, esto es, al fácil acceso a imágenes de la prensa y del audiovisual, la idea de belleza transciende todas las fronteras y el estándar se unifica (Bernárdez, 2015: 57).

Los medios de comunicación representan, también, los modelos de género. A partir de ellos construimos la idea de mujer y la idea de hombre. En el apartado anterior, hemos analizado las características del modelo de feminidad moderno. Sin embargo, para que este se expanda, necesitamos de una serie de agentes que lo transmitan: necesitamos del poder político y religioso, de la justicia y sus leyes, de la educación, de la cultura, de la familia, de los medios audiovisuales... Gracias a estos transmisores, y a través de los procesos de socialización, interiorizaremos y haremos nuestro el sistema simbólico que el poder dicta (Mateos, 2013: 298).

Llamamos socialización al proceso que se inicia en el momento del nacimiento y que dura toda la vida, gracias al cual las personas, en interacción con el medio, aprenden y asimilan los valores, las actitudes, las expectativas y los roles característicos de la sociedad en la que habitan. Este aprendizaje permitirá a la persona desenvolverse en el entorno social. Además de este proceso general, y muy ligado a él, se ha constatado que existe una socialización diferencial determinada por el sexo biológico. Esto es, a través de los agentes socializadores —recordemos: la educación, la familia, la religión, las leyes, los medios de comunicación...-, hombres y mujeres reciben mensajes distintos: hacen suyos valores diferentes y acaban comportándose en consecuencia a ellos (Bosch et al., 1991: 121-124).

Pues bien, como buenos agentes socializadores, los medios de comunicación nos enseñan a modelar las percepciones que tenemos de hombres y mujeres. Son los responsables de cambios en las relaciones interpersonales y son instrumentos que influyen en la autoimagen propia. En 1975, Busby elaboró un extenso informe sobre el mensaje que estos lanzaban y llegó a las siguientes conclusiones: que no se profundiza en 
los aspectos referentes a los roles de género; que los roles son tradicionales y que no reflejan ningún tipo de alternativa; que niños y niñas modelan su comportamiento en función de la información que reciben de estos; y que en la mayoría de los medios de comunicación son los hombres los que controlan la información (Pearson et al., 1993: 353-354).

Han pasado más de cuarenta años desde el informe de Busby y, en 2019, autoras como Ana Bernal-Triviño nos hablan del patriarcado mediático. Este se establece así por dos motivos, primero, porque los medios han estado (y están) dirigidos y protagonizados en su mayoría por hombres y, segundo, por el mensaje. La educación patriarcal provoca que, en su mayoría, se elaboren piezas que no rompen con el sistema de dominación. En este sentido, los medios de comunicación son uno de los agentes más criticados por contribuir a reforzar los estereotipos sobre las mujeres y a sustentar el sistema de organización social que permite al sexo masculino disfrutar de una serie de privilegios: el patriarcado mediático refleja un espacio de poder presencial y un espacio de poder en el contenido lo que, finalmente, favorece a la subordinación de las mujeres (BernalTriviño, 2019: 26).

La autora Isabel Menéndez también acusa la falta de evolución en el mensaje mediático. Los modelos de mujer apenas han variado a lo largo de la historia y se articulan, principalmente, entorno a dos representaciones simbólicas: el ángel o reina del hogar y la mujer objeto - cuyo sujeto es el varón y a de la que importa su belleza, juventud y delgadez- (Menéndez, 2006: 42). Si recordamos, son los mismos modelos normativos que han estructurado la vida de las mujeres desde el siglo XIX, cuando se impulsó la figura de madre y esposa dedicada en cuerpo y alma a su familia, hasta nuestros días, que el físico se ha impuesto como valor primordial en las mujeres.

Estas dos representaciones arquetípicas presentan sus variantes, evoluciones y contramodelos. Algunos de ellos son: la superwoman y la mujer de plástico —que analizaremos con un poco más de detenimiento-, la mala — mujer que comete actos delictivos—, la mujer consorte — esposa, hija, compañera de... algún hombre—, la mujer fatal —activa y desinhibida sexualmente—, la mujer compañera (del varón) —ejemplo de comprensión y valores supuestamente igualitarios—, la mujer profesional —encuentra su antítesis en la mujer que aprovecha sus armas de mujer para ascender socialmente-, la maruja —retrato despiadado de las generaciones de españolas que han tenido pocas 
oportunidades para elegir su proyecto vital— la mujer soltera —encarna el fracaso social al no haber conseguido esposo y es esencialmente mala-, la mujer devorahombres -mujer liberada pero hostil—, la otra —responsable de los fracasos matrimoniales cuando existe una infidelidad masculina—, la mujer escaparate -trofeo y símbolo de éxito masculino-y la mujer diez —imagen del cuerpo perfecto- (Menéndez, 2006: $62)$.

La superwoman aparece en torno a los años ochenta del siglo XX. Tal y como vimos, en esa década, el modelo identitario femenino se abría para incluir una nueva faceta: la del trabajo extradoméstico. Sin embargo, esta categoría no fue excluyente y se añadió a la de madre. Lo mismo sucederá con la representación mediática de la superwoman: ella no abandona la maternidad, pero sale al espacio público y, además, se le dota del atributo de la sexualidad. Quizá la representación más conocida sea la de la mujer ejecutiva que, además, es madre de familia y ofrece una imagen impecable (Menéndez, 2006: 56). En este sentido, el prototipo superwoman encarna la fusión total, la superposición de los roles: doméstica, bella, profesional y objeto (Suárez-Villegas, 2014: 177).

La mujer de plástico se encuentra más cercana a la mujer objeto que a la mujer ángel del hogar. Su interés hegemónico es el de la estética y su representación más visible - y casi única pues el modelo no admite apenas variaciones - es la de una mujer blanca, rubia, muy delgada y con las redondeces adecuadas — pecho, labios, pómulos- que podrán conseguirse a través de la cirugía plástica — de ahí que la autora la haya denominado mujer de plástico- Se obsesiona con una delgadez que le hace casi invisible pero incrementa el volumen de los atributos que, en teoría, resultarían excitantes para un varón heterosexual (Menéndez, 2006: 65-66).

El autor David Caldevilla, en un análisis sobre estereotipos femeninos en series de televisión, toma como punto de partida la clasificación de Isabel Menéndez y la aplica en el estudio de las 75 ficciones seriadas más populares que emitieron las cadenas televisivas — públicas y privadas — en España entre 1989 y 2010. A las representaciones expuestas por esta autora, añade, además, la mujer masculina —reúne rasgos típicamente varoniles y no tiene miedo de implicarse físicamente en tareas o enfrentamientos en los que no suelen inmiscuirse los personajes femeninos-, la víctima -mujer cuya existencia se resume en haber sufrido algún tipo de vejación, además, el trauma 
condiciona de forma absoluta su actitud y dificulta su desarrollo personal—y, también, amplía la representación de la feminista y de los estereotipos lésbicos (Caldevilla, 2010: 77).

La feminista, nos dice, es un personaje poco frecuente. Presenta un aspecto físico descuidado y una personalidad irresponsable para con los papeles clásicos de ángel o reina del hogar. Mientras, dentro de los estereotipos lésbicos, encontramos dos construcciones arquetípicas: la butch — muy masculinizada, tiene rasgos andróginos y se le exagera el porte y la gesticulación con el fin de evidenciar que se trata de un personaje típicamente homosexual - y la femme —esta representación, al contrario de lo que ocurría con la butch, cumple con los mandatos clásicos de la feminidad. Se juega con la creencia de que una mujer femenina no puede ser lesbiana dejando, así, abierta la posibilidad primera de que pueda intimar con algún varón-. Al finalizar el estudio, el autor nos cuenta que todos los personajes femeninos analizados pueden ser incluidos en alguno de los perfiles estándares atribuidos al hecho diferencial femenil (Caldevilla, 2010: 77-78). Es decir, ninguno de los personajes principales de las series se construyó alterando o rompiendo los moldes de las representaciones mediáticas femeninas.

Las series televisivas — como la literatura y el cine— por su condición de ficciones, no son tanto reproducciones de la realidad como mecanismos de producción de realidades. La ficción acude a esta, a la realidad, para reescribirla y contribuye a que el público se construya una idea de la misma (Torras, 2006: 79-80). La ficción produce un mensaje desde sesgos ideológicos determinados. En este caso, la ideología dominante presenta, en las ficciones audiovisuales, a personajes femeninos que no son el sujeto agente y que tienen la extraordinaria cualidad de amoldarse a los deseos de los varones en todos sus detalles y sentirse satisfechos con ello (Aguilar, 2017: 51). Cabe precisar, que la centralidad del hombre en la ficción —donde todos los elementos, incluidas las mujeres, giran en torno a él-, no es, ni mucho menos, un fenómeno novedoso.

Laura Mulvey, en 1989, publicaba Placer visual y cine narrativo, texto en el que la autora estudiaba el placer que experimenta el público durante la proyección fílmica. Mulvey expone las interrelaciones del placer erótico, su significado y, en particular, el lugar central de la imagen de la mujer. En este sentido, determina que el hombre es el poseedor de la mirada y proyecta sus fantasías sobre la figura femenina que se organiza de acuerdo con esa mirada. Así, la mujer exhibida funciona en dos niveles: como objeto 
erótico para los personajes de dentro de la narración y, también, como objeto erótico para el espectador de la sala. Este último, el espectador, se identifica con su semejante, con el personaje masculino, y crea la ilusión de que puede obtener el control y posesión de la mujer representada (Mulvey, 1989: 9-12).

Bud Boetticher, por su parte, nos informa de que los personajes femeninos no tienen transcendencia en sí mismos, sino que, en función de lo que provocan al hombre "es ella, o el amor o miedo que inspira en el héroe, o la atracción que él siente hacia ella, la que le hace actuar en el sentido que lo hace. En sí misma la mujer no tiene la menor importancia" (citado en Mulvey, 1989: 10). La imagen de la mujer en el cine clásico fue ampliamente trabajada por la teoría fílmica feminista y los estudios culturales. No solo Mulvey o Boetticher, si no que también Kay y Peary (1977), Kaplan (1978), Erens (1979), Bundson y Morley (1980), Ang (1985) o Modleski (1989) han analizado el tratamiento de los personajes femeninos en la gran pantalla. Estos estudios determinaron que el cine privilegiaba la mirada masculina. Además, los personajes masculinos estaban dotados de rasgos variados, mientras que las mujeres eran representaciones mucho más planas, estereotipadas y restringidas. Para él existía una individualidad, un tiempo y un espacio narrativo. Ella, reducida a un mito, se situaba en un espacio-tiempo abstracto e inmutable. Él era un sujeto activo, ella un objeto pasivo (Bermejo: 2002, 21-22).

La ficción audiovisual se ha construido a partir de la imagen de la mujer arquetípica y atemporal. Bermejo insta a que se formulen personajes femeninos que desmitifiquen el mito, que se sitúen en un tiempo y en un espacio y que contengan matices (Bermejo, 2002: 31). Es relevante, por tanto, que los personajes de mujeres se abran a nuevas representaciones. En este sentido, no debemos olvidar las palabras de Michel Foucault (1975) quien asegura que no es necesario recurrir a medios de fuerza para obligar "al condenado a la buena conducta" —o, en este caso, a la mujer a aceptar su opresión- ya que, en un contexto de dominación, la persona sometida es capaz de reproducir libremente las coacciones del poder.

(El que está sometido) inscribe en sí mismo la relación de poder en la cual juega simultáneamente los dos papeles; se convierte en el principio de su propio sometimiento. Por ello, el poder externo puede aligerar su peso físico; tiende a lo incorpóreo; y cuanto más se acerca a ese límite, más constantes, profundos, adquiridos de una vez para siempre e incesantemente prolongados serán sus efectos: perpetua victoria que evita todo enfrentamiento físico y que siempre se juega de antemano (Foucault, 2005: 206). 
Así, Foucault explica que cuanto más invisibles, escondidos e imperceptibles sean los mecanismos de los que se sirve la cultura dominante para transmitir su poder, mayor será el éxito de dominación. A lo largo de la historia del cine, belleza y sexualización como representación del poder femenino, han sido las constantes que han impedido la diversificación de los papeles para las mujeres (Bernárdez, 2018: 135). Además de estas, la crítica de cine Pilar Aguilar rescata otras de las características frecuentes en las representaciones fílmicas femeninas.

Por un lado, en la narración, el punto de vista es androcéntrico y el mundo se descubre a partir de los ojos de los hombres, provocando la ausencia y anulación de las mujeres como sujeto simbólico: la cámara las mira desde fuera, convirtiéndose ellas en el objeto de la visión. Así, asumen un papel marginal, siendo el trofeo del guerrero, su descanso, un peligro añadido, una rémora o una ayuda en el mejor de los casos. Los planos son estáticos y contemplativos, su cuerpo no nos aparece como un todo — no refleja a la persona — sino que vemos una figura troceada y cosificada — nalgas, pechos, piernas —. En cuanto a las relaciones íntimas, se filma a las mujeres felices y satisfechas con la sexualidad masculina, sin disfrutar de la suya propia: es lo que la autora denomina la sexualidad amputada (Aguilar, 2008: 9).

Por otro lado, cuando en la pantalla aparecen mujeres con características poco convencionales, suelen comportarse de una manera masculina, pareciendo que la única forma de reivindicarse como sujeto fuera adoptando actitudes que asociamos con los hombres. Mujeres violentas y brutales o que muestran una configuración del deseo erótico viril (Aguilar, 2008: 9). Además, para el feminismo, supone un gran conflicto que las mujeres adquieran poder solo a base de utilizar estrategias propias de lo masculino: la emulación de los hombres podría suponer el reconocimiento de un complejo de inferioridad de la feminidad respecto al código masculino que imita (Bernárdez, 2018: 138).

Finalmente, cabe destacar que las mujeres de la ficción no tienen criterios ideológicos ni políticos, piensan lo mismo que defiende el personaje masculino. Además, suelen ser caprichosas, incongruentes, absurdas, torpes e inútiles. Los personajes masculinos, por el contrario, deben mostrar mucha paciencia para con ellas y, generalmente, asumir los costes de compartir la trama, pues las mujeres resultan, casi siempre, un peligro añadido (Aguilar, 2008: 9). 
Por último, a pesar de algunas aperturas que puedan percibirse en la estereotipia femenina — desde finales de los años 90 se produce un mayor contenido de fícción donde se explota a la mujer profesional: Ally McBeal, Sexo en Nueva York o Mujeres Desesperadas serían tres ejemplos paradigmáticos—, aun así, se advierte, dentro de estos mismos productos, el retorno a valores tradicionales — romanticismo, pareja, maternidad, matrimonio, trabajo doméstico_ - valores que se funden con las directrices liberadoras del discurso postfeminista -el ocio, el placer, el hedonismo, el consumismo o la sexualidad- (Chicharro, 2013: 29). En este sentido, sigue latente una estructura tradicional de género, que se hace evidente en la insaciable búsqueda por parte de estas protagonistas del príncipe azul: el varón que aportará el sentido final a sus vidas (Bernárdez, 2015: 175).

Otro de los discursos mediáticos que conviene rescatar es el de la publicidad. La publicidad tiene la finalidad de emitir mensajes, a través de un emisor, y buscar receptores. Pretende convencer e incitar a consumir y, por ello, necesita conocer al grupo al que se dirige. A la hora de llegar a esa audiencia, el medio carga su mensaje con estereotipos, siendo los de género muy visibles: la mujer representada es ama de casa, madre de familia, sufridora y sin personalidad (Ortiz, 2003: 118). Carlota Garrido, por su parte, define así el discurso publicitario de principios de siglo:

\begin{abstract}
El culto a la imagen y el cuerpo impregna nuestra sociedad. La mujer sigue siendo el objetivo y la diana a quien lanzar las campañas publicitarias. Aparece una grandísima gama de productos adelgazantes. El ama de casa da paso a la profesional, a la superwoman, que es capaz de compatibilizar el trabajo con el hogar y con el alterne social. Se da una imagen polifacética y a la vez desvirtuada. Se entrecruzan la mujer bella e independiente con la sufridora silenciosa por un cuerpo enfermo. Cremas embellecedoras y perfumes diversos, coexisten con las pomadas antihemorroidales y los geles que calman las varices (Garrido, 2003: 150).
\end{abstract}

Mientras, un estudio elaborado por Felicidad Loscertales (véase tabla 9) nos habla de los prototipos de las mujeres en la publicidad, cuales son los más frecuentes y, al parecer, efectivos. Entre ellos encontramos, básicamente, cinco representaciones de mujeres adultas. Vemos al ángel del hogar —encarnado en la madre de familia de mediana edad, en la madre juvenil, responsable y activa y en la abuelita-, a la mujer objeto — así, aparece tanto la mujer objeto como la seductora (aunque esta última con más grado de acción que la mujer objeto)— a la mujer compañera —que es la novia, 
amante, compañera ideal—, a la superwoman — la profesional de éxito-y a la mujer fatal —anunciando productos de belleza exclusivos —. En cuanto a las representaciones de niñas y jóvenes, encontramos que las de menor edad tienden a encarnar el ángel del hogar y a las que son un poco más mayores se les encamina hacia la mujer objeto.

\begin{tabular}{|ll|}
\hline \multicolumn{2}{|c|}{ PROTOTIPOS DE MUJERES EN LA PUBLICIDAD } \\
\hline Niñas de varias edades & $\begin{array}{l}\text { Muy socializadas en papeles femeninos clásicos; por ejemplo: lavan ropitas } \\
\text { como las mamás. }\end{array}$ \\
\hline $\begin{array}{l}\text { Jovencitas y casi } \\
\text { adolescentes }\end{array}$ & $\begin{array}{l}\text { Más definidas como jóvenes que como mujeres; cuidan su imagen externa } \\
\text { pero también dan noticia del espíritu de grupo, la noción de juventud, etc. }\end{array}$ \\
\hline La abuelita & $\begin{array}{l}\text { Esta es muy escasa pero está bien definida. En los anuncios con protagonistas } \\
\text { mayores, se busca más al grupo de edad que al sexo. }\end{array}$ \\
\hline $\begin{array}{l}\text { La madre de familia de } \\
\text { mediana edad }\end{array}$ & $\begin{array}{l}\text { Feliz, sin cansancio, al servicio de todo y toda la familia. En ella se confunden } \\
\text { los roles de ama de casa, madre y esposa. }\end{array}$ \\
\hline $\begin{array}{l}\text { La madre juvenil, } \\
\text { responsable y activa }\end{array}$ & $\begin{array}{l}\text { Suele aparecer bella y feliz aunque esté embrazada o tenga uno o dos hijos, } \\
\text { casi siempre guapos y poco latosos. }\end{array}$ \\
\hline La mujer-objeto & Es pasiva, se presta a la contemplación y al deseo masculino sin tener opinión. \\
\hline $\begin{array}{l}\text { La seductora, mujer de } \\
\text { mundo }\end{array}$ & $\begin{array}{l}\text { No exactamente mujer fatal. En anuncios de perfumes, belleza, automóviles, } \\
\text { etc. }\end{array}$ \\
\hline La mujer fatal & $\begin{array}{l}\text { Anuncia perfumes o productos muy exclusivos y generalmente caros y } \\
\text { superfluos. }\end{array}$ \\
\hline $\begin{array}{l}\text { La novia, amante, } \\
\text { compañera ideal }\end{array}$ & Una variante de la seductora pero más sencilla y natural. \\
\hline La profesional de éxito & $\begin{array}{l}\text { Se le tiende a sumar alguno de los tipos anteriores, pero no abandona los } \\
\text { estereotipos clásicos de mujer de siempre. Viste elegante, da de comer bien a } \\
\text { sus hijos o elige libremente su coche. Coincide con el modelo de mujer } \\
\text { denominado superwoman. }\end{array}$ \\
\hline
\end{tabular}

TABLA 9. Prototipos de mujeres en publicidad.

FUENTE: "El lenguaje publicitario: estereotipos discriminatorios que afectan a las mujeres" (Loscertales, 2003: 101).

María Ángeles Pérez también analiza las distintas representaciones de las mujeres en publicidad. De la abuela añade que aporta felicidad al resto de la familia preparando exquisitos caldos y guisos. Además, señala que es un personaje recurrente en navidad, mientras que desaparece casi por completo durante las vacaciones de verano. En cuanto al perfil juvenil, nos presenta a la adolescente guay que gusta a los chicos y tiene una silueta estilizada — a pesar de anunciar refrescos, bollicaos, chicles...-. Aparece representada dentro de la pandilla, difundiendo el mensaje de que el consumo de ciertos productos favorece la integración en el grupo. No es empollona, pero tampoco casquivana, y parece independiente de la tutela adulta (Pérez, 2002: 47-48). 
Encontramos que, en la publicidad, las mujeres son el principal reclamo para vender productos de consumo o servicios. Ya en 1967, Guy Debord en La sociedad del espectáculo, decía que el cuerpo de las mujeres se había convertido en una de las mercancías más rentables para los medios. Según su análisis, el sexo femenino cumplía una doble función: se convertía en medio para vender el producto, pero, al mismo tiempo, era, también, el bien de consumo (Bernárdez, 2018: 68). Así, las mujeres están presentes en varios tipos de anuncios: en unos venden útiles específicamente femeninos - ropa interior, cremas, compresas...-, en otros son las protagonistas porque anuncian productos que se supone que utilizan mayoritariamente las mujeres —detergentes, electrodomésticos, alimentación, etc.- pero, también, aparecen en anuncios enfocados a un público masculino donde ellas son, tal y como adelantaba Guy Debord, parte del producto — cremas de afeitar, perfumes de hombre, ropa interior masculina, etc.(Pérez, 2002: 46-47).

Con respecto a este uso del cuerpo femenino, cabe destacar que desde la década de los 90, el imaginario pornográfico viene legitimando la construcción cultural contemporánea de la sexualidad. Brian McNair (1996) fue uno de los primeros teóricos en utilizar el concepto de pornograficación para explicar como este imaginario se ha naturalizado en la cultura del ocio y del entretenimiento: la industria, la moda, la música, la publicidad, programas de distracción y ficción televisiva, instalaciones, obras y performances artísticas... beben de la estética pornográfica. El concepto de pornograficación fue evolucionando $\mathrm{y}$, actualmente, se utiliza el término pornochic que explicaría esta transformación postmoderna del imaginario pornográfico como producto de consumo masivo (Esquirol, 2017: 79).

En la publicidad, la representación del cuerpo fotografiado con connotaciones sexuales fue propio de las campañas de moda, sin embargo, ha alcanzado otros nichos de mercado: desde los helados Magnum, productos alimenticios como salsas de tomate, las galletas Príncipe o la campaña de vodka Absolut evocan prácticas sexuales (Sánchez, 2015: 60).

Más allá de la narrativa de la publicidad, presente en varios soportes, la representación concreta de las mujeres en el discurso televisivo contempla diversos espacios. Por un lado, en los informativos, la imagen femenina es completamente tradicional y sigue encarnando los roles que, ya hemos dicho, son típicos del discurso 
mediático: víctima, ama de casa, mujer joven sexualizada... Es muy común el hecho de que, mientras los hombres representados sean profesionales integrados en las élites sociales, las mujeres son voces anónimas, sin identificar y no se valoran sus cualidades profesionales o sociales (López, 2005: 39).

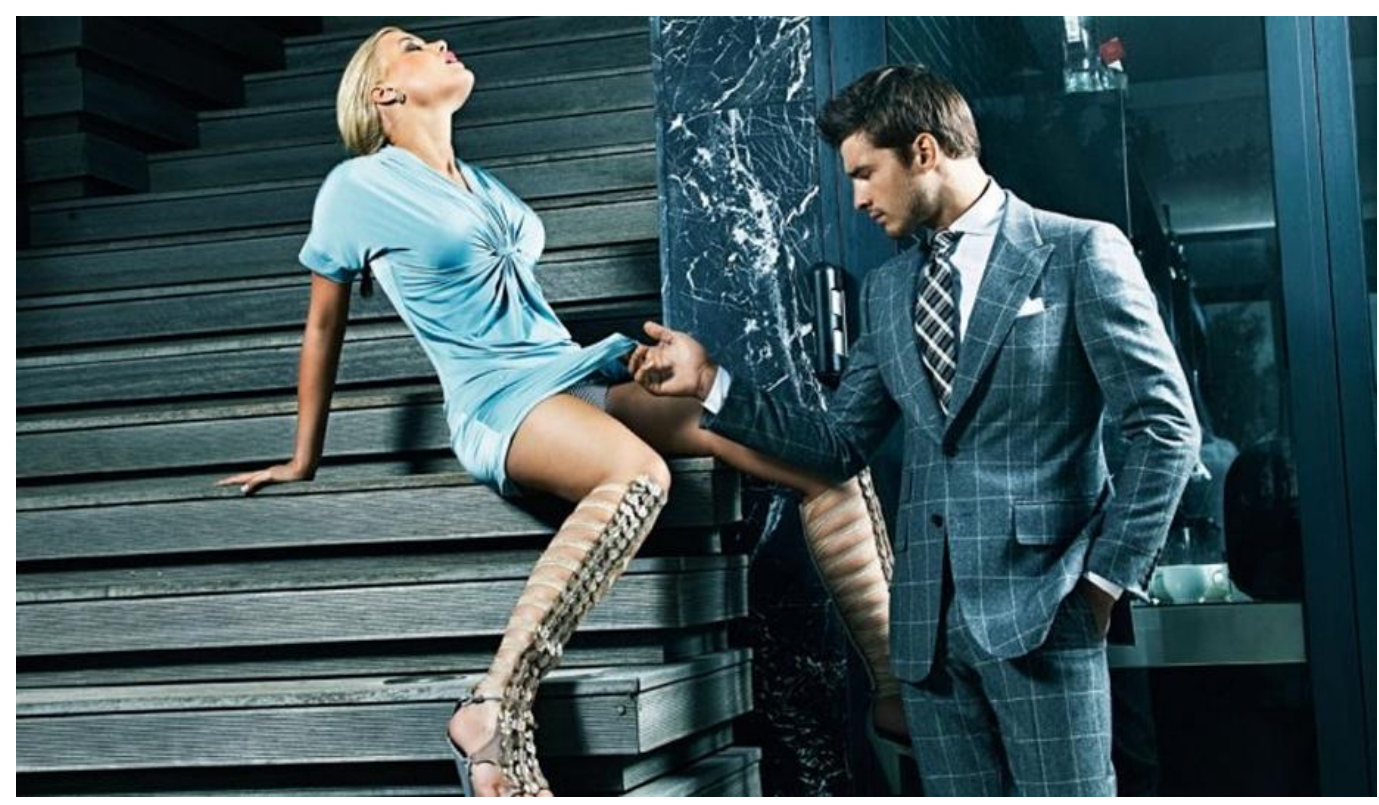

IMAGEN 4. Publicidad de la marca de moda masculina Suit Supply del año 2010. Fuente: Canon y estilo de la figura humana en la publicidad gráfica (Sánchez, 2015: 152).

En cuanto al lugar que ocupan en las estructuras de los informativos, existe una mayoría de varones dirigiendo los noticiarios de las distintas cadenas y, aunque las presentadoras sean frecuentes, es evidente la diferencia de edad o el menor tiempo de permanencia con respecto de los varones. Además, en los últimos años, la parrilla televisiva se ha llenado de programas de pseudo-información, donde las mujeres actúan de compañeras de los hombres que son quienes conducen el espacio (Bernárdez, 2015: 170). Como dato, cabe precisar, finalmente, la falta generalizada de mujeres directoras en todos los medios que transmiten informativos: no solo en la televisión, también en los periódicos, radios y en las plataformas digitales (Calleja, 2016: 60).

La telerrealidad es un fenómeno que ha transformado profundamente la televisión, suponiendo un antes y un después para el medio (Bienvenido, 2009:14). En este género televisivo, dejamos de ver a actores o actrices interpretando un papel y es la propia 
persona anónima, la que hasta ahora veía la televisión, que se convierte en personaje (López, 2016: 32). Las mujeres tienen un gran peso dentro de la telerrealidad — tanto de protagonistas como de espectadoras (Martínez, 2017: 100)_ y son mayoría en algunos de sus subgéneros: así sucede con los tipo makeover de transformaciones físicas. Dichos espacios venden —a través de los cambios de apariencia en los que, incluso, se llega a utilizar la cirugía estética—, un discurso liberador para las mujeres. En poco tiempo —esta construcción temporal es una característica compartida por todos los makeovers-, la protagonista arregla su vida transmitiendo la idea de que el cambio que precisaba era físico, era personal —en su malestar no intervenían aspectos sociales amplios-, y no requería de ningún tipo de esfuerzo (Oliva, 2009: 41). Dichas narrativas se inscriben dentro del discurso postfeminista y vienen a decirnos que el cambio de vida es fácil y está al alcance de cualquier mujer.

Otro subgénero muy feminizado es el del talk show. El talk show es un espectáculo que enlaza la conversación, lo interpersonal, con el espectáculo de los medios nacidos de la modernidad. Este posee las siguientes características: suele tratar casi siempre cuestiones sociales - mujeres maltratadas, desapariciones — o personales —abandonos, infidelidades - y se estructura en torno a la autoridad moral del presentador o presentadora — generalmente presentadora—. Además, la audiencia es mayoritariamente femenina (Lacalle, 2000: 86-87).

Dentro de estos espacios, la tendencia es la de que aparezcan modelos de mujeres altamente estereotipados: la mujer ama de casa sacrificada y un poco simple; la mujer fatal que no hace feliz a ningún hombre; la madre abnegada y sin deseos propios; la adolescente descerebrada; la mujer de pueblo sin formación pero con buenos sentimientos; la señora bien, clasista pero glamurosa, etc. Algunas críticas feministas han alertado de los problemas que pueden plantear estos programas para la imagen pública de las mujeres y es que, en muchos casos, se anima a las mismas a exaltar, de forma muy dramática, la experiencia como víctima desvalida de un conflicto, incidiendo en su fragilidad y dependencia y generando una atmosfera de victimización femenina (Bernárdez, 2015: 181-183).

Finalmente, nos gustaría destacar el papel de las mujeres dentro de los espacios de información rosa. El género del corazón ha tomado la pequeña pantalla y lo ha hecho de una manera muy agresiva. El público ha pasado de ver a los personajes en las páginas 
de la prensa especializada del corazón — que tradicionalmente mostraba la cara amable de las altas élites - a poder hacerlo en movimiento, en directo. De esta forma, ha sucedido una desmitificación que ha derivado en una pérdida de respeto provocando la mofa y la destrucción de la persona (Cáceres, 2000: 282-283).

En estos espacios, las mujeres son juzgadas desde una posición previa, un juicio moral que enturbia todo el discurso. Se trata de una crítica a la libertad de las mujeres, especialmente, a su libertad sexual. Se les hace responsables del comportamiento masculino: serán culpables si los hombres se divorcian o si tienen numerosas aventuras, si estos no han usado métodos anticonceptivos, si se han desentendido de la crianza de sus hijos o hijas, si ejercen violencia contra su pareja... Además, las mujeres son tachadas de retorcidas, juzgadas como malas madres y se trivializa la violencia que padecen. Por último, el juicio moral hacia la libertad femenina va acompañado de toda la estereotipia patriarcal que hemos ido viendo a lo largo de este apartado (Menéndez, 2006: 126-127).

Finalmente, nos gustaría lanzar algunas pinceladas sobre la prensa escrita de interés general. En primer lugar, esta se construye desde el nosotros - hombres — frente al ellas - las mujeres - (Gallego, 2007: 52). Dicha alteridad provoca, dentro del discurso, mujeres invisibles o mujeres estereotipadas. En este sentido, y aunque exista una fuerte feminización de la profesión periodística, lo cierto es que se denota una escasa evolución en cuanto a las representaciones (Ufarte, 2007: 411): las mujeres son nombradas sobre todo a través de alusiones a su aspecto, así, independientemente de la sección en la que nos encontremos — política, economía, deportes...—, las características físicas formarán parte de la noticia en sí misma (Bernárdez, 2015: 106).

Por otro lado, la invisibilidad femenina podemos detectarla en varios frentes. Primero, porque los temas con componentes de género son menospreciados, suponiendo el $1,5 \%$ de las previsiones totales en las redacciones. Además, las mujeres no están presentes a lo largo de todo el periódico, siendo las secciones en las que sí podemos encontrarlas las de comunicación, gente, cultura, espectáculos y sociedad. Por su lado, desde los propios consejos de redacción se adoptan prácticas muy masculinizadas valorando las noticias duras — política y economía—, frente a las blandas — sociedad o cultura- Esto también se traduce en el tipo de trato o prestigio que se les da a cada una de ellas, es decir, la propia estructura organizativa excluye perspectivas de noticias diferentes a las tradicionales, enfatizando unos escenarios mientras reduce otros y 
vertebrando la información a partir del desigual reparto del poder entre sexos (Gallego et al., 2002: 234-237).

Aunque desde las redacciones defiendan que el medio se destina a una audiencia neutra, lo cierto es que todas las pistas del discurso nos redirigen hacia el lector masculino, ignorando a las mujeres como posible audiencia (Bach, 2000: 27). También, del propio discurso rescatamos que existe una moral que enjuicia de manera asimétrica los comportamientos y las actitudes de cada sexo, dado el grado de familiaridad o irrespetuosidad con el que son tratadas las mujeres. Esto es así por dos motivos, uno, por la ya mencionada estructura organizativa que atiende de distinta manera la realidad social referente al sexo, $\mathrm{y}$, otro, por la propia implicación personal de los y las periodistas en ciertos asuntos y la sensibilización o perspectiva de género que puedan desarrollar y mostrar a nivel individual (Gallego et al. 2002: 238).

\section{HISTORIA Y ESTADO ACTUAL DE LAS REVISTAS DIRIGIDAS A MUJERES}

\subsection{La prensa femenina}

Una parte de la muestra de esta investigación está compuesta por revistas especializadas en estilo de vida femenino. Sin embargo, para llegar a dicha categoría tan concreta, ha sido necesario comenzar, primeramente, por explorar el término genérico conocido como prensa femenina, el cual empieza a aparecer en los textos científicos en un momento dado del análisis mediático. Llama la atención, además, que no nos encontramos, a nivel formal, con una prensa masculina. Así, surge un medio que, al parecer, se dirige o se refiere o recoge un discurso pensado específicamente para las mujeres, pero ¿qué características reúne este tipo de prensa? ¿Qué condiciones debe cumplir si quiere ser catalogada como tal?

Por un lado, uno de los requisitos que podría ayudarnos a acotar la definición de prensa femenina sería el de su consumo. En este sentido, las empresas anunciantes, a la hora de escoger dónde insertarán su publicidad, entienden que un producto consumido en un $60 \%$ por mujeres será un producto femenino y lo contrario ocurrirá en el caso de los 
hombres (Figueras, 2005: 51). La publicación corporativa IPMARK, mientras, eleva en un $15 \%$ el porcentaje y considera que la cifra debe situarse en el 75\% (Menéndez y Figueras 2013: 28). En cualquier caso, estaríamos moviéndonos por porcentajes superiores al $60 \%$.

Otro de los requisitos nos lo aportan Adolfo Perinat y María Isabel Marrades, quienes sostienen que es necesaria, por parte del medio de comunicación, una declaración de intenciones para entender que estamos ante un producto de prensa femenina. Estas publicaciones "ya sea por su título o subtítulo, ya sea por declararlo así a sus redactores, o ya sea por su temática, tienen como principal destinatario la mujer" (Perinat y Marrades, 1980: 56). Dicha aportación es interesante teniendo en cuenta el mercado actual, donde vemos revistas como Woman Madame Fígaro que, no solo la cabecera nombra específicamente a las mujeres, sino que, además, el eslogan del lomo reza El lujo de ser mujer. También, son especialmente significativos los títulos de la revista Elle o del suplemento Mujerhoy.
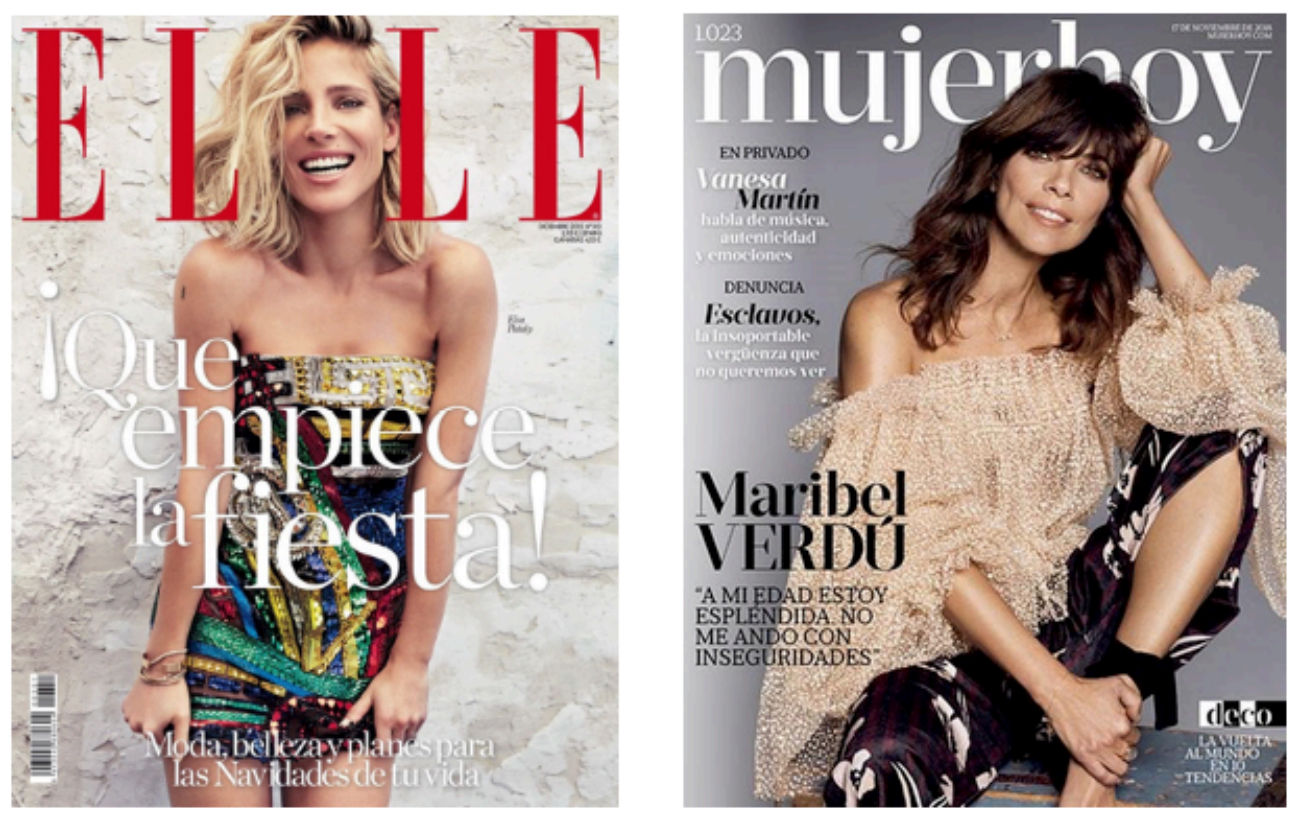

IMAGEN 5 A la izquierda, portada de diciembre de 2015 de la revista Elle y, a la derecha, portada del suplemento del grupo Vocento, Mujerhoy, de noviembre de 2018.

FuENTE: Elle y Mujerhoy.

Otras definiciones nos acercan a la idea de que la prensa femenina se conoce como tal porque su temática aborda cuestiones femeninas. De esta forma, la prensa trata temas que las mujeres están más capacitadas para decodificar debido a una mayor identificación e interés con los mismos (Pendones de Pedro, 1996: 311). Cabe preguntarnos, ¿cuáles 
serían esos temas? ¿Por qué las mujeres están capacitadas para entender y disfrutar un discurso que a los hombres les resulta ajeno o falto de interés?

Con el fin de abordar esta cuestión, es imprescindible acudir al análisis que Juana Gallego hace de los orígenes de la prensa femenina. Según nos explica la autora, sería necesario, primeramente, situar los dos espacios sociales imaginarios: esto es, el espacio público y el espacio privado (Gallego, 1990: 19). Como hemos analizado y como han estudiado diversas autoras, ambas esferas, aunque hayan ido presentando variaciones a lo largo de la historia, articulan el orden social y establecen una relación jerárquica entre hombres y mujeres. Así, el espacio más relevante es el espacio público, el que se adjudica a los hombres, y el de menor importancia será el espacio privado, ligado a las mujeres (Amorós, 1994: 23).

El espacio público, donde se realizan las actividades socialmente mejor valoradas, está expuesto a la mirada de los otros. En el privado, por el contrario, las actividades no cuentan con ese nivel de exposición ni son apreciadas públicamente. Se trata de un ámbito muy poco valorado y reservado para las mujeres (Amorós, 1994: 24). De esta manera, se atribuyen ciertas subjetividades — ciertos roles de género-, a uno y otro sexo entendiendo como femenino, entre otras, el maternalismo, la domesticidad o el cuidado y el apoyo emocional (Vélez, 2005: 153). Por ello, nos dice Juana Gallego, al igual que existen dos espacios o ámbitos, se desarrollan también dos tipos de prensa: la prensa de lo público y la prensa de lo privado (Gallego, 1990: 21).

Es importante tener en cuenta este origen de la prensa femenina, pues, para que toda una sociedad, ya no solo acepte, sino que se sienta cómoda en un mundo jerarquizado, necesita de una red de instituciones, creencias y representaciones que transmitan dicho universo simbólico. Son, lo que ya denominamos, los agentes socializadores. Así, la justicia, la iglesia, los medios de comunicación, la moral, las costumbres y la tradición operan en cuanto a canales de transmisión de los valores culturales (Gallego, 1990: 19).

En este sentido, lo femenino viene de fuera de las mujeres y no al revés. Es decir, es la estructura social la que está dictando con qué deben identificarse las mujeres y no las propias mujeres las que están elaborando su discurso. Simone de Beauvoir, al hilo del análisis que realiza sobre la alteridad femenina, añade lo siguiente: "el hombre se concibe 
sin la mujer. Ella no se concibe sin el hombre. Y ella no es más que lo que el hombre decida" (Beauvoir, 2008: 50).

La etiqueta femenina, por tanto, responde a esa socialización diferencial entre los sexos. El ámbito de lo público y de lo privado es, también, el área productiva, propia de los varones, y reproductiva, perteneciente a las mujeres. La separación tan estricta de los espacios hace que los hombres no muestren interés por el mundo de los afectos, de los cuidados y que, por consiguiente, a las mujeres les resulten poco atractivos asuntos públicos como la política o la economía (Menéndez, 2009: 286).

La prensa femenina, esta prensa de lo privado, apoya su discurso en la belleza, el amor y el hogar. En dicha narrativa, la belleza es una aspiración de las mujeres que va ligada, siempre, a la eterna juventud. El amor —entendido como amor romántico heterosexual—, forma parte ineludible de la felicidad de las mujeres, mientras que el hogar será el lugar seguro donde residir, reducto para las relaciones interpersonales gratificantes, lugar en el que reponer fuerzas físicas y psíquicas. Juana Gallego propone la siguiente secuencia lógica: "si obtenemos la belleza, conseguiremos el amor, que nos dará la felicidad, todo lo cual se materializará en el hogar” (Gallego, 1990: 50-52).

En los años 90, se introduce el pilar de la sexualidad en el discurso de la prensa femenina. Esto responde a la necesidad de combinar rasgos tradicionales y actuales, con el fin de que las lectoras sigan reconociéndose en la narrativa. Angela McRobbie detectó esta sexualidad presente en las revistas para mujeres y mujeres jóvenes y, precisamente, lo asoció con la necesaria renovación del mensaje que ayudaría a mantener a la audiencia más reciente, la cual, como hemos visto, ya bebía de nuevos mitos o discursos patriarcales (McRobbie, 1998: 271). Otras estrategias que han permitido la identificación con el público han sido las discursivas. La prensa femenina ofrece un léxico que sugiere cercanía, así, se utiliza un tono íntimo o conversacional que habla directamente con la lectora. De esta forma, se crea la falsa sensación de estar ante un producto individualizado, y no de masas, con el que la consumidora se identificará a nivel personal (Menéndez, 2013: 33).

Es interesante destacar que, cuando se usa la etiqueta femenino, en ocasiones implica que se trata de un producto elaborado por mujeres: literatura femenina, deporte femenino, cine femenino... No así sucede en la prensa femenina, que no necesariamente es escrita por mujeres, lo que nos da a entender que femenino hace referencia, en este 
caso, bien al público al que se dirige, bien a la temática que aborda. Dicho esto último y según lo visto hasta ahora, la prensa femenina sería un tipo de prensa especializada, intencionalmente dirigida a las mujeres, nacida del discurso de lo privado, donde ellas adquieren el protagonismo de la información. La autoría no tendría porqué ser femenina, pero sí estaría leída en su mayoría por mujeres, y trataría temas que atienden a la socialización diferencial femenina, alimentando y enalteciendo, que no cuestionando, la misma.
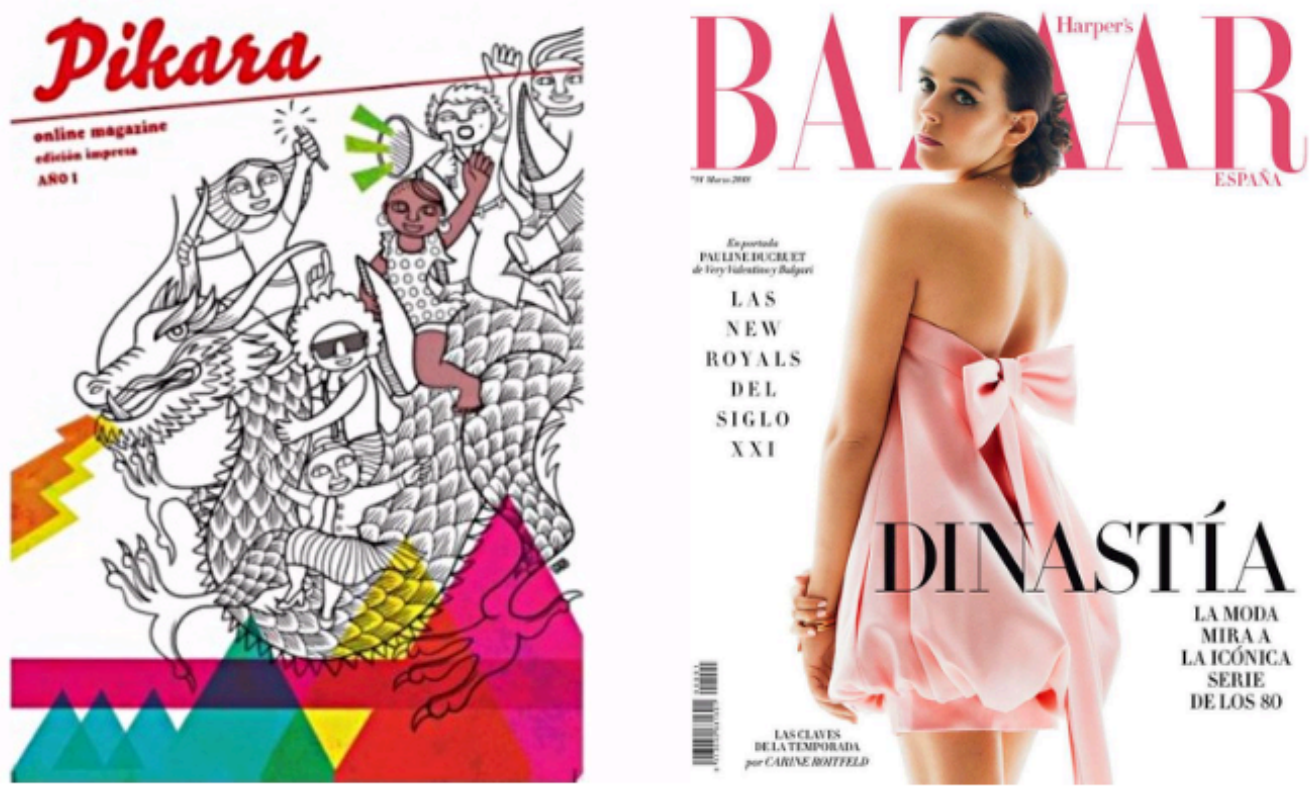

IMAGEN 6. A la izquierda, portada del primer número en papel, año 2013, de la revista feminista Pikara Magazine. A la derecha, portada de febrero de 2018 de la revista Harper's Bazaar España. Según algunas clasificaciones, la primera se trataría de prensa dirigida a mujeres y la segunda, de prensa femenina.

FuENTE: Pikara Magazine y Harper's Bazaar España.

Tal y como acabamos de señalar, la prensa femenina perpetúa la socialización diferencial entre hombres y mujeres, lo que nos lleva a una última problemática que es necesaria que tratemos. A lo largo de los estudios académicos, se usa, a veces indistintamente, prensa femenina y prensa dirigida a mujeres. Sin embargo, nos gustaría rescatar la reflexión de Juan José Fernández por considerar que viene al hilo de lo anteriormente expuesto:

Hay quien prefiere distinguir entre unas publicaciones que se ocupan, fundamentalmente de una temática relativa a la casa, la moda, la belleza (prensa femenina), y otras que se definen como dirigidas especialmente a la mujer, pero 
con otro tipo de intereses. Es este último grupo se encuentran, por ejemplo, las revistas de corte feminista (Fernández, 2002: 105).

Con esto, queríamos resaltar que no toda la prensa que se dirige a las mujeres es prensa femenina. La prensa femenina proporciona los elementos simbólicos necesarios para conformar conceptos tales como mujer, femenino, feminidad, madre, maternidad, etc. (Gallego, 2013: 117). Mientras, los objetivos de la prensa dirigida a mujeres, no buscan enaltecer la mística de la feminidad, sino que persiguen otro tipo de causas, como podría ser la transmisión de un discurso feminista.

\subsection{Evolución de la prensa dirigida a las mujeres en España}

Debemos acudir al panorama internacional para situarnos en los orígenes de la prensa femenina, concretamente, a los periódicos de información general de la tradición anglosajona. En ellos, empezaron a editarse unas páginas específicamente dirigidas a las mujeres: the women's pages (las páginas para mujeres). Así, estas secciones, que comenzaron a finales del siglo XVII y se desarrollaron durante 150 años, hablaban a las mujeres inglesas sobre moda, belleza, salud, asuntos domésticos, etc. El discurso era similar con independencia de la ideología del diario en el que estuvieran insertas (Gallego, 1990: 22).

Un siglo más tarde, comienza a editarse en España, concretamente en Madrid y en Cádiz, La Pensadora Gaditana (Menéndez y Figueras, 2013: 35). Su nacimiento data de 1768 y finalizará en 1770. El propósito de la misma fue hacer frente a los ataques antifeministas que Clavijo y Fajardo publicaron en El Pensador Matritense. Su principal firma era la de Beatriz Cienfuegos, que es un personaje al que no ha sido posible rastrear históricamente $\mathrm{y}$, por tanto, se cree que pueda tratarse de un pseudónimo. Los 52 discursos recogidos en la publicación nos ponen al tanto de las costumbres y de la situación de las mujeres en la época (Roig, 1989: 62-63).

A pesar de este título, deberemos esperar hasta el siglo XIX para empezar a ver las primeras publicaciones ajenas a asuntos políticos y dirigidas a mujeres (Hinojosa, 2005: 77). En 1811, se funda El Correo de las Damas que, precisamente por alejarse de ese carácter político que tenía La Pensadora Gaditana, algunas autoras lo consideran el inicio de la prensa femenina en España — aunque, cabe precisar que se editaba en Cuba— 
(Jiménez, 1992: 20). El Correo de las Damas centra sus contenidos en la llamada prensa de modas y salones, ofrece figurines y un discurso que vincula a las mujeres directamente con el hogar (González y Pérez, 2009: 55).

Once años más tarde, en 1822 se publica en Madrid El Periódico de las Damas, editado ya en la península. Se dice que su editor, León Amarita, introduce el periodismo femenino y de moda en España (Gómez, 1967: 159). Sus contenidos se centraban, de nuevo, en la moda, además de ofrecer consejos sobre salud, belleza, proporcionar entretenimiento en forma de acertijos o pequeñas poesías. El discurso último definía a las mujeres como seres sumisos, obedientes y entregados: las perfectas esposas y madres (Menéndez y Figueras, 2013: 35-36) o, lo que es lo mismo, dibujaban al ángel del hogar. Otras cabeceras que aparecieron en la época fueron La Espigadera (1837) que se definía de la siguiente manera: "correo de las señoras. Periódico de ameno e instructivo entretenimiento con exclusión de materias políticas", El Figurín (1839) que versaba sobre moda o La Mariposa (1840), periódico, esta vez, de literatura y moda (Roig, 1989: 100).

De esta época, la que tuvo más éxito fue $L a$ Moda que se publicó durante 85 años, desde 1842 hasta 1927 (Perinat y Marrades, 1980: 18-19). Nos dice la autora Mercedes Roig que se trataba de una revista semanal de literatura, teatro, costumbres y modas (1989: 100). En general, todas estas revistas contaban con una misma finalidad, la de instruir a las mujeres a través de temáticas amables, como pueden ser el ocio, la cultura y la moda y recordarles su posición dentro del escalafón social. Otros títulos de la época, de acuerdo con Roig (1989: 198), serían El Defensor del Bello Sexo (1845-46), La Elegancia, La Luna (1848) o el Álbum de Señoritas (1852).

Fue a partir de a mediados del siglo XIX, que se consolida la prensa femenina en España. Sin embargo, cabe destacar que, aunque se produjo una proliferación de cabeceras, estas eran efímeras puesto que su supervivencia dependía de las altas capas de la sociedad: las únicas con poder adquisitivo y que sabían leer —en 1860, el analfabetismo entre la población femenina española era de más del 80\%- (Orsini, 2014: $51-52)$.

Marta Selva e Isabel Segura han analizado las publicaciones femeninas que desde 1846 hasta 1937 encontraremos en Barcelona. La tipología de las mismas, aunque referente al área catalana, resulta igualmente útil para poder realizar un mapa mental de las publicaciones que veremos a lo largo de casi un siglo, estas son: revistas familiares o 
domésticas, revistas de higiene, revistas de modas, revistas religiosas y revistas que analizan la condición de la mujer (Selva y Segura, 1984).

Durante la primera mitad de la década de los ochenta del siglo XIX, en pleno optimismo económico por "la fiebre del oro" (Orsini, 2014: 52) llegaron a nacer en apenas cuatro años 18 publicaciones que versaban sobre moda, religión, la condición de la mujer, la higiene... También aparecieron los títulos feministas Ellas o La Mujer. La Mujer, periódico científico, artístico y literario sobre la condición femenina (1882) analiza, por vez primera, a la mujer como sujeto autónomo y no como un ser dependiente y definible a partir de sus vínculos emocionales con algún varón (Menéndez y Figueras, 2013: 36). Así, cuestiona la maternidad como único objetivo femenino y reivindica la libre decisión de vivir en la soltería (Gallego, 1990: 40).

En general, en el siglo XIX, tuvo la prensa femenina una muy importante batalla con la instrucción y la educación de la mujer. En este sentido, la instrucción hace referencia a la transmisión de los conocimientos científicos y humanísticos, mientras que la educación se refiere a todo lo relacionado con las buenas costumbres, es decir, educar para saber estar en la sociedad (Gallego, 1990: 38).

A principios del siglo $\mathrm{XX}$, proliferan nuevas publicaciones femeninas del estilo a las vistas anteriormente, como La Dama (1907-1913) o La Moda Práctica (1907-1936) que, de nuevo, hacen hincapié en el mundo de los figurines, las tendencias, el patronaje o la confección. También, veremos revistas de labores: tales son La Mujer Moderna (1906) y La Mujer y la Casa — suplemento del diario $A B C$ - (Roig, 1989: 207-209); y de cocina: El Gorro Blanco: revista española del arte de la gastronomía en general, cocina elegante y económica. Por último, cabe destacar, por su persistencia en el tiempo, la publicación El Hogar y la Moda nacida en 1909 y que existirá hasta 1971, solo interrumpiendo su actividad entre los años 1937 y 1941 (Sánchez, 2009: 207). Sin embargo, no serán estas las únicas temáticas que encontraremos a principios del siglo XX, es más, la autora Mercedes Roig, agrupa las publicaciones de aquellos años bajo las siguientes etiquetas: prensa católica, prensa anarquista, prensa feminista conservadora y prensa femenina (Roig, 1989: 207-209).

Por vez primera, y como consecuencia del nacimiento de la Acción Católica Femenina, la Iglesia Católica editará publicaciones dedicadas a las mujeres. Esto se debe a que la propia Iglesia no es ajena a la realidad de obreras y burguesas y tratará de ejercer 
su influencia a través de la prensa. La más conocida fue Acción Católica Femenina de 1911. Unos años antes, en 1906, ya había surgido La Mujer que Vive de su Trabajo, la cual pasó, posteriormente, a denominarse Instituto de la Mujer que Trabaja. Otras publicaciones fueron La Unión, de 1911, o La Mujer y el Trabajo, de 1924 (Roig, 1989: 207-208).

Mientras, de acuerdo con Roig (1989: 208), las publicaciones de prensa anarquista partieron de las propias organizaciones, algunas de las cuales editaron publicaciones que se dirigían al sexo femenino. La más emblemática fue el periódico quinquenal Humanidad Libre (1902), escrito por y para mujeres $\longrightarrow$ se sabe que participaron Soledad Gustavo, María Losada, María Caro, Rosa Lindón y Teresa Claramun-. Abordaban noticias de toda España sobre los conflictos de la clase obrera. Otro título relevante fue el del periódico bimensual La Mujer Moderna (1904).

Finalmente, la prensa feminista conservadora estaba compuesta por tres publicaciones: Pensamiento Femenino, Or i Grana y Feminal (Roig, 1989: 208). Feminal se publicó entre 1907 y 1917 y se gestó en Cataluña. Era un suplemento mensual de L'Ilustració Catalana. Su directora fue Carme Karr, quien también colaboró en Or $i$ Grana. Ambas revistas eran catalanistas y pretendían aumentar el nivel cultural de las mujeres, aunque se mostraban contrarias al sufragio femenino. Pensamiento Femenino, por otro lado, defendía los derechos de las mujeres (Sánchez, 2009: 220).

Hasta el estallido de la Guerra Civil en España, aparecerán diversos y variados títulos como La Voz de la Mujer (1917-1930), La Novela Corta (1918), Unión Feminista (1918), Agenda Anual (1923), Siluetas: Revista política, literaria y de actualidad (1923), El Amigo de las Madres (1923-30), Elegancias (1923-1926), Revista de Oro: Magazine del hogar (1923-27), Suplemento femenino de las noticias (1924), Mujer: Revista del mundo y de la moda (1925-1926), Aspiraciones (1932), Ellas: Semanario de las Mujeres Españolas (1932-34) o Cultura Integral y Femenina: La revista de unión social para una obra común de cultura general y femenina (1933-1934), donde escribirán Irene Falcón, Encarnación Fuyola o Rafael Alberti y se traducirán textos de Clara Zetkin y Stalin. (Sánchez, 2009: 227). También, en estos años, nació el semanario de arte y literatura Lecturas (1921), suplemento de la publicación El Hogar y la Moda, que, a día de hoy, sigue publicándose (Menéndez y Figueras, 2013: 37). 
La voz de la Mujer (1917-1930) propició que se celebrara, en 1926 en la ciudad madrileña, el primer encuentro feminista del país. Mientras, durante la Segunda República y la Guerra Civil, las distintas publicaciones recogían las tensiones y agitaciones sociales. Las revistas de carácter católico arremetían en contra de las medidas adoptadas por el gobierno, tal hacía La Sembradora (1932-1956), de la Juventud Católica Femenina, que mostraba su preocupación por temas como el divorcio o la enseñanza mixta y laica. Por su lado, las publicaciones de carácter republicano, socialista, marxista o anarquista escribían sobre la igualdad de género, el trabajo doméstico y remunerado o las mujeres como clase oprimida. Destaca, entre ellas, Mujeres Libres (1936), que abordaba temas como la maternidad consciente, la educación sexual, el derecho al aborto, discutía los roles de género y difundía nuevas propuestas de puericultura, higiene y educación (Orsini, 2014: 54-56).

Las publicaciones de corte feminista no pudieron sobrevivir más allá de la dictadura. A partir de 1939, las distintas cabeceras exaltaban los valores femeninos tradicionales, esto es, la figura de la esposa y la maternidad (Garrido, 2007: 68). De acuerdo con Mercedes Roig (1989: 322-323), en la década de los cuarenta, la Sección Femenina y Acción Católica lanzaron varios títulos conservadores: Consigna (1941), Medina (1941), Ventanal (1946-1951), Misión (1939-1947), Para Nosotras (1941-1964), Senda (1943-1956) y Cumbres (1949-1956).

El editorial número 1 (febrero de 1941) de Medina, perteneciente a la Sección Femenina, decía así: "el servicio de la mujer es heroico, militar, pero femenino. Un fusil en manos de una mujer deshonra el fusil, a la pobre infeliz que lo lleva y a los hombres que lo contemplan" (Gallego, 2013: 272). Por otro lado, en su número 14 de agosto de 1944 publicaba "la vida de toda mujer, a pesar de cuanto ella quiera simular $\longrightarrow$ o disimular - no es más que un eterno deseo de encontrar a quien someterse" (Gallego, 2013: 272). Mientras, la revista Consigna (1941-1960), que se dirigía a los mandos de la Sección Femenina y a las maestras, en su número de enero de 1942 rezaba:

Considerar al niño como futuro productor de valores económicos y como sujeto de autoridad y fuerza. A la niña consideradla como creadora de valores morales, principalmente, y colaboradora del hombre en el ejercicio de la autoridad y sujeto de resistencia. El niño mirará al mundo. La niña mirará al hogar (Gallego, 2013: 272). 
En esta década, aparecieron revistas que aún hoy podemos comprar en los quioscos. Estamos hablando de las publicaciones Semana (1940) y ¡Hola! (1944), además Lecturas (1941) retoma su actividad. Estas revistas ya no están tuteladas por la Iglesia o la Sección Femenina, sino que sus fundadoras son incipientes empresas de comunicación. Por su lado, también en 1941, aparece Siluetas, que se publicó hasta 1950, y destacaba por la calidad de su papel y la belleza de sus figurines, además, incluía ecos de la sociedad considerándose, pues, precursora de las revistas de corazón (Gallego, 2012: 273).

En la década de los cincuenta, se incorporan nuevos títulos como Platino, Astra (1950-1956) — cuya editorial recordaba a las revistas del siglo pasado- y Ambiente y Firmas (Roig: 1989, 380). También, vemos Ama, que se comercializó durante 29 años (1959-1989), y que incidía en el tema de la alimentación (Gallego, 2013: 274) Además, en esta década se funda Diez Minutos, revista del corazón que sigue editándose hoy en día (Menéndez y Figueras, 2013: 40). Aunque, si hay una revista que debemos destacar es Garbo (1953-1987), la cual incorpora algunas secciones de la prensa francesa como las historietas infantiles, el humor y los horóscopos (Roig, 1989: 380). Esta se decantó hacia el mundo del cine e incluyó relatos de grandes escritoras como Ana María Matute, Concha Alós o Carmen Kurtz y reportajes de temática social (Gallego, 2013: 274).

En la década de los sesenta es cuando se inicia la prensa femenina en España tal y como la conocemos hoy en día. Destaca la revista Telva (1963) — que rescata su nombre de la literatura asturiana - y que llegó al mercado emulando a los grandes títulos de la prensa internacional. Telva acopló en su discurso un nuevo rasgo femenino que respondía a la realidad de la época: por un lado, con su narrativa alimentaba los aspectos tradicionales — como el hogar, el matrimonio y los hijos e hijas - y, por el otro, introdujo el perfil de mujer trabajadora (Ganzabal, 2006b: s.p.). Más títulos importantes fueron el semanario Ella, que se publicó en 1965 (Menéndez, 2013: 76), o las revistas Cristal (1960), Bella (1962-1964), Club Fémina (1962-1967), Mía (1964-1965) y otras tantas cabeceras que continuaban explotando el trillado terreno de las típicas publicaciones femeninas (Roig, 1989: 410).

En mayo de 1976, nació Dunia, de la mano de Editora Nueva España, y se publicó hasta 1996. Dunia trajo aires progresistas, fue una revista novedosa "para la nueva mujer", e introducía temas que hasta entonces eran poco habituales en los medios de comunicación (Ganzabal, 2006b: s.p.). Este discurso contrastaba con el más conservador de Telva y, durante una década, las lectoras españolas se dividieron entre las dos revistas 
(Gallego, 2013: 120). También, en esta época aparecieron algunas publicaciones feministas, como Vindicación Feminista o Dones en Llutia y, a principios de los ochenta, La Mujer Feminista o Tribuna Feminista, sin embargo, ninguna logró sobrevivir largo tiempo en el mercado (Hinojosa, 2005: 92-93).
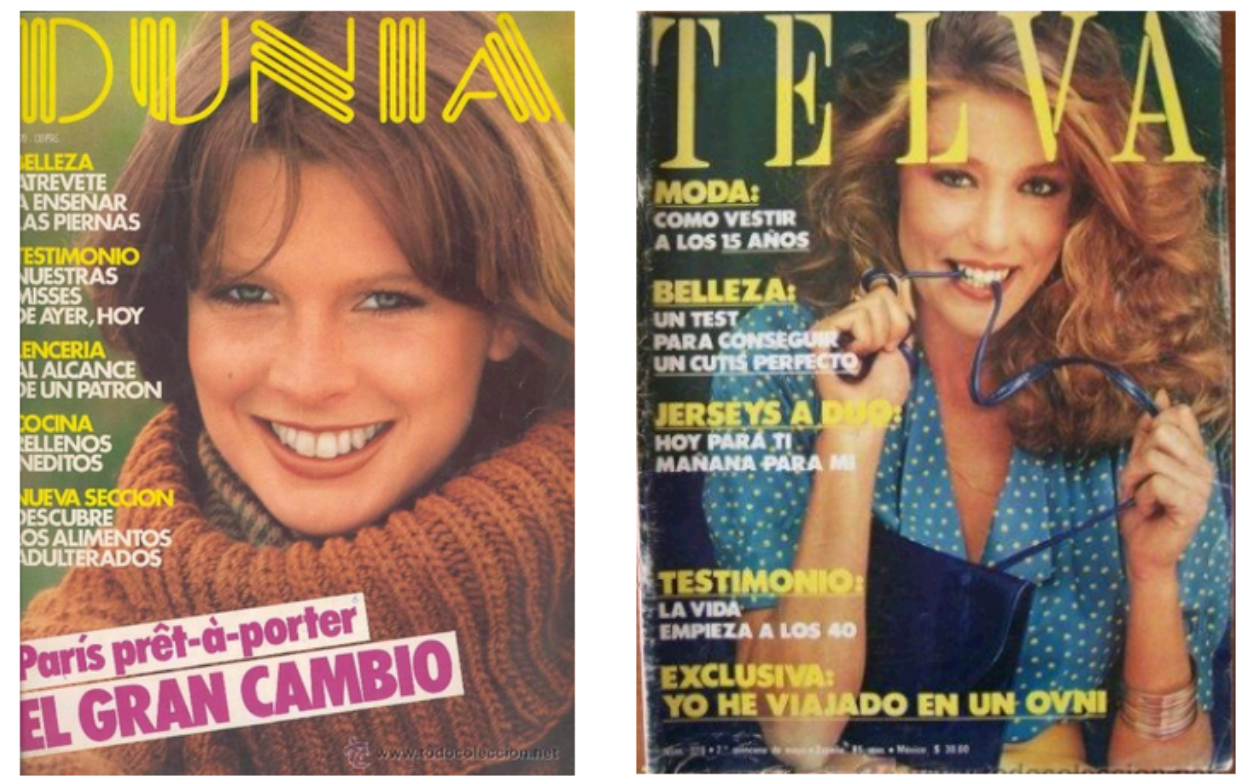

IMAGEN 7. A la izquierda, portada número 70 de la revista Dunia y, a la derecha, portada número 376 de la revista Telva.

Fuente: Red social Pinterest y Telva.

En 1984, se promulgó la Ley sobre inversiones extranjeras en empresas editoriales lo que permitió, tras su aprobación dos años más tarde, la entrada de las editoriales extranjeras en el mercado español (Gallego, 2013: 120). Así, la editora alemana Gruner \& Jahr fue la primera multinacional que invirtió en España. Compró Dunia y, posteriormente, lanzó la revista semanal Mía. El siguiente grupo editorial en desviar fondos a España fue Hachette Filipacchi, que lanzó, en octubre de 1986, la versión española de la cabecera francesa Elle (Ganzabal, 2006a: 409). Otras editoriales extranjeras que irrumpieron en estos años fueron Axel Springer, Condé Nast, Hearst Corporation o Jürg Marquad (Gallego, 2013: 120).

A finales de 1987, Marie Claire vuelve al mercado español. Esta cabecera de origen francés ya había intentado, en 1977, implantarse en nuestro país, sin embargo, su primera época apenas sobrepasó el año de vida (Menéndez, 2013: 75). Así, en 1987 Grupo 16 adquirió los derechos de la cabecera e invirtió 300 millones de las antiguas pesetas en 
su lanzamiento. Más adelante, en 1988, y tras un intento fallido del año 80, Vogue consigue hacerse un hueco en el mercado español de la mano del editor brasileño Luis Carta, quien, por cierto, declara:

\begin{abstract}
Somos elitistas y no nos dirigimos a cualquier mujer. La mujer Marie Claire o Elle son de clase media, trabaja pero no es directiva y en cierta forma aprende a vivir. La de Vogue tiene 30 años, si trabaja es directiva, si no tiene dinero por familia o matrimonio, pero es una mujer abierta mentalmente, que si bien gusta de pequeños consejos no necesita que le expliquen como tener un orgasmo... La diferenciación vendrá dada por el precio y por el contenido. Vogue sale a la calle al precio de 350 pesetas y un vestido de Vogue deberá costar por lo menos 10 veces más que uno de Marie Claire (citado en Ganzabal, 2006a: 409).
\end{abstract}

Cosmopolitan será la siguiente cabecera extranjera que florecerá en España y lo hará en el año 1990. Sin embargo, al igual que sucedió con Marie Claire y Vogue, se trataba ya del segundo intento. Su aventura editorial comenzó en 1976, cuando fracasó, y no será hasta 1990 que volverá a intentarlo (Menéndez, 2013: 75). Se caracterizará por incluir la temática sexual de una manera desenfadada y por su carácter optimista, alegre y jovial. Por otro lado, en septiembre de 1992, la editorial española Grupo Zeta apostó por lanzar una revista hecha en España, pero con apariencia internacional. Bajo esta premisa nació Woman que, además de escoger un nombre inglés para su cabecera, presentaba un cuidado diseño gráfico, contaba con director de arte e incluía reportajes y entrevistas de temas internacionales (Ganzabal, 2006a: 410).

Así, desde que en 1986 el mercado español se abriera a las editoriales internacionales, se vivió una etapa de intensos cambios donde el sector de las revistas femeninas sufrió una verdadera remodelación. Aunque inicialmente, tal y como vemos durante el primer periodo de las publicaciones Cosmopolitan (1976) y Marie Claire (1977), las cabeceras internacionales no parecían caminar en sintonía con la realidad de las lectoras españolas y, por tanto, les fue imposible asentarse en nuestro país, será a finales de los ochenta y principios de los noventa que estas volverán con un discurso lleno de mensajes evasivos y hedonistas que sí calará entre la audiencia femenina. Atrás quedarán, pues, otro tipo de discursos, como las páginas críticas que pudieron leerse durante el primer periodo de la revista Marie Claire (Menéndez, 2013: 82).

En muy pocos años, sucumbieron las revistas Garbo (1953-1987) y Ama (19591989), incapaces de hacer frente a las competidoras extranjeras e incluso Dunia (19761996), asentada como estaba, dejó de publicarse (Gallego, 2013: 121). Solo Telva - y las 
revistas del corazón— lograron sobrevivir, eso sí, la publicación hubo de adaptarse a las directrices internacionales: pasó a ser mensual, a utilizar la encuadernación tipo lomo, mejoró la calidad del papel, amplió el número de páginas y promovió reportajes exclusivos, en definitiva, apostó por ofrecer una mayor calidad. Aun con todo, siguió siendo fiel a su línea conservadora y se mantuvo bastante al margen de temas como la sexualidad (Menéndez y Figueras, 2013: 41-42).

Las apuestas nacionales que intentaron competir contra las grandes editoriales extranjeras fueron varias: Planeta Revistas probó suerte con dos publicaciones Práctica (1983-1993) y Entorno de Mujer (1991), el grupo Anaya con Biba (1991) y Grupo Z con You (1997-2007). Entorno de Mujer fue una revista de alta gama para mujeres de cierta edad y estatus económico y Práctica pretendía prestar ayuda ante problemas cotidianos de cocina, compras, familia, decoración, trabajo, etc. Mientras, Biba se anunció como una revista que "encierra las claves de tu universo femenino, una revista para las diferentes mujeres que hay en ti” (editorial, núm. 1, marzo 1991 citado en Gallego, 2013: 124). Por su lado, You fue la apuesta juvenil del Grupo Z, en este sentido, se concibió como la hermana pequeña de Woman - lanzada, recordemos, por este mismo grupo editorial en 1992 - y, aunque recibió grandes inversiones de dinero e introdujo novedades en el diseño, como una portada con brillo o titulares en quinta tinta, tras 10 años en el mercado dejó de publicarse (Gallego, 2013: 126).

Los años noventa fueron clave para las revistas femeninas: la información general vivió un estancamiento, desde los diarios se empezó a apostar por los suplementos editoriales, el periodismo se fragmentó y especializó, lo que supuso que el concepto de revista femenina saliese reforzado (Ganzabal, 2004: 95). El cambio de siglo también trajo novedades: nuevos títulos y nuevos estilos. En 2001, se utilizó por primera vez el poder de una persona con relevancia pública y nació $A R$, la revista de la periodista Ana Rosa Quintana editada por Hachette y que iba dirigida a las mujeres de a partir de entre $35 \mathrm{y}$ 40 años, un sector muchas veces olvidado por el resto de publicaciones (Ganzabal, 2006b: s.p.).

En 2002, Conde Nast lanza Glamour cabecera internacional con una trayectoria de 30 años en el mercado estadounidense, y que sigue publicándose a día de hoy. Glamour apostó por la calidad del diseño, la impresión, contenidos eminentemente prácticos y un precio reducido en comparación con el resto de revistas: 1,80 euros (Ganzabal, 2006a: 415). Además, Glamour, que eligió el formato de impresión pocket, es decir, un tamaño 
en torno a 170x220 centímetros, obligó al resto de revistas a salirse de las medidas tradicionales y realizar dos tiradas (Menéndez, 2010: 207). Cabe destacar que Glamour, hoy en día, dejó la exclusividad del tamaño pocket y ofrece ambos formatos.

En octubre de 2004, la revista ;Hola!, del grupo Hola, S.A., regaló el primer ejemplar de Chic, una publicación dirigida a la mujer urbana de entre 25 y 45 años, de clase alta y media-alta, con estilo propio, que cuida su imagen, con inquietudes por el mundo que le rodea y que quiere estar bien informada (Ganzabal, 2006a: 416). Su directora, Isabel Ottino, nos decía lo siguiente: eres Chic "cuando te preocupas por la moda y las tendencias, pero sin ser su esclava, cuando quieres estar guapa, pero no a cualquier precio, y decoras y mimas tu casa, pero por encima de todo la vives..." (citado en Gallego: 2013, 126).

También, en 2004 destacamos Nova, del Grupo Hachette, Única —que formó parte del grupo editorial Recoletos hasta 2005 y de RBA hasta 2008, año en el que desaparecería-, o InStyle "la revista de moda y estilo de las celebrities", que aún sigue en el mercado (Varela, 2015: 19). Posteriormente, en 2005 nacen los títulos Psychologies, cabecera con 10 ediciones internacionales editada en España por el Grupo Planeta y que se dirige a "una mujer sofisticada y de mentalidad abierta interesada en cultivar su inteligencia emocional"; ${ }^{40}$ la revista Citizen K (2005-2009) de Focus Ediciones, que contenía reportajes de moda, arquitectura, cine, fotografía, etc. y que dejó de publicarse en 2009, ${ }^{41}$ y Mujer Vital (2005-2008), editada por LV Magazine. Dos años más tarde, en 2007, aparece el proyecto relacionado Mujer (sana \& bella) de MC Ediciones - esta revista fue dirigida por Montserrat Mulero que en Mujer Vital figuraba como directora editorial—(Gallego: 2013, 127).

Mujer Vital era un híbrido entre la revista femenina y la de salud, así, intentaba recopilar las últimas tendencias en belleza, salud, nutrición, deportes, sexo, psicología o viajes (Gallego, 2013: 127). En cuanto a Mujer (sana \& bella), se tienen pocos datos de ella, sin embargo, sabemos que seguía la misma línea que el resto de publicaciones femeninas: “¿por qué Mujer (sana \& bella)? Porque somos mujeres, porque estamos

\footnotetext{
${ }^{40}$ Véase información publicada en la página web del Grupo Planeta. Recuperado el 27 de mayo de 2019 de https://www.planeta.es/es/psychologies

${ }^{41}$ Véase información publicada en 2009: "Cierra la revista Citizen K". Recuperado el 27 de mayo de 2019 de https://233grados.lainformacion.com/blog/2009/07/cierra-la-revista-citizen-k.html
} 
encantadas de serlo y porque pretendemos que la familia que forma parte de la revista sea cada día más sana y más bella, de cuerpo y mente" (citado en Gallego, 2013: 127).

También, en estos años, varias revistas adolescentes vieron la luz. En 2006, se fundó la empresa Nomoan, liderada por Antonio Ábalos, Richard Morla y Rocío Novoa y compuesta por 20 profesionales. El objetivo era el de cubrir el mercado infantil y juvenil. Así, en 2008 editaron Star2, Black!, Foq — revista oficial de la serie de televisión Física o Química - y TeenPosters. Un año más tarde, en 2009, relanzaron Ragazza, revista creada originariamente en 1989 por Hachette para un público joven y que estuvo en el mercado hasta 2008. Finalmente, y a pesar de los múltiples esfuerzos, Nomoan liquidó la mayor parte de sus revistas en mayo de 2012, entre ellas Ragazza y Star2 (Gallego, 2013:127-128). No fueron estas las únicas revistas juveniles que sucumbieron, también Super Pop (1977-2011), Loka Magazine (2004-2009), Nuevo Vale (1977-2012), y Bravo por ti (1995-2017) dejaron de publicarse (Varela, 2015: 19-20).

Ya en la última década, han seguido apareciendo nuevas publicaciones. En 2010, y como apuesta del grupo Hearst, comenzó a editarse Harper's Bazaar. Esta revista fue la primera publicación de moda de Estados Unidos (1867) y de las primeras revistas en colaborar con prestigiosos fotógrafos como Peter Lindgergh y Solve Sundsbo. A España, llegó dirigiéndose a un perfil de mujer intelectual, apasionada por la moda y las tendencias e interesada en la vida cultural y en viajar (Pérez et al., 2017: 27).

En 2013, Prisma Publicaciones - grupo Planeta- se aventuró a editar el semanario Grazia, el cual sobrevivió, apenas, durante un año y medio. ${ }^{42}$ Esta revista contaba con una gran trayectoria en Italia (1938), pero llegó a nuestro país en un momento de crisis y tampoco ofreció nada nuevo a sus lectoras, a pesar de todas las promesas, “¿una revista de moda informando sobre las consecuencias de la Guerra de Vietnam? ¿O abanderada de los derechos medioambientales? ¿O apostando por la igualdad de derechos y oportunidades entre hombres y mujeres? Pues sí", declaraban sus responsables en el primer número. Sin embargo, la revista fue un escaparate más para los espacios publicitarios de moda y belleza (Gallego, 2013: 147).

\footnotetext{
${ }^{42}$ Véase información publicada el 25 de junio de 2014 en Prnoticias: "La revista Grazia dice adiós en nuestro país: 20 puestos de trabajo en el aire". Recuperado el 15 de junio de 2019 de https://prnoticias.com/hemeroteca/433-ere-prensa/20132044-la-revista-grazia-dice-adios-en-nuestro-pais20-puestos-de-trabajo-en-el-aire-
} 
También en 2013, Motorpress Ibérica lanza Women 's Health, la versión femenina de la cabecera Men's Health, a la que la propia editorial califica como "la primera revista femenina de estilo de vida en España" (Varela, 2013: 25). Desde 2018, esta revista pertenece a Hearst España. ${ }^{43}$ En Women's Health encontramos “salud, deporte, nutrición, entrenamiento, bienestar, belleza y moda". ${ }^{44}$ La publicación explota el culto al cuerpo, al igual que sus compañeras, pero lo hace desde el fitness, aunque también proporciona contenidos de maquillaje, cosmética y moda.

Cabe mencionar, un último tipo de publicación, que es la de los suplementos femeninos de los periódicos. Se trata de revistas que sirven de reclamo para conseguir una mayor audiencia, pero que formalmente reúnen las características de las publicaciones que hemos ido mencionado hasta ahora. El primer suplemento dirigido a las mujeres fue La Vanguardia Mujer, el 30 de marzo de 1984, el cual pretendió hacerse un hueco entre las dos grandes revistas del momento: Telva y Dunia. Tenía un aspecto formal gráfico y tipográfico muy cuidado y una tirada de unos 300.000 ejemplares, sin embargo, en 1990, el periódico La Vanguardia se rediseñó y dejó de editarse. A La Vanguardia Mujer le siguió, en 1988 y hasta 1991 El País Estilo, del Grupo Prisa, que era una publicación de estilo de vida y tendencias y atendía a temas como la decoración o la belleza (González, 2011: 16).

El 17 de abril de 1999, aparece la revista suplemento Mujerhoy, la cual, actualmente, se sigue repartiendo los fines de semana con todos los periódicos del Grupo Vocento. Aunque Mujerhoy es equiparable en su primera etapa a una revista femenina práctica, como puede ser Mía y Clara, y no aspiracional - "no somos una revista de imagen al estilo de los mensuales femeninos de moda, que se ven pero no se leen", decía Mara Malibrán, primera directora de la revista (citado en González, 2011: 17)—, lo cierto es que, un rediseño posterior, la ha acercado a la prensa femenina de alta gama (González, 2011: 28), lo cual, por otra parte, no quiere decir que haya perdido su carácter práctico. Actualmente, incluye moda, tendencias, belleza, salud, familia, decoración y cocina. ${ }^{45}$

\footnotetext{
${ }^{43}$ Véase información publicada el 15 de enero de 2018 en la página web de Hearst España: "Hearst adquiere las editoriales Rodale y G+J Holanda". Recuperado el 15 de junio 2019 de http://www.hearst.es/sala-deprensa/hearst-adquiere-las-editoriales-rodale-y-g-j-holanda

${ }^{44}$ Véase información publicada en 2019 en la página web de Hearst España: Women's Health. Recuperado el 15 de junio de 2019 de http://www.hearst.es/nuestras-marcas/women-s-health

${ }^{45}$ Véase información publicada en 2019 en la página web de Vocento: Mujerhoy. Recuperado el 15 de junio de 2019 de https://www.vocento.com/nosotros/prensa/mujerhoy/
} 
Más tarde, el 7 de mayo de 2005, Unidad Editorial lanza Yo Dona, suplemento semanal de El Mundo. Llama la atención su diseño claro, elegante y cuidado donde la imagen desempeña un papel fundamental y que solo es posible gracias a los altísimos índices publicitarios. El contenido vuelve a ser de moda, tendencias, belleza, relaciones, estilo de vida, etc. (González, 2011: 24). Finalmente, el Grupo Prisa también decide apostar por los suplementos de estilo de vida dirigidos a un público femenino y, en 2011, llega SModa, proyecto en el que se involucra, además, el Grupo Condé Nast. La revista está dirigida por Empar Prieto, ex directora de Woman (González, 2011: 24-25) y puede adquirirse junto con El País el tercer sábado de cada mes o de manera independiente. Por su lado, el último jueves de cada mes, El País reparte Shopping \& Style que se dirige "a una mujer emprendedora, preocupada por su imagen y aspecto físico y con interés por la moda, la tecnología y las últimas tendencias" (Pérez et al., 2017: 10).

\subsection{Revistas especializadas en estilo de vida femenino}

Hay una serie de características que convierten a una publicación en una revista. En primer lugar, que sea consecuencia de una idea empresarial que busca llegar a un público segmentado al que intenta satisfacer una serie de necesidades más específicas que lo que viene haciéndose en otro tipo de soportes, como puede ser un diario. Además, es importante que mantenga un ritmo de salida al mercado, esto es, una periodicidad determinada — ya sea semanal, quincenal, mensual, bimestral, etc.—(Cabello, 1999: 2021). Por otro lado, estas publicaciones reúnen una serie de elementos formales — portadas diseñadas cuidadosamente, calidad del papel, grandes y coloridas fotografías...- que las distinguen de otros productos mediáticos (Ortega, 1997: 91).

Fue a mediados del siglo $\mathrm{XX}$, que las revistas comenzaron a editarse como las conocemos hoy día. Consecuencia de la reproducción fotográfica, de la automatización de la imprenta y de las nuevas fórmulas tipográficas y espaciales de diseño, las publicaciones empezaron a tener en cuenta la doble página, la jerarquía de las familias tipográficas —que ordenaban mejor los titulares y cuerpos de la noticia- o la importancia de la portada. Life, nacida en 1936, fue pionera en la implantación de las nuevas fórmulas de diseño y sentó los precedentes de las revistas que disfrutamos actualmente: altamente visuales y enfocadas al consumo (Menéndez, 2009: 279). 
Existe un concepto, el de revistas de alta gama, que conviene especificar, pues, en los textos académicos, aparece muy ligado a la prensa femenina. La revista de alta gama se caracteriza por ser una publicación especializada en moda y belleza, de una alta calidad técnica, que cuida el estilo y el diseño — ofrece, por ejemplo, un papel de mayor gramaje que otras revistas o una encuadernación propia de los libros-, donde se promueven hábitos relacionados con la alta costura y la cosmética y donde, por otro lado, vemos anunciados productos aspiracionales (Pérez y Romero, 2010: 15), es decir, productos que en la mayoría de ocasiones son incosteables por parte de sus lectoras.

Estas revistas brindan contenidos que mezclan, como hemos dicho, lo último y más elitista que podemos encontrar en el mundo de la moda y la belleza con reportajes sobre temas de actualidad que puedan afectar a las mujeres. Cabe destacar que el término revista de alta gama es una autodefinición emitida por el propio medio que pretende situarse "por encima de otras publicaciones más populares donde los productos anunciados o promocionados resultan más asequibles" (Pérez y Romero, 2010: 14). Debe entenderse, por tanto, que no toda la prensa femenina está compuesta por revistas de alta gama, pues no todas las revistas cumplen con estas especificaciones.

Visto lo anterior y teniendo en cuenta lo que ya habíamos mencionado de prensa femenina, querríamos rescatar la definición que elabora Isabel Menéndez sobre "revistas dirigidas a mujeres" en su estudio Aproximación teórica al concepto de prensa femenina, donde concluye que:

Revistas dirigidas a mujeres son aquellas publicaciones seriadas especializadas, de periodicidad variable y superior a una semana; distribuidas bajo distintas fórmulas de difusión (de pago, gratuitas o mixtas); cuyo público objetivo es explícita o implícitamente de sexo femenino, ya sea adulto o juvenil (circunstancia verificable a través de sus editoriales, la temática, sus inserciones publicitarias y los estilos de comunicación); cuya audiencia está mayoritariamente integrada por mujeres (entre 60 y el 75 por ciento como mínimo) y que, en función de sus características formales, pueden formar parte o no de las publicaciones de alta gama. En cuanto a los contenidos, son títulos que abordan bajo diferentes tipologías y con objetivos distintos, los aspectos relacionados con la socialización diferencial femenina y el espacio reproductivo $\mathrm{y}$, solo en algunos casos, la discriminación de género y/o la emancipación de las mujeres (Menéndez, 2009: 294). 
La crisis económica que acechó a España en el 2008 y la crisis del papel, propiciada por las publicaciones digitales, provocaron que, en el periodo de entre 20082013 se cerraran 182 revistas y se destruyeran un total de 1438 puestos de empleo, según el Informe Anual de la Profesión Periodística de 2013 (citado en Varela, 2015: 20). Si bien es cierto que las revistas han pasado por una época muy convulsa, en el estudio de mayo de 2019 de la AIMC, el 68\% de la muestra afirmó haber leído alguna revista en papel en los últimos 6 meses, siendo las mujeres las que lideraban la lectura de revistas, tanto en papel como online. ${ }^{46}$

La OJD, en el listado de revistas especializadas, nos propone hasta 25 títulos dentro del apartado revistas femeninas, donde conviven las revistas del corazón, las de carácter práctico o las de estilo de vida. También, fuera de la propia clasificación, aparecerán categorías tradicionalmente asociadas con la socialización diferencial femenina, como la gastronomía, la decoración o la salud (véase tabla 1). Esta mezcolanza de contenidos impide un análisis certero de las revistas dirigidas a mujeres y, es por ello, que nos resulta especialmente interesante el trabajo que elabora la autora Isabel Menéndez quien, después de realizar una panorámica por las clasificaciones propuestas desde los años setenta del siglo pasado hasta las más actuales (Menéndez, 2010: 212-223), determina que las revistas dirigidas a mujeres en el siglo XXI se dividen en cinco categorías y las recoge en las siguiente tabla, junto con otros aspectos como su periodicidad, la calidad formal, edad del público objetivo y el tipo de difusión(Menéndez, 2010: 225).

La novedad que incluye la autora, y que resulta de lo más esclarecedora, es que las revistas especializadas en estilo de vida femeninas abordan los temas de socialización diferencial desde el punto de vista de sus agentes, estos son, las mujeres, mientras que, por ejemplo, las especializadas en hogar se concentran en algún aspecto del espacio reproductivo, y no tanto en las protagonistas de dicho espacio: decoración de la casa, técnicas de cocina, arreglo de jardines, confección de indumentaria (Menéndez, 2010: 226-227). Lo mismo ocurriría con las revistas del corazón, que muestran la vida privada de personajes públicos, pero no están especializadas en enseñar lo que constituye el universo de valores femeninos (Gallego, 2013: 160).

\footnotetext{
${ }^{46}$ Véase información publicada en mayo de 2019 en el sitio web de AIMC: "Las revistas en papel continúan gustando a los internautas. Recuperado el 27 de mayo de 2019 de https://www.aimc.es/blog/las-revistaspapel-continuan-gustando-los-internautas/
} 


\begin{tabular}{|c|c|c|}
\hline \multicolumn{3}{|c|}{ PRENSA DE MASAS DIRIGIDA A MUJERES EN ESPAÑA EN EL PERIODO CONTEMPORÁNEO (SIGLO XXI) } \\
\hline \multirow{9}{*}{ ELEMENTOS } & \multicolumn{2}{|c|}{ TiPOLOGÍA } \\
\hline & \multicolumn{2}{|c|}{$\begin{array}{l}\text { Revistas especializadas en estilo de vida (antes femeninas): temática } \\
\text { relacionada con la socialización diferencial femenina en relación con sus } \\
\text { protagonistas, las mujeres. }\end{array}$} \\
\hline & \multirow{4}{*}{$\begin{array}{l}\text { Revistas especializadas de hogar: abordan } \\
\text { distintos aspectos del espacio reproductivo. }\end{array}$} & $\begin{array}{l}\text { Confección, patrones y } \\
\text { labores. }\end{array}$ \\
\hline & & Salud y bienestar. \\
\hline & & Gastronomía. \\
\hline & & Decoración. \\
\hline & \multicolumn{2}{|c|}{$\begin{array}{l}\text { Revistas prácticas o hibridas estilo de vida-hogar: incluyen temáticas de las } \\
\text { dos categorías. }\end{array}$} \\
\hline & \multicolumn{2}{|c|}{$\begin{array}{l}\text { Revistas de información gráfica, evasión o del corazón: tratan de la vida } \\
\text { sentimental de las personas famosas. }\end{array}$} \\
\hline & \multicolumn{2}{|c|}{$\begin{array}{l}\text { Revistas feministas: temática sobre las mujeres en el espacio público, } \\
\text { emancipación femenina e igualdad. }\end{array}$} \\
\hline \multirow{5}{*}{ PERIODICIDAD } & \multicolumn{2}{|l|}{ Semanal. } \\
\hline & \multicolumn{2}{|l|}{ Quincenal. } \\
\hline & \multicolumn{2}{|l|}{ Mensual. } \\
\hline & \multicolumn{2}{|l|}{ Trimestral. } \\
\hline & \multicolumn{2}{|l|}{ Otros formatos. } \\
\hline \multirow{3}{*}{ CALIDAD FORMAL } & \multicolumn{2}{|l|}{ Alta gama. } \\
\hline & \multicolumn{2}{|l|}{ Gama media. } \\
\hline & \multicolumn{2}{|l|}{ Gama baja. } \\
\hline \multirow{2}{*}{$\begin{array}{l}\text { EDAD DEL PÚBLICO } \\
\text { OBJETIVO }\end{array}$} & \multicolumn{2}{|l|}{ Juvenil. } \\
\hline & \multicolumn{2}{|l|}{ Mujeres adultas. } \\
\hline \multirow{3}{*}{ DIFUSIÓN } & \multicolumn{2}{|l|}{ De pago. } \\
\hline & \multicolumn{2}{|l|}{ Gratuitas. } \\
\hline & \multicolumn{2}{|l|}{ Combinadas. } \\
\hline
\end{tabular}

TABla 10. Tipología de la prensa dirigida a mujeres en España en el siglo XXI.

FuENTE: Imágenes de las mujeres en los medios de comunicación. Las revistas femeninas como escenarios de la corporeidad (Menéndez, 2010: 225).

Es decir, aunque las tres categorías se dirijan a mujeres, compartan una audiencia mayoritariamente femenina, se circunscriban al ámbito de lo privado o la publicidad esté acotada para un target femenino, solo en las primeras, en las especializadas en estilo de vida, las mujeres serán las protagonistas de la información. Cabe destacar que, también, en la última categoría, en la de las revistas feministas, las mujeres - como sujeto político del movimiento- adquirirán ese papel central, sin embargo, no serán estas un medio de enaltecimiento e instauración del sistema patriarcal ni contribuirán a la construcción de lo femenino, sino que, precisamente, su mensaje servirá para cuestionar y desafiar los pilares de una sociedad opresiva para con las mujeres. Además, tampoco su discurso se 
centrará en el ámbito de lo privado, sino que tratará, de igual manera, asuntos de la esfera pública.

Por otro lado, y como ya se ha mencionado, el término revistas femeninas y revistas de alta gama se usa, en muchas ocasiones, indistintamente. Si bien es cierto que el concepto alta gama puede hablarnos del contenido de las publicaciones — estas suelen ser revistas especializadas en moda y belleza (Pérez y Romero, 2010: 15)—, la autora Isabel Menéndez considera la alta gama como una cualidad, que más tiene que ver con el carácter formal de la revista — con el diseño premium o con las inserciones publicitarias que aportarán cierto estatus a la publicación—, que con sus contenidos en sí (Menéndez, 2010: 223). Es decir, dado el análisis que nos acontece, no tendría sentido situar las especificaciones formales por encima del mensaje.

Así, aunque algunas revistas incorporen elementos propios de la alta gama —papel de mayor gramaje, grandes reportajes fotográficos, tipografía cuidada y elegante-, el mensaje puede seguir manteniendo, por ejemplo, su carácter práctico. Esto lo vemos en el caso de los suplementos. Es importante reseñar que, estos últimos, aunque nacen como complemento de los diarios, con el paso del tiempo han ido adquiriendo peso específico en el quiosco hasta el punto de configurar un medio prácticamente autónomo, llegando a hablarse de una desnaturalización del producto e intromisión de los mismos en el campo de las revistas (González, 2011: 26).

Mientras que suplementos como Mujerhoy o Yo Dona formalmente reúnen características de las revistas de alta gama (González, 2011: 24-28), aun así, se tratan de revistas prácticas o híbridas de estilo de vida-hogar (Menéndez, 2018: 126). Otras revistas prácticas son Clara o Mía, esta última perteneciente a la gama media. De esta forma, la clasificación de la revista Mía, siguiendo el esquema propuesto por Menéndez, sería la siguiente: Mía, revista práctica, de pago, de gama media, de periodicidad semanal y dirigida a mujeres adultas (Menéndez, 2010: 227).

Tal y como veremos más adelante, de entre las revistas dirigidas a hombres, también podremos encontrar revistas especializadas en estilo de vida. Es por ello que son estas las que captan nuestro interés, porque nos permitirán realizar un estudio comparativo de ambos productos paralelos y segregados. Además, nos resulta especialmente interesante que sean los propios hombres —en el caso de las masculinas y las mujeres —en el caso de las femeninas_, los y las protagonistas de la información, 
agentes que vertebran el discurso central alrededor del cual se irán situando los distintos elementos que componen la revista: moda, belleza, cultura, gastronomía, tiempo libre...
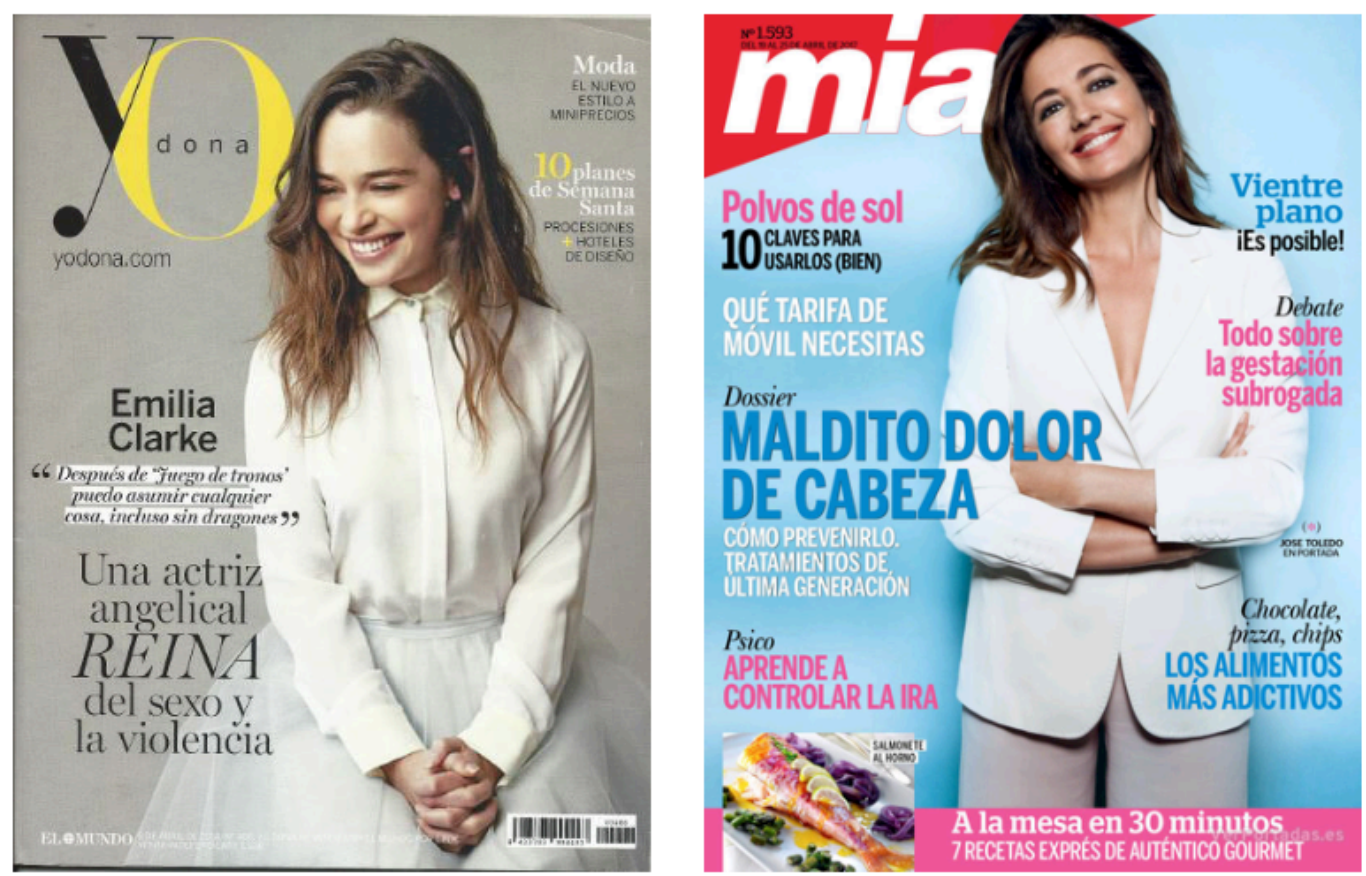

IMAGEN 8. A la izquierda, la portada de septiembre de 2017 de Yo dona, suplemento semanal de El Mundo, (publicación práctica de alta gama). A la derecha, portada de abril de 2017 de la revista Mía (publicación práctica de gama media).

FuenTE: Yo dona y Mía.

A día de hoy, existen 10 revistas especializadas en estilo de vida femenino. La principal empresa editora que controla este mercado es Hearst España, que reúne hasta cinco cabeceras —Elle (1986-), Marie Claire (1987-), Cosmopolitan (1990-), Harper's Bazaar España (2011-) y Women's Health (2013)_, por su lado, Condé Nast cuenta con Vogue (1988-) y Glamour (2002-). Unidad Editorial edita la más veterana de todas ellas, Telva (1963-). Finalmente, Woman Madame Fígaro (1992-) es propiedad de Grupo Z e InStyle (2004-), de RBA.

Algunas autoras, como Inés García-Albi (2007: 214) o Juana Gallego (2013: 128), coinciden en la idea de que la prensa femenina ya ha dejado de enseñar, de mostrarnos el camino de cómo ser mujer, y se ha transformado en una serie de revistas de estilo de vida que apuestan por el consumo. Para la autora Juana Gallego, es relevante que los nuevos títulos no sean títulos femeninos o hagan referencia a las mujeres, sino que encarnan una 
actitud, un estar: Glamour, Cosmopolitan, Instyle, Chic... En este sentido, las revistas femeninas se convierten en catálogos para los principales anunciantes que buscan llegar al mayor número posible de consumidoras.

\begin{tabular}{|ccccc|}
\hline \multicolumn{4}{|c|}{ REVISTAS ESPECIALIZADAS EN ESTILO DE VIDA FEMENINO (2019) } \\
\hline Nombre & Año & Periodicidad & Empresa editora & Difusión $^{\mathbf{4 7}}$ \\
\hline Telva & $1963-$ & Mensual & Unidad Editorial & 144.986 \\
\hline Elle & $1986-$ & Mensual & Hearst España & 138.558 \\
\hline Marie Claire & $1987-$ & Mensual & Hearst España & 66.922 \\
\hline Vogue & $1988-$ & Mensual & Condé Nast & 88.532 \\
\hline Cosmopolitan & $1990-$ & Mensual & Hearst España & 97.818 \\
\hline $\begin{array}{c}\text { Woman Madame } \\
\text { Figaro }\end{array}$ & $1992-$ & Mensual & Grupo Z & 150.604 \\
\hline Glamour & $2002-$ & Mensual & Condé Nast & 141.133 \\
\hline In Style & $2004-$ & Mensual & RBA & 73.874 \\
\hline $\begin{array}{c}\text { Harper's Bazaar } \\
\text { España }\end{array}$ & $2010-$ & Mensual & Hearst España & 41.040 \\
\hline Women's Health & $2013-$ & Mensual & Hearst España & - \\
\hline
\end{tabular}

TABla 11. Revistas especializadas en estilo de vida femenino, año 2019. FUENTE: Elaboración propia a partir de diversas fuentes.

Dicha evolución en el mensaje de las revistas femeninas la podemos apreciar desde el siglo XX. En las primeras décadas, pasan de ser un medio donde se promocionaban los derechos de las mujeres, a ser instrumentos elaborados por algún poder: primero fue el religioso y después el político hasta que, en la década de los ochenta, cayera en manos del poder económico (Menéndez, 2010: 209-210). Es más, si situamos en paralelo el análisis histórico del modelo de feminidad —expuesto en el epígrafe 1.1. de este capítulo— y la evolución de las revistas dirigidas a mujeres —epígrafe 2.2.—, veremos como estas publicaciones han ido recogiendo los distintos modelos de mujer.

Así, el ángel del hogar impregnará las páginas del siglo XIX y será desafiado en el primer tercio del siglo XX, cuando la nueva mujer o mujer moderna tome las calles y las letras. Durante los cuarenta años que dure la dictadura, las publicaciones volverán a

\footnotetext{
${ }^{47}$ Los datos pertenecen al periodo controlado entre julio de 2013 y junio de 2014. Actualmente, la OJD ha dejado de incluir la difusión de las revistas, a menos públicamente. Hemos intentado rescatar la difusión acudiendo a cada una de las mismas de manera individual, sin embargo, algunas aportaban el total de un consumo acumulado de varios meses, otras de un año, algunas no incluían el dato, otras sumaban la afluencia de las visitas en internet con las lecturas del papel... por lo que nos ha resultado imposible encontrar un patrón de seguimiento que fuera común a todas ellas.
} 
ser en su totalidad conservadoras, con tímidas aperturas hacia el final del régimen franquista, como sucedió en el caso de Telva, que introdujo el perfil de mujer trabajadora _el cual respondía a la realidad social de miles de mujeres que, bien se incorporaban, bien se les comenzaba a reconocer el trabajo asalariado-. Finalmente, a partir de los años 80 , las páginas empiezan a dedicarse casi en exclusiva a la moda y a la belleza, sucumbiendo, pues, al mito de la belleza y a los discursos postfeministas.

Naomi Wolf expone que, teniendo en cuenta el marco estadounidense —el cual posteriormente impregnará al resto de la cultura occidental—, la nueva ola periodística la inició Cosmopolitan en 1965. Propuso una fórmula que incluía un tono cargado de expectativas, individualismo y confianza, según el cual, no existirían condicionantes externos que impidieran a las mujeres llegar a lo más alto, más allá de los que ellas mismas pudiera autoimponerse. Además se introdujo, como analizará también Angela McRobbie años más tarde, la variable de la sexualidad, llenando las revistas de modelos femeninos erotizados — apenas algo más sutiles que los que se podían ver en las revistas eróticas dirigidas a hombres - y que pretendían ser un espejo de la liberación sexual femenina. Con todo, estas revistas vendían dieta, cuidado de la piel y cirugía estética, en palabras de Wolf, "la versión más mortífera del mito de la belleza" (Wolf, 1991: 89). Actualmente, la mayoría de las páginas de las revistas femeninas siguen estando dedicadas a la belleza, la moda y el ocio, lo que no deja espacio para otras temáticas — temáticas, por ejemplo, que fomentarían el empoderamiento de las lectoras-(Orsini, 2014: 550).

Precisamente, nos dice Isabel Menéndez que las revistas actuales son títulos que podrían clasificarse como postfeministas dado que se parte de la premisa de que la igualdad con los varones ya está conseguida y que las elecciones de las mujeres son siempre libres. Estas elecciones, que se basan en una libertad de consumo, además, invisibilizan la realidad política que existe detrás de cada acto individual (Menéndez, 2018: 123). El postfeminismo de los medios de masas fomenta narrativas en las que "la feminidad se celebra a partir de la obtención de bienes materiales y donde la cuestión de hacerse a una misma, pasa por conseguir la belleza, en detrimento de opciones académicas o profesionales" (Menéndez, 2016: 360).

Así, la mirada postfeminista rechaza la necesidad de los planteamientos feministas, pues la igualdad entre hombres y mujeres es ya casi una realidad, y recupera 
algunas ideas tradicionales de la feminidad, como el papel del maquillaje y los tacones. En este sentido, las revistas mantienen un discurso dual entre feminismo y postfeminismo (Orsini, 2014: 550-551). Por su lado, un trabajo publicado recientemente, en 2019, insiste en la pervivencia del modelo de mujer tradicional, que deviene del siglo XIX, el cual convive con la realidad de las mujeres de hoy en día: el machismo, el trabajo y la dificultad de compaginar la carrera y la familia (Velasco, 2019: 177).

Aun así, los guiños al feminismo, aunque presentes en prácticamente todas las revistas actuales, son escasos en comparación al espacio dedicado a otros asuntos (Orsini: 2014, 551). Igualmente se postula María Ganzabal, que considera que los contenidos feministas que han llegado a las revistas femeninas son poco relevantes teniendo en cuenta el espacio que se les reserva (Ganzabal, 2004: 143). Se podría decir que estas revistas se han unificado hasta presentarnos un solo perfil de mujer, cuyos intereses fundamentales parecen ser la moda y la belleza (Gallego, 2013: 147).

En este sentido, el modelo ideológico de mujer ama de casa, madre y esposa —ángel del hogar — ha sido sustituido por el modelo de una mujer trabajadora, amiga y pareja —superwoman - Las protagonistas aparecen fuera del ámbito del hogar y consagran su tiempo y dinero a la moda y la belleza, preocupándoles, en gran medida, su aspecto físico —mujeres de plástico—. Del hogar queda la decoración, relacionándola con conceptos como el lujo o el glamour. Las revistas de estilo de vida femenino muestran un mundo en el que el trabajo en casa y los cuidados ya no existen: descuidan a la mujer como ama de casa y apenas le otorgan importancia como madre, destacando en primer lugar su faceta como seguidora de la moda y la belleza y, en segundo lugar, aunque menos importante, como mujer trabajadora y amiga (Almansa-Martínez y Gómez de TravesedoRojas, 2017: 623-624). Así, se puede concluir que en este tipo de publicaciones encontramos representado, efectivamente, el mito de la belleza: la nueva imposición femenina una vez que, gracias a los esfuerzos feministas, discursos como el de la domesticidad habían sido superados. 


\title{
CAPÍTULO TERCERO. REPRESENTACIONES MEDIÁTICAS DE LA MASCULINIDAD: LAS REVISTAS DE ESTILO DE VIDA DIRIGIDAS A HOMBRES
}

\begin{abstract}
Ser un hombre —actuar en el teatro del trabajo, la política, el poder-se asumía sencillamente como algo natural; y cuando algunos pacifistas o contestatarios cuestionaban los rasgos supuestamente masculinos, como por ejemplo, la lucha, los marchitos varones europeos blancos que controlaban la academia y las ondas radiofónicas se las ingeniaban para descalificar aquellas críticas, considerándolas histéricas u utópicas, basándose en la máxima de que un hombre ha de hacer lo que ha de hacer [...]. Fue el movimiento de mujeres, cosa nada sorprendente, el primero que sometió la masculinidad a un interrogatorio exhaustivo.
\end{abstract}

Roy Porter

\section{CONSTRUCCIÓN MEDIÁTICA Y SOCIAL DE LA MASCULINIDAD}

Los estudios de masculinidades son una rama emergente del conocimiento social. Empezaron a extenderse en la década de los ochenta del siglo pasado y hoy forman parte de los estudios oficiales. Su línea de análisis defiende que la masculinidad es un elemento construido socialmente y que es, por tanto, modificable (Sanfélix y Cascales, 2019: 121122). Partiremos de esta idea para desarrollar, a lo largo de las siguientes páginas, los modelos de masculinidad, su funcionamiento y su evolución en la cultura occidental de los dos últimos siglos.

El modelo masculino hegemónico es un modelo dominador y así lo demuestran, entre otras, las representaciones mediáticas que alimentan y legitiman dicha construcción. Analizaremos estas representaciones, haciendo especial hincapié en el hombre bello, pues se trata de una imagen muy visible que, además, veremos recogida en las revistas de estilo de vida masculino. Será con el análisis de estas en particular, y de la prensa masculina en general, que cerraremos nuestro tercer bloque teórico.

\subsection{Construyendo lo masculino}

Como ya mencionamos en el capítulo anterior, el movimiento feminista se ha mostrado, desde sus orígenes, muy crítico respecto del género. Fue en los años setenta y por herencia de obras como El segundo sexo (1949) de Simone de Beauvoir o por los estudios médicos 
de John Money (1955) y Robert Stoller (1968), que la teoría feminista acabó por introducir dicha variable en las ciencias sociales. El género evidencia que la construcción de la identidad individual no la determina el sexo biológico, sino el hecho de que socializamos a las personas, desde el nacimiento, o incluso antes, como pertenecientes a uno u otro sexo. Es decir, en el proceso identitario, la asignación social del rol es más determinante que la carga genética, hormonal o biológica. El género se trataría, por tanto, de una categoría social que posee la base material en un fenómeno biológico —el sexoy que el patriarcado ha usado y usa de herramienta para la opresión de las mujeres (Facio y Fries, 2005: 268-269).

Desde el primer momento en que se tiene noticia de un embarazo, la posibilidad de que un bebé sea una niña o un varón moviliza diferentes expectativas en su entorno. La historia de cada nuevo sujeto estará marcada por los formatos preestablecidos de lo que para esa madre y ese padre, inmersos en una determinada cultura, representen la feminidad y la masculinidad. Será una categoría social impresa sobre las identidades subjetivas de hombres y mujeres (Levinton, 2000: 121).

Así, existe una combinación de elementos que configura la masculinidad y la feminidad. Se trataría de una red compuesta por el sujeto y el entorno, la autopercepción, las expectativas y las exigencias sociales. En consecuencia, los niños y las niñas alcanzan un sentimiento de identidad de género en sus dos primeros años de vida, propiciado por el ambiente y previo al reconocimiento de las diferencias anatómicas de los sexos (Levinton, 2000: 121).

Es preciso señalar que, para el feminismo, destapar esta idea no fue fácil. La cultura dominante venía defendiendo, a lo largo de la historia, desigualdades cognitivas innatas entre los hombres y las mujeres. Desde finales del siglo XIX y durante casi las cuatro primeras décadas del siglo XX, experimentaron un gran impulso los estudios de la inteligencia. Los primeros test, como los de Binet y Simon (1905), mostraron algunos contrastes entre hombres y mujeres en determinadas tareas cognitivas — se observaba una superioridad relativa en función de qué sexo realizara qué actividad—, lo que llevó a alimentar aun más la noción de que realmente existían diferencias sexuales innatas (Jayme y Sau, 2004: 164-166).

A pesar de que en los años treinta del siglo $\mathrm{XX}$, el conductismo como corriente de pensamiento adquirió cierto peso -imponiéndose así las teorías del desarrollo 
cognitivo de base ambiental sobre las de base biológica-, algunos test seguirían sin contemplar la variable social y las preguntas no se adecuarían al supuesto de que niñas y niños eran modelados por su entorno de manera distinta. Es lo que ocurrió en las pruebas de Weschler, que incluyeron un número desproporcionado de ítems —relacionados con preguntas relativas a geografía y ciencia-, que favorecieron a los niños por encontrarse ellos más familiarizados con estas áreas del conocimiento. En dichas pruebas, por cierto, las niñas puntuaban más alto en vocabulario, mientras que los niños lo hacían en aritmética (Jayme y Sau, 2004: 166).

Bien, como íbamos diciendo, el feminismo debía desarticular siglos y siglos de pensamiento científico — además de popular — que, de alguna u otra manera, justificaba desigualdades naturales entre hombres y mujeres. La autora Kate Millett, en su obra de 1969, denunciará el dominio ejercido por un sexo sobre el otro en virtud de la socialización diferencial de hombres y mujeres. Entre otras muchas aportaciones, Millett clarifica el esquema patriarcal que define ambos universos simbólicos: la agresividad, la inteligencia, la fuerza y la eficacia en el macho; la pasividad, la ignorancia, la docilidad, la virtud, la inutilidad en la hembra. En cuanto a la realización de las actividades, el servicio doméstico y el cuidado de la prole quedan reservados para las mujeres, el resto de campos de la productividad humana, para el varón (Millett, 2010: 72).

Vemos, por tanto, que la teoría feminista venía estudiando, activamente, las relaciones entre los sexos y de qué manera estas generaban un orden social jerárquico. Leyendo algunas definiciones sobre feminismo, como la tan acertadamente aportada por Nuria Varela, “el feminismo es una teoría y práctica política articulada por mujeres que tras analizar la realidad en la que viven toman conciencia de las discriminaciones que sufren por la única razón de ser mujeres y deciden organizarse para acabar con ellas" (Varela, 2013: 14), alguien podría cuestionarse el papel que cumplen los varones en todo esto. Como hemos señalado, el feminismo no solo ha estudiado a las mujeres, sino que ha sido primordial destacar la actuación de los varones para desgranar y comprender los mecanismos del sistema opresor, de lo contrario, jamás hubiese sido posible teorizar sobre conceptos como patriarcado, machismo, subordinación femenina, etc.

A pesar de ello, asistiremos, en las últimas décadas, a un despertar masculino que se traducirá en una serie de prácticas, como son las agrupaciones de hombres que cuestionan el modelo hegemónico, la llamada por parte de las instituciones a revisar los comportamientos de género o la aparición de los estudios de masculinidades en el ámbito 
universitario. En este sentido, a mediados de la década de los 70 del siglo XX, surgieron en Estados Unidos y en los países escandinavos los primeros grupos de hombres que reflexionaron sobre la condición masculina. Después, en 1995, la Declaración de Beijing aconsejará explícitamente alentar a los varones para que se involucren en las acciones encaminadas a lograr la igualdad. Por su lado, en España, será en el año 1985, en Valencia y Sevilla, que veremos las primeras reuniones masculinas; posteriormente, en 1999, en el Ayuntamiento de Jerez de la Frontera, Cádiz, aparecerá el primer programa permanente promovido por una administración pública; y, en 2001, surgirá la primera Asociación de Hombres por la Igualdad, AHIGE (Téllez y Verdú, 2011: 83-84).

En cuanto a la irrupción de los estudios de las masculinidades en el ámbito científico, en los años 80 , una década más tarde de que en la academia se introdujeran los estudios de género, aparecieron los men's studies (estudios de hombres). Primero lo hicieron en los países anglosajones y, progresivamente, fueron conquistando otras áreas geográficas (Quiles, 2019: 299). Así, en el currículum académico español, a día de hoy, podemos encontrar, efectivamente, estudios de masculinidades. Nos dice Nerea Aresti que es necesario precisar que estos estudios no versan sobre la historia de los hombres —nada tendría de novedoso una historia dedicada al varón como sujeto universal masculino-, sino que es la narrativa de los hombres como seres sexuados. Es decir, se analiza críticamente la posición de estos respecto de las mujeres y, no solo eso, también respecto de otros hombres, en el marco de las desigualdades de clase, de la orientación sexual, de las nacionalidades o de otros tipos (Aresti, 2018: 174).

Por su lado, el autor Guillermo Núñez puntualiza que, cuando se estudian masculinidades, las investigaciones atienden a la manera en que opera en los sujetos varones el sistema sexo-género - las ideologías y prácticas institucionalizadas que actúan sobre los cuerpos sexuados generando una serie de conductas- (Núñez, 2016: 27). Mientras, el psicoterapeuta Luis Bonino, centrándose en el ámbito médico, denuncia la ilusión de la normalidad de los varones, en este sentido, explica que, gracias a los estudios feministas, se han conseguido visibilizar muchas de las experiencias de las mujeres, contribuyendo enormemente a comprender, entre otras, el sufrimiento femenino, a estudiar sus trastornos de género y a despatologizar y despsiquiatrizar a las mismas. Argumenta, por tanto, que del mismo modo, se pueden utilizar los estudios de género, así como estudios (auto)críticos de varones para deconstruir la normalidad masculina (Bonino, 2000: 43). 
En este sentido, los estudios de las masculinidades colocan a los hombres en el papel de sujetos y protagonistas dentro de la narrativa de las relaciones de género. Dicho enfoque no ha estado exento de controversia, pues, a pesar de su especificidad, distintas autoras han cuestionado que este saber constituya un campo diferenciado, señalando, además, que se trata de un conocimiento ya implícito en los estudios feministas. A este respecto, sabemos que la irrupción de las masculinidades en el mundo académico fue recibido con cierto recelo por parte de algunas feministas, quienes argumentaban que no dejaba de ser un grupo privilegiado al que, de nuevo, se le estaba dotando de recursos desde las instituciones y, quienes, otra vez, estaban invadiendo espacios femeninos (Iriarte, 2016: 38). Mientras, existió y existe otra corriente de pensadoras que consideran esencial el estudio de las masculinidades —entendiéndolas como un ámbito del saber diferenciado_-, pues desafían la idea de que los hombres son el sujeto por excelencia, ese "sujeto neutral y no marcado por el género, a diferencia de las mujeres, quienes desde este punto de vista tradicional si estarían determinadas por su condición sexual" (Aresti, 2018: 174).

Encontramos, pues, que tanto Nerea Aresti como Luis Bonino insisten en la idea de sacar al hombre de la norma. De comprenderlo como un ser sexuado al que, al igual que sucede en el caso de las mujeres, le atraviesa la categoría del género. Un sujeto que se debe desencializar, deconstruir y desuniversalizar. Así, los estudios de las masculinidades van a plantear, como ya veíamos con la feminidad, que lo masculino es un constructo histórico y cultural, de modo que varía según tiempos y lugares: no existe un modelo continuo aplicable a cualquier época y a cualquier grupo social. Además, a la masculinidad le cruzan e influyen, también, las variables de la edad, la clase social o la etnia (Téllez y Verdú, 2011: 86).

A pesar de la evolución histórica y de las distintas acepciones culturales que el modelo pueda presentar, conviene hablar del concepto de masculinidad hegemónica. La hegemonía encuentra sus orígenes en el análisis que el italiano Antonio Gramsci elabora sobre las relaciones de clases. Este explica cómo una clase dominante controla aspectos fundamentales de la sociedad, imponiendo sus propias definiciones que se convierten en ideas predominantes, lo que se traduce en que el grupo exige y sostiene una posición de liderazgo en la vida social. Además, el autor señala que dichos procesos son consentidos por los grupos dominados. En este sentido, la definición asienta sus fundamentos principales en la teoría marxista. Así, la masculinidad hegemónica aparece en contextos 
históricos donde determinadas estructuras y prácticas permiten la adquisición del poder por parte de los hombres (Schongut, 2012: 44-45).

El concepto de masculinidad hegemónica fue utilizado por vez primera por Carrigan, Connell y Lee en el artículo Towards a new sociology of masculinity (Hacia una nueva sociología de la masculinidad) en el que abordaban, dentro de la realidad australiana, la construcción de la masculinidad y las experiencias corporales de los hombres, la inequidad social entre varones en el sistema escolar y el rol masculino en política (Schongut, 2012: 45). Para Raewyn W. Connell —antes Robert W. Connell—, la masculinidad hegemónica garantizaría la posición dominante de los hombres y la subordinación de las mujeres, pero, también, la posición dominante de los hombres respecto de otros hombres — como sería el caso de los varones heterosexuales respecto de los homosexuales que sufrirían, por parte de los primeros, exclusión política y cultural, violencia legal (encarcelamiento), violencia callejera, discriminación económica o boicots personales - (Connell, 1995: 12-13).

Aunque la masculinidad homosexual es la masculinidad subordinada más evidente, ciertos hombres heterosexuales también son expulsados del circuito legítimo —bien sea por su etnia, por su clase social o porque reúnan caracteres próximos a la feminidad—. Es más, no son muchos los hombres que cumplan al 100\% con el modelo hegemónico — podría tratarse más de un ideal normativo que de una realidad social—, sin embargo, sí son la mayoría de los hombres los que ganan con la pervivencia de la hegemonía ya que los varones, en su totalidad, disfrutan de privilegios sobre las mujeres. La complicidad entre los hombres — se encuentren más o menos alejados del modelo puro-, permite la supervivencia de la sociedad patriarcal (Connell, 1995: 14).

Así, Connell mantiene que existen distintos tipos de masculinidades y que no todas las representaciones participan del mismo grado de poder, cohabitando el modelo hegemónico junto con las variantes subordinadas. Eso sí, comprobamos que la sociedad privilegia el grado normativo frente al subordinado. En este sentido, se lee un análisis transversal de lo que supone ser hombre envuelto o cruzado por otras categorías sociales. Algo similar defendería Demetriou (2001), quien señala que existen dos representaciones y funciones de la masculinidad hegemónica: una hegemonía externa y otra interna. La primera, la hegemonía externa, representa la dominación de los hombres sobre las 
mujeres, mientras, que la interna es la que ejercen los hombres que encarnan el ideal hegemónico sobre otros grupos de hombres (Díez, 2015: 80).

Por su lado, Luis Bonino insiste en que el papel de las otras masculinidades, las que Connell habría calificado de subordinadas, es poco poderoso, al menos como organizadoras de identidad, puesto que no cuentan con ninguna legitimación social para convertirse en modelos alternativos identitarios. Bonino las agrupa en masculinidades periféricas y las define como líneas de fuga del modelo hegemónico, más que como transformaciones del mismo. La masculinidad hegemónica se encuentra, por su valor social, en lo más alto de la jerarquía, siendo por ello la representación dominante de lo masculino, la única que goza de legitimación social y que anula la posible construcción subjetiva del resto (Bonino, 2002: 7-9). Además, se trata de un modelo muy potente, haciéndose difícil su aperturismo o anulación:

Aun con algunas fisuras y quiebras, la masculinidad hegemónica permanece aunque cambien algunos discursos o actitudes de quienes la portan. A pesar de que antes proponía hombres de una sola pieza y ahora permite más flexibilidad, relativización, atenuación del absolutismo o desestimación de algunas de sus creencias y mandatos — especialmente en la imagen y la estética-, estos pesan aún mucho, y su hegemonía no permite fácilmente variaciones estructurales (Bonino, 2002: 12).

La masculinidad hegemónica se levanta en torno a una serie de creencias matrices que brindan el material simbólico e imaginario que permite la configuración de la identidad, aportando pautas identitarias, cognitivas, perceptivas, afectivas, comportamentales y vinculares. Estas creencias son fundamentalmente cuatro - la autosuficiencia prestigiosa, la heroicidad belicosa, el respeto a la jerarquía $y$, finalmente, la superioridad sobre las mujeres y la oposición a ellas-. Además, dichas creencias se relacionan con las definiciones biológicas de la masculinidad —independencia, dominio y jerarquía-(Bonino, 2002: 15).

Otros análisis, como el lanzado en 1976 por dos estudiantes norteamericanos de psicología, Deborah S. David y Robert Brandon, nos enuncian que los cuatro imperativos que conforman la masculinidad hegemónica son los siguientes: no sissy stuff —no ser femenino-, the big Wheel, — ser una persona importante—, the sturdy oak — duro como un roble-y give'em hell —al diablo con todos_-(Sambade, 2018: 298). Estos ideales los encarnaría un hombre heterosexual blanco — recordemos que estamos en un contexto 
norteamericano en los años setenta—, con éxito en la esfera pública y entre las mujeres, de carácter duro, sin sentimientos visibles y autosuficiente.

Mientras, para Elisabeth Badinter (1993), la representación de los valores hegemónicos la escenifica el varón que se muestra solitario e impasible, un hombre que, para no estar ligado a nada que pueda hacerle vulnerable, tiende a la huida y al aislamiento. Tomando la expresión de Helga Dierichs (1983) sería un mutilado de afecto. Con el fin de ilustrar dicho modelo, Badinter utiliza tres figuras del cine norteamericano: la del pistolero, la de Rambo y la de Terminator. El pistolero, en el cine western, es un héroe nómada, no establece vinculaciones afectivas y las mujeres son meros accesorios sexuales. El único placer que se permite experimentar es durante el combate, momento en el que demuestra el autocontrol de las emociones, la habilidad para matar y, también, la muerte heroica. El combate entre iguales sirve, a la vez, como reconocimiento de la masculinidad (Sambade, 2018: 298-299).

Por su lado, Rambo y Terminator recogen las características del pistolero, sin embargo, mientras que el héroe del western deja abierta una posibilidad de adivinar su humanismo — sus conflictos, sus sentimientos y, por ende, su debilidad-, Rambo y Terminator, al haber sido dotados de una fuerza sobrehumana, se han vaciado de todo sentimiento. De acuerdo con esto, el modelo evoluciona desde la represión de la emotividad, hasta la ausencia total de la misma. El cuerpo se ha vaciado de cualquier miedo dolor o moralidad y sirve para el ejercicio de la violencia (Sambade, 2018: 299).

Según los análisis de Kenneth Dutton (1995), hasta principios de los noventa se erige, también, otro icono de la masculinidad hegemónica: el hombre Marlboro, representado en numerosas vallas publicitarias y anuncios televisivos. Esta representación encarna a un hombre rudo, parco en palabras y gestos, en contacto con la naturaleza, robusto (Mira, 2015: 19). El hombre Marlboro, además, bebe de la iconografía western, concretamente, del pistolero mencionado en el análisis de Elisabeth Badinter.

Aunque son más los autores y autoras que han aportado su propio análisis sobre la construcción de la masculinidad —Rubén Mejía, Jacques Lacan, Erik Pescador, Enrique Gil Calvo, David Gilmore, Fran A. Zurian...-y, sin querer menospreciar su trabajo, consideramos que el recorrido elaborado hasta ahora nos permite dibujar la imagen mental del modelo masculino hegemónico: un hombre heterosexual, 
autosuficiente, fuerte, heroico, belicoso, solitario, impasible, admirado por sus iguales, que domina a las mujeres y se relaciona con ellas en términos sexuales.

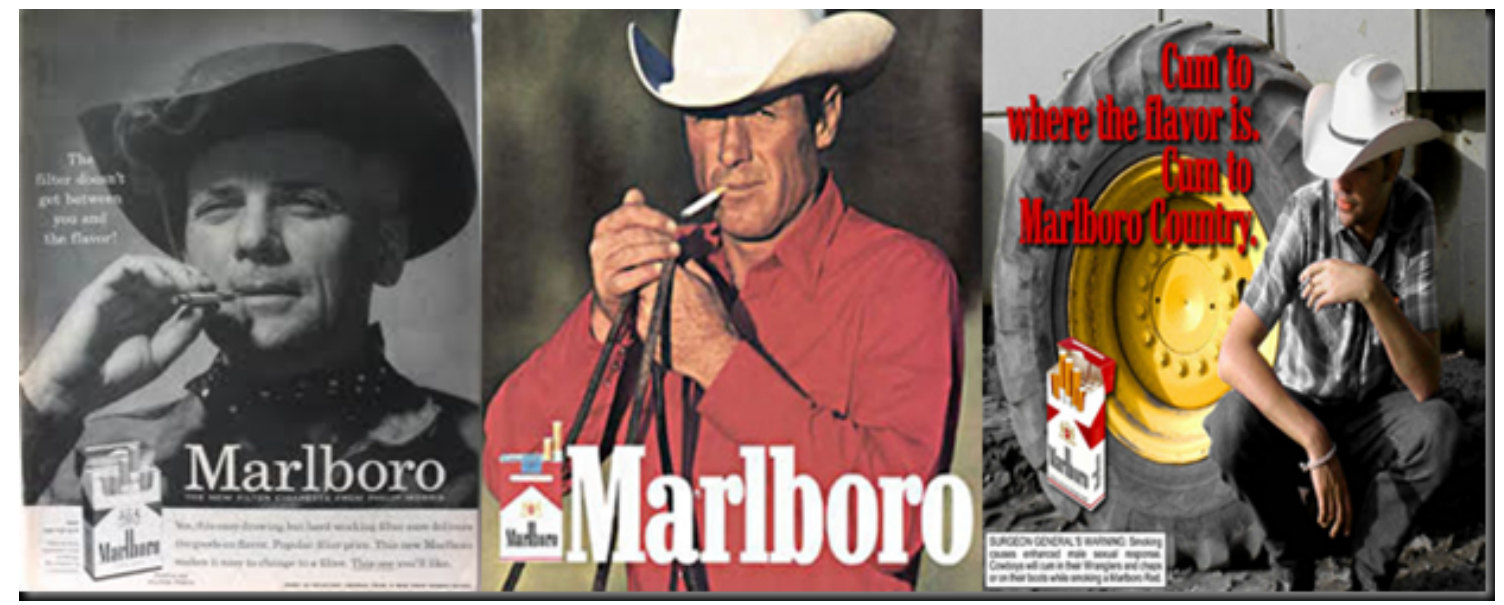

IMAGEN 9. Carteles publicitarios de la marca Marlboro. En 1953, la empresa de tabaco crea la figura de Marlboro cowboy.

FUENTE: El Mundo.

Nos dice Connell que, "aunque todas las sociedades cuentan con registros culturales de género, no todas tienen el concepto de la masculinidad" (Connell, 1995: 1). En este sentido, argumenta que las distintas definiciones de masculinidad y feminidad son un producto relativamente reciente, conceptos inherentemente occidentales que aparecen con posterioridad al siglo XIX, debido a la separación de distintas esferas sociales por parte de la burguesía (Schongut, 2012: 40). "La masculinidad existe solo en contraste con la femineidad. Una cultura que no trata a las mujeres y hombres como portadores de tipos de caracteres polarizados, por lo menos en principio, no tiene un concepto de masculinidad en el sentido de la cultura moderna" (Connell, 1995: 2).

En esta investigación, cuando abordamos la representación de la feminidad, lo hicimos partiendo de la realidad social del siglo XIX. Así, apreciamos la evolución cultural y social del modelo. En cuanto al propio recorrido de la masculinidad hegemónica, algunas de sus críticas pasan por denunciar, precisamente, el carácter monolítico y atemporal del término. En este sentido, el historiador John A. Tosh ha subrayado la importancia de la condición social, resaltando que cada clase posee sus propios códigos de masculinidad. Tosh, cuya obra comenzó a aparecer a finales de los 80 y principios de los 90, estudió a los varones de la clase media-alta de la sociedad británica 
del siglo XIX y percibió que, lejos de tratarse de un grupo homogéneo, presentaban valores distintos en función no solo de la clase, sino dentro del mismo grupo. Además, subrayó las diferentes representaciones dadas las circunstancias geopolíticas, por lo que el historiador hablaba de múltiples modelos de masculinidades (Macías-González, 2017: $60)$.

Mientras, Robert Nye ha investigado las diferencias entre masculinidades normativas comparando países y momentos históricos, evaluando variables como el trabajo, la paternidad, la propiedad, la solidaridad masculina, el dominio violento sobre las mujeres o los referentes militares en la construcción del hombre normativo. Sin embargo, ante estas voces críticas, apunta Nerea Aresti que trabajos posteriores han venido matizando y mejorando la propuesta inicial de Connell. Incluso Connell, junto con James W. Messerschmidt, en el año 2005 - Hegemonic masculinity. Rethinking the concept (Masculinidad hegemónica. Repensando el concepto)—, en un ejercicio de reformulación, realizaron una profunda revisión de la categoría poniendo especial énfasis en el papel de las mujeres y las jerarquías de género, la articulación de los niveles locales, regionales y globales, la relación con los cuerpos y las contradicciones inherentes al propio concepto (Aresti, 2018: 178).

Recordemos que, en el siglo XIX, el modelo de feminidad lo encarnaba el ángel del hogar o la perfecta casada (Ramos, 2014: 20). Las mujeres quedaban recluidas en el ámbito privado y su destino último era el de servir a los hombres, siendo la insistencia en el amor maternal el eje vertebrador de la feminidad. Mientras, la masculinidad se forjaba en la esfera pública, de modo que las características identitarias predominantes del modelo contemporáneo se relacionaban con la superioridad, el trabajo, la virilidad, la ciudadanía y el perfil de hombre público (Nash, 2006: 43). En el matrimonio, la subordinación de la mujer, leída esta como honestidad, era señal de la honorabilidad del marido. También, se potencia la institución de la familia que se vuelve más visible y el hombre viril ha de ser capaz de formarla: la masculinidad se medirá cada vez más por la capacidad objetiva del marido como sostén del núcleo familiar (Uría, 2014: 161-162). En cuanto a las capacidades cognitivas, los hombres eran, por naturaleza, racionales, objetivos, creativos, agresivos y ambiciosos, mientras que las mujeres se presentan sensibles, sentimentales, poco racionales, emocionales y compasivas (Jagoe, 1998: 30).

En las zonas rurales, las mujeres representan un papel activo más visible que en las urbanizadas, donde el reclutamiento en el hogar será más evidente y, por tanto, sus 
aportaciones, invisibles. El trabajo agrícola femenino otorgará un cierto estatus a las mujeres dentro del núcleo familiar, lo que se traducirá en el desafío de los hijos hacia el padre. Al verse cuestionada su virilidad, los varones responderán simbólicamente resaltando sus atributos masculinos. La agresividad y la fuerza se afianzan todavía más como señas distintivas y se exhibirán en competiciones de trabajo y en desafíos entre jóvenes. El campesino se yergue cual reserva de la virilidad en contraposición al ámbito urbano (Uría, 2014: 162).

Aun con todas las diferencias geográficas y de clase presentes, existirá un modelo contemporáneo que canalizará el imaginario masculino: el personaje ficticio Don Juan se convirtió en el arquetipo que funcionó para modelar la masculinidad española. Esta imagen, que fue ya recogida en los romances populares y las crónicas de la Edad Media, se concretó finalmente en el siglo XVII en El Burlador de Sevilla y convidado de piedra del dramaturgo Tirso de Molina. Al Don Juan le caracterizaba, entre otras, su faceta seductora: encandilaba y engañaba a las mujeres, de quienes manchaba su honra y a quienes convertía en culpables (Arlt, 1994: 181-183). Mientras que durante la contrarreforma, el mito fue condenado, en el romanticismo se vivió una idealización del mismo: de su virilidad, de su valor y de su agresividad (Floeck, 2005: 54). No será hasta partir del siglo XX, que se desmitificará el ideal donjuanesco de la masculinidad.

El Don Juan, espíritu aventurero y conquistador de mujeres, encarnó, por tanto, un ideal de hombría española muy extendido socialmente, sin embargo, a finales del siglo XIX, con la pérdida de las últimas colonias, la masculinidad española sufrió una crisis nacional. La retórica y las imágenes que acompañaron a aquel momento histórico, dentro y fuera de España, y los valores que les fueron asociados a los varones, chocaron con el modelo de masculinidad de occidente, encarnada por el sistema de representaciones medio-burguesas. La crisis del 98 estigmatizó el arquetipo viril representativo y los españoles fueron retratados como pasivos, mansos, vagos, irracionales, salvajes, incapaces de controlar sus instintos, irrespetuosos con las mujeres y, en un ataque último a su virilidad, castrados (Aresti, 2014: 55). Se creó la figura del bruto español, que fue la imagen más recurrente a la hora de representar a España en la prensa estadounidense (Aresti, 2014: 60).

La destrucción pública de la imagen de España, desembocó en una crisis de identidad nacional que llevó a que la ciudadanía se repensase a sí misma. Las figuras intelectuales del momento se unieron en debate sobre las causas de la decadencia de lo 
que había constituido un gran imperio. Personas tales como Miguel de Unamuno, Ramón Pérez de Ayala o Gregorio Marañón proclamarán su decepción, acusando al pueblo español de ignorante, indolente y perezoso y llamando al orden, la disciplina y la regeneración. Además, la incorporación de las mujeres a actividades consideradas tradicionalmente masculinas, supuso un foco de tensión para la identidad masculina. La percepción común de la época dibujaba a un hombre español que estaba perdiendo su proverbial fuerza, valentía y estoicidad (Paredes, 2007:1).

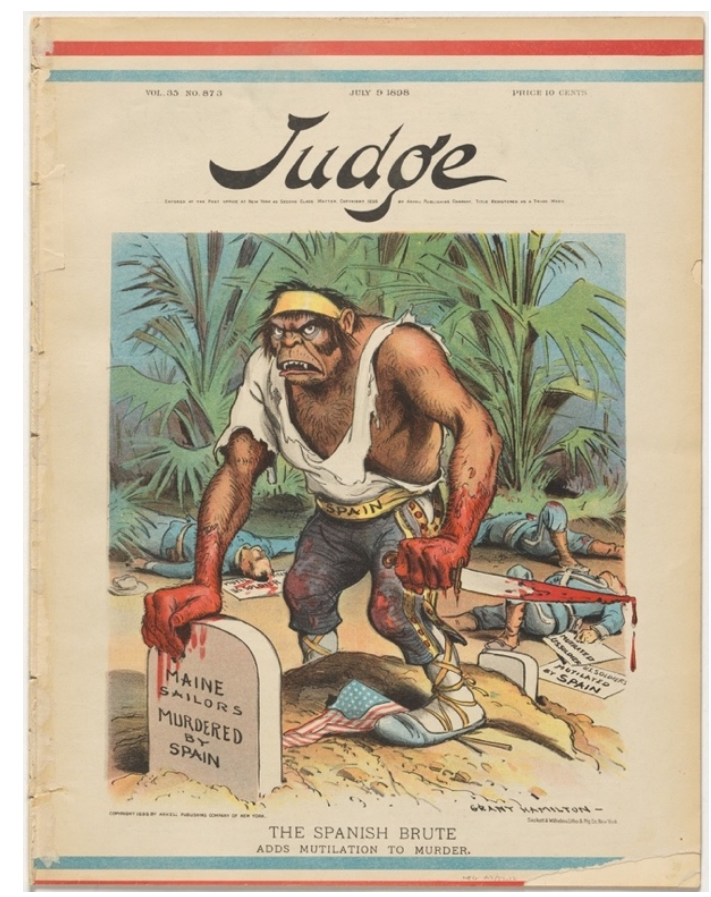

IMAGEN 10. "The spanish brute, adds mutilation to murder" (El bruto español, añade mutilación al asesinato), portada de Grant Hamilton, Judge, 9 de julio de 1989.

FuENTE: "A la nación por la masculinidad" (Aresti, 2014: 61).

Desde el punto de vista de las relaciones entre hombres y mujeres, el periodo de principios del siglo XX, se caracterizó por una distribución particularmente injusta de los derechos y deberes que regían la convivencia entre ambos sexos. A juzgar por los numerosos testimonios de la época, la irresponsabilidad paterna, el adulterio masculino, el abuso de poder y el absentismo del varón en la unidad familiar fueron firmes constantes en el comportamiento masculino (Aresti, 2001: 115). Para el pensamiento regeneracionista, era imprescindible eliminar la figura del Don Juan, puesto que su estilo de vida, ociosa y disipada, impedía la transición a la modernidad. Este personaje 
ejemplificaba un tipo de masculinidad cuya única actividad se centraba en la hazaña sexual, lo cual resultaba destructivo para la unidad primaria de organización social, esto es, la familia. En Europa, sobre todo en la sociedad británica y alemana, vemos que la promoción de la familia representa el conjunto de valores ideales contemporáneos (Paredes, 2007: 2).

El médico Gregorio Marañón se propuso incidir con sus teorías en la evolución del ideal de masculinidad, para así superar las nociones caballerescas e imponer un modelo de virilidad moderno y adaptado al liberalismo burgués. En este sentido, el donjuanismo era la más clara imagen del estereotipo que se quería combatir y pretendía hacerlo virar hacia un varón trabajador, responsable y racional. El modo en que el médico se propuso hacer esto fue feminizando la figura del Don Juan (Aresti, 2001: 119-120). Recordemos que, dentro de la masculinidad hegemónica, una de las premisas que se manejaban era la superioridad de los hombres sobre las mujeres y la oposición a ellas: no sissy stuff. De esta forma, si se conseguía relacionar al personaje de Don Juan con la feminidad, muchos hombres huirían del mito.

Marañón comenzó, por tanto, con una campaña de desacreditación del mismo. Para ello, afirmó que el don Juan corría tan solo en apariencia detrás de las mujeres: eran estas las que, en realidad, lo elegían a él. Así, al abandonar el tradicional papel masculino en el cortejo, este se veía feminizado. Otra de las teorías que articuló, era la del amor indiferenciado, difuso, que parecía experimentar el Don Juan, propio de las especies animales $\mathrm{y}$, en los humanos, de los débiles e intersexuales. También, arremetió contra su aspecto físico de indecisa varonía: era esbelto, elegante, de piel fina, cabello ondulado y rostro lampiño o adornado de leve barba puntiaguda y vestía minuciosamente cuidado. Finalmente, atacó su falta de productividad, pues hacía del culto a la mujer el objeto principal de su vida, no teniendo ninguna ocupación y viviendo de las rentas, lo que le alejaba del modelo burgués idealizado de la época (Aresti, 2001: 131-132). Así, Marañón convirtió al Don Juan en un ser afeminado, casi un homosexual.

Ya dijimos que en la época de entreguerras se vivió un distanciamiento con el modelo decimonónico de feminidad. Se llegó, incluso, a hablar de un tercer sexo, donde se ubicaban las mujeres ambiguas, las que desafiaban los límites culturales de la feminidad tradicional, accedían a espacios prohibidos y materializaban sus aspiraciones profesionales, personales y estéticas. Dentro de este grupo, también había espacio para los hombres que no respetaban el modelo hegemónico masculino: el tercer sexo podía ser 
la feminista marimacho, la mujer emancipada, la garçon, la sufragista solterona, la lesbiana o el homosexual (Ramos, 2014: 37).

En la España de los años 20, existe un miedo a la feminización de la masculinidad y a la masculinización de la feminidad. En 1923, el pensador Ortega y Gasset escribe que el país perdería población "no tanto por el hambre, peste u otros reveses, cuanto porque disminuye el poder genesíaco del hombre”, además, esta disminución en la virilidad "mengua el coraje civil. Comienza el reinado de la cobardía" (citado en Díaz, 2017: 42). Para Ortega era necesario un nuevo tipo de hombre. El pensador sostenía que el atenuamiento entre las diferencias de clases y, principalmente, entre los sexos, requería en mayor medida del nuevo modelo: "se nivelan las fortunas, se nivela la cultura entre las distintas clases sociales, se nivelan los sexos" (citado en Díaz, 2017: 44). El pensador, por tanto, defendía el endurecimiento de las diferencias de género, esto es, una masculinidad y una feminidad muy marcadas, para salvar la deriva de España en la época de entreguerras.

Junto con el llamamiento a la virilidad y al vigor patriótico de las clases intelectuales, surge, en los años 20, un nuevo héroe nacional, el futbolista. En esta década el deporte alcanza un nivel de institucionalización que sobrepasa los precarios horizontes de la preguerra: se expande el asociacionismo deportivo, sobre todo del fútbol — gracias a las nuevas condiciones laborales, que permiten más tiempo libre-, y se mejoran los estadios, cada vez más modernos y dotados de estructuras permanentes como las tribunas. Este deporte, pues, comienza a ganar adeptos y a hacerse más popular que el que fue el tradicional espectáculo mercantilizado en España, los toros. Gracias a las fotografías de la prensa, los cromos de las tabletas de chocolate, las postales o las biografías de pequeño formato, el futbolista materializará y personalizará sus virtudes generando iconografías de la masculinidad (Uría, 2014: 168).

En un contexto, recordemos, de desafío y redefinición de los estándares de la masculinidad, los futbolistas comienzan a encarnar las cualidades de la virilidad perdida. Estas figuras refuerzan valores como la violencia o el vigor físico, además de la agilidad, el sacrificio, la callada sujeción a las necesidades del equipo, la valentía, el temperamento o la resolución. Convierten al cuerpo — gimnástico, fuerte, potente-, en depositario de las esencias masculinas (Uría, 2014: 176). Los grandes ases del fútbol encarnan la virilidad por varios motivos: triunfan económica y socialmente, se les asocia con el éxito sexual, su plenitud física recuerda a la de los héroes clásicos y la prensa les reserva un 
papel de guerreros, reproduciendo los encuentros deportivos como si de una batalla se tratase (Uría, 2014: 183).

En la España franquista, la masculinidad experimentó, primeramente, una virilización y exaltación a través del discurso de la Falange y la experiencia de la guerra, para, posteriormente, acomodarse en un modelo de cariz más tradicional-católico, enalteciendo el papel del hombre como cabeza de familia (Blasco, 2014: 62). Se exaltan los valores del guerrero más viscerales: "gallardía, furia española, ímpetu y arrojo de los españoles, noble y caballeroso, justa ira, pecho invencible y generoso que todo lo sacrificó por la patria" escribía Federico Torres, autor de texto infantiles, cuando describía a Viriato, héroe de una pretendida resistencia española (citado en Blasco, 2014: 63).

Se destaca, del mismo modo, la disciplina, el respeto a la jerarquía y la obediencia como valores masculinos. Por último, se mezclan las virtudes-pasiones de la guerra con cualidades espirituales, tal es la austeridad, la pureza y la sencillez, las cuales se relacionaban con el monarca Felipe II, héroe nacional del Imperio Español. Durante la dictadura franquista, el sentimiento patriótico debía vertebrar la identidad de los hombres (Blasco, 2014: 63). Por su lado, la identidad femenina también se articuló en torno a la patria y a su servicio, pero asumiendo un papel secundario en la construcción de la nación: las misiones de las mujeres eran la de la maternidad y servidumbre a los varones (Guzmán, 2018: 530).

Vemos que, durante los cuarenta años de la dictadura, se reafirmó, por tanto, la masculinidad guerrera y el arquetipo de hombre productor y cabeza de familia (Nash, 2014: 192). En la transición española, se vivió un alejamiento con respecto a los discursos tradicionales y, mientras el movimiento feminista alzaba sus voces y se asistía a una progresiva liberación de las mujeres, surgía la necesidad de nuevos discursos sobre la masculinidad (Picornell, 2010: 291). Sin embargo, así como los estereotipos de género sí se abrían a la realidad de las mujeres, el sistema seguía férreo a las diferencias intergrupales, tal es que los hombres no asumían las responsabilidades en la esfera privada (Escartí et al., 1988: 218). Es en estos años cuando, como hemos dicho, se empiezan a dar las primeras reuniones de varones donde se tratarán temas identitarios masculinos: en los años 70 surgirán en contextos norteamericanos y escandinavos y, en España, será en el año 1985 que los hombres se agruparán en Valencia y Sevilla (Téllez y Verdú, 2011: 83-84). 
George L.Mosse en su libro The image of man: the creation of modern masculinity (La imagen del hombre: la creación de la masculinidad moderna), sitúa el nacimiento del ideal masculino moderno en las guerras napoleónicas. Este ideal, se configuraría en torno a la respetabilidad burguesa y a la heroicidad bélica, reforzándose durante la Primera Guerra Mundial y alcanzando su expresión más virulenta en el fascismo. Además, habría resistido embistes como los producidos por el movimiento feminista (Aresti, 2018: 181). Pues bien, en los años 90 del siglo XX, se origina una fuerte crisis de la masculinidad tradicional. Se trata del punto de inflexión más absoluto del modelo de toda la centena. En esta década, se publican varias obras que recogen las inquietudes masculinas: Masculinidad en crisis, de Roger Horrocks, “What next for men?” (¿Qué es lo próximo para los hombres?), en la revista Working with men o Slow motion: changing masculinities, changin men (A cámara lenta: cambiando masculinidades, cambiando hombres), de Lynee Segal, son algunos de los ejemplos. A medida que va transcurriendo la década se va desarrollando el debate, sobre todo en el mundo anglosajón, siendo la pluralidad de las masculinidades una de las corrientes más aceptadas (González, 2017: 21-22).

Las expresiones como crisis o decadencia han sido comúnmente utilizadas para hacer referencia a los procesos evolutivos del modelo de masculinidad. A nivel individual, los hombres circulan entre el espectro que separaría al feminismo — como expresión de liberación de las mujeres y, por tanto, como modelo de cesión de privilegios propios — del machismo - postura supremacista con respecto del sexo femenino-. Es posible que esta deriva individual provoque que se aferren a nociones de identidad colectiva, o así lo apuntan autores como Connell (1996), Luis Bonino (1999) o Michael Kimmel (2001) que nos dicen que actualmente podemos encontrar diferentes movimientos de hombres: el movimiento gay — lucha para que la orientación sexual no sea motivo de discriminación—, el movimiento profeminista o antisexista — trata de resquebrajar el patriarcado trabajando a favor de la igualdad de los sexos-, el movimiento mitopoético y de terapia masculina -intenta recuperar una energía masculina perdida de liderazgo natural— o el movimiento supremacista —defiende un proyecto político donde todas las mujeres, hombres homosexuales y heterosexuales no blancos quedan subordinados_-(Sánchez-Palencia e Hidalgo, 2001: 12-13). Otras voces añaden, también, los movimientos de liberación de hombres - grupos de autoayuda donde se enfatiza que los hombres sufren igual que las mujeres a causa del sistema de 
género- y las asociaciones de separados/divorciados —generalmente manejan un discurso reactivo, simplista, misógino y resentido-(Iriarte, 2016: 40-43).

En el contexto de la postmodernidad, los avances feministas son percibidos como una amenaza al orden masculino hegemónico. Entramos en una época que Miguel Lorente ha calificado de postmachismo, el cual, aunque aparece ya en una fase avanzada de la postmodernidad, es hijo de esta. Así como la postmodernidad intenta romper con las referencias de la Ilustración, el postmachismo pretende minar el proceso evolutivo del feminismo, para poder restaurar las referencias patriarcales sustituidas o desplazadas (Lorente, 2019: 34).

En el postmachismo, aparecen nuevos hombres nuevos, distintos en la forma, pero iguales en los planteamientos de percibir la realidad. Por otro lado, los elementos que predominan en la estrategia postmachista son la neutralidad — ni machismo, ni feminismo, igualdad-, el cientificismo —manipulación de datos, como es en el caso de las denuncias falsas_- el interés común —el postmachismo es quien de verdad defiende la igualdad buscando lo mejor para toda la sociedad-, el argumento del beneficio económico —ayudas, dinero público—, la idea de imposición y adoctrinamiento como parte de una ideología excluyente —a la que nombran ideología de género-y el ataque personal y descrédito de quienes se posicionan en contra del postmachismo —insultos personales, invención de historias profesionales y vitales, etc.—(Lorente, 2019: 42-45).

Nos dice Kimmel que el mercado, las empresas multinacionales y las instituciones transnacionales de ámbito geopolítico - Tribunal Internacional, Naciones Unidas, Nación Europea—, así como los principios ideológicos que las sustentan —racionalismo económico e individualismo liberal— asumen un modelo global de masculinidad que se está convirtiendo en el modelo dominante frente al del resto de masculinidades locales, regionales y nacionales. Este fenómeno, además, se traduce en un aumento en el poder de los países hegemónicos puesto que se produce, por todo el mundo, la repetición de su modelo (Kimmel, 2001: 51-52).

La versión global de la masculinidad hegemónica que emerge actualmente es fácilmente identificable: se sienta en salas de espera de clase preferente, se aloja en elegantes hoteles de negocios por todo el mundo, viste traje de diseño, habla inglés, come menú continental, usa teléfono móvil, se conecta a su ordenador portátil y ve CNN Internacional. En cuanto a su temperamento, es cada vez más cosmopolita, tiene gustos liberales en el consumo (y en el sexo) e ideas políticas 
conservadoras en lo referente a un limitado control gubernamental sobre la economía (Kimmel, 2001: 52).

Si la masculinidad se está transformando, aún no parecen existir indicios evidentes sobre cambios profundos en las estructuras de poder (Sanfélix y Cascales, 2019: 137138). Es más, para Miguel Lorente, la nueva masculinidad — reivindicada desde distintas esferas como la manera igualitaria de ser hombre en una sociedad patriarcal-, la encarnan los hombres de edad adulta, heterosexuales, de un determinado nivel socioeconómico y cultural y de raza blanca: hombres que ocupan una posición de poder social simplemente por el hecho de serlo (Lorente, 2019: 47). En este sentido, las esencias de la lógica de la dominación masculina no parecen haberse visto alteradas por ninguna respuesta rupturista, ni las crisis de masculinidad que hemos ido mencionando han tambaleado el poder patriarcal.

Por último, nos gustaría destacar la posición de este mismo autor ante la expresión nuevas masculinidades. Lorente nos dice que los hombres deben cuestionarse el rol que han venido desarrollando a lo largo de la historia y posicionarse de manera clara en contra de la desigualdad y de la violencia de otros hombres, sin embargo, apunta que esto no se conseguirá bajo ninguna nueva masculinidad, pues si se hace en nombre de esta, solo se logrará modificar lo existente: los elementos de dominación se adaptarán a los tiempos actuales, dejando intacta la raíz del problema (Lorente, 2019: 47).

Se plantea la reflexión desde una posición que es producto de la desigualdad, puesto que estamos hablando de una construcción basada en los géneros (masculinidad) que en el fondo es la consecuencia de esa creación artificial que ocupa una posición de poder respecto a la feminidad [...]. Este es el error en el que pueden caer algunos planteamientos actuales sobre el llamado "masculinismo", o la trampa diseñada por el machismo para este nuevo tiempo (Lorente, 2019: 47-48).

Es decir, si no derribamos el género, si seguimos perpetuándolo con masculinidades y feminidades, el mecanismo de opresión se mantendrá a salvo, moldeándose siempre a las nuevas circunstancias y narrativas sociales y legitimando un sistema jerarquizado. 


\subsection{Representaciones masculinas en el discurso mediático}

Pierre Bourdieu decía sorprenderse de que "el orden establecido, con sus relaciones de dominación, sus derechos y sus atropellos, sus privilegios y sus injusticias, se perpetúe, en definitiva, con tanta facilidad" (Bourdieu, 2000: 11). Precisamente, para que dicho orden se asiente y prolongue en el tiempo, son necesarios, como ya dijimos, distintos agentes socializadores que transmitan los valores culturales de la sociedad en la que habitamos. Siguiendo la línea de pensamiento de este mismo autor, la dominación masculina sería el ejemplo más paradigmático de las dominaciones sociales.

Siempre he visto en la dominación masculina, y en la manera como se ha impuesto y soportado, el mejor ejemplo de aquella sumisión paradójica, consecuencia de lo que llamo la violencia simbólica, violencia amortiguada, insensible e invisible para sus propias víctimas, que se ejerce esencialmente a través de los caminos puramente simbólicos de la comunicación y del conocimiento, o más exactamente, del desconocimiento, del reconocimiento o, en último término del sentimiento (Bourdieu, 2000: 12).

La dominación masculina se fundamenta, habitualmente, en una característica corporal absolutamente arbitraria, como puede ser el color de piel con respecto de otros hombres o las diferencias sexuales primarias y secundarias con respecto de las mujeres (Bourdieu, 2000: 12). El grupo privilegiado, por tanto, ejerce una serie de violencias sobre los grupos oprimidos. Se trata de violencias simbólicas o violencias invisibles que hacen de la dominación el orden natural de las cosas. Son recursos que legitiman la supervivencia de relaciones jerárquicas y que enaltecen las construcciones sociales masculinas.

La violencia simbólica hacia las mujeres se encuentra muy presente en los medios de comunicación. Vimos que el discurso mediático reproducía una narrativa sexista, patriarcal y misógina que descansaba en prejuicios y estereotipos. De acuerdo a esto, Isabel Moya (2010) nos dice que los medios de comunicación masivos representan a las mujeres según los cánones de la ideología androcéntrica, asociándolas a roles, juicios de valor, concepciones y teorías que naturalizan la subordinación de las mujeres y lo considerado femenino. Teniendo en cuenta esto, la violencia simbólica estaría presente en la publicidad —que usa a las mujeres como objeto sexual—, en las noticias — donde son reducidas a víctimas o ignoradas — en las series adolescentes —en las cuales las protagonistas solo viven para su físico—, en los programas televisivos—que las mujeres 
son objeto de violencia a fin de hacer con ellas un espectáculo de la vida real—o en las tertulias —donde se tratan asuntos de especial interés para las mujeres sin contar con sus voces y opiniones-(Moya, 2010: 105-106).

Especialmente relevante es la sexualización de las mujeres en los medios de comunicación. Natasha Walter afirma, incluso, que "las imágenes sexualizadas de las mujeres amenazan con borrar de la cultura popular cualquier otro tipo de representación femenina” (Walter, 2010: 91). Actualmente, encontramos, también, imágenes de hombres sexualizados. En 1994, el periodista británico Mark Simpson acuñó el término metrosexual. Pretendía, con esta etiqueta, retratar al nuevo hombre del siglo XXI, al que tildaba de consumista, superficial y narcisista. El vocablo metrosexual era el resultado de la conjunción metro - haciendo referencia a que era un hombre que vivía en la metrópoli- - y sexual — su manera de relacionarse con la estética se encontraba más cercana a la exigida para las mujeres que para los varones-. Son hombres que se hacen la manicura, se pintan las uñas, se tiñen el pelo, cambian de peinado, usan cremas antiarrugas, acuden a la cirugía estética... Cabe destacar que el termino cayó en el olvido hasta que en 2002 reapareciera un artículo de Simpson en la revista digital Salon y, fue entonces, cuando se popularizó enormemente (Rey, 2006: 20).

[El metrosexual] es un joven con dinero para gastar, que vive en la ciudad, donde están las mejores tiendas, clubs, gimnasios y las mejores peluquerías. Puede ser oficialmente gay, hetero o bisexual, pero esto no tiene tanta importancia porque se ve a sí mismo como su propio objeto de deseo y placer. De profesiones liberales como modelos, medios de comunicación y productoras o músicos pop $\mathrm{y}$, ahora, también deportistas, saben que atraen, aunque la verdad sea dicha, lo mejoran con productos cosméticos masculinos (Simpson, 2002, citado en Herrero y García, 2015: 253).

La figura del metrosexual tomó rápidamente el discurso mediático, siendo muy relevante su aparición en publicidad (Herrero y García, 2015: 253) y convirtiéndose, así, en modelo para los jóvenes y en nuevo perfil para las empresas (Rey, 2006: 22). Efectivamente, a partir del año 2000 comenzamos a ver estas representaciones masculinas, siendo el caso más paradigmático el del futbolista David Beckham que se irguió como figura metrosexual por excelencia. Beckham "es capaz de reinventarse con acierto cada seis meses, ha sido la inspiración para muchos estilistas. Sus admiradores y fans le copian el corte de pelo, la ropa vintage, los vaqueros rotos, las chaquetas de punto 
de cachemir, los pendientes y collares" (Barreto, 2006: 53). Su imagen comenzó a hacerse muy popular fuera de los estadios de fútbol y protagonizó numerosos anuncios publicitarios.

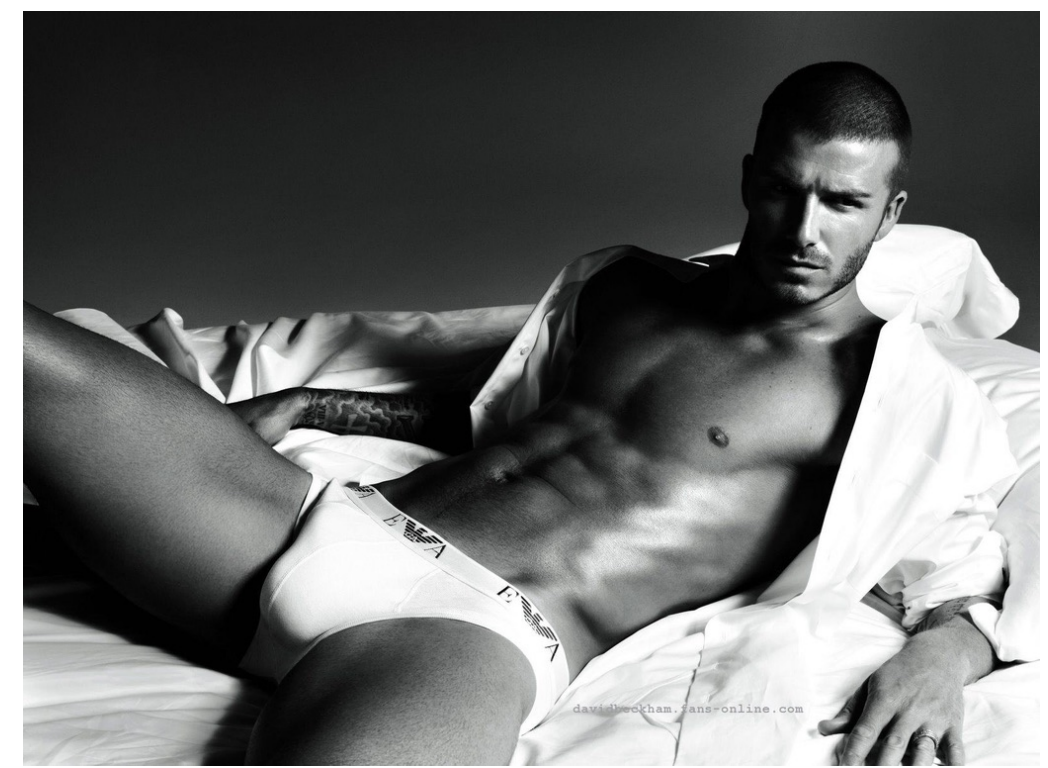

IMAGEN 11. Anuncio de Emporio Armani de la campaña otoño-invierno de 2008 protagonizado por David Beckham. FUENTE: Emporio Armani.

La metrosexualidad inserta una nueva representación masculina en el circuito mediático. Las figuras musculadas salen a la luz y los protagonistas comienzan a aparecer con poca ropa, siendo su cuerpo desnudo un atractivo más del propio anuncio, con independencia del producto que promocionen. Sin embargo, cabe destacar que estas imágenes sexualizadas no acarrean las mismas consecuencias en los hombres que en las mujeres. Es decir, el metrosexual no se ha situado al mismo nivel simbólico que la mujer objeto. No son productos paralelos. Hemos empezado este capítulo hablando, precisamente, del pensamiento de Pierre Bourdieu con respecto a la dominación masculina. El autor nos decía que el grupo dominante ejerce una serie de violencias, simbólicas, invisibles, sobre el grupo dominado. Uno de los transmisores que utiliza es el de los medios de comunicación, que construye un discurso misógino y estereotipado. "Los medios de comunicación, la publicidad, enseñan a la mujer que tiene el deber de seducir" (Vidal, 2002: 104). 
La autoconciencia del cuerpo es central en como el sujeto se ve a sí mismo y en cómo se define, cómo actúa, cómo se presenta ante los demás (Ferreiro, 2018: 4). Dentro de la descripción que Simpson propuso del hombre metrosexual insistió, justamente, en la manera en que este se percibía "se ve a sí mismo como su propio objeto de deseo y placer” (Simpson, 2002, citado en Herrero y García, 2015: 253). Es decir, la figura del metrosexual no está para gustar a nadie más que a sí mismo y, también, para reafirmar su posición. Es una exaltación, una celebración del nuevo hombre. No lo subordina, porque tampoco existe ningún orden estructural que pueda hacerlo. Esto es, en una sociedad donde el poder lo tiene un grupo de hombres, donde existe una dominación masculina, difícilmente un sujeto como David Beckham abandonará su posición dominante. Con las mujeres es distinto. "Los hombres miran a las mujeres. Las mujeres se contemplan a sí mismas mientras son miradas. Esto determina no solo la mayoría de las relaciones entre hombres y mujeres, sino también la relación de las mujeres consigo mismas" (Berger, 2000: 55). Dentro de este orden, los varones se construyen desde la identidad-sujeto y las mujeres lo hacen desde la identidad-objeto (Cobo, 2015: 14).

Si bien vivimos una época de exaltación del cuerpo, este hecho no tiene el mismo significado para hombres que para mujeres. Lo corporal es construido social y políticamente y el cuerpo de las mujeres expresa la narrativa patriarcal sobre la sexualidad femenina. De este modo se expresa Rosa Cobo que, además, nos dice:

El cuerpo de las mujeres y de los varones no está construido de la misma forma, pues ambas construcciones traducen la jerarquía del género. El cuerpo del varón está construido para el poder y el cuerpo de las mujeres está construido para el no-poder. Las mujeres reciben el mandato de que sus cuerpos deben crearse en función de la mirada masculina y, precisamente por ello, la sexualidad debe ocupar un lugar central en las representaciones de lo femenino (Cobo, 2015: 14).

Aunque es cierto que la figura del metrosexual tuvo una gran acogida y pronto se hizo un hueco en el discurso mediático y en el propio imaginario masculino, contaba con un problema, y era la débil frontera que separaba, según apreciaciones culturales, al metrosexual del homosexual. Como hemos visto en el anterior epígrafe, la homosexualidad es un fantasma que amenaza los cimientos de la masculinidad hegemónica, siendo esta una orientación sexual denigrante por asociarse con la feminidad —no sissy stuff, nada de cosas femeninas, dice uno de los imperativos de la masculinidad-. "Entre lo que se percibe como masculino y lo que se percibe como 
femenino hay una jerarquía implícita y una asimilación que une a los hombres con la masculinidad y esta con la heterosexualidad, y lo femenino con la homosexualidad" (Cruz, 2002: 13).

La metrosexualidad, efectivamente, se movía por terrenos resbaladizos. Las empresas, junto con los medios de comunicación, intentaron disociar ambas etiquetas. Empezamos a leer artículos donde, seguido de la palabra metrosexual, aparece una nota aclaratoria acerca de la condición sexual "varones urbanos que, sin ser homosexuales, se preocupan más que antes y que otros por su apariencia personal", "no son afeminados", "no es una cuestión de género, sino de estética". Mientras, las empresas lanzan mensajes con los que excusar a los hombres, contándoles que venden productos creados para ellos. Cremas que dicen ser "for men" (para hombres), "exclusivamente masculina", "una respuesta completa a las necesidades específicas de la piel masculina", productos que "se adaptan a las necesidades reales de los hombres" y un largo etcétera con el que aliviar las desviaciones hacia la feminidad del nuevo modelo (Rey, 2006: 21-22).

A pesar de los esfuerzos, en el 2005, la agente de publicidad Mariam Salzam acuña una nueva etiqueta en su libro El futuro del hombre. Se trata del übersexual. La autora escogió la partícula alemana über — que significa más allá de, por encima de — y cuenta que lo hizo para reflejar que ese hombre era el más grande, el mejor. En este caso, el übersexual también cuida su imagen, pero de una manera más sutil. El prototipo lo encarnaría el actor George Clooney — quien apenas exige una loción no demasiado estridente después del afeitado y un bonito traje- (Rey, 2006: 24). Este modelo representa un retorno a elementos propios de la masculinidad tradicional: pelo en pecho, barba aparentemente descuidada, trajes oscuros de corte clásico. El übersexual corrige, por tanto, las deficiencias del primer modelo y busca a los hombres que, huyendo del metrosexual por considerarlo demasiado femenino, no quieren permanecer ajenos a los cuidados estéticos (Sambade, 2018: 303).

Ambos modelos, metrosexual y ürbesexual "surgen en el seno de la sociedad como tendencia casi imperceptible al principio, son tomados por las empresas, debido a su potencial económico, y los devuelve luego amplificados por el discurso publicitario" (Rey, 2006: 27). En esta última década, vivimos, de nuevo, una reformulación del modelo. Se trata del lumbersexual. En este caso, el prefijo lumber hace referencia a leñador. Son hombres que llevan un aspecto supuestamente desaliñado: barba frondosa, botas, camisa de leñador... Prefieren la vida al aire libre que el cuidado del cuerpo en el 
gimnasio, pero siguen estando preocupados por su físico. Los actores estadounidenses Joe Manganiello o Vicent Gallo, el canadiense Ryan Gosling o el británico Gerard Butler encarnarían este modelo (Herrero y Jennifer, 2015: 255).
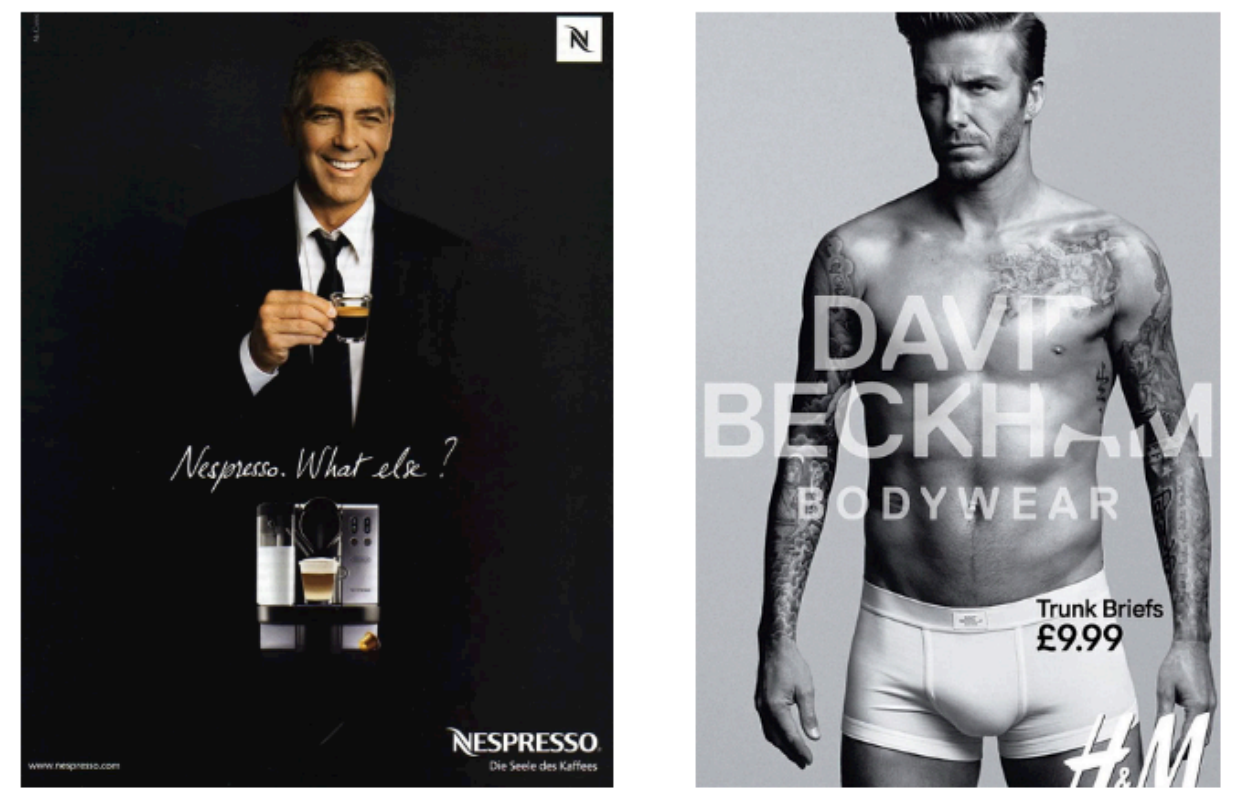

IMAGEN 12. Anuncio de Nespresso de la campaña de 2007 protagonizado por George Clooney y anuncio de H\&M de la campaña de 2012 protagonizado por David Beckham.

FuENTE: Nespresso y H\&M.

Sea como fuere, el discurso publicitario ha potenciado la imagen del hombre bello, creando un escenario donde los varones pueden encontrar los objetos de consumo que les permitirán acercarse a los modelos que representan cada uno de los estereotipos mencionados (Herrero y Jennifer, 2015: 255). Por supuesto, la publicidad no solo vive de la imagen del hombre bello. Es más, los primeros estudios en este campo en España, elaborados por María Luisa Balaguer en 1985, detectaban cuatro tipos de hombre: el ejecutivo, el hombre en casa, el hombre con sus hijos y el hombre conquistador. Contrastan estas cuatro representaciones con las femeninas que eran: mujer ama de casa, mujer trabajadora, mujer belleza (objeto), mujer inferior al hombre y mujer-valor asociado a un producto (Garrido, 2007: 59).

Cabe señalar que no se tratan estas de representaciones paralelas. La mujer es ama de casa mientras que el hombre está en casa — probablemente atendido por la mujer-. La mujer es trabajadora y el hombre ejecutivo — con todo el estatus social que encierra 
ese término-. La mujer es belleza (objeto), inferior al hombre y valor asociado a un producto, mientras que el hombre es conquistador. Para que la mujer — como identidad objeto (Cobo, 2015: 14)—, desempeñara el papel de conquistadora, requeriría de un campo de acción reservado a los hombres. La alternativa que le proponía la sociedad patriarcal era la de adoptar un rol pasivo que la exponía y la colocaba en la posición del objeto, siendo un producto más del anuncio. Hemos visto que el modelo de hombre ha evolucionado y, ahora, incluye, del mismo modo, al hombre bello. Sin embargo, hemos visto, también, que esta representación no acarrea consecuencias similares para ninguno de los dos sexos, pues parten de realidades distintas — dominador y dominada- $-\mathrm{y}$, por tanto, la lectura que se hace de esos cuerpos - como cuerpos en los que se asienta, inevitablemente, una carga política y social—, no puede ser la misma.

El imaginario publicitario proyecta a los hombres como protagonistas de grandes aventuras, profesiones y actividades atractivas e independientes. La aventura, la libertad y la transgresión de las normas se asocia a territorios masculinos (Altés, 2012: 205). Los anuncios orientados a este público, como son los de coches o fragancias masculinas, recurren con frecuencia a mundos por conquistar, a desiertos. La velocidad del automóvil representa la fuerza y el poder y la mujer junto al objeto a consumir simboliza la futura conquista (Pérez, 2002: 50). Los hombres que aparecen están musculados y son fuertes y seguros, además de prestigiosos, con dinero y éxito. La disponibilidad de tiempo fuera del trabajo parece ser ilimitada y dedicada al placer y a los amigos, no a la familia (Ferreiro, 2018: 4-5).

En los casos en los que sí son representados en casa, lo hacen de la siguiente manera: hombres que realizan tareas en el hogar por causas excepcionales y no por cotidianeidad — ayudan - y hombres que, como viven solos, se ocupan de los trabajos domésticos - aquí se transmite la imagen de un hombre inexperto y alguna mujer cercana aparece para salvar la situación_. En cuanto a la paternidad, tienen una relación democrática con sus hijos e hijas, con los que juegan o discuten cariñosamente. Cabe precisar que las relaciones de la madre nunca se representan así, es raro que ella se incorpore a los juegos y suele ser transmisora de conocimientos hogareños, tales son los culinarios (Pérez, 2002: 51).

Carlos Lomas nos dice que el hombre es ahora más consumidor, pero eso no significa que se haya librado de las ataduras del arquetipo tradicional de masculinidad 
dominante, ni que muestre voluntad alguna de compartir de manera equitativa el trabajo doméstico o de esforzarse en la educación sentimental y afectiva de los hijos e hijas. Lo que ocurre es que, al haberse desarrollado la sociedad de consumo, los hombres están más presentes que nunca en los anuncios y son consumidores de productos que antes no lo eran. Sin embargo, sigue existiendo una clara asimetría en la representación publicitaria de conductas y ámbitos donde, al final, encontramos vigentes los estereotipos clásicos (Lomas, 2005: 270-271).

Finalmente, cabe destacar la voz masculina como criterio de autoridad y legitimidad (Altés, 2012: 204). En este sentido, cuando aparecen expertos, científicos, médicos... son representados por hombres o, como mucho, por equipos mixtos, pero nunca o casi nunca por mujeres solas (Pérez, 2002: 50). Un estudio que tomó de muestra 390 anuncios emitidos en España en el año 2006 determinó que los varones ocupaban hasta el 80\% de los papeles de autoridad. También, concluía diciendo que, con frecuencia, la innovación, la inversión de roles o el carácter transgresor del anuncio, se desmontaba ante una mirada más detenida y crítica, pues la propuesta innovadora era solo una estrategia que, en última instancia, llevaba a los mismos y tópicos valores (Berganza y del Hoyo, 2006: 173).

Dentro del discurso televisivo, una imagen muy presente es la del futbolista. Como dijimos, surge en los años 20 del siglo pasado y pronto se incorpora al imaginario masculino, simbolizando una representación deseable que encarna valores de la masculinidad: éxito económico y social, además de un entendido éxito sexual, plenitud física que recuerda a la de los héroes clásicos, reciben el tratamiento de guerreros por parte de los periodistas... (Uría, 2014: 183). Es más, con respecto a esto último, el ritual del fútbol presenta semejanzas con el ritual de la batalla: tiene lugar en la esfera pública, posee un atavío o uniforme determinado y significativo, durante el encuentro se canta el himno del equipo y, de igual modo, canciones ofensivas e intimidatorias dirigidas al equipo contrario y, también, se celebra la victoria y se humilla al equipo perdedor (Martín y García, 2011: 89). En cuanto a los jugadores, son ídolos contemporáneos, siempre varones, que exhiben su masculinidad reflejada en sus cuerpos a través de cualidades físicas — fuerza o resistencia- y valores y actitudes como la autoridad, el coraje o la superioridad. El fútbol se convierte, así, en un ámbito donde impera el modelo de masculinidad hegemónica (Martínez, 2019: 94). 
Además, en televisión, vemos distintos espacios que transmiten eventos deportivos masculinos: el ya mencionado fútbol, baloncesto, ciclismo, espacios de motor como la Formula 1 ... y en los canales temáticos orientados a un público masculino, existe, además, una tendencia actual a producir formatos de supervivencia. En algunos de estos deportes el riesgo físico es considerable, siendo incluso mortal en las actividades con vehículos de motor, o en el ciclismo, donde, aunque no suceda en las pantallas porque las competiciones están controladas, fuera de ellas fallecen ciclistas atropellados con relativa frecuencia (Martínez, 2019: 92). No es baladí que la televisión retransmita eventos deportivos. La práctica deportiva, en general, posibilita aspectos propios de la masculinidad hegemónica, así nos lo exponen Antonio Martín y Almudena García que nos dictan algunos de ellos:

El culto al cuerpo, el ejercicio de poder y acción en la esfera pública, la constitución de grupos de pares donde exista unas normas, rituales, leyes y sentimiento de identidad grupal, la acción violenta y la posibilidad de la victoria, la lucha, las estrategias, las normas de equipo, el trabajo individual y el colectivo, el liderazgo, la transmisión de cultura y valores sociales, la rivalidad, la hegemonía y superación, la comparación con el otro, la virilidad y la sexualidad heterosexual, el deseo (Martín y García, 2011: 87).

Es preciso señalar que la idea de supremacía física masculina va más allá del mundo deportivo. Muchos productos de ficción que vemos están hechos, también, para satisfacer una especie de ego masculino, plasmado en grandes hazañas que ellos llevan a cabo saltándose, si hace falta, las leyes de la física (Bernárdez, 2017: 170). En la década de los setenta y de los ochenta, en el cine, se forjó un tipo de héroe agresivo, asociado a la beligerancia. Los dos actores más representativos fueron Sylvester Stallone —Rocky (1976), Rambo (1982)— y Arnold Schawarzenegger —Conan el bárbaro (1982), Terminator (1984)_. En sus ficciones, encarnan la idea del cuerpo masculino autosuficiente. Persiguen la conquista del universo, el cual preservarán de cualquier catástrofe o ataque universal (Lema, 2003: 228-229).

Más tarde, ya en el año 2000, el actor Tom Cruise se convierte, también, en héroe gracias a la serie cinematográfica Misión Imposible — la saga, que empezó en 1996, cuenta con seis películas, la última de 2018- Este tipo de ficciones son conocidas como acción por acción: en ellas vemos una sucesión de explosiones, máquinas sofisticadas de destrucción, armas inagotables, vehículos que vuelan por los aires y que sobrepasan todo 
tipo de obstáculos... A diferencia de las películas clásicas, en Misión Imposible no hay reflejado un hogar confortable que espere el héroe, sino que sólo existe una velocísima sucesión de movimientos imparables y una acción descontrolada (Lema, 2003: 230). Así, los modelos hegemónicos de representación de las masculinidades se basan en el disciplinamiento físico y emocional y en las culturas de riesgo y la violencia (Sambade, 2018: 318).

Cuantitativamente, el cine está plagado de personajes masculinos. Además, durante su tránsito por el relato, desprenden el ya mencionado halo de heroicidad, el cual raramente vemos en los personajes femeninos. Así, la clásica figura del cine de Hollywood es un tipo bien definido, apuesto, esforzado, valeroso y solitario: el acrobático aventurero, el atleta deportivo o el luchador musculoso, el explorador de la selva, el conquistador del lejano Oeste o el campeón intergaláctico (Bernárdez et al., 2008: 131). En este sentido, son los hombres quienes mueven la acción, contrariamente a lo que ocurre con las mujeres, que sufren la acción — les pasan cosas-. También, otra característica dentro del cine, es que la mayoría de las películas se narran desde el punto de vista de los personajes masculinos, de forma que el relato se focaliza en los hombres e, incluso, llegamos a conocer lo que las mujeres piensan a través de ellos (Bernárdez et al., 2008: 112-113).

Por su lado, dentro de las series televisivas, encontramos, entre otras, las actiondriven series, las cuales se dirigen a un público masculino. Estas, al contrario que las character-driven series, que son aquellas que se resuelven en torno a las relaciones de los personajes y que tienden a ser vistas por mujeres, centran su fuerza en la acción. Se trata de formatos menos verbales donde las motivaciones psicológicas y los vínculos humanos tienen poco peso. Remarcan la individualidad de un héroe que persigue un objetivo concreto. Además, estos personajes ejercen un control sobre la situación, sobre otros personajes y sobre sí mismos, anulando cualquier tipo de impulso emocional y atisbo de vulnerabilidad. No dependen de nadie para desarrollar su potencial y persiguen fuertemente su objetivo (Medina, 2015: 154-155).

En 2014, Mark Simpson, quien, en 1994 comenzara a hablar de hombres metrosexuales, acuñó el término spornosexual para referirse a una nueva configuración en las representaciones masculinas que empezaba a verse en la publicidad, las revistas, distintos géneros televisivos —como el reality show- y, también, en los productos de ficción (Mira, 2015: 16). El término spornosexual es una contracción de sportman, porn 
y sexual (deportista, porno y sexual). Se basa, pues, en representaciones que iconográficamente contienen elementos del deporte y del porno - especialmente del porno gay_-, caracterizado por una masa muscular hipertrófica, tatuajes y actitud narcisista. Este nuevo modelo resignifica la metrosexualidad (Sambade, 2018: 304). Distintos actores, tanto en España como en Hollywood, representan esta tendencia: el actor australiano Chris Hemsworth o el español Mario Casas serían algunos de los ejemplos (Mira, 2015: 16).

Gracias a la pornograficación —el proceso por el cual el imaginario pornográfico se ha naturalizado en la cultura del ocio y del entretenimiento (Esquirol, 2017: 79)resulta más fácil aceptar que la exhibición del cuerpo masculino no es sinónimo de desvirilización. Dentro de la ficción de nuestro país, es común ver a Mario Casas actuando sin camiseta o, incluso, protagonizando desnudos integrales, como en la serie de televisión Sin miedo a nada y en las películas Mentiras y gordas, Fuga de cerebros y Tres metros sobre el cielo (Mira, 2015: 23). Nos cuenta Alberto Mira que, aunque, efectivamente, el imaginario pornográfico legitime ciertas representaciones, el modelo resulta molesto para la crítica masculina. Al fin y al cabo, Mario Casas exhibe su cuerpo para un público de mujeres adolescentes y hombres homosexuales, categorías degradadas dentro del imaginario hegemónico.

Habría que apuntar que la crítica que se expresa con sarcasmo cuando Casas muestra su cuerpo acepta sin problemas la belleza y la exhibición de sus compañeras de reparto. [...] En una crítica de Fuga de cerebros, Pablo Kurt, crítico en la página web FilmAffinity, mostraba su inquietud ante el desnudo de Casas y sugería que Fuga de cerebros mejoraría con un desnudo de su compañera de reparto Amaia Salamanca. La reseña en Cinemanía de Grupo 7 acumula piropos a Antonio de la Torre (icono de la masculinidad tradicional no exhibicionista) añadiendo a regañadientes que Casas "deja de ser solo un chico guapo". Lo problemático en estas películas no es que el cuerpo se exprese y se convierta en un objeto de deseo para el espectador, sino que ese cuerpo sea masculino. La crítica de cine en España, compuesta en una aplastante mayoría por hombres que hacen gala de una mirada masculina tradicional, deja ver la ansiedad que produce el cuerpo de Mario Casas y acaba por revelar más sobre su punto de vista que de Casas (Mira, 2015: 28).

De este modo, el spornosexual se une a los modelos de metrosexual, übersexual y lumbersexual. Como ya explicamos con anterioridad, la exhibición del cuerpo masculino y la hipersexualización femenina no son fenómenos paralelos. De nuevo nos lo recuerda 
Iván Sambade, quien asegura "metro, über y spornosexuales no son objetos de deseo, sino sujetos que desean ser deseados y que se ubican en la posición de objetos, sólo dentro de las posibilidades que les concede formar parte de una élite de la sociedad de consumo" (Sambade, 2018: 318).

\section{HISTORIA Y ESTADO ACTUAL DE LAS REVISTAS DIRIGIDAS A HOMBRES}

\subsection{La prensa masculina}

Antes de abordar el concepto de revistas especializadas en estilo de vida masculino, conviene hablar, de una manera genérica, de la prensa masculina. El primer inconveniente con el que nos topamos es que esta no existe a nivel formal. Por poner un ejemplo, y aunque hemos visto que la clasificación de la OJD es muy cuestionable e insuficiente, este organismo no incluye, como sí sucedía en el caso femenino, ningún tipo de etiqueta que nos indique que estamos ante un producto mediático dirigido a los varones (véase tabla 1).

De la prensa femenina hemos convenido que, dada la fragmentación de la audiencia y la especificidad de sus contenidos, es un tipo de periodismo especializado y, también, hemos señalado que, debido a la socialización diferencial por género, estos contenidos no responden a narrativas afines al universo simbólico masculino. Es importante tener en cuenta el concepto de periodismo especializado pues nos permitirá iniciar el análisis hacia una definición de la prensa masculina.

Frente al periodismo especializado, contamos con otro periodismo de interés general, ahora bien, ¿a qué nos estamos refiriendo cuando hablamos de periodismo de interés general? Según el Informe Estadístico de la Unesco de 1985, recogido en una de las obras de Juana Gallego, la prensa de información general se entendería como:

Publicaciones periódicas destinadas al gran público y que tengan especialmente por objeto constituir una fuente de información escrita sobre los acontecimientos de actualidad relacionados con asuntos públicos, cuestiones internacionales, etc. (citado en Gallego, 1990: 20). 
Para la autora, es reseñable que la definición utilice los vocablos asuntos públicos e interpreta que, por tanto, el periodismo de información general es la prensa que da cobertura a "aquello que ocurra en el ámbito de lo público" (Gallego, 1990: 20). Tal y como hemos razonado, es este el ámbito donde se establecen las relaciones sociales entre los hombres, por lo tanto, se entiende que una prensa que recoja los asuntos públicos, será una prensa dirigida a ellos. Cabe añadir que, al igual que el espacio público es la esfera mejor valorada socialmente y la que encabeza el sistema jerárquico, lo mismo sucede con la prensa de información general: será esta la más preciada pues abarca los asuntos importantes y relevantes, aquellos que ocurren en el espacio de los varones (Gallego, 1990: 21).

Los estudios feministas ya han señalado de qué manera opera el concepto falsamente neutro del hombre como sinónimo de humanidad. La pensadora Simone de Beauvoir recoge esta idea en su obra más representativa, El segundo sexo: "la mujer se determina y se diferencia con respecto al hombre, y no a la inversa; ella es lo inesencial frente a lo esencial. Él es el Sujeto, es el Absoluto: ella es la Alteridad" (Beauvoir, 2005: 50). Así, encontramos que la norma es inherente a lo masculino, que lo masculino es lo universal y, por tanto, no necesitará de ninguna etiqueta que especifique su condición, mientras que, en lo referente a las mujeres, sí leemos una marca diferenciadora: literatura femenina, cine femenino, deporte femenino...

El informe de Global Media Monitoring Project (GMMP): “¿Quién figura en las noticias?" 48 proporciona información detallada sobre la prensa de interés general a escala internacional. Nos interesa hablar brevemente de él pues nos permite comprobar si, bajo la aparente neutralidad de la prensa de información general, se esconde un producto dirigido al público masculino. Así, Global Media Monitoring Proyect, o el Proyecto de Monitoreo Global de Medios, es un estudio realizado a nivel global —en el año 2015 participaron 144 países_- que analiza la representación de hombres y mujeres en la prensa general y el impacto que esto supone a la hora de luchar contra la discriminación por razón de género. Contamos, hasta la fecha, con 4 informes: uno del año 2000, otro del año 2005, el siguiente de 2010 y, finalmente, el de 2015.

Entre otros muchos datos, el GMMP ofrece un estudio detallado sobre la centralidad de las mujeres en las noticias. Tal y como observamos en la tabla 12, las cifras

\footnotetext{
${ }^{48}$ Véase información publicada en 2015: El Proyecto de Monitoreo Global de Medios de 2015. Recuperado el 19 de mayo de 2019 de http://cdn.agilitycms.com/who-makes-the-news
} 
se muestran estables a lo largo de los 15 años (10\%), con una leve variación en 2010 (13\%) y una vuelta al nivel inicial en 2015 (10\%). Vemos, pues, que las mujeres son protagonistas de un $10 \%$ de las noticias, habiendo alcanzado sus niveles más altos en el año 2000 en la esfera de lo social y legal (19\%) y en el año 2010 en crímenes y violencia (19\%) (GMMP, 2015: 78). Este mismo estudio nos revela, además, los principales temas en los que es más probable que las mujeres sean protagonistas frente a los diez en los que raramente las encontramos, así podemos comprobar en la tabla 13.

\begin{tabular}{lcccc}
\hline \multicolumn{5}{c}{ LAS MUJERES COMO SUJETO DE LA NOTICIA } \\
& $\mathbf{2 0 0 0}$ & $\mathbf{2 0 0 5}$ & $\mathbf{2 0 1 0}$ & $\mathbf{2 0 1 5}$ \\
\hline Política y gobierno & $7 \%$ & $8 \%$ & $13 \%$ & $7 \%$ \\
\hline Economía & $4 \%$ & $3 \%$ & $4 \%$ & $5 \%$ \\
\hline Ciencia y salud & $11 \%$ & $6 \%$ & $11 \%$ & $14 \%$ \\
\hline Social y legal & $19 \%$ & $17 \%$ & $17 \%$ & $8 \%$ \\
\hline Crimen y violencia & $10 \%$ & $16 \%$ & $19 \%$ & $17 \%$ \\
\hline Celebridades, arte y medios, deportes & $16 \%$ & $17 \%$ & $16 \%$ & $14 \%$ \\
\hline GENERAL & $10 \%$ & $10 \%$ & $13 \%$ & $10 \%$ \\
\hline
\end{tabular}

TABLA 12. Centralidad de las mujeres en las noticias por tema principal (2000-2015).

Fuente: Global Media Monitoring Project (2015: 78).

Según estos datos, las mujeres aparecen en noticias que tengan que ver con la reproducción, las relaciones familiares, la estética, el mundo de las celebridades y la violencia de género a escala familiar o cultural. También, cuando son interpeladas directamente porque ostentan cargos políticos, protagonizan movimientos activistas y cuando sus derechos o avances sociales puedan ser noticia. Por el contrario, es poco probable que sean centralidad en los asuntos económicos, en los laborales, en el cambio climático, los tratados de paz y negociaciones, temas de consumo, transportes y en la violencia de género perpetuada por el Estado (GMMP, 2015: 79).

Hemos venido hablando de la diferencia entre el ámbito público y el ámbito privado y de cómo cada uno de ellos se asocia a un sexo. Dicha separación de los espacios implica una narrativa que articula dos universos simbólicos opuestos y jerarquizados. Esta simbología se transmite culturalmente gracias a diversos mecanismos y canales, entre otros, los medios de comunicación. En nuestro caso concreto, y tras la exposición de este estudio, detectamos una tendencia: cuando la prensa de interés general trata temas 
asociados a la esfera privada las mujeres cuentan con una mayor probabilidad de protagonizar la noticia, no así en los temas vinculados con el ámbito público, donde apenas aparecerán. Con todo, no podemos olvidar que la representación femenina total es de un $10 \%$, lo que nos lleva a afirmar que la prensa de interés general es una prensa que aparta a las mujeres de su discurso y que alimenta el dimorfismo cultural.

\begin{tabular}{|l|l|}
\hline \multicolumn{1}{|c|}{$\begin{array}{c}\text { Los 10 temas principales en los que aparecen } \\
\text { las mujeres }\end{array}$} & $\begin{array}{c}\text { Los últimos 10 temas en importancia para las } \\
\text { mujeres }\end{array}$ \\
\hline $\begin{array}{l}\text { Participación de las mujeres en el proceso } \\
\text { económico. }\end{array}$ & Otros temas de desarrollo, sostenibilidad, etc. \\
\hline $\begin{array}{l}\text { Control de natalidad, fertilidad, esterilización, } \\
\text { irrupción del embarazo... }\end{array}$ & Cambio climático, calentamiento global. \\
\hline $\begin{array}{l}\text { Relaciones familiares, conflictos } \\
\text { intergeneracionales, padres. }\end{array}$ & Violencia de género perpetuada por el Estado. \\
\hline $\begin{array}{l}\text { Concursos de belleza, modelos, moda, cirugía } \\
\text { estética. }\end{array}$ & Otras noticias en la economía. \\
\hline $\begin{array}{l}\text { Violencia de género por razones culturales, } \\
\text { familiares, relaciones interpersonales; feminicidio, } \\
\text { acoso, violación, ataques sexuales, trata de } \\
\text { personas, mutilación genital... }\end{array}$ & $\begin{array}{l}\text { Crisis económica, rescate de empresas por parte } \\
\text { etc. Estado, adquisición de empresas y fusiones, }\end{array}$ \\
\hline $\begin{array}{l}\text { Cambios en las relaciones de género (fuera del } \\
\text { hogar). }\end{array}$ & $\begin{array}{l}\text { Políticas económicas, estrategias, módulos, } \\
\text { indicadores, mercados de valores, etc. }\end{array}$ \\
\hline Políticas, candidatas a puestos de elección... & Paz, negociaciones, tratados. \\
\hline Movimientos femeninos, activismos, eventos, etc. & Transporte, tráfico, caminos... \\
\hline $\begin{array}{l}\text { Derechos humanos, derechos de las mujeres, } \\
\text { derechos de las minorías sexuales, derechos de las } \\
\text { minorías religiosas, etc. }\end{array}$ & $\begin{array}{l}\text { Temas de consumo, protección al consumidor, } \\
\text { fraude... }\end{array}$ \\
\hline $\begin{array}{l}\text { Noticias sobre celebridades, cumpleaños, bodas, la } \\
\text { realeza, etc. }\end{array}$ & Otros temas laborales (huelgas, sindicatos, etc.). \\
\hline
\end{tabular}

TABLA 13. Temas con mayor y menor presencia de mujeres en las noticias en el año 2015. FueNTE: Global Media Monitoring Project (GMMP: 2015: 79).

Puede que sea, precisamente, la falta de centralidad en el discurso y protagonismo en las noticias lo que aleje, en mayor medida, a las mujeres de ser consumidoras de este tipo de prensa. En el año 2018, los diarios fueron leídos en un 40,3\% por las mujeres y en un 59,7\% por los hombres (AIMC, 2019: 14). El dato resulta relevante pues roza el $60 \%$ que utilizan las empresas anunciantes para escoger dónde insertarán su publicidad — de esta forma, veíamos que, cuando una publicación contaba con una audiencia compuesta por más de un $60 \%$ de hombres, las empresas anunciantes determinaban, 
según sus criterios, que era un producto mediático masculino y viceversa (Figueras, 2005:51)-.

Cuando acotábamos la definición de prensa femenina, nos encontrábamos con que convivían dos términos, estos son, prensa femenina y prensa dirigida a las mujeres. Los mismo podría suceder en el caso de la prensa masculina. Se entiende, como hemos visto, que el periodismo de información general —además de ser consumido en mayor porcentaje por hombres_-, recoge su realidad y que, por tanto, se trataría esta de una prensa configurada para ellos —aunque no contenga ningún tipo de etiqueta distintiva ni se especifique formalmente- Así, mientras que existe una prensa dirigida a las mujeres — de índole feminista y que trata asuntos sobre las mismas en el espacio público, como son la discriminación por género o la emancipación del sexo femenino-, existiría, también, una prensa que retrata la esfera pública pero, esta vez, dirigida a los varones, en la que, como hemos visto, ellos son protagonistas del discurso en un $90 \%$.

Ahora bien, ¿cuál es la prensa masculina? Retomando de nuevo los paralelismos con la prensa femenina, sería, entonces, aquella que hable de lo masculino, es decir, que su narrativa se articule en torno a la socialización diferencial de género. Sin embargo, nos gustaría introducir un matiz, y es que la prensa masculina, como la femenina, va a asentar sus bases en el ámbito privado, ámbito que, ya explicamos, se asoció y se asocia al sexo femenino. Por tanto, la prensa masculina recogerá lo que nuestra cultura dice que debería ser un hombre en la esfera privada: sus gustos, ocio, entretenimiento, preferencias culturales...

A diferencia de la información dirigida a las mujeres, que hemos visto que implicaba la totalidad del ser femenino — vida privada, familia, hogar, belleza, amor, psicología, relaciones sentimentales, maternidad, etc.- es decir, que incluía todas las dimensiones de lo que se supone conformaba la identidad femenina, los hombres recibían una información exterior, del mundo público, racional, sin implicación emocional alguna. Ese es el primer cambio de estas nuevas revistas para hombres: que se empieza a incluir otras dimensiones masculinas, más allá de la única que se había permitido presentar — la erótica—. (Gallego, 2013: 151).

Por otro lado, en prensa femenina, destacábamos, también, la declaración de intenciones que desde el propio medio de comunicación se lanza sobre si un producto está pensado exclusivamente para un determinado público (Perinat y Marrades, 1980: 
56). En este sentido, sí existen publicaciones en nuestro país que, ya sea en su título, ya sea en la definición que lo acompaña, apelan directamente al sexo masculino. Así, la revista Esquire es "La revista para hombres interesantes", Men's Health, "La mayor revista masculina del mundo" o DT "La revista para hombres que saben lo que quieren".

Haciendo una recopilación de lo hasta ahora expuesto, la prensa masculina sería un tipo de prensa especializada, nacida de la carencia de un discurso mediático que abordara la dimensión masculina en el ámbito privado, intencionalmente dirigida a los hombres, donde ellos son los protagonistas de la información. La autoría no tendría porqué ser masculina, pero sí estaría leída en su mayoría por varones y trataría temas que tienen que ver con la socialización diferencial masculina, alimentando y enalteciendo, que no cuestionando, la misma.

\subsection{Evolución de las revistas masculinas a lo largo de la historia}

Aunque debemos situar el inicio de las revistas masculinas, tal y como las conocemos hoy en día, en el siglo XX, los primeros ejemplares datan del siglo XVIII. The Gentleman's Magazine, creada por Edward Cave —bajo el sinónimo de Sylvanus Urban- en Londres, en el año 1731, es considerada la primera revista moderna dirigida a los varones (Varela, 2015: 20). Previamente, en 1692, Peter Motteux, un refugiado francés, había fundado The Gentleman's Journal. Este periódico, que duró 3 años y que ofrecía noticias, poemas, filosofía, historia, música y traducciones se convirtió en el prototipo para la revista The Gentleman's Magazine (Henry y Parker, 1856: 6-7).

The Gentleman's Magazine contó con una periodicidad mensual y estuvo en el mercado casi 200 años (1731-1922). Fue la primera publicación en autodenominarse, por decisión de su autor, magazine — palabra proveniente del francés que significaba “almacén”- pues, la intención de Edward Cave era la de, y traducimos literalmente, almacenar en sus páginas "todos los tesoros de ingenio, humor e inteligencia que pudieran ser recopilados de la totalidad de la prensa efímera" (Henry y Parker, 1856: 8). En este sentido, se lee ya una intencionalidad que caracteriza a las revistas modernas y que las distingue de la prensa: la perdurabilidad en el tiempo. Hoy, sabemos que las revistas "no se agotan de un vistazo ni se relegan al terminar el día; permiten una lectura fragmentada a lo largo del tiempo y, con frecuencia, se convierten en colección en muchos hogares" (Menéndez, 2009: 279). 


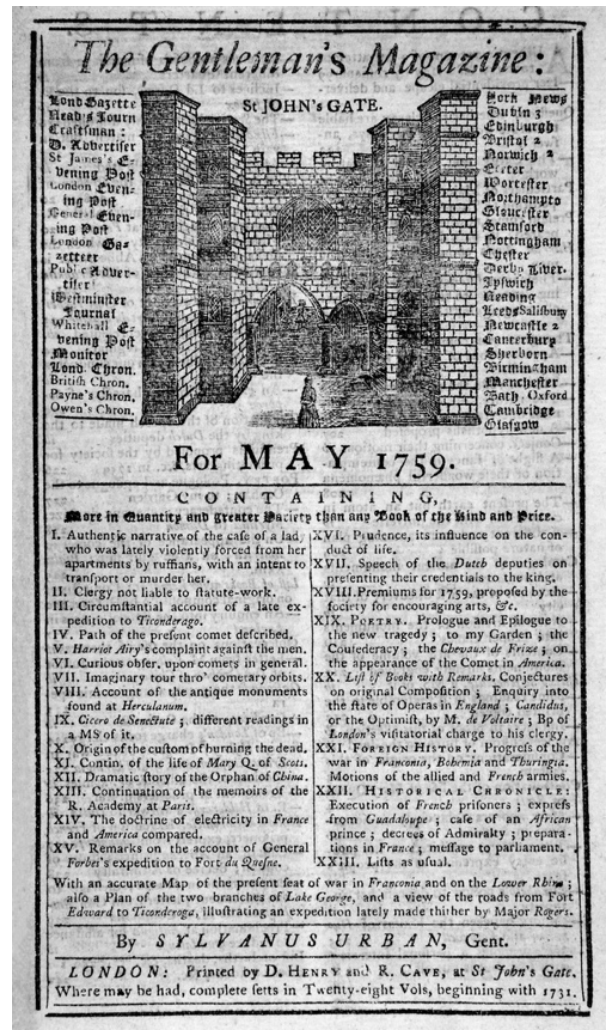

IMAGEN 13. Portada de la revista The Gentleman's Magazine de mayo de 1759. La componen una ilustración de St. John's Gate, lugar donde se imprimía la revista, y el índice de contenidos. Encontramos, entre otros, temas políticos, literarios y sensacionalistas.

FuENTE: Wikipedia.

The Gentleman's Magazine incluía, entre sus contenidos, artículos de diversa índole como historia, poemas, comentarios políticos, etc. (Varela, 2015: 20). A finales del siglo XIX, se generó, en la prensa londinense, un debate sobre las mujeres periodistas (Shelley, 2009: 1). Se alimentó la imagen de la reportera soltera masculina, amargada y sin responsabilidades domésticas. Pues bien, The Gentleman's Magazine no fue ajena a la polémica y, en un artículo titulado "La mujer periodista: vista por un hombre", afirmaba: "no hay duda de que no sea capaz de escribir... pero no podrá encarnar a la perfecta ama de casa... ella no contribuirá en su salud y felicidad... los regalos efectivos de la mujer doméstica... el matrimonio debería ser la vocación de todas estas garabateadoras" (Shelley, 2009: 6; la traducción es nuestra).

Otros títulos publicados desde el siglo XIX hasta mediados del siglo XX fueron Gentleman's Magazine of Fashion (1829-1824), Wide World (1898-1965) Fancy Clothes, Gentleman's Pictorial, The Gentleman (A Cosmopolitan Journal), Country Gentleman, 
The Gentleman 's Journal y Man about a Town (1952-1968). Todas ellas presentaban una temática más o menos similar: asuntos relacionados con la moda, la vida social y la importancia de ser un caballero. La mayoría dejaron de publicarse en 1914 con el estallido de la I Guerra Mundial, aunque, cabe destacar la larga trayectoria de Wide Word que, bajo el subtítulo "historias verdaderas de peligro y aventuras", sobrevivió hasta 1965 (Varela, 2015: 21).

Estas revistas, que sí mostraban su intencionalidad de convertirse en un producto de consumo masculino - los propios títulos apelaban, en muchos de los casos, al caballero o al hombre-, no encerraban un discurso tan orientado como el que encontrábamos en las revistas femeninas contemporáneas, aunque, cabe destacar, que también incluían "ciertos mensajes de cómo debería comportarse un caballero de la época" (Varela, 2015: 21). Son, pues, los primeros coletazos de un sector que acabará por despegar en el siglo XX: será en 1933 que nacerá Esquire de la mano del editor Arnold Gingrich. Esta revista estadounidense se fundó bajo el eslogan The magazine for men (la revista para los hombres) (Breazeale, 1994: 1) y sentará las bases, a nivel mundial, del nuevo fenómeno mediático que, poco a poco, irá desarrollándose.

En España, no fue hasta mediados de los años 80 que vimos publicada la primera revista masculina. Sin embargo, querríamos, previamente, hablar de las revistas para hombres que proliferaron en nuestro país en la década de los setenta. Estas publicaciones, nacidas incluso durante la propia dictadura, incluían textos de política, artículos sobre intereses masculinos — viajes, deportes y motor-y reportajes fotográficos de mujeres más o menos desnudas. La vida de las mismas, en muchos de los casos, fue efímera. Al fin y al cabo, eran los primeros intentos de lanzar al mercado un producto, la prensa masculina, aún sin definir en nuestro país (Alcázar, 2012: 72).

De entre ellas, cabe destacar la revista Bocaccio 70 (1970-1974), una publicación explícitamente dirigida al público masculino con un alto nivel adquisitivo y de clase privilegiada (Rosón, 2017: 57). Esta revista, localizada en Barcelona, junto con la madrileña Flashmen, fueron, poco a poco, incrementando su contenido erótico, hasta el punto de que era habitual que la policía se presentase en sus redacciones. No olvidemos que nos encontramos, todavía, en los últimos años de la dictadura franquista (Pagès, 2016: 20). El sumun de dichas revistas llegó, cuando, en 1976, se fundó Interviú —originariamente interviu en minúsculas y sin tilde— de la mano de la Editorial 
Zeta y dirigida por Antonio Álvarez Solís. Interviü ${ }^{49}$ impuso un nuevo tipo de modelo informativo donde imperaba el sexo, el escándalo y el sensacionalismo, mezclando todo ello con columnas de personajes conocidos del mundo del periodismo, la escritura, la política y la sociedad (Alcázar, 2012: 73). Este tipo de revistas, se encuentran a mitad de camino entre lo que podría ser un producto de interés general — vemos presencia de asuntos políticos, económicos y sociales - y la prensa masculina - ya que incluyen intereses que responden a la socialización diferencial masculina en el ámbito de lo privado- En cualquier caso, son revistas dirigidas a hombres.

Ya en la década de los ochenta, aparecieron las publicaciones Hombres Dunia (1986-1991), Hombres de Hoy (1986-1987), Man (1987-2012) y Varón. Estas revistas proponen una narrativa ampliada de las dimensiones masculinas (Gallego, 2013: 151). El ejemplar de El País del 3 de noviembre de 1987 recoge la siguiente pieza publicitaria acerca de Man:

Única en formato, papel, grafismo y tratamiento periodístico. El hombre visto desde el hombre. El lado humano y carismático de los protagonistas de nuestro tiempo [...] Entrevistas solo con personajes humanamente interesantes. Mujeres con algo más que un buen cuerpo que enseñar. Y toda la información que el hombre que viene necesita sobre moda, música, cine, artes, libros, viajes, coches, motos, escena, negocios y sociedad en acción (citado en Gallego: 2013: 152).

La revista Man, perteneciente al Grupo Zeta, era la réplica exacta de las revistas femeninas de alta gama que por aquel entonces conformaban el mercado (Marín et al., 2010: 261). Cabe destacar que su portada estuvo protagonizada, en sus inicios y solo durante unos meses, por un personaje masculino. Sin embargo, ya en 1988, revertieron la fórmula y empezaron a aparecer, únicamente, mujeres adoptando poses eróticas. Este fue el caso de la portada de Ana Obregón, de noviembre de 1988, la de Mónica Molina, de marzo de 1991, y la de otro par de cientos de mujeres que han sido protagonistas a lo largo de los 294 números de vida de esta revista. Finalmente, Man lanzó su último ejemplar en el verano de 2012 con la cantautora y actriz Nawja Nimri en portada (Gallego: $2013,152)$.

\footnotetext{
49 Interviú, que nació en 1976 publicó su último número el 29 de enero de 2018 por "la imposibilidad de seguir sosteniendo por más tiempo las importantes pérdidas generadas". Véase información publicada en 2018: “Interviú publica su último número con una de sus portadas más polémicas". Recuperado el 24 de mayo de https://www.20minutos.es/noticia/3246723/0/interviu-ultimo-numero-portada-marisol/
} 

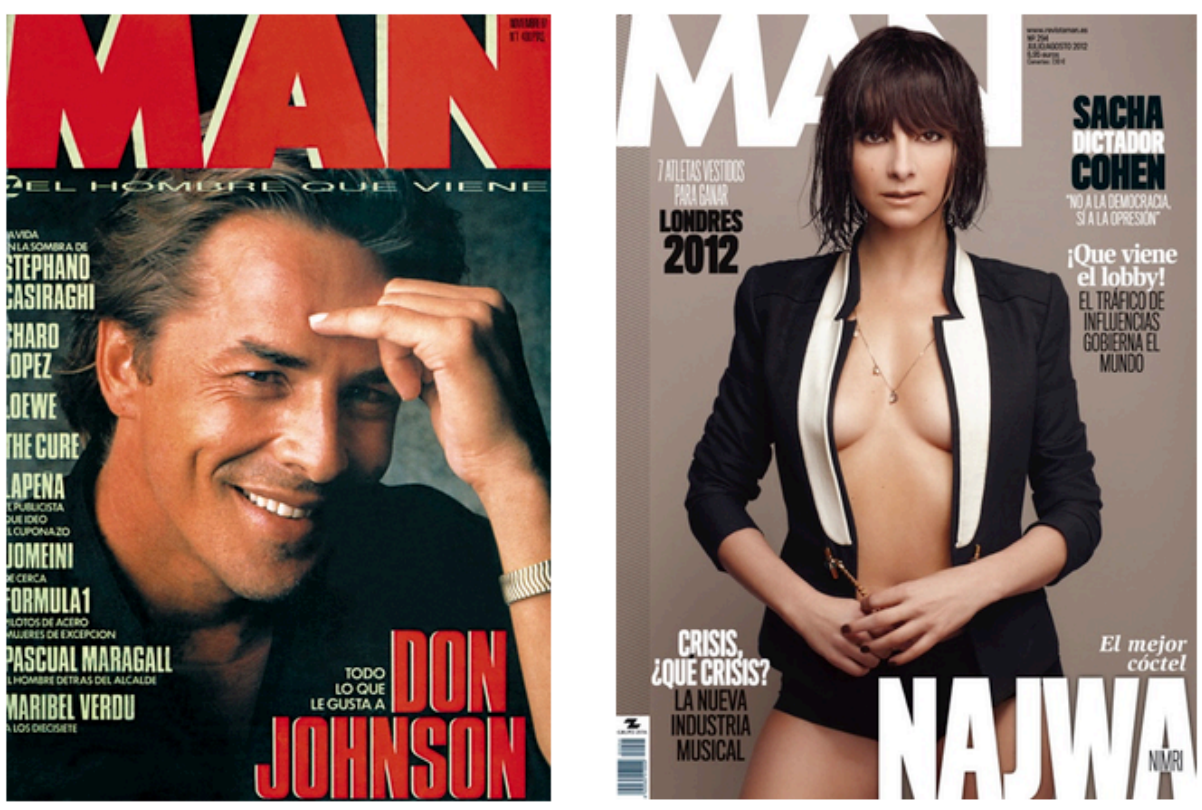

IMAGEN 14. A la izquierda, la portada del primer número de la revista Man de noviembre de 1987. A la derecha, el último número de la revista (verano de 2012).

FueNTE: Blog Quintatinta.

En 1994, la editorial Condé Nast, trae a España la cabecera internacional $G Q$ (Gentleman Quartely). Esta revista nació en Estados Unidos en 1957. Para conocer su aceptación en el mercado español, antes de lanzarse como bimestral, fue, en la primera etapa, suplemento de la revista femenina Vogue (Iriarte, 2016: 107). Su directora, María Malibrant —única mujer participe en el proyecto por aquel entonces_- en una entrevista que concedió al periódico El País, el 4 de noviembre de 1994, explicaba lo siguiente acerca de la publicación:

No haremos una revista para homosexuales. Tampoco somos una revista sólo de moda para hombres. Queremos dar una información integral y didáctica para el hombre. [...] Al hombre español hay que enseñarle, adoctrinarle en determinadas áreas como la moda. A mí me entristece la forma de vestir del español, siempre de gris o de azul. Por eso vamos a ofrecer una moda muy didáctica e informativa, de ideas, y muy realista, que no huela a vanguardia. [...] Nos dirigimos a los hombres jóvenes, entre 25 y 34 años, con una formación cultural y una clase social media alta, especialmente profesionales muy independientes de la mujer (citado en Varela, 2015: 22).

Estas declaraciones nos ayudan a entender la temática de la revista. Además de moda, $G Q$ enseñará y adoctrinará — dos términos, por cierto, presentes en el análisis y 
evolución de las revistas femeninas — a los hombres en el ámbito personal, en el ámbito de lo privado. Las "doctrinas a impartir para el nuevo hombre incluyen el fitness, salud, cosmética, motor, deportes y temas tradicionalmente de los varones como la calvicie, la impotencia, la infidelidad..." (Gallego, 2013: 153). Vemos, pues, que GQ sigue la línea ya marcada por las revistas femeninas.

En los años sucesivos, surgieron, además, una serie de cabeceras enfocadas a los hombres homosexuales — cabe destacar que no encontramos las mismas revistas para un público femenino-: Shangay, de distribución gratuita desde 1993 (Iriarte, 2016: 107), Zero, que se comercializó entre 1998 hasta 2009, y, más adelante, Vanity Gay y Oh my god! La publicación Zero nació en el seno de la editorial independiente Zero Press, la cual, con una tirada inicial de 50.000 ejemplares, se distribuyó, primeramente, de manera gratuita en Madrid y, después, pasó a convertirse en revista mensual de pago (Varela, 2015: 23). Se describía a sí misma como "la primera revista gay de información y estilo de vida" (René, 2011: 173). La publicación dejó de editarse en 2009, pero reapareció en versión digital en 2015, al igual que Shangay, la cual, aparte de contar con la versión digital, continúa, también, distribuyéndose gratuitamente (Iriarte, 2016: 107).

En 2001, llegó a España la cabecera internacional Men's Health de la mano de Motorpress Ibérica. Men's Health nació en Estados Unidos en 1987 y se caracterizó por tratar, en su sentido más amplio, el tema de la salud masculina. A raíz de su éxito, la revista fue ampliando la temática hasta incluir deporte, fitness, sexo, belleza, viajes, cuidado personal, etc. (Gallego, 2013: 153). Esta revista cuenta, desde 2013, con Women's Health (Varela, 2015: 23), versión orientada a un público femenino y especializada en los mismos temas. En 2018, cuando Hearst España adquirió las editoriales Rodale y G+J Holanda, Men's Health pasó a ser propiedad del grupo Hearst. ${ }^{50}$

Down Town fue una revista que apareció en el año 1992, era bimestral y centrada en coches, motos, tecnología, moda y ocio. Sin embargo, no fue hasta 2003 que consiguió despegar en el mercado español. En diciembre de ese mismo año, la revista modificó su diseño — cambió la tipografía y estilo—, se transformó en mensual y simplificó su

\footnotetext{
${ }^{50}$ Véase información publicada el 15 de enero de 2018 en la página web de Hearst España: "Hearst adquiere las editoriales Rodale y G+J Holanda". Recuperado el 17 de junio de 2019 de http://www.hearst.es/salade-prensa/hearst-adquiere-las-editoriales-rodale-y-g-j-holanda
} 
nombre, que pasó a ser DT. Hasta que dejara de publicarse en $2018,{ }^{51}$ la revista perteneció, primero, a Focus Ediciones y, más adelante, a MC Ediciones (Gallego, 2013: 154-155).

También, en 2003, el grupo Prisa lanzó Gentleman, publicación que se define "como una revista cosmopolita, para hombres urbanos de clase alta y elevado nivel de formación, inquietos, sensibles a productos de lujo, maduros, inteligentes, que disfrutan con la información y saben escoger sus placeres" (Gallego, 2013: 154). Actualmente, y tras no renovarse en 2014 la concesión que tenía con el grupo Prisa, Luxury Media es quien edita Gentleman. ${ }^{52}$ En 2004, la cabecera internacional FHM (For Him Magazine) aterriza en España gracias a Focus Ediciones. Esta publicación, de procedencia inglesa -Reino Unido, 1985-, duró 13 años en el mercado. En febrero de 2017, la revista anunció su cierre a través de su cuenta de Twitter, utilizando la imagen de una mujer de espaldas y en ropa interior.

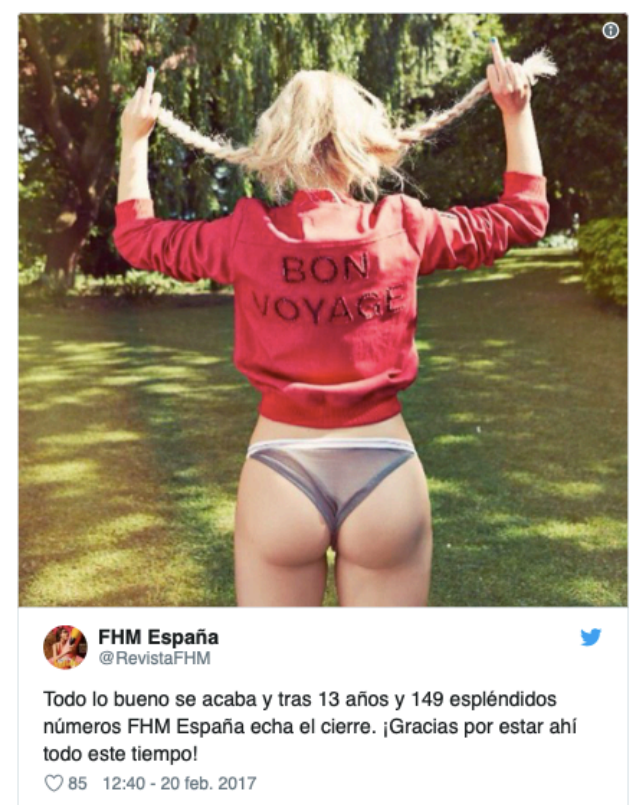

IMAGEN 15. Mensaje de la cuenta oficial de Twitter de la revista $F H M$ en el que se anuncia el fin de la publicación. Fuente: Twitter.

\footnotetext{
${ }^{51}$ Véase información publicada el 2 de febrero de 2018: "Cierra la revista masculina $D T$ tras 26 años en el mercado". Recuperado el 24 de mayo de 2019 de https://www.periodisticos.com/cierra-la-revistamasculina-dt-tras-26-anos-en-el-mercado-por-aprensamadrid/2018/02/02

52 Véase información publicada el 7 de enero de 2014 en Europapress: "La revista Gentleman seguirá llegando a los quioscos tras acuerdo de Luxury Media y Class Editori”. Recuperado el 17 de junio de 2019 de https://www.europapress.es/sociedad/noticia-revista-gentleman-seguira-llegando-quioscos-acuerdoluxury-media-class-editori-20140107164639.html
} 
No es de extrañar el uso que el equipo de la revista hace de esta fotografía. FHM se caracterizó por su alto contenido en imágenes eróticas femeninas (Varela, 2015: 23). Al igual que hacía Man (1987-2012), ofrecía a sus lectores portadas de mujeres altamente sexualizadas. Dicha fórmula, que habíamos dejado de ver en Men's Health y Gentleman, es también recurrente en $G Q$ y $D T$, aunque, en el caso concreto de estas últimas, combinan las portadas masculinas y femeninas — cabe destacar que en las masculinas sus personajes no aparecen sexualizados, al contrario de lo que ocurre con las mujeres que sí son presentadas siempre en poses eróticas y con poca ropa- Un contenido que gozaba de gran popularidad en FHM era el suplemento especial Las 100 mujeres más sexys del mundo, elaborado mediante encuestas entre sus lectores y publicado desde el año 2004 hasta el $2013 .{ }^{53}$

Otras revistas que se publicaron en estos años fueron Nox (2003), que trataba temas sobre arquitectura, arte, fotografía, cultura y moda y Stuff (2007), especializada en tecnologías. Además, ambas revistas utilizaban, también, a las mujeres como reclamo tanto en la portada como en el interior de las mismas (Gallego, 2013: 155). La revista Maxim (2005-2006), a diferencia de las otras revistas que abrían nuevas vías temáticas para los hombres, centró su discurso en los contenidos eróticos. Rescatando las palabras de su fundador, el británico, Félix Dennis, esta revista era "para hombres más interesados en el sexo que en el color de sus calcetines" (citado en Gallego, 2013: 156). De esta manera, no solo no exploraba los nuevos horizontes masculinos, sino que se burlaba de ellos.

En el año 2007, la mítica cabecera Esquire llega a nuestro país gracias a Hearst España. Recordemos que esta revista nació en Estados Unidos en 1933 y fue el primer intento consciente de organizar a la audiencia masculina bajo un producto especializado de este tipo (Breazeale, 1994: 1). Así, consolidó las bases de la prensa masculina a nivel mundial. En cuanto a España, dicha revista ha supuesto un antes y un después en la prensa masculina (Varela, 2015: 24). La apuesta de Esquire es cultural, con un estilo sobrio en el diseño, reportajes largos y, como protagonistas, hombres maduros y experimentados (Iriarte, 2016: 119).

La portada del primer número, octubre de 2007, estuvo protagonizada por el director y actor de cine Woody Allen. Nos advierte Juana Gallego de que, aunque la

\footnotetext{
${ }^{53}$ Véase información recuperada el 24 de mayo de 2019 de https://es.wikipedia.org/wiki/FHM_España
} 
apuesta era la de no mostrar a mujeres sexualizadas como reclamo en sus portadas "la mayoría de las mujeres que han aparecido en la portada de la edición americana lo han hecho ligeritas de ropa y con poses muy sexys, a diferencia de los hombres, cuya totalidad ha estado vestida y con actitudes más bien serias" (Gallego, 2013: 156). Además, y como veremos en nuestra muestra, los reportajes de mujeres en el interior de la revista siguen apostando por el mismo tipo de fotografías sexualizadas, pero con un toque de sofisticación.

En 2011 nace el suplemento Código Único del grupo Vocento. Este se distribuye mensualmente con los diarios $A B C$ y el Periódico de Catalunya. Va dirigido "a los hombres que exigen lo mejor". ${ }^{54}$ Incluye entrevistas, reportajes, deportes, moda, belleza, motor y tecnología. En la versión digital, en la pestaña "placeres” encontramos la sección "mujeres" con reportajes como "los bikinis más sexys de Blanca Suárez", "Las 20 fotos de Aitana más sexys en Instagram", "Rihana se atreve con la lencería más salvaje" o "Las fotos de Paula Echevarría que siempre quisiste ver". ${ }^{55}$ Así, aunque cuidada en diseño, sigue apostando por contenidos eróticos, al más puro estilo de Man, FHM o Maxim.
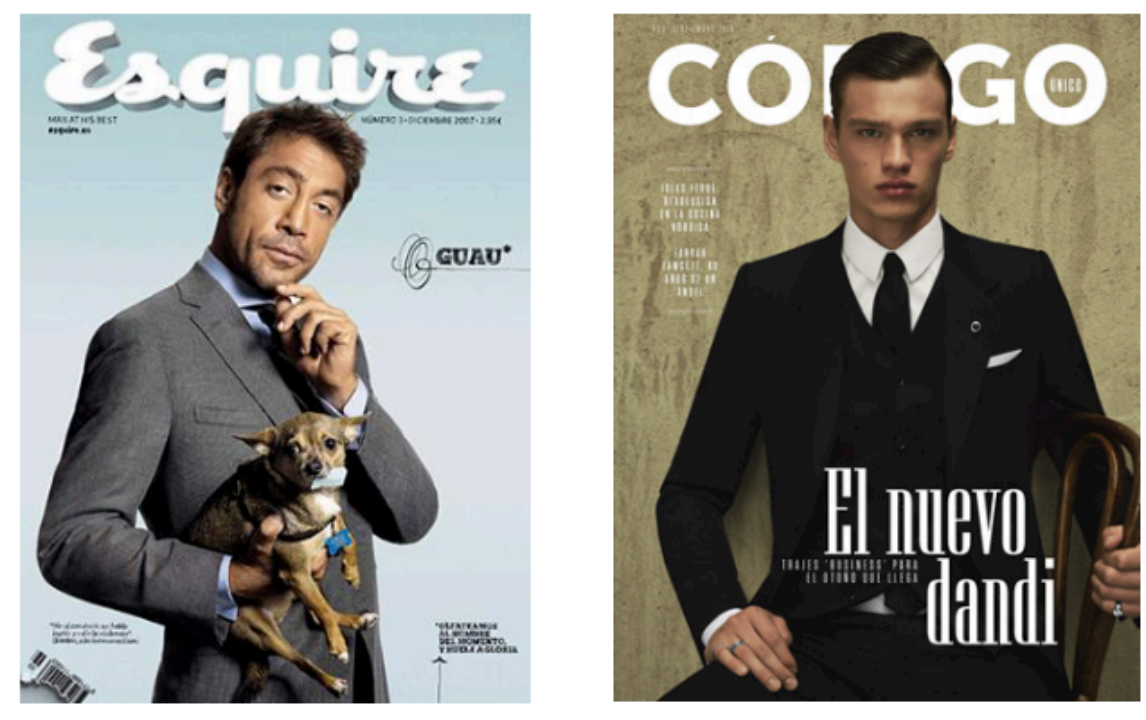

IMAGEN 16. A la izquierda, portada de la revista Esquire de diciembre de 2007. A la derecha, la revista Código Único, nacida en 2013. Esquire supuso un antes y un después en el concepto de revistas masculinas en nuestro país. Fuente: Esquire y Código Único.

\footnotetext{
${ }^{54}$ Véase información publicada en la página web del grupo Vocento. Recuperado el 25 de mayo de 2019 de https://www.vocento.com/nosotros/prensa/codigo-unico/

${ }^{55}$ Véase información publicada en la versión digital de Código Único. Recuperado el 25 de mayo de 2019 de https://www.codigounico.com/placeres/mujeres
} 
Dos años más tarde, en 2013, el Grupo Prisa también apuesta por crear una revista masculina. Nace, pues, Icon, suplemento mensual de El País (Iriarte, 2016: 151). Icon es hija de Esquire, lo vemos en el diseño elegante y en el refinamiento de los contenidos, que intentan cautivar al hombre con clase. A propósito del lanzamiento de Icon, el director de la revista, Lucas Arraut, hizo las siguientes declaraciones a Europa Press: "las revistas masculinas han vivido un montón de fases diferentes y de alguna manera ya hemos superado los tópicos de las chicas con bikini, los coches rápidos y los gadget inútiles, pero siempre nuevos, y también hemos pasado el miedo a la moda" (citado en Iriarte, 2016: 151). Aun así, los contenidos de Icon siguen versando, entre otros, sobre motor y tecnología. Cabe destacar que esta revista no está recogida ni en la lista de la OJD ni en los informes anuales de El Estudio General de Medios, EGM.

Finalmente, en marzo de 2015 nace Ego, del grupo Hearst España, el mismo grupo que edita Esquire. De esta revista, que tampoco aparece recogida ni en la OJD ni en el EGM y de la que se publican cuatro números al año, su empresa editorial nos dice:

Ego es la revista de estilo de vida sofisticada e inteligente para hombres globales que buscan exclusividad. Desvela las claves para el hombre contemporáneo que busca lujo y diferenciación, destacando las últimas tendencias en moda, complementos, cosméticos, gastronomía, motor, tecnología, viajes... ${ }^{56}$

\subsection{Revistas especializadas en estilo de vida masculino}

Explica Victoria Sau que el androcentrismo es "el hombre como medida de todas las cosas" (Sau, 2000: 45) o, lo que es lo mismo, que la realidad de los varones se universaliza hasta tal punto que, cuando nos topamos con cuestiones masculinas, no vemos el sesgo de género. Esto es, precisamente, lo que ocurre con la prensa que venimos analizado, a la cual, en lugar de añadir algún tipo de etiqueta distintiva — como sucede en la clasificación de la OJD de revistas femeninas—, se ha categorizado bajo el término estilo de vida. "Lo que para las mujeres es su esencia, aquello definido simplemente como femenino, para los hombres ha sido ennoblecido mediante una nueva categoría, de nombre tan sugerente y elitista como Estilo de vida" (Gallego, 2006: 21).

Dentro de la clasificación de medios en papel proporcionada por la OJD, encontramos, hasta en tres ocasiones, el apartado estilo de vida: en las revistas de

\footnotetext{
${ }^{56}$ Véase información publicada en la página web de Hearts España. Recuperado el 25 de mayo de 2019 de http://www.hearst.es/nuestras-marcas/ego/ego
} 
información especializada, en los suplementos temáticos y en las publicaciones de distribución gratuita de interés temático. Estos productos, no son sino copias de la prensa femenina. "Las revistas para hombres nacen cuando el modelo de publicaciones femeninas está ya asentado en el mercado, de ahí que no ocultan en su estructura y diseño las fuentes de las que beben" (Armentia et al., 2011: 284).

Tal y como ocurría en el apartado de revistas especializadas femeninas de la OJD —que mezclaba distintas tipologías de revistas—, tampoco la categoría estilo de vida se encuentra bien delimitada puesto que vemos, no solo estilo de vida masculino, sino que también revistas especializadas en el mundo de los negocios y las finanzas, como Forbes, deportivas, como Sport Life, tecnológicas, Gadget, gastronómicas, Tapas, o de salud, Integral. Además, más allá de la categoría estilo de vida, existen otras tipologías que tradicionalmente se han asociado con la masculinidad y que posiblemente estén orientadas a un público masculino - hecho fácilmente constatable viendo las inserciones publicitarias_-, como son las deportivas, de motor, de economía, empresas y negocios (véase tabla 1).

Sin embargo, como ya se ha mencionado y siguiendo el esquema que propone Isabel Menéndez (2010: 225) para esclarecer las distintas tipologías de revistas dirigidas a mujeres, podemos entender que también existen diversas revistas dirigidas a hombres, pero que serán las de estilo de vida masculino las que convierten a los varones en los protagonistas de la información. Así, veremos sus gustos, preferencias, en qué invierten el tiempo libre, la música que escuchan, las películas que ven... Es decir, mientras que una revista de estilo de vida sitúa a los hombres en el centro del discurso, una deportiva haría lo propio con el deporte, una automovilística con los coches, etc. En la tabla 14, recogemos la prensa dirigida a varones que encontramos en nuestro país en el periodo más reciente.

Así, por ejemplo, la revista Esquire sería una revista especializada en estilo de vida masculino, mensual, de gama alta para hombres adultos y de pago. Zero, mientras, aunque es de estilo de vida, está enfocada a un público homosexual. Las primeras revistas que se comercializaron en España dirigidas a varones en la época de los setenta eran revistas que empezaban a incluir temas de estilo de vida, pero también interés general y elementos eróticos, lo que las convertiría en productos híbridos. La archiconocida Interviú, nacida en 1976, fue una revista híbrida de interés general-erótica. Por su lado, y tomando como referencia el ámbito internacional, Playboy es una revista erótica 
—aunque, como veremos más adelante, el descenso en las ventas ha obligado a virar su temática y está reformulándose—. Revistas de automóvil, deportivas, de negocios... es decir, especializadas en ámbitos tradicionalmente masculinos, son, también, productos orientados a varones. Finalmente, las revistas o la propia prensa de interés general sigue entendiéndose — desde las mismas redacciones y el discurso que elaboran, las empresas publicitarias y el consumo por parte del público_ como un producto masculino.

\begin{tabular}{|c|c|}
\hline \multicolumn{2}{|c|}{$\begin{array}{l}\text { PRENSA DE MASAS DIRIGIDA A HOMBRES EN ESPAÑA EN EL PERIODO CONTEMPORÁNEO (SIGLO } \\
\text { XXI) }\end{array}$} \\
\hline \multirow{7}{*}{ ELEMENTOS } & TIPOLOGÍA \\
\hline & $\begin{array}{l}\text { Revistas especializadas en estilo de vida: temática relacionada con la } \\
\text { socialización diferencial masculina en relación con sus protagonistas, los } \\
\text { hombres. }\end{array}$ \\
\hline & Revistas especializadas en estilo de vida para un público homosexual. \\
\hline & $\begin{array}{l}\text { Revistas especializadas en ámbitos tradicionalmente masculinos: revistas } \\
\text { deportivas, de motor, económicas, de negocios... }\end{array}$ \\
\hline & Revistas eróticas. \\
\hline & Revistas o prensa de interés general: tratan aspectos del espacio público. \\
\hline & $\begin{array}{l}\text { Revistas hibridas de estilo de vida-interés general-eróticas: pueden incluir } \\
\text { elementos de dos o incluso de las tres categorías. }\end{array}$ \\
\hline \multirow{5}{*}{ PERIODICIDAD } & Semanal. \\
\hline & Quincenal. \\
\hline & Mensual. \\
\hline & Trimestral. \\
\hline & Otros formatos. \\
\hline \multirow{3}{*}{ CALIDAD FORMAL } & Alta gama. \\
\hline & Gama media. \\
\hline & Gama baja. \\
\hline \multirow{2}{*}{$\begin{array}{l}\text { EDAD DEL PÚBLICO } \\
\text { OBJETIVO }\end{array}$} & Juvenil. \\
\hline & Hombres adultos. \\
\hline \multirow{3}{*}{ DIFUSIÓN } & De pago. \\
\hline & Gratuitas. \\
\hline & Combinadas. \\
\hline
\end{tabular}

TABLA 14. Tipología de la prensa dirigida a hombres en España en el siglo XXI.

FUENTE: Elaboración propia.

Actualmente, encontramos 7 cabeceras en nuestro país especializadas en estilo de vida masculino, de las cuales, cinco son revistas y dos suplementos, sin embargo, estos últimos reúnen las características formales de las revistas — recordemos que, con algunos suplementos, ha ocurrido una desnaturalización del producto e intromisión de los mismos 
en el campo de las revistas (González, 2011: 26)—. Así, Hearst España es el grupo editorial que más publicaciones edita: cuenta con Men's Health (2001-), Esquire (2007-) y Ego (2015-). De la más veterana de todas ellas, GQ (1994-), se ocupa Condé Nast, mientras que Luxury Media edita, desde 2014, Gentleman (2003-). Por último, Código Único (2011-) e Icon (2013-) son los suplementos de Vocento y del Grupo Prisa respectivamente.

\begin{tabular}{|l|c|c|c|c|c|}
\hline \multicolumn{5}{|c|}{ PUBLICACIONES ESPECIALIZADAS EN ESTILO DE VIDA DIRIGIDAS A HOMBRES } \\
\hline & Año & Tipo & Periodicidad & Empresa editora & Difusión $^{\mathbf{5 7}}$ \\
\hline $\boldsymbol{G Q}$ & $1994-$ & Revista & Mensual & Condé Nast & 22.434 \\
\hline Men's Health & $2001-$ & Revista & Mensual & Hearst España & 33.781 \\
\hline Gentleman & $2003-$ & Revista & Mensual & Luxury Media & 21.088 \\
\hline Esquire & $2007-$ & Revista & Mensual & Hearst España & 28.202 \\
\hline Código Único & $2011-$ & $\begin{array}{c}\text { Suplemento } \\
\text { ABC }\end{array}$ & Mensual & Vocento & - \\
\hline Icon & $2013-$ & $\begin{array}{c}\text { Suplemento } \\
\text { El Pais }\end{array}$ & Mensual & Grupo Prisa & - \\
\hline Ego & $2015-$ & Revista & Trimestral & Hearst España & - \\
\hline
\end{tabular}

TABLA 15. Cabeceras de prensa masculina en España en el año 2019.

FuENTE: Elaboración propia.

Entre las distintas cabeceras, podemos detectar dos tendencias: aquellas que apuestan por un modelo de masculinidad más tradicional y las que han sofisticado sus contenidos y se dirigen a un hombre cultivado intelectualmente y con intereses refinados "más inclinado a las actividades culturales, intelectuales y artísticas, incluyendo el gusto por la moda y que no ensalzan el sexo como valor definitorio, aunque no rehúyan, naturalmente, de este aspecto" (Gallego, 2013: 157). Si bien es cierto que está disminuyendo la presencia de las mujeres en portadas o ganando peso la oferta intelectual frente a la sexual, también es verdad que se está reformulando la manera en la que las mujeres aparecen: se siguen usando sus cuerpos, pero ahora respondiendo a nuevas narrativas de sofisticación.

\footnotetext{
${ }^{57}$ Los datos pertenecen al periodo controlado entre julio de 2013 y junio de 2014. Actualmente, la OJD ha dejado de incluir la difusión de las revistas, a menos públicamente. Hemos intentado rescatar la difusión acudiendo a cada una de las mismas de manera individual, sin embargo, algunas aportaban el total de un consumo acumulado de varios meses, otras de un año, algunas no incluían el dato, otras sumaban la afluencia de las visitas en internet con las lecturas del papel... por lo que nos ha resultado imposible encontrar un patrón de seguimiento que fuera común a todas ellas.
} 

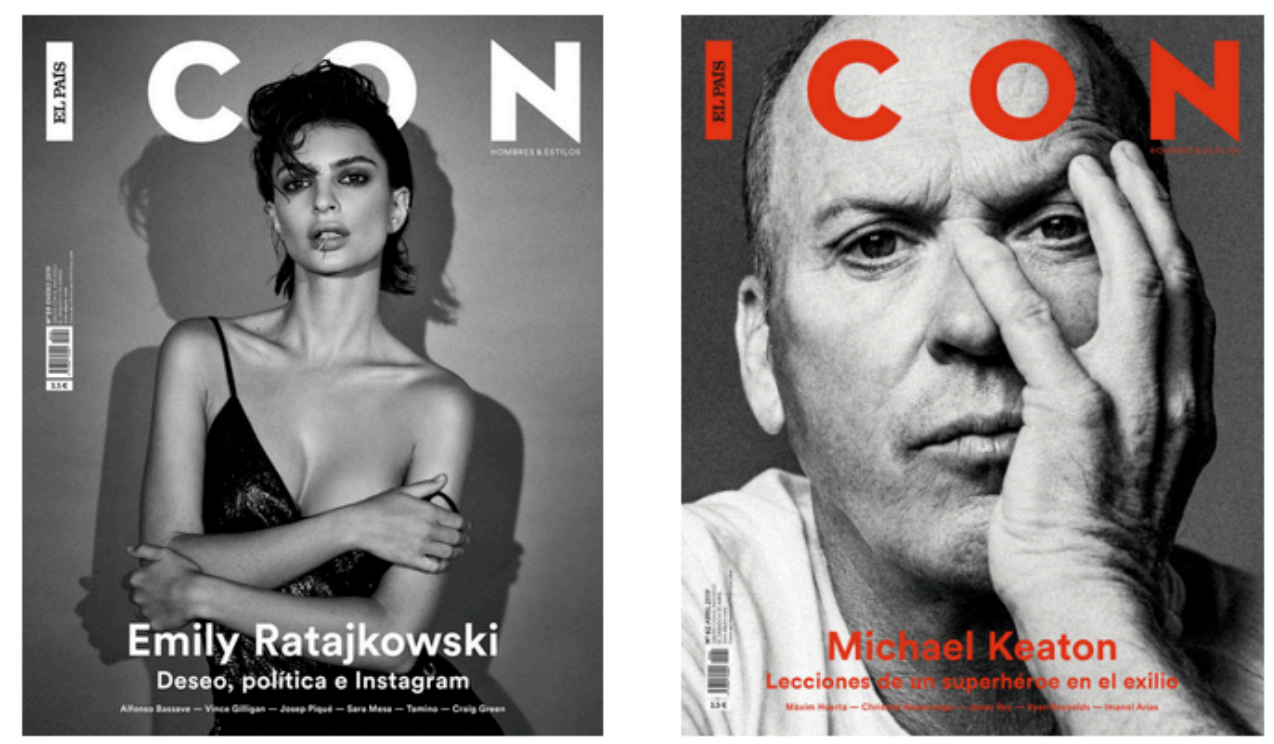

IMAGEN 17. A la izquierda, portada número 59 de enero de 2019 y, a la derecha, portada número 62 de abril de 2019 del suplemento Icon. Podemos ver la diferencia entre cómo aparece retratada la modelo y cómo lo hace el actor.

FUENTE: Icon.

Playboy, revista erótica internacional — fundada en Estados Unidos en 1953 y que llegó a España en noviembre de 1978 (Román, 1980: 125)—, dejaba, con la intención de recuperar audiencia, de mostrar desnudos integrales en sus páginas en marzo de 2015. Desde la revista, achacaron la bajada de ventas a la expansión de internet —al fin y al cabo, se trata de un medio cargado de material sexual y fácilmente accesible que convierte a las revistas eróticas en elementos del pasado- La nueva apuesta fue la de incluir fotos de mujeres en poses atrevidas, no desnudas, y seguir eligiendo a la conejita —así denominan a la mujer protagonista de cada mes —, además de reforzar los reportajes y entrevistas en profundidad. ${ }^{58}$ Cabe destacar que, dos años después, la revista rescató los desnudos integrales femeninos, estrategia que anunció Cooper Hefner, hijo del fundador de Playboy, en su cuenta de Twitter: "reconozco que la forma en que la revista mostraba las escenas de desnudos ha caducado, pero eliminarlas por completo ha sido un error". ${ }^{5}$ Desde 2018, se especula sobre la continuidad de la misma, debido a que ya no consigue la difusión que lograba hace años. Ben Kohn, accionista de Playboy, anunció en una

\footnotetext{
${ }^{58}$ Véase información publicada el 14 de octubre de 2015 en El Pais: "Adiós a los desnudos en Playboy". Recuperado el 18 de junio de 2019 de https://elpais.com

${ }^{59}$ Véase información publicada el 15 de febrero de 2017 en ComputerHoy: La revista Playboy vuelve a los desnudos tras su fallido experimento". Recuperado el 18 de junio de 2019 de https://computerhoy.com/noticias/life/revista-playboy-vuelve-desnudos-su-fallido-experimento-58410
} 
entrevista "la idea es hacer una transición de una compañía de medios a una que gestiona una marca", lo que significaría la creación de un Mundo Playboy y la apertura de clubes y casinos en ciudades estratégicas. ${ }^{60}$

En España, el 7 de enero de 2018, Grupo Z anunció al cierre de Interviú. Recordemos que esta revista nació en 1976 y se caracterizó por imponer un tipo de modelo informativo donde imperaba el sexo, el escándalo y el sensacionalismo (Alcázar, 2012: 73). La revista mezclaba los reportajes de actualidad con los desnudos femeninos, los cuales siempre aparecían en el interior de la publicación y en la propia portada. El éxito que Interviú cosechó en sus inicios fue enorme, vendía 600.000 ejemplares semanales, llegando a rechazar publicidad porque imprimir más páginas provocaba pérdidas de dinero. El 16 de septiembre de 1976, seis meses después de su lanzamiento, alcanzó el millón de ejemplares gracias a la portada que mostraba el desnudo de Marisol, la actriz española que protagonizó numerosas películas durante su infancia y juventud. A mediados de los años 80 , cuando el periodismo de denuncia ya no era tan rentable por estar más asentada la democracia y existir una mayor competencia de medios, se intentó un cambio de modelo hacia una revista de articulismo, sin embargo, el cambio no cuajó y las ventas fueron descendiendo, desde los 350.000 ejemplares hasta los 26.000 con los que cerró en el año $2018 .{ }^{61}$

Aunque, como hemos analizado, estas revistas no sean consideradas de estilo de vida masculino, nos permiten comprender de qué manera una fórmula que resultó altamente exitosa - la de mostrar a mujeres desnudas —, ya no genera los mismos niveles de rentabilidad. El fácil acceso a internet, que permite consumir cualquier tipo de imagen de mujer en el momento en el que se desee, ha obligado a las revistas a repensar y reubicar los distintos elementos. Ello no quiere decir que los cuerpos de las mujeres hayan desaparecido - la objetualización de las mismas y la banalización de la sexualidad se ha convertido en parte de la cultura popular (Cobo, 2015: 16) - , sino que dado que el producto se ha intentado sofisticar, así también lo han hecho sus elementos eróticos.

\footnotetext{
${ }^{60}$ Véase información publicada el 1 de julio de 2018 en Semana: “Adiós a la emblemática revista española Interviü". Recuperado el 18 de junio de 2019 de https://www.semana.com/mundo/articulo/cierre-de-lasrevistas-de-papel-en-el-mundo/552915

${ }^{61}$ Véase información publicada el 8 de enero de 2018 en El Pais: El Grupo Zeta cierra Interviú y Tiempo por sus importantes pérdidas" Recuperado el 18 de junio de 2019 de https://elpais.com/politica/2018/01/08/actualidad/1515411044_174991.html
} 

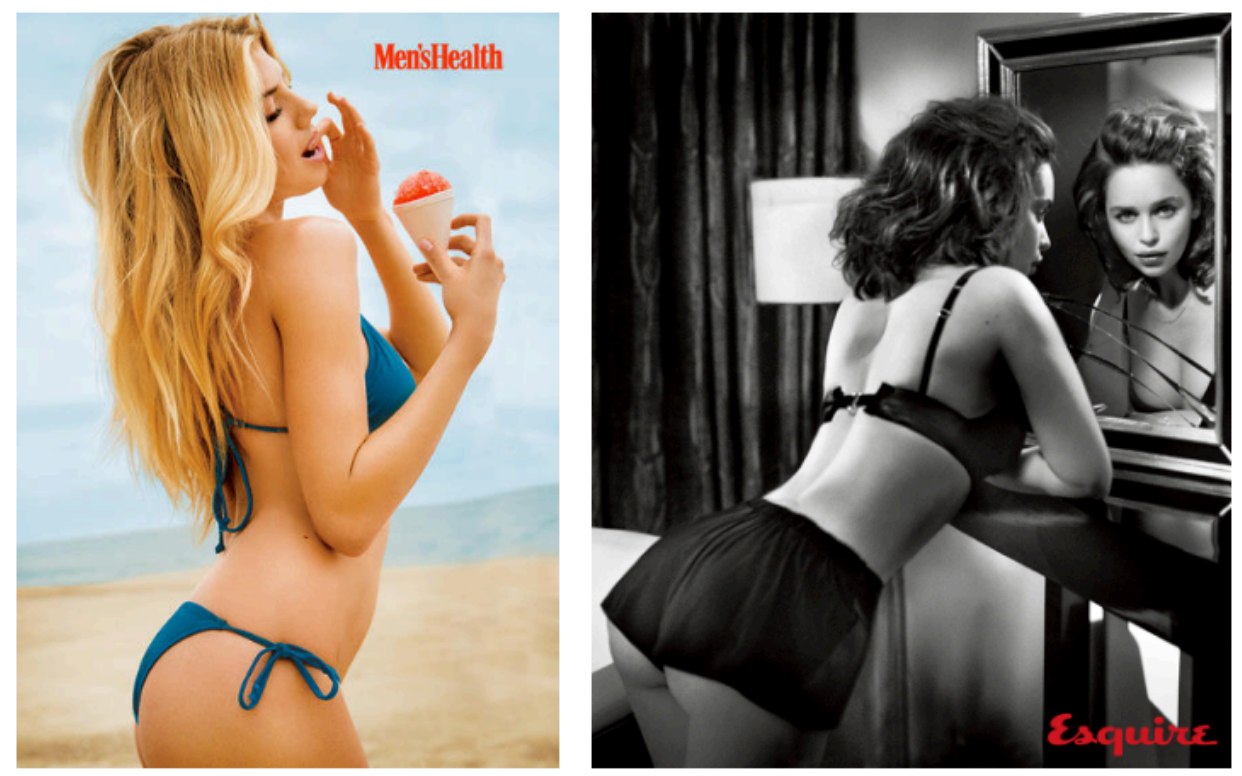

IMAGEN 18. A la izquierda, la modelo Charlotte McKinney en la revista Men's Health (núm. 162, 2015). A la derecha, la actriz Emilia Clarke en la revista Esquire (núm. 91, 2015).

Fuente: Men's Health y Esquire.

Siguiendo con lo expuesto por Juana Gallego (2013: 157), encontramos dos perfiles de revistas especializadas en estilo de vida masculino, las que continúan agarrándose al modelo de masculinidad tradicional y las que apuestan por el hombre cultivado intelectualmente y de intereses refinados. A lo largo del trabajo de campo de esta investigación, podremos ver como Men's Health se encuadraría en las primeras, mientras que Esquire lo haría en las segundas. Cabe destacar que, aunque presentándolo de distinta manera, tanto las viejas como las nuevas masculinidades siguen instrumentalizando el cuerpo de las mujeres. "La mujer desnuda o semidesnuda, en poses eróticas cercanas a lo pornográfico, junto a unos textos en muchos casos denigrantes para el sexo femenino son algunas de las características más significativas de este tipo de publicaciones" (Marín et. al, 2010: 285).

El autor Felipe Viero Kolinski, en un análisis sobre la revista Men's Health, nos dice que esta, aunque siga mostrando a mujeres, construye su narrativa en torno al cuerpo del hombre. De este modo, los cuerpos que aparecen en las portadas son los que los lectores quieren poseer, convirtiéndose los mismos en referentes de la masculinidad anhelada. Así, a partir de sus reportajes y material fotográfico, la revista determina el conjunto de atributos que el lector necesita para alzarse en una posición de poder dominante (Kolinski, 2019: 84). 
Revistas como la mencionada Men's Health o GQ presentan contenidos de escasa profundidad donde las relaciones sexuales y afectivas tienen una importante presencia cuantitativa: consultorios, testimonios de mujeres, relatos eróticos, reportajes de corte informativo... Mientras, Gentleman, Esquire e Icon ofrecen contenidos dirigidos a un perfil de hombre más maduro y abordan temas de mayor alcance y con una mayor profundidad periodística. Además, las relaciones de hombres y mujeres, así como el sexo, no ocupan un lugar tan destacado (Iriarte, 2016: 365). Por su lado, las desaparecidas FHM y $D T$ — esta última formará parte del trabajo de campo de nuestra investigación-, también pertenecían al primer grupo.

La aparición y desaparición de tantas revistas orientadas a un público masculino debe achacarse, ya no solo a la crisis económica, sino a la inutilidad de construir un modelo de hombre:

\begin{abstract}
Mientras que la prensa para mujeres ha sido un fenómeno internacional que emerge cuando se dan las condiciones técnicas adecuadas para producir publicaciones periódicas interesadas en modelar el papel de la mujer en la sociedad, no puede hablarse de un fenómeno semejante en relación a los hombres, entre otras cosas porque el papel hegemónico ejercido por los hombres no necesitaba de la creación de un instrumento ideológico que ayudara a fijar la identidad masculina (Gallego, 2013: 159).
\end{abstract}

Para Naomi Wolf, la relación entre las lectoras y sus revistas difiere en gran medida de la relación entre los hombres y las revistas dirigidas a ellos. Esto es debido a que la cultura ofrece a los varones innumerables perspectivas. Por ejemplo, como ya vimos, la cultura general adopta un punto de vista masculino frente a lo que es noticia, apareciendo un evento deportivo en primera página mientras que un cambio de legislación relativo a la infancia no ocupará una posición relevante. Las cuestiones que, se entiende, atañen a las mujeres suelen llevar algún tipo de etiqueta, tal es páginas femeninas, no ocurriendo lo mismo en el caso de los hombres. Para una mujer, una revista femenina es una de las pocas opciones que le ofrece la cultura de masas, mientras que los hombres cuentan con todo lo demás, de ahí que no se cree ese vínculo tan fuerte entre el lector y la publicación o que la fórmula de revistas de estilo de vida masculino no sea tan exitosa como lo han sido las de estilo de vida femenino (Wolf, 1991: 90).

Por su lado, Elena Varela indica que, si bien la prensa femenina fue fruto de la necesidad de crear un discurso dirigido a las mujeres - un discurso instructivo, 
modelador y que recogiera los intereses del ámbito de lo privado-, el nacimiento de las revistas de estilo de vida masculino debe achacarse a que los grupos editoriales entendieron que al igual que existía una industria rentable basada en las publicaciones femeninas, podía crearse un producto paralelo para los hombres. Es decir, empresas y publicistas quisieron sacar provecho del poder de estas revistas como prescriptoras de propuestas de consumo (Varela, 2015: 27).

Sobre este paralelismo, también hace alusión Teresa Iriarte, quien nos informa de que las revistas de estilo de vida masculino son, como las femeninas, fundamentalmente soportes publicitarios. En este sentido, encontramos que ofrecen contenidos de periodismo de servicio redactados de manera atractiva (Iriarte, 2016: 365). Aun así, como hemos señalado, los temas están relacionados con la socialización diferencial masculina y, más concretamente, con el hacer. Vemos temas vinculados con "el sexo, el riesgo, la aventura, el peligro, la osadía y el poder simbólico material o ambos, así como con aspectos estéticos que afectan a los cuerpos masculinos como el afeitado, la calvicie o la disfunción eréctil” (Iriarte, 2016: 367).

Al igual que la prensa femenina se creó atendiendo a un discurso de representación de lo privado, las revistas de estilo de vida masculino también recogen aspectos de la esfera privada, sin embargo, ambas narrativas difieren: las revistas masculinas se centran en el cuidado propio, personal o estético, y no en el cuidado de las otras personas - un ejemplo lo veríamos con las referencias a la paternidad, que existen de manera aislada—. La revolución de los nuevos hombres consiste en cuidarse sin sentirse acomplejado y sin asociar esto a comportamientos femeninos. Por otro lado, no existe un cuestionamiento de los privilegios masculinos, ni de la sociedad patriarcal, tampoco se problematiza el concepto de masculinidad y la igualdad, en general, es vista como un problema exclusivo de las mujeres, situando a los hombres en el papel de espectadores (Iriarte, 2016: 367369).

Se pretende, por tanto, que la belleza y el cuidado del cuerpo no reste virilidad al sexo masculino, por lo que se recurre a tópicos machistas tradicionales. En cuanto a las aficiones, a los hombres se les ofrece coches, motos, deportes y todo aquello relacionado con las nuevas tecnologías: ordenadores, internet, telefonía móvil y videojuegos. La cocina presente es cocina de autor y suelen aparecer, entre las páginas de estas revistas, una selección de bebidas y alimentos gourmet. En cuanto al ocio y a la cultura, sí se han suavizado las diferencias entre los sexos y sus propuestas se asocian más con estilos de 
vida que retratan indistintamente a hombres y a mujeres, ambos consumidores hedonistas y narcisistas (Marín, 2010: 286-287). 
SEGUNDA PARTE. ESTUDIO EMPÍRICO 


\section{CAPÍTULO CUARTO. ANÁLISIS DE LA MUESTRA: LAS REVISTAS ESPECIALIZADAS EN ESTILO DE VIDA FEMENINO Y MASCULINO}

La desigualdad ya no se reproduce por la coacción explícita de las leyes, ni por la aceptación de ideas sobre "la inferioridad de la mujer", sino a través de la "libre elección" de aquello a lo que nos han encaminado.

Ana de Miguel

\section{MARCO METODOLÓGICO}

El segundo gran bloque de esta investigación está dedicado al análisis del objeto de estudio, en nuestro caso, las revistas de estilo de vida y los canales de televisión especializados. Como recogimos durante la introducción, el objetivo general de esta tesis era el de establecer una posible relación entre los mensajes de ambos medios de comunicación y comprobar si se generaba diálogo alguno.

Al estar nuestra muestra compuesta por dos medios distintos, hemos dividido este bloque, también, en dos capítulos. En el presente, abordaremos la prensa, para ello, se colocarán, en primer lugar, las revistas de estilo de vida femenino y se procederá a mostrar un análisis detallado de las mismas: veremos su ficha morfológica, sus apuntes de identidad, la descripción de las portadas, se expondrá la agenda temática y, finalmente, se ofrecerá un análisis detallado de los y las protagonistas que conforman el interior de cada una de las publicaciones. Este mismo procedimiento se llevará a cabo en las revistas de estilo de vida masculino. Finalmente, y con la intención de conocer las representaciones de la masculinidad y la feminidad desplegadas a lo largo de la muestra, un último epígrafe enfrentará ambas realidades.

\subsection{Delimitación del corpus de estudio}

La delimitación del corpus de estudio se ha visto condicionada, como es lógico, por el objetivo principal de la tesis. Ya que nuestra intención era la de entender el mensaje de los nuevos canales de televisión temáticos a través de un estudio comparativo con la prensa, optamos por escoger, para ambos casos, una muestra que comprendiera idéntico 
periodo de tiempo, pues queríamos saber de qué manera se alimentaban las narrativas en un mismo contexto temporal. Debido a que cuando se planteó el estudio, en 2015, los canales llevaban en antena entre diez años — así sucedía con Nova, la más longeva - y tres años —en el caso de Discovery Max y Energy_, nos pareció oportuno recoger la muestra ese mismo 2015, pues algunas de las cadenas aún estaban despegando y resultaba interesante conocer la forma en qué empezaban a configurar su programación y cómo orientaban los contenidos según el sexo al que se dirigieran. Es por ello que, del mismo modo, los ejemplares de las revistas que se han seleccionado y que veremos a continuación pertenecen al año 2015, pues esto nos permite, como dijimos, fijar ambos medios bajo el mismo paraguas temporal.

El tamaño de la muestra se ha determinado teniendo en cuenta el criterio de saturación. Las revistas están compuestas por secciones estables y, en relación a las femeninas, ya otras investigaciones nos han demostrado que cuatro números son más que suficientes para conseguir una visión detallada de las mismas, pues estas no varían sustancialmente ni en la temática ni en la estructura (Garrido, 2007: 220). Como se quiere obtener el recorrido de un año completo, se ha optado por seleccionar las publicaciones bajo un criterio trimestral, quedando formada la muestra por los ejemplares del mes de marzo, junio, septiembre y diciembre de cada una de las cabeceras.

\begin{tabular}{|c|c|c|c|c|}
\hline \multicolumn{6}{|c|}{ REVISTAS ESPECIALIZADAS EN ESTILO DE VIDA FEMENINO } \\
\hline Nombre & Año & Periodicidad & Empresa editora & Difusión \\
\hline Woman Madame Fígaro & $1992-$ & Mensual & Grupo Z & 150.604 \\
\hline Telva & $1963-$ & Mensual & Unidad Editorial & 144.986 \\
\hline Glamour & $2002-$ & Mensual & Condé Nast & 141.133 \\
\hline
\end{tabular}

Tabla 16. Revistas especializadas en estilo de vida femenino que componen la muestra. Denominadas como revistas femeninas en la clasificación de la OJD.

FUENTE: Elaboración propia.

A la hora de seleccionar qué títulos entraban a formar parte del objeto de estudio, se tuvieron en cuenta los criterios de difusión. Es este sentido, se acudió a la información proporcionada por la OJD y se escogieron las publicaciones más leídas según datos que comprendían el periodo de julio de 2013 y junio de 2014, pues eran los últimos a los que tuvimos acceso en el momento en el que delimitamos nuestra muestra. Como ya explicamos ampliamente en el marco teórico, la clasificación de la OJD es, desde nuestro 
punto de vista errónea, y, por ello, para poder reunir el mismo tipo de publicación fue necesario acudir a dos clasificaciones paralelas: por un lado, a las denominadas revistas especializadas en estilo de vida y, por el otro, a las catalogadas como femeninas. A partir de ahí, y teniendo en cuenta los criterios de difusión, extrajimos los seis títulos que se ajustaban a la tipología para las publicaciones dirigidas a hombres y a mujeres que desarrollamos en el epígrafe 2.3. de los capítulos segundo y tercero de esta investigación (véase tabla 10 y tabla 14).

\begin{tabular}{|l|c|c|c|c|}
\hline \multicolumn{5}{|c|}{ REVISTAS ESPECIALIZADAS EN ESTILO DE VIDA MASCULINO } \\
\hline Nombre & Año & Periodicidad & Empresa editora & Difusión \\
\hline Men's Health & $2001-$ & Mensual & Hearst España & 33.781 \\
\hline Esquire & $2007-$ & Mensual & Hearst España & 28.202 \\
\hline$D T$ & $1992-2018$ & Mensual & MC Ediciones & 25.434 \\
\hline
\end{tabular}

TABla 17. Revistas especializadas en estilo de vida masculino que componen la muestra. Denominas como revistas de estilo de vida en la clasificación de la OJD.

FUENTE: Elaboración propia.

De este modo, la muestra de prensa queda compuesta por 24 ejemplares, 12 revistas femeninas y 12 revistas masculinas. Los meses recogidos, como ya se ha mencionado, han sido los de marzo, junio, septiembre y diciembre. En la siguiente tabla, encontramos la lista completa de ejemplares que, finalmente, integran nuestro corpus de estudio para esta primera parte del análisis.

\begin{tabular}{|c|c|c|c|c|}
\hline Ã̃o 2015 & MARZO & JUNIO & SEPTIEMBRE & DICIEMBRE \\
\hline WOMAN MADAME FÍGARO & Núm. 270 & Núm. 273 & Núm. 276 & Núm. 279 \\
\hline TELVA & Núm. 911 & Núm. 914 & Núm. 917 & Núm. 920 \\
\hline GLAMOUR & Núm. 149 & Núm. 152 & Núm. 155 & Núm. 158 \\
\hline MEN’S HEALTH & Núm. 157 & Núm. 160 & Núm. 162 & Núm. 165 \\
\hline ESQUIRE & Núm. 83 & Núm. 86 & Núm. 88 & Núm. 91 \\
\hline$D T$ & Núm. 216 & Núm. 219 & Núm. 221 & Núm. 224 \\
\hline
\end{tabular}

TABLA 18. Número de ejemplar de cada revista que compone la muestra.

FUENTE: Elaboración propia.

\subsection{Propuesta metodológica}

Para conocer a fondo el mensaje de las revistas, hemos acudido a la línea metodológica conocida como análisis de contenido, por tratarse de un enfoque específico empleado con 
frecuencia en todas las áreas relacionadas con los medios de comunicación (Wimmer y Dominick, 1996: 169). El análisis de contenido es una herramienta, supone una guía práctica para la acción. Existen muchas definiciones sobre el mismo, una de ellas, la de los autores Wimmer y Dominick, especifica que se trata de un método de estudio y análisis de comunicación que de forma sistemática, objetiva y cuantitativa permite medir determinadas variables (Wimmer y Dominick, 1996: 170).

Este método contempla varias fases independientes, necesarias de ir resolviendo con el fin de poder llegar, de esta manera, hasta la formulación de conclusiones y la búsqueda de explicaciones. Así, primeramente, deberíamos establecer las preguntas de investigación o hipótesis, para, después, definir el objeto de estudio y seleccionar, partiendo de dicho objeto, las unidades de análisis. Tras este proceso, se construirían las distintas categorías de contenido que fueran a emplearse y se determinaría un sistema de cuantificación para las mismas (Wimmer y Dominick, 1996: 174). Dicha serie de pasos, convierten al análisis de contenido en una metodología reproducible, gracias a la cual otra persona podría enfrentarse a la muestra y extraer idénticos resultados, lo que evidencia la fiabilidad del mismo (Krippendorf, 1990: 29).

Las hipótesis y preguntas de investigación, referidas a la primera fase del método, las desarrollamos en el epígrafe introductorio de esta investigación. Nuestra hipótesis principal sostiene que los nuevos soportes de comunicación que segmentan sus audiencias en función del género — ciertos canales de televisión temáticos_, buscan la identificación con su público mediante la elaboración de un discurso sexista y estereotipado como ya lo hizo, anteriormente, la prensa. Además de la hipótesis principal, establecimos otras secundarias que hacían más sencillo y operativo el proceso de análisis.

Tras las preguntas de investigación, convenía delimitar el corpus de estudio. Así hicimos en el anterior apartado donde establecimos que se tomaría una muestra trimestral de las seis publicaciones de estilo de vida con más difusión del año 2015. Ahora bien, para enfrentarnos a las distintas cabeceras y seleccionar las unidades de análisis cuantificables, ha sido necesario realizar, en primer lugar, un vaciado de las revistas. Dicho objetivo, se ha conseguido fragmentando el interior de cada una de las cabeceras en su unidad más pequeña. Según otros estudios, para este tipo de revistas, encontramos tres unidades mínimas: las unidades administrativas —que son las que comprenden características más técnicas como el sumario o la identificación del ejemplar-, las unidades publicitarias -formadas por los contenidos comerciales identificados 
explícitamente como tal一, y las unidades redaccionales —en las que veríamos los artículos, reportajes, fotorreportajes, editoriales o piezas informativas (Vargas, 2006: 86).

Serán estas últimas, las unidades redaccionales, las que funcionen como elemento mínimo de cuantificación. Así, una vez diseccionadas las 24 publicaciones y rescatada cada unidad mínima, procederemos a determinar las categorías de contenido que se van a emplear. Como nuestra intención es la de elaborar un análisis completo de todas las publicaciones, no se seleccionarán ciertas partes o temáticas de las revistas, sino que las unidades redaccionales de cada ejemplar serán categorizadas en su totalidad.

Dada la naturaleza de las publicaciones y sirviéndonos de referencia los análisis de investigaciones previas, las categorías que nos han servido para, primero, desmigar y, después, agrupar la muestra han sido las de belleza, decoración, gastronomía, hogar, moda, ocio y cultura, relaciones, salud, sociedad y tecnología. En los casos en los que la unidad redaccional no se ajustaba a ninguna de las categorías propuestas, se ha incluido en la temática otros. En los anexos que acompañan a esta tesis doctoral, se puede observar un mapa de todas las revistas, su posterior despiece y la adscripción de cada unidad individual a una de las etiquetas. A continuación, se procede a detallar que tipo de contenidos encontraremos en los diferentes grupos:

- Belleza: aquí se incluirán las unidades redaccionales que recogen productos tales como maquillaje, tintes para el pelo, manicuras, fragancias, cosméticos... y, también, las intervenciones clínicas de tipo estético: cirugías plásticas o tratamientos rejuvenecedores, adelgazantes, etc. Además, se añaden las piezas que, bajo el supuesto nombre de la salud o la nutrición, realmente encierran fines estéticos.

- Decoración: engloba todos contenidos relacionados con el aspecto de los espacios, mayoritariamente domésticos, bien sean fotorreportajes que nos muestran el interior de las mismos o aquellas unidades redaccionales que exponen piezas de decoración de diseño o en tendencia.

- Gastronomía: esta etiqueta incorpora las páginas en las que se ofrece algún tipo de alimento, bebida u oferta de ocio relacionada con la restauración.

- Hogar: son las unidades redaccionales que enseñan cómo llevar o dirigir un hogar, por ejemplo, los recetarios que incluyen algunas de las revistas.

- Moda: todo contenido que gire en torno a la ropa, zapatos, bolsos, joyas, relojes, corbatas o complementos en general. 
- Ocio y cultura: bajo esta etiqueta encontraremos las propuestas de viajes, estrenos de cartelera, exposiciones, literatura, conciertos...

- Relaciones: se trataría de las piezas dedicadas a cómo interactuar con otra persona en un contexto o bien sexual o afectivo-sexual u amoroso.

- Salud: esta categoría engloba aquellas unidades redaccionales que tienen que ver con el bienestar físico o mental, la nutrición y el deporte — entendidos ambos dos desde un prisma de salud y no de culto al cuerpo. Cuando así fuera, el contenido se clasificaría en la categoría de belleza-.

- Sociedad: son los reportajes que tratan asuntos de interés social como podrían ser, a modo de ejemplo, una entrevista política o una revisión de la última reforma laboral.

- Tecnología: incluye todas las piezas sobre motor, gadgets —móviles de última generación, altavoces inalámbricos, relojes inteligentes...-, apps o internet.

Finalmente, ya categorizadas las unidades redaccionales, se procederá a una medición nominal para averiguar el porcentaje de contenido que las publicaciones nos ofrecen de cada temática. Esto nos permitirá realizar un análisis comparativo entre las distintas revistas. Cabe destacar que dicho análisis no solo quedará restringido al ámbito numérico, ya que se extraerán fragmentos textuales, fotografías o se abordará la presencia de personajes. Así, analizaremos qué sexo protagoniza las unidades redaccionales, por qué lo hace o cómo aparece retratado. Todos estos aportes apoyarán la primera línea de análisis y nos aportarán una visión completa del interior de cada una de las cabeceras.

\section{REVISTAS ESPECIALIZADAS EN ESTILO DE VIDA FEMENINO}

Durante este segundo epígrafe, llevaremos a cabo una exposición detallada de las revistas de estilo de vida femenino. Así, de todas ellas, se especificará su ficha morfológica, se proporcionarán los apuntes de identidad, la descripción de las portadas y se expondrá la agenda temática. Por último, se ofrecerá, también, un análisis de los y las protagonistas que conforman el interior de cada una de las publicaciones, por lo qué, tal y como explicamos unas líneas más arriba, conoceremos la función de cada personaje, cuál es el retrato que vemos, las causas a las que se debe su aparición, etc. 


\subsection{Woman Madame Fígaro}

\section{WOMMring}

IMAGEN 19. Logotipo de la revista Woman Madame Figaro.

FuENTE: Woman Madame Figaro.

FICHA MORFOLÓGICA DE LA REVISTA WOMAN MADAME FÍGARO

\begin{tabular}{|c|c|}
\hline NOMBRE & Woman Madame Figaro \\
\hline DESCRIPCIÓN & El lujo de ser mujer \\
\hline DIRECCIÓN ONLINE & www.woman.es \\
\hline ORIGEN & España \\
\hline GRUPO EDITORIAL & $\begin{array}{l}\text { Zeta Gestión de Medios, S.A. (bajo el acuerdo exclusivo con Société } \\
\text { du Figaro) }\end{array}$ \\
\hline LUGAR DE EDICIÓN & Barcelona \\
\hline DIRECTORA & Mayka Sánchez Pastor \\
\hline \multirow[t]{2}{*}{ PRIMER NÚMERO } & 1992 (Woman) \\
\hline & $\begin{array}{l}2011 \text { (Woman Madame Figaro) } \\
\text { Mensual }\end{array}$ \\
\hline DIFUSIÓN & 150.604 ejemplares (OJD: julio 2013/ junio 2014) ${ }^{62}$ \\
\hline PRECIO & $\begin{array}{l}3,95 € \text { edición normal } \\
1,90 € \text { edición de bolsillo }\end{array}$ \\
\hline PÁGINAS $^{63}$ & $\begin{array}{l}\text { Máximo: } 290 \text { (marzo) } \\
\text { Mínimo: } 218 \text { (junio y diciembre) }\end{array}$ \\
\hline FORMATO & $\begin{array}{l}225 \times 297 \mathrm{~mm} \text { edición normal } \\
170 \times 223 \mathrm{~mm} \text { edición de bolsillo }\end{array}$ \\
\hline EDICIONES INTERNACIONALES & $\begin{array}{l}\text { Arabia Saudí, Baréin, China, Chipre, Emiratos Árabes, Francia, } \\
\text { Grecia, Japón, Kuwait, Omán, Portugal, Qatar y Tailandia. }\end{array}$ \\
\hline CATEGORÍA TEMÁTICA & Revista femenina (OJD) \\
\hline
\end{tabular}

TABLA 19. Ficha morfológica de la revista Woman Madame Figaro.

FUENTE: Elaboración propia.

\footnotetext{
${ }^{62}$ Como apuntamos, la OJD dejó de mostrar, a menos públicamente, los datos de difusión, por tanto estas son las últimas cifras con la que contamos.

${ }^{63}$ El número de páginas está calculado según la cata individual, es decir, según los números de marzo, junio, septiembre y diciembre de 2015. Así será para el resto de publicaciones.
} 
Woman Madame Figaro $^{64}$ es la revista femenina con más difusión en nuestro país. De procedencia española, originariamente era conocida como Woman, sin embargo, en 2011 se fusionó con Madame Figaro, el suplemento de moda y estilo de vida del diario francés Le Figaro. ${ }^{65}$ El lujo de ser mujer es el eslogan que aparece en el lomo de la revista. Según la descripción que ofrece su grupo editorial, el Grupo Zeta, va dirigida "a la mujer actual, urbana y activa, interesada por las últimas tendencias en moda y belleza”. Sus lectoras comprenden edades de entre 25 y 44 años. ${ }^{66}$

Cuando Woman apareció en el mercado, en septiembre de 1992, las grandes cabeceras internacionales llegaban también a España. Esto significó que debía competir con una mayor oferta de publicaciones. La estrategia que adoptó — top models internacionales, importancia del diseño gráfico, director de arte, el nombre de mujer en inglés... - le permitió hacerse un hueco en el mercado hasta consolidarse como una de las publicaciones de referencia dentro de la prensa femenina (Ganzabal, 2006b: s.p.). Nació de la mano del Grupo Z y su primera directora fue Joana Bonet. A fecha de noviembre de 2019, pertenece al mismo grupo editorial y su directora es Mayka Sánchez Pastor.

Junto a la publicación mensual, Woman ofrece suplementos como Woman Fitness o Woman Shopping. También, realiza colaboraciones puntuales, así vimos en septiembre de 2016 que Woman y bodas.net se aliaron, ofreciendo una segunda revista dirigida a novias que planearan casarse. ${ }^{67}$ A parte de la versión en papel, Woman cuenta con la versión digital (www.woman.es) donde ofrece contenido dividido en las secciones de Moda, Belleza, lifestyle, Celebrities, Blogs, Horóscopo y Woman TV. No se trata de una copia de la publicación que encontramos en los quioscos, sino que ofrece contenido propio que va actualizándose con asiduidad. Como era de esperar, esta versión incluye contenido audiovisual, mucha información gráfica y es una ventana perfecta para promocionar la revista en papel.

\footnotetext{
${ }^{64}$ En adelante nos referiremos a la revista como Woman.

${ }^{65}$ Véase información publicada en 2011: "La revista Woman se alía con Madame Fígaro". Recuperado el 20 de septiembre de 2016 de http://www.periodistadigital.com/periodismo/prensa

${ }^{66}$ Véase información publicada en 2016: "Grupo Zeta. Woman". Recuperado el 20 de septiembre de 2016 de http://www.zetagestion.com/pdfs/Revistas.pdf?2016-1

${ }^{67}$ Véase información publicada en 2016: "El portal online bodas.net saca un especial en papel junto a la revista de moda Woman Madame Fígaro". Recuperado el 19 de noviembre de 2017 de http://www.europapress.es/chance/moda
} 
En el año 2015 y en el año 2017 se celebraron la primera y segunda edición de los Premios Woman, los cuales reconocen los logros sociales de sus protagonistas. Así, en la segunda edición (2017) se galardonó a la Fundación Aladina, que trabaja para combatir el cáncer infantil, también, a la ingeniera Rebeca Minguela, por abrirse paso como programadora en un campo fuertemente masculinizado y, finalmente, a Candice Huffine, modelo de tallas grandes, quien lucha por una apertura en la industria de la moda que llegue a contemplar otros tipos de cuerpos. ${ }^{68}$

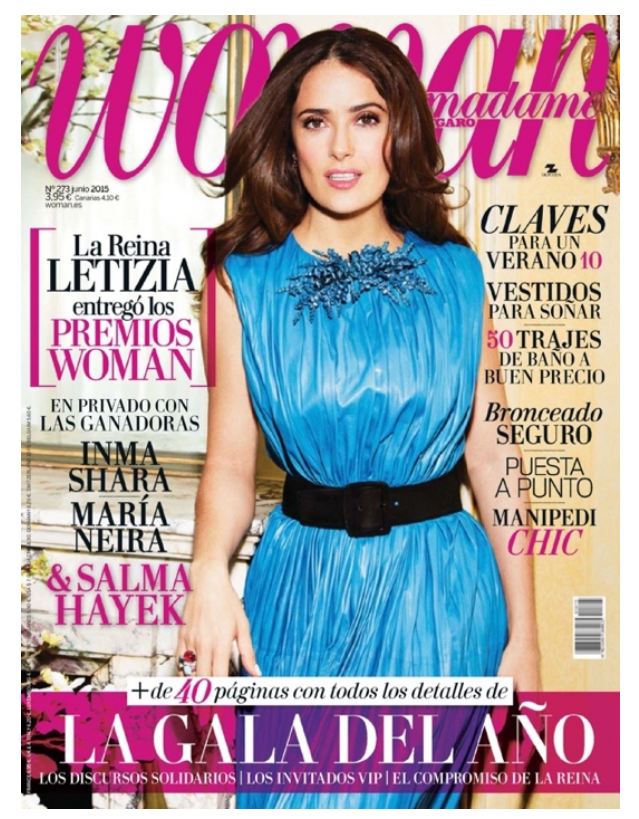

IMAGEN 20. Salma Hayek en la portada de la revista Woman de junio de 2015.

FUENTE: Woman.

Si acudimos a la propia revista, vemos, en primer lugar, que la portada de Woman cuenta con tres términos compositivos, esto son: los titulares, una imagen figurativa y la cabecera. El primer término compositivo lo ocupan los titulares que se distribuyen en torno a la imagen figurativa. El principal, de mayor tamaño, avanza contenido relacionado con el mundo de la moda: "244 páginas de moda" (Woman, núm. 276, 2015) o "Nuestras estilistas eligen los mejores looks de noche” (Woman, núm. 279, 2015). Los secundarios, por su lado, adelantan diversas temáticas como ocio, belleza o consumo: "12 nuevos restaurantes para dejarse ver" (Woman, núm. 270, 2015), “Claves para un verano 10”

68 Véase información publicada en 2017: "La revista Woman premia a Fundación Aladina, Rebeca Minguela y Candice Huffine”. Recuperado el 19 de noviembre de 2017 de http://www.woman.es/premioswoman/premiados/woman-premia-fundacion-aladina-rebeca-minguela-candice-huffine 
(Woman, núm. 273, 2015) o "Los 360 regalos con + likes de navidad” (Woman, núm. 279, 2015). Los colores principales de la fuente son el blanco y el negro, aunque se juega con un tercer color que servirá de llamada de atención como sucede, por ejemplo, en la imagen 20, que se ha utilizado el rosa ("Premios Woman" "Salma Hayek" Woman, núm. $273,2015)$ o en el número de diciembre, donde se emplea el rojo (“+ 35 planes” Woman, núm. 279, 2015). La tipografía de los titulares es mayúscula, salvo excepciones, con cuerpo y con serifa.

El segundo término compositivo lo protagoniza la fotografía de un personaje femenino. En marzo de 2015 lo hace Lindsay Ellingson, modelo, en junio la actriz Salma Hayek, en septiembre la también modelo Heather Marks, y, en diciembre, Clara Lago, actriz, y Dani Rovira, actor, posan en una portada conjunta. Todas nuestras protagonistas se ajustan a los cánones de belleza normativos: juventud, belleza y delgadez. La única vía de escape ante este conjunto de representaciones homogéneas sería Salma Hayek, sin embargo, su aspecto juvenil la convierte en una copia más del resto de representaciones (véase imagen 20).

Las cuatro protagonistas llevan vestidos, melenas sueltas y largas. El pelo moreno en dos casos y rubio en los otros dos. La expresión del rostro es similar: mirada a cámara y boca entreabierta, salvo la modelo de septiembre que la mantiene cerrada. Se hace un uso natural del maquillaje, tonos tierra en los ojos y labios no excesivamente marcados. El resultado son mujeres atractivas de apariencia natural. Para las cuatro portadas se ha utilizado un plano americano, el cual nos permite visualizar la complexión de los cuerpos. Las fotografías son luminosas, apenas encontramos zonas de sombras en las modelos, lo que crea un conjunto alegre. Por otro lado, existen tres fondos monocromáticos, dos rojos y uno blanco, y un tercero que simula una estancia interior.

\begin{tabular}{cccc} 
Marzo & JUNIO & SEPTIEMBRE & DiCIEMBRE \\
\hline Inicio & Inicio & Inicio & Inicio \\
\hline Inspírate & Inspírate & Inspírate & Inspírate \\
\hline- & Premios Woman & - & - \\
\hline Lo más W & Lo más W & Lo más W & Lo más W \\
\hline (Especial) Moda & Moda & (Especial) Moda & Moda \\
\hline- & Shopping & - & Shopping \\
\hline Belleza & Belleza & Belleza & Belleza \\
\hline Tendencias & Tendencias & Tendencias & Tendencias
\end{tabular}

TABla 20. Estructura de la revista Woman en 2015 (ejemplares de marzo, junio, septiembre y diciembre). FUENTE: Elaboración propia. 
En cuanto a su agenda temática, desplegada en la tabla 20, vemos que la revista Woman se encuentra estructurada en distintas secciones fijas con alteraciones o bien estacionales, comprobamos que los meses de junio y diciembre incluyen la sección exclusiva Shopping, o bien puntuales, como es el caso del mes de junio, donde se dedican varias páginas a los I Premios Woman.

Las primeras páginas, a las que hemos denominado Inicio, incluyen la editorial, los datos de la revista y el sumario, además de un par de artículos donde las actrices Kira Miró e Irene Montalá asesoran sobre temas como ocio, gastronomía o moda. El editorial lo firma la directora de Woman Mayka Sánchez Pastor y en ella realiza un breve adelanto de los contenidos de la revista. En cuanto a la sección de Kira Miró e Irene Montalá, se trata de escaparates de una página sin apenas texto, inundados de fotografías que proponen distintos destinos, música, restauración o cosméticos: "Planes diferentes by Kira Miró. La actriz y bloguera de WOMAN MF te propone nuevas y originales opciones para tus ratos libres" (Woman, núm. 279, 2015).

Inspírate es la sección que abre la revista. Esta abarca, principalmente, moda (48\%) belleza (31\%), aunque encontramos también pinceladas de tecnología, ocio y cultura, gastronomía y decoración. Lo componen una media de 12 unidades redaccionales y el $85 \%$ de las mismas no supera la página de extensión. Son artículos breves donde el peso recae en lo visual y el texto es escaso y cuyo propósito es servir de soporte publicitario a las distintas marcas.

Al tratarse de una sección donde la moda ocupa casi la mitad del espacio, vemos que las páginas están plagadas de diseñadoras de moda, en este caso, Marina Rinaldi, Ángela Esteban Librero, Ana Cardona, France Lamy Herbeau, Langley Fox Hemingway, Anna Molinari e Irene Magro; diseñadores tales como Raf Simons, Gianpalo Tarabini, Domenico Dolce, Stefano Gabbana, Tomas Maier, Alessandro Michele y John Galliano. Del mismo modo, encontramos diseñadoras de joyas: Victoire de Castellane, JJ Martín, Marina Casal, Sara Lasry, Ana Corbalán, Laura Somoza, y Almudena Gil y a los, también diseñadores de joyas, Andrés Gallardo y Luis Yanes. Aparecen las modelos Miranda Kerr y Jeanne Damas. Además, las actrices Patricia Arquette ("Una historia de belleza real" Woman, núm. 276, 2015) y Jane Levy (“Girl next door” Woman, núm. 273, 2015), protagonizan sendas unidades redaccionales de moda.

En belleza encontramos cosméticos del tipo de cremas faciales y corporales (“Resetear la piel” Woman, núm. 276, 2015), perfumes (“Azul oceánico para sirenas” 
Woman, núm. 273, 2015) o distintos tipos de maquillaje como pueden ser polvos bronceadores ("El primer bronzing” Woman, núm. 273, 2015) o esmaltes (“Arte alternativo" Woman, núm. 276, 2015). En cuanto a las unidades redaccionales protagonizadas, vemos la entrevista a la modelo Jasmine Tookes y al modelo Tobias Sorensen ("Lo eterno es ahora" Woman, núm. 276, 2015) quienes son imagen de una campaña de perfume. Las actrices María Valverde ("La sonrisa más bonita" Woman, núm. 273, 2015), Clara Lago ("Clara, al natural” Woman, núm. 279, 2015) y Astrid Bergès-Frisbey (“¿Quién es esta chica?” Woman, núm. 279, 2015), también protagonizan unidades redaccionales dedicadas a la belleza.

Para tecnología encontramos la etiqueta fija Tecno. Se trata de una página en la que vemos fotografías de gadgets, junto con una breve descripción y el precio. Son móviles, cámaras, ordenadores, auriculares... todos objetos de alta gama. En ocio y cultura hay cine, como sucede en el artículo dedicado a la actriz Lily James ("Cuento de hadas" Woman, núm. 276, 2015) o propuestas de exposiciones ("Una despedida de lujo" Woman, núm. 279, 2015; "En junio, rodéate de belleza” Woman, núm. 273, 2015). En “¿Y tú de qué tribu eres?” (Woman, núm. 279, 2015) encontramos, también, objetos de decoración y gastronomía.

Tras Inspírate, llega Lo más $W$, sección dedicada al ocio y la cultura, tal y como atestigua el 78\% de su contenido, que nos informa sobre novedades en cine, música, literatura, arte o exposiciones. Encontramos una media de 11 unidades redaccionales, de extensión variable — algunas están compuestas por una o dos páginas, aunque también hay reportajes de hasta 11 páginas-. Lo más $W$ es el apartado que cuenta con una mayor presencia de unidades redaccionales protagonizadas (el 58\% de las mismos lo son), principalmente, en forma de entrevista. En total aparecen 61 personas, 20 hombres y 41 mujeres.

Los retratos abarcan a personajes del mundo del cine como son actrices (Michelle Williams, Mia Wasikowska, Blanca Suárez, María Valverde, Marion Cotillard, Leticia Dolera, Emma Stone, Clara Lago y Daisy Ridley), actores (Yon González, Quim Gutiérrez y Dani Rovira) o directores de cine (Fernando León de Aranoa, Alejandro Amenábar, Julio Medém y Álex de la Iglesia). Del mundo de la televisión vemos a la presentadora Eva González en un reportaje que mezcla belleza, vida personal y profesional (“Eva González. Buena materia prima” Woman, núm. 276, 2015). 
En cuanto a la música, encontramos cantantes (Aldo Comas, Mónica Vázquez, Florence Welch y Ana López Rodríguez) y, en el reportaje de 10 páginas de extensión "DJS de moda" (Woman, núm. 64, 2015), nos acercamos hasta 9 DJs, 6 mujeres y 4 hombres. En literatura, vemos a la escritora Elvira Lindo (Elvira Lindo se desnuda, Woman, núm. 279, 2015) y en “Grandes autoras” (Woman, núm. 273, 2015) aparece una pequeña fotografía de 10 autoras junto con una recomendación de sus libros. "Universo ilustrado" (Woman, núm. 276, 2015) trata sobre 4 ilustradoras.

El reportaje de 11 páginas de extensión "Lo español, de moda" (Woman, núm. 270, 2015) mezcla moda, belleza y ocio y cultura. Así, vemos a la diseñadora de moda Ana Locking y a los diseñadores Juanjo Oliva, Arnaud Maillard, Álvaro Castejón, Modesto Lomba, Roberto Torretta, Moisés Nieto, Ángel Schlesser y Juan Duyos que visten a la actriz Barbara Lennie y a la modelo Marta Español. Ambas posan con distintos looks de ropa y maquillaje. Finalmente, las modelos Lindsay Ellingson (“Angel girl” Woman, núm. 270, 2015) y Anne-Marie van Dijk (“Modelo a seguir” Woman, núm. 273, 2015) protagonizan sendos reportajes que tratan sobre su carrera profesional y aspectos de su vida personal. "Todopoderoso Koons” informa de la última exposición del escultor Jeff Koons y, en el número de junio, conocemos a Paula Carrera, empresaria del mundo de la comunicación ("Paula Carrera conquista” Woman, núm. 273, 2015).

La tercera de las secciones es Moda, en los números de junio y diciembre, y (Especial) Moda, en los números de marzo y septiembre. Moda propone las últimas tendencias en el mundo de las exclusivas marcas textiles. El 77\% de los contenidos se dedican a ello y lo hacen, principalmente, en forma de fotorreportajes donde muestran ideas de conjuntos completos. (Especial) Moda ofrece, también, reportajes sobre el trabajo de diseñadores o modelos. La belleza está presente en esta sección (14\%) puesto que, en ocasiones, el maquillaje supone el broche final para algunos de los looks.

Vemos unidades redaccionales extensas, de hasta 10 páginas. En el número de junio encontramos 2 unidades redaccionales y 3 en el de diciembre, sin embargo, los especiales de marzo y septiembre cuentan con 13 y 15 respectivamente. Los fotorreportajes los protagonizan modelos como Heather Marks ("Esto es moda" Woman, núm. 276, 2015), Lindsay Ellington (“Electic girl” Woman, núm. 270, 2015) o Vanesa Lorenzo ("VL" Woman, núm. 279, 2015). Por su parte, el diseñador de moda Tommy Hilfiger responde a una entrevista en "Mente tecnológica" (Woman, núm. 276, 2015). Mientras, en "No sin mi estilista", (Woman, núm. 276, 2015) conocemos a siete estilistas 
que visten a las grandes estrellas de Hollywood y en "Red carpet vs. Street style" los looks de 12 actrices son puestos a examen. Finalmente, el equipo de moda de Woman protagoniza un reportaje titulado "Vestidos para marcar moda" (Woman, núm. 275, 2015) donde comparten sus tendencias, colores y accesorios favoritos del momento.

Shopping complementa, además, las secciones Moda en los números de junio y diciembre, las cuales, como acabamos de ver, no eran muy extensas. Esta sección cuenta con 6 y 9 unidades redaccionales de entre una y 8 páginas. La moda vuelve a ser la gran protagonista (72\%). Las páginas se llenan con fotos de diferentes prendas y accesorios, el texto es escaso, tan solo un titular y dos breves líneas que informan sobre la marca y el precio del ítem. Propone distintos conjuntos de ropa siempre tomando como referencia las grandes marcas de lujo: "Tienes una fiesta. Carolina Herrera te da las claves para no fallar" (Woman, núm. 279, 2015). En Shopping, vemos dos unidades redaccionales protagonizadas: "Nueva perla made in Spain” (Woman, núm. 279, 2015), en la que leemos que la modelo Laura Sánchez es la imagen de una conocida marca de joyas y "Una forma de reinventarse" (Woman, núm. 279, 2015), donde la actriz Macarena García y el actor Pablo Rivero posan en un reportaje que mezcla moda y cine.

Tanto en la sección Moda como en Shopping, Emma Riverola, escritora, firma una columna en la que toca diversos temas: en "Al otro lado" (Woman, núm. 273, 2015) divaga sobre la posibilidad de evadirse de las situaciones incómodas, "Sin cuentos tristes" (Woman, núm. 279, 2015) trata sobre narraciones navideñas, en "Libertad de movimientos" Woman, núm. 276, 2015) presenta a la bailarina Isadora Duncan y, finalmente, "Shirtwaist" (Woman, núm. 270, 2015) es una columna a propósito del 8 de marzo, Día Internacional de las Mujeres, donde repasa la historia de un tipo de camisa, shirtwaist, que sustituyó a los corpiños.

Tras ofrecernos el apartado de moda, Woman incluye Belleza. Esta sección la componen una media de 8 unidades redaccionales por revista que ocupan entre una y 8 páginas. El 89\% de sus contenidos versan sobre maquillaje y cosméticos. Encontramos distintas formas de presentar los productos, bien sea insertándolos como simples fotografías con su correspondiente marca, precio y una breve explicación (“¿Te atreves? Decídete" Woman, núm. 276, 2015), o dentro de reportajes que incluyen mayor carga textual (“Escuela de sol” Woman, núm. 273, 2015).

Belleza propone distintos tipos de maquillajes, ("10 looks de temporada" Woman, núm. 270, 2015), cremas, (“Aliados para lucir piernas”, Woman, núm. 273, 2015), 
peinados ("12 ideas para cambiar" Woman, núm. 270, 2015), tratamientos en centros especializados (“Ácido hialurónico, la clave de la juventud” Woman, núm. 270, 2015) e, incluso, encontramos un espacio dedicado a la cirugía estética ("Glúteos a la carta" Woman, núm. 270, 2015).

Las actrices Leighton Meester ("Más que una cara bonita” Woman, núm. 270, 2015) y Katie Holmes (“Se siente bien en su piel” Woman, núm. 270, 2015), embajadoras de dos marcas de belleza, protagonizan sendos reportajes sobre cosméticos. Lo mismo ocurre con los actores Johnny Deep, Liam Hemsworth y Theo James ("Nuevos perfumes, vuelve el hombre" Woman, núm. 279, 2015), que se han convertido en imagen de tres fragancias. El maquillador Massimiliano Della Maggesa contesta una breve entrevista dentro del espacio "Mediterránea, femenina y sensual” (Woman, núm. 273, 2015) y en "No sólo genética" (Woman, núm. 276, 2015), una hija, Ana Rodríguez, y una madre, Amelia Bono, hablan sobre su rutina de belleza, también interviene la esteticista Maribel Yébenes contando su experiencia personal y el dermatólogo Ángel Durántez asesora a las lectoras.

Por último, la revista cierra con el apartado Tendencias. Las temáticas son variadas y se reparten en torno a 10 unidades redaccionales por publicación. La moda vuelve a ocupar un mayor número de espacio (35\%), seguida por el ocio y la cultura (25\%), gastronomía (12\%) y decoración ( $8 \%$ ). La extensión de las unidades redaccionales oscila entre una y 11 páginas. Esta sección incluye información de servicio, como es el directorio donde señala los teléfonos y webs de las distintas tiendas o el horóscopo, que ofrece las predicciones, además de añadir una prenda o accesorio, con su correspondiente marca y precio, por cada signo del zodiaco. La moda también la vemos dentro de la etiqueta Ideas, presente en todos los ejemplares, o en Flechazo, unidad redaccional que cierra la revista y que está compuesta por una gran foto de una joya con un pequeño texto referencial.

El ocio y la cultura aparecen, esencialmente, en forma de destinos. En cada ejemplar se nos ofrece un viaje como Granada ("Hay mucha Granada” Woman, núm. 270, 2015), las Islas Baleares (“¡Aún queda verano!” Woman, núm. 276, 2015) o Italia ("Viajeras con estilo" Woman, núm. 273, 2015), entre otros. Del mundo del cine encontramos la entrevista a la actriz Juana Acosta que protagoniza, junto con el chef Ramón Freixa, un espacio donde se mezcla ocio, cultura y gastronomía ("Sobremesa de fiesta con Juana Acosta" Woman, núm. 279, 2015). Dentro de esta última categoría, 
también encontramos la entrevista a Jordi Roca, Joan Roca y Josep Roca ("El mundo es de los Roca" Woman, núm. 279, 2015), además de bebidas ("El mejor brindis” Woman, núm. 279, 2015; "Las copas son para el verano" Woman, núm. 273, 2015) y un reportaje sobre distintos mercados (“Mercados VIP” Woman, núm. 270, 2015).

Finalmente, la decoración se mezcla con la moda, así, las diseñadoras Maya Hasen (“Maya Hansen” Woman, núm. 270, 2015), Belén Barbero ("Beba's closet” Woman, núm. 270, 2015), los diseñadores Fernando y Antonio García ("Moda de cine” Woman, núm. 273, 2015) y el diseñador de joyas Anton Heunis (“Anton Heunis” Woman, núm. 276, 2015) enseñan algunas estancias de sus casas o sus ateliers. Para concluir, en el número de junio vemos un reportaje a la memoria de la fotoperiodista Queca Campillo (“En la memoria, Woman, núm. 273, 2015), y la deportista paralímpica Teresa Perales protagoniza una entrevista ("Rumbo al éxito" Woman, núm. 276, 2015).

En el número de junio encontramos un especial llamado Premios Woman. Son 5 unidades redaccionales, cuatro de ellas con presencia de protagonistas y, la quinta, de 16 páginas de extensión, consta de una sucesión de fotografías que dejan constancia de las invitadas e invitados que acudieron a la gala de los Premios Woman. Así, el espacio lo abre un reportaje dedicado a la Reina de España Letizia Ortiz, encargada de entregar los galardones. El texto repasa las distintas causas en las que la Reina participa activamente como son "la infancia, el hambre en el mundo, la nutrición y las enfermedades minoritarias" ("Reina solidaria” Woman, núm. 273, 2015).

Woman premió a tres mujeres: a la actriz Salma Hayek, a la directora de orquesta Inma Shara y a la directiva de la Organización Mundial de la salud María Neira. Cada una de ellas protagoniza una entrevista de 5 y 6 páginas de extensión. Iman Shara en "La música es un grito de compromiso y una obsesión" (Woman, núm. 273, 2015) responde a preguntas sobre su vida profesional y alguna pincelada personal y lo mismo sucede con Salma Hayek (“Salma Hayek” Woman, núm. 273. 2015). En "Batalla por la salud” (Woman, núm. 273, 2015), se repasa la carrera de la directiva María Neira. Tanto a Iman Shara como a María Neira se les pregunta por su situación como mujer dentro de su carrera profesional y a Salma Hayek sobre su influencia como referente femenino.

Una vez descrita su agenda temática, querríamos, tal y como explicamos al inicio del epígrafe, resaltar la función y el papel de las personas que han dio apareciendo a lo largo de los cuatro ejemplares. En este sentido, son muchas las personalidades famosas que nos muestra la revista Woman. Así, en el $40 \%$ de las unidades redaccionales, 
encontramos que una persona protagoniza, asesora o firma el espacio. Más concretamente, un 33\% de las unidades redaccionales están protagonizadas, un 4\% las firma alguien y en un 3\% un experto o experta asesora sobre algún tema. En total, contamos con la presencia de hasta 153 personas que se dividen entre las tres funciones. De las 153 personas, un $96 \%$ desempeñan la función de protagonistas, un 2\% escriben y el $2 \%$ restante asesoran.

\begin{tabular}{lccc} 
& Protagoniza & Escribe & Asesora \\
\hline MuJERES & 103 & 3 & 2 \\
\hline HOMBRES & 44 & - & 1 \\
Tabla 21. Función de las personas en la revista & Woman (muestra año 2015). \\
& Fuente: Elaboración propia.
\end{tabular}

Kirá Miró e Irene Montalá, ambas actrices y ambas con sección permanente, asesoran en temas de belleza, ocio y cultura, decoración, salud, moda... Mientras, el dermatólogo Ángel Durántez aparece en "No sólo genética" (Woman, núm. 276, 2015) dando consejos sobre cómo sentirse más joven. Por su lado, la función de escribir la desempeñan la directora de Woman, Mayka Sánchez Pastor, que abre todos los números ofreciendo un avance del contenido interior de la revista, la escritora Emma Riverola, quien cuenta con columna fija donde trata algún tema relacionado con la actualidad y Letizia Ortiz (Reina de España) que en el número de junio firma un discurso a propósito de los Premios Woman llamado "Muchas cosas por cambiar" (Woman, núm. 273, 2015) en el que aborda la difícil situación de las mujeres en el mundo.

La función que más gente reúne es la de protagonista, donde contamos hasta 147 personas. De ellas, un 70\% son mujeres mientras que un 30\% son hombres. La profesión más repetida para las mujeres es la de actriz (30) y para los hombres la de diseñador de moda o joyas (21). El resto de profesiones de las mujeres son: diseñadora de moda o joyas (17), escritora (11), ámbito musical (10), modelo (9), ilustradora (6), empresaria o directiva (4) y otras (6). Los hombres, después de diseñadores, son actores (7), directores de cine (4), chefs (4), pertenecen al ámbito musical (4) o a otras profesiones (4).

Todas estas personas son relevantes debido a que ejercen una profesión con notoriedad pública, sin embargo, el motivo al que se debe su protagonismo no siempre es el profesional. Si bien es cierto que para los hombres es así en un $98 \%$ de las ocasiones 
- la excepción es el diseñador de joyas Anton Heunis quien, dentro de Tendencias, en la etiqueta Deco, nos enseña su casa (“Anton Heunis” Woman, núm. 276, 2015) —, para las mujeres lo es en un $81 \%$ del espacio.

En las protagonistas encontramos que se repite, principalmente, una tendencia y es la de utilizar a actrices en el papel de modelos tanto de ropa como de belleza (15\%). ${ }^{69}$ Esto sucede, entre otras, con la actriz Jane Levy en "Girl next door" donde se analizan sus estilismos (Woman, núm. 273, 2015) o con la también actriz Barbara Lennie en "Lo español, de moda" (Woman, núm. 270, 2015) que hace de modelo para productos de maquillaje. En el 4\% restante de las ocasiones se abordan rutinas de belleza (María Valverde, actriz, en "La sonrisa más bonita" Woman, núm. 273, 2015) o asuntos personales (tal sería el caso de Juana Acosta en "Sobremesa de fiesta con Juana Acosta" Woman, núm. 279, 2015, reportaje dedicado a la vida familiar de la protagonista).

Así, ya sea sirviéndose de una personalidad relevante ( $41 \%$ de los casos), o prescindiendo de cualquier protagonismo humano (59\% de los casos), Woman ahonda, principalmente, en tres temáticas: la moda (37\%), el ocio y la cultura $(25 \%)$ y la belleza (24\%). Aunque en menor medida, su agenda llega también hasta otros aspectos como son la decoración (3\%), la gastronomía (3\%), la tecnología (3\%) y la sociedad (2\%).

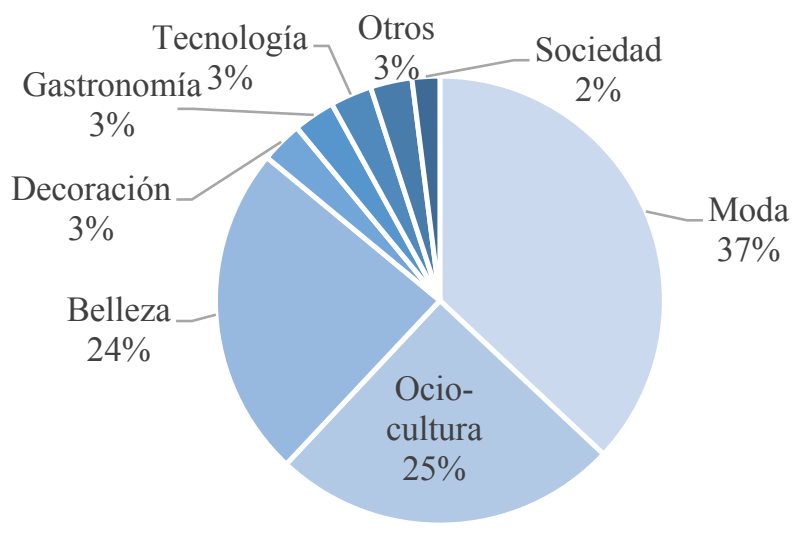

GráfiCo 11. Contenidos de la revista Woman en marzo, junio, septiembre y diciembre de 2015.

FUENTE: Elaboración propia.

\footnotetext{
69 En ocasiones, las actrices son embajadoras o imagen de algunas de las marcas de moda y belleza, entonces, se les pregunta por su rutina de cuidados personales o protagonizan fotorreportajes de moda. En estos casos, la aparición se ha contabilizado como profesional. El mismo procedimiento se ha seguido en el caso de los hombres cuando se convierten en imagen de marca (suele suceder con colonias, cosméticos o coches).
} 


\subsection{Telva}

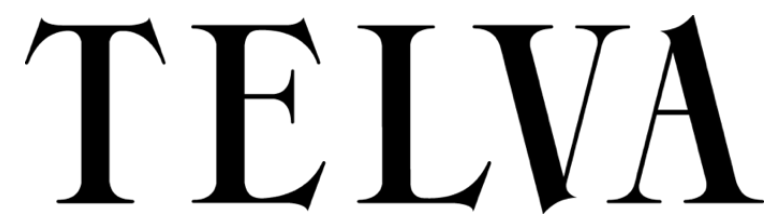

IMAGEN 21. Logotipo de la revista Telva.

FUENTE: Telva.

FICHA MORFOLÓGICA DE LA REVISTA TELVA

\begin{tabular}{|c|c|}
\hline NOMBRE & Telva \\
\hline SITIO WEB & www.telva.com \\
\hline ORIGEN & España \\
\hline GRUPO EDITORIAL & Unidad Editorial Revistas, S.L.U. \\
\hline LUGAR DE EDICIÓN & Madrid \\
\hline DIRECTORA & Olga Ruiz \\
\hline PRIMER NÚMERO & 1963 \\
\hline PERIODICIDAD & Mensual \\
\hline DIFUSIÓN & 144.986 (OJD: julio 2013/ junio 2013) \\
\hline \multirow[t]{2}{*}{ Precio } & $3,95 €$ edición normal \\
\hline & $1,90 €$ edición de bolsillo \\
\hline \multirow[t]{2}{*}{ PÁginas } & Máximo: 306 (diciembre) \\
\hline & Mínimo: 258 (junio) \\
\hline \multirow[t]{2}{*}{ FORMATO } & $224 \times 298$ mm edición normal \\
\hline & $165 \times 225$ mm edición de bolsillo \\
\hline DISTRIBUCIÓN & $\begin{array}{l}\text { Alemania, Austria, Bélgica, Francia, Grecia, Italia, Reino Unido, } \\
\text { Irlanda, Luxemburgo, Malta, México, Portugal, Suiza. }\end{array}$ \\
\hline CATEGORÍA TEMÁTICA & Revista femenina (OJD) \\
\hline
\end{tabular}

TABLA 22. Ficha morfológica de la revista Telva.

FUENTE: elaboración propia.

Telva, con más de cinco décadas a sus espaldas, es una revista de estilo de vida dirigida a mujeres. De creación española "se ha convertido en el referente máximo de las nuevas tendencias en moda, belleza y estilo de vida"70 asegura Olga Ruiz, directora de la misma. La publicación abarca "belleza, moda, estilo de vida, cocina, niños, joyas y accesorios". Sus lectoras comprenden entre los 25 y los 64 años. ${ }^{71}$

\footnotetext{
${ }^{70}$ Véase información publicada en 2016: "Unidad Editorial. Telva". Recuperado el 20 de septiembre de 2016 de http://www.unidadeditorial.es/producto.aspx?id=telva

${ }^{71}$ Véase información publicada en 2016: "Unidad Editorial. Telva". Recuperado el 20 de septiembre de 2016 de http://www.unidadeditorial.com/publicidad/Revista/telva.html
} 
La autora María Ganzabal asegura que Telva supuso un cambio en el modo de hacer prensa femenina. Aunque de apariencia moderna, los valores que defendía para la mujer eran de lo más tradicionales (religión, matrimonio e hijos) hecho, por otra parte, totalmente previsible teniendo en cuenta que vino de la mano de la editorial Sarpe —cercana al Opus Dei_-(Ganzabal, 2006a: 406). Salió a la venta en octubre de 1963 en un contexto de dictadura franquista, su primera directora fue Pilar Salcedo, contaba con una periodicidad quincenal y costaba 75 pesetas (Menéndez, 2010: 395-396).

Telva se convirtió en la publicación que mejor representaba a la mujer de clase, aquella que compaginaba sus obligaciones del hogar, matrimonio y crianza con un trabajo de alto nivel (Ganzabal, 2006b: s.p.). Es más, en su primera editorial, Pilar Salcedo se alzó defensora de los valores más tradicionales. A Pilar Salcedo le sucedió, en el año 1970, Covadonga O'Shea, que dirigió la revista hasta 1997. Durante su dirección, en 1989, la publicación sufrió una serie de modificaciones en el tipo de encuadernación, el papel, el número de páginas y la periodicidad (pasó a ser mensual), modificaciones de forma, que lograron aumentar su tirada, aunque el contenido siguió siendo conservador (Menéndez, 2010: 403). Posteriormente, bajo la dirección de Nieves Fontana, Telva fue galardonada con el "Premio al Medio de Comunicación Impulsor de las Mujeres Profesionales" (otorgado en el 2008 por la Federación Española de Mujeres Directivas, Ejecutivas y Profesionales y Empresarias) ${ }^{72}$ y, desde enero de 2011, dirige la publicación Olga Ruiz.

A la publicación en papel le acompañan distintos suplementos especializados. Así, encontramos Telva fitness \& running, Telva colecciones y accesorios, Telva niños, Telva belleza, Telva novias, Telva navidad y Telva cocina. La versión digital (www.telva.com) nació en 2007 y, actualmente, cuenta con las secciones de Belleza, Moda, Celebrities, Fitness, Estilo de vida, Cocina, Novias y Videos. Ofrece contenido exclusivo que no encontramos en la versión en papel, aunque, se podría decir, que el fin de la página web es el de fidelizar a las lectoras en el formato "tradicional". Se actualiza con regularidad e incluye mucha información gráfica y audiovisual.

Anualmente, la revista Telva organiza los Premios T de Telva. Estos comenzaron en el año 1986 con la categoría Premios Telva Solidaridad, le siguieron, en el año 1991, los Premios Telva Moda, posteriormente, se incluyeron los Premios Telva Belleza (1993),

72 Véase información publicada en 2008: “iTelva se merecía un premio así!” Recuperado el 19 de noviembre de 2017 en http://www.telva.com/2008/11/27/trabajoactualidad/1227777349.html 
Premios Telva Motor (1998), Premios Telva Niños (2011) y Premios Telva a las Artes, las Ciencias y el Deporte (2011). ${ }^{73}$ Finalmente, destacar que Telva se considera a sí misma un referente en el mundo culinario, no solo por los contenidos de cocina que ofrece y mantiene desde los inicios de la revista, también por la Escuela de cocina Telva, la cual encontramos anunciada hacia el final de la publicación y ofrece cursos en sus centros físicos de Madrid y Barcelona.

Al igual que sucedía con Woman, la portada de Telva se estructura en torno tres términos compositivos: en el primer término los titulares, posteriormente la imagen figurativa y, finalmente, la cabecera. Los titulares principales introducen temas de moda: "12 maneras inesperadas de combinar jersey \& fiesta" o "España es cool, looks para copiar con las 4 chicas de moda". Los secundarios, por su lado, avanzan variedad de temas: "Científicas. Margarita Salas y María Blasco. Conversaciones de salón" (Telva, núm. 917, 2015), "Habla el servicio del ala privada de la Casa Blanca” (Telva, núm. 914, 2015) o "25 consejos que las directoras de moda y belleza de Telva dan a sus amigas" (Telva, núm. 911, 2015). Los colores usados son el blanco y el negro como colores base y el rojo para resaltar algunos de los titulares. La tipografía es sencilla, nada sofisticada, predomina un tipo de letra recta, en mayúsculas, que se combina en algunas ocasiones con otra de estilo cursiva con serifa.

El segundo término compositivo lo protagoniza la imagen figurativa de un personaje femenino. En el número de marzo de 2015 aparece retratada la actriz Blanca Suarez, en septiembre la modelo Patricia Van Der Vliet y en diciembre la bloguera de moda Chiara Ferragni. En el número de junio no se especifica el nombre de la protagonista. El físico es normativo: complexión delgada, juventud y belleza occidental. El conjunto queda tremendamente homogéneo no pudiendo destacar nada que escape de la norma.

El vestuario varía en función de la estacionalidad. En junio la modelo posa en biquini, mientras que en diciembre Chiara Ferragni lleva gorro y jersey. En las otras dos portadas se aprecian sendas camisas. El pelo lo llevan suelto y de color rubio y el maquillaje no es marcado. Las cuatro mujeres miran a cámara con expresión seria. En el mes de junio el pelo mojado tapa parte de la cara a la modelo que, añadido a que solo lleva el biquini, se convierte en la portada más erótica (véase imagen 22). Por último,

\footnotetext{
73 Véase los premios del 2017 en "Premios Telva". Recuperado el 19 de noviembre de 2017 en http://www.telva.com/premios-telva.html
} 
destacar que se han utilizado dos planos medios y dos americanos y que los fondos con monocromáticos, apareciendo el color gris y el blanco.

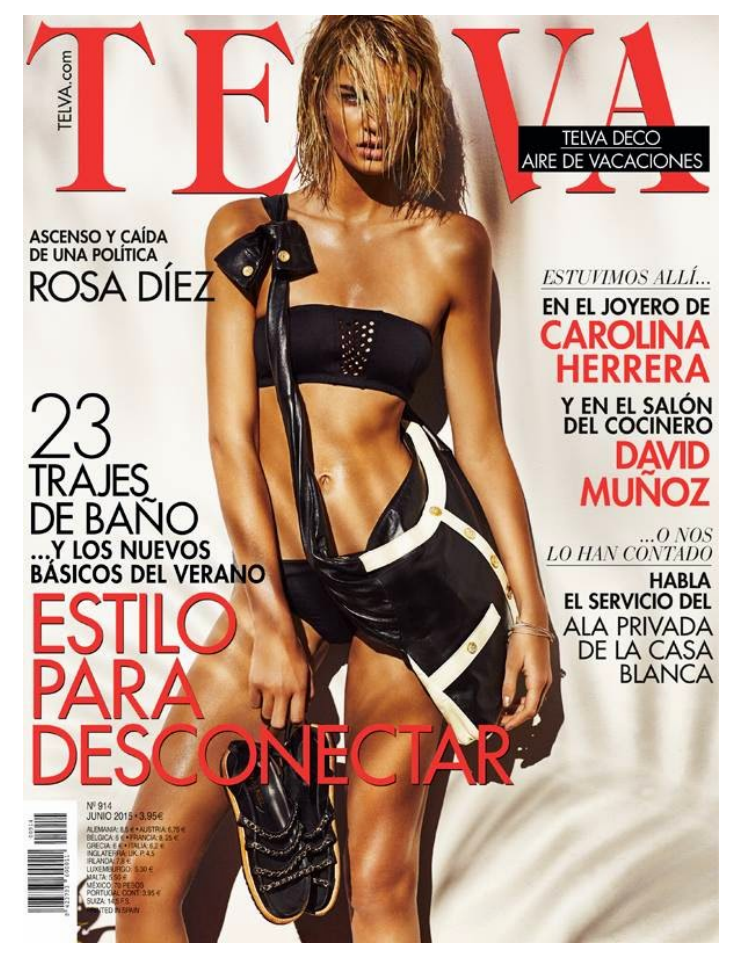

IMAGEN 22. Portada de la revista Telva de junio de 2015. FuENTE: Telva.

El tercer término compositivo lo ocupa la cabecera que se sitúa en la parte superior de la portada. Está formada por el logotipo de la revista y el sitio web de la misma. Parte del logotipo se encuentra cubierto por la modelo, siendo la L la letra que tiende a desaparecer. La tipografía es clásica con serifa triangular, remate que aporta elegancia, y en mayúsculas, hecho que estiliza el conjunto. Los logotipos aparecen sombreados y son de color rojo en dos ocasiones, negro en una y blanco en otra.

En cuanto a la agenda temática, las primeras páginas de la publicación incluyen los datos de la revista, el sumario, el editorial, un consultorio y el Carnet secreto, que se trata de una unidad redaccional de una página de extensión con propuestas del mundo de la moda, la belleza o el ocio y la cultura. El editorial lo firma Olga Ruiz, directora de Telva y trata distintos temas: en "Un país de modistas" (Telva, núm. 917, 2015) habla sobre oficios que se han perdido o en "Cuidado: tienes en casa una community manager" (Telva, núm. 911, 2015) escribe acerca de las adolescentes y su uso de las redes sociales. 
La etiqueta Línea directa con Telva recoge las cartas de las lectoras, donde, en unas ocasiones, comparten vivencias personales y, en otras, agradecen a la revista este u otro artículo. Tras estas primeras páginas, Telva abre su lista de contenidos con un espacio al cual hemos denominado Gente. Posteriormente, se suceden las secciones Tiempo libre, Lo último, Decoración, Cocina y Últimas noticias.

\begin{tabular}{cccc} 
MARzo & JUNIO & SEPTIEMBRE & DICIEMBRE \\
\hline Inicio & Inicio & Inicio & Inicio \\
\hline Gente & Gente & Gente & Gente \\
\hline Tiempo libre & Tiempo libre & Tiempo libre & Tiempo libre \\
\hline Lo último & Lo último & Lo último & Lo último \\
\hline- & - & - & Premios Telva \\
\hline- & Decoración & Decoración & Deco (Navidad) \\
\hline Cocina & Cocina & Cocina & Cocina (Navidad) \\
\hline Últimas noticias & Últimas noticias & Últimas noticias & Últimas noticias
\end{tabular}

TABLA 23. Estructura de la revista Telva en 2015 (ejemplares de marzo, junio, septiembre y diciembre). FUENTE: Elaboración propia.

El espacio Gente es un apartado que comprende distintos reportajes o entrevistas a personas pertenecientes a las esferas de la moda, del arte o de la política. Se reserva entre tres y cuatro unidades redaccionales para estos retratos que ocupan, cada uno de ellos, una media de seis páginas de extensión. Tras las unidades redaccionales protagonizadas, encontramos siempre una columna de opinión con la etiqueta Escribe firmada, en marzo y junio, por el escritor José Luis Olaizola y, en septiembre y diciembre, por el también escritor Eloy Tizón. El primero narra vivencias personales ("Un extraño en la cocina (2)” Telva, núm 911, 2015; “En familia. Besos” Telva, núm. 914, 2015), el segundo reflexiona acerca del arte ("El enigma del vaso" Telva, núm. 917, 2015) y el cine “Rozar lo imposible" Telva, núm. 920, 2015).

El total de personas que aparecen son diez mujeres y cinco hombres. En el número de marzo, la celebrity y empresaria Isabel Preysler ("Isabel se reinventa" Telva, núm. 911, 2015) concede una entrevista a propósito de su línea de cosméticos, donde se repasan tanto sus aspectos profesionales como personales, y nos acercamos hasta la vida de Rachel Bunny Mellon, multimillonaria y coleccionista de arte, joyas, muebles y vestidos de costura. Posteriormente, en junio, la política Rosa Díez responde a una serie de preguntas sobre el fin de su carrera política (“Adiós a un sueño” Telva, núm. 914, 2015). 
En septiembre, la modelo y empresaria de moda Alessandra de Osma protagoniza un fotorreportaje acompañado por dos páginas de texto que ahondan en su trayectoria personal y profesional. "Un lugar en el sol” (Telva, núm. 917, 2015) mezcla gastronomía con aspectos de la vida de Conchita de la Lastra (Banca March). En ese mismo número, dedican un espacio a Pilar Salcedo, primera directora de Telva ("Entre nosotras" Telva, núm. 917, 2015). En diciembre, conocemos a Chiara Ferragni, bloguera de moda, ("La blogguer que... conquistó Harvard” Telva, núm. 920, 2015) y Malia Obama, hija del ex presidente Barack Obama cierra este bloque de contenidos al ser protagonista de "Malia: la teen favorita (a su pesar)" (Telva, núm. 920, 2015).

Además, vemos a Carolina Herrera, diseñadora de moda, y a su hija, también conocida como Carolina Herrera y también diseñadora. La primera, concede una entrevista junto a su marido, el editor Reinaldo Herrera ("La buena educación” Telva, núm. 920, 2015) y, la segunda, hace lo propio junto al artista Grillo Demo ("Pétalos preciosos" Telva, núm. 914, 2015) en la que presentan una colección de joyas conjunta. Finalmente, conocemos la exposición del artista experimental Olafur Eliasson ("El gran simulador" Telva, núm. 911, 2015), visitamos el palacio sevillano La Casa Pilatos, propiedad de la familia de Pablo de Hohenlohe, quien recientemente había lanzado una línea de perfumes, y leemos sobre Tamin bin Hamad al Thani, Emir de Qatar en (“¿Quién es el que va con la reina?” Telva, núm. 917, 2015).

Una vez se han sucedido las entrevistas o reportajes del principio, llegamos a Tiempo libre, que es una sección amplia, con una media de 16 unidades redaccionales por ejemplar, de extensión variable, entre una y 10 páginas. Aquí, se concentran el mayor número de unidades redaccionales dedicadas al ocio y la cultura: un $70 \%$ de los contenidos así lo hacen. También, la moda tiene algo de peso al aparecer repetida un 16\%.

Las etiquetas que encontramos son Libros, Cine, Arte, Música, Teatro, Tele, Dónde ir, Viaje y Hoteles, todas ellas, repletas de distintas propuestas. Además, el 20\% de las unidades redaccionales están protagonizadas. Vemos 10 hombres y 25 mujeres, principalmente actrices (Isabella Rossellini, Michelle Dockery, Manuela Velasco, Emily Van Camp, Robin Wright, Ingrid García Jonsson y Carey Mulligan), actores (Tim Robbins y Sir Iam McKellen), cantantes (Manolo García, Soleá Morente y Malú), escritoras (Lucrecia Zappi, Elvira Lindo y Marina Klein) y escritores (Boris Izaguirre y Patricio Pron). También, del ocio y la cultura, encontramos a los directores de orquesta 
David Afhkam y Pablo Heras-Casado, al compositor Lucas Vidal y a la pintora Blanca Gracia.

La moda aparece mezclada con el ocio y la cultura, como sucede en "La última reina de París" (Telva, núm. 920, 2015), donde se nos presenta la exposición dedicada a la diseñadora de moda Jacqueline de Ribes. También, la colaboradora Alejandra Rojas, en su sección A-list, trata moda y ocio y cultura, principalmente. En "Una joyera con historia" (Telva, núm. 914, 2015), visita el taller de trabajo de la diseñadora de accesorios Lisa Salzer, en "La sorprendente Erica Pelosoni... y su increíble boda" (Telva, núm. 911, 2015) habla de su relación con esta diseñadora de moda y en "Anfitriones perfectos" (Telva, núm. 920, 2015), Alejandra de Rojas propone como destino de fin de semana la finca de cacería La Nava del Barranco, a la par que conocemos a su director Javier Medem y a su directora Almudena del Moral. En "Vida de palacio", (Telva, núm. 920, 2015), propone visitar el palacio de Cadaval en Évora, propiedad de las empresarias Diana y Alexandra de Cadaval.

El chef David Muñoz concede una entrevista en "En casa de David Muñoz" (Telva, núm. 917, 2015). Por otro lado, la directora del Centro Nacional de Investigaciones Oncológicas María Blasco y la bioquímica Margarita Salas protagonizan "Mentes maravillosas" (Telva, núm. 917, 2015), entrevista que repasa la trayectoria profesional de ambas científicas. "La vida sin ellos" (Telva, núm. 920, 2015) es un reportaje que nos aproxima a las experiencias de Lillian Tintori, deportista, Isabel Carmona, política, María Corina Machado y Mitzy Capriles, mujeres que viven en Venezuela y que cuentan con algún miembro de su familia encarcelado.

Tras Tiempo Libre, llega Lo último, que es la sección más amplia. Tiene una media de 20 unidades redaccionales, de extensión variable, y trata las temáticas de belleza (39\%) y moda (37\%) aunque, también, pinceladas de ocio y cultura, tecnología, gastronomía, salud o sociedad. E1 30\% de las unidades redaccionales están protagonizadas, apareciendo 14 hombres y 21 mujeres. Así, gran parte del espacio lo dedican a la belleza. El maquillador Roberto Siguero, junto a la maquilladora Rocío Galera, asesora en "La hora del maquillaje" (Telva, núm. 911, 2015) y, junto al maquillador José María Neira, en "Sesión de pelo y maquillaje" (Telva, núm. 917, 2015). Paloma Artola, directora de belleza de Telva, también ofrece sus técnicas en los meses de junio y diciembre en el espacio Sin secretos. “Comunidad beauty” (Telva núm. 920, 2015) es un reportaje en el que varias empresarias cuentan sus rutinas y trucos de belleza. 
Por su lado, los maquilladores Massimiliano della Maggesa ("El rey del rouge" Telva, núm. 914, 2015), Peter Philips (“Maestro de maestros” Telva, núm. 917, 2015) y la maquilladora Lisa Eldrigde ("Al hablar con Lisa" Telva, núm. 920, 2015) conceden tres entrevistas. También, las actrices Clara Lago ("En la playa siempre con sombrero" Telva, núm. 914, 2015) y Nerea Barros (“Zapping de ondas con la chica de moda” Telva, núm. 914, 2015) protagonizan espacios de belleza. Del mismo modo, encontramos cosméticos —así sucede en "Los trucos de Anna Selezneva” (Telva, núm. 911, 2015), donde la modelo concede una entrevista - y distintos tratamientos ("Lifting con ultrasonidos" Telva, núm. 911, 2015).

La moda aparece en forma de distintos fotorreportajes de varias páginas de extensión: se proponen diferentes conjuntos de ropa y accesorios y en ellos posan las modelos Patricia Van der Vliet ("Piezas maestras" Telva, núm. 917, 2015) o Alba Galocha y Marta Ortiz que, junto a las actrices Blanca Suárez y Bárbara Lennie, protagonizan "4 Chicas que triunfan" (Telva, núm. 911, 2015). También, son relevantes las entrevistas a diseñadores de moda (Paul Marciano, José Urrutia, Jorge Vázquez, Azzedine Alaïa, Raf Simons, Lázaro Hernández y Jack McCollough) de joyas (Vicente Gracia), a las diseñadoras Leticia de la Cuesta y Ann-Sofi Storbacka o el reportaje a Victoire de Castellane, directora creativa de Dior. En "Los códigos de una comida de trabajo" (Telva, núm. 917, 2015) varias expertas y un experto asesoran sobre cómo vestir en reuniones laborales fuera del lugar de trabajo.

En tecnología, encontramos cuatro unidades redaccionales, todas ellas dedicadas a motor y 3 de ellas mezcladas con moda. En “Algo salvaje” (Telva, núm. 911, 2015), “Llegada triunfal” (Telva, núm. 920, 2015) y "Con 1001 opciones para personalizar" (Telva, núm. 917, 2015), se anuncia un vehículo y se muestran distintos looks de ropa. Además, en el último caso, aparece incluida una pequeña entrevista a Leyre Olabairra, ingeniera de SEAT. En "En ruta con... Alex González” (Telva, núm. 920, 2015), al actor le preguntan sobre su relación con la conducción.

En salud (2\%), se abordan temas nutricionales como “¿Es sano comer lácteos después de la lactancia?” (Telva, núm. 914, 2015), donde escriben las nutricionistas Rosa Burgos y Paloma Castaño o "Movimiento verde" (Telva, núm. 917, 2015) que, además de hablarnos de alimentos saludables, incluye algunas recetas. Encontramos, también, propuestas gastronómicas, que nos acercan a algunos alimentos "Todo lo que tienes que saber de la tortilla de patatas" (Telva, núm. 911, 2015) o "Del cerdo... hasta los andares" 
(Telva, núm. 917, 2015). Por otro lado, leemos el debate "Multiculturalismo, ¿es posible?" (Telva, núm. 911, 2015) escrito por la investigadora Haizam Amirah Fernández y la periodista Isabel San Sebastián y en "Kanye \& Kim en la Casa Blanca” (Telva, núm. 920, 2015) el escritor Jordi Soler imagina, en clave de humor, como sería un mundo gobernado por el rapero Kanye West y la empresaria Kim Kardasian.

Hacia el final de la revista, en los números de junio y septiembre, encontramos el apartado Decoración. Además, en el número de diciembre, en la sección Navidad vemos el reportaje "8 ideas para vestir la casa" (Telva, núm. 920, 2015), de 6 páginas de extensión, el cual hemos incluido dentro de este bloque de contenidos. Tanto en junio como en septiembre contamos 4 unidades redaccionales, 3 de ellas protagonizadas y extensas, mientras que las 6 restantes son de una y dos páginas, a excepción de "El patio de mi casa" (Telva, núm. 914, 2015), amplio reportaje que nos enseña las estancias de una finca en el campo.

Esta sección se centra en la decoración del hogar. "Mi terraza a precio chollo" (Telva, núm. 914, 2015), “Tanta belleza” (Telva, núm. 914, 2015) y “Gran idea” (Telva, núm. 917, 2015) recopilan fotografías de muebles y objetos decorativos mientras que "Hora de recreo" (Telva, núm. 917, 2015) propone libros de decoración. Por su lado, en "Placeres de verano" (Telva, núm. 914, 2015), la artesana Bárbara Pan de Soraluce, la jardinera Sandra Carretié y el paisajista Jesús Moraime enseñan sus trabajos, ofreciendo, así, claves de decoración. Lo mismo sucede en "Un festín para la vista” (Telva, núm. 917, 2015) reportaje que presenta las creaciones de la interiorista India Mahadavi. Otra interiorista, Pepa Yuste, nos muestra su peculiar colección de vajilla en "Mesas de otoño" (Telva, núm. 917, 2015) y, finalmente, la diseñadora de moda Carla Saibene enseña rincones de su casa decorados a propósito de la navidad.

El bloque de contenidos Cocina está dedicado al hogar y lo componen una media de dos unidades redaccionales. La primera es un recetario en el que se explica, paso a paso cómo preparar ciertos platos. Son recetas diseñadas para seis personas. Como ejemplo, en "Un plato de pasta, basta" (Telva, núm. 917, 2015) encontramos distintas elaboraciones de pasta y en "Menú paso a paso" (Telva, núm. 911, 2015) aparecen las indicaciones para diseñar un menú completo (pimientos rellenos, pollo a la crema y bolos de nata). En el número de diciembre, los contenidos de cocina están dentro de "Navidad", así vemos "Nochebuena en el campo" (Telva, núm. 920, 2015) y “iViva la fiesta!” (Telva, núm. 920, 2015). La segunda unidad redaccional, llamada "Escuela de cocina" sugiere 
un número de clases, cursos y monográficos sobre cocina. Además, también proponen talleres para las niñas y los niños.

La publicación cierra siempre con la sección Últimas noticias en la que, de nuevo, la moda (45\%) y el ocio y la cultura (36\%), son los grandes protagonistas. Se trata de una sección muy breve, en torno a tres unidades redaccionales, que sirve como escaparate final para que las marcas anuncien sus productos. Además, encontramos la "Guía de tiendas", un listado que incluye la dirección, teléfono o página web de las tiendas de moda, maquillaje y accesorios.

Casi la mitad de las unidades redaccionales están protagonizadas. Los actores Hugh Jackman y Matthew McConaughey, la modelo Georgia May Jagger y la actriz Jessica Chastain protagonizan En privado un espacio que cierra la publicación. Se trata de una página en la que la persona invitada revela sus favoritos de la moda, la belleza o el ocio y la cultura. También, en "Para coleccionar" (Telva, núm. 920, 2015) conocemos los gustos de Iván Martínez-Cubells y, además, algunos de los aspectos de la revista Fuera de serie, publicación que él mismo dirige. En "Nuestro objetivo es el buen periodismo" (Telva, núm. 914, 2015) Aurelio Fernández, director de Unidad Editorial, responde a una serie de preguntas y Antonio Fernández-Galiano, presidente del mismo grupo de comunicación, protagoniza el espacio “Contra la violencia” (Telva, núm. 914, 2015) que informa acerca de una iniciativa de concienciación sobre violencia de género.

Como se ha mencionado, la moda cuenta con peso dentro de esta sección. Elena Benarroch, diseñadora, protagoniza un concurso en el que se sortea un abrigo de piel diseñado por ella misma (“¿Y si te toca?” Telva, núm. 920, 2015), además, tres de las cuatro revistas incluyen una unidad redaccional dedicada a moda de niñas y niños: “Compra la ropa de tus hijos en Shopping by TELVA niños” (Telva, núm. 920, 2015).

Excepcionalmente, en el número de diciembre encontramos el especial Premios Telva moda. Se trata de un espacio con tres unidades redaccionales dedicadas a la moda. La primera, "El cielo es el límite" (Telva, núm. 920, 2015) es un fotorreportaje de 6 páginas que enseña looks elaborados a partir de la colección de la diseñadora Carolina Herrera, a quien Telva premió por su carrera. Le sigue otro fotorreportaje ("Je ne sais quoi” Telva, núm. 920, 2015), esta vez con prendas de Isabel Marant, que consiguió el galardón a la mejor diseñadora internacional. La sección la cierra la entrevista a Juan Vidal (“Juan y las mujeres", Telva, núm. 920, 2015) premio Telva al mejor diseñador 
nacional. En ella, el diseñador contesta a varias preguntas y las actrices Macarena García, Silvia Alonso e Ingrid García Jonsson posan con su colección.

Como hemos ido viendo a lo largo de las páginas anteriores, son muchas las personalidades famosas que aparecen en la revista Telva. Así, en el 51\% de las unidades redaccionales, encontramos que una persona o grupo de personas protagonizan, asesoran o firman el espacio. Más concretamente, un 36\% de las unidades redaccionales están protagonizadas, un $8 \%$ cuentan con firma y en un $7 \%$ algún experto o experta asesora sobre diversos temas. En total, contamos con la presencia de hasta 130 personas que se dividen entre las tres funciones (véase tabla 24). El mayor porcentaje de personalidades protagoniza la unidad redaccional $(80 \%)$, posteriormente, un $12 \%$ asesora y un $8 \%$ escribe.

\begin{tabular}{lccc} 
& Protagoniza & Escribe & Asesora \\
\hline MUJERES & 69 & 6 & 11 \\
\hline HOMBRES & 36 & 4 & 4
\end{tabular}

TABLA 24. Función de las personas en la revista Telva (muestra año 2015).

FUENTE: Elaboración propia.

Varias trabajadoras de la revista, como la directora general de Telva, la directora de belleza o la de moda, aparecen en distintas ocasiones asesorando sobre temas referentes a la moda, la belleza o el ocio y la cultura. Especial relevancia tiene Paloma Artola, directora de belleza, que aparece en cuatro ocasiones (dos en marzo, una en junio y otra en diciembre). También, Alejandra Rojas, colaboradora de la revista, ofrece sus consejos en cuatro unidades redaccionales, proponiendo lugares para visitar ("Hacienda de San Rafael” Telva, núm. 917, 2015), o aconsejando sobre libros, ropa, restauración... ("Mi nuevo hobby. Los bolsos más buscados" Telva, núm. 911, 2015). Por otro lado, personalidades ajenas a la revista, como son los maquilladores Roberto Siguero y José María Neira o el presidente de la Escuela Internacional de Protocolo Gerardo Correas, asesoran en temas de belleza y moda.

La revista Telva cuenta con la columna de los escritores José Luis Olaizola y Eloy Tizón. Otro espacio fijo que encontramos es el de la directora de la publicación, Olga Ruiz, quien en las páginas iniciales firma la editorial de la revista. Como colaboraciones puntuales, tenemos la del escritor Jordi Soler, que escribe desde el humor, la de la 
fundadora de Telva Covadonga O'Shea, quien habla de moda, y, finalmente, en los espacios de debate “Multiculturalismo, ¿es posible?” (Telva, núm. 911, 2015) y “Es sano comer lácteos después de la lactancia?”, vemos, por un lado, a la investigadora Haizam Amirah Fernández y a la periodista Isabel San Sebastián y, por el otro, a las nutricionistas Rosa Burgos y Paloma Castaño.

Como ya se ha avanzado, la función en la que más gente encontramos es en la de protagonista, donde aparecen hasta 105 personas. De ellas, un $66 \%$ son mujeres y un $30 \%$ son hombres. La profesión más repetida para las mujeres es la de actriz (15), mientras que para los hombres es la de diseñador de moda o joyas (10). El resto de profesiones de las mujeres son: diseñadora de moda o joyas (12), empresaria, directora, fundadora o propietaria (11), modelo (6), artistas varias (6), cantante (4), escritora (3), política (3), bloguera (2), otras profesiones (4) y, finalmente, existen 3 casos en los que no se especifica o no tiene profesión (3). Para los hombres, tras los diseñadores encontramos actores (6), maquilladores (3), escritores (2), profesionales del ámbito musical (4), artistas (2), directores o presidentes de empresas (5) y otras profesiones (4).

Las personas arribas mencionadas son, en principio, relevantes debido al tipo de profesión que ejercen. Sin embargo, el motivo al que se debe su protagonismo no siempre es el profesional. Si bien es cierto que para los hombres es así en un $92 \%$ de las ocasiones, para las mujeres lo es en un 65\% del espacio. Las excepciones para los hombres coinciden con la sección En privado que cierra la publicación, donde, en este caso concreto, los actores Hugh Jackman y Matthew MacConaughey exponen sus gustos en temas de moda, cosméticos, destinos, ocio...

El $35 \%$ de las veces que las mujeres protagonizan una unidad redaccional no lo hacen por aspectos profesionales. El caso más repetido es el de utilizar a mujeres, en este caso actrices, como modelos en temas de belleza o prendas de vestir. Así, se analizan sus estilismos o aparecen posando con distintos conjuntos de ropa o maquillajes (14\%). La siguiente desviación más típica es la de ahondar en sus cuidados personales (7\%). Esto sucede en "Comunidad beauty" (Telva, núm. 920, 2015) donde la fundadora de Manolo Maestre, una diseñadora de bolsos, una calígrafa, la copropietaria del restaurante Beker y una diseñadora de joyas son utilizadas con el fin de conocer sus rutinas de belleza diarias.

Encontramos, también, que se exponen gustos personales (5\%) y, finalmente, cabe destacar el reportaje "La vida sin ellos" (Telva, núm. 920, 2015) donde cinco mujeres que 
viven en Venezuela hablan de la ausencia de sus maridos e hijo, los cuales han sido arrestados o permanecen en el exilio. Este asunto, de relevancia social, se trata desde el entorno privado de las cinco mujeres y carece de contexto o de voces expertas que guíen el tema. Algunas de las declaraciones que la propia publicación ha decidido resaltar son: "No soy la nueva Winnie Mandela: ella era guerrillera y a mí no me gusta la guerra, ella se enamoró del abogado de Nelson... ¡y a mí no me gusta ninguno de los letrados de Leopoldo!", "Me prohibieron viajar para la graduación de mi hija en la universidad. Me quedé aquí sola, viendo el acto por Internet con mi botellita de vino para celebrarlo, mientras mi hija gritaba a la cámara, ¡mamá, mamá!, porque sabía que la estaba viendo” (Telva, núm. 920, 2015). Por ello, y debido al tratamiento de la noticia, se ha considerado que se hace una exposición de estas mujeres más cercana a la privacidad de sus vidas que a asuntos públicos o profesionales.

Finalmente y, a modo de sumario, destacar que Telva, ya sea sirviéndose de una personalidad relevante (51\% de los casos), o prescindiendo de cualquier protagonismo humano (49\% de los casos), ahonda, principalmente, en tres temáticas: la moda (30\%), el ocio y la cultura (30\%) y la belleza (20\%). Sin embargo, su agenda llega hasta otros aspectos como son la decoración (4\%), el hogar (4\%), la gastronomía (2\%), la sociedad $(2 \%)$, la salud (2\%) y la tecnología (2\%).

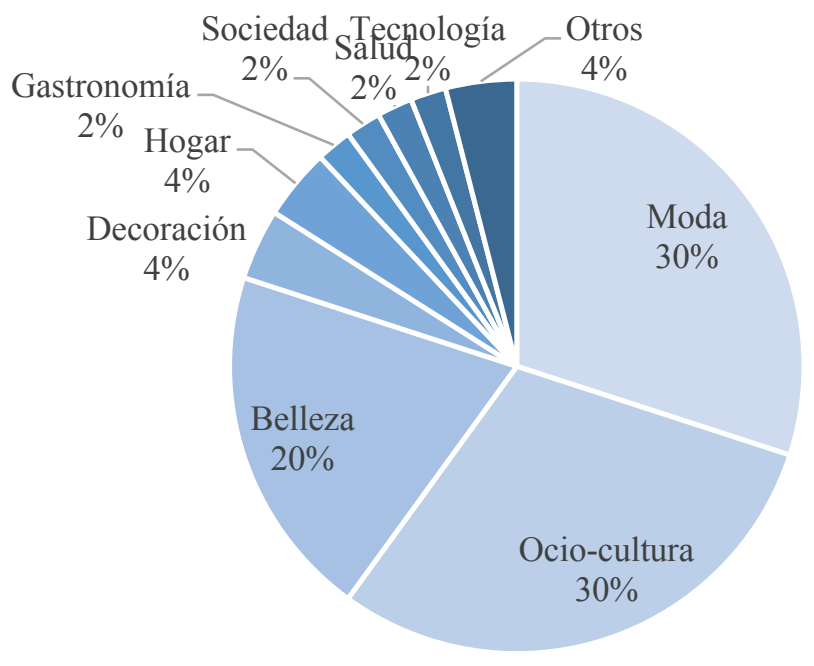

GráfiCo 12. Contenidos de la revista Telva en marzo, junio, septiembre y diciembre de 2015.

FUENTE: Elaboración propia. 


\subsection{Glamour}

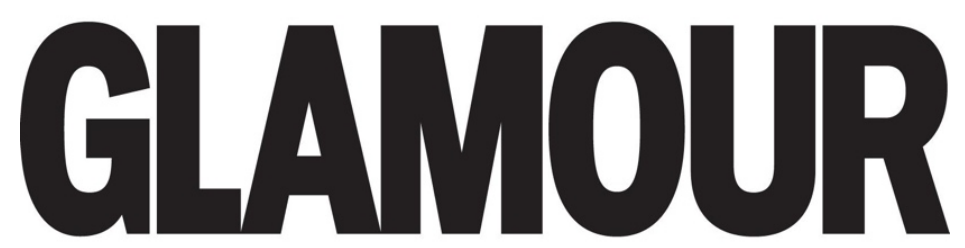

IMAGEN 23. Logotipo de la revista Glamour. FUENTE: Glamour.

FICHA MORFOLÓGICA DE LA REVISTA GLAMOUR

\begin{tabular}{|c|c|}
\hline NOMBRE & Glamour \\
\hline DESCRIPCIÓN & La revista de moda para la mujer líder \\
\hline SITIO WEB & www.glamour.es \\
\hline ORIGEN & Estados Unidos \\
\hline GRUPO EDITORIAL & Ediciones Condé Nast, S.A. \\
\hline LUGAR DE EDICIÓN & Madrid \\
\hline DIRECTORA & Marta Hurtado de Mendoza \\
\hline \multirow[t]{2}{*}{ PRIMER NÚMERO } & 1939 (Estados Unidos) \\
\hline & 2002 (España) \\
\hline PERIODICIDAD & Mensual \\
\hline DIFUSIÓN & 141.133 ejemplares (OJD julio 2013/ junio 2014) \\
\hline \multirow[t]{2}{*}{ Precio } & $3,00 €$ edición normal \\
\hline & $1,80 €$ edición de bolsillo \\
\hline \multirow[t]{2}{*}{ Páginas } & Máximo: 306 (marzo) \\
\hline & Mínimo: 274 (diciembre) \\
\hline \multirow[t]{2}{*}{ FORMATO } & $215 \times 285$ mm edición normal \\
\hline & $166 \times 222 \mathrm{~mm}$ edición bolsillo \\
\hline EDICIONES INTERNACIONALES & $\begin{array}{l}\text { Estados Unidos, Reino Unido, Francia, Italia, Alemania, Rusia, } \\
\text { México, Brasil, Bulgaria, Hungría, Islandia, Países Bajos, Polonia, } \\
\text { Rumanía, Sudáfrica y Turquía. }\end{array}$ \\
\hline CATEGORÍA TEMÁTICA & Revista femenina (OJD) \\
\hline
\end{tabular}

TABLA 25. Ficha morfológica de la revista Glamour.

FUENTE: elaboración propia.

Glamour se anuncia a sí misma como La revista de moda para la mujer líder, eslogan que encontramos en el lomo de la revista. Condé Nast, la editorial a la que pertenece, ofrece también la siguiente descripción: "Glamour es una marca de estilo de vida para la mujer en la treintena". El 40\% de su audiencia tiene entre 18 y 30 años, mientras que el otro $60 \%$ abarca desde los 31 hasta $\operatorname{los} 54 .{ }^{74}$ Se trata de una revista femenina muy longeva,

\footnotetext{
74 Véase información publicada en 2016: “Condé Nast. Glamour”. Recuperado el 20 de septiembre de 2016 de http://cnworld.es/pdf/mk-glamour.pdf
} 
lanzada por primera vez en Estados Unidos en 1939, aunque no fue hasta el 2002 que llegó a España. Estamos, pues, ante la edición nacional de una cabecera internacional.

La irrupción de Glamour en el mercado español, año 2002, supuso un cambio de paradigma para el resto de publicaciones femeninas, las cuales rediseñaron sus páginas con el fin de adecuarse a las nuevas dimensiones propuestas por esta publicación que, con su formato pocket (de bolsillo), obligó a las viejas revistas españolas a repensar su modo de dirigirse al público (Ganzabal, 2006b: s.p.). Prueba de ello, comprobamos como Woman, en el año 2006, y Telva, en el año 2008, lanzaron sus propias versiones de bolsillo. Cinco años después de que Glamour saliese al mercado, esta alcanzará la mayor difusión dentro de su segmento poblacional (Torres, 2008: 3). El 31 de octubre de 2019, Alicia Parro, quien llevaba a la cabeza de la publicación desde su nacimiento en 2002, fue sustituida por Marta Hurtado de Mendoza, convirtiéndose esta última en la nueva directora de Glamour. $^{75}$

Junto a la publicación mensual, Glamour ofrece suplementos de moda (Glamour goes shopping, Glamour Fashion Shows) y de belleza (Glamour belleza \& Stars). Por otro lado, Glamour también cuenta con la versión online (www.glamour.es) que contiene las secciones Moda, Belleza, Celebrities, Placeres, Work \& Techno, Blogs, Glamounity y Glamour $T V$. El sitio web presenta contenido exclusivo, pero sirve, también, de promoción para la versión en papel. Anualmente, Glamour entrega los Premios Glamour Belleza los cuales premian desde los mejores cosméticos, perfumes y maquillajes hasta el Rostro más bello del año, Pareja más bella, Rostro más bello del cine, New face del público o New face del jurado. ${ }^{76}$

En cuanto a la portada de Glamour, sigue el mismo esquema que sus antecesoras. Los elementos principales se ordenan en tres términos compositivos: titulares, imagen figurativa y cabecera. Los titulares ocupan el primer término compositivo y abarcan varias temáticas. El principal nos habla de moda: "Un look sexy” (Glamour, núm. 149, 2016) o "Moda fabulosa" (Glamour, núm. 155, 2015), mientras que los secundarios avanzan belleza o reportajes diversos: "Matcha, el té mágico de Nueva York" (Glamour,

\footnotetext{
${ }^{75}$ Véase información publicada el 31 de octubre de 2019: "Marta Hurtado de Mendoza, nueva directora editorial, y Clara Montoya, nueva directora de negocio de Glamour España”. Recuperado el 1 de noviembre de 2019 de https://www.traveler.es/viajeros/articulos

${ }^{76}$ Véanse los premios del año 2017 en “Los ganadores de los Premios Glamour Belleza 2017”. Recuperado el 19 de noviembre de 2017 de http://www.glamour.es/belleza/tratamientos/galerias
} 
núm. 158, 2015), "Mujer y sexo, la feminidad que te hace llegar lejos" (Glamour, núm. 155, 2015) o "Muy cool, peinados que dan que hablar" (Glamour, núm. 152, 2015).

Existen dos colores principales que se aplican a la fuente, estos son el negro y el blanco. En dos de las portadas encontramos, además, el rojo como tercer color para enfatizar y resaltar titulares o palabras. La tipografía es sencilla, de corte recto generalmente, aunque con uso de serifa en cifras numéricas y serifa con cursiva para algunos términos. En casi la mayoría de los casos se opta por usar la mayúscula.

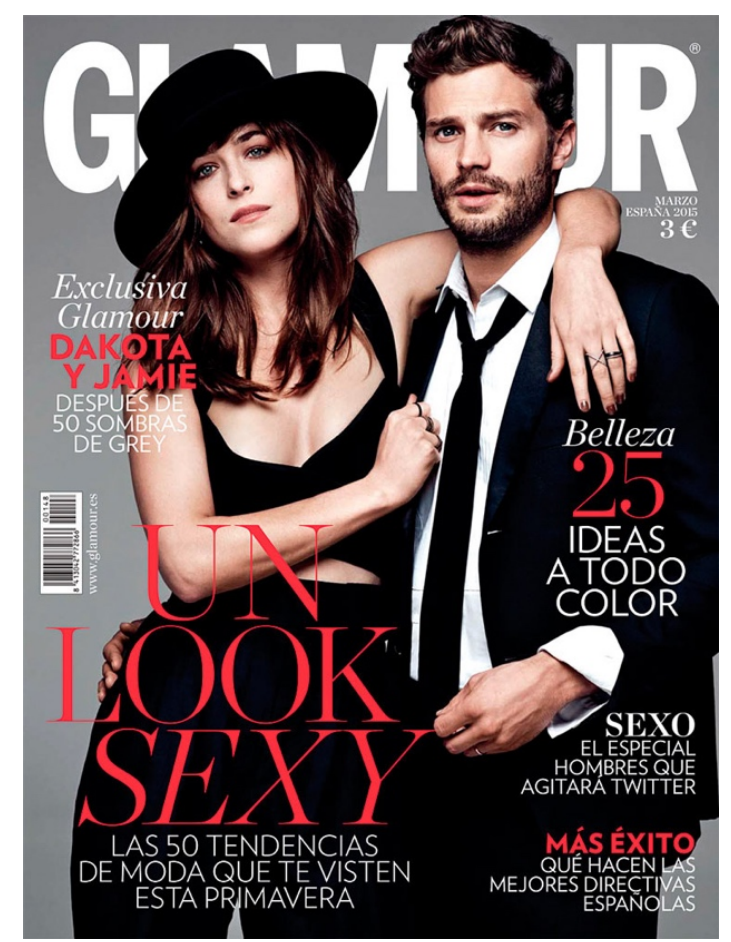

IMAGEN 24. Portada de la revista Glamour de marzo de 2015.

FUENTE: Glamour.

El segundo término compositivo lo protagoniza la imagen figurativa de un personaje femenino, a excepción del número 149 en el que la portada es conjunta (véase imagen 24). Así, en marzo de 2015 la actriz Dakota Johnson comparte espacio junto con el actor Jamie Dornan, en junio encontramos a la cantante Taylor Swift, en septiembre a la modelo Emily DiDonato y en diciembre a la también modelo Lara Stone. De cánones normativos, son mujeres bellas, jóvenes y delgadas.

El vestuario se muestra desenfadado y sugerente: transparencias, escotes, vestidos minis... Jamie Dorman, único personaje masculino, lleva traje. El pelo aparece suelto, rubio en dos casos y algo más oscuro en los otros dos. Las cuatro protagonistas sostienen 
la mirada ante la cámara y su expresión es seria. En diciembre el maquillaje aparece más resaltado, tanto en labios como en ojos, sin embargo, para el resto se ha optado por simular los tonos naturales de la piel. Tres de las cuatro fotografías están tomadas en un plano americano y, la última, perteneciente al número de diciembre, en un plano medio corto. Los fondos sobre los que posan las modelos son monocromáticos y planos (blanco, gris y naranja) o, en un único caso, desenfocado en tono crema.

El tercer término compositivo queda reservado para la cabecera, situada en la parte superior de la portada. La componen el logotipo de la revista, la fecha y el precio de la misma. El logotipo, elemento principal, utiliza una tipografía sencilla, de corte recto con caracteres gruesos y en caja alta. Los colores que encontramos son el blanco para dos de los casos, el negro y el granate.

\begin{tabular}{cccc} 
Marzo & JunIO & SEPTIEMBRE & DiCIEMBRE \\
\hline Inicio & Inicio & Inicio & Inicio \\
\hline Hype & Hype & Hype & Hype \\
\hline Glamourama & Glamourama & Glamourama & Glamourama \\
\hline Top & Top & Top & Top \\
\hline Stars & Stars & Stars & Stars \\
\hline Club & Club & Club & Club \\
\hline Fun \& Pleasure & Fun \& Pleasure & Fun \& Pleasure & Fun \& Pleasure \\
\hline Especial mujer & - & - & - \\
\hline Shop & Shop & Shop & Shop \\
\hline Belleza & Belleza & Belleza & Belleza \\
\hline Estilo & Estilo & Estilo & Estilo \\
\hline Glam life & Glam life & Glam life & Glam life
\end{tabular}

Tabla 26. Estructura de la revista Glamour en 2015 (ejemplares marzo, junio, septiembre y diciembre).

FUENTE: Elaboración propia.

De entre las tres revistas de estilo de vida femenino, Glamour es la que cuenta con un mayor número de secciones. Las más extensas son Top Glamour, con 13 unidades redaccionales de media, Glamourama, 9 unidades redaccionales, y Shop Glamour, que tiene 8 unidades. Las secciones suelen ofrecer un contenido mixto, donde priman los temas de moda, ocio y cultura y belleza. La publicación abre con una serie de contenidos a los que hemos denominado Inicio. Se trata del sumario, el editorial, los datos de la revista y las cartas de las lectoras. La editorial la firma Alicia Parro, directora de Glamour en 2015, que realiza un avance de lo que vamos a encontrar a lo largo de la publicación. 
Hype es una pequeña sección, tres unidades redaccionales de media, dedicada a la moda: el 80\% de sus contenidos así lo atestigua. En este sentido, presenta algunas prendas o accesorios exclusivos bajo la etiqueta Irresistible y propone ideas para vestir. Los otros temas tratados son el ocio y la cultura (cine) y la belleza (maquillaje). En el número de junio, la actriz María Valverde posa con hasta cinco modelos de ropa y nos habla de sus próximos trabajos ("María en la Riviera” Glamour, núm. 152, 2015). Lo mismo sucede en el número de septiembre con la actriz Mélanie Thierry quien luce ropa, maquillaje y leemos un recorrido por su vida profesional y personal ("Mélanie Therry. Ángel o demonio" Glamour, núm. 155, 2015).

Tras Hype, llega Glamourama, una de las secciones más extensas: cuenta con 9 unidades redaccionales de media, generalmente de una página, aunque existen excepciones. Encontramos, en su mayoría, la categoría ocio y cultura, que ocupa un $47 \%$ de los contenidos. La moda cuenta también con gran presencia al verse en el 39\% de las páginas. Por otro lado, existen dos secciones fijas: la ilustración de Dani Wilde, que hace humor sobre algún tema relacionado con la moda ("Siguiente" Glamour, núm. 149, 2015) o el mundo de las celebrities ("30 millones de seguidores sin tener que seguir a nadie" Glamour, núm. 152, 2015), y la sección de Ariadne Artiles, Ari's list, una página en la que la modelo ofrece sus propuestas personales sobre cosméticos, maquillaje u opciones de ocio.

La categoría ocio y cultura nos viene dada en forma de viajes, locales de restauración, exposiciones y funciones de teatro. Al cine nos acercamos de la mano de la directora Sofia Coppola, del actor Ed Skrein y de las actrices Gina Rodriguez, Britt Robertson y Elizabeth Debicki a quienes Glamour realiza pequeños reportajes. Por su lado, las actrices Dakota Johnson y Miriam Giovanelli posan con distintos looks que nos permiten conocer las últimas tendencias en el mundo de la moda. El cantante Mario Vaquerizo presenta su colección de camisetas y las modelos Laura Ponte y Emily Didonato protagonizan dos reportajes en los que no solo posan con distintas prendas, si no que, también, nos acercan a su vida personal. El reportaje "En modo viaje" (Glamour, núm. 152, 2015), nos ofrece un contenido mixto, donde la jefa de belleza, la de estilismo y la directora de Glamour proponen distintos destinos, las prendas más adecuadas y sus accesorios.

Finalmente, vemos el trabajo de Gray Malin, fotógrafo, a quien Glamour dedica una página en el número de junio (“La geometría del verano” Glamour, núm. 152, 2015), 
y el de la artista Libby Schoettle, creadora de Phoebe New York ("El delicado e irónico universo de Phoebe New York" Glamour, núm. 158, 2015). En ese mismo número, el reportaje "Hello, baby" (Glamour, núm. 152, 2015) nos lleva hasta siete mujeres: Liya Kebede, diseñadora de moda, Sasha Pivorarova, modelo, Georgina Chapman, cofundadora de Marchesa, Cass Bird, fotógrafa, Ali Bird, agente de talentos, Isabel Dupré, estilista y Wangechi Mutu, artista. Posan junto a sus hijos e hijas mientras apoyan a distintas ONGs. En septiembre, "La nueva ola se llama muppies" (Glamour, núm. 155, 2015) dedica un reportaje a varias mujeres emprendedoras.

Top Glamour es la sección en la que más unidades redaccionales encontramos: una media de 13 por revista. La tendencia es que sean breves (de una página) salvo por algunos reportajes más extensos. La moda es la gran protagonista con un $42 \%$ del espacio, le sigue el ocio y la cultura (21\%) y la belleza (12\%). Como secciones fijas, vemos El mundo de Marta, Hot topic y You you you. El mundo de Marta es la columna de opinión de la escritora Marta Rivera de la Cruz, que versa sobre estilo de vida. Por su lado, You, you, you se centra tanto en el bienestar de la propia lectora como en sus relaciones de pareja. En este sentido, propone formas de impulsar la vida personal "Ego boost, chute de autoestima" (Glamour, núm. 149, 2015) o profesional "Nunca es tarde para reinventarse" (Glamour, núm. 158, 2015) y ofrece consejos de cara a las relaciones sentimentales, siempre entre hombre y mujer ("Cariño, tenemos que hablar" Glamour, núm. 152, 2015). En Hot topic se tratan temas polémicos: “Quitarte 15 años, ¿new trend?" (Glamour, núm. 155, 2015) habla sobre famosas que aparentan menos edad de la que realmente tienen y "Alerta Hollywood... ¡Ellos siguen cobrando más!” (Glamour, núm. 149, 2015) repasa la brecha salarial entre actores y actrices.

Tal y como se ha adelantado, la moda es la protagonista. Lo vemos, entre otros, en los espacios que se les dedica a los diseñadores de moda Óscar de la Renta, Mark Eley, Tommaso Aquilano, Roberto Rimondi, Karl Lagerfeld, Massimo Giorgetti y a la diseñadora Wakako Kishimoto. También, en “Joyas de la jet set” (Glamour, núm. 152, 2015), encontramos a varias diseñadoras y a un diseñador de joyas. Kaia Gerber, modelo, protagoniza un reportaje de 4 páginas donde habla sobre su vida personal, profesional y posa con distintas prendas ("Family business" Glamour, núm. 149, 2015). Mientras, la actriz Olivia Palermo y el modelo Johannes Huebl presentan la colección de verano de Tommy Hilfiger en un espacio breve de una página ("Preppy couple. Editores invitados" Glamour, núm. 152, 2015). El resto de moda aparece en forma de fotografías de prendas 
u accesorios a las que acompaña un pequeño texto. Mientras, el ocio y la cultura, $21 \%$ de los contenidos, comprende propuestas de libros, viajes, exposiciones, cine, etc. El reportaje "I need an artist" (Glamour, núm. 152, 2015) versa sobre el trabajo de las artistas Ophelia Filke, John Allen, Alexandra Kehayoglou, Hiroshi Sujimoto y sobre el del director de arte Mat Maitland. Por otro lado, conocemos a las fotógrafas Annemarie Schwarzenbach, Sasha Einseman y Lee Miller.

Tras Top Glamour, llega Stars Glamour, que es una pequeña sección que comprende de 2 a 5 unidades redaccionales por revista. El ocio y la cultura se encuentra presente en el $50 \%$ del espacio, mientras que la moda ocupa un 30\%. Las unidades redaccionales son largas, puesto que se trata de una sección en la que encontramos numerosos reportajes y entrevistas a actrices: Dakota Johnson, Riley Keough, Jennifer Lawrence y Julia Roberts; también actores: Jamie Dornan, Nicholas Hoult y Alex García; vemos al director de cine Cary Fukunaga y a la directora Sam Taylor-Johnson. En el reportaje "Balenciaga, to be continued..." (Glamour, núm. 158, 2015), conocemos a cuatro diseñadores de moda: Demma Gvasalia, Alexander Wang, Ghesquière Cristóbal y Balenciaga. Finalmente, en "Pon una Olivia Pope en tu vida" (Glamour, núm. 152, 2015) leemos una crónica de la política Cristina Cifuentes y su jefa de comunicación, Marisa González.

La siguiente sección, Club Glamour, cuenta con siete unidades redaccionales de media. El protagonista indiscutible es el ocio y la cultura, que ocupa un 90\% de los contenidos. Así, la revista nos presenta las novedades relacionadas con este mundo y nos acerca a sus creadores y creadoras. Las unidades redaccionales son variadas, encontramos tanto de una página, como reportajes más extensos. El 67\% del espacio está dedicado a cantantes (Natalie Prass, Leon Bridges, Mahaut Mondino, Kate Akhurst, Carmen Boza, Jamie XX, Ludovic Navarre, Soléa Morente, Arcángel, Mariza, Claire Bouche), escritoras (Carrie Snyder, Almudena de Arteaga, Anna Told, Laura Gutman, Marta Robles, Carmen Posadas, Svetlana Alexiévich, Kate Morton, Alicia Giménez), guionistas (Amy Schumer, Daniel Sánchez Arévalo) o actrices y actores (Jessica Chastain, Colin Farrel, Isabella Rossellini, Chris Pratt, Chris Hemsworth). En el otro 33\% vemos libros, restaurantes, exposiciones, estrenos de cine y televisión, música...

Fun \& Pleasure Glamour es una pequeña sección que comprende tres unidades redaccionales de media, si bien es cierto que se trata de piezas de varias páginas. Los temas son diversos, vemos, como es habitual, moda (37\%), ocio y cultura (26\%), aunque 
también encontramos belleza, tecnología y salud entre otros. En moda, la campeona de salto Jessica Springteen, protagoniza un reportaje dedicado a los nuevos estilismos que el público femenino adopta para acudir a las carreras de caballos ("Una tarde en las carreras" Glamour, núm. 152, 2015). También, en “D20. Los reyes del estilo” (Glamour, núm. 149, 2015), Glamour nos pone en contacto con el trabajo de los diseñadores de moda Dean Caten y Dan Caten. En ocio y cultura encontramos, de nuevo, reportajes a actrices y a actores (Marta Hazas, Julia Christine y Javier Veiga).

En “Una causa común” (Glamour, núm. 152, 2015), viajamos hasta América del Sur para entrar en contacto con el trabajo que la actriz Eva Longoria y la modelo Elisa Sednaoui han realizado como parte de un documental sobre la desigualdad entre hombres y mujeres. En el número de septiembre, existen dos reportajes nombrados bajo la etiqueta Especial mujer. En uno de ellos, "La identidad de lo femenino" (Glamour, núm. 155, 2015), la psicóloga Isabel Fernández habla sobre sexualidad y amor entre hombres y mujeres, además de incluir experiencias de la actriz Alma Jodorowsky y de cómo se ha construido a ella misma. Por otro lado, "La moda y el éxito van con ella" (Glamour, núm. $155,2015)$ es una entrevista que mezcla la vida profesional y personal de la abogada Inmaculada Pérez Castellanos.

La moda es la categoría protagonista en Shop Glamour al ocupar un 85\% de espacio. Esta sección cuenta con una media de ocho unidades redaccionales, las cuales tienden a ser de varias páginas. Aquí desfilan las prendas, accesorios y looks propuestos por las distintas marcas. Encontramos espacios muy visuales, cargados de fotografías, sin apenas más texto que la referencia y el precio de cada propuesta. Así, esta sección nos acerca a diseñadoras de moda como Judith Milgrom y Julie de Libran. En el reportaje “Gold generation” (Glamour, núm. 158, 2015) conocemos a diez diseñadoras de joyas. En "Stars Swimming” (Glamour, núm, 152, 2015) las actrices Laura Put, Alicia Sanz y las blogueras Anna Ponsa y Dulceida posan junto con accesorios, prendas y productos de belleza para el verano. Zendaya Coleman, actriz, protagoniza un reportaje en el que aparece con varios looks ("Run the world" Glamour, núm. 149, 2015). También, vemos a la actriz Ana Fernández, las modelos Julia Restoin y Rocío Crusset, a la jefa de producción de la marca Levi's, Karyn Hillman, o a la bailarina María Pedraza posando en "El secreto del new sexy” (Glamour, núm. 155, 2015).

Tras Shop Glamour, encontramos Belleza Glamour, compuesta por una media de 8 unidades redaccionales por revista. El 71\% de sus contenidos versa sobre maquillaje y 
cosméticos y un $10 \%$ sobre salud. Las unidades redaccionales son extensas, predominando las de 4 o 5 páginas. Se proponen distintos tipos de maquillaje ("Ideas que hacen magia" Glamour, núm. 155, 2015), las tendencias de la temporada ("Bold make up, te atreves? Glamour, núm. 158, 2015), los últimos cosméticos ("Primeros rayos para una piel nueva" Glamour, núm. 149, 2015), o se enseñan peinados (como hace el estilista Sam Maknight en "Más allá del hippy” Glamour, núm. 152, 2015).

Al tratarse de la sección de belleza, encontramos a varias modelos: Bella Hadid, quien habla de cosméticos ("Color trends" Glamour, núm. 149, 2015), Emily Didonato, que anuncia maquillaje ("Los imprescindibles de Emily” Glamour, núm. 155, 2015) y, finalmente, Abbey Lee, quien hace lo propio con un perfume ("Un perfume para sentirse en el paraíso" Glamour, núm. 155, 2015). Sin embargo, también la actriz Lily Collins, la bloguera de moda Gala González e, incluso, la piloto de coches Carmen Jordá sirven de soporte para las distintas marcas. Además, como hemos mencionado, aparecen algunos temas de salud, que se mezclan con belleza, así ocurre en "Energía en tu piel” (Glamour, núm. 152, 2015) donde nos hablan de distintas vitaminas a la vez que nos anuncian cosméticos. Por otro lado, y retomando la parte puramente estética, encontramos propuestas de tratamientos para rejuvenecer el rostro o reafirmar el cuerpo "Tratamientos red carpet” (Glamour, núm. 149, 2015).

En Estilo Glamour, la moda ocupa un $67 \%$ y el ocio y la cultura un $20 \%$. La media de unidades redaccionales es de 7 , algunas de ellas de más de diez páginas ya que es aquí donde encontramos los extensos fotorreportajes a diversas modelos, como son Ariadne Artiles, Emily Didonato, Lara Stone, Emma Ferrer, Violetta Sánchez o al modelo Marlon Teixieira. También, la actriz Agathe Bonitzer y la cantante Taylor Switft protagonizan fotorreportajes de moda acompañados por entrevistas que mezclan preguntas personales y profesionales.

En "Fresssssh Hollywood" (Glamour, núm. 158, 2015), conocemos a los actores y actrices más jóvenes de Hollywood. En "El príncipe del gótico resucita a su reina" (Glamour, núm. 158, 2015), una entrevista con el autor Benjamin Lacombe nos acerca hasta su último libro sobre la reina María Antonieta. El político Albert Rivera protagoniza una entrevista en la que repasa su campaña y algunas de las propuestas políticas de su partido (“On the road" Glamour, núm. 158, 2015). Como era de esperar por el tipo de sección, también hay sitio para la diseñadora de moda Elena Benarroch y para el diseñador de moda Raf Simons. 
Glamour cierra su número con el apartado Glam life Glamour. Se trata de una sección variada que comprende moda, ocio y cultura, decoración, gastronomía y belleza, entre otros. Además, alberga el horóscopo y el directorio de tiendas. Como los temas son diversos, encontramos tanto un reportaje a las panaderas Beatriz Echevarría, Carla Medrano y Susana Gaona ("La revolución del pan” Glamour, núm. 149, 2015) como a los hosteleros Abel Matutes y Pablo Trapote ("La nueva movida madrileña" Glamour, núm. 155, 2015). Además, conocemos a un restaurador, Javier Sánchez Medina, junto con un sastre, Fernando García de la Calera, un paisajista, Álvaro Sampredo, y un diseñador de bicicletas, Álvaro Basterra, en "Los nuevos artesanos” (Glamour, núm. 158, 2015). Vemos, también, propuestas de ocio y cultura (destinos y restauración, principalmente). No podía faltar la moda y la belleza en el fotorreportaje de 10 páginas "Una noche de compras" (Glamour, núm. 152, 2015). Finalmente, aprendemos distintas recetas en "Show cooking. Cocinando entre estrellas" (Glamour, núm. 258, 2015).

En el número de marzo, con motivo del Día Internacional de las Mujeres, Glamour añade una sección denominada Especial mujer Glamour. Se trata de 4 unidades redaccionales que ocupan 21 páginas. Los títulos que encontramos son "Mujeres HighTech” (Glamour, núm. 149, 2015), ¿Hay una conspiración para que no seas madre?” (Glamour, núm. 149, 2015), “Europa unida por la moda” (Glamour, núm. 149, 2015) y “Los problemas de él” (Glamour, núm. 149, 2015).

"Mujeres High-Tech" lo protagonizan Irene Cano, directora general de Facebook España, Elena Carasso, directora de Mango online, Elena Pisonero, presidenta de Hispasat, y Nuria Oliver, directora científica de Telefónica I+D. En el reportaje, estas cuatro directivas hablan de su experiencia dentro del sector de la tecnología, un campo altamente masculinizado. Por otro lado, “Hay una conspiración para que no seas madre?" trata sobre cómo influye la maternidad en la vida profesional de las mujeres. "Europa unida por la moda" presenta la exposición Fashion Art Eu, que fusiona arte y moda. Finalmente, "Los problemas de él" es un reportaje sobre sexualidad enfocado a que las mujeres ayuden a los hombres a superar sus problemas sexuales.

De las seis publicaciones, Glamour es la que cuenta con una mayor presencia de personalidades famosas. Así, en el 49\% de las unidades redaccionales, encontramos que una persona o grupo de personas protagonizan, asesoran, ilustran o firman el espacio. Más concretamente, un $40 \%$ de las unidades redaccionales están protagonizadas, un $6 \%$ las firma alguien, en un 1,5\% un experto o experta asesora sobre algún tema y, finalmente, 
en el 1,5\% restante vemos ilustraciones. En total, contamos con la presencia de hasta 202 personas que se dividen entre las tres funciones (véase tabla 27). Así, un 94\% desempeñan la función de protagonista, un 3\% asesora, un 2,5\% escribe y el 0,5\% restante ilustra.

\begin{tabular}{lccc} 
& Protagoniza & Escribe & Asesora \\
\hline MUJERES & 128 & 6 & - \\
\hline HOMBRES & 60 & - & 1
\end{tabular}

TABLA 27. Función de las personas en Glamour (muestra año 2015).

FuENTE: Elaboración propia.

Las siete profesionales que asesoran pertenecen al ámbito de la belleza y la moda, (Mónica Oliver — jefa de estilismo de Glamour—, Leyre Moreno — jefa de belleza de Glamour - y Aída Artiles — modelo-), aunque, también, encontramos a la actriz Mariam Hernández, quien ofrece consejos de belleza y salud. Finalmente, las coaches Mar Carrascosa (Ego boost, chute de autoestima" Glamour, núm. 149, 2015) y Mónica Salvador ("Nunca es tarde para reinventarse" Glamour, núm. 158, 2015) hablan sobre aceptarse a una misma y emprender nuevas metas. Ninguna de ellas cuenta con sección permanente, se trata, pues, de colaboraciones puntuales.

Donde sí encontramos colaboraciones fijas es entre las escritoras. Concretamente, la por aquel entonces directora de Glamour Alicia Parro, la escritora Marta Rivera de la Cruz y la modelo Ariadne Artiles firman cada mes. Alicia Parro lo hace en las primeras páginas, en las que avanza el contenido que podremos ver a lo largo de la revista. Marta Rivera de la Cruz cuenta con una columna que versa sobre moda, sociedad o relaciones y, finalmente, Ariadne Artiles aborda la belleza el ocio y la cultura desde un punto de vista personal. Por su lado, la escritora Dorothy Parker escribe un relato navideño en el número de diciembre ("Dorothy Parker te regala un cuento de Navidad”, Glamour, núm. 158, 2015), la modelo Karlie Kloss habla sobre el diseñador Oscar de la Renta en "Una primavera de Óscar" (Glamour, núm. 149, 2015) y, para concluir, la psiquiatra Julie Holland en "Bendita histeria", (Glamour, núm. 155, 2015) profundiza sobre las emociones de las mujeres.

Como ya se ha avanzado, la función en la que más gente encontramos es en la de protagonista, donde contamos hasta 188 personas. De ellas, un 68\% son mujeres mientras que un $32 \%$ son hombres. La profesión más repetida para las mujeres es la de actriz (28) 
y para los hombres la de diseñador de moda o joyas (14). El resto de profesiones para las mujeres son: diseñadora de moda o joyas (23), modelo (15), ámbito musical (12), jefa, fundadora, presidenta, directora o empresaria (11), escritora (9), artista (6), ámbito gastronómico o de la restauración (5), bloguera (4), fotógrafa (4), directora de cine (2), estilista (2), deportista (2), abogada (2) y otras (3). En los hombres, a los diseñadores de moda o joyas les siguen los actores (13), profesionales del ámbito musical (8), programadores (5), escritores (2), modelos (2), artistas varios (8), hosteleros (2) y otros (6).

La mayoría de estas personas son relevantes debido a que ejercen una profesión con cierto grado de notoriedad pública, sin embargo, el motivo al que se debe su protagonismo no siempre es el profesional. Para los hombres lo es así en un 90\% de las ocasiones y para las mujeres en el 85\%. En el reportaje "Dónde están y quiénes son los solteros de oro" (Glamour, núm. 152, 2015), Glamour hace un repaso por las relaciones amorosas de los fundadores de Snapchat, Twitter, Facebook, Change.org e Instagram. En “Test de Cooper. Lo ponemos a prueba" (Glamour, núm. 152, 2015), el actor Javier Veiga y la actriz Marta Hazas, pareja en la vida real, son sometidos al "Test de Cooper" (test ideado por un psicólogo norteamericano que consiste en contestar a 36 preguntas para saber si una relación puede convertirse en duradera).

Tal y como ocurría en las otras dos publicaciones femeninas, la mayoría de veces que una mujer no es noticia por su profesión, lo es por servir como modelo de productos de belleza o prendas de ropa (6\%). También, encontramos que en un 5\% de las veces se tratan los gustos personales de las protagonistas, así es el caso de la entrevista "Ellos... siempre con bigote" (Glamour, núm. 149, 2015) a la cantautora Carmen Boza. Otros ejemplos a resaltar serían el mencionado anteriormente de la actriz Marta Hazas, que aparece en un espacio sobre relaciones amorosas; el de la diseñadora de moda Barbara Boccara, quien muestra su casa en "Boho para tu casa" (Glamour, núm. 149, 2015); y, finalmente, destacamos el reportaje "Show cooking. Cocinando entre estrellas" (Glamour, núm. 158, 2015) donde las empresarias Marta Cárdenas, Tamara Falcó, Margarita Vargas y Eliza Arcaya hablan de cómo ser la perfecta anfitriona en el banquete navideño.

A modo de conclusión, vemos que Glamour, bien sea sirviéndose de una personalidad relevante ( $49 \%$ de los casos), o prescindiendo de cualquier protagonismo humano (51\% de los casos), la revista ahonda, principalmente, en tres temáticas: la moda 
(40\%), el ocio y la cultura (29\%) y la belleza (15\%). En menor medida, su agenda llega también hasta otros aspectos como son la sociedad (3\%), la tecnología (2\%), la decoración ( $2 \%)$, la gastronomía (2\%), las relaciones de pareja heterosexuales $(2 \%)$ y la salud $(1 \%)$.

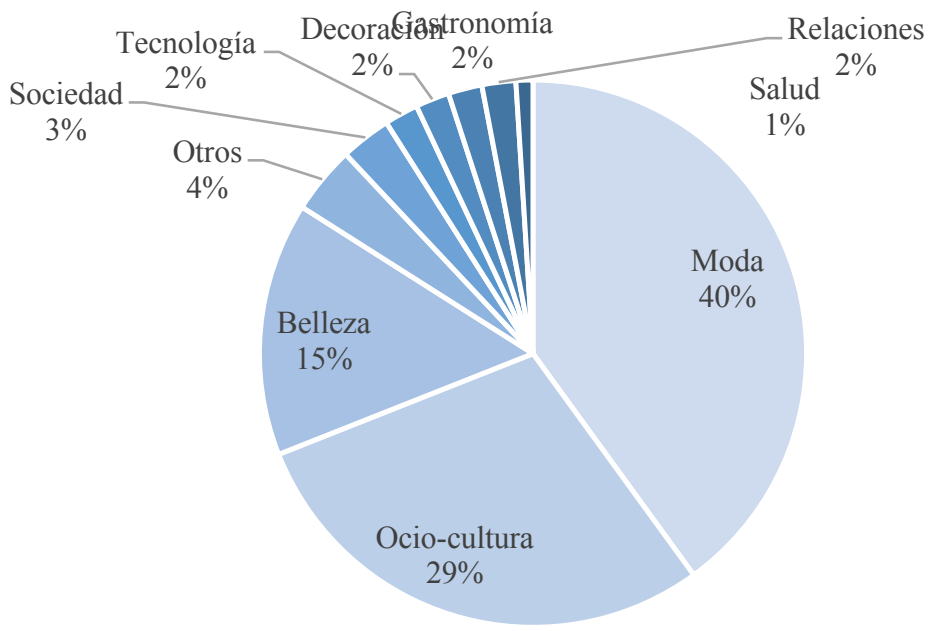

GráFICo 13. Contenidos de la revista Glamour en marzo, junio, septiembre y diciembre de 2015.

FUENTE: Elaboración propia.

\section{REVISTAS ESPECIALIZADAS EN ESTILO DE VIDA MASCULINO}

\subsection{Men's Health}

Men's Health es la revista de estilo de vida masculino con más difusión en nuestro país. En la descripción de la portada leemos La revista para hombres, mientras que en el lomo nos adelanta su alcance: La mayor revista masculina del mundo. Efectivamente, cuenta con 47 ediciones en 61 países. De origen estadounidense, su lector medio es de 33 años. Trata temas de salud —nutrición y ejercicio físico—, aunque, también, incluye belleza, moda, sexo o motor. ${ }^{77}$

\footnotetext{
${ }^{77}$ Véase información publicada en 2016: “Men's Health". Recuperado el 24 de septiembre de 2016 de http://www.menshealth.es/rcs/externos/pdf/MH-MediaKit-2016.pdf
} 


\section{Men'sHealth}

IMAGEN 25. Logotipo de la revista Men's Health.

FuENTE: Men's Health.

\begin{tabular}{|c|c|}
\hline NOMBRE & Men's Health \\
\hline DESCRIPCIÓN & La revista para los hombres \\
\hline DIRECCIÓN ONLINE & www.menshealth.com \\
\hline ORIGEN & Estados Unidos \\
\hline GRUPO EDITORIAL & Hearst España \\
\hline LUGAR DE EDICIÓN & Barcelona \\
\hline DIRECTOR & Jordi Martínez \\
\hline PRIMER NÚMERO & $\begin{array}{l}1987 \text { (Estados Unidos) } \\
2001 \text { (España) }\end{array}$ \\
\hline PERIODICIDAD & Mensual \\
\hline DifuSión & 33.781 ejemplares (OJD: julio 2013/junio 2014) \\
\hline PreCIO & $3,80 €$ \\
\hline Páginas & 146 (marzo, junio, septiembre, diciembre) \\
\hline FORMATO & $203 \times 275 \mathrm{~mm}$ \\
\hline EDICIONES INTERNACIONALES & $\begin{array}{l}\text { Alemania, Australia, Brasil, Bulgaria, China, Corea del Sur, } \\
\text { Croacia, Eslovenia, Estados Unidos, Filipinas, Grecia, Holanda, } \\
\text { Hungría, India, Indonesia, Italia, Kazajistán, Malasia, Polonia, } \\
\text { Portugal, Reino Unido, Rumanía, Rusia, Serbia, Singapur, } \\
\text { Sudáfrica, Tailandia, Turquía, Ucrania, Argentina, Aruba, Chile, } \\
\text { Colombia, Costa Rica, Curaçao, Ecuador, El Salvador, Guatemala, } \\
\text { Honduras, México, Nicaragua, Panamá, Perú, República } \\
\text { Dominicana y Venezuela. }\end{array}$ \\
\hline CATEGORÍA TEMÁTICA & Estilo de vida (OJD) \\
\hline
\end{tabular}

TABLA 28. Ficha morfológica de la revista Men's Health.

FUENTE: Elaboración propia.

Men's Health nació en Estados Unidos en 1987 y llegó a España en abril de 2001 de la mano del Grupo Motorpress Ibérica y la editorial Rodale. Motorpress Ibérica —que edita publicaciones de deporte (Runner's world, Bike) y motor (Motociclismo, Autopista) — pretendía llegar a un público masculino interesado por el estilo de vida y el cuidado personal. Además, la editorial Rodale había lanzado ya su edición en Italia, la cual había conseguido "más del doble de circulación de resto de las revistas para 
hombres", aspecto que generaba una mayor confianza en la apuesta. ${ }^{78}$ Cabe destacar que, en 2018, cuando Hearst España adquirió las editoriales Rodale y G+J Holanda, Men's Health pasó a ser propiedad del grupo Hearst. ${ }^{79}$

La publicación cuenta con sitio web (www.menshealth.es), el cual ofrece contenido exclusivo y, como no podía ser de otra manera, promociona la revista en papel. En esta versión online encontramos hasta 33 secciones (Reto MH, Perder Peso, Fitness, Deportes, Nutrición, Sexo y un largo etc.). Finalmente, destacar los Premios Cuídate que son unos galardones que Men's Health entrega a productos de cuidado personal masculino. ${ }^{80}$

Al igual que en el caso de las portadas femeninas, Men's Health también distribuye sus elementos principales en tres términos compositivos. El primer término lo ocupan los titulares, en un segundo plano aparece la imagen figurativa y, finalmente, podemos leer la cabecera. El titular principal "Operación cambia tu cuerpo" (Men's Health, núm. 162, 2015) u “Operación verano, ¡así en 30 días!” (Men’s Health, núm. 160, 2015) trata sobre la apariencia física mientras que los secundarios, o bien siguen con la misma temática "Gym en casa, cambia tu cuerpo en 4 semanas solo con un fitball" (Men's Health, núm. 165, 2015), o bien introducen moda, nutrición o sexo "Vístete ¡así! Tus 10 looks para este otoño” (Men's Health, núm. 162, 2015), “6 nuevas reglas para tener más sexo" (Men's Health, núm. 157, 2015).

El color predominante de la fuente es el negro, seguido por el gris y el blanco. Todas las portadas incluyen, además, algún toque de color en azul, amarillo, rojo o dorado. La tipografía es sencilla, de corte recto sin adornos ni remates, siempre en mayúsculas salvo alguna excepción en el número de marzo. La letra tiene mucho cuerpo o volumen, creando peso visual.

El segundo término compositivo lo protagoniza la imagen figurativa de un personaje masculino. En el número de marzo de 2015 lo hace Juan Betancourt, en junio Ignacio Ondategui, en septiembre Parker Gregory y en diciembre Diego Miguel. Todos ellos son modelos y todos ellos son jóvenes, con cuerpos muy esculpidos y atractivos. A

\footnotetext{
${ }^{78}$ Véase información publicada en 2001: "La revista masculina Men's Health llega a España". Recuperado el 20 de noviembre de 2017 de https://www.marketingdirecto.com/anunciantes-general/medios

79 Véase información publicada el 15 de enero de 2018: "Hearst adquiere las editoriales Rodale y G+J Holanda". Recuperado el 17 de junio de 2019 de http://www.hearst.es/

${ }^{80}$ Véanse los premios de 2017: "Premios Cuidate 2017: Los ganadores". Recuperado el 20 de noviembre de 2017 de http://www.menshealth.es/cuidado-personal/articulo/premios-cuidate-2017
} 
pesar de sus diversas nacionalidades, encajan dentro de los cánones de belleza occidentales. Los modelos posan con el torso desnudo, los cuerpos son fotografiados de frente siempre dejando muy visible el abdomen pecho y brazos. La expresión tiende a ser seria, aunque en marzo Juan Betancourt sonríe abiertamente, además, tres de ellos sostienen la mirada a la cámara. El pelo es corto, al igual que la barba, una constante en las cuatro portadas. Se aprecia la ausencia de vello corporal, salvo en brazos y zona inferior del ombligo.

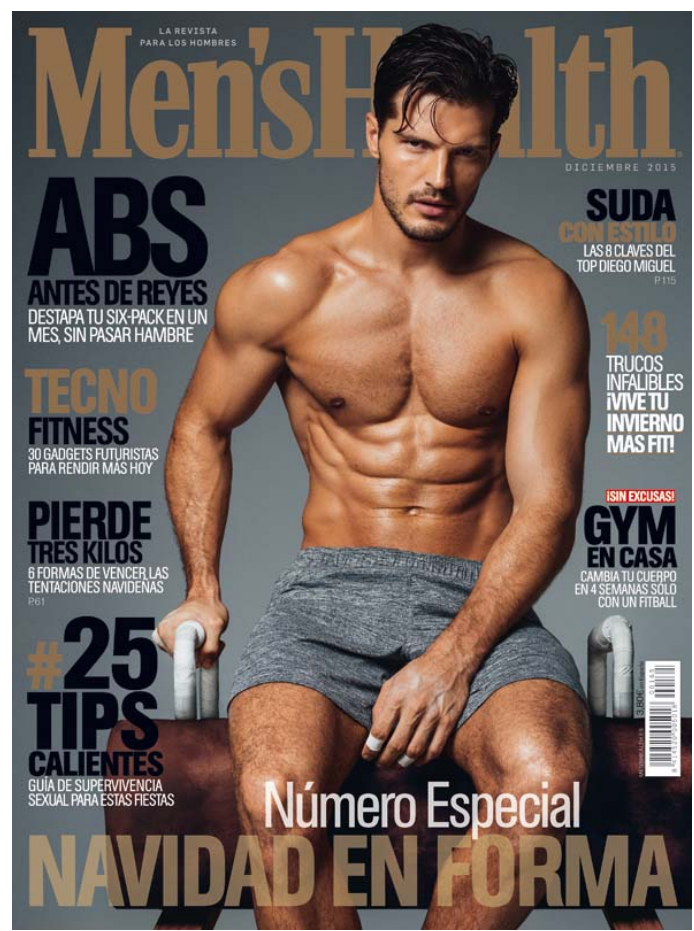

IMAGEN 26. Portada de la revista Men's Health de diciembre de 2015.

FuENTE: Men's Health.

En el tercer término compositivo encontramos la cabecera que se sitúa en la parte superior de la página. Esta está formada por el logotipo de la revista, el eslogan ('La revista para los hombres"), la fecha y el precio. De entre todos los elementos, el logotipo es el que adquiere un mayor protagonismo al ser el que más espacio ocupa. La tipografía del logo combina la caja alta y la caja baja, así, la primera letra de Men's y de la de Health van en mayúscula. La letra es recta, gruesa, con mucho cuerpo e incluye serifa cuadrada. La tipografía del eslogan, la fecha y el precio es mucho más fina y pequeña. El color del logotipo es blanco en dos ocasiones, negro en una y dorado en la restante. Tal y como ha 
ocurrido con las revistas dirigidas a mujeres, no es el color lo que caracteriza al logo, el cual es variable, sino su tipografía.

\begin{tabular}{cccc} 
Marzo & JUNIO & SEPTIEMBRE & DICIEMBRE \\
\hline Inicio & Inicio & Inicio & Inicio \\
\hline Noticias & Noticias & Noticias & Noticias \\
\hline Cool & Cool & Cool & Cool \\
\hline Hombres alfa & Hombres alfa & Hombres alfa & Hombres alfa \\
\hline Varios & Varios & Varios & Varios \\
\hline Estilo & Estilo & Estilo & Estilo \\
\hline Coach & Coach & Coach & Coach
\end{tabular}

TABLA 29. Estructura de la revista Men's Health en 2015 (ejemplares de marzo, junio, septiembre, diciembre).

FUENTE: Elaboración propia.

El interior de Men's Health comienza con una serie de contenidos a los que hemos denominado Inicio. Se trata de los datos de la revista, el sumario, el editorial y un consultorio. Al contrario de lo que ocurría en las revistas femeninas, el editorial ya no es un avance del interior de la revista, sino que, Jordi Martínez, director de Men's Health, escribe sobre temas tan variados como son los selfies (“\#Selfitmania” Men’s Health, núm. 1160, 2015), los mensajes en las galletas de la fortuna ("El mono listo" Men's Health, núm. 162, 2015) o incluso utiliza su página para despedirse de Gerard Solé, director de moda en Men's Health, (“Insustituible” Men’s Health, núm. 165, 2015).

Tanto en el número de junio como en el de septiembre, en el sumario aparece una foto a gran tamaño de una mujer en ropa interior. Mientras, el consultorio, etiquetado bajo la llamada Pregunta a $M H$ sirve para volcar todo tipo de dudas que les surgen a los lectores: “¿Vale la pena pagar más por un colchón de látex? (Men’s Heatlh, núm. 157, 2015), “En una idiotez empezar a utilizar cremas antiedad antes de los 35?” (Men's Health, núm. 165, 2015), “¿En qué se diferencian los antitranspirantes de los desodorantes? (Men's Health, núm. 162, 2015).

La primera sección que encontramos en la revista Men's Health es la de Noticias: comprende 6 unidades redaccionales de media, son siempre de una página de extensión y el tema más repetido es la salud (83\%). El porcentaje restante se lo dividen a partes iguales las relaciones entre mujeres y hombres y la belleza. Se trata de un espacio muy 
visual, generalmente cada unidad redaccional consta de una imagen a gran tamaño alrededor de la cual se distribuye el texto.

Dentro de salud, que es la categoría más repetida, vemos nutrición, deporte y prevención. Nutrición introduce los beneficios de consumir ciertos alimentos, así ocurre en “Corazón salvado” (Men's Health, núm. 160, 2015), que relaciona la ingesta de salvado de avena con el descenso del colesterol, o en "La presión de la remolacha" (Men's Health, núm. 162, 2015). Deporte ofrece técnicas para mejorar en ciertas disciplinas: “Tu mejor táctica" (Men's Health, núm. 165, 2015) se centra en las medias maratones, mientras que "Buena técnica, menos caídas" (Men's Health, núm. 162, 2015) trata sobre ciclismo. En prevención encontramos estrategias para para evitar problemas de salud, así, “Bloquea las distracciones (Men's Health, núm. 157, 2015) habla del peligro de utilizar varios dispositivos — móviles, ordenadores, etc. — a la vez, comportamiento que puede derivar en depresiones, otro ejemplo sería "Huele a mareo" (Men's Health, núm. 160, 2015), el cual explica que oler ciertas fragancias inhibe la sensación de mareo.

Dos unidades redaccionales se centran en belleza, concretamente en el culto al cuerpo. De esta manera, “Apunta alto” (Men’s Health, núm. 157, 2015) y “Aumenta la exigencia de tus zancadas" (Men's Health, núm. 165, 2015) enseñan a modelar el cuerpo de forma que se ajuste a la estética que venden en sus portadas: cuerpos musculados trabajados en el gimnasio. Por último, las dos unidades redaccionales restantes versan sobre relaciones entre mujeres y hombres. "No enseñes los billetes" (Men's Health, núm. 160, 2015) es un estudio que asegura que las mujeres se sienten más atraídas por hombres ahorradores y "Mejor repartido" (Men's Health, núm. 157, 2015) es otro estudio que incide en la importancia de repartir el trabajo en casa para lograr mayor felicidad dentro de la pareja.

Tras Noticias, encontramos Cool que es un pequeño apartado que comprende 3 unidades redaccionales de media. La sección la abre siempre un reportaje que ocupa de 3 a 4 páginas, sin embargo, el resto de unidades redaccionales ocupan una página cada una. El tema más tratado es el ocio y la cultura (50\%) seguido de la tecnología (29\%). La primera unidad redaccional queda reservada, sin excepción, a un fotorreportaje sobre un nuevo modelo de coche o moto. Vemos el vehículo a doble página y las características del mismo. El asesoramiento viene de la mano de Adolfo Randulfe, especialista en motor de Men 's Health. Una página más tarde, otras marcas son presentadas como "Los rivales". Los titulares bajo los que conocemos a estos coches son "Segunda juventud" (Men's 
Health, núm. 160, 2015), "Lígate la ciudad” (Men’s Health, núm. 157, 2015) o "Siempre ganas" (Men's Health, núm. 165, 2015).

En cuanto al ocio y la cultura, lo vemos dentro de esta sección en las etiquetas Tiempo libre y Escapadas. Men's Health nos propone destinos como Croacia "Croacia: el paraíso encontrado" (Men’s Health, núm. 162, 2015) o Barcelona "Hacia el infinito y más allá” (Men's Health, núm. 160, 2015). También sugiere una exposición en el museo Guggenheim "Los animales de Koons" (Men’s Health, núm. 160, 2015) o la última novela de Danny Miller, Besos para los malditos (Men’s Health, núm. 157, 2015).

La sección más larga es la de Hombres alfa, con una media de 14 unidades redaccionales. Un primer reportaje de tres páginas abre el bloque de contenidos, el resto de unidades redaccionales son de una página de extensión. Se tratan diversos temas, siendo los más repetidos la salud (37\%), la belleza (25\%) y la moda (20\%), aunque también vemos ocio y cultura, relaciones entre hombres y mujeres, sexualidad, gastronomía o ciencia. De nuevo, salud comprende las temáticas de prevención, deporte y nutrición, tal y como había ocurrido en la sección Noticias. Sin embargo, esta vez, en nutrición encontramos la voz de la experta Anabel Fernández y en deporte los consejos del experto en rendimiento Fito Florensa y del experto en fitness Guillermo Alvarado.

En belleza vemos cosméticos y culto al cuerpo. Los cosméticos aparecen en la etiqueta fija Cuidado personal y en otras variables como Producto estrella o Fragancia estrella. Cremas ("Protección outdoor" Men's Health, núm. 157, 2015), perfumes (“¿Juegas para ganar? Men’s Health, núm. 165, 2015) o cuchillas de afeitar (“Afeitados a domicilio" Men's Health, núm. 162, 2015) son anunciadas en esta sección. En cuanto el culto al cuerpo, la propuesta es la de encajar dentro de unos cánones de belleza físicos. Por otro lado, la etiqueta fija Apuesta $M H$ nos introduce en el mundo de la moda, vendiendo algún tipo de prenda, como puede ser una cazadora (“Ande yo caliente” Men's Health, núm. 157, 2015), aunque también encontramos accesorios como relojes ("Hora de aventuras", Men's Health, núm. 157, 2015) o gemelos ("Pásate al lado oscuro, Men's Health, núm. 165, 2015).

Hombres alfa es la primera sección que incluye entre sus páginas a personajes famosos. Bajo la etiqueta Primera persona se agrupan cuatro entrevistas, una en cada número a analizar, que nos permiten conocer aspectos profesionales y personales del actor Chris Evans, del deportista de parkour Kie Willis, del surfista Kai Lenny y del boxeador Robert Minniti. También, aparece el actor Santi Millán en una competición de ciclismo 
y en Chica MH la modelo Ariadne Artiles, que posa en ropa interior, responde a una serie de preguntas personales.

Tras Hombres alfa, llega un siguiente bloque de contenidos al que hemos denominado Varios. Como la anterior, se trata de una sección larga, con una media de 14 unidades redaccionales. Las piezas son más extensas de lo que veníamos observando, pudiendo ocupar entre 2 y 9 páginas. De nuevo los temas más tratados son la salud (55\%) y la belleza (20\%). Encontramos también relaciones entre hombres y mujeres y tecnología.

Como en secciones anteriores, la salud incluye nutrición, prevención y deporte. Las voces expertas que escriben dentro de este bloque de contenidos son los deportistas Israel Llansola y Joel González. Para la categoría belleza volvemos a ver culto al cuerpo con el entrenador Jonathan Cañada y con el experto en rendimiento Fito Florensa. Tecnología aparece sobre todo en diciembre, con motivo de la época navideña: auriculares ("Pon la oreja” Men's Health, núm. 165, 2015), cámaras de última generación (“A ráfagas" Men's Health, núm. 165, 2015) o unas pesas inteligentes ("Deporte con cabeza" Men's Health, núm. 165, 2015) son algunos de los gadgets propuestos.

Un $12 \%$ de los contenidos se centra en las relaciones entre hombres y mujeres, principalmente en el aspecto sexual de las mismas. Así lo vemos en "Tu chica, tu táctica" (Men's Health, núm., 162, 2015), “Arrasa en las apps” (Men's Health, núm. 160, 2015) o “Las 6 nuevas formas del sex appeal” (Men’s Health, núm. 157, 2015). En septiembre, encontramos un reportaje extenso, de hasta 9 páginas, titulado "Calienta el septiembre" (Men's Health, núm. 162, 2015), donde se ofrecen técnicas de conquista masculina para ligar con mujeres, a la vez que se ilustran las páginas con fotos en biquini de la modelo Charlotte Mackinney.

En cuanto a los reportajes protagonizados por famosos, en el número de junio conocemos a los deportistas Vicent Fabra, Ahmed Labban, Florian Bornschier, Ben Gregory, James Lorenzo y Gabriel Pacca que, en "La armada invencible" (Men's Health, núm. 160, 2015), desvelan sus técnicas para competir en el deporte de élite. También vemos a los deportistas Víctor Trasende, Parker Gregory y a Josef Ajram y Raúl Gómez, estos últimos retándose en "Duelo en la Gran Manzana" (Men’s Health, núm. 165, 2015). Finalmente, el chef Paco Roncero saca su lado deportivo en "En forma con Paco Roncero" (Men's Health, núm. 165, 2015). 
La siguiente sección propuesta es la Estilo, donde la belleza ocupa un 45\% y la moda un 35\%. La media de unidades redaccionales es de 4 , algunas de ellas de hasta 9 páginas. Es en esta sección que encontramos los extensos fotorreportajes de moda. Tal y como ocurría en Hombres alfa, Estilo también incluye las etiquetas Producto estrella y Fragancia estrella que anuncian cosméticos tales como cremas o perfumes. La experta Alba Dorado y la dermatóloga M. Agustina Segurado asesoran dentro del reportaje “Operación bañador” (Men's Health, núm. 160, 2015), donde encontramos distintos tipos de desodorantes, técnicas de depilación, cremas solares o productos reductores. Por otro lado, los fotorreportajes de Estilo los protagonizan modelos anónimos, que posan con distintos conjuntos de ropa, salvo en el número de junio que es el propio modelo Ignacio Ondategui quien presenta los looks.

La publicación cierra con una sección llamada Coach. Cuenta con una media de 6 unidades redaccionales de entre una y dos páginas de extensión. Este bloque de contenidos se compone de belleza (77\%) y salud (8\%). El formato de Coach hace pensar en una revista dentro de la propia revista. Cuenta con su propia portada y se resalta la fecha a gran tamaño en todas las hojas, además de que el tipo de papel cambia y las páginas dejan de estar numeradas. La portada reza: Tu entrenador personal de bolsillo, lo que hace suponer que se podría tratar de un tipo de coleccionable útil para desprender del resto de la revista.

Aunque aparentemente se trate de una sección dedicada al deporte, encontramos principalmente belleza, ya que en el $77 \%$ de las ocasiones el contenido va enfocado al modelaje del cuerpo según la estética que Men's Health propone a sus lectores. De esta forma, se suceden las fotografías que enseñan cómo hacer pesas o series de ejercicios para ganar volumen y definir los músculos. En “¡Acelera tu metabolismo!” (Men's Health, núm. 157, 2015), el entrenador Marc Solá realiza un asesoramiento sobre ejercicios que se llevan a cabo en un cuarto de hora y en "Directo al éxito" (Men's Health, núm. 157), conocemos al boxeador Manny Pacquiao.

Finalmente, la salud, presente en el 23\% del espacio, la encontramos en las páginas de nutrición, como puede ser en “¿Cuánto pollo es suficiente?” (Men’s Health, núm. 160, 2015), que informa sobre los beneficios de este tipo de carne; también en el contenido relacionado con el deporte - “Consigue un 10” (Men's Health, núm. 165, 2015), que trata sobre atletismo - o en las unidades redaccionales de prevención, como sería “Sal por piernas” (Men's Health, núm. 165, 2015) que describe distintas lesiones. 
De las seis publicaciones, Men's Health es la que cuenta con el número más reducido de personalidades famosas. Solo en el 21\% de las unidades redaccionales encontramos que una persona o grupo de personas asesoren, protagonicen o firmen el espacio. Más concretamente, en un $11 \%$ de las unidades redaccionales un experto o experta asesora sobre algún tema, un $8 \%$ están protagonizadas y un 2\% las firma alguien. En total, contamos con la presencia de hasta 31 personas que se dividen entre las tres funciones (véase tabla 30). De las 31 personas, el 67\% desempeñan la función de protagonistas, el 30\% asesoran y el 3\% restante escribe.

\begin{tabular}{lccc} 
& Protagoniza & Escribe & Asesora \\
\hline MuJERES & 2 & - & 2 \\
\hline HOMBRES & 18 & 1 & 7 \\
TABLA 30. Función de las personas en Men's Health (muestra año 2015). \\
FuENTE. Elaboración propia.
\end{tabular}

Adolfo Randulfe, especialista en motor, Fito Florensa, experto en rendimiento, Guillermo Alvarado, experto en fitness y Anabel Fernández, experta en nutrición, cuentan con sección fija todos los meses en la que ofrecen consejos sobre su especialidad. Por otro lado, puntualmente nos encontramos con el asesoramiento de los deportistas Israel Llansola y Joel González, de los entrenadores Jonathan Cañada y Marc Solá y de la experta (no se especifica en qué) Alba Dorado. Mientras, en todos los números escribe Jordi Martínez, director de la revista. Lo hace en las primeras páginas de la publicación bajo la etiqueta Primeras palabras y trata temas variados.

Como ya se ha avanzado, la función en la que más gente encontramos es en la de protagonista, donde se reúnen 20 personas. De ellas, un 90\% son hombres mientras que el $10 \%$ restante son mujeres. La profesión más repetida para los hombres es la de deportista (14), seguida de la de actor (2), chef (1) y modelo (1). Las mujeres son ambas modelos. Los motivos que les llevan a protagonizar las páginas son en un 95\% profesionales para los hombres y otros motivos para las mujeres.

Así, el único hombre que no protagoniza una unidad redaccional por su profesión es el chef Paco Roncero, quien habla de su pérdida de peso y su actual forma física ("En forma con Paco Roncero" Men's Health, núm. 165, 2015). Mientras, la modelo Ariadne Artiles responde a preguntas personales en "Nuestra top más top" (Men’s Health, núm. 
165, 2015) y Charlotte McKinney protagoniza un reportaje en el que aparece posando sensualmente y ofreciendo consejos para ligar ("Calienta el septiembre” Men's Health, núm. 162, 2015).

Men's Health, por tanto, bien sea sirviéndose de una personalidad más o menos relevante $(21 \%$ de los casos) o prescindiendo de cualquier protagonismo humano $(79 \%$ de los casos), ahonda, principalmente, en dos temáticas: la salud (40\%) y la belleza (31\%). Aunque en menor medida, su agenda llega también hasta otros aspectos como son la moda $(10 \%)$, la tecnología (7\%), las relaciones heterosexuales $(5 \%)$, el ocio y la cultura (4\%).

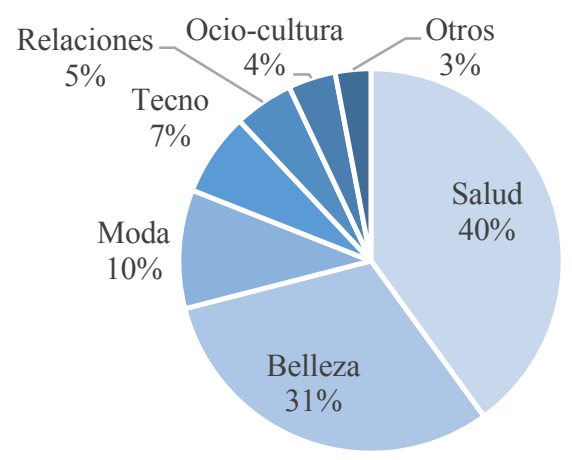

GrÁFICo 14. Contenidos de la revista Men's Health en marzo, junio, septiembre y diciembre de 2015.

FuENTE: Elaboración propia.

\subsection{Esquire}

Esquire es La revista para hombres interesantes según el eslogan de la propia publicación. Esta revista masculina nació en Estados Unidos hace más de ocho décadas. Su editorial nos informa de que va dirigida a "hombres intelectualmente curiosos. Atentos a la actualidad, la moda y el estilo de vida". Además, ofrece "artículos sobre diversos temas, desde política hasta salud, pasando por la moda, el arte o la gastronomía”. El 74\% de sus lectores comprenden entre 30 y 50 años. ${ }^{81}$

La licencia española llegó en 2007 por parte de Hearst Magazine International y puso a la cabeza a Andrés Rodríguez, quien se ocupó de Esquire durante sus diez primeros años de vida. Desde octubre de 2017, Jorge Alcalde, también director de la revista QUO,

81 Véase información publicada en 2016. "Esquire". Recuperado el 24 de septiembre de 2016 de http://spainmedia.es/esquire/ 
dirige la publicación. Andrés Rodríguez asegura que el impacto de Esquire en el mercado español fue tal que supuso un antes y un después para el resto de publicaciones hermanas.

Esta idea la leemos en el medio online El Español el 27 de agosto de 2017:

Desde que publiqué Esquire, cuando nadie pronunciaba bien su nombre, el sector de las revistas masculinas ha cambiado radicalmente. Lo escribo con toda la humildad del mundo, pero el detonante de dicho cambio fue la llegada de Esquire. Desapareció la legendaria Man de la que tanto hemos aprendido, $D T$ fue vendida por mi amigo Daniel Medvene, FHM dejó de editarse y llegó Icon como suplemento de El País. GQ se ha revitalizado y está mejor que nunca con mi compañero Daniel Entrialgo como director, con el que he compartido tantos buenos ratos imaginando Esquire. ${ }^{82}$

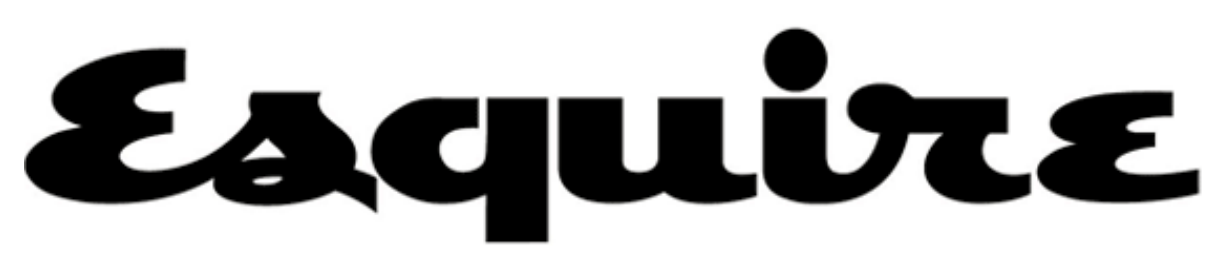

IMAGEN 27. Logotipo de la revista Esquire. Fuente: Esquire.

Esquire cuenta con versión digital (www.esquire.es) en la que encontramos contenido inédito que se actualiza con regularidad. Vemos información gráfica y audiovisual. Presenta hasta 17 secciones (Moda, Grooming, En forma, Cine, Música, Gastro, Motor, Sexo y Relaciones...), una de las cuales, Revista, anuncia del número que podemos encontrar en papel.

En cuanto a la portada de Esquire, esta rompe con el esquema composicional básico que llevábamos viendo en las anteriores revistas. Cinco elementos componen la página: la cabecera, la imagen figurativa, el número del ejemplar, una frase y el código de barras. Se trata de una portada minimalista que, por norma general, no precisa de términos compositivos ya que los elementos no llegan a superponerse. La cabecera se encuentra en la parte superior de la portada y está formada por el logotipo, el sitio web, la fecha y el precio. La tipografía del logotipo es caligráfica y de corte recto, en mayúscula la primera letra. Se trata de un diseño con cuerpo, de trazos gordos y caracteres

\footnotetext{
${ }^{82}$ Véase información publicada en 2017: “Así dejé de editar Esquire”. Recuperado el 20 de noviembre de 2017 de https://www.elespanol.com/reportajes/20170826/242105789_13.html
} 
redondeados. Los colores usados son el blanco en dos ocasiones, el negro en una y el rosa en una. El sitio web, la fecha y el precio son sencillos y de trazo fino.

\begin{tabular}{|c|c|}
\hline NOMBRE & Esquire \\
\hline DESCRIPCIÓN & La revista para hombres interesantes \\
\hline DIRECCIÓN ONLINE & www.esquire.es \\
\hline ORIGEN & Estados Unidos \\
\hline GRUPO EDITORIAL & Hearst España \\
\hline LUGAR DE EDICIÓN & Madrid \\
\hline DIRECTOR & Jorge Alcalde \\
\hline PRIMER NÚMERO & $\begin{array}{l}1933 \text { (Estados Unidos) } \\
2007 \text { (España) }\end{array}$ \\
\hline PERIODICIDAD & Mensual \\
\hline DIFUSIÓN & 28.202 ejemplares (OJD: julio 2013/ junio 2014) \\
\hline PRECIO & $3,50 €$ \\
\hline Páginas & $\begin{array}{l}\text { Máximo: } 254 \text { (marzo) } \\
\text { Mínimo: } 182 \text { (junio, septiembre) }\end{array}$ \\
\hline FORMATO & $201 \times 274 \mathrm{~mm}$ \\
\hline EDICIONES INTERNACIONALES & $\begin{array}{l}\text { Bulgaria, China, Colombia, Corea, Estados Unidos, Filipinas, } \\
\text { Grecia, Holanda, Hong Kong, Indonesia, Kazajistán, Latinoamérica, } \\
\text { Malasia, Oriente Medio, Reino Unido, República Checa, Rumaní, } \\
\text { Rusia, Serbia, Singapur, Tailandia, Taiwán, Turquía y Vietnam. }\end{array}$ \\
\hline
\end{tabular}

TABLA 31. Ficha morfológica de la revista Esquire.

FueNTE: Elaboración propia.

La imagen figurativa de la portada la protagonizan cuatro personajes masculinos. En el número de marzo lo hace Ethan Hawke, en junio James John Gandolfini, en septiembre Steve Carell y en diciembre Tenzin Gyatso. Los tres primeros son actores mientras que el último es el actual Dalai Lama. Al no ajustarse ninguno de estos personajes a los cánones de belleza normativos, entendemos que no se trata este de un requisito a tener en cuenta a la hora de protagonizar la portada de Esquire y que pesa más la identidad que el valor físico.

De los cuatro varones, solo Steve Carrell mira a cámara. De su cara cuelga un rollo de cinta adhesiva que aprisiona sus facciones y hace referencia a la vuelta al trabajo (véase imagen 28). La foto de James John Gandolfini es de su juventud y aparece en blanco y negro. Ambos actores llevan traje mientras que el Dalai Lama viste su túnica roja y amarilla. Las fotografías están tomadas en un primer plano, resaltando el rostro, 
esto es, la identidad de los protagonistas, por encima de su físico. El fondo es de color gris para tres de las portadas y azul para la cuarta.

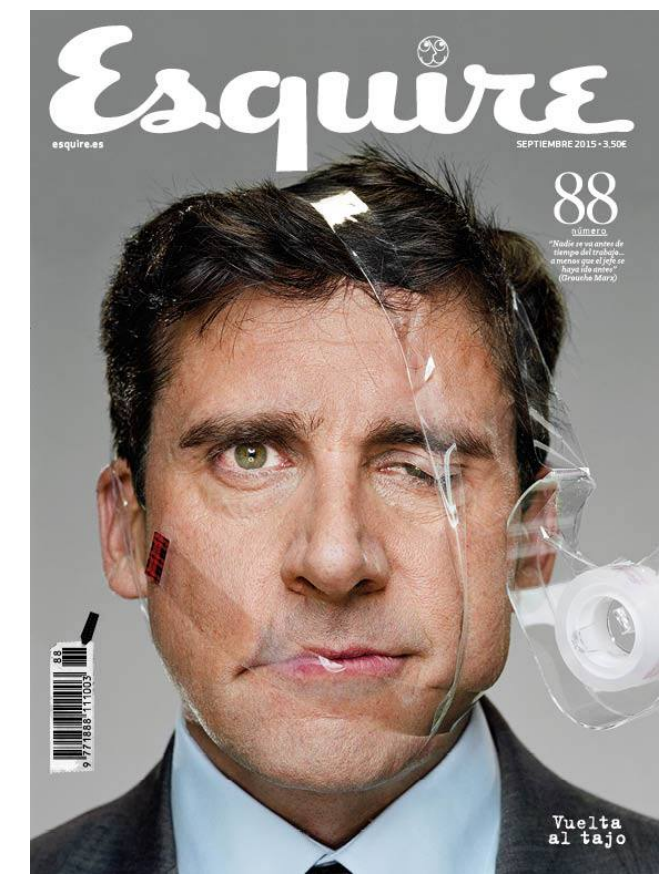

IMAGEN 28. El actor Steve Carrell en la portada de septiembre de 2015 de Esquire.

FUENTE: Esquire.

Esquire incorpora en cada una de las portadas una cita de algún personaje famoso: "Para tener éxito en estos tiempos, vale más ser un atleta que un drogadicto (Steve Van Zandt)" (Esquire, núm. 83, 2015) o "Nadie se va antes de tiempo del trabajo... a menos que el jefe se haya ido antes (Groucho Marx)" (Esquire, núm. 88, 2015). Siempre es presentada en letra pequeña, en minúsculas, cursiva y adornada con remates. También, en el mes de junio y en el de septiembre se incluyen las siguientes frases “¿Aún ves la maldita televisión?” (Esquire, núm. 86, 2015) y "Vuelta al tajo" (Esquire, núm. 88, 2015) a modo de titulares, aunque muy breves y escuetos.

El número del ejemplar resalta por su gran tamaño. Este, situado siempre sobre la cita, presenta una tipografía sencilla pero elegante, con remate en aquellas cifras que se prestan a ello. El color es blanco o negro, depende del fondo sobre el que se proyecte. Que el número adquiera tanta importancia dentro del conjunto total de la portada hace que pensemos en la revista Esquire como en un elemento de coleccionista, aportándole así un cierto estatus. 


\begin{tabular}{cccc} 
MARZO & JUNIO & SEPTIEMBRE & DICIEMBRE \\
\hline Inicio & Inicio & Inicio & Inicio \\
\hline Checkin & Checkin & Checkin & Checkin \\
\hline Gastro & Gastro & Gastro & Gastro \\
\hline En esto creo & En esto creo & En esto creo & En esto creo \\
\hline El gurú & El gurú & El gurú & El gurú \\
\hline Grooming & Grooming & Grooming & Grooming \\
\hline Business class & Business class & Business class & Business class \\
\hline- & Teleadictos & - & - \\
\hline Varios & Varios & Varios & Varios \\
\hline Estilo & Estilo & Estilo & Estilo \\
\hline Gheckout & Checkout & Checkout & Checkout \\
\hline Cierre & Cierre & Cierre & Cierre
\end{tabular}

TABlA 32. Estructura de la revista Esquire en 2015 (ejemplares de marzo, junio, septiembre y diciembre).

FUENTE: Elaboración propia.

Esquire abre con una serie de contenidos a los que hemos denominado Inicio. Se trata del sumario, el editorial y las cartas de los lectores. El editorial, etiquetad bajo el título La carta del director aborda en cada número un tema distinto. Lo firma Andrés Rodríguez, director en el 2015 de Esquire. En "Malditos oficios" (Esquire, núm. 88, 2015), escribe sobre la vuelta a la rutina y aconseja el libro Budismo para principiantes con el fin de hacer más llevadero el mes de septiembre, mientras que “¿Dónde estás?” (Esquire, núm. 83, 2015) son unas líneas que dedica a su padre. También, en el número de marzo el escritor Jordi Soler ("Novelas, sueño y memoria” Esquire, núm. 83, 2015) y en el de junio el guionista Eduardo Ladrón de Guevara ("Una reflexión sobre nuestra ficción televisiva" Esquire, núm. 86, 2015) escriben algunas de sus reflexiones. Además, a lo largo del sumario aparecen fotografías que avanzan contenidos del interior de la revista. Mientras, en el apartado Las cartas de los lectores es el propio público quien escribe sobre lo que más le ha gustado del número anterior.

La primera sección que encontramos en la revista Esquire es la de Checkin, la cual comprende 10 unidades redaccionales de media, principalmente de una página de extensión. El gran protagonista absoluto es el ocio y la cultura (93\%). Tan solo vemos pinceladas de tecnología, gastronomía y moda en la entrevista "Los favoritos de... Collin Farrell" (Esquire, núm. 86, 2015), donde el actor responde acerca de sus gustos personales en cuanto a alimentos, ropa o coches.

La primera página de Chekin lleva la etiqueta Chicas que nos ponen de buen humor. La protagoniza siempre una actriz, en este caso encontramos a Michelle Calvó, 
María Guinea, Berta Vázquez e Ivana Baquero todas ellas posando de manera sensual. La foto de las actrices es a página completa y la acompaña una columna de texto encabezada por un chiste y una pequeña biografía. Otra de las etiquetas que encontramos en esta sección es la de Arte, donde conocemos al artista visual Daniel G. Andújar, al fotógrafo Manuel Franquelo, a la artista y escultora Louise Bourgeois y a la fotógrafa Tina Modotti. También aparece el artista Andy Warhol. Entrevista nos acerca a Maggi Marco, de nuevo artista, y Fotografia hasta el fotógrafo Bruce Davidson. Literatura lo protagonizan los escritores Martín Caparros y Andrew Croft, Libros los periodistas Dick Lehr y Gerard O’Neill y Poesía el poeta Carlos Miguel Cortés.

En Música vemos a los cantantes Merle Haggard, Josh Ritter y a la cantante Natalie Prass. También aparecen los músicos Graham Parker, Lou Reed, John Cale, Sterling Morrison, la música Moe Tucker y el compositor Mark Ronson. Vida de una canción lo protagoniza Frank Sinatra en el número de septiembre y la banda The Who en diciembre. En Danza aparece el bailaor Curro de Candela. Para Cine vemos al empresario Peter Becker, al actor Armie Hammer y a los directores Apichatpong Weerasethakul, Lázló Nemes y Hou Hsiao-Hsien. En los meses de junio y diciembre leemos la etiqueta Fotos con historia. Narra el suceso que rodea a una foto antigua. Los protagonistas son el músico Bob Dylan y el actor y director de cine Woody Allen. Lo mismo sucede en Biblioteca Esquire con el fotógrafo Douglas Kirkland y la actriz Marilyn Monroe. Por último, Filosofía nos acerca hasta el filósofo Yves Michaud.

Tras Checkin, Esquire ofrece la sección Gastro. Como su propio nombre indica, dedica sus contenidos al mundo de la gastronomía: así lo atestiguan el 67\% de sus contenidos. Se trata de una sección no muy larga, comprende entre 4 y 5 unidades redaccionales de una o dos páginas de extensión. Por Gastro desfilan bebidas como la ginebra ("Escoge bien tus compañías" Esquire, núm. 83, 2015), el vermú ("Sesión vermú" Esquire, núm. 86, 2015), el champán (“My champagne is rich”, Esquire, núm. 86, 2015), el vodka ("Máxima pureza" Esquire, núm. 86, 2015) o el vino ("El otro freixenet" Esquire, núm. 91, 2015). Encontramos salsas ("Mejor con salsa" Esquire, núm. 83, 2015), mortadela ibérica ("Lo nunca visto" Esquire, núm. 83, 2015), aceites de oliva virgen extra ("Un jardín en la botella” Esquire, núm. 88, 2015) o queso ("Ha llegado el invitado perfecto" Esquire, núm. 88, 2015). Son productos gourmet que encajan con el encabezado de la sección Alimento para paladares exquisitos. 
La restauración $(28 \%)$ es la otra temática que cuenta con bastante peso: nos proponen distintos locales (“Al menos una vez en la vida” Esquire, núm. 88, 2015 o "No te quedes dentro" Esquire, núm. 86, 2015) y conocemos al barman Paris Durante y al carnicero Dario Cecchini. En el mes de diciembre, bajo la etiqueta Receta del mes, se enseña a hacer un tartar de salmón (Esquire, núm. 91, 2015).

Seguidamente, encontramos el apartado En esto creo. Se trata de una pequeña sección que ahonda en aspectos personales de distintos personajes famosos. Concretamente, encontramos a los actores Ray Winstone e Iam McKellen, al escritor Jonathan Coe, al tenista Boris Becker, al sociólogo y filósofo Zygmunt Bauman, al Dalai Lama Tenzin Gyatson y a Justo Gallego, un antiguo monje conocido por llevar desde 1963 construyendo él mismo una catedral en Mejorada del Campo, Madrid. También, en el número de diciembre, el arma de guerra AK-47 aparece personificada hablando sobre su trayectoria. Son unidades redaccionales de dos páginas cada una, la primera la ocupa el texto, la segunda una fotografía del protagonista. En ellas se pueden leer reflexiones, hábitos, creencias, rutinas, lazos familiares, carreras profesionales, inclinaciones políticas, sueños o gustos personales de quienes dan voz a estas líneas.

La sección El gurú es la más larga de Esquire, con una media de 13 unidades redaccionales. Por primera vez, vemos a la moda ganar protagonismo sobre el resto de categorías, y es que la encontramos en el 93\% del espacio. E1 7\% restante es tecnología, ocio y cultura. Las piezas presentan una extensión variable: una o dos páginas cuando se anuncia un producto aislado o serie de productos aislados y hasta 10 páginas si estamos hablando de un fotorreportaje de moda.

En El gurú las marcas de ropa y accesorios encuentran el escaparate perfecto donde mostrar sus últimos lanzamientos. En la mayoría de las páginas vemos ropa, zapatos y relojes. También aparecen algunos personajes como son los guionistas Mark Duplass y Jay Duplass, el piloto de Fórmula 1 Nico Rosberg y los actores Joel Bosqued e Idris Elva, que nos enseñan su estilo a la hora de vestir. Finalmente, conocemos una de las pocas relojerías independientes que quedan en Suiza de la mano del relojero Theodore Schneider y descubrimos cuáles son los rincones favoritos de Tokio para el director creativo de Louis Vuitton, Kim Jones.

La belleza ocupa un 73\% de la siguiente sección Grooming, siendo la temática principal en este espacio. El resto de categorías que encontramos son moda, ocio y cultura y salud. No se trata esta de una sección muy larga, cuenta con una media de tres unidades 
redaccionales por ejemplar. La extensión de las mismas es variable, dependiendo de si estamos ante un fotorreportaje, que puede ser de hasta 6 páginas, o ante un producto aislado, entonces veremos una página o dos. Los productos que encontramos en su mayoría son cosméticos (perfumes y cremas). En el número de marzo conocemos al perfumista Bon Vivant. Por su lado, los reportajes “Al son de las olas” (Esquire, núm. 86, 2015) y “A todo gas” (Esquire, núm. 86, 2015) incluyen ropa y accesorios, de ahí que también veamos moda en esta sección. Además, el último de ellos, sugiere una lectura. La salud la encontramos en "Tu nuevo yo" (Esquire, núm. 83, 2015) que incluye consejos para cuidar el cuerpo: hacer ejercicio, beber agua, dormir las suficientes horas, comer mejor o evitar el consumo excesivo de alcohol son algunos de ellos.

Tras Grooming, llega el espacio Business class, en el que Esquire se sumerge en el mundo de los negocios. Lo componen una media de 4 unidades redaccionales cuya extensión suele ser de una o dos páginas. Encontramos cuatro etiquetas fijas: Ejecutivo del mes, Otros negocios, Perfil y Tendencias. La sección abre con la etiqueta Ejecutivo del mes. Se trata de un reportaje a doble página en el que nos acercamos a los aspectos profesionales de cuatro empresarios: el mes de marzo lo protagoniza Juli Guiu, empresario musical, en junio aparece Ignacio Miranda, director general de Samsonite, posteriormente, el mes de septiembre es para Jesús Alonso, consejero delegado de Ford, y, finalmente, Yancey Strickler, fundador de Kickstarter, cierra el año.

Otros negocios es un espacio similar al anterior. En este caso, conocemos al diseñador de moda Felipe Oliveira Baptista, al CEO y empresario Marco Palmieri, a los directores creativos Pablo de Campo (Saatchi\&Saatchi) y Juan García Escudero (Leo Burnett) y al presidente y cofundador de Artsy Sebastian Cwilich. Para Perfil vemos a Juan Manuel, director de Lavinia y a José Luque García, director del hotel Fuerte Miramar. Finalmente, "Tokyo Camera Style" (Esquire, núm. 86, 2015) es un fotorreportaje de 10 páginas que nos enseña el trabajo del fotógrafo John Sypal.

Seguidamente de Business class, se despliega un bloque de contenidos al que hemos denominado Varios. Cuenta con una media de 7 unidades redaccionales por ejemplar, todas ellas extensas. Los temas tratados van desde el ocio y la cultura (51\%), hasta la gastronomía, la moda, la tecnología o la belleza. Ocio y cultura, la categoría más relevante, se compone principalmente de reportajes personales a profesionales del sector: a los músicos Bruce Springsteen y Paul McCartney, al director de orquesta, Zubin Mehta, a la actriz Emilia Clarke, a los actores Ethan Hawke, Jason Statham y Steve Carell, a los 
fotógrafos Jean-Baptiste, Alejandro Guijarro y Alejandro Almaraz, al escritor Philip Kerr, al diseñador gráfico Ryan Germick, al pintor y artista gráfico Juan Genovés, al funambulista Philippe Petit, al ilustrador Ian Johnson y al promotor de Ibermúsica Alfonso Aijón. Vemos, también, el trabajo del fotógrafo Nigel Parry en "Dead stars" (Esquire, núm. 86, 2015), ocho páginas en las que aparecen los retratos de Lou Reed, músico, Margaret Thatcher, política, Alexander McQueen, diseñador de moda, Allen Ginsberg, poeta, Luciano Pavarotti, cantante de ópera y Alfred Eisenstaedt, fotógrafo.

En "10 cosas que aún no sabes de las mujeres” (Esquire, núm. 83, 2015), la actriz Melani Olivares posa de manera sensual. Lo mismo ocurre en los reportajes categorizados como Woman we love, donde vemos a Evangeline Lilly, actriz ("Verdades y mentiras" Esquire, núm. 83, 2015), María Sharapova, tenista ("Hay mucho que amar de la historia detrás de María” Esquire, núm. 86, 2015) y Kate Mara, actriz (“iQué delicia... Kate Mara!” Esquire, núm. 88, 2015), que posan en ropa interior. En el número de diciembre, la actriz Emilia Clarke también protagoniza su propio reportaje lleno de fotografías sensuales (“El maravilloso equilibrio de Emilia Clarke” Esquire, núm. 91, 2015).

La belleza, la tecnología, la gastronomía y la moda las encontramos en Obsesiones, que es un fotorreportaje que se repite a lo largo de los números de marzo, junio y diciembre. Son 10 páginas en las que los productos se presentan en forma de ilustraciones dibujadas a mano. "Doodles" (Esquire, núm. 83, 2015) es otro fotorreportaje sobre los diferentes diseños de la plataforma Google. En "Muy lejos” (Esquire, núm. 83, 2015) conocemos a Scott Kelly, astronauta y "Sex o délica” (Esquire, núm. 83, 2015), habla del movimiento hippie de los años 60. Se trata de un reportaje en el que aparecen varias fotos de la época de mujeres posando desnudas.

Trasn belleza, vemos la sección de Estilo, que es la que menos unidades redaccionales abarca, pero en la que más extensas son: los números de septiembre y diciembre constan de una unidad redaccional, ambas de 14 páginas; mientras, en marzo y junio vemos dos piezas por ejemplar, de 8, 10, 18 y 20 páginas. Se tratan de fotorreportajes, todos ellos dedicados a la moda, en los que modelos anónimos posan con distintos conjuntos de prendas y accesorios.

La última sección que encontramos es Checkout. La media de unidades redaccionales es de 6, todas ellas breves, de entre una o dos páginas de extensión. Lo que más vemos en este apartado es tecnología, ocupando un 54\% del espacio, seguido de ocio y cultura $(31 \%)$. 
La tecnología lo componen gadgets y motor. Bajo la etiqueta El coche del mes, que se repite en todos los ejemplares, aparece un reportaje de dos páginas anunciando las características de un nuevo vehículo. También, en "Propón a la vida" (Esquire, núm. 88, 2015), “Actitud ante todo" (Esquire, núm. 86, 2015), "En frasco pequeño” (Esquire, núm. 83, 2015) e "Imaginando formas" (Esquire, núm. 91, 2015) encontramos más coches. Los gadgets van desde altavoces, (“Melómano confeso" Esquire, núm. 83, 2015, "Música por (y hacia) todos los lados" Esquire, núm. 86, 2015) hasta equipos completos de música (“Música sin límites...” Esquire, núm. 88, 2015) pasando por, incluso, drones ("Esto ya es otra historia” Esquire, núm. 91, 2015).

En ocio y cultura nos presentan planes como el festival Starlite ("Cerca de las estrellas" Esquire, núm. 88, 2015), viajes a la Ciudad de México ("La ciudad abrumadora" Esquire, núm. 91, 2015), un recorrido por "Los mejores spas del mundo" (Esquire, núm. 83, 2015) o conocemos al pintor Juan Uslé en el reportaje a doble página titulado "El artista que quiere ser artista" (Esquire, núm. 88, 2015).

Finalmente, Esquire cierra su publicación con un último bloque de contenidos al que hemos denominado Cierre. Se trata de una sección breve, 3 unidades redaccionales de media de una o dos páginas de extensión, dedicada al ocio y la cultura. Este espacio lo componen tres etiquetas fijas In memoriam, Backstage y Tarjetero.

In memoriam comprende una foto antigua de un personaje famoso. En los casos del músico B. B. King, del cantautor Javier Krahe y del diseñador gráfico Michael C. Gross, la foto ocupa toda una página. Mientras, cuando se trata del productor de televisión Toni Verna, del periodista Jesús Hermida y del actor José Sazatornil la foto es a doble página. Para Backstage encontramos la misma fórmula, una fotografía antigua ocupando una página en la que reconocemos, en el mes de marzo, a la actriz Audrey Hepburn junto con el director de cine George Cukor, al actor Telly Savalas en junio, al director y actor Orson Welles en septiembre y al actor Richard Gere en diciembre. Finalmente, Tarjetero incluye distintas tarjetas de visita de locales donde poder comer o tomar unas copas, ya no solo en España, sino que por todo el mundo.

Cabe añadir que, en el número de junio, encontramos el especial Teleadictos. Son 5 unidades redaccionales dedicadas al mundo de la televisión. Cada una de ellas está protagonizada por alguien relacionado con este mundo. El bloque de contenidos lo abre el reportaje al actor ya fallecido James Gandolfini, donde leemos acerca de su biografía (“La leyenda de un Soprano” Esquire, núm. 86, 2015). Le sigue una entrevista al profesor 
de física y astronomía David Saltzberg que resulta ser asesor científico en la serie televisiva The Big Bang Theory ("Mr. Big Bang" Esquire, núm. 86, 2015). En “Transparent" (Esquire, núm. 86, 2015), conocemos los logros profesionales del actor Jeffrey Tambor. Posteriormente, la actriz Kerry Bishé, posa en ropa interior en el artículo "Un chiste divertido por Kerry Bishé” (Esquire, núm. 86, 2015), donde, a parte del chiste, se añaden unas líneas con su biografía. Por último, el actor Bob Odenkirk protagoniza un fotorreportaje de moda "Better call saul" (Esquire, núm. 86, 2015), que finaliza con una página dedicada a conocer su carrera en el mundo de la actuación.

Tal y como hemos ido viendo a lo largo de las páginas anteriores, son muchas las personalidades famosas que aparecen en la revista Esquire. Así, en el 46\% de las unidades redaccionales, encontramos que una persona o grupo de personas protagonizan o firman el espacio. Más concretamente, un $43 \%$ de las unidades redaccionales están protagonizadas y un 3\% están firmadas. En total, contamos con la presencia de hasta 117 personas que se dividen entre las dos funciones (véase tabla 33). El mayor porcentaje de personalidades protagonizan la unidad redaccional (97\%) y el 3\% restante escribe.

\begin{tabular}{lccc} 
& Protagoniza & Escribe & Asesora \\
\hline MUJERES & 17 & - & - \\
\hline HOMBRES & 96 & 3 & - \\
TABLA 33. Función de las personas en Esquire (muestra año 2015). \\
FuENTE: Elaboración propia.
\end{tabular}

Andrés Rodríguez, director de la publicación en el 2015, firma La carta del director, editorial que encontramos en las primeras páginas de la revista. El escritor Jordi Soler y el guionista Eduardo Ladrón de Guevara tienen su columna en los meses de marzo y junio respectivamente. Como ya se ha avanzado, la función en la que más gente encontramos es en la de protagonista, donde contamos hasta 114 personas. De ellas, un $85 \%$ son hombres y el 15\% restante son mujeres. Las profesiones más representadas para los varones son aquellas pertenecientes al ámbito musical (20), mientras que las mujeres son actrices (11). En los hombres también vemos actores (15), empresarios, directores o fundadores de negocios (13), fotógrafos (10), artistas en general (7), directores de cine (6), escritores (4), periodistas (3), deportistas (2), diseñadores de moda (2), filósofos (2), diseñadores gráficos (2), guionistas (2) y otros (9). En cuanto a las mujeres, aparte de las 
mencionadas actrices, encontramos dos pertenecientes al ámbito musical, una escultora, una fotógrafa, una política y una tenista.

El motivo por el que aparecen en la publicación es profesional tanto para el $89 \%$ de los varones como para el $88 \%$ de las mujeres. En los casos restantes, seis de los protagonistas masculinos protagonizan el espacio En esto creo, el cual repasa las convicciones personales de cada uno de ellos. Por otro lado, los actores Bob Odenkirk y Joel Bosqued ponen su imagen a espacios de moda, así como los guionistas Mark Duplass y Jay Duplass. Finalmente, vemos los gustos en cuanto a ocio y cultura, tecnología, gastronomía o moda de Colin Farrell ("Los favoritos de... Colin Farrell” Esquire, núm. $86,2015)$ y los lugares favoritos de Tokio del director creativo de Louis Vuitton, Kim Jones (“Tokio de la mano de Kim Jones” Esquire, núm. 91, 2015).

Cuando las mujeres no aparecen en las unidades redaccionales por motivo de su profesión, lo hacen por motivos personales, como es el caso de la tenista María Sharapova en la entrevista "Hay mucho que amar de la historia detrás de María" (Esquire, núm. 86, 2015) que ahonda en temas de su vida privada y, en "10 cosas que aún no sabes de las mujeres" (Esquire, núm. 83, 2015), la actriz Melani Olivares lanza diez afirmaciones con las que se pretende englobar el modo de pensar del sexo femenino.

Finalmente, y a modo de resumen, destacar que, ya sea con la ayuda de una personalidad relevante ( $46 \%$ de los casos), o prescindiendo de cualquier protagonismo humano (54\% de los casos), Esquire ahonda, principalmente, en dos temáticas: el ocio y la cultura (41\%) y la moda (29\%). Aunque, en menor medida, su agenda llega también hasta otros aspectos como son la tecnología (9\%), la gastronomía (7\%), la belleza (5\%), y la sociedad $(2 \%)$.

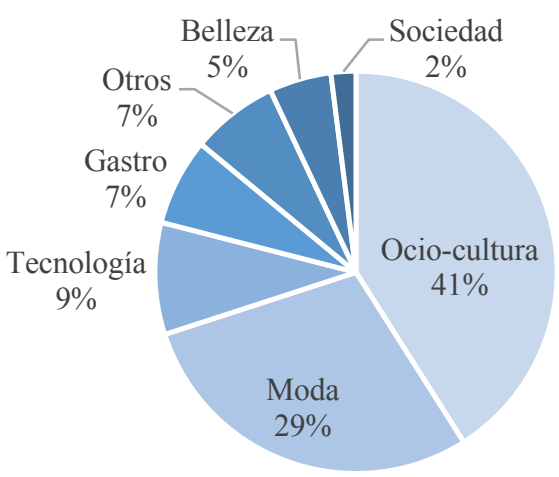

GráfICo 15. Contenidos de la revista Esquire en marzo, junio, septiembre y diciembre de 2015.

FUENTE: Elaboración propia. 


\subsection{DT}

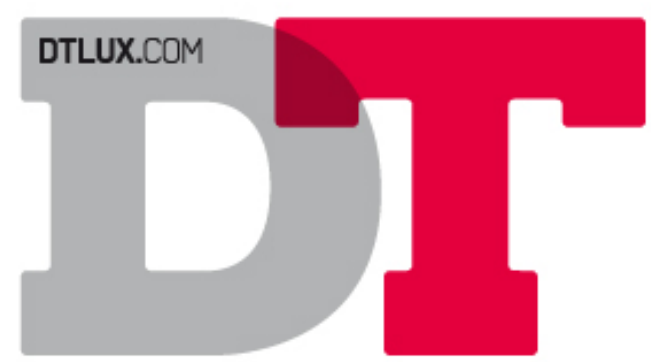

IMAGEN 29. Logotipo de la revista $D T$.

FUENTE: $D T$.

\section{FICHA MORFOLÓGICA DE LA REVISTA $D T$}

NOMBRE $D T$

\begin{tabular}{|c|c|}
\hline DESCRIPCIÓN & La revista para hombres que saben lo que quieren \\
\hline DIRECCIÓN ONLINE & www.dtlux.com \\
\hline ORIGEN & España \\
\hline GRUPO EDITORIAL & MC Ediciones, S.A. \\
\hline LUGAR DE EDICIÓN & Madrid \\
\hline ÚLTIMO DIRECTOR & Miguel Bañón \\
\hline PRIMER NÚMERO & 1992 \\
\hline ÚLTIMO NÚMERO & 2018 \\
\hline PERIODICIDAD & Mensual \\
\hline DIFUSIÓN & 25.434 ejemplares (OJD: julio 2013/ junio 2014) \\
\hline PRECIO & $3,00 €$ \\
\hline \multirow[t]{2}{*}{ Páginas } & Máximo: 194 (marzo) \\
\hline & Mínimo: 146 (junio, septiembre y diciembre) \\
\hline FORMATO & $210 \times 283 \mathrm{~mm}$ \\
\hline DISTRIBUCIÓN & Alemania, Francia, Grecia, Reino Unido, Italia, Portugal y Suiza. \\
\hline TEGORÍA TEMÁTICA & Estilo de vida (OJD) \\
\hline
\end{tabular}

TABLA 34. Ficha morfológica de la revista $D T$.

FUENTE: Elaboración propia.

Hasta que dejara de publicarse en $2018,{ }^{83} \mathrm{DT}$ se anunciaba a sí misma como $\mathrm{La}$ revista para hombres que saben lo que quieren, según su propio eslogan, el cual podíamos encontrar en el lomo de la publicación. Fundada en 1992, ofrecía moda, motor, tecnología, cine, música, viajes, etc. Su público comprendía entre los 35 y 44 años de

${ }^{83}$ Véase información publicada el 2 de febrero de 2018: “Cierra la revista masculina DT tras 26 años en el mercado". Recuperado el 24 de mayo de 2019 de https://www.periodisticos.com 
edad. ${ }^{84}$ DT llegó al mercado en 1992 de la mano de Focus Ediciones (Armentia et al., 2011: 15), grupo que también editaba otras cabeceras masculinas como FHM y STUFF.

Su primer director fue Daniel Medvene. Medvene asegura que $D T$ nació como una revista de estilo de vida para hombres y para mujeres. Sin embargo, en 1998, surgieron serios problemas con los anunciantes, los cuales preferían enfocar sus presupuestos hacia la prensa específicamente segregada. Esto provocó que $D T$ se reinventase como una cabecera plenamente masculina. ${ }^{85}$ En 2010, Focus Ediciones fue absorbida por MC Ediciones, siendo este el último grupo editorial de $D T .{ }^{86}$ Desde febrero de 2015 hasta su cierre, Miguel Bañón, anterior director de la revista Zero, ${ }^{87}$ dirigió DT.

Los meses de marzo y octubre, DT lanzaba la edición Platinum, que contaba con más páginas de las habituales. Además, junto a $D T$, se incluían suplementos — como $D T$ especial relojes - u otras revistas pertenecientes a MC Ediciones —así ocurrió en septiembre de 2015, cuando la revista de decoración Casa Viva se adjuntó gratuitamente- Mientras, la versión digital (www.dtlux.com) presentaba contenido elaborado expresamente para la plataforma online, esto es, información gráfica y, también, audiovisual. Disponía de un menú desplegable que comprendía las secciones Home, Selected, Must, Dolce vita y Contacto. Del mismo modo, promocionaba su número en papel.

$D T$ presenta una peculiaridad en sus portadas que no habíamos visto en otras revistas. A lo largo del primer semestre del año 2015, comercializó dos portadas diferentes para un mismo ejemplar. Ambas se estructuraban en los tres niveles compositivos que ya habíamos ido encontrando anteriormente - titulares, imagen figurativa y cabecera-, la diferencia radicaba en que, en uno de los casos, la imagen figurativa la protagonizaba un hombre y en el otro una mujer (véase imagen 30).

Los titulares ocupan el primer término compositivo. El titular principal de $D T$ incluye el nombre de la famosa o el famoso que aparece en portada y una breve descripción que alude a su vida profesional. De David Muñoz se señala que es "El

\footnotetext{
${ }^{84}$ Véase información publicada en 2012: "MC Ediciones. DT". Recuperado el 24 de septiembre de 2016 de http://www.mcediciones.com/mediakits/DT 2011.pdf

${ }^{85}$ Véase información publicada en 2009: "Marketing periodístico: estrategias para seguir creciendo". Recuperado el 20 de noviembre de 2017 de https://blogdeperiodismocreativo.wordpress.com

${ }^{86}$ Véase información publicada en 2010: "MC Ediciones absorbe a Focus Ediciones". Recuperado el 20 de noviembre de 2017 de http://www.elpublicista.es/medios/mc-ediciones-absorbe-focus-ediciones

87 Véase información publicada en 2016: "Los 50 hombres gais más influyentes de España". Recuperado el 20 de noviembre de 2017 de http://amenzing.com
} 
cocinero que lo cambió todo" (DT, núm. 224, 2015) y de Naomi Campbell "La top model infinita" (DT, núm. 216, 2015). Los titulares secundarios abordan diversos temas como tecnología, motor, cine, televisión y viajes: "Paraísos de invierno, de Laponia a las Maldivas" (DT, núm. 224, 2015) o "Superdeportivos de última generación” (DT, 216, núm. 2015).

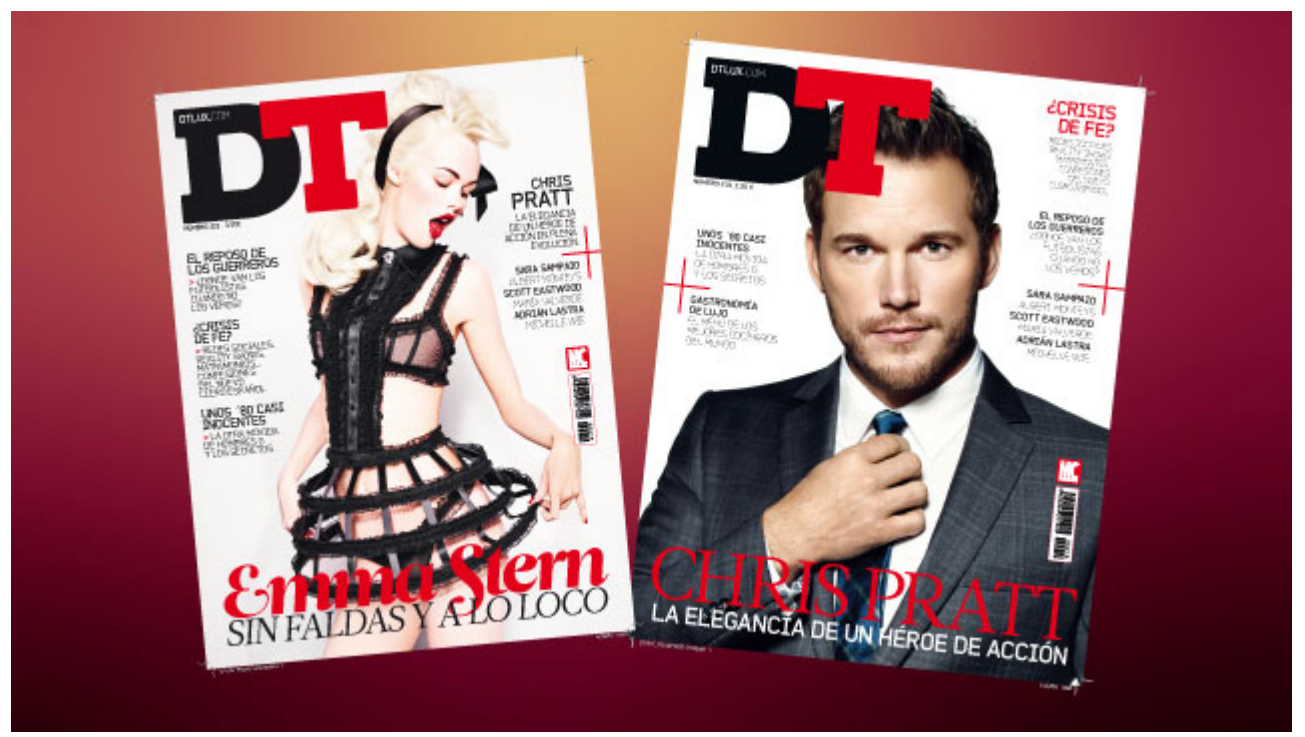

IMAGEN 30. Las dos portadas de la revista $D T$ de junio de 2015.

FUENTE: $D T$.

Los colores predominantes de la fuente son el blanco y el negro. El toque de color, rojo y naranja en este caso, aparece en los titulares principales. Cabe diferenciar entre dos tipos de tipografía: la de los titulares secundarios es simple, de corte recto y de trazo fino, sin adornos y en mayúsculas, mientras que la de los principales incorpora remates, es de estilo caligráfico y juega con las cursivas y el mayor grosor de trazo. Los titulares secundarios son mucho más sobrios y discretos que los de su compañera Men's Health o que los de las revistas femeninas.

En el segundo término compositivo, encontramos la imagen figurativa. En marzo de 2015 aparece la modelo Naomi Campbell, por un lado, y el actor John Corbett, por el otro. En junio Emma Stern, modelo, y Chriss Pratt, actor. En septiembre lo hace el jugador de baloncesto Ricky Rubio y en diciembre el chef David Muñoz. Las dos mujeres protagonizan planos más largos que los hombres (véase imagen 31). Ellas son retratadas en un plano americano, mientras que a los varones los sacan en planos cortos (dos planos 
medios y un primer plano, a excepción de Ricky Rubio que aparece en plano americano). Tal y como había ocurrido en las otras publicaciones, se enfatiza el cuerpo, en el caso de las mujeres, y el rostro, en el caso de los hombres.

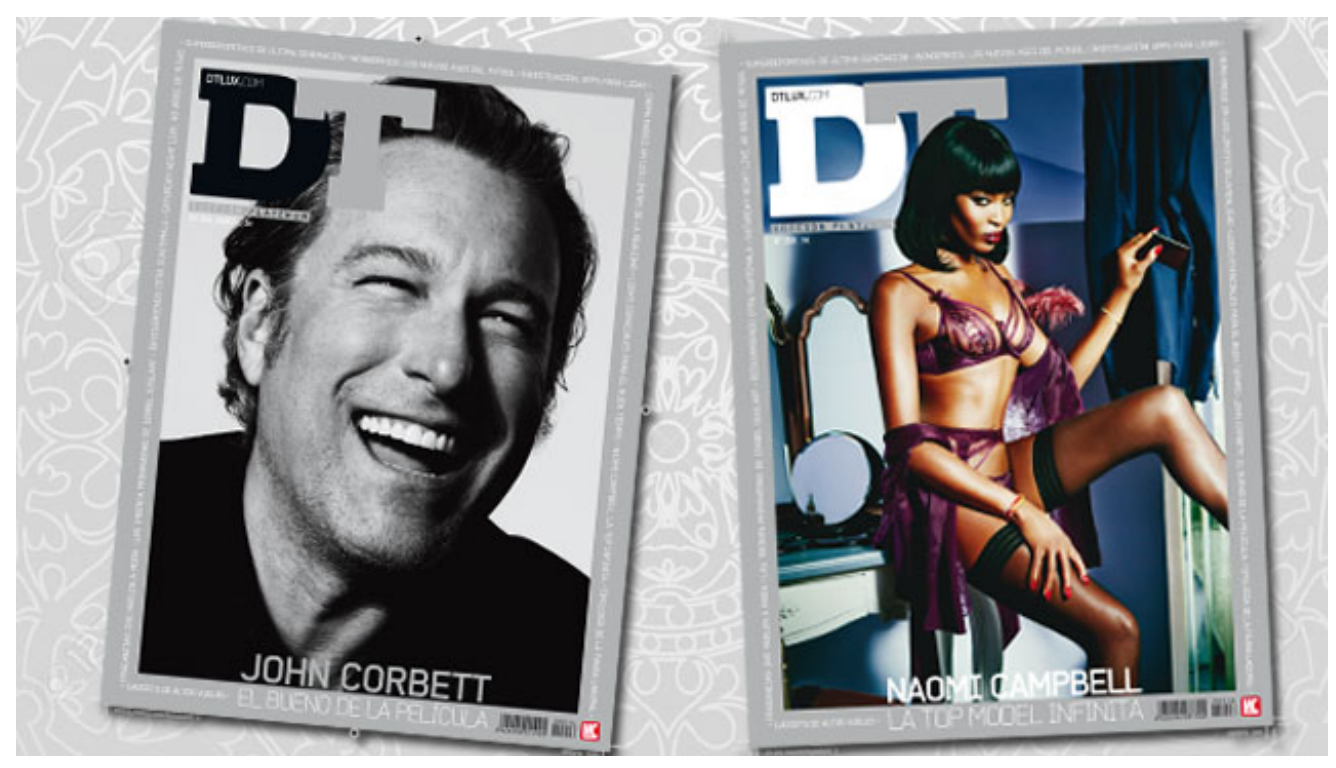

IMAGEN 31. Las dos portadas de la revista $D T$ de marzo de 2015.

FUENTE: $D T$.

El vestuario para las dos modelos es escaso, ambas posan en ropa interior, mientras que los hombres lo hacen en traje o, en el caso de David Muñoz, con su uniforme de trabajo. Las mujeres adoptan una pose sensual que intenta seducir a cámara, al contrario que los hombres. Además, se resaltan los labios femeninos con color rojo. Los fondos son monocromáticos (blanco, gris y rojo) excepto para Naomi Campbell que es retratada sobre un tocador permitiendo así al espectador contemplarla en un espacio íntimo.

En el tercer término compositivo encontramos la cabecera. Está formada por el logotipo de la revista, el sitio web, el número del ejemplar y el precio. El logotipo aparece en mayúsculas, la tipografía es recta con serifa cuadrada y de trazo muy grueso. Cada letra es de un color, detalle que no habíamos encontrado en el resto de publicaciones, aunque siempre aparece el blanco o el negro.

En cuanto a su agenda temática, la publicación abre con una serie de contenidos a los que hemos denominado Inicio. Se trata del sumario, los datos de la revista y el editorial. Este último lo firma Miguel Bañón, director de la revista en 2015, y aborda en 
cada número un tema distinto. En "Tiempo a solas" (DT, núm. 216, 2015) narra cuando conoció a la modelo Naomi Campbell, en "Divino tesoro" (DT, núm. 219, 2015) se retrotrae hasta su adolescencia, "Volver a lo mejor" (DT, núm. 224, 2015) trata sobre la rutina y "Pluralidad y realidad" (DT, núm. 224, 2015) habla de la navidad y los regalos.

\begin{tabular}{cccc} 
MARZo & JUNIO & SEPTIEMBRE & DICIEMBRE \\
\hline Inicio & Inicio & Inicio & Inicio \\
\hline Selected & Selected & Selected & Selected \\
\hline Varios & Varios & Varios & Varios \\
\hline Estilo & Estilo & Estilo & Estilo \\
\hline DT on & DT on & DT on & DT on \\
\hline Must & Must & Must & Must
\end{tabular}

TABLA 35. Estructura de la revista $D T$ en 2015 (ejemplares de marzo, junio, septiembre, diciembre). FUENTE: Elaboración propia.

La primera sección que encontramos es la de Selected. Es un apartado muy extenso, con una media de 26 unidades redaccionales por revista que comprenden una o dos páginas. Predomina la moda (34\%), aunque también vemos ocio y cultura $(25 \%)$, tecnología (14\%), gastronomía (13\%) y belleza (9\%). El 39\% de las unidades redaccionales de Selected están protagonizadas, lo que supone que, en total, desfilan hasta 67 personajes, 14 mujeres y 53 hombres.

La moda aparece tanto en unidades redaccionales donde vemos las prendas y accesorios, como en espacios en los que conocemos a profesionales del sector. En "Reunión de elegancia" (DT, núm. 219, 2015), siete bloggers presentan sus apuestas personales de vestuario para acudir a un evento. Paul y Cat, sastres, nos presentan su sastrería en "Paul \& Cat. Sastrería 21" (DT, núm. 221, 2015). El diseñador Enzo Fusco protagoniza "Enzo Fusco. El líder de moda" (DT, núm. 221, 2015). La modelo Stella Mylläry y los bailarines Laurent Bourgeois y Larry Bourgeois posan en "Una colección con swing” (DT, núm. 216, 2015). También, las modelos Isabeli Fontana ("Kendall y sus amigas" DT, núm. 221, 2015) y Naomi Campbell (“Oro negro” DT, núm. 221, 2015) cuentan con sendos espacios en los que podemos ver las fotos de sus últimas campañas de lencería. En cuanto a profesionales del mundo del ocio y la cultura, encontramos actrices (Julianna Florrick, Inma Cuesta, Kate Mulgrew, Kimmy Schimidt, Emmy Rossum), actores (Domhall Gleeson, Adrián Lastra, Scott Eastwood, Javi Rey), directores 
de cine (Win Wenders, Ion de Sosa), cantantes (Gonçal Planas, Anni B Sweet, Enrique Bunburi), o bandas completas de música (Durán, Arte de Vivir).

La tecnología se nos presenta en forma de motor, de gadgets — bajo la etiqueta $4 \times 4$ vista en todos los ejemplares — y de apps — como en "Zona de descarga" (DT, núm. 224, 2015) —. Motor es la que más relevancia tiene, así, varias unidades redaccionales patrocinan coches: "Historias del capó" (DT, núm. 216, 2015), "La perla del mediterráneo", "Liberad a la bestia” y "Los hijos del viento 2015” (DT, núm. 219, 2015); "El alma de un coche único" y "Para llegar muy lejos” (DT, núm. 221, 2015); “Conducir un best-seller" y "Tres asientos son multitud” (DT, núm. 224, 2015). Además, otras unidades redaccionales hacen lo propio con las motos: "La conquista de la ciudad (DT, núm. 219, 2015) y "Moto por Montera" (DT, núm. 221, 2015). También, conocemos al director de comunicación de SEAT, Fernando Salvador, en "Vida al volante" (DT, núm. 219, 2015).

Para gastronomía encontramos bebidas y alimentos, como en "Comer es un placer” (DT, núm. 219, 2015), y leemos sobre Javier García Vicuña, experto en la preparación de cócteles ("El arte se sirve frío” DT, núm. 221, 2015) o sobre el chef Iván Domínguez ("Mareas vivas en Madrid" DT, núm. 224, 2015). Finalmente, en belleza vemos cosméticos, como fragancias (“Oler con mucho carácter” $D T$, núm. 216, 2015) o cremas ("Mucho cuidado" DT, núm. 221, 2015), y nos acercamos hasta la vida profesional de Jean Claude Ellena, perfumero (“La pasión de oler” DT, núm. 224, 2015).

Tras Selected llega un bloque de contenidos al que hemos denominado Varios. Son diez unidades redaccionales de media por revista, cuya extensión varía entre las 2 páginas como mínimo y las 10 como máximo. Encontramos, principalmente, ocio y cultura (50\%), aunque también vemos moda (15\%), tecnología (9\%) o gastronomía (9\%). Al igual que sucedía en Selected, la presencia de protagonistas es elevada, pudiendo contar hasta 56 personas, 11 mujeres y 45 hombres.

La música está muy presente en el número de junio, donde vemos sendas entrevistas al conjunto musical Hombres G (“Están locos... ¿y qué?” DT, núm. 219, 2015) y a Los Secretos (“Inmunes a las modas" DT, núm. 219, 2015). Del mundo del cine y la televisión encontramos a varios actores (John Corbett, Michael Fassbender y Ricardo Gómez) y en el reportaje "La forma que ellos miran" (DT, núm. 216, 2015) asistimos, a lo largo de 8 páginas, al trabajo de 4 fotógrafas y 6 fotógrafos. Además, vemos las obras 
del arquitecto Le Corbusier ("Genio y figura” DT, núm. 219, 2015) y del artista Chema Madoz ("El pequeño mundo de un genio" DT, núm. 216, 2015).

Los espectáculos deportivos también tienen cabida: "Wonder Kids, las nuevas estrellas del fútbol mundial" (DT, núm. 216, 2015) presenta a 8 jóvenes promesas del fútbol masculino y, en diciembre, leemos una entrevista al futbolista profesional John Neeskens. En el reportaje "El Draft. Bienvenidos al gran sueño americano" (DT, núm. 221, 2015), los jugadores de baloncesto Kristaps Porzingis y Robert Horry responden a varias preguntas sobre su carrera. El espacio lo cierra una entrevista a la estilista en la NBA Lorjelyn Baclig. Por último, el piloto de Fórumula 1, Andy Soucek, habla sobre su trayectoria profesional en "Un piloto con estilo" (DT, núm. 221, 2015).

Bajo la etiqueta Protagonista, presente en los números de junio, septiembre y diciembre, hay tres reportajes de 6 y 8 páginas al actor Chris Pratt, al jugador de baloncesto Ricky Rubio y al chef David Muñoz. Con la etiqueta Chica DT, presente en los cuatro ejemplares, nos acercamos hasta las modelos Izabel Goulart, Eva Doll, Emma Stern Nielsen, Candice Swanepoel y a la cantante Rita Ora. Protagonizan reportajes de 4 y 6 páginas. Estos cuentan con menos texto que los de Protagonista y mayor presencia de fotografías, en las que posan en ropa interior. Lo mismo ocurre con la modelo Sara Sampaio, que, bajo la etiqueta Chica explosiva, aparece a lo largo de 5 páginas en biquini, quedando una para el texto.

Otros personajes a los que conocemos son a los chefs Dani García, Thomas Bühner, Pascal Barbot y Grant Achatz (“A cuatro manos” DT, núm. 219, 2015). También, al maestro de yoga Marcos Jassan, al coach nutricional Leo Cerrudo y a los atletas Josef Ajram y Chema Martínez en un reportaje sobre deporte y nutrición llamado "Puesta a punto" (DT, núm. 221, 2015). En "Confesiones de sacristía, cómo responder ante Dios" (DT, núm. 219, 2015), el sacerdote Plácido y el seminarista Álex reflexionan sobre la situación actual de la fe y de la Iglesia.

La siguiente sección es la de Estilo. Aquí, la moda es la gran protagonista, ocupando el 100\% del espacio. La media de unidades redaccionales por ejemplar es de 8 , siendo estas de extensión variable. Por un lado, seguimos viendo las noticias, artículos o pequeños reportajes de una o dos páginas de extensión, mientras que, por el otro, nos encontramos con amplios fotorreportajes que presentan los looks masculinos del momento. Estos rondan las 10 páginas, aunque en el número de marzo encontramos uno de hasta 26 páginas ("La crème de la crème” DT, núm. 216, 2015). 
Las unidades redaccionales que no están protagonizadas nos muestran relojes (“En el preciso momento” DT, núm. 219, 2015; “Piezas elegidas” DT, núm. 216, 2015), maletines ("Seguridad y comodidad” DT, núm. 216, 2015), carteras, cinturones, zapatos ("El toque decisivo" DT, núm. 216, 2015), maletas ("Equipaje tatuado" DT, núm. 221, 2015), sudaderas (“La saliva por la garganta...” DT, núm. 221, 2015) o gafas ("Las gafas del camerino" DT, núm. 224, 2015), entre otros.

Además, encontramos reportajes a distintos profesionales del sector de la moda. La etiqueta Nombres propios nos acerca, en el mes de marzo, hasta el trabajo del diseñador de moda Giancarlo Petriglia y de los directores ejecutivos Eraldo Polleto (Furla) y Stéphane Crèmieux (Crèmieux). En Innovación, en el número de junio, conocemos al director de G-Star Shubhankar Ray, quien enseña sus propuestas en cuanto a mezclar la ecología y la moda se refiere. Como Icono, en diciembre, vemos al diseñador de moda Tommy Hilfiger. En el número de septiembre leemos sobre Ricardo Orlando, director del sur de Europa de Asos.

Hacia el final de la revista, aparece la sección DT on, que cuenta con una media de 7 unidades redaccionales por ejemplar. El mayor protagonismo es para la tecnología, que ocupa un $38 \%$ del espacio, le sigue el ocio y la cultura (31\%). También, vemos gastronomía, belleza y decoración. Dentro de esta sección, en cada número aparece anunciado un vehículo: varias motos en las etiquetas Abriendo gas (DT, núm. 221, 2015) y Dos ruedas (DT, núm. 224, 2015), cuatro coches en la etiqueta Motor (DT, núm. 216, 2015) y, finalmente, los últimos modelos de bicicletas eléctricas en A pedales (DT, núm. 219, 2015). El resto de la tecnología aparece en forma de gadgets: auriculares, cámaras de fotos, altavoces, móviles, equipos de música ("Sube el nivel” DT, núm. 216, 2015) o drones y relojes sumergibles (“Al agua gadgets” DT, núm. 219, 2015) son solo algunos de los ejemplos. Lo cierto es que estos aparatos, todos de alta gama, ocupan reportajes de varias páginas.

Dentro de DT on, encontramos dos etiquetas fijas: Viajes y Direcciones. Ambas proponen destinos, restauración y gastronomía. Algunas de las opciones que $D T$ ofrece a sus lectores son, por ejemplo, viajes a Alaska ("La última frontera” DT, núm. 219, 2015), Finlandia ("Laponia Finlandesa, en medio de la nada" DT, núm. 224, 2015) u hoteles y locales exclusivos (“El mundo a tus pies y a tu gusto” DT, núm. 216, 2015).

La belleza la vemos en forma de fragancias ("Inspira y vuelve a inspirar" $D T$, núm. 219, 2015) y la decoración aparece en la pieza "El cofre del tesoro", cajonera de 
diseño (DT, núm. 221, 2015). El chef Pedro Larumbe ("La despensa de otoño e invierno" DT, núm. 224, 2015) y Carlos Padura, Fundador del grupo Mercado de la Reina ("Un día en diurno" DT, núm. 224, 2015), protagonizan gastronomía. Finalmente, conocemos la trayectoria de Carlos Calero, director de Vincci Hoteles en "A la conquista del cinco estrellas" (DT, núm. 219, 2015).

$D T$ cierra sus ejemplares con la sección Must. Se trata de un último bloque de contenidos de dos unidades redaccionales, una de ellas de entre 8 a 12 páginas y la otra de una página de extensión. Encontramos, principalmente, ocio y cultura y algo de gastronomía. De las dos unidades redaccionales, la que es más extensa, aparece categorizada bajo la etiqueta Citas. Propone distintas exposiciones, los últimos estrenos en cine y en teatro, informa acerca de festivales, las nuevas novelas o los recientes trabajos musicales. También, informa sobre videojuegos y series, bebidas e incluso propone rutas gastronómicas.

En cuanto a la unidad redaccional de una página, aparece siempre protagonizada por algún personaje famoso y sirve para clausurar la revista. Con la etiqueta En primera persona, conocemos en el mes de marzo al cantante Mikel Erentxun, en junio al dibujante Albert Monteys, en septiembre al actor Carles Francino y en diciembre al también actor Alex González. Se trata de un espacio donde hablan en primera persona sobre sus gustos, vivencias, carreras profesionales y aspectos personales.

\begin{tabular}{lccc} 
& Protagoniza & Escribe & Asesora \\
\hline MUJERES & 17 & - & - \\
\hline HOMBRES & 96 & 3 & -
\end{tabular}

TABLA 36. Función de las personas en $D T$ (muestra año 2015).

FUENTE: Elaboración propia.

Como hemos ido viendo a lo largo de las páginas anteriores, son muchas las personalidades famosas que aparecen en la revista DT. Así, en el 38\% de las unidades redaccionales, encontramos que una persona o grupo de personas protagonizan o firman el espacio. Más concretamente, un $36 \%$ de las unidades redaccionales están protagonizadas y un $2 \%$ aparecen firmadas. En total, contamos con la presencia de hasta 136 personas que se dividen entre las dos funciones (véase tabla 36). El mayor porcentaje de personalidades protagonizan la unidad redaccional (99\%) y el 1\% restante escribe. La 
publicación de $D T$ no cuenta con columnas fijas o firmas puntuales, como si ocurría en el resto de revistas. En este caso concreto, solo su director en el año 2015, Miguel Bañón, escribe el editorial, en el que trata temas variados. Tampoco aparece ningún experto o experta asesorando sobre alguna temática.

Así, la función en la que más gente encontramos es en la de protagonista, donde contamos hasta 135 personas. De ellas, un 81\% son hombres y el 19\% restante son mujeres. Las profesiones más representadas para los varones son aquellas pertenecientes al ámbito musical (22), mientras que las mujeres son modelos (9). El resto de profesiones de los hombres son: deportistas (17), actores (16), director, CEO, fundador (13), blogueros (8), chefs (7), fotógrafos (7), diseñadores de moda (3), directores de cine (3) y otras profesiones (13). Las mujeres, después de modelos, son actrices (7), fotógrafas (4), cantantes (2) y otras profesiones (4).

Principalmente, el motivo por el que aparecen los y las protagonistas entre las páginas de la publicación es el profesional. Así ocurre con la totalidad de las mujeres y con el 97\% de los hombres. Las excepciones las encontramos en el guionista Antonio Hernández y el director de cine Blas Egea, ambos protagonizando una unidad redaccional del ámbito de la moda (“Fiebre de Cambios" DT, núm. 224, 2015). También, el director de la revista, Miguel Bañón, hace lo propio en “Moto por montera” (DT, núm. 221, 2015).

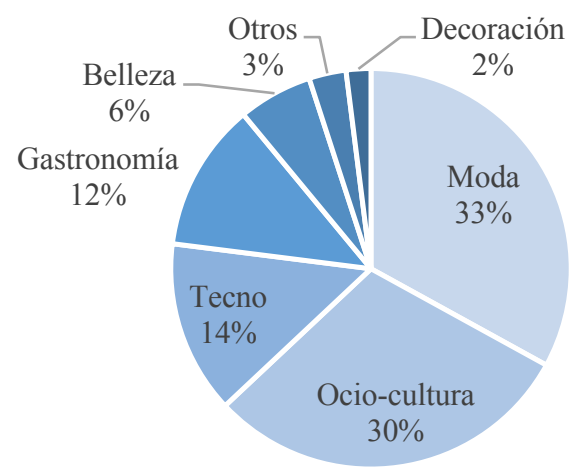

GrÁFICo 16. Contenidos de la revista $D T$ en marzo, junio, septiembre y diciembre de 2015.

FuENTE: Elaboración propia.

A modo de conclusión, vemos que $D T$, ya sea con la ayuda de una personalidad relevante (38\% de los casos), o prescindiendo de cualquier protagonismo humano $(62 \%$ de los casos), ahonda, principalmente, en dos temáticas: la moda (33\%) y el ocio y la 
cultura (30\%). Aunque en menor medida, su agenda llega también hasta otros aspectos como son la tecnología (14\%), la gastronomía (12\%), la belleza (6\%) y la decoración $(2 \%)$.

\section{LAS REVISTAS DE ESTILO DE VIDA Y SUS REPRESENTACIONES DE LA FEMINIDAD Y LA MASCULINIDAD}

Para abordar las representaciones que las revistas de estilo de vida hacen de la masculinidad y de la feminidad, enfrentaremos las distintas categorías que hemos ido viendo en el anterior epígrafe. Además, extraeremos textos literales y fotografías que nos permitirán explicar con más detalle cuál es el mensaje propuesto por la prensa en lo que a los modelos masculinos y femeninos se refiere.

Un primer análisis nos permite comprobar que las revistas de estilo de vida comparten, a grandes rasgos, el mismo tipo de contenidos. Sin embargo, encontramos diferencias en el espacio que dedican a cada categoría o en cómo la abordan.

\begin{tabular}{|rccc|ccc|}
\cline { 2 - 7 } \multicolumn{1}{c}{} & WOMAN & TELVA & GLAMOUR & MEN'S HEALTH & ESQUIRE & DT \\
\hline BELLEZA & $24 \%$ & $20 \%$ & $15 \%$ & $31 \%$ & $5 \%$ & $6 \%$ \\
\hline DECORACIÓN & $3 \%$ & $4 \%$ & $2 \%$ & - & - & $2 \%$ \\
\hline GASTRONOMÍA & $3 \%$ & $2 \%$ & $2 \%$ & - & $7 \%$ & $12 \%$ \\
\hline HOGAR & - & $4 \%$ & - & $10 \%$ & $29 \%$ & $33 \%$ \\
\hline MODA & $37 \%$ & $30 \%$ & $40 \%$ & $4 \%$ & $41 \%$ & $30 \%$ \\
\hline OCIO-CULTURA & $25 \%$ & $30 \%$ & $28 \%$ & $5 \%$ & - & - \\
\hline RELACIONES & - & - & $2 \%$ & $40 \%$ & - & - \\
\hline SALUD & - & $2 \%$ & $1 \%$ & - & $2 \%$ & - \\
\hline SOCIEDAD & $3 \%$ & $2 \%$ & $3 \%$ & $7 \%$ & $7 \%$ & $14 \%$ \\
\hline TECNOLOGÍA & $3 \%$ & $2 \%$ & $2 \%$ & $3 \%$ & $3 \%$ \\
\hline OTROS & $3 \%$ & $4 \%$ & $4 \%$ & & & $7 \%$ \\
\hline
\end{tabular}

TABlA 37. Contenidos de las principales revistas especializadas en estilo de vida en España (muestra año 2015).

FuENTE: Elaboración propia.

Vemos que la moda, el ocio y la cultura, la belleza y la tecnología son las cuatro categorías que comparten las seis publicaciones. Las tres temáticas predominantes en las revistas femeninas son la belleza, la moda, el ocio y la cultura, mientras que, en $D T$ y Esquire en lugar de encontrar belleza, encontramos tecnología. Men's Health se desmarca 
de sus compañeras ofreciendo como tema predominante la salud, seguido de belleza y moda.

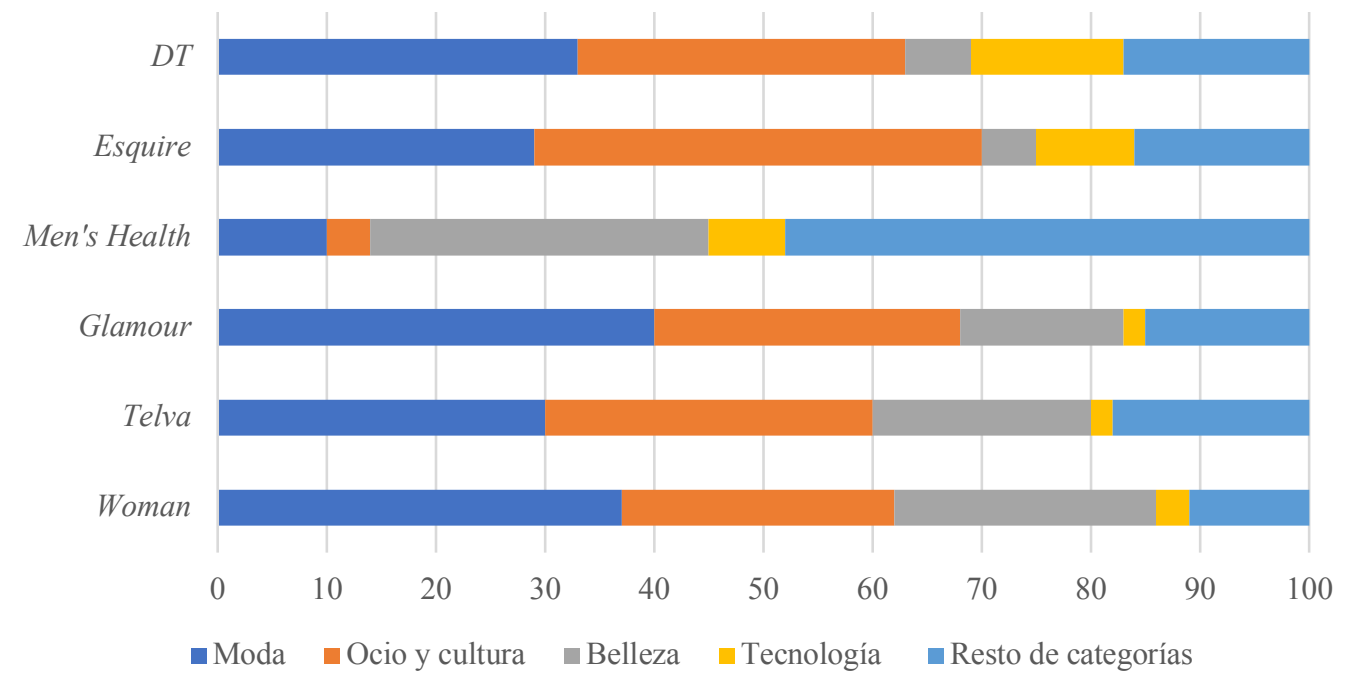

GráFICo 17. Distribución de las cuatro categorías que comparten las seis revistas de estilo de vida (muestra año 2015).

FUENTE: Elaboración propia.

\subsection{La tecnología, la decoración y el hogar como categorías diferenciadoras}

Aunque, como hemos mencionado, las revistas de estilo de vida compartan, en mayor o menor medida las mismas categorías, no todas aparecen del mismo modo. Así sucede con tecnología, más relevante en las revistas masculinas, o decoración, que tiene un mayor peso en las revistas femeninas. Mientras, hogar es una categoría que solo encontramos en la revista femenina Telva.

La tecnología es la tercera categoría más relevante en las publicaciones de $D T$ (14\%) y Esquire (9\%) y la cuarta en Men's Health (7\%). Las revistas femeninas, sin embargo, dedican menos espacio a esta temática: un 3\% Woman y un 2\% Telva y Glamour. Los temas tratados son apps e internet, gadgets y motor. Las publicaciones masculinas dedican el mayor número de unidades redaccionales al mundo del motor (41), seguidamente encontramos gadgets (23) y, finalmente, apps e internet (5). La relación entre los coches y la masculinidad se fragua desde edades bien tempranas. En un estudio realizado por la Universidad de Vigo, cuyos resultados fueron publicados en diciembre de 2017, se observa, según datos cualitativos, que tanto niños como niñas entienden que los coches son juguetes masculinos (Álvarez, Carrera-Fernández y Cid-Fernández, 2017: 
332). Durante la edad adulta, y por el discurso que rescatamos de las revistas analizadas, poseer un coche es garantía de éxito para los hombres (se entiende como éxito la conquista de mujeres): "el combate contra la decadencia masculina lleva librándose desde que el primer tipo con pelo en las orejas soltó una pasta para comprarse un coche que dejara alucinadas a las chicas" (Men's Health, núm. 165, 2015).

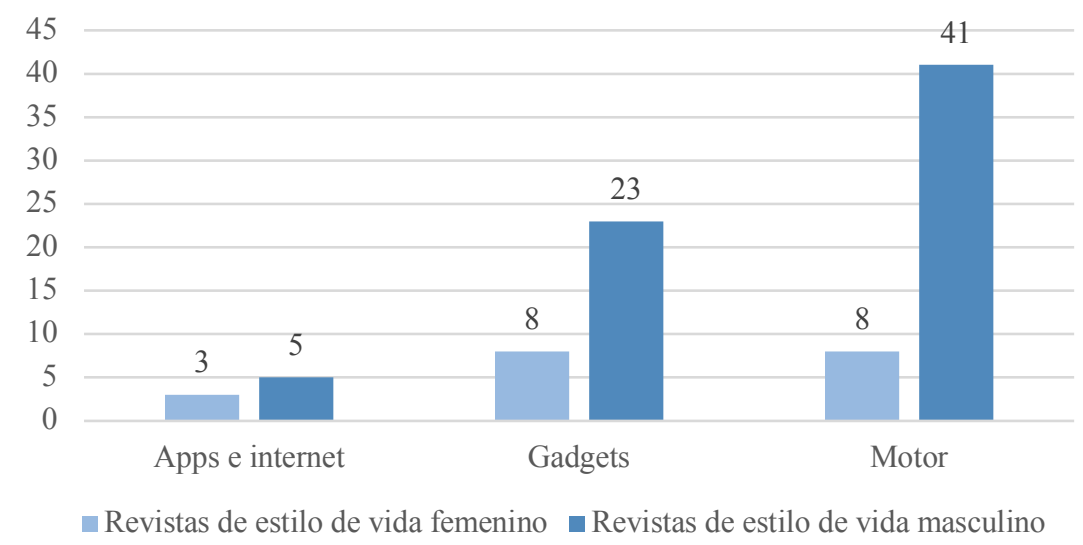

GráfiCo 18. Número de unidades redaccionales dedicadas a tecnología (muestra año 2015).

FUENTE: Elaboración propia.

En Men's Health, la sección Cool empieza siempre con una unidad redaccional dedicada al motor. Anuncia un modelo de coche o moto que introduce con titulares que alimentan la relación coches, masculinidad y éxito: "Lígate la ciudad” (Men's Health, núm. 157, 2015), "Siempre ganas" (Men’s Health, núm. 165, 2015), "Segunda juventud" (Men's Health, núm. 160, 2015). Una página más tarde aparece la etiqueta "los rivales", que es como denominan a otros modelos de coches o motos que también podrían ofrecer resultados similares para su conductor.

Esquire, por su lado, deja muy claro el valor que se le atribuye desde la masculinidad al mundo del motor: "no queremos presionarte, pero estaría bien que tomaras conciencia de la mejora que puede experimentar tu cuerpo (y tu mente) con una serie de pasos muy sencillos. La cosa es simple; cuídalo como si de tu moto/ coche se tratara" (Esquire, núm. 83. 2015). De las tres revistas, DT es la que más unidades redaccionales dedica a esta temática (un total de 18) y las introduce con titulares como "Liberar a la bestia” (DT, núm. 219, 2015), "Los hijos del viento" (DT, núm. 219, 2015), 
"La conquista de la ciudad" (DT, núm. 219, 2015) o "Cabalgar el hierro" (DT, núm. 224, 2015).

Mientras, las publicaciones femeninas apenas dedican espacio a la promoción de coches o motos ( 8 unidades redaccionales para ellas frente a 41 para ellos). Tampoco es especialmente relevante el espacio reservado a los gadgets, que son dispositivos electrónicos como móviles, auriculares, altavoces, reproductores de música, cámaras de fotos... Donde sí tienen mayor importancia es en las revistas masculinas (23 unidades redaccionales para ellos frente a 8 para ellas). La revista $D T$ llega, incluso, a relacionar gadgets y testosterona: "buscando la excelencia y nuestra propia razón de ser (somos una revista para hombres muy auténticos) hemos hecho gran hincapié en aquellas propuestas más cargadas de testosterona, esos juguetes para adultos que son los gadgets" (DT, núm. 224, 2015).

Por su lado, decoración es una categoría que, aunque no cuente con gran peso dentro de las publicaciones, vemos que sí aparece en todas las femeninas, Woman (3\%), Telva (4\%), Glamour (2\%), también en DT (2\%) y en una unidad redaccional de Esquire. En Esquire en "Bella geometría", se promociona una mesa de diseño (Esquire, núm. 88, 2015), por su lado, desde DT nos recomiendan una exposición sobre objetos de decoración ("Arte y estilo" DT, núm. 219, 2015), unas lujosas alfombras ("Pisando en blanco" DT, núm. 221, 2015), una cómoda de coleccionista ("El cofre del tesoro" DT, $221,2015)$ y una mesa con un singular diseño que incorpora un compartimento especial para poner hielo: "ya no tendrás que tomar más cerveza calentorra por pereza a levantarte hasta la cocina", nos dicen desde la publicación ("Sin ticket regalo", DT, núm. 224, 2015). En total, son 5 unidades redaccionales en las que la decoración está presente.

Las publicaciones femeninas, por el contrario, sí que incluyen más contenido relacionado con la temática -20 unidades redaccionales- $-\mathrm{y}$, en especial, Telva, la cual incorpora la sección exclusiva Decoración. Como sucedía en el caso de las masculinas, algunas de las piezas se centra en ofrecernos objetos de decoración (9 de ellas), una décima nos sugiere libros acerca de la temática y, algo que no ocurre en las revistas para hombres, accedemos al interior de hasta nueve casas y un atelier de moda.

Teniendo en cuenta las dos categorías anteriores, tecnología y decoración, podemos ir intuyendo de qué manera las revistas masculinas y femeninas entienden la distribución del espacio público y el espacio privado para hombres y mujeres. Mientras que a ellos les ofrecen coches con los que circular por la vía pública, a las mujeres se les 
proporciona una mayor cantidad de contenidos de decoración e interiorismo. Además, dado el desequilibrio de unidades redaccionales existentes en tecnología, se entiende que esta es, en general, una competencia masculina. Pues bien, existe un tercer ámbito que merece la pena abordar: el hogar.

La revista Telva incluye contenido de hogar (4\%) en su sección de cocina. Esta suele estar formada por una media de dos unidades redaccionales, comprende unas 8 páginas. Encontramos dos apartados: un recetario y los cursos de Escuela de Cocina Telva. El recetario está pensado para abastecer a 6 personas y, en total, incorpora hasta 38 recetas de lo más variadas. Se proponen en forma de platos sueltos o de menú completo —etiqueta Menú paso a paso, donde encontramos primer plato, segundo y postre-. Mientras, la Escuela de Cocina propone cursos y clases de cocina a las lectoras y a los niños y niñas. Glamour, aunque no incorpora sección de cocina, ofrece recetarios en dos ocasiones: "Show Cooking, cocinando entre estrellas" (Glamour, núm. 158, 2015) donde, a propósito de la navidad, reúne a algunas famosas para hablar "del perfecto banquete navideño" e incluye 6 recetas. Por otro lado, en "La revolución del pan" (Glamour, núm. 149, 2015), tres panaderas enseñan cómo hacer 3 tipos de pan.

En Men's Health vemos diez unidades redaccionales que incluyen recetas. En el mes de marzo, con la etiqueta Nutrición, encontramos cuatro recetas a base de pescado — pues la intención del reportaje es que los lectores incorporen omega 3 en su dieta(Men's Health, núm. 157, 2015). En junio, mientras, ofrecen una ensalada y un desayuno a los que han llamado “quemagrasas” (Men's Health, núm. 160, 2015). En septiembre, 4 aperitivos, 3 platos hechos de barbacoa (por considerarlos más sanos) y 4 recetas détox para los excesos del verano - todas las recetas están etiquetadas en nutrición- (Men's Health, núm. 162, 2015). Finalmente, vemos tanto "Sobrevive a las navidades sin engordar" (Men's Health, núm. 165, 2015), donde encontramos 3 aperitivos, una ensalada y una crema, como "Este invierno lo tienes crudo" (Men's Health, núm. 165, 2015), que incluye cinco recetas que no necesitan cocinarse. En total, 27 recetas.

En Esquire encontramos la sección Gastro con una media de entre 4 y 5 unidades redaccionales de una o dos páginas de extensión. Dedica sus contenidos a la gastronomía y la restauración. Principalmente, leemos propuestas de bebidas, alimentos gourmet o distintos locales. Comprobamos que en el mes de diciembre introducen una receta de un tartar de salmón ("Lo fácil si bueno" Esquire, núm. 91, 2015). Destacar que ni en DT ni en Woman hay ninguna receta. 
Tenemos pues, 47 recetas en las publicaciones femeninas (38 para Telva y 9 en Glamour) y 28 recetas en las publicaciones masculinas (27 en Men's Health y 1 en Esquire). Sin embargo, lo más significativo no es que las revistas femeninas nos ofrezcan 19 recetas más, sino la forma en que lo hacen. Podemos observar de qué manera Telva se centra en el abastecimiento del hogar proponiendo menús para toda la familia, mientras que Men's Health encaja sus recetas dentro de nutrición (gozar de mejor salud a través de los alimentos) o belleza. Glamour sigue insistiendo en la idea del hogar en su reportaje de diciembre acerca de las navidades.

Esquire, por su lado, ofrece una sección de gastronomía que nada tiene que ver con la de cocina de Telva. "Gastro, alimento para paladares exquisitos", que así sería su nombre completo, son propuestas de consumo de bebidas selectas — vermú, champán, vodka - y alimentos gourmet - mortadela ibérica, aceites de oliva virgen extra, quesoque no requieren elaboración alguna, a excepción de la receta del tartar de salmón. De esta forma, vemos que cada revista introduce desde distintos enfoques el tema de la alimentación, lo cual encierra distintas connotaciones: en Telva y Glamour encontramos hogar, en Men's Health nutrición y belleza y en Esquire gastronomía.

\subsection{El mito de la belleza en las revistas de estilo de vida}

La belleza es la temática más discordante entre publicaciones femeninas y publicaciones masculinas. Las revistas femeninas ofrecen un 24\% (Woman), 20\% (Telva) y 15\% (Glamour) de contenidos relacionados con la belleza. Woman incluye una sección exclusiva con una media de 8 unidades redaccionales que ocupan, cada una de ellas, entre una y 8 páginas. Telva inserta dicha temática, principalmente, en su sección Lo último, donde la belleza aparece hasta en un 39\% de las ocasiones. Lo hace con la etiqueta Belleza. Glamour, al igual que Woman, incorpora sección exclusiva, Belleza Glamour, la cual está formada por una media de 8 unidades redaccionales que ocupan entre 4 y 5 páginas cada una.

Esquire y DT dedican un 5\% y un 6\% respectivamente a esta temática. Ninguna de las dos publicaciones cuenta con una sección denominada de tal modo ni lo incorporan en sus etiquetas, salvo en una sola ocasión: en la página 28 del número de septiembre, $D T$ utiliza la etiqueta Belleza en el artículo "Mucho cuidado" (DT, núm. 211, 2015) que trata sobre cosmética —anuncian un set de limpiadores, exfoliantes y bálsamo—. Esquire, por 
su parte, aglutina los contenidos referidos a esta temática en la sección Grooming ("aseo" en inglés), que cuenta con una media de tres unidades redaccionales por ejemplar. Ambas publicaciones ofrecen fragancias, lociones de afeitado, limpiadores faciales o cremas.

Men's Health, sin embargo, le reserva un 31\% del espacio. Debemos distinguir entre dos tipos de contenidos que nos ofrece la revista. Por un lado, estarían los de culto al cuerpo ( $72 \%$ de la categoría belleza) y, por el otro, en los que encontramos cosméticos (que suponen el $28 \%$ dentro de esta categoría). Los primeros, aparentemente, son de salud, sin embargo, el fin último es el de modelar el físico de una determinada forma, lo cual se traduce en resultados estéticos. El editorial del mes de marzo, escrito por Jordi Martínez, “Lo quiero ¡ya!” resume muy bien este concepto:

\section{“¿¿¿PERO QUÉ MIERDA DE MUNDO ES ÉSTE??? ¡iACABO DE HACER POR LO MENOS DIEZ FLEXIONES Y AÚN TENGO MENOS BRAZO QUE UN PERIQUITO!!!” El que no haya pensado algo parecido después de mirarse por enésima vez en el espejo del gym que tire la primera mancuerna... Sí, amigo, el género humano no se distingue precisamente por su paciencia. Y menos aún si uno de sus especímenes decide dar el paso y trabajarse un físico más saludable (y más atractivo para futuros compañeros de apareamiento, no nos engañemos) a golpe de esfuerzo, dietas, sudor y repeticiones (Men's Health, núm. 157, 2015).}

Vemos que aquí Jordi Martínez no se centra solo en la parte saludable del deporte, sino en la que transformaría al lector en alguien más atractivo. El cuerpo de hombre que propone Men's Health es un cuerpo fuerte, con mucho volumen en los músculos: una estética de "macho alfa", tal y como aclaran en "Cuerpo y fitness, ¿qué aspecto tienes?" (Men's Health, núm. 162, 2015): "para conseguir una musculatura de macho alfa no hay nada mejor que seguir un programa estructurado de pesas". Dicho tipo de cuerpo se relaciona directamente con la masculinidad, en este sentido, leemos: "tu poderío físico puede ponerla a mil. Hacer que se sienta delicada y frágil es una expresión de masculinidad. Utiliza tu fuerza física en los preliminares de antes del dormitorio: en peleas juguetonas o arrinconándola contra la pared para besarla" (Men's Health, núm. 162, 2015). Estas declaraciones, aparte de perpetuar las dicotomías tradicionales hombrefuerte/mujer-débil y ahondar en la idea violenta de que a las mujeres les gusta ser sometidas por el sexo masculino, dan cuenta de la construcción identitaria entorno a la fuerza.

No encontramos que la belleza en Men's Health suponga ningún tipo de ruptura o de transformación de roles, se trata, simplemente, de una reafirmación de la 
masculinidad hegemónica. Abogan por hombres fuertes que ejerzan su dominio y que lideren - “eres el gallo del corral, no te conviertas en una bolita de grasa" (Men's Health, núm. 160, 2015)—, explotan y alientan la supremacía física masculina desde el culto al cuerpo.

Como ya hemos avanzado, dentro de las publicaciones femeninas, la belleza es la tercera categoría con más peso. Además, debemos destacar que no solo encontramos belleza en las unidades redaccionales propias de esta temática (donde nos venden maquillaje, cosméticos, tintes para el pelo, manicuras, exfoliantes, tratamientos corporales, tratamientos rejuvenecedores, tipos de peinados...), sino que, también, se alude a ella cuando se hace referencia a las mujeres. Así lo vemos reflejado en los retratos de las famosas, donde la vida profesional se entremezcla con la descripción física, otorgando verdadero valor e importancia al atractivo de la mujer en cuestión. Encontramos un claro ejemplo en el reportaje mixto de Woman a la actriz Juana Acosta y al chef Ramón Freixa, en el que podemos observar de qué forman describen a ella y cómo lo hacen con él:

Cuando la tienes cara a cara, no puedes apartar tus ojos de los suyos: su mirada es enigmática, pero cálida y sonriente. Juana Acosta viste un palabra de honor rojo, un color que le sienta como a pocas. Al natural es aún más guapa, porque su cercanía, simpatía y dulzura son cien por cien auténticas. El archipremiado chef Ramón Freixa, a su lado, nos deja claro que -él también- es un enamorado de la moda. Acaba de llegar a la tierra de la actriz, donde ha inaugurado From, su segundo restaurante en Colombia, y abre para WOMAN MF las puertas de su espléndido Ramón Freixa Madrid, galardonado con dos estrellas Michelin (ubicado en el Hotel Único). El brillo en los ojos de ambos desvela que tienen ante sí días de actividad frenética y muchas celebraciones por vivir. Con tres estrenos en el cine y nuevos proyectos, Juana disfruta intensamente de estas fechas con su marido, el también actor Ernesto Alterio, y la hija de ambos, Lola, de nueve años (Woman, núm. 279, 2015).

La descripción física de la actriz es extensa y abre el reportaje. Los logros profesionales llegan al final, junto con su vida en familia. El retrato de Ramón Freixa, sin embargo, aporta datos sobre su carrera de chef, pero sin desvelar ninguna de sus características físicas. Juana Acosta no es la única que se ve retratada desde el prisma de la belleza. Sobre la actriz Emma Stone podemos leer que posee una "mirada felina" (Woman, núm. 273, 2015), la cantante Caótica Florence tiene "una cara sacada del Renacimiento" (Woman, núm. 273, 2015), la actriz Jennifer Lawrence cuenta con "una belleza adictiva" (Glamour, núm.155, 2015) y la también actriz Julia Roberts es "la mujer 
tras la sonrisa" (Glamour, núm. 158, 2015). Conchita de la Lastra tiene "los ojos claros y una belleza de gran felino" (Telva, núm. 917, 2015) y a la diseñadora de joyas Sabien Ghanem le denominan "la belleza libanesa-egipcia” (Glamour, núm. 149, 2015).

Además, en los reportajes de mujeres, se incluyen varias páginas con imágenes en las que ellas posan de manera sensual. Ocurre, por ejemplo, en el de la presentadora Eva González (Woman, núm. 273, 2015), pero donde más llama la atención es en los reportajes que son mixtos. La actriz Blanca Suárez y el actor Yon González protagonizan "Feliz reencuentro" (Woman, núm. 270, 2015), un espacio donde tres de las seis páginas se han destinado a posados de la actriz en ropa interior y comportándose de manera sensual ante la cámara, ni mucho menos ocurre lo mismo con Yon González, del que tenemos una fotografía de su rostro. También tres de las seis páginas del reportaje de Juana Acosta y Ramón Freixa (Woman, núm. 279, 2015) están dedicadas a fotografías a toda página de la actriz enfundada en un vestido rojo ajustado.

En el reportaje "Red carpet vs. Street style" (Woman, núm. 270, 2015), se ponen a prueba los estilismos de diferentes actrices y encontramos un sinfín de alusiones a la belleza de las mismas: "ni sobre el asfalto ni sobre el mullido material rojo se le va la mano con el sex appeal en el que tan desafortunadamente caen otras adolescentes con prisas" (Elle Fanning), “cenicienta y princesa a la vez” (Anna Kendrick), "su físico de muñeca" (Choë Moretz), "si hay hoy una novia de América, una sucesora de Julia Roberts, esa es Amy Adams" (Amy Adams).

La belleza es una característica que se asume en las actrices, a veces, incluso, llegando a atribuir más mérito a esta que a sus facultades interpretativas, como sucede en el caso de Elizabeth Debicki de quien se dice que "la belleza y la elegancia de esta australiana de 25 años le ha llevado a protagonizar taquillazos como Operación U.N.C.L.E. o más recientemente ese drama de altura que es Everest." (Glamour, núm. $158,2015)$.

Esta misma idea se deja ver, también, en la descripción a la piloto de automovilismo Carme Jordá: "la piloto, natural de Alcoy y residente en Valencia, nos recibe con una sonrisa y el destello de su melena rubia, cuidada por Kérastase. Podría tratarse de una top o de una actriz de cine" (Glamour, núm. 152, 2015). Por supuesto, se resalta la belleza de la piloto, pero, además, se asume que, gracias a ella, tendría abiertas las puertas de la actuación. El reportaje, llamado "Belleza intrépida" (Glamour, núm. 152, 
2015), continúa de la siguiente manera: "el hecho de formar parte de un mundo de hombres no le ha robado un ápice de feminidad” (Glamour, núm. 152, 2015).

El propio concepto de belleza normativa conlleva asociado, en el discurso mediático, juventud y delgadez (Menéndez, 2006: 46). Comprobamos que las referencias, tanto a lo uno como a lo otro, son constantes. Sobre la edad, de Katie Holmes se señala que "nadie diría que ha cumplido ya los 36 años" (Woman, núm. 273, 2015), mientras que a la presentadora Eva González se le aborda con la siguiente pregunta " ¿Te pesan los trentaitantos? Hombre, los 30 se notan, sí. Ya la piel no está igual que cuando tenía 20 años y las cosas empiezan a caerse" (Woman, núm. 273, 2015).

El reportaje de “Ácido hialurónico. La clave de la juventud” (Woman, núm. 270, 2015), que anuncia cosméticos antiarrugas, insiste en la idea de las mujeres eternamente jóvenes. "No solo genética" nos introduce en las rutinas de belleza de una madre y de su hija: "Ana tiene 57 años magníficamente llevados — isin retoques estéticos! — y ha inculcado a sus hijas la importancia de cuidarse" (Woman, núm. 276, 2015). Se resalta de nuevo la belleza como un valor femenino del que sentirse orgullosa: "dermatólogos y expertos en estética aseguran que mirando a tu madre podrás prever como vas a envejecer. Amelia es una afortunada porque su madre, Ana Rodríguez, no aparenta ni de lejos los 57 años" (Woman, núm. 276, 2015). También, en este mismo reportaje, encontramos una relación recurrente: la de belleza y salud. Así, la esteticista Maribel Yébenes habla de cuidarse, sin embargo, lo que aporta son claves estéticas:

Cuidarse bien. [...] Es suficiente con $100 €$ al mes para cuidarse. El neceser básico debe incluir limpiadora, tónico, tratamiento y un buen contorno de ojos. [...] Encuentra tiempo. Dedica un mínimo de 10 a 15 minutos al día para cuidarte y no pongas la socorrida excusa de falta de tiempo (Woman, núm. 276, 2015).

Estos consejos resultan tremendamente perversos porque proponen una rutina de belleza de 100 euros mensuales, sin cuestionar tan siquiera la cifra, además de culpabilizar a las propias mujeres que no son capaces de sacar tiempo diario para aplicarse distintas cremas. De este modo, el mensaje que extraemos es que si alguien no se mantiene perfecta y joven es únicamente debido a su vagancia.

La esteticista añade un último consejo: "gustarte a ti misma es clave para gustar a los demás. Y para ello hay que empezar por aceptarnos tal como somos y aprender a sacarnos el máximo partido" (Woman, núm. 276, 2015). De nuevo, tras varias lecciones 
acerca de cómo debemos tratar nuestro cuerpo y así amoldarlo a los cánones estéticos, se cae en la contradicción de asegurar que lo importante es "aceptarnos tal y como somos". Eso sí, esta vez se le añade la coletilla de "aprender a sacarnos el máximo partido", o, lo que es lo mismo, debemos gustarnos, pero solo a medias.

En el reportaje “Quitarte 15 años, ¿new trend?” (Glamour, núm. 155, 2015), Glamour denuncia el hecho de que las mujeres se vuelvan invisibles a partir de cierta edad "frases como 'has hecho un pacto con el diablo' o 'por ti los años no pasan' se reciben como un caramelo dulce tras el que se esconde algo preocupante. ¿Por qué una mujer de 40 años tiene que aparentar 10 menos?" (Glamour, núm. 155, 2015). A esta denuncia, que por supuesto tiene su razón de ser dentro de la sociedad patriarcal, le siguen las siguientes afirmaciones hechas desde la propia redacción de la revista: “¿de verdad Cher cree que le sienta bien llevar transparencias a los 69 años? ¿Y Jennifer López vestirse como si fuese una monitora de aerobic?” (Glamour, núm. 155, 2015). Es decir, primero Glamour toma conciencia del problema de la invisibilidad, pero, en lugar de ofrecer una visión crítica y global, arremete contra mujeres concretas que están haciendo uso de mecanismos de supervivencia. Cabe destacar que, gracias al pensamiento de la autora feminista Audre Lorde, hoy sabemos que estos mecanismos son tramposos y, que en última instancia, no son útiles para la liberación del sexo femenino: "las herramientas del amo no desmantelarán la casa del amo" (Lorde, 1983; la traducción es nuestra).

En el mismo número donde leemos el reportaje que supuestamente denuncia la imposición de la juventud femenina, encontramos otro en el que se explican varias técnicas para rejuvenecer la piel "Retoques high tech" (Glamour, núm. 155, 2015) y, también, un artículo con la etiqueta Must have que se titula "Piel de bebé, tus tres nuevas claves" (Glamour, núm. 196, 2015). En el número de marzo, un reportaje de varias páginas ahonda en la misma temática: "Tratamientos red carpet” (Glamour, núm. 149, 2015). En "Best fitness \& friends" (Glamour, núm. 149, 2015), Glamour recomienda a sus lectoras eliminar los productos procesados con el fin de lucir un rostro más joven. Finalmente, en "La mujer tras la sonrisa" (Glamour, núm. 158, 2015), Julia Roberts ofrece su opinión sobre este tema:

Con 47 años, se enfrenta a algunos de los papeles más importantes de su carrera, pero cuando le pregunto si piensa que las actrices pasados los 40 consiguen mejores trabajos dice: "Es curioso cuando tratamos de hablar de igualdad en las mujeres. Creo que parte del problema está en ese tipo de calificaciones como "lo 
mejor de las mujeres mayores de 40". Nadie habla nunca de "lo mejor de los hombres mayores de 40" (Glamour, núm. 158, 2015).

Como hemos adelantado hace unos párrafos, la delgadez sería el tercer elemento, junto a la belleza y la juventud, del discurso estético que imponen los medios de comunicación (Menéndez, 2006: 46). Es más, para estas publicaciones, la delgadez se sitúa al mismo nivel de importancia que asuntos de índole profesional: "no demores aspectos claves como la organización de tus vacaciones, ponerte a dieta o leer tus mails del trabajo por la mañana.” (Glamour, núm. 152, 2015). En el reportaje “¿Quieres adelgazar? Conoce el 'Talking”" (Glamour, núm. 152, 2015) leemos el siguiente consejo: "si hay comida familiar digo que tengo gastroenteritis y como antes de ir" (Glamour, núm. 152, 2015). Una reflexión distinta nos llega por parte de la actriz Jennifer Lawrence, quien, ante la pregunta de si le preocupa su físico, responde:

Pienso en ello más de lo que me gustaría. Todas nacemos con ciertos atributos y es importante trabajar con ellos. Cada vez que se cruza por mi mente el pensamiento de cambiar alguna parte de mí misma pienso: “¿Realmente me gustaría? ¿De verdad no quiero beberme una copa de vino durante la cena? ¿De verdad no quiero comer carbohidratos pasadas las cuatro de la tarde?" No. Prefiero mantener mi talla, seguir comiendo y ser feliz (Glamour, núm. 155, 2015).

En Telva, a Isabel Preysler se le pregunta, tal y como se ha hecho con Jennifer Lawrence, por su físico: “¿hasta qué punto te preocupa tu físico?” y, también, si es "muy estricta con la dieta" (Telva, núm. 920, 2015). En el reportaje "Galesterapia” (Telva, núm. $914,2015)$ se concede una especie de permiso para poder comer lo que una quiera, pero solo durante el periodo vacacional: "perderse por el norte de Gales es una cura anti estrés efectiva: valles bañados por lagos, playas silenciosas, kilómetros de campo en los que no ves ni un alma — con perdón de las ovejas—. Una infalible terapia que incluye — ¡bien!saltarse la dieta". (Telva, núm. 914, 2015). Por otro lado, a través de las declaraciones de Katie Holmes, se entiende que comer dos trozos de pizza es algo que la lectora no debería permitirse muy a menudo: “"yo también me acuesto algunas veces sin desmaquillarme o me como dos trozos de pizza con doble de queso y pepperoni'. A pesar de esas licencias, Katie cuida su rostro con una rutina básica que aconseja a todas las mujeres" (Woman, núm. 270, 2015). 
La belleza que proponen estas publicaciones no conoce barrera alguna, nos lo dice Glamour en "Efectos especiales": "lo que la genética no te ha dado el mercado lo tiene" (Glamour, núm. 155, 2015) y lo corrobora Woman en el reportaje "Glúteos a la carta" (Woman, núm. 270, 2015) que, no solo insta a las mujeres a pasar por quirófano por cuestiones estéticas —obviando, por supuesto, todos los peligros que una intervención así puede acarrear_-, sino que habla de la belleza como una cuestión de modas — “el trasero de Kim Kardashian, aunque es desmesurado, marca una tendencia: vuelve la mujer con curvas"-, modas a la que las mujeres deben aprender a acoplarse tantas veces como fuera necesario:

Trending topic corporal: vuelve la silueta con formas. [...] Puede que la naturaleza no te haya regalado las curvas de Scarlett Johansson, Kate Winslet o Lara Stone. Las últimas técnicas de relleno (pasando o no por quirófano) permiten darles una nueva proyección a los glúteos con resultados naturales (Woman, núm. 270, 2015).

Además, incluyen las opiniones de expertos — hombres - que dictaminan cómo tienen que ser los glúteos de las mujeres. El doctor García-Guilarte asegura que "unos glúteos equilibrados tienen forma redondeada. La cadera debe ensancharse en un 30-40 por ciento respecto a la cintura y tener unos $10 \mathrm{~cm}$ de proyección en su vista lateral" (Woman, núm. 270, 2015). "Deben resaltar a partir de la zona lumbar, ser redondos y no más anchos de frente que la anchura de las caderas" (Woman, núm. 270, 2015), añade el doctor Moreno Moraga. Por su parte, el doctor Orestes concluye afirmando que la anatomía es la correcta cuando "son glúteos que guardan simetría con el resto del cuerpo y se encuentran dentro de las proporciones armónicas” (Woman, núm. 270, 2015).

También, resulta especialmente preocupante el artículo "Con la belleza al cuello" (Glamour, núm. 152, 2015) donde se informa de que los hábitos actuales de consumo de móvil están provocando la aparición de una arruga en la zona del cuello, es la denominada "arruga tecnológica" o "tech neck". Sin embargo, desde la publicación explican que se puede combatir gracias "a la tendencia de las gargantillas rígidas tamaño XXL" (Glamour, núm. 152, 2015), es decir, usando un collar que reste movilidad al cuello. Lo ilustran con una fotografía de un maniquí con el cuello extralargo y lleno de gargantillas, el cual recuerda a las mujeres jirafa, una práctica extremadamente cruel y opresora que sufren las habitantes de algunas zonas de Tailandia.

En esta misma publicación, también en el número de junio, se frivoliza con el tema del maquillaje al equipararlo con un derecho femenino por el que valdría la pena 
luchar. Así, leemos lo siguiente: "reivindica tu derecho a ir maquillada hasta en la playa" (Glamour, núm. 152, 2015). Si tenemos en cuenta que el maquillaje es una obligatoriedad social para las mujeres, hablar del mismo en términos de "derecho" suena completamente ridículo. La reivindicación real sería el derecho a no usarlo ni en la playa, ni en la calle, ni en el trabajo, ni nunca.

Vemos que se insiste en la idea de la belleza como un arma liberadora que permite a las mujeres quererse a sí mismas. En el reportaje mencionado anteriormente a Katie Holmes ("Katie Holmes se siente bien en su piel”), se resaltan las siguientes declaraciones de la actriz: "lo que más me llamó la atención de Olay es la defensa que hacen de las mujeres sin complejos. El objetivo final es estar bien contigo misma" (Woman, núm. 270, 2015). Por si no fuera suficiente la contradicción de una marca de cosmética que aboga por mujeres sin complejos, el bloque de belleza de Woman del mes de marzo cierra con el siguiente artículo: "triunfa el look natural. Se lleva la tez perfecta sin artificios". Este look "natural" se consigue, eso sí, utilizando maquillaje que "se vuelve invisible" (Woman, núm. 270, 2015).

Teniendo en cuenta la manera en que estas publicaciones resaltan el físico de sus protagonistas, resulta irrisorio que desde Telva aseguren encontrar sorprendente que a las mujeres jóvenes les obsesione la aparición de las arrugas, tal y como leemos en el reportaje "Comunidad Beauty” (Telva, núm. 920, 2015):

Lo que más preocupa a este grupo de amigas (para mi sorpresa) son las arrugas. "No dedico mucho tiempo a cuidarme, pero lo fundamental para mí es la cara", confiesa Victoria, de 34 años. "Me hidrato, la protejo, me desmaquillo... Estoy muy concienciada". En el caso de Miriam (25 años), "antes era más pasota, pero ahora estoy más encima de la piel del rostro y es en lo que más invierto". Cantidades desorbitadas para algunos, pero que ellas gastan con tal de evitar las temidas arrugas. "No quiero tener que ponerme bótox así que prefiero prevenir ahora”, asegura Jimena (27) (Telva, núm. 920, 2015).

Este grupo de mujeres, todas ellas trabajadoras entre la veintena y la treintena, asume que las arrugas no son una opción. Es más, el bótox se convierte en una obligatoriedad ("no quiero tener que") en el caso de que las mismas no puedan ser prevenidas de ninguna otra manera. Por otro lado, en el reportaje también se trata el tema de la alimentación — recordemos la delgadez obligatoria — "desayuno avena con leche; tiene fibra, es buenísima y te llena tanto que no tienes tentación de picar en toda la 
mañana" (Telva, núm. 920, 2015), dice una de ellas. "Ahora tomamos espirulina para la piel y semillas de chía con el yogur. Se hinchan y te sacian” (Telva, núm. 920, 2015).

Las publicaciones femeninas venden belleza: desde los artículos que anuncian maquillaje, cosméticos o, incluso, tratamientos quirúrgicos, hasta el tipo de preguntas que les formulan a las protagonistas femeninas y las fotos y descripciones que hacen de ellas. Todo parece estar encaminado a lograr una belleza que se convierte en el valor más destacable si eres mujer. No ocurre lo mismo en el caso de los hombres, donde los contenidos de índole estética son escasos y los aspectos profesionales resaltan por encima de su belleza física, como veremos en los siguientes apartados.

\subsection{El mundo laboral para las mujeres y para los hombres}

La presencia de hombres y mujeres en las publicaciones es elevada. El $42 \%$ de las unidades redaccionales contemplan algún tipo de intervención, bien sea protagonizando, asesorando, escribiendo o ilustrando. Contamos un total de 768 personas, 485 en las publicaciones femeninas y 283 en la prensa masculina, de las cuales, la mayoría, 708, protagonizan el espacio.

REVISTAS DE ESTILO DE VIDA MASCULINO

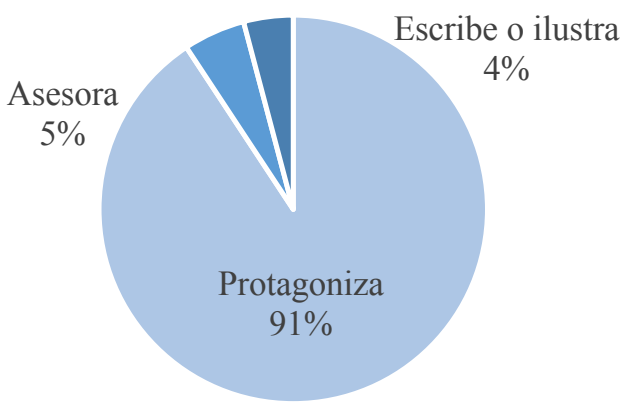

REVISTAS DE ESTILO DE VIDA FEMENINO

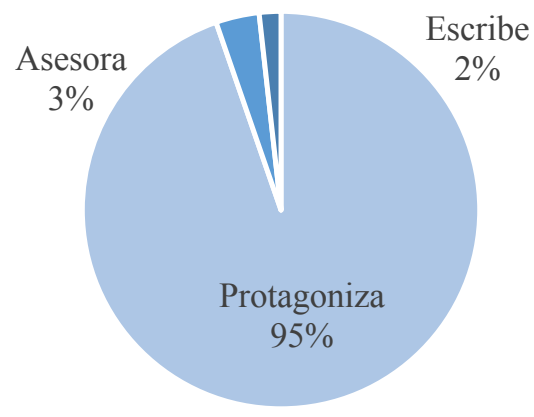

GráFICo 19. Funciones de las personas en las revistas de estilo de vida masculino (izquierda) y femenino (derecha), muestra año 2015.

FUENTE: Elaboración propia.

Como hemos ido viendo, las revistas se cuidan de delimitar qué sexo debe moverse en la esfera privada y cuál en la pública. Si bien los motivos por los que los y 
las protagonistas de las distintas unidades redaccionales aparecen en las revistas son en la mayoría de los casos motivos profesionales, encontramos una mayor tendencia a que esto sea así en el caso de los hombres (93\%) que en el de las mujeres (82\%).

En Esquire, la sección Bussines Class abre cada número con un reportaje a algún empresario. Lo hace con la etiqueta Ejecutivo del mes. Además, incorpora un segundo y un tercer reportaje que etiqueta Otros negocios donde sigue retratando la vida profesional de sus protagonistas. En total, leemos el perfil de once empresarios y podemos ver el trabajo de un fotógrafo. No incluye a ninguna mujer. Mientras, en las revistas femeninas, no encontramos ninguna sección dedicada a tal cometido, aunque sí distintas alusiones al mundo del empleo: sírvase de ejemplo el reportaje que Glamour dedica a la brecha salarial que, aunque empieza preguntándose si las afectadas "deberían" quejarse ante dicha injusticia (Glamour, núm. 149, 2015), lo cierto es que aporta datos interesantes sobre la situación en Hollywood, donde, por supuesto, las actrices están cobrando hasta diez veces menos que sus compañeros de reparto.

También leemos reportajes a trabajadoras, como la entrevista "Mentes maravillosas" (Telva, núm. 917, 2015) a Margarita Salas, bioquímica española, y María Blasco, directora del Centro Nacional de Investigaciones Oncológicas, CNIO, la cual resulta especialmente interesante para reflexionar sobre las mujeres y su papel en el circuito profesional:

¿Se han sentido alguna vez intrusas en un campo tan plagado tradicionalmente de hombres?

Margarita: Yo hice mi tesis doctoral en 1961, a la vez que mi marido, Eladio Viñuela. Mi director no creía en mí para nada. Cuando se refería a mi trabajo le hablaba a mi marido, son lo cual más que intrusa me he sentido invisible.

María: [...] Cuando alcanzas posiciones de responsabilidad, te das cuenta de que hay personas que no están cómodas cuando se encuentran con mujeres directoras.

Margarita: También es culpa de las propias mujeres el no ocupar los puestos que nos merecemos [...].

¿Hablas de barreras autoimpuestas?

Margarita: Sí. Es más cómodo quedarte en el laboratorio, donde lo tienes todo controlado.

María: [...] En el CNIO tenemos un departamento de Mujeres y Ciencia. Nos hemos dado cuenta de que, en el período de la especialización, las mujeres tienden a quedarse más tiempo en el laboratorio antes de buscar una posición independiente...

Margarita: ¡Pero eso es culpa de ellas! 
María: Y, ¿por qué lo hacen? Quizá porque el hábitat que van a encontrar fuera no es atractivo para ellas. Hay que crear una igualdad de oportunidades real. Pero el avance es lento (Telva, núm. 917, 2015).

El debate que mantienen ambas mujeres es, desafortunadamente, usual en nuestra sociedad. Incluso habiendo vivido una situación de discriminación por razón de sexo, Margarita Salas no duda en culpabilizar a las propias mujeres de la falta de avances. María Blasco, sin embargo, se muestra más crítica y cuestiona los mecanismos sociales que impiden el progreso.

La cuestión que le sigue a este debate es tremendamente esclarecedora. Una vez María Blasco ha opinado acerca de la falta de igualdad de oportunidades, desde la redacción lanzan la siguiente pregunta "¿Cómo combina una investigadora de élite trabajo y familia?" (Telva, núm. 917, 2015) redirigiendo, de este modo, la entrevista hacia la esfera de lo privado. Si bien es cierto que ambas utilizan sus respuestas para mostrarse combativas — “es un problema [...]. Aún siguen siendo las mujeres las que se ocupan de los hijos y atienden a sus mayores” (Telva, núm. 917, 2015), dice Margarita Salas_-, es verdad que este tipo de preguntas no se dan en los casos masculinos.

Aunque en un $82 \%$ del tiempo las mujeres protagonicen las unidades redaccionales por motivos profesionales, encontramos alusiones a la vida privada con demasiada frecuencia. Así, en la entrevista realizada a la política Rosa Diez "Adiós a un sueño” (Telva, núm. 914, 2015) la última pregunta dice “¿Es cierto que tus hijos le han pedido que lo deje ya?" (Telva, núm. 914, 2015). En “Isabel se reinventa” (Telva, núm. 911, 2015), reportaje que versa sobre el lanzamiento de una línea de cosméticos por Isabel Preysler, la batería de preguntas que tienen relación directa con la maternidad es infinita:

¿Cómo has conseguido que tus hijos te quieran tanto? [...] ¿Crees que ha sido determinante para tu familia que fueran tus maridos los que se amoldaran a tu vida, a tus hijos, a tu casa, y no al revés? [...] ¿Cómo se educa a unos niños que lo tienen todo? [...] ¿Quiénes son los más obedientes? [...] ¿Eres una madre estricta con tus hijas? [...] ¿Tener una madre tan perfecta ha supuesto alguna presión para tus hijas? [...] Pero que tu madre tenga más tipazo que tú quizá desmoraliza... (Telva, núm. 911, 2015).

La actriz Cate Blanchett en el reportaje “¡Ellos siguen cobrando más!” (Glamour, núm. 149, 2015) demuestra su preocupación por el hecho de que siempre le pregunten 
por su condición de madre y actriz. Este fenómeno, afecta, en general, a cualquier mujer que aparezca en los medios de comunicación. Mientras que a Julia Roberts se le pregunta sobre: “qué aspectos de tu educación tratas de inculcar a tus hijos?” (Glamour, núm. 158, 2015), la abogada y consultora de marcas de lujo Inmaculada Pérez, es avasallada con toda una batería de preguntas personales: "Eres madre, casada por segunda vez... ¿Sacrificaste mucho por tener éxito? [...] ¿Qué cualidades debe tener tu pareja? [...] ¿Qué consejos les das a tus hijas? [...] ¿Cuál fue tu mentor o mentores?” (Glamour, núm. 155, 2015).

Sobre la última cuestión, resulta interesante comprobar cómo de las mujeres se destaca que exista un varón que las haya enseñado y/o ayudado a llegar hasta dónde están ahora. De la actriz Elizabeth Debicki se dice que "su bautismo en el cine vino de la mano de Leonardo DiCaprio y Tobey Maguire en el remake de El gran Gatsby" (Glamour, núm. 158, 2015). De Brit Robertson que "vivirá un viaje inolvidable al futuro de la mano de George Clooney en Tomorrowland, su pasaporte directo a la fama" (Glamour, núm. 152, 2015). Y de la diseñadora de moda Julie De Libran, que ha crecido con los mejores diseñadores, como Gianni Versace o Jean-Charles de Castelbajac (Glamour, núm. 155, 2015).

En el número de junio de Glamour, encontramos un reportaje sobre la política Cristina Cifuentes ("Pon una Olivia Pope en tu vida" Glamour, núm. 152, 2015) y en diciembre sobre el político Albert Rivera (“On the road” Glamour, núm. 158, 2015). E1 año 2015 fue un año de elecciones, así, Albert Rivera responde una batería de preguntas acerca de su tipo de campaña y también de su postura ante la conciliación laboral, las bajas de maternidad, la cláusula suelo o la situación de los trabajadores y trabajadoras autónomas en España. El reportaje de Cristina Cifuentes, por su lado, se trata de una crónica en la que nos hablan del estrés del día a día, cómo afronta los cambios de última hora en la agenda o de qué manera cuida su aspecto físico:

La furgoneta de la candidata tiene un pequeño guardarropa. [...] "Me he olvidado en casa el neceser. Tengo las gotas para la conjuntivitis y todas las pinturas. Le digo que ese comentario no se lo escucharíamos a un hombre. "Ya... pero mi jornada va a durar quince horas. Me hará falta retocarme. Te aseguro que no trabajo peor por preocupar de mi aspecto". [...] Tras aprovisionarse de maquillaje, compran cafés en el Starbucks (Glamour, núm. 152, 2015).

En el caso de Cristina Cifuentes no se ahonda en política. Las frases resaltadas son las siguientes: "en dos días ha besado a 600 personas", "cuida todos los detalles de 
su look" y "le encantan los animales, tiene dos gatos" (Glamour, núm. 152, 2015). Muy distinta es la entrevista de Albert Rivera, donde sus destacados nos dicen "proponemos bonificar la contratación de mujeres y mayores de 45 años", "que cada pareja pueda decidir cómo se reparten la baja por maternidad" y "los autónomos por debajo del salario mínimo sin cuota fija” (Glamour, núm. 158, 2015).

También, crianza y mundo laboral se entremezclan. Sobre la maternidad, la revista Glamour nos adelanta que se trata del "momento más apasionante de la vida de cualquier mujer” (Glamour, núm. 149, 2015). La frase se enmarca dentro del reportaje “¿Hay una conspiración para que no seas madre?” (Glamour, núm. 149, 2015), el cual denuncia las injusticias a las que se enfrentan las trabajadoras cuando han de pedir la baja por maternidad. Así, la publicación comienza a analizar los problemas que llevan a esta terrible discriminación, asegurando que el primero, y más importante, lo generamos las propias mujeres:

Quizá haya llegado el momento de reescribir la realidad poniendo nuestros problemas encima de la mesa. Algunos son transparentes, pero existen. El primero lo encontramos en casa. Ante el feliz alumbramiento del hijo, desarrollamos un instinto protector cuya primera consecuencia es que descatalogamos del diccionario la palabra "delegar". Ante esa tesitura, en ocasiones el hombre descubre que resulta muy cómodo seguir siendo actor de reparto que aparece y desaparece en función del guion. La situación se prolonga en el tiempo y se extiende a las tareas domésticas (Glamour, núm. 149, 2015).

En lugar de realizar un análisis crítico de por qué las mujeres se ocupan del trabajo doméstico, apela a un tipo de "instinto protector" que aparece con la maternidad. Esto es muy peligroso, ya que los instintos son biológicos, por tanto, justificamos que las mujeres deban ocuparse de su descendencia por naturaleza. Además, las culpabiliza en tanto son ellas las que no permiten a sus parejas hacerse cargo de la criatura y, por extensión, de todas las tareas del hogar. Según este reportaje, anterior a la llegada de la nueva vida, los hombres sí se ocupaban del trabajo doméstico.

Como ya se ha mencionado, existe un $18 \%$ de mujeres, frente a un $7 \%$ de hombres, que protagonizan las unidades redaccionales por motivos que no son profesionales. ${ }^{88}$ Para las mujeres, la primera razón por la que aparecen en las revistas, después de la profesional,

\footnotetext{
${ }^{88}$ Una investigación parcial con algunos de los resultados que van a mostrarse a continuación fueron avanzados en ILLERA, PAULA (2017): "Mujeres y hombres en la prensa segregada: presencia, imágenes y representaciones de género", en Actas. IX Congreso Internacional Latina de Comunicación Social. Tenerife: Universidad de la Laguna, págs. 1502-1511.
} 
es para servir de "modelo", lo cual significa que, o bien se utiliza su rostro o su cuerpo con el fin de mostrar algún tipo de maquillaje o de prenda de ropa, o bien su estilismo es sometido a juicio. Esto sucede sobre todo con las actrices y lo vemos en 34 ocasiones.

Los hombres, a su vez, aparecen hablando de sus gustos (9) o de creencias personales (8). De "modelo" hacen en 6 ocasiones, todas ellas por temas estilísticos, nunca maquillajes o peinados. A las mujeres, pues, les siguen persiguiendo las cuestiones de índole estética. También lo vemos en las 3 protagonistas que aparecen en espacios dedicados a conocer su rutina de belleza (frente a los 0 hombres que encontramos en esta categoría).

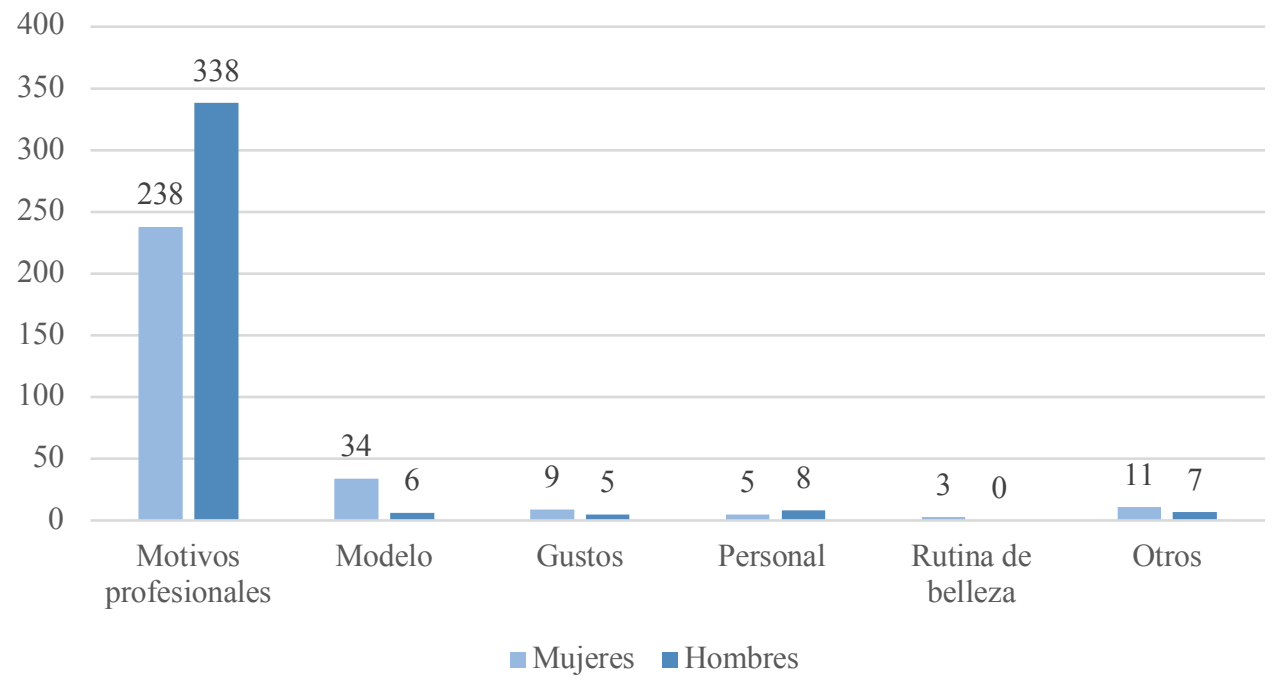

GRÁFICO 20. Función de los y las protagonistas en las revistas de estilo de vida (muestra año 2015). FUENTE: Elaboración propia.

Como hemos ido viendo en páginas anteriores, la belleza es un valor resaltable, cuando no el primero a tener en cuenta, en la construcción de la identidad de las mujeres. Esto afecta a la manera en que se proyecta el éxito femenino: "sexys, poderosas y femeninas, recopilamos personajes que merecen la categoría de iconos" (Glamour, núm. 158, 2015). Dar visibilidad a las mujeres poderosas es necesario, decir que se lo merecen por ser sexys y femeninas supone todo un despropósito. En este sentido, cuando las mujeres ocupan la esfera pública se les exige el plus físico. Se trata, además, de una premisa altamente normalizada, tal y como podemos leer en la columna de opinión de la colaboradora Marta Rivera de la Cruz “Dress Code. ¿Sí o no a las normas?”: 
Cada capítulo es una lección de estilo para ejecutivas... excepto cuando aparece en escena Kalinda, la misteriosa detective que trabaja para el bufete, y que usa atuendos más bien vulgares, faldas apretadas y botas de vaquero conjuntadas con cazadoras de piel de imitación. A pesar de que su sueldo le permitiría otros outfits, Kalinda está intentando subrayar que no pertenece a la estirpe de las letradas. Por eso, y aunque es una trabajadora imprescindible, Kalinda será siempre considerada como una empleada de segunda división, a la que incluso los becarios hablan con un deje de displicencia mientras menean la cabeza ante sus blusas chillonas y sus chaquetas baratas (Glamour, núm. 149, 2015).

En este caso, la autora defiende que esta mujer vale lo que demuestra su apariencia. Que, si el aspecto se descuida, también puede descuidarse la manera en que nos dirigimos a ella. Por supuesto, Kalinda no es femenina, Kalinda es ordinaria, como demuestran sus chaquetas baratas de polipiel y sus botas de vaquero. Esto la sitúa en una posición de vulnerabilidad dentro del bufete, la cual merece por no prestar atención a su físico "Kalinda será siempre considerada como una empleada de segunda".

De la misma colaboradora es la columna del mes de diciembre, "El sexo ya no vende" (Glamour, núm. 158, 2015), que reflexiona acerca de la decisión de la revista Playboy de dejar de incluir a mujeres desnudas dentro de sus páginas:

Se trata de un caso de supervivencia empresarial, no de cambio de paradigma. Sea como sea, a partir de ahora el que compre Playboy lo hará alentado por sus contenidos, no por las fotos de señoritas sin ropa. Tenedlo en cuenta si encontráis un ejemplar entre las cosas de vuestra pareja: no está buscando cuerpazos, sino contenidos de altura. La dirección de Playboy ha asegurado que las chicas guapas seguirán teniendo un sitio preferente en su publicación, pero ahora aparecerán digo yo - con jersey de cuello vuelto, gafas de concha, faldas midi y un diccionario en la mano. Y empiezo a pensar en la posibilidad de quejarme por intrusismo. Si ahora las mujeres explosivas van de intelectuales, ¿qué posibilidades nos quedan a las normalitas? ¿O acaso debemos ver la botella medio llena y, ya que soplan nuevos tiempos, aspirar a ser la chica del mes de agosto? (Glamour, núm. 158, 2015).

La idea que subyace tras el texto es la tantas veces promulgada por el patriarcado de que las mujeres guapas no son inteligentes y viceversa. Otro columnista, en este caso el escritor José Luis Olaizola, colaborador en Telva, nos habla de "una chica muy mona" que aparece en el programa de cocina de Karlos Arguiñano. Esa chica "mona”, la cual no tiene nombre, se ríe de los chistes de Arguiñano "aunque ha confesado que no sabe bien de qué van" (Telva, núm. 911, 2015). La misma fórmula se utiliza cuando se cataloga a la actriz Julie Christine de ser "más que una cara bonita” (Glamour, núm. 158, 2015). 
Según los ejemplos citados, existen mujeres que solo son belleza y de las que solo se espera que sean adornos, es decir, las chicas que aparecen en la revista Playboy o la presentadora "mona" que no entiende los chistes. Otras, además de ser belleza, también pueden presentan una esfera de raciocinio, entonces, se remarca como algo excepcional. Este sería el caso de la actriz Julie Christine. Y, finalmente, hay aquellas que no son guapas, que son las que saben desempeñar los trabajos intelectuales, como la colaboradora Marta Rivera de la Cruz, quien, en vez de cuestionarse los rígidos esquemas patriarcales, propone quejarse por "intrusismo" si las mujeres normativamente bellas comienzan a acceder a puestos de índole intelectual. Además, añade que, si por ella fuera, preferiría pertenecer al primer grupo y convertirse en "la chica del mes de agosto". Así de cruel es el patriarcado.

La visión de Marta Rivera de la Cruz se sostiene, entre otras cosas, porque la cultura popular, ya lo vamos viendo, nos vende que las mujeres son su físico. Que ello es lo que más deben valorar y cuidar de sí mismas, como extraemos por las preguntas o descripciones que les hacen a las protagonistas, por el tipo de unidades redaccionales que protagonizan o por la cantidad de contenidos de belleza presentes en las revistas femeninas. Pero, después, nos indican que todas aquellas mujeres con un físico normativo no tienen valía intelectual. Se trata, por supuesto, de una gran trampa que impide el empoderamiento femenino.

Las portadas de nuestras publicaciones también merecen ser objeto de análisis. Si bien las revistas masculinas han utilizado a mujeres desnudas o semidesnudas en sus portadas como objeto de reclamo - lo acabamos de ver en Playboy y, anteriormente, en Man o FHM (véanse imágenes 14 y 15) —, comprobamos que en nuestras revistas se hace un uso distinto de los y las protagonistas. Mientras que la elección de los varones se basa en cuestiones relacionadas con su notoriedad pública, de las mujeres no importan tanto los aspectos profesionales, como sí el físico que tengan.

Las diferencias de trato entre las portadas protagonizadas por mujeres y aquellas protagonizadas por hombres en $D T$ son evidentes (véase imagen 30 y 31 ), en tanto que las mujeres aparecen en lencería mientras que los hombres lo hacen en traje o camisa. Además, los planos que escogen DT y Esquire para sus protagonistas varones son más cortos que los que escogen las revistas femeninas, priorizando la identidad del personaje, su cara, sobre el cuerpo del mismo. Mientras, en las revistas dirigidas a mujeres encontramos planos amplios, escotes y transparencias, poses sensuales, belleza 
homogénea y una horquilla de edad mucho menor que en el caso de las revistas masculinas, donde los protagonistas no deben cumplir con exigencias físicas tan marcadas (véase imagen 32).
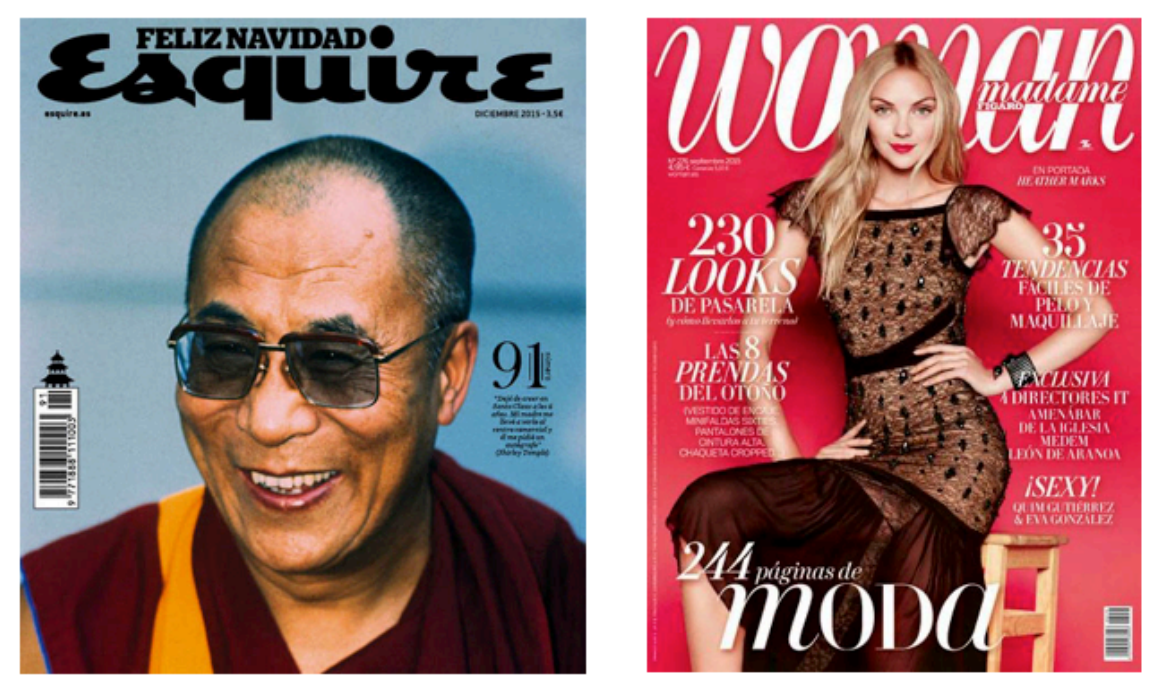

Imagen 32. Portada de la revista Esquire de diciembre de 2015 y de la revista Woman de septiembre de 2015.

Fuente: Esquire y Woman.

Yéndonos al interior de las revistas, descubrimos más datos sobre la relación entre el mundo laboral y la belleza, relación que sigue afectando de diferente manera a cada sexo. En la categoría de protagonistas, las revistas masculinas incorporan a 45 mujeres (17\%), mientras que las revistas femeninas incluyen a 140 hombres (32\%). Esta mayor apertura en las publicaciones femeninas responde al androcentrismo social, donde las actividades de los varones tienen mayor relevancia que las ejercidas por las mujeres (Sau, 2000: 45-46)

\section{REVISTAS DE ESTILO DE VIDA FEMENINO}

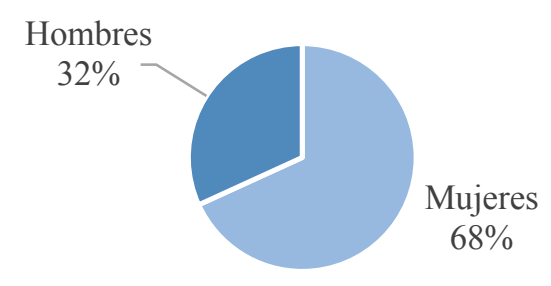

REVISTAS DE ESTILO DE VIDA

MASCULINO

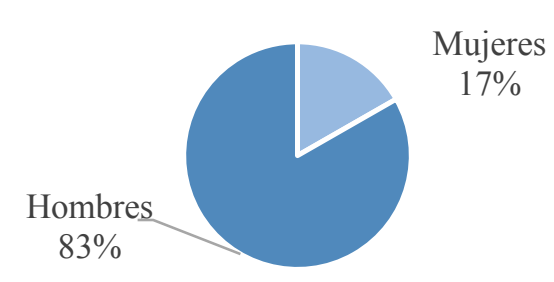

GráFiCo 21. Presencia de hombres y mujeres en las publicaciones de estilo de vida femenino (izquierda) y en las de estilo de vida masculino (derecha), según muestra del año 2015.

FUENTE. Elaboración propia. 
Men's Health cuenta con una presencia baja de protagonistas. De 20 personas, solo 2 son mujeres. Ambas son modelos y ambas posan en ropa interior. En Esquire, de las 17 mujeres, 11 protagonizan sesiones fotográficas donde aparecen ligeras de ropa. Todas son actrices menos la tenista María Sharapova. Mientras, en DT, aparecen 26 mujeres, 9 de las cuales, modelos y actrices, posan en ropa interior, biquini o transparencias. En total, 21 de las 45 profesionales son sexualizadas, frente a un hombre de 140 .
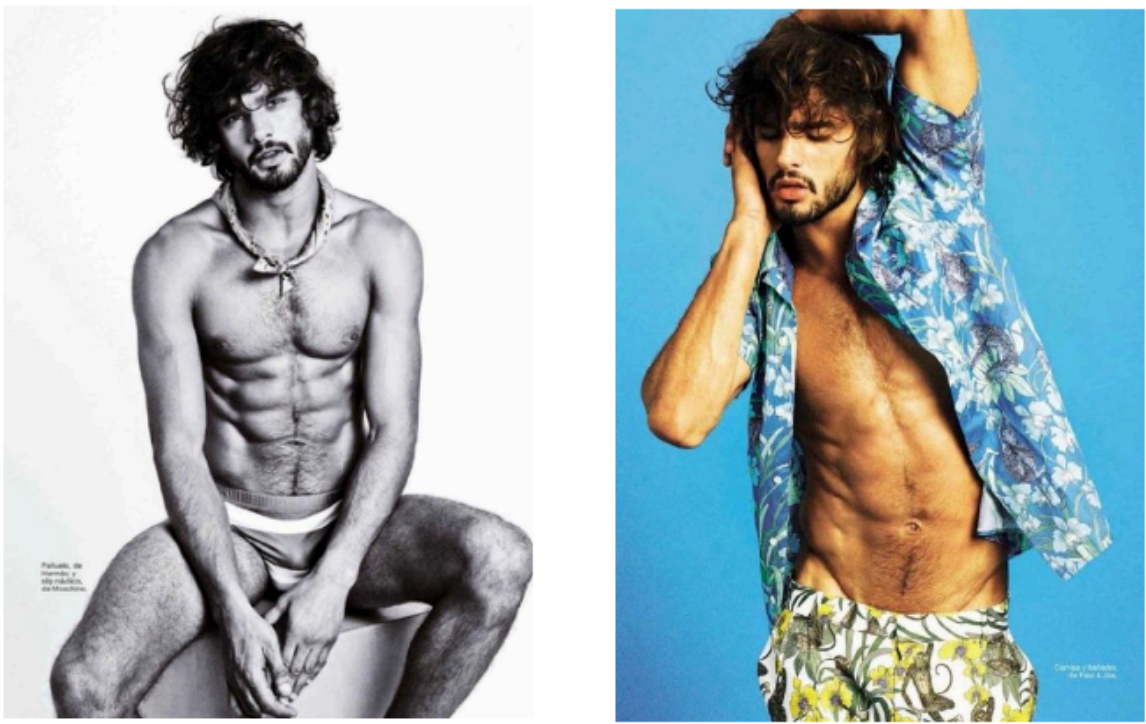

IMAGEN 33. El modelo Marlon Teixiera posa para Glamour (Glamour, núm. 152, 2015). Se trata del único hombre en ropa interior dentro de las revistas de estilo de vida femenino (muestra año 2015).

FUENTE: Glamour.

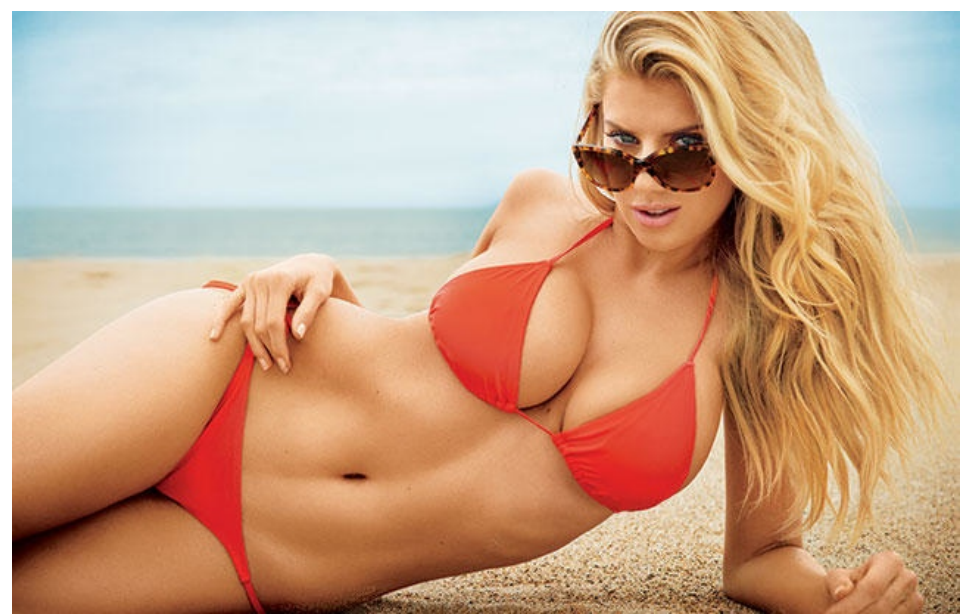

IMAGEN 34. La modelo Charlotte McKinney en la revista Men's Health (Men's Health, núm. 162, 2015). FuENTE: Men's Health. 
Mientras que DT opta, en muchos de los casos, por traer a la palestra a modelos que hayan trabajado en campañas de lencería o trajes de baño e insertar varias fotografías de esas campañas (la tendencia es de media página de texto y cinco páginas de fotos), Esquire prefiere los reportajes fotográficos de actrices. En cualquier caso, el nivel de cosificación es muy elevado (tal y como se ha avanzado anteriormente, el 47\% de las mujeres son sexualizadas). En este sentido, las revistas masculinas ponen el foco en el cuerpo de las protagonistas, ofreciéndolas como regalo y disfrute para los lectores y alimentando la idea de que el físico es imprescindible en el éxito femenino.
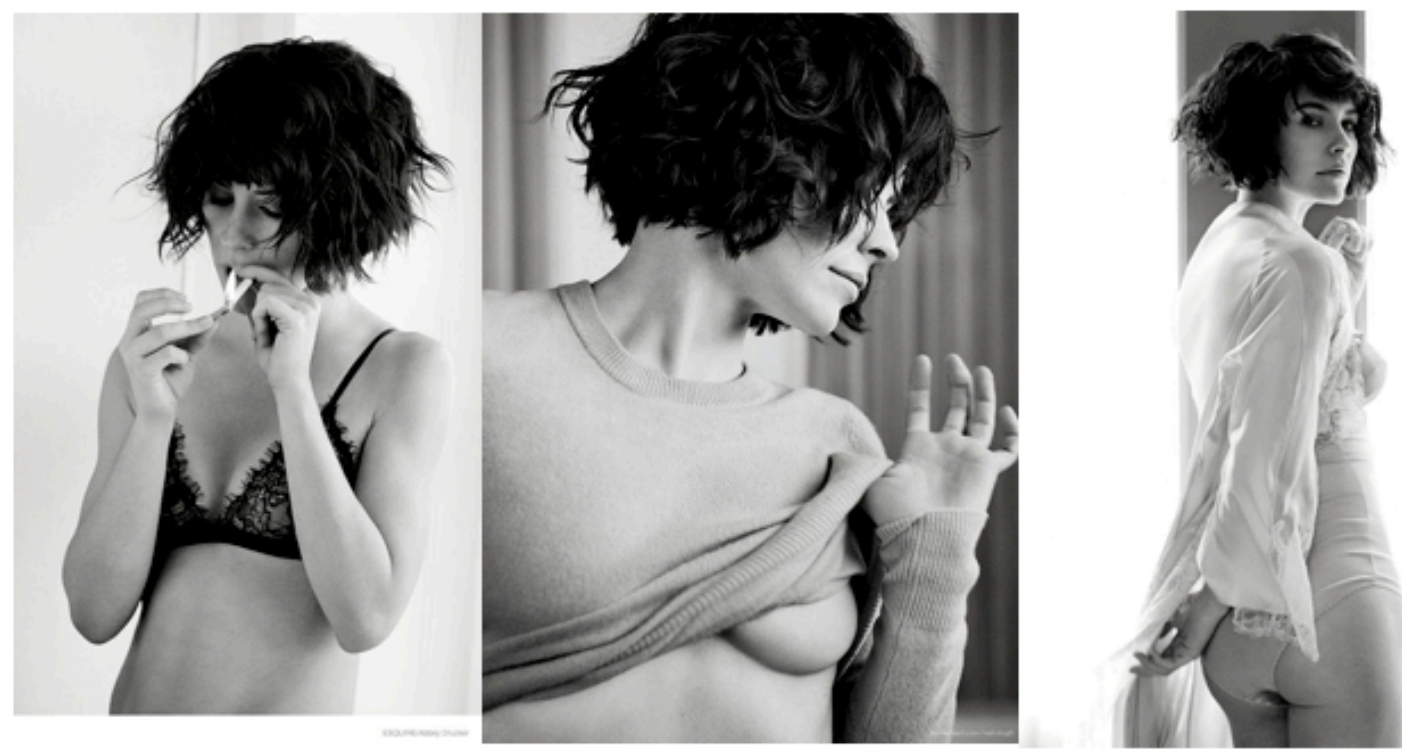

IMAGEN 35. Algunas de las fotografías que podemos encontrar en el reportaje de Esquire sobre la actriz Evangeline Lilly (Esquire, núm. 83, 2015).

FuENTE: Esquire.

Además de en las fotos, en el texto de los reportajes se resalta el cuerpo de las protagonistas. Si ya veíamos esta tendencia en las revistas femeninas, ahora podemos comprobar lo mismo, pero con alusiones sexuales. En el reportaje de DT a la modelo Sara Sampaio leemos "semidiosa espectacular de mirada penetrante, carnosos labios y un cuerpazo de escándalo" (DT, núm. 219, 2015). Sara Sampaio es imagen de la marca calcedonia, más concretamente, de los trajes de baño. Resulta "curioso" que esta prenda femenina sea de interés para un público masculino. Entendemos que lo interesante radica 
en las fotos de la sesión. Esta misma idea defiende el reportaje "Kendall y sus amigas" (DT, núm. 221, 2015), también de la revista $D T$ :

Visualiza esta escena: es un aburrido miércoles por la tarde. La semana parece que no se va a acabar nunca y el finde está aún lejísimos. Pero de pronto te encuentras con esta imagen [foto en ropa interior de la modelo Isabeli Fontana] de la sesión de fotos de Kendall Jener. Resulta que es su campaña "The Original Sexy" para Calvin Klein Underwear. Y de pronto, la vida parece de otro color... (DT, núm. 221, 2015).

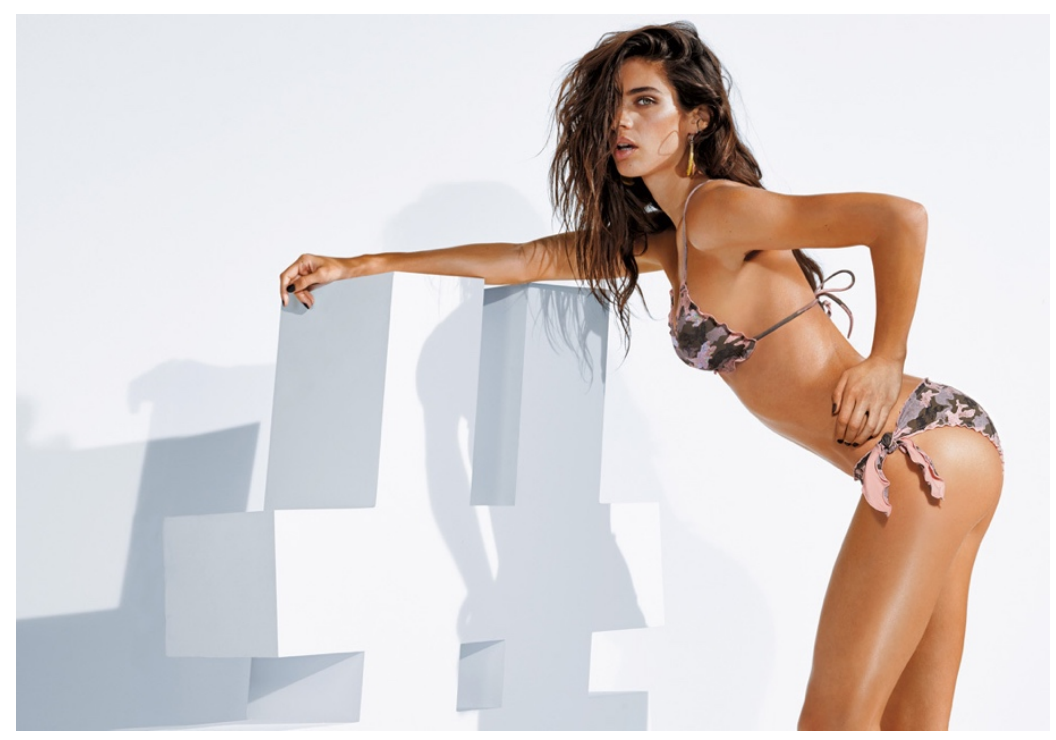

IMAGEN 36. $D T$ dedica un reportaje en el mes de junio a la modelo Sara Sampaio por su campaña de trajes de baño (DT, núm. 219, 2015).

FUENTE: $D T$.

Finalmente, destacar el reportaje que las modelos Emma Stern y Eva Doll protagonizan, el cual DT etiqueta como Fiesta de pijamas (DT, núm. 219, 2015). En este espacio, compuesto por 5 fotografías de una página cada una, más media página de texto, leemos:

¿Quién no sueña con un ménage a trois dirigido por dos diosas de la pasarela como esta? La walkiria escandinava, habitual de portadas de revistas en medio mundo, quiere invitarte a su particular fiesta de pijamas junto a una traviesa compañera de juegos: Eva Doll, una prometedora modelo que a sus 23 años ya ha sido portada de Harper's bazzar Rumanía e imagen de firmas como Jonas Bowman. Sin embargo, aunque por separado tengan una carrera prometedora, jutas representan la fantasía de cualquier hombre. Si a una belleza utópica le sumamos una puesta en escena compuesta por jaulas y espejos tenemos todos los ingredientes para dejar volar nuestra imaginación, sin límites (DT, núm. 219, 2015). 


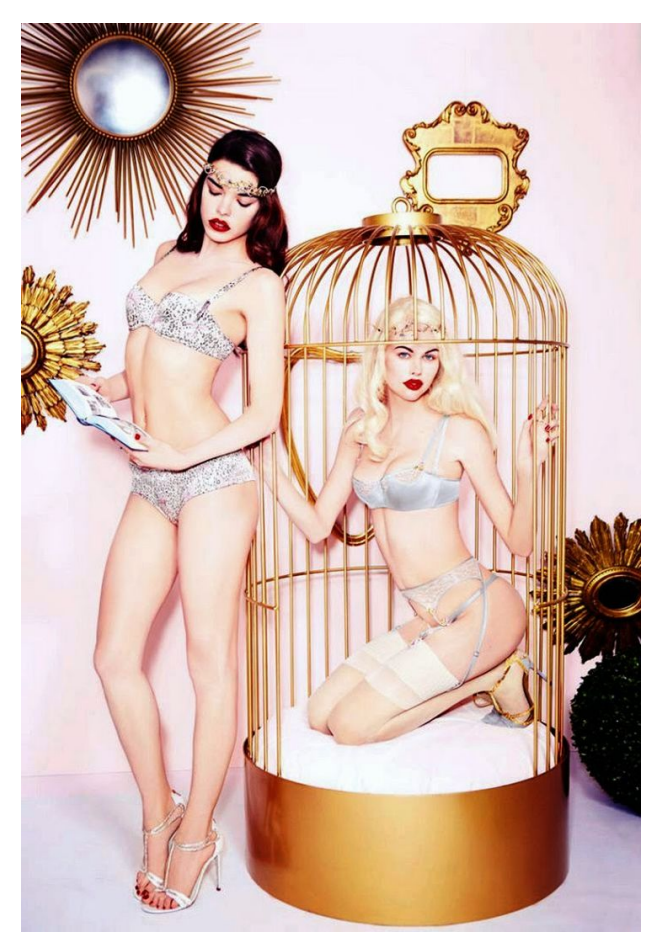

IMAGEN 37. Las modelos Emma Stone y Eva Doll en $D T$ (DT, núm. 219, 2015).

FuenTE: DT.

\subsection{Las contradicciones del discurso feminista en las revistas de estilo de vida}

No querríamos acabar este análisis de las publicaciones sin mencionar de qué manera se aborda el feminismo. En el "Compromiso contra la violencia” (Telva, núm. 914, 2015), Antonio Fernández-Galiano se refiere a la violencia de género como "una lacra social que sólo puede combatirse a través de la concienciación y la formación de opinión pública” (Telva, núm. 914, 2015). Sin embargo, un párrafo más adelante, leemos: "según un reciente estudio del Ministerio de Sanidad e Igualdad, uno de cada cuatro jóvenes de entre 14 y 19 años se ha sentido coaccionado por su pareja” (Telva, núm. 914, 2015). Resulta que el presidente de Unidad Editorial utiliza el masculino para hablar de las víctimas de violencia de género, víctimas que, por la propia definición del término, sólo pueden ser mujeres. De esta forma, no solo quedan invisibilizadas en el discurso, lo cual es absurdo, sino que el asegurar que tanto los jóvenes cómo las jóvenes pueden sufrir dicha violencia destruye el sentido de la reivindicación en sí.

Tampoco el diseñador de moda Juan Vidal se muestra nada preciso cuando intenta defenderse de unas acusaciones de misoginia. "Hubo gente que me llamó misógino, cuando he crecido en un taller de costura con clientas de todo tipo, vivo rodeado de 
mujeres, trabajo para ellas... Yo, que siempre trato de trabajar la cintura, los volúmenes, las caderas. Me encanta un cuerpo de mujer-mujer" (Telva, núm. 920, 2015). Estar acompañado por mujeres no convierte a nadie en feminista, ni mucho menos asegurar que los cuerpos de mujeres que realmente merecen tal apelativo son aquellos con curvas. Todos los cuerpos de mujeres son cuerpos de mujeres: lo son aquellos que la cultura patriarcal ha definido como tal (y que coinciden, "sorprendentemente", con los que alaba el diseñador) y lo son el resto.

En el reportaje "And the oscar goes to" (Telva, núm. 920, 2015) Meryl Streep anuncia su disconformidad con el término feminismo, además de demostrar una falta de conocimiento sobre lo que realmente significa: "no me gusta la etiqueta de feminista. Yo me considero humanista, porque creo que lo mejor es un buen equilibrio entre los sexos". Unas líneas más adelante, la revista lanza la siguiente opinión:
“Por qué la palabra feminista se ha hecho tan incómoda?”, se preguntaba Emma Watson el año pasado en la sede de la ONU, en un discurso que conviene repasar. Quizá la llamada de acción que Watson extendía también a los hombres sea lo más brillante de su audaz intervención: "He visto hombres sentirse frágiles e inseguros por lo que se considera éxito masculino. Los hombres tampoco tienen los beneficios de la igualdad" (Telva, núm. 920, 2015; énfasis en el original).

Lo realmente inspirador del discurso de Emma Watson fue, según dictamina Telva, apelar al sufrimiento de los hombres en una sociedad que supuestamente les oprime. Validar el feminismo por los beneficios que pueda reportar en los varones es una muestra más del machismo que impregna el pensamiento social. Así, un fenómeno cobrará mayor importancia cuanto más favorezca al sexo masculino. No deja de resultar ridículo considerar "brillante" que el mensaje de un movimiento que aboga por la liberación de las mujeres se centre en los hombres, como igual de ridículo resultaría si un discurso que abogaba por el final de la esclavitud en Estados Unidos hubiera convertido en protagonista a la población blanca.

Por su lado, la actriz Carey Mulligan nos acerca a una visión más precisa del término:

Para Mulligan es feminista quien considera que cualquier persona, sea hombre o mujer, tiene los mismos derechos. "Hoy en día, a muchas mujeres les pagan menos que a los hombres por realizar el mismo trabajo, y hay países donde las mujeres aún no votan, como es Arabia Saudí. Es triste que aún tengamos que luchar por esto, pero nos queda un largo camino por recorrer" (Telva, núm. 920, 2015). 
El reportaje "La identidad de lo femenino" (Glamour, núm. 155, 2015) intenta responder a cuestiones de índole identitaria. Se plantea si la fisiología humana es la que determina el comportamiento de las personas, así, busca responder a la pregunta de "qué es ser mujer y cómo serlo" (Glamour, núm. 155, 2015), tema, por otro lado, de especial interés para el feminismo. Finalmente, llega a la conclusión de que una mujer puede ser lo que desee:

A día de hoy una mujer puede desplegar su maternidad, su sexualidad, sus sanas aspiraciones profesionales, aficiones, talento, etc. Tenemos que dar las gracias a todas las que se rebelaron contra el rol de santas madres, esposas inmaculadas, des-carnadas. Aquellas mujeres valientes que rescataron la feminidad reprimida, oculta en la mujer-toda-madre. En mi opinión, se puede llegar a ser una Mujer, con mayúsculas, por méritos propios, sin tener que arrebatarle nada al varón (Glamour, núm. 155, 2015; énfasis en el original).

Si en algo acierta el anterior párrafo, es en agradecer la lucha a todas las mujeres que se rebelaron en contra de la opresión. Sin embargo, el patriarcado nunca ha reprimido la feminidad, como afirma la autora, es más, la ha alentado. Por tanto, ni ha tenido que ser rescatada ni significa ningún tipo de ruptura con el sistema anterior. Tampoco es lo apropiado hablar de llegar a ser "Mujer" y sí debería serlo de "mujeres" ya que, en el primer caso, se sigue reduciendo la realidad a una única forma de ser (que es lo que precisamente denunciaba la autora unas líneas antes). En cuanto a que no se le tiene que arrebatar nada al varón, sabemos que la subordinación femenina se sustenta, entre otras cosas, gracias a que los hombres disfrutan de unos privilegios a costa de la libertad de las mujeres, "el hombre [...] solo acepta a la mujer en el mundo masculino si la convierte en criada, si le arrebata su trascendencia; la libertad que se le entrega solo puede tener un uso negativo" (Beauvoir, 2008: 279-280), lo cual se traduciría en que son los varones los que han robado derechos a sus legítimas dueñas.

En ese mismo reportaje, se ve, de manera aún más clara, cómo la autora interpreta la realidad desde parámetros tradicionales: "el hombre en posición masculina deseante hacia la mujer la busca, la conquista, la quiere hacer suya sexualmente y, quizá también amorosamente. Le gusta que goce con él —explica Isabel Fernández—. Y es la mujer la que introduce la demanda del amor." (Glamour, núm. 155, 2015). Perpetuar el binarismo hombre-sexualidad/mujer-amor es decir exactamente lo mismo que llevan diciendo los discursos dominantes a lo largo de la historia. Además, ahonda en el mito del amor 
romántico, pues sitúa en posición activa al varón que "busca" y "conquista" a la mujer (objeto pasivo).

En términos de amor romántico se dirigen también a la modelo Laura Ponte a la que le preguntan sobre su príncipe azul y si "sigue" soñando con él (suponiendo, pues, que en algún momento tuvo que hacerlo como mujer que es):

¿Sigues soñando con tu príncipe azul?

Ya no vivo en esa utopía. Vivo al día, conozco a gente maravillosa y lo estoy pasando genial porque me he liberado. No creo en esa proyección del amor de tu vida... Creo que tenemos una capacidad de amar tremenda. Unas veces me seduce la bondad, otras el humor, su capacidad de trabajo... Pero no podemos pedir. Cada uno da lo que da. No se puede vivir en una pretensión, y más aún por amor, cuando el amor es libertad... (Glamour, núm. 149, 2015).

En el reportaje "Una causa común" (Glamour, núm. 152, 2015) se narra un viaje solidario que las actrices Eva Longoria y Elisa Sednaoui realizaron a Colombia. Entre las denuncias, está la de los altos índices de adolescentes embarazadas "cada paso que dábamos nos encontrábamos con otra niña embarazada. Ninguna de ellas iba a clase" (Glamour, núm. 152, 2015). Ese mismo número recoge un reportaje llamado "Dónde están y quiénes son los solteros de oro" (Glamour, núm. 152, 2015). A la hora de mencionar a Ben Rattray, el fundador de Change.org, leemos el siguiente apunte "se gana a todo el público femenino cada vez que dice cosas como que apoya la petición de las mujeres de Arabia Saudí para que las dejen conducir. ¡Irresistible!” (Glamour, núm. 152, 2015).

Los problemas de las mujeres son muchos y muy graves, y más si tenemos en cuenta los países en vías de desarrollo, como avanzaba el reportaje "Una causa común". Apoyar una causa feminista no convierte a un hombre en "irresistible", al igual que no le convertiría en encantador afirmar que todo el mundo tiene derecho a votar. La lucha feminista no es una lucha de segunda, es una cuestión de derechos fundamentales y merece, por tanto, un tratamiento digno. 


\title{
CAPÍtUlo QUINTO. ANÁlisis de LA MUESTRA: LOS CANALES DE TELEVISIÓN ESPECIALIZADOS SEGREGADOS POR GÉNERO
}

\author{
Lo que en un determinado momento histórico y en \\ una determinada sociedad se considera "natural" es \\ tan solo el "mundo natural" que ha fabricado la \\ ideología dominante. \\ Pilar Aguilar
}

\section{MARCO METODOLÓGICO}

El siguiente capítulo se centra en el estudio de la muestra televisiva. Para proceder al mismo, actuaremos igual que en el caso de la prensa. Primero, se realizarán dos análisis paralelos: uno acerca de los canales orientados a un público femenino y otro de aquellos dirigidos al público masculino. Así, conoceremos, de las cuatro cadenas, la ficha morfológica, los apuntes de identidad y su agenda temática. En último lugar, y con la intención de explorar las representaciones de la feminidad y de la masculinidad, un epígrafe final reunirá los resultados de los cuatro canales, enfrentando así, la totalidad de los mensajes.

\subsection{Delimitación del corpus de estudio}

Al abordar las revistas de estilo de vida, explicamos que la delimitación de nuestro corpus de estudio se veía condicionada, como es lógico, por el objetivo principal de la tesis. Así, a través de un estudio comparativo entre la prensa y la televisión, nos proponíamos conocer las posibles similitudes, o diferencias, entre los dos discursos mediáticos. Es por ello que escogimos, para ambos casos, una muestra que abarcara idéntico periodo temporal, pues nos permitía situarlos en el mismo contexto.

Cuando planteamos el estudio en 2015, los canales segregados en función del género eran productos jóvenes, por tanto, vimos oportuno recoger la muestra ese mismo año, pues tres de las cuatro cadenas estaban despegando - así sucedía con Discovery Max o Energy (2012) y, también, con Divinity (2011) - . La cuarta, Nova, contaba con 10 años. Dicha muestra, nos permitiría conocer la forma en qué estos canales de televisión 
segregados en función del género empezaban a configurar su programación y cómo orientaban las temáticas según el sexo al que se dirigieran.

El tamaño de la muestra se ha definido teniendo en cuenta el criterio de saturación. Del mismo modo que sucedió con las revistas, que se determinó que cuatro números serían suficientes para extraer una visión completa del año, así se ha hecho con los canales televisivos, que se ha convenido que cuatro semanas de seguimiento, una en el mes de marzo, otra en junio, otra en septiembre y otra en diciembre proporcionarían esa perspectiva completa.

\begin{tabular}{|c|c|c|c|c|c|}
\hline AÑO 2015 & MARZO & JUNIO & SEPTIEMBRE & DICIEMBRE & AUDIENCIA \\
\hline NOVA & $16 / 03-22 / 03$ & $15 / 06-21 / 06$ & $14 / 09-20 / 09$ & $14 / 12-20 / 12$ & 2,4 \\
\hline DIVINITY & $9 / 03-15 / 03$ & $7 / 06-13 / 06$ & $7 / 09-13 / 09$ & $7 / 12-13 / 12$ & 2,3 \\
\hline DISCOVERY MAX & $23 / 03-29 / 03$ & $22 / 06-28 / 06$ & $21 / 09-27 / 09$ & $21 / 12-27 / 12$ & 2,1 \\
\hline ENERGY & $2 / 03-8 / 03$ & $1 / 06-7 / 06$ & $31 / 08-6 / 09$ & $30 / 11-6 / 12$ & 1,5 \\
\hline
\end{tabular}

TABLA 38. Semanas de seguimiento de cada canal que compone la muestra.

FUENTE: Elaboración propia.

En cuanto a los canales que compondrían el objeto de estudio, al haber únicamente, en el año que se tomó la muestra, dos canales orientados a un público femenino - Nova y Divinity — y dos a un público masculino - Discovery Max y Energy - determinamos que sería posible afrontar el análisis de los cuatro.

\subsection{Propuesta metodológica}

Para conocer a fondo el mensaje de los canales de televisión se ha acudido, tal y como sucedió en el caso de la prensa, a la metodología del análisis de contenido. Recordemos que este método contempla varias fases independientes que abarcan un proceso muy amplio: desde el planteamiento de las hipótesis, hasta la formulación de conclusiones y la búsqueda de explicaciones. En primer lugar, sería necesario establecer las preguntas de investigación, posteriormente, definir el objeto de estudio para, después, seleccionar, partiendo de dicho objeto, las unidades de análisis. Una vez estas han sido determinadas, estableceríamos las categorías de contenido que fuéramos a emplear y estableceríamos un sistema de cuantificación para las mismas (Wimmer y Dominick, 1996: 174). Así, recordemos, dicha serie de pasos, convierten al análisis de contenido en una metodología 
reproducible, gracias a la cual otra persona podría enfrentarse a la muestra y extraer idénticos resultados, lo que evidencia la fiabilidad del mismo (Krippendorff, 1990: 29).

Las hipótesis y preguntas de investigación, referidas a la primera fase, las desarrollamos en el epígrafe introductorio de esta investigación. Así, nuestra hipótesis principal sostiene que los nuevos soportes de comunicación que segmentan sus audiencias en función del género — ciertos canales de televisión temáticos-, buscan la identificación con su público mediante la elaboración de un discurso sexista y estereotipado como ya lo hizo, anteriormente, la prensa. Además de la hipótesis principal, establecimos otras secundarias que hacían más sencillo y operativo el proceso de análisis.

En el anterior capítulo, delimitamos el corpus de estudio y establecimos que se tomaría una muestra trimestral de las revistas especializadas en estilo de vida. Ahora bien, para enfrentarnos a los distintos canales y seleccionar las unidades de análisis de las que nos hablan Wimmer y Dominick, ha sido necesario realizar, en primer lugar, un vaciado de los mismos. Las unidades mínimas que hemos encontrado son de tres tipos: espacios publicitarios —espacios de carácter comercial identificados claramente como tal: así puede ser un programa de Teletienda-, espacios de ficción - compuestos por la fícción seriada y los largometrajes - y los espacios de no ficción — que compondrían el resto de programación, esto es, telerrealidad, noticiarios, concursos, magazines, documentales, consultorios...-. Aunque se realizará un análisis tanto de los espacios de ficción como de los espacios de no ficción, serán estos últimos los que, dada su naturaleza más cercana a la de los contenidos de las revistas, permitan una comparación, quizá más exacta, con las publicaciones. Sin embargo, los largometrajes y las ficciones seriadas no se desestimarán y servirán de apoyo en todo el proceso analítico.

Una vez diseccionados los cuatro canales y rescatada cada unidad mínima, procederemos a determinar las categorías de contenido que se van a emplear. Como nuestra intención es la de elaborar el análisis completo de cada uno de los canales, no se seleccionarán ciertos espacios, sino que la parrilla será categorizada en su totalidad —a excepción de los espacios publicitarios- . A la hora de fijar las categorías intentamos, primeramente, que fueran las mismas que establecimos para la prensa, por aquello del diálogo que pretendemos generar entre ambos soportes, sin embargo, las etiquetas de la prensa no resultaron ser suficientes para abarcar todas las temáticas que nos ofrece el medio televisivo, por lo tanto, tuvimos que generar algunas nuevas. Procedemos, pues, a enumerar cada una de ellas: 
- Belleza y moda: son los espacios relacionados con la estética.

- Cocina y restauración: esta categoría general engloba los contenidos de hogar y gastronomía que vimos en el caso de las revistas de estilo de vida.

- Ciencia y tecnología: incluye espacios de ingeniería, construcción, fabricación de objetos, explicaciones científicas de procesos cotidianos...

- Interiorismo: es la etiqueta paralela a la de decoración fijada en el medio escrito. Encontramos, principalmente, programas de reformas.

- Motor: aunque en las revistas incluimos el mundo del motor dentro de la tecnología, en este caso hemos extraído la variable por considerar que había suficientes espacios como para crear una categoría autónoma.

- Ocio y cultura: recoge la programación relacionada con los estrenos de cartelera, los espacios musicales o los eventos deportivos.

- Salud: incluye los consultorios sobre bienestar físico o mental que encontramos en algunos canales.

- Sociedad: al igual que en la prensa, en esta categoría hemos agrupado aquellos espacios que tratan asuntos de interés social, como pueden ser unos informativos, pero, principalmente, sirve para recoger espacios que retratan la forma en la que vive una parte de la sociedad: aquellos en los que alguien experimenta un tipo de vida que le es ajena, como en el programa 21 días, o que nos acercan a grupos culturales minoritarios, tal es Palabra de gitano.

- Subastas: esta categoría no cuenta con su homónima en la prensa, pero engloba un tipo de programación recurrente en los canales masculinos basada en la retransmisión de subastas y los beneficios que se obtienen de las mismas.

- Supervivencia y naturaleza: incluye todos los espacios que se suceden en la naturaleza y cuyo principal objetivo es sobrevivir, también, vemos la programación vinculada con animales.

- Relaciones sentimentales: esta etiqueta agrupa contenidos donde vemos a parejas interactuar, como en los programas de citas. También, reúne los espacios de consejos encaminados a la seducción.

- Violencia y misterio: se muestran sucesos violentos a los que les rodea un halo de misterio, fenómenos paranormales, crímenes $\mathrm{y}$, del mismo modo, espacios de magia. 
- Convivencia: son formatos de telerrealidad que exhiben el día a día de un grupo de personas al que se le graba las 24 horas.

- Prensa rosa: incluye aquellos magazines sobre crónica social o del corazón.

- Historia: bajo esta etiqueta, encontramos documentales que abordan algún suceso histórico.

- Negocios: es la programación que gira en torno al día a día de un negocio o acerca de cómo funciona el mismo.

- Juegos y entretenimiento: la última de las categorías está compuesta por espacios en clave de humor o aquellos juegos en los que la audiencia puede intervenir bajo la realización de apuestas.

En cuanto a los espacios de ficción, estos se han categorizado a partir de las etiquetas tradicionales que permiten conocer la naturaleza de su contenido. En nuestro caso concreto, encontraremos drama, con sus variaciones de drama romántico, si relata una historia de amor, drama femenino, cuando el argumento gira en torno a protagonistas mujeres o drama profesional, si el escenario en el que se suceden los hechos es un lugar de trabajo. También, vemos comedia, es decir, aquellos largometrajes o ficciones seriadas que se desarrollan en clave de humor, y comedia romántica, donde el argumento principal describe una relación amorosa. Encontraremos, del mismo modo, los thriller o tramas de suspense, con sus variaciones de thriller policiaco, en las que se resuelven una serie de misterios o crímenes, y thriller profesional, aquí, de nuevo, el escenario que reúne a los y las protagonistas es su lugar de trabajo. Además de estos, los distintos canales, explotan el género fantástico, el de aventuras, acción y ciencia ficción.

Así, una vez clasificados y categorizados los espacios, se procederá a la medición nominal de los mismos para averiguar los porcentajes que las cuatro cadenas televisivas nos ofrecen de cada temática. Esto nos permitirá realizar un análisis comparativo entre, por un lado, los canales femeninos, por el otro, los canales masculinos y, finalmente, enfrentar ambas realidades. Señalar, por último, que el análisis no solo quedará restringido al ámbito numérico, sino que se expondrán detalladamente los espacios más relevantes de cada categoría, lo que permitirá aportarnos una panorámica amplia sobre los cuatro canales. 


\section{CANALES DE TELEVISIÓN ESPECIALIZADOS ORIENTADOS A UN PÚBLICO FEMENINO}

A lo largo de los epígrafes segundo y tercero de este capítulo, realizaremos una descripción detallada de los cuatro canales de televisión que incluirá: su ficha morfológica, los apuntes de identidad y la agenda temática. En último lugar, un cuarto epígrafe reunirá los resultados, enfrentando los mensajes y permitiéndonos conocer, así, las representaciones de la feminidad y de la masculinidad que nos proponen estos canales.

\subsection{Nova}
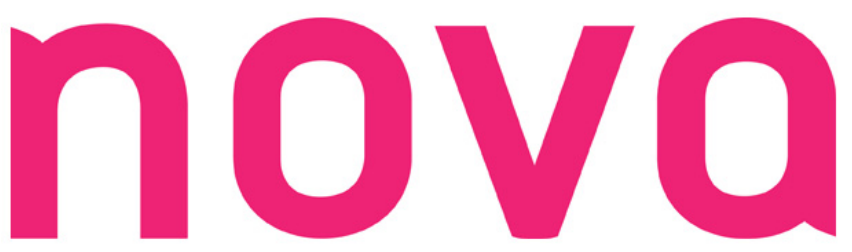

IMAGEN 38. Logotipo del canal televisivo Nova. FueNTE: Nova.

\begin{tabular}{|c|c|}
\hline NOMBRE & Nova \\
\hline DESCRIPCIÓN & Ponte nova ${ }^{89}$ \\
\hline SITIO WEB & www.nova.atresmedia.com \\
\hline TRANSMISIÓN POR INTERNET & www.atresplayer.com \\
\hline ORIGEN & España \\
\hline PROPIETARIO & Atresmedia Corporación \\
\hline GRUPO DE COMUNICACIÓN & Atresmedia Televisión \\
\hline ÁREA DE TRANSMISIÓN & España y Andorra \\
\hline LUGAR DE TRANSMISIÓN & Madrid \\
\hline DIRECTOR & Javier Bardají (director general de Atresmedia TV) \\
\hline INICIO DE TRANSMISIONES & $\begin{array}{l}30 \text { de noviembre de } 2005 \text { (Antena.Nova) } \\
6 \text { de agosto de } 2010 \text { (Nova) }\end{array}$ \\
\hline AUDIENCIA & $2,4 \%$ (año 2015) \\
\hline PROGRAMaCión & Entretenimiento \\
\hline CATEGORÍA & Temático, orientado a un público femenino \\
\hline
\end{tabular}

TABLA 39. Ficha morfológica del canal televisivo Nova.

FUENTE: Elaboración propia.

\footnotetext{
${ }^{89}$ El eslogan de los canales televisivos es cambiante. El eslogan que se muestra tanto para Nova como para el resto de canales televisivos será el registrado en el año 2015, cuando se tomó la muestra.
} 
Antena.Nova inicia sus emisiones el 30 de noviembre de 2005 en el relanzamiento de la Televisión Digital Terrestre en España (González y Alfeo, 2011: 399). En el año 2010 cambia su nombre por el actual, Nova, y en el año 2015, momento en el que se toma nuestra muestra, cumple su décimo aniversario. ${ }^{90}$ Nova nace como un canal pensado para un público femenino (Videla y Costa, 2012: 52) que, según datos de Kantar Media, encuentra sus fortalezas entre las franjas de edad de 13 a 44 años y de 55 a 64 .

Tal y como afirma José Antonio Antón — director de los canales temáticos de Atremesdia en 2015-, ${ }^{91}$ su programación incluye, en buena parte, telenovelas, pero también series, películas y programas de telerrealidad. Se trata de formatos reciclados, salvo pequeñas aportaciones (Mi casa como nueva o Hoy cocinas tú dos programas producidos por Bainet para Nova). ${ }^{92}$ De entre los cuatro canales temáticos que componen nuestra muestra, este es el que más audiencia cosecha.

A parte del procedimiento tradicional, es decir, vía televisión, podemos consumir Nova a través de la plataforma Atresplayer (www.atresplayer.com) que incluye todos los contenidos del grupo Atresmedia y que diferencia los de Nova de los de los otros cinco canales de Atresmedia porque marca sus títulos con color rosa. Otra forma de acceder a los contenidos del canal femenino en la web es clicando sobre el propio logotipo de Nova, presente en la esquina superior izquierda. Ahí, un menú desplegable diferencia entre las etiquetas Series y Programas.

El seguimiento de Nova fue trimestral y comprendió, como ya se ha mencionado, cuatro semanas del año 2015. La primera semana recogida fue en marzo (lunes 16 de marzo a domingo 22 de marzo), la segunda en junio (lunes 15 de junio a domingo 21 de junio), la tercera en septiembre (lunes 14 de septiembre a domingo 27 de septiembre) y, finalmente, la cuarta en diciembre (lunes 21 de diciembre a domingo 20 de diciembre). Así pues, se grabaron un total de 28 días en lo que se emitieron hasta 98 programas distintos. Una primera categorización nos hace distinguir entre espacios de ficción, espacios de no ficción y programas de publicidad.

\footnotetext{
${ }^{90}$ Véase información publicada en 2015: "Nova cumple 10 años: descubre sus 25 emisiones más vistas". Recuperado el 21 de noviembre de 2017 de http://www.formulatv.com/noticias

${ }^{91}$ Véase información publicada en 2015: "José Antonio Antón: vamos más allá de batallas entre canales, buscamos una oferta global y complementaria dentro del grupo". Recuperado el 21 de noviembre de 2017 de http://www.formulatv.com/noticias/51293/entrevista-jose-antonio-anton-director-neox-nova/

${ }^{92}$ Véase información publicada en 2015: "Nova estrena imagen y renueva contenidos con programas de producción propia". Recuperado el 21 de noviembre de 2017 de http://www.lavanguardia.com/television
} 


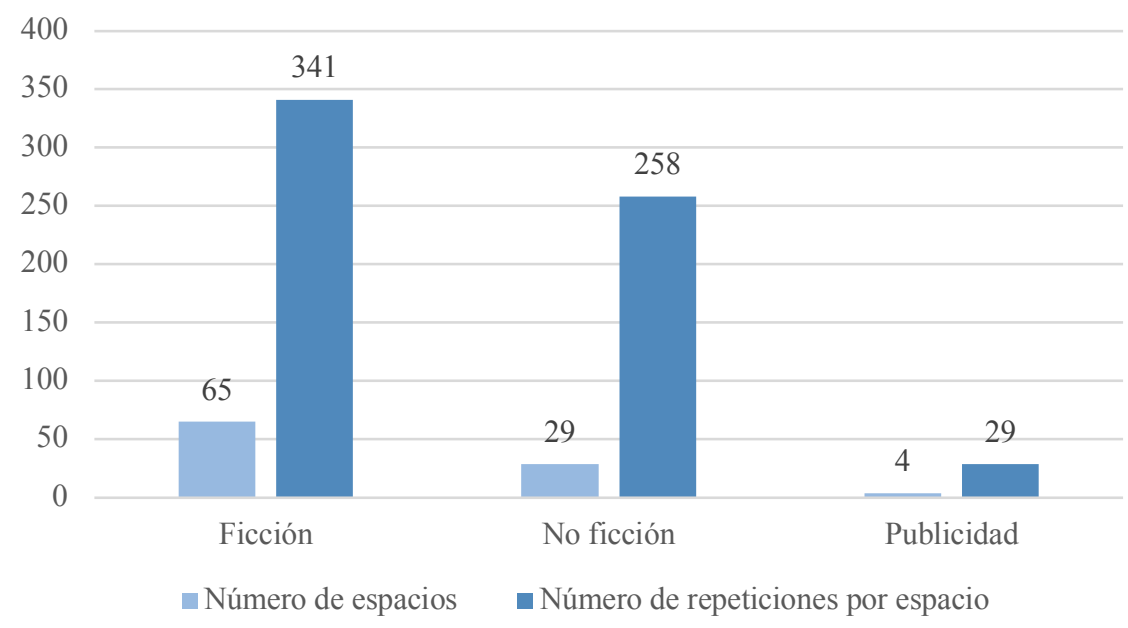

GrÁFICO 22. Tipo de programación en Nova y número de repeticiones (muestra año 2015). FUENTE: Elaboración propia.

El primer gran bloque de contenidos es el que está compuesto por espacios de ficción. Vemos hasta 65 espacios que se repiten en 341 ocasiones. Es, pues, la categoría más relevante, tanto por tiempo de emisión como por la cantidad de títulos que abarca. Los formatos de ficción son series (37 series y 334 repeticiones) y películas (30 películas). Estos se dividen, a su vez, en distintas subcategorías: dentro de la ficción seriada distinguimos entre drama, drama romántico, fantasía y thriller policiaco. Mientras, en los largometrajes volvemos a ver thrillers y, también, comedias románticas.

En la ficción seriada, el contenido que más se repite es el de drama romántico. Se han registrado hasta 26 telenovelas repetidas en 228 ocasiones, lo que supone el $36 \%$ del total de la programación de Nova. Dichos espacios se emiten los días de entresemana tanto por las mañanas como por las tardes. Los títulos que encontramos son los siguientes: Abismo de pasión, Amor bravío, Bella calamidades, Corazón indomable, Cuando me enamoro, Cuidado con el ángel, El cuerpo del deseo, El color de la pasión, El señor de los cielos, Emperatriz, Esperanza mía, La gata, La impostora, La patrona, La sombra del pasado, La viuda de blanco, Lo que la vida me robó, Los miserables, Mar de amor, Marido en alquiler, Mi corazón es tuyo, Muchacha italiana viene a casarse, Pasión de gavilanes, Sortilegio, Tierra de reyes y, por último, Yo no creo en los hombres.

Muchacha italiana viene a casarse ha sido la más emitida (25 repeticiones). En junio lo hizo diariamente a las 20:00 de la tarde y durante septiembre y diciembre, no solo 
se pudo ver por las tardes, sino que también por las mañanas. Su protagonista es Gianna, que intentará casarse con un hombre que le prometió que correría con los gastos de la hermana enferma de Gianna. Marido en alquiler (20 repeticiones) se emitió por las mañanas y por las tardes de los meses de junio y septiembre y nos acerca a la vida de Griselda, viuda que debe sacar adelante a su familia y que se enamorará locamente de Reinaldo Ibarra. Cuidado con el ángel (19 repeticiones) es la tercera más emitida, de nuevo cuenta con doble capítulo los días de entresemana durante los meses de septiembre y diciembre. En este caso, su protagonista es huérfana y se enamora de Juan Miguel San Román, un psicoanalista.

En Abismo de pasión (5 repeticiones), cuatro jóvenes no pueden perseguir sus sueños porque sus progenitores tienen otros planes para ellos. En Amor bravio (5 repeticiones), Camila está enamorada de Daniel, sin embargo, debe casarse con Alonso, un hombre con un pasado oculto. Mientras, en Bella calamidades (10 repeticiones), Lola, huérfana, sufre los maltratos de su tía. Confía en que algún hombre le salve de esa situación. Corazón indomable (5 repeticiones) es la historia de Maricruz Olivares quien debe cuidar de su abuelo y de su hermana muda. En Cuando me enamoro (5 repeticiones), Renata se casa con Jerónimo, un hombre vengativo. El cuerpo del deseo (10 repeticiones) narra la reencarnación de Pedro José, un hombre rico que muere súbitamente.

En El color de la pasión (10 repeticiones), Rebeca se casa con el marido de su hermana cuando esta muere. El señor de los cielos (5 repeticiones) es la historia del narcotraficante Aurelio Casillas que, tras una infidelidad, desea que su mujer le perdone. En Emperatriz (5 repeticiones), una mujer lucha por recuperar a su hija mientras se va vengando de quiénes la humillaron en el pasado. Esperanza mía (9 repeticiones) narra el amor entre Julia Albarracín y el sacerdote Tomás Ortiz. En La gata (5 repeticiones) Esmeralda, de clase social humilde, se enamora del adinerado Pablo. La familia de este pone todo tipo de trabas a la relación.

La impostora (10 repeticiones) es la historia de amor entre Blanca Guerrero, quien se desvive económicamente por su familia, y Eduardo Altamira. La patrona (5 repeticiones) narra la venganza de Gabriela Suárez que fue violada por uno de los hijos de La Patrona a la vez que se había enamorado de otro de ellos. En La sombra del pasado (10 repeticiones), dos jóvenes de familias enfrentadas viven una historia de amor prohibido. En La viuda de blanco (10 repeticiones), Alicia Guardiola sufre una condena injusta acusada de asesinar a su marido después de que su suegra engañase a la justicia. 
Al salir de la cárcel, se enamora de su cuñado Diego Blanco. En Lo que la vida me robó (10 repeticiones), Monserrat y José Luis están enamorados, sin embargo, Monserrat es obligada por su madre a casarse con un hombre rico.

En Mar de amor (5 repeticiones), León, un hombre rico, quiere que Estrella sea su mujer y pondrá todo tipo de trabas para que ella y Víctor Manuel no puedan vivir su amor sincero. En Mi corazón es tuyo (5 repeticiones), Ana, de vocación bailarina, irá poco a poco quedándose prendada del hombre viudo para el que trabaja cuidando de sus hijas e hijos. Pasión de gavilanes (5 repeticiones), es la historia de tres hermanos: Juan, Oscar y Franco quienes se enamoran de las hermanas Norma, Jimena y Sarita, hijas de un empresario poderoso.

En Sortilegio (5 repeticiones), María José cree que va a contraer matrimonio con Alejandro Lombardo, pero realmente se trata de Bruno, su rico hermanastro, quien le ha usurpado la identidad. En Tierra de reyes (10 repeticiones), los hermanos Arturo, Samuel y Flavio quieren vengar la muerte de su hermana, asesinada por la familia Junco. Sin embargo, se enamoran de las hijas de la familia: Sofía, Andrea e Irina. Yo no creo en los hombres (10 repeticiones) es la historia de María Dolores, quien ha estado en la cárcel por matar al hombre que intentó abusar de ella. María Dolores no confía en ningún hombre hasta que conoce a Gustavo, abogado, que se enamora de ella. En Los miserables (5 repeticiones), Lucia es perseguida por el departamento de narcóticos, a pesar de ser inocente. Ella está enamorada de Daniel Ponce, jefe del departamento.

Tras drama romántico, la siguiente categorías más relevante es la de thriller policiaco que abarca 6 series y 71 repeticiones. Los títulos son Bajo sospecha, Bones, El mentalista, Ley y orden: unidad de víctimas especiales, Life y Perception. Estos thrillers ocupan las noches de los fines de semana. Bones, la más emitida (23 repeticiones), trata sobre la investigación forense, su protagonista, la doctora Brennan es una antropóloga que trabaja junto al FBI y su equipo de profesionales. Bones no solo muestra la resolución de distintos casos, también las relaciones personales entre sus protagonistas. Ley y orden: Unidad de víctimas especiales (22 repeticiones) se centra en la ciudad de Nueva York y en como la Unidad de Víctimas Especiales resuelve casos de crímenes que tienen lugar en la gran manzana.

En Perception (11 repeticiones), el médico Daniel Pierce colabora con el FBI en los casos en los que todo parece indicar que es necesario la intervención de un neurólogo. También, en El mentalista (10 repeticiones), el mentalista Patrick Jane trabaja junto al 
agente de policía Lisbon con el fin de poder vengarse del asesino de su esposa y su hija. Life (4 repeticiones) narra los intentos del detective Charlie Crews por encontrar a la persona que causó el triple asesinato que condenó al detective a pasar 12 años en prisión injustamente. Finalmente, en Bajo sospecha (1 repetición), los policías Víctor y Laura tienen una misión: encontrar a una niña que desapareció el día de su primera comunión. Esta vez es la propia familia de la niña quien pone difícil la resolución del caso.

Posteriormente, en drama encontramos El guardián (4 repeticiones) donde Nick defiende a menores víctimas de abusos y delitos varios. En El tiempo entre costuras (2 repeticiones) Sira vivirá los convulsos años que rodean a la Guerra Civil española. A través de su taller de costura, realizará labores de espionaje que serán claves para el bando inglés en su lucha contra Hitler. Sin identidad (2 repeticiones) trata sobre María quien quiere vengarse de la familia que la adoptó.

Finalmente, dentro de la ficción seriada, vemos un último título para la categoría de fantasía: Érase una vez emitida en 5 ocasiones. La serie fusiona el mundo de los cuentos con el mundo real. El hijo de Emma Swan encuentra a su madre 10 años después de que ella lo diera en adopción. Entonces, cree que su madre vive en el cuento de Blancanieves y que es hija de este personaje.

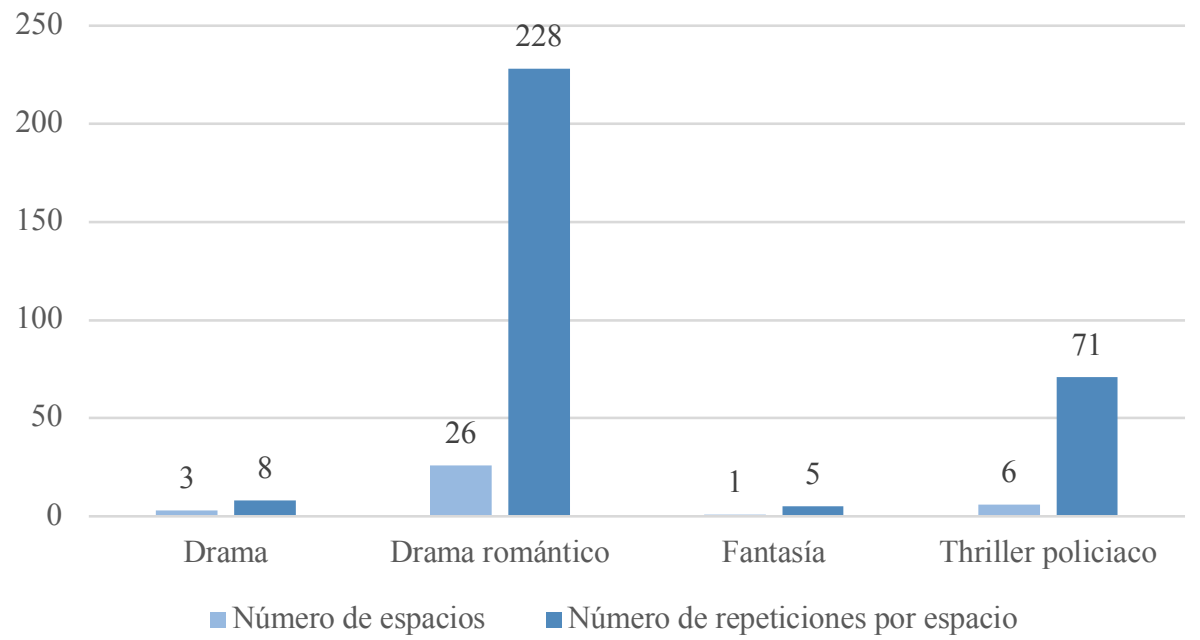

GRÁFICO 23. Ficción seriada en Nova y número de repeticiones (muestra año 2015). FUENTE: Elaboración propia.

En cuanto a los largometrajes, durante los 28 días se han emitido 29 películas: 13 de ellas son dramas, 14 son thrillers y 2 comedias románticas. Se han televisado en las 
noches de entresemana, de lunes a jueves, dentro de las siguientes secciones: Noche de película, Cine, Cine supernova y Navidades nova. Así, para la categoría de drama encontramos Acoso en la red social, Beloved, Cautiva, Contra su voluntad, El precio de la infidelidad, La ayudante perfecta, La decisión de Anne, Nunca más, Las flores de la guerra y Pearl Harbor. También vemos África en el corazón, La mujer prohibida, Susurros en el desierto y una Esposa para papá que son drama romántico.

El argumento de Acoso en la red social gira en torno a Taylor a quien han usurpado su identidad por internet. En el lado contrario, encontramos Beloved una película que narra las aventuras de Sethe, esclava fugitiva que duda sobre la verdadera identidad de la joven que se hace llamar Beloved. Cautiva trata sobre la desaparición de su protagonista, Jessica Crowder. Contra su voluntad es la búsqueda que lleva a cabo una madre a la que arrebataron a su hija recién nacida.

En El precio de la infidelidad, el marido de Alice secuestra al amante de su esposa con el fin de vengarse de ella. Mientras, en La ayudante perfecta, Rachel, obsesionada con su jefe, llegará incluso a matar a la mujer de este. La decisión de Anne trata sobre la forma que tiene una familia de salvar a su hija, a la que diagnostican leucemia. Las flores de la guerra narra el encuentro entre bandos enemigos. Así, tras la Guerra de Secesión, un soldado estadounidense cae en manos de una madre y una hija que se ocupan de su recuperación. Pearl Harbor también sigue las aventuras de soldados estadounidenses, esta vez, durante la Segunda Guerra Mundial.

Como bien se ha mencionado, algunas de las películas entran dentro de la categoría de drama romántico. Así, África en el corazón narra la historia de amor entre la doctora Catherine y el hermano gemelo de su marido ya fallecido, Stephan. Susurros en el desierto también es la historia de amor entre un príncipe y una doctora. En La mujer prohibida los amantes son Vereena y Khalid quienes no pueden casarse porque la familia de Khalid, perteneciente a la realeza, le obliga a contraer matrimonio con otra mujer. En Esposa para papá, Crystal se enamora del padre de Olivia, una niña que le ha pedido a Santa Claus que su padre viudo vuelva a tener pareja.

En cuanto a los thrillers, los largometrajes que encontramos son Al cruzar el límite, Atrapada en la oscuridad, Cuidado con lo que deseas, El color de la noche, El secreto de la selva negra, Hasta que la muerte nos separe, Jackie Brown, La hija del éxito, La mujer de negro, La sombra de los otros, Marea letal, Nunca más, Plan de vuelo: desaparecida y Un lugar seguro. 
En Al cruzar el límite, el neurólogo Lawrence Myrick está utilizando a gente marginal para realizar sus experimentos. En Atrapada en la oscuridad, una reportera de guerra pierde la visión mientras está trabajando. Posteriormente, dos hombres que buscan un botín asaltan su casa con ella dentro. Cuidado con lo que deseas es la historia de un estudiante que pasa a convertirse en sospechoso número uno cuando el marido de su amante aparece muerto. El color de la noche nos lleva hasta el asesinato de Jim, un médico al que mata uno de sus pacientes. En El secreto de la selva negra se resuelve la desaparición de la ex mujer de un reputado forense.

En Hasta que la muerte nos separe, el profesor de un colegio será detenido injustamente por un ataque de celos que sufre el marido de su compañera Sara. La protagonista de Jackie Brown es una azafata que se pone al servicio de Robbie. Un día, la policía le descubre y solo podrá librarse de la condena si les conduce hasta el mafioso. En La hija del éxito, la hija del alcalde celebra su cumpleaños cuando su casa es asaltada. Los invitados e invitadas de la fiesta serán tomados como rehenes. La mujer de negro trata sobre la aparición que Arthur Kipps cree ver en la casa de uno de sus clientes ya fallecido.

En La sombra de los otros, una psiquiatra descubre que un paciente con personalidad múltiple al que ya había tratado está adoptando las personalidades de víctimas de asesinato. Mientras, Kate Mathiesen es engañada en Marea letal por un multimillonario que pretende utilizarla para permanecer junto a un tiburón fuera de la jaula. En Nunca más, Slim inventa una nueva identidad con el fin de huir de su pareja. La hija de Kyle Pratt, Julia, desaparece en Plan de vuelo: desaparecida. Ambas viajaban hasta Nueva York, sin embargo, nadie que va a bordo creerá a Kyle. Finalmente, el asesinato en serie de varias mujeres compone la trama de Un lugar seguro donde la agente Carly Segan investigará el suceso.

Finalmente, Buscando a Santa desesperadamente y Regalo de cumpleaños son dos comedias románticas. En Buscando a Santa desesperadamente Jennifer comienza a fijarse en David, el Papá Noel que ella seleccionó para la campaña de Navidad de un supermercado. Mientras, Regalo de cumpleaños es la historia de Jackie Laurens, una mujer de 40 años que se enamora de un surfista menor que ella, hecho que provoca la desaprobación de toda su familia. 


\section{LARGOMETRAJES EN NOVA (2015)}

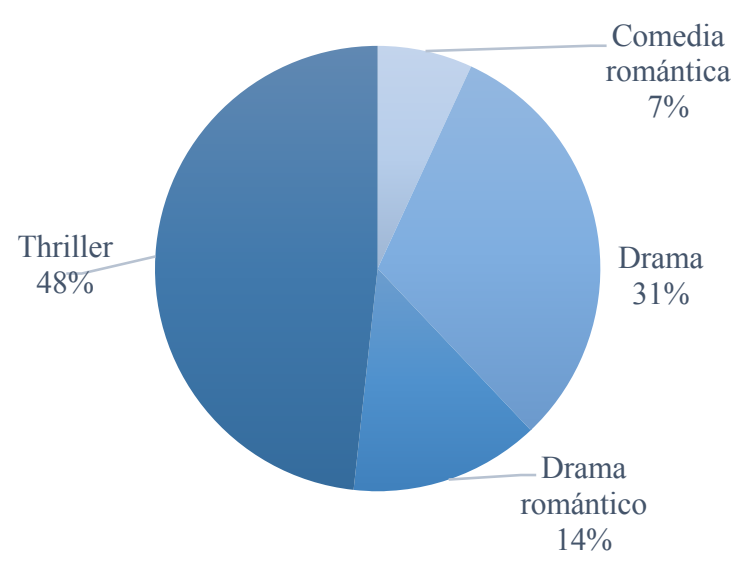

GráFiCo 24. Largometrajes en Nova (muestra año 2015). FUENTE. Elaboración propia.

El segundo gran bloque de contenidos es el que está compuesto por espacios de no ficción. Vemos 29 espacios que se repiten 258 ocasiones. Observamos, además, que Nova llena su parrilla de los fines de semana con estos formatos. Las categorías que nos han permitido clasificar los contenidos de no ficción han sido las de belleza y moda, cocina y restauración, interiorismo, ocio y cultura, salud y sociedad.

Cocina y restauración es la categoría más relevante dentro de la no ficción (28\%). Comprende 8 espacios emitidos un total de 73 veces, estos son: Cocina con Bruno, Cocineros españoles por el mundo, Hoy cocinas tú, Karlos Arguiñano en tu cocina, Pesadilla en la cocina, Pesadilla en la cocina EEUU, Top chef y Top chef(USA). Cocina con Bruno (20 repeticiones) y Karlos Arguiñano en tu cocina (20 repeticiones) son los dos espacios más veces emitidos. Aunque, como se ha mencionado, la tendencia dentro de los formatos de no ficción sea a ocupar la parrilla de los fines de semana, estos espacios se emiten sobre la hora de comer (dos de la tarde) de lunes a viernes. Ambos programas elaboran platos completos mientras guían a la audiencia para que también pueda hacerlo. Además, en Cocina con Bruno el cocinero no solo cocinará, sino que también acudirá al mercado para mostrar los mejores y más económicos alimentos. Por último, en Hoy cocinas tú (4 repeticiones) Eva Arguiñano enseña a un invitado o invitada cómo preparar un plato principal y su postre. 
El tercer espacio más repetido es Pesadilla en la cocina EEUU (10 repeticiones) en el que el chef Gordon Ramsay intenta rescatar negocios de restauración que, por distintos motivos, no son solventes económicamente. Pesadilla en la cocina (9 repeticiones) es la versión española, conducida por el chef Alberto Chicote que también se propone reflotar restaurantes con problemas. En Top chef (USA) (7 repeticiones) chefs de menor categoría compiten ante un juzgado compuesto por grandes chefs, enfrentándose entre sí a través de diversos retos culinarios. Top chef (1 repetición) es la versión española del formato y comparte la misma mecánica. Finalmente, Cocineros españoles por el mundo ( 2 repeticiones) muestra el trabajo que distintas cocineras y cocineros desempeñan fuera del territorio español.

Mientras, interiorismo lo componen 5 espacios repetidos un total de 46 veces. Los títulos que encontramos son: Bricomanía, Decogarden, Escuela de decoración, Mi casa como nueva y Se alquila. Decogarden es el que más veces se ha emitido (18 repeticiones). En este programa, una experta decoradora acude a las casas de gente que quiere renovar alguna de las estancias de su hogar sin invertir demasiado dinero. Además, se ofrecen consejos para el cuidado de plantas y mascotas. Mi casa como nueva (2 repeticiones) sigue la misma mecánica, aunque esta vez las inquilinas e inquilinos se pondrán en manos de una arquitecta de interiores, un decorador y un experto en reciclaje de muebles.

Por su parte, Bricomanía (17 repeticiones) enseña a la audiencia a cómo elaborar distintos muebles partiendo de cero. En Escuela de decoración (1 repetición) el equipo de la cadena de muebles Ikea acude a casas donde distintas familias cuentan con problemas de distribución o espacio para intentar solucionarlo mediante un proceso de redecoración. En Se alquila (8 repeticiones) viejos inmuebles en alquiler serán rediseñados por Jordi y su equipo con el fin de que se adapten a los gustos de sus próximos ocupantes.

Belleza y moda lo componen 2 espacios repetidos 8 veces. Los programas que encontramos son: $B$ a la moda y De compras en nova. De compras en nova (7 repeticiones) es un programa dedicado a la moda: muestra las últimas tendencias, lo que podemos encontrar en las tiendas o qué ha sido lo más visto en pasarelas. B a la moda (1 repetición) lo protagoniza Belén Canalejo, famosa por su blog de moda y su canal en YouTube donde además ofrece lifestyle. También, enseña tendencias y diversos consejos relacionados. 
En ocio y cultura, vemos 3 espacios emitidos un total de 55 veces, estos son: Minutos musicales, Nova sound, Tú cara me suena y Ver cine. El programa con un mayor número de emisiones es Minutos musicales (52 repeticiones), que se proyecta todas las madrugadas, generalmente a partir de las 3. Es un espacio dedicado enteramente a la música donde artistas interpretan sus trabajos. En Nova sound (1 repetición), encontramos otro espacio dedicado a la música. Tú cara me suena (1 repetición) es un talent show en el que personajes famosos imitarán a cantantes ofreciendo, así, un espectáculo musical y Ver cine (1 repetición) presenta los estrenos de la cartelera.

En cuanto a salud, lo componen 3 espacios repetidos 13 veces. Los programas que encontramos son: Enfermedades embarazosas, Objetivo bienestar y Qué me pasa doctor. El médico Beltrán dirige el consultorio de salud Qué me pasa doctor (8 repeticiones) dónde será la propia audiencia la que exponga sus dudas médicas. En Objetivo bienestar (4 repeticiones) se ofrecen consejos para llevar una vida más saludable. Finalmente, Enfermedades embarazosas (1 repetición) pretende llegar a pacientes que sufren enfermedades poco comunes y que les resulta vergonzoso acudir a que se les diagnostique. En este sentido, les enseña los pasos que deben seguir para curarse.

Finalmente, sociedad y actualidad comprende 4 espacios emitidos un total de 36 veces, estos son: El jefe, El jefe infiltrado, Millonario anónimo y Noticias de la mañana. Así, El jefe (15 repeticiones) y El jefe infiltrado (11 repeticiones) son dos programas de telerrealidad en los que el jefe o la jefa se infiltra de manera anónima en el día a día de su empresa con el fin de conocer cuál es el rendimiento laboral o por qué problemas atraviesa el negocio. En Millonario anónimo (6 repeticiones), serán empresarios o empresarias que gozan de muy buena economía quienes vivan por un tiempo de incognito dentro de un barrio marginal, al que acaban por donar grandes cantidades de dinero. Finalmente, Noticias de la mañana (4 repeticiones) es el espacio dedicado a tratar la actualidad política, económica y social.

En una última categoría denominadas otros, encontramos los espacios Crímenes imperfectos (22 repeticiones), serie en la que se recrean distintos asesinatos (el móvil, cómo se ejecutaron...), Casados a primera vista (1 repetición) reality show que da la vuelta al mundo de las relaciones y propone empezarlas el día de la boda — así, 5 parejas pasarán por el altar y, posteriormente, convivirán durante un mes con el fin de conocer si desean continuar o no la relación-y, finalmente, English house (4 repeticiones) espacio destinado a aprender inglés. 


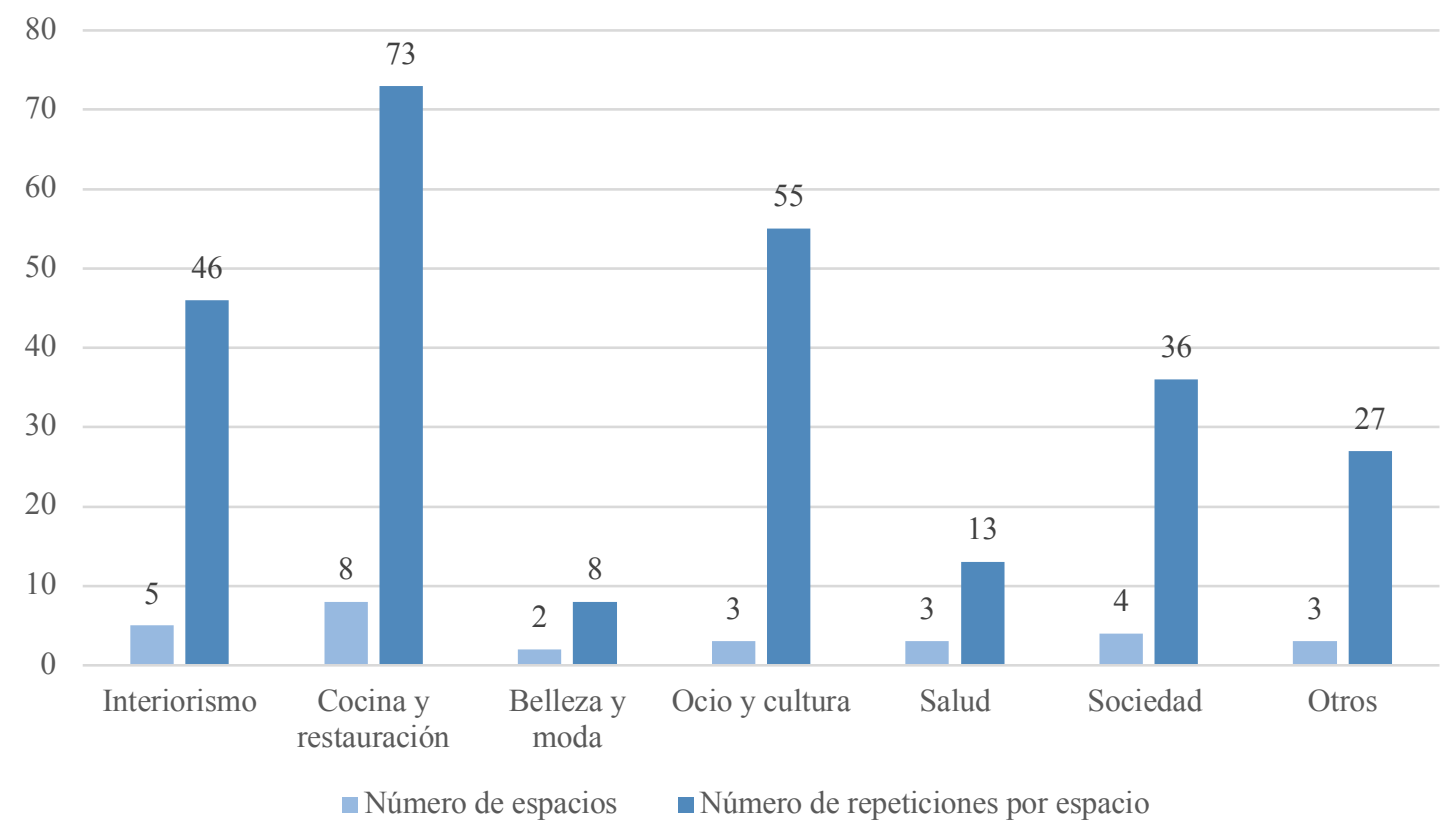

GRÁFICO 25. Espacios de no ficción en Nova y número de repeticiones (muestra año 2015).

FUENTE: Elaboración propia.

Finalmente, encontramos el bloque de contenidos que está compuesto por distintos espacios los cuales sirven para promocionar marcas y productos. Vemos Beta, Comprando en casa nova, La tienda tv y Teletienda club. Comprando en casa nova (13 repeticiones), La tienda tv (8 repeticiones) y Teletienda club ( 7 repeticiones) son espacios que ofrecen demostraciones acerca del funcionamiento y eficacia de distintos productos, bien sean de hogar, belleza, deporte, electrónica, ocio... la audiencia puede adquirirlos en ese preciso instante mediante venta telefónica. Por su lado, Beta (1 repetición) es un cortometraje de Gas Natural Fenosa.

\subsection{Divinity}

Divinity, propiedad de Mediaset España Comunicación, comenzó a emitirse, en versión de pruebas, el 1 de marzo de 2011. Fue un mes después, el 1 de abril, cuando se lanzó la versión definitiva del mismo. ${ }^{93}$ Lo hizo con un maratón de la popular serie Sexo en Nueva York y su eslogan de arranque fue El nuevo canal de televisión de las mujeres. Según un comunicado de Mediaset, Divinity complementaba la oferta del grupo comunicacional

\footnotetext{
${ }^{93}$ Véase información publicada en 2011: "El grupo Telecinco lanza Divinity, un nuevo canal para el público femenino". Recuperado el 20 de noviembre de 2017 de http:/www.formulatv.com/noticias/18525/grupotelecinco-lanza-divinity-nuevo-canal-publico-femenino/
} 
ofreciendo este canal "especialmente diseñado para las mujeres urbanas, de entre 16 y 44 años, con nivel social alto y medio-alto". ${ }^{94} \mathrm{Su}$ director es Sergio Calderón, director al mismo tiempo de Energy, el canal masculino del grupo.

\section{divinily}

IMAGEN 39. Logotipo del canal televisivo Divinity.

FuENTE: Divinity.

\begin{aligned} & FiCHA MORFOLÓGICA DEL CANAL TELEVISIVO DIVINITY \\ & NOMBRE Divinity \\ & \hline DESCRIPCIÓN Is a must! \\ & \hline SiTIO WEB www.divinity.es \\ & \hline TRANSMISIÓN POR INTERNET www.mitele.es \\ & \hline ORIGEN España \\ & \hline PROPIETARIO Mediaset España Comunicación \\ & \hline GRUPO DE COMUNICACIÓN Mediaset España Comunicación \\ & \hline ÁREA DE TRANSMISIÓN España y Andorra \\ & \hline LUGAR DE TRANSMISIÓN Madrid \\ & \hline DIRECTOR Sergio Calderón (director de los canales temáticos Divinity, Energy \\ & y BeMad) \\ & \hline INICIO DE TRANSMISIONES 1 de marzo de 2011 \\ & \hline AUDIENCIA $2,3 \%$ (año 2015) \\ & \hline PROGRAMACIÓN Entretenimiento \\ & \hline TIPO DE CANAL Temático, orientado a un público femenino \\ & \hline\end{aligned}

TABLA 40. Ficha morfológica del canal televisivo Divinity.

FUENTE: Elaboración propia.

La programación que podemos encontrar abarca ficción, reality shows y espacios rosas, entre otros. El mejor éxito lo cosecha en la franja de edad que abarca desde los 13 hasta los 54 años (Barlovento Comunicación, diciembre 2015). Su estrategia pasa por encadenar el mismo producto y ofrecer varios capítulos seguidos —estrategia de comunicación conocida como dúplex-(Videla y Costa, 2012: 54). Los formatos son reciclados, a excepción del programa del corazón Cazamariposas, la serie Yo quisiera, el

\footnotetext{
${ }^{94}$ Véase información publicada en 2011: "Divinity arranca con un maratón de "Sexo en Nueva York". Recuperado el 21 de noviembre de 2017 de http://www.mediaset.es/telemania/Divinity-maraton-SexoNueva-York_0_1197000018.html
} 
talent-show Quiero ser, el concurso Luce tu pueblo, el mini espacio de ocio Divinity jukebox, los resúmenes de los realities de Mediaset o la cobertura que se hace de diversos eventos musicales como los Premios 40 Principales de la popular emisora de radio. Aun sin tratarse de muchos formatos, puede presumir de concentrar bastante más producción propia que sus otros canales hermanos de la TDT. ${ }^{95}$

El sitio web de Divinity (www.divinity.es) se asemeja a las versiones digitales de las revistas de estilo de vida o del corazón. Ofrece noticias del mundo de la moda, la belleza o las celebrities. Contiene galerías de fotos sobre distintos eventos, entrevistas a personajes del corazón, del cine, la música o el modelaje, además de información en formato audiovisual. El menú de pestañas está formado por DModa, DBelleza, DBodas, DMamás, DCasas, DCooltura, TV, DMujeres y Blogs. Casi no existe autopromoción del canal televisivo en sí. Es desde Mi tele (www.mitele.com), la plataforma online de Mediaset que aglutina toda la programación del grupo, que se puede acceder al contenido televisado.

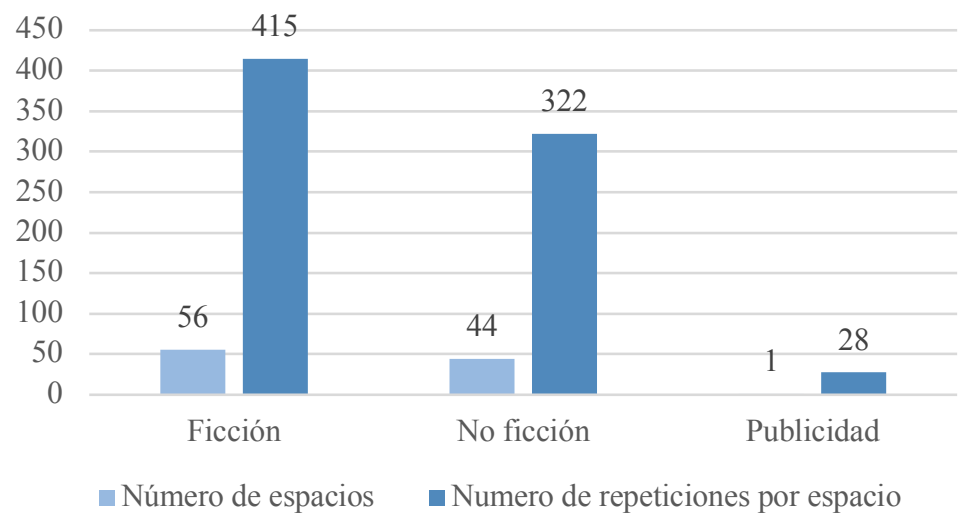

GráfiCo 26. Tipo de programación en Divinity y número de repeticiones (muestra año 2015). FUENTE: Elaboración propia.

El seguimiento de Divinity fue trimestral y comprendió, como ya se ha mencionado, cuatro semanas del año 2015. La primera semana recogida fue en marzo (lunes 9 de marzo a domingo 15 de marzo), la segunda en junio (lunes 7 de junio a domingo 13 de junio), la tercera en septiembre (lunes 7 de septiembre a domingo 13 de septiembre) y, finalmente, la cuarta en diciembre (lunes 7 de diciembre a domingo 13 de

\footnotetext{
${ }^{95}$ Véase información publicada en 2016: “¿Por qué Mediaset centra la mayoría de su producción propia para TDT en Divinity?" Recuperado el 21 de noviembre de 2017 de http://www.lamoscamediatica.com
} 
diciembre). Así pues, se grabaron un total de 28 días en lo que se emitieron hasta 101 programas distintos. Una primera categorización nos permite distinguir entre espacios de ficción, espacios de no ficción y publicidad.

El primer gran bloque de contenidos es el que está compuesto por los espacios de ficción. Vemos hasta 56 espacios que se repiten en 415 ocasiones. Es, pues, la categoría más relevante, tanto por tiempo de emisión como por la cantidad de títulos que abarca. Dentro de este bloque, encontramos ficción seriada y películas. En cuanto a la primera, durante los 28 días se han emitido un total de 33 series que se han repetido 392 veces. Por su naturaleza, estas se dividen en comedia romántica, drama femenino, drama profesional, drama romántico y fantasía.

La comedia romántica la componen los títulos de Ciega a Citas y Yo quisiera. Ciega a citas (7 repeticiones) es la historia de Lucía, que se propone encontrar novio en siete meses, justo el tiempo que falta para la boda de su hermana menor. Yo quisiera (5 repeticiones) es una serie adolescente en la que Lana, autora del blog "Yo quisiera", se enamora de André, que, aunque trabaje como camarero de la cafetería del instituto, su verdadera pasión es el piano.

Mientras, para drama femenino vemos tres series: Criadas y malvadas, Gossip girl y Mujeres desesperadas. Mujeres desesperadas cuenta con 26 repeticiones. Sus protagonistas son Susan, Lynette, Gabriell y Bree cuatro mujeres que viven en el adinerado barrio de Wisteria Lane. Aparentan llevar una vida perfecta, sin embargo, varios asuntos atormentan a cada una de ellas, bien sean amorosos, laborales o familiares. Gossip girl (5 repeticiones) narra el día a día de un grupo de jóvenes de la alta clase de Manhattan. Tras un tiempo ausente, Serena van der Woodsen regresa a su antiguo círculo y debe asumir unos asuntos amorosos del pasado que le enfrentan directamente con su mejor amiga. En Criadas y malvadas (1 repetición), cinco asistentas trabajan en las casas más ricas de Beverly Hills. Es debido al asesinato de una empleada del hogar, que comenzarán a salir a la luz asuntos ilegales que enturbian la idílica vida del barrio.

Drama profesional es la categoría donde más títulos encontramos, un total de 20: Ladrón de guante blanco, Los nuestros, Franklin y Bash, Rockie blue, Terapia de choque, Anatomía de Grey, Sin cita previa, Bella y Bestia, Blue bloods: familia de policías, C.S.I Miami, Caso abierto, Castle, El cuerpo del delito, Elementary, Imborrable, Medium, Scandal, Sin rastro, The closer y The finder. 
La mayoría de estas series son policiacas, aunque también encontramos de medicina o derecho. En Ladrón de guante blanco (2 repeticiones) Neal Caffrey es ayudante en el FBI. Rockie blue (1 repetición) narra la carrera profesional de cinco policías. Catherine Chandler es detective de Homicidios en Bella y Bestia (1 repetición). En Blue bloods: familia de policías (12 repeticiones), cuatro miembros de una familia ejercen o han ejercido como policías. En C.S.I Miami (4 repeticiones), la investigación forense se mezcla con la policial para resolver los crímenes acontecidos en la ciudad de Miami. Caso abierto (54 repeticiones) se desarrolla en el Estado de Filadelfia, donde la detective Lilly Rush trabaja en el departamento policial.

El protagonista de Castle (76 repeticiones) es un escritor que ve como alguien está llevando a cabo los asesinatos de sus novelas. La detective Kate Beckett y el escritor serán los encargados de iniciar una investigación. En El cuerpo del delito (30 repeticiones), la forense Hunt investiga las muertes de sus pacientes. En Elementary (3 repeticiones), Sherlock Holmes y la doctora Joan Watson trabajan junto con la policía de Nueva York. La hipertimesia que sufre Carrie Wells, que recuerda las situaciones con todo detalle, se convierte en una herramienta eficaz a la hora de resolver crímenes en Imborrable (7 repeticiones).

En Medium (9 repeticiones) el fiscal Devalos contrata a Patricia Arquette, una médium capaz de hablar con los muertos y, por tanto, resolver crímenes. En Sin rastro (25 repeticiones), seguimos la pista del FBI que resuelve distintas desapariciones. Brenda Johnson será la encargada de los casos de homicidio de la ciudad de Texas en The closer (19 repeticiones). En Los nuestros (1 repetición), el ejército español debe solucionar un secuestro llevado a cabo por una organización yihadista en Malí.

Addison empieza a trabajar en una clínica privada en Sin cita previa (27 repeticiones). En Anatomía de Grey (15 repeticiones) vemos el día a día del equipo de cirujanos del Hospital Seattle Grace, donde las tramas profesionales se mezclan con las amorosas. En Terapia de choque (3 repeticiones) Dani Santino lleva una consulta de psicoterapia. Por último, en The finder (1 repetición), debido a una lesión en el cerebro, Walter Sherman tiene la capacidad de encontrar lo que sus clientes deseen, objetos escondidos o, incluso, personas en paradero desconocido. Scandal (5 repeticiones) trata sobre la agencia de Olivia Pope, "Pope \& Associates", quien evita que la imagen pública de sus clientes se vea salpicada por cualquier escándalo. En Franklin y Bash (2 repeticiones), Jared y Peter trabajan en un importante bufete de abogados de Los Ángeles. 
Por su lado, drama romántico lo forman cinco telenovelas: Avenida Brasil, Destilando amor, La dama velada, La tempestad y Un gancho al corazón. En Avenida Brasil (9 repeticiones), a Rita su madrastra le robó la herencia familiar cuando era pequeña, una vez ha crecido, desea vengarse de ella. En La tempestad (5 repeticiones), Marina y Damián se enfrentan a Hernán, un mafioso envuelto en el negocio de la trata de mujeres y que quiere acabar con la fábrica en la que Marina y Damián trabajan. En Un gancho al corazón (5 repeticiones), Valentina debe mantener económicamente a su novio y a su suegra, a pesar de que ya no puede ejercer su trabajo, boxeadora profesional, debido a una lesión en la mano. Destilando amor (3 repeticiones) es la historia de Teresa, una jornalera que se queda embarazada de Rodrigo, quien heredará el negocio familiar si consigue un descendiente varón. En La dama velada (4 repeticiones), Clara Grandi también se ve obligada a engendrar un descendiente varón para heredar, aun así, su tía y su primo pretenden quedarse el negocio de la familia e intentan asesinarla. Entonces, Clara se hará pasar por otra persona para así vengarse.

Finalmente, fantasía incluye las series Entre fantasmas y Sobrenatural. En Entre fantasmas (13 repeticiones), Melinda Gordon es capaz de comunicarse con los espíritus, a los que ayuda con sus asuntos pendientes para que puedan, finalmente, descansar en paz. En Sobrenatural (10 repeticiones) dos hermanos hacen frente a criaturas sobrenaturales mientras se dirigen tras la pista de su padre desaparecido. Revenge (2 repeticiones) es un thriller desarrollado en los Hamptons, comunidad que provocó la muerte del padre de Emily una vez quedó en la ruina. Emily vuelve para vengarle.

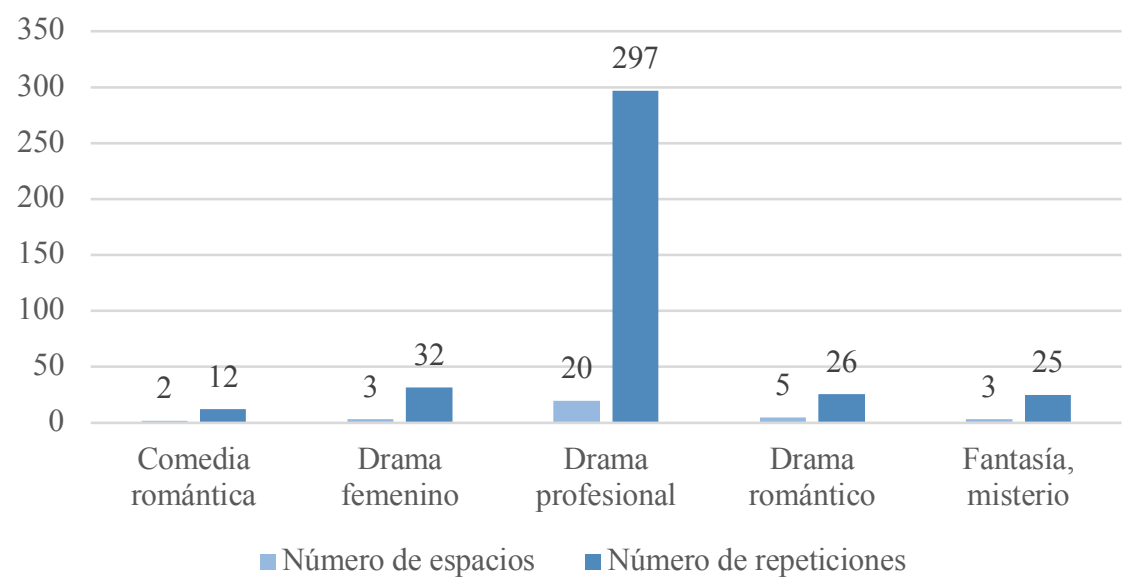

GráFICO 27. Ficción seriada en Divinity y número de repeticiones (muestra año 2015).

FUENTE: Elaboración propia. 
Durante los 28 días de seguimiento, se han emitido en Divinity 23 películas que abarcan los géneros de acción, comedia y comedia romántica, drama, fantasía y aventuras y thriller. Así, en el género de acción tenemos Sesenta segundos, donde Randall Raines debe robar 50 coches en menos de 72 horas si pretende liberar a su hermano secuestrado. En fantasía y aventuras vemos Hermosas criaturas, Midnight sun: una aventura polar y Oz un mundo de fantasía. En Hermosas criaturas Lena descubre a Ethan, un adolescente al que le gustaría vivir aventuras fuera de su pueblo, cuando precisamente allí, en Gatlin, se esconde todo tipo de magia. Midnight sun: una aventura polar es el viaje de Luke y un oso polar, al que acompaña en la búsqueda de su madre. En Oz un mundo de fantasía, el mago Oscar Diggs se muda al país de Oz con el fin de triunfar como mago, sin embargo, su dudosa reputación le precede, hecho que no se les pasará por alto a las brujas Theodora, Evanora y Glinda.

Dentro de comedia, vemos Nada que perder y Buscando a Susan desesperadamente, y en comedia romántica: Bridget Jones: Sobreviviré, Chalet girl, Dance-off, Shall we dance? y Siete dias y una vida. En Nada que perder, Nick Beam secuestra al atracador que intenta robarle. Juntos inician una enloquecida carrera en la que se verán envueltos en más atracos y delitos varios. Buscando a Susan desesperadamente, es la historia de Roberta Glass quien conoce a Susan, una mujer impulsiva que meterá a ambas en numerosos líos. En Bridget Jones: Sobreviviré, Bridget había encontrado la estabilidad amorosa con Mark Darcy, sin embargo, la aparición de Rebeca, compañera de Mark, provocará la ruptura de la pareja. Bridget se refugiará en sus amigas y en su ex, que la guiarán por todo tipo de situaciones cómicas.

En Dance-off, Brandon y Jasmine, rivales en la pista de baile, terminan enamorándose. En Shall we dance? John Cark, un abogado de mediana edad, descubre su pasión por el baile. John oculta a su familia su nueva afición, lo que le separa todavía más de su mujer. Sin embargo, tras muchos malentendidos, el abogado descubre que cuando más disfruta del baile es cuando finalmente lo comparte con su familia. Chalet girl es la historia de Kim Matthews, quien se convertirá en campeona de snowboard a la par que se enamorará durante una competición en los Alpes. Por último, en Siete días y una vida Lanie Kerrigan descubre que le quedan 7 días de vida, tiempo suficiente para vivir una historia de amor con Peter, un novio del pasado.

Para drama vemos los títulos El vuelo, Un hogar para navidad, Una casa para navidad y, en drama romántico, encontramos La Bella y la Bestia y Sobreviviré,. En El 
vuelo, un piloto evita que su avión sufra un accidente. La euforia inicial se ve aplacada cuando la policía descubre que se trata de un hombre con problemas de drogas y alcohol. En Un hogar para navidad, Martha ha adoptado a su sobrino y a sus dos sobrinas. La navidad está cerca y debe encontrar una casa en la que poder vivir si no quiere que los servicios sociales las separen. En Una casa para navidad, Julie está atravesando por una mala época después de que su marido haya iniciado una relación con una mujer más joven. Su hija quiere pasar las navidades con ella, pero Julie tiene problemas económicos.

En La Bella y la Bestia, tras un incendio, un príncipe francés queda con la cara desfigurada. El príncipe obliga a Maurice Dubois a que le entregue a su hija, Bella, como sirviente. Sobreviviré es la historia de Marga e Iñaki. Marga atraviesa el momento más complicado de su vida tras la muerte de su novio y saberse embarazada. Iñaki y Marga se enamoran y, aunque la historia no funciona, ayuda a Marga a seguir adelante.

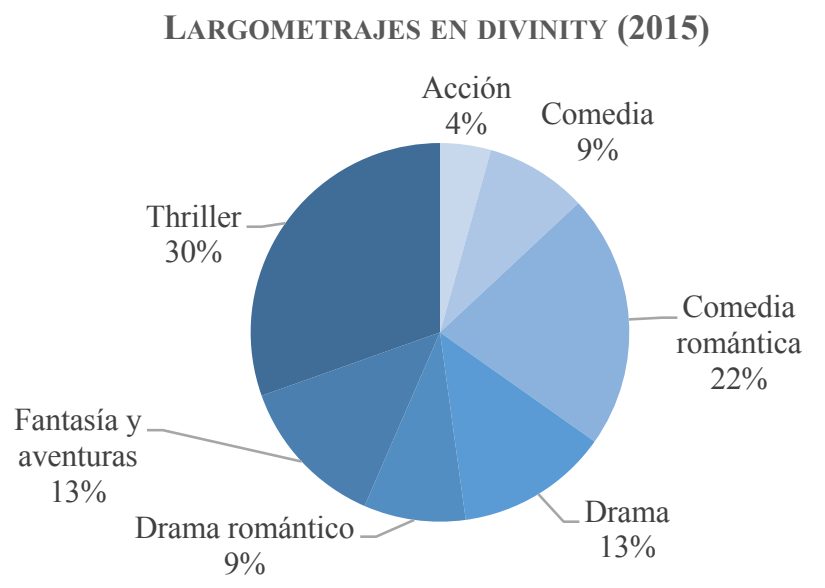

GRÁFICO 28. Largometrajes en Divinity (muestra año 2015).

FUENTE: Elaboración propia.

Finalmente, en thriller vemos 7 títulos: Efectos secundarios, El demonio bajo la piel, Los secretos de la casa de acogida, Mientras no estás, Obsesionada, Toda la verdad y Un Santa Claus especial. En Efectos Secundarios, Emily, que padece depresión, sigue un tratamiento médico por el que sufrirá varios efectos secundarios. En El demonio bajo la piel, Lou Ford, sheriff adjunto, se convierte en principal sospechoso de los asesinatos que están sucediendo en su jurisdicción. Los secretos de la casa de acogida trata sobre una casa de acogida de mujeres víctimas de maltrato. Los maridos de estas mujeres 
comienzan a aparecer asesinados y Wendy, una de las mujeres, se convierte en principal sospechosa.

Mientras no estás es la historia de Linda y Mark, quienes, después de poner cámaras por toda su casa, descubren que su nueva niñera no se está comportando debidamente. En Obsesionada, la examante de un prestigioso hombre de negocios hace peligrar la vida laboral y familiar de este cuando se obsesiona con él. La verdadera identidad de Tom, ex militar, aparece a la luz en Toda la verdad. Tras quince años llevando una falsa vida, el FBI lo acusa de haber asesinado a civiles inocentes en la guerra de El Salvador. Finalmente, en Un Santa Claus especial, Jen se enamora de Chris, quien trabaja como Papá Noel en un centro comercial. Poco a poco, Jen va descubriendo que Chris no es lo que aparentaba ser.

Tras los formatos de ficción, el segundo gran bloque de contenidos de Divinity es el que está compuesto por los espacios de no ficción. Vemos hasta 44 espacios que se repiten en 322 ocasiones. Las categorías que nos han permitido clasificar los contenidos de no ficción han sido las de belleza y moda, convivencia, ocio y cultura, prensa rosa, interiorismo, cocina y restauración y relaciones sentimentales.

Belleza y moda comprende 7 espacios emitidos un total de 40 veces, estos son: Cambia de look, Cámbiame, Extreme makeover: cambio radical, Fashionistas, Guerra de estilistas, Locos por las compras y Los duques de Melrose. Cambia de look es el espacio que más veces se ha repetido, 19 ocasiones. La concursante, con ayuda de dos personas de su entorno y el asesoramiento de una estilista, deberá escoger un nuevo look que supuestamente mejora su aspecto. También en Cámbiame (10 repeticiones) los y las concursantes sufren una transformación física gracias a un cambio de vestuario, peinado y maquillaje de la mano de Pelayo Díaz, Cristina Rodríguez y Natalia Ferviú, estilistas. Extreme makeover: cambio radical (1 repetición) sigue la misma mecánica que los anteriores, sin embargo, recurre, esta vez, a la cirugía plástica para modificar la apariencia física.

En Guerra de estilistas (4 repeticiones) Taylor Jacobson, Brett Allan, Sammy y Juddy hacen un repaso por los secretos de las alfombras rojas. Fashionistas (2 repeticiones) sigue el día a día de la boutique de moda "Second Time Around" y Los duques de Melrose (2 repeticiones) nos transporta hasta otra boutique, esta vez la de Decades, de Christos Garkinos y Cameron Silver. Se trata de una tienda de alta costura situada en Hollywood. Finalmente, Locos por las compras (2 repeticiones) es un docu- 
reality protagonizado por personas adictas a las compras. El programa ilustra las terapias que siguen con el fin de rehabilitarse.

Por su lado, convivencia lo componen 7 espacios repetidos 27 veces. Los programas que encontramos son: Gran hermano 16: la casa en directo, Gran hermano 16: resumen diario, Gran hermano VIP 2015: la casa en directo, Gran hermano VIP 2015: resumen diario, S.O.S Supervivientes, Supervivientes 2015: resumen diario, Supervivientes diario desde Honduras.

En Gran hermano 16: resumen diario (4 repeticiones) y Gran hermano 16: la casa en directo (4 repeticiones) varios concursantes, de ambos sexos, conviven en la misma casa durante varios meses. Su día a día es captado por las cámaras y retransmitido a la audiencia. Lo mismo sucede en Gran hermano VIP 2015: resumen diario (5 repeticiones) y Gran hermano VIP 2015: la casa en directo (5 repeticiones) solo que, en esta ocasión, son famosos y famosas quienes conviven dentro de la casa. En Supervivientes 2015: resumen diario (5 repeticiones), S.O.S Supervivientes (2 repeticiones) y Supervivientes diario desde Honduras (2 repeticiones) de nuevo personajes famosos conviven, esta vez en una isla y con pocos recursos. Semanalmente deberán ir abandonando la isla en función de los votos de la audiencia hasta que alguien se alce como ganador o ganadora.

Ocio y cultura comprende 7 espacios emitidos un total de 51 veces, estos son: Cazamariposas pre-show. Premios 40 principales 2015, Concierto Alejandro Sanz: gira sirope, Concierto Pablo Alborán, Divinity jukebox live, Incluye divinity jukebox, Premios 40 principales 2015, Taquilla mediaset. En Taquilla mediaset (28 repeticiones) aparecen anunciados los últimos estrenos en el mundo del cine, el teatro o los espectáculos. Es un breve espacio de cinco minutos que se emite diariamente a las 4 de la madrugada. Divinity jukebox live (1 repetición) e Incluye divinity jukebox (1 repetición) se centran en ofrecer novedades musicales, ya sea el trabajo de artistas o sus giras, conciertos o incluso festivales.

Divinity retransmitió los Premios 40 principales 2015, premios ofrecidos por la cadena musical de radio donde se galardona el trabajo musical de artistas tanto nacionales como internacionales. Previamente, emitió un especial con el equipo de Cazamariposas, al que tituló Cazamariposas pre-show. Premios 40 principales 2015 (1 repetición). También ha retransmitido los conciertos Concierto Alejandro Sanz: gira sirope (1 repetición) y Concierto Pablo Alborán (1 repetición). 
En prensa vemos 3 espacios repetidos 29 veces. Los programas que encontramos son: Cazamariposas, Divinity stars y Más cazamariposas. Cazamariposas (18 repeticiones) y Más cazamariposas (9 repeticiones) son dos programas que nos ofrecen las últimas noticias del mundo del corazón. Además, Más cazamariposas incluye moda. Divinity stars (2 repeticiones) también se dedica a la crónica rosa.

Interiorismo es la categoría más relevante para Divinity (21\%), que comprende 7 espacios emitidos un total de 88 veces, estos son: La casa de mis sueños, D. Lujo, Million dollar decorators, Tú al centro, yo a las afueras, Tu casa a juicio, Tu casa a juicio: Vancouver, Tu casa lo vale y Vender para comprar. La casa de mis sueños es el programa más veces emitido con 23 repeticiones. Lo protagonizan dos hermanos, Jonathan y Drew Scott, uno de ellos, experto inmobiliario, encuentra pisos de segunda mano para distintas parejas, pisos que, posteriormente, su hermano, constructor, transformará completamente. Jonathan y Drew Scott también aparecen en el espacio de telerrealiad Vender para comprar (10 repeticiones), donde mejoran la casa actual de los y las participantes para así obtener el mayor beneficio a la hora de venderla.

Tú al centro, yo a las afueras (17 repeticiones) es el segundo espacio más emitido. De nuevo lo dirigen dos hermanos que asesoran a una pareja. Estos les ofrecen las mejores ofertas en tema inmobiliario, tanto dentro de la ciudad, como fuera. La pareja deberá escoger cuál de todas las opciones se adapta mejor a sus expectativas y estilo de vida.En Tu casa a juicio (14 repeticiones), una pareja no sabe si vender su casa o reformarla. La interiorista Hillary Farr inicia el proceso de reforma mientras que el agente inmobiliario David Visentin les muestra otras casas. Tu casa a juicio: Vancouver (13 repeticiones) es la versión canadiense del reality-show. Esta vez son Jillian Harris y Todd Talbot quienes dirigen el programa. En Million dollar decorators (9 repeticiones), nos acercamos hasta el mundo del interiorismo de la mano de Martyn Lawrence Bullard, Kathryn Ireland, Jeffrey Alan Marks y Mary McDonald. Finalmente, en Tu casa lo vale (2 repeticiones), Scott McGilivay, carpintero, realiza reformas en distintas casas con el fin de revalorizar los inmuebles.

Por su lado, cocina y restauración lo componen 6 espacios repetidos 9 veces. Los programas que encontramos son: Chocofantasy, Cupcakes maniacs, Dulces e increíbles, Guerra de cupcakes, Las mañanas divinas y Planet cake. Guerra de cupcakes (4 repeticiones) es el espacio con más presencia. Se trata de un concurso en el que reposteros y reposteras se enfrentan entre sí a lo largo de varias pruebas donde deberán elaborar 
distintos postres. En Dulces e increíbles (1 repetición), Duff Goldman y su equipo elaborarán, siempre con el cronómetro en marcha, complejos dulces. También, en Chocofantasy (1 repetición), seguimos la actividad de otro equipo, el de los y las trabajadoras de la pastelería "Choccywoccydoodah" dirigida por Christine. En Planet cake (1 repetición), asistimos a los encargos más exclusivos realizados por gente famosa.

Finalmente, Cupcakes maniacs y Las mañanas divinas muestran a la audiencia cómo elaborar distintas recetas. Cupcakes maniacs (1 repetición), está dirigido por Alma Obregón. Enseña a preparar postres, a la par que nos presentan negocios y escuelas de repostería. Las mañanas divinas deja de lado los dulces para centrarse en la elaboración de otro tipo de platos. Este espacio, que vemos emitido una vez, dura cinco minutos y muestra recetas rápidas.

La última categoría es la de relaciones sentimentales, que comprende 5 espacios emitidos un total de 36 veces, estos son: Bebé a bordo, ¿Felices para siempre?, Mujeres y hombres y viceversa, Seduciendo con Tionna y Una boda perfecta. Mujeres y hombres y viceversa cuenta con 17 repeticiones. Se trata de un dating-show donde los y las concursantes buscan pareja. En Una boda perfecta (9 repeticiones) David Tutera, organizador profesional de bodas, se pone a disposición de las parejas e intenta que el día de su boda todo esté como habían deseado. En Seduciendo con Tionna (4 repeticiones), conocemos a la socióloga Tionna Smalls, que enseñará a mujeres cómo seducir a los hombres. Bebé a bordo (1 repetición) acompaña a las madres y padres que acaban de aumenta la familia resolviendo sus dudas. Para ello cuentan con la presencia de una coach y de una matrona. Finalmente, ¿Felices para siempre? (5 repeticiones) recrea situaciones reales de parejas en la que uno de los miembros, o incluso ambos, han fallecido el día de su boda o en fechas cercanas. La encargada de guiar el programa es la psicóloga Wendy Walsh.

Para finalizar, y relegados a otros, nos quedan los espacios El zapping de surferos y D. Lujo. El zapping de surferos se ha repetido un total de 38 veces. Es una recopilación de escenas previamente emitidas en otros programas de televisión y que llaman la atención, bien sea por resultar graciosas, impactantes o curiosas. Por otro lado, D.Lujo (4 repeticiones) realiza un recorrido por los hoteles, restaurantes y servicios más caros del mundo. 


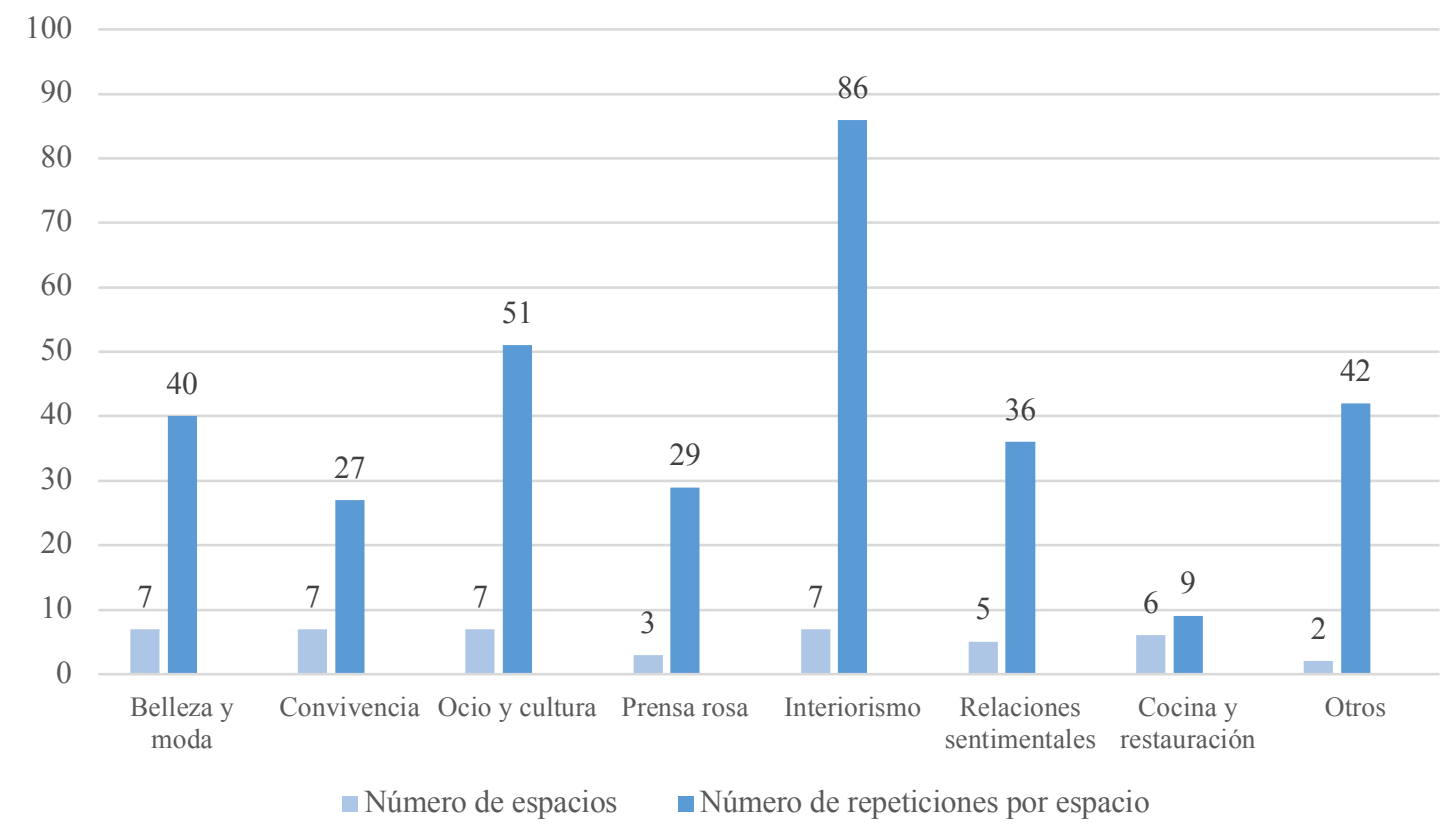

GráfiCo 29. Espacios de no ficción de Divinity y número de repeticiones (muestra año 2015).

FuENTE: Elaboración propia.

El tercer bloque de contenidos, el que abarca los programas de publicidad, está compuesto por el espacio Infocomerciales repetido en 28 ocasiones. Este programa se emite diariamente a las 4 de la madrugada y cuenta con dos horas de duración. En él, se ofrecen demostraciones acerca del funcionamiento y eficacia de distintos productos, bien sean de hogar, belleza, deporte, electrónica, ocio... Además, la audiencia puede adquirirlos en ese preciso momento gracias a la venta telefónica.

\section{CANALES DE TELEVISIÓN ESPECIALIZADOS ORIENTADOS A UN PÚBLICO MASCULINO}

\subsection{Discovery Max}

Discovery Max comenzó a emitirse el 12 de enero de 2012, a partir de un acuerdo entre el grupo comunicacional Veo Televisión, perteneciente a Unidad Editorial, y la compañía global de medios y entretenimiento Discovery Networks. ${ }^{96}$ En febrero de 2015, en su página web se podía leer que se dirigían a un público muy amplio, sin embargo, ese

96 Véase información publicada en 2011: "Discovery Max llegará a España el 12 de enero en Veo Televisión". Recuperado el 21 de noviembre de 2017 de http://www.elmundo.es/elmundo 
mismo mes, Fernando Jerez, director general de Discovery Max por aquel entonces, se pronunció al respecto declarando que el canal era principalmente masculino. ${ }^{97}$ Los datos de Kantar Media, publicados por Barlovento Comunicación en diciembre de 2015, nos dicen que muestra un perfil de audiencia masculino de entre 13 a 54 años.

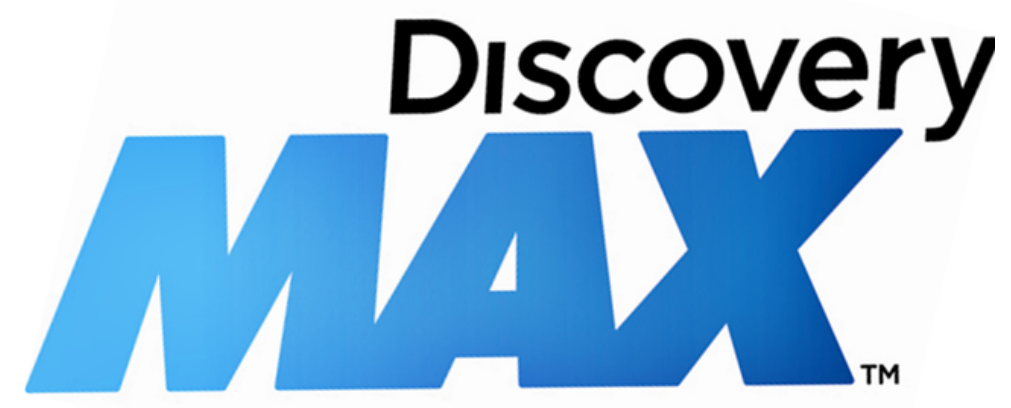

IMAGEN 40. Logotipo del canal televisivo Discovery Max.

FuenTE: Discovery Max.

\section{FICHA MORFOLÓGICA DEL CANAL TELEVISIVO DISCOVERY MAX}

\begin{aligned} NOMBRE & Discovery Max \\ \hline DESCRIPCIÓN & Max cerca, Max grande \\ \hline SITIO WEB & www.dmax.marca.com \\ \hline TRANSMISIÓN POR INTERNET & www.dmax.marca.com \\ \hline ORIGEN & España \\ \hline PROPIETARIO & Discovery Networks \\ \hline GRUPO DE COMUNICACIÓN & Veo Televisión \\ \hline ÁREA DE TRANSMISIÓN & España y Andorra \\ \hline LUGAR DE TRANSMISIÓN & Madrid \\ \hline DIRECTOR & Antonio Ruiz \\ \hline INICIO DE TRANSMISIONES & 12 de enero de 2012 \\ \hline AUDIENCIA & $2,1 \%$ (año 2015) \\ \hline PROGRAMACIÓN & Entretenimiento \\ \hline TIPO DE CANAL & Temático, orientado a un público masculino \end{aligned}

TABLA 41. Ficha morfológica del canal televisivo Discovery Max.

FUENTE. Elaboración propia.

\footnotetext{
${ }^{97}$ Véase información publicada en 2015: "Las mujeres, la asignatura pendiente de Discovery Max". Recuperado el 21 de noviembre de $2017 \mathrm{de} \mathrm{http://bluper.elespanol.com}$

${ }^{98}$ Fernando Jerez fue el director en el momento en el que se tomó la muestra (año 2015). Posteriormente, el 12 de septiembre de 2016, Discovery Max pasó a denominarse DMAX y ocurrieron una serie de cambios. Así, Vera Buzanello se convirtió en la nueva directora, hasta que, el 12 de diciembre de 2017 Antonio Ruiz tomó el relevo.
} 
Se trata de un canal de televisión temático donde lo habitual es encontrar documentales de telerrealidad y docudramas -referentes al motor, deportes, construcción, ciencia, naturaleza - espacios, por otro lado, que ofrecen escándalo, morbo y espectáculo (Fernández y Roel: 2014). El 12 de septiembre de 2016, Discovery Max pasó a denominarse DMAX, alterando con ello parte de su programación —ahora se emiten formatos de ficción-, ${ }^{99}$ pero manteniendo la esencia de la no ficción y el target masculino. Su estrategia de comunicación consiste en ofrecer un mismo programa en bucle, encadenando un capítulo con el siguiente de formatos principalmente reciclados, aunque encontramos algunos de producción propia, como son las aventuras de Frank Cuesta en Wild Frank, el programa de restauración de coches antiguos House of cars o la serie documental Amazonas clandestino, entre otros.

En el sitio web (www.dmax.marca.com), desde la pestaña Player se pueden visionar los episodios completos de los programas que anteriormente se han retransmitido por televisión. También, la pestaña Series Discovery nos permite acceder a los capítulos online, solo que esta vez los agrupan por categorías (Territorio supervivencia, Territorio motor, Territorio misterio...) mientras que en Player lo hacían alfabéticamente. A parte, incorpora las pestañas Guía $T V$, que ofrece el horario de la programación y Noticias, apartado en el que se muestran los últimos descubrimientos del mundo animal y natural.

Para conocer la agenda temática de Discovery Max, se hizo un seguimiento trimestral que comprendió, como ya se ha mencionado, cuatro semanas del año 2015. La primera semana data de marzo (lunes 23 de marzo a domingo 29 de marzo), la segunda de junio (lunes 22 de junio a domingo 28 de junio), la tercera de septiembre (lunes 21 de septiembre a domingo 27 de septiembre) y, finalmente, la cuarta de diciembre (lunes 21 de diciembre a domingo 27 de diciembre). Así pues, se grabaron un total de 28 días en lo que se emitieron hasta 129 programas distintos, todos ellos enmarcados en la no ficción.

Al contrario que lo que ocurre en el resto de canales televisivos, Discovery Max ofrece un único gran bloque de contenidos. No encontramos ni películas ni series, todos los espacios nos acercan a la realidad desde la no ficción. En cuanto a la naturaleza de los contenidos, hemos agrupado los distintos espacios bajo las siguientes categorías: supervivencia y naturaleza (divida, por su volumen de espacios, en animales y naturaleza y aventura y supervivencia), ciencia y tecnología (también fragmentada entre ingeniería

\footnotetext{
${ }^{99}$ Véase información publicada en 2016: "Discovery Max se transforma en DMAX". Recuperado el 21 de noviembre de 2017 de https://elpais.com/cultura/2016/09/09/television/1473439600_949210.html
} 
y ciencia y tecnología), violencia y misterio (de nuevo compuesta por las subcategorías misterio y magia y delincuencia y crímenes), historia, motor, subastas y negocios.

Animales y naturaleza comprende 14 espacios que se han repetido hasta en 87 ocasiones. Los títulos que podemos encontrar son: Avispas asesinas, Buscando bichos con Dominic Monagham, Corwin: aventura salvaje, Devorahombres, El rey de la manada, Fieras indomables, Fuerzas de la naturaleza, Monster nigth, Monstruos de río, Norte América, Pesca extrema con Robson Green, Sobrevivir a un tiburón, Tiburón zombie y Wild Frank.Monstruos de río es el espacio que más veces se ha emitido (36 repeticiones). Sigue las aventuras del pescador Jeremy Wade, quien busca los más grandes y salvajes peces que vivan en agua dulce. El segundo espacio más repetido es Wild Frank, con 23 emisiones. En este caso, es Frank Cuesta quien recorre el mundo en busca de los reptiles y anfibios de cada región. Lo mismo sucede en Buscando bichos con Dominic Monagham (4 repeticiones) donde Dominic Monagham nos muestra los insectos más grandes de la geografía mundial. También en Corwin: aventura salvaje (2 repeticiones) su protagonista viaja por distintos países en busca de animales. En Pesca extrema con Robson Green (4 repeticiones), nos adentramos en los océanos para descubrir su fauna.

Avispas asesinas (1 repetición) muestra a un grupo de cazadores que se enfrenta al avispón asiático, un insecto de grandes proporciones. Monster nigth (2 repeticiones) consiste en dar caza a animales que aterrorizan a diversas poblaciones. Lo mismo sucede en Fieras indomables ( 2 repeticiones), que nos habla de animales salvajes y de los miedos que provocan. Devorahombres (5 repeticiones) también vuelve a mostrarnos animales salvajes, como serpientes o grandes felinos. El rey de la manada (1 repetición) es un documental que se centra en revelarnos la vida y costumbres de los leones de Mapogo, en Sudáfrica. En Tiburón zombie (1 repetición), otro documental, el hipnotizador Eli Martínez asegura poder controlar la voluntad de los tiburones. Sobrevivir a un tiburón (1 repetición) lo conduce Les Straus quien nos habla de estos animales y de cómo evitarlos.

Finalmente, Fuerzas de la naturaleza (2 repeticiones) exhibe los desastres naturales provocados por volcanes, ciclones, terremotos... y Norte América (3 repeticiones) nos ofrece un recorrido por los paisajes naturales, grandes lagos, montañas, desiertos, etc. del norte del continente, sin olvidar también a los animales que allí habitan.

Su categoría hermana, aventura y supervivencia, está compuesta por 16 espacios emitidos 145 veces, estos son: Aventura en pelotas, Aventura en pelotas XL, Chef rubio, 
Comida salvaje, Dúo de supervivientes, Ed Stafford: solo en la isla, El misterio de las islas perdidas, El último superviviente, En lo desconocido con Ed Stafford, Mundos perdidos, ¡Qué no cunda el pánico!, Si fallas estás muerto, Supervivencia en pareja, Te lo dije, Un pringao por el mundo y Vivos de milagro.

El último superviviente ha sido emitido en 51 ocasiones. El militar Bear Grylls se enfrenta a situaciones extremas sin más ayuda que la que pueda ofrecerle el propio medio. Aventura en pelotas es el siguiente espacio más repetido, 34 veces, donde una pareja de desconocidos, hombre y mujer, sobreviven durante 21 días desnudos en la naturaleza. Las parejas ganadoras se retan, posteriormente, en el espacio Aventura en pelotas XL (4 repeticiones). En Dúo de supervivientes (11 repeticiones) también vemos a una pareja sobrevivir al medio, solo que en esta ocasión se trata de los profesionales Dave Canterbury y Cody Lundin. Ocurre lo mismo en Supervivencia en pareja (7 repeticiones) con Ruth England y Mykel Hawke como protagonistas. Ed Stafford: solo en la isla (2 emisiones) y En lo desconocido con Ed Stafford (1 emisión) repite la misma mecánica.

El espacio Te lo dije (18 repeticiones) es el tercero más visto. Este programa muestra vídeos elaborados por gente anónima, que se enfrenta a pruebas de supervivencia, elabora distintos experimentos, etc. Vivos de milagro (4 repeticiones) también consiste en una recopilación de vídeos de situaciones catastróficas. En Si fallas estás muerto (4 repeticiones), se trata de decidir, a partir de vídeos reales, la alternativa que salvaría la vida de sus protagonistas. ¡Qué no cunda el pánico! (2 repeticiones) consiste en una recopilación de testimonios de personas que sobrevivieron a la muerte tras graves accidentes. En Mundos perdidos (1 repetición) los expertos Monty Hall y Leo Houlding acuden a lugares aún sin explorar. En El misterio de las islas perdidas (1 repetición), el zoólogo Dave Salmoni viaja a distintas islas geográficamente peligrosas.

Finalmente, Un pringao por el mundo (2 repeticiones) nos muestra las Siete Maravillas a manos de Karl Pilkinton, quien, a lo largo de sus viajes deberá sobrevivir a diversas situaciones. En Chef rubio (2 repeticiones), el chef recorre los lugares más inhóspitos de Italia con el fin de desafiar a los cocineros callejeros que vaya encontrando y mejorar sus recetas. En Comida salvaje (1 repetición), el cazador Josh y el chef Matt tratan de hacerse con los mejores platos de comida mientras viajan por Estados Unidos.

Ciencia y tecnología comprende 11 espacios que se han repetido en 21 ocasiones. Los títulos que podemos encontrar son: ADN MAX, Cómo funciona la Tierra, Curiosity, Descubriendo el mañana con Stephen Hawking, Desmontando el cosmos, El universo 
según Stephen Hawking, Expediente ovni, La historia del universo, Macabro, pero cierto, Mundo hacker y ¿Qué pasó después?

Macabro, pero cierto es el espacio más veces repetido (5 emisiones). Se introduce en el mundo de la ciencia para hablarnos de experimentos extremos o investigaciones que llegaron a acabar con la vida de las personas. Le sigue Desmontando el cosmos (4 repeticiones) que se trata de un espacio que pretende divulgar los secretos del universo con el fin de que puedan ser fácilmente asimilables por la audiencia. La historia del universo (2 repeticiones) también nos descubre los funcionamientos de la galaxia. Expediente ovni (2 repeticiones) investiga desde un punto de vista científico la posibilidad de que exista vida fuera de nuestro planeta y en Cómo funciona la Tierra (1 repetición) se intentan resolver muchos de los interrogantes sobre fenómenos terrestres, en especial geográficos.

En El universo según Stephen Hawking (2 repeticiones), el científico nos introduce en sus distintas teorías sobre el universo y en Descubriendo el mañana con Stephen Hawking (1 repetición), comparte su visión de futuro en campos como la tecnología, la ingeniería o la biología. Por su lado, Xavier Sardá conduce el espacio ADN $M A X$ (1 repetición) donde se analizan los últimos descubrimientos en el campo de la ciencia y la tecnología. Finalmente, Curiosity (1 repetición) intenta resolver incógnitas científicas de muy diversa índole. El espacio Mundo hacker (1 repetición) alerta sobre los peligros de internet, bien sean virus informáticos, pagos online... y nos previene de ellos. Por último, en ¿Qué pasó después? (1 repetición) se ofrecen distintos desenlaces, todos científicamente posibles, para una situación que se queda en pausa en el momento de mayor peligro.

Mientras, ingeniería (englobada junto a ciencia y tecnología), está compuesta por 18 espacios emitidos hasta un total de 129 veces, estos son: Acuarios XXL, Antiguas superestructuras, Asedio al castillo con Dan Snow, Así se hace, Cómo funciona la ciudad, ¿Cómo lo hacen?, Food Factory, Grandes fracasos de la ingeniería, Maestros de la madera, Megatraslados, Mi casa en un árbol, Nueva York zona cero, Piscinas insólitas, Superpiscinas, Superyates, Titanes mecánicos, Un porche con vistas y, finalmente, Y el mundo cambió.

¿Cómo lo hacen? es el espacio que más veces se ha emitido (63 veces). Son reportajes que nos llevan por las distintas cadenas de montaje y nos permiten conocer cómo se fabrican, de principio a fin, objetos que usamos en nuestro día a día. Food 
Factory es el espacio que ocupa el segundo lugar en número de emisiones (17 repeticiones). En este caso se adentra en los procesos industriales de elaboración de la comida. Así se hace (2 repeticiones) repite el mismo esquema que las anteriores.

Mi casa en un árbol (10 repeticiones) sigue al constructor Pete Nelson que fabrica casas en todo tipo de árboles. En Piscinas insólitas (3 repeticiones) es Anthony ArcherWills quien nos va mostrando su obra. Los mismo hace Lucas Congdon en Superpiscinas (1 repetición) y Wayde King y Brett Raymer en Acuarios XXL (2 repeticiones). También Superyates (1 repetición) muestra los grandes yates y cuenta con las intervenciones de quienes los han diseñado y construido. En Un porche con vistas (1 repetición), acompañamos a Lafrance durante la construcción de distintas terrazas, patios o porches.

Los hermanos Daniels protagonizan Maestros de la madera (7 repeticiones), espacio en el que construyen casas. En Asedio al castillo con Dan Snow (6 repeticiones), vemos, de la mano de Dan Snow, edificios que han sobrevivido al paso de los siglos. Antiguas superestructuras (1 repetición) supone, también, un recorrido por históricos y majestuosos edificios. Desde el punto de vista contrario, Grandes fracasos de la ingeniería (2 repeticiones) realiza un repaso a través de los mayores errores que se han cometido en este campo.

Megatraslados (3 repeticiones) consiste en la reubicación geográfica, ya no solo de edificios, a veces de ciudades completas. En Y el mundo cambió (2 repeticiones), se analizan los logros de la ingeniería, la ciencia y la tecnología que han hecho posible la vida como la conocemos hoy en día. Cómo funciona la ciudad (1 repetición) hace lo propio, pero centrándose en las redes que permiten que una población tenga agua, luz o comida. Nueva York zona cero (1 repetición) sigue la construcción del One World Trade Center, el tercer edificio más alto del mundo y, finalmente, Titanes mecánicos (1 repetición) trata de dar con las cinco mejores máquinas que se hayan construido a nivel mundial.

Otra etiqueta que encontramos es delincuencia y crímenes, que junto a misterio y magia, se englobaría dentro de la gran categoría violencia y misterio. Delincuencia y crímenes está compuesta por 12 espacios emitidos 74 veces, estos son: Amazonas clandestino, Asesinos en serie, Control de aduanas y Control de aduanas, Canadá, Desde la celda, El asesino de al lado, Esquivando la muerte, La prueba del crimen, Mercenarios, Perfil de un psicópata, Redrum (murder) y Ross Kemp: lucha por el Amazonas. 
El espacio con más presencia es Control de aduanas, Canadá (26 repeticiones) que, junto a Control de aduanas (8 repeticiones), muestra los múltiples intentos diarios por violar los controles fronterizos y traspasar objetos, sustancias e incluso personas de manera ilegal. Perfil de un psicópata es el segundo título más repetido (11 ocasiones), donde el doctor Stone analiza a criminales que intentaron encubrir sus asesinatos. $E l$ asesino de al lado (10 repeticiones) se fundamenta en la posibilidad de estar conviviendo en el mismo lugar que un asesino, siempre basándose en la reconstrucción de historias reales. Asesinos en serie (6 repeticiones) nos acerca, a través de una serie de entregas, a los más famosos asesinos a lo largo de la historia.

En Esquivando la muerte (3 repeticiones), se nos narran casos de personas que habían sido secuestradas y lograron escapar. La prueba del crimen (2 repeticiones) también pone el foco en la víctima para, a partir de su historia concreta, averiguar quién la mató. En Redrum (murder) (2 repeticiones), se analiza de qué manera consigue la investigación criminal desenmascarar los diversos asesinatos. Amazonas clandestino (3 repeticiones) realiza toda una panorámica sobre los distintos crímenes que se suceden en la zona amazónica: guerrillas, narcotráfico, sicarios... También hasta el Amazonas nos lleva Ross Kemp en Ross Kemp: lucha por el Amazonas (1 repetición) y nos destapa las presiones a las que se enfrenta la población autóctona. En Desde la celda (1 repetición), Lou Ferrante, anteriormente jefe de la mafia, se adentra en las cárceles para comprobar el grado de influencia que algunas bandas siguen ejerciendo sobre el exterior. Finalmente, Mercenarios (1 repetición) trata del mercado ilegal de armas y los ejércitos que se forman a espaldas de la ley.

Mientras, misterio y magia comprende 21 espacios que se han repetido en 99 ocasiones. Los títulos que podemos encontrar son: Alienígenas: caso abierto, Ben Earl, el ilusionista, Contacto alienígena, Creencias mortales, Derren Brown al descubierto, Desaparecidos, Detrás de la magia, Dynamo: el mago, El mago pop, El mago pop, 48 horas con...., Exodus: ¿podría pasar hoy?, Expediente no resuelto, Expedientes misterio de la antigüedad, Killing Jesus, La evidencia perdida, Los enigmas de Jesucristo, Los secretos de la Biblia, Mitos y leyendas, Sociedades secretas, Tesoros al descubierto y Vida en Marte.

Mitos y leyendas (18 repeticiones) es el espacio más veces televisado. Rescata los principales mitos transmitidos a lo largo de generaciones y busca cuánto de real hay en ellos apoyándose en la ciencia. Le sigue Desaparecidos (13 repeticiones) que pretende 
resolver casos de personas en paradero desconocido. En Alienígenas: caso abierto (12 repeticiones), se investigan los avistamientos de ovnis y los encuentros con extraterrestres que, teóricamente, han ocurrido en nuestro planeta. Contacto alienígena (2 repeticiones) sigue la misma temática. Expediente no resuelto (2 repeticiones) analiza sucesos extraños que han tenido lugar en la Tierra y que, parece, solo podrían explicarse si han intervenido fuerzas extraterrestres. Vida en Marte (2 repeticiones) ahonda sobre la posibilidad de que existan formas de vida en el planeta vecino.

Antonio Díaz sale a la calle en El mago pop (5 repeticiones) para realizar sus trucos de magia y en El mago pop, 48 horas con... (1 repetición) convive con un personaje famoso mientras no deja de mostrarnos su magia. El programa Ben Earl, el ilusionista (4 repeticiones) nos acerca a este ilusionista y su carrera profesional y en Detrás de la magia (2 repeticiones) acompañamos a tres jóvenes magos (Ben Hanlin, James Galea, Wayne Houchin) y a la maga (Billy Kidd) a quienes veremos realizar sus distintos trucos. Los enigmas de Jesucristo (9 repeticiones) es una serie documental que ahonda en la vida de Jesús de Nazaret, mientras que Killing Jesus (1 repetición) se centra en el contexto sociopolítico que le rodeó. Los secretos de la Biblia (3 repeticiones) intenta arrojar verdad científica e histórica al relato bíblico y en Exodus: ¿podría pasar hoy? (1 repetición), se analizan las plagas que encontramos descritas en la Biblia.

Tesoros al descubierto (4 repeticiones) recorre alguna de las maravillas antiguas, como pueden ser las pirámides, e intenta descifrar los secretos que las rodean. Expedientes misterio de la antigüedad (2 repeticiones) hace lo propio con leyendas del mundo antiguo y trata de comprobar su veracidad. En Sociedades secretas (1 repetición) y Creencias mortales (2 repeticiones) intentan descubrir qué esconden algunos de los grupos y sectas más misteriosos de la historia. La evidencia perdida ( 2 repeticiones) hace un repaso por las teorías conspirativas que con más fuerza se han alzado y su fundamento teórico. Finalmente, en Derren Brown al descubierto (1 repetición), el mentalista trata de averiguar si es cierto que algunas personas tienen poderes sobrenaturales.

Historia, por su lado, comprende 8 espacios que se han repetido en 37 ocasiones. Los títulos que podemos encontrar son: Black ops de la antigüedad, Caballeros medievales, Cazadores de nazis, El infierno de la Primera Guerra Mundial, Grandes civilizaciones, Grandes misiones de la NASA, La Segunda Guerra Mundial en color y Leyendas del salvaje oeste. 
La Segunda Guerra Mundial en color es el más repetido, con 10 emisiones. Se trata de una serie de documentales que ilustran la Segunda Guerra Mundial usando tan solo imágenes de la época. En El infierno de la Primera Guerra Mundial (3 repeticiones), el documental se centra en explicar algunas de las claves de este gran conflicto armado. Cazadores de nazis (2 repeticiones) narra la persecución y detención de nazis que cayeron en manos de la justicia.

Black ops de la antigüedad es el segundo espacio más emitido (6 repeticiones). Esta serie de documentales nos presentan a los distintos ejércitos de las más importantes civilizaciones. Caballeros medievales (3 repeticiones) hace lo propio, pero con figuras medievales. En Grandes misiones de la NASA (5 repeticiones), volvemos a los primeros años de la organización espacial. Finalmente, Leyendas del salvaje oeste (5 repeticiones) habla de los conflictos que tuvieron lugar en el oeste de los Estados Unidos y de los personajes que han quedado en la memoria, mientras que Grandes civilizaciones (3 repeticiones) hace un repaso por los pueblos más importantes de la historia, su vida y costumbres.

Otra categoría que encontramos es la de motor. Motor está compuesta por 11 espacios emitidos hasta en 75 ocasiones, estos son: Car to the limit, Chapa y pintura, Coches con historia, Cuba car club, Este coche es para mí, Fast n'loud, Joyas sobre ruedas, Los rescatacoches, Misfit garage, Subastas sobre ruedas y Supermotos. El programa más veces emitido es Fast n'loud (38 repeticiones) donde Richard Rawling compra coches viejos y Aaron Kaufman los transforma para posteriormente venderlos en subasta púbica. En Joyas sobre ruedas (18 repeticiones), el mecánico Edd China también revaloriza coches antiguos que Mike Brewer se ocupará de vender. Lo mismo ocurre en Coches con historia (4 repeticiones), donde se ponen a punto viejos automóviles y en Los rescatacoches (1 repetición) de la mano, esta vez, de Chuck Palumbo y Rick Dore. En Chapa y pintura (2 repeticiones), Dave Kindig y su equipo crean vehículos desde cero.

Subastas sobre ruedas (1 repetición) ofrece a los propietarios de los coches parte de los beneficios que obtendrán por sus viejos coches si permiten a Dennis Pittsengarget y Slick restaurarlos y sacarlos a subasta. Este coche es para mí (1 repetición) también nos acerca hasta las subastas de automóviles de segunda mano, donde el fin es el de transformar los coches para venderlos posteriormente. Car to the limit (5 repeticiones) mezcla motor y supervivencia. Gary y Bill circulan por lugares inhóspitos donde el terreno es peligroso y escasean los recursos. En el espacio Cuba car club (2 repeticiones) 
viajamos hasta Cuba para conocer coches que cuentan con varias décadas y que siguen funcionando. También Supermotos (2 repeticiones) nos invita a viajar por el mundo en busca de las motos más rápidas y mejor diseñadas. Finalmente, en Misfit garaje (1 repetición) Richard Rawlings, Tom Smith y Jordan Butler montan un taller en el que transforman distintos coches.

En cuanto a negocios, lo componen 9 espacios repetidos en 74 ocasiones, estos son: 24 kilates, El rey de Espadas, La fiebre del oro, La pesca del oro, Madrid Ink, Maestros de la Restauración, Negocios de familia, Pesca radical y ¿Qué esconde esta caja? El programa más repetido es La fiebre del oro (25 repeticiones) que muestra cómo se lleva a cabo la extracción de este mineral. La pesca del oro (3 repeticiones) sigue a un grupo de cazafortunas que acuden hasta el Mar de Bering con el fin de encontrar oro entre sus aguas. También, 24 kilates (2 repeticiones) se centra en el preciado material mostrándonos el taller de los hermanos Cimadevilla que fabrican joyas exclusivamente de oro.

Pesca radical (22 repeticiones) es un espacio dedicado a la pesca del cangrejo real en Alaska. Maestros de la restauración (12 repeticiones) sigue la vida profesional de Drew Pritchard y su equipo, quienes restauran objetos abandonados. En Madrid Ink (5 repeticiones), son el tatuador Leo Millares y su equipo quienes nos muestran su trabajo artístico. En ¿Qué esconde esta caja? (2 repeticiones) Phil Crawford y Blaze buscan cajas de seguridad que hayan sido abandonadas para descubrir qué hay en su interior. Finalmente, Negocios de familia (2 repeticiones) explora los negocios más extravagantes que se lleven a cabo en familia y en El rey de espadas (1 repetición) conocemos una fragua en la que se recrean armas hasta ahora solo presentes en los relatos de ficción.

Subastas es una categoría de bastante peso en Discovery Max, porque, aunque solo comprenda 6 espacios, estos se han repetido en 181 ocasiones. Los títulos que podemos encontrar son: Cazasubastas, Container wars, ;Me lo quedo!, Pareja a la puja, Perdido, vendido y Trato hecho. Cazasubastas (60 repeticiones) es el espacio más veces emitido. Allen Haf y Ton Jones acuden a las subastas de trasteros que se realizan en Estados Unidos con el fin de lograr las mayores gangas. Le sigue de cerca Pareja a la puja (59 repeticiones), protagonizada por el matrimonio Brandon y Bernier Lori, que también pujan en subastas de distintos almacenes. En ;Me lo quedo! (22 repeticiones), las subastas se realizan, esta vez, desde los garajes canadienses. Será John Kunkle quien, en Container wars (22 repeticiones), acuda hasta los puertos para pujar por el interior de 
los grandes contenedores. Por su lado, las subastas de Perdido, vendido ( 8 repeticiones) tienen lugar en los aeropuertos y estaciones donde cada día aparece equipaje extraviado. Finalmente, Trato hecho (10 repeticiones) muestra el funcionamiento de una casa de subastas.

Existen 3 espacios que hemos incluido en una categoría denominada otros y que se han repetido en 3 ocasiones, estos son: árboles de navidad XXL, La invasión de las luces navideñas y Vice. Árboles de navidad XXL (1 repetición) y La invasión de las luces navideñas (1 repetición) son espacios que se emitieron en diciembre. El primero recorre distintos puntos de la geografía para dar con los árboles más grandes y con mayor número de decoraciones. El segundo se adentra en seis casas de Estados Unidos a las que han incorporado sorprendentes sistemas de iluminación para así decorarlas por navidad. Por último, Vice (1 repetición) ahonda en temas de actualidad como bien pueden ser conflictos políticos, inmigración ilegal, guerra por los recursos naturales... cada episodio es presentado en forma de reportaje de tipo documental.

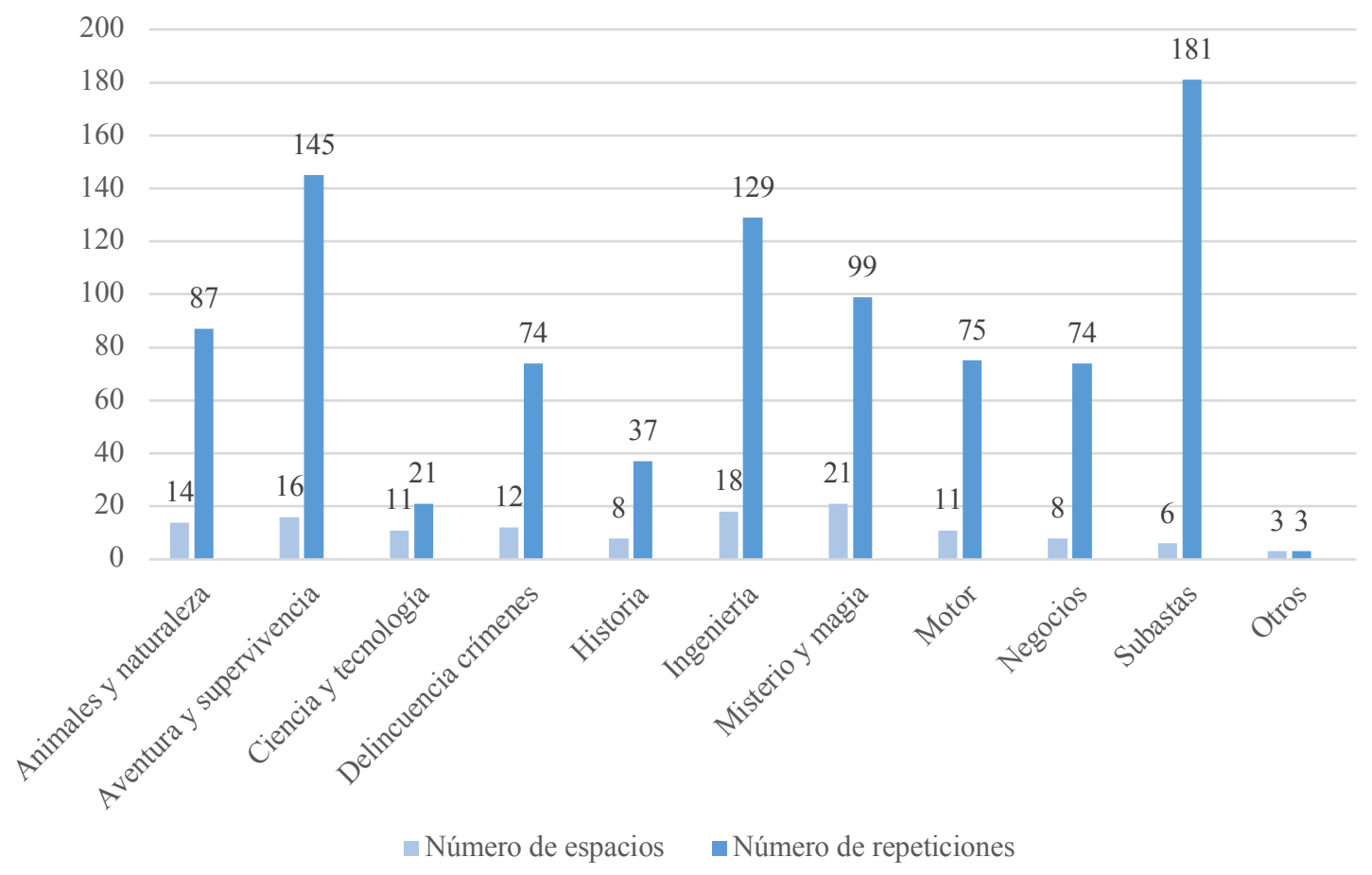

Gráfico 30. Tipo de programación en Discovery Max y número de repeticiones (muestra año 2015).

FUENTE: Elaboración propia. 


\subsection{Energy}

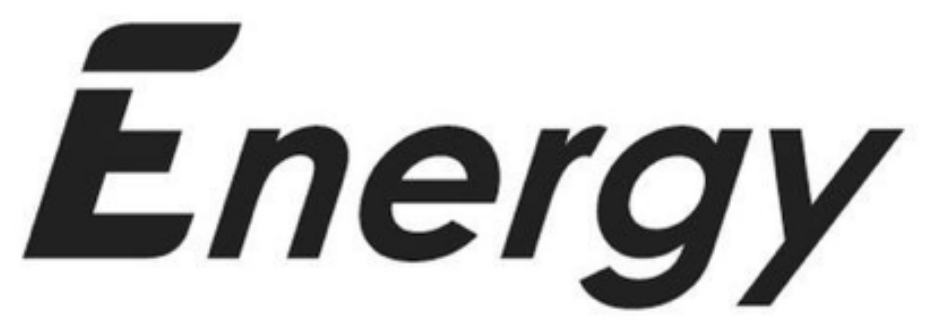

IMAGEN 41. Logotipo del canal televisivo Energy.

FuENTE: Energy.

\begin{tabular}{|c|c|}
\hline NOMBRE & Energy \\
\hline DESCRIPCIÓN & El canal de las series de verdad \\
\hline SITIO WEB & www.energytv.es \\
\hline TRANSMISIÓN EN INTERNET & www.mitele.es \\
\hline ORIGEN & España \\
\hline PROPIETARIO & Mediaset España Comunicación \\
\hline GRUPO DE COMUNICACIÓN & Mediaset España Comunicación \\
\hline ÁREA DE TRANSMISIÓN & España y Andorra \\
\hline LUGAR DE TRANSMISIÓN & Madrid \\
\hline DIRECTOR & $\begin{array}{l}\text { Sergio Calderón (director de los canales temáticos Divinity, Energy } \\
\text { y BeMad) }\end{array}$ \\
\hline INICIO DE TRANSMISIONES & 9 de enero de 2012 \\
\hline AUDIENCIA & $1,5 \%$ (año 2015) \\
\hline Programación & Entretenimiento \\
\hline TIPO DE CANAL & Temático, orientado a un público masculino \\
\hline
\end{tabular}

TABla 42. Ficha morfológica del canal televisivo Energy.

FUENTE: Elaboración propia.

Energy entró a formar parte de la parrilla televisiva en enero de 2012. Propiedad de Mediaset España Comunicación, se configuró con el fin de llegar a un público masculino. ${ }^{100} \mathrm{Su}$ director es Sergio Calderón, quien también dirige Divinity, el canal orientado a un público femenino del grupo Mediaset. A propósito de esta diferenciación de contenidos, el propio director aseguró en una entrevista de 2013 que no encontraba sexista segregar sus productos en función del sexo, es más, sostenía que pretendían acabar con los estereotipos y que desde Energy se buscaba poner fin a la imagen del hombre

\footnotetext{
${ }^{100}$ Véase información publicada en 2012: "Llegan dos nuevos canales a la TDT: Energy y Discovery Max". Recuperado el 20 de noviembre de 2017 de http:/ecodiario.eleconomista.es/sociedad/noticias/
} 
embrutecido. ${ }^{101}$ Según datos de Kantar Media, recogidos por Barlovento Comunicación en diciembre de 2015, la recepción del canal es mayor en hombres de edades comprendidas entre los 25 y los 54 años.

Al inicio del canal, sus principales emisiones eran deportivas, documentales de actualidad, cine y ficción extranjera (Videla y Costa, 2012: 46). En noviembre de 2015, el contenido de Energy sufrió una transformación y se centró en la emisión de series internacionales, alejándose así de los docurrealities o los programas de entretenimiento a los que tenía acostumbrado a su público. Este cambio coincidió con la llegada de Atres Series, cadena de ficción del grupo Atresmedia, su principal competidor. El anuncio lo introdujeron bajo el siguiente lema: "Una nueva manera de sentir la emoción, la acción y el riesgo. Una nueva forma de disfrutar de la aventura, la adrenalina, el misterio y el terror". ${ }^{102}$

En el sitio web de Energy (www.energytv.com), un menú desplegable contiene las siguientes pestañas Directo, donde poder ver Energy a tiempo real, Series de élite, Noticias, esto es, actualizaciones de los nuevos contenidos, cambios de horarios, etc., Fotos, que incluyen fotos míticas del mundo de la ficción, Videos, donde vemos pequeños teasers o anuncios de la programación, Las series de Energy, online, que redirige a la plataforma de Mediaset Mitele, y Guía TV, apartado que informa de lo que se está retrasmitiendo a tiempo real en los siete canales del grupo Mediaset. En el sitio web Mitele (www.mitele.es) se puede volver a ver el contenido previamente emitido en Energy.

Para conocer la agenda temática de Energy, se hizo un seguimiento trimestral que comprendió, como ya se ha mencionado cuatro semanas del año 2015. La primera semana fue en marzo (lunes 2 de marzo a domingo 8 de marzo), la segunda en junio (lunes 1 de junio a domingo 7 de junio), la tercera en septiembre (lunes 31 de agosto a domingo 6 de septiembre) y, finalmente, la cuarta en diciembre (lunes 30 de noviembre a domingo 6 de diciembre). Así pues, se grabaron un total de 28 días en lo que se emitieron hasta 90 programas distintos. Una primera categorización nos permite distinguir entre espacios de ficción, espacios de no ficción y publicidad.

\footnotetext{
101 Véase información publicada en 2013: "Sergio Calderón: "Diferenciar contenidos masculinos de femeninos puede parecer sexista, pero en Energy y Divinity intentamos romper estereotipos”. Recuperado el 21 de noviembre de 2017 de http://www.periodistadigital.com/periodismo/tv

102 Véase información publicada en 2015: "Energy se transforma en el canal masculino de series USA". Recuperado el 21 de noviembre de 2017 de http://vertele.eldiario.es/verteletv/actualidad
} 


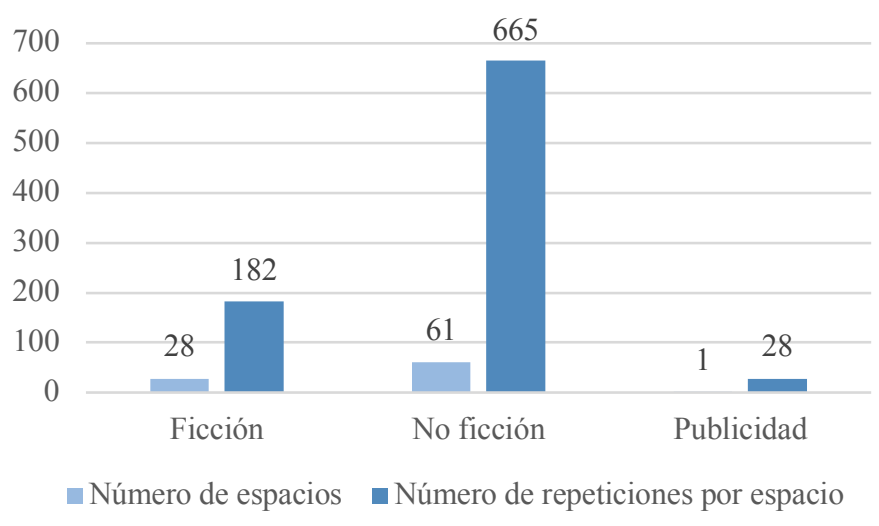

GRÁFICo 31. Tipo de programación en Energy y número de repeticiones (muestra año 2015).

FUENTE: Elaboración propia.

El primer gran bloque de contenidos es el que está compuesto por espacios de ficción. Este reúne 12 largometrajes y 16 series. Los géneros abarcados dentro de los largometrajes han sido los de ficción, drama y thriller, mientras que en ficción seriada encontramos acción, ciencia ficción y thriller.

La categoría que recoge un mayor número de series es el thriller profesional: Alphas, Cuenta atrás, Dexter, El comisario, El último poli duro, Hawai 5.0, Las reglas del juego, Last resort, NCIS: Los Ángeles y Último aviso. De las 10 series, Hawai 5.0 es la más emitida con un total de 42 repeticiones. El horario escogido para su emisión es el de las noches de entre semana. Hawaii 5.0 es un thriller policiaco, como lo son también Cuenta atrás (5 repeticiones), El comisario (5 repeticiones) y El último poli duro (4 repeticiones).

En cuanto a Alphas (2 repeticiones) y Las reglas del juego (13 repeticiones), ambas las protagonizan un grupo de gente con una serie de habilidades que persiguen a distintos criminales. NCIS: Los Ángeles (12 repeticiones) mantiene el mismo esquema, pero con agentes reconocidos por el Estado. Dexter ( 2 repeticiones) es un forense que asesina a criminales que han escapado de la ley. Último aviso (3 repeticiones) trata de un agente que también resuelve distintas tramas criminales y Last resort (3 repeticiones) es la historia de un grupo de militares en un submarino que han desobedecido la orden de lanzar un ataque contra Pakistán.

Mientras, en ciencia ficción, encontramos cuatro series: Invasión jurásica, Marvel - agentes de S.H.I.E.L.D., Sobrenatural y The strain. Sobrenatural es la más emitida con 
un total de 37 repeticiones. El horario de emisión ha sido por las mañanas entre las 12:00 y las 17:00. Trata de dos hermanos que luchan contra criaturas sobrenaturales mientras intentan dar con el paradero de su padre desaparecido. Invasión jurásica, vista hasta en 19 ocasiones, también recrea un escenario de peleas entre el equipo del zoólogo Nick Cutter y dinosaurios, insectos gigantes o parásitos provenientes de épocas pasadas. En Marvel-agentes de S.H.I.E.L.D, emitida 12 veces, un equipo de agentes lucha contra superhéroes o alienígenas. Finalmente, The strain, repetida en 2 ocasiones, ahonda en lo que, a todas luces, se trata de una plaga de vampiros.

Las últimas dos series que encontramos son de acción. Ambas nos hacen viajar hasta el antiguo imperio romano: Spartacus: la guerra de los condenados y Spartacus: venganza. Han sido emitidas en 4 ocasiones cada una y en ellas podemos contemplar las guerras que se lidiaron entre los gladiadores, liderados por Espartaco, y el ejército romano.

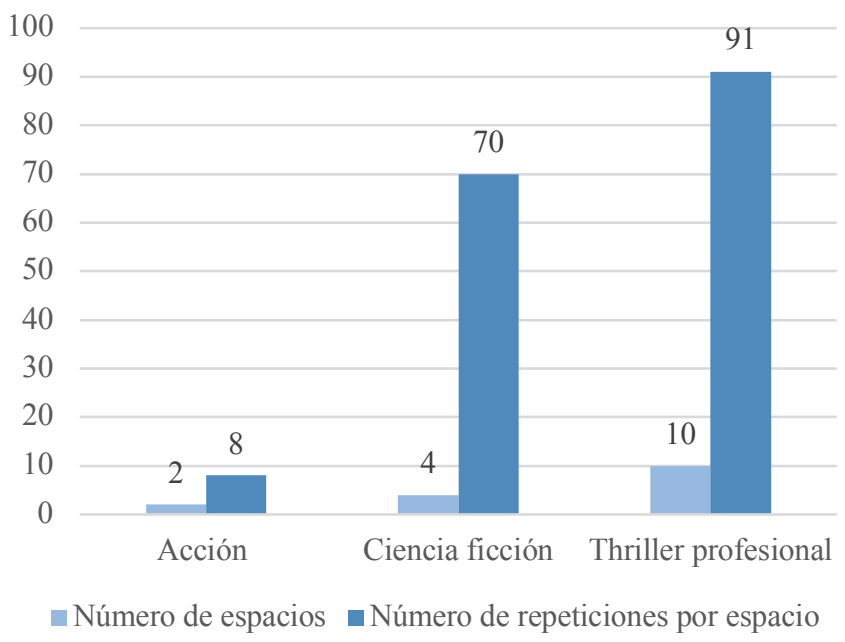

GráfiCo 32. Ficción seriada en Energy y número de repeticiones (muestra año 2015).

FUENTE: Elaboración propia.

Por otro lado, la franja horaria escogida para la emisión de los largometrajes ha sido la noche del fin de semana, tanto sábados como domingos, aunque también se han emitido durante la noche del jueves y viernes. Como dijimos, las películas se enmarcan dentro de los géneros de ciencia ficción (8 películas), drama, (1 película), y thriller (3 películas). 
La categoría ciencia ficción la componen Amenaza subterránea, Frankenstein, Hydra, El mundo perdido, La profecía del juicio final, Pánico en el mar, Trampa de cristal y Stargate. Todas las películas se han repetido en una ocasión a excepción de Hydra, que ha sido emitida dos veces. El hilo conductor que une a estos largometrajes de ciencia ficción es la lucha que se produce contra algún tipo de monstruo o fenómeno natural: bolas de fuego, criaturas de múltiples cabezas, extraños fenómenos geológicos, hormigas gigantes, monstruos marinos, animales prehistóricos... Cometas en el cielo es un drama que relata la vida de un niño afgano y los enfrentamientos de una población dividida. Finalmente, Estado Crítico, Headhunter y The wicker man son thrillers que nos internan en tramas de criminalidad. Todas estas películas han sido emitidas en una sola ocasión.

\section{LARGOMETRAJES EN ENERGY (2015)}

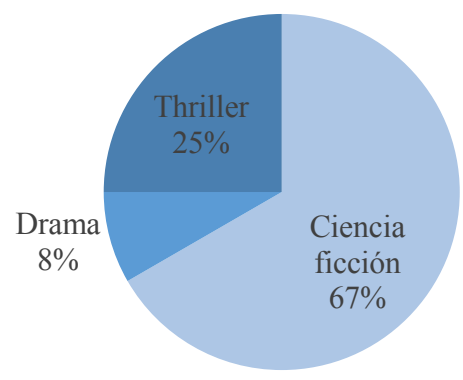

GRÁFICO 33. Largometrajes en Energy (muestra año 2015).

FUENTE: Elaboración propia.

El segundo gran bloque de contenidos es el que está compuesto por espacios de no ficción. Vemos hasta 61 espacios que se repiten 665 ocasiones. Es, pues, la categoría más relevante, tanto por tiempo de emisión como por la cantidad de programas que abarca. Las categorías que nos han permitido clasificar los contenidos de no ficción han sido las de supervivencia y naturaleza, ciencia y tecnología, cocina y restauración, violencia y misterio, ocio y cultura, juegos y entretenimiento, motor, relaciones sentimentales, sociedad, subastas y belleza y moda.

Supervivencia y naturaleza comprende 9 espacios que se han emitido hasta en 98 ocasiones, lo que la sitúa entre las 3 categorías más relevantes. Los programas que podemos encontrar son Billy el exterminador, Desafio extremo, El planeta de los dinosaurios, En el vientre materno, Frank de la jungla, Los viajes del veterinario al 
rescate, Planeta Calleja, ¿Qué hago yo aquí? y Veterinario al rescate. Veterinario al rescate es el espacio más repetido, llegando a ocupar el $60 \%$ de las emisiones de esta categoría (59 repeticiones). Sus protagonistas Chris Brown, Lisa Chimes y su equipo cuidan y mejoran la salud de distintos animales que necesitan algún tipo de intervención. Le sigue Los viajes del veterinario al rescate, emitida en 15 ocasiones, donde Chris Brown viaja por distintos países para conocer el trabajo de otras clínicas y las mascotas típicas de cada región.

Billy el exterminador se repite un total de 12 veces y nos muestra como Billy Bretherton acude a distintos hogares con problemas de ratas, arañas, hormigas o incluso cocodrilos. Este profesional acaba con la plaga reubicando a los animales en su medio. Frank de la jungla (3 repeticiones) también nos hace entrar en contacto con los animales, sobre todo con los reptiles y anfibios, mostrándolos de una manera cercana. El planeta de los dinosaurios (3) y En el vientre materno (1) son series documentales sobre el mundo animal. Desafio extremo (3) y Planeta Calleja (1) están presentados por el deportista Jesús Calleja y en él se nos enseñan distintas actividades extremas, como escalada en altas montañas. Finalmente, ¿Qué hago yo aquí? (1 repetición) graba la crudeza de algunos lugares en los que viven españoles y españolas que decidieron emigrar.

Por su lado, cocina y restauración está compuesto por 7 espacios emitidos 68 veces. Los programas que encontramos son Adam Richman el mejor bocadillo de América, Comiendo en América, Crónicas carnívoras, Duelo de chefs, Los restaurantes más frikis del mundo, Restaurante imposible y Sabotaje en la cocina. El espacio más repetido es Restaurante imposible (19 veces) donde el chef Robert Irvine se propone rescatar restaurantes que están a punto de quebrar en tan solo dos días y con 10.000 dólares de presupuesto. Los restaurantes más frikis del mundo (10 repeticiones) también nos abre las puertas de distintos restaurantes, esta vez mostrándonos sus propuestas más curiosas.

Crónicas carnívoras (13 repeticiones) y Adam Richman el mejor bocadillo de América (7 repeticiones) son dos espacios dirigidos por el presentador Adam Richman. En el primero, acepta los retos que proponen los distintos locales —normalmente consisten en ingerir grandes cantidades de comida en un breve periodo de tiempo- En el segundo, viaja por Estados Unidos en busca de lo que, según él, será el mejor bocadillo del país. La misma tónica viajera sigue Comiendo en América (8 repeticiones), espacio en el que Guy Fieri aprende a preparar las recetas de distintos establecimientos. 
Finalmente, Sabotaje en la cocina (7 repeticiones) y Duelo de chefs (4 repeticiones) son retos culinarios en los que los y las concursantes deberán elaborar recetas, no sin contar con distintas complicaciones: sabotajes entre participantes, ingredientes especiales o tiempos muy limitados.

Mientras, violencia y misterio comprende 7 espacios emitidos un total de 106 veces, estos son: Cabo Vadillo, Cuarto Milenio, Dog el cazarrecompensas, Investigadores del más allá, La ley del Pantano, Los timadores y Multas, multas y más multas. Los timadores es el programa más repetido (44 emisiones). En él, dos actores y una actriz recrean distintos timos y la audiencia puede comprobar cómo la gente es víctima de los mismos. Multas, multas y más multas (36 repeticiones) sigue el día a día de agentes que se ocupan de penalizar a aquellas personas que comenten imprudencias al volante. Cabo Vadillo (3 repeticiones) nos muestra al policía Pablo Vadillo que patrulla por distintos barrios alrededor del mundo. Finalmente, en Dog el cazarrecompensas (2 repeticiones) asistimos a la persecución de fugitivos por parte del exconvicto Duane Chapman y su familia.

En cuanto al misterio, Investigadores del más allá (15 repeticiones) es el más relevante por número de emisiones. Este espacio explica casos de homicidio que han sido resuelto por médiums. En La ley del pantano (5 repeticiones), la justicia también se mezcla con el misterio. Policías y detectives protegen unos pantanos al sur de Luisiana, donde en ocasiones se han avistado monstruos. También deben mantener a raya los enfrentamientos entre el vecindario y la caza furtiva. Cuarto Milenio (1 repetición) es un programa en el que Iker Jiménez estudia distintos mitos, leyendas y teorías que ahondan en lo paranormal.

La categoría ciencia y tecnología la componen 3 espacios repetidos hasta en un total de 70 ocasiones. Los programas que encontramos son Ciencia para torpes, Mudanzas imposibles y Ciudades bajo tierra. El espacio Ciencia para torpes se ha emitido en 27 ocasiones. Sirviéndose de experimentos fallidos colgados en la red, Richard Hammond explica, según las leyes de la ciencia, por qué no fueron exitosos. En Mudanzas imposibles (27 repeticiones) un equipo de profesionales y sus grandes medios de transporte mueven inmuebles completos de un lugar a otro. Mientras, Ciudades bajo tierra (16 repeticiones) nos muestra qué tipo de tecnología ha sido posible para crear las ciudades que conocemos hoy en día, las cuales, en muchos de los casos, fueron edificadas sobre antiguas poblaciones. 
Ocio y cultura comprende 4 eventos deportivos emitidos un total de 6 veces, estos son: Campeonato de España de velocidad, Danone nations cup, Eurobasket 2015 y Fútbol femenino. El Campeonato de España de velocidad (1 repetición) se trata de un torneo de motos, mientras que Danone nations cup (1 repetición) es una competición infantil de fútbol. En Eurobasket 2015 (3 repeticiones) se retransmite la competición entre equipos de baloncesto de países europeos y Fútbol Femenino (1 repetición) recoge un partido de fútbol entre jugadoras.

Por su lado, en juegos y entretenimiento encontramos 4 espacios emitidos en un total de 73 ocasiones. Los programas que vemos son El zapping de surferos, Juego de gadgets, Premier casino, la ruleta VIP y World series of poker. El zapping de surferos (38 repeticiones) es una recopilación de escenas previamente emitidas en otros programas de televisión, las imágenes suelen ser graciosas y curiosas. En Juego de gadgets (4 repeticiones), Atanasio Cantero nos expone las últimas novedades en el mundo de los pequeños aparatos tecnológicos o gadgets. Premier casino, la ruleta VIP (28 repeticiones) y World series of poker (3 repeticiones) son programas donde la audiencia juega y apuesta en directo.

La categoría motor comprende 3 espacios emitidos un total de 12 veces. Los programas que encontramos son: Más que coches, Más que motos y Si parpadeas. Más que motos (5 repeticiones) y Más que coches (3 repeticiones) son dos programas que nos presentan las novedades en el mundo del motor, así como las últimas exhibiciones, competiciones o consejos útiles. Por su parte, Si parpadeas... (4 repeticiones) también nos informa acerca de novedades automovilísticas y emite distintos reportajes sobre competiciones.

En relaciones sentimentales hay 3 espacios repetidos un total de 17 veces. Los programas que encontramos son: Adán y Eva, Amores reñidos y ¿Felices para siempre? El más relevante es Amores reñidos (7 ocasiones). En el programa, el asesor Steven Ward enseña a 8 mujeres técnicas para seducir a los hombres. Adán y Eva (5 repeticiones) es un concurso de citas donde los y las participantes son llevados hasta un entorno tropical y cuentan con unos días para conocerse. Deberán participar sin ningún tipo de ropa. El tercer espacio, ¿Felices para siempre? (5 repeticiones), recrea situaciones reales de parejas en la que uno de sus miembros o ambos han fallecido el día de su boda o en fechas cercanas. La encargada de guiar el programa es la psicóloga Wendy Walsh. 
Sociedad lo componen 9 espacios repetidos un total de 81 veces. Los programas que encontramos son 21 días, Callejeros, Callejeros viajeros, Conexión Samanta, En movimiento, Especial callejeros, Ola, ola, Los gipsy kings y Palabra de gitano. Tanto Callejeros viajeros (34 repeticiones), Callejeros (24 repeticiones) como Especial callejeros (5 repeticiones) siguen la misma tónica. Un equipo compuesto de dos periodistas se traslada hasta distintos lugares, ya sea dentro del territorio nacional -Callejeros-, o internacional —Callejeros viajeros—, para recoger los testimonios que relatan, en primera persona, aspectos del día a día. Ola, ola (6 repeticiones) utiliza la misma fórmula, aunque sus escenarios son, exclusivamente, las playas españolas.

En el espacio En movimiento (5 repeticiones) una personalidad famosa participa por un tiempo en una ONG o algún proyecto de voluntariado. Por su parte, Conexión Samanta (3 repeticiones) y 21 días (2 repeticiones) son espacios conducidos por Samanta Villar. En 21 días la periodista cambia sus rutinas para adaptarse a otras costumbres o tipos de vida que le son ajenas. En Conexión Samanta convive con algunos famosos y famosas mostrándonos así su día a día más privado. Finalmente, Los gipsy kings (1 repetición) y Palabra de gitano (1 repetición) son espacios dedicados a conocer la cultura gitana de mano del propio pueblo gitano. Tanto en Los gipsy Kings como en Palabra de gitano distintas familias exhiben sus costumbres y modos de vivir.

Mientras, la categoría subastas comprende 4 espacios emitidos un total de 82 veces. Los espacios son: ¿Quién da más?, ¿Quién da más? Nueva York, ¿Quién da más? Texas y Transportes imposibles. En Transportes imposibles (36 repeticiones) un grupo de transportistas puja para conseguir trasladar una mercancía en el menor tiempo posible. ¿Quién da más? (16 repeticiones), ¿Quién da más? Nueva York (15 repeticiones) y ¿Quién da más? Texas (15 repeticiones) son tres espacios dedicados a las subastas de trasteros. Pujadores profesionales ofrecen una cantidad de dinero por el contenido de un almacén que no pueden ver. Una vez descubierto qué hay dentro, intentan revender los distintos objetos.

Por último, la categoría belleza y moda la componen 4 programas repetidos 40 veces. Por un lado, encontramos los espacios que se centran en el mundo de la estética del tatuaje, estos son Best Ink, Maldito tatuaje y Tatuajes hasta el amanecer y, por el otro, nos topamos con el programa de culto al cuerpo El método Osmin (10 repeticiones). En este último, los y las participantes que quieran modificar su forma física deberán 
seguir las exigentes instrucciones de Osmin Hernández, ex militar que, como peculiaridad, usa el mobiliario urbano para sus entrenamientos.

En cuanto a Best Ink, Maldito tatuaje y Tatuajes hasta el amanecer ahondan en el mundo de los tatuajes. En Best Ink (14 repeticiones), 10 tatuadores se enfrentan entre sí por 100.000 dólares y protagonizar la portada de la revista Tatto. En Maldito tatuaje (8 repeticiones) personas arrepentidas de sus tatuajes acuden a los profesionales Dirk y Ruckus para que cubran sus viejos diseños con uno nuevo. Por último, Tatuajes hasta el amanecer (8 repeticiones) graba estudios de madrugada y a la gente que acude allí.

Finalmente, existen 4 espacios que hemos incluido en una categoría denominada otros y que se han repetido en 12 ocasiones, estos son: Dr. Oz, Los Ángeles confidential, Divinity stars y Making of: Ocho apellidos catalanes. En Los Ángeles confidential (2 repeticiones) acudimos a las terapias de distintos psicólogos. Divinity Stars (1 repetición), es un programa de la prensa del corazón que sigue la vida profesional y personal de artistas del panorama nacional e internacional, Making of: Ocho apellidos catalanes (1 repetición) se trata de un reportaje sobre cómo se hizo la popular película y, por último, Dr. Oz. (8 repeticiones) es un consultorio de salud donde se responden dudas de la audiencia.

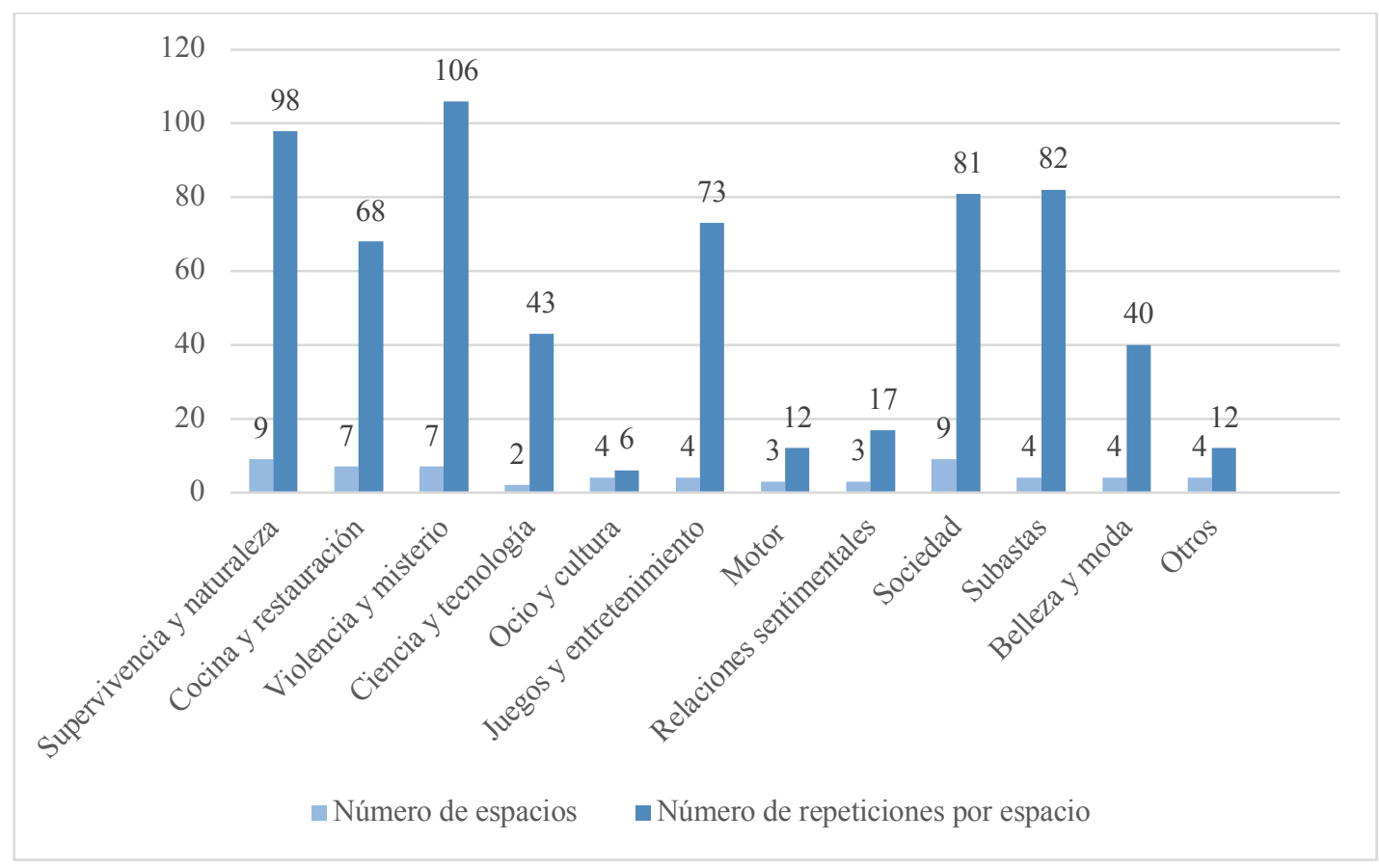

GrÁFICo 34. Espacios de no fícción de Energy y número de repeticiones (muestra año 2015). FUENTE: Elaboración propia. 


\section{LOS CANALES DE TELEVISIÓN SEGREGADOS POR GÉNERO Y SU CONSTRUCCIÓN DE LA FEMINIDAD Y LA MASCULINIDAD}

En este último epígrafe, enfrentaremos el discurso de los canales segregados por género, con el fin de conocer las representaciones que el medio televisivo hace de la feminidad y de la masculinidad. Abordaremos el análisis desde tres perspectivas: por un lado, veremos las categorías que comparten los canales masculinos y femeninos, por el otro, analizaremos las presentes exclusivamente en los canales femeninos $\mathrm{y}$, finalmente, haremos lo propio con los masculinos. Un último epígrafe expondrá los contenidos de ficción con el fin de comprobar si apoyan la narrativa presente de los formatos de no ficción.

\begin{tabular}{|c|c|c|c|c|}
\hline \multicolumn{5}{|c|}{ CONTENIDOS DE NO FICCIÓN } \\
\hline & Nova & Divinity & Discovery Max & Energy \\
\hline Belleza y moda & $3 \%$ & $13 \%$ & - & $6 \%$ \\
\hline $\begin{array}{l}\text { Cocina y } \\
\text { restauración }\end{array}$ & $28 \%$ & $3 \%$ & - & $10 \%$ \\
\hline \multirow[t]{2}{*}{$\begin{array}{l}\text { Ciencia y } \\
\text { tecnología }\end{array}$} & \multirow[t]{2}{*}{-} & \multirow[t]{2}{*}{-} & $\begin{array}{l}\text { Ciencia y } \\
\text { tecnología }(2 \%)\end{array}$ & \multirow[t]{2}{*}{$6 \%$} \\
\hline & & & Ingeniería (14\%) & \\
\hline Interiorismo & $18 \%$ & $27 \%$ & - & - \\
\hline Motor & - & - & $8 \%$ & $6 \%$ \\
\hline Ocio y cultura & $21 \%$ & $16 \%$ & - & $1 \%$ \\
\hline Salud & $5 \%$ & - & - & - \\
\hline Sociedad & $14 \%$ & - & - & $12 \%$ \\
\hline Subastas & - & - & $20 \%$ & $12 \%$ \\
\hline \multirow[t]{2}{*}{$\begin{array}{l}\text { Supervivencia y } \\
\text { naturaleza }\end{array}$} & \multirow[t]{2}{*}{-} & \multirow[t]{2}{*}{-} & $\begin{array}{l}\text { Animales y } \\
\text { naturaleza }(9 \%)\end{array}$ & \multirow[t]{2}{*}{$15 \%$} \\
\hline & & & $\begin{array}{l}\text { Aventura y } \\
\text { supervivencia } \\
(16 \%)\end{array}$ & \\
\hline $\begin{array}{l}\text { Relaciones } \\
\text { sentimentales }\end{array}$ & - & $11 \%$ & - & $3 \%$ \\
\hline \multirow[t]{2}{*}{$\begin{array}{l}\text { Violencia y } \\
\text { misterio }\end{array}$} & \multirow[t]{2}{*}{ - } & \multirow[t]{2}{*}{-} & $\begin{array}{l}\text { Delincuencia y } \\
\text { crímenes }(8 \%)\end{array}$ & \multirow[t]{2}{*}{$16 \%$} \\
\hline & & & $\begin{array}{l}\text { Misterio y magia } \\
(11 \%)\end{array}$ & \\
\hline \multirow[t]{3}{*}{ Otros } & \multirow[t]{3}{*}{ Otros $(11 \%)$} & Convivencia $(8 \%)$ & Historia (4\%) & \multirow{3}{*}{$\begin{array}{l}\text { Juegos y } \\
\text { entretenimiento } \\
(11 \%)\end{array}$} \\
\hline & & Prensa rosa $(9 \%)$ & Negocios $(8 \%)$ & \\
\hline & & Otros $(13 \%)$ & Otros $(0,3 \%)$ & \\
\hline
\end{tabular}

Tabla 43. Categorías de los contenidos de no ficción en Nova, Divinity, Discovery Max y Energy en 2015.

FUENTE: Elaboración propia. 
Tal y como hemos expuesto, los canales de televisión nos ofrecen contenidos enmarcados en la ficción, la no ficción y la publicidad. Los contenidos de no ficción los encontramos en los cuatro canales televisivos. Hemos visto un total de 263 espacios de no ficción repetidos 2.180 veces. Según su naturaleza, podemos determinar que comparten trece de las diecisiete categorías totales (véase tabla 43).

\subsection{Categorías que comparten los canales femeninos y masculinos}

A priori, no existe ninguna categoría que compartan los 4 canales de televisión. Lo que podemos encontrar son belleza y moda, cocina y restauración y ocio y cultura tanto en Nova, Divinity y Energy.

En este sentido, la belleza y la moda aparecen en los canales femeninos Nova y Divinity y en el masculino Energy. Vemos 2 programas y 8 repeticiones en Nova, mientras que Divinity cuenta con 7 programas y 40 repeticiones. En cuanto a Energy, reúne 4 programas y emitidos en 40 ocasiones. Debemos puntualizar que Discovery Max también ofrece un espacio relacionado con la estética, este es Madrid Ink, (5 repeticiones) que hace referencia al mundo de los tatuajes, sin embargo, no lo habíamos englobado en esa categoría específica por tratarse del único espacio que ofrecía el canal. Aun así, hemos visto conveniente rescatarlo para este análisis.

Existe una primera diferenciación entre lo que significa la belleza y la moda en los canales femeninos y lo que representa para los masculinos. En los femeninos, vemos como el contenido se divide, principalmente, entre los programas de transformaciones (makeover shows) y aquellos de actualidad y consejos. Los programas de actualidad y consejos son espacios descriptivos donde encontramos propuestas estilísticas (Fashionistas, Guerra de estilistas, Los Duques de Melrose, De Compras en Nova y B a la moda). Los canales masculinos, mientras, no cuentan con temáticas de este tipo.

Una parte importante del contenido de Divinity son los makeover shows, programas cuyo argumento gira en torno a la transformación de una persona. Cambia de look está presente en la programación de junio y Cámbiame tanto en septiembre como en diciembre. Estos espacios renuevan la imagen personal de las concursantes —en el caso de Cambio de look son siempre mujeres las que se someten a la transformación, en Cámbiame, la mayoría de las mismas (Martínez, 2017: 104) — y lo hacen bajo el pretexto de que un cambio de imagen es primordial para conseguir una mayor autoestima. Así, las 
mujeres se ponen en manos de un equipo experto en peluquería, maquillaje y vestuario. Extreme makeover: cambio radical no solo apuesta por transformaciones estilísticas, sino que realiza intervenciones de cirugía estética.

Por su lado, Energy y Discovery Max proponen un contenido un tanto diferente al que vemos en los canales femeninos. Su temática se centra en los programas de tatuajes y, también, encontramos el espacio El Método Osmin (Made in USA). Este último, aunque pueda parecer un programa de salud, tan solo encierra pretensiones estéticas. En El Método Osmin (made in USA) —espacio de 60 minutos de duración presentado por el ex militar Osmin Hernández y emitido en Energy_- los y las participantes se someten a una serie de ejercicios durante un mes. Son ejercicios intensivos donde se utiliza el mobiliario urbano, los parques, las playas... y donde la dieta consiste en pescado, ensaladas y agua. La motivación de los y las participantes es la de adelgazar. En nuestra muestra, grabada el 1 de septiembre de 2015 a las 05:15, Yanderis Lodos, modelo, quiere bajar de la talla 48 a la talla 44 porque ya no consigue tantos trabajos como antes. Osmin somete a la modelo a 30 días de ejercicios sin descanso bajo una dieta muy estricta y le grita frases como "las modelos no están gordas", "no queremos gordos aquí", "yo soy el entrenador y tú eres la gorda". Yanderis se queja de lo irrespetuoso que es Osmin. Osmin, por su lado, llega a afirmar que no entiende el concepto de modelos de tallas grandes.

El programa gira en torno a los enfrentamientos entre Osmin y los y las participantes, quienes se sienten humilladas por las pruebas a las que les somete el entrenador o por su manera de dirigirse a ellas. Carece de una línea médica — no hay presencia de profesionales-, el método seguido es tremendamente agresivo (dieta poco variada, sesiones extremas de ejercicios, falta de descansos, imposibilidad del cuerpo para recuperarse, bajadas de peso bruscas...). Aunque pueda parecer que se trate de un espacio que apuesta por mejorar la forma física de sus concursantes, lo cierto es que las intervenciones tan agresivas — sin ningún tipo de rigor médico—y la forma de expresarse de Osmin, delatan que la única intención es la de que la gente consiga un cambio notable de peso en apenas un mes. No se establecen pautas ni rutinas de vida o de dieta a largo plazo, siendo imposible que la audiencia aprenda ni sobre salud ni sobre nutrición.

Es decir, estaríamos ante un programa con un contenido meramente estético que puede recordarnos a los makeover de belleza que encontrábamos en Divinity. Sin embargo, El método Osmin (made in USA) a diferencia de Cámbiame o Cambia de look no se centra en transformar el vestuario, el peinado o el maquillaje, terrenos asociados en 
mayor medida con la feminidad. Tampoco actúa como en Extreme makeover: cambio radical donde las transformaciones se hacen a través del quirófano, en El método Osmin (made in USA), Osmin es brusco en las formas, pone en práctica duros ejercicios, prepara entrenamientos militares... esto es, se mueve dentro de unos parámetros que asociaríamos con la masculinidad.

En cuanto al resto de programas en los canales masculinos, consisten esencialmente en espacios de tatuajes. Así, se adentran en un mundo de la estética muy determinado y lo hacen sirviéndose de los espacios Madrid Ink en el caso de Discovery Max y Best Ink, Maldito tatuaje y Tatuajes hasta el amanecer en el caso de Energy. Mientras que los dos últimos formatos de Energy y el de Discovery Max nos enseñan el día a día de los estudios de tatuajes, Best Ink es un espacio de competición entre profesionales, donde muestran sus mejores trabajos con el fin de alzarse con el premio y ser portada de la revista Tattoo. De esta forma, vemos como el cuerpo es intervenido de manera muy distinta en los canales femeninos y en los canales masculinos.

\begin{tabular}{|c|c|c|c|c|}
\hline \multicolumn{5}{|c|}{ BELLEZA Y MODA } \\
\hline & Nova & Divinity & Energy & Discovery Max \\
\hline \multirow[t]{4}{*}{ Transformaciones } & \multirow[t]{4}{*}{-} & Cambia de look (19) & Best Ink (14) & \multirow[t]{4}{*}{ Madrid Ink (5) } \\
\hline & & Cámbiame (10) & $\begin{array}{l}\text { Maldito tatuaje } \\
\text { (8) }\end{array}$ & \\
\hline & & \multirow[t]{2}{*}{$\begin{array}{l}\text { Extreme makeover: cambio } \\
\text { radical (1) }\end{array}$} & $\begin{array}{l}\text { Tatuajes hasta el } \\
\text { amanecer (8) }\end{array}$ & \\
\hline & & & $\begin{array}{l}\text { El método } \\
\text { Osmin (10) }\end{array}$ & \\
\hline \multirow[t]{3}{*}{$\begin{array}{l}\text { Actualidad/ } \\
\text { Consejos }\end{array}$} & $\begin{array}{l}\text { De compras } \\
\text { en Nova ( } 7)\end{array}$ & Fashionistas (2) & \multirow[t]{3}{*}{-} & \multirow[t]{3}{*}{-} \\
\hline & \multirow{2}{*}{$\begin{array}{l}\text { B a la moda } \\
\text { (1) }\end{array}$} & Guerra de estilistas (4) & & \\
\hline & & Los duques de Melrose (2) & & \\
\hline Otros & - & Locos por las compras (2) & - & - \\
\hline
\end{tabular}

TABla 44. Programación de belleza y moda en Divinity, Nova, Energy y Discovery Max en 2015. FUENTE: Elaboración propia.

La categoría cocina y restauración es otra categoría que, también, comparten los canales femeninos Nova y Divinity y el masculino Energy. Vemos 8 programas y 73 repeticiones en Nova, mientras que Divinity cuenta con 6 programas y 9 repeticiones. Para Nova, cocina y restauración es la categoría más importante $(28 \%)$ dentro de la no 
ficción, tanto en número de repeticiones como en variedad de espacios. En cuanto a Energy, reúne 7 programas y 68 repeticiones.

Según su finalidad, encontramos espacios de tres tipos: los que enseñan a cocinar, los que muestran distintos tipos de negocios y a su equipo profesional y los que generan competiciones entre concursantes. En los programas de negocios asistimos al día a día o a un intento de reflote de los mismos y tanto Divinity, Energy, como Nova aportan un número similar de espacios, siendo, pues, en los programas que enseñan a cocinar y en los de competición en los que detectamos mayores diferencias de contenido.

\begin{tabular}{|c|c|c|c|}
\hline & Nova & Divinity & Energy \\
\hline \multirow[t]{3}{*}{ Negocios } & $\begin{array}{l}\text { Cocineros españoles por } \\
\text { el mundo (2) }\end{array}$ & Chocofantasy (1) & Restaurante imposible (19) \\
\hline & Pesadilla en la cocina (9) & Dulces e increibles (1) & $\begin{array}{l}\text { Los restaurantes más frikis } \\
\text { del mundo (10) }\end{array}$ \\
\hline & $\begin{array}{l}\text { Pesadilla en la cocina } \\
\text { EEUU (10) }\end{array}$ & Plantet cake (1) & Comiendo en América (8) \\
\hline \multirow[t]{3}{*}{ Didácticos } & Cocina con Bruno (20) & Cupcakes maniacs (1) & \multirow[t]{3}{*}{-} \\
\hline & Hoy cocinas tú (4) & \multirow[t]{2}{*}{ Las mañanas divinas (1) } & \\
\hline & $\begin{array}{l}\text { Karlos Arguiñano en tu } \\
\text { cocina }(20)\end{array}$ & & \\
\hline \multirow[t]{4}{*}{ Competiciones } & Top Chef (1) & \multirow[t]{4}{*}{ Guerra de cupcakes (4) } & $\begin{array}{l}\text { Adam Richman el mejor } \\
\text { bocadillo de América (7) }\end{array}$ \\
\hline & \multirow[t]{3}{*}{ Top chef (USA) (7) } & & Crónicas carnívoras (13) \\
\hline & & & Duelo de chefs (4) \\
\hline & & & Sabotaje en la cocina (7) \\
\hline
\end{tabular}

TABLA 45. Programación de cocina y restauración en Nova, Divinity y Energy en 2015.

FUENTE: Elaboración propia.

Una parte de la programación en Nova y Divinity es didáctica, es decir, enseña cómo elaborar distintas recetas. Cocina con Bruno, Karlos Arguiñano en tu cocina y Hoy cocinas tú son los tres programas de Nova. Tanto Cocina con Bruno como Karlos Arguiñano en tu cocina se emiten los días de entresemana a las 14:00 y a las 14:30 y los presentan cocineros varones. Mientras, Hoy cocinas tú está reservado a los fines de semana con horario variable. En este programa, será la chef Eva Arguiñano quien muestre el paso a paso de las recetas tanto a la invitada o invitado de turno como a la audiencia. En Divinity vemos Cupcakes maniacs, dirigido por Alma Obregón, experta en repostería creativa, que se centra en la elaboración de postres y también sale a la calle a visitar 
distintos negocios. Mientras, Las mañanas divinas es un microespacio de cinco minutos donde se elaboran recetas fáciles.

Los espacios de competición son siete, cuatro de los cuales los ofrece Energy, dos vemos en Nova y, el último, en Divinity. En Nova encontramos la edición española y la edición americana del concurso Top Chef, en el que chefs profesionales compiten por llegar hasta la final. La misma mecánica sigue Guerra de cupcakes de Divinity y Duelo de chefs y Sabotaje en la cocina de Energy. Por otro lado, en Adam Richman el mejor bocadillo de América y Crónicas Carnívoras (Energy) tanto Adam Richman como personajes anónimos intentarán comer grandes cantidades de comida en un tiempo limitado.

De esta forma, observamos que el mundo de la cocina y restauración se retrata desde primas distintos. Mientras que en los canales dirigidos a un público femenino encontramos materiales didácticos, en Energy la cocina se convierte en un escenario de competición.

\begin{tabular}{|c|c|c|c|}
\hline \multicolumn{4}{|c|}{ OCIO Y CULTURA } \\
\hline & Nova & Divinity & Energy \\
\hline Cine & Ver cine (1) & Taquilla Mediaset (28) & - \\
\hline \multirow[t]{4}{*}{ Deportes } & \multirow[t]{4}{*}{ - } & \multirow[t]{4}{*}{-} & $\begin{array}{l}\text { Campeonato de España de } \\
\text { velocidad (CEV) } 2015 \text { (1) }\end{array}$ \\
\hline & & & Danone nations cup (1) \\
\hline & & & Eurobasket 2015 (3) \\
\hline & & & Fútbol femenino (1) \\
\hline \multirow[t]{6}{*}{ Música } & $\begin{array}{l}\text { Minutos musicales } \\
\text { (52) }\end{array}$ & $\begin{array}{l}\text { Concierto Alejandro Sanz Gira } \\
\text { Sirope (1) }\end{array}$ & \multirow[t]{6}{*}{ - } \\
\hline & Nova sound (1) & Concierto Pablo Alborán (1) & \\
\hline & \multirow[t]{4}{*}{$\begin{array}{l}\text { Tu cara me suena } \\
\text { (1) }\end{array}$} & $\begin{array}{l}\text { Divinity cazamariposas pre-show. } \\
\text { Premios } 40 \text { principales } 2015 \text { (1) }\end{array}$ & \\
\hline & & Divinity jukebox live (18) & \\
\hline & & Incluye divinity jukebox (1) & \\
\hline & & Premios 40 principales 2015 (1) & \\
\hline
\end{tabular}

TABLA 46. Programación de ocio y cultura en Nova, Divinity y Energy en 2015.

FUENTE: Elaboración propia.

En cuanto al ocio y la cultura, también es abordado por Nova, Divinity y Energy y también nos ofrecen contenidos diferenciados. Vemos 4 programas y 55 repeticiones en Nova, mientras que Divinity cuenta con 7 programas y 51 repeticiones. En cuanto a 
Energy, reúne 3 programas y 6 repeticiones. En este caso concreto, observamos como los espacios dedicados al cine y a la música están en los canales femeninos mientras que Energy contempla otro tipo de ocio televisado: el de los espectáculos deportivos.

Por otro lado, sirviéndose de la telerrealidad, en Nova y Energy encontramos un tipo de programación que retrata la forma de vida de una parte de nuestra sociedad. También, incluimos en este apartado los informativos de Nova. De esta forma, Nova reúne 4 programas repetidos 36 veces y Energy, 9 espacios emitidos en un total de 81 ocasiones. Cabe señalar que el programa D.Lujo (4 repeticiones) de Divinity, categorizado en otros por no haber más espacios de la misma naturaleza dentro de su canal, se encuadraría en este apartado.

\begin{tabular}{|c|c|c|c|}
\hline \multicolumn{4}{|c|}{ SOCIEDAD } \\
\hline & Nova & Divinity & Energy \\
\hline Actualidad & $\begin{array}{l}\text { Noticias de la mañana } \\
\text { (4) }\end{array}$ & - & - \\
\hline \multirow[t]{8}{*}{ Sociedad } & El jefe (15) & \multirow[t]{8}{*}{ D.Lujo (4) } & 21 dias (2) \\
\hline & \multirow[t]{7}{*}{ El jefe infiltrado (11) } & & Callejeros (24) \\
\hline & & & Callejeros viajeros (34) \\
\hline & & & Conexión Samanta (3) \\
\hline & & & Especial callejeros (5) \\
\hline & & & Ola, ola (6) \\
\hline & & & Los gipsy kings (1) \\
\hline & & & Palabra de gitano (1) \\
\hline Solidaridad & Millonario anónimo (6) & - & En movimiento (5) \\
\hline
\end{tabular}

TABla 47. Programación de sociedad en Nova, Divinity y Energy en 2015.

FUENTE: Elaboración propia.

En este bloque, priman los contenidos donde una cámara recoge momentos cotidianos de la gente. Hay un mayor número de espacios en Energy —el más popular es Callejeros viajeros, programa de 50 minutos de duración que se desplaza hasta distintos rincones del mundo con el fin de conocerlos a través de la mirada de sus habitantes-. Mientras, Nova cuenta con menos espacios, siendo El jefe el más importante. En este programa de telerrealidad, nos adentramos en distintos negocios de la mano de su jefe o jefa, quién comprobará desde dentro cómo funciona su propia empresa. En Divinity, vemos un único espacio, D.Lujo, el cual nos muestra hoteles, restaurantes y servicios exclusivos. Por otro lado, tanto Nova como Energy incluyen los programas de solidaridad Millonario anónimo y En movimiento. 
Divinity y Energy recogen una serie de programación que gira en torno a las relaciones de pareja. Divinity cuenta con 5 programas repetidos un total de 36 veces y Energy con 3 programas repetidos 17 veces. La programación la podemos dividir en tres categorías según su contenido: los espacios de citas, los programas de consejos y los familiares. Por su lado, Nova también presenta un programa, Casados a primera vista (una repetición), que, aunque fue categorizado en otros por no encontrar más espacios de su misma naturaleza dentro del canal, aborda el terreno de las relaciones en pareja.

\begin{tabular}{|c|c|c|c|}
\hline \multicolumn{4}{|c|}{ RELACIONES SENTIMENTALES } \\
\hline & Nova & Divinity & Energy \\
\hline Citas & $\begin{array}{l}\text { Casados a } \\
\text { primera vista (1) }\end{array}$ & $\begin{array}{l}\text { Mujeres y hombres y } \\
\text { viceversa }(17)\end{array}$ & Adán y Eva (5) \\
\hline \multirow[t]{2}{*}{ Consejos } & \multirow[t]{2}{*}{-} & Seduciendo con Tionna (4) & \multirow[t]{2}{*}{ Amores reñidos (7) } \\
\hline & & Una boda perfecta (9) & \\
\hline Familiares & - & Bebé a bordo (1) & - \\
\hline Otros & - & Felices para siempre (5) & Felices para siempre (5) \\
\hline
\end{tabular}

TABla 48. Programación de relaciones sentimentales de Nova, Divinity y Energy en 2015.

FUENTE: Elaboración propia.

Cada uno de los canales presenta un programa de citas. En Casados a primera vista, una pareja que no se conocía previamente celebra su boda $\mathrm{y}$, posterior a ello, comienzan los distintos encuentros. Mujeres y hombres y viceversa se celebra entre el plató televisivo y los varios lugares donde los y las participantes van conociéndose y, finalmente, en Adán y Eva, la peculiaridad que encontramos es que se concursa sin ropa.

Mientras, en el bloque de consejos, vemos el programa Seduciendo con Tionna, de Divinity, en el que la asesora Tionna Smalls muestra a distintas mujeres cómo resultar más atractivas para los hombres. Lo mismo ocurre en Energy en Amores reñidos de Steve Ward, quien hace lo propio con ocho mujeres. Por último, Divinity televisa Una boda perfecta en la que David Tutera ayuda a organizar los enlaces matrimoniales de los y las protagonistas.

Finalmente, un último bloque recogería una trama más familiar con el programa Bebé a bordo de Divinity. En nuestra muestra, grababa el sábado 12 de junio de 2015 a las 12:40, el matrimonio formado por Cristina y Alberto tienen a Carla. El programa se centra en mostrar las primeras veinticuatro horas de la pareja con la bebé en casa: refleja sus estados de ánimo, sus emociones, sus dudas —cuándo hay que darle de comer, si 
puede usar chupete o cómo hay que sacarle los gases-. A lo largo de los 30 minutos de duración, la enfermera Dorota Wójcik, matrona, intenta resolver todas estas cuestiones. El programa lo presenta Fabiola Martínez en calidad de coach.

De esta manera, aunque existe un tipo de programación compartida, tal es la de citas y la de seducción, el terreno de las bodas y de la crianza lo vemos en el canal femenino Divinity y, en menor medida, en Nova.

\subsection{Categorías que comparten los canales femeninos}

Tanto Nova como Divinity comparten, en exclusiva, los contenidos de interiorismo. En Nova encontramos 5 espacios (46 repeticiones), mientras que en Divinity vemos 7 espacios emitidos un total de 86 veces. Todos los programas se centran en la redecoración y el rediseño de distintas estancias de la casa o de casas completas, algunos con el fin de adecuar una vivienda a los gustos de las familias y otros con el objetivo de hacer más fácil su venta.

\begin{tabular}{|c|c|c|c|c|}
\hline \multicolumn{5}{|c|}{ DECOGARDEN } \\
\hline $21 / 03 / 2015$ & $13: 55$ & Nuria & Baño & $\begin{array}{l}\text { Reforma del baño con el fin } \\
\text { de que sea más sencillo } \\
\text { alquilar una habitación }\end{array}$ \\
\hline $20 / 06 / 2015$ & $14: 25$ & Inma & Dormitorio & $\begin{array}{l}\text { Dormitorio de la } \\
\text { protagonista }\end{array}$ \\
\hline $19 / 09 / 2015$ & $13: 35$ & Merche & Dormitorio & $\begin{array}{l}\text { Dormitorio de la } \\
\text { protagonista y de su marido }\end{array}$ \\
\hline $19 / 12 / 2015$ & $13: 45$ & Mónica & $\begin{array}{l}\text { Dormitorio } \\
\text { infantil }\end{array}$ & $\begin{array}{l}\text { Dormitorio de Hugo, el } \\
\text { hermano pequeño de } \\
\text { Mónica }\end{array}$ \\
\hline
\end{tabular}

TABLA 49. Contenido del programa Decogarden en Nova, año 2015.

FuENTE: Elaboración propia.

En Nova el programa más importante de esta categoría es Decogarden (18 repeticiones), emitido los sábados y domingos a lo largo de los cuatro meses en los que se recogió la muestra. Este makeover dura 30 minutos y lo dirige Yolanda Alzola, quien acude a las casas que lo solicitan y redecora los espacios usando técnicas sencillas, materiales baratos o reciclando los viejos muebles. En este sentido, vemos la figura de una mujer realizando tareas de bricolaje. Por otro lado, el perfil de las solicitantes es 
variado: gente joven en casas de alquiler o que aún no se han independizado, familias que buscan renovar una habitación... En la tabla 48, podemos ver a las protagonistas y los espacios que Yolanda Alzola modifica en la muestra que tenemos grabada.

La casa de mis sueños es el espacio con más peso en Divinity (23 repeticiones). El makeover, de 42 minutos de duración y emitido durante los fines de semana, está presentado por los hermanos gemelos Drew y Jonathan Scott. Drew Scott es agente inmobiliario y consigue una casa por un precio que pueda permitirse la pareja o el matrimonio. Posteriormente, Jonathan Scott transformará la casa con el fin de que se ajuste a los nuevos gustos. El programa siempre se desarrolla en contextos familiares: familias extensas, padres y madres primerizas, parejas que buscan independizarse por primera vez... En nuestra muestra grabada contamos con los siguientes perfiles:

\begin{tabular}{|c|c|c|c|c|}
\hline \multicolumn{5}{|c|}{ LA CASA DE MIS SUEÑOS } \\
\hline Fecha & Hora & Protagonistas & Características & \\
\hline $7 / 09 / 2015$ & $18: 10$ & Vicent y Helena & $\begin{array}{l}\text { Pareja heterosexual sin } \\
\text { hijos/as. }\end{array}$ & Primera vivienda \\
\hline $7 / 12 / 2015$ & $08: 45$ & Connie y José & $\begin{array}{l}\text { Pareja heterosexual con } \\
\text { dos hijos y una hija. }\end{array}$ & $\begin{array}{l}\text { Cambio de vivienda } \\
\text { por motivos de espacio }\end{array}$ \\
\hline $12 / 12 / 2015$ & $10: 00$ & Wyatt y Whitney & $\begin{array}{l}\text { Pareja heterosexual sin } \\
\text { hijos/as. }\end{array}$ & Primera vivienda \\
\hline
\end{tabular}

TABLA 50. Contenido del programa La casa de mis sueños en Divinity, año 2015.

FUENTE: Elaboración propia.

Por último, cabe destacar que, aunque Energy no presenta una categoría de decoración como tal, sí emite un programa que combina este campo con el mundo de la ingeniería. Se trata de Mudanzas imposibles (27 repeticiones) el cual, a priori, puede recordar a los programas de decoración que vemos en Nova y Divinity. En este espacio, distintos perfiles solicitan el traslado de una casa de un lugar a otro. Así, entran en juego grandes maquinarias que despiezan y mueven la vivienda hasta la nueva ubicación. Los encargados del traslado son equipos de mudanza locales y, en nuestra muestra, están compuestos por varones. Las y los solicitantes no tienen por qué ser una pareja o matrimonio si no que, en este caso concreto, a parte de dos parejas, vemos también a unos hermanos que quieren reubicar la casa que construyó su padre. Los elementos decorativos de las viviendas se destacan, pero con el fin de resaltar el peso, volumen o el reto que va a suponer su traslado. 


\begin{tabular}{|c|c|c|c|c|c|}
\hline \multicolumn{6}{|c|}{ MUDANZAS IMPOSIBLES } \\
\hline Fecha & Hora & Protagonistas & Características & & \\
\hline $2 / 03 / 2015$ & $12: 30$ & Tina y Walter & $\begin{array}{l}\text { Pareja } \\
\text { heterosexual con } \\
\text { tres hijos }\end{array}$ & $\begin{array}{l}\text { Trasladar una } \\
\text { vivienda recién } \\
\text { comprada a otra } \\
\text { parcela }\end{array}$ & $\begin{array}{l}24 \mathrm{~km} \mathrm{de} \\
\text { traslado }\end{array}$ \\
\hline $5 / 09 / 2015$ & $07: 25$ & Waine y Sean & $\begin{array}{l}\text { Pareja de } \\
\text { hermanos }\end{array}$ & $\begin{array}{l}\text { Trasladar la casa } \\
\text { familiar a un lugar } \\
\text { cercano al trabajo } \\
\text { de ambos }\end{array}$ & $\begin{array}{l}80 \mathrm{~km} \mathrm{de} \\
\text { traslado }\end{array}$ \\
\hline $5 / 09 / 2015$ & $07: 50$ & Vicky y Garry & $\begin{array}{l}\text { Pareja } \\
\text { heterosexual con } \\
\text { hijos/as }\end{array}$ & $\begin{array}{l}\text { Trasladar la casa de } \\
\text { vacaciones por } \\
\text { temas de seguridad } \\
\text { del terreno }\end{array}$ & $\begin{array}{l}1,5 \mathrm{~km} \mathrm{de} \\
\text { traslado }\end{array}$ \\
\hline
\end{tabular}

TABLA 51. Contenido del programa Mudanzas imposibles en Energy, año 2015.

FUENTE: Elaboración propia.

Vemos, pues, diferentes tipos de contenido. Divinity ofrece uno centrado en la búsqueda de casa propio de una familia tradicional que quiere independizarse o a la que su vivienda anterior se le ha quedado pequeña. De esta búsqueda y acondicionamiento del inmueble se encargan los gemelos Scott. Mientras, Nova ha apostado porque el programa y las distintas reformas las haga Yolanda Alzola y se ha desligado del discurso excesivamente familiar al mostrar a las personas como individuos en lugar de como parejas o matrimonios. Finalmente, Energy, aunque pueda ofrecer una línea similar, ha mezclado el mundo de las mudanzas y la decoración con la ingeniería, centrándose en el reto que supone un megatraslado y destacando las inclemencias encontradas en el terreno y las dificultades de la reubicación del inmueble.

\subsection{Categorías que comparten los canales masculinos}

Los canales masculinos comparten, en exclusiva, un total de cinco categorías: ciencia y tecnología, motor, supervivencia y naturaleza, subastas y violencia y misterio. A lo largo del siguiente epígrafe, veremos, de forma más detallada, qué contenidos encontramos en cada temática. Así, iremos comprobando qué programa es el más relevante por número de repeticiones y qué tipo de modelo de masculinidad está ofreciendo a su público — si se trata de una imagen rompedora que trasciende los parámetros del género o, si, por el contrario, explota una visión tradicional-. 
Para ciencia y tecnología, en Discovery Max vemos dos subcategorías: ciencia y tecnología con 11 espacios y 21 repeticiones e ingeniería que abarca 18 espacios repetidos un total de 129 veces. Mientras, en Energy tenemos 3 espacios emitidos en 70 ocasiones. El programa más repetido en Discovery Max es ¿Cómo lo hacen? (63 veces). No solo se trata del más importante dentro de esta categoría, sino que es el más emitido de todo Discovery Max. Son pequeños documentales, de 22 minutos de duración televisados entre semana, en los que se muestra el proceso de fabricación de objetos cotidianos, en ocasiones comprenden desde que se extraen las primeras materias primas hasta que se ensambla la última pieza. Se centra, por tanto, en mostrarnos procesos tecnológicos y de ingeniería que la mayoría de la audiencia desconoce.

\begin{tabular}{|l|l|l|}
\hline \multirow{2}{*}{ Fecha } & Hora & Contenido \\
\hline $23 / 03 / 2015$ & $09: 30$ & Vidrio termo resistente \\
\cline { 3 - 3 } & & Cajeros automáticos \\
\hline $22 / 06 / 2015$ & $06: 00$ & Pintar la Torre Eiffel \\
\cline { 3 - 3 } & & Tablas de snowboard \\
\hline $21 / 09 / 2015$ & \multirow{2}{*}{$07: 30$} & Mantenimiento de las pistas de despegue y aterrizaje en los aeropuertos \\
\cline { 3 - 3 } & & Revistas \\
\cline { 3 - 3 } & & Coche deportivo eléctrico \\
\hline \multirow{2}{*}{$21 / 12 / 2015$} & $07: 30$ & Sombrero "de vaquero" \\
\cline { 3 - 3 } & & Equipación de los buceadores/as \\
\cline { 3 - 3 } & & Comida en los aviones \\
\hline
\end{tabular}

TABla 52. Contenido del programa ¿Cómo lo hacen? en Discovery Max, año 2015.

FUENTE: Elaboración propia.

De Energy, Mudanzas Imposibles —desarrollado anteriormente-y Ciencia para torpes, ambos con 27 repeticiones, son los espacios más emitidos. En Ciencia para torpes, visto diariamente durante el mes de septiembre, encontramos capítulos de 25 minutos de duración donde se mezcla la ciencia con la comedia. Lo presenta Richard Hammond, quien explica el razonamiento científico por el cual una situación no ha salido como su protagonista esperaba. Así, en nuestra muestra, vemos vídeos caseros donde la gente falla en el intento de saltar con un coche o con una moto, de sumergirse dentro de un kayak en el agua, etc. Estos clips de vídeo se intercalan con los del presentador, que nos habla de las variables científicas que entran en juego en cada uno de los experimentos: el centro de gravedad, la velocidad, la fuerza o la masa. 


\begin{tabular}{|c|c|c|c|}
\hline \multicolumn{4}{|c|}{ CIENCIA PARA TORPES } \\
\hline Fecha & Hora & Experimento fallido & Explicación científica \\
\hline \multirow[t]{5}{*}{$31 / 09 / 2015$} & \multirow[t]{5}{*}{$15: 10$} & Coches estrellándose & $\begin{array}{l}\text { "Ley del impulso y el momento": velocidad, } \\
\text { rotación y fuerza de impacto en saltos de coches }\end{array}$ \\
\hline & & Saltos fallidos (caídas) & $\begin{array}{l}\text { "Teorema del trabajo energía" para saltos físicos } \\
\text { verticales }\end{array}$ \\
\hline & & $\begin{array}{l}\text { Plankings fallidos } \\
\text { (caídas) }\end{array}$ & $\begin{array}{l}\text { Centro de gravedad corporal para practicar } \\
\text { planking (estirarse como una tabla sobre un objeto } \\
\text { dejando parte del cuerpo al aire) }\end{array}$ \\
\hline & & $\begin{array}{l}\text { Gente cayendo del } \\
\text { kayak }\end{array}$ & $\begin{array}{l}\text { Ángulo adecuado para lanzarse al agua en kayak, } \\
\text { con el fin de que la flotabilidad eleve la proa a la } \\
\text { izquierda trazando un arco suave y controlado }\end{array}$ \\
\hline & & $\begin{array}{l}\text { Conductores cayendo } \\
\text { de las motos }\end{array}$ & $\begin{array}{l}\text { Centro de masa de las motos para poder subir } \\
\text { cuestas }\end{array}$ \\
\hline
\end{tabular}

TABLA 53. Contenido del programa Ciencia para torpes en Energy, año 2015.

FUENTE: Elaboración propia.

Por su lado, los contenidos referidos al mundo del motor los vemos en Discovery Max, con 11 espacios y 75 repeticiones y en Energy, que comprende 4 espacios emitidos un total de 39 veces.

\begin{tabular}{|c|c|c|c|}
\hline \multicolumn{4}{|c|}{ FAST N'LOUD } \\
\hline Fecha & Hora & Coche & Contenido \\
\hline \multirow[t]{3}{*}{$23 / 03 / 2015$} & \multirow[t]{3}{*}{$19: 35$} & Ford Gasser del 60 & $\begin{array}{l}\text { Compra, restauración y venta en } \\
\text { subasta }\end{array}$ \\
\hline & & Cadillac & $\begin{array}{l}\text { Compra, restauración y venta a otro } \\
\text { taller }\end{array}$ \\
\hline & & Pontiac Coupe del 32 & $\begin{array}{l}\text { Compra, restauración y venta en } \\
\text { subasta }\end{array}$ \\
\hline \multirow[t]{3}{*}{$22 / 06 / 2015$} & \multirow[t]{3}{*}{$19: 40$} & Bronco & $\begin{array}{l}\text { Compra, restauración y venta en } \\
\text { subasta }\end{array}$ \\
\hline & & Pontiac Chieftain del 55 & $\begin{array}{l}\text { Compra, limpieza y venta a un } \\
\text { particular }\end{array}$ \\
\hline & & Pontiac Sedan del 40 & $\begin{array}{l}\text { Compra, limpieza y venta a un } \\
\text { particular }\end{array}$ \\
\hline \multirow[t]{3}{*}{$21 / 09 / 2015$} & \multirow[t]{3}{*}{$18: 35$} & Ford Galaxie Fairlane del 59 & $\begin{array}{l}\text { Compra, restauración y venta en } \\
\text { subasta }\end{array}$ \\
\hline & & Ford A Coupe de 1930 & $\begin{array}{l}\text { Compra restauración y venta a un } \\
\text { particular }\end{array}$ \\
\hline & & Chevy Bel air del 54 & Compra y venta a un particular \\
\hline \multirow[t]{3}{*}{$21 / 12 / 2015$} & \multirow[t]{3}{*}{$17: 45$} & Ford Galaxie 500 del 67 & Restauración y venta a un particular \\
\hline & & Nash Healey Roadster & Compra y venta a un particular \\
\hline & & Messerschmitt & Venta en subasta \\
\hline
\end{tabular}

TABla 54. Contenido del programa Fast n'Loud en Discovery Max, año 2015.

FUENTE: Elaboración propia. 
En Discovery Max, Fast n'Loud cuenta con 38 repeticiones. De 45 minutos de duración, este programa de telerrealidad enseña el día a día del taller Gas Monkey en Dallas, Texas. Su propietario, Richard Rawlings, junto con el jefe de mecánicos, Aaron Kaufmann, acuden en busca de coches que se encuentren en mal estado con el fin de restaurarlos y poder venderlos a un buen precio. En nuestra muestra, comprobamos que cada uno de los capítulos lo conforma un proyecto más ambicioso, esto es el vehículo que finalmente venden en subasta, y dos proyectos que requieren de menos arreglos y que venden a particulares, a otros talleres o, en algunos casos, también en subasta. Los coches son grandes clásicos del mundo del motor y durante los capítulos no solo vemos su proceso de restauración, sino que también se nos informa de sus características técnicas, así como de su historia. El programa hace hincapié en las dificultades durante el proceso de reparación y en el beneficio logrado con cada coche.

El programa de motor popular en Energy es Más que motos (5 repeticiones). Se trata de un espacio de 25 minutos dirigido por Carolina Alcázar, quien aparece físicamente presentando los distintos modelos de motos que posteriormente serán probados. Tras sus intervenciones, una voz en off masculina narra las características técnicas de las motos. Son vehículos que acaban de salir al mercado por lo que los comparan con otros anteriores. Se resaltan rasgos como la potencia, la fuerza o la velocidad. En nuestra muestra conocemos las siguientes motos:

\begin{tabular}{|c|c|c|}
\hline \multicolumn{3}{|r|}{ MÁS QUE MOTOS } \\
\hline Fecha & Hora & Contenido \\
\hline \multirow{4}{*}{$07 / 03 / 2015$} & \multirow[t]{4}{*}{ 09:00 } & Kymco Yager GT 300i \\
\hline & & Indian Chef Dark Horse \\
\hline & & Yamaha V-Max \\
\hline & & Honda NC750X \\
\hline \multirow[t]{2}{*}{$06 / 06 / 2015$} & \multirow[t]{2}{*}{$09: 15$} & BMW S100XR \\
\hline & & Escultura de mármol de moto Ducati \\
\hline \multirow[t]{3}{*}{$05 / 09 / 2015$} & \multirow[t]{3}{*}{ 09:20 } & Ducati Scrambler \\
\hline & & Scooter Honda \\
\hline & & Triumph Tiger 800 \\
\hline \multirow[t]{3}{*}{$05 / 12 / 2015$} & \multirow[t]{3}{*}{$11: 30$} & Suzuki strom $650 \mathrm{xt}$ \\
\hline & & Quad honda trx $250 \mathrm{x}$ \\
\hline & & Montesa Cota 300RR \\
\hline
\end{tabular}

TABla 55. Contenido del programa Más que motos en Energy, año 2015. FUENTE: Elaboración propia. 
Otra categoría que vemos tanto en Discovery Max como en Energy es la de las subastas. En Discovery Max vemos 6 espacios y 181 repeticiones, mientras que Energy comprende 4 espacios y 82 repeticiones.

En Discovery Max, Cazasubastas (60 repeticiones) es el programa más importante de esta categoría y el segundo con mayor número de repeticiones de todo el canal. Allen Haf y Tom Jones son quienes protagonizan este espacio de telerrealidad de 22 minutos de duración. Acuden a emplazamientos de trasteros en Estados Unidos que salen a subasta. El interior de estos trasteros se encuentra medio oculto y tan solo es posible intuir algunos objetos que guardan. La finalidad de la pareja protagonista es dar con mercancía de valor y poder revenderla. Así, en cada trastero encuentran uno o dos objetos por los que sacan unos miles de dólares. En nuestra muestra, vemos una mesa de billar, un buggy — vehículo pequeño-, una motocicleta, una pistola de red, objetos militares, una caja fuerte, una pistola antigua y un traje espacial ruso (que consiguen vender por 19.000 dólares). Los beneficios van desde los 8.575 dólares hasta los 20.000 dólares.

\begin{tabular}{|l|l|l|l|l|}
\hline \multicolumn{5}{|c|}{ CAZASUBASTAS } \\
\hline Fecha & Hora & Pagado en subasta & Venta de objetos & Beneficio \\
\hline $23 / 03 / 2016$ & $14: 45$ & 440 dólares & 21.420 dólares & 20.000 dólares \\
\hline $22 / 06 / 2015$ & $15: 00$ & 1.450 dólares & 10.550 dólares & 9.100 dólares \\
\hline $26 / 09 / 2015$ & $13: 05$ & 1.875 dólares & 10.450 dólares & 8.575 dólares \\
\hline $25 / 12 / 2015$ & $12: 25$ & 3.300 dólares & 22.200 dólares & 18.900 dólares \\
\hline
\end{tabular}

TABla 56. Contenido del programa Cazasubastas en Discovery Max, año 2015.

FUENTE: Elaboración propia.

En Energy, Transportes imposibles es el programa con más peso (36 repeticiones). Este espacio de telerrealidad de 30 minutos es un híbrido del mundo de las subastas y del motor. Roy Garber, Jarrett Joyce, Marc Springer, Jennifer Brennan y las parejas formadas por Scott y Susie y Chris y Robbie son transportistas independientes que pujan por los encargos que la casa de subastas de Austin, Texas, saca diariamente. Cuentan con 10 minutos en los que ofrecer el precio más bajo y así hacerse con el trabajo. Cada programa empieza con la subasta para, posteriormente, mostrar la competición de los y las transportistas, quienes proponen la cantidad por la que realizarán el encargo. Tras la subasta, el ganador o la ganadora se iniciará en una carrera a contrarreloj con el fin de 
entregar el producto dentro del tiempo establecido. En nuestra muestra, vemos complicaciones relacionadas con averías, falta de gasolina... También, se revelan los trucos que llevan a cabo, como el ir aceptando otros encargos por el camino, lo cual les permite ganar un dinero extra al acordado en la subasta. Los objetos a transportar son grandes, en este caso tenemos una estatua de caballo, una figura de atrezo, 200 guitarras y hasta un yate.

\begin{tabular}{|l|l|l|l|l|}
\hline \multicolumn{5}{|c|}{ TRANSPORTES IMPOSIBLES } \\
\hline Fecha & Hora & Objeto & Características & Subasta \\
\hline $2 / 03 / 2015$ & $14: 00$ & $\begin{array}{l}\text { Estatua de un } \\
\text { caballo }\end{array}$ & $\begin{array}{l}\text { De Nueva York a Florida } \\
\text { antes de 36 horas }\end{array}$ & Roy: 4000 dólares \\
\cline { 3 - 5 } & & $\begin{array}{l}\text { Venus } \\
\text { atrapamoscas } \\
\text { (atrezo) }\end{array}$ & $\begin{array}{l}\text { De Bristol (Connecticut) a } \\
\text { San Diego (California) en } \\
8 \text { días }\end{array}$ & Jarrett: 1350 dólares \\
\hline $1 / 06 / 2015$ & $11: 45$ & $\begin{array}{l}200 \text { guitarras } \\
\text { Fender }\end{array}$ & $\begin{array}{l}\text { De Corona a Patterson } \\
\text { (California) en 1 día }\end{array}$ & Marc: 1040 dólares \\
\cline { 3 - 5 } & Yate & $\begin{array}{l}\text { Sarasota a Cayo Hueso } \\
\text { (Florida) en un día }\end{array}$ & $\begin{array}{l}\text { Chris y Robbie: } 1500 \\
\text { dólares }\end{array}$ \\
\hline
\end{tabular}

TABLA 57. Contenido del programa Transportes imposibles en Energy, año 2015. FUENTE: Elaboración propia.

De entre todas las categorías, supervivencia y naturaleza es la que más espacios y repeticiones reúne dentro de los contenidos masculinos. En Discovery Max (animales y naturaleza / aventura y supervivencia) encontramos 30 programas, repetidos un total de 232 veces, y en Energy, 9 espacios vistos 98 veces.

En Discovery Max, El último superviviente es el programa con más peso (51 repeticiones). Se trata de un espacio de telerrealidad, de 45 minutos de duración, donde Bear Grylls, ex militar británico, sobrevive en situaciones límite. Para ello, cuenta con una mochila en la que lleva enseres básicos (navaja, cuerda...), pero, principalmente, se sirve de las materias primas que le ofrece el entorno para salir adelante. Las localizaciones presentan dificultades climatológicas y geográficas. En nuestra muestra, sobrevive en el desierto de Mojabe, en una isla del Pacífico y en Islandia. A parte, uno de los episodios se trata de una recopilación, por tanto, le vemos en varios puntos: en la selva de Panamá, en Kimberley (Sudáfrica), en Kenia y en Everglades (Estados Unidos).

A parte de las dificultades del terreno y las climatológicas, se enfrenta a los animales de la zona: animales salvajes, como los cocodrilos, o venenosos, como 
serpientes, ranas, escorpiones... Para sobrevivir, Bear Grylls pesca, caza y recolecta frutos. En ocasiones, come animales crudos y extrae agua de excrementos u orines. El programa resalta continuamente la crudeza de la experiencia y las dificultades a las que se enfrenta el protagonista.

\begin{tabular}{|c|c|c|c|}
\hline \multicolumn{4}{|c|}{ EL ÚLTIMO SUPERVIVIENTE } \\
\hline Fecha & Hora & Destino & Dificultades y técnicas para sobrevivir \\
\hline \multirow[t]{3}{*}{$23 / 03 / 2015$} & \multirow[t]{3}{*}{ 08:45 } & \multirow{3}{*}{ Desierto de Mojabe } & Tormenta de arena \\
\hline & & & Riada \\
\hline & & & Serpiente de cascabel \\
\hline \multirow{4}{*}{$22 / 06 / 2015$} & \multirow[t]{4}{*}{ 09:10 } & Selva de Panamá & Comer una serpiente \\
\hline & & Kimberley & Beber orina \\
\hline & & Kenia & Beber fluidos de los excrementos \\
\hline & & Everglades & Comer una rana \\
\hline \multirow[t]{3}{*}{$21 / 09 / 2015$} & \multirow[t]{3}{*}{ 08:20 } & \multirow[t]{3}{*}{ Isla del Pacífico } & $\begin{array}{l}\text { Elaboración de un arcón con un esqueleto de } \\
\text { un ave }\end{array}$ \\
\hline & & & $\begin{array}{l}\text { Elaboración de una hamaca para no dormir } \\
\text { sobre el suelo de la selva y así evitar los } \\
\text { ataques de animales. }\end{array}$ \\
\hline & & & $\begin{array}{l}\text { Construcción de una balsa con unas maderas } \\
\text { para abandonar la isla. }\end{array}$ \\
\hline \multirow[t]{2}{*}{$21 / 12 / 2015$} & \multirow[t]{2}{*}{ 08:20 } & \multirow[t]{2}{*}{ Islandia } & $\begin{array}{l}\text { Glacial: clima extremo, vendaval con rachas } \\
\text { de } 80 \mathrm{~km} \text { por hora. Sensación térmica de }-20 \\
\text { grados, nieve y niebla. }\end{array}$ \\
\hline & & & Área geotérmica, actividad volcánica \\
\hline
\end{tabular}

TABLA 58. Contenido del programa El último superviviente en Discovery Max, año 2015.

FUENTE: Elaboración propia.

En Energy, Veterinario al rescate es el espacio más repetido (59 repeticiones). Este programa de telerrealidad narra el día a día del veterinario Chris Brown (clínica Bondi Junction Veterinary Hospital), la veterinaria Lisa Chimes, el veterinario Andrew Marchevsky (Small animal specialist hospital) y del director del Parque de reptiles en Sídney Tim Paulkner. Atienden casos de animales tanto domésticos, en la muestra vemos perros y gatos, como salvajes (serpientes, arañas, leones, tigres...). El programa, de 45 minutos de duración, presenta el diagnostico de los animales, el tratamiento y su curación.

Por último, querríamos destacar que Divinity cuenta, entre su programación, con los espacios Supervivientes 2015: resumen diario (5 repeticiones), S.O.S Supervivientes (2 repeticiones) y Supervivientes diario desde Honduras (2 repeticiones). En estos reality shows, grabados en una isla, sus participantes ven restringida la comida y deben superar 
ciertas pruebas: yincanas, circuitos con acertijos... sin embargo, el foco del programa gira en torno a las relaciones - destacando en los resúmenes y galas las peleas, alianzas y amistades de ellos y ellas - y no tanto en torno a la dureza del medio, que pasaría a un segundo plano. Así, dichos híbridos se sitúan más próximos al reality show de convivencia —como podría ser Gran Hermano, también presente en Divinity—que a los espacios que vemos en Energy y Discovery Max para las categorías de supervivencia, naturaleza o aventura.

\begin{tabular}{|c|c|c|c|c|}
\hline \multicolumn{5}{|c|}{ VETERINARIO AL RESCATE } \\
\hline Fecha & Hora & Animal & Problema & Intervención \\
\hline \multirow{3}{*}{$2 / 03 / 2015$} & \multirow[t]{3}{*}{$17: 00$} & Perro & Problemas de respiración & Operación \\
\hline & & Cisne & $\begin{array}{l}\text { Desnutrición por } \\
\text { quedarse atrapado en una } \\
\text { verja }\end{array}$ & $\begin{array}{l}\text { Diversas pruebas, } \\
\text { comida, agua } \mathrm{y} \\
\text { medicamentos }\end{array}$ \\
\hline & & Gato & Picadura de garrapata & Medicación \\
\hline \multirow[t]{3}{*}{$2 / 03 / 2015$} & \multirow[t]{3}{*}{$17: 45$} & Araña & Venenosa & Extracción del veneno \\
\hline & & Serpiente & Rescatada de una playa & $\begin{array}{l}\text { Cuidados hasta su } \\
\text { recuperación }\end{array}$ \\
\hline & & Perro & Paladar hendido & Operación \\
\hline \multirow[t]{3}{*}{$1 / 06 / 2015$} & \multirow[t]{3}{*}{$16: 55$} & Perro & Heridas en el paladar & Aparato dental \\
\hline & & León & $\begin{array}{l}\text { Cachorro rechazado por } \\
\text { su madre }\end{array}$ & Vacunas \\
\hline & & Serpiente pitón & Bulto en la espalda & Operación \\
\hline \multirow[t]{4}{*}{$31 / 08 / 2015$} & \multirow[t]{4}{*}{$17: 00$} & Equidna & Se desconoce el sexo & Sexar (macho) \\
\hline & & Perra & Dilatación gástrica & Operación \\
\hline & & Casuarios & $\begin{array}{l}\text { Peligra el futuro de la } \\
\text { especie }\end{array}$ & $\begin{array}{l}\text { Aparear un macho y una } \\
\text { hembra }\end{array}$ \\
\hline & & Tigre & & Implante anticonceptivo \\
\hline
\end{tabular}

TABLA 59. Contenido del programa Veterinario al rescate en Energy, año 2015.

FUENTE: Elaboración propia.

Finalmente, una última categoría nos lleva hasta la violencia y el misterio. Así vemos en Discovery Max que reúne 33 espacios y 173 repeticiones y en Energy con 7 espacios y 106 repeticiones. En Discovery Max, Control de aduanas, Canadá es el espacio más repetido, 26 veces, dentro de la categoría. Este programa de telerrealidad dura 25 minutos y graba distintos emplazamientos aduaneros. Así, en nuestra muestra, encontramos el puerto, el aeropuerto internacional y el centro de correos de Vancouver, el aeropuerto de Montreal-Trudeau y los pasos fronterizos de Douglas y de la Autopista del Pacífico. El objetivo del programa es mostrarnos las irregularidades que pueden darse 
en estos puntos aduaneros con las distintas mercancías o el tráfico ilegal de personas. En la siguiente tabla, se especifican detalladamente los inconvenientes encontrados a lo largo de los episodios grabados:

\begin{tabular}{|c|c|c|c|c|}
\hline \multicolumn{5}{|c|}{ CONTROL DE ADUANAS, CANADÁ } \\
\hline Fecha & Hora & \multicolumn{3}{|l|}{ Contenido } \\
\hline \multirow[t]{4}{*}{$23 / 03 / 2015$} & \multirow[t]{4}{*}{$00: 20$} & $\begin{array}{l}\text { Puerto de } \\
\text { Vancouver }\end{array}$ & Registro barco & $\begin{array}{l}\text { Más cantidad de alcohol de la } \\
\text { declarada }\end{array}$ \\
\hline & & $\begin{array}{l}\text { Aeropuerto } \\
\text { Internacional de } \\
\text { Vancouver }\end{array}$ & Pasajero coreano & Documentación irregular \\
\hline & & $\begin{array}{l}\text { Aeropuerto } \\
\text { Internacional de } \\
\text { Vancouver }\end{array}$ & Pasajero ruso & $\begin{array}{l}\text { Antecedentes. Mintió en la } \\
\text { solicitud del visado. Deportado }\end{array}$ \\
\hline & & $\begin{array}{l}\text { Aeropuerto } \\
\text { Internacional de } \\
\text { Vancouver }\end{array}$ & $\begin{array}{l}\text { Pasajero } \\
\text { estadounidense }\end{array}$ & $\begin{array}{l}\text { Productor de música. Viene a } \\
\text { colaborar con una cantante } \\
\text { canadiense. Se le permite la } \\
\text { entrada }\end{array}$ \\
\hline \multirow[t]{3}{*}{$25 / 09 / 2015$} & \multirow[t]{3}{*}{$23: 55$} & $\begin{array}{l}\text { Aeropuerto } \\
\text { Internacional de } \\
\text { Vancouver }\end{array}$ & $\begin{array}{l}\text { Pasajero } \\
\text { estadounidense }\end{array}$ & $\begin{array}{l}\text { Visado de turista, sospechas de } \\
\text { que intente entrar a Canadá para } \\
\text { trabajar }\end{array}$ \\
\hline & & $\begin{array}{l}\text { Centro de } \\
\text { Correos de } \\
\text { Vancouver }\end{array}$ & Paquete & $\begin{array}{l}\text { Peluches con botes de } \\
\text { testosterona en el interior }\end{array}$ \\
\hline & & $\begin{array}{l}\text { Paso fronterizo de } \\
\text { Douglas }\end{array}$ & $\begin{array}{l}\text { Ciudadano } \\
\text { estadounidense }\end{array}$ & $\begin{array}{l}\text { Problemas de salud. Se sospecha } \\
\text { que quiere utilizar el servicio de } \\
\text { salud canadiense }\end{array}$ \\
\hline \multirow[t]{4}{*}{$26 / 12 / 2015$} & \multirow[t]{4}{*}{$19: 10$} & $\begin{array}{l}\text { Aeropuerto } \\
\text { Internacional } \\
\text { Montreal- } \\
\text { Trudeau }\end{array}$ & Pareja francesa & $\begin{array}{l}\text { No ha declarado la comida que } \\
\text { tiene en la maleta. Aparecen } 7 \\
\text { botellas de alcohol, ajo, } \\
\text { embutidos, carne de cerdo, } \\
\text { salchichas... Multa de } 400 \text { euros }\end{array}$ \\
\hline & & $\begin{array}{l}\text { Paso fronterizo de } \\
\text { la Autopista del } \\
\text { Pacífico }\end{array}$ & $\begin{array}{l}\text { Camión } \\
\text { estadounidense }\end{array}$ & Control rutinario. \\
\hline & & $\begin{array}{l}\text { Puerto de } \\
\text { Vancouver }\end{array}$ & Buque carguero & $\begin{array}{l}\text { Pistola eléctrica a bordo que no se } \\
\text { ha declarado. Se requisa. }\end{array}$ \\
\hline & & $\begin{array}{l}\text { Aeropuerto } \\
\text { Internacional de } \\
\text { Vancouver }\end{array}$ & Pasajera filipina & $\begin{array}{l}\text { Visado de turista. Se cree que } \\
\text { quiere trabajar. Finalmente, se le } \\
\text { permite la entrada por dos meses }\end{array}$ \\
\hline
\end{tabular}

TABLA 60. Contenido del programa Control de aduanas, Canadá en Discovery Max, año 2015.

FUENTE: Elaboración propia.

En Energy, Los timadores es el programa con más numero de emisiones (44). Este espacio de telerrealidad, de 25 minutos de duración, recrea distintos timos gracias al 
trabajo de la actriz Jessica-Jane Clement (apodada la embaucadora sexy) y de los actores Alexis Connan (el estafador de incautos) y Paul Wilson (maestro del timo). Se rueda en Reino Unido y el papel de Jess, Alex y Paul es el de preparar el escenario perfecto para llevar a cabo algunos de los timos más populares de la actualidad, de tal manera que el programa pueda explicar las características y el triunfo del engaño. Al final del programa, las personas estafadas son avisadas y se les devuelve el dinero extraído. A continuación se detallan los siete timos encontrados en nuestra muestra grabada:

\begin{tabular}{|c|c|c|c|}
\hline \multicolumn{4}{|c|}{ LOS TIMADORES } \\
\hline Fecha & Hora & Nombre del timo & Timo \\
\hline \multirow[t]{4}{*}{$1 / 06 / 2015$} & \multirow[t]{4}{*}{ 09:00 } & El timo de los DVD & $\begin{array}{l}\text { Jess vende DVD piratas en un bar y, } \\
\text { posteriormente, Alex y Paul, disfrazados de } \\
\text { policía, multan con } 50 \text { libras a las personas que } \\
\text { los han comprado }\end{array}$ \\
\hline & & $\begin{array}{l}\text { Famosos timadores. } \\
\text { Famoso involucrado: } \\
\text { periodista Ian Lee }\end{array}$ & $\begin{array}{l}\text { Con la excusa de reparar las cañerías de una } \\
\text { casa, roban en su interior }\end{array}$ \\
\hline & & $\begin{array}{l}\text { El timo del comprador } \\
\text { misterioso }\end{array}$ & $\begin{array}{l}\text { Una empresa falsa contrata a hombres y mujeres } \\
\text { para que hagan compras y se pueda evaluar el } \\
\text { mercado. Les pagan con cheques falsos }\end{array}$ \\
\hline & & El timo de la gorra roja & $\begin{array}{l}\text { Mediante un falso servicio de facturación rápida } \\
\text { en el aeropuerto, el equipo roba el equipaje a } \\
\text { distintas personas }\end{array}$ \\
\hline \multirow[t]{3}{*}{$31 / 08 / 2015$} & \multirow[t]{3}{*}{$08: 50$} & La sesión de fotos falsa & $\begin{array}{l}\text { El equipo alquila unos diamantes, valorados en } \\
15.000 \text { libras, para una sesión fotográfica. Aún } \\
\text { habiendo personal vigilando los diamantes } \\
\text { durante la sesión, el equipo consigue robarlos }\end{array}$ \\
\hline & & Apuestas imposibles & $\begin{array}{l}\text { En un bar, el equipo consigue trucar las una } \\
\text { apuesta para sacar el dinero a la clientela }\end{array}$ \\
\hline & & $\begin{array}{l}\text { Timo del alquiler de } \\
\text { coches }\end{array}$ & $\begin{array}{l}\text { El equipo cobra multas falsas a turistas que han } \\
\text { alquilado un coche gracias a una encuesta que } \\
\text { les hace Jess en la que facilitan sus datos tras } \\
\text { devolver el vehículo }\end{array}$ \\
\hline
\end{tabular}

TABLA 61. Contenido del programa Los Timadores en Energy, año 2015.

FUENTE: Elaboración propia.

\subsection{Contenidos de ficción en los canales femeninos y masculinos}

A parte de los contenidos de no ficción, Nova, Divinity y Energy televisan contenidos de ficción. Hemos visto un total de 149 espacios repetidos 938 veces. Según su naturaleza, se dividen en ficción seriada y largometrajes. Aunque estos contenidos no suponen el grueso del análisis, sí queríamos utilizarlos como instrumento de apoyo para el momento 
en el que hagamos una apreciación completa de los contenidos y enfrentemos ambos soportes mediáticos.

\begin{tabular}{|c|c|c|}
\hline \multirow{2}{*}{ Nova } & FICCIÓN SERIADA & Energy \\
\hline- & Divinity & Acción \\
\hline- & - & Ciencia ficción \\
\hline- & - & - \\
\hline Drama & Comedia romántica & - \\
\hline- & Drama & - \\
\hline- & Drama femenino & - \\
\hline Drama romántico & Drama profesional & - \\
\hline Fantasía & Drama romántico & - \\
\hline Thriller policiaco & Fantasía, misterio & Thriller profesional \\
\hline- & - & \\
\hline
\end{tabular}

TABla 62. Contenidos de ficción seriada en Nova, Divinity y Energy, año 2015.

FUENTE: Elaboración propia.

Aunque, según la tabla, pueda parecer que no encontramos, para ficción seriada, una categoría que compartan enteramente los canales femeninos y masculinos, es cierto que thriller policiaco de Nova, drama profesional de Divinity y thriller profesional de Energy son similares.

Drama profesional de Divinity reúne, en sí misma, distintas subcategorías, la más importante sería la de thriller. Esta cuenta con 13 series repetidas en 246 ocasiones. Luego, en Energy, thriller profesional es la categoría más relevante de la ficción tanto por espacios como por números de repeticiones (con 10 series repetidas 91 veces). Mientras, thriller policiaco es la segunda más importante en Nova (con 6 series emitidas 71 veces). Castle (76 repeticiones) de Divinity, Hawái 5.0 (42 repeticiones) de Energy y Bones (23 repeticiones) de Nova, han sido las más televisadas. Las tres las encontramos emitidas a lo largo de todos los meses de nuestra muestra por las noches.

Este bloque de contenidos se caracteriza por presentarnos, en su mayoría, tramas que implican la resolución de algún crimen. Para ello se van destapando distintas pistas que permitirán llegar hasta los y las culpables. Son escenarios policiacos, donde también vemos conocimientos de medicina o incluso poderes sobrenaturales.

Por su lado, los canales femeninos comparten los contenidos de drama, drama romántico y fantasía. En este punto nos encontramos la categoría más importante de Nova: drama romántico, compuesto por telenovelas. Se trata de 26 telenovelas 
-repetidas 228 veces en horario de entresemana-, donde la trama central es una historia de amor imposible: los enfrentamientos familiares, la pertenencia a distinta clase social o los asuntos dolorosos del pasado son los conflictos más habituales. De las 26 telenovelas, 19 están protagonizadas por una mujer. También Divinity cuenta con este género, aunque su importancia es menor: 5 títulos y 26 repeticiones. De nuevo nos topamos con historias de amor imposibles y protagonistas femeninos en 4 de los 5 títulos.

Drama y fantasía también están presentes en la ficción seriada. En Divinity, fantasía se junta con el misterio para ofrecernos tres series con fantasmas y criaturas fantásticas - Entre fantasmas (13 repeticiones), Revenge (2 repeticiones) y Sobrenatural (10 repeticiones) —. Por su lado, Nova nos ofrece una única serie -Érase una vez (5 repeticiones)— dónde se mezclan los cuentos y la realidad. Finalmente, Divinity es el canal que más desarrolla el drama. Lo vemos con drama, drama femenino, drama profesional y drama romántico —estos dos últimos mencionados anteriormente-. Drama femenino lo componen tres series que se centra en la vida de un grupo de mujeres -Criadas y malvadas (1 repetición), Gossip girl (5 repeticiones), Mujeres desesperadas (26 repeticiones) - convirtiéndolas en protagonistas de distintas tramas que incluyen amor, amistad y vida profesional.

Mientras, Energy prescinde del drama o el romance para ofrecernos, a parte de thriller profesional, acción ( 2 series, 8 repeticiones) y ciencia ficción (4 series, 70 repeticiones). Ambas categorías desarrollan tramas que se centran en la lucha: bien entre dos bandos (como vemos en las series de Spartacus de acción), bien contra un enemigo (como sucede en las de ciencia ficción, donde sus protagonistas luchan contra dinosaurios, grandes insectos, alienígenas, vampiros...).

\begin{tabular}{|c|c|c|}
\hline Nova & LARGOMETRAJES & Energy \\
\hline- & Divinity & - \\
\hline- & Acción & Ciencia ficción \\
\hline- & - & - \\
\hline Comedia romántica & Comedia & Drama \\
\hline Drama & Dramedia romántica & - \\
\hline Drama romántico & Drama romántico & - \\
\hline- & Fantasía, aventuras & Thriller \\
\hline Thriller & Thriller & $\sim$ \\
\hline
\end{tabular}

TABla 63. Tipos de largometrajes en Nova, Divinity y Energy, año 2015.

FUENTE: Elaboración propia. 
En cuanto a los largometrajes, Nova, Divinity y Energy ofrecen películas del tipo thriller y dramático. A parte, Energy cuenta con 4 de ciencia ficción en su parrilla y Divinity con una de acción y 3 de fantasía y aventura. Las categorías de comedia, comedia romántica y drama romántico son para los canales femeninos. Es decir, existe una clara tendencia, que ya hemos visto en las series, a la hora de distribuir tramas: el canal masculino se queda con los contenidos de peleas, luchas, grandes amenazas, invasiones, guerras... y en los canales femeninos se explotan los entresijos románticos, familiares y las tramas con muchas menos dosis de violencia explícita. 
TERCERA PARTE. EXPOSICIÓN DE LOS RESULTADOS 


\section{DISCUSIÓN DE RESULTADOS}

Varón y mujer, igualmente personas, son presentadas como personas distintas.

Blanca Castilla y Cotázar

El último bloque de nuestra investigación está destinado a la exposición de los resultados. Se ha dividido en dos epígrafes: la discusión de los mismos —que ofrece una interpretación todavía concreta de la muestra - y las conclusiones generales — donde se rescatan las hipótesis iniciales y se realiza una valoración global de los resultados-.

A lo largo de todo el estudio empírico, hemos mantenido el análisis de ambos soportes - revistas y televisión-, separados, lo cual ha hecho más operativa la categorización y comprensión de la muestra. Sin embargo, el objetivo principal de esta tesis doctoral era el de, precisamente, establecer una posible relación entre los mensajes emitidos por la prensa y los generados desde el medio televisivo. Por tanto, llegadas a este punto concreto de la investigación, procedemos a enfrentar los resultados y a generar un diálogo entre ellos.

Para abordar el análisis de las revistas de estilo de vida femenino y masculino, se han generado diez categorías que conseguían englobar casi la totalidad del contenido de las seis revistas — una última categoría denominada otros ha recogido las temáticas sueltas - y, de esas categorías, cuatro estaban presentes en todas las publicaciones: belleza, tecnología, moda, ocio y cultura. Si bien es cierto que las revistas de estilo de vida femenino presentaban bastante uniformidad en cuanto a la cantidad de contenidos que insertaban de cada temática — belleza entre el 15\% y el 24\%, moda entre el $30 \%$ y el $40 \%$, ocio y cultura entre el $25 \%$ y el $30 \%$ y tecnología entre el $2 \%$ y el $3 \%$-, no ocurría lo mismo con las revistas de estilo de vida masculino, donde los porcentajes entre publicaciones han oscilado a gran escala. Así, por ejemplo, encontrábamos un $31 \%$ de contenidos de belleza en Men's Health, mientras que Esquire presentaba un 5\% y DT un 6\%. Lo mismo ocurría con la moda, el ocio y la cultura, explotadas en bastante mayor medida en las páginas de Esquire - $29 \%$ moda, $41 \%$ ocio y cultura - y DT - 33\% moda, 
$30 \%$ ocio y cultura - que en las páginas de Men's Health - $10 \%$ moda, 4\% ocio y cultura-

\begin{tabular}{|c|c|c|c|c|c|c|c|}
\hline & Categoría & Woman & Telva & Glamour & Men's Health & Esquire & $D T$ \\
\hline \multirow{4}{*}{$\begin{array}{l}\text { Temática } \\
\text { compartida en } \\
\text { las } 6 \text { revistas }\end{array}$} & Belleza & $24 \%$ & $20 \%$ & $15 \%$ & $31 \%$ & $5 \%$ & $6 \%$ \\
\hline & Moda & $37 \%$ & $30 \%$ & $40 \%$ & $10 \%$ & $29 \%$ & $33 \%$ \\
\hline & Ocio-cultura & $25 \%$ & $30 \%$ & $28 \%$ & $4 \%$ & $41 \%$ & $30 \%$ \\
\hline & Tecnología & $3 \%$ & $2 \%$ & $2 \%$ & $7 \%$ & $9 \%$ & $14 \%$ \\
\hline \multirow{7}{*}{$\begin{array}{l}\text { Temática } \\
\text { compartida en } \\
\text { las revistas de } \\
\text { estilo de vida } \\
\text { femenino }\end{array}$} & & & & & & & \\
\hline & Belleza & $24 \%$ & $20 \%$ & $15 \%$ & & & \\
\hline & Decoración & $3 \%$ & $4 \%$ & $2 \%$ & & & $2 \%$ \\
\hline & Gastronomía & $3 \%$ & $2 \%$ & $2 \%$ & & $7 \%$ & $12 \%$ \\
\hline & Moda & $37 \%$ & $30 \%$ & $40 \%$ & & & \\
\hline & Ocio y cultura & $25 \%$ & $30 \%$ & $28 \%$ & & & \\
\hline & Sociedad & $3 \%$ & $2 \%$ & $2 \%$ & & & \\
\hline & & & & & & & \\
\hline \multirow{4}{*}{$\begin{array}{l}\text { Temática } \\
\text { compartida en } \\
\text { las revistas de } \\
\text { estilo de vida } \\
\text { masculino }\end{array}$} & Belleza & & & & $31 \%$ & $5 \%$ & $6 \%$ \\
\hline & Moda & & & & $10 \%$ & $29 \%$ & $33 \%$ \\
\hline & Ocio-cultura & & & & $4 \%$ & $41 \%$ & $30 \%$ \\
\hline & Tecnología & & & & $7 \%$ & $9 \%$ & $14 \%$ \\
\hline \multirow{4}{*}{$\begin{array}{l}\text { Resto de } \\
\text { temáticas }\end{array}$} & Hogar & & $4 \%$ & & & & \\
\hline & Relaciones & & & $2 \%$ & $5 \%$ & & \\
\hline & Salud & & $2 \%$ & $1 \%$ & $40 \%$ & & \\
\hline & Otros & $3 \%$ & $4 \%$ & $4 \%$ & $3 \%$ & $7 \%$ & $3 \%$ \\
\hline
\end{tabular}

Tabla 64. Temática en las seis principales revistas de estilo de vida femenino y masculino de España (muestra año 2015).

FUENTE: Elaboración propia.

Esta mayor uniformidad en los contenidos de las revistas femeninas frente a los contenidos de las revistas masculinas nos da a entender que nos encontramos ante dos modelos en distinto grado de evolución. Por un lado, el modelo femenino, más establecido y acotado socialmente, sobre el que existe un mayor consenso de cómo debe ser; y el modelo masculino, en el que observamos una mayor discordancia. De las tres revistas de nuestra muestra, DT fue la que nació antes, en 1992, y su contenido se centraba en coches, motos, tecnología, moda y ocio. En el año 2003, DT realizó una serie de modificaciones que afectaron a la forma de la misma: cambió de nombre — había nacido siendo Down Town-, incluyó una nueva tipografía y estilo y adquirió una periodicidad mensual, lo que consiguió un despegue en las ventas (Gallego, 2013: 154-155). 
Había sido, precisamente, a finales de los ochenta cuando en nuestro país habían aterrizado las revistas de estilo de vida masculino. Aunque encontrábamos las cabeceras Hombres Dunia (1986-1991) y Hombres de Hoy (1986-1987), será la revista Man (19872012) la que sobreviva durante más tiempo. En sus inicios, la publicación aventuró que su contenido versaría sobre moda, música, cine, artes, libros, viajes, coches, motos, negocios y sociedad (Gallego, 2013: 179). Además de Man o DT, también la revista $G Q$ llegaría a España en el mismo periodo, en el año 1994. Sobre ella, su primera directora, María Malibrant, aseguraba "no haremos una revista para homosexuales. [...] Al hombre español hay que enseñarle, adoctrinarle en determinadas áreas como la moda" (citado en Varela, 2015: 22).

Fue, también, en los años 90 del siglo XX que se originó una fuerte crisis de la masculinidad tradicional lo que generó un gran debate, sobre todo en el mundo anglosajón, siendo, finalmente, la pluralidad de las masculinidades la corriente más aceptada (González, 2017: 21-22). Pues bien, la crisis de la masculinidad de la última década del siglo XX y las revistas de estilo de vida masculino fueron dos fenómenos simultáneos: el modelo tradicional se resquebrajaba y el discurso mediático empezó a abrirse a nuevos modelos masculinos, más interesados por la moda, la belleza y la oferta cultural en términos literarios, musicales, artísticos o fílmicos.

Esta apertura no acabó por enterrar los viejos mandatos de la masculinidad hegemónica y, en el caso de las revistas de estilo de vida masculino, se mezclaron los nuevos horizontes con las manidas imágenes de mujeres sexualizadas, apareciendo estas en las portadas o en los reportajes del interior de las publicaciones, como pudimos ver en el análisis de la revista $D T$. Las fotografías de mujeres sexualizadas se convirtieron, de este modo, en una manera de tranquilizar a la audiencia masculina, que seguía encontrando elementos de identificación tradicionales los cuales, además, salvaguardaban su posición dominante con respecto del sexo femenino y hacían incuestionable su heterosexualidad.

A partir del año 2000, se popularizó la figura del metrosexual, que elevaba la estética masculina y convertía a los hombres en "su propio objeto de deseo y placer" (Simpson, 2002, citado en Herrero y García, 2015: 253). La cabecera Men's Health llegó a nuestro país en 2001 y, de las tres revistas masculinas analizadas, se trata de la que más contenidos de belleza tiene. No solo desbanca a sus compañeras - $31 \%$ vemos en Men's Health, frente al 5\% de Esquire y el 6\% en DT-, sino que también sobrepasa a las 
revistas de estilo de vida femenino, que presentan porcentajes de entre el $15 \%$ y el $24 \%$. Si a lo largo de aquella primera década del siglo XXI el futbolista David Beckham se alzó como icono de la metrosexualidad y pudimos verlo protagonizando distintas campañas de ropa interior que no escondían un ápice de su musculatura (véase imagen 11), las portadas de Men's Health se transformaron en una pasarela donde deportistas, modelos, actores o personajes relevantes posaban del mismo modo.

Cabe destacar que, tal y como se desarrolló a lo largo del análisis de la muestra, los contenidos de belleza de Men's Health distan de los contenidos ofrecidos en las revistas femeninas. El 72\% de las ocasiones que encontramos una pieza dedicada al mundo de la belleza, se hace desde el culto al cuerpo, relacionando una mayor musculatura con la figura de "macho alfa" (Men's Health, núm. 162, 2015) o conectando un físico esculpido con el éxito sexual en términos de dominio: "tu poderío físico puede ponerla a mil. Hacer que se sienta delicada y frágil es una expresión de masculinidad" (Men's Health, núm. 162, 2015). El 28\% restante es cosmética, donde se anuncian fragancias, lociones y cuchillas para el afeitado, limpiadores faciales o cremas hidratantes, exactamente el mismo contenido que encontramos en los apartados de belleza de Esquire (5\%) y DT(6\%). Así, aunque las revistas de estilo de vida ampliaran la belleza, no ofrecen lo mismo a los hombres que a las mujeres. En el caso femenino, se vende- $\mathrm{a}$ parte de toda la cosmética (anunciada para paliar los signos de la madurez) - infinitas marcas de maquillaje, tintes para el pelo, manicuras, tratamientos corporales, tratamientos rejuvenecedores, cirugía estética, depilación, peinados...

Más allá del aspecto estético, Men's Health nos presenta a un hombre embrutecido, sin apenas inquietudes culturales - las piezas de ocio y cultura suponen el 4\%-, preocupado por modelar su físico, convertirse en líder — “ensombrece a tus rivales" (Men 's Health, núm. 162, 2015)—, gustarse a sí mismo y, cómo no, a las mujeres - un 5\% del contenido son reportajes enfocados a la seducción, contenido que, por otra parte, no encontramos en Esquire o DT- El autor Bonino nos decía que, aunque ahora el modelo de masculinidad hegemónica se muestre más flexible, especialmente con el tema de la imagen y la estética, los mandatos tradicionales pesan aún mucho y no se permiten fácilmente variaciones estructurales (Bonino, 2002: 12).

La última de las tres revistas en llegar al mercado fue Esquire, que lo hizo, en nuestro país, en el año 2007. Esquire apostó por los contenidos de ocio y culturales: literatura, arte, cine... llegando a suponer, según datos de nuestra muestra, el $41 \%$ del 
interior de la revista. Tampoco le tuvo miedo a la moda, presente en un $29 \%$ de las páginas. Además, explota la faceta del hombre de negocios, con su sección mensual Business Class y sus etiquetas fijas Ejecutivo del mes u Otros negocios. El hombre de Esquire recuerda a la descripción que Kimmel hizo del retrato bajo el cual empezaba a perfilarse la masculinidad hegemónica del siglo XXI: "se sienta en salas de espera de clase preferente, se aloja en elegantes hoteles de negocios por todo el mundo, viste traje de diseño, habla inglés, come menú continental, usa teléfono móvil, se conecta a su ordenador portátil y ve CNN Internacional” (Kimmel, 2001: 51-52).

En 2005, dos años antes del lanzamiento de Esquire, la autora Mariam Salzam perfiló la etiqueta del übersexual: se trataba de un hombre que cuidaba su imagen de una manera más sutil que el metrosexual y, como figura representativa, encontraríamos al actor George Clooney (Rey, 2006: 24). Así, este modelo huye de la ostentación y necesita poco más que "una loción no demasiado estridente después del afeitado y un bonito traje" (Rey, 2006: 24). Esquire recogió esta imagen, la del hombre de negocios, trajeado, elegante, interesado por la oferta cultural, con gustos refinados en cuanto a la comida y a la bebida se refiere. Sobre esto último, Esquire incorpora la sección mensual Gastro, unas páginas donde se nos anuncian distintos productos alimenticios y bebidas gourmet. Ya destacamos, a lo largo del análisis empírico, que las revistas masculinas no se han abierto al mundo de la alimentación desde el prisma del hogar o abastecimiento familiar, como bien podría hacer Telva con su recetario, sino que la comida se nos presenta en su versión más placentera y hedonista.

Las revistas de estilo de vida masculino, en unos pocos años, han recogido distintas formas de cómo ser hombre. El porcentaje que por separado dedican a cada contenido es menos uniforme que el presente en las revistas femeninas, lo que deja ver que se maneja un espectro más amplio de la masculinidad, aunque igualmente útil en términos de dominación. Es decir, ninguna de estas publicaciones supone una ruptura real con el modelo de privilegios establecido, si acaso, una capitalización de la moda y la cosmética. Mientras, las tres revistas de estilo de vida femenino son productos casi calcados, discordantes en la categoría de hogar y relaciones, pero con porcentajes realmente similares en el resto de temáticas.

De las tres revistas femeninas, Telva es la más longeva. Nació en el año 1963, en plena dictadura franquista, cuando el modelo del ángel del hogar estaba fuertemente asentado. La narrativa de Telva alimentaba, por un lado, los aspectos tradicionales - 
como el hogar, el matrimonio y la crianza-y, por el otro, introdujo el perfil de mujer trabajadora (Ganzabal, 2006b: s.p.). Se podría determinar que, a rasgos generales y a pesar de esto último, desarrolló una línea conservadora (Gallego, 2013: 120). A día de hoy, al contrario de lo que ocurre en Woman o Glamour, Telva todavía conserva contenidos relacionados con el hogar, así vemos los recetarios mensuales compuestos por menús para toda la familia.

En el año 1992 nació Woman. Un año antes, en 1991, la autora Naomi Wolf había publicado su libro el Mito de la belleza, donde aseguraba que, superados viejos discursos, como el de la domesticidad, emergía un nuevo mecanismo de control femenino: se trataba del dominio por medio de las imposiciones estéticas (Wolf, 1991: 14-15). Además, en su obra señalaba que las revistas dirigidas a mujeres vendían dieta, cuidado de la piel y cirugía plástica "la versión más mortífera del mito de la belleza” (Wolf, 1991: 89). Dentro de nuestra muestra femenina, es Woman la que más contenidos de belleza ofrece, hasta en un 24\%, contando con la sección exclusiva Belleza. También Glamour edita el apartado Belleza Glamour y Telva incluye la mayoría de sus contenidos de belleza en la sección Lo último.

Puede que lo más reseñable de este fenómeno no sea que la belleza cuente con unidades redaccionales exclusivas dentro de las revistas, sino de qué manera esta impregna el resto de las páginas. Los reportajes o entrevistas a famosas incluyen descripciones físicas — cosa que no ocurre en el caso de los hombres-, se destacan atributos como la sonrisa o la mirada, los cuales aparecen entremezclados con datos profesionales, las fotografías son sensuales, se juzgan los estilismos o se asume que el físico es valor suficiente para abrirse camino en el mundo profesional, al mismo tiempo que se infravalora la inteligencia de mujeres con una belleza normativa. También, a las propias famosas les preguntan sobre su cuerpo, cómo se encuentran con él, sobre su dieta, etc. De esta manera, las distintas páginas alimentan la unión indisoluble entre mujeres y belleza.

La última de las publicaciones en aparecer fue Glamour, en el año 2002. Como dijimos, las tres revistas presentan bastante uniformidad en cuanto a los contenidos: perfilan un modo de ser mujer interesada por la moda, la belleza y el consumismo. Ofrecen oferta cultural, contenidos en decoración, pinceladas de temas relevantes a nivel social y de tecnología. Además de esto, la revista Glamour incluye contenido referido a las relaciones en pareja. Se trata de unidades redaccionales centradas en aconsejar a las 
lectoras dentro de un modelo de pareja heterosexual y joven: "es inevitable pensar en bodas cuando tus mejores amigas empiezan a pasar por el altar [...]. Antes de soltar la pregunta bomba, piensa si tus ganas de convertirte en `Señora de...'no son simplemente fruto de la envidia — ¿sana?_-“ (Glamour, núm. 152, 2015). "Si al hablar de niños tu chico no se muestra muy receptivo... no interpretes su actitud como un no rotundo y absoluto. Nada de cerrarte en banda. Escucha sus motivos e intenta entenderlo" (Glamour, núm. 152, 2015). Así, explora el mundo de las citas y las relaciones sentimentales en sus primeras fases. Es decir, no se sumerge en la crianza como pudo hacer la prensa con anterioridad, no integra el modelo de pareja homosexual o no contempla relaciones longevas (esto último puede deberse al público al que va dirigido).

Las revistas de estilo de vida femenino se han despojado de viejas temáticas desfasadas. El ángel del hogar ya no es un reflejo reconocible para las lectoras y los contenidos sobre hogar, maternidad y matrimonio han dado paso a la moda, la belleza o el ocio. Las páginas se han llenado de fotografías de mujeres sensuales y las relaciones sentimentales adquieren poco peso, siendo más importante el momento de la conquista o las primeras fases, que la relación en sí. Para las revistas masculinas tampoco es trascendental la paternidad, el hogar o el matrimonio. Sus páginas se han llenado, también, de imágenes de mujeres en poses provocativas, descripciones físicas de las mismas y alusiones sexuales.

Las revistas de estilo de vida femenino y masculino son un reflejo de la sociedad actual: la liberación sexual traducida en cuerpos de mujeres desnudas, un mayor respeto por el tratamiento a las figuras masculinas, intromisión en el ámbito privado de las protagonistas, mayor interés por la vida profesional en el caso de los hombres... Así, no es de extrañar que, según datos de nuestra muestra, las publicaciones femeninas hayan incluido a 140 hombres en sus reportajes, de los cuales, uno apareció en ropa interior. Las masculinas, mientras, hicieron lo propio con 45 mujeres, de las cuales, 21 aparecieron sexualizadas.

Las revistas de estilo de vida mantienen un discurso frívolo. Las publicaciones femeninas explotan el mito de la belleza, nueva cárcel para las mujeres (Wolf, 1991), desde una óptica liberadora — "reivindica tu derecho a ir maquillada hasta en la playa" (Glamour, núm. 152, 2015)—, e invisibilizan el trabajo en casa o los cuidados. Como dijimos, tampoco las publicaciones masculinas incluyen estas temáticas dentro de sus páginas, manteniéndola ajena a la identidad masculina. Se trata de un campo que ha 
desaparecido y con él, desaparece cualquier tipo de oportunidad de análisis, debate, denuncia o ampliación del espectro identitario. Ya no hay mitificación, como ocurría anteriormente, pero, al borrarse del discurso femenino, al no incluirse tampoco en la narrativa masculina, no deja margen al análisis, no permite reconocer quién ocupa qué posición en la sociedad. Simplemente, ese campo — con toda su problemática y discriminación asociada-ya no existe.

Así, mientras que unas elevan a rito diario y revisten de modernidad la última opresión de las mujeres, las otras recogen formas de ser masculinas que saltan de una a otra tendencia, que explotan al hombre bello o al hombre cultivado intelectualmente, que ofrecen una perspectiva más de las muchas que la cultura popular tiene reservada para los varones. El modelo masculino, como modelo dominante, no solo cuenta con una mayor flexibilidad en sus representaciones, sino que, a parte de verse reflejado en las revistas de estilo de vida, lo hace en la prensa generalista donde, como nos decía Naomi Wolf, un evento deportivo aparecerá en primera página, mientras que un cambio de legislación relativo a la infancia no ocupará una posición relevante (Wolf, 1991: 90). Puede que este sea uno de los motivos por el cual dichas publicaciones presenten tal desfase de ventas frente a las femeninas: porque una cultura patriarcal es una cultura androcéntrica, hecha por y para los hombres, y, por tanto, los intereses asociados con la masculinidad ya estaban recogidos mucho antes de que las revistas de estilo de vida aterrizaran en el mercado.

En cuanto a lo ocurrido en el medio televisivo, fue en 2005, con el relanzamiento de la televisión digital terrestre y el reparto de un multiplex para las cadenas privadas y dos para las públicas (Izquierdo-Castillo, 2016: 739-740), que aparecieron los canales orientados a un público femenino. El primero fue Nova (Atresmedia, 2005-), el cual forma parte de nuestra muestra, y, posteriormente, le sucedieron Hogar 10 (La Sexta, 20072009) La Sexta 2 (Atresmedia, 2010-2012), Divinity (Mediaset, 2011-), Nueve (Mediaset, 2012-2014) y Dkiss (Radio Blanca, 2016-). Actualmente, existen 3 canales dirigidos a un público femenino.

Tal y como sucedió con la prensa, se perfiló primero el producto femenino, fruto del androcentrismo que impregna a la narrativa mediática. Vemos, por ejemplo, que una de las apuestas fuertes de los canales generalistas que nacieron en la primera década del 2000, estos son Cuatro (2005-) y La Sexta (2005-), había sido la deportiva, con la retransmisión en Cuatro del Mundial de fútbol masculino del año 2006 (González, 2006: 
591) pero, sobre todo, con las grandes dosis de deporte que, desde sus inicios, incluyó La Sexta dentro de su programación - principalmente fútbol masculino, baloncesto masculino y Formula 1 masculina (García, 2009: 532)—. Si la narrativa generalista dejaba descuidadas temáticas asociadas con la feminidad, entonces la creación de canales dirigidos específicamente a las mujeres significaba un nicho de mercado por explotar.

Cinco años más tarde de que comenzara a emitirse el primer producto específicamente femenino y por, en palabras de Bernd Reichart, director de canales del grupo Antena 3 Televisión, el supuesto "desnivel que existe a favor de las mujeres"103 en el medio televisivo, nació Nitro (Atresmedia, 2010-2014). Posteriormente, aparecieron Energy (Mediaset, 2012-), DMax (Veo Televisión, 2012-), Xplora (Atresmedia, 20122014), Mega (Atresmedia, 2015-) y Be Mad (Mediaset, 2016-). Por tanto, al igual que en el caso femenino, se han sucedido un total de 6 canales, sin embargo, a día de hoy perviven 4 (uno más que para las mujeres).

Nuestra muestra la componen los canales que estaban en antena durante el año 2015, estos son Nova, Divinity, Discovery Max y Energy. Los cuatro siguen emitiéndose, aunque Discovery Max transformó su nombre en DMax el 12 de septiembre de 2016 al igual que parte de su contenido, pues pasó a incluir series y largometrajes - hasta ese momento era una cadena especializada en telerrealidad-.

A la hora de categorizar la muestra, hemos encontrado una mayor discordancia entre el contenido que nos ofrecían los canales femeninos y los canales masculinos, que el que existía entre las propias revistas de estilo de vida. Como dijimos, para la prensa establecimos diez categorías que englobaban las distintas temáticas, cuatro de las cuales estaban presentes en las seis publicaciones. Para la televisión, y centrándonos solo en los contenidos de no ficción - pues Discovery Max no ofrecía, por aquel entonces, otro tipo de programación - se lanzaron doce categorías y ninguna de ellas aglutinó a los cuatro canales a la vez. Es decir, la televisión ha creado dos esferas totalmente enfrentadas, en las que los intereses que se entienden masculinos apenas sí se rozan, en contadas ocasiones, con los intereses femeninos.

A excepción de Men's Health, veíamos que el ocio y la cultura era una categoría para la que las revistas de estilo de vida habían dedicado un porcentaje nada desdeñable.

\footnotetext{
${ }^{103}$ Véase información publicada el 16 de julio de 2010 en La Vanguardia: "Las teles insisten en la audiencia femenina". Recuperado el 1 de noviembre de 2019 de https://www.lavanguardia.com
} 
Aunque, en el caso de la televisión, esta categoría ocupe un espacio considerable, así es en los canales femeninos, debemos tener en cuenta que se trata de un contenido emitido generalmente en las madrugadas, cuando las audiencias son mínimas. Estaríamos ante espacios musicales o de cine, principalmente novedades de cartelera, en el caso de los canales dirigidos a mujeres, y ante espacios deportivos, en el caso de Energy.

Junto al ocio y la cultura, la moda y la belleza eran dos temáticas en las que la prensa había volcado una parte importante de sus esfuerzos. La belleza y la moda son categorías presentes en los canales femeninos, pero con distinto peso. Nova apenas explota el contenido (3\%), mientras que para Divinity adquiere una mayor relevancia (13\%). En Nova, habíamos encontrado dos espacios dedicados a la moda y a la belleza, De compras en Nova y $B$ a la moda, y ambos ofrecían consejos estilísticos a su audiencia. Por su lado, Divinity, a parte de emitir este tipo de contenidos, incluía, también, los makeover shows, es decir, los programas de transformaciones físicas. Estos espacios guardan una estrecha relación con el discurso presente en las revistas de estilo de vida femenina: lejos de cuestionar el carácter opresor de la belleza, se vende, la misma, como un arma liberadora. El mensaje último que nos lanzan es el de que la vida de la protagonista mejorará enormemente tras un cambio de imagen. A veces, ese cambio se consigue a través de la peluquería, maquillaje e interviniendo en el estilismo, sin embargo, en otras ocasiones, como es en el programa Extreme makeover: cambio radical se apuesta por someter a las mismas a una cirugía.

En Energy y Discovery Max, hay, también, algunos espacios de índole estética. Se trata de la programación que gira en torno al mundo de los tatuajes. Esta intervención corporal es, en muchas ocasiones, elevada al grado de arte, como ocurre en el programa Best Ink, espacio de competición entre profesionales, donde nos muestran sus mejores trabajos con el fin de alzarse con el premio y ser portada de la revista Tatto. El resto de programación gira en torno al día a día de los estudios de tatuajes. Energy nos ofrece, además, El Método Osmin: made in USA espacio en el que se instrumentaliza el ejercicio físico, que sirve como vía para lograr unos objetivos estéticos. Así, nos encontramos ante otro makeover show. Es importante destacar las diferencias entre los programas de transformaciones femeninos y este masculino. Mientras que en el primer caso se hace uso de la peluquería, el maquillaje y vestuario, en el segundo, cumpliendo con los mandatos de la masculinidad hegemónica, se explotan terrenos que tienen que ver con la fuerza. No sissy stuff o the sturdy oak — nada de cosas femeninas y duro como un roble- son 
algunos de los principios que enarbola el entrenador Osmin, personaje, por otro lado, tremendamente autoritario e irrespetuoso.

Cuando analizábamos las revistas de estilo de vida femenino, señalábamos que el modelo ángel del hogar, anteriormente mitificado por la prensa, había desaparecido, quedando de él algunos coletazos en la revista Telva, con su recetario, o las contadas unidades redaccionales en las que Glamour abordaba el campo de las relaciones amorosas. Pues bien, existe una última categoría que también encontramos en las revistas femeninas y que nos introduce hasta el corazón mismo de los hogares: la de la decoración. Lo cierto es que no se trata de contenido especialmente abundante, un 3\% en Woman, un 4\% en Telva - esta cuenta con sección específica en tres de los cuatro ejemplares analizados-y un 2\% en Glamour, pero sí nos permite entrar hasta en nueve casas o empaparnos de las últimas tendencias. Mientras, en el caso de las masculinas, a lo largo de la muestra $D T$ promociona cuatro objetos de diseño y Esquire hace lo propio con uno. Puede que la principal diferencia radique, no solo en que haya menos contenido relacionado con la decoración en las revistas masculinas, sino en la naturaleza del mismo.

Como hemos dicho, las revistas femeninas exponen el espacio privado fotografiando distintos hogares. Pues bien, en el caso de la televisión, los canales femeninos han explotado los formatos sobre casas y reformas hasta el punto de convertirse en la categoría de más peso para Divinity (27\%) y la tercera más importante en el caso de Nova (18\%) — cabe destacar que la segunda categoría por orden de relevancia para Nova es ocio y cultura, pero como vimos, ocupa franjas horarias nocturnas de mínima audiencia, lo que suma importancia al contenido relacionado con la decoración, que es emitido los fines de semana en horario diurno-. Pues bien, la dinámica de los distintos espacios televisivos es la de realizar intervenciones a una casa para que se amolde más a los gustos de quienes viven en ella y, en algunos de los casos, por si esto no se consiguiera, a la par que se realizan los cambios o reformas, se busca una nuevo inmueble que pueda ser comprado. Así, este tipo de contenido, tan numeroso y relevante en los canales orientados a un público femenino, es inexistente en el caso de los masculinos.

Explicábamos anteriormente que la revista Telva, la más longeva de todas ellas, incluía recetarios en cada uno de sus números, lo que suponía un 4\% del contenido de la misma. A la hora de enfrentarnos a la muestra televisiva, nos hemos topado con que Nova incluye, también, temática relacionada con la cocina, esta vez en un $28 \%$, siendo su 
categoría más relevante dentro de los contenidos de no ficción. Principalmente, encontramos dos programas tipo recetario que se emiten diariamente, es decir, espacios en los que el cocinero - la figura sabia ha sido asumida por un hombre-, enseña cómo elaborar una receta paso a paso. A parte, vemos competiciones de cocina y programas que muestran el día a día de negocios de restauración. También Divinity incluye este tipo de contenidos, aunque en su caso solo supone el 3\% de los espacios de no ficción.

Al igual que sucedió en las revistas de estilo de vida, que los formatos masculinos abordaron la alimentación desde una óptica hedonista ofreciendo al lector una serie de alimentos gourmet, tampoco el medio televisivo ha incluido para su audiencia masculina una visión de la alimentación desde la perspectiva familiar o del hogar. En los casos en los que vemos comida en Energy, se trata, o bien de mostrar negocios de restauración, o bien de retransmitir competiciones — comprobar quién es capaz de ingerir más alimentos en menos tiempo o quien consigue realizar el mejor plato ante un jurado-

Otra de las temáticas que, hemos señalado, las revistas de estilo de vida femenino habían ido dejando atrás era la de las relaciones sentimentales. En el análisis que Juana Gallego lanzó en 1990 sobre la prensa femenina nos decía que el amor —entendido como amor romántico heterosexual- era uno de los ejes fundamentales sobre el que se cimentaba el discurso de las publicaciones dirigidas a mujeres. Además, realizaba la siguiente secuencia lógica: "si obtenemos la belleza, conseguiremos el amor, que nos dará la felicidad, todo lo cual se materializará en el hogar" (Gallego, 1990: 52). Pues bien, el medio televisivo explota esta temática en Divinity, suponiendo el $11 \%$ dentro de los contenidos de no ficción y lo hace, principalmente, por medio de los programas de citas y de asesoramiento. De nuevo, los contenidos giran en torno a las primeras fases de la relación, como en el dating show Mujeres y hombres y viceversa o en Una boda perfecta, donde se ayuda a las protagonistas a preparar el día de su enlace. Además, entre la programación, encontramos el espacio Bebé a bordo, centrado en la crianza.

Energy también incluye contenido de relaciones sentimentales $(3 \%)$, con el programa de citas Adán y Eva, donde el filón reside en que los y las concursantes aparecen, a lo largo de todo el programa, sin ropa. Cabe destacar que, aunque relacionado con la temática de aventura y supervivencia, Discovery Max cuenta, del mismo modo, con dos espacios en los que una pareja aparece desnuda: Aventura en pelotas y Aventura en pelotas XL. Por su lado, a parte del programa de Adán y Eva, Energy ofrece Amores reñidos en el que un profesional enseña a distintas mujeres cómo resultar atractivas para 
los hombres. El mismo formato está en Divinity bajo el nombre de Seduciendo con Tionna.

Como venimos señalando, Divinity es el canal que en mayor medida explota entre sus contenidos de no ficción las relaciones sentimentales. Ahora bien, Divinity, Nova y Energy ofrecen, a la par que los contenidos de no ficción, contenidos de ficción. A la hora de enfrentar los tres canales encontramos que drama romántico y comedia romántica son dos temáticas recurrentes en las cadenas dirigidas a mujeres. No sucede así en Energy, donde vemos acción, ciencia ficción, thriller y drama. En el caso concreto de Nova, el drama romántico seriado está compuesto por telenovelas, cuyo argumento gira en torno a una historia de amor imposible. Debemos señalar que este contenido supone el $36 \%$ del total de la programación de la cadena y el $67 \%$ de la ficción.

Comprobamos como los canales de televisión dirigidos a mujeres recogen una porción de la feminidad que las revistas de estilo de vida femenino habían enterrado. Si bien entendíamos que la prensa, al invisibilizar ciertas temáticas por considerarlas desfasadas, había perdido la oportunidad de mostrarse crítica y fomentar un discurso que incluyera a los hombres dentro de la esfera de los cuidados o del espacio privado, tampoco la televisión asume una posición que rompa con el esquema social. En este caso concreto, las fronteras que ha creado el medio televisivo encierran a las mujeres en temáticas tradicionales, vendiendo, además, discursos narrativos que no dan pie a la movilidad de los sexos, al aperturismo identitario de mujeres y hombres.

En el análisis de las revistas dirigidas a los hombres, encontrábamos distintos modelos masculinos. El modelo embrutecido, preocupado por la estética en términos narcisistas y de dominio: dominio sobre el resto de los hombres, gracias a su fuerza física, y dominio sobre las mujeres, a las que poseerá sexualmente. Dicho modelo mezclaba los aspectos de la masculinidad hegemónica arquetípica con una de sus ramificaciones: la de la figura del metrosexual. Encontrábamos, además, al hombre cultivado intelectualmente, el cual mostraba otro tipo de evolución que partía, también, del mismo arquetipo: este hombre no aparece en la esfera privada ni se le vincula con la reproductiva, su identidad más reseñable es la de los negocios, disfruta de placeres tales como viajar, ir a museos, leer $\mathrm{y}$, por qué no, poseer a mujeres (recordemos que las imágenes de mujeres sexualizadas estaban presentes en todas las revistas).

En cuanto a los canales orientados a un público masculino, encontramos que ofrecen, entre otros, contenidos de ciencia, tecnología, ingeniería o motor. También las 
revistas masculinas vendían temáticas similares, con porcentajes que iban desde el $7 \%$ en Men's Health, al 9\% en Esquire y al 14\% en DT. Así, dentro de la temática, el contenido más explotado era el de motor que se relacionaba con la furia, el dominio o la competición: "Lígate la ciudad" (Men’s Health, núm. 157, 2015), "Liberar a la bestia" (DT, núm. 219, 2015), "La conquista de la ciudad” (DT, núm. 219, 2015) o "Cabalgar el hierro" (DT, núm. 224, 2015), son algunos de los titulares que nos ofrecía la prensa. En televisión encontramos, del mismo modo, motor: un 8\% en Discovery Max y un 6\% en Energy, aunque adquieren mayor relevancia las categorías relacionadas con la ciencia, la tecnología o la ingeniería. Dichos espacios explotan el mundo de la construcción, con especial interés por las grandes obras que requieren de un mayor despliegue de fuerza, maquinaria o medios: Acuarios XXL, Antiguas superestructuras, Megatraslados, Superpiscinas, Superyates, Titanes mecánicos, Mudanzas imposibles — donde se traslada un inmueble completo de un punto geográfico a otro-, Ciudades bajo tierra...

La temática más importante para Discovery Max y la segunda más significativa para Energy es la relacionada con la supervivencia y la naturaleza. Discovery Max ofrece un $25 \%$ de contenidos y sus títulos hacen referencia a monstruos, fieras, supervivencia, aventura... El programa más relevante, por ser el que más veces se ha retransmitido, es El último superviviente, donde Bear Grylls, ex militar, se enfrenta, en solitario y con unos pocos enseres básicos y todo lo que pueda ofrecerle la naturaleza, a situaciones límite. Lo vemos en desiertos, selvas, islas, glaciares... También Energy incluye contenido en el que un protagonista debe superar las inclemencias del terreno, como es Desafio extremo, u ofrece temática relacionada con animales, principalmente salvajes: Frank de la jungla, Billy el exterminador y Veterinario al rescate son algunos de los ejemplos. Decíamos, además, que la temática más importante en Energy es la de violencia y misterio (16\%) y que también es una categoría, la de delincuencia y crímenes, presente en Discovery Max $(8 \%)$.

Cuando hablábamos de la masculinidad hegemónica, rescatábamos el análisis de Elisabeth Badinter (1993) quien, sirviéndose de tres figuras del cine estadounidense como son el pistolero, Rambo y Terminator, conseguía ejemplificar el sistema de valores que articulan al modelo: del pistolero señalaba que era un héroe nómada cuyo único placer que se permitía experimentar era durante el combate, momento en el que demostraba su habilidad para matar, y quien además sufriría, llegado el caso, una muerte heroica. Mientras, de Rambo y Terminator señalaba la falta total de emociones y la fuerza 
sobrehumana, que servía, esta última, para el ejercicio de la violencia. Kennedt Dutton (1995), por su lado, traía otra representación, la del hombre Marlboro: un hombre rudo, robusto, parco en palabras y gestos y en contacto con la naturaleza.

Lo cierto es que las temáticas más explotadas por los canales de televisión orientados a un público masculino encajan en las anteriores descripciones: la violencia asociada a los crímenes, el uso de la fuerza, el hombre en contacto con la naturaleza, el hombre-máquina, o Terminator, capaz de desafiar cualquier obstáculo y construir las mayores superestructuras y el héroe solitario que hace frente a los peligros (como podrían ser los generados por el terreno o los provenientes de animales salvajes).

Además de las anteriores características, también la competición es un rasgo propio de la masculinidad hegemónica: el combate entre iguales sirve como reconocimiento de la misma (Sámbade, 2018: 299). En los canales masculinos, el mundo de las subastas adquiere un peso realmente importante, siendo la segunda categoría de mayor importancia en Discovery Max (20\%) y la tercera en Energy (15\%). Dentro de las subastas, vemos ese combate, ese duelo entre iguales que nos llevaría, de nuevo, hasta el pistolero descrito anteriormente. Además, la rivalidad también la encontramos en los contenidos que Discovery Max nos ofrece sobre Historia. El canal escoge, precisamente, varios documentales acerca de las dos guerras mundiales, otro titulado Leyendas del salvaje oeste y, también, los Black ops de la antigüedad que, junto a Caballeros medievales, nos muestran distintos ejércitos de épocas pasadas, apostando otra vez por la competición y la violencia. Finalmente, recordar que, a parte de los contenidos de no ficción, Energy presenta largometrajes y ficciones seriadas las cuales, debemos señalar, van en consonancia con el resto de las temáticas ya analizadas: encontramos acción, ciencia ficción, thriller y drama.

Si la tendencia actual de las revistas de estilo de vida masculino es la de explotar un modelo más cosmopolita — no solo lo vemos en Esquire, también en los títulos que nacieron después y recuerdan, tanto en diseño como en contenidos a esta última-, parece que los canales de televisión han optado por representar la masculinidad hegemónica sin artificios, más cercana a la que encontrábamos en Men's Health. Se trata, pues, de una masculinidad desnuda, básica, que no esconde ni su violencia ni sus ansias de dominio. De esta forma, la televisión se coloca sobre el arquetipo, en el punto mismo de salida. De igual modo, también los canales orientados a un público femenino se han situado por 
detrás de las revistas, recogiendo los aspectos de la feminidad que aquellas habían desechado. 


\section{CONCLUSIONES}

La civilización democrática se salvará únicamente si hace del lenguaje de la imagen una provocación a la reflexión critica, y no una invitación a la hipnosis.

Umberto Eco

Tal y como aventuramos, el objetivo principal de nuestra tesis doctoral era el de establecer una relación entre los mensajes de la prensa escrita segregada por género y los canales de televisión temáticos orientados a un público, por un lado femenino $\mathrm{y}$, por el otro masculino. Además, nos interesaba trabajar esta línea de investigación por el carácter novedoso de la misma, pues todavía no se habían dedicado esfuerzos desde el ámbito académico a enfrentar ambos soportes y a asentar un posible diálogo entre ellos. Una vez alcanzado dicho propósito, el cual ha requerido de su propia vía de análisis tanto teórica como empírica, es el momento de rescatar las hipótesis con las que abrimos este trabajo de investigación.

Nuestra hipótesis principal afirmaba que los nuevos soportes de comunicación que segmentaban sus audiencias en función del género — ciertos canales de televisión temáticos-, buscaban la identificación con su público mediante la elaboración de un discurso sexista y estereotipado como ya lo hizo, anteriormente, la prensa. Cuando empezamos a perfilar este estudio, éramos conscientes de que la academia había abordado los discursos de la prensa femenina y, aunque en menor medida, también encontrábamos algunos estudios referidos a la masculina. A lo largo del marco teórico, se han ido recopilando estos trabajos y exponiendo las principales aportaciones de los mismos. Era importante que trazáramos dicha red, pues sobre esa base, se sostenía parte de nuestra hipótesis principal: que la prensa segregada en función del género proyectaba una realidad estereotipada.

Además, no solo debíamos acudir a los análisis de prensa. Si entendíamos que los medios de comunicación dibujaban y ofrecían una panorámica sexista, teníamos, también, que acudir a la realidad misma y encontrar las construcciones culturales que conformaban los mandatos del género. De esta forma, en el marco teórico, se explotaron 
paralelamente dos vías: una centrada en conocer dicho sistema y sus dos representaciones — la de la feminidad y la de la masculinidad — y otra enfocada en la narrativa mediática, lo que nos permitía entender de qué forma la segunda recogía a la primera. Así, ya desde la teoría conocimos que, efectivamente, la prensa segregada en función del género mostraba un estilo de vida enfrentado para hombres y para mujeres, sostenido sobre las directrices de la masculinidad y la feminidad.

Aun con todo, nuestra hipótesis se situaba en el momento actual y, para su resolución, requería de un diálogo entre el medio escrito y el televisivo, por ello, a parte de exponer los trabajos que previamente se habían realizado sobre prensa, debíamos reunir nuestra propia muestra y comprobar, por un lado, si a día de hoy la tendencia en las revistas de estilo de vida había cambiado con respecto de los trabajos realizados con anterioridad y, por el otro, detectar si el mensaje escrito se asemejaba al televisivo. Esto nos llevó a recopilar las publicaciones con más difusión del año 2015, una por trimestre, lo que nos permitiría comprobar la línea discursiva y narrativa de las mismas.

Leíamos como, desde la academia, acusaban que la prensa femenina había pasado por distintas fases, recogiendo los discursos de la feminidad que funcionaron como instrumento de control en cada época, siendo pocas las ocasiones en las que había servido para la promoción y la liberación de las mujeres. Debido al devenir histórico, las revistas de estilo de vida actuales se habían convertido en un catálogo de moda, ocio y belleza donde la felicidad pasaba por la consecución de un físico normativo y la obtención de bienes materiales. Cuando analizamos nuestra muestra, comprendimos que, efectivamente, el discurso actual de las revistas de estilo de vida femenino se enmarcaba dentro de la era postfeminista.

Como dijimos, vivimos un momento histórico en el que la inmediatez y el individualismo rompen con la noción de colectividad, convirtiendo en valores subjetivos cualquier realidad material. De esta forma, las revistas de estilo de vida analizadas no incluyen temáticas que afecten a las mujeres desde una perspectiva estructural $\mathrm{y}$, en los pocos casos en los que se ha lanzado alguna idea sobre la discriminación del sexo femenino, se ha hecho desde la visión postmoderna que sostiene que el cambio personal es posible siempre y cuando se tenga ganas, pues no existen condicionantes externos que frenen ni obstaculicen el desarrollo de nadie "a día de hoy una mujer puede desplegar su maternidad, su sexualidad, sus sanas aspiraciones profesionales, aficiones, talento, etc. 
[...] En mi opinión, se puede llegar a ser una Mujer, con mayúsculas por méritos propios, sin tener que arrebatarle nada al varón” (Glamour, núm. 155, 2015).

Las revistas de estilo de vida femenino venden, como fórmula infalible del éxito, el atractivo sexual, la belleza. Dictaminan que no hay problema que no pueda resolverse con una buena mascara de pestañas y un pintalabios rojo, subiéndose a unos tacones y llevando el último bolso que marquen las tendencias. Las revistas han evolucionado en su modelo de mujer, sí, pero siguen siendo igual de carcelarias. Ahora, como aseguraba Naomi Wolf (1991) nos venden el mito de la belleza: la felicidad a través de la eterna juventud, de la delgadez y de la normatividad física. Ninguna de las mujeres que protagonizaban la portada de nuestra muestra tenía canas, arrugas o vestía una talla grande. No sucedía lo mismo en el caso de las revistas de estilo de vida masculino, donde los hombres podían alterar los cánones normativos de belleza. En la prensa, si una mujer no cumple con ciertos requisitos, simplemente, desaparece.

Aunque similares en la forma, veíamos que una de las diferencias entre las revistas de estilo de vida masculino y las de estilo de vida femenino radicaba en la apertura del espectro identitario: se contemplaban y aprobaban más formas de ser hombre que de ser mujer. Las protagonistas que aparecen en las revistas de estilo de vida femenino son espejos las unas de las otras: mismos físicos, mismas edades, mismos gustos, mismas preocupaciones. Para los hombres, en cambio, no existe esa uniformidad tan evidente. Eso sí, ninguno de los modelos propuestos rompe con los mandatos de la masculinidad hegemónica, idea que, por otro lado, nos permite comenzar a resolver las hipótesis secundarias.

A parte de la hipótesis principal, se habían establecido una serie de hipótesis secundarias que hacían más sencillo y operativo el proceso de análisis. La primera de ellas, resuelta durante la exposición teórica, aseguraba que la masculinidad y la feminidad eran construcciones culturales que formaban el género, herramienta de la que se servía el patriarcado para sustentar la jerarquización de los sexos. Ya vimos, a lo largo de los capítulos segundo y tercero, de qué forma la cultura, a través del proceso de socialización, modelaba los comportamientos de mujeres y hombres, construyendo, a partir de ellos, los esquemas de la feminidad y la masculinidad. Vimos, también, que no se trataban de ordenes simbólicos paralelos, ya que como ambos servían para el control de las mujeres, la masculinidad siempre se situaba por encima de la feminidad. 
Teniendo esto en cuenta, en una segunda hipótesis, asegurábamos que era irrelevante cuánto evolucionara la feminidad o la masculinidad, que al ser ambos modelos parte indisoluble del sistema opresivo del género, seguirían cumpliendo con el fin último de subordinar a las mujeres. Así ha sucedido en el caso de la prensa femenina, que aunque a lo largo de sus más de dos siglos de trayectoria haya variado el modelo de mujer propuesto, este ha resultado ser igualmente útil para los intereses de dominación patriarcales. Del mismo modo, sucede con el modelo masculino y con sus posibles variaciones y evoluciones.

Decíamos, anteriormente, que las revistas de estilo de vida contemplaban y aprobaban más formas de ser hombre. Asegurábamos, también, que no se trataba de ningún modelo rupturista. Así, aunque más flexibles con el modo de ser masculino, estas publicaciones no cuestionan el sistema de privilegios, no incluyen facetas como las de la paternidad o los cuidados y siguen objetualizando a las mujeres. El modelo se ha abierto a cuestiones de índole estética, al hombre bello, y lo ha hecho como una forma más de autoadmiración. Los distintos reportajes inciden en la dimensión profesional y culta, aspectos, por otro lado, tradicionalmente asociados con la masculinidad. Además, los gustos de los nuevos hombres, se han elevado y enaltecido. A su vez, la prensa propone otros modelos más violentos, igualmente asentados en el discurso mediático, donde el dominio sobre las mujeres se ejerce desde la superioridad física más que moral o intelectual.

La tercera hipótesis establecía que los medios de comunicación de masas recogían los discursos de la feminidad y la masculinidad, alentando la continuidad del orden social existente. Así, en el marco teórico, en los capítulos dos y tres, mostrábamos las distintas representaciones que sobre hombres y mujeres lanzaban la publicidad, la televisión o la prensa y de qué forma estas representaciones se sustentaban sobre los estereotipos de género. Más adelante, en la cuarta hipótesis, puntualizábamos que, concretamente, y para conseguir la identificación y aprobación de la audiencia, los medios de comunicación orientados a uno u otro sexo explotaban, de una manera explícita, los valores de la feminidad y la masculinidad.

Una de las primeras cosas que nos llamó la atención mientras examinábamos la muestra fue la forma en que los contenidos ofertados por el medio televisivo eran más dispares entre sí que los ofrecidos por la prensa, es decir, mientras que las etiquetas que servían para categorizar los contenidos de las revistas femeninas seguían siendo, en 
general, operativas para las revistas masculinas, no ocurría lo mismo con los canales televisivos, que presentaban menos uniformidad, hasta el punto de apenas encontrar contenido similar entre los canales dirigidos a las mujeres y los dirigidos a los hombres.

Aunque las revistas de estilo de vida exploten, como hemos visto, los discursos de la masculinidad y la feminidad, es cierto que, en esencia, se tratan ambos de catálogos al servicio de las grandes empresas de moda, belleza o tecnología. Son soportes publicitarios entre los que es más sencillo establecer una línea de análisis común. Por otro lado, la oferta cultural se ha estandarizado y se ofrecen, indistintamente a ambos sexos, viajes, exposiciones, libros, música...

Aun con todo, se aprecian diferencias en el interior de las revistas. La más reseñable es la transversalidad de la belleza, que, para las publicaciones femeninas, está presente tanto en las secciones dedicadas a ella como fuera de las mismas: la leemos en las descripciones de las protagonistas, la vemos en sus reportajes fotográficos y la encontramos, de nuevo, en la naturaleza de las preguntas. Además, aunque ampliamente recogida en Men's Health, sus compañeras Esquire o DT dedican a esta temática un 5\% y un $6 \%$ respectivamente, cuando en las femeninas el porcentaje se movía entre el $15 \%$ y el $24 \%$. También los desfases existentes en la temática relacionada con tecnología suponen una diferencia a tener en cuenta. Dicha categoría, si bien está presente en las seis revistas, en las femeninas supone entre el 2\% y el 3\% del contenido, cuando en las masculinas va desde el 7\% al 14\%. Por otro lado, los contenidos de decoración los vemos, principalmente, en las publicaciones femeninas, mientras que los de gastronomía son más importantes en el soporte masculino.

También, a la hora de dedicar una unidad redaccional a un hombre, es más probable que este la protagonice por motivos profesionales, es así en un $93 \%$ de los casos, que si es una mujer, de quien su profesión será relevante en el $82 \%$ de las ocasiones, y, además, existe una mayor tendencia a que a ellas se les pregunte por su vida privada y familiar. Por otro lado, la inclusión de fotografías eróticas de mujeres en la prensa masculina hace alusión al tipo de sexualidad esperada en los hombres que, aunque despojada toda ella de sentimientos y donde la identidad de la mujer es un factor secundario, ocupa un lugar relevante en la construcción de la identidad masculina.

De este modo, aunque aparentemente más similares, un análisis profundo nos permite comprender que las revistas de estilo de vida masculino y femenino perfilan dos realidades humanas. Pues bien, en el caso de la televisión, las diferencias de escenarios 
comenzaron a saltar desde el momento mismo de la creación de las categorías, cuando veíamos que las que funcionaban para el soporte femenino no lo hacían en el masculino y viceversa. La televisión ha enfrentado, de una manera más explícita que la prensa, dos mundos, dos tipos de gustos, de preocupaciones, de intereses y de inquietudes. Expusimos, en el anterior epígrafe, que los canales dirigidos a los hombres explotaban la masculinidad hegemónica arquetípica y que aquellos dirigidos a mujeres se situaban en los discursos cercanos al hogar, las relaciones amorosas y la belleza. Así, los contenidos que se nos ofrecían desde los soportes masculinos hacía alusión a la fuerza, la violencia, la batalla o el dominio, siendo este tipo de temáticas inexistentes o poco frecuente en los canales femeninos - si acaso en los programas de competición- y, de igual forma, ocurría con los contenidos femeninos, que no encontraban su hueco dentro de los soportes dirigidos a hombres.

Así, y retomando la cuarta hipótesis, entendemos que tanto la prensa como lo televisión orientada a uno u otro sexo explotan los valores de la masculinidad y de la feminidad, aunque, ya se dijo, han tomado como referencia modelos en distinto grado de evolución. Puede que esto último se deba a la longevidad de uno y otro medio. Mientras que la prensa femenina se originó en nuestro país en el siglo XIX y las revistas de estilo de vida llegaron al mercado a finales de la década de los años 80, la televisión segregada en función del género comenzó su andadura en 2005, en el caso de los canales femeninos, y en 2010, con los masculinos. Este desfase temporal ofrece, para las revistas, un mayor margen en la posible expansión o evolución de las representaciones mediáticas. Ya destacamos que la prensa dirigida a las mujeres había ido recogiendo los discursos de la feminidad que funcionaban como instrumento de control en cada época, mientras que las revistas de estilo de vida masculino, a lo largo de sus tres décadas de historia, habían, como mínimo, perfilado dos formas de ser hombre: una más tradicional donde la fuerza, el dominio y la sexualidad recibían un mayor protagonismo y otra en la que el hombre era un ser cultivado intelectualmente y su superioridad tomaba un cariz más clasista y moral.

En el caso del medio televisivo, cuando se tomó la muestra, Nova, la más longeva, contaba con diez años de historia, Divinity con cuatro y Energy y Discovery Max con tres. Nos encontrábamos, pues, en el punto de salida de los canales segregados por género. Actualmente, y como apuntábamos en el primer capítulo del marco teórico, vivimos una especialización mediática y, puede que por ello, hayan proliferado los canales en antena 
que beben del mismo modelo de negocio y que han segmentado su público en función del sexo. Así, encontramos las cadenas Mega y Be Mad, dirigidas a una audiencia masculina, y DKiss, pensada para un público femenino. Como vimos, la multiplicidad de los soportes no tiene por qué traducirse en un mayor número de representaciones —recordemos que las tres revistas femeninas son, prácticamente, medios calcados_-, aunque sí puede dar pie, como sucedió en las publicaciones masculinas, a que se incluyan variaciones del modelo.

Esto nos lleva, directamente, a las hipótesis número cinco y seis. Por un lado, entendíamos que la sectorización de las audiencias en función del sexo había superado los tradicionales soportes de papel y se estaba asentando fuertemente en el medio televisivo. Pero, por el otro lado, también afirmábamos que la pluralidad de los medios no era tal y que su discurso dominante imposibilitaba la identificación con formas de ser que transcendieran las establecidas por el sistema sexo-género.

Efectivamente, en el medio televisivo están naciendo nuevos canales que perfilan los intereses de la audiencia en función de gustos o inquietudes relacionadas con el género. Cuando acotamos nuestra muestra, en el 2015, pudimos abarcar la totalidad de los canales que por aquel momento orientaban sus contenidos en base al sexo: existían dos femeninos y dos masculinos. Actualmente, en el medio televisivo español, contamos con siete cadenas, tres dirigidas a mujeres y cuatro a hombres. Según el análisis extraído en la muestra de 2015, el patrón que dibujaban los masculinos era bastante similar: se acudía a las características arquetípicas que conforman la masculinidad hegemónica y, de ahí, se proyectaba a un hombre competitivo, violento, fuerte, dominante. Lo mismo sucedía en los femeninos, donde encontrábamos esa similitud para el modelo de mujer, con un mayor peso de la belleza en Divinity, posiblemente por el target — más joven que el de Nova- al que va dirigido.

Nos es imposible saber el modelo que están promocionando las nuevas cadenas, desconocemos si se encuentra, en el caso de las mujeres, más cercano al mito de la belleza o, si por el contario, gira en torno al discurso de la domesticidad; si ha sofisticado la figura del hombre o si continúa la línea propuesta por los anteriores canales. Lo que sí sabemos es que la pluralidad del mensaje queda invalidada en el momento en el que es el sistema de género la base sobre la que se erige el discurso. Unos medios de comunicación que explotan las fantasías de la masculinidad y la feminidad no son unos medios plurales, son unos medios restrictivos al servicio del poder dominante. 
Si hemos asumido que los canales de creación más reciente seguirán alguna de estas tendencias, es porque un medio de comunicación que segmenta a su público por sexos está ocasionando, de base, dos realidades enfrentadas. Acepta las desigualdades que el género ha establecido entre mujeres y hombres y las promociona a través de sus mensajes. Se convierte, pues, en cómplice de un sistema opresor. En nuestra última hipótesis, decíamos, precisamente, que la fragmentación de la audiencia en función del sexo llevaba a comprender el mundo de una manera dual donde, cabe señalar, lo considerado masculino siempre tendrá más valor que lo femenino.

Como bien señalábamos, el sistema de género es el que sustenta la narrativa de los soportes segregados. Dicho sistema jerarquiza la realidad, concediendo poder y privilegios a los hombres en detrimento de la libertad de las mujeres. Pues bien, la superioridad asociada al sexo masculino, conlleva una serie de consecuencias, como que los órdenes simbólicos de la masculinidad y de la feminidad no se situarán al mismo nivel. Cuando analizábamos el nacimiento de la prensa femenina, acusábamos la falta de cabida que las temáticas relacionadas con las mujeres tenían en la prensa de interés general. Esto pasó en el siglo XVIII. A día de hoy, resulta que un canal generalista articula una parte considerable de su oferta en torno al deporte masculino y, desgraciadamente, sigue sin sorprendernos.

Los medios de comunicación han adoptado, tradicionalmente, un punto de vista androcéntrico. Difundido un discurso insuficiente y paralizante para con la construcción de la propia identidad y, además, han alimentado la dominación masculina. Dichas realidades tienen unas consecuencias devastadoras. A pesar de ello, y volviendo a la hipótesis principal, advertimos que no existe una ruptura entre viejos y nuevos medios. Que los canales de televisión están desarrollando estrategias de segmentación en base al género, ofreciendo contenidos estereotipados como técnica de identificación con su audiencia. Observamos, también, que es posible establecer un diálogo entre estos y la prensa, soporte que, históricamente, desestimó la realidad de millones de mujeres y las relegó a un segundo plano; medio que, a día de hoy, ha enaltecido y sofisticado un arma de control como es la masculinidad. 


\section{CONCLUSIONS}

A democratic civilisation will only be saved if it makes the language of imagery a provocation to critical reflection and not an invitation to

hypnosis.

Umberto Eco

As we ventured into this topic, the main objective of our doctoral thesis was to establish a relationship between the messages of the written free press, segregated by gender and thematic television channels aimed at a female audience on the one hand and at a male one on the other. In addition, we were interested in working on this line of research because of the novel nature of it, because efforts had not yet been made from the academic field to face both supports and to establish a possible dialogue between them. Once this purpose has been achieved, which required its own theoretical and empirical analysis, it is time to rescue the hypothesis with which we open this research paper.

Our main hypothesis stated that the new communication media that segmented their audiences according to gender - certain thematic television channels - sought identification with their audience through the elaboration of a sexist and stereotyped discourse as the press previously did. When we began to outline this study, we were aware that since the academy's efforts had been devoted to analysing the discourses of the female press and, although to a lesser extent, we also found some studies that addressed those of the male. Throughout the theoretical framework, these works have been compiled and exposing their main contributions. It was important that we draw this network, because on that basis, part of our main hypothesis held that: the gender-segregated press projected a stereotyped reality.

In addition, we should not only rely on press analysis. If we understood that the media drew and offered a sexist panorama, we also had to go to reality itself and find the cultural constructions that shaped the gender mandates. In this method of the theoretical framework, two ways were explored parallel to each other: one focused on knowing this system and its two representations - that of femininity and that of masculinity - and the other focused on the media narrative, which allowed us to understand in what form the 
second picked up the first. Thus, from the theory we knew that, indeed, the gender segregated press showed a confronted lifestyle for men and women, based on the guidelines of masculinity and femininity.

Even with everything in place, our hypothesis was at the present time and for its resolution, requiring a dialogue between the written medium and television media, therefore, apart from exposing the work that had previously been done on the press, we had to gather our own sample and check, on the one hand, if today the trend in lifestyle magazines had changed with respect to the work done previously and, on the other, detect if the written message resembled the television. This led to us to collect publications with more coverage by 2015 , one per quarter, which would allow us to verify the discursive and narrative line of them.

We read how, from the academy, they accused that the women's press had gone through different phases, collecting the discourses of femininity that functioned as an instrument of control in each epoch, being few occasions in which it had served for the promotion and liberation of women. Due to the historical evolution, the current lifestyle magazines had become a catalogue of fashion, leisure and beauty where happiness went through the achievement of a normative physicist and the obtaining of material goods. When we analysed our sample, we understood that, indeed, the current discourse of women's lifestyle magazines was framed within the post-feminist era.

As we said, we live a historical moment in which immediacy and individualism break with the notion of the collective, turning any material reality into subjective values. In this way, the lifestyle magazines analysed do not include topics that affect women from a structural perspective and in the few cases in which any idea about discrimination against women has been launched, it has been done from the perspective of the postmodern that maintains that personal change is possible as long as you feel like it, because there are no external conditions that stop or hinder anyone's development "today a woman can display her motherhood, sexuality, professional aspirations, hobbies, talent etc. [...] In my opinion, one can become a Woman, capitalizing on her own merits, without having to take anything from the man" (Glamour, No. 155, 2015).

Women's lifestyle magazines sell, as an infallible formula of success, sexual attractiveness and beauty. They say that all problems can be solved with a good mascara, red lipstick, popping on some heels and carrying the last bag that sets the trends. Magazines have evolved in their view of the model of female, yes, but they are still just 
as incarcerating. Now, as Naomi Wolf (1991) claimed, they sell us the myth of beauty: happiness through eternal youth, thinness and physical normativity. None of the women who starred on the cover of our show had grey hair, wrinkles or wearing a large size. The same did not happen in the case of male lifestyle magazines, where men could alter the normative canons of beauty. In the press, if a woman does not meet certain requirements, it simply disappears.

Although similar in form, we saw that one of the differences between the magazines of masculine lifestyle and those of feminine lifestyle lay in the opening of the identity spectrum: more ways of being a man than of being a woman were contemplated and approved. The protagonists that appear in women's lifestyle magazines are mirrors of each other: same physicists, same ages, same tastes and same concerns. For men, on the other hand, there is no such obvious uniformity. Of course, none of the proposed models breaks with the mandates of hegemonic masculinity, an idea that, on the other hand, allows us to begin solving secondary hypotheses.

Apart from the main hypothesis, a series of secondary hypothesis had been established that made the analysis process much easier and more operative. The first one, resolved during the theoretical exposition, assured that masculinity and femininity were cultural constructions that formed gender, a tool used by patriarchy to support the hierarchy of the sexes. We have already seen, throughout the second and third chapters, how culture, through the process of socialization, modelled the behaviours of women and men, building, from them, the schemes of femininity and masculinity. We also saw that they were not parallel symbolic orders, since as both served to control women, masculinity was always above femininity.

Taking this into account, in a second hypothesis, we assured that it was irrelevant how much femininity or masculinity evolved, since both models were an indissoluble part of the oppressive gender system, they would continue to fulfill the ultimate goal of subordinating women. This has been the case in the case of the women's press, which although the proposed woman model has varied over its more than two centuries of history, it has proved equally useful for patriarchal domination interests. Similarly, it happens with the male model and with its possible variations and evolutions.

We used to say that lifestyle magazines contemplated and approved more ways of being a man. We also assured that it was not a ruptures model. Thus, although more flexible with the way of being masculine, these publications do not question the system 
of privileges, do not include facets such as paternity or care and continue to objectify women. The model has opened up to questions of aesthetic nature, to the beautiful man, and has done so as another form of self-admiration. The different reports affect the professional and educated dimension, aspects, on the other hand, traditionally associated with masculinity. In addition, the tastes of new men have risen and exalted. In turn, the press proposes other more violent models, also based on media discourse, where the dominance over women is exercised from physical superiority rather than moral or intellectual.

The third hypothesis established that the mass media collected the discourses of femininity and masculinity, encouraging the continuity of the existing social order. Thus, in the theoretical framework, in chapters two and three, we showed the different representations that men, women launched advertising, television or the press and how these representations were based on gender stereotypes. Later, in the fourth hypothesis, we pointed out that, specifically, and to achieve the identification and approval of the audience, the media oriented to one or the other sex explicitly exploited the values of femininity and masculinity.

One of the first things that caught our attention while we were examining the sample was the way in which the contents offered by the television media were more different from each other than those offered by the press, that is, while the labels used to categorise the contents of women's magazines remained, in general, operative for men's magazines. The same was not the case with television channels, which presented less uniformity, to the point of barely finding similar content between the channels aimed at women and those aimed at the men.

Although lifestyle magazines exploit the discourses of masculinity and femininity, it is true that in essence they are both catalogues at the service of large fashion, beauty or technology companies. They are advertising media among which it is easier to establish a common line of analysis. On the other hand, the cultural offer has been standardized and offered, regardless of sexes, trips, exhibitions, books, music...

Even with everything, differences can be seen inside the magazines. The most noteworthy is the mainstreaming of beauty, which, for women's publications, is present both in the sections dedicated to it and outside them: we read it in the descriptions of the protagonists, we see it in their photographic reports and we find it, again, in the nature of the questions. In addition, although widely collected in Men's Health, their Esquire or 
DT companions dedicate $5 \%$ and $6 \%$ respectively to this subject, when in women the percentage moved between $15 \%$ and $24 \%$. In addition, the existing lags in the technologyrelated subject matter make a difference to take into account. This category, although it is present in the six journals, in women it represents between $2 \%$ and $3 \%$ of the content, when in women it ranges from $7 \%$ to $14 \%$. On the other hand, the contents of decoration we see them, mainly, in the feminine publications, while those of gastronomy are more important in the masculine support.

Furthermore, when it comes to dedicating an editorial unit to a man, it is more likely that he will star for professional reasons, that is, in $93 \%$ of cases, that if he is a woman, whose profession will be relevant in $82 \%$ of the time and in addition, there is a greater tendency for them to be asked about their private and family life. On the other hand, the inclusion of erotic photographs of women in the male press refers to the type of sexuality expected in men who, although stripped of all feelings and whether the identity of women is a secondary factor, occupies a relevant place in the construction of male identity.

Although apparently more similar, an in-depth analysis allows us to understand that male and female lifestyle magazines outline two human realities. Well, in the case of television, the differences in scenarios began to jump from the moment of the creation of the categories, when we saw that those that worked for female support did not in the male and vice versa. Television has faced, in a more explicit way than the press, two worlds, two types of tastes, concerns, interests and concerns. We explained, in the previous section, that channels directed at men exploited archetypal hegemonic masculinity and that those directed at women were located in speeches close to home, love relationships and beauty. Thus, the contents that were offered to us from the male media referred to force, violence, battle or dominance, being this type of themes non-existent or infrequent in the female channels - if in competition programs - and in the same way, it happened with the feminine contents, that did not find their hollow inside the supports directed to men.

Returning to the fourth hypothesis, we understand that both the press and television oriented to one or the other sex exploit the values of masculinity and femininity, although, it has already been said, they have taken as reference models in different degrees of evolution. This may be due to the longevity of both media. While the female press originated in our country in the 19th century and lifestyle magazines reached the 
market in the late $80 \mathrm{~s}$, gender-segregated television began in 2005 , in the case of female channels, and in 2010, with male channels. This time lag offers, for magazines, a greater margin in the possible expansion or evolution of media representations.

We already emphasize that the press directed to women had been collecting the discourses of femininity that functioned as an instrument of control at each time, while the magazines of male lifestyle, throughout its three decades of history, had, as At least, two ways of being a man were outlined: a more traditional one where strength, dominance and sexuality received a greater prominence and another in which man was an intellectually cultivated being and his superiority took on a more classist and moral aspect.

In the case of the television medium, when the sample was taken, Nova, the oldest, had ten years of history, Divinity with four and Energy and Discovery Max with three. We were, then, at the exit point of the channels segregated by gender. Currently, and as we pointed out in the first chapter of the theoretical framework, we are experiencing a media specialization and, perhaps, the antenna channels that drink from the same business model and that have segmented their audience according to sex have proliferated. Thus, we find the chains Mega and Be Mad, aimed at a male audience, and DKiss, designed for a female audience. As we saw, the multiplicity of the media does not have to be translated into a greater number of representations — remember that the three women's magazines are, practically, traced media-, although it can give rise, as happened in the male publications, to which include model variations.

This leads us, directly, to hypotheses number five and six. On the one hand, we understood that the sectoring of the audiences based on sex had surpassed the traditional paper supports and was settling heavily in the television medium. But, on the other hand, we also affirmed that the plurality of the media was not such and that its dominant discourse made it impossible to identify with ways of being that transcend those established by the sex-gender system.

Indeed, new channels are emerging in the television medium that outline the interests of the audience based on taste or concern related to gender. When we limited our sample, in 2015, we were able to cover all the channels that at that time oriented its contents based on sex: there were two female and two male. Currently, in the Spanish television medium, we have seven channels, three aimed at women and four at men. According to the analysis extracted in the 2015 sample, the pattern that the men drew was 
quite similar: the archetypal characteristics that make up the hegemonic masculinity were used and hence a competitive, violent, strong, dominant man was projected. The same happened in women, where we found that similarity for the female model, with a greater emphasis of beauty in Divinity, possibly because of the target - younger than Nova - to which it is addressed.

It is impossible for us to know the model that the new chains are promoting, we do not know if it is, in the case of women, closer to the myth of beauty or, if, on the contrary, it revolves around the discourse of domesticity; if the figure of man has been sophisticated or if the line proposed by the previous channels continues. What we do know is that the plurality of the message is invalidated now in which the gender system is the basis on which the discourse is built. Media that exploit the fantasies of masculinity and femininity are not plural means; they are restrictive means at the service of the dominant power.

If we have assumed that the most recent channels of creation will follow any of these trends, it is because a means of communication that segments its audience by sex is causing, on the basis, two realities faced. Accept the inequalities that gender has established between women and men and promote them through their messages. It thus becomes an accomplice of an oppressive system. In our last hypothesis, we were saying, precisely, that the fragmentation of the audience based on sex led us to understand the world in a dual way where, it should be noted, what is considered masculine will always have more value than the feminine.

As we pointed out, the gender system is what sustains the narrative of segregated media. This system hierarchizes reality, granting power and privileges to men to the detriment of women's freedom. Well, the superiority associated with the male sex entails a series of consequences, such as that the symbolic orders of masculinity and femininity will not be at the same level. When we analysed the birth of the female press, we accused the lack of room that the issues related to women had in the press of general interest. This happened in the 18th century. To this day, it turns out that a generalist channel articulates a considerable part of its offer around men's sport and, unfortunately, continues to surprise us.

The media have traditionally adopted an androcentric point of view. Disseminated an insufficient and paralyzing discourse towards the construction of one's identity and, in addition, have fuelled male domination. These realities have devastating 
consequences. Despite this, and returning to the main hypothesis, we warn that there is no break between old and new media. That television channels are developing gender segmentation strategies, offering stereotyped content as an identification technique with their audience. We also observe that it is possible to establish a dialogue between them and the press, a support that historically dismissed the reality of millions of women and relegated them to the background; medium that, today, has exalted and sophisticated a control weapon such as masculinity. 


\section{REFERENCIAS BIBLIOGRÁFICAS}

AIMC (2019). Marco general de los medios en España 2019. [En línea] Fecha de consulta mayo de $2019<$ https://www.aimc.es>

Aguilar, Pilar (2008). ¿Somos las mujeres de cine? Prácticas de análisis filmico. Oviedo: Instituto Asturiano de la Mujer.

Aguilar, Pilar (2017). "Escenificaciones de violencia sexual en la ficción audiovisual" en MenÉndez, Isabel e Illera, Paula (eds.). Guerras simbólicas: el papel del audiovisual en la lucha contra la violencia de género. Palma de Mallorca: Edicions UIB, págs. 39-75.

AlBÚJAR, MARTA (2014). La estructura de la televisión española tras el apagón analógico (Trabajo de fin de máster). Barcelona: Universidad Autónoma de Barcelona.

AlOnso, NADiA (2017). "Evolución del consumo televisivo en España desde el encendido digital: puntos de inflexión y cambios de tendencia", Textual \& Visual Media 10, págs. 153-170.

Almansa-Martínez, Ana y Gómez de Travesedo-Rojas, Ruth (2017). "El estereotipo de mujer en las revistas femeninas españolas de alta gama durante la crisis", Revista Latina de Comunicación Social 72, págs. 608-628.

Álvarez, Nuria, Carrera Fernández, María Victoria y Cid-Fernández, Xosé MANUEL (2017). “¿Juegos de niñas y juegos de niños? La influencia de los estereotipos de género en la elección de juguetes", Revista de Estudios e Investigación en Psicología y Educación 5, págs. 330-333.

ALCÁZAR, FrANCISCO JAVIER (2012). “Los tebeos eróticos durante la transición”, Revista de estudios sobre la historieta: historietas 2, págs. 68-88.

ALTÉS, ELVIRA (2012). “La publicidad o la venta del imaginario oculto. ¿Existe violencia sexista en los anuncios?", Cuestiones de género: de la igualdad y la diferencia 7, págs. 197-205.

AmOrós, Celia (1994). Feminismo, igualdad y diferencia. México: UNAM. 
Aresti, Nerea (2001). Médicos, donjuanes y mujeres modernas: los ideales de feminidad y masculinidad en el primer tercio del siglo XX. Bilbao: Servicio Editorial de la Universidad del País Vasco.

ARESTI, NEREA (2014). “A la nación por la masculinidad. Una mirada de género a la crisis del 98" en NASH, MARY (ed). Feminidades y masculinidades. Arquetipos y prácticas de género. Madrid: Alianza editorial, págs. 21-46.

Aresti, NerEA (2018). "La historia de género y el estudio de las masculinidades. Reflexiones sobre conceptos y métodos", en GALLEGO, HeNAR (ed.). Feminidades y masculinidades en la historiografía de género. Granada: Comares, págs. 173194.

ARlt, MirTa (1994). "Don Juan y la presencia del mito en el teatro", en PeLletTIERI, Osvaldo (ed.). De Lope de Vega a Roberto Cossa. Teatro español, iberoamericano y argentino. Buenos Aires: Editorial Galerna, págs.179-188

Armentia, José Ignacio, Ganzabal, María y Marín, Ma. Flora (2011). "La perspectiva de género en las ediciones digitales de las revistas femeninas y masculinas españolas", en Actas. III Congreso Internacional Latina de Comunicación Social. Tenerife: Universidad de la Laguna, págs. 1-23.

BACH, MARTA (2000). El sexo de la noticia. Reflexiones sobre el género en la información y recomendaciones de estilo. Barcelona: Icaria.

BALlarín, PilAR (2001). La educación de las mujeres en la España contemporánea. Siglos XIX-XX. Madrid: Síntesis.

BARRETO, CARMEn MARINA (2006). “Cultura visual y erotización en el deporte” en Actas. IX Congreso AEISAD. Las Palmas de Gran Canaria: Universidad de Las Palmas de Gran Canaria, págs. 49-56.

BARLOVENTO (2007). Análisis televisivo anual 2006 [En línea] Fecha de consulta mayo de $2019<$ https://www.barloventocomunicacion.es $>$

BARlovento (2019a). Análisis televisivo 2018. [En línea] Fecha de consulta mayo de $2019<$ https://www.barloventocomunicacion.es>

BARLOVENTO (2019b). Análisis mensual del comportamiento de la audiencia TV, mayo 2019. [En línea] Fecha de consulta junio de 2019 $<$ https://www.barloventocomunicacion.es $>$ 
BARriga, Ma José (2013). "La fusión de Antena 3 y La Sexta: la legitimación de una tendencia en el mercado audiovisual español" en Actas. IV Congreso Nacional ULEPICC. Barcelona: Universitat Jaume I, págs. 74-86.

BEAUVOIR, SimONE DE (2008) [1949]. El segundo sexo. Madrid: Catedra.

BELMONTE, IRENE (2016). Los medios de comunicación audiovisuales y la violencia de género adolescente (Tesis doctoral). Madrid: Universidad Complutense de Madrid.

Berganza, María Rosa y Del Hoyo, Mercedes (2006). "La mujer y el hombre en la publicidad televisiva: imágenes y estereotipos”, Zer 21, págs. 161-175.

BERGER, JOHN (2000) [1974]. Modos de ver. Barcelona: Gustavo Gili.

BERMEJO, Jesús (2002). "Narrativas de ella, narrativas de él: la construcción de la identidad de género en el cine", en Actas. Mujeres, Hombres y Medios de Comunicación. Tomo I. Junta de Castilla y León, págs. 21-32.

Bernal, Triviño (2019). Hacia una comunicación feminista. Cómo informar e informarse sobre violencia machista. Barcelona: UOC.

BernáRdeZ, ASUnCión (2015). Mujeres en medio(s). Propuestas para analizar la comunicación masiva con perspectiva de género. España: Fundamentos.

BERNÁRDEZ, ASUNCIÓN (2017). "Fútbol y masculinidad: jugadores en el Edén perdido", en MenÉndez, IsABel e Illera, PAUla (eds.). Guerras simbólicas: el papel del audiovisual en la lucha contra la violencia de género. Palma de Mallorca: Edicions UIB, págs. 163-180.

BERNÁRDEZ, ASUNCIÓN (2018). Soft power: heroínas y muñecas en la cultura mediática. España: Fundamentos.

Bernárdez, Asunción, García Irene y GonzÁlez, Soraya (2008). Violencia de género en el cine español. Análisis y guía didáctica. Madrid: Editorial Complutense.

BIENVENIDO, LEÓN (2009). "Introducción”, en BIENVENIDO, LEÓN (coord.). Telerrealidad. El mundo tras el cristal. Sevilla: Comunicación Social Ediciones y Publicaciones, págs. 13-23.

BLASCO, INMACULADA (2014). "Género y nación durante el franquismo" en 
Michonneau, StÉPhane y NúÑEZ, Xosé (coords.). Imaginarios y representaciones de España durante el franquismo. Madrid: Casa de Velázquez, págs. 49-73.

BOLTER, DAVID y GRUSIN, RICHARD (2011). “Inmediatez, hipermediación, remediación”, Cuadernos de información y comunicación 6, págs. 29-57.

BONINO, LUIS (2000). "Varones, género y salud mental: deconstruyendo la normalidad masculina", en SEgARrA, MARTA y CARABí, Ángels (eds.). Nuevas masculinidades. Barcelona: Icaria, págs. 41-64.

BONINO, LUIS (2002). "Masculinidad hegemónica e identidad masculina", Dossiers Feministes: Mites, De/construccions i Masacarades 6, págs. 7-35.

BOURDIEU, PIERRE (2000). La dominación masculina. Barcelona: Anagrama.

Bosch, Esperanza, Ferrer, Victoria A. y Gili, Margarita (1999). Historia de la misoginia. Barcelona: Anthropos Editorial.

BREAZEALE, KENON (1994). "In spite of women: Esquire magazine and the construction of the male consumer", Signs 20 (1), págs. 1-22.

Bueno, Gustavo (2002). Telebasura y democracia. Barcelona: Ediciones B.

Bustamante, Enrique y García, Ma TRINIDAD (2017). “La TDT de servicio público estatal y RTVE: balance y futuro", en GUTIÉRREZ, ELADIO (coord.). Televisión abierta. Situación actual y tendencias de futuro de la TDT. España: Colegio Oficial de Ingenieros de Telecomunicación, págs. 21-38.

CABEllo, Fernando (1999). El mercado de revistas en España: concentración informativa. Barcelona: Ariel.

CABrera, Ma ÁngEles y Gómez, TAMARA (2008). “Consumo televisivo y perfiles de las audiencias: un modo personalizado de ver la TV", Comunicar: Revista Científica de Comunicación 26 (31), págs. 635-640.

CÁCERES, MARÍA DOLORES (2000). "La crónica rosa en televisión o el espectáculo de la intimidad”, CIC. Cuadernos de Información y Comunicación, págs. 277-290.

Caldevilla, David (2010). "Estereotipos femeninos en series de TV", Revista Latinoamericana de Comunicación Chasqui 111, págs. 73-78.

CAlleja, José María (2016). Cómo informar sobre la violencia machista. Madrid: 
Cátedra.

CALlejo, JAVIER (2007). "Transformaciones del sistema televisivo español: una explicación estructural", Nueva época 7, págs. 197-226.

CAMPILlo, Olga (2016). "Crítica radical feminista a la cultura", Oxímora Revista Internacional de Ética y Política 8, págs. 63-74.

CAMPOS, FrANCISCO (2015). "Las estrategias europeas para la televisión conectada a Internet", Infoamérica: Iberoamerican Communication Review 9, págs. 37-58.

CARvallo, Pedro M. (2006). “Género, posmodernismo y relaciones internacionales. La identidad femenina en el discurso de las organizaciones internacionales", Confines 2/3, págs. 89-100.

CASero-Ripollés, Andreu (2012). "Más allá de los diarios: el consumo de noticias de los jóvenes en la era digital”, Comunicar 39 (20), págs. 151-158.

CHICHARRO, MAR (2013). "Representaciones de la mujer en la ficción postfeminista: Ally McBeal, Sex and the City y Desperate Housewives", Papers 98 (1), págs. 11-31.

CoBo, RosA (2005). “El género en las ciencias sociales” en Cuadernos de Trabajo Social 18, págs. 249- 258.

Cobo, Rosa (2015). "El cuerpo de las mujeres y la sobrecarga de sexualidad", Investigaciones Feministas 6, págs. 7-19.

CONNELl, ROBERT W. (1995). “The Social Organization of Maculinity”, en CONNELL, Robert W. Masculinities. Berkeley: Univsersity of California Press. [En línea] Fecha de consulta 1 de julio de $2019<$ https://www.jerez.es/fileadmin/Document os/hombresxigualdad/fondo_documental/Identidad_masculina/la_organizaci_n_ social_de_la_masculinidad.pdf $>$

COSTA, ANTÓN (1990). "Guirnaldas de la historia: la construcción cultural y social del género femenino en la escuela del franquismo", en Actas. VI Coloquio de historia de la educación. Santiago de Compostela: Universidad de Santiago de Compostela, págs. 111-119.

COSTAS, JAIME (2014). "El flow se estanca: el contramodelo televisivo de Netflix", Revista de Estudos da Comunicaçao 38 (15), págs. 244-256.

CROVI, Delia (2002). “Sociedad de la información y el conocimiento. Entre el optimismo 
y la desesperanza", Revista Mexicana de ciencias políticas y sociales 45 (185), págs. 13-33.

CRUZ, SAlVADOR (2002). “Homofobia y masculinidad”, El Cotidiano 18 (113), págs.. 814.

DÍAZ, PILAR (2008). "El trabajo de las mujeres durante la dictadura franquista", en CAPEL, Rosa (dir.). Cien años trabajando por la igualdad. Madrid: Fundación Largo Caballero e Instituto de la Mujer, págs. 167-180.

DíAZ-ANDREU, MARGARITA (2005). “Género y arqueología: una nueva síntesis” en SÁNCHEZ, MARGARITA (ed.). Antropología y género. Granada: Editorial Universidad de Granada, págs. 13-51.

DÍAZ, JosÉ JAVIER (2017). “Miguel de Unamuno: la feminización de la masculinidad moderna", Cuadernos de Historia Contemporánea 39, págs. 39-58.

DíEZ, ENRIQUE JAVIER (2015). “Códigos de masculinidad hegemónica en educación”, Revista Iberoamericana de Educación 68, págs. 79-98.

DiezhandinO, María Pilar (1997). "Especialización y periodismo de servicio", en ESTEVE, FRANCISCO (coord.). Estudios sobre Información Periodística Especializada. Valencia: Fundación San Pablo-CEU, págs. 83-90.

ECO, UMBERTO (1983). Viagem na irrealidade quotidiana. Lisboa: Cosmos.

Escartí, Amparo, Musitu, GonZalo y Gracia, EnRIQUe (1988). "Estereotipos sexuales y roles sociales", en FERNÁNDEZ, JUAN (coord.). Nuevas Perspectivas en el desarrollo del sexo y el género. Madrid: Pirámide, págs. 205-225.

ESPIGADO, GLORIA (2018). “El ángel de hogar uso y abuso historiográfico de un arquetipo de feminidad" en GALlego, HenAR (ed.). Feminidades y masculinidades en la historiografía de género. Granada: Comares, págs. 195-212.

ESQUIROL, MERITXELL (2017). "50 shades of grey: adiestramiento y pornograficación de clase" en MenÉndez, IsABel e Illera, Paula (eds.). Guerras simbólicas: el papel del audiovisual en la lucha contra la violencia de género. Palma de Mallorca: Edicions UIB, págs. 77-94.

ESTEVE, FRANCISCO (2014). "Fundamentos de la especialización periodística", en, CAMACHO, IDOIA (coord.). La especialización en el periodismo. Formarse para 
informar. Zamora: Comunicación Social, págs. 11-26

ESTRADA, JOHN HAROLD (2009). “La articulación de las categorías género y salud: un desafío inaplazable", Revista Gerencia y Políticas de Salud 8 (17), págs. 106-122.

FACIO, AldA y FrIES, LORENA (2005). "Feminismo, género y patriarcado" en Revista sobre enseñanza del derecho de Buenos Aires 6, págs. 259-294.

FASSIN, ÉRIC (2002). "El imperio del género. La ambigua historia política de una herramienta conceptual", Discurso, teoría y análisis 31, págs. 11-35.

FERNÁNDEZ, JUAN JOSÉ (2002). "Sobre el estado actual de la investigación acerca de la historia de la prensa especializada en España”, en Actas. Congreso Prensa y Periodismo Especializado. Historia y realidad actual. Guadalajara: Universidad de Guadalajara, págs. 91-116.

FERNÁNDEZ, LAURA y ROEL, MARTA (2014). “Las actuales estrategias de programación de la TDT en España: entre la comunicación de servicio público y la temática oferta privada", Razón y palabra 18, [En línea] Fecha de consulta 21 de noviembre de $2017<$ http://www.redalyc.org/articulo.oa $>$

FernáNDEZ, MARÍA y GARCÍA-VeGA, Elena (2012). "Variables clínicas en el trastorno de la identidad de género", Psicothema 24 (4), págs. 555-560.

FERreiro, ANA CARolina (2018). "Masculinidades en el discurso publicitario". Question 1 (58), págs. 1-26.

Figueras, MònICA (2005). Premsa juvenil femenina i identitat corporal (Tesis doctoral). Barcelona: Universidad Pompeu Fabra.

FloeCK, WiLfRIED (2005). "Mito e identidad femenina. Los cambios de la imagen de Penélope en el teatro español del siglo XX”, en VILCHES DE FrUTOS, M ${ }^{a}$ FRANCISCA (ed.). Mitos e identidades en el teatro español contemporáneo. Ámsterdam-Nueva York: Rodopi, págs. 53-64.

Foucault, Michel (2005) [1975]. Vigilar y castigar. Nacimiento de la prisión. México: Siglo XXI.

FORNER, ÁNGEL y CARRO, LUIS (1997). “Orientaciones para la elaboración de trabajos académicos y científicos: interpretación y adaptación de la normativa APA", Revista Interuniversitaria de Formación del Profesorado 28, págs. 271-285. 
Friedan, BetTy (2016) [1963]. La mística de la feminidad. España: Ediciones Cátedra.

Gallardo-Camacho, Jorge y Sierra SÁnchez, JaVier (2017). "La importancia de la audiencia en diferido en el reparto del poder entre las cadenas generalistas y temáticas en España”, Prisma social 18, págs. 172-191.

Gallego, Juana (1990). Mujeres de papel. De ¡Hola! a Vogue: la prensa femenina en la actualidad. Barcelona: Icaria.

Gallego, Juana, Altés, Elvira, Melús, María Eugenia, Soriano, Jaume y Cantón, MARÍA JOSÉ (2002). "La prensa diaria por dentro: mecanismos de transmisión de estereotipos de género en la prensa de información general”, Anàlisi 28, págs. 225242.

Gallego, JuAna (2006). “Prólogo”, en MenÉNDez, Ma. ISABEl. El zapato de cenicienta. El cuento de hadas del discurso mediático. Oviedo: Ediciones Trabe, págs. 11-16.

Gallego, JuAna (2007). “Lenguaje periodístico y discriminación de género”, en PlazA, JuAn F. y Delgado, CARMEN (eds.). Género y comunicación. Madrid: Editorial Fundamentos, págs. 49-72.

Gallego, Juana (2013). De reinas a ciudadanas. Medios de comunicación, ¿motor o rémora para la igualdad? España: Aresta Mujeres.

GANZABAL, MARÍA (2004). La revista femenina española en los 90. Análisis hemerográfico de seis revistas femeninas actuales, Woman, Elle, Marie Claire, Telva, Dunia y Cosmopolitan (Tesis doctoral). Leoia: Universidad del País Vasco.

GANZABAL, MARÍA (2006a). "Nacimiento, evolución y crisis de la prensa femenina contemporánea en España”, Ámbitos 15, págs. 405-420.

GANZABAL, MARÍA (2006b). "Nacimiento, remodelación y crisis de la prensa femenina contemporánea en España”, Revista Latina de Comunicación Social 61, s.p.

García, Antonio, Tur-Viñes, Victoria y Pastor, Yolanda (1990). “Consumo mediático de adolescentes y jóvenes. Noticias, contenidos audiovisuales y medición de audiencias", Icono 1416 (1), págs. 22-46.

GARCÍA, FERNANDO (2009). El nacimiento de La Sexta: análisis de una nueva estrategia competitiva de televisión "generalista" (Tesis doctoral). Madrid: Universidad Complutense de Madrid. 
GARCÍA DE CASTRO, MARIO (2007). La ficción televisiva popular. Una evolución de las series de televisión española. Barcelona: Editorial Gedisa.

GARCÍA-AlBI, InÉS (2007). Nosotras que contamos. Mujeres periodistas en España. Barcelona: Plaza \& Janés.

GARCíA-Mina, ANA (2003). Desarrollo del género en la feminidad y la masculinidad. Madrid: Ediciones Narcea.

GARRIDO, CARLOTA (2003). "Un siglo de publicidad”, en AMECO (ed.). La imagen de la mujer en la publicidad y su influencia en los medios de comunicación. España: AMECO, págs. 141-154.

GARRIDO, MANUEL (2007). "Estereotipos de género en publicidad. La creatividad en la encrucijada sociológica", Revista Creatividad y Sociedad 11, págs. 53-71.

GARRIDO, MARÍA (2007). Los rasgos temáticos y de estilo propios del periodismo de servicio en las revistas femeninas de alta gama (Tesis doctoral). Salamanca: Universidad Pontificia de Salamanca.

GMMP (2015). ¿Quién figura en las noticias? [En línea] Fecha de consulta mayo de 2019 $<$ http://cdn.agilitycms.com/who-makes-thenews/Imported/reports_2015/global/gmmp_global_report_es.pdf>

Gómez, Pedro (1967). Historia del periodismo español. Desde la "Gaceta de Madrid" (1661) hasta el destronamiento de Isabel II. Madrid: Editorial Nacional.

GONZÁlez, ÁlVARO (2017). Masculinidad y estereotipos. Imagen y valores del nuevo modelo de hombre en publicaciones especializadas (Trabajo fin de grado). Sevilla: Universidad de Sevilla.

GONZÁlez, CRISTINA (2006). La continuidad televisiva en la era digital. Nuevos discursos publicitarios de expresión de Identidad Corporativa. El nacimiento de Cuatro (Tesis doctoral). Castellón: Univsersitat Jaume I.

GONZÁlez de GARAy, BeATriz y AlfeO, JuAN CARLOS (2011). “Género y programación televisiva: el caso de Nitro y Nova", Revista Icono 14 9, págs. 396-409.

GONZÁLEZ, LAURA (2011). "Los suplementos semanales dirigidos a la mujer en la prensa diaria española: Mujer hoy, Yo Dona y S Moda”, en Actas. III Jornadas de Diseño en la Sociedad de la Información. Madrid: Universidad CEU San Pablo de 
Madrid, págs. 15-30.

GonzÁlez, LAURA y PÉREZ, Pedro (2009). “La Moda Elegante Ilustrada y El Correo de las Damas, dos publicaciones especializadas en moda en el siglo XIX”, Doxa. Comunicación 8, págs. 53-71.

GONZÁLEZ, TERESA (2009). “Los programas escolares y la transmisión de roles en el franquismo: la educación para la maternidad”, Bordón 61 (3), págs. 93-105

GuILlÁN, RAQUEL (2017). Análisis del panorama televisivo español con la implantación de la TDT desde 2011 hasta la actualidad: estructura empresarial, audiencias y su evolución (Trabajo fin de grado). Tenerife: Universidad de La Laguna.

GUZMÁN, JESÚs (2018). "La División Azul en Y. Revista para la mujer (1941-1943)", Creneida 6, págs. 526-551.

HENRY, JOHN y PARKER, JAMES (1856). The Gentleman's Magazine and historical review. Londres: J.B. Nichols.

HeRnÁndez, JuAn Francisco y MARTínez, Miguel Ángel (2016). "Nuevos modelos de consumo audiovisual: los efectos del binge-watching sobre los jóvenes universitarios", AdComunica. Revista Cientifica de Estrategias, Tendencias e Innovación en Comunicación 13, págs. 201-221.

Herrero, Olga y García, Jennifer (2015). "El hombre metrosexual como Narciso contemporáneo: el papel del discurso publicitario actual en la construcción de la masculinidad", Documentación de las Ciencias de la Información 38, págs. 245263.

Hinojosa, Ma PAZ (1992). La persuasión de la prensa femenina: análisis de las modalidades de la enunciación. Murcia: Universidad de Murcia.

Hinojosa, Ma PaZ (2005). Análisis de las modalidades de la enunciación en los textos de moda y belleza de la prensa femenina de alta gama (Tesis doctoral). Murcia: Universidad de Murcia.

IGLESIAS, MAR (2012). "Radiografía del consumo de medios de comunicación en estudiantes universitarios", Icono 14, 10 (3), págs. 100-115.

IMBERT, GÉRARD (2003). El zoo visual. De la televisión espectacular a la televisión especular. Barcelona: Editorial Gedisa. 
IRIARTE, TERESA (2016). Las revistas dirigidas a hombres en España y sus contenidos: masculinidades, feminidades y violencia simbólica (Tesis doctoral). País Vasco: Universidad del País Vasco.

IZQUIERDO-CASTILLO, JESSICA (2016). "La evolución del sector televisivo: un oligopolio frente a Internet”, Historia y Comunicación Social 19. Núm. Especial Enero, págs. 735-745.

JagOe, CATHRine (1994). Ambiguous Angels. Gender in the Novels of Galdós. Berkeley: University of California Press.

JaGOE, CATHRine(1998). "La misión de la mujer" en JAGOE, CATHERINe, BlanCO, AldA y ENRIQUE DE SALAMANCA, CRISTINA (eds.). La mujer en los discursos de género. Textos y contextos en el siglo XIX. Barcelona: Icaria, págs. 21-54.

Jayme, María y SaU, Victoria (2004) [1996]. Psicología diferencial del sexo y el género. España: Icaria.

JiMÉNEZ, InMACULADA (1992). La prensa femenina en España (desde sus orígenes a 1869). Madrid: Ediciones de la Torre.

JÓDAR, JUAN ÁNGEL (2010). "La era digital: nuevos medios, nuevos usuarios y nuevos profesionales”. Razón y palabra 15 (71), [En línea] Fecha de consulta 19 de mayo de 2019 <http://www.redalyc.org/pdf/1995/199514914045.pdf>

KiMMEL, MiCHAEL (2001). "Masculinidades globales, restauración y resistencia”, en Sánchez-Palencia, Carolina e Hidalgo, Juan Carlos (eds.). Masculino plural: construcciones de la masculinidad. Lleida: Edicions de la Universitat de Lleida, págs. 47-76.

KOHAN, NÉSTOR (2006). "Desafíos actuales de la teoría crítica frente al posmodernismo", Mimeo. [En línea] Fecha de consulta 4 de julio de 2019 $<$ https://www.lahaine.org/amauta/b2-img/nestor_desa.pdf $>$

KOLINSKI, FELIPE VIERO (2019). Masculinidades a la deriva en la prensa para hombres. Análisis de Junior y Men's Health Portugal. España: InCom-UAB/ Editorial UOC.

KRIPPENDORFF, KlAUS (1990). Metodología de análisis de contenido. Teoría y práctica. Barcelona: Ediciones Paidós. 
LACALlE, CHARO (2000). "Mitologías televisivas y pequeños rituales televisivos. Los talk shows", Anàlisi 24, págs. 79-92.

LEMA, EVA VICTORIA (2003). Los modelos de género masculino y femenino en el cine de Hollywood, 1990-2000 (Tesis doctoral). Madrid: Universidad Complutense de Madrid.

LEVINTON, NoRA (2000). El superyó femenino. La moral en las mujeres. Madrid: Biblioteca Nueva.

LOMAS, CARLOS (2005). “EEl otoño del patriarcado? El aprendizaje de la masculinidad y de la feminidad en la cultura de masas y la igualdad entre hombres y mujeres", Cuadernos de trabajo social 18, págs. 259-278.

LOMBARdo, EnMANUEla y LeÓn, MARgARita (2014). "Políticas de igualdad de género y sociales en España: origen, desarrollo y desmantelamiento en un contexto de crisis económica", Investigaciones Feministas 5, págs. 13-35.

LÓPEZ, MARÍA y MARCELO, LÓPEZ (2001). "Información sobre la intimidad, el dolor y la violencia: una respuesta ética", en GALDÓN, GABRIEL (coord.). Introducción a la comunicación y la información. Barcelona: Ariel, págs. 175-193.

LÓPEZ, Miguel (2016). "La desigualdad de género en televisión: la mujer en los nuevos formatos de telerrealidad”, Revista Internacional de Cultura Visual 3 (1), págs. $31-43$.

LÓPEZ, PILAR (2005). Representación de género en los informativos de radio y televisión. Madrid: Instituto de la Mujer e Instituto Oficial de Radio y Televisión.

LORDE, AUDRE (1983). “The master's tools will never dismantle the master's house”, in Moraga, CherríE and AnZALdúA, Gloria (eds.). This bridge called my back: writtings by radical women of color. NY: Kitchen Table, Women of Color Press. 98-101.

LORENTE, Miguel (2019). "El nuevo machismo del posmachismo", en TÉLlez, Anastasia, Martínez, JAVIER Eloy y SANFÉliX, JoAn (eds.). Masculinidades igualitarias y alternativas. Procesos, avances y reacciones. Valencia: Tirant Humanidades, págs. 30-50.

LOSCERTALES, FELICIDAD (2003). "El lenguaje publicitario: estereotipos discriminatorios que afectan a las mujeres”, en Instituto ANDALuZ DE LA Mujer (ed.). Medios de 
comunicación y violencia contra las mujeres. Sevilla: Instituto Andaluz de la Mujer y Fundación Audiovisual de Andalucía, págs. 95-110.

MACÍAS-GONZÁLEZ, VÍCTOR M. (2017). “Apuntes sobre la historiografía de la masculinidad y sus usos para los estudios históricos de género en México", Navegando 7, págs. 55-68.

MANOVICH, LEV (2005). El lenguaje de los nuevos medios de comunicación: la imagen en la era digital. Barcelona: Paidós.

Marín, Ma . Flora, Armentia, José Ignacio y Ganzabal, María (2010). “Claves de la construcción de género en las revistas femeninas y masculinas: análisis cuantitativo", Estudios sobre el mensaje periodístico 16, págs. 259-289.

MARTÍN, ANTONIO y GARCÍA, ALMUDENA (2011). "Construyendo la masculinidad: fútbol, violencia e identidad", RIPS. Revista de Investigaciones Políticas y Sociológicas 10 (2), págs. 73-95.

MARTÍNEZ, BEATRIZ (2014). “Televisión para hombres y televisión para mujeres: un estudio de la programación de los canales de Mediaset España que incluyen la perspectiva de género", en RODRÍGUEZ, JosÉ (coord.). Creaciones audiovisuales actuales. Madrid: ACCI, págs. 281-300.

MARTÍNEZ, JAVIER EloY (2019). "Cuerpos en riesgo. Implicaciones y consecuencias de la masculinidad en las corporeidades" en MARTíNEZ, JAVIER ELOY, TÉLLEZ, AnASTASIA y SANFÉLIX, JOAN (eds.). Deconstruyendo la masculinidad. Cultura, género e identidad. Valencia: Tirant Humanidades, págs. 85-108.

MARTÍNEZ, LOURDES (2005). "La participación de los usuarios en los contenidos periodísticos de la Red”, en LóPEZ, GuILlERMo (ed.). El ecosistema digital: modelos de comunicación, nuevos medios y público en Internet. Valencia: Universitat de València, págs. 269-332.

MARTíNEZ, NATALIA (2017). "Y todos me miran: telerrealidad y violencia de género en Cámbiame", en MENÉNDEZ, ISABEL e ILlERA, PAULA (eds.). Guerras simbólicas: el papel del audiovisual en la lucha contra la violencia de género. Palma de Mallorca: Edicions UIB, págs. 97-114.

Mateo, Carolina (2013). "Domesticidades disidentes en la ficción televisiva contemporánea", Revista Europea de Investigación en Arquitectura, págs. 117- 
127.

Mateos-PÉrez, Javier y Rebollo, Ma Antonia Paz (2018). "De la vieja a la nueva televisión en España: 1990-1994”, en MONTERO, JULIO (dir.). Una televisión con dos cadenas. La programación en España (1956-1990). Madrid: Ediciones Cátedra, págs. 805-848.

Mateos Sillero, Sara (2013). "Construcción de la feminidad normativa y sujeto político", Investigaciones Feministas 4, págs. 297-321.

McRobBie, Angela (1998). "More!: nuevas sexualidades en las revistas para chicas y mujeres", en MORley, DAVID, WALKerdine, VALERIE y CURRAN, JAMES (coord.). Estudios culturales y comunicación: análisis, producción y consumo cultural de las políticas de identidad y el posmodernismo. Barcelona: Paidós, págs. 263-296.

MedinA, HeLenA (2015). "La construcción de la masculinidad en la ficción televisiva", en Zurian, Francisco A. (coord.). Diseccionando a Adán. Representaciones audiovisuales de la masculinidad. Madrid: Síntesis, págs. 153-162.

Melgar, Luis TOMÁs (2003). Historia de la televisión. Madrid: Acento Editorial.

MenÉndeZ, Ma. IsABel (2006). El zapato de cenicienta. El cuento de hadas del discurso mediático. Oviedo: Ediciones Trabe.

MENÉNDEZ, Ma. IsABEL (2009). “Aproximación teórica al concepto de prensa femenina”, Comunicación y sociedad 22 (2), págs. 277-297.

MENÉNDEZ, Ma . ISABEL (2010). Imágenes de las mujeres en los medios de comunicación: las revistas femeninas como escenarios de la corporeidad (1976-2006) (Tesis doctoral). España: UNED.

MEnÉndeZ, Ma. IsABel (2013). "Prensa femenina internacional en la transición española: el fracaso de Cosmopolitan y Marie Claire", Ámbitos 23, 71-86.

MenÉndeZ, Ma. IsABel y Figueras, MòniCa (2013). "La evolución de la prensa femenina en España: de La Pensadora Gaditana a los blogs", Comunicació. Revista de recerca i d'anàlisi 30 (1), págs. 25-48.

MENÉNDEZ, Ma . ISABEL (2016). "Violencia simbólica en los medios de masas: postfeminismo e hipersexualización de lo femenino", en KABOUS, MAGALI, 
ZunZunegui, SAntos, Reveyron, Nicolas y SAMPER, EdGar (eds.). Image et Violence. Le cahiers du Grimh. Lyon: Université de Lyon, págs. 355-364.

MENÉNDEZ, Ma. ISABEL (2018). "Para ellas y para ellos: aproximación a las características diferenciales de la prensa femenina y masculina", en ZURIAN, FrANCISCO A. y GONZÁLEZ, DANNY (eds.). Cultura, Igualdad e Inclusión. Barranquilla, Colombia: Universidad del Atlántico, págs. 117-135.

MerCAdo, Ma. Teresa (2006). “Aportaciones teóricas en torno al concepto de periodismo especializado", Question 1 (9), [En línea] Fecha de consulta 20 de mayo de $2019<$ https://www.perio.unlp.edu.ar/ojs/index.php/question>

Millett, Kate (2010) [1969]. Política sexual. Madrid: Ediciones Cátedra.

MirA, AlBerTo(2015). "Mario Casas y el hombre depornosexual: la espectacularización erótica del cuerpo masculino", Área abierta 15 (1), págs. 15-30.

Montero, Julio y Antona, TAMARA (2018). "Programación y estrategias de programación en la televisión franquista”, en MONTERO, JULIO (dir.). Una televisión con dos cadenas. La programación en España (1956-1990). Madrid: Ediciones Cátedra, págs. 21-38.

Moya, IsABel (2010). Sin contraseña. Discurso mediático y transgresión. Madrid: AMECO.

Mulvey, LAURA (1988). "Placer visual y cine narrativo", Eutopías $2^{\circ}$ Época. Documentos de Trabajo 1, págs. 1-22.

NASH, MARY (2004). Mujeres en el mundo, historias retos y movimientos. Madrid: Alianza Editorial.

NASH, MARY (2006). "Identidades de género, mecanismos de subalternidad y procesos de emancipación femenina" en Revista Cidob d'Afers Internacionals 73-74, págs. $39-57$.

NASH, MARY (2008). "Mujeres, conciencia de género y movilizaciones sociales”, en CAPEl, Rosa MARÍA (dir.). Cien años trabajando por la igualdad. Madrid: Fundación Largo Caballero e Instituto de la Mujer, págs. 117-130. 
NASH, MARY (2014). "Nuevas mujeres de la transición. Arquetipos y feminismo", en NASH, MARY (ed.). Feminidades y masculinidades. Arquetipos y prácticas de género. Madrid: Alianza editorial págs. 189-216.

NúÑEZ, GUILlermo (2016). "Los estudios de género de los hombres y las masculinidades: ¿qué son y qué estudian?”, Culturales 4 (1), págs. 9-31.

Oliva, Mercè (2009). “¡Transfórmame, por favor! Un análisis semio-narrativo de los realities de transformación", en BIENVENIDO, LEÓN (coord.). Telerrealidad. El mundo tras el cristal. Sevilla: Comunicación Social Ediciones y Publicaciones, págs. $36-47$.

ONU (1995). Declaración de Beijing y plataforma para la acción. IV Conferencia mundial sobre las mujeres. Madrid: Ministerio de Asuntos Sociales e Instituto de la Mujer.

OrSINI, MARTA L. (2014). Prensa femenina: ¿herramienta de empoderamiento de las mujeres? (Tesis doctoral). Barcelona: Universidad Autónoma de Barcelona.

ORTEGA, EnRIQUe (1997). La comunicación publicitaria. Madrid: Pirámide.

ORTEGA, EstíbALIZ (2017). “Jóvenes adultos y prensa: un análisis de la relación y la cobertura mediática de los jóvenes al Norte y Sur del mediterráneo", Ámbitos 38, págs. 1-14.

Ortiz, MARTA (2003). "Los límites de la publicidad”, en AMECO (ed.). La imagen de la mujer en la publicidad y su influencia en los medios de comunicación. España: AMECO, págs. 117-139.

OSBORne, RAQUel y MOLINA, CRISTINA (2008). "La evolución del concepto de género: selección de textos de S. de Beauvoir, K. Millett, G. Rubin y J. Butler” en Revista de Metodología de Ciencias Sociales 15, págs. 147-182.

PAGÈS, MARÍA Del VALLE (2016). La revista Interviú como factor clave en la normalización del sexo en España (Trabajo de fin de grado). Barcelona: Universidad autónoma de Barcelona.

PALACIO, MANUEL (2002). "Francisco Franco y la televisión en España”, Materiales para una iconografía de Francisco Franco. Archivos de la Filmoteca de la Generalitat Valenciana 44, págs. 72-95. 
Palacio, Manuel (2003). Historia de la televisión en España. Barcelona: Editorial Gedisa.

PALAcios, IRENE (2007). "Mujeres aleccionando a mujeres. Discursos sobre la maternidad en el siglo XIX”, Historia de la Educación 26, págs. 111-142.

PAREDES, Francisca (2007). “Las hijas de Don Juan de Blanca de los Ríos y otros textos: donjuanismo y flamenquismo vs. regeneración nacional", Espéculo. Revista de Estudios Literarios. [En línea] Fecha de consulta 3 de julio de 2019 $<$ http://biblioteca.org.ar/libros/151855.pdf $>$

PARRATT, SONIA (2010). "Consumo de medios de comunicación y actitudes hacia la prensa por parte de los universitarios", ZER: Revista de Estudios de Comunicación 15 (28), págs. 133-149.

Pearson, Judy C., Turner, Lynn H. y ToOd-Mancillas, W. (1993) [1985]. Comunicación y género. Barcelona: Paidós Ibérica.

PeinAdo, Matilde (2012). Enseñando a señoritas y sirvientas. Formación femenina y clasismo en el franquismo. Madrid: Los Libros de la Catarata.

Pendones de Pedro, Covadonga (1996). "Estrategias discursivas en las revistas femeninas", en Actas. Congreso Internacional la Lengua y los Medios de Comunicación. Madrid: Universidad Complutense de Madrid, págs. 311-322.

Pérez, Concha, Luque, Sergio y Villena, Eduardo (2017). "Influencia de las revistas especializadas en el consumo de moda. Estudio de casos: Smoda, Elle y Harper's Bazaar", Ámbitos 39, págs. 1-27.

PÉReZ, MARÍA Ángeles (2002). "Modelos publicitarios” en Actas. Mujeres, Hombres y Medios de Comunicación. Tomo I. Junta de Castilla y León, págs. 43-53.

PÉRez, MARÍA José y Romero, María (2010). "El mercado mediático de la belleza. Estudio de la estructura de ingresos en revistas femeninas de alta gama", Revista Icono 14. Revista científica de comunicación y Tecnologías emergentes 8 (3), págs. 9-25.

PERINAT, AdOLFO y MARRADES, Mª ISABel (1980). Mujer, prensa y sociedad en España: 1800-1939. Madrid: Centro de Investigaciones sociológicas. 
PiCORNELl, MERCÈ (2010). “¿De una España viril a una España travesti? Transgresión transgénero y subversión del poder franquista en la transición española hacia la democracia”, Feminismo/s 16, págs. 281-304.

PoSADA, LUISA (2015). "El género, Foucault y algunas tensiones feministas" en Estudios de Filosofia 52, págs. 29-43.

Puleo, Alicia (2007). "Introducción al concepto de género" en PlazA, JuAN F. y Delgado, CARMEN (eds.). Género y comunicación. Madrid: Editorial Fundamentos, págs. 13-32.

Quesada, Montserrat (1998). Periodismo especializado. Madrid: Ediciones Internacionales Universitarias.

QuiLeS, MARÍA (2019). "Políticas de formación e investigación en género en la universidad española: estudios de masculinidades", en TÉLlEZ, ANASTASIA, MARTÍNEZ, JAVIER ElOY y SANFÉLIX, JOAN (eds.). Masculinidades igualitarias y alternativas. Procesos, avances y reacciones. Valencia: Tirant Humanidades, págs. 299-324.

Quintas-Froufe, NATAlia y DíAZ-GonzÁlez, María Jesús (2014). "Del apagón analógico al temático: el comportamiento de la audiencia televisiva española", Prisma Social 13, págs. 705-736.

RAMOS, MARÍA DOLORES (2014). "La construcción cultural de la feminidad en España: desde el fin del siglo XIX a los locos y politizados años veinte y treinta” en NASH, MARY (ed.). Feminidades y masculinidades. Arquetipos y prácticas de género. Madrid: Alianza editorial, págs. 21-46.

RENÉ, RENAUD (2011). "De la ambigüedad del clóset a la cultura del gueto gay: género y homosexualidad en París, Madrid y México", La ventana 34, págs. 146-190.

REY, JUAN (2006). "Los metrosexuales y übersexuales como artefactos publicitarios", Comunicar 27, págs. 19-27.

RICHERI, GIUSEPPE (1994). La transición de la televisión. Análisis del audiovisual como empresa de comunicación. Barcelona: Bosch Casa Editorial.

Roel, MARTA y GRANDíO, Ma DEL MAR (1989). “Audiencia y consumo televisivo en la era socialista", en MONTERO, Julio (dir.). Una televisión con dos cadenas. La programación en España (1956-1990). Madrid: Ediciones Cátedra. 
Roig, Mercedes (1989). A través de la prensa. La mujer en la historia. Madrid: Ministerio de Asuntos Sociales.

RomÁn, GUBERN (1980). "Permisividad sexual y comunicación social", Anàlisi: quaderns de comunicación i cultura 2, págs. 105-126.

ROSÓN, MARÍA (2017). “Colita en contexto: fotografía y feminismo durante la transición española”, Arte y politicas de identidad 16, págs. 55-74.

RUEDA, JOSÉ CARLOS (2005). “La televisión en España: expansión y consumo social, 1963-1969”, Análisi 32, págs. 45-71.

Rueda, José CARLOS y CHICHARRO, Ma DEL MAR (2006). La televisión en España (19562006). Política, consumo y cultura televisiva. Madrid: Editorial Fragua.

RUIZ, ROSARIO (2008). "Mujer y sociedad durante el franquismo”, en CAPEL, ROSA (dir.). Cien años trabajando por la igualdad. Madrid: Fundación Largo Caballero e Instituto de la Mujer, págs. 151-166.

SAINZ DE VARANDA, Clara (2013). "Orígenes de la prensa diaria deportiva: El Mundo deportivo", Materiales para la Historia del Deporte 1, págs. 7-27.

SAlgado, Alejandro (2010). "Actualidad, humor y entretenimiento en los programas de televisión: de la terminología a la realidad profesional”, Trípodos 27, págs. 5973.

SAMBADE, IVÁN (2018). "Masculinidades, cambios sociales y representación en la cultura de masas", Brocar 42, págs. 293-322.

SÁNCHEZ, MARÍA F. (2009). "Evolución de las publicaciones femeninas en España. Localización y análisis", Documentación de las Ciencias de la Información 32, págs. 217-244.

SÁnchez-Palencia, Carolina e Hidalgo, Juan Carlos (2001). "Introducción”, en Sánchez-Palencia, Carolina e Hidalgo, Juan Carlos (eds.). Masculino plural: construcciones de la masculinidad. Lleida: Edicions de la Universitat de Lleida, págs. 7-20.

SÁNCHEZ, RAMÓN (2015). Canon y estilo de la figura humana en la publicidad gráfica (Tesis doctoral). Sevilla: Universidad de Sevilla. 
SANFELIU, LuZ(2010). "Reformulando las imágenes del poder en torno a la domesticidad. La educación formal e informal como base de la ciudadanía femenina", Feminismo/s 16, págs. 83-105.

SÁnFelix, JoAn y CASCAlES, JORge (2019). "Problematizando las masculinidades igualitarias que se configuran alrededor de la estrategia de las nuevas masculinidades", en TÉllez, ANASTASIA, MARTínEZ, JAVIER EloY y SANFÉLIX, JOAN (eds.). Masculinidades igualitarias y alternativas. Procesos, avances y reacciones. Valencia: Tirant Humanidades págs. 121-142.

SAU, Victoria (2000) [1981]. Diccionario ideológico feminista. Volumen I. Barcelona: Icaria.

SCHONGUT, NiCOLAS (2011). "La construcción social de la masculinidad: poder, hegemonía y violencia”, Psicología, Conocimiento y Sociedad 2 (2), págs. 27-65.

SCHWAB, KlaUs (2016). La cuarta revolución industrial. Barcelona: Penguin Random House.

SCOTT, JOAN W. (2011). “Género: ¿Todavía una categoría útil para el análisis?” en La manzana de la discordia 6 (1), págs. 95-101.

Selva, Marta y Segura, Isabel (1984). Revistes de Dones, 1846-1935. Barcelona: Edhasta, 1984.

SHELLEY, LORNA (2009). "Female journalists and journalism in fin-de-siècle magazine stories”, Nineteenth-Century Gender Studies: Issue 5.2 (Summer 2009), [En línea] Fecha de consulta 23 de mayo de 2019 $<$ https://www.ijpc.org/uploads/files/Female\%20Journalists\%20Lorna\%20Shelle y.pdf $>$

SuÁREZ-VILlEgas, JuAN CARlos (2014). “Identidades de género y comunicación. El orden simbólico de la maternidad para educar a los hombres en igualdad", Convergencia Revista de Ciencias Sociales 65, págs. 171-191.

TÉllez, ANASTASIA y Verdú, ANA DOLORES (2011). "El significado de la masculinidad para el análisis social”, Revista Nuevas Tendencias en Antropología 2, págs. 80103. 
TORRAS, Meri (2006). "Cuerpos en serie: roles, géneros y sexualidades en CSI”, en AMECO (ed.). Mujeres en serie. Discursos de género en la ficción televisiva del nuevo milenio. Madrid: AMECO, págs. 79-102.

TORRES, ROSARIO (2008). "El creciente éxito de las revistas de moda y belleza y la mujer española contemporánea”, Global Media Journal 5, [En línea] Fecha de consulta 19 de noviembre de $2017<$ http://www.redalyc.org/articulo.oa?id=68701002>

TORTAJADA, IOLANDA y ARAÜNA, NURIA (2014). "Mujeres, violencia y posfeminismo en los vídeos de Madonna”, Área Abierta, 14 (3), págs. 24-41.

TúÑEZ, MigueL (2009). “Jóvenes y prensa en papel en la era Internet. Estudios de hábitos de lectura, criterios de jerarquía de noticias, satisfacción con los contenidos informativos y ausencias temáticas", Estudios sobre el Mensaje Periodístico 15, págs. 503-524.

UfARTE, Ma JOSÉ (2007). "Las mujeres en el seno de la profesión periodística: de la discriminación a la inserción”, Ámbitos 16, págs. 409-421.

URÍA, JORGE (2014). "Iconos de masculinidad. Los años veinte y los ases del fútbol español”, en NASh, MARY (ed). Feminidades y masculinidades. Arquetipos y prácticas de género. Madrid: Alianza editorial, págs. 159-188.

VAliENTE, Celia (2003). "Las políticas para las mujeres trabajadoras durante el franquismo", en NiElfA, GlORIA (ed.). Mujeres y hombres en la España franquista: sociedad, economía, política, cultura. Madrid: Editorial Complutense, págs. 145-180.

Varela, Elena (2015). Prensa para mujeres y para hombres. Aproximación a sus características formales y discursivas (Trabajo fin de máster). Burgos: Universidad de Burgos.

VAREla, NuRIA (2013) [2005]. Feminismo para principiantes. Barcelona: Ediciones B.

VARGAS, Mª SoledAD (2006). Estilos de vida, ética y estética en los dominicales de los diarios ABC, La Vanguardia y El País (1974-1999) (Tesis doctoral). Barcelona: Universidad Autónoma de Barcelona.

VELASCO, ANA MARÍA (2019). "De la prensa femenina tradicional a la política y los/as influencers", Revista Prisma Social 24, págs. 153-185. 
VÉLEZ, GraCiELA (2005). "Espacio y subjetividad. Orden social desde lo privado y lo público", Espacios Públicos 8 (15), págs. 150-161.

VERDUGO, ViCENTA (2010). “Desmontando el patriarcado: prácticas políticas y lemas del movimiento feminista español en la transición democrática", Feminismo/s 16, págs. 259-279.

VIDAL, Ma. CARMEN ÁFriCA (2002). “El cuerpo colonizado”, Asparkía 13, págs. 103-114.

VIDELA, José JuAN y COSTA, CARMEN (2012). “Los nuevos canales de televisión digital terrestre en España. Reconfiguración de la oferta televisiva en abierto dos años después del encendido digital”, Fonseca, Journal of Communication 5, págs. 3667.

WALter, NATASHA (2010). Muñecas vivientes. El regreso del sexismo. Madrid: Turner.

WIMMER, ROGER D. y DOMINICK, JOSEPH R. (1996). La investigación científica de los medios de comunicación. Una introducción a sus métodos. Barcelona: Bosch.

WEBSTER, FrANK (2006). "La sociedad de la información revisitada", Biblioteca Universitaria 9 (1), págs. 22-44.

WiLliams, RAYMOND (1992). Television: technology and cultural form. Londres: Routledge.

Wolf, NAOMi (1991). El mito de la belleza. Barcelona: Emecé Editores. 
ANEXOS 


\section{ANEXO 1. FICHAS DE IDENTIFICACIÓN DE LAS PUBLICACIONES QUE COMPONEN EL CORPUS DE ESTUDIO}

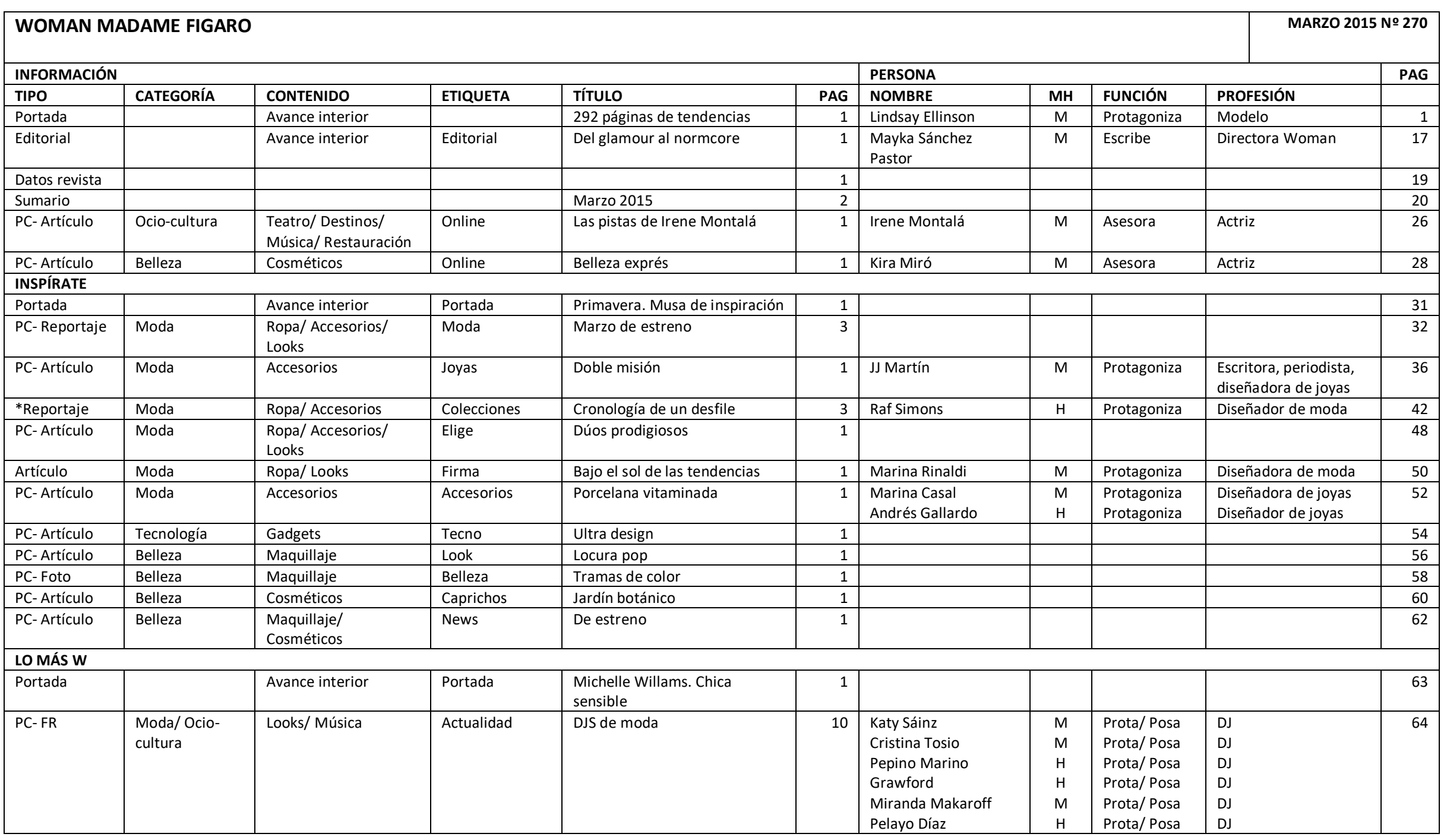




\begin{tabular}{|c|c|c|c|c|c|c|c|c|c|c|}
\hline & & & & & & $\begin{array}{l}\text { Bimba Bosé } \\
\text { Beatriz Valdivia } \\
\text { Brianda Fitz-James } \\
\text { Stuart }\end{array}$ & $\begin{array}{l}M \\
M \\
M\end{array}$ & $\begin{array}{l}\text { Prota/ Posa } \\
\text { Prota/ Posa } \\
\text { Prota/ Posa }\end{array}$ & $\begin{array}{l}\text { DJ } \\
\text { DJ } \\
\text { DJ }\end{array}$ & \\
\hline $\begin{array}{l}\text { *PC- } \\
\text { Entrevista }\end{array}$ & Ocio-cultura & Cine + personal & Entrevista & $\begin{array}{l}\text { Michelle Williams. Alma } \\
\text { sensible }\end{array}$ & 8 & Michelle Williams & $\mathrm{M}$ & Prota/ Posa & Actriz & 75 \\
\hline $\begin{array}{l}\text { *PC- } \\
\text { Entrevista }\end{array}$ & Moda & Moda + personal & En portada & Angel girl. Lindsay Ellingson & 2 & Lindsay Ellingson & $\mathrm{M}$ & Prota/ Posa & Modelo & 82 \\
\hline PC- Reportaje & Moda & Looks & La gran cita & Un love affair de Oscar & 6 & Boris Izaguirre & $\mathrm{H}$ & Escribe & Escritor & 85 \\
\hline *PC- FR & $\begin{array}{l}\text { Moda/ Ocio- } \\
\text { cultura/ Belleza }\end{array}$ & $\begin{array}{l}\text { Looks/ Maquillaje (en } \\
\text { mujeres) }\end{array}$ & Protagonistas & Lo español, de moda & 11 & $\begin{array}{l}\text { Juanjo Oliva } \\
\text { Barbara Lennie } \\
\text { Arnaud Maillard } \\
\text { Marta Español } \\
\text { Álvaro Castejón } \\
\text { Modesto Lomba } \\
\text { Ana Locking } \\
\text { Roberto Torretta } \\
\text { Moisés Nieto } \\
\text { Ángel Schlesser } \\
\text { Juan Duyos } \\
\end{array}$ & $\begin{array}{l}\mathrm{H} \\
\mathrm{M} \\
\mathrm{H} \\
\mathrm{M} \\
\mathrm{H} \\
\mathrm{H} \\
\mathrm{M} \\
\mathrm{H} \\
\mathrm{H} \\
\mathrm{H} \\
\mathrm{H}\end{array}$ & $\begin{array}{l}\text { Protagoniza } \\
\text { Posa } \\
\text { Protagoniza } \\
\text { Posa } \\
\text { Protagoniza } \\
\text { Protagoniza } \\
\text { Prota/ Posa } \\
\text { Protagoniza } \\
\text { Protagoniza } \\
\text { Protagoniza } \\
\text { Protagoniza } \\
\end{array}$ & $\begin{array}{l}\text { Diseñador de moda } \\
\text { Actriz } \\
\text { Diseñador de moda } \\
\text { Modelo } \\
\text { Diseñador de moda } \\
\text { Diseñador de moda } \\
\text { Diseñadora de moda } \\
\text { Diseñador de moda } \\
\text { Diseñador de moda } \\
\text { Diseñador de moda } \\
\text { Diseñador de moda } \\
\end{array}$ & 94 \\
\hline PC-Artículo & Ocio-cultura & Cine & Cine & Un mundo feliz & 1 & & & & & 106 \\
\hline *Entrevista & Ocio-cultura & Cine + personal & Entrevista & $\begin{array}{l}\text { La llama oculta de Mia } \\
\text { Wasikowska }\end{array}$ & 2 & Mia Wasikowska & $\mathrm{M}$ & Protagoniza & Actriz & 108 \\
\hline $\begin{array}{l}\text { *PC- } \\
\text { Entrevista }\end{array}$ & Ocio-cultura & Cine + personal & Protagonistas & $\begin{array}{l}\text { Blanca Suarez \& Yon González. } \\
\text { Feliz reencuentro }\end{array}$ & 6 & $\begin{array}{l}\text { Blanca Suarez } \\
\text { Yon González }\end{array}$ & $\begin{array}{l}\mathrm{M} \\
\mathrm{H}\end{array}$ & $\begin{array}{l}\text { Prota/ Posa } \\
\text { Prota/ Posa }\end{array}$ & $\begin{array}{l}\text { Actriz } \\
\text { Actor }\end{array}$ & 110 \\
\hline Entrevista & Ocio-cultura & Música & Música & Brillante Anni B Sweet & 1 & Ana López Rodríguez & $\mathrm{M}$ & Protagoniza & Música & 116 \\
\hline PC-Artículo & Ocio-cultura & Ropa/ Expo & Expos & Diseños de altura & 1 & & & & & 118 \\
\hline *PC- Artículo & Ocio-cultura & Expo & Arte & Ellas pintan mucho & 1 & & & & & 120 \\
\hline *PC-Artículo & Ocio-cultura & Libros & Libros & Club de lectura & 2 & & & & & 122 \\
\hline PC-Artículo & Ocio-cultura & Series & Televisión & Tus próximas series de culto & 2 & & & & & 124 \\
\hline PC-Artículo & Ocio-cultura & Teatro & Escena & Teatro con firma & 1 & & & & & 126 \\
\hline Artículo & Ocio-cultura & Cine/ Música & Tuits & Trending topics & 1 & & & & & 128 \\
\hline \multicolumn{11}{|c|}{ (Especial) MODA } \\
\hline Portada & & Avance interior & Portada & $\begin{array}{l}\text { Esta primavera reina de la } \\
\text { novedad }\end{array}$ & 1 & & & & & 129 \\
\hline PC- FR & Moda & Looks & & Eclectic Girl & 10 & Lindsay Ellington & $\mathrm{M}$ & Prota/ Posa & Modelo & 130 \\
\hline PC- FR & Moda/Belleza & Looks/ Maquillaje & & Inspiración en el salvaje oeste & 10 & & & & & 140 \\
\hline PC- FR & Moda & Looks/ Accesorios & & Manifiesto 70's & 8 & & & & & 151 \\
\hline PC- Reportaje & Moda & Looks & & Sigue las nuevas tendencias & 14 & & & & & 158 \\
\hline PC- Fotos & Moda & Ropa/ Accesorios & & 6 prendas TOP & 6 & & & & & 172 \\
\hline PC- FR & Moda/Belleza & Looks/ Cosméticos & & $\begin{array}{l}\text { Gente corriente. } 10 \text { looks de } \\
\text { moda real }\end{array}$ & 12 & & & & & 178 \\
\hline
\end{tabular}




\begin{tabular}{|c|c|c|c|c|c|c|c|c|c|c|}
\hline PC- Reportaje & Moda & $\begin{array}{l}\text { Ropa/ Accesorios/ } \\
\text { Looks }\end{array}$ & & Cuatro países que inspiran & 8 & & & & & 190 \\
\hline $\begin{array}{l}\text { *PC- } \\
\text { Reportaje }\end{array}$ & Moda & Looks & & $\begin{array}{l}\text { Red carpet vs. Street style. } \\
\text { Secretos y mentiras }\end{array}$ & 8 & $\begin{array}{l}\text { Kristen Stewart } \\
\text { Elle Fanning } \\
\text { Anna Kendrick } \\
\text { Emma Stone } \\
\text { Jennifer Lawrence } \\
\text { Lupita Nyong'o } \\
\text { Shailene Woodley } \\
\text { Chloë Moretz } \\
\text { Jessica Chastain } \\
\text { Rooney Mara } \\
\text { Amy Adams } \\
\text { Emma Watson }\end{array}$ & $\begin{array}{l}M \\
M \\
M \\
M \\
M \\
M \\
M \\
M \\
M \\
M \\
M \\
M\end{array}$ & $\begin{array}{l}\text { Prota/ Posa } \\
\text { Prota/ Posa } \\
\text { Prota/ Posa } \\
\text { Prota/ Posa } \\
\text { Prota/ Posa } \\
\text { Prota/ Posa } \\
\text { Prota/ Posa } \\
\text { Prota/ Posa } \\
\text { Prota/ Posa } \\
\text { Prota/ Posa } \\
\text { Prota/ Posa } \\
\text { Prota/ Posa }\end{array}$ & $\begin{array}{l}\text { Actriz } \\
\text { Actriz } \\
\text { Actriz } \\
\text { Actriz } \\
\text { Actriz } \\
\text { Actriz } \\
\text { Actriz } \\
\text { Actriz } \\
\text { Actriz } \\
\text { Actriz } \\
\text { Actriz } \\
\text { Actriz }\end{array}$ & 198 \\
\hline PC - Fotos & Moda & Ropa/Accesorios & & Los más buscados & 6 & & & & & 206 \\
\hline PC - Fotos & Moda & Accesorios & & Composiciones formidables & 2 & & & & & 212 \\
\hline *Artículo & $\begin{array}{l}\text { Moda/ } \\
\text { Sociedad }\end{array}$ & Moda/ Feminismo & & $\begin{array}{l}\text { Nosotras vestimos, nosotras } \\
\text { decidimos }\end{array}$ & 2 & & & & & 214 \\
\hline $\begin{array}{l}\text { *PC- } \\
\text { Reportaje }\end{array}$ & Moda/Belleza & $\begin{array}{l}\text { Ropa/ Accesorios/ } \\
\text { Maquillaje/ } \\
\text { Cosméticos }\end{array}$ & & Vestidos para marcar moda & 6 & $\begin{array}{l}\text { Marta Lasierra } \\
\text { Carmen Melgar } \\
\text { Arantxa Romann } \\
\text { Oscar Visitación }\end{array}$ & $\begin{array}{l}M \\
M \\
M \\
H\end{array}$ & $\begin{array}{l}\text { Prota/ Posa } \\
\text { Prota/ Posa } \\
\text { Prota/ Posa } \\
\text { Prota/ Posa }\end{array}$ & $\begin{array}{l}\text { Directora de moda } \\
\text { Woman } \\
\text { Jefa de moda Woman } \\
\text { Estilista Woman } \\
\text { Estilista Woman }\end{array}$ & 216 \\
\hline *Opinión & $\begin{array}{l}\text { Moda/ } \\
\text { Sociedad }\end{array}$ & Moda/ Feminismo & $\begin{array}{l}\text { Historias del } \\
\text { armario }\end{array}$ & Shirtwaist & 1 & Emma Riverola & $\mathrm{M}$ & Escribe & Escritora & 222 \\
\hline \multicolumn{11}{|l|}{ BELLEZA } \\
\hline Portada & & Avance interior & Portada & $\begin{array}{l}\text { Cambio de look. Avance de } \\
\text { tendencias }\end{array}$ & 1 & & & & & 225 \\
\hline $\begin{array}{l}\text { *PC- } \\
\text { Entrevista }\end{array}$ & $\begin{array}{l}\text { Ocio-cultura/ } \\
\text { Belleza }\end{array}$ & $\begin{array}{l}\text { Cine/ Música/ } \\
\text { Cosméticos + personal }\end{array}$ & Entrevista & $\begin{array}{l}\text { Leighton Meester. Más que } \\
\text { una cara bonita }\end{array}$ & 4 & Leighton Meester & $M$ & Protagoniza & Actriz & 226 \\
\hline PC- Reportaje & Belleza & Maquillaje & Maquillaje & El look que + se lleva. Baby face & 3 & & & & & 230 \\
\hline PC- Reportaje & Belleza & Maquillaje & Avance & 10 looks de temporada & 3 & & & & & 234 \\
\hline PC- Reportaje & Belleza & Cosméticos & Cabello & 12 ideas para cambiar & 4 & & & & & 238 \\
\hline $\begin{array}{l}\text { *PC- } \\
\text { Reportaje }\end{array}$ & $\begin{array}{l}\text { Ocio-cultura/ } \\
\text { Belleza }\end{array}$ & $\begin{array}{l}\text { Cine/ Cosméticos + } \\
\text { personal }\end{array}$ & Reportaje & $\begin{array}{l}\text { Kathie Holmes. Se siente bien } \\
\text { en su piel }\end{array}$ & 4 & Katie Holmes & $M$ & Protagoniza & Actriz & 242 \\
\hline $\begin{array}{l}\text { *PC- } \\
\text { Reportaje }\end{array}$ & Belleza & Cosméticos/ Cirugía & Cuerpo & Glúteos a la carta & 6 & & & & & 246 \\
\hline *PC-Reportaje & Belleza & $\begin{array}{l}\text { Cosméticos/ } \\
\text { Tratamientos }\end{array}$ & Cuidados & $\begin{array}{l}\text { Ácido hialurónico. La clave de } \\
\text { la juventud }\end{array}$ & 4 & & & & & 252 \\
\hline PC-Artículo & Belleza & Maquillaje & Making-of & Pasarela de maquillaje & 1 & & & & & 256 \\
\hline PC- Artículo & Belleza & Maquillaje & Make up & Exótica en bronce y tierra & 1 & & & & & 257 \\
\hline
\end{tabular}




\begin{tabular}{|c|c|c|c|c|c|c|c|c|c|c|}
\hline PC- Artículo & $\begin{array}{l}\text { Ocio-cultura/ } \\
\text { Belleza }\end{array}$ & Cine/ Maquillaje & Manipedi & Manicura de película & 1 & & & & & 258 \\
\hline PC-Artículo & Belleza & Cosméticos & A fondo & A prueba de exfoliantes & 1 & & & & & 259 \\
\hline PC-Artículo & Belleza & $\begin{array}{l}\text { Maquillaje/ } \\
\text { Cosméticos }\end{array}$ & Clips & Triunfa en look natural & 1 & & & & & 260 \\
\hline \multicolumn{11}{|l|}{ TENDENCIAS } \\
\hline Portada & & Avance interior & Portada & $\begin{array}{l}\text { Descubre y vive el embrujo de } \\
\text { Granada }\end{array}$ & 1 & & & & & 261 \\
\hline PC- Entrevista & $\begin{array}{l}\text { Moda/ } \\
\text { Decoración }\end{array}$ & Ropa/ Casa & Deco & Maya Hansen & 4 & Maya Hansen & $M$ & Protagoniza & Diseñadora de moda & 262 \\
\hline PC- Entrevista & $\begin{array}{l}\text { Moda/ } \\
\text { Decoración }\end{array}$ & Ropa/ Casa & Deco & Beba's closet & 4 & Belén Barbero & $\mathrm{M}$ & Protagoniza & Diseñadora de moda & 266 \\
\hline PC- Reportaje & Ocio-cultura & Destinos & Escapada & Hay mucha Granada & 4 & & & & & 270 \\
\hline PC- Reportaje & Ocio-cultura & Restauración & Restaurantes & Déjate sorprender & 3 & & & & & 274 \\
\hline PC-Artículo & Gastronomía & Restauración & Gourmet & Mercados VIP & 2 & & & & & 278 \\
\hline PC- Artículo & Ocio-cultura & $\begin{array}{l}\text { Destinos/ } \\
\text { Restauración }\end{array}$ & Ciudades & Avilés: tercera vía & 1 & & & & & 280 \\
\hline PC-Artículo & Tecnología & Motor & Motor & Audi TT Roadster destapado & 1 & & & & & 281 \\
\hline PC-Artículo & Moda & Ropa & Tendencias & Astros & 1 & & & & & 282 \\
\hline Directorio & & & Tendencias & Direcciones & 2 & & & & & 286 \\
\hline PC- Artículo & Moda/Belleza & $\begin{array}{l}\text { Ropa/ Accesorios/ } \\
\text { Maquillaje/ } \\
\text { Cosméticos }\end{array}$ & Ideas & Últimos apuntes & 2 & & & & & 288 \\
\hline PC-Artículo & Moda & Accesorios & Flechazo & T de triunfo & 1 & & & & & 290 \\
\hline
\end{tabular}




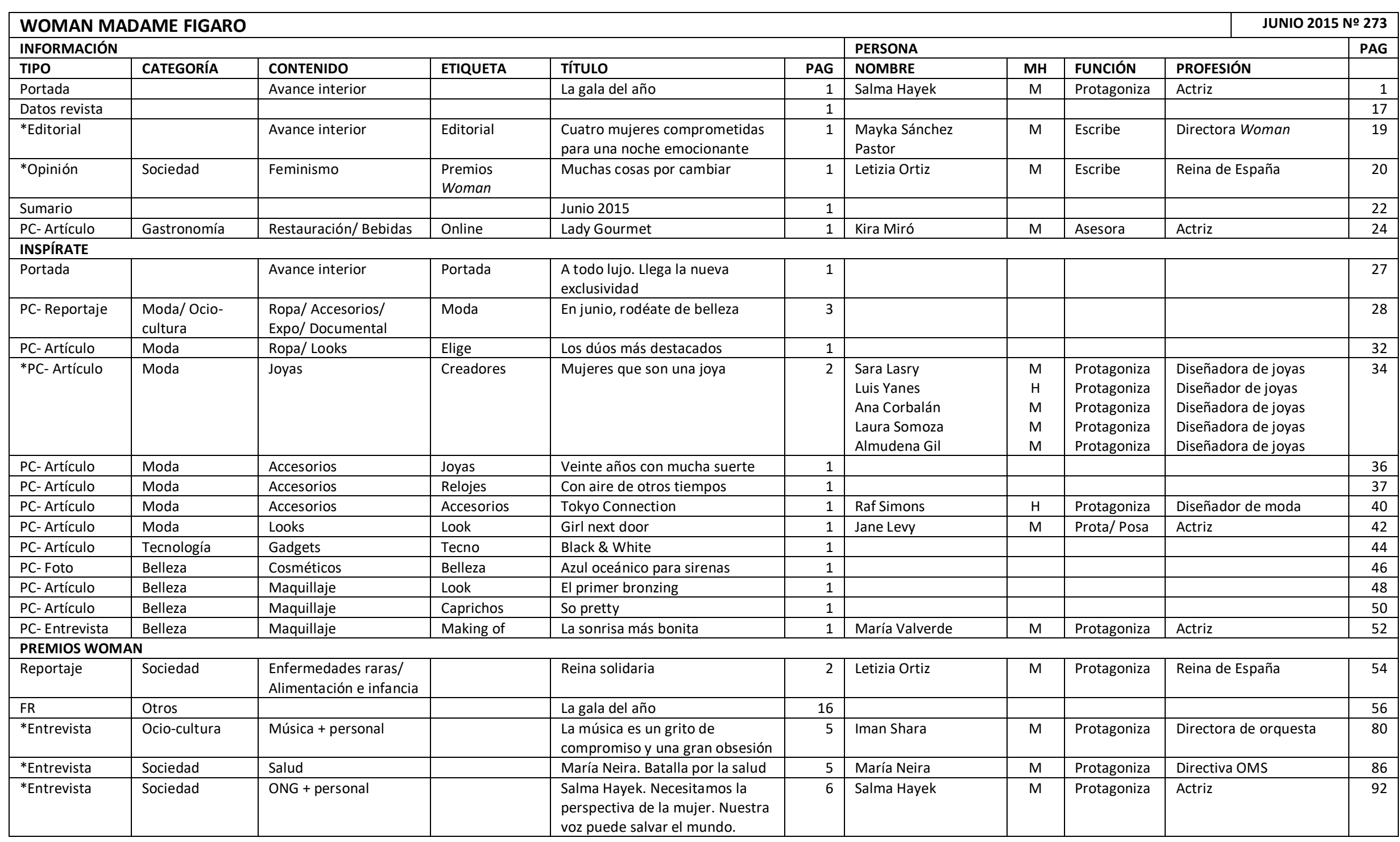




\begin{tabular}{|c|c|c|c|c|c|c|c|c|c|c|}
\hline \multicolumn{11}{|l|}{ LO MÁs W } \\
\hline Entrevista & Moda & $\begin{array}{l}\text { Moda/ Cosméticos + } \\
\text { personal }\end{array}$ & Entrevista & $\begin{array}{l}\text { Modelo a seguir. Anne-Marie } \\
\text { van Dijk }\end{array}$ & 2 & Anne-Marie van Dijk & $M$ & Protagoniza & Modelo & 100 \\
\hline Entrevista & Ocio-cultura & Cine + personal & Cine & $\begin{array}{l}\text { Dani Rovira \& María Valverde. } \\
\text { Pareja de Goya }\end{array}$ & 6 & $\begin{array}{l}\text { Dani Rovira } \\
\text { María Valverde }\end{array}$ & $\begin{array}{l}\mathrm{H} \\
\mathrm{M}\end{array}$ & $\begin{array}{l}\text { Protagoniza } \\
\text { Protagoniza }\end{array}$ & $\begin{array}{l}\text { Actor } \\
\text { Actriz }\end{array}$ & 101 \\
\hline Reportaje & Ocio-cultura & Cine & Icono & Marion Cotillard & 2 & Marion Cotillard & $\mathrm{M}$ & Protagoniza & Actriz & 108 \\
\hline PC-Artículo & Ocio-cultura & Cine & Cine & Leticia Dolera dirige & 1 & Leticia Dolera & $M$ & Protagoniza & Actriz & 110 \\
\hline PC- Entrevista & Ocio-cultura & Música & Música & Una promesa eléctrica & 1 & Mónica Vázquez & $\mathrm{M}$ & Protagoniza & Cantante & 111 \\
\hline PC-Artículo & Ocio-cultura & Festival & Agenda & Todos a bailar & 1 & & & & & 112 \\
\hline *PC- Artículo & Ocio-cultura & Música & Perfil & Caótica Florence & 1 & Florence Welch & $\mathrm{M}$ & Protagoniza & Cantante & 113 \\
\hline Entrevista & Otros & Profesional & De cerca & Paula Carrera conquista & 1 & Paula Carrera & $M$ & Protagoniza & $\begin{array}{l}\text { Empresaria de la } \\
\text { comunicación }\end{array}$ & 114 \\
\hline PC-Artículo & Ocio-cultura & Libros & Libros & Grandes autoras & 1 & $\begin{array}{l}\text { Isabel Allende } \\
\text { Jessie Burton } \\
\text { Lorrie Moore } \\
\text { Marian Engel } \\
\text { Cynthia Ozick } \\
\text { Rosa Tibas } \\
\text { Sissel-Jo Gazan } \\
\text { Mari Jungs-tedt } \\
\text { Mariam Petros-jan } \\
\text { Christine Kabus }\end{array}$ & $\begin{array}{l}M \\
M \\
M \\
M \\
M \\
M \\
M \\
M \\
M \\
M\end{array}$ & $\begin{array}{l}\text { Protagoniza } \\
\text { Protagoniza } \\
\text { Protagoniza } \\
\text { Protagoniza } \\
\text { Protagoniza } \\
\text { Protagoniza } \\
\text { Protagoniza } \\
\text { Protagoniza } \\
\text { Protagoniza } \\
\text { Protagoniza }\end{array}$ & $\begin{array}{l}\text { Escritora } \\
\text { Escritora } \\
\text { Escritora } \\
\text { Escritora } \\
\text { Escritora } \\
\text { Escritora } \\
\text { Escritora } \\
\text { Escritora } \\
\text { Escritora } \\
\text { Escritora }\end{array}$ & 115 \\
\hline PC-Artículo & Ocio-cultura & Arte & Expos & Todopoderoso Koons & 1 & Jeff Koons & $\mathrm{H}$ & Protagoniza & Escultor & 116 \\
\hline PC-Artículo & Ocio-cultura & Expo & Arte & Objetivo latino & 1 & & & & & 118 \\
\hline \multicolumn{11}{|l|}{ MODA } \\
\hline Portada & & Avance interior & Portada & $\begin{array}{l}\text { Pura moda. El verano se viste de } \\
\text { magia }\end{array}$ & 1 & & & & & 119 \\
\hline PC- FR & Moda & Looks & & Vestidos que alegran el verano & 8 & & & & & 120 \\
\hline PC-FR & Moda & Looks & & Look road movie & 6 & & & & & 128 \\
\hline \multicolumn{11}{|l|}{ SHOPPING } \\
\hline PC- Reportaje & Moda & Ropa/ Accesorios & Tendencias & Claves de verano & 8 & & & & & 134 \\
\hline PC- FR & Moda & Ropa & Tendencias & Blanco \& arena & 6 & & & & & 142 \\
\hline PC- Fotos & Moda & Ropa/ Accesorios & Básicos & Cuando calienta el sol & 8 & & & & & 149 \\
\hline PC-Artículo & Moda & Ropa & Firma & Un verano de ensueño & 1 & & & & & 158 \\
\hline Opinión & Otros & & $\begin{array}{l}\text { Historias del } \\
\text { armario }\end{array}$ & Al otro lado & 1 & Emma Riverola & $M$ & Escribe & Escritora & 160 \\
\hline PC-Artículo & Moda & Ropa/Accesorios & Tendencias & Nuevas sensaciones & 1 & & & & & 162 \\
\hline \multicolumn{11}{|l|}{ BELLEZA } \\
\hline Portada & & Avance interior & Portada & $\begin{array}{l}\text { Make up seductor. Piel perfecta } \\
\text { bajo el sol }\end{array}$ & 1 & & & & & 163 \\
\hline PC- FR & Belleza & Maquillaje & Maquillaje & $\begin{array}{l}\text { Mediterránea, femenina y } \\
\text { sensual }\end{array}$ & 6 & $\begin{array}{l}\text { Massimiliano Della } \\
\text { Maggesa }\end{array}$ & $\mathrm{H}$ & Protagoniza & Maquillador & 164 \\
\hline
\end{tabular}




\begin{tabular}{|c|c|c|c|c|c|c|c|c|c|c|}
\hline PC- Reportaje & Belleza & Maquillaje & $\begin{array}{l}\text { Premios } \\
\text { Woman }\end{array}$ & Guapas para la gala & 2 & & & & & 170 \\
\hline PC- Reportaje & Belleza & Cosméticos & Cuidados & Escuela de sol & 6 & & & & & 172 \\
\hline PC- Reportaje & Belleza & Cosméticos & Novedad & Lo último en bronceado & 2 & & & & & 180 \\
\hline PC- Reportaje & Belleza & Cosméticos & Cuerpo & Aliados para lucir piernas & 2 & & & & & 182 \\
\hline PC- Reportaje & Belleza/Moda & Maquillaje/ Accesorios & Tendencias & Mani.pedi 3.0 & 3 & & & & & 184 \\
\hline PC- Reportaje & Belleza & Maquillaje & Tendencias & 3 efectos de temporada & 2 & & & & & 188 \\
\hline PC-Artículo & Belleza & Cosméticos & Clips & Lista para pisar la playa... & 1 & & & & & 190 \\
\hline \multicolumn{11}{|l|}{ TENDENCIAS } \\
\hline Portada & & Avance interior & Portada & Especial viajes. Volando voy & 1 & & & & & 191 \\
\hline PC- Reportaje & $\begin{array}{l}\text { Ocio-cultura/ } \\
\text { Moda }\end{array}$ & Destinos/Looks & Hot list & Viajeras con estilo & 11 & & & & & 192 \\
\hline *Reportaje & $\begin{array}{l}\text { Moda/ } \\
\text { Decoración }\end{array}$ & Atelier/Moda & Deco & Moda de cine & 4 & $\begin{array}{l}\text { Fernando García } \\
\text { Antonio García }\end{array}$ & $\begin{array}{l}\mathrm{H} \\
\mathrm{H} \\
\end{array}$ & $\begin{array}{l}\text { Protagoniza } \\
\text { Protagoniza }\end{array}$ & $\begin{array}{l}\text { Diseñador de moda } \\
\text { Diseñador de moda }\end{array}$ & 204 \\
\hline PC-Artículo & Gastronomía & Bebidas & Gourmet & Las copas son para el verano & 2 & & & & & 208 \\
\hline Artículo & Salud & Deporte & & El equilibrio perfecto & 1 & & & & & 209 \\
\hline Artículo & Otros & $\begin{array}{l}\text { Profesional (in } \\
\text { memoriam) }\end{array}$ & Comunicación & En la memoria & 1 & Queca Campillo & $M$ & Protagoniza & Fotoperiodista & 210 \\
\hline PC- Horóscopo & Moda & Accesorios & Tendencias & Astros & 1 & & & & & 212 \\
\hline Directorio & & & Tendencias & Direcciones & 1 & & & & & 215 \\
\hline PC- Reportaje & Belleza & Cosméticos/Maquillaje & Ideas & Últimos apuntes & 2 & & & & & 216 \\
\hline PC-Artículo & Moda & Accesorios & Flechazo & Un oasis mediterráneo & 1 & & & & & 218 \\
\hline
\end{tabular}




\begin{tabular}{|c|c|c|c|c|c|c|c|c|c|c|}
\hline \multirow{2}{*}{\multicolumn{6}{|c|}{$\begin{array}{l}\text { WOMAN MADAME FIGARO } \\
\text { INFORMACIÓN }\end{array}$}} & & \multicolumn{2}{|c|}{$\begin{array}{r}\text { SEPTIEMBRE } 2015 \\
\text { № } 276\end{array}$} \\
\hline & & & & & & PERSONA & & & & PAG \\
\hline TIPO & CATEGORÍA & CONTENIDO & ETIQUETA & TÍTULO & PAG & NOMBRE & MH & FUNCIÓN & PROFESIÓN & \\
\hline Portada & & Avance interior & & 244 páginas de moda & 1 & Heather Marks & $\mathrm{M}$ & Protagoniza & Modelo & 1 \\
\hline Editorial & & Avance interior & Editorial & La moda te pertenece & 1 & $\begin{array}{l}\text { Mayka Sánchez } \\
\text { Pastor }\end{array}$ & $M$ & Escribe & Directora Woman & 17 \\
\hline Datos revista & & & & & 1 & & & & & 19 \\
\hline Sumario & & & & Septiembre 2015 & 2 & & & & & 20 \\
\hline PC- Artículo & $\begin{array}{l}\text { Salud/ Ocio- } \\
\text { cultura }\end{array}$ & Deporte/ Destinos & Online & Detoxícate con Kira Miró & 1 & Kira Miró & $M$ & Asesora & Actriz & 24 \\
\hline $\begin{array}{l}\text { PC- Artículo } \\
\text { Entrevista }\end{array}$ & $\begin{array}{l}\text { Decoración } \\
\text { Decoración }\end{array}$ & $\begin{array}{l}\text { Objetos deco } \\
\text { Profesional }\end{array}$ & Online & $\begin{array}{l}\text { Redecora con Irene Montalá } \\
\text { "El vintaje toca a su fin en deco" }\end{array}$ & 1 & $\begin{array}{l}\text { Irene Montalá } \\
\text { Patricia Galdón }\end{array}$ & $\begin{array}{l}\mathrm{M} \\
\mathrm{M}\end{array}$ & $\begin{array}{l}\text { Asesora } \\
\text { Protagoniza }\end{array}$ & $\begin{array}{l}\text { Actriz } \\
\text { Interiorista }\end{array}$ & 26 \\
\hline \multicolumn{11}{|l|}{ INSPÍRATE } \\
\hline Portada & & Avance interior & Portada & Bienvenido, plan renove & 1 & & & & & 29 \\
\hline PC- Reportaje & Moda & Ropa/ Accesorios & Moda & Despierta tu pasión por lo nuevo & 3 & $\begin{array}{l}\text { Alessandro Michele } \\
\text { John Galliano } \\
\text { Ángela Esteban } \\
\text { Librero } \\
\text { France Lamy } \\
\text { Herbeau } \\
\text { Jeanne Damas }\end{array}$ & $\begin{array}{l}\mathrm{H} \\
\mathrm{H} \\
\mathrm{M} \\
\mathrm{M} \\
\mathrm{M}\end{array}$ & $\begin{array}{l}\text { Protagoniza } \\
\text { Protagoniza } \\
\text { Protagoniza } \\
\text { Protagoniza } \\
\text { Protagoniza } \\
\end{array}$ & $\begin{array}{l}\text { Diseñador de moda } \\
\text { Diseñador de moda } \\
\text { Diseñadora de moda } \\
\text { Diseñadora de moda } \\
\text { Modelo }\end{array}$ & 30 \\
\hline PC- Artículo & Moda & Accesorios & Relojes & Horas diurnas y nocturnas & 1 & & & & & 36 \\
\hline PC- Artículo & Moda & Ropa & Tejidos & El poder de lo exquisito & 1 & $\begin{array}{l}\text { Anna Molinari } \\
\text { Gianpalo Tarabini }\end{array}$ & $\begin{array}{l}\mathrm{M} \\
\mathrm{H}\end{array}$ & $\begin{array}{l}\text { Protagoniza } \\
\text { Protagoniza }\end{array}$ & $\begin{array}{l}\text { Diseñador de moda } \\
\text { Diseñadora de moda }\end{array}$ & 38 \\
\hline PC- Artículo & Moda & Ropa & Making of & Viva la mamma! & 1 & $\begin{array}{l}\text { Domenico Dolce } \\
\text { Stefano Gabbana }\end{array}$ & $\begin{array}{l}\mathrm{H} \\
\mathrm{H} \\
\end{array}$ & $\begin{array}{l}\text { Protagoniza } \\
\text { Protagoniza }\end{array}$ & $\begin{array}{l}\text { Diseñador de moda } \\
\text { Diseñador de moda }\end{array}$ & 42 \\
\hline PC-Artículo & Moda & Ropa/ Accesorios & Elige & Tandems que funcionan & 1 & & & & & 44 \\
\hline *PC- Artículo & Moda & Moda & Firma & Una historia de belleza real & 1 & Patricia Arquette & M & Protagoniza & Actriz & 46 \\
\hline PC-Artículo & Ocio-cultura & Cine & Celeb & Cuento de hadas & 1 & Lily James & $\mathrm{M}$ & Protagoniza & Actriz & 48 \\
\hline PC- Artículo & Moda & Zapatos & Accesorios & El rescate del artesano & 1 & $\begin{array}{l}\text { Irene Magro } \\
\text { Ana Cardona }\end{array}$ & $\begin{array}{l}\mathrm{M} \\
\mathrm{M}\end{array}$ & $\begin{array}{l}\text { Protagoniza } \\
\text { Protagoniza }\end{array}$ & $\begin{array}{l}\text { Diseñadora de moda } \\
\text { Diseñadora de moda }\end{array}$ & 52 \\
\hline PC- Fotos & Tecno & Gadgets & Tecno & Golden age & 1 & & & & & 54 \\
\hline PC-Artículo & Belleza & Cosméticos & Belleza & Resetear la piel & 1 & & & & & 56 \\
\hline PC-Artículo & Belleza & Maquillaje & Look & ¡Hello strobing! & 1 & & & & & 58 \\
\hline *PC- Entrevista & Belleza & Perfume + personal & News & Lo eterno es ahora & 1 & $\begin{array}{l}\text { Tobias Sorensen } \\
\text { Jasmine Tookes* }\end{array}$ & $\begin{array}{l}\mathrm{H} \\
\mathrm{M}\end{array}$ & $\begin{array}{l}\text { Protagoniza } \\
\text { Protagoniza }\end{array}$ & $\begin{array}{l}\text { Modelo } \\
\text { Modelo }\end{array}$ & 60 \\
\hline PC-Artículo & Belleza & Maquillaje & Caprichos & Arte alternativo & 1 & & & & & 62 \\
\hline \multicolumn{11}{|l|}{ LO MÁs W } \\
\hline Portada & & Avance interior & Portada & $\begin{array}{l}\text { Con regresión. Vuelve el mejor } \\
\text { Amenábar }\end{array}$ & 1 & & & & & 65 \\
\hline
\end{tabular}




\begin{tabular}{|c|c|c|c|c|c|c|c|c|c|c|}
\hline Entrevista & Ocio-cultura & Cine & Cine & Los cuatro magníficos & 6 & $\begin{array}{l}\text { Fernando León de } \\
\text { Aranoa } \\
\text { Alejandro Amenábar } \\
\text { Julio Medém } \\
\text { Álex de la Iglesia } \\
\end{array}$ & $\begin{array}{l}\mathrm{H} \\
\mathrm{H} \\
\mathrm{H} \\
\mathrm{H}\end{array}$ & $\begin{array}{l}\text { Protagoniza } \\
\text { Protagoniza } \\
\text { Protagoniza } \\
\text { Protagoniza } \\
\end{array}$ & $\begin{array}{l}\text { Director de cine } \\
\text { Director de cine } \\
\text { Director de cine } \\
\text { Director de cine }\end{array}$ & 66 \\
\hline${ }^{*}$ Artículo & Ocio-cultura & Cine & Cine & La mirada del éxito & 1 & Emma Stone & $\mathrm{M}$ & Protagoniza & Actriz & 72 \\
\hline PC-Artículo & Ocio-cultura & Cine & Estrenos & Contra viento y marea & 1 & & & & & 74 \\
\hline PC- Reportaje & Ocio-cultura & Series & Televisión & Avalancha de series & 2 & & & & & 76 \\
\hline PC- Entrevista & Ocio-cultura & Cine & Entrevista & $\begin{array}{l}\text { Quim Gutiérrez presenta } \\
\text { Anacleto }\end{array}$ & 4 & Quim Gutiérrez & $\mathrm{H}$ & Protagoniza & Actor & 80 \\
\hline *Entrevista & $\begin{array}{l}\text { Ocio-cultura/ } \\
\text { Belleza }\end{array}$ & Televisión + personal & Primer plano & $\begin{array}{l}\text { Eva González. Buena materia } \\
\text { prima }\end{array}$ & 6 & Eva González & $M$ & Prota/ Posa & $\begin{array}{l}\text { Presentadora de } \\
\text { televisión }\end{array}$ & 84 \\
\hline PC- Entrevista & Ocio-cultura & Libros + personal & Tendencia & Universo ilustrado & 3 & $\begin{array}{l}\text { Lyona } \\
\text { Agustina Guerrero } \\
\text { Paula Bonet } \\
\text { Sara Herranz } \\
\text { Raquel Córcoles } \\
\text { Sara Morante } \\
\end{array}$ & $\begin{array}{l}\mathrm{M} \\
\mathrm{M} \\
\mathrm{M} \\
\mathrm{M} \\
\mathrm{M} \\
\mathrm{M}\end{array}$ & $\begin{array}{l}\text { Protagoniza } \\
\text { Protagoniza } \\
\text { Protagoniza } \\
\text { Protagoniza } \\
\text { Protagoniza } \\
\text { Protagoniza } \\
\end{array}$ & $\begin{array}{l}\text { Ilustradora } \\
\text { llustradora } \\
\text { Ilustradora } \\
\text { llustradora } \\
\text { Ilustradora } \\
\text { Ilustradora }\end{array}$ & 90 \\
\hline PC-Artículo & Ocio-cultura & Exposición & Arte & Nueva mirada pop & 1 & & & & & 94 \\
\hline PC-Artículo & Ocio-cultura & Libros & Libros & Las mil caras de Bowie & 1 & & & & & 96 \\
\hline PC-Artículo & Ocio-cultura & Teatro & Agenda & Una rentrée intensa & 1 & & & & & 98 \\
\hline PC-Artículo & Ocio-cultura & Música & Música & Están de vuelta & 1 & & & & & 99 \\
\hline \multicolumn{11}{|c|}{ (Especial) MODA } \\
\hline Portada & & Avance interior & Portada & Septiembre. Marca el ritmo & 1 & & & & & 101 \\
\hline PC- FR & Moda & Looks & Especial moda & Esto es moda & 10 & Heather Marks & M & Prota/ Posa & Modelo & 102 \\
\hline PC- FR & Moda/ Belleza & Looks/ Maquillaje & Especial moda & Alta elegancia & 10 & & & & & 112 \\
\hline PC- Reportaje & Moda & Looks & Especial moda & Tendencias que arden & 10 & & & & & 122 \\
\hline PC- Fotos & Moda & Ropa/ Accesorios & Especial moda & 8 prendas que amar & 8 & & & & & 132 \\
\hline PC- Entrevista & Moda & Moda & Especial moda & Al descubierto Heather Marks & 2 & Heather Marks & $\mathrm{M}$ & Prota/ Posa & Modelo & 140 \\
\hline PC- FR & Moda/Belleza & Looks/ Maquillaje & Especial moda & Cómo ser trendy & 10 & & & & & 142 \\
\hline PC- Reportaje & Moda & Accesorios & Especial moda & $\begin{array}{l}\text { Los mejores } 26 \text { accesorios del } \\
\text { año }\end{array}$ & 6 & & & & & 152 \\
\hline PC- Entrevista & Moda & Moda + personal & Especial moda & $\begin{array}{l}\text { Tommy Hil Figger. Mente } \\
\text { tecnológica }\end{array}$ & 4 & Tommy Hil Figger & $\mathrm{H}$ & Protagoniza & Diseñador de moda & 158 \\
\hline PC- Reportaje & $\begin{array}{l}\text { Moda/ Ocio- } \\
\text { cultura }\end{array}$ & Looks/Cine & Especial moda & El lado oscuro de la moda & 2 & & & & & 162 \\
\hline PC- Reportaje & Moda & Moda & Especial moda & Louis Vuitton. Una galería en casa & 4 & & & & & 164 \\
\hline PC- Reportaje & Moda & Ropa/Accesorios & Especial moda & Looks para un otoño perfecto & 2 & & & & & 168 \\
\hline Reportaje & Moda & Looks & Especial moda & No $\sin$ mi estilista & 6 & $\begin{array}{l}\text { Micaela Erlanger } \\
\text { Kate Young } \\
\text { Petra Flannery } \\
\text { Elizabeth Stewart }\end{array}$ & $\begin{array}{l}\mathrm{M} \\
\mathrm{M} \\
\mathrm{M} \\
\mathrm{M}\end{array}$ & $\begin{array}{l}\text { Protagoniza } \\
\text { Protagoniza } \\
\text { Protagoniza } \\
\text { Protagoniza }\end{array}$ & $\begin{array}{l}\text { Estilista } \\
\text { Estilista } \\
\text { Estilista } \\
\text { Estilista }\end{array}$ & 170 \\
\hline
\end{tabular}




\begin{tabular}{|c|c|c|c|c|c|c|c|c|c|c|}
\hline & & & & & & $\begin{array}{l}\text { Leslie Fremar } \\
\text { Leith Clark } \\
\text { Rebecca Corbin- } \\
\text { Murray }\end{array}$ & $\begin{array}{l}M \\
M \\
M\end{array}$ & $\begin{array}{l}\text { Protagoniza } \\
\text { Protagoniza } \\
\text { Protagoniza }\end{array}$ & $\begin{array}{l}\text { Estilista } \\
\text { Estilista } \\
\text { Estilista }\end{array}$ & \\
\hline PC-Artículo & Moda & Ropa/Accesorios & Especial moda & El ritmo de Londres & 1 & & & & & 176 \\
\hline *Opinión & $\begin{array}{l}\text { Moda/ } \\
\text { Sociedad }\end{array}$ & Moda/ Feminismo & $\begin{array}{l}\text { Historias del } \\
\text { armario }\end{array}$ & Libertad de movimientos & 1 & Emma Riverola & $\mathrm{M}$ & Escribe & Escritora & 177 \\
\hline PC- Artículo & Moda & Ropa & Especial moda & Un otoño en vaqueros & 1 & & & & & 178 \\
\hline \multicolumn{11}{|l|}{ BELLEZA } \\
\hline Portada & & Avance interior & Portada & $\begin{array}{l}\text { Grandes Hits. Todo lo nuevo está } \\
\text { aquí }\end{array}$ & 1 & & & & & 179 \\
\hline PC- Reportaje & Belleza & Maquillaje & Maquillaje & 12 looks que llevarás & 4 & & & & & 180 \\
\hline PC- FR & Belleza & Maquillaje & Maquillaje & Arreglos florales & 6 & & & & & 184 \\
\hline PC- Reportaje & Belleza & $\begin{array}{l}\text { Perfumes/ } \\
\text { Cosméticos/ } \\
\text { Tratamientos/ } \\
\text { Maquillaje }\end{array}$ & Estreno & Qué hay de nuevo & 6 & & & & & 190 \\
\hline *PC- Entrevista & Belleza & Cosméticos + personal & Protagonistas & No solo genética & 4 & $\begin{array}{l}\text { Amelia Bono } \\
\text { Maribel Yébenes } \\
\text { Ana Rodríguez } \\
\text { Ángel Durántez }\end{array}$ & $\begin{array}{l}M \\
M \\
M \\
H\end{array}$ & $\begin{array}{l}\text { Prota/ Posa } \\
\text { Prota/ Posa } \\
\text { Prota/ Posa } \\
\text { Asesora }\end{array}$ & $\begin{array}{l}\text { No especifica } \\
\text { Esteticista } \\
\text { No especifica } \\
\text { Dermatólogo }\end{array}$ & 198 \\
\hline PC- Reportaje & Belleza & Cosméticos & Cuidados & Plan renove por - de $50 €$ & 3 & & & & & 202 \\
\hline PC- Artículo & Belleza & Cosméticos & Innovación & Revolución pro firmeza & 1 & & & & & 205 \\
\hline PC- Reportaje & Belleza & Cosméticos & Cabello & La hora del cambio & 4 & & & & & 206 \\
\hline PC-Artículo & Belleza & Maquillaje & Making of & Las 2 caras del make up & 1 & & & & & 210 \\
\hline \multicolumn{11}{|l|}{ TENDENCIAS } \\
\hline Portada & & Avance interior & Portada & Destinos cool. Un baño futurista & 1 & & & & & 211 \\
\hline PC- Reportaje & Moda & Pasarelas & Destinos & Nuevas capitales de la moda & 4 & & & & & 212 \\
\hline Entrevista & Deco/Moda & Joyas/Casa & Deco & Anton Heunis & 4 & Anton Heunis & $\mathrm{H}$ & Protagoniza & Diseñador de joyas & 216 \\
\hline PC- Reportaje & Ocio-cultura & Destinos & Escapadas & Hoteles bikefriendly & 3 & & & & & 220 \\
\hline PC- Reportaje & Ocio-cultura & Destinos & Hoteles & ¡Aún queda verano! & 2 & & & & & 224 \\
\hline PC- Artículo & Ocio-cultura & Restauración & Restaurantes & Dónde celebrar la rentrée & 2 & & & & & 226 \\
\hline PC- Artículo & Ocio-cultura & Bebidas & Gourmet & La fiebre del vermut & 1 & & & & & 228 \\
\hline Entrevista & Otros & Deporte + personal & Emprendedoras & Rumbo al éxito & 4 & Teresa Perales & $M$ & Protagoniza & Deportista paralímpica & 230 \\
\hline PC- Artículo & Ocio-cultura & Destinos & Ciudades & Poble Nou renace & 1 & & & & & 234 \\
\hline PC-Artículo & Ocio-cultura & Teatro & Firmas & Pasiones indomables & 1 & & & & & 234 \\
\hline PC-Artículo & Tecnología & Motor & Motor & Siéntete poderosa & 1 & & & & & 236 \\
\hline PC- Horóscopo & Moda & Accesorios & Horóscopo & Virgo & 1 & & & & & 237 \\
\hline Direcciones & & & Tendencias & Direcciones & 1 & & & & & 239 \\
\hline PC- Reportaje & Moda/Belleza & $\begin{array}{l}\text { Accesorios/ } \\
\text { Maquillaje/ } \\
\text { Cosméticos }\end{array}$ & Tendencias & Últimos apuntes & 2 & & & & & 240 \\
\hline
\end{tabular}




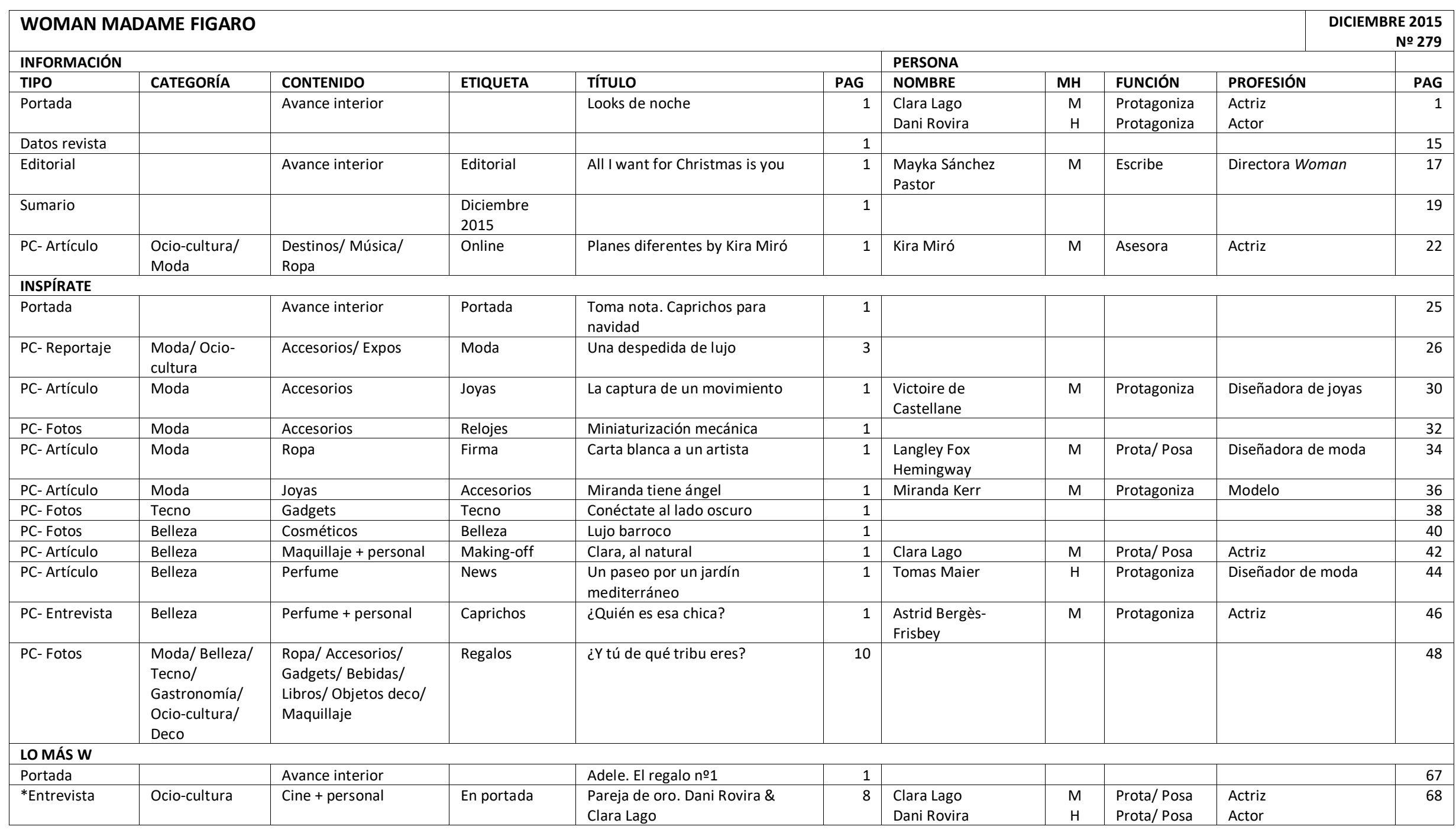




\begin{tabular}{|c|c|c|c|c|c|c|c|c|c|c|}
\hline PC-Reportaje & $\begin{array}{l}\text { Ocio-cultura/ } \\
\text { Moda/Belleza }\end{array}$ & $\begin{array}{l}\text { Expos/Maquillaje/ } \\
\text { Accesorios/ Música/ } \\
\text { Lecturas/ Teatro }\end{array}$ & Ocio & 18 planes apasionantes & 6 & & & & & 76 \\
\hline Entrevista & Ocio-cultura & Cine & Protagonista & Daisy Ridley. El rostro del futuro & 2 & Daisy Ridley & $M$ & Protagoniza & Actriz & 86 \\
\hline PC- Reportaje & Ocio-cultura & Cine & Cine & Galaxia Star Wars & 2 & & & & & 88 \\
\hline Entrevista & Ocio-cultura & Música + personal & Entrevista & Descifrando a Aldo Comas & 2 & Aldo Comas & $\mathrm{H}$ & Protagoniza & Cantante & 92 \\
\hline PC-Artículo & Ocio-cultura & Libros & Lecturas & Diversión entre libros & 1 & & & & & 94 \\
\hline Entrevista & Ocio-cultura & Libros + personal & Primer plano & Elvira Lindo se desnuda & 2 & Elvira Lindo & $\mathrm{M}$ & Protagoniza & Escritora & 96 \\
\hline Reportaje & Moda & Marca & Evento & Un show único & 4 & & & & & 100 \\
\hline \multicolumn{11}{|l|}{ MODA } \\
\hline Portada & & Avance interior & Portada & $\begin{array}{l}\text { Despide el año. La mejor moda } \\
\text { para brillar }\end{array}$ & 1 & & & & & 107 \\
\hline PC- FR & Moda/ Belleza & Looks/ Maquillaje & & Preparty & 10 & & & & & 108 \\
\hline PC- FR & Moda & Looks & & El show más dulce & 8 & & & & & 118 \\
\hline PC- FR & Moda & Looks & & $\mathrm{VL}$ & 8 & Vanesa Lorenzo & $\mathrm{M}$ & Prota/Posa & Modelo & 126 \\
\hline \multicolumn{11}{|l|}{ SHOPPING } \\
\hline PC- Reportaje & Moda/Belleza & $\begin{array}{l}\text { Ropa/ Accesorios/ } \\
\text { Maquillaje }\end{array}$ & Fiesta & Hot fashion Christmas & 8 & & & & & 134 \\
\hline PC-FR & Moda & Accesorios & Accesorios & La última fiesta del año & 4 & & & & & 143 \\
\hline PC- Fotos & Moda & Ropa/ Accesorios & Prendas & Inversión segura & 4 & & & & & 148 \\
\hline PC- Reportaje & $\begin{array}{l}\text { Moda/ Ocio- } \\
\text { cultura }\end{array}$ & Marca/ Cine & Jeans & Una forma de reinventarse & 4 & $\begin{array}{l}\text { Macarena García } \\
\text { Pablo Rivero }\end{array}$ & $\begin{array}{l}\mathrm{M} \\
\mathrm{H}\end{array}$ & $\begin{array}{l}\text { Prota/ Posa } \\
\text { Prota/Posa }\end{array}$ & $\begin{array}{l}\text { Actriz } \\
\text { Actor }\end{array}$ & 152 \\
\hline PC- Reportaje & Moda & Ropa/Accesorios & Tiendas & Soñar, pedir y comprar & 2 & & & & & 156 \\
\hline PC- Reportaje & $\begin{array}{l}\text { Moda/ Ocio- } \\
\text { cultura }\end{array}$ & $\begin{array}{l}\text { Moda/ Destinos/ } \\
\text { Restauración }\end{array}$ & Direcciones & Una ruta con encanto & 2 & & & & & 158 \\
\hline *PC- Artículo & Moda & Accesorios & Firma & Nueva perla made in Spain & 1 & Laura Sánchez & $\mathrm{M}$ & Prota/ Posa & Modelo & 160 \\
\hline PC- Artículo & Moda & Marca & Evento & Desigual \& Woman & 1 & & & & & 161 \\
\hline Opinión & Otros & & $\begin{array}{l}\text { Historias del } \\
\text { armario }\end{array}$ & Sin cuentos tristes & 1 & Emma Riverola & M & Escribe & Escritora & 162 \\
\hline \multicolumn{11}{|l|}{ BELLEZA } \\
\hline Portada & & Avance interior & Portada & Cuenta atrás. Lista para celebrar & 1 & & & & & 163 \\
\hline PC- Reportaje & Belleza & $\begin{array}{l}\text { Maquillaje/ } \\
\text { Cosméticos }\end{array}$ & Fiesta & A punto para brillar & 8 & & & & & 164 \\
\hline PC-Artículo & Belleza & Maquillaje & Make up & Catrice très belle & 1 & & & & & 172 \\
\hline *PC- Entrevista & Belleza & Perfumes & $\begin{array}{l}\text { Perfumes + } \\
\text { personal }\end{array}$ & $\begin{array}{l}\text { Nuevos perfumes. Vuelve el } \\
\text { hombre }\end{array}$ & 8 & $\begin{array}{l}\text { Johnny Deep } \\
\text { Liam Hemsworth } \\
\text { Theo James }\end{array}$ & $\begin{array}{l}\mathrm{H} \\
\mathrm{H} \\
\mathrm{H}\end{array}$ & $\begin{array}{l}\text { Prota/ Posa } \\
\text { Prota/ Posa } \\
\text { Prota/ Posa }\end{array}$ & $\begin{array}{l}\text { Actor } \\
\text { Actor } \\
\text { Actor }\end{array}$ & 174 \\
\hline PC-Artículo & Belleza & Maquillaje & Clips & Allure parisino & 1 & & & & & 188 \\
\hline \multicolumn{11}{|l|}{ TENDENCIAS } \\
\hline Portada & & Avance interior & Portada & $\begin{array}{l}\text { Especial gastro. ¿Preparada para } \\
\text { celebrar? }\end{array}$ & 1 & & & & & 191 \\
\hline
\end{tabular}




\begin{tabular}{|c|c|c|c|c|c|c|c|c|c|c|}
\hline *PC- Entrevista & $\begin{array}{l}\text { Ocio-cultura/ } \\
\text { Gastronomía }\end{array}$ & $\begin{array}{l}\text { Gastro/ } \\
\text { Cine + personal }\end{array}$ & Entrevista & $\begin{array}{l}\text { Sobremesa de fiesta con Juana } \\
\text { Acosta }\end{array}$ & 6 & $\begin{array}{l}\text { Juana Acosta } \\
\text { Ramón Freixa }\end{array}$ & $\begin{array}{l}\mathrm{M} \\
\mathrm{H}\end{array}$ & $\begin{array}{l}\text { Prota/ Posa } \\
\text { Prota/ Posa }\end{array}$ & $\begin{array}{l}\text { Actriz } \\
\text { Chef }\end{array}$ & 192 \\
\hline PC- Fotos & Gastronomía & $\begin{array}{l}\text { Bebidas/ Alimentos/ } \\
\text { Libros }\end{array}$ & Regalos & Bocados Gourmet & 5 & & & & & 198 \\
\hline PC- Reportaje & Ocio-cultura & Restauración & Restaurantes & ¡Vamos a celebrar! & 4 & & & & & 204 \\
\hline *Entrevista & Gastronomía & Gastro + personal & Entrevista & El mundo es de los Roca & 2 & $\begin{array}{l}\text { Joan Roca } \\
\text { Josep Roca } \\
\text { Jordi Roca }\end{array}$ & $\begin{array}{l}\mathrm{H} \\
\mathrm{H} \\
\mathrm{H}\end{array}$ & $\begin{array}{l}\text { Protagoniza } \\
\text { Protagoniza } \\
\text { Protagoniza }\end{array}$ & $\begin{array}{l}\text { Chef } \\
\text { Chef } \\
\text { Chef }\end{array}$ & 208 \\
\hline PC- Fotos & Gastronomía & Bebidas & Bodega & El mejor brindis & 2 & & & & & 210 \\
\hline PC- Horóscopo & Moda & Accesorios & Astros & Sagitario & 1 & & & & & 213 \\
\hline Directorio & & & Tendencia & Direcciones & 1 & & & & & 214 \\
\hline PC- Reportaje & Moda/Tecno & $\begin{array}{l}\text { Ropa/ Accesorios/ } \\
\text { Gadget }\end{array}$ & Ideas & Últimos apuntes & 2 & & & & & 216 \\
\hline PC-Artículo & Moda & Accesorios & Flechazo & Magia en la ciudad del sol & 1 & & & & & 218 \\
\hline
\end{tabular}




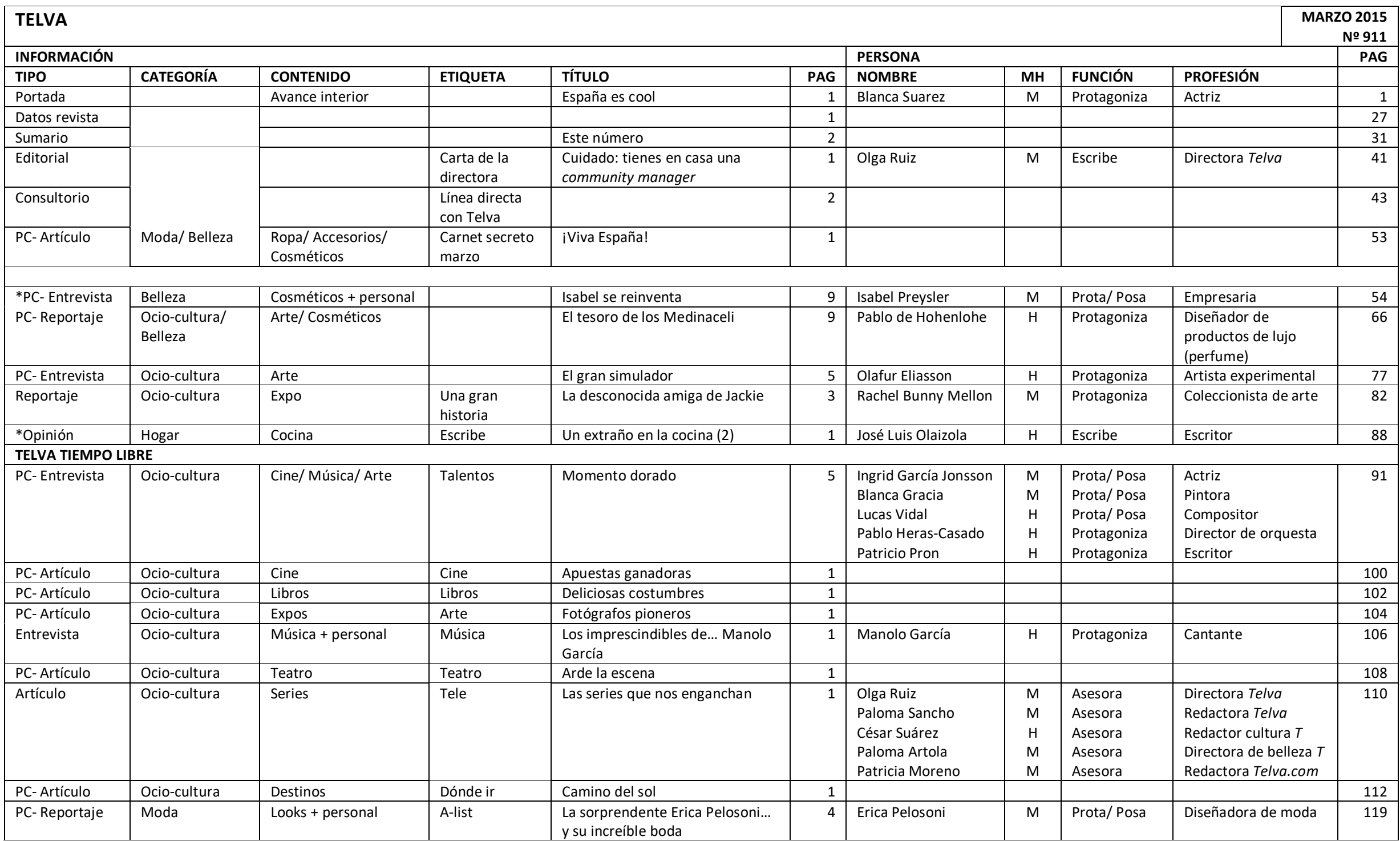




\begin{tabular}{|c|c|c|c|c|c|c|c|c|c|c|}
\hline PC-Artículo & Ocio-cultura & $\begin{array}{l}\text { Libros/Ropa/ } \\
\text { Restauración }\end{array}$ & A-list & $\begin{array}{l}\text { Mi nuevo hobby /los bolsos + } \\
\text { buscados }\end{array}$ & 1 & Alejandra Rojas & $M$ & Asesora & Freelance & 124 \\
\hline PC- Reportaje & Moda/Belleza & $\begin{array}{l}\text { Ropa/ Accesorios/ } \\
\text { Cosméticos/ } \\
\text { Maquillaje }\end{array}$ & & $\begin{array}{l}25 \text { preguntas que siempre les } \\
\text { hacen sus amigas a las directoras } \\
\text { de moda y belleza }\end{array}$ & 6 & $\begin{array}{l}\text { Alicia Chapa } \\
\text { Paloma Artola }\end{array}$ & $\begin{array}{l}M \\
M\end{array}$ & $\begin{array}{l}\text { Asesora } \\
\text { Asesora }\end{array}$ & $\begin{array}{l}\text { Directora moda Telva } \\
\text { Directora belleza } \\
\text { Telva }\end{array}$ & 135 \\
\hline FR & Moda/Belleza & Looks & & XXVII Premios Telva Belleza 2015 & 8 & & & & & 148 \\
\hline Opinión & Moda & Otros & Más que moda & Lady V. & 1 & Lorenzo Caprile & $\mathrm{H}$ & Escribe & Modista & 158 \\
\hline \multicolumn{11}{|c|}{ TELVA LO ÚLTIMO } \\
\hline *PC- Reportaje & Moda & Ropa & Moda & 3 vaqueros con historia & 5 & Paul Marciano & $\mathrm{H}$ & Protagoniza & Diseñador de moda & 161 \\
\hline PC- Reportaje & Moda & Ropa/ Looks & Moda & Género western & 2 & & & & & 166 \\
\hline PC- Reportaje & Moda & Ropa/ Accesorios & Moda & Los 14 magníficos & 4 & & & & & 168 \\
\hline Reportaje & Otros & & Trabajo & Siete vidas laborales & 4 & & & & & 172 \\
\hline Opinión & Sociedad & & Sociedad & Multiculturalismo, ¿̇es posible? & 1 & $\begin{array}{l}\text { Haizam Amirah } \\
\text { Fernández } \\
\text { Isabel San Sebastián }\end{array}$ & $\begin{array}{l}M \\
M\end{array}$ & $\begin{array}{l}\text { Escribe } \\
\text { Escribe }\end{array}$ & $\begin{array}{l}\text { Investigadora } \\
\text { Periodista }\end{array}$ & 176 \\
\hline PC- Reportaje & $\begin{array}{l}\text { Ocio-cultura/ } \\
\text { Gastronomía }\end{array}$ & $\begin{array}{l}\text { Restauración/ } \\
\text { Alimentos }\end{array}$ & Gastronomía & $\begin{array}{l}\text { Todo lo que tienes que saber de } \\
\text { la tortilla de patatas }\end{array}$ & 3 & & & & & 178 \\
\hline PC- Reportaje & $\begin{array}{l}\text { Tecnología/ } \\
\text { Moda }\end{array}$ & Motor/Ropa/ Looks & Motor & Algo salvaje & 2 & & & & & 182 \\
\hline PC- Entrevista & Belleza & Cosméticos + personal & Belleza & Los trucos de Anna Selezneva & 2 & Anna Selezneva & $\mathrm{M}$ & Protagoniza & Modelo & 184 \\
\hline PC- Reportaje & Belleza & $\begin{array}{l}\text { Cosméticos/ } \\
\text { Tratamientos/ } \\
\text { Maquillaje }\end{array}$ & Belleza & El tono es lo que importa & 4 & & & & & 186 \\
\hline PC-Artículo & Belleza & Cosméticos & Belleza & Las mechas babylights & 1 & & & & & 192 \\
\hline PC- Reportaje & Belleza & Maquillaje & Belleza & Ese pincel mítico & 2 & & & & & 194 \\
\hline PC- Reportaje & Belleza & Tratamientos & Belleza & Lifting con ultrasonidos & 2 & & & & & 196 \\
\hline PC- Reportaje & Belleza & $\begin{array}{l}\text { Maquillaje/ } \\
\text { Cosméticos }\end{array}$ & Belleza & Sin secretos & 2 & & & & & 198 \\
\hline PC- Entrevista & Belleza & Maquillaje & Belleza & La hora del maquillaje & 2 & $\begin{array}{l}\text { Roberto Siguero } \\
\text { Rocío Galera }\end{array}$ & $\begin{array}{l}\mathrm{H} \\
\mathrm{M}\end{array}$ & $\begin{array}{l}\text { Asesora } \\
\text { Asesora }\end{array}$ & $\begin{array}{l}\text { Maquillador } \\
\text { Maquilladora }\end{array}$ & 200 \\
\hline PC- Reportaje & Belleza & $\begin{array}{l}\text { Cosméticos/ } \\
\text { Tratamientos }\end{array}$ & Belleza & Varios & 2 & & & & & 202 \\
\hline PC- FR & Belleza/Moda & Looks/ Maquillaje & Belleza & Chica sixties & 7 & & & & & 204 \\
\hline PC- Reportaje & Belleza & Maquillaje & Belleza & Premios Telva belleza 2015 & 11 & & & & & 214 \\
\hline $\begin{array}{l}\text { PC- FR + } \\
\text { Entrevista }\end{array}$ & $\begin{array}{l}\text { Moda/ Ocio- } \\
\text { cultura }\end{array}$ & Looks/ Cine + personal & Moda & 4 chicas que triunfan & 35 & $\begin{array}{l}\text { Blanca Suárez } \\
\text { Alba Galocha } \\
\text { Bárbara Lennie } \\
\text { Marta Ortiz }\end{array}$ & $\begin{array}{l}\mathrm{M} \\
\mathrm{M} \\
\mathrm{M} \\
\mathrm{M}\end{array}$ & $\begin{array}{l}\text { Prota/ Posa } \\
\text { Prota/ Posa } \\
\text { Prota/ Posa } \\
\text { Prota/ Posa }\end{array}$ & $\begin{array}{l}\text { Actriz } \\
\text { Modelo } \\
\text { Actriz } \\
\text { Modelo } \\
\end{array}$ & 225 \\
\hline PC-FR & Moda & Looks & Moda & iOlé! & 10 & & & & & 260 \\
\hline *PC- Entrevista & Moda & Accesorios + personal & Moda & El joyero su mecenas & 7 & $\begin{array}{l}\text { Vicente Gracia } \\
\text { Juana Roig }\end{array}$ & $\begin{array}{l}\mathrm{H} \\
\mathrm{M}\end{array}$ & $\begin{array}{l}\text { Protagoniza } \\
\text { Prota/ Posa }\end{array}$ & $\begin{array}{l}\text { Diseñador de joyas } \\
\text { Empresaria }\end{array}$ & 270 \\
\hline
\end{tabular}




\begin{tabular}{|c|c|c|c|c|c|c|c|c|c|c|}
\hline Recetario & Hogar & Cocina & Cocina & Comer con los dedos & 8 & & & & & 278 \\
\hline Recetario & Hogar & Cocina & Cocina & Menú paso a paso & 2 & & & & & 286 \\
\hline PC- Artículo & Hogar & Cocina & $\begin{array}{l}\text { Escuela de } \\
\text { cocina }\end{array}$ & Una delicia & 1 & & & & & 288 \\
\hline \multicolumn{11}{|c|}{ ÚLTIMAS NOTICIAS } \\
\hline PC- Reportaje & Moda & Ropa/ Looks & $\begin{array}{l}\text { Últimas } \\
\text { noticias }\end{array}$ & Varios & 4 & & & & & 290 \\
\hline Directorio & & & \multirow[b]{2}{*}{ En privado } & Guía de tiendas & 2 & & & & & 296 \\
\hline PC-Artículo & Ocio-cultura & Cine + personal & & Hugh Jackman & 1 & Hugh Jackman & $\mathrm{H}$ & Protagoniza & Actor & 298 \\
\hline
\end{tabular}




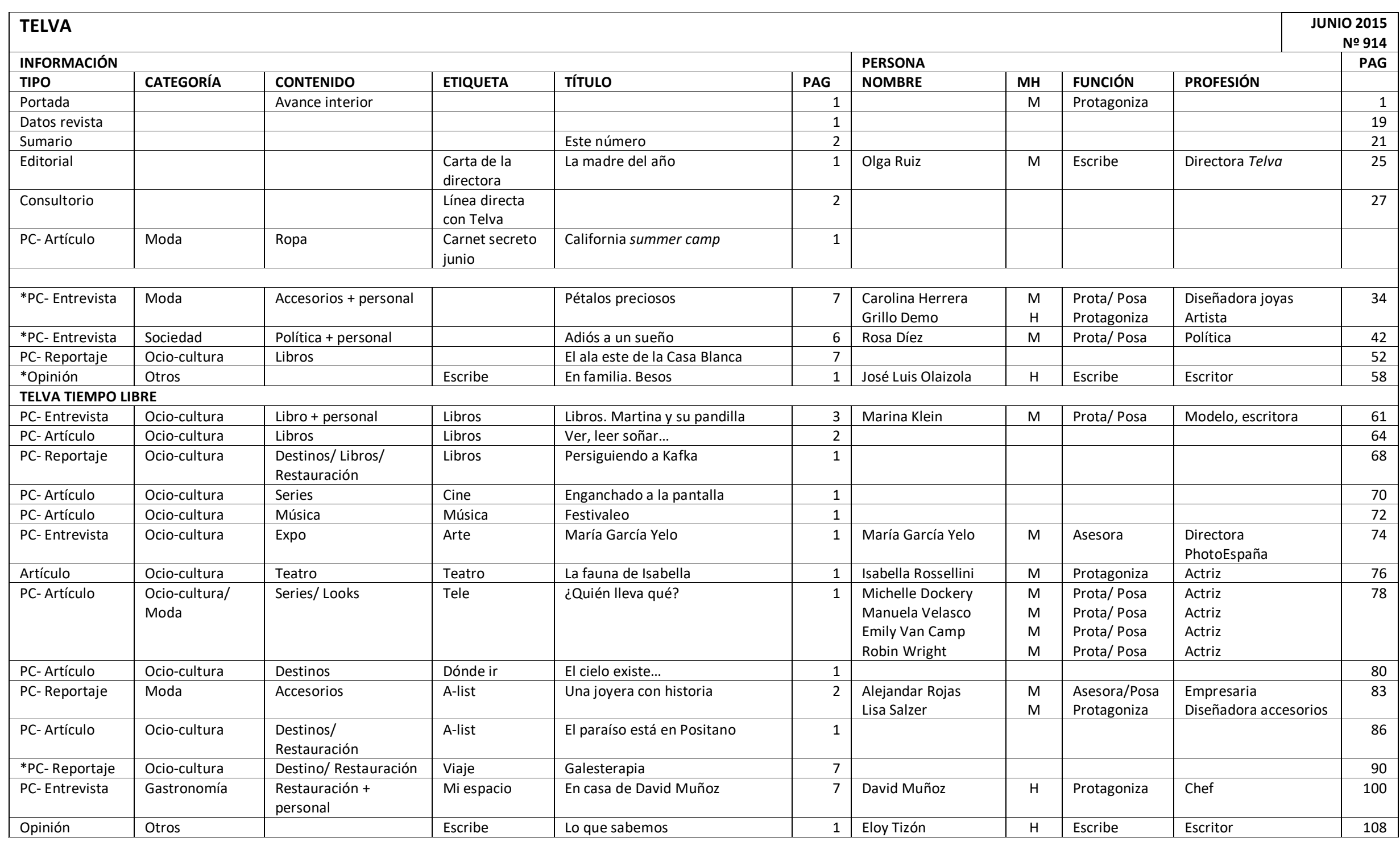




\begin{tabular}{|c|c|c|c|c|c|c|c|c|c|c|}
\hline \multicolumn{11}{|c|}{ TELVA LO ÚLTIMO } \\
\hline PC- Reportaje & Moda & Looks & Moda & No dar puntada sin hilo & 4 & & & & & 111 \\
\hline PC- Fotos & Moda & Ropa/Accesorios & Moda & Deseado verano & 3 & & & & & 118 \\
\hline PC- Reportaje & Ocio-cultura & Expo & Moda & ¿Por qué amamos estos relojes? & 3 & & & & & 124 \\
\hline PC- Entrevista & Moda & Moda + personal & Moda & 10 preguntas a... & 1 & $\begin{array}{l}\text { José Urrutia } \\
\text { Leticia de la Cuesta }\end{array}$ & $\begin{array}{l}\mathrm{H} \\
\mathrm{M}\end{array}$ & $\begin{array}{l}\text { Protagoniza } \\
\text { Protagoniza }\end{array}$ & $\begin{array}{l}\text { Diseñador de moda } \\
\text { Diseñadora de moda }\end{array}$ & 128 \\
\hline PC-Artículo & $\begin{array}{l}\text { Ocio-cultura/ } \\
\text { Moda }\end{array}$ & Expo/ Ropa & De lo último & En tierra firme... o en alta mar & 2 & & & & & 130 \\
\hline Artículo & Salud & Nutrición & Sociedad & $\begin{array}{l}\text { ¿Es sano comer lácteos después } \\
\text { de la lactancia? }\end{array}$ & 1 & $\begin{array}{l}\text { Rosa Burgos } \\
\text { Paloma Castaño }\end{array}$ & $\begin{array}{l}M \\
M\end{array}$ & $\begin{array}{l}\text { Escribe } \\
\text { Escribe }\end{array}$ & $\begin{array}{l}\text { Nutricionista } \\
\text { Nutricionista }\end{array}$ & 136 \\
\hline $\begin{array}{l}\text { *PC- FR + } \\
\text { entrevista }\end{array}$ & $\begin{array}{l}\text { Belleza/ Ocio- } \\
\text { cultura }\end{array}$ & $\begin{array}{l}\text { Peinados/Cine + } \\
\text { personal }\end{array}$ & Belleza & $\begin{array}{l}\text { Zapping de ondas con la chica de } \\
\text { moda }\end{array}$ & 6 & Nerea Barros & $M$ & Prota/ Posa & Actriz & 138 \\
\hline PC- Artículo & Belleza & Maquillaje & Belleza & $\begin{array}{l}\text { Una periodista de Telva en el } \\
\text { espejo virtual }\end{array}$ & 1 & Roberto Siguero & $\mathrm{H}$ & Protagoniza & Maquillador & 144 \\
\hline *PC- Entrevista & Belleza & Maquillaje & Belleza & El rey del rouge & 3 & $\begin{array}{l}\text { Massimiliano della } \\
\text { Maggesa }\end{array}$ & $\mathrm{H}$ & Protagoniza & Maquillador & 146 \\
\hline PC- Reportaje & Belleza & Maquillaje & Belleza & $\begin{array}{l}\text { Radiante nude + sandalia } \\
\text { gladiador }\end{array}$ & 4 & & & & & 150 \\
\hline PC- Artículo & Belleza & Cosméticos & Belleza & Gotas de sol/ Sin secretos & 1 & Paloma Artola & M & Asesora & Directora Telva & 154 \\
\hline PC- Artículo & Belleza & Cosméticos & Belleza & Varios & 1 & & & & & 156 \\
\hline PC- Artículo & Belleza & Cosméticos & Belleza & Dame agua & & & & & & 158 \\
\hline PC- Reportaje & Belleza/ Salud & $\begin{array}{l}\text { Cosméticos/ } \\
\text { Prevención }\end{array}$ & Belleza & Crónica de tu piel bajo el sol & 5 & & & & & 164 \\
\hline PC- Entrevista & Belleza & Personal & Personaje & $\begin{array}{l}\text { Clara Lago. "En la playa siempre } \\
\text { con sombrero" }\end{array}$ & 1 & Clara Lago & $M$ & Prota/ Posa & Actriz & 170 \\
\hline PC- FR & Moda & Looks & Moda & Negro (con un toque de oro) & 10 & & & & & 172 \\
\hline PC- FR & Moda & Looks & Moda & Un biquini y... algo más & 8 & & & & & 182 \\
\hline PC- FR & Moda & Looks & Moda & Reina de los mares & 12 & & & & & 190 \\
\hline Reportaje & Moda & Accesorios & Moda & El extraño sueño de Victoire & 5 & $\begin{array}{l}\text { Victoire de } \\
\text { Castellane }\end{array}$ & $\mathrm{M}$ & Protagoniza & Directora creativa Dior & 202 \\
\hline \multicolumn{11}{|c|}{ TELVA DECORACIÓN } \\
\hline Portada & & Avance interior & Portada & ¡Todos al porche! & 1 & & & & & 209 \\
\hline PC- Reportaje & Decoración & Casa & Deco & El patio de mi casa & 9 & & & & & 210 \\
\hline PC- Reportaje & Decoración & Casa/ Objetos deco & Deco & Placeres de verano & 9 & $\begin{array}{l}\text { Bárbara Pan de } \\
\text { Soraluce } \\
\text { Jesús Moraime } \\
\text { Sandra Carretié }\end{array}$ & $\begin{array}{l}\mathrm{M} \\
\mathrm{H} \\
\mathrm{M}\end{array}$ & $\begin{array}{l}\text { Protagoniza } \\
\text { Protagoniza } \\
\text { Protagoniza }\end{array}$ & $\begin{array}{l}\text { Artesana } \\
\text { Paisajista } \\
\text { Jardinera }\end{array}$ & 220 \\
\hline PC- Fotos & Decoración & Objetos deco & Deco & Mi terraza (a precio chollo) & 2 & & & & & 230 \\
\hline PC- Reportaje & Decoración & Objetos deco & Deco & Tanta belleza & 2 & & & & & \\
\hline \multicolumn{11}{|l|}{ COCINA } \\
\hline Recetario & Hogar & Cocina & Cocina & 30 salsas frías & 7 & & & & & 236 \\
\hline
\end{tabular}




\begin{tabular}{|c|c|c|c|c|c|c|c|c|c|c|}
\hline PC-Artículo & Hogar & Cocina & $\begin{array}{l}\text { Escuela de } \\
\text { cocina }\end{array}$ & Plan de verano & 1 & & & & & 244 \\
\hline \multicolumn{11}{|c|}{ ÚLTIMAS NOTICIAS } \\
\hline PC- Reportaje & $\begin{array}{l}\text { Moda/ Ocio- } \\
\text { cultura }\end{array}$ & $\begin{array}{l}\text { Ropa/ Accesorios/ } \\
\text { Expo/ Destinos }\end{array}$ & $\begin{array}{l}\text { Últimas } \\
\text { noticias }\end{array}$ & Citas de junio & 3 & & & & & 245 \\
\hline Entrevista & Otros & Profesional & Comunicación & $\begin{array}{l}\text { "Nuestro objetivo es el buen } \\
\text { periodismo" }\end{array}$ & 1 & Aurelio Fernández & $\mathrm{H}$ & Protagoniza & $\begin{array}{l}\text { Director Unidad } \\
\text { Editorial }\end{array}$ & 248 \\
\hline *Artículo & Sociedad & Feminismo & Compromiso & Contra la violencia & 1 & $\begin{array}{l}\text { Antonio Fernández- } \\
\text { Galiano }\end{array}$ & $\mathrm{H}$ & Protagoniza & $\begin{array}{l}\text { Presidente Unidad } \\
\text { Editorial }\end{array}$ & 249 \\
\hline *PC- Artículo & Moda & Looks & $\begin{array}{l}\text { Últimas } \\
\text { noticias }\end{array}$ & $\begin{array}{l}\text { Shooping by Telva... y ahora } \\
\text { también para los niños }\end{array}$ & 2 & & & & & 250 \\
\hline Directorio & & & Guía de tiendas & & 2 & & & & & 256 \\
\hline PC-Artículo & $\begin{array}{l}\text { Moda/ Belleza/ } \\
\text { Ocio-cultura }\end{array}$ & Personal & En privado & Georgia May Jegger & 1 & Georgia May Jagger & $\mathrm{M}$ & Protagoniza & Modelo & 257 \\
\hline
\end{tabular}




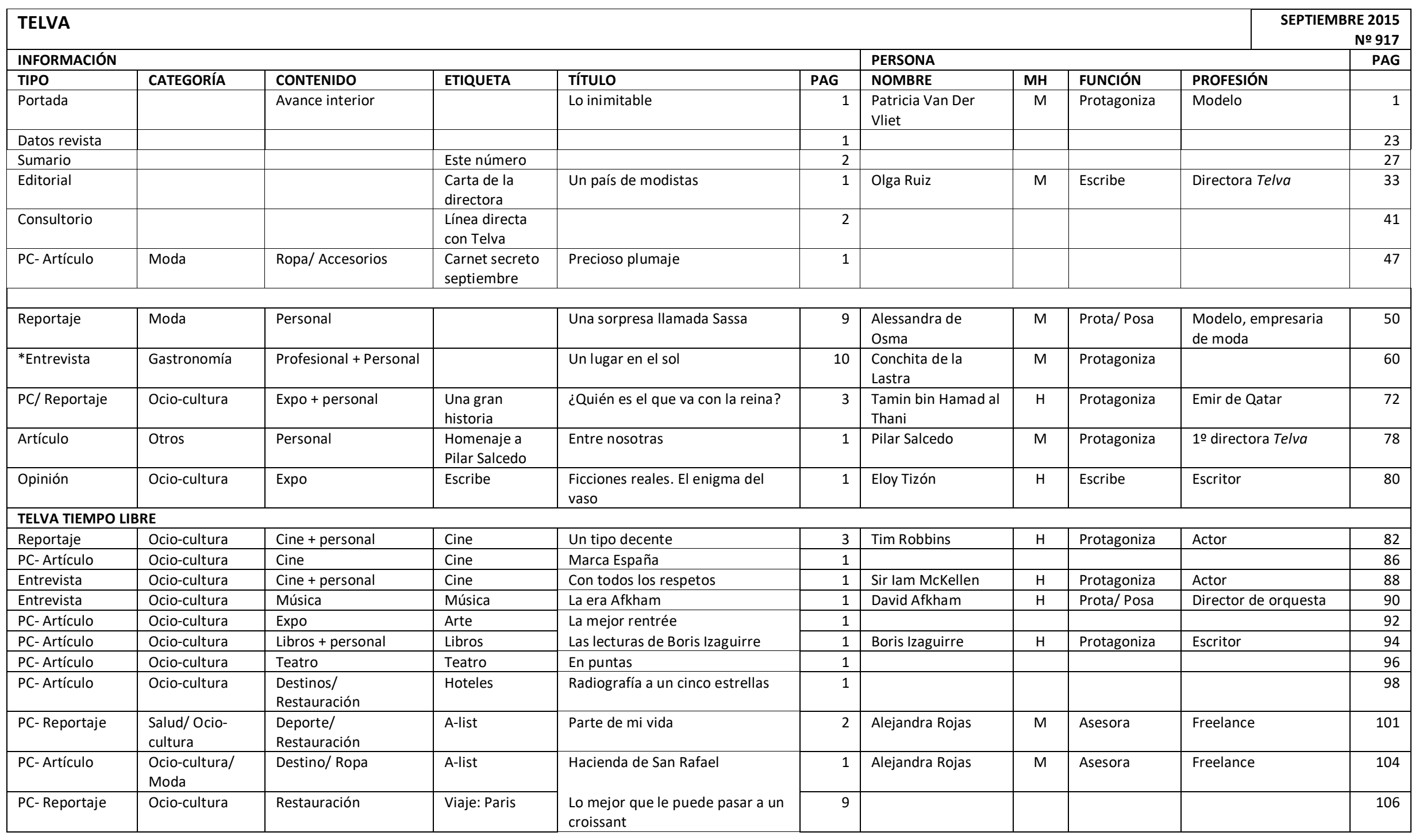




\begin{tabular}{|c|c|c|c|c|c|c|c|c|c|c|}
\hline *Entrevista & Sociedad & Ciencia + personal & A dúo & $\begin{array}{l}\text { Margarita Salas y María Blasco. } \\
\text { Mentes maravillosas }\end{array}$ & 7 & $\begin{array}{l}\text { Margarita Salas } \\
\text { María Blasco }\end{array}$ & $\begin{array}{l}\mathrm{M} \\
\mathrm{M} \\
\end{array}$ & $\begin{array}{l}\text { Protagoniza } \\
\text { Protagoniza }\end{array}$ & $\begin{array}{l}\text { Bioquímica } \\
\text { Directora CNIO }\end{array}$ & 116 \\
\hline PC- Reportaje & Moda & Looks & & Un gran homenaje a la moda & 10 & & & & & 124 \\
\hline Opinión & Otros & & Escribe & $\begin{array}{l}\text { Más que moda. Las locuras de } \\
\text { Galliano }\end{array}$ & 1 & & & & & 136 \\
\hline \multicolumn{11}{|c|}{ TELVA LO ÚLTIMO } \\
\hline PC- Entrevista & Moda & Moda & Moda & Un lujo posible & 4 & Jorge Vázquez & $\mathrm{H}$ & Protagoniza & Diseñador moda & 143 \\
\hline PC-Artículo & Moda & Marca & Moda & \multirow{2}{*}{$\begin{array}{l}\text { Mucho más que pulseras } \\
10 \text { preguntas a Väska }\end{array}$} & 2 & & & & & 148 \\
\hline PC- Entrevista & Moda & Moda + personal & Moda & & 1 & Ann-Sofi Storbacka & $M$ & Protagoniza & Diseñadora bolsos & 150 \\
\hline PC- Reportaje & Moda & $\begin{array}{l}\text { Ropa/Accesorios/ } \\
\text { Look }\end{array}$ & $\begin{array}{l}\text { Lo último de lo } \\
\text { último }\end{array}$ & \multirow{2}{*}{$\begin{array}{l}\text { El nuevo gipsy } \\
\text { Para todos los gustos }\end{array}$} & 2 & & & & & 152 \\
\hline PC- Reportaje & Ocio-cultura & Restauración & Gastronomía & & 2 & & & & & 154 \\
\hline PC-Artículo & Gastronomía & Alimentos & Gastronomía & Del cerdo... hasta los andares & 1 & & & & & 156 \\
\hline Reportaje & Moda & & Sociedad & $\begin{array}{l}\text { Los códigos de una comida de } \\
\text { trabajo }\end{array}$ & 2 & $\begin{array}{l}\text { Gerardo Correas } \\
\text { Montse Guals } \\
\text { Ana Guzmán } \\
\text { Manuela Llagoster }\end{array}$ & $\begin{array}{l}\mathrm{H} \\
\mathrm{M} \\
\mathrm{M} \\
\mathrm{M}\end{array}$ & $\begin{array}{l}\text { Asesora } \\
\text { Asesora } \\
\text { Asesora/Posa } \\
\text { Asesora/Posa }\end{array}$ & $\begin{array}{l}\text { Presidente Escuela Int. } \\
\text { Protocolo } \\
\text { Directora de ¿Qué me } \\
\text { pongo? } \\
\text { Responsable } \\
\text { desarrollo de negocio } \\
\text { Co-directora A-list } \\
\end{array}$ & 160 \\
\hline $\begin{array}{l}\text { PC- Reportaje + } \\
\text { entrevista }\end{array}$ & Tecno & Motor & Motor & \multirow{4}{*}{$\begin{array}{l}\text { Con } 1.001 \text { opciones para } \\
\text { personalizar } \\
\text { Sesión de pelo y maquillaje }\end{array}$} & 2 & Leyre Olabarria & $M$ & Protagoniza & Ingeniera SEAT & 165 \\
\hline PC- Reportaje & Belleza & Maquillaje & Belleza & & 6 & $\begin{array}{l}\text { Roberto Siguero } \\
\text { José María Neira }\end{array}$ & $\begin{array}{l}\mathrm{H} \\
\mathrm{H} \\
\end{array}$ & $\begin{array}{l}\text { Asesora } \\
\text { Asesora }\end{array}$ & $\begin{array}{l}\text { Maquillador } \\
\text { Maquillador }\end{array}$ & 166 \\
\hline PC- Fotos & Belleza & Cosméticos & Belleza & & 1 & & & & & 173 \\
\hline PC- Reportaje & Belleza & Cosméticos & Belleza & & 5 & & & & & \\
\hline PC- Entrevista & Belleza & Maquillaje & Belleza & \multirow{2}{*}{$\begin{array}{l}\text { Maestro de maestros } \\
\text { Telva elige/ iHallazgo! / Sin } \\
\text { secretos }\end{array}$} & 3 & Peter Philips & $\mathrm{H}$ & Protagoniza & Maquillador & 181 \\
\hline PC-Artículo & Belleza & Cosméticos & Belleza & & 1 & & & & & 183 \\
\hline *PC-Reportaje & Belleza/ Moda & Moda + personal & Belleza & \multirow{2}{*}{$\begin{array}{l}\text { Alaïa sólo hay uno } \\
\text { Tu aroma/ Hemos probado/ } \\
\text { Buena compra }\end{array}$} & 2 & Azzedine Alaïa & $\mathrm{H}$ & Protagoniza & Diseñador moda & 186 \\
\hline PC- Artículo & Belleza & $\begin{array}{l}\text { Tratamientos/ } \\
\text { Cosméticos }\end{array}$ & Belleza & & 1 & & & & & 188 \\
\hline PC- Reportaje & Belleza & Peinados & Belleza & El gran libro de las trenzas & 6 & & & & & 190 \\
\hline PC- Reportaje & Salud & Deporte & Fitness & El gimnasio... ien casa! & 4 & & & & & 196 \\
\hline $\begin{array}{l}\text { Artículo + } \\
\text { recetario }\end{array}$ & Salud & Nutrición & Fitness & Movimiento verde & 1 & & & & & 200 \\
\hline PC- FR & Moda & Looks & Moda & De la pasarela a la realidad & 14 & & & & & 202 \\
\hline PC-FR & Moda & Looks & Moda & Piezas maestras & 12 & $\begin{array}{l}\text { Patricia Van Der } \\
\text { Vliet }\end{array}$ & $\mathrm{M}$ & Prota/ Posa & Modelo & 216 \\
\hline PC-FR & Moda & Looks & Moda & Me fui a los bosques & 8 & & & & & 228 \\
\hline Reportaje & Moda & Moda & Moda & Lo inimitable & 4 & Raf Simons & $\mathrm{H}$ & Protagoniza & Diseñador moda & 237 \\
\hline
\end{tabular}




\begin{tabular}{|c|c|c|c|c|c|c|c|c|c|c|}
\hline \multicolumn{11}{|c|}{ TELVA DECORACIÓN } \\
\hline Portada & & Avance interior & Portada & Atrévete con el color & 1 & & & & & 241 \\
\hline PC- Reportaje & Decoración & Casa + personal & La experta & Un festín para la vista & 10 & India Mahadavi & $M$ & Prota/ Posa & Interiorista & 242 \\
\hline PC- Artículo & Decoración & Libros & Libros & \multirow{2}{*}{$\begin{array}{l}\text { Hora de recreo } \\
\text { Mesas de otoño }\end{array}$} & 2 & & & & & 252 \\
\hline PC- Reportaje & Decoración & Objetos deco & Vajillas & & 4 & Pepa Yuste & $M$ & Protagoniza & Interiorista & 254 \\
\hline PC-Artículo & Decoración & Objetos deco & Guía útil & Gran idea & 1 & & & & & 259 \\
\hline \multicolumn{11}{|l|}{ COCINA } \\
\hline Recetario & Hogar & Alimentos & Cocina & Un plato de pasta, basta & 7 & & & & & 260 \\
\hline Directorio & & & Guía de tiendas & & 1 & & & & & 267 \\
\hline PC- Artículo & Hogar & Cocina & $\begin{array}{l}\text { Escuela de } \\
\text { cocina }\end{array}$ & ¡Saboooor! & 2 & & & & & 268 \\
\hline \multicolumn{11}{|c|}{ ÚLTIMAS NOTICIAS } \\
\hline PC- Artículo & Moda & Looks & $\begin{array}{l}\text { Últimas } \\
\text { noticias }\end{array}$ & $\begin{array}{l}\text { Shopping by Telva... y en } \\
\text { shopping online niños }\end{array}$ & 2 & & & & & 270 \\
\hline PC-Artículo & $\begin{array}{l}\text { Ocio-cultura/ } \\
\text { Belleza/ Moda }\end{array}$ & Personal & En privado & Matthew McConaughey & 1 & $\begin{array}{l}\text { Matthew } \\
\text { McConaughey }\end{array}$ & $\mathrm{H}$ & Protagoniza & Actor & 274 \\
\hline
\end{tabular}




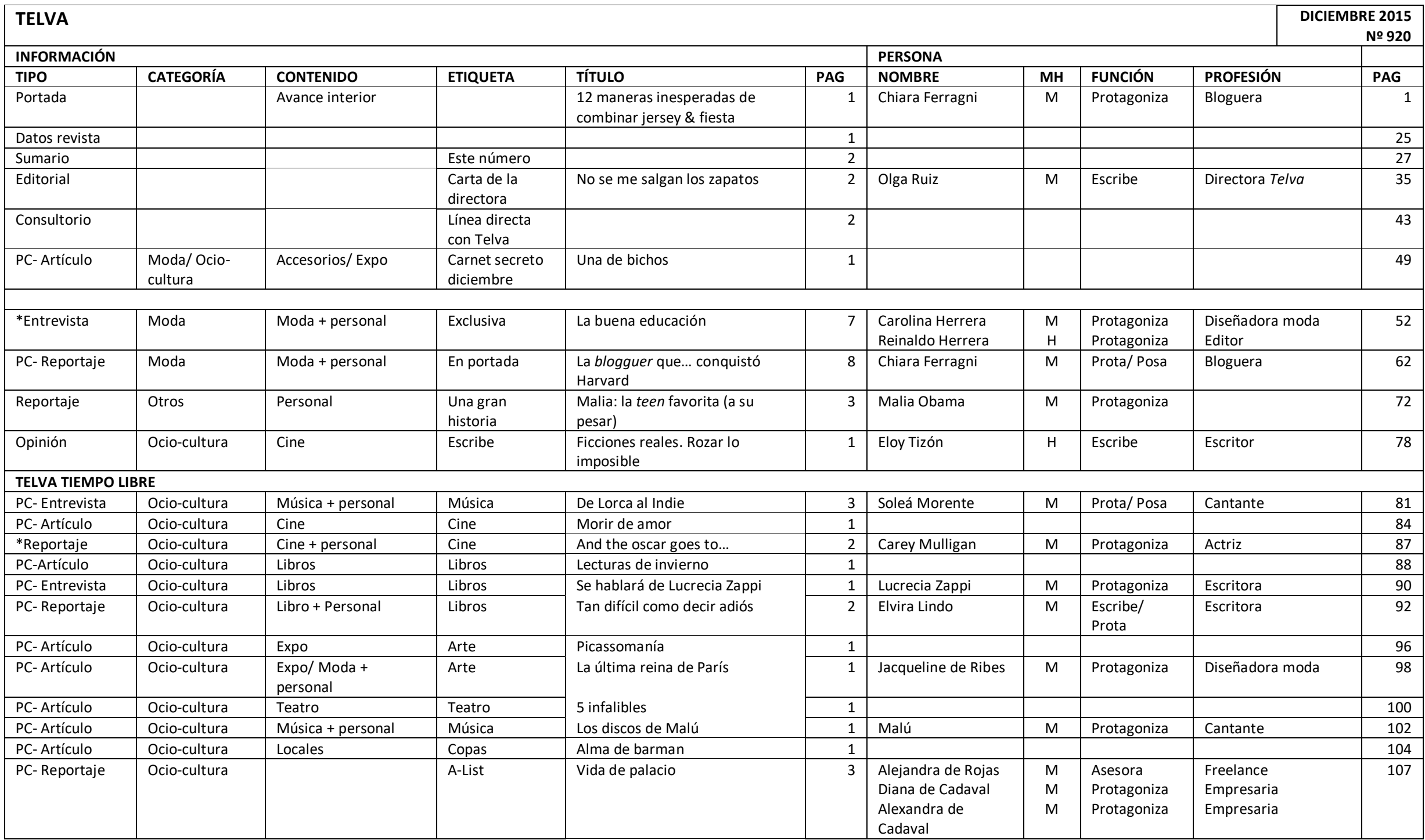




\begin{tabular}{|c|c|c|c|c|c|c|c|c|c|c|}
\hline *PC- Artículo & Otros & Personal & A-list & Anfitriones perfectos & 1 & $\begin{array}{l}\text { Javier Medem } \\
\text { Almudena del Moral }\end{array}$ & $\begin{array}{l}\mathrm{H} \\
\mathrm{M} \\
\end{array}$ & $\begin{array}{l}\text { Protagoniza } \\
\text { Protagoniza } \\
\end{array}$ & $\begin{array}{l}\text { Director La Nava } \\
\text { (Cacería) } \\
\text { Directora La Nava } \\
\end{array}$ & 110 \\
\hline PC- Reportaje & Ocio-cultura & Destino/ Restauración & $\begin{array}{l}\text { Viaje: Tánger, } \\
\text { Marruecos }\end{array}$ & La tierra caliente & 10 & & & & & 120 \\
\hline Reportaje & Sociedad & Política + personal & & La vida sin ellos & 14 & $\begin{array}{l}\text { Lillian Tintori } \\
\text { María Corina } \\
\text { Machado } \\
\text { Mitzy Capriles } \\
\text { Isabel Carmona } \\
\end{array}$ & $\begin{array}{l}\mathrm{M} \\
\mathrm{M} \\
\mathrm{M} \\
\mathrm{M}\end{array}$ & $\begin{array}{l}\text { Protagoniza } \\
\text { Protagoniza } \\
\text { Protagoniza } \\
\text { Protagoniza } \\
\end{array}$ & $\begin{array}{l}\begin{array}{l}\text { Deportista } \\
\text { Política }\end{array} \\
\text { Política } \\
\end{array}$ & 124 \\
\hline PC-Reportaje & Moda & Looks & $\begin{array}{l}\text { Premios Telva a } \\
\text { las artes, las } \\
\text { ciencias y el } \\
\text { deporte } 2015\end{array}$ & Aquí hay talento & 8 & & & & & 144 \\
\hline Opinión & Moda & Personal & Escribe & Más que moda. Mi primo Arthur & 1 & Covadonga O'Shea & $\mathrm{M}$ & Escribe & Escritora & 158 \\
\hline \multicolumn{11}{|c|}{ TELVA LO ÚLTIMO } \\
\hline PC- Reportaje & $\begin{array}{l}\text { Ocio-cultura/ } \\
\text { Moda }\end{array}$ & $\begin{array}{l}\text { Destino/ Looks + } \\
\text { Personal }\end{array}$ & Moda & \multirow{2}{*}{$\begin{array}{l}\text { Mis } 48 \text { horas en Seúl } \\
20 \text { vestidos y una noche }\end{array}$} & 5 & Kristen Stewart & $\mathrm{M}$ & Protagoniza & Actriz & 161 \\
\hline PC- Fotos & Moda & $\begin{array}{l}\text { Ropa/ Accesorios/ } \\
\text { Looks }\end{array}$ & Moda & & 4 & & & & & 166 \\
\hline PC-Artículo & Moda & Looks/Ropa & Moda & Báilalo bien & 1 & & & & & 174 \\
\hline PC- Reportaje & Moda & Ropa/ Looks & Moda & Jersey Arán & 4 & & & & & 176 \\
\hline PC- Entrevista & Moda & Accesorios & Moda & El bolso college & 1 & $\begin{array}{l}\text { Lázaro Hernández } \\
\text { Jack McCollough }\end{array}$ & $\begin{array}{l}\mathrm{H} \\
\mathrm{H} \\
\end{array}$ & $\begin{array}{l}\text { Protagoniza } \\
\text { Protagoniza }\end{array}$ & $\begin{array}{l}\text { Diseñador moda } \\
\text { Diseñador moda }\end{array}$ & 182 \\
\hline PC- Reportaje & $\begin{array}{l}\text { Moda/ Ocio- } \\
\text { cultura/ Belleza }\end{array}$ & $\begin{array}{l}\text { Ropa/ Libros/ Expo/ } \\
\text { Cosméticos }\end{array}$ & $\begin{array}{l}\text { Lo último de lo } \\
\text { último }\end{array}$ & Destino Crucero & 2 & & & & & 184 \\
\hline Opinión & Otros & & Humor & Kanye \& Kim en la Casa Blanca & 2 & Jordi Soler & $\mathrm{H}$ & Escribe & Escritor & 188 \\
\hline PC-Artículo & Tecno/Moda & Motor/ Looks & Motor & Llegada triunfal & 2 & & & & & 190 \\
\hline PC- Entrevista & Tecno & Profesional (imagen) & Motor & En ruta con... Alex González & 1 & Alex González & $\mathrm{H}$ & Protagoniza & Actor & 192 \\
\hline *PC- Reportaje & Belleza & Cosméticos + personal & Belleza & Comunidad beauty & 6 & $\begin{array}{l}\text { Miriam Maestre } \\
\text { Dávila } \\
\text { Guiomar Fernández- } \\
\text { Castaño Ozores } \\
\text { Silvia Galí } \\
\text { Victoria Sainz de } \\
\text { Vicuña } \\
\text { Jimena Von } \\
\text { Knoblock }\end{array}$ & $\begin{array}{l}M \\
M \\
M \\
M \\
M\end{array}$ & $\begin{array}{l}\text { Prota/ Posa } \\
\text { Prota/ Posa } \\
\text { Prota/ Posa } \\
\text { Prota/ Posa } \\
\text { Prota/ Posa }\end{array}$ & $\begin{array}{l}\text { Fundadora Manolo } \\
\text { Maestre } \\
\text { Diseñadora bolsos } \\
\text { Calígrafa } \\
\text { Copropietaria } \\
\text { restaurante Beker } \\
\text { Diseñadora joyas }\end{array}$ & 196 \\
\hline PC- Reportaje & Belleza & Cosméticos & Belleza & \multirow{2}{*}{$\begin{array}{l}\text { Fitness facial } \\
\text { Para llevar o regalar }\end{array}$} & 2 & & & & & 206 \\
\hline PC- Fotos & Belleza & $\begin{array}{l}\text { Maquillaje/ } \\
\text { Cosméticos }\end{array}$ & Belleza & & 2 & & & & & 208 \\
\hline
\end{tabular}




\begin{tabular}{|c|c|c|c|c|c|c|c|c|c|c|}
\hline PC- Entrevista & Belleza & Maquillaje + personal & Belleza & Al habla con Lisa & 5 & Lisa Eldrigde & $\mathrm{M}$ & Protagoniza & $\begin{array}{l}\text { Bloguera, } \\
\text { maquilladora }\end{array}$ & 212 \\
\hline PC- Reportaje & $\begin{array}{l}\text { Moda/ Belleza/ } \\
\text { Ocio-cultura }\end{array}$ & $\begin{array}{l}\text { Ropa/ Cosméticos/ } \\
\text { Cine+ personal }\end{array}$ & Belleza & Soy James, Theo James & 2 & Theo James & $\mathrm{H}$ & Protagoniza & Actor & 219 \\
\hline PC-Artículo & Belleza & $\begin{array}{l}\text { Maquillaje/ } \\
\text { Cosmética/ } \\
\text { Tratamientos }\end{array}$ & Belleza & \multirow{2}{*}{$\begin{array}{l}\text { Sin secretos/ iHallazgo! / Telva } \\
\text { elige } \\
\text { Tu aroma/ Hemos probado/ } \\
\text { Buena compra }\end{array}$} & 1 & Paloma Artola & $\mathrm{M}$ & Asesora & $\begin{array}{l}\text { Directora de belleza } \\
\text { Telva }\end{array}$ & 220 \\
\hline PC- Artículo & Belleza & Cosméticos & Belleza & & 1 & & & & & 222 \\
\hline PC-Artículo & Belleza/Moda & Cosméticos/ Look & Belleza & El misterio de Rochas & 1 & & & & & 224 \\
\hline PC- Entrevista & Belleza & Cosméticos + personal & Belleza & Asuntos de familia & 8 & $\begin{array}{l}\text { Philippe d'Ornano } \\
\text { Christine d'Ornano }\end{array}$ & $\begin{array}{l}\mathrm{H} \\
\mathrm{M}\end{array}$ & $\begin{array}{l}\text { Protagoniza } \\
\text { Prota/ Posa }\end{array}$ & $\begin{array}{l}\text { Presidente Sisley } \\
\text { Vicepresidenta Sisley }\end{array}$ & 226 \\
\hline \multicolumn{11}{|c|}{ PREMIOS TELVA MODA 2015} \\
\hline PC- FR & Moda & Looks & $\begin{array}{l}\text { Premios Telva } \\
\text { Moda } 2015\end{array}$ & \multirow{2}{*}{$\begin{array}{l}\text { El cielo es el límite } \\
\text { Ese "je ne sais quoi" }\end{array}$} & 6 & & & & & 236 \\
\hline $\begin{array}{l}\text { PC- FR + } \\
\text { Entrevista }\end{array}$ & Moda & Looks & $\begin{array}{l}\text { Premios Telva } \\
\text { Moda } 2015\end{array}$ & & 5 & Isabel Marant & $\mathrm{M}$ & Protagoniza & Diseñadora moda & 242 \\
\hline *PC- Entrevista & Moda & Moda & $\begin{array}{l}\text { Premios Telva } \\
\text { Moda } 2015\end{array}$ & Juan y las mujeres & 6 & $\begin{array}{l}\text { Juan Vidal } \\
\text { Macarena García } \\
\text { Ingrid García } \\
\text { Jonsson } \\
\text { Silvia Alonso } \\
\end{array}$ & $\begin{array}{l}\mathrm{H} \\
\mathrm{M} \\
\mathrm{M} \\
\mathrm{M}\end{array}$ & $\begin{array}{l}\text { Protagoniza } \\
\text { Posa } \\
\text { Posa } \\
\text { Posa } \\
\end{array}$ & $\begin{array}{l}\text { Diseñador de moda } \\
\text { Actriz } \\
\text { Actriz } \\
\text { Actriz } \\
\end{array}$ & 248 \\
\hline \multicolumn{11}{|l|}{ TELVA NAVIDAD } \\
\hline Portada & & Avance interior & & Súper detallista & 1 & & & & & 255 \\
\hline PC- Reportaje & Decoración & Casa + personal & Decoración & 8 ideas para vestir la casa & 6 & Carla Saibene & $\mathrm{M}$ & Protagoniza & Diseñadora moda & 256 \\
\hline PC- Fotos & $\begin{array}{l}\text { Belleza/ Moda/ } \\
\text { Gastronomía }\end{array}$ & $\begin{array}{l}\text { Maquillaje/ Ropa/ } \\
\text { Accesorios/Bebidas }\end{array}$ & Regalos & Deja de buscar & 18 & & & & & 262 \\
\hline Recetario & Hogar & Cocina & Cocina & Nochebuena en el campo & 7 & & & & & 280 \\
\hline $\begin{array}{l}\text { PC-Artículo + } \\
\text { receta }\end{array}$ & Hogar & Cocina & $\begin{array}{l}\text { Escuela de } \\
\text { cocina }\end{array}$ & ¡Viva la fiesta! & 1 & & & & & 288 \\
\hline \multicolumn{11}{|c|}{ ÚLTIMAS NOTICIAS } \\
\hline PC- Reportaje & Ocio-cultura & Deporte & Últimas noticias & Chicas... ia correr! & 5 & & & & & 290 \\
\hline PC-Artículo & $\begin{array}{l}\text { Ocio-cultura/ } \\
\text { Moda }\end{array}$ & Libros/Marcas/Ópera & Últimas noticias & Ponte al día & 1 & & & & & 296 \\
\hline PC- Entrevista & Ocio-cultura & Guía de ocio & Últimas noticias & Para coleccionar & 1 & $\begin{array}{l}\text { Iván Martínez- } \\
\text { Cubells }\end{array}$ & $\mathrm{H}$ & Protagoniza & $\begin{array}{l}\text { Director Fuera de } \\
\text { serie }\end{array}$ & 297 \\
\hline Concurso & Moda & Ropa & Últimas noticias & ¿Y si te toca? & 1 & Elena Benarroch & $\mathrm{M}$ & Protagoniza & Diseñadora moda & 298 \\
\hline PC-Artículo & Moda & Ropa & Últimas noticias & $\begin{array}{l}\text { Compra en TELVA.com... Y } \\
\text { también la ropa de niños }\end{array}$ & 2 & & & & & 300 \\
\hline Directorio & & & Guía de tiendas & & 1 & & & & & 303 \\
\hline
\end{tabular}




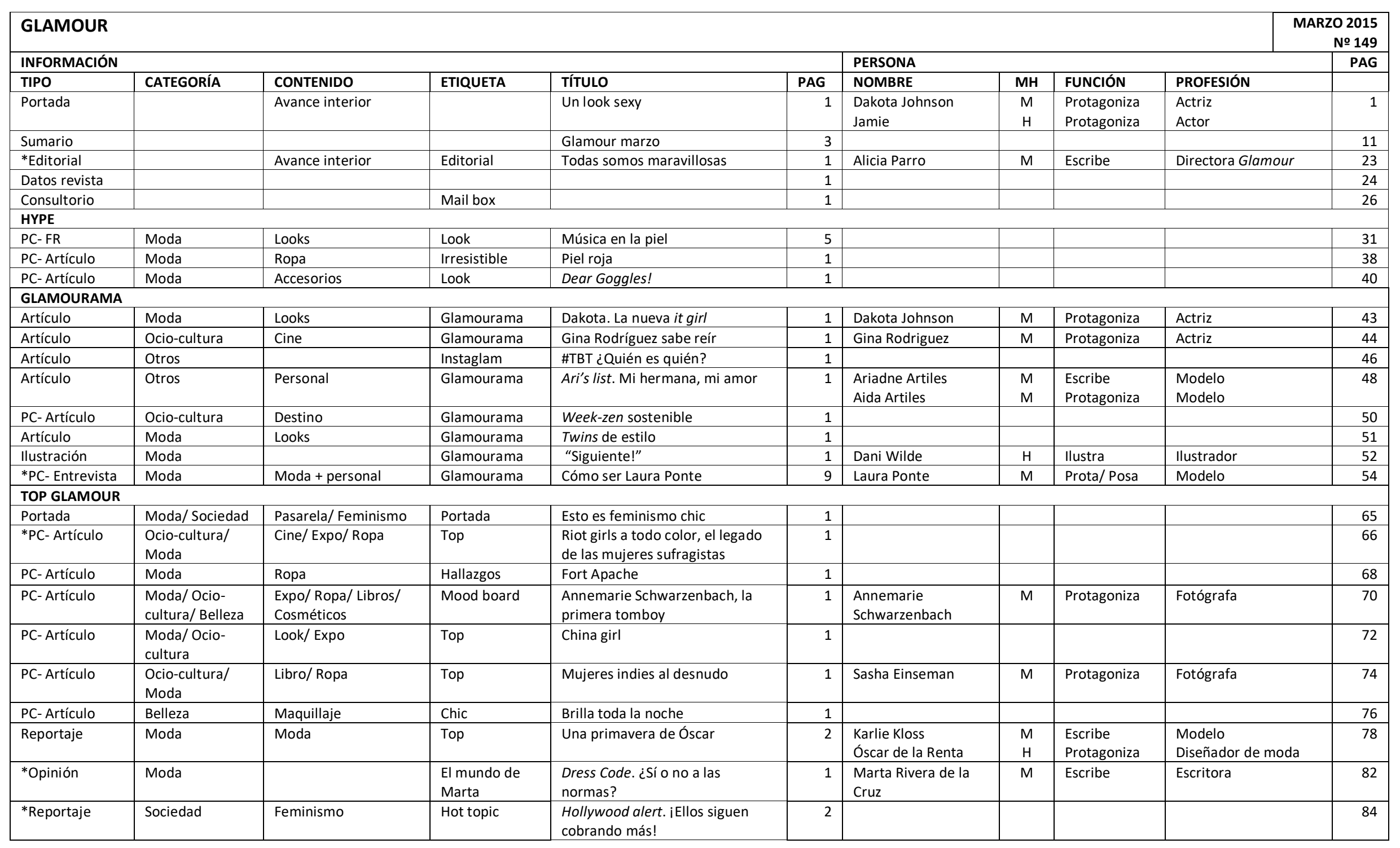




\begin{tabular}{|c|c|c|c|c|c|c|c|c|c|c|}
\hline PC- Reportaje & Moda & $\begin{array}{l}\text { Looks }+ \text { Moda }+ \\
\text { personal }\end{array}$ & Top & Family business & 4 & Kaia Gerber & M & Prota/ Posa & Modelo & 88 \\
\hline Artículo & Otros & & You you you & Ego boost, chute de autoestima & 1 & Mar Carrascosa & $\mathrm{M}$ & Asesora & Coach & 92 \\
\hline PC-Artículo & Ocio-cultura & Libros/Videojuegos & You you you & $\begin{array}{l}\text { Game on, aumenta tu } \\
\text { inteligencia }\end{array}$ & 1 & & & & & 94 \\
\hline \multicolumn{11}{|c|}{ STARS GLAMOUR } \\
\hline PC- Entrevista & $\begin{array}{l}\text { Ocio-cultura/ } \\
\text { Moda }\end{array}$ & Cine + personal/ Looks & Stars & $\begin{array}{l}\text { Dakota y Jamie. Así cambió su } \\
\text { vida } 50 \text { sombras de Grey }\end{array}$ & 6 & $\begin{array}{l}\text { Dakota Johnson } \\
\text { Jamie Dornan } \\
\text { Sam Taylor-Johnson }\end{array}$ & $\begin{array}{l}\mathrm{M} \\
\mathrm{H} \\
\mathrm{M}\end{array}$ & $\begin{array}{l}\text { Prota/ Posa } \\
\text { Prota/ Posa } \\
\text { Protagoniza }\end{array}$ & $\begin{array}{l}\text { Actriz } \\
\text { Actor } \\
\text { Directora de cine }\end{array}$ & 95 \\
\hline PC- Reportaje & Moda & $\begin{array}{l}\text { Looks/Ropa/ } \\
\text { Accesorios }\end{array}$ & Stars & El ritmo enciende tu estilo & 4 & & & & & 102 \\
\hline PC- Entrevista & Ocio-cultura & Cine + personal & Stars & Reese se vuelve salvaje & 5 & Reese Witherspoon & $\mathrm{M}$ & Prota/ Posa & Actriz & 108 \\
\hline Entrevista & Ocio-cultura & Expo/Arte & Stars & $\begin{array}{l}\text { Pablo Genovés y la paradoja del } \\
\text { ser humano }\end{array}$ & 5 & Pablo Genovés & $\mathrm{H}$ & Protagoniza & Artista & 114 \\
\hline \multicolumn{11}{|l|}{ CLUB GLAMOUR } \\
\hline Artículo & Ocio-cultura & Música & Portada & Ver, oír y callar & 1 & Mahaut Mondino & $\mathrm{M}$ & Protagoniza & Cantante & 119 \\
\hline Entrevista & Ocio-cultura & Música & Club & $\begin{array}{l}\text { Bautismo electrónico/ Ángeles } \\
\text { del indie }\end{array}$ & 1 & $\begin{array}{l}\text { Kate Akhurst } \\
\text { Markus Dextegen } \\
\text { Hampus Nordgren }\end{array}$ & $\begin{array}{l}\mathrm{M} \\
\mathrm{H} \\
\mathrm{H}\end{array}$ & $\begin{array}{l}\text { Protagoniza } \\
\text { Protagoniza } \\
\text { Protagoniza } \\
\end{array}$ & $\begin{array}{l}\text { Cantante } \\
\text { Instrumentista } \\
\text { Instrumentista } \\
\end{array}$ & 120 \\
\hline PC-Artículo & Ocio-cultura & Libros & Libros & Varios & 1 & & & & & 121 \\
\hline PC- Entrevista & $\begin{array}{l}\text { Ocio-cultura/ } \\
\text { Belleza }\end{array}$ & $\begin{array}{l}\text { Cine }+ \text { personal/ } \\
\text { Cosméticos }\end{array}$ & Cine & Colin Farrell, su año más intenso & 2 & Colin Farrell & $\mathrm{H}$ & Protagoniza & Actor & 122 \\
\hline Artículo & Ocio-cultura & Cine & Cine & Jessica Chastain se vuelve mala & 1 & Jessica Chastain & $\mathrm{H}$ & Protagoniza & Actriz & 124 \\
\hline PC-Artículo & Gastronomía & Restauración & Gourmet & Miss Foodies favoritos & 1 & & & & & 125 \\
\hline Entrevista & Otros & Personal & Off Glamour & "Ellos... siempre con bigote" & 1 & Carmen Boza & $\mathrm{M}$ & Protagoniza & Cantautora & 126 \\
\hline \multicolumn{11}{|c|}{ FUN \& PLEASURE GLAMOUR } \\
\hline PC- Entrevista & Moda & Moda & Fun \& Pleasure & \#D20 Los reyes de estilo & 7 & $\begin{array}{l}\text { Dean Caten } \\
\text { Dan Caten }\end{array}$ & $\begin{array}{l}\mathrm{H} \\
\mathrm{H} \\
\end{array}$ & $\begin{array}{l}\text { Protagoniza } \\
\text { Protagoniza }\end{array}$ & $\begin{array}{l}\text { Diseñador de moda } \\
\text { Diseñador de moda }\end{array}$ & 127 \\
\hline PC-Artículo & $\begin{array}{l}\text { Moda/ Ocio- } \\
\text { cultura }\end{array}$ & Expo/ Marcas & Fun \& Pleasure & Milán sigue la pista & 1 & & & & & 134 \\
\hline PC- Reportaje & Moda & Ropa/ Looks & Fun \& Pleasure & Vive una experiencia inolvidable & 4 & & & & & 142 \\
\hline \multicolumn{11}{|c|}{ ESPECIAL MUJER GLAMOUR } \\
\hline Portada & & Avance interior & Portada & Generación éxito & 1 & & & & & 143 \\
\hline *PC- Reportaje & Otros & Profesional & Especial mujer & Mujeres High-Tech & 9 & $\begin{array}{l}\text { Irene Cano } \\
\text { Elena Carasso } \\
\text { Elena Pisonero } \\
\text { Nuria Oliver }\end{array}$ & $\begin{array}{l}M \\
M \\
M \\
M\end{array}$ & $\begin{array}{l}\text { Protagoniza } \\
\text { Protagoniza } \\
\text { Protagoniza } \\
\text { Prota/ Posa }\end{array}$ & $\begin{array}{l}\text { Directora General } \\
\text { Facebook España } \\
\text { Directora Mango } \\
\text { online } \\
\text { Presidenta Hispasat } \\
\text { Directora científica } \\
\text { telefónica I+D }\end{array}$ & 144 \\
\hline *PC- Reportaje & Sociedad & Feminismo & Especial mujer & $\begin{array}{l}\text { ¿Hay una conspiración para que } \\
\text { no seas madre? }\end{array}$ & 4 & & & & & 155 \\
\hline
\end{tabular}




\begin{tabular}{|c|c|c|c|c|c|c|c|c|c|c|}
\hline PC- Reportaje & Ocio-cultura & Expo & Especial mujer & Europa unida por la moda & 4 & & & & & 158 \\
\hline *PC- Reportaje & Relaciones & Hombre- mujer & Especial mujer & Los problemas de él & 4 & & & & & 162 \\
\hline PC- Entrevista & Sociedad & Política + personal & Fuera de serie & Albert Rivera. Un nuevo estilo & 5 & Albert Rivera & $\mathrm{H}$ & Prota/ Posa & Político & 166 \\
\hline \multicolumn{11}{|l|}{ SHOP GLAMOUR } \\
\hline *PC- Reportaje & $\begin{array}{l}\text { Moda/ Ocio- } \\
\text { cultura }\end{array}$ & $\begin{array}{l}\text { Looks/ Ropa/ } \\
\text { Accesorios/Cine + } \\
\text { personal }\end{array}$ & Shop & Run the world & 7 & Zendaya Coleman & M & Prota/ Posa & Actriz & 171 \\
\hline PC- Reportaje & Moda & $\begin{array}{l}\text { Looks/Ropa/ } \\
\text { Accesorios }\end{array}$ & Shop & $\begin{array}{l}\text { Master Class. Claves de } \\
\text { temporada }\end{array}$ & 12 & & & & & 178 \\
\hline PC- Reportaje & Moda & Accesorios & Shop & Accesorios. Clases de geometría & 8 & & & & & 190 \\
\hline PC- Fotos & $\begin{array}{l}\text { Moda/ Ocio- } \\
\text { cultura/ Belleza }\end{array}$ & $\begin{array}{l}\text { Ropa/ Restauración/ } \\
\text { Cosméticos }\end{array}$ & $\begin{array}{l}\text { Miss G walks } \\
\text { around }\end{array}$ & & 3 & & & & & 198 \\
\hline \multicolumn{11}{|c|}{ BELLEZA GLAMOUR } \\
\hline Portada & & Avance interior & Portada & Primavera intrépida & 1 & & & & & 201 \\
\hline PC- Reportaje & Belleza & Cosméticos & Belleza & $\begin{array}{l}\text { Primeros rayos para una piel } \\
\text { nueva }\end{array}$ & 4 & & & & & 202 \\
\hline *PC- Reportaje & Belleza/ Salud & $\begin{array}{l}\text { Cosméticos/ } \\
\text { Nutrición/ Deporte }\end{array}$ & Belleza & $\begin{array}{l}\text { Best fitness \& Friends, silueta } \\
\text { nueva en un fin de semana }\end{array}$ & 6 & $\begin{array}{l}\text { Mariam Hernández } \\
\text { Aída Artiles }\end{array}$ & $\begin{array}{l}M \\
M\end{array}$ & $\begin{array}{l}\text { Asesora/Posa } \\
\text { Asesora/Posa }\end{array}$ & $\begin{array}{l}\text { Actriz } \\
\text { Modelo }\end{array}$ & 208 \\
\hline PC-Artículo & Belleza & Maquillaje & Favoritos & Esponja, la nueva brocha & 1 & & & & & 216 \\
\hline *PC- Entrevista & Belleza & $\begin{array}{l}\text { Maquillaje/ } \\
\text { Cosméticos + personal }\end{array}$ & Belleza & Una belleza original & 3 & Lily Collins & $M$ & Protagoniza & Actriz & 218 \\
\hline PC-FR & Belleza & Maquillaje & Belleza & Color trends & 6 & Bella Hadid & $\mathrm{M}$ & Prota/Posa & Modelo & 222 \\
\hline *PC- Reportaje & Belleza & $\begin{array}{l}\text { Tratamientos/ } \\
\text { Cosméticos/ } \\
\text { Maquillaje } \\
\end{array}$ & Belleza & Tratamientos red carpet & 5 & & & & & 229 \\
\hline \multicolumn{11}{|c|}{ ESTILO GLAMOUR } \\
\hline Portada & & Avance interior & Portada & Sexy boom & 1 & & & & & 245 \\
\hline PC- FR & Moda & Looks & & Primavera a todo print & 14 & & & & & 246 \\
\hline PC- Entrevista & $\begin{array}{l}\text { Moda/ Ocio- } \\
\text { cultura }\end{array}$ & $\begin{array}{l}\text { Cine y moda }+ \\
\text { personal }\end{array}$ & & Delicada Agathe & 7 & Agathe Bonitzer & $M$ & Prota/ Posa & Actriz & 261 \\
\hline Artículo & Moda & Moda & & & 1 & Raf Simons & $\mathrm{H}$ & Protagoniza & Diseñador de moda & 266 \\
\hline PC- FR & Moda & Looks & & Girl from Sunset Strip & 12 & & & & & 268 \\
\hline PC- Entrevista & Moda & Moda & & Una musa española en París & 6 & Violetta Sánchez & $\mathrm{M}$ & Prota/ Posa & Modelo & 280 \\
\hline PC- FR & Moda & Accesorios & & Must entre las flores & 4 & & & & & 286 \\
\hline \multicolumn{11}{|c|}{ GLAM LIFE GLAMOUR } \\
\hline PC- Reportaje & Decoración & Casa + personal & & Boho para tu casa & 5 & Barbara Boccara & $\mathrm{M}$ & Protagoniza & Diseñadora de moda & 291 \\
\hline $\begin{array}{l}\text { Reportaje/ } \\
\text { Recetario }\end{array}$ & Gastronomía & Alimentos & Glam life & La revolución del pan & 4 & $\begin{array}{l}\text { Beatriz Echevarría } \\
\text { Carla Medrano } \\
\text { Susana Gaona }\end{array}$ & $\begin{array}{l}M \\
M \\
M\end{array}$ & $\begin{array}{l}\text { Protagoniza } \\
\text { Protagoniza } \\
\text { Protagoniza } \\
\end{array}$ & $\begin{array}{l}\text { Panadera } \\
\text { Panadera } \\
\text { Panadera }\end{array}$ & 297 \\
\hline PC- Reportaje & Moda/Belleza & Ropa/Maquillaje & Glam life & Todas somos maravillosas & 2 & & & & & 300 \\
\hline Horóscopo & & & Horóscopo & & 1 & & & & & 302 \\
\hline
\end{tabular}




\begin{tabular}{|l|l|l|l|l|l|l|l|l|}
\hline PC- Artículo & Ocio-cultura & Destinos & Pistas & $\begin{array}{l}\text { Palihouse Holloway. A los pies de } \\
\text { Hollywood }\end{array}$ & 1 & 303 \\
\hline Directorio & & & Direcciones & & 2 & & & \\
\hline PC-Artículo & Ocio-cultura & Libros & Guinda & La magia de la cámara & 1 & & & \\
\hline
\end{tabular}




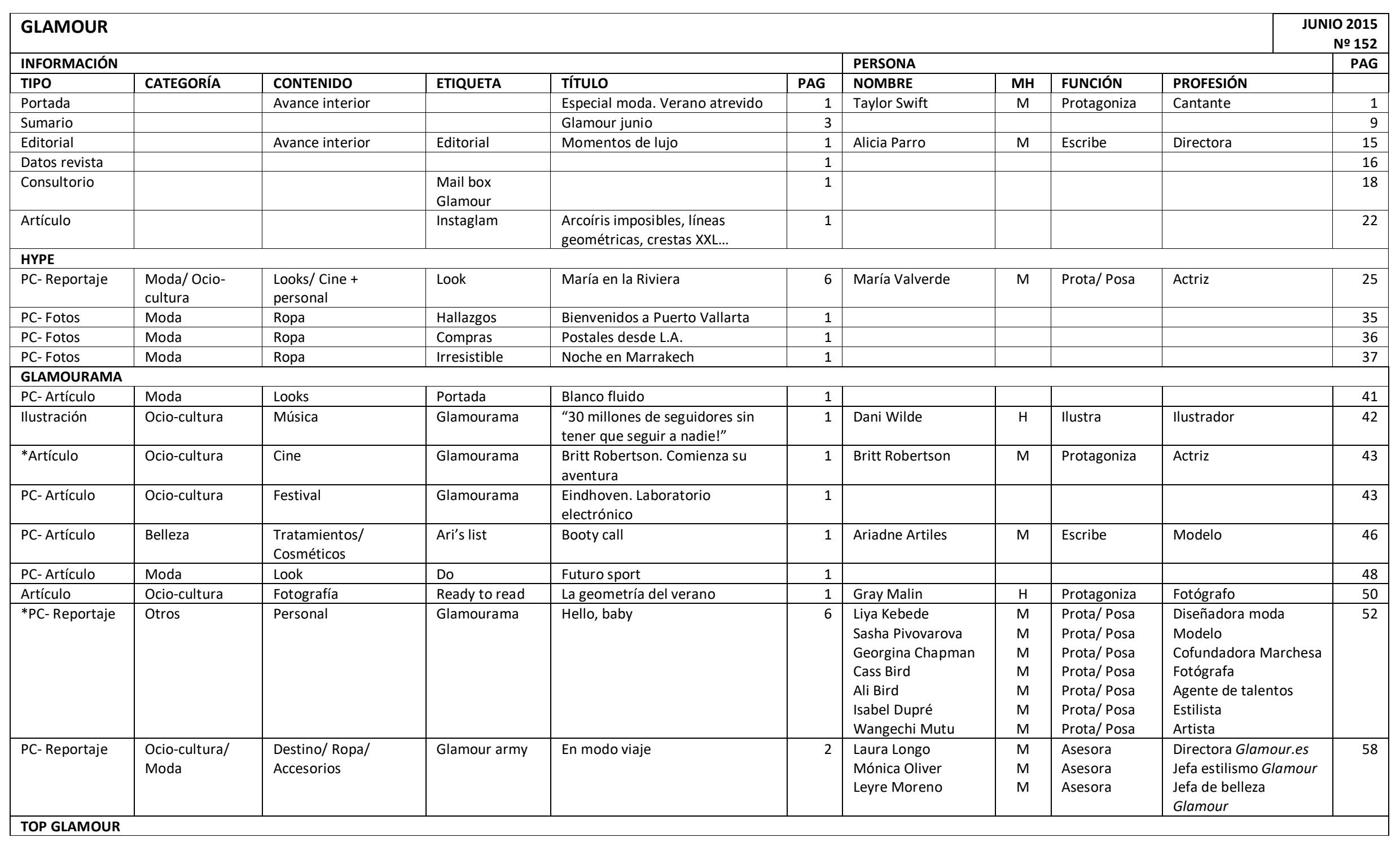




\begin{tabular}{|c|c|c|c|c|c|c|c|c|c|c|}
\hline PC- Reportaje & $\begin{array}{l}\text { Moda/ Deco/ } \\
\text { Ocio-cultura }\end{array}$ & $\begin{array}{l}\text { Ropa/ objetos deco/ } \\
\text { Restauración }\end{array}$ & Portada & Un estilo natural & 3 & & & & & 63 \\
\hline *PC-Artículo & Belleza & Cosméticos & Chic & Con la belleza al cuello & 1 & & & & & 66 \\
\hline PC-Artículo & Moda & Marca & Top & Preppy couple. Editores invitados & 1 & $\begin{array}{l}\text { Olivia Palermo } \\
\text { Johannes Huebl }\end{array}$ & $\begin{array}{l}\mathrm{M} \\
\mathrm{H} \\
\end{array}$ & $\begin{array}{l}\text { Protagoniza } \\
\text { Protagoniza } \\
\end{array}$ & $\begin{array}{l}\text { Actriz } \\
\text { Modelo }\end{array}$ & 67 \\
\hline PC-Artículo & Moda & Looks & Top & La era de los superprints & 1 & & & & & 68 \\
\hline PC-Artículo & Tecno & Gadgets & Top & $\begin{array}{l}\text { Regreso a 2015. El hito de estos } \\
\text { días }\end{array}$ & 1 & & & & & 70 \\
\hline PC-Artículo & Moda & Ropa & Top & Falda sí, pero ¿cuál? & 1 & & & & & 72 \\
\hline PC-Artículo & Moda & Accesorio & Top & $\begin{array}{l}\text { Artesanía de lujo/ Ríndete a lo } \\
\text { efímero/ It bags }\end{array}$ & 1 & & & & & 73 \\
\hline PC-Artículo & $\begin{array}{l}\text { Ocio-cultura/ } \\
\text { Moda }\end{array}$ & Libros/Accesorios & Top & $\begin{array}{l}\text { Vuelve a ser una niña/ Grandes } \\
\text { sombreros }\end{array}$ & 1 & & & & & 74 \\
\hline PC-Artículo & Moda & Look & Must have & Navy de ciudad & 1 & & & & & 75 \\
\hline Reportaje & Ocio-cultura & Arte & Top & I need an artist & 4 & $\begin{array}{l}\text { Ophelia Filke } \\
\text { John Allen } \\
\text { Alexandra } \\
\text { Kehayoglou } \\
\text { Mat Maitland } \\
\text { Hiroshi Sujimoto }\end{array}$ & $\begin{array}{l}\mathrm{M} \\
\mathrm{H} \\
\mathrm{M} \\
\mathrm{H} \\
\mathrm{H} \\
\mathrm{H}\end{array}$ & $\begin{array}{l}\text { Protagoniza } \\
\text { Protagoniza } \\
\text { Protagoniza } \\
\text { Protagoniza } \\
\text { Protagoniza } \\
\end{array}$ & $\begin{array}{l}\text { Artista } \\
\text { Artista textil } \\
\text { Artista } \\
\text { Director de arte } \\
\text { Artista } \\
\end{array}$ & 78 \\
\hline Opinión & Sociedad & & $\begin{array}{l}\text { El mundo de } \\
\text { Marta }\end{array}$ & El lujo, hoy & 1 & $\begin{array}{l}\text { Marta Rivera de la } \\
\text { Cruz }\end{array}$ & $\mathrm{M}$ & Escribe & Escritora & 81 \\
\hline *Reportaje & Otros & & Hot topic & $\begin{array}{l}\text { Dónde están y quiénes son los } \\
\text { nuevos solteros de oro }\end{array}$ & 2 & $\begin{array}{l}\text { Evan Spiegel } \\
\text { Jack Dorsey } \\
\text { Mark Zuckerberg } \\
\text { Ben Rattray } \\
\text { Kevin Systrom } \\
\end{array}$ & $\begin{array}{l}\mathrm{H} \\
\mathrm{H} \\
\mathrm{H} \\
\mathrm{H} \\
\mathrm{H} \\
\end{array}$ & $\begin{array}{l}\text { Protagoniza } \\
\text { Protagoniza } \\
\text { Protagoniza } \\
\text { Protagoniza } \\
\text { Protagoniza } \\
\end{array}$ & $\begin{array}{l}\text { Fundador Snapchat } \\
\text { Fundador Twitter } \\
\text { Fundador Facebook } \\
\text { Fundador change.org } \\
\text { Fundador Instagram }\end{array}$ & 84 \\
\hline *PC- Reportaje & Moda & Accesorios & Top & Joyas de la jet set & 4 & $\begin{array}{l}\text { Sabine Ghanem } \\
\text { Eugenie Niarchos } \\
\text { Noors Fares } \\
\text { Fernando Jorge } \\
\text { Bianca Brandolini } \\
\text { D'Adda } \\
\end{array}$ & $\begin{array}{l}\mathrm{M} \\
\mathrm{M} \\
\mathrm{M} \\
\mathrm{H} \\
\mathrm{M}\end{array}$ & $\begin{array}{l}\text { Prota/ Posa } \\
\text { Prota/ Posa } \\
\text { Prota/ Posa } \\
\text { Protagoniza } \\
\text { Prota/ Posa }\end{array}$ & $\begin{array}{l}\text { Diseñadora joyas } \\
\text { Diseñadora joyas } \\
\text { Diseñadora joyas } \\
\text { Diseñador joyas } \\
\text { Diseñadora joyas }\end{array}$ & 86 \\
\hline *Artículo & Otros & & You you you & ¿Pero tú... procrastinas? & 1 & & & & & 90 \\
\hline Artículo & Relaciones & Hombre-mujer & You you you & Cariño, tenemos que hablar & 1 & & & & & 92 \\
\hline \multicolumn{11}{|c|}{ STARS GLAMOUR } \\
\hline PC- Entrevista & Ocio-cultura & Cine + personal & Stars & Generación cool & 5 & $\begin{array}{l}\text { Riley Keough } \\
\text { Nicholas Hoult }\end{array}$ & $\begin{array}{l}\mathrm{M} \\
\mathrm{H}\end{array}$ & $\begin{array}{l}\text { Prota/ Posa } \\
\text { Prota/ Posa }\end{array}$ & $\begin{array}{l}\text { Actriz } \\
\text { Actor }\end{array}$ & 93 \\
\hline Reportaje & Moda & Looks & Stars & $\begin{array}{l}\text { Streetstyle. Nuevos rostros de la } \\
\text { moda }\end{array}$ & 3 & & & & & 100 \\
\hline Reportaje & Ocio-cultura & Cine & Stars & $\begin{array}{l}\text { El rey chic de Hollywood, Cary } \\
\text { Fukunaga }\end{array}$ & 2 & Cary Fukunaga & $\mathrm{H}$ & Protagoniza & Director & 106 \\
\hline
\end{tabular}




\begin{tabular}{|c|c|c|c|c|c|c|c|c|c|c|}
\hline *Reportaje & Sociedad & Personal & Stars & Pon una Olivia Pope en tu vida & 4 & $\begin{array}{l}\text { Cristina Cifuentes } \\
\text { Marisa González }\end{array}$ & $\begin{array}{l}M \\
M\end{array}$ & $\begin{array}{l}\text { Protagoniza } \\
\text { Protagoniza }\end{array}$ & $\begin{array}{l}\text { Política } \\
\text { Jefa de comunicación }\end{array}$ & 108 \\
\hline \multicolumn{11}{|l|}{ CLUB GLAMOUR } \\
\hline PC- Artículo & Ocio-cultura & Festival & Portada & Mézclate con ellos & 3 & Ruby Rose & $\mathrm{M}$ & Protagoniza & DJ & 113 \\
\hline Entrevista & Ocio-cultura & Música & Música & Un universo a todo color & 1 & Jamie XX & $\mathrm{H}$ & Protagoniza & Cantante & 114 \\
\hline Artículo & Ocio-cultura & Música & Música & Larga vida a los DJs & 1 & & & & & 115 \\
\hline PC- Reportaje & Ocio-cultura & Teatro & Teatro & $\begin{array}{l}\text { El sexo más animal con Isabella } \\
\text { Rossellini }\end{array}$ & 2 & Isabella Rossellini & M & Protagoniza & Actriz & 116 \\
\hline *Entrevista & Ocio-cultura & Cine + personal & Cine & $\begin{array}{l}\text { ¿Por qué nos cae tan bien Chris } \\
\text { Pratt? }\end{array}$ & 2 & Chris Pratt & $\mathrm{H}$ & Protagoniza & Actor & 118 \\
\hline PC- Reportaje & Ocio-cultura & Libros & Libros & Primera página de un bestseller & 6 & $\begin{array}{l}\text { Almudena de } \\
\text { Arteaga } \\
\text { Laura Gutman } \\
\text { Anna Told }\end{array}$ & $\begin{array}{l}M \\
M \\
M\end{array}$ & $\begin{array}{l}\text { Prota/ Posa } \\
\text { Prota/ Posa } \\
\text { Prota/ Posa }\end{array}$ & $\begin{array}{l}\text { Escritora } \\
\text { Escritora } \\
\text { Escritora }\end{array}$ & 120 \\
\hline PC- Artículo & Ocio-cultura & Expo & Estuvimos en... & Vive con un icono & 1 & & & & & 126 \\
\hline \multicolumn{11}{|c|}{ FUN \& PLEASURE GLAMOUR } \\
\hline PC- Reportaje & Moda & Looks & Fun \& Pleasure & Una tarde en las carreras & 5 & Jessica Springteen & $\mathrm{M}$ & Protagoniza & Campeona de salto & 127 \\
\hline *Reportaje & Sociedad & & Fun \& Pleasure & Una causa común & 4 & $\begin{array}{l}\text { Eva Longoria } \\
\text { Elisa Sednaoui }\end{array}$ & $\begin{array}{l}M \\
M\end{array}$ & $\begin{array}{l}\text { Prota/ Posa } \\
\text { Protagoniza }\end{array}$ & $\begin{array}{l}\text { Actriz } \\
\text { Modelo }\end{array}$ & 134 \\
\hline Reportaje & Relaciones & Hombre-mujer & Fun \& Pleasure & $\begin{array}{l}\text { Test de Cooper. Lo ponemos a } \\
\text { prueba }\end{array}$ & 4 & $\begin{array}{l}\text { Marta Hazas } \\
\text { Javier Veiga }\end{array}$ & $\begin{array}{l}\mathrm{M} \\
\mathrm{H}\end{array}$ & $\begin{array}{l}\text { Prota/ Posa } \\
\text { Prota/ Posa }\end{array}$ & $\begin{array}{l}\text { Actriz } \\
\text { Actor }\end{array}$ & 136 \\
\hline PC- Horóscopo & Moda/Belleza & $\begin{array}{l}\text { Ropa/ Accesorio/ } \\
\text { Cosméticos/ } \\
\text { Maquillaje }\end{array}$ & Fun \& Pleasure & Horóscopo especial de verano & 12 & & & & & 142 \\
\hline \multicolumn{11}{|c|}{ SHOP GLAMOUR } \\
\hline PC- Reportaje & Moda & $\begin{array}{l}\text { Ropa/ Accesorios/ } \\
\text { Looks }\end{array}$ & Shop & Verano en el horizonte & 7 & & & & & 155 \\
\hline PC- Reportaje & Moda & Ropa & Shop & El suceso del verano & 2 & & & & & 162 \\
\hline PC- Fotos & Moda & Ropa/Accesorios & Shop & Un baño, una época & 6 & & & & & 164 \\
\hline PC- Reportaje & Moda & Ropa/Accesorios & Shop & Stars Swimming & 4 & $\begin{array}{l}\text { Anna Ponsa } \\
\text { Laura Put } \\
\text { Alicia Sanz } \\
\text { Dulceida }\end{array}$ & $\begin{array}{l}M \\
M \\
M \\
M\end{array}$ & $\begin{array}{l}\text { Protagoniza } \\
\text { Protagoniza } \\
\text { Protagoniza } \\
\text { Protagoniza }\end{array}$ & $\begin{array}{l}\text { Blogger } \\
\text { DJ, actriz } \\
\text { Actriz } \\
\text { Influencer }\end{array}$ & 172 \\
\hline PC-FR & Moda & Looks & Shop & Alma mediterránea & 6 & & & & & 176 \\
\hline PC- Entrevista & Moda & $\begin{array}{l}\text { Ropa/ Accesorios + } \\
\text { personal }\end{array}$ & Shop & Judith Milgrom, elegancia slow & 2 & Judith Milgrom & $\mathrm{M}$ & Prota/ Posa & Diseñadora moda & 180 \\
\hline PC- Reportaje & Moda & Ropa & Shop & Pañuelo en juego & 2 & & & & & 182 \\
\hline PC- Reportaje & Moda & Ropa/Accesorios & Shop & Distrito vintage & 2 & & & & & 184 \\
\hline $\begin{array}{l}\text { PC- FR } \\
\end{array}$ & Moda & Accesorios & Shop & 15 miradas & 6 & & & & & 186 \\
\hline PC-Artículo & Moda & Accesorios & Shop & Siempre o'clock & 1 & & & & & 194 \\
\hline \multicolumn{11}{|c|}{ BELLEZA GLAMOUR } \\
\hline Portada & & Avance interior & Portada & Que no se ponga el sol & 1 & & & & & 195 \\
\hline
\end{tabular}




\begin{tabular}{|c|c|c|c|c|c|c|c|c|c|c|}
\hline PC- Reportaje & Belleza & $\begin{array}{l}\text { Cosméticos/ } \\
\text { Maquillaje }\end{array}$ & Belleza & $\begin{array}{l}\text { Dame el color y quédate con lo } \\
\text { demás }\end{array}$ & 6 & & & & & 196 \\
\hline *PC- Artículo & Belleza & Maquillaje & Favoritos & A prueba de agua & 1 & & & & & 202 \\
\hline PC-Artículo & Belleza & Peinados & Belleza & Revolución wavy & 1 & & & & & 204 \\
\hline $\begin{array}{l}\text { PC-FR } \\
\end{array}$ & Belleza & Peinado/ Maquillaje & Belleza & Más allá del hippie & 6 & Sam Maknight & $\mathrm{H}$ & Protagoniza & Estilista & 206 \\
\hline *PC- Entrevista & Belleza/Tecno & $\begin{array}{l}\text { Peinados/ } \\
\text { Cosméticos/Motor + } \\
\text { personal }\end{array}$ & Belleza & $\begin{array}{l}\text { Carmen Jordá. La belleza } \\
\text { intrépida }\end{array}$ & 5 & Carmen Jordá & $M$ & Prota/ Posa & Piloto de coches & 212 \\
\hline PC- Reportaje & Belleza/ Salud & Cosméticos/ Nutrición & Belleza & Energía en tu piel & 4 & & & & & 218 \\
\hline *PC- Reportaje & Salud & Nutrición & Belleza & $\begin{array}{l}\text { ¿Quieres adelgazar? Conoce el } \\
\text { 'talking' }\end{array}$ & 2 & & & & & 222 \\
\hline PC- Reportaje & Moda/ Belleza & $\begin{array}{l}\text { Ropa/ Accesorios/ } \\
\text { Cosméticos }\end{array}$ & $\begin{array}{l}\text { Miss G walks } \\
\text { around }\end{array}$ & $\begin{array}{l}\text { Heroínas de estilo/ Discípulas de } \\
\text { Coachella }\end{array}$ & 3 & & & & & 224 \\
\hline \multicolumn{11}{|c|}{ ESTILO GLAMOUR } \\
\hline Portada & & Avance interior & Portada & El verano más sexy & 1 & & & & & 227 \\
\hline *PC-Reportaje & Ocio-cultura & Música + personal & & El mundo a sus pies & 10 & Taylor Swift & $M$ & Prota/ Posa & Cantante & 228 \\
\hline PC- FR & Moda & Looks & & Paraíso urbano & 6 & Ariadne Artiles & $M$ & Prota/ Posa & Modelo & 236 \\
\hline PC- FR & Moda & Looks & & Atomic Debbie & 10 & & & & & 244 \\
\hline PC- Reportaje & Otros & Profesional + personal & & La agenda del millón... de amigos & 8 & Macarena Blanchón & M & Prota/ Posa & Partner Be Agency & 254 \\
\hline *PC- Entrevista & Moda & Moda + personal & & Marlon Teixeira & 6 & Marlon Teixeira & $\mathrm{H}$ & Prota/ Posa & Modelo & 262 \\
\hline PC-Artículo & Moda & Ropa/ Accesorios & Impactos & Destino Alabama & 1 & & & & & 268 \\
\hline \multicolumn{11}{|c|}{ GLAM LIFE GLAMOUR } \\
\hline Portada & & Avance interior & Portada & Objetivo evasión & 1 & & & & & 269 \\
\hline PC- Reportaje & $\begin{array}{l}\text { Ocio-cultura/ } \\
\text { Moda }\end{array}$ & $\begin{array}{l}\text { Destinos/ } \\
\text { Restauración/Marcas }\end{array}$ & Glam life & 24 horas en Saigón & 2 & & & & & 270 \\
\hline PC- Reportaje & $\begin{array}{l}\text { Moda/ } \\
\text { Decoración }\end{array}$ & $\begin{array}{l}\text { Moda/ Casa + } \\
\text { personal }\end{array}$ & Glam life & Cool Chloé & 4 & Clare Waight Keller & $M$ & Prota/ Posa & $\begin{array}{l}\text { Directora creativa } \\
\text { Chloé }\end{array}$ & 272 \\
\hline PC- FR & Moda/Belleza & $\begin{array}{l}\text { Ropa/ Accesorios/ } \\
\text { Maquillaje/ } \\
\text { Cosméticos }\end{array}$ & Shopping night & Una noche de compras & 10 & & & & & 276 \\
\hline Horóscopo & & & Horóscopo & & 1 & & & & & 286 \\
\hline PC-Artículo & Ocio-cultura & Destino/ Restauración & Pistas & Day \& night & 1 & & & & & 287 \\
\hline Directorio & & & Direcciones & & 2 & & & & & 288 \\
\hline PC-Artículo & Ocio-cultura & Libro & Guinda & Aprende a posar con Bodhi & 1 & $\begin{array}{l}\text { Yena Kim } \\
\text { David Fung }\end{array}$ & $\begin{array}{l}\mathrm{M} \\
\mathrm{H}\end{array}$ & $\begin{array}{l}\text { Protagoniza } \\
\text { Protagoniza }\end{array}$ & $\begin{array}{l}\text { Artista } \\
\text { Artista }\end{array}$ & 290 \\
\hline
\end{tabular}




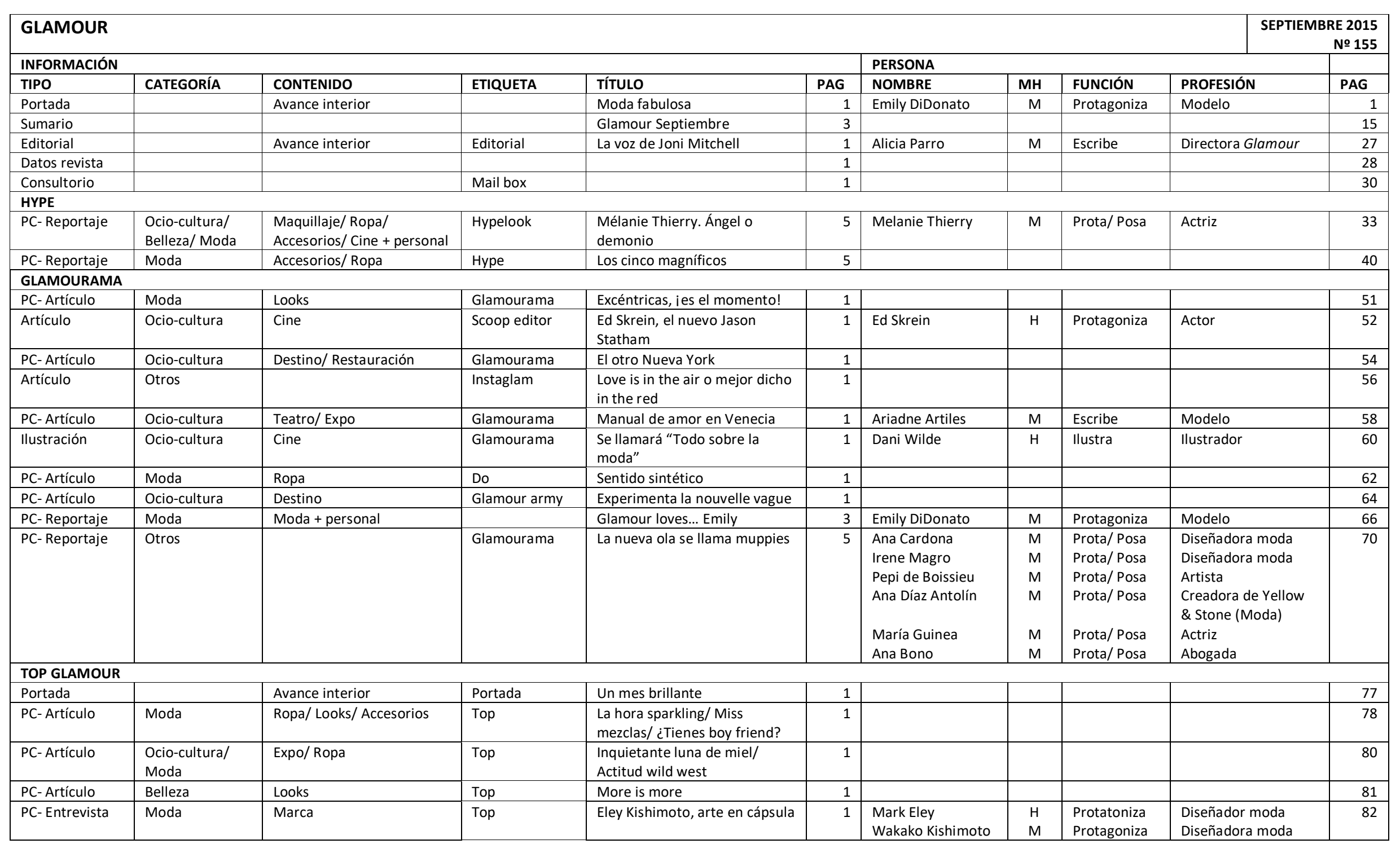




\begin{tabular}{|c|c|c|c|c|c|c|c|c|c|c|}
\hline PC-Artículo & Moda & Ropa & Top & Mean Girls, el triunfo & 1 & & & & & 84 \\
\hline PC-Artículo & Moda & Marca & Mood board & La victoria del college & 1 & $\begin{array}{l}\text { Tommaso Aquilano } \\
\text { Roberto Rimondi }\end{array}$ & $\begin{array}{l}\mathrm{H} \\
\mathrm{H} \\
\end{array}$ & $\begin{array}{l}\text { Protagoniza } \\
\text { Protagoniza }\end{array}$ & $\begin{array}{l}\text { Diseñador moda } \\
\text { Diseñador moda }\end{array}$ & 86 \\
\hline PC-Artículo & $\begin{array}{l}\text { Decoración/ } \\
\text { Moda }\end{array}$ & Look/ objetos deco & Top & Folk season & 1 & & & & & 88 \\
\hline PC-Artículo & Moda/Belleza & Ropa/ Cosméticos & Top & $\begin{array}{l}\text { \#NoGender/ Territorio } \\
\text { neutral/ Olfato unisex }\end{array}$ & 1 & & & & & 89 \\
\hline PC- Entrevista & $\begin{array}{l}\text { Belleza/ Ocio- } \\
\text { cultura }\end{array}$ & $\begin{array}{l}\text { Cosméticos/Cine + } \\
\text { personal }\end{array}$ & Top & Jonny Depp en esencia & 2 & & & & & 90 \\
\hline Opinión & $\begin{array}{l}\text { Tecno/ } \\
\text { Relaciones }\end{array}$ & Apps/ Familia & $\begin{array}{l}\text { El mundo de } \\
\text { Marta }\end{array}$ & ¿Cama con móvil? & 1 & $\begin{array}{l}\text { Marta Rivera de la } \\
\text { Cruz }\end{array}$ & $M$ & Escribe & Escritora & 94 \\
\hline *PC- Reportaje & Sociedad & Feminismo & Hot topic & Quitarte 15 años. ¿New trend? & 2 & & & & & 96 \\
\hline Reportaje & Moda & Moda & Top & Karl \& Fendi & 4 & Karl Lagerfeld & $\mathrm{H}$ & Protagoniza & Diseñador moda & 98 \\
\hline Reportaje & Relaciones & Hombre-mujer & You you you & $\begin{array}{l}\text { Cómo disfrutar de una } \\
\text { aventura }\end{array}$ & 1 & & & & & 102 \\
\hline \multicolumn{11}{|c|}{ STARS GLAMOUR } \\
\hline *PC- Entrevista & $\begin{array}{l}\text { Ocio-cultura/ } \\
\text { Belleza }\end{array}$ & $\begin{array}{l}\text { Cosméticos/Maquillaje/ } \\
\text { Cine + personal }\end{array}$ & Stars & Una belleza adictiva & 5 & Jennifer Lawrence & $M$ & Protagoniza & Actriz & 103 \\
\hline PC- Reportaje & Moda & Looks & Stars & El largo que viene & 4 & & & & & 110 \\
\hline \multicolumn{11}{|l|}{ CLUB GLAMOUR } \\
\hline Portada & & Avance interior & Portada & Rebeldes con causa & 1 & & & & & 115 \\
\hline PC- Artículo & Ocio-cultura & Cine & & $\begin{array}{l}\text { Tras los pasos de James/ } \\
\text { Contra las normas }\end{array}$ & 1 & & & & & 116 \\
\hline PC- Artículo & Ocio-cultura & Series & Cine & $\begin{array}{l}\text { El humor irreverente de Amy } \\
\text { Schumer }\end{array}$ & 1 & Amy Schumer & $M$ & Protagoniza & Guionista y actriz & 117 \\
\hline PC-Artículo & Ocio-cultura & Música & Música & Los nuevos oldies & 1 & $\begin{array}{l}\text { Natalie Prass } \\
\text { Leon Bridges }\end{array}$ & $\begin{array}{l}\mathrm{M} \\
\mathrm{H}\end{array}$ & $\begin{array}{l}\text { Protagoniza } \\
\text { Protagoniza }\end{array}$ & $\begin{array}{l}\text { Cantante } \\
\text { Cantante }\end{array}$ & 118 \\
\hline PC-Artículo & Ocio-cultura & Expo & Expos & $\begin{array}{l}\text { Arte club urbano/ Fascinados } \\
\text { por la fama }\end{array}$ & 1 & $\begin{array}{l}\text { Shepard Fairey } \\
D^{*} \text { Face }\end{array}$ & $\begin{array}{l}\mathrm{H} \\
\mathrm{H}\end{array}$ & $\begin{array}{l}\text { Protagoniza } \\
\text { Protagoniza }\end{array}$ & $\begin{array}{l}\text { Artista } \\
\text { Artista }\end{array}$ & 119 \\
\hline PC- Entrevista & Ocio-cultura & Libros & Libros & $\begin{array}{l}\text { Una leyenda que hizo historia/ } \\
\text { La biblia para bingers/ Todo } \\
\text { por amor }\end{array}$ & 1 & Carrie Snyder & M & Protagoniza & Escritora & 120 \\
\hline PC-Artículo & Ocio-cultura & Expo & Arquitectura & $\begin{array}{l}\text { El corazón de Madrid, desde } \\
\text { dentro }\end{array}$ & 1 & & & & & 121 \\
\hline PC- Reportaje & Ocio-cultura & Destino & Fuera de serie & $\begin{array}{l}\text { Organiza un final de verano } \\
\text { alla grande }\end{array}$ & 3 & & & & & 123 \\
\hline \multicolumn{11}{|c|}{ FUN \& PLEASURE GLAMOUR } \\
\hline Portada & & Avance interior & Portada & $\begin{array}{l}\text { Especial mujer. Logra tus } \\
\text { sueños }\end{array}$ & 1 & & & & & 127 \\
\hline *PC- Reportaje & $\begin{array}{l}\text { Relaciones/ } \\
\text { Ocio-cultura }\end{array}$ & $\begin{array}{l}\text { Hombre-mujer/ Cine + } \\
\text { personal }\end{array}$ & Especial mujer & La identidad de lo femenino & 5 & Alma Jodorowsky & $M$ & Actriz & Prota/Posa & 128 \\
\hline
\end{tabular}




\begin{tabular}{|c|c|c|c|c|c|c|c|c|c|c|}
\hline *PC- Entrevista & Moda & & Especial mujer & La moda y el éxito van con ella & 5 & $\begin{array}{l}\text { Inmaculada Pérez } \\
\text { Castellanos }\end{array}$ & $\mathrm{M}$ & Prota/ Posa & Abogada & 134 \\
\hline \multicolumn{11}{|l|}{ SHOP GLAMOUR } \\
\hline Portada & & Avance interior & Portada & Al ritmo del invierno & 1 & & & & & 139 \\
\hline PC- Fotos & Moda & Ropa/Accesorios & Shop & Inversiones fall 15 & 6 & & & & & 140 \\
\hline *PC- Reportaje & Moda & Looks/Moda & Shop & $\begin{array}{l}\text { Julie de Libran, el chic } \\
\text { inteligente }\end{array}$ & 4 & Julie de Libran & $\mathrm{M}$ & Prota/ Posa & Diseñadora moda & 146 \\
\hline PC- Reportaje & Moda & Ropa/ Looks & Shop & Una prenda, tres edades & 2 & & & & & 150 \\
\hline PC- Reportaje & Moda & Looks/ Ropa/ Accesorios & Shop & Guerrilla chic & 4 & & & & & 153 \\
\hline PC- FR & Moda & Looks & Shop & Las musas de la temporada & 5 & & & & & 156 \\
\hline PC- Fotos & Moda & Ropa & \multirow{2}{*}{$\begin{array}{l}\text { Shop } \\
\text { Flechazos }\end{array}$} & Una mirada al pasado & 1 & & & & & 161 \\
\hline PC- Reportaje & Moda & Ropa/Accesorios & & $\begin{array}{l}\text { Eslabones Chic/ Silueta caja/ } \\
\text { Pliegues infinitos/Medida } \\
\text { perfecta }\end{array}$ & 4 & & & & & 162 \\
\hline PC- Reportaje & Moda & Marca & Shop & El secreto del new sexy & 2 & $\begin{array}{l}\text { Karyn Hillman } \\
\text { María Pedraza }\end{array}$ & $M$ & $\begin{array}{l}\text { Protagoniza } \\
\text { Prota/ Posa }\end{array}$ & $\begin{array}{l}\text { Jefa de producción } \\
\text { Levis } \\
\text { Bailarina }\end{array}$ & 166 \\
\hline PC-Artículo & Moda & Accesorios & Shop & Tesoros dark en tu joyero & 1 & & & & & 168 \\
\hline \multicolumn{11}{|c|}{ BELLEZA GLAMOUR } \\
\hline Portada & & Avance interior & Portada & Una imagen a medida & 1 & & & & & 169 \\
\hline $\begin{array}{l}\text { PC-FR } \\
\end{array}$ & Belleza & Maquillaje & Belleza & Ideas que hacen magia & 5 & & & & & 170 \\
\hline PC- Artículo & Belleza & Maquillaje & Belleza & Efectos especiales & 1 & & & & & 174 \\
\hline PC- Reportaje & Belleza & Cosméticos & Belleza & $\begin{array}{l}\text { Tus infalibles de esta } \\
\text { temporada }\end{array}$ & 2 & & & & & 176 \\
\hline PC- Reportaje & Belleza & Maquillaje & Belleza & Los imprescindibles de Emily & 2 & Emily DiDonato & $\mathrm{M}$ & Prota/ Posa & Modelo & 178 \\
\hline *PC- Reportaje & Belleza & Tratamientos/Cosméticos & Belleza & $\begin{array}{l}\text { Retoques high tech. } \\
\text { Rejuvenece tu piel }\end{array}$ & 4 & & & & & 180 \\
\hline PC- Entrevista & Belleza/ Moda & $\begin{array}{l}\text { Maquillaje/ Moda + } \\
\text { personal }\end{array}$ & Belleza & Espíritu rock & 6 & Gala González & $\mathrm{M}$ & Prota/ Posa & Bloguera & 184 \\
\hline *PC- Reportaje & $\begin{array}{l}\text { Ocio-cultura/ } \\
\text { Salud }\end{array}$ & Libros/Prevención & Belleza & $\begin{array}{l}\text { Bendita histeria/ Guía para } \\
\text { paliar tu SPM }\end{array}$ & 4 & Julie Holland & $M$ & Escribe & Psiquiatra & 190 \\
\hline PC- Entrevista & Belleza & Cosméticos + personal & Stars news & $\begin{array}{l}\text { Abbey Lee. Un perfume para } \\
\text { sentirse en el paraíso }\end{array}$ & 2 & Abbey Lee & $\mathrm{M}$ & Protagoniza & Modelo & 194 \\
\hline *PC- Artículo & Belleza & Cosméticos & \multirow{2}{*}{$\begin{array}{l}\text { Must have } \\
\text { Miss G walks } \\
\text { around }\end{array}$} & $\begin{array}{l}\text { Piel de bebé. Tus tres nuevas } \\
\text { claves }\end{array}$ & 1 & & & & & 196 \\
\hline PC- Reportaje & $\begin{array}{l}\text { Moda/ } \\
\text { Gastronomía/ } \\
\text { Tecno/ Ocio- } \\
\text { cultura }\end{array}$ & $\begin{array}{l}\text { Ropa/ Accesorios/ Bebidas/ } \\
\text { Alimentos/ Motor/ Festival }\end{array}$ & & ¿Varios? ¿en blanco? & 3 & & & & & 210 \\
\hline \multicolumn{11}{|c|}{ ESTILO GLAMOUR } \\
\hline PC-FR & Moda & Looks & & Fashion Ligths & 13 & Emily DiDonato & $\mathrm{M}$ & Prota/ Posa & Modelo & 211 \\
\hline PC- Entrevista & Ocio-cultura & Danza + personal & & "¿Gustar a todos? Eso nunca" & 6 & Nacho Duato & $\mathrm{H}$ & Protagoniza & Coreógrafo & 226 \\
\hline
\end{tabular}




\begin{tabular}{|c|c|c|c|c|c|c|c|c|c|c|}
\hline Reportaje & Moda & Marca & & De la luz a la oscuridad & 4 & & & & & 232 \\
\hline Reportaje & Moda & Moda + personal & & El rostro del nuevo estilo & 8 & Emma Ferrer & $M$ & Protagoniza & Modelo & 236 \\
\hline PC- FR & Moda & Ropa/ Accesorios & & $\begin{array}{l}\text { Viste para complacerte a ti } \\
\text { misma }\end{array}$ & 6 & & & & & 244 \\
\hline $\begin{array}{l}\text { PC-FR } \\
\end{array}$ & Moda & Looks & & Motel of love & 14 & Emily DiDonato & $M$ & Protagoniza & Modelo & 250 \\
\hline PC- Reportaje & Moda & Moda & & $\begin{array}{l}\text { Destino NY } 30 \text { años después de } \\
\text { su gran debut }\end{array}$ & 8 & Elena Benarroch & $M$ & Prota/Posa & Diseñadora moda & 264 \\
\hline \multicolumn{11}{|c|}{ GLAM LIFE GLAMOUR } \\
\hline Portada & & Avance interior & Portada & Guía High Class & 1 & & & & & 273 \\
\hline PC- Reportaje & $\begin{array}{l}\text { Ocio-cultura/ } \\
\text { Decoración/ } \\
\text { Belleza }\end{array}$ & $\begin{array}{l}\text { Destinos/Restauración/ } \\
\text { objetos deco/ Música + } \\
\text { personal/ Moda + personal }\end{array}$ & Glam life & Places to be cool & 2 & $\begin{array}{l}\text { Sophie Auster } \\
\text { Vanessa Bruno } \\
\text { Natalia Ferviú } \\
\text { Eleonora Carisi }\end{array}$ & $\begin{array}{l}M \\
M \\
M \\
M\end{array}$ & $\begin{array}{l}\text { Protagoniza } \\
\text { Protagoniza } \\
\text { Protagoniza } \\
\text { Protagoniza }\end{array}$ & $\begin{array}{l}\text { Cantante } \\
\text { Diseñadora bolsos } \\
\text { Estilista } \\
\text { Blogger }\end{array}$ & 274 \\
\hline Horóscopo & & & Horóscopo & & 1 & & & & & 280 \\
\hline PC- Reportaje & Ocio-cultura & Locales + personal & Glam life & La nueva movida madrileña & 5 & $\begin{array}{l}\text { Pablo Trapote } \\
\text { Abel Matutes }\end{array}$ & $\begin{array}{l}\mathrm{H} \\
\mathrm{H} \\
\end{array}$ & $\begin{array}{l}\text { Prota/ Posa } \\
\text { Prota/Posa }\end{array}$ & $\begin{array}{l}\text { Hostelero } \\
\text { Hostelero } \\
\end{array}$ & 281 \\
\hline PC- Entrevista & Ocio-cultura & Personal & Glam life & Una mirada a Río de Janeiro & 2 & Adriana Lima & $\mathrm{M}$ & Protagoniza & Modelo & 286 \\
\hline Directorio & & & Direcciones & & 2 & & & & & 288 \\
\hline PC-Artículo & Moda & Ropa & Guinda & $\begin{array}{l}\text { El Rey Sol y su imperio de la } \\
\text { moda }\end{array}$ & 1 & & & & & 290 \\
\hline
\end{tabular}




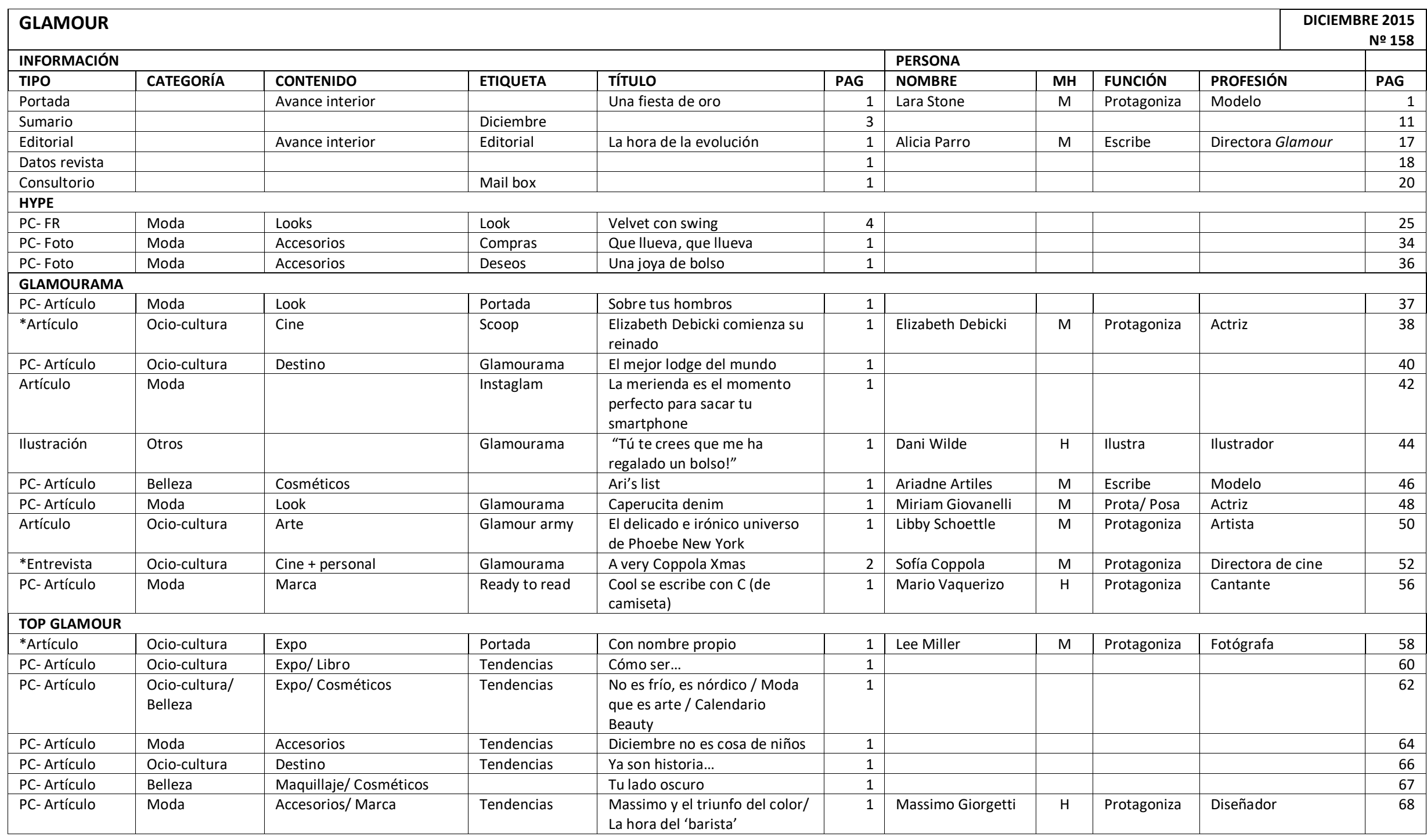




\begin{tabular}{|c|c|c|c|c|c|c|c|c|c|c|}
\hline PC- Reportaje & Moda & Pasarela & Top & $\begin{array}{l}\text { Cruisse 2016. Arquitectura } \\
\text { protagonista }\end{array}$ & 4 & & & & & 70 \\
\hline *Artículo & Sociedad & & Hot topic & ¿Qué iconos tenemos ahora? & 1 & & & & & 76 \\
\hline Artículo & Otros & & You you you & $\begin{array}{l}\text { Nunca es tarde para } \\
\text { reinventarse }\end{array}$ & 1 & Mónica Salvador & $\mathrm{M}$ & Asesora & Coach & 78 \\
\hline \multicolumn{11}{|c|}{ STARS GLAMOUR } \\
\hline Portada & & Avance interior & Portada & Magnetismo personal & 1 & & & & & 79 \\
\hline *PC- Reportaje & Ocio-cultura & Cine + personal & Stars & $\begin{array}{l}\text { Julia Roberts, la mujer tras la } \\
\text { sonrisa }\end{array}$ & 5 & Julia Roberts & $M$ & Prota/ Posa & Actriz & 80 \\
\hline Reportaje & Moda & Moda & Stars & Balenciaga, to be continued... & 5 & $\begin{array}{l}\text { Demma Gvasalia } \\
\text { Alexander Wang } \\
\text { Ghesquière } \\
\text { Cristóbal } \\
\text { Balenciaga }\end{array}$ & $\begin{array}{l}\mathrm{H} \\
\mathrm{H} \\
\mathrm{H} \\
\mathrm{H}\end{array}$ & $\begin{array}{l}\text { Protagoniza } \\
\text { Protagoniza } \\
\text { Protagoniza } \\
\text { Protagoniza }\end{array}$ & $\begin{array}{l}\text { Diseñador moda } \\
\text { Diseñador moda } \\
\text { Diseñador moda } \\
\text { Diseñador moda }\end{array}$ & 90 \\
\hline PC/ Entrevista & Ocio-cultura & Cine + personal & Stars & $\begin{array}{l}\text { Álex García. Un héroe } \\
\text { romántico }\end{array}$ & 5 & Alex García & $\mathrm{H}$ & Prota/ Posa & Actor & 96 \\
\hline *Opinión & Sociedad & Feminismo & $\begin{array}{l}\text { El mundo de } \\
\text { Marta }\end{array}$ & ¿El sexo ya no vende? & 1 & $\begin{array}{l}\text { Marta Rivera de la } \\
\text { Cruz }\end{array}$ & $M$ & Escribe & Escritora & 102 \\
\hline \multicolumn{11}{|c|}{ CLUB GLAMOUR } \\
\hline Portada & & Avance interior & Portada & Citas invernales & 1 & & & & & 105 \\
\hline Entrevista & Ocio-cultura & \multirow{2}{*}{$\begin{array}{l}\text { Cine } \\
\text { Cine }\end{array}$} & Cine & $\begin{array}{l}\text { Chris Hemsworth se lanza al } \\
\text { mar }\end{array}$ & 1 & Chris Hemsworth & $\mathrm{H}$ & Protagoniza & Actor & 106 \\
\hline PC-Artículo & Ocio-cultura & & Cine & $\begin{array}{l}\text { El despertar sexual de los } 70 \text { / } \\
\text { Que la fuerza te acompañe / } \\
\text { Estrenos }\end{array}$ & 1 & & & & & 107 \\
\hline PC-Artículo & Ocio-cultura & Música & Música & $\begin{array}{l}\text { Música de raíz / Sintetízate con } \\
\text { Grimes }\end{array}$ & 1 & $\begin{array}{l}\text { Ludovic Navarre } \\
\text { Soleá Morente } \\
\text { Arcángel } \\
\text { Mariza } \\
\text { Claire Bouche }\end{array}$ & $\begin{array}{l} \\
M \\
H \\
M \\
M\end{array}$ & $\begin{array}{l}\text { Protagoniza } \\
\text { Protagoniza } \\
\text { Protagoniza } \\
\text { Protagoniza } \\
\text { Protagoniza }\end{array}$ & $\begin{array}{l}\text { Cantante } \\
\text { Cantante } \\
\text { Cantante } \\
\text { Cantante } \\
\text { Cantante } \\
\end{array}$ & 108 \\
\hline PC-Artículo & Ocio-cultura & \multirow{2}{*}{$\begin{array}{l}\text { Series } \\
\text { Libros }\end{array}$} & Series & Reales como la vida & 1 & & & & & 109 \\
\hline PC-Artículo & Ocio-cultura & & Libros & $\begin{array}{l}\text { Cómo superar la Navidad con } \\
\text { buenos modos }\end{array}$ & 1 & $\begin{array}{l}\text { Marta Robles } \\
\text { Camen Posadas }\end{array}$ & $\begin{array}{l}M \\
M\end{array}$ & $\begin{array}{l}\text { Protagoniza } \\
\text { Protagoniza }\end{array}$ & $\begin{array}{l}\text { Escritora } \\
\text { Escritora }\end{array}$ & 110 \\
\hline \multirow{2}{*}{$\begin{array}{l}\text { PC- Artículo } \\
\text { PC- Entrevista }\end{array}$} & Ocio-cultura & Libros & Libros & Nobel a las historias reales & 1 & Svetlana Alexiévich & $\mathrm{M}$ & Protagoniza & Escritora, nobel & 111 \\
\hline & Ocio-cultura & Libros & Libros & La reina del best seller & 1 & Kate Morton & $\mathrm{M}$ & Protagoniza & Escritora & 112 \\
\hline PC-Artículo & Ocio-cultura & Libros & Libros & $\begin{array}{l}\text { Alma e intriga conquistan el } \\
\text { planeta/ Asiáticos al rescate/ } \\
\text { Biografías }\end{array}$ & 1 & $\begin{array}{l}\text { Alicia Giménez } \\
\text { Daniel Sánchez } \\
\text { Arévalo }\end{array}$ & $\begin{array}{l}\mathrm{M} \\
\mathrm{H}\end{array}$ & $\begin{array}{l}\text { Protagoniza } \\
\text { Protagoniza }\end{array}$ & $\begin{array}{l}\text { Escritora } \\
\text { Escritor, guionista }\end{array}$ & 113 \\
\hline PC-Artículo & Ocio-cultura & Expo & Expos & Art around the world & 1 & & & & & 114 \\
\hline \multicolumn{11}{|l|}{ FUN GLAMOUR } \\
\hline Portada & & Avance interior & Portada & Emociones encontradas & 1 & & & & & 115 \\
\hline
\end{tabular}




\begin{tabular}{|c|c|c|c|c|c|c|c|c|c|c|}
\hline *Reportaje & Ocio-cultura & Cine & Fun & $\begin{array}{l}\text { Julie Christie. Glamour y } \\
\text { libertad }\end{array}$ & 3 & Julia Christine & M & Protagoniza & Actriz & 116 \\
\hline Reportaje & Tecno/ Moda & Internet + moda & Fun & $\begin{array}{l}\text { Tech \& fashion, tu nuevo } \\
\text { trabajo }\end{array}$ & 4 & & & & & 120 \\
\hline PC- Reportaje & $\begin{array}{l}\text { Salud/ Ocio- } \\
\text { cultura }\end{array}$ & Nutrición/ Restauración & Fun & Té matcha, el elixir de moda & 4 & & & & & 124 \\
\hline *PC-Reportaje & Tecno & Apps & Fun & En el corazón del sexo del s.XXI & 4 & & & & & 128 \\
\hline PC- Cuento & Ocio-cultura & Libros & Fun & $\begin{array}{l}\text { Dorothy Parker te regala un } \\
\text { cuento de Navidad }\end{array}$ & 4 & Dorothy Parker & $\mathrm{M}$ & Escribe & Escritora & 132 \\
\hline \multicolumn{11}{|l|}{ SHOP GLAMOUR } \\
\hline Portada & & Avance interior & Portada & Lujo cotidiano & 1 & & & & & 137 \\
\hline PC- Reportaje & Moda & Looks/ Ropa/ Accesorios & Shop & Código Chelsea & 5 & & & & & 138 \\
\hline PC- Reportaje & Moda & Accesorios & Shop & Gold generation & 2 & $\begin{array}{l}\text { Jordan Askill } \\
\text { Carolina Neri } \\
\text { Bérengère Lux } \\
\text { Charlotte Chesnasis } \\
\text { Cristina Zazo } \\
\text { Alice Cicolini } \\
\text { Ana Khouri } \\
\text { Andra Neen } \\
\text { Mava Haze } \\
\text { Magdalena } \\
\text { Frackowaik } \\
\end{array}$ & $\begin{array}{l}M \\
M \\
M \\
M \\
M \\
M \\
M \\
M \\
M \\
M\end{array}$ & $\begin{array}{l}\text { Protagoniza } \\
\text { Protagoniza } \\
\text { Protagoniza } \\
\text { Protagoniza } \\
\text { Protagoniza } \\
\text { Protagoniza } \\
\text { Protagoniza } \\
\text { Protagoniza } \\
\text { Protagoniza } \\
\text { Protagoniza }\end{array}$ & $\begin{array}{c}\text { Diseñadora joyas } \\
\text { Diseñadora joyas } \\
\text { Diseñadora joyas } \\
\text { Diseñadora joyas } \\
\text { Diseñadora joyas } \\
\text { Diseñadora joyas } \\
\text { Diseñadora joyas } \\
\text { Diseñadora joyas } \\
\text { Diseñadora joyas } \\
\text { Diseñadora joyas }\end{array}$ & 144 \\
\hline PC- Foto & Moda/Tecno & Accesorios/ Gadgets & Shop & Tesoros escondidos & 2 & & & & & 146 \\
\hline PC- Reportaje & Moda & Ropa/Accesorios/ Looks & Shop & 2 prendas, 3 edades & 4 & & & & & 148 \\
\hline PC- Entrevista & Moda & Moda + personal & Shop & La chica del sur & 5 & Rocío Crusset & $\mathrm{M}$ & Prota/ Posa & Modelo & 152 \\
\hline PC-Artículo & Moda & Accesorios & Flechazos & Beauty hair & 1 & & & & & 158 \\
\hline PC-Artículo & Moda & Ropa & Flechazos & Baila bailarina & 1 & & & & & 159 \\
\hline PC-Artículo & Moda & Accesorios & Flechazos & La joya de la corona & 1 & & & & & 160 \\
\hline PC- Artículo & Moda & Ropa & \multirow[t]{2}{*}{ Flechazos } & Efecto Lamé & 1 & & & & & 161 \\
\hline PC- Reportaje & $\begin{array}{l}\text { Ocio-cultura/ } \\
\text { Moda/ } \\
\text { Gastronomía }\end{array}$ & $\begin{array}{l}\text { Destino/ Accesorios/ Ropa/ } \\
\text { Bebida/ Cine + personal/ } \\
\text { Moda + personal }\end{array}$ & & Miss $\mathrm{G}$ walks around & 4 & $\begin{array}{l}\text { Ana Fernández } \\
\text { Julia Restoin }\end{array}$ & $\begin{array}{l}M \\
M\end{array}$ & $\begin{array}{l}\text { Prota/ Posa } \\
\text { Protagoniza }\end{array}$ & $\begin{array}{l}\text { Actriz } \\
\text { Modelo }\end{array}$ & 162 \\
\hline PC-Artículo & Moda & Accesorios & Shop & Satellites of love & 1 & & & & & 166 \\
\hline \multicolumn{11}{|c|}{ BELLEZA GLAMOUR } \\
\hline Portada & & Avance interior & Portada & Beauty party & 1 & & & & & 167 \\
\hline PC-FR & Belleza & Looks/ Maquillaje & Belleza & Bold make up, ¿te atreves? & 6 & & & & & 168 \\
\hline PC- Foto & Belleza & Maquillaje/ Cosméticos & \multirow{2}{*}{$\begin{array}{l}\text { Favoritos } \\
\text { Belleza }\end{array}$} & Desearás guardar la caja & 1 & & & & & 174 \\
\hline PC- Reportaje & Belleza & Cosméticos/Tratamientos & & $\begin{array}{l}\text { Un plan beauty Xmas. Mejor } \\
\text { piel y cabello }\end{array}$ & 6 & & & & & 176 \\
\hline *PC- Reportaje & Belleza & Cosméticos/Tratamiento & A fondo & Tu cara, tu mayor lujo & 4 & & & & & 184 \\
\hline PC- Reportaje & Belleza & Tratamiento & Ensayo & Tus ojos lo dicen todo & 2 & & & & & 188 \\
\hline
\end{tabular}




\begin{tabular}{|c|c|c|c|c|c|c|c|c|c|c|}
\hline PC- Fotos & Belleza & Maquillaje/ Cosméticos & Belleza & Un tocador de cine & 3 & & & & & 190 \\
\hline PC-Artículo & Belleza & Peinados & Master class & Readhead. El perfecto peinado & 2 & & & & & 194 \\
\hline PC-Artículo & Belleza & Cosméticos & Belleza & Pon un aceite en tu vida & 1 & & & & & 196 \\
\hline \multicolumn{11}{|c|}{ ESTILO GLAMOUR } \\
\hline Portada & & Avance interior & Portada & Desea, sueña y ama la Navidad & 1 & & & & & 197 \\
\hline PC-Entrevista & Belleza/Moda & Cine + personal & & Poderosa Lara Stone & 8 & Lara Stone & $\mathrm{M}$ & Prota/ Posa & Modelo & 198 \\
\hline PC- FR & Moda & Looks & & Romance al amanecer & 12 & & & & & 206 \\
\hline *PC- Entrevista & Sociedad & Política & & On the road & 6 & Albert Rivera & $\mathrm{H}$ & Prota/ Posa & Político & 218 \\
\hline PC-FR & Moda/Belleza & Looks & & Una fiesta a todo volumen & 8 & & & & & 224 \\
\hline Reportaje & Ocio-cultura & Música + personal & & $\begin{array}{l}\text { Édith Piaf. El día que se } \\
\text { apasionó con Non, je ne rerette } \\
\text { rien }\end{array}$ & 4 & Edith Piaf & $M$ & Protagoniza & Cantante & 232 \\
\hline PC- FR & Ocio-cultura & Cine & & Fressssh Hollywood & 8 & $\begin{array}{l}\text { Maddie Ziegler } \\
\text { Patrick } \\
\text { Shwarzenegger } \\
\text { Stacy Martin } \\
\text { Jacob } \\
\text { Tony Revolori } \\
\text { Hayley Kioyo } \\
\text { Antoine Olivier } \\
\text { Karidja Touré } \\
\text { Tom Phelan }\end{array}$ & $\begin{array}{l}\mathrm{M} \\
\mathrm{H} \\
\mathrm{M} \\
\mathrm{H} \\
\mathrm{H} \\
\mathrm{M} \\
\mathrm{H} \\
\mathrm{M} \\
\mathrm{H}\end{array}$ & $\begin{array}{l}\text { Prota/ Posa } \\
\text { Prota/ Posa } \\
\\
\text { Prota/ Posa } \\
\text { Prota/ Posa } \\
\text { Prota/ Posa } \\
\text { Prota/ Posa } \\
\text { Prota/ Posa } \\
\text { Prota/ Posa } \\
\text { Prota/ Posa }\end{array}$ & $\begin{array}{l}\text { Bailarina } \\
\text { Actor } \\
\text { Actriz } \\
\text { Actor } \\
\text { Actor } \\
\text { Actriz } \\
\text { Actor } \\
\text { Actriz } \\
\text { Actor }\end{array}$ & 236 \\
\hline PC- Entrevista & Ocio-cultura & Libros & & $\begin{array}{l}\text { El príncipe del gótico resucita a } \\
\text { su reina }\end{array}$ & 4 & Benjamin Lacombe & $\mathrm{H}$ & Protagoniza & Escritor & 244 \\
\hline PC- FR & Moda & Ropa/ Accesorios & & Mis mejores deseos & 8 & & & & & 246 \\
\hline \multicolumn{11}{|c|}{ GLAM LIFE GLAMOUR } \\
\hline Portada & & Avance interior & Portada & ¿Clásica o moderna? & 1 & & & & & 257 \\
\hline $\begin{array}{l}\text { *Reportaje + } \\
\text { Recetario }\end{array}$ & Hogar & Personal/ Alimentación & Glam life & $\begin{array}{l}\text { Show cooking. Cocinando } \\
\text { entre estrellas }\end{array}$ & 8 & $\begin{array}{l}\text { Marta Cárdenas } \\
\text { Tamara Falcó } \\
\text { Margarita Vargas } \\
\text { Eliza Arcaya } \\
\end{array}$ & $\begin{array}{l}\mathrm{M} \\
\mathrm{M} \\
\mathrm{M} \\
\mathrm{M}\end{array}$ & $\begin{array}{l}\text { Prota/ Posa } \\
\text { Prota/ Posa } \\
\text { Prota/ Posa } \\
\text { Prota/ Posa }\end{array}$ & $\begin{array}{l}\text { Restauración } \\
\text { Empresaria } \\
\text { Restauración } \\
\end{array}$ & 258 \\
\hline PC- Entrevista & Otros & Profesional & Glam life & Los nuevos artesanos & 4 & $\begin{array}{l}\text { Javier Sánchez } \\
\text { medina } \\
\text { Fernando García de } \\
\text { la Calera } \\
\text { Álvaro Sampedro } \\
\text { Álvaro Basterra } \\
\end{array}$ & $\begin{array}{l}\mathrm{H} \\
\mathrm{H} \\
\mathrm{H} \\
\mathrm{H}\end{array}$ & $\begin{array}{l}\text { Prota/ Posa } \\
\text { Prota/ Posa } \\
\text { Prota/ Posa } \\
\text { Prota/ Posa }\end{array}$ & $\begin{array}{l}\text { Restaurador } \\
\text { Sastre } \\
\text { Paisajista } \\
\text { Diseñador bicicletas }\end{array}$ & 266 \\
\hline Horóscopo & & & Horóscopo & & 1 & & & & & 270 \\
\hline PC-Artículo & Gastronomía & Bebidas & Glam life & Ruta sumiller & 1 & & & & & 271 \\
\hline Directorio & & & Direcciones & & 2 & & & & & 272 \\
\hline PC- Foto & Moda & Ropa/ Accesorios & Guinda & Yo voto Glamour & 1 & & & & & 274 \\
\hline
\end{tabular}


INFORMACIÓN

\begin{tabular}{|l|l|l|}
\hline TIPO & CATEGORÍA & CONTENIDO \\
\hline Portada & & Avance interior \\
\hline Datos revista & & \\
\hline Sumario & & \\
\hline *Editorial & & \\
\hline *Consultorio & & \\
\hline NOTICIAS & & \\
\hline${ }^{*}$ A & & \\
\hline
\end{tabular}

\begin{tabular}{|l|l|l|}
\hline ETIQUETA & TíTULO & PAG \\
\hline & Un cuerpo iasí! & \\
\hline $\begin{array}{l}\text { Primeras } \\
\text { palabras }\end{array}$ & Lo quiero iya! & \\
\hline Pregunta a MH & & \\
\hline
\end{tabular}

\section{PERSONA}

\section{NOMBRE} Juan Betancourt

\section{NOTICIAS}

\begin{tabular}{|l|l|l|l|l|l|}
\hline${ }^{*}$ Artículo & Relaciones & Hombre-mujer & Portada & Mejor repartido & \\
\hline Artículo & Salud & Nutrición & Nutrición & Con un par (de tazas) & \\
\hline Artículo & Salud/ Belleza & Deporte/ Culto al cuerpo & Fitness & Apunta alto & \\
\hline Artículo & Salud & Nutrición & Perder peso & El enemigo más dulce & \\
\hline${ }^{*}$ Artículo & Salud & Prevención & Sexo & El alcohol contagia & \\
\hline Artículo & Salud & Prevención & Mente & Bloquea las distracciones & \\
\hline COOL & \multicolumn{4}{|l}{} & \\
\hline
\end{tabular}

\begin{tabular}{|c|c|c|}
\hline & & \multirow{2}{*}{ FUNCIÓN } \\
\hline NOMBRE & $\mathrm{MH}$ & \\
\hline
\end{tabular}

\begin{tabular}{|l|l|}
\hline PC- FR & Tecnología \\
\hline PC-Aticulo & Salud
\end{tabular}

PC- Artículo

\begin{tabular}{l|l|l}
\hline Tecnología & Motor & Portada \\
\hline Salud & Nution & Gourmet \\
\hline
\end{tabular}

\begin{tabular}{l|l|l}
\hline PC- Artículo & Moda/ Ocio- & Ropa/ Expos/ \\
& cultura & Restauración/
\end{tabular}

cultura $\quad$ Restauración/ Libros

HOMBRES ALFA

Ocio-cultura $\quad$ Destinos

Gourmet $\quad$ Antioxidantes: así, sí

colcto alcuerpo/

\begin{tabular}{l|l|l}
\hline *PC- Entrevista & $\begin{array}{l}\text { Ocio-cultura/ } \\
\text { Belleza }\end{array}$ & $\begin{array}{l}\text { Cine/ Culto al cuerpo/ } \\
\text { Cosméticos + personal }\end{array}$ \\
\hline
\end{tabular}

Salud

Deporte

\begin{tabular}{l|l|l}
\hline *Artículo & Relaciones & Hombre-mujer \\
\hline Artículo & Belleza & Culoalcuerpo
\end{tabular}

Artículo

Belleza

Hombre-muje

\begin{tabular}{l|l|l}
\hline Artículo & Salud & Culto al cuerpc \\
\hline PC-Articulo & Salud
\end{tabular}

\begin{tabular}{|l|l|l}
\hline PC- Artículo & Salud & Prevencion \\
\hline
\end{tabular}

\begin{tabular}{l|l|l} 
PC- Artículo & Belleza & Cosméticos \\
\hline
\end{tabular}

\begin{tabular}{l|l|l}
\hline PC-Artículo & Moda & Ropa \\
\hline
\end{tabular}

\begin{tabular}{l|l|l}
\hline PC-Artículo & Tecnología & Gadgets \\
\hline
\end{tabular}

\begin{tabular}{l|l} 
PC-Artículo & Moda/ Salud \\
\hline Articulo & Salud
\end{tabular}

Artículo

Artículo

Salud

\begin{tabular}{l|l} 
A Articula Moda \\
\hline PC-Artículo & Moda
\end{tabular}

Prevención

Looks

Primera persona

Antioxidantes: así, sí

Escápate un "finde"

1 Jordi Martínez

$\mathrm{H}$

Escribe

Director Men's

Health

\begin{tabular}{|l|l|l|l|l|} 
& & & \\
& & & & 12 \\
\hline
\end{tabular}

Moda

Accesorios

\begin{tabular}{|l|l|}
\hline $\begin{array}{l}\text { Máximo } \\
\text { rendimiento }\end{array}$ \\
\hline Tipo medio \\
\hline Nutrición \\
\hline Salud \\
\hline $\begin{array}{l}\text { Entrenador } \\
\text { personal }\end{array}$ \\
\hline Lanzamiento \\
\hline Apuesta MH \\
\hline Tecno \\
\hline Tendencia \\
\hline Ciencia \\
\hline Estilo \\
\hline En punto \\
\hline
\end{tabular}

Un héroe con estrella

Pilates es más

Tómale las medidas

Ácido para tus músculos

Apuesta al esperma ganador

¿Necesitas ser flexible?

\begin{tabular}{|c|l|l|l|l|l|}
\hline 1 & & & & & 14 \\
\hline 1 & & & & & 16 \\
\hline 1 & & & & & 18 \\
\hline 1 & & & & & 20 \\
\hline 1 & & & & & 22 \\
\hline
\end{tabular}

Protección outdoor

Con estilo propio

Estilo sonoro

Estilo superior

Ronquidos accidentales

4 trucos con estilo

Hora de aventuras

\begin{tabular}{r|l|l|l|l|r|}
\hline 3 & Adolfo Randulfe & $\mathrm{H}$ & Asesora & Especialista en motor & 26 \\
\hline 1 & & & & & 30 \\
\hline 1 & & & & & 32 \\
\hline 1 & & & & & 34 \\
\hline
\end{tabular}

\begin{tabular}{|c|l|r|l|l|r|}
\hline 3 & Chris Evans & H & Protagoniza & Actor & 37 \\
\hline 1 & Fito Florensa & H & Asesora & Experto rendimiento & 40 \\
\hline 1 & & & & & \\
\hline 1 & Anabel Fernández & M & Asesora & Experta nutrición & 42 \\
\hline 1 & & & & & 46 \\
\hline 1 & Guillermo Alvarado & H & Asesora & Experto fitness & 48 \\
\hline 1 & & & & & \\
\hline 1 & & & & & 50 \\
\hline 1 & & & & & 52 \\
\hline 1 & & & & & 56 \\
\hline 1 & & & & & 58 \\
\hline 1 & & & & & 60 \\
\hline
\end{tabular}




\begin{tabular}{|c|c|c|c|c|c|c|c|c|c|c|}
\hline *Artículo & Relaciones & Hombre - mujer & Sexo & $\begin{array}{l}\text { Las } 6 \text { nuevas normas del sex } \\
\text { appeal }\end{array}$ & 3 & & & & & 63 \\
\hline Artículo & Salud & Deporte & Fitness & $\begin{array}{l}\text { En busca del gimnasio } \\
\text { perfecto }\end{array}$ & 2 & & & & & 66 \\
\hline Artículo & Salud & Nutrición & Perder peso & Licua el michelín & 2 & & & & & 68 \\
\hline *PC- Artículo & Salud & Deporte & Fitness & Mírate el ombligo & 2 & & & & & 70 \\
\hline Recetario & Salud & Nutrición & Nutrición & \multirow{2}{*}{$\begin{array}{l}\text { Conviértete en un pez gordo } \\
\text { Juan Betancourt }\end{array}$} & 2 & & & & & 73 \\
\hline Entrevista & Salud/ Belleza & $\begin{array}{l}\text { Culto al cuerpo/ Deporte/ } \\
\text { Nutrición + personal }\end{array}$ & On top & & 6 & & & & & 74 \\
\hline Artículo & Relaciones & Hombre - mujer & Sexo & \multirow{2}{*}{$\begin{array}{l}\text { Hogar dulce hogar } \\
\text { Piérdelo todo }\end{array}$} & 4 & & & & & 82 \\
\hline Reportaje & Salud & Nutrición & Perder peso & & 6 & & & & & 84 \\
\hline Reportaje & Belleza & Culto al cuerpo & Fitness & ¡Adiós pesas! & 8 & & & & & 89 \\
\hline Reportaje & Salud & $\begin{array}{l}\text { Prevención/ Nutrición/ } \\
\text { Deporte }\end{array}$ & & Que la primavera no te altere & 7 & & & & & 99 \\
\hline *Reportaje & Salud & Prevención & & ¿Hora de dormir? & 6 & & & & & 106 \\
\hline \multicolumn{11}{|l|}{ ESTILO } \\
\hline PC-FR & Moda & Looks & Estilo & Material boy & 9 & & & & & 113 \\
\hline PC-Artículo & $\begin{array}{l}\text { Moda/ } \\
\text { Tecnología }\end{array}$ & Ropa/ Motor & Moda práctica & Hombre logo & 1 & & & & & 118 \\
\hline PC-Artículo & Moda & Ropa & Moda práctica & Retro running & 1 & & & & & 123 \\
\hline PC- Reportaje & Belleza & Cosméticos & Cuidado personal & Padres de cuidado & 4 & & & & & 124 \\
\hline PC-Artículo & Belleza & Cosméticos & Producto estrella & Pasa la bola & 1 & & & & & 128 \\
\hline PC-Artículo & Belleza & Cosméticos & Fragancia estrella & Mar de acero & 1 & & & & & 129 \\
\hline \multicolumn{11}{|l|}{$\mathrm{COACH}$} \\
\hline Portada & & Avance interior & Portada & \multirow{2}{*}{$\begin{array}{l}\text { Tu entrenador personal de } \\
\text { bolsillo } \\
\text { Marca tu six-pack }\end{array}$} & 1 & & & & & 131 \\
\hline Reportaje & Belleza & Culto al cuerpo & Coach & & 2 & & & & & 132 \\
\hline Reportaje & Belleza & Culto al cuerpo & Suplementos & Beneficios suplementarios & 2 & & & & & 134 \\
\hline Reportaje & Belleza & Culto al cuerpo & Músculo & Una mano de hierro & 2 & & & & & 136 \\
\hline Artículo & Belleza & Culto al cuerpo & Sigue mi consejo & Directo al éxito & 1 & Manny Pacquiao & $\mathrm{H}$ & Protagoniza & Boxeador & 138 \\
\hline Artículo & Belleza & Culto al cuerpo & Movimientos & Entrena vuelta y vuelta & 1 & & & & & 139 \\
\hline Reportaje & Belleza & Culto al cuerpo & Entrenamiento & El mejor día después & 2 & & & & & 140 \\
\hline Reportaje & Belleza & Culto al cuerpo & Sentadillas & Resultados garantizados & 2 & & & & & 142 \\
\hline Reportaje & Belleza & Culto al cuerpo & CrossFit & \multirow{2}{*}{$\begin{array}{l}\text { iAcelera tu metabolismo! } \\
\text { Últimas palabras }\end{array}$} & 2 & Marc Solá & $\mathrm{H}$ & Asesora & Entrenador & 144 \\
\hline Artículo & Belleza & Culto al cuerpo & Trucos & & 1 & & & & & 146 \\
\hline
\end{tabular}




\begin{tabular}{|c|c|c|c|c|c|c|c|c|c|c|}
\hline \multicolumn{10}{|c|}{ MEN'S HEALTH } & $\begin{array}{r}\text { JUNIO } 2015 \\
\text { № } 160\end{array}$ \\
\hline \multicolumn{6}{|l|}{ INFORMACIÓN } & \multicolumn{4}{|l|}{ PERSONA } & PAG \\
\hline & SECCIÓN & TEMÁTICA & ETIQUETA & TÍTULO & PAG & NOMBRE & MH & FUNCIÓN & PROFESIÓN & \\
\hline Portada & & Avance interior & & $\begin{array}{l}\text { Operación verano, iasí! en } 30 \\
\text { días }\end{array}$ & 1 & Ignacio Ondategui & $\mathrm{H}$ & Protagoniza & & 1 \\
\hline Datos revista & & & & & 1 & & & & & 3 \\
\hline Sumario & & & & & 2 & & & & & 6 \\
\hline Editorial & & & $\begin{array}{l}\text { Primeras } \\
\text { palabras }\end{array}$ & \#Selfitmania & 1 & Jordi Martínez & $\mathrm{H}$ & Escribe & $\begin{array}{l}\text { Director Men's } \\
\text { Health }\end{array}$ & 10 \\
\hline Consultorio & & & Pregunta a MH & & 2 & & & & & 12 \\
\hline \multicolumn{11}{|l|}{ NOTICIAS } \\
\hline Artículo & Salud & Deporte & Portada & $\begin{array}{l}\text { Los hombres de hielo acaban } \\
\text { antes }\end{array}$ & 1 & & & & & 14 \\
\hline Artículo & Salud & Nutrición & Nutrición & Corazón salvado & 1 & & & & & 16 \\
\hline PC-Artículo & Salud & Nutrición/ Deporte & Cardio & Suda la bola & 1 & & & & & 18 \\
\hline *Artículo & Relaciones & Hombre - mujer & Sexo & No enseñes los billetes & 1 & & & & & 20 \\
\hline Artículo & Salud & Prevención & Salud & Huele a mareo & 1 & & & & & 22 \\
\hline Artículo & Salud & Nutrición & Perder peso & En la oficina, cierra la boca & 1 & & & & & 24 \\
\hline \multicolumn{11}{|l|}{ COOL } \\
\hline PC- FR & Tecnología & Motor & Motor & Segunda juventud & 4 & Adolfo Randulfe & $\mathrm{H}$ & Asesora & $\begin{array}{l}\text { Especialista en } \\
\text { motor }\end{array}$ & 26 \\
\hline PC- Artículo & $\begin{array}{l}\text { Ocio-cultura/ } \\
\text { Salud }\end{array}$ & Destinos/ Deporte/ Expo & Tiempo libre & Por dentro y por fuera & 1 & & & & & 30 \\
\hline PC-Artículo & Ocio-cultura & Restauración & Gourmet & Pescado más delicioso y sano & 1 & & & & & 32 \\
\hline PC-Artículo & Ocio-cultura & Destinos & Escapadas & Hacia el infinito y más allá & 1 & & & & & 33 \\
\hline \multicolumn{11}{|l|}{ HOMBRES ALFA } \\
\hline PC- Entrevista & Salud/Belleza & Deporte/ Cosméticos & Primera persona & Superando obstáculos & 3 & Kie Willis & $\mathrm{H}$ & Prota/ Posa & Deportista & 35 \\
\hline Artículo & Salud & Prevención & Salud & Tonto el que se muera & 1 & & & & & 38 \\
\hline PC-Artículo & Salud & Deporte & Tecno & Rema hacia la diversión & 1 & & & & & 39 \\
\hline PC-Artículo & Belleza & Culto al cuerpo & Fitness & \multirow{2}{*}{$\begin{array}{l}\text { Bajo control } \\
\text { 'Wearables' para echar a } \\
\text { correr }\end{array}$} & 1 & & & & & 40 \\
\hline PC-Artículo & Tecno & Gadgets & Equipo & & 1 & & & & & 41 \\
\hline PC- Fotos & Moda & Accesorios & En punto & \multirow{2}{*}{$\begin{array}{l}\text { Escoge tu hora } \\
\text { Suéltate el pelo }\end{array}$} & 1 & & & & & 42 \\
\hline *PC-Artículo & Belleza & Cosméticos & Cuidado personal & & 1 & & & & & 44 \\
\hline *Artículo & Salud & Prevención & Ciencia & Estrés por la boca & 1 & & & & & 45 \\
\hline Artículo & Sexualidad & & Relaciones & $\begin{array}{l}\text { Seis cosas que decir durante } \\
\text { 'la charla' }\end{array}$ & 1 & & & & & 46 \\
\hline Infografía & Salud & Nutrición & Gourmet & \multirow{2}{*}{$\begin{array}{l}\text { Que no te den orgánico por } \\
\text { liebre } \\
\text { Frenazo a los accidentes }\end{array}$} & 1 & & & & & 48 \\
\hline PC-Artículo & Salud & Prevención & Estrategia & & 1 & & & & & 49 \\
\hline
\end{tabular}




\begin{tabular}{|c|c|c|c|c|c|c|c|c|c|c|}
\hline Artículo & Salud & Nutrición/ Deporte & Nutrición & Tus aliados contra la fatiga & 1 & Anabel Fernández & $\mathrm{M}$ & Asesora & Experta nutrición & 50 \\
\hline PC-Artículo & Tecno/Moda & Motor/Ropa & $360 \%$ & El look más motero & 1 & & & & & \\
\hline PC-Artículo & Belleza & Culto al cuerpo & $\begin{array}{l}\text { Entrenador } \\
\text { personal }\end{array}$ & Acierta con tu gym & 1 & Guillermo Alvarado & $\mathrm{H}$ & Asesora & Experto fitness & 52 \\
\hline PC- Artículo & Belleza & Culto al cuerpo & $\begin{array}{l}\text { Máximo } \\
\text { rendimiento }\end{array}$ & 6 formas de ganar músculo & 1 & Fito Florensa & $\mathrm{H}$ & Asesora & $\begin{array}{l}\text { Experto } \\
\text { rendimiento }\end{array}$ & 53 \\
\hline PC-Artículo & Moda & Accesorios & Tecno & El futuro deslumbrante & 1 & & & & & 54 \\
\hline PC-Artículo & Moda & Ropa & Apuesta MH & El nuevo hombre & 1 & & & & & 55 \\
\hline & & & & & & & & & & \\
\hline *Reportaje & Relaciones & Hombre-mujer / Sexo & Sexo + relaciones & $\begin{array}{l}\text { El ataque de los estorbos } \\
\text { sexuales }\end{array}$ & 2 & & & & & 56 \\
\hline Reportaje & Salud & Prevención & Salud & Y tú, ¿cómo te cuidas? & 2 & & & & & 58 \\
\hline Reportaje & Belleza & Culto al cuerpo & Fitness & Un problema de peso & 2 & & & & & 60 \\
\hline Recetario & Salud & Nutrición & Nutrición & Todo por la pasta & 2 & & & & & 62 \\
\hline Entrevista & Salud & Deporte & Superación & Un poder de desafío & 2 & Victor Tasende & $\mathrm{H}$ & Protagoniza & Deportista & 64 \\
\hline Reportaje & Salud & Prevención & Perder peso & La dieta de las horas & 2 & & & & & 66 \\
\hline *Reportaje & Otros & & Estrategia & Habilidades de 'boy scout' & 2 & & & & & 68 \\
\hline Reportaje & Belleza & Culto al cuerpo & & $\begin{array}{l}\text { Perder grasa sin perder } \\
\text { músculo }\end{array}$ & 6 & & & & & 72 \\
\hline *Reportaje & Salud & Prevención & & \multirow{2}{*}{$\begin{array}{l}\text { El 'coco' del sexo ocasional } \\
\text { La Armada Invencible }\end{array}$} & 6 & & & & & 76 \\
\hline Reportaje & Belleza & Culto al cuerpo & & & 8 & $\begin{array}{l}\text { Vicent Fabra } \\
\text { Ahmed Labban } \\
\text { Florian Bornschier } \\
\text { Ben Gregory } \\
\text { James Lorenzo } \\
\text { Gabriel Pacca }\end{array}$ & $\begin{array}{l}\mathrm{H} \\
\mathrm{H} \\
\mathrm{H} \\
\mathrm{H} \\
\mathrm{H} \\
\mathrm{H}\end{array}$ & $\begin{array}{l}\text { Protagoniza } \\
\text { Protagoniza } \\
\text { Protagoniza } \\
\text { Protagoniza } \\
\text { Protagoniza } \\
\text { Protagoniza }\end{array}$ & Deportista & 84 \\
\hline Recetario & Salud & Nutrición & & \multirow{2}{*}{$\begin{array}{l}\text { Come limpio } \\
\text { A.M.M. Artes marciales } \\
\text { mixtas }\end{array}$} & 6 & & & & & 92 \\
\hline Reportaje & Salud & Deporte & & & 6 & & & & & 96 \\
\hline *Reportaje & $\begin{array}{l}\text { Relaciones/ } \\
\text { Tecno }\end{array}$ & $\begin{array}{l}\text { Hombre-mujer/Sexo/ } \\
\text { Apps }\end{array}$ & & Arrasa en las apps & 4 & & & & & 102 \\
\hline Reportaje & Otros & & & $\begin{array}{l}\text { Por qué todo hombre } \\
\text { necesita un gran rival }\end{array}$ & 6 & & & & & 106 \\
\hline \multicolumn{11}{|l|}{ ESTILO } \\
\hline PC-FR & Moda & Looks & Estilo & Todoterreno & 8 & Ignacio Ondategui & $\mathrm{H}$ & Prota/ Posa & Modelo & 113 \\
\hline PC-Artículo & Moda/ Salud & Accesorios/Deporte & Moda práctica & \multirow{2}{*}{$\begin{array}{l}\text { Alta tecnología } \\
\text { Ignacio Ondategui }\end{array}$} & 1 & & & & & 121 \\
\hline PC-Artículo & Moda/Salud & Ropa/ Deporte & Moda & & 2 & Ignacio Ondategui & $\mathrm{H}$ & Protagoniza & Modelo & 122 \\
\hline *PC- Reportaje & Belleza & Cosméticos & Belleza & Operación bañador & 4 & Alba Dorado & $\mathrm{M}$ & Asesora & Experta & 124 \\
\hline PC-Artículo & Belleza & Cosméticos & Fragancia estrella & El mejor saque del verano & 1 & & & & & 128 \\
\hline PC- Artículo & Belleza & Cosméticos & Producto estrella & Protección diaria & 1 & & & & & 129 \\
\hline
\end{tabular}




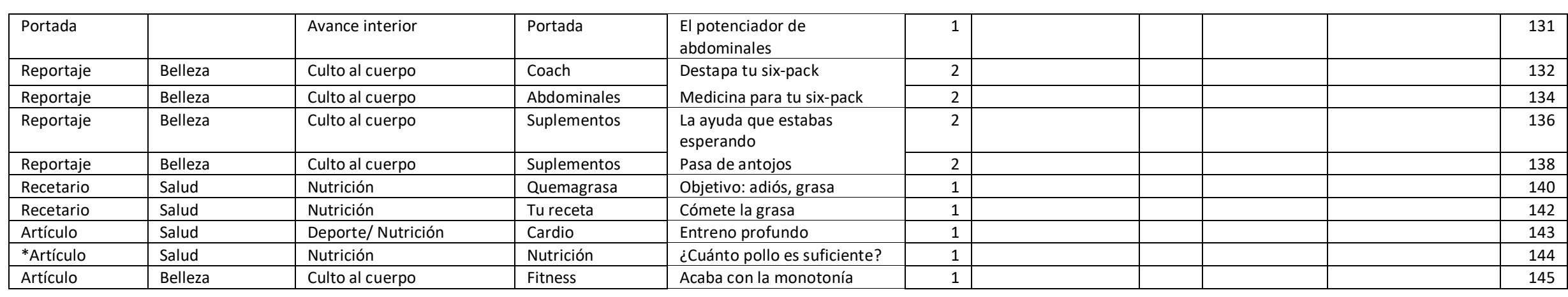




\section{MEN'S HEALTH}

SEPTIEMBRE 2015

INFORMACIÓN

\section{TIPO}

\begin{tabular}{l|l} 
& CATEGORÍA \\
\hline
\end{tabular}

Portada

*Sumario

Editorial

Consultorio

NOTICIAS

\begin{tabular}{|l|r|r|l|l|l|} 
Parector \\
Health
\end{tabular}

№ 162

№ 162

\begin{tabular}{|l|l|l|}
\hline Artículo & Salud & Deporte
\end{tabular}

\begin{tabular}{|l|l|}
\hline Portada & Camina antes de correr (más \\
\hline
\end{tabular} rápido)

\begin{tabular}{|l|l|l|l|l|l}
\hline Artículo & Salud & & Salud & Educa tu mente & \\
\hline Artículo & Salud & Prevención & Mente & No cortocircuites tu cerebro & \\
\hline Articulo
\end{tabular}

\begin{tabular}{|l|l|}
\hline Artículo & Salud \\
\hline Articulo & Salud
\end{tabular}

Artículo $\quad$ Salud

\begin{tabular}{ll|l|l|l} 
Artículo & Nutrición & Nutrición & La presión de la remolacha \\
\hline
\end{tabular}

COOL

\begin{tabular}{|l|l|l|l|l|}
\hline PC- Reportaje & Tecno & Motor & Motor & Ciuda \\
\hline Artículo & Ocio-cultura & Destino & Tiempo libre & $\begin{array}{l}\text { Cr } \\
\text { enco }\end{array}$ \\
\hline PC- Artículo & Ocio-cultura & Destino & Escapadas & La \\
\hline
\end{tabular}

PERSONA

NOMBRE

Ciudadano equilibrado

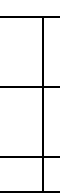

PC- Artículo

HOMBRES ALFA

\begin{tabular}{|l|l|l|l}
\hline PC- Entrevista & Salud & Deporte & Primera persona
\end{tabular}

La joya de Manhattan

PC-Artículo $\quad$ Tecno

\begin{tabular}{l|l} 
Tecno & Motor \\
\hline & Curiosidac \\
\hline
\end{tabular}

\begin{tabular}{l|l} 
Motor & Life \\
\hline
\end{tabular}

Primera persona $\quad$ El hombre de agua

\begin{tabular}{|l|l|}
\hline Life & Monta una leyenda \\
\hline Ciencia & ¿Por qué duelen los helados? \\
\hline
\end{tabular}

¿Por qué duelen los helados?

Artículo

\begin{tabular}{|l|l|}
\hline Deporte & Máximo
\end{tabular}

Artículo

Salud

\begin{tabular}{l|l} 
& Belleza \\
\hline PC- Artículo & Belleza
\end{tabular}

\begin{tabular}{l|l} 
& rendimiento \\
\hline Culto al cuerpo & Entrenador
\end{tabular} A punto

Artículo

\begin{tabular}{l|l} 
& personal \\
\hline Cosméticos & Grooming \\
\hline
\end{tabular}

\begin{tabular}{ll} 
PC- Artículo & Gastronomía \\
\hline
\end{tabular}

Artículo

Deporte

PC- Artículo

Salud

\begin{tabular}{l|l} 
& \\
\hline PC- Artículo & Salud \\
\hline
\end{tabular}

Nutrición

Belleza

Tratamientos

Grooming

Cuando superas la sentadilla

Deporte

Culto al cuerpo

Gourmet

Afeitados a domicilio

Elige el gym perfecto

Ron, ron, ron

¿Qué pasa, whey?

Psico

Empieza septiembre con una

PC- Artículo

Una victoria imparable

Recupera tu forma

\begin{tabular}{|r|l|r|l|l|r|}
\hline 3 & Adolfo Randulfe & H & Asesora & $\begin{array}{l}\text { Especialista en } \\
\text { motor }\end{array}$ & 24 \\
\hline 1 & & & & & 28 \\
\hline 1 & & & & & 29 \\
\hline
\end{tabular}

\begin{tabular}{|c|c|c|c|c|c|}
\hline 3 & Kai Lenny & $\mathrm{H}$ & Protagoniza & Deportista & 31 \\
\hline 1 & & & & & 34 \\
\hline 1 & & & & & 35 \\
\hline 1 & Fito Florensa & $\mathrm{H}$ & Asesora & $\begin{array}{l}\text { Experto } \\
\text { rendimiento }\end{array}$ & 36 \\
\hline 1 & Guillermo Alvarado & $\mathrm{H}$ & Asesora & Experto fitness & 38 \\
\hline 1 & & & & & 39 \\
\hline 1 & & & & & 40 \\
\hline 1 & & & & & 42 \\
\hline 1 & Anabel Fernández & $\mathrm{M}$ & Asesora & Experta nutrición & 44 \\
\hline 1 & & & & & 45 \\
\hline 1 & Santi Millán & $\mathrm{H}$ & Protagoniza & Actor & 46 \\
\hline 1 & & & & & 47 \\
\hline
\end{tabular}




\begin{tabular}{|c|c|c|c|c|c|c|c|c|c|c|}
\hline *Reportaje & Relaciones & Hombre-mujer & Sexo + relaciones & Tu chica, tu táctica & 3 & & & & & 49 \\
\hline PC- Reportaje & Salud & Equipación deportiva & Equipo & Ensombrece a tus rivales & 2 & & & & & 52 \\
\hline PC- Reportaje & Salud & Deporte & Sácale partido & ¡Surfea sin agua! & 2 & Israel Llansola & $\mathrm{H}$ & Asesora & Deportista & 54 \\
\hline Reportaje & Salud & Bienestar & Salud & $\begin{array}{l}20 \text { secretos para una vida } \\
\text { más feliz }\end{array}$ & 3 & & & & & 56 \\
\hline Recetario & Salud & Nutrición & Perder peso & $\begin{array}{l}\text { Prepara los snacks más } \\
\text { ligeros }\end{array}$ & 2 & & & & & 60 \\
\hline Reportaje & Salud & Deporte & Taekwondo & Aprende de un campeón & 2 & Joel González & $\mathrm{H}$ & Asesora & Deportista & 62 \\
\hline PC- Reportaje & Belleza & Culto al cuerpo & Nutrición & Polvo de estrellas & 2 & & & & & 65 \\
\hline Recetario & Salud & Nutrición & Nutrición & El rey del grill & 4 & & & & & 66 \\
\hline PC- Reportaje & Salud & Equipación deportiva & Equipo & ¡Tírate a la piscina! & 2 & & & & & 70 \\
\hline Reportaje & Salud & Deporte & Triatlón & El deporte de moda & 9 & Parker Gregory & $\mathrm{H}$ & Prota/ Posa & Modelo, deportista & 72 \\
\hline *Reportaje & Belleza & Culto al cuerpo & Cuerpo y fitness & ¿Qué aspecto tienes? & 2 & & & & & 81 \\
\hline Reportaje & Salud & Bienestar & Salud y bienestar & ¿Cómo te sientes? & 2 & & & & & 84 \\
\hline Reportaje & Salud & Bienestar & $\begin{array}{l}\text { Equilibrio } \\
\text { trabajo/vida }\end{array}$ & ¿Cómo rindes? & 2 & & & & & 86 \\
\hline PC- Reportaje & Belleza & Culto al cuerpo & Tu tren superior & Duro como un tronco & 6 & Jonathan Cañada & $\mathrm{H}$ & Asesora & $\begin{array}{l}\text { Entrenador } \\
\text { deportivo }\end{array}$ & 88 \\
\hline $\begin{array}{l}\text { Reportaje + } \\
\text { Recetario }\end{array}$ & Salud & Nutrición & & $\begin{array}{l}\text { Purga tus excesos de este } \\
\text { verano }\end{array}$ & 4 & & & & & 94 \\
\hline *PC- Reportaje & Relaciones & Hombre-mujer & $\begin{array}{l}\text { Verano al } \\
\text { máximo }\end{array}$ & Calienta el septiembre & 10 & $\begin{array}{l}\text { Charlotte } \\
\text { Makinney } \\
\end{array}$ & $M$ & Protagoniza & Modelo & 97 \\
\hline Reportaje & Salud & Bienestar & & $\begin{array}{l}\text { El picante puede salvarte la } \\
\text { vida }\end{array}$ & 5 & & & & & 108 \\
\hline \multicolumn{11}{|l|}{ ESTILO } \\
\hline PC-FR & Tecno/Moda & Motor/ Looks & Estilo & Conecta con tu estilo & 9 & & & & & 115 \\
\hline PC- Reportaje & Belleza & Cosméticos & Belleza & Alarga el verano & 4 & & & & & 124 \\
\hline PC-Artículo & Belleza & Cosméticos & Producto estrella & ¿Tienes las pilas cargadas? & 1 & & & & & 128 \\
\hline *PC- Artículo & Belleza & Cosméticos & Fragancia estrella & Hablando en plata & 1 & & & & & 129 \\
\hline \multicolumn{11}{|l|}{$\mathrm{COACH}$} \\
\hline Portada & & Avance interior & Portada & Mejora tu sprint & 1 & & & & & 131 \\
\hline Reportaje & Belleza & Culto al cuerpo & Coach & Listo para la carrera & 2 & & & & & 132 \\
\hline Reportaje & Belleza & Culto al cuerpo & Sácale partido & Barra libre de músculo & 2 & & & & & 134 \\
\hline Artículo & Belleza & Culto al cuerpo & Nutrición & Para presumir de cuerpo & 1 & & & & & 136 \\
\hline Artículo & Belleza & Culto al cuerpo & $\begin{array}{l}\text { Movimiento } \\
\text { perfecto }\end{array}$ & Gira tus abdominales & 1 & & & & & 138 \\
\hline PC- Reportaje & Belleza & Culto al cuerpo & Entrenamiento & Toca con la banda & 2 & & & & & 140 \\
\hline Artículo & Belleza & Culto al cuerpo & Challenge & Aprende a planchar & 1 & & & & & 144 \\
\hline Artículo & Belleza & Culto al cuerpo & Trucos & Quédate colgado & 1 & & & & & 146 \\
\hline
\end{tabular}




\section{MEN'S HEALTH}

DICIEMBRE 2015

INFORMACIÓN

TIPO

CATEGORÍA

\begin{tabular}{|c|c|c|}
\hline & Avance interior & \\
\hline \multicolumn{3}{|c|}{ Datos revista } \\
\hline Sumario & & \\
\hline Editorial & & Primeras palabras \\
\hline
\end{tabular}

TíTULO

\begin{tabular}{|l|c|l|l|r|}
\hline PERSONA & \multicolumn{2}{r|}{ № 165} \\
\hline NOMBRE & MH & FUNCIÓN & PROFESIÓN & PAG \\
\hline Diego Miguel & H & Protagoniza & Modelo & 1 \\
\hline
\end{tabular}

\begin{tabular}{|l|c|l|l|r|}
\hline PERSONA & \multicolumn{2}{r|}{ № 165} \\
\hline NOMBRE & MH & FUNCIÓN & PROFESIÓN & \\
\hline Diego Miguel & H & Protagoniza & Modelo & PAG \\
\hline & & & & 1 \\
\hline
\end{tabular}

Consultorio

Pregunta a MH

\begin{tabular}{|c|c|c|c|}
\hline Artículo & Salud & Nutrición & Portada \\
\hline Artículo & Salud & Deporte & Cardio \\
\hline Artículo & Salud & Nutrición & Nutrición \\
\hline Artículo & Belleza & Culto al cuerpo & Fitness \\
\hline Artículc & Salud & Nutrición & \\
\hline
\end{tabular}

Insustituible

H Protagoniza Modelo

\begin{tabular}{|c|c|c|c|}
\hline PC- Reportaje & Tecno & Motor & Motor \\
\hline
\end{tabular}

\begin{tabular}{|l|l|}
\hline & 2 \\
\hline
\end{tabular}

\begin{tabular}{|l|r|l|l|r|}
\hline Jordi Martínez & H & Escribe & $\begin{array}{l}\text { Director Men's } \\
\text { Health }\end{array}$ & 11 \\
\hline
\end{tabular}

\begin{tabular}{|l|l|l|l|}
\hline Reportaje & Salud & Deporte + personal & Primera persona \\
\hline *Infografía & Sociedad & Tipo medio \\
\hline Entrevista & Salud & Deporte + personal & Chica MH \\
\hline Artículo & Salud & Nutrición & Nutrición \\
\hline PC-Artículo & Belleza & Cosméticos & Producto estrella \\
\hline PC- Artículo & Belleza & Culto al cuerpo & $\begin{array}{l}\text { Entrenador } \\
\text { personal }\end{array}$ \\
\hline *PC-Artículo & Relaciones & Hombre-mujer & Relaciones \\
\hline *PC-Artículo & Moda & Accesorios & Apuesta MH \\
\hline PC-Artículo & Salud & Deporte & Training camp \\
\hline PC-Artículo & Salud & Equipación deportiva & Equipo \\
\hline PC-Artículo & Moda & Ropa & Lanzamiento \\
\hline PC-Artículo & Belleza & Cosméticos & Fragancia estrella \\
\hline PC-Artículo & Moda & Ropa & Apuesta MH \\
\hline PC-Artículo & Moda & Ropa & A medida \\
\hline & & & \\
\hline
\end{tabular}

\begin{tabular}{l|r|}
\hline Dale al té & 1 \\
\hline Tu mejor táctica & 1 \\
\hline Cáscaras! & 1 \\
\hline Aumenta la exigencia de tus & 1 \\
zancadas & \\
\hline Baja panza & 1 \\
\hline
\end{tabular}

Baja panza

\begin{tabular}{|r|l|l|l|l|r|}
\hline 1 & & & & & 18 \\
\hline 1 & & & & & 20 \\
\hline 1 & & & & & 22 \\
\hline 1 & & & & & 24 \\
\hline 1 & & & & 26 \\
\hline
\end{tabular}

La redención de R. Minniti El arte de regalar

Nuestra top más top

Vivir sin proteína (animal)

Tu energía secreta

Tu lista de grandes fracasos

Pásate al lado oscuro

Trail sin secretos

Da un salto adelante

No te las quitarás

¿Juegas para ganar?

Ande yo caliente...

\begin{tabular}{|c|c|c|c|c|c|c|c|c|c|c|}
\hline PC-Artículo & Moda & Ropa & A medida & Hazte diseñador & 1 & & & & & 58 \\
\hline & & & & & & & & & & \\
\hline $\begin{array}{l}\text { PC- } \text { Reportaje + } \\
\text { recetario }\end{array}$ & Belleza & Culto al cuerpo & Perder peso & $\begin{array}{l}\text { Sobrevive a las navidades sin } \\
\text { engordar }\end{array}$ & 3 & & & & & 61 \\
\hline Reportaje & Belleza & Culto al cuerpo & Fitness & Hombros de piedra & 2 & & & & & 64 \\
\hline PC- Reportaje & Salud & Deporte + personal & Maratón Man & En forma con Paco Roncero & 2 & Paco Roncero & $\mathrm{H}$ & Protagoniza & Chef & 66 \\
\hline
\end{tabular}




\begin{tabular}{|c|c|c|c|c|c|c|c|c|c|c|}
\hline Reportaje & Salud & Prevención & Salud & $\begin{array}{l}\text { Dile a la gran C que se vaya a } \\
\text { la M }\end{array}$ & 3 & & & & & 68 \\
\hline PC- Reportaje & Salud & Deporte + personal & Maratón NY & Duelo en la Gran Manzana & 3 & $\begin{array}{l}\text { Josef Ajram } \\
\text { Raúl Gómez }\end{array}$ & $\begin{array}{l}\mathrm{H} \\
\mathrm{H} \\
\end{array}$ & $\begin{array}{l}\text { Protagoniza } \\
\text { Protagoniza }\end{array}$ & $\begin{array}{l}\text { Deportista } \\
\text { Deportista }\end{array}$ & 72 \\
\hline PC-Artículo & Tecno & Gadgets & En punto & A buenas horas & 1 & & & & & 77 \\
\hline PC- Reportaje & Salud & Equipación deportiva & Deporte extremo & Pedalea hacia la aventura & 2 & & & & & 78 \\
\hline PC-Artículo & Tecno & Gadgets & A tu ritmo & Pon la oreja... & 1 & & & & & 80 \\
\hline PC- Artículo & Tecno & Gadgets & Tecnosport & \multirow{2}{*}{$\begin{array}{l}\text { Deporte con cabeza } \\
\text { A ráfagas }\end{array}$} & 1 & & & & & 81 \\
\hline PC-Artículo & Tecno & Gadgets & Fotografía y vídeo & & 1 & & & & & 82 \\
\hline PC-Artículo & Belleza & Cosméticos & Bonus track & Buena impresión & 1 & & & & & 83 \\
\hline Recetario & Salud & Nutrición & & Este invierno lo tienes crudo & 6 & & & & & 84 \\
\hline *Reportaje & Relaciones & Hombre-mujer & & $\begin{array}{l}25 \text { formas de salvar tu } \\
\text { matrimonio (y tu vida) }\end{array}$ & 8 & & & & & 90 \\
\hline Reportaje & Belleza & Culto al cuerpo & Fitness & Entrena a tu bola & 4 & Fito Florensa & $\mathrm{H}$ & $\begin{array}{l}\text { Prota/ } \\
\text { Asesora }\end{array}$ & $\begin{array}{l}\text { Experto } \\
\text { rendimiento }\end{array}$ & 99 \\
\hline *Reportaje & Salud & Tratamiento & & Testosterona para todos & 6 & & & & & 102 \\
\hline *Reportaje & Otros & & & El día del juicio final & 6 & & & & & 108 \\
\hline \multicolumn{11}{|l|}{ ESTILO } \\
\hline PC- FR & Moda & Looks & Estilo & Feliz moda nueva & 9 & & & & & 114 \\
\hline PC- FR & Belleza & Cosméticos & Belleza & Un regalo de narices & 6 & & & & & 124 \\
\hline \multicolumn{11}{|l|}{$\mathrm{COACH}$} \\
\hline Portada & & Avance interior & Portada & \multirow{2}{*}{$\begin{array}{l}\text { Quema grasa más rápido } \\
\text { Tu plan de apoyo }\end{array}$} & 1 & & & & & 131 \\
\hline Reportaje & Belleza & Culto al cuerpo & Coach & & 2 & & & & & 132 \\
\hline Reportaje & Salud & Deporte & Running & Consigue un 10 & 2 & & & & & 134 \\
\hline Artículo & Salud & Prevención & Lesiones & Sal por piernas & 1 & & & & & 136 \\
\hline Artículo & Salud & Reportaje & $\begin{array}{l}\text { Movimiento } \\
\text { perfecto }\end{array}$ & Muerte por burpee & 1 & & & & & 138 \\
\hline Artículo & Salud & Deporte & Coach & Pierde un par & 1 & & & & & 139 \\
\hline Artículo & Belleza & Culto al cuerpo & Complemento & Toques de balón & 1 & & & & & 140 \\
\hline Artículo & Belleza & Culto al cuerpo & Ejercicio & El señor de las anillas & 1 & & & & & 141 \\
\hline Reportaje & Belleza & Culto al cuerpo & Sácale partido & $\begin{array}{l}\text { Apúntate al programa } \\
\text { casero con cinta de } \\
\text { resistencia }\end{array}$ & 2 & & & & & 142 \\
\hline Artículo & Belleza & Culto al cuerpo & Músculo & Aumenta tus expectativas & 1 & & & & & 144 \\
\hline Artículo & Belleza & Culto al cuerpo & Trucos & ¿Se muscula con TRX? & 1 & & & & & 145 \\
\hline
\end{tabular}




\begin{tabular}{|c|c|c|c|c|c|c|c|c|c|c|}
\hline \multicolumn{10}{|l|}{ ESQUIRE } & $\begin{array}{r}\text { MARZO } 2015 \\
\text { № } 83\end{array}$ \\
\hline \multicolumn{6}{|l|}{ INFORMACIÓN } & \multicolumn{4}{|l|}{ PERSONA } & PAG \\
\hline TIPO & CATEGORÍA & CONTENIDO & ETIQUETA & TíTULO & PAG & NOMBRE & MH & FUNCIÓN & PROFESIÓN & \\
\hline Portada & & & & & 1 & Ethan Hawke & $\mathrm{H}$ & Protagoniza & Actor & 1 \\
\hline Sumario & & & & & 4 & & & & & 15 \\
\hline Editorial & & & $\begin{array}{l}\text { La carta del } \\
\text { director }\end{array}$ & ¿Dónde estás? & 1 & Andrés Rodríguez & $\mathrm{H}$ & Escribe & Director Esquire & 20 \\
\hline Cartas lectores & & & Prólogo & $\begin{array}{l}\text { Sobre el número anterior/ Sobre } \\
\text { qué nos habéis escrito }\end{array}$ & 2 & & & & & 22 \\
\hline *Opinión & Ocio- cultura & Libros & El ruido y la furia & Novelas, sueño y memoria & 1 & Jordi Soler & $\mathrm{H}$ & Escribe & Escritor & 26 \\
\hline \multicolumn{11}{|l|}{ CHECKIN } \\
\hline *Artículo & Ocio-cultura & Cine + personal & Portada & $\begin{array}{l}\text { Chicas que nos ponen de buen } \\
\text { humor }\end{array}$ & 1 & Michelle Calvó & $M$ & Protagoniza & Actriz & 29 \\
\hline PC- Reportaje & Ocio-cultura & Libros & Filosofía & Los placeres y los días & 1 & Yves Michaud & $\mathrm{H}$ & Protagoniza & Filósofo & 30 \\
\hline PC- Reportaje & Ocio-cultura & Expo & Arte & El vigilante vigilado & 1 & Daniel G. Andujar & $\mathrm{H}$ & Protagoniza & Artista visual & 32 \\
\hline PC- Reportaje & Ocio-cultura & Música & Música & La estrella es el productor & 1 & Mark Ronson & $\mathrm{H}$ & Protagoniza & Compositor & 34 \\
\hline PC- Reportaje & Ocio-cultura & Libros & Literatura & El derecho olvidado & 1 & Martín Caparros & $\mathrm{H}$ & Protagoniza & Escritor & 36 \\
\hline PC- Reportaje & Ocio-cultura & Cine/ Libros & Cine & El Ferrari del cine & 2 & Peter Becker & $\mathrm{H}$ & Protagoniza & Empresario & 38 \\
\hline PC- Artículo & Ocio-cultura & Series & Televisión & Un padre fuera de serie & 1 & & & & & 40 \\
\hline PC- Reportaje & Ocio-cultura & Expos & Arte & La mujer araña & 3 & Louise Bourgeois & $M$ & Protagoniza & Artista, escultora & 42 \\
\hline PC- Entrevista & Ocio-cultura & & Entrevista & El concepto maggi & 1 & Marco Maggi & $\mathrm{H}$ & Protagoniza & Artista & 46 \\
\hline Reportaje & Ocio-cultura & Música & $\begin{array}{l}\text { Fotos con } \\
\text { historia }\end{array}$ & El día que Dylan se electrocutó & 3 & Bob Dylan & $\mathrm{H}$ & Protagoniza & Músico & 48 \\
\hline PC-Artículo & Ocio-cultura & Libros & Postdata & Negro, que me gusta negro & 1 & & & & & 52 \\
\hline \multicolumn{11}{|l|}{ GASTRO } \\
\hline PC-Artículo & Ocio-cultura & Restauración & Portada & Mejor con salsa & 1 & & & & & 55 \\
\hline PC-Artículo & Gastronomía & Bebidas & Gastro & Escoge bien tus compañías & 2 & & & & & 56 \\
\hline PC-Artículo & Gastronomía & Alimentos & Gastro & Lo nunca visto & 2 & & & & & 58 \\
\hline PC-Artículo & Ocio-cultura & Restauración & Gastro & Puerto refugio & 1 & & & & & 61 \\
\hline \multicolumn{11}{|l|}{ EN ESTO CREO } \\
\hline Reportaje & Otros & Personal & En esto creo & Ray Winstone & 2 & Ray Winstone & $\mathrm{H}$ & Protagoniza & Actor & 62 \\
\hline Reportaje & Otros & Personal & En esto creo & Jonathan Coe & 2 & Jonathan Coe & $\mathrm{H}$ & Protagoniza & Escritor & 64 \\
\hline \multicolumn{11}{|l|}{ EL GURÚ } \\
\hline PC- Reportaje & Moda & Ropa & Gurú & Apreciado comodín & 4 & & & & & 67 \\
\hline PC- Fotos & Moda & Ropa/ Accesorios & Gurú & Los bulevares periféricos & 2 & & & & & 74 \\
\hline PC-Artículo & Moda & Ropa/ Accesorios & Gurú & Extra $10 \%$ & 1 & & & & & 76 \\
\hline PC-Artículo & Moda & Ropa & Gurú & El lujo y la flor & 1 & & & & & 78 \\
\hline PC-Artículo & Moda & Accesorios & Gurú & Clásicos placeres & 1 & & & & & 80 \\
\hline *PC- Artículo & Moda & Ropa & Gurú & El 'preppy' francés & 1 & & & & & 83 \\
\hline PC- Artículo & Moda & Accesorios & Gurú & Viajar en primera clase & 1 & & & & & 84 \\
\hline
\end{tabular}




\begin{tabular}{|c|c|c|c|c|c|c|c|c|c|c|}
\hline PC-Artículo & Moda & Accesorios & Gurú & Fundido en negro & 1 & & & & & 86 \\
\hline PC-Artículo & Moda & Accesorios & Gurú & Madre naturaleza & 1 & & & & & 89 \\
\hline PC-Artículo & Moda & Accesorios & Gurú & Futuros deseos & 1 & & & & & 91 \\
\hline PC-Artículo & Moda & Looks & Gurú & Traje sencillo & 2 & $\begin{array}{l}\text { Mark Duplass } \\
\text { Jay Duplass }\end{array}$ & $\begin{array}{l}\mathrm{H} \\
\mathrm{H} \\
\end{array}$ & $\begin{array}{l}\text { Prota/ Posa } \\
\text { Prota/ Posa }\end{array}$ & $\begin{array}{l}\text { Guionista } \\
\text { Guionista }\end{array}$ & 92 \\
\hline PC-Artículo & Moda & Ropa & Gurú & Nuevos aires para el zapato & 1 & & & & & 95 \\
\hline PC-Artículo & Moda & Looks & Gurú & Fin de semana & 1 & & & & & 97 \\
\hline PC- Reportaje & Moda & Ropa & Gurú & La camisa blanca & 2 & & & & & 98 \\
\hline \multicolumn{11}{|l|}{ GROOMING } \\
\hline PC-Artículo & Belleza & Cosméticos & Portada & Pisando fuerte & 1 & & & & & 101 \\
\hline PC- Fotos & Belleza & Cosméticos & Grooming & De tal palo... & 4 & & & & & 102 \\
\hline *PC- Artículo & Salud & $\begin{array}{l}\text { Deporte/ Nutrición/ } \\
\text { Prevención }\end{array}$ & Grooming & Tu nuevo yo & 1 & & & & & 106 \\
\hline *PC- Artículo & Belleza & Cosméticos & Mantenimiento & Puesta a punto & 1 & & & & & 107 \\
\hline PC-Artículo & Belleza & Cosméticos & Grooming & Sutil y adictivo & 2 & & & & & 109 \\
\hline PC-Artículo & Belleza & Cosméticos & Club Esquire & Bon Vivant & 1 & Bon Vivant & $\mathrm{H}$ & Protagoniza & Perfumista & 110 \\
\hline \multicolumn{11}{|c|}{ BUSINESS CLASS } \\
\hline Reportaje & Ocio-cultura & Música & Ejecutivo del mes & Juli Guiu & 2 & Juli Guiu & $\mathrm{H}$ & Protagoniza & Empresario musical & 112 \\
\hline Reportaje & Moda & Marca & Otros negocios & Crocodile rock & 2 & $\begin{array}{l}\text { Flipe Oliveira } \\
\text { Baptista } \\
\end{array}$ & $\mathrm{H}$ & Protagoniza & Diseñador moda & 114 \\
\hline *Artículo & Sociedad & & Análisis & Déjalo que corra & 1 & & & & & 117 \\
\hline Reportaje & Moda & Marca & Otros negocios & Ligero equipaje & 1 & Marco Palmieri & $\mathrm{H}$ & Protagoniza & CEO, empresario & 119 \\
\hline PC-Artículo & Ocio-cultura & Destino & Tendencias & $\begin{array}{l}\text { La hora del café/ Vacaciones } \\
\text { coworking/ Madrid, Madrid/ } \\
\text { Trastornos digitales }\end{array}$ & 1 & & & & & 120 \\
\hline *Artículo & Relaciones & Hombre-mujer & & $\begin{array}{l}10 \text { cosas que aún no sabes de las } \\
\text { mujeres }\end{array}$ & 1 & Melani Olivares & $M$ & Protagoniza & Actriz & 121 \\
\hline Reportaje & Ocio-cultura & Música + personal & & Estamos vivos & 20 & Bruce Springsteen & $\mathrm{H}$ & Protagoniza & Músico & 122 \\
\hline *Reportaje & Ocio-cultura & Cine + personal & Woman we love & Verdades y mentiras & 6 & \begin{tabular}{|l} 
Evangeline Lilly \\
\end{tabular} & $\mathrm{M}$ & Protagoniza & Actriz & 134 \\
\hline PC- FR & $\begin{array}{l}\text { Gastronomía/ } \\
\text { Moda }\end{array}$ & $\begin{array}{l}\text { Bebidas/Ropa/ } \\
\text { Accesorios }\end{array}$ & E10 & Obsesiones & 12 & & & & & 140 \\
\hline Reportaje & Ocio-cultura & Libros + personal & & Philip Kerr & 6 & Philip Kerr & $\mathrm{H}$ & Protagoniza & Escritor & 154 \\
\hline Reportaje & Tecno & Internet & & Doodles & 8 & Ryan Germick & $\mathrm{H}$ & Protagoniza & Diseñador gráfico & 158 \\
\hline Reportaje & Ocio-cultura & Cine + personal & & Ethan Hawke & 6 & Ethan Hawke & $\mathrm{H}$ & Protagoniza & Actor & 167 \\
\hline *Reportaje & Sociedad & & & Sex o délica & 12 & & & & & 172 \\
\hline Reportaje & Sociedad & & & Muy lejos & 10 & Scott Kelly & $\mathrm{H}$ & Protagoniza & Astronauta & 184 \\
\hline Reportaje & Ocio-cultura & Música & & Alfonso Aijón & 4 & Alfonso Aijón & $\mathrm{H}$ & Protagoniza & $\begin{array}{l}\text { Promotor de } \\
\text { Ibermusica }\end{array}$ & 196 \\
\hline Reportaje & Ocio-cultura & Fotografía & & Jean- Baptiste & 6 & Jean-Baptiste & $\mathrm{H}$ & Protagoniza & Fotógrafo & 201 \\
\hline
\end{tabular}




\begin{tabular}{|c|c|c|c|c|c|c|c|c|c|c|}
\hline PC-FR & Moda & Looks & Estilo Esquire & Suburbia & 20 & & & & & 204 \\
\hline PC- FR & Moda & Looks & Estilo Esquire & Brotherhood & 8 & & & & & 224 \\
\hline \multicolumn{11}{|l|}{ CHECKOUT } \\
\hline PC- Artículo & Tecno & Gadgets & Portada & \multirow{2}{*}{$\begin{array}{l}\text { Melómano confeso } \\
\text { Él se atrevería }\end{array}$} & 1 & & & & & 233 \\
\hline PC-Artículo & Tecno & Motor & El coche del mes & & 2 & & & & & 234 \\
\hline PC-Artículo & Tecno & Motor & Checkout & En frasco pequeño & 1 & & & & & 236 \\
\hline PC- Artículo & Ocio-cultura & Destino & Viajes & El punto de partida perfecto & 1 & & & & & 237 \\
\hline *PC- Artículo & Ocio-cultura & Destino & Viajes & Los mejores spas del mundo & 4 & & & & & 238 \\
\hline PC-Artículo & Ocio-cultura & Restauración & Tarjetero & \multirow{3}{*}{$\begin{array}{l}\text { Varios } \\
\text { Toni Verna, inventor de la } \\
\text { moviola } \\
\text { Un set para Audrey }\end{array}$} & 1 & & & & & 251 \\
\hline Foto & Ocio-cultura & Televisión & In memoriam & & 2 & Toni Verna & $\mathrm{H}$ & Protagoniza & Productor televisión & 252 \\
\hline Foto & Ocio-cultura & Cine & Backstage & & 1 & $\begin{array}{l}\text { Audrey Hepburn } \\
\text { George Cukor }\end{array}$ & $\begin{array}{l}\mathrm{M} \\
\mathrm{H}\end{array}$ & $\begin{array}{l}\text { Protagoniza } \\
\text { Protagoniza }\end{array}$ & $\begin{array}{l}\text { Actriz } \\
\text { Director de cine }\end{array}$ & 254 \\
\hline
\end{tabular}




\begin{tabular}{|c|c|c|c|c|c|c|c|c|c|c|}
\hline \multicolumn{10}{|l|}{ ESQUIRE } & $\begin{array}{r}\text { JUNIO } 2015 \\
\text { No } 86\end{array}$ \\
\hline \multicolumn{6}{|l|}{ INFORMACIÓN } & \multicolumn{4}{|l|}{ PERSONA } & \\
\hline TIPO & CATEGORÍA & CONTENIDO & EITQUETA & TíTULO & PAG & NOMBRE & $\mathrm{MH}$ & FUNCIÓN & PROFESIÓN & PAG \\
\hline Portada & & & & ¿Aún ves la maldita televisión? & 1 & James Gandolfini & $\mathrm{H}$ & Protagoniza & Actor & 1 \\
\hline Sumario & & & & & 3 & & & & & 6 \\
\hline Editorial & & & $\begin{array}{l}\text { La carta del } \\
\text { director }\end{array}$ & Tiradme de las orejas & 1 & Andrés Rodríguez & $\mathrm{H}$ & Escribe & Director Esquire & 12 \\
\hline Cartas lectores & & & Prólogo & Sobre el número anterior & 2 & & & & & 14 \\
\hline Opinión & & & El ruido y la furia & $\begin{array}{l}\text { Una reflexión sobre nuestra } \\
\text { ficción televisiva }\end{array}$ & 2 & $\begin{array}{l}\text { Eduardo Ladrón de } \\
\text { Guevara }\end{array}$ & $\mathrm{H}$ & Escribe & Guionista & 22 \\
\hline \multicolumn{11}{|l|}{ CHECKIN } \\
\hline *Artículo & Ocio-cultura & Cine + personal & Portada & $\begin{array}{l}\text { Chicas que nos ponen de buen } \\
\text { humor }\end{array}$ & 1 & María Guinea & $M$ & Protagoniza & Actriz & 27 \\
\hline Artículo & Ocio-cultura & Libros & Literatura & El escritor fantasma & 1 & Andrew Croft & $\mathrm{H}$ & Protagoniza & Escritor & 28 \\
\hline PC-Artículo & $\begin{array}{l}\text { Ocio-cultura/ } \\
\text { Tecno/ } \\
\text { Gastronomía/ } \\
\text { Moda }\end{array}$ & Personal & Teleadictos & Los favoritos de... Colin Farrell & 1 & Colin Farrell & $\mathrm{H}$ & Protagoniza & Actor & 30 \\
\hline Artículo & Ocio-cultura & Música & $\begin{array}{l}\text { Vida de una } \\
\text { canción }\end{array}$ & Y el orgasmo se hizo melodía & 1 & & & & & 32 \\
\hline PC- Artículo & \begin{tabular}{|l|} 
Ocio-cultura \\
\end{tabular} & Expo/ Libros & $\begin{array}{l}\text { Cogiendo el } \\
\text { ritmo }\end{array}$ & $\begin{array}{l}\text { Galería Marlborough/ Solo para } \\
\text { adultos }\end{array}$ & 1 & & & & & 34 \\
\hline *PC-Reportaje & Ocio-cultura & Expo + personal & Arte & La brigada Modotti & 2 & Tina Modotti & $M$ & Protagoniza & Fotógrafa & 36 \\
\hline PC-Artículo & Ocio-cultura & Música & Danza & Toma candela & 1 & Curro de Candela & $\mathrm{H}$ & Protagoniza & Bailaor & 38 \\
\hline PC-Artículo & Ocio-cultura & Música & Música & Parker nunca para & 1 & Graham Parker & $\mathrm{H}$ & Protagoniza & Músico & 40 \\
\hline PC- Artículo & Ocio-cultura & Libros & $\begin{array}{l}\text { Buenas ideas, } \\
\text { buenos discos }\end{array}$ & Éramos tan jóvenes... & 1 & & & & & 42 \\
\hline \multicolumn{11}{|l|}{ GASTRO } \\
\hline PC-Artículo & Gastronomía & Bebidas & Portada & Sección vermú & 1 & & & & & 45 \\
\hline PC-Artículo & Gastronomía & Bebidas & Coctelería & My champagne is rich & 1 & & & & & 46 \\
\hline PC- Reportaje & Gastronomía & Bebidas & Gastro & \multirow{2}{*}{$\begin{array}{l}\text { Máxima pureza } \\
\text { No te quedes dentro }\end{array}$} & 2 & & & & & 48 \\
\hline PC- Artículo & Ocio-cultura & Restauración & Restaurantes & & 1 & & & & & 52 \\
\hline \multicolumn{11}{|l|}{ EN ESTO CREO } \\
\hline Reportaje & Otros & Personal & En esto creo & Ian McKellen & 2 & Ian McKellen & $\mathrm{H}$ & Actor & Protagoniza & 54 \\
\hline \multicolumn{11}{|l|}{ EL GURÚ } \\
\hline *PC- Artículo & Moda & Accesorios & Gurú & Rodarán maletas & 4 & & & & & 57 \\
\hline PC-Artículo & Moda & Ropa/ Accesorios & Gurú & Extra $10 \%$ & 1 & & & & & 61 \\
\hline PC- Foto & Moda & Ropa/ Accesorios & Gurú & \multirow{3}{*}{$\begin{array}{l}\text { The good traveller } \\
\text { Ligeros de equipaje } \\
\text { Material sensible }\end{array}$} & 2 & & & & & 62 \\
\hline PC-Artículo & Moda & Accesorios & Gurú & & 1 & & & & & 64 \\
\hline PC-Artículo & Moda & Accesorios & Gurú & & 1 & & & & & 65 \\
\hline
\end{tabular}




\begin{tabular}{|c|c|c|c|c|c|c|c|c|c|c|}
\hline PC-FR & Moda & Ropa/ Accesorios & Gurú & Islanders & 4 & & & & & 66 \\
\hline PC-Artículo & Moda & Accesorios & Gurú & El hijo pródigo & 1 & & & & & 70 \\
\hline PC-Artículo & Moda & Accesorios & Gurú & El reloj de lapo Elkann & 1 & & & & & 71 \\
\hline PC-Artículo & Moda & Ropa/ Accesorios & Gurú & \multirow{2}{*}{$\begin{array}{l}\text { Pureza dinámica } \\
\text { Trilogía alemana }\end{array}$} & 1 & & & & & 72 \\
\hline PC- Artículo & Tecno/Moda & $\begin{array}{l}\text { Moda/ Motor + } \\
\text { profesional }\end{array}$ & Club Esquire & & 1 & Nico Rosberg & $\mathrm{H}$ & Protagoniza & Piloto F1 & 74 \\
\hline \multicolumn{11}{|l|}{ GROOMING } \\
\hline PC- Artículo & Belleza & Cosméticos & Portada & Refrescante & 1 & & & & & 77 \\
\hline PC- Reportaje & Moda/Belleza & $\begin{array}{l}\text { Ropa/Accesorios/ } \\
\text { Cosméticos }\end{array}$ & Grooming & Al son de las olas & 2 & & & & & 78 \\
\hline PC- Reportaje & $\begin{array}{l}\text { Moda/Belleza/ } \\
\text { Ocio-cultura }\end{array}$ & $\begin{array}{l}\text { Ropa/ Accesorios/ } \\
\text { Cosméticos/Libros }\end{array}$ & Grooming & A todo gas & 2 & & & & & 80 \\
\hline PC- Reportaje & Belleza & Cosméticos & Grooming & Verano perfecto & 4 & & & & & 82 \\
\hline \multicolumn{11}{|l|}{ BUSINESS CLASS } \\
\hline Reportaje & Moda & Accesorios & $\begin{array}{l}\text { Ejecutivo del } \\
\text { mes }\end{array}$ & Ignacio Miranda & 2 & Ignacio Miranda & $\mathrm{H}$ & Protagoniza & $\begin{array}{l}\text { Director general } \\
\text { Samsonite }\end{array}$ & 86 \\
\hline \multirow[t]{2}{*}{ Artículo } & Gastronomía & Bebidas & Perfil & De 'niñato' a maestro & 1 & Juan Manuel & $\mathrm{H}$ & Protagoniza & Director Lavinia & 88 \\
\hline & $\begin{array}{l}\text { Ocio-cultura/ } \\
\text { Sociedad }\end{array}$ & Destinos/Economía & Tendencias & $\begin{array}{l}\text { ¿Sweatworking?/ Destino } \\
\text { Tequila/ La afectividad como } \\
\text { negocio/ Ciudades de negocios } \\
\text { "prohibitivas" }\end{array}$ & 1 & & & & & 89 \\
\hline FR & Ocio-cultura & Arte & & Tokyo Camera Style & 10 & John Sypal & $\mathrm{H}$ & Protagoniza & Fotógrafo & 90 \\
\hline \multicolumn{11}{|l|}{ TELEADICTOS } \\
\hline Reportaje & Ocio-cultura & Cine + personal & Teleadictos & La leyenda de un Soprano & 4 & James Gandolfini & $\mathrm{H}$ & Protagoniza & Actor & 100 \\
\hline Entrevista & Ocio-cultura & Series & Teleadictos & Mr. Big Bang & 2 & David Saltzberg & $\mathrm{H}$ & Protagoniza & $\begin{array}{l}\text { Profesor de física y } \\
\text { astronomía }\end{array}$ & 104 \\
\hline Reportaje & Ocio-cultura & Series & Teleadictos & Transparent & 4 & Jeffrey Tambor & $\mathrm{H}$ & Protagoniza & Actor & 106 \\
\hline *Reportaje & Ocio-cultura & Series + personal & Teleadictos & $\begin{array}{l}\text { Un chiste divertido* por Kerry } \\
\text { Bishé }\end{array}$ & 2 & Kerry Bishé & $M$ & Protagoniza & Actriz & 110 \\
\hline PC- FR + artículo & $\begin{array}{l}\text { Moda/ Ocio- } \\
\text { cultura }\end{array}$ & Cine + personal & Teleadictos & Better call saul & 8 & Bob Odenkirk & $\mathrm{H}$ & Prota/ Posa & Actor & 112 \\
\hline PC- FR & $\begin{array}{l}\text { Belleza/Tecno/ } \\
\text { Moda/ } \\
\text { Gastronomía }\end{array}$ & $\begin{array}{l}\text { Cosméticos/Motor/ } \\
\text { Ropa/ Bebidas/ } \\
\text { Accesorios }\end{array}$ & E10 & Obsesiones & 10 & & & & & 120 \\
\hline PC- Reportaje & Ocio-cultura & Expo & & Dead stars & 8 & $\begin{array}{l}\text { Nigel Parry } \\
\text { Lou Reed } \\
\text { Margaret Thatcher } \\
\text { Alexander McQueen } \\
\text { Allen Ginsberg } \\
\text { Luciano Pavarotti } \\
\text { Alfred Eisenstaedt }\end{array}$ & $\begin{array}{l}\mathrm{H} \\
\mathrm{H} \\
\mathrm{M} \\
\mathrm{H} \\
\mathrm{H} \\
\mathrm{H} \\
\mathrm{H}\end{array}$ & $\begin{array}{l}\text { Protagoniza } \\
\text { Posa } \\
\text { Posa } \\
\text { Posa } \\
\text { Posa } \\
\text { Posa } \\
\text { Posa }\end{array}$ & $\begin{array}{l}\text { Fotógrafo } \\
\text { Músico } \\
\text { Política } \\
\text { Diseñador moda } \\
\text { Poeta } \\
\text { Cantante ópera } \\
\text { Fotógrafo }\end{array}$ & 130 \\
\hline
\end{tabular}




\begin{tabular}{|c|c|c|c|c|c|c|c|c|c|c|}
\hline *Entrevista & Otros & Personal & Woman we love & $\begin{array}{l}\text { Hay mucho que amar de la } \\
\text { historia detrás de María }\end{array}$ & 4 & María Sharapova & $M$ & Protagoniza & Tenista & 138 \\
\hline \multicolumn{11}{|l|}{ ESTILO } \\
\hline PC- FR & Moda & Looks & & Let's get lost & 10 & & & & & 142 \\
\hline PC- FR & Moda & Looks & Estilo Esquire & Me quedo contigo & 18 & & & & & 152 \\
\hline \multicolumn{11}{|l|}{ CHECKOUT } \\
\hline PC-Artículo & Ocio-cultura & Destinos & Portada & Directo al mar & 1 & & & & & 171 \\
\hline PC-Artículo & Moda & Ropa & Ciclismo & Una pedalada más allá & 1 & & & & & 172 \\
\hline PC-Artículo & Moda & Accesorios & Viaje & Un baúl para dominarlos a todos & 1 & & & & & 173 \\
\hline PC- Reportaje & Tecno & Motor & El coche del mes & Maneja la situación & 2 & & & & & 175 \\
\hline PC-Artículo & Tecno & Motor & Motor & Actitud ante todo & 1 & & & & & 176 \\
\hline PC-Artículo & Tecno & Gadgets & Música & Música por (y hacia) todos lados & 1 & & & & & 177 \\
\hline Foto & Otros & Profesional & In memoriam & \multirow{2}{*}{$\begin{array}{l}\text { Jesús Hermida } \\
\text { B.B.King }\end{array}$} & 2 & Jesús Hermida & $\mathrm{H}$ & Protagoniza & Periodista & 178 \\
\hline Foto & Ocio-cultura & Música & In memoriam & & 1 & B. B. King & $\mathrm{H}$ & Protagoniza & Músico & 180 \\
\hline PC- Artículo & Ocio-cultura & $\begin{array}{l}\text { Destinos/ } \\
\text { Restauración }\end{array}$ & Tarjetero & \multirow{2}{*}{$\begin{array}{l}\text { Varios } \\
\text { ¡Esta noche pincha Kojak! }\end{array}$} & 1 & & & & & 181 \\
\hline Foto & Ocio-cultura & Cine & Backstage & & 1 & Telly Savalas & $\mathrm{H}$ & Protagoniza & Actor & 182 \\
\hline
\end{tabular}




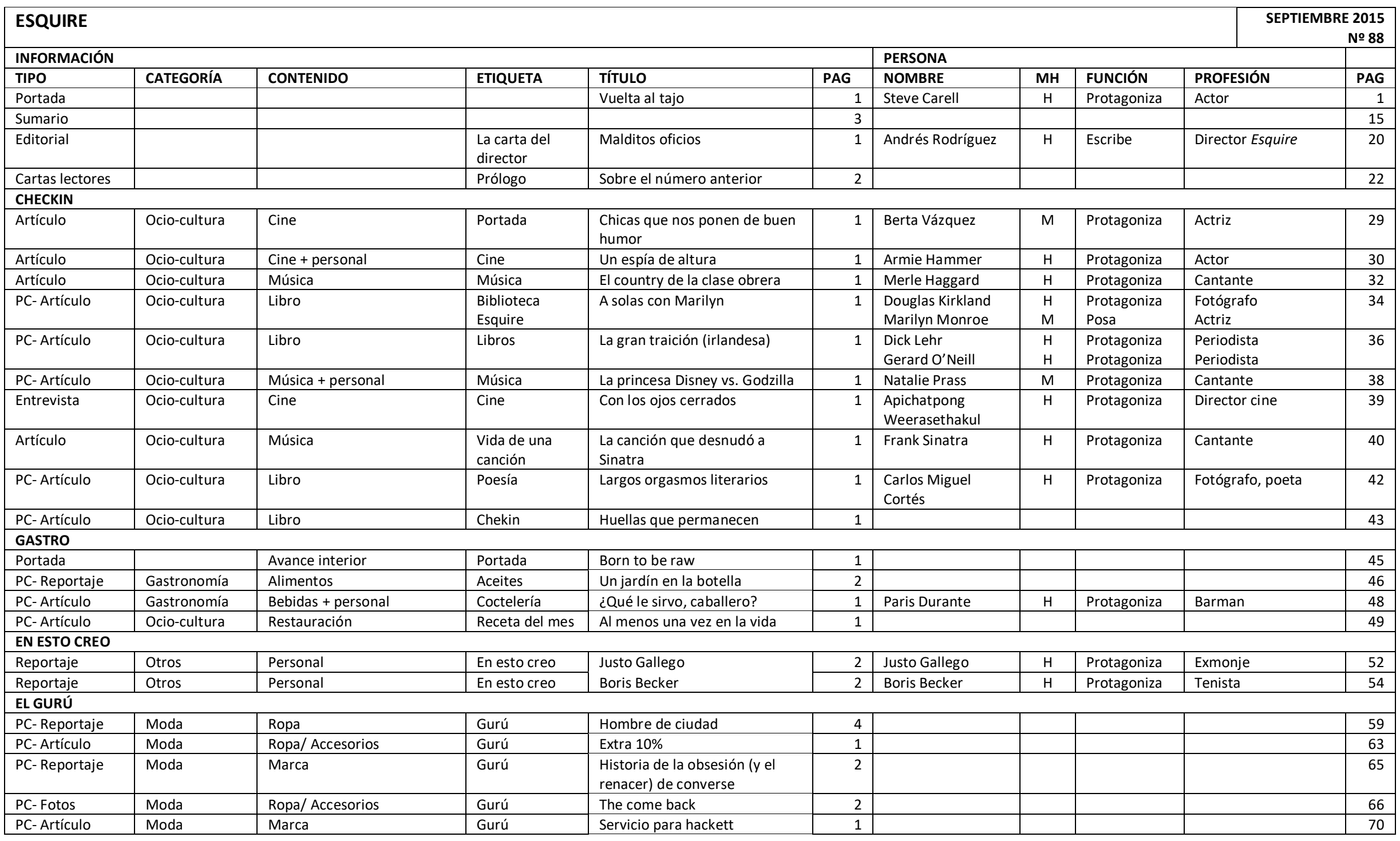




\begin{tabular}{|c|c|c|c|c|c|c|c|c|c|c|}
\hline PC-Artículo & Moda & Marca & Gurú & Romanticismo 'tecno-sartorial' & 1 & & & & & 71 \\
\hline PC-Artículo & Moda & Accesorios & Gurú & Diseño extremo & 1 & & & & & 72 \\
\hline PC-Artículo & Moda & Marca & Gurú & The normal man & 1 & & & & & 73 \\
\hline PC-Artículo & Moda & Accesorios & Gurú & \multirow{2}{*}{$\begin{array}{l}\text { Nuevas experiencias } \\
\text { Utilidad ante todo }\end{array}$} & 1 & & & & & 74 \\
\hline PC-Artículo & Moda & Accesorios & Gurú & & 1 & $\begin{array}{l}\text { Theodore } \\
\text { Schneider }\end{array}$ & $\mathrm{H}$ & Protagoniza & Relojero & 75 \\
\hline PC- Artículo & Moda & Accesorios & Gurú & Buenas intenciones & 1 & & & & & 76 \\
\hline PC-Artículo & Moda & Accesorios & Gurú & Pequeño pero matón & 1 & & & & & 77 \\
\hline \multicolumn{11}{|l|}{ GROOMING } \\
\hline *PC- FR & Belleza & Cosméticos & Grooming & Reflejos de estilo & 6 & & & & & 79 \\
\hline \multicolumn{11}{|c|}{ BUSINESS CLASS } \\
\hline Reportaje & Tecno & Motor & $\begin{array}{l}\text { Ejecutivo del } \\
\text { mes }\end{array}$ & Jesús Alonso & 2 & Jesús Alonso & $\mathrm{H}$ & Protagoniza & $\begin{array}{l}\text { Consejero delegado } \\
\text { Ford } \\
\end{array}$ & 86 \\
\hline Reportaje & Otros & Profesional & Otros negocios & Pablo del Campo & 2 & Pablo de Campo & $\mathrm{H}$ & Protagoniza & $\begin{array}{l}\text { Director creativo } \\
\text { Saatchi\&Saatchi } \\
\end{array}$ & 88 \\
\hline Reportaje & Ocio-cultura & Destinos & Perfil & Salto al vacío & 1 & José Luque García & $\mathrm{H}$ & Protagoniza & $\begin{array}{l}\text { Director Hotel Fuerte } \\
\text { Miramar } \\
\end{array}$ & 90 \\
\hline PC- Artículo & Ocio-cultura & $\begin{array}{l}\text { Destinos/ Expo/ } \\
\text { Restauración }\end{array}$ & Tendencias & $\begin{array}{l}\text { 'Farm break'/ Lujo en el País } \\
\text { Vasco/ ¿Eres un 'yucci'?/ Sano } \\
\text { y para llevar }\end{array}$ & 1 & & & & & 91 \\
\hline FR & Ocio-cultura & Arte & & La vida secreta de las pizarras & 14 & Alejandro Guijarro & $\mathrm{H}$ & Protagoniza & Fotógrafo & 92 \\
\hline Reportaje & Ocio-cultura & Cine + personal & & $\begin{array}{l}\text { Jason Statham es pura } \\
\text { diversión }\end{array}$ & 8 & Jason Statham & $\mathrm{H}$ & Protagoniza & Actor & 106 \\
\hline Reportaje & Ocio-cultura & Música & & Zubin Metha & 4 & Zubin Mehta & $\mathrm{H}$ & Protagoniza & Director orquesta & 114 \\
\hline FR + artículo & Ocio-cultura & Arte & & Skate and Jazz & 14 & lan Johnson & $\mathrm{H}$ & Protagoniza & Ilustrador & 118 \\
\hline Reportaje & Ocio-cultura & Cine & & $\begin{array}{l}\text { Steve Carell, este tipo quiere } \\
\text { ser tu jefe }\end{array}$ & 4 & Steve Carell & $\mathrm{H}$ & Protagoniza & Actor & 132 \\
\hline *Reportaje & Ocio-cultura & Cine + personal & $\begin{array}{l}\text { Woman we } \\
\text { love }\end{array}$ & ¡Qué delicia... Kate Mara! & 6 & Kate Mara & $M$ & Protagoniza & Actriz & 136 \\
\hline *Reportaje & Otros & Lifestyle & & Las nuevas reglas masculinas & 10 & & & & & 142 \\
\hline \multicolumn{11}{|l|}{ ESTILO } \\
\hline FR & Moda & Looks & Estilo Esquire & A wide space & 14 & & & & & 152 \\
\hline \multicolumn{11}{|l|}{ CHECKOUT } \\
\hline PC-Artículo & Tecno & Gadgets & Portada & Déjate llevar & 1 & & & & & 166 \\
\hline PC- Reportaje & Tecno & Motor & $\begin{array}{l}\text { El coche del } \\
\text { mes }\end{array}$ & Ahora nos divertimos & 2 & & & & & 168 \\
\hline PC-Artículo & Ocio-cultura & Festival & Checkout & Cerca de las estrellas & 1 & & & & & 170 \\
\hline PC-Artículo & Tecno & Gadgets & Diseño & Música sin limites & 1 & & & & & 171 \\
\hline Reportaje & Ocio-cultura & Arte & Pintura & El artista que quiere ser artista & 2 & Juan Uslé & $\mathrm{H}$ & Protagoniza & Pintor & 172 \\
\hline PC-Artículo & Tecno & Motor & Motor & Propón a la vida & 1 & & & & & 174 \\
\hline
\end{tabular}




\begin{tabular}{|c|c|c|c|c|c|c|c|c|c|c|}
\hline PC-Artículo & Deco & Objeto deco & Decoración & Bella geometría & 1 & & & & & 175 \\
\hline PC- Reportaje & Ocio-cultura & Destinos & Viajes & $\begin{array}{l}\text { Siéntete como un auténtico } \\
\text { duque italiano }\end{array}$ & 2 & & & & & 176 \\
\hline Foto & Ocio-cultura & Cine & In memoriam & José Sazatornil 'Saza' & 2 & José Sazatornil & $\mathrm{H}$ & Protagoniza & Actor & 178 \\
\hline Foto & Ocio-cultura & Música & In memoriam & Javier Krahe & 1 & Javier Krahe & $\mathrm{H}$ & Protagoniza & Cantautor & 180 \\
\hline PC-Artículo & Ocio-cultura & Restauración & Tarjetero & Varios & 1 & & & & & 181 \\
\hline Foto & Ocio-cultura & Cine & Backstage & Sí, Otelo era negro & 1 & Orson Welles & $\mathrm{H}$ & Protagoniza & Director, actor & 182 \\
\hline
\end{tabular}




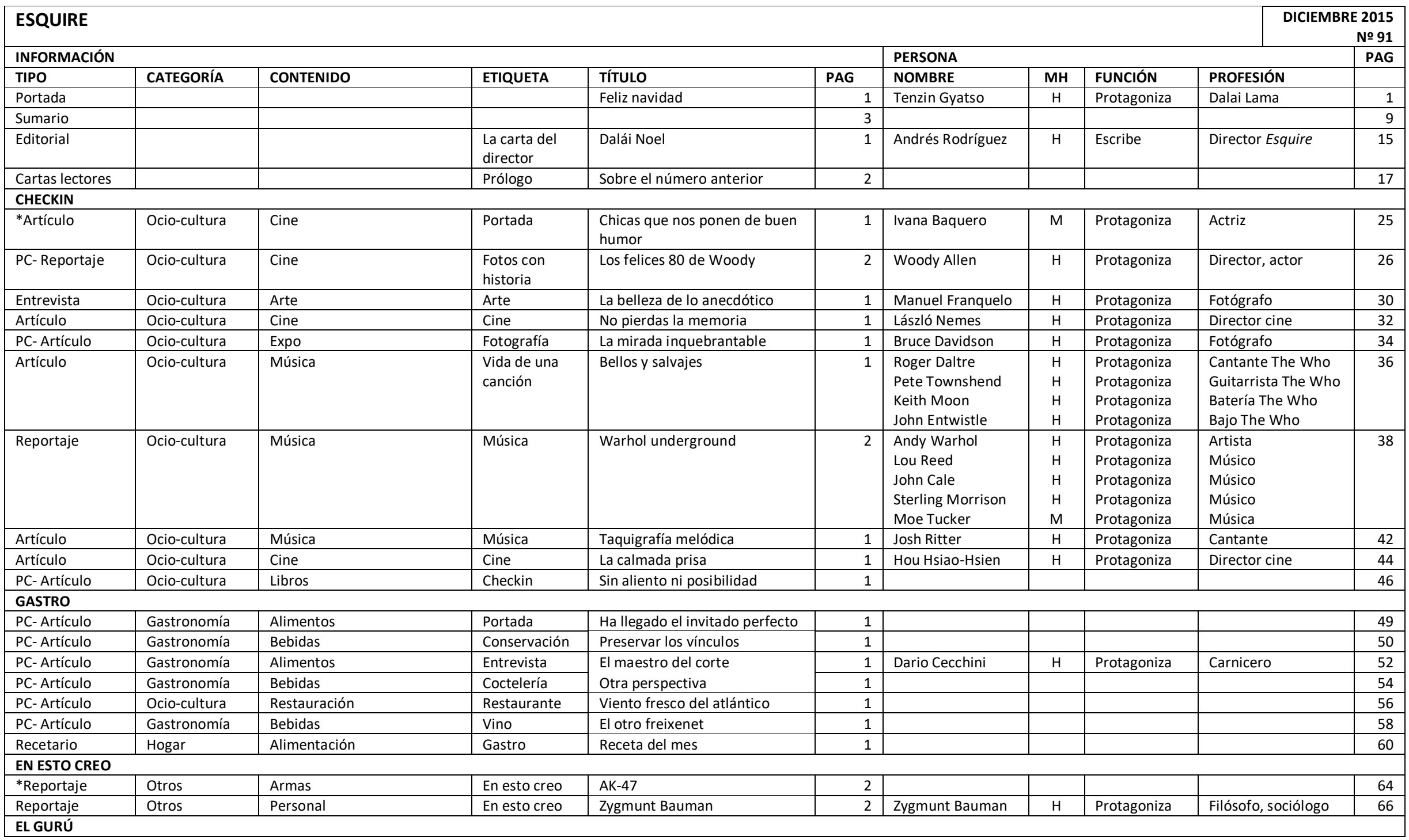




\begin{tabular}{|c|c|c|c|c|c|c|c|c|c|c|}
\hline PC- Reportaje & Moda & Ropa & Gurú & Noches de fiesta & 5 & & & & & 69 \\
\hline PC-Artículo & Moda & Ropa/ Accesorios & Gurú & Extra $10 \%$ & 1 & & & & & 77 \\
\hline PC- Fotos & Moda & Ropa/Accesorios & Gurú & Cocktail a las 8pm & 2 & & & & & 78 \\
\hline PC-Artículo & Moda & Accesorios & Gurú & \multirow{2}{*}{$\begin{array}{l}\text { Para toda la vida } \\
\text { Cómodo en su papel }\end{array}$} & 1 & & & & & 80 \\
\hline PC- Artículo & $\begin{array}{l}\text { Moda/ Ocio- } \\
\text { cultura }\end{array}$ & Look/ Cine & Club Esquire & & 1 & Joel Bosqued & $\mathrm{H}$ & Prota/ Posa & Actor & 81 \\
\hline PC-Artículo & Moda & Marca & Gurú & El frío debe esperar & 1 & & & & & 82 \\
\hline PC-Artículo & Moda & Accesorios & Gurú & Bienvenido al lado oscuro & 1 & & & & & 83 \\
\hline PC- FR & Moda & Looks & Estilo Esquire & The light vision & 6 & & & & & 84 \\
\hline PC- Artículo & Moda & Accesorios & Gurú & Compra con cabeza & 1 & & & & & 90 \\
\hline PC-Artículo & Moda & Marca & Gurú & Bajos fondos & 1 & & & & & 91 \\
\hline PC- Reportaje & Moda & Marca & Gurú & \multirow{4}{*}{$\begin{array}{l}24 \text { horas con Idris Elba } \\
\text { Filosofía de la vida } \\
\text { Aquí se cura el tiempo } \\
\text { Love me }\end{array}$} & 2 & Idris Elba & $\mathrm{H}$ & Protagoniza & Actor & 93 \\
\hline PC- Reportaje & Moda & Marca & Gurú & & 2 & & & & & 94 \\
\hline PC- Reportaje & Moda & Accesorios & Gurú & & 2 & & & & & 97 \\
\hline PC- FR & Moda & Looks & Estilo Esquire & & 10 & & & & & 98 \\
\hline PC- Reportaje & Tecno & Motor & Gurú & Haz juego & 2 & & & & & 108 \\
\hline PC- Artículo & Ocio-cultura & Destino/Moda & Gurú & Tokio de la mano de Kim Jones & 1 & Kim Jones & $\mathrm{H}$ & Protagoniza & $\begin{array}{l}\text { Director creativo } \\
\text { Louis Vuitton }\end{array}$ & 110 \\
\hline PC- Artículo & Moda & Marca & Gurú & Vayamos por partes & 1 & & & & & 111 \\
\hline PC- Artículo & Moda & Marca & Gurú & Calor (de verdad) & 1 & & & & & 113 \\
\hline \multicolumn{11}{|l|}{ GROOMING } \\
\hline PC- Reportaje & Belleza & Cosméticos & & Las mil y una noches & 6 & & & & & 115 \\
\hline \multicolumn{11}{|l|}{ BUSINESS CLASS } \\
\hline Reportaje & Otros & Profesional & $\begin{array}{l}\text { Ejecutivo del } \\
\text { mes }\end{array}$ & Yancey Strickler & 2 & Yancey Strickler & $\mathrm{H}$ & Protagoniza & $\begin{array}{l}\text { Fundador } \\
\text { Kickstarter }\end{array}$ & 122 \\
\hline Reportaje & Sociedad & Política & $\begin{array}{l}\text { Otros } \\
\text { negocios }\end{array}$ & Locos por el poder & 3 & & & & & 124 \\
\hline Artículo & Otros & Profesional & $\begin{array}{l}\text { Otros } \\
\text { negocios }\end{array}$ & En el buen camino & 1 & $\begin{array}{l}\text { Juan García } \\
\text { Escudero }\end{array}$ & $\mathrm{H}$ & Protagoniza & $\begin{array}{l}\text { Director general } \\
\text { creativo Leo Burnett }\end{array}$ & 127 \\
\hline Artículo & $\begin{array}{l}\text { Ocio-cultura/ } \\
\text { Tecno }\end{array}$ & Arte & $\begin{array}{l}\text { Otros } \\
\text { negocios }\end{array}$ & Popularizar el arte & 1 & Sebastian Cwilich & $\mathrm{H}$ & Protagoniza & $\begin{array}{l}\text { Presidente y } \\
\text { cofundador Artsy }\end{array}$ & 129 \\
\hline Reportaje & Sociedad & Política + personal & En esto creo & Dálai Lama & 6 & Tenzin Gyatso & $\mathrm{H}$ & Protagoniza & Dalai Lama & 130 \\
\hline PC- FR & $\begin{array}{l}\text { Belleza/ Tecno/ } \\
\text { Gastronomía/ } \\
\text { Moda }\end{array}$ & $\begin{array}{l}\text { Cosméticos/ Motor/ } \\
\text { Bebidas/ Accesorios/ } \\
\text { Gadgets }\end{array}$ & E10 & Obsesiones & 10 & & & & & 136 \\
\hline Reportaje & Ocio-cultura & Arte + personal & & $\begin{array}{l}\text { Vida y milagros del pintor } \\
\text { español más combativo }\end{array}$ & 6 & Juan Genovés & $\mathrm{H}$ & Protagoniza & $\begin{array}{l}\text { Pintor y artista } \\
\text { gráfico }\end{array}$ & 146 \\
\hline $\begin{array}{l}\text { *PC- Reportaje, } \\
\text { entrevista }\end{array}$ & Ocio-cultura & Música + personal & & McCartney & 14 & Paul McCartney & $\mathrm{H}$ & Prota/ Posa & Músico & 156 \\
\hline
\end{tabular}




\begin{tabular}{|c|c|c|c|c|c|c|c|c|c|c|}
\hline FR & Ocio-cultura & Arte & $\begin{array}{l}\text { Esquire } \\
\text { presenta }\end{array}$ & Las mil caras del poder & 12 & Alejandro Almaraz & $\mathrm{H}$ & Protagoniza & Fotógrafo & 166 \\
\hline Reportaje & Ocio-cultura & Profesional & & Asaltar los cielos & 4 & Philippe Petit & $\mathrm{H}$ & Protagoniza & Funambulista & 181 \\
\hline *Reportaje & Ocio-cultura & Series + personal & & $\begin{array}{l}\text { El maravilloso equilibrio de } \\
\text { Emilia Clarke }\end{array}$ & 7 & Emilia Clarke & $M$ & Protagoniza & Actriz & 182 \\
\hline \multicolumn{11}{|l|}{ ESTILO } \\
\hline PC-FR & Moda & Looks & Estilo Esquire & Era medianoche & 14 & & & & & 190 \\
\hline \multicolumn{11}{|l|}{ CHECKOUT } \\
\hline PC- Artículo & Tecno & Gadgets & Portada & Esto ya es otra historia & 1 & & & & & 205 \\
\hline PC- Reportaje & Ocio-cultura & Expo & Viajes & La ciudad abrumadora & 2 & & & & & 206 \\
\hline PC-Artículo & Tecno & Motor & Motor & Imaginando formas & 1 & & & & & 208 \\
\hline *PC- Artículo & Tecno & Gadget/ Navaja & Gadgets & Siéntete capaz de todo & 1 & & & & & 209 \\
\hline PC- Artículo & Deporte & Equipación deportiva & Deportes & Pisa sobre seguro & 1 & & & & & 211 \\
\hline PC-Artículo & Ocio-cultura & Libros & Diseño & Objetos de deseo & 2 & & & & & 212 \\
\hline PC- Reportaje & Tecno & Motor & $\begin{array}{l}\text { El coche del } \\
\text { mes }\end{array}$ & Domingos de traje & 2 & & & & & 214 \\
\hline Foto & Ocio-cultura & Arte & In memoriam & Michael C. Gross & 1 & Michael C.Gross & $\mathrm{H}$ & Protagoniza & Diseñador gráfico & 216 \\
\hline PC- Artículo & Ocio-cultura & Destinos/Restauración & Tarjetero & Varios & 1 & & & & & 217 \\
\hline Foto & Ocio-cultura & Cine & Backstage & El amigo budista & 1 & Richard Gere & $\mathrm{H}$ & Protagoniza & Actor & 218 \\
\hline
\end{tabular}




\begin{tabular}{|c|c|c|c|c|c|c|c|c|c|c|}
\hline \multirow{2}{*}{\multicolumn{6}{|c|}{ INFORMACIÓN }} & \multirow{2}{*}{\multicolumn{4}{|c|}{ PROTAGONISTA }} & $\begin{array}{r}\text { MARZO } 2015 \\
\text { № } 216\end{array}$ \\
\hline & & & & & & & & & & PAG \\
\hline TIPO & CATEGORÍA & CONTENIDO & ETIQUETA & TÍTULO & PAG & NOMBRE & MH & FUNCIÓN & PROFESIÓN & \\
\hline Portada & & Avance interior & & $\begin{array}{l}\text { Naomi Campbell. La top model } \\
\text { infinita }\end{array}$ & 1 & Naomi Campbell & $\mathrm{M}$ & Protagoniza & Modelo & 1 \\
\hline Sumario & & & Contenido & & 3 & & & & & 7 \\
\hline Datos de revista & & & Staff & & 1 & & & & & 12 \\
\hline Editorial & & & Editorial & El tiempo a solas & 1 & Miguel Bañón & $\mathrm{H}$ & Escribe & Director $D T$ & 14 \\
\hline \multicolumn{11}{|c|}{ SELECTED. NO BUSQUES MÁS. LO QUE TE INTERSA ESTÁ AQUÍ } \\
\hline *Artículo & Ocio-cultura & Serie/ Profesión & Portada & ¿Qué más sabes hacer? & 2 & Emmy Rossum & $\mathrm{M}$ & Protagoniza & Actriz & 16 \\
\hline PC- Artículo & $\begin{array}{l}\text { Tecno/Moda/ } \\
\text { Belleza }\end{array}$ & $\begin{array}{l}\text { Gadgets/Cosméticos/ } \\
\text { Ropa/ Accesorios }\end{array}$ & Lo último & Tres & 1 & & & & & 18 \\
\hline Entrevista & Ocio-cultura & Cine/ Profesión & Cine & Benidorm, año 2052 & 1 & Ion de Sosa & $\mathrm{H}$ & Protagoniza & Director cine & 20 \\
\hline PC- Reportaje & Ocio-cultura & Destino & Metrópolis & Ciudad de las puertas abiertas & 2 & & & & & 22 \\
\hline PC-Artículo & Gastronomía & Bebidas & La bodega & Mide tu temperatura & 1 & & & & & 24 \\
\hline PC- Entrevista & Ocio-cultura & Música/ Profesión & Lanzamiento & El nuevo rock echa el ancla & 2 & Gonçal Planas & $\mathrm{H}$ & Protagoniza & Cantante & 26 \\
\hline PC- Artículo & Moda & Looks & Toma nota & Una colección con swing & 1 & $\begin{array}{l}\text { Stella Mylläry } \\
\text { Laurent Bourgeois } \\
\text { Larry Bourgeois } \\
\end{array}$ & $\begin{array}{l}\mathrm{M} \\
\mathrm{H} \\
\mathrm{H}\end{array}$ & $\begin{array}{l}\text { Prota/ Posa } \\
\text { Prota/ Posa } \\
\text { Prota/ Posa }\end{array}$ & $\begin{array}{l}\text { Modelo } \\
\text { Bailarín } \\
\text { Bailarín } \\
\end{array}$ & 28 \\
\hline *Entrevista & Ocio-cultura & Cine/ Profesión & Protagonista & Yo, humano & 2 & Domhnall Gleeson & $\mathrm{H}$ & Protagoniza & Actor & 30 \\
\hline PC- Artículo & Moda & Ropa & Must have & Estrecha los límites & 1 & & & & & 32 \\
\hline PC-Artículo & Moda & Ropa & & Zapatos con ADN propio & 1 & & & & & 33 \\
\hline Entrevista & Ocio-cultura & $\begin{array}{l}\text { Música/ Profesión + } \\
\text { personal }\end{array}$ & Protagonista & Sin miedos, sin complejos & 2 & Anni B Sweet & $\mathrm{M}$ & Protagoniza & Cantante & 34 \\
\hline PC- Reportaje & Belleza & Cosméticos & Fragancias & Oler con mucho carácter & 4 & & & & & 36 \\
\hline PC-Artículo & Tecno & Motor & Motor & Historias del capó & 1 & & & & & 40 \\
\hline PC-Artículo & Otros & Profesión & & Sabios consejos & 1 & Euprepio Padula & $\mathrm{H}$ & Prota/ Posa & Coach & 41 \\
\hline PC-Artículo & Ocio-cultura & Expo & Arte & $\begin{array}{l}\text { El hilo reclama su lugar en el } \\
\text { arte }\end{array}$ & 2 & & & & & 42 \\
\hline PC-Artículo & Moda & Ropa/ Looks & Paso a paso & Primavera británica & 2 & & & & & 44 \\
\hline *Reportaje & Moda & Profesión + personal & Apuesta DT & Naomi Campbell. El futuro era & 10 & & & & & 50 \\
\hline Reportaje & Ocio-cultura & Cine/ Profesión & En cartelera & $\begin{array}{l}\text { John Corbett. El triunfo de un } \\
\text { buen tipo }\end{array}$ & 6 & John Corbett & $\mathrm{H}$ & Protagoniza & Actor & 56 \\
\hline Entrevista & Ocio-cultura & Arte/ Expo & Porfolio & $\begin{array}{l}\text { Chema Madoz. El 'pequeño } \\
\text { mundo de un genio' }\end{array}$ & 8 & Chema Madoz & $\mathrm{H}$ & Protagoniza & Artista & 64 \\
\hline PC- Reportaje & Tecno & Apps & Reportaje & $\begin{array}{l}\text { Manifiesto para adictos a e- } \\
\text { datting }\end{array}$ & 4 & & & & & 70 \\
\hline PC- Reportaje & Ocio-cultura & Televisión & Televisión & Cuando la risa llegó a televisión & 4 & & & & & 74 \\
\hline
\end{tabular}




\begin{tabular}{|c|c|c|c|c|c|c|c|c|c|c|}
\hline PC- Reportaje & Otros & & A fondo & $\begin{array}{l}\text { Y tú, ¿qué clase de trabajador } \\
\text { eres? }\end{array}$ & 2 & & & & & 78 \\
\hline Reportaje & Ocio-cultura & Fotografía & Porfolio & La forma en que ellos miran & 8 & $\begin{array}{l}\text { Evangelia Kranioti } \\
\text { Polly Tootal } \\
\text { Sushant Chhabria } \\
\text { Wawrzyniec } \\
\text { Kolbusz } \\
\text { David Magnusson } \\
\text { Oezden Yorulmaz } \\
\text { Thomas Rousset } \\
\text { Filippo Patrese } \\
\text { Sjoerd Knibbeler } \\
\text { Jeannie Abert }\end{array}$ & $\begin{array}{l}\mathrm{M} \\
\mathrm{M} \\
\mathrm{M} \\
\mathrm{H} \\
\mathrm{H} \\
\mathrm{H} \\
\mathrm{H} \\
\mathrm{H} \\
\mathrm{H} \\
\mathrm{M}\end{array}$ & $\begin{array}{l}\text { Protagoniza } \\
\text { Protagoniza } \\
\text { Protagoniza } \\
\text { Protagoniza } \\
\text { Protagoniza } \\
\text { Protagoniza } \\
\text { Protagoniza } \\
\text { Protagoniza } \\
\text { Protagoniza } \\
\text { Protagoniza }\end{array}$ & $\begin{array}{l}\text { Fotógrafa } \\
\text { Fotógrafa } \\
\text { Fotógrafa } \\
\text { Fotógrafo } \\
\\
\text { Fotógrafo } \\
\text { Fotógrafo } \\
\text { Fotógrafo } \\
\text { Fotógrafo } \\
\text { Fotógrafo } \\
\text { Fotógrafa }\end{array}$ & 80 \\
\hline Reportaje & Ocio-cultura & Deportes/Profesión & Deportes & $\begin{array}{l}\text { Wonder Kids. Las nuevas } \\
\text { estrellas del fútbol mundial }\end{array}$ & 6 & $\begin{array}{l}\text { Martin Odegaard } \\
\text { Munir El-Haddadi } \\
\text { José Luis Gayá } \\
\text { Hachim Mastour } \\
\text { Alen Halilovic } \\
\text { Marco Asensio } \\
\text { Ángel Correa } \\
\text { Rubén Neves }\end{array}$ & $\begin{array}{l}\mathrm{H} \\
\mathrm{H} \\
\mathrm{H} \\
\mathrm{H} \\
\mathrm{H} \\
\mathrm{H} \\
\mathrm{H} \\
\mathrm{H}\end{array}$ & $\begin{array}{l}\text { Protagoniza } \\
\text { Protagoniza } \\
\text { Protagoniza } \\
\text { Protagoniza } \\
\text { Protagoniza } \\
\text { Protagoniza } \\
\text { Protagoniza } \\
\text { Protagoniza }\end{array}$ & $\begin{array}{l}\text { Futbolista } \\
\text { Futbolista } \\
\text { Futbolista } \\
\text { Futbolista } \\
\text { Futbolista } \\
\text { Futbolista } \\
\text { Futbolista } \\
\text { Futbolista }\end{array}$ & 88 \\
\hline *Reportaje & Moda & Profesión & Chica DT & En la cima & 6 & Izabel Goulart & $\mathrm{M}$ & Protagoniza & Modelo & 94 \\
\hline \multicolumn{11}{|c|}{ ESTILO. MANUAL PARA EL HOMBRE PLATINUM } \\
\hline PC- Artículo & Moda & Ropa & Portada & Seguridad y comodidad & 1 & & & & & 101 \\
\hline Entrevista & Moda & Profesión & Nombres propios & Renovarse y vivir & 2 & Giancarlo Petriglia & $\mathrm{H}$ & Protagoniza & Diseñador de moda & 102 \\
\hline PC- FR & Moda & Looks & Tendencias & La crème de la crème & 26 & & & & & 104 \\
\hline Reportaje & Moda & Profesión & Nombres propios & Líder de elegancia & 2 & Eraldo Polleto & $\mathrm{H}$ & Protagoniza & Director ejecutivo Furla & 130 \\
\hline PC- Fotos & Moda & Ropa/ Accesorios & Detalles & El toque decisivo & 6 & & & & & 132 \\
\hline PC- Entrevista & Moda & Profesión & Nombres propios & Nada literal & 2 & Stéphane Crèmieux & $\mathrm{H}$ & Protagoniza & $\begin{array}{l}\text { Director ejecutivo } \\
\text { Crèmieux }\end{array}$ & 138 \\
\hline PC- Fotos & Moda & Accesorios & Relojes & Piezas elegidas & 8 & & & & & 140 \\
\hline PC- Reportaje & Moda & $\begin{array}{l}\text { Accesorios/Ropa/ } \\
\text { Looks }\end{array}$ & Novedades & 25 imprescindibles & 5 & & & & & 148 \\
\hline \multicolumn{11}{|c|}{ DT ON. LA VIDA ES MUY CORTA PARA ESTAR APAGADO } \\
\hline PC-Artículo & Tecno & Motor & Portada & Hija del capricho & 1 & & & & & 155 \\
\hline PC- FR & Tecno & Motor & Motor & Bólidos de pasarela & 8 & & & & & 156 \\
\hline PC- Reportaje & Ocio-cultura & Destino & Viajes & La gran pasión & 4 & & & & & 164 \\
\hline PC- FR & Tecno & Gadgets & High tech & Sube de nivel & 8 & & & & & 168 \\
\hline PC-Artículo & Ocio-cultura & $\begin{array}{l}\text { Destinos/ } \\
\text { Restauración }\end{array}$ & Direcciones & El mundo a tus pies y a tu gusto & 4 & & & & & 176 \\
\hline PC- Artículo & Belleza & Culto al cuerpo & Wellness & En forma y mejor & 1 & & & & & 180 \\
\hline
\end{tabular}




\begin{tabular}{|l|l|l|l|l|c|c|c|c|c|}
\hline PC- Reportaje & Ocio-cultura & $\begin{array}{l}\text { Series/ Expo/ } \\
\text { Videojuegos/ Teatro/ } \\
\text { Música/ Cine }\end{array}$ & Citas & Toca salir de las trincheras & 12 & 182 & & & \\
\hline Entrevista & Ocio-cultura & Música + personal & $\begin{array}{l}\text { En primera } \\
\text { persona }\end{array}$ & Mikel Erentxun & 1 & Mikel Erentxun & H Protagoniza & Cantante \\
\hline
\end{tabular}




\section{DT}

\begin{tabular}{|l}
\hline INFORMACIÓN \\
\hline TIPO
\end{tabular}

\begin{tabular}{|l|l|l|}
\hline TIPO & CATEGORÍA & CONTENIDO \\
\hline Portada & & Avance interior \\
\hline *Sumario & & \\
\hline Datos revista & & \\
\hline Editorial & &
\end{tabular}

SELECTED. NO BUSQUES MÁS. LO QUE TE INTERESA ESTÁ AQU

\begin{tabular}{|l|l|l|}
\hline *Reportaje & Ocio-cultura & Cine \\
\hline PC- Artículo & Belleza/Moda & Cosméticos/Ropa/ \\
\hline
\end{tabular}

\begin{tabular}{|l|l|l|}
\hline PC- Artículo & Belleza/ Moda & $\begin{array}{l}\text { Cosméticos/Ropa/ } \\
\text { Accesorios }\end{array}$ \\
\hline PC- Reportaje & Ocio-cultura/ & Destinos/ Restauración \\
\hline
\end{tabular}

\begin{tabular}{|l|l|l|}
\hline PC- Reportaje & $\begin{array}{l}\text { Ocio-cultura/ } \\
\text { Gastronomía }\end{array}$ & Destinos/ Restauración \\
\hline PC-Artículo & Tecno & Motor \\
\hline Entrevista & Oc & Mearo \\
\hline
\end{tabular}

\begin{tabular}{|l|l|l|}
\hline Entrevista & Ocio-cultura & Teatro \\
\hline PC-Artículo & Tecno & Motor \\
\hline PC-Articlo & Teno & Motor
\end{tabular}

\begin{tabular}{|l|l|l|}
\hline PC-Artículo & Tecno & Motor \\
\hline PC- Artículo & Gastronomía/ & Bebidas/ Fotografía
\end{tabular}

\begin{tabular}{|l|l|l|} 
& Ocio-cultura & \\
\hline PC- Entrevista & $\begin{array}{l}\text { Ocio-cultura/ } \\
\text { Belleza }\end{array}$ & $\begin{array}{l}\text { Cine + personal/ } \\
\text { Cosméticos }\end{array}$ \\
\hline & Ocio-cultura & Festival \\
\hline
\end{tabular}

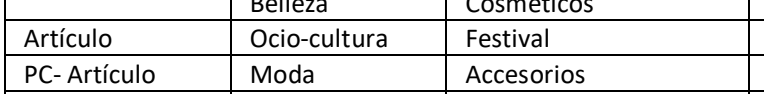

\begin{tabular}{l|l|l}
\hline PC- Artículo & Moda & Looks
\end{tabular}

\begin{tabular}{l|l}
\hline Looks & \\
\hline Lotal looks
\end{tabular}

\begin{tabular}{|l|l} 
Portada & Con derecho a roce \\
\hline $4 \times 4$ & Unos/ Tres/Cuatro
\end{tabular}

Metrópolis

Competición

Muchas tablas

Superdeportivos

Actitud refrescante

\begin{tabular}{l|l} 
ADN de actor & El hombre sin miedo a nada
\end{tabular}

Música

(

Reunión de elegancia

\begin{tabular}{|l|l}
\hline Los Andes a tus pies & 2 \\
\hline
\end{tabular}

El sueño de ser actor ya es real

Liberad a la bestia

\begin{tabular}{l|l} 
Reunión de elegancia & 1
\end{tabular}

\begin{tabular}{|l|l|l|}
\hline *PC- Artículo & Belleza & Cosmética \\
\hline PC- & \\
\hline
\end{tabular}

PC-Artículo

Moda

PC-Artículo

Tecno

PC-Artículo

Gastronomía

PC-Artículo

Moda

Gastronomí

\begin{tabular}{|l|l}
\hline Motor + personal & \\
\hline Bebidas & Ropa \\
\hline Almast Bebidas & GC
\end{tabular}

Bañadores

Mar y asfalto

Como la seda

Arena en los bolsillos

PC-Artículo

Alimentos/Bebidas

Cócteles

Fernando Salvador. Vida al

volante

\begin{tabular}{l|l} 
Cocteles & Holanda con dos hielos
\end{tabular}

Reinventarse o morir

Gourmet

Comer es un placer

\section{PROTAGONISTA}

NOMBRE

Emma Stern

4

\begin{tabular}{|l|r|l|l|l|} 
& & & & 10 \\
\hline Miguel Bañón & $\mathrm{H}$ & Escribe & Director DT & 12 \\
\hline
\end{tabular}

JUNIO 2015 №

219

\begin{tabular}{|c|c|c|c|}
\hline $\mathrm{MH}$ & FUNCIÓN & PROFESIÓN & PAG \\
\hline \multirow[t]{3}{*}{$M$} & Protagoniza & Modelo & 1 \\
\hline & & & 3 \\
\hline & & & 10 \\
\hline $\mathrm{H}$ & Escribe & Director DT & 12 \\
\hline
\end{tabular}

\begin{tabular}{|c|c|c|c|c|}
\hline \multirow[t]{2}{*}{ Julianna Florrick } & $\mathrm{M}$ & Protagoniza & Actriz & 14 \\
\hline & & & & 16 \\
\hline & & & & 18 \\
\hline & & & & 20 \\
\hline \multirow[t]{3}{*}{ Adrián Lastra } & $\mathrm{H}$ & Protagoniza & Actor & 22 \\
\hline & & & & 23 \\
\hline & & & & 24 \\
\hline Mario Testino & $\mathrm{H}$ & Protagoniza & Fotógrafo & 25 \\
\hline Scott Eastwood & $\mathrm{H}$ & Protagoniza & Actor & 26 \\
\hline \multirow{2}{*}{ James Buell } & $\mathrm{H}$ & Protagoniza & Director Hard Rock & 28 \\
\hline & & & & 29 \\
\hline Can Direkli & $\mathrm{H}$ & Protagoniza & Blogger & 30 \\
\hline Alberto Ortiz Rey & $\mathrm{H}$ & Protagoniza & Blogger & \\
\hline Nas Abraham & H & Protagoniza & Blogger & \\
\hline Joris Van Velzen & $\mathrm{H}$ & Protagoniza & Blogger & \\
\hline $\begin{array}{l}\text { Yoeru Khryrian } \\
\text { Jonker }\end{array}$ & $\mathrm{H}$ & Protagoniza & Blogger & \\
\hline Maga Umhaev & $\mathrm{H}$ & Protagoniza & Blogger & \\
\hline Ricky Thomason & $\mathrm{H}$ & Protagoniza & Blogger & \\
\hline \multirow[t]{4}{*}{ Federico Rodriguez } & $\mathrm{H}$ & Protagoniza & Blogger & \\
\hline & & & & 30 \\
\hline & & & & 32 \\
\hline & & & & 34 \\
\hline Fernando Salvador & $\mathrm{H}$ & Protagoniza & $\begin{array}{l}\text { Director } \\
\text { comunicación SEAT }\end{array}$ & 35 \\
\hline & & & & 36 \\
\hline & & & & 37 \\
\hline & & & & 38 \\
\hline
\end{tabular}




\begin{tabular}{|c|c|c|c|c|c|c|c|c|c|c|}
\hline *Artículo & Ocio-cultura & Cine & & María Valverde. Sin límites & 1 & & & & & 39 \\
\hline PC- Artículo & Gastronomía & Bebidas & Evento DT & Entre amigos & 1 & & & & & 40 \\
\hline PC-Artículo & Tecno & Motor & & La conquista de la ciudad & 1 & & & & & 41 \\
\hline Reportaje & Ocio-cultura & Deporte & Hoyo en uno & Un golpe perfecto & 2 & Michelle Wie & $\mathrm{M}$ & Protagoniza & Golfista & 43 \\
\hline PC- Reportaje & ración & Exposición & Diseño & Arte $y$ estilo & 4 & & & & & 44 \\
\hline *Reportaje & Moda & Marca & Chica DT & Ángel o demonio & 6 & $\begin{array}{l}\text { Eva Doll } \\
\text { Emma Stern } \\
\text { Nielsen }\end{array}$ & $\begin{array}{l}M \\
M\end{array}$ & $\begin{array}{l}\text { Protagoniza } \\
\text { Protagoniza }\end{array}$ & $\begin{array}{l}\text { Modelo } \\
\text { Modelo }\end{array}$ & 49 \\
\hline Entrevista & Ocio-cultura & Cine & Protagonista & $\begin{array}{l}\text { Chris Pratt. La teoría de la } \\
\text { evolución }\end{array}$ & 6 & Chris Pratt & $\mathrm{H}$ & Protagoniza & Actor & 55 \\
\hline PC- Reportaje & Ocio-cultura & Arte & Arquitectura & Genio y figura & 4 & Le Corbusier & $\mathrm{H}$ & Protagoniza & Arquitecto & 60 \\
\hline PC- Reportaje & Ocio-cultura & Deporte & Reportaje & Llega la hora del verde & 2 & & & & & 64 \\
\hline Reportaje & Sociedad & Religión & Reportaje & $\begin{array}{l}\text { Confesiones de sacristía. Cómo } \\
\text { responder ante Dios. }\end{array}$ & 6 & $\begin{array}{l}\text { Plácido } \\
\text { Álex }\end{array}$ & $\begin{array}{l}\mathrm{H} \\
\mathrm{H} \\
\end{array}$ & $\begin{array}{l}\text { Protagoniza } \\
\text { Protagoniza }\end{array}$ & $\begin{array}{l}\text { Sacerdote } \\
\text { Seminarista }\end{array}$ & 66 \\
\hline Reportaje & Ocio-cultura & Música & Dossier & La otra movida & 2 & & & & & 72 \\
\hline Entrevista & Ocio-cultura & Música & Dossier & Están locos... ¿̇y qué? & 2 & $\begin{array}{l}\text { David Summers } \\
\text { Rafa Gutiérrez } \\
\text { Dani Mezquita } \\
\text { Javi Molina } \\
\end{array}$ & $\begin{array}{l}\mathrm{H} \\
\mathrm{H} \\
\mathrm{H} \\
\mathrm{H} \\
\end{array}$ & $\begin{array}{l}\text { Protagoniza } \\
\text { Protagoniza } \\
\text { Protagoniza } \\
\text { Protagoniza } \\
\end{array}$ & $\begin{array}{l}\text { Músico Hombres G } \\
\text { Músico Hombres G } \\
\text { Músico Hombres G } \\
\text { Músico Hombres G }\end{array}$ & 74 \\
\hline Entrevista & Ocio-cultura & Música & Dossier & Inmunes a las modas & 2 & $\begin{array}{l}\text { Álvaro Urquijo } \\
\text { Ramón Arroyo } \\
\text { Jesús Redondo } \\
\text { Juanjo Ramos } \\
\text { Santiago Fernández }\end{array}$ & $\begin{array}{l}\mathrm{H} \\
\mathrm{H} \\
\mathrm{H} \\
\mathrm{H} \\
\mathrm{H}\end{array}$ & $\begin{array}{l}\text { Protagoniza } \\
\text { Protagoniza } \\
\text { Protagoniza } \\
\text { Protagoniza } \\
\text { Protagoniza } \\
\end{array}$ & $\begin{array}{l}\text { Músico Los Secretos } \\
\text { Músico Los Secretos } \\
\text { Músico Los Secretos } \\
\text { Músico Los Secretos } \\
\text { Músico Los Secretos }\end{array}$ & 76 \\
\hline *Reportaje & Moda & Marca & Chica explosiva & $\begin{array}{l}\text { Sara Sampaio. La sonrisa } \\
\text { portuguesa }\end{array}$ & 6 & Sara Sampaio & M & Protagoniza & Modelo & 79 \\
\hline PC- Reportaje & Gastronomía & Restauración & Reportaje & A cuatro manos & 4 & $\begin{array}{l}\text { Dani García } \\
\text { Thomas Bühner } \\
\text { Pascal Barbot } \\
\text { Grant Achatz }\end{array}$ & $\begin{array}{l}\mathrm{H} \\
\mathrm{H} \\
\mathrm{H} \\
\mathrm{H}\end{array}$ & $\begin{array}{l}\text { Protagoniza } \\
\text { Protagoniza } \\
\text { Protagoniza } \\
\text { Protagoniza }\end{array}$ & $\begin{array}{l}\text { Chef } \\
\text { Chef } \\
\text { Chef } \\
\text { Chef }\end{array}$ & 84 \\
\hline PC- Reportaje & Ocio-cultura & Destinos & Fútbol & Del campo a la playa & 4 & & & & & 88 \\
\hline \multicolumn{11}{|c|}{ ESTILO. MANUAL PARA EL HOMBRE PERFECTO } \\
\hline Portada & & Avance interior & Portada & El triunfo de la alegría & 1 & & & & & 93 \\
\hline PC- FR & Moda & Looks & Tendencias & Mirando al horizonte & 12 & & & & & 94 \\
\hline PC- Fotos & Moda & Accesorios & Relojes & En el preciso momento & 4 & & & & & 106 \\
\hline PC-Artículo & Moda & Looks & Moda urbana & Escuadra y cartabón & 1 & & & & & 110 \\
\hline PC-Artículo & Moda & Ropa & & Más confort en verano & 1 & & & & & 111 \\
\hline PC- Entrevista & Moda & Marca & Innovación & Ecología y moda & 1 & Shubhankar Ray & $\mathrm{H}$ & Protagoniza & Director G-Star & 112 \\
\hline PC-Artículo & Moda & Marca & & Bienvenido cocodrilo & 1 & & & & & 113 \\
\hline \multicolumn{11}{|c|}{ DT ON. LA VIDA ES MUY CORTA PARA ESTAR APAGADO } \\
\hline PC-Artículo & Tecno & Gadgets & Portada & Licencia para fumar & 1 & & & & & 115 \\
\hline
\end{tabular}




\begin{tabular}{|c|c|c|c|c|c|c|c|c|c|c|}
\hline PC- Reportaje & Tecno & Motor & A pedales & $\begin{array}{l}\text { Las bicicletas eléctricas son } \\
\text { para el verano }\end{array}$ & 4 & & & & & 116 \\
\hline PC- Reportaje & Ocio-cultura & Destinos & Viajes & Alaska. La última frontera & 4 & & & & & 120 \\
\hline PC- Reportaje & Tecno & Gadgets & High tech & Al agua gadgets & 4 & & & & & 124 \\
\hline Entrevista & Ocio-cultura & Destinos & Triunfador & $\begin{array}{l}\text { Carlos Calero. A la conquista } \\
\text { del cinco estrellas }\end{array}$ & 2 & Carlos Calero & $\mathrm{H}$ & Protagoniza & $\begin{array}{l}\text { Director Vincci } \\
\text { Hoteles }\end{array}$ & 128 \\
\hline PC- Reportaje & $\begin{array}{l}\text { Ocio-cultura/ } \\
\text { Gastronomía }\end{array}$ & Destinos/Restauración & Direcciones & Un extra de energía & 4 & & & & & 130 \\
\hline PC-Artículo & Belleza & Cosméticos & Fragancias & Inspira y vuelve a inspirar & 1 & & & & & 134 \\
\hline \multicolumn{11}{|c|}{ MUST. OCIO URBANO PARA TIPOS MODERNOS } \\
\hline PC- Reportaje & $\begin{array}{l}\text { Ocio-cultura/ } \\
\text { Gastronomía }\end{array}$ & $\begin{array}{l}\text { Festivales/Expo/ } \\
\text { Bebidas/ Cine/ } \\
\text { Videojuegos/Serie }\end{array}$ & Citas & Elogio de la pereza & 10 & & & & & 140 \\
\hline PC- Entrevista & Ocio-cultura & Libros & En primera persona & Albert Monteys & 1 & Albert Monteys & $\mathrm{H}$ & Protagoniza & Dibujante & 146 \\
\hline
\end{tabular}




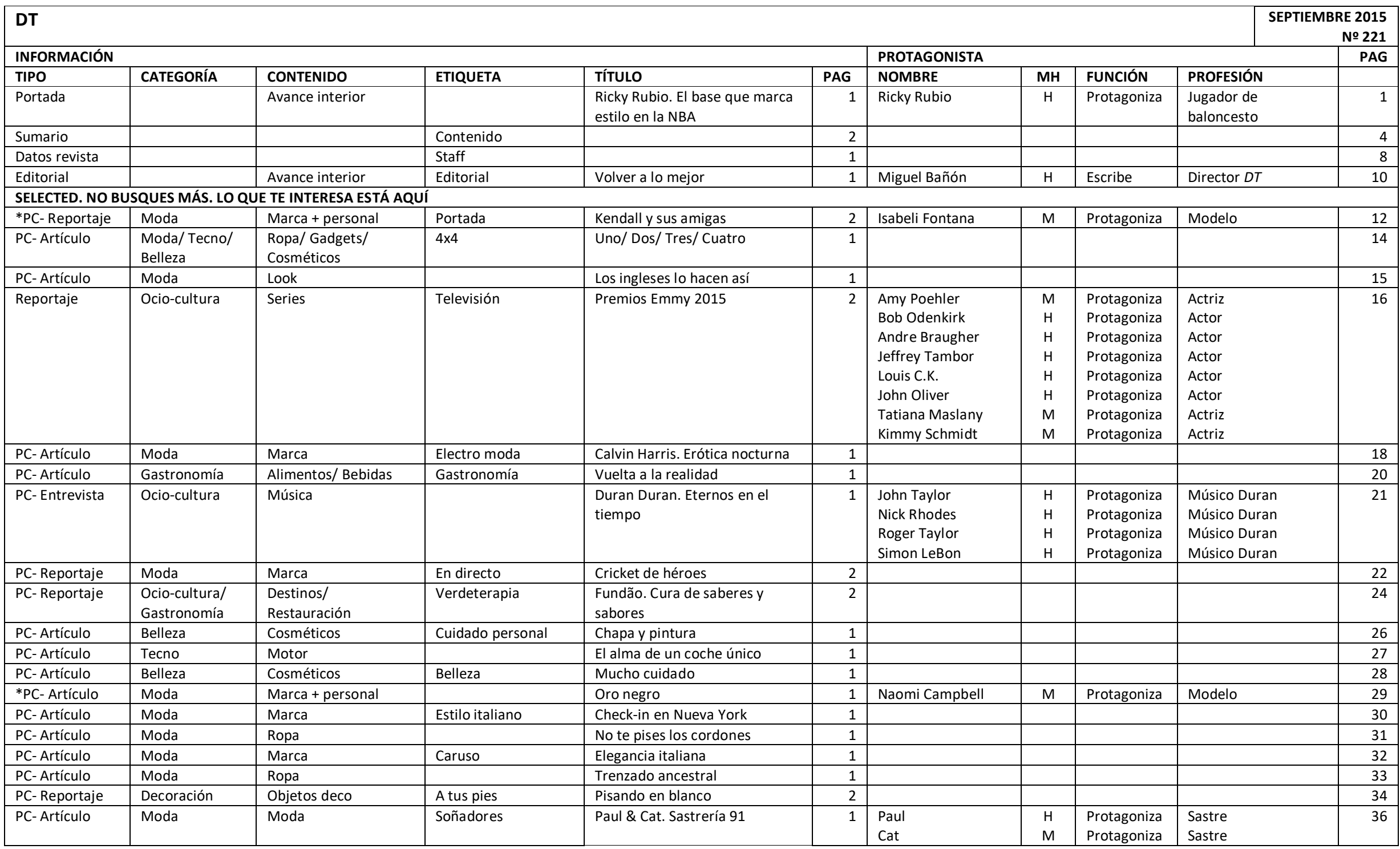




\begin{tabular}{|c|c|c|c|c|c|c|c|c|c|c|}
\hline PC-Artículo & Moda & Marca & & Avec plaisir & 1 & & & & & 37 \\
\hline Entrevista & Ocio-cultura & Cine + personal & Rey de la pantalla & Por fin, actitud y aptitud & 2 & Javi Rey & $\mathrm{H}$ & Protagoniza & Actor & 38 \\
\hline Entrevista & Otros & Profesional & Visionario & $\begin{array}{l}\text { Moray Maclennan. El poder de } \\
\text { la persuasión }\end{array}$ & 1 & Moray Maclennan & $\mathrm{H}$ & Protagoniza & CEO M\&C Saatchi & 40 \\
\hline PC-Artículo & Ocio-cultura & Festival & & Homenaje a la cultura pop & 1 & & & & & 41 \\
\hline PC- Reportaje & Tecno & Motor & Todocaminos & Para llegar muy lejos & 2 & & & & & 42 \\
\hline PC-Artículo & Moda & Marca & Botones & Un patrón muy añejo & 1 & & & & & 44 \\
\hline PC- Artículo & Gastronomía & Bebidas & & $\begin{array}{l}\text { La isla del tesoro. Ibiza se baña } \\
\text { en el lujo }\end{array}$ & 1 & & & & & 45 \\
\hline PC-Artículo & Tecno/Moda & Motor/Accesorios & Madrid tour & Moto por montera & 1 & Miguel Bañón & $\mathrm{H}$ & Protagoniza & Director DT & 46 \\
\hline PC- Artículo & Otros & Profesional & & $\begin{array}{l}\text { Jordi García Mercader. Polo } \\
\text { positivo }\end{array}$ & 1 & $\begin{array}{l}\text { Jordi García } \\
\text { Mercader }\end{array}$ & $\mathrm{H}$ & Protagoniza & $\begin{array}{l}\text { General Manager de } \\
\text { Vía Comunicación }\end{array}$ & 47 \\
\hline PC- Reportaje & Ocio-cultura & Destinos & Hotel paisaje & El lujo de la evasión & 2 & & & & & 48 \\
\hline PC-Artículo & Ocio-cultura & Expo & Cinco siglos de arte & Un arte de andar por casa & 1 & & & & & 50 \\
\hline PC- Entrevista & Moda & Marca & & Enzo Fusco. El líder de moda & 1 & Enzo Fusco & $\mathrm{H}$ & Protagoniza & Diseñador moda & 51 \\
\hline PC- Artículo & Gastronomía & Bebidas & Coctelero & $\begin{array}{l}\text { Javier García Vicuña. El arte se } \\
\text { sirve frío }\end{array}$ & 1 & Javier García Vicuña & $\mathrm{H}$ & Protagoniza & Mixólogo & 52 \\
\hline PC-Artículo & Moda & Marca & & Clásica bohème & 1 & & & & & 53 \\
\hline Reportaje & Ocio-cultura & Deporte & La roja & De Francia al Olimpo & 2 & & & & & 54 \\
\hline PC- Entrevista & Ocio-cultura & Deporte & Protagonista & Ricky Rubio. El base del éxito & 8 & Ricky Rubio & $\mathrm{H}$ & Prota/ Posa & Jugador baloncesto & 56 \\
\hline PC- Reportaje & $\begin{array}{l}\text { Ocio-cultura/ } \\
\text { Salud }\end{array}$ & Libros/Bienestar & Reportaje & Los beneficios de no pensar & 4 & & & & & 64 \\
\hline Entrevista & Tecno & Motor & Reportaje & $\begin{array}{l}\text { Andy Soucek. Un piloto con } \\
\text { estilo }\end{array}$ & 4 & Andy Soucek & $\mathrm{H}$ & Prota/ Posa & Piloto F1 & 68 \\
\hline PC- Reportaje & Ocio-cultura & Expo & Reportaje & Destilando creatividad & 4 & & & & & 72 \\
\hline *Reportaje & Moda/Belleza & $\begin{array}{l}\text { Moda/ Cosméticos + } \\
\text { personal }\end{array}$ & Chica DT & Candice Swanepoel & 6 & Candice Swanepoel & $M$ & Protagoniza & Modelo & 76 \\
\hline Entrevista & Salud & Deporte/ Nutrición & En forma & Puesta a punto & 8 & $\begin{array}{l}\text { Jose Ajram } \\
\text { Marcos Jassan } \\
\text { Chema Martínez } \\
\text { Leo Cerrudo } \\
\end{array}$ & $\begin{array}{l}\mathrm{H} \\
\mathrm{H} \\
\mathrm{H} \\
\mathrm{H}\end{array}$ & $\begin{array}{l}\text { Protagoniza } \\
\text { Protagoniza } \\
\text { Protagoniza } \\
\text { Protagoniza } \\
\end{array}$ & $\begin{array}{l}\text { Atleta } \\
\text { Maestro yoga } \\
\text { Atleta olímpico } \\
\text { Coach nutricional } \\
\end{array}$ & 82 \\
\hline PC- Reportaje & Gastronomía & Bebidas & La buena vida & Tiempo de vendimia & 4 & & & & & 90 \\
\hline $\begin{array}{l}\text { Reportaje + } \\
\text { entrevista }\end{array}$ & Ocio-cultura & Deportes & NBA Draft 2015 & $\begin{array}{l}\text { El Draft. Bienvenidos al gran } \\
\text { sueño americano }\end{array}$ & 4 & $\begin{array}{l}\text { Kristaps Porzingis } \\
\text { Robert Horry } \\
\text { Lorjelyn Baclig }\end{array}$ & $\begin{array}{l}\mathrm{H} \\
\mathrm{H} \\
\mathrm{M}\end{array}$ & $\begin{array}{l}\text { Protagoniza } \\
\text { Protagoniza } \\
\text { Protagoniza }\end{array}$ & $\begin{array}{l}\text { Jugador baloncesto } \\
\text { Jugador baloncesto } \\
\text { Estilista }\end{array}$ & 94 \\
\hline \multicolumn{11}{|c|}{ ESTILO. MANUAL PARA EL HOMBRE PERFECTO } \\
\hline Portada & & Avance interior & Portada & Ni blanco ni negro & 1 & & & & & 98 \\
\hline PC-FR & Moda & Looks & Tendencias & Estudiado & 8 & & & & & 100 \\
\hline PC- Reportaje & Moda & Accesorios & Complementos & Marsupialia & 4 & & & & & 108 \\
\hline PC-Artículo & Moda & Looks & Cúbrete & La playa de invierno & 1 & & & & & 112 \\
\hline
\end{tabular}




\begin{tabular}{|c|c|c|c|c|c|c|c|c|c|c|}
\hline PC- Entrevista & Moda & Marca & & $\begin{array}{l}\text { Ricardo Orlando. Calidad y } \\
\text { moda en la red }\end{array}$ & 1 & Ricardo Orlando & $\mathrm{H}$ & Protagoniza & $\begin{array}{l}\text { Director sur de } \\
\text { Europa Asos }\end{array}$ & 113 \\
\hline PC- Artículo & Moda & Accesorios & Sobre ruedas & Equipaje tatuado & 1 & & & & & 114 \\
\hline PC-Artículo & Moda & Marca & & Quién sabe dónde & 1 & & & & & 115 \\
\hline PC- Fotos & Moda & Ropa & Sudaderas & \multirow{2}{*}{$\begin{array}{l}\text { La saliva por la garganta... } \\
\text { De compras en el museo }\end{array}$} & 1 & & & & & 116 \\
\hline PC-Artículo & Moda & Marca & & & 1 & & & & & 117 \\
\hline \multicolumn{11}{|c|}{ DT ON. LA VIDA ES MUY CORTA PARA ESTAR APAGADO } \\
\hline PC-Artículo & Decoración & Objetos deco & Portada & El cofre del tesoro & 1 & & & & & 119 \\
\hline PC- Reportaje & Tecno & Motor & Abriendo gas & Diversión extrema & 4 & & & & & 120 \\
\hline PC- Reportaje & $\begin{array}{l}\text { Ocio-cultura/ } \\
\text { Gastronomía }\end{array}$ & $\begin{array}{l}\text { Destinos/ } \\
\text { Restauración }\end{array}$ & Viajes & Zanzíbar. La isla de las especias & 4 & & & & & 124 \\
\hline PC- Reportaje & Tecno & Gadgets & Salud 4.0 & Ponte en forma & 4 & & & & & 128 \\
\hline PC- Reportaje & Ocio-cultura & Destinos & Direcciones & Din don, última llamada & 4 & & & & & 132 \\
\hline PC-Artículo & Gastronomía & Restauración & Restaurantes & Amor por la comida & & & & & & 136 \\
\hline \multicolumn{11}{|c|}{ MUST. OCIO URBANO PARA TIPOS MODERNOS } \\
\hline PC- Reportaje & Ocio-cultura & $\begin{array}{l}\text { Festival/ Expo/ } \\
\text { Música/ Libros/ } \\
\text { Teatro/ Cine/ } \\
\text { Videojuegos }\end{array}$ & Citas & $\begin{array}{l}\text { Otoño entrante, citas } \\
\text { abundantes }\end{array}$ & 8 & & & & & 138 \\
\hline Entrevista & Ocio-cultura & Cine & En primera persona & Carles Francino & 1 & Carles Francino & $\mathrm{H}$ & Protagoniza & Actor & 146 \\
\hline
\end{tabular}




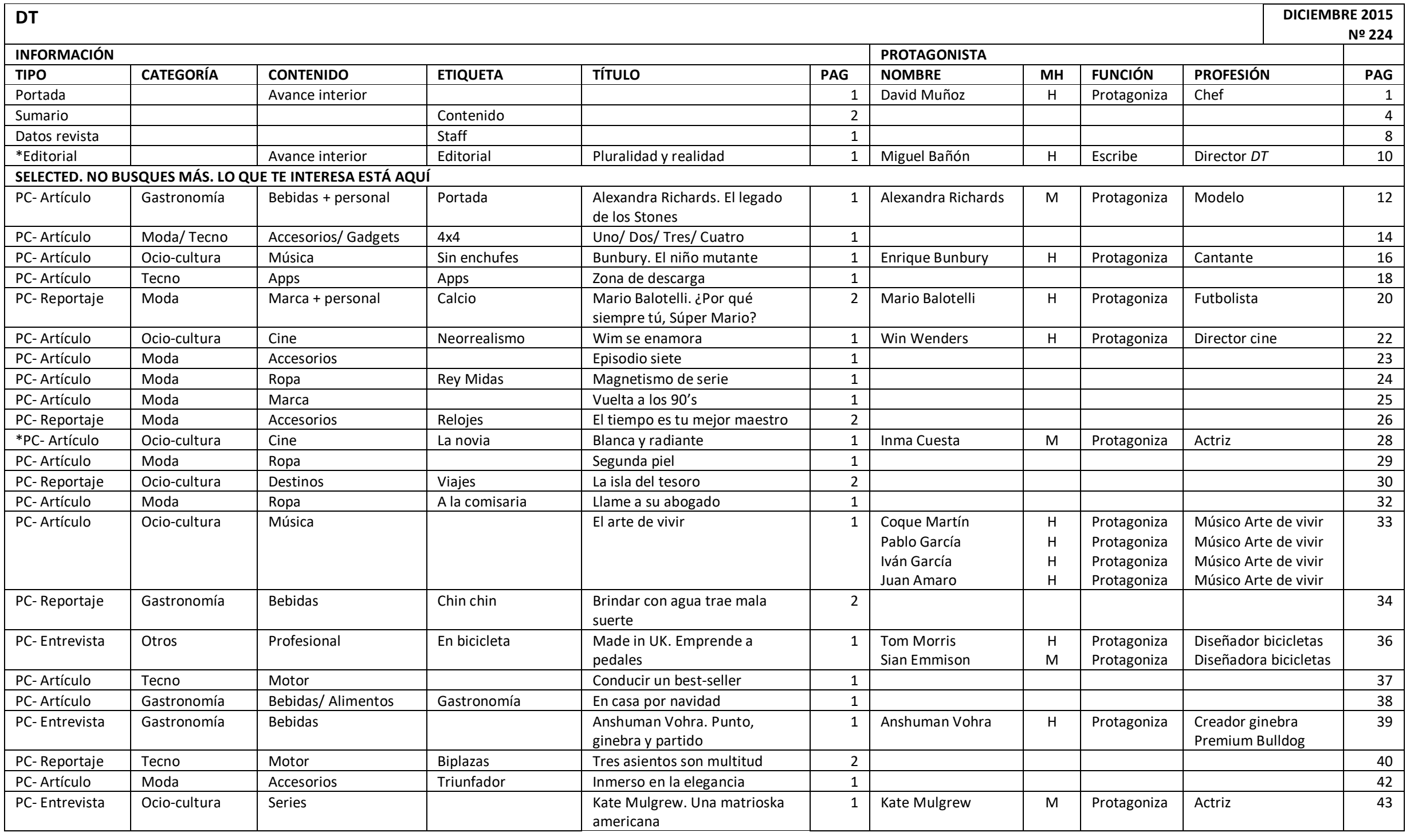




\begin{tabular}{|c|c|c|c|c|c|c|c|c|c|c|}
\hline PC-Entrevista & Tecno & Apps & Consejero & El guía de tu ciudad & 1 & Jeremy Stoppelman & $\mathrm{H}$ & Protagoniza & Director Yelp & 44 \\
\hline PC-Artículo & Moda & Marca & & Fiebre de cambios & 1 & $\begin{array}{l}\text { Antonio Hernández } \\
\text { Centeno } \\
\text { Blas Egea }\end{array}$ & $\begin{array}{l}\mathrm{H} \\
\mathrm{H}\end{array}$ & $\begin{array}{l}\text { Prota/ Posa } \\
\text { Prota/ Posa }\end{array}$ & $\begin{array}{l}\text { Guionista } \\
\text { Director audiovisual }\end{array}$ & 45 \\
\hline PC-Artículo & Moda & Moda & Convocatoria & Dale una vuelta & 1 & & & & & 46 \\
\hline PC-Artículo & Belleza & Cosméticos & & Que no te den las uvas & 1 & & & & & 47 \\
\hline PC- Entrevista & Belleza & Cosméticos & Héroe de estilo & $\begin{array}{l}\text { Jean Claude Ellena. La pasión } \\
\text { de oler }\end{array}$ & 3 & Jean Claude Ellena & $\mathrm{H}$ & Protagoniza & Perfumero & 48 \\
\hline PC- Entrevista & Moda & Accesorios + personal & & $\begin{array}{l}\text { Pelayo Pintado. El hombre } \\
\text { idóneo }\end{array}$ & 1 & Pelayo Pintado & $\mathrm{H}$ & Protagoniza & CEO Samsonite & 51 \\
\hline PC-Artículo & Ocio-cultura & Destinos & De crucero & Vacaciones en el mar & 1 & & & & & 52 \\
\hline PC-Entrevista & Gastronomía & Restauración & & $\begin{array}{l}\text { Iván Domínguez. Mareas vivas } \\
\text { en Madrid }\end{array}$ & 1 & Iván Domínguez & $\mathrm{H}$ & Protagoniza & Chef & 53 \\
\hline PC- Reportaje & Gastronomía & Bebidas/Restauración & Protagonista & David Muñoz & 6 & David Muñoz & $\mathrm{H}$ & Protagoniza & Chef & 54 \\
\hline PC- Reportaje & Ocio-cultura & Deportes & Deporte & \multirow{3}{*}{$\begin{array}{l}\text { San Silvestre Vallecana } \\
\text { Fass Bender } \\
\text { Compostura y desenfreno }\end{array}$} & 2 & & & & & 60 \\
\hline Entrevista & Ocio-cultura & Cine & Cine & & 4 & Michael Fassbender & $\mathrm{H}$ & Protagoniza & Actor & 62 \\
\hline PC-Entrevista & Tecno & Motor + personal & Embajador & & 6 & Ricardo Gómez & $\mathrm{H}$ & Prota/ Posa & Actor & 66 \\
\hline PC- Reportaje & Ocio-cultura & Cine & Cine & El lado oscuro de la leyenda & 4 & & & & & 72 \\
\hline *PC- Entrevista & Moda & Marca + personal & Chica DT & Que trabaje Rita & 4 & Rita Ora & $\mathrm{M}$ & Protagoniza & Cantante & 76 \\
\hline PC- Reportaje & $\begin{array}{l}\text { Gastronomía/ } \\
\text { Ocio-cultura/ } \\
\text { Moda/ Tecno/ } \\
\text { Belleza/ Deco } \\
\end{array}$ & $\begin{array}{l}\text { Bebidas/ Libros/ } \\
\text { Accesorios/ Gadgets/ } \\
\text { Cosméticos/ Objetos } \\
\text { deco }\end{array}$ & Tentaciones & Sin ticket regalo & 10 & & & & & 80 \\
\hline PC- Entrevista & Ocio-cultura & Deportes + personal & Soccer & \multirow{2}{*}{$\begin{array}{l}\text { John Neeskens } \\
\text { Un esfuerzo común }\end{array}$} & 4 & John Neeskens & $\mathrm{H}$ & Prota/ Posa & Futbolista & 90 \\
\hline PC- Reportaje & Ocio-cultura & Libro & Portfolio & & 4 & & & & & 94 \\
\hline \multicolumn{11}{|c|}{ ESTILO. MANUAL PARA EL HOMBRE PERFECTO } \\
\hline PC-Artículo & Moda & Ropa & Portada & A raya rayos UV & 1 & & & & & 98 \\
\hline PC- Reportaje & Moda & Looks & Tendencias & $\begin{array}{l}\text { Cuando la elegancia se vuelve } \\
\text { real }\end{array}$ & 8 & & & & & 100 \\
\hline Pc-Artículo & Moda & Accesorios & Mochilas & A falta de guantes... & 1 & & & & & 108 \\
\hline PC-Artículo & Moda & Accesorios & & Las gafas del camerino & 1 & & & & & 109 \\
\hline PC- Entrevista & Moda & Marca & Icono & $\begin{array}{l}\text { Tommy Hilfiger. Tres décadas } \\
\text { de etiqueta }\end{array}$ & 2 & Tommy Hilfiger & $\mathrm{H}$ & Protagoniza & Diseñador moda & 110 \\
\hline PC-Artículo & Moda & Ropa & Casi 200 & $\begin{array}{l}\text { La chinela que conquistó la } \\
\text { calle }\end{array}$ & 1 & & & & & 112 \\
\hline PC-Artículo & Moda & Marca & & De París para el mundo & 1 & & & & & 113 \\
\hline PC-Reportaje & Moda & Ropa & Abrigos & Corazón caliente & 2 & & & & & 114 \\
\hline PC-Artículo & Moda & Marca & Puntos de venta & Sobre monopatín en pajarita & 1 & & & & & 116 \\
\hline \multicolumn{11}{|c|}{ DT ON. LA VIDA ES MUY CORTA PARA ESTAR APAGADO } \\
\hline PC-Artículo & Tecno & Gadgets & Portada & Para novelistas vintage & 1 & & & & & 117 \\
\hline
\end{tabular}




\begin{tabular}{|c|c|c|c|c|c|c|c|c|c|c|}
\hline PC- Reportaje & Tecno & Motor & Dos ruedas & Cabalgar el hierro & 4 & & & & & 118 \\
\hline PC- Reportaje & Ocio-cultura & Destinos & Viajes & $\begin{array}{l}\text { Laponia finlandesa en medio de } \\
\text { la nada }\end{array}$ & 4 & & & & & 122 \\
\hline PC- Reportaje & Tecno & Gadgets & Tecnoregalos & Queridos Reyes Magos... & 8 & & & & & 126 \\
\hline PC- Artículo & Ocio-cultura & Destinos & Direcciones & \multirow{2}{*}{$\begin{array}{l}\text { Rebeldes con causa } \\
\text { La despensa de otoño e } \\
\text { invierno }\end{array}$} & 1 & & & & & 134 \\
\hline PC-Artículo & Gastronomía & Restauración & & & 1 & Pedro Larumbe & $\mathrm{H}$ & Protagoniza & Chef & 135 \\
\hline PC- Reportaje & Gastronomía & Restauración & Carta navideña & \multirow{2}{*}{$\begin{array}{l}\text { In situ o in un paquete } \\
\text { Un día en diurno }\end{array}$} & 2 & & & & & 136 \\
\hline PC- Artículo & Gastronomía & Restauración & Gastro & & 1 & Carlos Padura & $\mathrm{H}$ & Protagoniza & $\begin{array}{l}\text { Fundador del grupo } \\
\text { Mercado de la Reina }\end{array}$ & 138 \\
\hline \multicolumn{11}{|c|}{ MUST. OCIO URBANO PARA TIPOS MODERNOS } \\
\hline PC- Reportaje & $\begin{array}{l}\text { Ocio-cultura/ } \\
\text { Gastronomía }\end{array}$ & $\begin{array}{l}\text { Expo/ Cine/ Libros/ } \\
\text { Alimentos/Música/ } \\
\text { Videojuegos }\end{array}$ & Citas & $\begin{array}{l}\text { Planes otoñales, frívolos y } \\
\text { geniales }\end{array}$ & 8 & & & & & 140 \\
\hline *PC- Entrevista & Ocio-cultura & Cine + personal & En primera persona & Álex González & 1 & Alex González & $\mathrm{H}$ & Protagoniza & Actor & 146 \\
\hline
\end{tabular}


ANEXO 2. PROGRAMACIÓN DE LOS CANALES DE TELEVISIÓN QUE COMPONEN EL CORPUS DE ESTUDIO

PROGRAMACIÓN ENERGY 2015

MARZO 2015 - ENERGY

Lunes 2 de marzo de 2015

\begin{tabular}{ll} 
00:35 & Callejeros viajeros: "Groenlandia" \\
\hline $01: 30$ & Dexter: "Primera sangre" \\
\hline $02: 15$ & Dexter: "Todo está iluminado" \\
\hline $03: 00$ & Premier casino, la ruleta VIP \\
\hline $04: 30$ & Infocomerciales \\
\hline $05: 00$ & El zapping de surferos \\
\hline $06: 30$ & Dr. Oz \\
\hline $06: 55$ & Dr. Oz \\
\hline $07: 30$ & Frank de la jungla: "Serpientes en Bangkok" \\
\hline $08: 30$ & Frank de la jungla: "Cobra y pitón" \\
\hline $09: 30$ & Frank de la jungla: "Osos" \\
\hline $10: 30$ & Frank de la jungla: "Dragón en Komodo" \\
\hline $11: 30$ & Frank de la jungla: "Orangutanes" \\
\hline $12: 30$ & Mudanzas imposibles \\
\hline $12: 55$ & Mudanzas imposibles \\
\hline $13: 20$ & Mudanzas imposibles \\
\hline $13: 40$ & Mudanzas imposibles \\
\hline $14: 00$ & Transportes imposibles \\
\hline $14: 20$ & Transportes imposibles \\
\hline $14: 40$ & Transportes imposibles \\
\hline $15: 00$ & Transportes imposibles \\
\hline $15: 15$ & ¿Quién da más? Nueva York: "El maestro de la subasta" \\
\hline $15: 35$ & ¿Quién da más? Nueva York: "Sólo pasa en Queens Village" \\
\hline $16: 00$ & ¿Quién da más?: "Cabeza de caballo" \\
\hline $16: 20$ & ¿Quién da más?: "Chinatown" \\
\hline $17: 00$ & Veterinario al rescate \\
\hline $17: 45$ & Veterinario al rescate \\
\hline $18: 05$ & Veterinario al rescate \\
\hline $18: 45$ & Veterinario al rescate \\
\hline $19: 15$ & Billy el exterminador \\
\hline $20: 00$ & Billy el exterminador \\
\hline $20: 20$ & Billy el exterminador \\
\hline $20: 40$ & Sabotaje en la cocina \\
\hline $22: 15$ & Callejeros: "Casas rotas" \\
\hline $23: 00$ & Callejeros: "Bodas" (iqué vivan los novios!) \\
\hline
\end{tabular}

Martes 3 de marzo de 2015

\begin{tabular}{ll} 
00:25 & Callejeros: "La paz y la fama" \\
\hline $01: 00$ & Callejeros: "Vacaciones en Andorra" \\
\hline $01: 45$ & Callejeros: "Torres y cúpulas" \\
\hline $02: 20$ & Premier casino, la ruleta VIP \\
\hline $04: 30$ & Infocomerciales \\
\hline $05: 00$ & El zapping de surferos \\
\hline $06: 30$ & Dr. Oz \\
\hline $07: 10$ & Dr. Oz
\end{tabular}




\begin{tabular}{ll}
$07: 30$ & Frank de la jungla: "Viaje animal $\left(2^{\circ}\right.$ parte $)$ \\
\hline $08: 30$ & Frank de la jungla: "Adiós Costa Rica y vuelta a Bangkok" \\
\hline $09: 30$ & Frank de la jungla: "Mongolia" \\
\hline $10: 30$ & Frank de la jungla: "La selva de Bangkok" \\
\hline $11: 30$ & Frank de la jungla: "Tigres" \\
\hline $12: 30$ & Mudanzas imposibles \\
\hline $12: 50$ & Mudanzas imposibles \\
\hline $13: 15$ & Mudanzas imposibles \\
\hline $13: 35$ & Mudanzas imposibles \\
\hline $14: 00$ & Transportes imposibles \\
\hline $14: 40$ & Transportes imposibles \\
\hline $15: 00$ & Transportes imposibles \\
\hline $15: 15$ & Transportes imposibles \\
\hline $15: 35$ & ¿Quién da más? Nueva York: "Una tortuga crece en Harlem" \\
\hline $16: 00$ & ¿Quién da más? Nueva York: "Una historia del Bronx" \\
\hline $16: 20$ & ¿Quién da más?: "Más bien la playa equivocada" \\
\hline $17: 00$ & ¿Quién da más?: "Todo vale en quién da más" \\
\hline $17: 45$ & Veterinario al rescate \\
\hline $18: 05$ & Veterinario al rescate \\
\hline $19: 00$ & Veterinario al rescate \\
\hline $20: 45$ & Fútbol femenino: "España - Nueva Zelanda” \\
\hline $21: 40$ & Sabotaje en la cocina \\
\hline $23: 00$ & Los gipsy Kings \\
\hline
\end{tabular}

Miércoles 4 de marzo de 2015

\begin{tabular}{|c|c|}
\hline $00: 25$ & Cuarto Milenio \\
\hline $02: 30$ & Premier casino, la ruleta VIP \\
\hline 04:30 & Infocomerciales \\
\hline 05:00 & El zapping de surferos \\
\hline $06: 15$ & Dr. $\mathrm{Oz}$ \\
\hline $06: 55$ & Dr. $\mathrm{Oz}$ \\
\hline $07: 30$ & Frank de la jungla: "Tribus" \\
\hline $08: 30$ & Frank de la jungla: "Un río llamado Mekong" \\
\hline 09:30 & Frank de la jungla: "Desmontando mitos animales" \\
\hline $10: 30$ & Frank de la jungla: "Elefantes" \\
\hline $11: 30$ & Frank de la jungla \\
\hline $12: 30$ & Mudanzas imposibles \\
\hline $12: 50$ & Mudanzas imposibles \\
\hline $13: 15$ & Mudanzas imposibles \\
\hline $13: 35$ & Mudanzas imposibles \\
\hline $14: 00$ & Transportes imposibles \\
\hline $14: 20$ & Transportes imposibles \\
\hline $14: 40$ & Transportes imposibles \\
\hline 15:00 & Transportes imposibles \\
\hline $15: 15$ & ¿Quién da más? Nueva York: "Travesuras en Brooklyn” \\
\hline $15: 35$ & ¿Quién da más? Nueva York: "La subasta viviente" \\
\hline 16:00 & ¿Quién da más?: "De cabo a rabo" \\
\hline $16: 20$ & ¿Quién da más?: “Operación vagabundo” \\
\hline 17:00 & Veterinario al rescate \\
\hline $17: 45$ & Veterinario al rescate \\
\hline 18:05 & Veterinario al rescate \\
\hline $18: 45$ & Veterinario al rescate \\
\hline
\end{tabular}


20:00 Billy el exterminador

20:20 Billy el exterminador

20:40 Sabotaje en la cocina

21:40 Hawai 5.0: "Íntegra"

22:20 Hawai 5.0: "Por una buena causa"

23:05 Hawai 5.0: "Restos sagrados"

23:50 Hawai 5.0: "La cura"

Jueves 5 de marzo de 2015

\begin{tabular}{ll}
$00: 35$ & Hawai 5.0: "Identidad" \\
\hline $01: 25$ & Hawai 5.0: "Engaño" \\
\hline $02: 31$ & World series of poker \\
\hline $03: 30$ & Premier casino, la ruleta VIP \\
\hline $04: 30$ & Infocomerciales \\
\hline $05: 00$ & El zapping de surferos \\
\hline $06: 05$ & En el vientre materno: "Animales" \\
\hline $07: 30$ & Frank de la jungla: "Momentos inéditos" \\
\hline $08: 30$ & Frank de la jungla: "Supervivencia en la selva" \\
\hline $09: 30$ & Frank de la jungla: "Animales extraños" \\
\hline $10: 30$ & Frank de la jungla: "Serpientes" \\
\hline $11: 30$ & Frank de la jungla: "Víboras" \\
\hline $12: 30$ & Mudanzas imposibles \\
\hline $12: 50$ & Mudanzas imposibles \\
\hline $13: 15$ & Mudanzas imposibles \\
\hline $13: 35$ & Mudanzas imposibles \\
\hline $14: 00$ & Transportes imposibles \\
\hline $14: 20$ & Transportes imposibles \\
\hline $14: 40$ & Transportes imposibles \\
\hline $15: 00$ & Transportes imposibles \\
\hline $15: 15$ & ¿Quién da más? Nueva York: "Escuela de suerte" \\
\hline $15: 35$ & ¿Quién da más? Nueva York: "Subastas y hockey" \\
\hline $16: 00$ & ¿Quién da más?: "Échale la culpa a la lluvia"” \\
\hline $16: 20$ & ¿Quién da más?: "Mal de altura" \\
\hline $17: 00$ & Veterinario al rescate \\
\hline $17: 45$ & Veterinario al rescate \\
\hline $18: 05$ & Veterinario al rescate \\
\hline $18: 45$ & Veterinario al rescate \\
\hline $19: 15$ & Billy el exterminador \\
\hline $20: 00$ & Billy el exterminador \\
\hline $20: 20$ & Billy el exterminador \\
\hline $21: 40$ & Sabotaje en la cocina \\
\hline & Cinergetic: "El mundo perdido" \\
\hline
\end{tabular}

Viernes 6 de marzo de 2015

00:05 Cinergetic: "Hydra"

01:55 The Strain: "Criaturas de la noche"

02:35 The Strain: "Desaparecida"

03:15 World series of poker 


06:15 Dr. Oz

06:45 Dr. Oz

07:30 Frank de la jungla: "Perdido en Costa Rica ( $\left(1^{\circ}\right.$ parte)"

08:30 Frank de la jungla: "Safari animal"

09:30 Frank de la jungla: "Cocodrilos"

$10: 30$

Frank de la jungla: "Orangután"

11:30 Frank de la jungla: "Cuevas y murciélagos"

12:30 Mudanzas imposibles

12:50 Mudanzas imposibles

13:15 Mudanzas imposibles

13:35 Mudanzas imposibles

14:00 Transportes imposibles

14:20 Transportes imposibles

14:40 Transportes imposibles

15:00 Transportes imposibles

15:15 ¿Quién da más? Nueva York: "Demasiado donde elegir"

15:35 ¿Quién da más? Nueva York: "Leyendas en la niebla"

16:00 ¿Quién da más?: "En Montebello"

16:20 ¿Quién da más?: "Dede Rusia con deportivas"

17:00 Veterinario al rescate

17:45 Veterinario al rescate

18:05 Veterinario al rescate

18:45 Veterinario al rescate

19:15 Billy el exterminador

20:00 Billy el exterminador

20:20 Billy el exterminador

20:40 Sabotaje en la cocina

21:40 Especial callejeros: "Fronteras y aduanas"

22:35 Callejeros: "Acción Policial"

23:15 Callejeros: "Agentes"

23:50 Cabo Vadillo: "Chile"

Sábado 7 de marzo de 2015

00:50 Cabo Vadillo: "Colombia"

01:50 Cabo Vadillo: "Perú"

02:30 Premier casino, la ruleta VIP

04:30 Infocomerciales

05:00 El zapping de surferos

06:30 El zapping de surferos

07:15 Los restaurantes más frikis del mundo

07:35 Los restaurantes más frikis del mundo

07:55 Los restaurantes más frikis del mundo

08:15 Los restaurantes más frikis del mundo

08:35 Los restaurantes más frikis del mundo

09:00 Más que motos

09:31 Más que coches

10:00 Ciudades bajo tierra: "Boston y Filadelfia" 


\begin{tabular}{|c|c|}
\hline $11: 45$ & Ciudades bajo tierra: "Nueva York, las sociedades secretas" \\
\hline $12: 30$ & Comiendo en América \\
\hline $12: 50$ & Comiendo en América \\
\hline $13: 30$ & Adam Richman el mejor bocadillo de América \\
\hline $13: 50$ & Adam Richman el mejor bocadillo de América \\
\hline $14: 10$ & Adam Richman el mejor bocadillo de América \\
\hline $14: 30$ & Adam Richman el mejor bocadillo de América \\
\hline $15: 05$ & ¿Quién da más?: "Este cofre es mío" \\
\hline $15: 25$ & ¿Quién da más?: "Este cofre sigue siendo mío" \\
\hline $16: 00$ & ¿Quién da más?: "Más bien la playa equivocada" \\
\hline $16: 20$ & ¿Quién da más?: "Todo vale en quién da más” \\
\hline $16: 45$ & ¿Quién da más?: "De cabo a rabo" \\
\hline $17: 05$ & ¿Quién da más?: "Operación vagabundo" \\
\hline $17: 30$ & Los viajes del veterinario al rescate \\
\hline $17: 50$ & Los viajes del veterinario al rescate \\
\hline 18:10 & Los viajes del veterinario al rescate \\
\hline 19:00 & Callejeros viajeros: "Tennesse" \\
\hline $20: 00$ & Callejeros viajeros: "Chicago" \\
\hline $21: 00$ & Callejeros viajeros: "Washington" \\
\hline 22:00 & Adán y Eva \\
\hline 23:00 & Adán y Eva \\
\hline
\end{tabular}

Domingo 8 de marzo de 2015

\begin{tabular}{ll} 
00:05 & Adán y Eva \\
\hline $01: 31$ & 21 días: "21 días en la industria del porno" \\
\hline $02: 30$ & Premier casino, la ruleta VIP \\
\hline $04: 30$ & Infocomerciales \\
\hline $05: 00$ & El zapping de surferos \\
\hline $06: 30$ & El zapping de surferos \\
\hline $07: 15$ & Los restaurantes más frikis del mundo \\
\hline $07: 35$ & Los restaurantes más frikis del mundo \\
\hline $07: 55$ & Los restaurantes más frikis del mundo \\
\hline $08: 15$ & Los restaurantes más frikis del mundo \\
\hline $08: 35$ & Los restaurantes más frikis del mundo \\
\hline $09: 00$ & Si parpadeas... \\
\hline $09: 30$ & Juego de gadgets \\
\hline $10: 05$ & Ciudades bajo tierra: "Chicago, el submundo de la mafia" \\
\hline $11: 00$ & Ciudades bajo tierra: "Las vegas, la ciudad del pecado" \\
\hline $11: 45$ & Ciudades bajo tierra: "Washington, la sede del poder" \\
\hline $12: 30$ & Comiendo en América \\
\hline $12: 50$ & Comiendo en América \\
\hline $13: 30$ & Adam Richman el mejor bocadillo de América \\
\hline $13: 50$ & Adam Richman el mejor bocadillo de América \\
\hline $14: 10$ & Adam Richman el mejor bocadillo de América \\
\hline $15: 05$ & ¿Quién da más? Nueva York: "Long Island ciudad de sueños" \\
\hline $15: 25$ & ¿Quién da más? Nueva York: "Te vendo un puente en Brooklyn" \\
\hline $15: 55$ & ¿Quién da más? Nueva York: "Travesuras en Brooklyn" \\
\hline $16: 15$ & ¿Quién da más? Nueva York : "La subasta viviente” \\
\hline $16: 55$ & ¿Quién da más? Nueva York: "Escuela de suerte" \\
\hline
\end{tabular}


18:45 Los viajes del veterinario al rescate

19:15 Desafío extremo: Amazonas en globo. Aterriza como puedas $\left(1^{\circ}\right.$ parte $)$

20:15 Desafío extremo: Amazonas en globo. Récord en la jungla $\left(2^{\circ}\right.$ parte $)$

21:30 ¿Qué hago yo aquí?

22:15 Callejeros Viajeros: "Los yanomamis del amazonas"

\section{JUNIO 2015 - ENERGY}

Lunes 1 de junio de 2015

\begin{tabular}{ll}
$00: 40$ & Callejeros viajeros: "Costa dálmata (Croacia)" \\
\hline $01: 45$ & Callejeros viajeros: "Mykonos y Santorini" \\
\hline $02: 30$ & Especial callejeros viajeros: "viajeros a la playa" \\
\hline $03: 00$ & Premier casino, la ruleta VIP \\
\hline $04: 55$ & Infocomerciales \\
\hline $05: 25$ & Amores reñidos \\
\hline $06: 05$ & Divinity Stars: "Modern Family" \\
\hline $06: 50$ & El zapping de surferos \\
\hline $07: 15$ & Frank de la jungla: "La selva de Bangkok" \\
\hline $08: 05$ & Frank de la jungla: "Elefantes" \\
\hline $09: 00$ & Los timadores \\
\hline $09: 35$ & Los timadores \\
\hline $10: 00$ & Los timadores \\
\hline $10: 45$ & Los timadores \\
\hline $11: 10$ & Los timadores \\
\hline $11: 45$ & Transportes imposibles \\
\hline $12: 15$ & Transportes imposibles \\
\hline $12: 40$ & Transportes imposibles \\
\hline $13: 00$ & Callejeros viajeros: "Viena" \\
\hline $14: 00$ & Callejeros viajeros: "Viena tiene un precio" \\
\hline $15: 00$ & Callejeros viajeros: "Praga" \\
\hline $16: 00$ & Los viajes del veterinario al rescate \\
\hline $16: 20$ & Los viajes del veterinario al rescate \\
\hline $16: 55$ & Veterinario al rescate \\
\hline $17: 45$ & Veterinario al rescate \\
\hline $18: 30$ & Veterinario al rescate \\
\hline $19: 20$ & Veterinario al rescate \\
\hline $20: 10$ & Restaurante imposible \\
\hline $21: 05$ & Restaurante imposible \\
\hline $21: 55$ & Callejeros: “Ordeno y multo" \\
\hline $23: 20$ & Callejeros: "Policías locales" \\
\hline & Callejeros: "Mossos de Escuadra" \\
\hline
\end{tabular}

Martes 2 de junio de 2015

\begin{tabular}{ll} 
00:00 & Callejeros: "Alto policía" \\
\hline $00: 45$ & Callejeros: "Guardia de noche" \\
\hline $01: 20$ & Callejeros: "Acción policial" \\
\hline $02: 10$ & Callejeros: "Armas"
\end{tabular}


04:55 Infocomerciales

05:25 Amores reñidos

06:05 Amores reñidos

06:50 El zapping de surferos

07:15 Frank de la jungla: "Serpientes"

08:00 Frank de la jungla: "Orangután"

09:00 Los timadores

09:35 Los timadores

10:10 Los timadores

10:45 Los timadores

11:20 Los timadores

11:50 Transportes imposibles

12:30 Transportes imposibles

12:45 Transportes imposibles

13:15 Callejeros viajeros: "Venecia"

14:00 Callejeros viajeros: "Florencia"

15:00 Callejeros viajeros: "Florencia, la más bella"

16:00 Los viajes del veterinario al rescate

16:20 Los viajes del veterinario al rescate

16:50 Veterinario al rescate

17:45 Veterinario al rescate

18:30 Veterinario al rescate

19:30 Veterinario al rescate

20:15 Restaurante imposible

21:10 Restaurante imposible

22:00 Hawai 5.0: "Negocio familiar" (ep.70)

22:45 Hawai 5.0: "Adiós, cuídate mucho"

23:35 Hawai 5.0: "Necesidad mutua"

Miércoles 3 de junio de 2015

00:30 Hawai 5.0: "Como pez fuera del agua"

01:15 Hawai 5.0: "La verdad interior"

02:00 Hawai 5.0: "Hasta que la muerte nos separe"

02:45 Hawai 5.0: "Héroe caído"

03:30 Premier casino, la ruleta VIP

04:55 Infocomerciales

05:25 Amores reñidos

06:05 Amores reñidos

06:50 El zapping de surferos

07:20 Frank de la jungla: "El arca de Frank"

\begin{tabular}{ll}
\hline $08: 00$ & Frank de la jungla: "Tigres" \\
\hline 09:00 & Los timadores
\end{tabular}

10:00 Los timadores

10:40 Los timadores

11:15 Los timadores

11:45 Transportes imposibles

12:25 Transportes imposibles 
Transportes imposibles

$13: 15$

Callejeros viajeros: "Chicago"

\begin{tabular}{ll}
\hline 14:00 & Callejeros viajeros: "Washington DC" \\
\hline $15: 00$ & Callejeros viajeros: "Tennesse" \\
\hline $16: 00$ & Los viajes del veterinario al rescate \\
\hline $16: 30$ & Los viajes del veterinario al rescate \\
\hline $17: 00$ & Veterinario al rescate \\
\hline $17: 45$ & Veterinario al rescate \\
\hline $18: 30$ & Veterinario al rescate \\
\hline $19: 20$ & Veterinario al rescate \\
\hline $20: 00$ & Restaurante imposible \\
\hline $21: 00$ & Restaurante imposible \\
\hline $22: 45$ & Hawai 5.0: "Dañado" \\
\hline $23: 25$ & Hawai 5.0: "Rescoldos" \\
\hline
\end{tabular}

Jueves 4 de junio de 2015

00:15 Hawai 5.0: "Justicia para todos"

01:05 Hawai 5.0: "Desde lo más hondo"

01:50 Hawai 5.0: "Compañeros a la fuerza"

02:30 Hawai 5.0: "Feliz día de acción de gracias"

03:10 Premier casino, la ruleta VIP

04:55 Infocomerciales

05:25 Amores reñidos

06:05 Amores reñidos

06:50 El zapping de surferos

07:15 Frank de la jungla

08:15 Frank de la jungla: "víboras"

09:05 Los timadores

09:45 Los timadores

10:15 Los timadores

10:50 Los timadores

11:30 Los timadores

11:55 Transportes imposibles

12:30 Transportes imposibles

12:50 Transportes imposibles

13:15 Callejeros viajeros: "Milán tiene un precio"

14:00 Callejeros viajeros: "Praga"

15:05 Callejeros viajeros: "Danubio"

\begin{tabular}{ll}
\hline $16: 05$ & Los viajes del veterinario al rescate \\
\hline $16: 45$ & Veterinario al rescate
\end{tabular}

17:35 Veterinario al rescate

18:25 Veterinario al rescate

19:15 Veterinario al rescate

20:00 Restaurante imposible

21:00 Cinergetic: "Headhunters"

22:45 Cinergetic: "The Wicker Man" 
Viernes 5 de junio de 2015

00:45 Cinergetic: "La profecía del juicio final"

02:25 Dog el cazarrecompensas: "Paternidad"

02:45 Dog el cazarrecompensas: "Polis y delincuentes"

03:00 World series of poker

03:45 Premier casino, la ruleta VIP

04:55 Infocomerciales

05:25 La ley del pantano

06:05 El zapping de surferos

07:20 Frank de la jungla: "Cuevas y murciélagos"

08:10 Frank de la jungla: "Vida de Frank en Bangkok parte 1"

09:05 Los timadores

09:45 Los timadores

10:25 Los timadores

10:50 Los timadores

11:30 Los timadores

11:50 Transportes imposibles

12:30 Transportes imposibles

12:45 Transportes imposibles

12:45 Transportes imposibles

13:15 Callejeros viajeros: "Canales de Bélgica"

14:00 Callejeros viajeros: "Canales de Ámsterdam"

15:00 Callejeros viajeros: "Canales de Venecia"

16:00 Los viajes del veterinario al rescate

16:20 Los viajes del veterinario al rescate

16:50 Veterinario al rescate

17:40 Veterinario al rescate

18:30 Veterinario al rescate

19:20 Veterinario al rescate

20:10 Restaurante imposible

21:00 Restaurante imposible

21:50 El planeta de los dinosaurios: "Los nuevos gigantes"

22:40 El planeta de los dinosaurios: "Asesinos de élite"

23:45 El planeta de los dinosaurios: "Mundo alienígena"

Sábado 6 de junio de 2015

00:50 Cinergetic: "Cometas en el cielo"

03:00 Premier casino, la ruleta VIP

04:55 Infocomerciales

05:25 La ley del pantano

05:45 La ley del pantano

06:05 El zapping de surferos

07:20 Último aviso: "La cara oculta"

08:05 En movimiento: "La grua"

08:45 Más que coches

09:15 Más que motos

09:45 Ciudades bajo tierra: "Washington, la sede del poder"

10:35 Ciudades bajo tierra: "Nueva York"

11:20 Ciudades bajo tierra: "Bajo la roca (San Francisco)" 


14:00 Best ink

14:50 Best ink

15:30 Maldito tatuaje: "Guerra de tatuajes"

16:05 Maldito tatuaje: "Tatuaje animal"

16:20 Maldito tatuaje: "Delitos y faltas"

16:50 Maldito tatuaje: "Operación taturgica"

17:10 Tatuajes hasta el amanecer

17:40 Tatuajes hasta el amanecer

18:05 Tatuajes hasta el amanecer

18:25 Tatuajes hasta el amanecer

18:45 Planeta Calleja: "David Muñoz"

20:15 Callejeros viajeros: "Punta del Este"

21:15 Callejeros viajeros: "Montevideo"

22:20 Callejeros viajeros: "Santiago de Chile"

23:15 Callejeros viajeros: "Cartagena de Indias"

Domingo 7 de junio de 2015

00:10 Callejeros viajeros: "Playas de Colombia"

01:15 Callejeros viajeros: "Florianópolis (Brasil)"

02:10 Callejeros viajeros: "Los Cayos, un puente hacia..."

03:05 Premier casino, la ruleta VIP

04:55 Infocomerciales

05:25 La ley del pantano

05:45 La ley del pantano

06:05 El zapping de surferos

07:20 Último aviso: "Chantaje"

08:00 En movimiento: "La antigüedad"

08:45 Si parpadeas..

09:25 Juego de gadgets

09:55 Ciudades bajo tierra: "Berlin, la guarida de Hitler"

10:40 Ciudades bajo tierra: "El último secreto de Hitler"

11:30 Ciudades bajo tierra: "Bélgica, las trincheras de Hitler"

12:20 Multas, multas y más multas

12:50 Multas, multas y más multas

13:15 Danone nations cup

\begin{tabular}{ll}
\hline $14: 20$ & Best ink \\
\hline $15: 15$ & Best ink \\
\hline $16: 00$ & Maldito tatuaje: "La mamá, su bebé y el tatuaje" \\
\hline $16: 20$ & Maldito tatuaje: "Todo vale en el amor y el tatuaje" \\
\hline $16: 50$ & Maldito tatuaje: "La familia que se tatúa unida..." \\
\hline $17: 10$ & Maldito tatuaje: "Chicas y tatuajes salvajes" \\
\hline $17: 40$ & Tatuajes hasta el amanecer \\
\hline $18: 05$ & Tatuajes hasta el amanecer \\
\hline $18: 25$ & Tatuajes hasta el amanecer \\
\hline $19: 00$ & Tatuajes hasta el amanecer \\
\hline $19: 20$ & Desafío extremo: "Siberia, los últimos nómadas"
\end{tabular}


21:35 Callejeros viajeros: "Groenlandia"

22:30 Callejeros viajeros: "Aguas de Estocolmo"

23:30 Callejeros viajeros: "Fiordos noruegos"

\section{SEPTIEMBRE 2015 - ENERGY}

Lunes 31 de agosto de 2015

\begin{tabular}{|c|c|}
\hline $01: 35$ & Cinergetic: "Amenaza subterránea" \\
\hline $03: 10$ & Premier casino, la ruleta VIP \\
\hline $05: 00$ & Infocomerciales \\
\hline $05: 30$ & Los Ángeles confidential \\
\hline $05: 55$ & Los Ángeles confidential \\
\hline 06:50 & El zapping de surferos \\
\hline 07:20 & Los reyes del trueque \\
\hline 07:40 & Los reyes del trueque \\
\hline 08:00 & Los reyes del trueque \\
\hline 08:50 & Los timadores \\
\hline 09:20 & Los timadores \\
\hline 09:50 & Los timadores \\
\hline $10: 25$ & Los timadores \\
\hline $10: 50$ & Multas, multas y más multas \\
\hline $11: 25$ & Multas, multas y más multas \\
\hline $11: 45$ & Multas, multas y más multas \\
\hline $12: 20$ & Multas, multas y más multas \\
\hline $12: 40$ & Multas, multas y más multas \\
\hline $13: 10$ & Multas, multas y más multas \\
\hline $13: 30$ & Best ink \\
\hline $14: 15$ & Best ink \\
\hline $15: 10$ & Ciencia para torpes \\
\hline $15: 35$ & Ciencia para torpes \\
\hline $16: 05$ & Ciencia para torpes \\
\hline $16: 25$ & Ciencia para torpes \\
\hline $17: 00$ & Veterinario al rescate \\
\hline $17: 55$ & Veterinario al rescate \\
\hline $18: 30$ & Veterinario al rescate \\
\hline $19: 15$ & Veterinario al rescate \\
\hline $20: 00$ & Restaurante imposible \\
\hline $20: 45$ & Restaurante imposible \\
\hline $21: 45$ & Callejeros: "Especial callejeros de tráfico (vivir)" \\
\hline $22: 35$ & Callejeros: "Socorro" \\
\hline $23: 25$ & Callejeros: "Prostitución universitaria" \\
\hline
\end{tabular}

Martes 1 de septiembre de 2015

00:15 Callejeros: "Prostitutas de Barcelona"

00:50 Callejeros: "Prostitución por crisis"

01:25 Callejeros: "Al aire libre"

02:10 Especial callejeros: "Club"

03:00 Premier casino, la ruleta VIP 


\begin{tabular}{|c|c|}
\hline $04: 45$ & Infocomerciales \\
\hline $05: 15$ & El método Osmin (made in USA) \\
\hline $05: 55$ & El método Osmin (made in USA) \\
\hline $06: 50$ & El zapping de surferos \\
\hline 07:30 & Los reyes del trueque \\
\hline 07:50 & Los reyes del trueque \\
\hline 08:05 & Los reyes del trueque \\
\hline $08: 50$ & Los timadores \\
\hline $09: 30$ & Los timadores \\
\hline $09: 55$ & Los timadores \\
\hline $10: 35$ & Los timadores \\
\hline $11: 00$ & Multas, multas y más multas \\
\hline $11: 35$ & Multas, multas y más multas \\
\hline $11: 55$ & Multas, multas y más multas \\
\hline $12: 30$ & Multas, multas y más multas \\
\hline $12: 55$ & Multas, multas y más multas \\
\hline $13: 25$ & Multas, multas y más multas \\
\hline $13: 45$ & Best ink \\
\hline $14: 25$ & Best ink \\
\hline $15: 20$ & Ciencia para torpes \\
\hline $15: 45$ & Ciencia para torpes \\
\hline $16: 15$ & Ciencia para torpes \\
\hline $16: 45$ & Ciencia para torpes \\
\hline $17: 05$ & Veterinario al rescate \\
\hline $17: 55$ & Veterinario al rescate \\
\hline $18: 30$ & Veterinario al rescate \\
\hline $19: 15$ & Veterinario al rescate \\
\hline 20:00 & Restaurante imposible \\
\hline $20: 45$ & Restaurante imposible \\
\hline $21: 45$ & NCIS: Los Ángeles \\
\hline $22: 30$ & NCIS: Los Ángeles \\
\hline $23: 25$ & Las reglas del juego: "El golpe del sacacorchos" \\
\hline
\end{tabular}

Miércoles 2 de septiembre de 2015

\begin{tabular}{ll}
$00: 20$ & Las reglas del juego: "El golpe del juguete" \\
\hline $01: 05$ & Las reglas del juego: "El golpe del largo adiós" \\
\hline $01: 50$ & Las reglas del juego: "El golpe nigeriano" \\
\hline $02: 30$ & Las reglas del juego: "Golpe de la vuelta a casa" \\
\hline $03: 10$ & Premier casino, la ruleta VIP \\
\hline $04: 55$ & Infocomerciales \\
\hline $05: 25$ & El método Osmin (Made in USA) \\
\hline $05: 55$ & El método Osmin (Made in USA) \\
\hline $06: 50$ & El zapping de surferos \\
\hline $07: 10$ & Los reyes del trueque \\
\hline $07: 50$ & Los reyes del trueque \\
\hline $08: 35$ & Los timadores \\
\hline $09: 05$ & Los timadores \\
\hline $09: 40$ & Los timadores \\
\hline $10: 50$ & Multas, multas y más multas \\
\hline $11: 25$ & Multas, multas y más multas
\end{tabular}


11:45 Multas, multas y más multas

12:25 Multas, multas y más multas

12:45 Multas, multas y más multas

13:15 Multas, multas y más multas

13:35 Best ink

14:20 Best ink

15:15 Ciencia para torpes

15:35 Ciencia para torpes

16:10 Ciencia para torpes

16:30 Ciencia para torpes

17:00 Veterinario al rescate

17:55 Veterinario al rescate

18:30 Veterinario al rescate

19:10 Veterinario al rescate

20:00 Restaurante imposible

20:45 Restaurante imposible

21:45 Hawai 5.0: "Abandonado"

22:25 Hawai 5.0: "El toque de la muerte"

23:15 Hawai 5.0: "Apresado"

Jueves 3 de septiembre de 2015

00:10 Hawai 5.0: "Muerte en la familia"

01:00 Hawai 5.0: "El día de la madre"

01:45 Hawai 5.0: "La duda"

02:25 Hawai 5.0: "A la deriva"

03:05 Premier casino, la ruleta VIP

04:55 Infocomerciales

05:25 El método Osmin (Made in USA)

05:55 El método Osmin (Made in USA)

06:50 El zapping de surferos

07:15 Los reyes del trueque

07:35 Los reyes del trueque

07:55 Los reyes del trueque

08:40 Los timadores

09:15 Los timadores

09:45 Los timadores

10:25 Los timadores

10:50 Multas, multas y más multas

11:25 Multas, multas y más multas

11:50 Multas, multas y más multas

12:25 Multas, multas y más multas

12:45 Multas, multas y más multas

13:15 Multas, multas y más multas

13:40 Best ink

14:20 Best ink

15:10 Ciencia para torpes

15:35 Ciencia para torpes

16:05 Ciencia para torpes

16:25 Ciencia para torpes

17:00 Veterinario al rescate 


\begin{tabular}{ll}
$17: 50$ & Veterinario al rescate \\
\hline $18: 30$ & Veterinario al rescate \\
\hline $19: 15$ & Veterinario al rescate \\
\hline $20: 05$ & Restaurante imposible \\
\hline $20: 45$ & Restaurante imposible \\
\hline $21: 45$ & Ola, ola \\
\hline $22: 30$ & Ola, ola \\
\hline $23: 25$ & Ola, ola
\end{tabular}

Viernes 4 de septiembre de 2015

\begin{tabular}{|c|c|}
\hline $00: 30$ & Ola, ola \\
\hline $01: 25$ & Ola, ola \\
\hline $02: 15$ & Ola, ola \\
\hline 03:00 & Premier casino, la ruleta VIP \\
\hline $04: 55$ & Infocomerciales \\
\hline $05: 25$ & El método Osmin (made in USA) \\
\hline $06: 10$ & El método Osmin (made in USA) \\
\hline $06: 50$ & El zapping de surferos \\
\hline $07: 20$ & Los reyes del trueque \\
\hline $07: 40$ & Los reyes del trueque \\
\hline 08:40 & Los timadores \\
\hline $09: 15$ & Los timadores \\
\hline $09: 45$ & Los timadores \\
\hline $10: 25$ & Los timadores \\
\hline $10: 50$ & Multas, multas y más multas \\
\hline $11: 25$ & Multas, multas y más multas \\
\hline $11: 45$ & Multas, multas y más multas \\
\hline $12: 25$ & Multas, multas y más multas \\
\hline $12: 45$ & Multas, multas y más multas \\
\hline $13: 15$ & Multas, multas y más multas \\
\hline $13: 40$ & Best ink \\
\hline $14: 20$ & Best ink \\
\hline $15: 10$ & Ciencia para torpes \\
\hline $15: 35$ & Ciencia para torpes \\
\hline $16: 05$ & Ciencia para torpes \\
\hline $16: 25$ & Ciencia para torpes \\
\hline $17: 00$ & Veterinario al rescate \\
\hline $17: 55$ & Veterinario al rescate \\
\hline $18: 30$ & Veterinario al rescate \\
\hline $19: 15$ & Veterinario al rescate \\
\hline $20: 05$ & Restaurante imposible \\
\hline $20: 45$ & Restaurante imposible \\
\hline $21: 45$ & Adán y Eva \\
\hline $22: 50$ & Adán y Eva \\
\hline
\end{tabular}

Sábado 5 de septiembre de 2015

\begin{tabular}{ll}
$00: 20$ & Conexión Samanta: "Sexo de alquiler" \\
\hline $01: 15$ & Conexión Samanta: "Vida en un burdel" \\
\hline $02: 20$ & Conexión Samanta: "El otro banderas"
\end{tabular}



Infocomerciales

05:15 El método Osmin (made in USA)

05:55 El método Osmin (made in USA)

06:35 El zapping de surferos

06:45 Comiendo en América

07:05 Comiendo en América

07:25 Mudanzas imposibles

07:50 Mudanzas imposibles

08:10 Mudanzas imposibles

08:30 Mudanzas imposibles

08:55 Mudanzas imposibles

09:20 Más que motos

09:50 Más que motos

10:20 En movimiento: "La grúa"

11:15 En movimiento: "El ejército"

12:10 Ciudades bajo tierra: "Nueva York"

13:00 Ciudades bajo tierra: "Los Ángeles"

14:00 Ciudades bajo tierra: "Katrina (Nueva Orleans)"

15:00 Eurobasket 2015: "Alemania - Islandia"

16:40 El zapping de surferos

16:50 Ciencia para torpes

17:10 Ciencia para torpes

17:30 Ciencia para torpes

18:00 Ciencia para torpes

18:20 Sabotaje en la cocina

19:05 Sabotaje en la cocina

20:00 Crónicas carnívoras

20:20 Crónicas carnívoras

20:40 Crónicas carnívoras

21:20 Crónicas carnívoras

21:40 Crónicas carnívoras

22:00 Crónicas carnívoras

22:35 Cinergetic: "Hydra"

Domingo 6 de septiembre de 2015

00:10 Cinergetic: "Trampa de cristal"

01:35 Cinergetic: "Pánico en el mar"

03:10 Premier casino, la ruleta vip

04:55 Infocomerciales

05:25 Duelo de chefs

05:45 Duelo de chefs

06:05 Duelo de chefs

06:25 Duelo de chefs

06:50 El zapping de surferos

07:20 Comiendo en América

07:40 Comiendo en América

08:00 Mudanzas imposibles

08:25 Mudanzas imposibles

08:45 Si parpadeas... 
09:30 Juego de gadgets

\begin{tabular}{ll}
\hline $10: 00$ & En movimiento: "Rescate de aviones" \\
\hline $11: 00$ & Campeonato de España de velocidad (CEV) 2015 \\
\hline $13: 55$ & Ciudades bajo tierra: "Portland, la ciudad de los contrabandistas" \\
\hline $15: 00$ & Eurobasket 2015: "Serbia - Alemania" \\
\hline $16: 45$ & Ciencia para torpes \\
\hline $17: 05$ & Ciencia para torpes \\
\hline $18: 00$ & Ciencia para torpes \\
\hline $19: 45$ & Eurobasket 2015: "Islandia - Italia" \\
\hline $20: 05$ & Crónicas carnívoras \\
\hline $21: 00$ & Crónicas carnívoras \\
\hline $21: 20$ & Crónicas carnívoras \\
\hline $21: 40$ & Crónicas carnívoras \\
\hline $22: 05$ & Crónicas carnívoras \\
\hline $22: 30$ & Crónicas carnívoras \\
\hline
\end{tabular}

\section{DICIEMBRE 2015 - ENERGY}

Lunes 30 de noviembre de 2015

\begin{tabular}{|c|c|}
\hline 01:20 & Cinergetic: "Frankenstein" \\
\hline $03: 55$ & Premier casino, la ruleta VIP \\
\hline $04: 55$ & Infocomerciales \\
\hline $05: 25$ & El zapping de surferos \\
\hline 07:05 & Cuenta atrás: "Bosque del olvido, 18:40 horas" \\
\hline $07: 55$ & El zapping de surferos \\
\hline 09:00 & El comisario: "No hay enemigo pequeño" \\
\hline $10: 30$ & ¿Felices para siempre? \\
\hline $11: 15$ & Investigadores del más allá \\
\hline $11: 50$ & Investigadores del más allá \\
\hline $12: 25$ & Investigadores del más allá \\
\hline $12: 50$ & Sobrenatural: "Episodio piloto" \\
\hline $13: 45$ & Sobrenatural: "Wendigo" \\
\hline $14: 25$ & Sobrenatural: "Muerto en el agua" \\
\hline $15: 15$ & Sobrenatural: "El viajero fantasma" \\
\hline $16: 05$ & Sobrenatural: "Bloody Mary" \\
\hline $17: 00$ & Making of: Ocho apellidos catalanes \\
\hline $17: 15$ & Invasión jurásica \\
\hline $18: 15$ & Invasión jurásica \\
\hline $19: 15$ & Invasión jurásica \\
\hline $20: 10$ & Hawai 5.0: "Episodio piloto" \\
\hline $21: 00$ & Hawai 5.0: "Familia" \\
\hline $21: 45$ & Hawai 5.0: "Respeto por la tierra" \\
\hline $22: 30$ & Las reglas del juego: "El golpe del estudio" \\
\hline $23: 15$ & Las reglas del juego: "El golpe de la pesca" \\
\hline
\end{tabular}

Martes 1 de diciembre de 2015 


\begin{tabular}{|c|c|}
\hline $00: 50$ & Las reglas del juego: "El golpe de la reina" \\
\hline $01: 35$ & Las reglas del juego: "El golpe subterráneo" \\
\hline $02: 20$ & Las reglas del juego: "El golpe rashomon" \\
\hline 03:00 & El último poli duro: "El 5 mandamiento" \\
\hline $03: 45$ & Premier casino, la ruleta VIP \\
\hline 04:55 & Infocomerciales \\
\hline $05: 25$ & El zapping de surferos \\
\hline 07:00 & Cuenta atrás: "Océano atlántico, aguas jurisdiccionales" \\
\hline 07:50 & El zapping de surferos \\
\hline 09:00 & El comisario: "Secreto a voces" \\
\hline $10: 30$ & ¿Felices para siempre? \\
\hline $11: 25$ & Investigadores del más allá \\
\hline $11: 50$ & Investigadores del más allá \\
\hline $12: 30$ & Investigadores del más allá \\
\hline $12: 50$ & Sobrenatural: "Piel" \\
\hline $13: 40$ & Sobrenatural: "El hombre garfio" \\
\hline $14: 20$ & Sobrenatural: "Bichos" \\
\hline $15: 15$ & Sobrenatural: "Hogar" \\
\hline $16: 05$ & Sobrenatural: "Manicomio" \\
\hline $16: 55$ & Invasión jurásica \\
\hline $17: 10$ & Invasión jurásica \\
\hline $18: 10$ & Invasión jurásica \\
\hline 19:10 & Invasión jurásica \\
\hline 20:05 & Hawai 5.0: "Victoria" \\
\hline $20: 45$ & Hawai 5.0: "Missing" \\
\hline $21: 40$ & Hawai 5.0: "Costa norte de Oahu” \\
\hline $22: 25$ & Spartacus: La guerra de los condenados: "Enemigos de Roma" \\
\hline $23: 25$ & Spartacus: La guerra de los condenados: "Lobos en la puerta" \\
\hline
\end{tabular}

Miércoles 2 de diciembre de 2015

\begin{tabular}{ll}
$00: 30$ & Spartacus: Venganza: "Fugitivus" \\
\hline $01: 30$ & Spartacus: Venganza: "Un lugar en este mundo" \\
\hline $02: 25$ & Homeland: "Homeland" \\
\hline $03: 15$ & Homeland: "Gracias" \\
\hline $04: 05$ & Premier casino, la ruleta VIP \\
\hline $04: 55$ & Infocomerciales \\
\hline $05: 25$ & El zapping de surferos \\
\hline $07: 00$ & Cuenta atrás: "Unidad 7 policía judicial, 13:35 horas" \\
\hline $07: 55$ & El zapping de surferos \\
\hline $10: 30$ & El comisario: "Dulce amargo" \\
\hline $11: 20$ & ¿Felices para siempre? \\
\hline $11: 50$ & Investigadores del más allá \\
\hline $12: 25$ & Investigadores del más allá \\
\hline $12: 50$ & Investigadores del más allá \\
\hline $13: 40$ & Sobrenatural: "Espantapajaros" \\
\hline $14: 25$ & Sobrenatural: "Fe" \\
\hline $15: 15$ & Sobrenatural: "Ruta 666" \\
\hline $16: 05$ & Sobrenatural: "Pesadilla" \\
\hline $16: 55$ & Sobrenatural: "Los Benders" \\
\hline
\end{tabular}




\begin{tabular}{ll}
$17: 35$ & Invasión jurásica \\
\hline $18: 30$ & Invasión jurásica \\
\hline $19: 30$ & Invasión jurásica \\
\hline $20: 10$ & Hawai 5.0: “Aceptación” \\
\hline $21: 05$ & Hawai 5.0: “Confianza” \\
\hline $21: 50$ & Hawai 5.0: "El cerco" \\
\hline $22: 40$ & Last resort: último destino: “Capitán” \\
\hline $23: 30$ & Last resort: último destino: "Azul contra azul”
\end{tabular}

Jueves 3 de diciembre de 2015

\begin{tabular}{|c|c|}
\hline $00: 30$ & Last resort: último destino: "Ocho campanas" \\
\hline $01: 10$ & Alphas: "Despertar" \\
\hline 02:00 & Alphas: "El rápido y el muerto" \\
\hline $02: 40$ & Sobrenatural: "Episodio piloto" \\
\hline $03: 25$ & Sobrenatural: "Wendigo" \\
\hline $03: 45$ & Premier casino, la ruleta VIP \\
\hline $04: 55$ & Infocomerciales \\
\hline $05: 25$ & El zapping de surferos \\
\hline 07:00 & Cuenta atrás: "Mercado puerta de Toledo, 18:35 hs" \\
\hline 07:50 & El zapping de surferos \\
\hline 09:00 & El comisario: "Las lágrimas de la virgen" \\
\hline $10: 35$ & ¿Felices para siempre? \\
\hline $11: 25$ & Investigadores del más allá \\
\hline $11: 50$ & Investigadores del más allá \\
\hline $12: 30$ & Investigadores del más allá \\
\hline $12: 50$ & Sobrenatural: "Sombra" \\
\hline $13: 45$ & Sobrenatural: "Casa infernal" \\
\hline $14: 20$ & Sobrenatural: "Algo maligno" \\
\hline $15: 15$ & Sobrenatural: "Procedencia" \\
\hline $16: 05$ & Sobrenatural: "Sangre de muerto" \\
\hline $17: 00$ & Invasión jurásica \\
\hline $17: 30$ & Invasión jurásica \\
\hline $18: 30$ & Invasión jurásica \\
\hline $19: 30$ & Invasión jurásica \\
\hline $20: 15$ & Hawai 5.0: "La carrera" \\
\hline $21: 05$ & Hawai 5.0: "Paraíso" \\
\hline $21: 50$ & Hawai 5.0: "Medidas desesperadas" \\
\hline $22: 35$ & NCIS: Los Ángeles \\
\hline $23: 30$ & NCIS: Los Ángeles \\
\hline
\end{tabular}

Viernes 4 de diciembre de 2015

\begin{tabular}{ll}
$00: 30$ & NCIS: Los Ángeles \\
\hline $01: 10$ & NCIS: Los Ángeles \\
\hline $02: 00$ & NCIS: Los Ángeles \\
\hline $02: 40$ & El último poli duro: "No sé nada" \\
\hline $03: 25$ & El último poli duro: "La guardería de los horrores" \\
\hline $04: 00$ & Premier casino, la ruleta VIP \\
\hline $04: 55$ & Infocomerciales \\
\hline $05: 25$ & El zapping de surferos
\end{tabular}


09:00 El Comisario: "Una vida por otra"

10:30 ¿Felices para siempre?

11:25 Investigadores del más allá

11:50 Investigadores del más allá

12:30 Investigadores del más allá

12:50 Sobrenatural: "Salvación

13:40 Sobrenatural: "La trampa del diablo"

14:20 Sobrenatural: "Cuando llegue mi hora"

15:15 Sobrenatural: "A todo el mundo le gustan los payasos"

16:05 Sobrenatural: "Sed de sangre"

17:00 Invasión jurásica

17:35 Invasión jurásica

18:35 Invasión jurásica

19:30 Invasión jurásica

20:10 Hawai 5.0: "El comienzo"

21:00 Hawai 5.0: "Víctima inocente"

21:50 Hawai 5.0: "La trampa"

22:40 Marvel - Agentes de S.H.I.E.L.D.: "V.I.A.S."

23:20 Marvel - Agentes de S.H.I.E.L.D.: "La chica del vestido de flores"

Sábado 5 de diciembre de 2015

$00: 1$

01:05

02:00

$02: 35$

$03: 15$

04:00

04:55

05:25

06:50

08:00

08:20

08:40

09:00

09:25

$09: 45$

10:05

$10: 30$

$10: 55$

$11: 30$

12:00

$12: 50$

$13: 45$

$14: 25$

$15: 20$

16:05

17:00

Marvel - Agentes de S.H.I.E.L.D.: "Zumbidos"

Marvel - Agentes de S.H.I.E.L.D.: "El Hub"

Marvel - Agentes de S.H.I.E.L.D.: "El pozo"

Marvel - Agentes de S.H.I.E.L.D.: "Reparaciones"

El último poli duro: "Necesidad de amor"

Premier casino, la ruleta VIP

Infocomerciales

El zapping de surferos

¿Quién da más? Texas

¿Quién da más? Texas

¿Quién da más? Texas

¿Quién da más? Texas

¿Quién da más? Texas

¿Quién da más? Texas

¿Quién da más? Texas

¿Quién da más? Texas

$17: 45$

Más que coches

Más que motos

Sobrenatural: "Muerto en el agua"

Sobrenatural: "El viajero fantasma"

Sobrenatural: "Hermano de sangre"

Sobrenatural: "Adios, extraño"

Sobrenatural: "Frikis y cerebritos"

C.S.I New York: "Ahora me oyen"

C.S.I New York: "Las profundidades"

C.S.I New York: "Solo se muere una vez" 


\begin{tabular}{ll}
\hline $19: 20$ & NCIS: Los Ángeles \\
\hline $20: 10$ & NCIS: Los Ángeles \\
\hline $21: 00$ & NCIS: Los Ángeles \\
\hline $21: 50$ & NCIS: Los Ángeles \\
\hline $22: 35$ & NCIS: Los Ángeles \\
\hline $23: 30$ & Último aviso: “Tierra calcinada”
\end{tabular}

Domingo 6 de diciembre de 2015

00:25 Spartacus: La guerra de los condenados: "Enemigos de Roma"

01:20 Spartacus: La guerra de los condenados: "Lobos en la puerta"

$02: 15$

03:05

03:55

04:55

$05: 25$

Spartacus: Venganza: "Fugitivus"

$06: 50$

Spartacus: Venganza: "Un lugar en este mundo"

07:50

$08: 10$

Premier casino, la ruleta VIP

08:50

Infocomerciales

09:10

El zapping de surferos

09:35

09:55

$10: 20$

$10: 30$ El zapping de surferos

$11: 15$ ¿Quién da más? Texas

12:00 ¿Quién da más? Texas

$12: 55$ ¿Quién da más? Texas

¿Quién da más? Texas

$13: 45$ ¿Quién da más? Texas

$14: 30$ ¿Quién da más? Texas

$15: 20$ Si parpadeas...

$16: 05$ Juego de gadgets

17:00 Sobrenatural: "Bloody Mary"

$17: 50$ Sobrenatural: "Piel"

$18: 45$

Sobrenatural: "Consuelo sureño"

Sobrenatural: "Taxi driver"

$19: 25$

Sobrenatural: "Fiebre de come cocos"

$20: 15$

Marvel - Agentes S.H.I.E.L.D.: "La chica del vestido de flores

21:05 Marvel - Agentes S.H.I.E.L.D.: "Zumbidos"

21:55

Marvel - Agentes S.H.I.E.L.D.: "El hub"

Marvel - Agentes S.H.I.E.L.D.: "El pozo"

Marvel - Agentes S.H.I.E.L.D.: "Reparaciones"

Marvel - Agentes S.H.I.E.L.D.: "V.I.A.S."

$22: 40$ Las reglas del juego: "El golpe del rey Jorge" 


\section{PROGRAMACIÓN DIVINITY 2015}

\section{MARZO 2015 - DIVINITY}

Lunes 9 de marzo de 2015

\begin{tabular}{ll} 
00:15 & El cuerpo del delito \\
\hline $01: 00$ & El cuerpo del delito \\
\hline $01: 45$ & El cuerpo del delito \\
\hline $02: 35$ & Sin cita previa: "Mundo separados" \\
\hline $03: 15$ & Sin cita previa: "Contaminación” \\
\hline $04: 15$ & Taquilla mediaset \\
\hline $04: 20$ & Infocomerciales \\
\hline $05: 55$ & Divinity jukebox live \\
\hline $06: 30$ & El zapping de surferos \\
\hline $07: 00$ & Ciega a citas \\
\hline $08: 30$ & Avenida Brasil \\
\hline $10: 15$ & Mujeres y hombres y viceversa \\
\hline $11: 00$ & Gossip girl \\
\hline $12: 30$ & Mujeres desesperadas \\
\hline $14: 00$ & Sin cita previa \\
\hline $15: 00$ & Anatomía de Grey \\
\hline $16: 00$ & Gran Hermano VIP 2015: la casa en directo \\
\hline $17: 00$ & Cazamariposas \\
\hline $19: 15$ & Anatomía de Grey \\
\hline $21: 00$ & Vender para comprar \\
\hline $22: 00$ & Gran Hermano VIP 2015: resumen diario \\
\hline $23: 15$ & Anatomía de Grey \\
\hline
\end{tabular}

Martes 10 de marzo de 2015

\begin{tabular}{ll} 
01:25 & Dcine: "Nada que perder" \\
\hline $03: 00$ & Sin cita previa: "Regreso al hogar" \\
\hline $03: 40$ & Sin cita previa: "Nada que temer" \\
\hline $04: 20$ & Taquilla mediaset \\
\hline $04: 25$ & Infocomerciales \\
\hline $05: 55$ & Divinity Jukebok Live \\
\hline $06: 30$ & El zapping de surferos \\
\hline $08: 30$ & Cita a ciegas \\
\hline $09: 00$ & Avenida Brasil \\
\hline $10: 15$ & Mujeres y hombres y viceversa \\
\hline $11: 00$ & Gossip girl \\
\hline $12: 30$ & Mujeres desesperadas \\
\hline $14: 00$ & Sin cita previa \\
\hline $15: 00$ & Anatomía de Grey \\
\hline $16: 00$ & Gran hermano VIP 2015: la casa en directo \\
\hline $17: 00$ & Cazamariposas \\
\hline $19: 30$ & Anatomía de Grey \\
\hline $22: 00$ & Vender para comprar \\
\hline
\end{tabular}


Miércoles 11 de marzo de 2015

\begin{tabular}{|c|c|}
\hline $00: 30$ & El cuerpo del delito \\
\hline $01: 15$ & El cuerpo del delito \\
\hline 02:00 & Caso abierto: "Infierno en la disco" \\
\hline $02: 45$ & Caso abierto: "Voluntarios" \\
\hline 03:30 & Caso abierto: "El alma perdida de Herman Lester" \\
\hline 04:10 & Sin cita previa: "Segundas oportunidades" \\
\hline 04:50 & Taquilla mediaset \\
\hline 05:00 & Infocomerciales \\
\hline 05:55 & Divinity jukebox live \\
\hline 06:30 & El zapping de surferos \\
\hline 07:00 & Cita a ciegas \\
\hline $08: 30$ & Avenida Brasil \\
\hline 09:00 & Mujeres y hombres y viceversa \\
\hline $10: 15$ & Gossip girl \\
\hline $11: 00$ & Mujeres desesperadas \\
\hline $12: 30$ & Sin cita previa \\
\hline $14: 00$ & Anatomía de Grey \\
\hline $15: 00$ & Gran hermano VIP 2015: la casa en directo \\
\hline $16: 00$ & Cazamariposas \\
\hline $17: 00$ & Anatomía de Grey \\
\hline $19: 30$ & Vender para comprar \\
\hline $21: 00$ & Gran hermano VIP: resumen diario \\
\hline $21: 45$ & Imborrable: "Pasado pretérito" \\
\hline $22: 35$ & Imborrable: "Corre o calla" \\
\hline $23: 20$ & Imborrable: "Mapas y leyendas" \\
\hline
\end{tabular}

Jueves 12 de marzo de 2015

\begin{tabular}{ll}
$00: 10$ & Imborrable: "Hora omega" \\
\hline $01: 00$ & The finder: "El niño con un cubo" \\
\hline $01: 45$ & Sin cita previa: “Aceptación" \\
\hline $02: 30$ & Sin cita previa: "Ex vida" \\
\hline $03: 05$ & Sin cita previa: "Espera y verás" \\
\hline $03: 45$ & Taquilla mediaset \\
\hline $03: 50$ & Infocomerciales \\
\hline $05: 55$ & Divinity jukebox live \\
\hline $06: 30$ & El zapping de surferos \\
\hline $08: 00$ & Cita a ciegas \\
\hline $09: 00$ & Avenida Brasil \\
\hline $10: 15$ & Mujeres y hombres y viceversa \\
\hline $11: 00$ & Gossip Girl \\
\hline $12: 30$ & Mujeres deseperadas \\
\hline $14: 00$ & Sin cita previa \\
\hline $15: 00$ & Anatomía de Grey \\
\hline $16: 00$ & Gran hermano VIP 2015: la casa en directo \\
\hline $17: 00$ & Cazamariposas \\
\hline
\end{tabular}


Vender para comprar

21:00 Gran hermano VIP 2015: resumen diario

21:55 Dcine: "Siete días y una vida"

23:30 Dcine: "Mientras no estás"

Viernes 13 de marzo de 2015

01:00 Dcine: "Los secretos de la casa de acogida"

\begin{tabular}{ll}
\hline $02: 30$ & Sin cita previa: "Terminado" \\
\hline $03: 15$ & Sin cita previa: "Lo que quieren las mujeres" \\
\hline $04: 00$ & Sin cita previa: "Hacer lo correcto" \\
\hline $04: 30$ & Taquilla mediaset \\
\hline $04: 45$ & Infocomerciales \\
\hline $05: 55$ & Divinity jukebox live \\
\hline $06: 30$ & El zapping de surferos \\
\hline $07: 00$ & Ciega a citas \\
\hline $08: 30$ & Avenida Brasil \\
\hline 9::00 & Mujeres y hombres y viceversa \\
\hline $11: 00$ & Gossip girl \\
\hline $12: 30$ & Mujeres desesperadas \\
\hline $14: 00$ & Sin cita previa \\
\hline $15: 00$ & Anatomía de Grey \\
\hline $16: 00$ & Gran hermano VIP 2015: la casa en directo \\
\hline $17: 00$ & Cazamariposas \\
\hline $18: 45$ & Anatomía de Grey \\
\hline $21: 30$ & Vender para comprar \\
\hline $22: 30$ & Gran hermano VIP 2015: resumen diario \\
\hline $23: 25$ & Castle: “Aquellos maravillosos 70" \\
\hline
\end{tabular}

Sábado 14 de marzo de 2015

\begin{tabular}{ll}
$00: 10$ & Castle: "La fan número 1" \\
\hline $01: 05$ & Castle: "El tiempo lo dirá" \\
\hline $01: 55$ & Castle: "El busca de la pista" \\
\hline $02: 35$ & Castle: "El tercer hombre" \\
\hline $03: 15$ & Castle: "El régimen suicida" \\
\hline $03: 55$ & Castle: "El ama siempre azota dos veces" \\
\hline $04: 35$ & Taquilla mediaset \\
\hline $04: 40$ & Infocomerciales \\
\hline $05: 55$ & Divinity jukebox live \\
\hline $06: 30$ & El zapping de surferos \\
\hline $07: 00$ & Extreme makeover: cambio radical \\
\hline $08: 45$ & El zapping de surferos \\
\hline $09: 30$ & D.Lujo \\
\hline $09: 45$ & Una boda perfecta \\
\hline $14: 00$ & Tu casa lo vale \\
\hline $15: 30$ & Los nuestros \\
\hline $17: 00$ & Castle \\
\hline $22: 15$ & Gran hermano VIP 2015: resumen diario \\
\hline $23: 15$ & Blue bloods: familia de policías
\end{tabular}




\begin{tabular}{ll} 
00:00 & Blue bloods: Familia de policías: “Asuntos de familia” \\
\hline $00: 45$ & Caso abierto: "propósitos" \\
\hline $01: 30$ & Caso abierto: “últimas vueltas" \\
\hline $02: 20$ & Caso abierto: "codicia" \\
\hline $03: 00$ & Caso abierto: "instinto maternal” \\
\hline $03: 40$ & Caso abierto: "el plan" \\
\hline $04: 20$ & Taquilla mediaset \\
\hline $05: 55$ & Infocomerciales \\
\hline $06: 30$ & Divinity jukebox live \\
\hline $07: 00$ & El zapping de surferos \\
\hline $09: 30$ & Planet cake \\
\hline $11: 30$ & Chocofantasy \\
\hline $11: 35$ & Las mañanas divinas \\
\hline $14: 00$ & Dulces e increíbles \\
\hline $22: 30$ & Tu casa lo vale \\
\hline $23: 15$ & Castle \\
\hline
\end{tabular}

\section{JUNIO 2015 - DIVINITY}

Lunes 7 de junio de 2015

\begin{tabular}{|c|c|}
\hline 00:00 & El cuerpo del delito \\
\hline $00: 55$ & El cuerpo del delito \\
\hline 01:40 & El cuerpo del delito \\
\hline $02: 30$ & El cuerpo del delito \\
\hline 03:05 & El cuerpo del delito \\
\hline 03:50 & El cuerpo del delito \\
\hline 04:25 & Taquilla mediaset \\
\hline 04:30 & Infocomerciales \\
\hline 05:55 & Divinity jukebox live \\
\hline $06: 30$ & El zapping de surferos \\
\hline 07:10 & Un gancho al corazón \\
\hline $07: 55$ & Ciega a citas: "De vuelta a los fogones" \\
\hline 08:50 & La tempestad \\
\hline 09:40 & Mujeres y hombres y viceversa \\
\hline 11:00 & Medium: "Como ganar pasta en los negocios (Segunda parte) \\
\hline $11: 50$ & Medium: "Como ganar pasta en los negocios" \\
\hline $12: 45$ & Sobrenatural: "Salvación” \\
\hline $13: 35$ & Sobrenatural: "La trampa del diablo" \\
\hline $14: 15$ & Entre fantasmas: "Hasta que la muerte nos una" \\
\hline $15: 05$ & Entre fantasmas: "Repetición" \\
\hline 16:00 & Entre fantasmas: "Motivo de alarma" \\
\hline $17: 00$ & Anatomía de Grey \\
\hline 18:05 & Cambia de look \\
\hline 19:05 & Cambia de look \\
\hline $20: 15$ & Cazamariposas \\
\hline $21: 15$ & Supervivientes 2015: resumen diario \\
\hline
\end{tabular}


Martes 8 de junio de 2015

\begin{tabular}{|c|c|}
\hline 00:50 & Dcine: "Efectos secundarios" \\
\hline 02:40 & Dcine:: "Obsesionada" \\
\hline 04:00 & Divinity stars: "Lo más dulce de los ángeles" \\
\hline $04: 25$ & Taquilla mediaset \\
\hline 04:30 & Infocomerciales \\
\hline 05:55 & Divinity jukebox live \\
\hline 06:30 & El zapping de surferos \\
\hline 07:00 & Un gancho al corazón \\
\hline 07:45 & Ciega a citas: "educando a Jaime" \\
\hline 08:40 & La tempestad \\
\hline 09:30 & Mujeres y hombres y viceversa \\
\hline 11:00 & Medium: "El hombre del espejo" \\
\hline $11: 45$ & Medium: "El primer mordisco es el más profundo" \\
\hline $12: 45$ & Sobrenatural: "Cuando llegue mi hora" \\
\hline $13: 30$ & Sobrenatural: "A todo el mundo le gustan los payasos" \\
\hline $14: 15$ & Entre fantasmas: "Perdidamente enamorado" \\
\hline $15: 00$ & Entre fantasmas: "El pacto con el diablo" \\
\hline 16:00 & Entre fantasmas: "Juego letal" \\
\hline 17:00 & Anatomía de Grey \\
\hline 18:15 & Cambia de look \\
\hline 19:00 & Cambia de look \\
\hline 20:00 & Cazamariposas \\
\hline 21:00 & Supervivientes 2015: resumen diario \\
\hline $21: 50$ & Caso abierto: "Una bala" \\
\hline $22: 30$ & Caso abierto: "Amor libre" \\
\hline $23: 30$ & Caso abierto: "Justicia" \\
\hline
\end{tabular}

Miércoles 9 de junio de 2015

\begin{tabular}{ll}
\hline $00: 30$ & Caso abierto: "Familia" \\
\hline $01: 10$ & Caso abierto: "Últimas vueltas" \\
\hline $02: 00$ & El cuerpo del delito \\
\hline $02: 45$ & El cuerpo del delito \\
\hline $03: 30$ & El cuerpo del delito \\
\hline $04: 00$ & El cuerpo del delito \\
\hline $04: 45$ & Taquilla mediaset \\
\hline $04: 50$ & Infocomerciales \\
\hline $05: 55$ & Divinity jukebox live \\
\hline $06: 30$ & El zapping de surferos \\
\hline $07: 15$ & Un gancho al corazón \\
\hline $08: 00$ & Ciega a citas: "En tierra de nadie" \\
\hline $08: 50$ & La tempestad \\
\hline $09: 40$ & Mujeres y hombres y viceversa \\
\hline $11: 00$ & Medium: "El talento de la señorita Boddicker" \\
\hline $11: 50$ & Medium: "Quiero la cabeza de Oswaldo" \\
\hline $12: 45$ & Sobrenatural: "Sed de sangre"
\end{tabular}


$13: 30$

$14: 15$

$15: 10$

$16: 00$

$17: 00$

$17: 50$

$18: 40$

$19: 45$

$20: 30$

21:40

22:00

22:50

23:30

Sobrenatural: "Niños no juguéis con cosas muertas"

Entre fantasmas: "Perdida en las sombras"

Entre fantasmas: "Excesivo celo"

Entre fantasmas: "Ondas de muerte"

Anatomía de Grey

Cambia de look

Cambia de look

Cambia de look

Cazamariposas

Supervivientes diario desde Honduras

Supervivientes 2015: resumen diario

Imborrable: "Liquidando cuentas"

Imborrable: "El corte de pelo"

Jueves 10 de junio de 2015

00:40 Imborrable: "Una fiesta ambulante"

01:15 C.S.I. Miami: "Un asesino pardo"

02:10 C.S.I. Miami: "Triple amenaza"

02:50 C.S.I. Miami: "Linaje"

03:30 C.S.I. Miami: "El copión"

04:10 Taquilla mediaset

04:15 Infocomerciales

05:55 Divnity Jukebox live

06:30 El zapping de surferos

06:50 Un gancho al corazón

07:30 Ciega a citas: "La boda de Don Juan"

08:25 La tempestad

09:10 Mujeres y hombres y viceversa

09:45 Mujeres desesperadas: "Episodio piloto"

10:40 Mujeres desesperadas: "Ah, pero en el fondo"

11:30 Mujeres desesperadas: "Imágenes idílicas"

12:25 Sobrenatural: "Simón dijo"

13:15 Sobrenatural: "Sin salida"

13:55 Entre fantasmas: "No hay mal que por bien no venga"

14:35 Entre fantasmas: "Felices sueños"

15:30 S.O.S Supervivientes

16:20 Cambia de look

16:40 Cambia de look

17:35 Cambia de look

18:30 Cambia de look

19:25 Cambia de look

20:20 Cazamariposas

21:05 Más cazamariposas

21:35 Supervivientes diario desde Honduras

22:10 Supervivientes 2015: resumen diario

23:00 Rockie blue: "Sálvese quien pueda"

23:50 Blue bloods: Familia de policías: "Bogeyman" 
Viernes 11 de junio de 2015

00:45 Blue bloods: Familia de policías: "La encerrona"

01:35 Blue bloods: Familia de policías: "Chicas trabajando"

02:15 Blue bloods: Familia de policías: "Daños colaterales"

03:05 Blue bloods: Familia de policías: "El día de la madre"

03:40 Rookie blue: "Sálvese quien pueda"

04:20 Taquilla mediaset

04:25 Infocomerciales

05:55 Divinity jukebox live

06:30 El zapping de surferos

06:45 Un gancho al corazón

07:30 Ciega a citas: "Yo la quería"

\begin{tabular}{ll}
$08: 15$ & La tempestad \\
\hline $09: 05$ & Mujeres y hombres y viceversa
\end{tabular}

09:45 Mujeres desesperadas: “¿Quién es esa mujer?"

10:35 Mujeres desesperadas: "Entra, desconocido"

11:30 Mujeres desesperadas: "Correr y no avanzar"

12:30 Sobrenatural: "Sospechosos habituales"

13:20 Sobrenatural: "Cruce de caminos"

14:00 Entre fantasmas: "Muerto para mí"

14:45 Entre fantasmas: "Implosión"

15:30 S.O.S. Supervivientes

16:30 Cambia de look

17:40 Cambia de look

18:30 Cambia de look

19:20 Cambia de look

20:15 Cazamariposas

21:00 Más cazamariposas

21:30 Supervivientes 2015: resumen diario

22:15 Castle: "El factor humano"

23:00 Castle: "El contacto"

Sábado 12 de junio de 2015

00:00 Castle: "Resurreción"

00:50 Castle: "El mundo de los sueños"

02:15 Castle: "Envuelta en la muerte"

03:00 Medium: "El talento de la señorita Boddicker"

03:35 Medium: "Quiero la cabeza de Oswaldo"

04:20 Medium: "Una vez en la vida"

04:55 Taquilla mediaset

05:00 Infocomerciales

05:55 Divinity jukebox live

06:30 El zapping de surferos

07:20 Guerra de estilistas: "Guerra de estilistas"

08:00 Guerra de estilistas: "Guerra de estilistas"

08:50 El zapping de surferos

09:00 D.Lujo

09:30 Los duques de melrose

09:50 Los duques de melrose 
$10: 15$

Fashionistas

$10: 40$

Fashionistas

$11: 00$

Seduciendo con tionna: "seduciendo con tionna"

11:20 Seduciendo con tionna: "seduciendo con tionna"

11:50 Cambia de look

12:40 Bebé a bordo

13:10 Cambia de look

14:10 Cambia de look

15:10 $\quad$ El cuerpo del delito

16:00 El cuerpo del delito

16:50 El cuerpo del delito

17:40 El cuerpo del delito

18:30 El cuerpo del delito

19:25 Castle: "Horario mortal"

20:15 Castle: "Cortadores de cabezas"

21:15 Castle: "La vuelta de los muertos vivientes"

22:00 Castle: "Siempre"

22:50 Castle: "Valkiria"

23:30 Caso abierto: "Casi en el paraíso"

Domingo 13 de junio de 2015

\begin{tabular}{ll}
$00: 35$ & Caso abierto: "8 años" \\
\hline $01: 15$ & Caso abierto: "Permanencias" \\
\hline $02: 00$ & Caso abierto: "Codicia" \\
\hline $02: 45$ & Caso abierto: "Instinto maternal" \\
\hline $03: 30$ & Caso abierto: "El plan" \\
\hline $04: 10$ & Caso abierto: "Paseo de los amantes" \\
\hline $04: 40$ & Taquilla mediaset \\
\hline $04: 45$ & Infocomerciales \\
\hline $05: 55$ & Divinity jukebox live \\
\hline $06: 30$ & El zapping de surferos \\
\hline $07: 30$ & Divinity stars: "Tori Spelling" \\
\hline $08: 10$ & Tu casa a juicio \\
\hline $08: 55$ & Tu casa a juicio \\
\hline $09: 40$ & Tu casa a juicio \\
\hline $10: 30$ & Tu casa a juicio \\
\hline $11: 20$ & Tu casa a juicio \\
\hline $12: 20$ & Tu casa a juicio \\
\hline $13: 20$ & Tu casa a juicio \\
\hline $14: 10$ & Cupcakes maniacs \\
\hline $14: 30$ & El cuerpo del delito \\
\hline $15: 30$ & El cuerpo del delito \\
\hline $16: 20$ & El cuerpo del delito \\
\hline $17: 15$ & El cuerpo del delito \\
\hline $18: 15$ & Castle: "Una mala influencia" \\
\hline $19: 10$ & Castle: "Una muerte a lo loco" \\
\hline $20: 00$ & Castle: "Retroceso" \\
\hline $21: 00$ & Castle: "La dura realidad" \\
\hline $21: 50$ & Castle: "El objetivo" \\
\hline $22: 40$ & Castle: "De tal palo tal astilla" \\
\hline
\end{tabular}




\section{SEPTIEMBRE 2015 - DIVINITY}

Lunes 7 de septiembre de 2015

\begin{tabular}{|c|c|}
\hline $00: 50$ & La dama velada: "En la casa paterna" \\
\hline $01: 40$ & La dama velada: "Una esposa infeliz" \\
\hline 02:40 & La dama velada: "Confianza traicionada" \\
\hline 03:30 & ¿Felices para siempre? \\
\hline $04: 15$ & ¿Felices para siempre? \\
\hline 04:50 & Taquilla mediaset \\
\hline 04:55 & Infocomerciales \\
\hline 05:55 & Divinity Jukeox Live \\
\hline 06:30 & El zapping de surferos \\
\hline $07: 30$ & Million dollar decorators \\
\hline 08:20 & Million dollar decorators \\
\hline 09:00 & Mujeres y hombres y viceversa \\
\hline $10: 30$ & Mujeres desesperadas: “¿Qué habría pasado si...?” \\
\hline $11: 15$ & Mujeres desesperadas: “Tienes que desnudarte” \\
\hline $12: 10$ & Sin cita previa: “...para cambiar lo que puedo cambiar” \\
\hline 13:00 & Sin cita previa: "Dios se ríe" \\
\hline $13: 45$ & Sin rastro: "Res ipsa" \\
\hline $14: 25$ & Sin rastro: "Bagaje" \\
\hline $15: 20$ & Caso abierto: "Asesinato en el hipódromo" \\
\hline $16: 15$ & Caso abierto: "Lee entre líneas" \\
\hline $17: 10$ & Caso abierto: "Chinatown" \\
\hline $18: 10$ & La casa de mis sueños \\
\hline 19:00 & La casa de mis sueños \\
\hline $19: 45$ & Cámbiame \\
\hline $20: 30$ & Cazamariposas \\
\hline $21: 15$ & Más cazamariposas \\
\hline $21: 55$ & Criadas y malvadas \\
\hline $22: 40$ & Dcine: "Sobreviviré” (Alfonso Albacete) \\
\hline
\end{tabular}

Martes 8 de septiembre de 2015

\begin{tabular}{ll}
$00: 40$ & Deine: “La Bella y la Bestia” \\
\hline $02: 15$ & ¿Felices para siempre? \\
\hline $03: 10$ & ¿Felices para siempre? \\
\hline $04: 00$ & ¿Felices para siempre? \\
\hline $04: 45$ & Taquilla mediaset \\
\hline $04: 50$ & Infocomerciales \\
\hline $05: 55$ & Divinity jukebox live \\
\hline $06: 30$ & El zapping de surferos \\
\hline $07: 30$ & Million dollar decorators \\
\hline $08: 10$ & Million dollar decorators \\
\hline $09: 00$ & Mujeres y hombres y viceversa \\
\hline $10: 15$ & Mujeres desesperadas: “¿Qué tal un psicólogo amable?” \\
\hline $11: 00$ & Mujeres desesperadas: “Una vida glamurosa”
\end{tabular}


Sin cita previa: "Supéralo"

\begin{tabular}{ll}
\hline $13: 40$ & Sin rastro: "Corre" \\
\hline $14: 20$ & Sin rastro: "Dónde y por qué" \\
\hline $15: 10$ & Caso abierto: "Derecho" \\
\hline $16: 10$ & Caso abierto: "Muerte en el hielo" \\
\hline $17: 00$ & Caso abierto: "El buen soldado" \\
\hline $17: 55$ & La casa de mis sueños \\
\hline $18: 55$ & La casa de mis sueños \\
\hline $19: 55$ & La casa de mis sueños \\
\hline $20: 50$ & Cámbiame \\
\hline $21: 30$ & Cazamariposas \\
\hline $22: 10$ & Más cazamariposas \\
\hline $22: 40$ & Dcine: "El vuelo" (2012) Robert Zemeckis
\end{tabular}

Miércoles 9 de septiembre de 2015

01:20 Dcine: "Sesenta segundos" (Nicolas cage, angelina Jolie)

\begin{tabular}{ll}
\hline $03: 20$ & Dcine: "Demonio bajo la piel, el” (Michael Winterbottom 2010) \\
\hline $05: 00$ & Taquilla mediaset \\
\hline $05: 05$ & Infocomerciales \\
\hline $05: 55$ & Divinity jukebox live \\
\hline $06: 30$ & El zapping de surferos \\
\hline $07: 30$ & Million dollar decorators \\
\hline $08: 15$ & Million dollar decorators \\
\hline $09: 00$ & Mujeres y hombres y viceversa \\
\hline $10: 10$ & Mujeres desesperadas: "Preciosa" \\
\hline $11: 00$ & Mujeres desesperadas: "La persecución" \\
\hline $11: 55$ & Sin cita previa: "Acuérdate de mí" \\
\hline $12: 50$ & Sin cita previa: "El primer paso" \\
\hline $13: 40$ & Sin rastro: "Absalon" \\
\hline $14: 20$ & Sin rastro: "Pelea o huye" \\
\hline $15: 10$ & Caso abierto: "La fuga de Bunny" \\
\hline $16: 10$ & Caso abierto: "Grafiteros" \\
\hline $17: 00$ & Caso abierto: "Metamorfosis" \\
\hline $17: 55$ & La casa de mis sueños \\
\hline $18: 55$ & La casa de mis sueños \\
\hline $19: 55$ & Cámbiame \\
\hline $20: 35$ & Cazamariposas \\
\hline $21: 15$ & Más cazamariposas \\
\hline $21: 55$ & Bella y Bestia: "Boda a toda costa" \\
\hline $22: 35$ & Sin rastro: "22x42" \\
\hline $23: 30$ & Sin rastro: "Última llamada"
\end{tabular}

Jueves 10 de septiembre de 2015

\begin{tabular}{ll}
$00: 25$ & Sin rastro: "Verdadero o falso" \\
\hline $01: 10$ & Sin rastro: "Niño perdido" \\
\hline $01: 55$ & Sin rastro: "Operación de limpieza" \\
\hline $02: 35$ & Sin rastro: "Res ipsa" \\
\hline $03: 15$ & Sin rastro: "Bagaje" \\
\hline $03: 55$ & Sin rastro: "Corre"
\end{tabular}


04:40 Infocomerciales

05:55 Divinity jukebox live

06:30 El zapping de surferos

07:30 Million dollar decorators

08:10 Million dollar decorators

09:00 Mujeres y hombres y viceversa

10:15 Mujeres desesperadas: "Un pasado explosivo"

11:05 Mujeres desesperadas: "Mis dos hombrecitos"

12:00 Sin cita previa: "Si no hubiera olvidado"

12:55 Sin cita previa: "No pares hasta tener suficiente"

13;45 Sin rastro: "Un paso en falso"

14:25 Sin rastro: "Efecto Papa Noel"

15:15 Caso abierto: "Dos bodas"

16:15 Caso abierto: "La caída"

17:05 Caso abierto: "Deflagración"

18:00 La casa de mis sueños

18:50 La casa de mis sueños

19:35 Cámbiame

20:30 Cazamariposas

21:10 Más cazamariposas

21:50 The closer: "Extremaunción"

22:40 The closer: "Respuesta armada"

23:20 The closer: "La última palabra"

Viernes 11 de septiembre de 2015

00:10 The closer: "Pillado"

01:05 The closer: "Tercer delito"

01:50 The closer: "Campos Elíseos"

02:35 The closer: "Suplantación de identidad"

03:15 The closer: "Huele a asesinato"

04:00 The closer: "Instinto maternal"

04:40 Taquilla mediaset

04:45 Infocomerciales

05:55 Divinity jukebox live

06:30 El zapping de surferos

07:15 Revenge: "Penitencia"

07:33 El zapping de surferos

08:15 Million dollar decorators

09:00 Mujeres y hombres y viceversa

10:05 Mujeres desesperadas: "Todos merecemos morir"

11:00 Mujeres desesperadas: "Epifania"

11:50 Sin cita previa: "Quienes somos"

12:45 Sin cita previa: "El giro clave"

13:40 Sin rastro: " $4 \mathrm{~g}$ "

14:20 Sin rastro: "Artículo 32"

15:10 Caso abierto: "El último autocine"

16:05 Caso abierto: "Una bala"

17:00 Caso abierto: "Amor libre"

17:50 La casa de mis sueños 


\begin{tabular}{ll}
$18: 50$ & La casa de mis sueños \\
\hline $19: 50$ & Cámbiame \\
\hline $20: 30$ & Cazamariposas \\
\hline $21: 15$ & Más cazamariposas \\
\hline $21: 50$ & Castle: "Morir de miedo" \\
\hline $22: 30$ & Castle: "Un abogado cadaver" \\
\hline $23: 25$ & Castle: "El contacto"
\end{tabular}

Sábado 12 de septiembre de 2015

\begin{tabular}{|c|c|}
\hline 00:10 & Castle: "El irlandés errante" \\
\hline 01:05 & Castle: "La vida de los otros" \\
\hline $01: 55$ & Castle: "Veloz y peludo" \\
\hline $02: 40$ & Castle: "3XA" \\
\hline 03:20 & Franklin y Bash: "En los tiempos del rock and roll" \\
\hline 04:00 & Franklin y Bash: "Asuntos del corazón” \\
\hline 04:40 & Taquilla mediaset \\
\hline $04: 45$ & Infocomerciales \\
\hline $05: 55$ & Divinity jukebox live \\
\hline $06: 30$ & El zapping de surferos \\
\hline $07: 30$ & Guerra de cupcakes \\
\hline 08:10 & Guerra de cupcakes \\
\hline 08:55 & El zapping de surferos \\
\hline 09:05 & D.Lujo \\
\hline 09:40 & Locos por las compras \\
\hline $10: 25$ & Locos por las compras \\
\hline $11: 15$ & Una boda perfecta \\
\hline $12: 05$ & Una boda perfecta \\
\hline $13: 10$ & Una boda perfecta \\
\hline $14: 00$ & Una boda perfecta \\
\hline 15:00 & Una boda perfecta \\
\hline 16:00 & Una boda perfecta \\
\hline $16: 50$ & Una boda perfecta \\
\hline $17: 45$ & Una boda perfecta \\
\hline $18: 45$ & Castle: "El pichón y la codorniz" \\
\hline 19:40 & Castle: "El factor humano" \\
\hline $20: 15$ & Incluye divinity jukebox \\
\hline $20: 20$ & Castle: "Aguas divididas" \\
\hline $21: 10$ & Castle: "Valkiria" \\
\hline $21: 55$ & Castle: "El mundo de los sueños" \\
\hline $22: 45$ & Ladrón de guante blanco: "Honor entre ladrones" \\
\hline $23: 30$ & Ladrón de guante blanco: "Golpe de gracia" \\
\hline
\end{tabular}

Domingo 13 de septiembre de 2015

\begin{tabular}{ll}
$00: 25$ & Caso abierto: "Justicia" \\
\hline $01: 15$ & Caso abierto: "Familia" \\
\hline $02: 00$ & Caso abierto: "Sabotaje" \\
\hline $02: 40$ & Caso abierto: "Arañas" \\
\hline $03: 30$ & Caso abierto: "Andy en do menor" \\
\hline $04: 10$ & Caso abierto: "La carretera"
\end{tabular}




\begin{tabular}{|c|c|}
\hline 04:50 & Taquilla mediaset \\
\hline $04: 55$ & Infocomerciales \\
\hline $05: 55$ & Divinity jukebox live \\
\hline $06: 30$ & El zapping de surferos \\
\hline 07:30 & Guerra de cupcakes \\
\hline $08: 15$ & Guerra de cupcakes \\
\hline 09:00 & El zapping de surferos \\
\hline $09: 15$ & Tú al centro, yo a las afueras \\
\hline 09:40 & Tú al centro, yo a las afueras \\
\hline $10: 20$ & Tú al centro, yo a las afueras \\
\hline $10: 50$ & Tú al centro, yo a las afueras \\
\hline $11: 15$ & Tú al centro, yo a las afueras \\
\hline $11: 40$ & Tu casa a juicio \\
\hline $12: 30$ & Tu casa a juicio \\
\hline $13: 30$ & Tu casa a juicio \\
\hline $14: 20$ & Tu casa a juicio \\
\hline $15: 20$ & Tu casa a juicio \\
\hline $16: 15$ & Tu casa a juicio \\
\hline $17: 10$ & Tu casa a juicio \\
\hline 18:05 & Castle: "3Xa" \\
\hline $18: 55$ & Castle: "Confidencial" \\
\hline $19: 50$ & Castle: "La fan número uno" \\
\hline $20: 35$ & Castle: "El tiempo lo dirá" \\
\hline $21: 30$ & Castle: "El busca de la pista" \\
\hline $22: 10$ & Castle: "De tal palo, tal astilla" \\
\hline 23:00 & Scandal: "La llave" \\
\hline $23: 45$ & La dama velada: "Aurora" \\
\hline
\end{tabular}

\section{DICIEMBRE 2015 - DIVINITY}

Lunes 7 de diciembre de 2015

\begin{tabular}{ll}
$00: 30$ & Scandal: "Tú no puedes con el mundo" \\
\hline $01: 15$ & Scandal: "Una mujer despreciada" \\
\hline $02: 00$ & Castle: "Una muerte en la familia" \\
\hline $02: 40$ & Castle: "Préstamo mortal" \\
\hline $03: 20$ & Castle: "Doble o nada" \\
\hline $04: 00$ & Castle: "Inventando a la chica" \\
\hline $04: 50$ & Taquilla mediaset \\
\hline $05: 00$ & Infocomerciales \\
\hline $07: 00$ & El zapping de surferos \\
\hline $07: 55$ & Avenida Brasil \\
\hline $08: 40$ & Destilando amor \\
\hline $08: 45$ & El zapping de surferos \\
\hline $09: 35$ & La casa de mis sueños \\
\hline $10: 35$ & La casa de mis sueños \\
\hline $11: 25$ & La casa de mis sueños \\
\hline $12: 25$ & La casa de mis sueños \\
\hline $13: 20$ & La casa de mis sueños \\
\hline $14: 00$ & La casa de mis sueños \\
\hline
\end{tabular}


Castle: "Si me engañas una vez..."

15:40 Castle: "Cuando la rama se rompe"

16:45 Castle: "Érase una vez un crimen"

17:35 Castle: "Bailando con la muerte"

18:20 Castle: "47 segundos"

19:10 Castle: "El inglés"

20:00 Yo quisiera: Ponte al día

20:05 Yo quisiera: Se acerca el certamen

20:45 Gran hermano 16: la casa en directo

21:00 Cazamariposas

21:30 Más cazamariposas

22:10 Gran hermano 16: resumen diario

23:00 The closer: "Quema controlada"

23:55 The closer: "El badén"

Martes 8 de diciembre de 2015

\begin{tabular}{|c|c|}
\hline $00: 45$ & The closer: "Coger cerezas" \\
\hline $01: 25$ & The closer: "Cámara oculta" \\
\hline $02: 15$ & The closer: "Crimen perfecto para provenza" \\
\hline $02: 55$ & The closer: "Niño problemático" \\
\hline $03: 30$ & The closer: "Muerte súbita" \\
\hline $04: 15$ & The closer: "Quema controlada" \\
\hline 05:00 & Taquilla mediaset \\
\hline $05: 10$ & Infocomerciales \\
\hline $07: 10$ & El zapping de surferos \\
\hline $07: 15$ & Avenida Brasil \\
\hline $07: 55$ & Destilando amor \\
\hline $08: 15$ & El zapping de surferos \\
\hline 08:30 & Tú al centro, yo a las afueras \\
\hline $08: 55$ & Tú al centro, yo a las afueras \\
\hline 09:20 & Tú al centro, yo a las afueras \\
\hline 09:45 & Tú al centro, yo a las afueras \\
\hline $10: 10$ & Tú al centro, yo a las afueras \\
\hline $10: 30$ & Tú al centro, yo a las afueras \\
\hline $10: 50$ & Tú al centro, yo a las afueras \\
\hline $11: 15$ & Tu casa a juicio: Vancouver \\
\hline $12: 15$ & Tu casa a juicio: Vancouver \\
\hline $13: 05$ & Tu casa a juicio: Vancouver \\
\hline $14: 05$ & Tu casa a juicio: Vancouver \\
\hline $15: 00$ & Castle: "Fin de semana de vampiros" \\
\hline $15: 40$ & Castle: "Unas últimas palabras muy famosas" \\
\hline $16: 30$ & Castle: "Matar al mensajero" \\
\hline $17: 30$ & Castle: "Cortadores de cabeza" \\
\hline $18: 15$ & Castle: "La vuelta de los muertos vivientes" \\
\hline 19:10 & Castle: "Siempre" \\
\hline $20: 00$ & Yo quisiera: "El certamen. Parte 1" \\
\hline $20: 40$ & Gran hermano 16: la casa en directo \\
\hline 21:00 & Gran hermano 16: resumen diario \\
\hline $21: 45$ & Esperando la navidad: "Un Santa Claus especial" ["my santa" 2013] \\
\hline $23: 05$ & Dcine: "Oz un mundo de fantasía" \\
\hline
\end{tabular}


Miércoles 9 de diciembre de 2015

01:25 Dcine: "Hermosas criaturas" [Richard Lafravenese -2013]

\begin{tabular}{|c|c|}
\hline 03:30 & The closer: "El badén" \\
\hline 04:10 & The closer: "Coger cerezas" \\
\hline 05:00 & Taquilla mediaset \\
\hline 05:05 & Infocomerciales \\
\hline $06: 45$ & El zapping de surferos \\
\hline $07: 10$ & Avenida Brasil \\
\hline $07: 55$ & Destilando amor \\
\hline $08: 45$ & El zapping de surferos \\
\hline 09:10 & Mujeres y hombres y viceversa \\
\hline $09: 35$ & Terapia de choque: "Ahí está la puerta" \\
\hline $10: 30$ & Mujeres desesperadas: “¿Qué haríamos sin ti? \\
\hline $11: 20$ & Mujeres desesperadas: "Hoy me caso" \\
\hline $12: 10$ & Sin cita previa: "El giro clave" \\
\hline $13: 00$ & Sin cita previa: “¿Eres mi madre? \\
\hline $13: 50$ & El cuerpo del delito \\
\hline $14: 30$ & El cuerpo del delito \\
\hline $15: 25$ & Caso abierto: "Masacre" \\
\hline $16: 20$ & Caso abierto: "La guerra en casa" \\
\hline $17: 15$ & Caso abierto: "Barreneros" \\
\hline $18: 15$ & Caso abierto: "Baby blues" \\
\hline 19:05 & Caso abierto: "Salvar a Sammy" \\
\hline 20:00 & Yo quisiera: "El certamen. Parte 2" \\
\hline $20: 45$ & Gran hermano 16: la casa en directo \\
\hline 21:00 & Cazamariposas \\
\hline $21: 30$ & Más cazamariposas \\
\hline $22: 10$ & Gran hermano 16: resumen diario \\
\hline 23:00 & Sin rastro: "Sin ti" \\
\hline $23: 55$ & Sin rastro: "Aguas profundas" \\
\hline
\end{tabular}

Jueves 10 de diciembre de 2015

\begin{tabular}{ll}
$00: 50$ & Sin rastro: “Conexiones" \\
\hline $01: 30$ & Sin rastro: "Candy" \\
\hline $02: 20$ & Sin rastro: "Teléfono de urgencias" \\
\hline $03: 00$ & Sin rastro: "Todos para uno" \\
\hline $03: 40$ & Sin rastro: "El daño hecho" \\
\hline $04: 15$ & Cámbiame \\
\hline $05: 05$ & Taquilla mediaset \\
\hline $05: 15$ & Infocomerciales \\
\hline $07: 30$ & El zapping de surferos \\
\hline $07: 55$ & Avenida Brasil \\
\hline $08: 40$ & Cámbiame \\
\hline $09: 00$ & El zapping de surferos \\
\hline $09: 45$ & Mujeres y hombres y viceversa \\
\hline $10: 40$ & Terapia de choque: "Nadar o hundirse” \\
\hline $11: 35$ & Mujeres desesperadas: "Ahora ya lo sabes" \\
\hline $12: 25$ & Mujeres desesperadas: "Sonrisas de una noche de verano"
\end{tabular}


13:15

Sin cita previa: "Perdiendo batallas"

\begin{tabular}{ll}
\hline 14:00 & El cuerpo del delito \\
\hline $14: 40$ & El cuerpo del delito \\
\hline 15:30 & Caso abierto: "Confusión" \\
\hline 16:25 & Caso abierto: "La llave" \\
\hline $17: 15$ & Caso abierto: "Luciérnagas" \\
\hline $18: 15$ & Caso abierto: "Corazones solitarios" \\
\hline $19: 05$ & Caso abierto: "Azul para siempre" \\
\hline $20: 00$ & Yo quisiera: "El grafiti" \\
\hline $20: 45$ & Gran hermano 16: la casa en directo \\
\hline $21: 00$ & Cazamariposas \\
\hline $21: 35$ & Gran hermano 16: resumen diario \\
\hline $21: 45$ & Dcine: "Midnight sun: una aventura polar" [2014 Roger Spottiswoode] \\
\hline $23: 00$ & Dcine: "Shall we dance? (ibailamos?) [2004 Peter Chelson Produccion]
\end{tabular}

Viernes 11 de diciembre de 2015

\begin{tabular}{|c|c|}
\hline $01: 30$ & Esperando la navidad: "Una casa para navidad" [Gail Harvey 2006] \\
\hline 03:00 & Esperando la navidad: "Un hogar para navidad" [Richard Compton 2005] \\
\hline $04: 30$ & Taquilla mediaset \\
\hline 04:40 & Infocomerciales \\
\hline $06: 40$ & El zapping de surferos \\
\hline 07:20 & Concierto Alejandro Sanz: gira Sirope \\
\hline $08: 45$ & Concierto Pablo Alborán \\
\hline 09:40 & Terapia de choque: "esquivar y protegerse" \\
\hline $10: 35$ & Mujeres desesperadas: "El juego" \\
\hline $11: 30$ & Mujeres desesperadas: "Si hay algo que no puedo soportar..." \\
\hline $12: 25$ & Dcine: “Dance off" [2014 Alex Di Marco] \\
\hline 14:00 & Cinepop: "Buscando a Susan Desesperadamente" [Susan Seidelman 1985] \\
\hline $15: 50$ & Dcine: "Chalet Girl" [2011 Phil Trail] \\
\hline $17: 45$ & Cazamariposas pre-show. Premios 40 principales 2015 \\
\hline 19:00 & Premios 40 principales 2015 \\
\hline $22: 00$ & Blue bloods: Familia de Policías: "La verdad sobre la mentira" \\
\hline $22: 50$ & Blue bloods: Familia de Policías: "Perdido y recuperado" \\
\hline $23: 35$ & Blue bloods: Familia de Policías: "Jóvenes en edad de madurar" \\
\hline
\end{tabular}

Sábado 12 de diciembre de 2015

00:30 Blue bloods: familia de policías: "La encerrona"

\begin{tabular}{ll}
\hline 01:20 & Blue bloods: familia de policías: "Dinero sucio" \\
\hline $02: 10$ & Castle: "Hasta que la muerte nos separe" \\
\hline $02: 50$ & Castle: "Todos contra el alcalde" \\
\hline $03: 30$ & Castle: "Un misterio muy canino" \\
\hline $04: 10$ & Castle: "La mariposa azul" \\
\hline $04: 55$ & Taquilla mediaset \\
\hline $05: 00$ & Infocomerciales \\
\hline $07: 00$ & El zapping de surferos \\
\hline $08: 15$ & Cámbiame \\
\hline $08: 50$ & D.Lujo \\
\hline $09: 20$ & Cámbiame \\
\hline $10: 00$ & La casa de mis sueños
\end{tabular}


$10: 55$

$11: 50$

$12: 45$

13:45

$14: 30$

$15: 25$

$16: 20$

$17: 20$

$18: 15$

19:10

20:00

20:55

$21: 45$

22:30

23:30

La casa de mis sueños

La casa de mis sueños

La casa de mis sueños

La casa de mis sueños

Vender para comprar

Vender para comprar

Vender para comprar

Vender para comprar

Vender para comprar

Castle: "Érase una vez un crimen"

Castle: "Bailando con la muerte"

Castle: "47 segundos"

Castle: "Tras la tormenta"

Castle: "Nuboso con posibilidades de asesinato"

Castle: "El secreto está a salvo conmigo"

Domingo 13 de diciembre de 2015

00:25 Elementary: "La aventura de la solución de nuez moscada"

01:10 Elementary: "La fuerza de la sangre"

02:00 Elementary: "Camaradas"

02:40 Caso abierto: "Casi en el paraíso"

03:20 Caso abierto: "Destruida"

04:00 Caso abierto: "Mirar otra vez"

04:50 Taquilla mediaset

05:00 Infocomerciales

07:00 El zapping de surferos

07:25 Revenge: "Compromiso"

08:10 El zapping de surferos

08:25 Cámbiame

09:00 Tú al centro, yo a las afueras

09:25 Tú al centro, yo a las afueras

09:50 Tú al centro, yo a las afueras

10:15 Tú al centro, yo a las afueras

10:45 Tú al centro, yo a las afueras

11:05 Tu casa a juicio: Vancouver

12:00 Tu casa a juicio: Vancouver

13:00 Tu casa a juicio: Vancouver

14:00 Tu casa a juicio: Vancouver

14:55 Tu casa a juicio: Vancouver

15:40 Tu casa a juicio: Vancouver

16:45 Tu casa a juicio: Vancouver

17:35 Tu casa a juicio: Vancouver

18:25 Tu casa a juicio: Vancouver

19:20 Castle: "El inglés"

20:15 Castle: "Cortadores de cabezas"

21:05 Castle: "La vuelta de los muertos vivientes"

21:55 Castle: "Se ha escrito un crimen"

22:50 Castle: "Causa probable"

23:35 Castle: "La última frontera" 


\section{PROGRAMACIÓN NOVA 2015}

\section{MARZO 2015 - NOVA}

Lunes 16 de marzo de 2015

\begin{tabular}{ll}
$00: 27$ & Bones \\
\hline $01: 11$ & Bones \\
\hline $02: 15$ & Ver cine \\
\hline $02: 20$ & Comprando en casa nova \\
\hline $03: 00$ & Minutos musicales \\
\hline $06: 00$ & Noticias de la mañana \\
\hline $08: 15$ & Bella calamidades \\
\hline $09: 30$ & Érase una vez \\
\hline $10: 30$ & Mar de amor \\
\hline $12: 15$ & Corazón indomable \\
\hline $14: 00$ & Cocina con Bruno \\
\hline $15: 35$ & Karlos Arguiñano en tu cocina \\
\hline $15: 45$ & El color de la pasión \\
\hline $16: 30$ & Abismo de pasión \\
\hline $18: 00$ & Bella calamidades \\
\hline $20: 00$ & Mi corazón es tuyo \\
\hline $20: 45$ & La impostora \\
\hline $21: 15$ & Pasión de gavilanes \\
\hline $22: 40$ & Los miserables \\
\hline
\end{tabular}

Martes 17 de marzo de 2015

\begin{tabular}{ll}
$00: 30$ & Cine: Jackie Brown \\
\hline $03: 00$ & Comprando en casa nova \\
\hline $04: 00$ & Minutos musicales \\
\hline $06: 00$ & Minutos musicales \\
\hline $07: 55$ & English house \\
\hline $08: 00$ & Bella calamidades \\
\hline $09: 30$ & Érase una vez \\
\hline $10: 20$ & Mar de amor \\
\hline $11: 55$ & Corazón indomable \\
\hline $14: 55$ & Cocina con Bruno \\
\hline $14: 55$ & Karlos Arguiñano en tu cocina \\
\hline $15: 40$ & El color de la pasión \\
\hline $16: 35$ & Abismo de pasión \\
\hline $18: 00$ & Bella calamidades \\
\hline $20: 00$ & Mi corazón es tuyo \\
\hline $21: 00$ & La impostora \\
\hline $21: 20$ & Pasión de gavilanes \\
\hline $22: 40$ & Los miserables \\
\hline
\end{tabular}


Miércoles 18 de marzo de 2015

\begin{tabular}{ll}
$00: 35$ & Cine: la mujer de negro \\
\hline $02: 15$ & Comprando en casa nova \\
\hline $03: 15$ & Minutos musicales \\
\hline $06: 00$ & Minutos musicales \\
\hline $08: 05$ & English house \\
\hline $08: 15$ & Bella calamidades \\
\hline $09: 40$ & Érase una vez \\
\hline $10: 30$ & Mar de amor \\
\hline $12: 05$ & Corazón indomable \\
\hline $13: 55$ & Cocina con Bruno \\
\hline $14: 30$ & Karlos Arguiñano en tu cocina \\
\hline $14: 55$ & El color de la pasión \\
\hline $15: 35$ & Abismo de pasión \\
\hline $16: 30$ & Bella calamidades \\
\hline $18: 00$ & Mi corazón es tuyo \\
\hline $20: 00$ & La impostora \\
\hline $20: 50$ & Pasión de gavilanes \\
\hline $21: 15$ & Los miserables \\
\hline
\end{tabular}

Jueves 19 de marzo de 2015

\begin{tabular}{ll}
$00: 12$ & Sin identidad \\
\hline $01: 35$ & Enfermedades embarazosas \\
\hline $02: 10$ & Comprando en casa nova \\
\hline $03: 10$ & Minutos musicales \\
\hline $06: 00$ & Minutos musicales \\
\hline $08: 00$ & English house \\
\hline $08: 05$ & Bella Calamidades \\
\hline $09: 30$ & Érase una vez \\
\hline $10: 20$ & Mar de amor \\
\hline $11: 55$ & Corazón indomable \\
\hline $14: 55$ & Cocina con Bruno \\
\hline $14: 55$ & Karlos Arguiñano en tu cocina \\
\hline $15: 40$ & El color de la pasión \\
\hline $16: 35$ & Abismo de pasión \\
\hline $18: 00$ & Bella calamidades \\
\hline $20: 00$ & Mi corazón es tuyo \\
\hline $20: 55$ & La impostora \\
\hline $21: 15$ & Pasión de gavilanes \\
\hline $22: 40$ & Los miserables \\
\hline
\end{tabular}

Viernes 20 de marzo de 2015

00:45 Cine: el color de la noche

\begin{tabular}{ll}
\hline $03: 05$ & Comprando en casa nova \\
\hline $04: 05$ & Minutos musicales \\
\hline $06: 00$ & Minutos musicales
\end{tabular}




\begin{tabular}{ll}
$08: 00$ & English house \\
\hline $08: 15$ & Bella calamidades \\
\hline $09: 40$ & Érase una vez \\
\hline $10: 30$ & Mar de amor \\
\hline $12: 15$ & Corazón indomable \\
\hline $13: 55$ & Cocina con Bruno \\
\hline $14: 30$ & Karlos Arguiñano en tu cocina \\
\hline $14: 55$ & El color de la pasión \\
\hline $15: 40$ & Abismo de pasión \\
\hline $16: 30$ & Bella calamidades \\
\hline $20: 00$ & Mi corazón es tuyo \\
\hline $20: 55$ & La impostora \\
\hline $21: 20$ & Pasión de gavilanes \\
\hline $22: 45$ & Los miserables \\
\hline $23: 31$ & El mentalista \\
\hline
\end{tabular}

Sábado 21 de marzo de 2015

\begin{tabular}{|c|c|}
\hline $00: 22$ & El mentalista \\
\hline $01: 13$ & El mentalista \\
\hline 02:00 & Comprando en casa nova \\
\hline 03:00 & Minutos musicales \\
\hline 06:00 & Minutos musicales \\
\hline $06: 50$ & Crímenes imperfectos \\
\hline $07: 25$ & Crímenes imperfectos \\
\hline $07: 55$ & Qué me pasa doctor \\
\hline $08: 30$ & Millonario anónimo \\
\hline $09: 15$ & Se alquila \\
\hline $09: 40$ & La tienda tv \\
\hline $10: 00$ & Se alquila \\
\hline $10: 25$ & Pesadilla en la cocina EEUU \\
\hline $11: 15$ & Pesadilla en la cocina EEUU \\
\hline $12: 00$ & Pesadilla en la cocina EEUU \\
\hline $12: 45$ & Pesadilla en la cocina EEUU \\
\hline $13: 55$ & Decogarden \\
\hline $14: 10$ & Decogarden \\
\hline $14: 50$ & Decogarden \\
\hline $15: 30$ & Bricomanía \\
\hline $16: 05$ & Bricomanía \\
\hline $16: 40$ & Bricomanía \\
\hline $17: 05$ & El jefe \\
\hline 18:08 & El jefe \\
\hline $18: 40$ & Casados a primera vista \\
\hline $20: 30$ & Bones \\
\hline $21: 20$ & Bones \\
\hline $22: 10$ & Bones \\
\hline $22: 55$ & Life \\
\hline $23: 46$ & Life \\
\hline
\end{tabular}


Domingo 22 de marzo de 2015

\begin{tabular}{|c|c|}
\hline $00: 32$ & Life \\
\hline $01: 18$ & Life \\
\hline 02:05 & Comprando en casa nova \\
\hline 03:00 & Minutos musicales \\
\hline 06:00 & Minutos musicales \\
\hline $06: 55$ & Crímenes imperfectos \\
\hline $07: 25$ & Crímenes imperfectos \\
\hline $07: 50$ & Crímenes imperfectos \\
\hline 08:00 & Qué me pasa doctor \\
\hline $08: 35$ & Millonario anónimo \\
\hline 09:20 & Objetivo bienestar \\
\hline $09: 55$ & La tienda tv \\
\hline $10: 00$ & Se alquila \\
\hline $10: 30$ & El jefe \\
\hline $11: 15$ & El jefe \\
\hline $12: 00$ & El jefe \\
\hline $12: 45$ & El jefe \\
\hline $13: 50$ & Bricomanía \\
\hline $14: 10$ & Bricomanía \\
\hline $14: 50$ & Bricomanía \\
\hline $15: 30$ & Decogarden \\
\hline $16: 05$ & Decogarden \\
\hline $16: 40$ & Decogarden \\
\hline $17: 15$ & Pesadilla en la cocina EEUU \\
\hline $18: 08$ & Pesadilla en la cocina EEUU \\
\hline 19:00 & Ley y orden: unidad de víctimas especiales \\
\hline $19: 49$ & Ley y orden: unidad de víctimas especiales \\
\hline $20: 38$ & Ley y orden: unidad de víctimas especiales \\
\hline $21: 27$ & Ley y orden: unidad de víctimas especiales \\
\hline $22: 15$ & Bajo sospecha \\
\hline
\end{tabular}

\section{JUNIO 2015 - NOVA}

Lunes 15 de junio de 2015

\begin{tabular}{ll}
$00: 39$ & Bones \\
\hline $01: 27$ & Bones \\
\hline $02: 15$ & Bones \\
\hline $03: 10$ & Comprando en casa nova \\
\hline $04: 10$ & Minutos musicales \\
\hline $06: 00$ & Noticias de la mañana \\
\hline $08: 15$ & Marido en alquiler \\
\hline $10: 15$ & El guardián \\
\hline $11: 00$ & Sortilegio \\
\hline $12: 45$ & Lo que la vida me robó \\
\hline $14: 00$ & Cocina con Bruno \\
\hline $14: 35$ & Karlos Arguiñano en tu cocina \\
\hline $15: 05$ & La sombra del pasado \\
\hline $15: 45$ & El color de la pasión
\end{tabular}




\begin{tabular}{ll}
\hline $18: 00$ & Marido en alquiler \\
\hline $20: 00$ & Muchacha italiana viene a casarse \\
\hline $20: 40$ & La impostora \\
\hline $21: 10$ & Tierra de reyes \\
\hline $22: 40$ & Cine supernova: Pearl Harbor
\end{tabular}

Martes 16 de junio de 2015

\begin{tabular}{ll} 
01:45 & Cine: Beloved \\
\hline $04: 30$ & Minutos musicales \\
\hline $06: 00$ & Minutos musicales \\
\hline $08: 00$ & Marido en alquiler \\
\hline 09:45 & El Guardián \\
\hline 10:40 & Sortilegio \\
\hline $12: 40$ & Lo que la vida me robó \\
\hline $13: 50$ & Cocina con Bruno \\
\hline $14: 30$ & Karlos Arguiñano en tu cocina \\
\hline $14: 55$ & La sombra del pasado \\
\hline $15: 40$ & El color de la pasión \\
\hline $16: 55$ & Emperatriz \\
\hline $18: 00$ & Marido en alquiler \\
\hline $20: 00$ & Muchacha italiana viene a casarse \\
\hline $20: 50$ & La impostora \\
\hline $21: 25$ & Tierra de Reyes \\
\hline $22: 50$ & Cine supernova: Cautiva
\end{tabular}

Miércoles 17 de junio de 2015

00:30 Cine: el precio de la infidelidad

\begin{tabular}{ll}
\hline $02: 15$ & Comprando en casa nova \\
\hline $03: 15$ & Minutos musicales \\
\hline $06: 00$ & Minutos musicales \\
\hline $08: 00$ & Marido en alquiler \\
\hline $09: 45$ & El guardián \\
\hline $10: 40$ & Sortilegio \\
\hline $12: 40$ & Lo que la vida me robó \\
\hline $13: 50$ & Cocina con Bruno \\
\hline $14: 30$ & Karlos Arguiñano en tu cocina \\
\hline $14: 55$ & La sombra del pasado \\
\hline $16: 40$ & El color de la pasión \\
\hline $18: 05$ & Emperatriz \\
\hline $20: 00$ & Marido en alquiler \\
\hline $20: 55$ & Muchacha italiana viene a casarse \\
\hline $21: 25$ & La impostora \\
\hline $22: 45$ & Tierra de reyes \\
\hline
\end{tabular}

Jueves 18 de junio de 2015

00:40

Cine: África en el corazón 


\begin{tabular}{ll}
\hline $02: 20$ & Comprando en casa nova \\
\hline $03: 20$ & Minutos musicales \\
\hline $06: 00$ & Minutos musicales \\
\hline $08: 15$ & Marido en alquiler \\
\hline $10: 15$ & El guardián \\
\hline $11: 00$ & Sortilegio \\
\hline $12: 45$ & Lo que la vida me robó \\
\hline $14: 00$ & Cocina con Bruno \\
\hline $15: 35$ & Karlos Arguiñano en tu cocina \\
\hline $15: 45$ & La sombra del pasado \\
\hline $16: 45$ & El color de la pasión \\
\hline $18: 00$ & Emperatriz \\
\hline $20: 00$ & Marido en alquiler \\
\hline $20: 40$ & Muchacha italiana viene a casarse \\
\hline $21: 00$ & La impostora \\
\hline $22: 40$ & Tierra de reyes \\
\hline
\end{tabular}

Viernes 19 de junio de 2015

\begin{tabular}{ll}
$00: 15$ & Cine: La sombra de los otros \\
\hline $02: 25$ & Comprando en casa nova \\
\hline $03: 25$ & Minutos musicales \\
\hline $06: 00$ & Minutos musicales \\
\hline $08: 00$ & Marido en alquiler \\
\hline 09:45 & El guardián \\
\hline $10: 40$ & Sortilegio \\
\hline $13: 40$ & Lo que la vida me robó \\
\hline $14: 30$ & Cocina con Bruno \\
\hline $14: 55$ & Karlos Arguiñano en tu cocina \\
\hline $15: 40$ & La sombra del pasado \\
\hline $16: 50$ & El color de la pasión \\
\hline $18: 05$ & Emperatriz \\
\hline $20: 00$ & Marido en alquiler \\
\hline $20: 55$ & Muchacha italiana viene a casarse \\
\hline $21: 20$ & La impostora \\
\hline $22: 25$ & Tierra de reyes \\
\hline $23: 21$ & Perception \\
\hline
\end{tabular}

Sábado 20 de junio de 2015

\begin{tabular}{ll}
$00: 03$ & Perception \\
\hline $00: 43$ & Perception \\
\hline $01: 24$ & Perception \\
\hline $02: 40$ & Comprando en casa nova \\
\hline $03: 40$ & Minutos musicales \\
\hline $06: 00$ & Minutos musicales \\
\hline $06: 45$ & Crímenes imperfectos \\
\hline $07: 15$ & Crímenes imperfectos \\
\hline $07: 50$ & Qué me pasa doctor
\end{tabular}




\begin{tabular}{ll}
$08: 30$ & Millonario anónimo \\
\hline $09: 15$ & Se alquila \\
\hline $09: 40$ & La tienda tv \\
\hline $10: 00$ & El jefe \\
\hline $10: 45$ & El jefe \\
\hline $11: 40$ & El jefe \\
\hline $13: 35$ & El jefe \\
\hline $14: 25$ & Hoy cocinas tú \\
\hline $15: 00$ & Decogarden \\
\hline $15: 25$ & Decogarden \\
\hline $16: 15$ & Bricomanía \\
\hline $18: 30$ & Bricomanía \\
\hline $19: 25$ & Mi casa como nueva \\
\hline $20: 50$ & Pesadilla en la cocina \\
\hline $22: 25$ & Pesadilla en la cocina \\
\hline $23: 01$ & Pesadilla en la cocina \\
\hline $23: 47$ & Ley y orden: unidad de víctimas especiales \\
\hline
\end{tabular}

Domingo 21 de junio de 2015

00:33 Ley y orden: unidad de víctimas especiales

\begin{tabular}{|c|c|}
\hline 01:19 & Ley y orden: unidad de víctimas especiales \\
\hline 03:10 & Comprando en casa nova \\
\hline 04:10 & Minutos musicales \\
\hline 06:00 & Minutos musicales \\
\hline 07:05 & Crímenes imperfectos \\
\hline $07: 25$ & Crímenes imperfectos \\
\hline $07: 50$ & Crímenes imperfectos \\
\hline $08: 15$ & Qué me pasa doctor \\
\hline 08:45 & Millonario anónimo \\
\hline 09:30 & Objetivo bienestar \\
\hline 09:45 & La tienda tv \\
\hline $10: 05$ & Pesadilla en la cocina EEUU \\
\hline $10: 45$ & Pesadilla en la cocina EEUU \\
\hline $11: 40$ & Pesadilla en la cocina EEUU \\
\hline $13: 30$ & Hoy cocinas tú \\
\hline $14: 20$ & Bricomanía \\
\hline $14: 50$ & Bricomanía \\
\hline $15: 10$ & Bricomanía \\
\hline $15: 45$ & Decogarden \\
\hline $16: 00$ & Decogarden \\
\hline $16: 30$ & Decogarden \\
\hline $17: 30$ & Mi casa como nueva \\
\hline $18: 25$ & El jefe infiltrado \\
\hline $19: 25$ & El jefe infiltrado \\
\hline $20: 50$ & El jefe infiltrado \\
\hline $22: 20$ & Bones \\
\hline 23:01 & Bones \\
\hline $23: 47$ & Bones \\
\hline
\end{tabular}




\section{SEPTIEMBRE 2015 - NOVA}

Lunes 14 de septiembre de 2015

\begin{tabular}{ll}
$00: 24$ & Bones \\
\hline $01: 07$ & Bones \\
\hline $01: 50$ & Bones \\
\hline $03: 10$ & Teletienda club \\
\hline $04: 10$ & Minutos musicales \\
\hline $06: 00$ & Noticias de la mañana \\
\hline $09: 55$ & Cuidado con el ángel \\
\hline $10: 25$ & Marido en alquiler \\
\hline $11: 20$ & Muchacha italiana viene a casarse \\
\hline $12: 40$ & Amor bravío \\
\hline $13: 55$ & Lo que la vida me robó \\
\hline $14: 30$ & Cocina con Bruno \\
\hline $14: 55$ & Karlos Arguiñano en tu cocina \\
\hline $15: 50$ & El cuerpo del deseo \\
\hline $16: 45$ & La sombra del pasado \\
\hline $17: 40$ & La viuda de blanco \\
\hline $19: 20$ & Cuidado con el ángel \\
\hline $20: 00$ & Marido en alquiler \\
\hline $21: 05$ & Muchacha italiana viene a casarse \\
\hline $22: 40$ & Tierra de reyes \\
\hline
\end{tabular}

Martes 15 de septiembre de 2015

\begin{tabular}{ll}
$00: 13$ & El tiempo entre costuras \\
\hline $02: 00$ & Cine: Acoso en la red social \\
\hline $03: 00$ & Teletienda club \\
\hline $04: 00$ & Minutos musicales \\
\hline $06: 00$ & Minutos musicales \\
\hline $08: 00$ & Cuidado con el ángel \\
\hline $09: 45$ & Marido en alquiler \\
\hline $10: 05$ & Muchacha italiana viene a casarse \\
\hline $11: 05$ & Amor bravío \\
\hline $13: 40$ & Lo que la vida me robó \\
\hline $14: 35$ & Cocina con Bruno \\
\hline $14: 55$ & Karlos Arguiñano en tu cocina \\
\hline $15: 50$ & El cuerpo del deseo \\
\hline $16: 40$ & La sombra del pasado \\
\hline $17: 40$ & La viuda de blanco \\
\hline $19: 25$ & Cuidado con el ángel \\
\hline $20: 00$ & Marido en alquiler \\
\hline $21: 05$ & Muchacha italiana viene a casarse \\
\hline $22: 40$ & Tierra de reyes \\
\hline
\end{tabular}


Miércoles 16 de septiembre de 2015

\begin{tabular}{ll}
$00: 15$ & Cine: Susurros en el desierto (jorg grunler) \\
\hline $02: 15$ & Cine: El secreto de la selva negra (thorsten nater) \\
\hline $03: 30$ & Teletienda club \\
\hline $04: 30$ & Minutos musicales \\
\hline $06: 00$ & Minutos musicales \\
\hline $08: 00$ & Cuidado con el ángel \\
\hline $09: 45$ & Marido en alquiler \\
\hline $10: 20$ & Muchacha italiana viene a casarse \\
\hline $12: 40$ & Amor bravío \\
\hline $13: 55$ & Lo que la vida me robó \\
\hline $14: 30$ & Cocina con Bruno \\
\hline $14: 55$ & Karlos Arguiñano en tu cocina \\
\hline $15: 50$ & El cuerpo del deseo \\
\hline $16: 40$ & La sombra del pasado \\
\hline $17: 40$ & La viuda de blanco \\
\hline $19: 25$ & Cuidado con el ángel \\
\hline $20: 00$ & Marido en alquiler \\
\hline $21: 05$ & Muchacha italiana viene a casarse \\
\hline $22: 40$ & Tierra de reyes \\
\hline
\end{tabular}

Jueves 17 de septiembre de 2015

\begin{tabular}{ll}
$00: 15$ & Cine: Marea letal \\
\hline $02: 15$ & Cine: La ayudante perfecta \\
\hline $03: 40$ & Teletienda club \\
\hline $04: 40$ & Minutos musicales \\
\hline $06: 00$ & Minutos musicales \\
\hline $08: 00$ & Cuidados con el ángel \\
\hline $09: 45$ & Marido en alquiler \\
\hline $10: 15$ & Muchacha italiana viene a casarse \\
\hline $11: 05$ & Amor bravío \\
\hline $13: 05$ & Lo que la vida me robó \\
\hline $13: 50$ & Cocina con Bruno \\
\hline $14: 30$ & Karlos Arguiñano en tu cocina \\
\hline $15: 50$ & El cuerpo del deseo \\
\hline $16: 40$ & La sombra del pasado \\
\hline $18: 15$ & La viuda de blanco \\
\hline $19: 25$ & Cuidado con el ángel \\
\hline $20: 00$ & Marido en alquiler \\
\hline $21: 05$ & Muchacha italiana viene a casarse \\
\hline $22: 45$ & Tierra de reyes \\
\hline $23: 18$ & Forever \\
\hline $23: 56$ & Forever \\
\hline
\end{tabular}


Viernes 18 de septiembre de 2015

\begin{tabular}{ll}
\hline $00: 34$ & Forever \\
\hline $01: 12$ & Forever \\
\hline $01: 50$ & Forever \\
\hline $03: 20$ & Teletienda club \\
\hline $04: 20$ & Minutos musicales \\
\hline $06: 00$ & Minutos musicales \\
\hline $09: 45$ & Cuidado con el ángel \\
\hline $10: 14$ & Marido en alquiler \\
\hline $11: 05$ & Muchacha italiana viene a casarse \\
\hline $12: 40$ & Amor bravío \\
\hline $13: 55$ & Lo que la vida me robó \\
\hline $14: 30$ & Cocina con Bruno \\
\hline $14: 55$ & Karlos Arguiñano en tu cocina \\
\hline $15: 55$ & El cuerpo del deseo \\
\hline $16: 40$ & La sombra del pasado \\
\hline $17: 40$ & La viuda de blanco \\
\hline 19:25 & Cuidado con el ángel \\
\hline $20: 00$ & Marido en alquiler \\
\hline $22: 05$ & Muchacha italiana viene a casarse \\
\hline $23: 18$ & Tierra de reyes \\
\hline
\end{tabular}

Sábado 19 de septiembre de 2015

\begin{tabular}{ll}
\hline $00: 34$ & Perception \\
\hline $01: 12$ & Perception \\
\hline $01: 50$ & Perception \\
\hline $02: 50$ & Teletienda club \\
\hline $03: 50$ & Minutos musicales \\
\hline $06: 00$ & Minutos musicales \\
\hline $06: 50$ & Crímenes imperfectos \\
\hline $07: 25$ & Crímenes imperfectos \\
\hline $07: 40$ & Crímenes imperfectos \\
\hline $08: 30$ & Qué me pasa doctor \\
\hline $09: 20$ & Millonario anónimo \\
\hline $09: 45$ & Se alquila \\
\hline $10: 05$ & La tienda tv \\
\hline $10: 55$ & Hoy cocinas tú \\
\hline $11: 49$ & Top chef(USA) \\
\hline $12: 38$ & Top chef (USA) \\
\hline $13: 30$ & Top chef(USA) \\
\hline $13: 35$ & B a la moda \\
\hline $13: 50$ & Decogarden \\
\hline $14: 35$ & Decogarden \\
\hline $15: 23$ & Bricomanía \\
\hline $15: 40$ & Bricomanía \\
\hline
\end{tabular}




\begin{tabular}{ll} 
18:00 & Pesadilla en la cocina \\
\hline $19: 35$ & Pesadilla en la cocina \\
\hline $20: 55$ & Pesadilla en la cocina \\
\hline $22: 20$ & Ley y orden: unidad de víctimas especiales \\
\hline $22: 58$ & Ley y orden: unidad de víctimas especiales \\
\hline $23: 41$ & Ley y orden: unidad de víctimas especiales
\end{tabular}

Domingo 20 de septiembre de 2015

\begin{tabular}{|c|c|}
\hline 00:24 & Ley y orden: unidad de víctimas especiales \\
\hline 01:07 & Ley y orden: unidad de víctimas especiales \\
\hline 01:50 & Ley y orden: unidad de víctimas especiales \\
\hline 03:10 & Teletienda club \\
\hline $04: 10$ & Minutos musicales \\
\hline 06:00 & Minutos musicales \\
\hline 06:50 & Crímenes imperfectos \\
\hline 07:05 & Crímenes imperfectos \\
\hline 07:30 & Crímenes imperfectos \\
\hline 07:55 & Qué me pasa doctor \\
\hline 08:30 & Millonario anónimo \\
\hline 09:15 & Objetivo bienestar \\
\hline 09:30 & La tienda tv \\
\hline 09:50 & Hoy cocinas tú \\
\hline $10: 45$ & Top chef(USA) \\
\hline $11: 49$ & Top chef(USA) \\
\hline $12: 38$ & Top chef(USA) \\
\hline $13: 27$ & Top chef(USA) \\
\hline $14: 05$ & Bricomanía \\
\hline $14: 40$ & Bricomanía \\
\hline $15: 05$ & Bricomanía \\
\hline $15: 50$ & Decogarden \\
\hline $16: 15$ & Decogarden \\
\hline $17: 25$ & El jefe infiltrado \\
\hline $18: 19$ & El jefe infiltrado \\
\hline $19: 38$ & El jefe infiltrado \\
\hline $20: 57$ & El jefe infiltrado \\
\hline $22: 25$ & Bones \\
\hline $22: 58$ & Bones \\
\hline $23: 41$ & Bones \\
\hline
\end{tabular}

\section{DICIEMBRE 2015 - NOVA}

Lunes 14 de diciembre de 2015

\begin{tabular}{ll}
$00: 39$ & Bones \\
\hline $01: 27$ & Bones \\
\hline $02: 15$ & Nova sound \\
\hline $02: 30$ & De compras en nova \\
\hline $03: 30$ & Minutos musicales \\
\hline $06: 00$ & Noticias de la mañana \\
\hline $08: 15$ & Cuidado con el ángel
\end{tabular}


Yo no creo en los hombres

\begin{tabular}{ll}
\hline $11: 00$ & Muchacha italiana viene a casarse \\
\hline $11: 45$ & La gata \\
\hline $12: 30$ & Cuando me enamoro \\
\hline $14: 00$ & Cocina con Bruno \\
\hline $14: 35$ & Karlos Arguiñano en tu cocina \\
\hline $15: 00$ & La patrona \\
\hline $15: 45$ & El cuerpo del deseo \\
\hline $16: 45$ & La viuda de blanco \\
\hline $18: 00$ & Esperanza mía \\
\hline 19:00 & Cuidado con el ángel \\
\hline $20: 00$ & Yo no creo en los hombres \\
\hline $21: 25$ & Muchacha italiana viene a casarse \\
\hline $21: 50$ & El señor de los cielos \\
\hline $22: 35$ & Tu cara me suena
\end{tabular}

Martes 15 de diciembre de 2015

\begin{tabular}{ll} 
03:15 & De compras en nova \\
\hline $04: 15$ & Minutos musicales \\
\hline $06: 00$ & Minutos musicales \\
\hline $08: 00$ & Esperanza mía \\
\hline 09:30 & Cuidado con el ángel \\
\hline $10: 15$ & Yo no creo en los hombres \\
\hline $11: 25$ & Muchacha italiana viene a casarse \\
\hline $12: 10$ & La gata \\
\hline $12: 40$ & Cuando me enamoro \\
\hline $14: 05$ & Cocina con Bruno \\
\hline $14: 40$ & Karlos Arguiñano en tu cocina \\
\hline $15: 05$ & La patrona \\
\hline $15: 40$ & El cuerpo del deseo \\
\hline $16: 45$ & La viuda de blanco \\
\hline $18: 00$ & Esperanza mía \\
\hline $19: 10$ & Cuidado con el ángel \\
\hline $20: 00$ & Yo no creo en los hombres \\
\hline $21: 50$ & Muchacha italiana viene a casarse \\
\hline $21: 55$ & El señor de los cielos \\
\hline $22: 45$ & Noche de película: nunca más [2002, Michael Apted]
\end{tabular}

Miércoles 16 de diciembre de 2015

00:55 Cine: Al cruzar el límite [Michael apted, 1996]

\begin{tabular}{ll}
\hline $02: 55$ & De compras en nova \\
\hline $03: 55$ & Minutos musicales \\
\hline $06: 00$ & Minutos musicales \\
\hline $08: 00$ & Esperanza mía \\
\hline $09: 10$ & Cuidado con el ángel \\
\hline $09: 50$ & Yo no creo en los hombres \\
\hline $11: 00$ & Muchacha italiana viene a casarse \\
\hline $11: 40$ & La gata \\
\hline $12: 40$ & Cuando me enamoro
\end{tabular}




\begin{tabular}{ll}
$14: 00$ & Cocina con Bruno \\
\hline $14: 30$ & Karlos Arguiñano en tu cocina \\
\hline $15: 05$ & La patrona \\
\hline $15: 40$ & El cuerpo del deseo \\
\hline $16: 45$ & La viuda de blanco \\
\hline $17: 55$ & Esperanza mía \\
\hline $19: 00$ & Cuidado con el ángel \\
\hline $20: 00$ & Yo no creo en los hombres \\
\hline $21: 05$ & Muchacha italiana viene a casarse \\
\hline $21: 55$ & El señor de los cielos \\
\hline $22: 45$ & Navidades nova: una esposa para papá [Jason Priestley 2001]
\end{tabular}

Jueves 17 de diciembre de 2015

00:30 Navidades nova: buscando a Santa desesperadamente [Craig Pryce 2011]

02:05 Navidades nova: regalo de cumpleaños [Mikael Salomon 2008]

03:30 De compras en nova

04:30 Minutos musicales

06:00 Minutos musicales

08:00 Esperanza mía

09:15 Cuidado con el ángel

09:55 Yo no creo en los hombres

11:00 Muchacha italiana viene a casarse

11:50 La gat

12:40 Cuando me enamoro

14:00 Cocina con Bruno

14:35 Karlos Arguiñano en tu cocina

15:05 La patrona

15:45 El cuerpo del deseo

16:45 La viuda de blanco

17:55 Esperanza mía

19:10 Cuidado con el ángel

20:00 Yo no creo en los hombres

21:05 Muchacha italiana viene a casarse

21:55 El señor de los cielos

22:45 Cine supernova: contra su voluntad [Michael Feifer, 2013]

Viernes 18 de diciembre de 2015

00:20 Cine: La hija del éxito [Jonathan M. Levine - 2013]

01:40 Cine: Un lugar seguro [Mark Griffiths - 2006]

03:15 De compras en Nova

04:15 Minutos musicales

06:00 Minutos musicales

08:00 Esperanza mía

09:15 Cuidado con el ángel

09:55 Yo no creo en los hombres

11:00 Muchacha italiana viene a casarse

\begin{tabular}{ll}
\hline $11: 45$ & La gata \\
\hline $12: 40$ & Cuando me enamoro
\end{tabular}




\begin{tabular}{ll}
\hline $15: 05$ & La patrona \\
\hline $15: 40$ & El cuerpo del deseo \\
\hline $16: 45$ & La viuda de blanco \\
\hline $18: 00$ & Esperanza mía \\
\hline 19:00 & Cuidado con el ángel \\
\hline $20: 00$ & Yo no creo en los hombres \\
\hline $20: 50$ & Muchacha italiana viene a casarse \\
\hline $21: 30$ & El señor de los cielos \\
\hline $22: 30$ & El mentalista \\
\hline $23: 23$ & El mentalista
\end{tabular}

Sábado 19 de diciembre de 2015

\begin{tabular}{ll}
$00: 06$ & El mentalista \\
\hline $00: 40$ & El mentalista \\
\hline $01: 32$ & El mentalista \\
\hline $02: 15$ & El mentalista \\
\hline $03: 10$ & De compras en nova \\
\hline $04: 10$ & Minutos musicales \\
\hline $06: 00$ & Minutos musicales \\
\hline $07: 10$ & Crímenes imperfectos \\
\hline $07: 25$ & Crímenes imperfectos \\
\hline $08: 20$ & Crímenes imperfectos \\
\hline $08: 55$ & Qué me pasa doctor \\
\hline $09: 08$ & Se alquila \\
\hline $09: 45$ & Se alquila \\
\hline $10: 05$ & La tienda tv \\
\hline $10: 20$ & Corto: Beta [gas natural y atresmedia - Anabel Alonso...] \\
\hline $10: 56$ & El jefe \\
\hline $11: 42$ & El jefe \\
\hline $12: 28$ & El jefe \\
\hline $13: 14$ & El jefe \\
\hline $13: 45$ & El jefe \\
\hline $14: 15$ & Decogarden \\
\hline $14: 40$ & Decogarden \\
\hline $15: 10$ & Bricomanía \\
\hline $17: 15$ & Pesadilla en la cocina \\
\hline $19: 30$ & Pesadilla en la cocina \\
\hline $21: 45$ & Pesadilla en la cocina \\
\hline $23: 30$ & Ley y orden: Unidad de víctimas especiales \\
\hline & Ley y orden: Unidad de víctimas especiales \\
\hline 0 & \\
\hline 0 & Ley orden: Unidad de víctimas especiales \\
\hline 0
\end{tabular}

Domingo 20 de diciembre de 2015

\begin{tabular}{ll}
$00: 00$ & Ley y orden: Unidades de víctimas especiales \\
\hline $00: 45$ & Ley y orden: Unidades de víctimas especiales \\
\hline $01: 30$ & Ley y orden: Unidades de víctimas especiales \\
\hline $02: 15$ & Ley y orden: Unidades de víctimas especiales \\
\hline $03: 10$ & De compras en Nova
\end{tabular}




\begin{tabular}{ll}
\hline $04: 10$ & Minutos musicales \\
\hline $06: 00$ & Minutos musicales \\
\hline $07: 25$ & Crímenes imperfectos \\
\hline $07: 40$ & Crímenes imperfectos \\
\hline $07: 50$ & Crímenes imperfectos \\
\hline $08: 30$ & Qué me pasa doctor \\
\hline $09: 05$ & Se alquila \\
\hline $09: 35$ & Objetivo bienestar \\
\hline $10: 10$ & La tienda tv \\
\hline $10: 25$ & Cocineros españoles por el mundo \\
\hline $11: 10$ & Cocineros españoles por el mundo \\
\hline $14: 35$ & Pesadilla en la cocina EEUU \\
\hline $15: 05$ & Bricomania \\
\hline $16: 00$ & Escuela de decoración \\
\hline $16: 30$ & Decogarden \\
\hline $17: 45$ & El jefe infiltrado \\
\hline $19: 00$ & El jefe infiltrado \\
\hline $20: 15$ & El jefe infiltrado \\
\hline $21: 45$ & El jefe infiltrado \\
\hline $22: 15$ & Bones \\
\hline $23: 00$ & Bones \\
\hline $23: 45$ & Bones \\
\hline
\end{tabular}




\section{PROGRAMACIÓN DISCOVERY MAX 2015}

\section{MARZO 2015 - DISCOVERY MAX}

Lunes 23 de marzo de 2015

\begin{tabular}{|c|c|}
\hline $00: 20$ & Control de aduanas, Canadá \\
\hline 00:50 & Control de aduanas \\
\hline $01: 15$ & Control de aduanas \\
\hline 01:40 & Control de aduanas \\
\hline $02: 10$ & Asesinos en serie \\
\hline 03:00 & Perfil de un psicópata \\
\hline 03:45 & Desaparecidos \\
\hline 04:30 & El asesino de al lado \\
\hline $05: 15$ & El asesino de al lado \\
\hline 06:00 & ¿Cómo lo hacen? \\
\hline $06: 25$ & Te lo dije \\
\hline 07:10 & Monstruos de río \\
\hline 08:00 & Aventura en pelotas \\
\hline 08:45 & El último superviviente \\
\hline 09:35 & El último superviviente \\
\hline $10: 20$ & Dúo de supervivientes \\
\hline $11: 10$ & Monstruos de río \\
\hline $12: 00$ & Wild Frank \\
\hline $12: 55$ & Trato hecho \\
\hline $13: 20$ & Trato hecho \\
\hline $13: 50$ & Pareja a la puja \\
\hline $14: 15$ & Pareja a la puja \\
\hline $14: 45$ & Cazasubastas \\
\hline $15: 15$ & Cazasubastas \\
\hline $15: 45$ & Grandes civilizaciones \\
\hline $16: 40$ & Asedio al castillo con Dan Snow \\
\hline $17: 40$ & Cazasubastas \\
\hline 18:05 & Cazasubastas \\
\hline $18: 35$ & Pareja a la puja \\
\hline 19:05 & Pareja a la puja \\
\hline $19: 35$ & Fast n'loud \\
\hline $20: 30$ & Joyas sobre ruedas \\
\hline $21: 30$ & ¿Cómo lo hacen? \\
\hline $22: 00$ & ¿Cómo lo hacen? \\
\hline $22: 30$ & Subastas sobre ruedas \\
\hline $23: 30$ & Fast n'loud \\
\hline
\end{tabular}

Martes 24 de marzo de 2015

\begin{tabular}{ll}
$00: 25$ & Fast n'loud \\
\hline $01: 20$ & Fast n'loud \\
\hline $02: 10$ & El último superviviente \\
\hline $03: 00$ & El último superviviente \\
\hline $03: 45$ & Fuerzas de la naturaleza \\
\hline $04: 30$ & Fuerzas de la naturaleza
\end{tabular}


05:15

06:00

06:25

07:10

08:00

08:45

09:35

10:20

11:10

12:00

12:55

13:20

13:50

$14: 15$

14:45

$15: 15$

$15: 45$

$16: 40$

$17: 40$

18:05

$18: 35$

19:05

19:35

20:30

21:30

22:00

22:30

23:30

Cómo funciona la Tierra

¿Cómo lo hacen?

Te lo dije

Monstruos de río

Aventura en pelotas

El último superviviente

El último superviviente

Dúo de supervivientes

Monstruos de río

Wild Frank

Trato hecho

Trato hecho

Pareja a la puja

Pareja a la puja

Cazasubastas

Cazasubastas

Grandes civilizaciones

Asedio al castillo con Dan Snow

Cazasubastas

Cazasubastas

Pareja a la puja

Pareja a la puja

Fast n'loud

Joyas sobre ruedas

¿Cómo lo hacen?

¿Cómo lo hacen?

Amazonas clandestino

Amazonas clandestino

Miércoles 25 de marzo de 2015

\begin{tabular}{ll}
$00: 25$ & Norte América \\
\hline $01: 20$ & Norte América \\
\hline $02: 10$ & Ross Kemp: Lucha por el Amazonas \\
\hline $03: 00$ & Antiguas superestructuras \\
\hline $03: 45$ & Asedio al castillo con Dan Snow \\
\hline $04: 30$ & iQué no cunda el pánico! \\
\hline $05: 15$ & iQué no cunda el pánico! \\
\hline $06: 00$ & ¿Cómo lo hacen? \\
\hline $06: 25$ & Te lo dije \\
\hline $07: 10$ & Monstruos de río \\
\hline $08: 00$ & Aventura en pelotas \\
\hline $08: 45$ & El último superviviente \\
\hline $09: 35$ & El último superviviente \\
\hline $10: 20$ & Dúo de supervivientes \\
\hline $11: 10$ & Monstruos de río \\
\hline $12: 00$ & Wild Frank \\
\hline $12: 55$ & Trato hecho \\
\hline $13: 20$ & Trato hecho \\
\hline $13: 50$ & Pareja a la puja \\
\hline $14: 15$ & Pareja a la puja
\end{tabular}




\begin{tabular}{ll}
$14: 45$ & Cazasubastas \\
\hline $15: 15$ & Cazasubastas \\
\hline $15: 45$ & Grandes civilizaciones \\
\hline $16: 40$ & Asedio al castillo con Dan Snow \\
\hline $17: 40$ & Cazasubastas \\
\hline $18: 05$ & Cazasubastas \\
\hline $18: 35$ & Pareja a la puja \\
\hline $19: 05$ & Pareja a la puja \\
\hline $20: 35$ & Fast n'loud \\
\hline $21: 30$ & Joyas sobre ruedas \\
\hline $22: 00$ & ¿Cómo lo hacen? \\
\hline $22: 30$ & ¿Cómo lo hacen? \\
\hline $23: 30$ & Desmontando al cosmos \\
\hline
\end{tabular}

Jueves 26 de marzo de 2015

\begin{tabular}{|c|c|}
\hline $00: 25$ & Alienígenas: caso abierto \\
\hline $00: 50$ & Alienígenas: caso abierto \\
\hline $01: 20$ & Alienígenas: caso abierto \\
\hline 01:45 & Alienígenas: caso abierto \\
\hline $02: 10$ & Titanes mecánicos \\
\hline 03:00 & Megatraslados \\
\hline $03: 45$ & Super yates \\
\hline $04: 30$ & Ed Stafford: solo en la isla \\
\hline $05: 15$ & Ed Stafford: solo en la isla \\
\hline 06:00 & ¿Cómo lo hacen? \\
\hline $06: 25$ & Te lo dije \\
\hline $07: 10$ & Monstruos de río \\
\hline 08:00 & Aventura en pelotas \\
\hline 08:45 & El último superviviente \\
\hline $09: 35$ & El último superviviente \\
\hline $10: 20$ & Dúo de supervivientes \\
\hline $11: 10$ & Monstruos de río \\
\hline $12: 00$ & Wild Frank \\
\hline $12: 55$ & Trato hecho \\
\hline $13: 20$ & Trato hecho \\
\hline $13: 50$ & Pareja a la puja \\
\hline $14: 15$ & Pareja a la puja \\
\hline $14: 45$ & Cazasubastas \\
\hline $15: 15$ & Cazasubastas \\
\hline $15: 45$ & Caballeros medievales \\
\hline $16: 40$ & Asedio al castillo con Dan Snow \\
\hline $17: 40$ & Cazasubastas \\
\hline $18: 05$ & Cazasubastas \\
\hline $18: 35$ & Pareja a la puja \\
\hline 19:05 & Pareja a la puja \\
\hline $19: 35$ & Fast n'loud \\
\hline $20: 30$ & Joyas sobre ruedas \\
\hline $21: 30$ & ¿Cómo lo hacen? \\
\hline $22: 00$ & ¿Cómo lo hacen? \\
\hline
\end{tabular}


Viernes 27 de marzo de 2015

\begin{tabular}{ll}
$00: 25$ & El infierno de la Primera Guerra Mundial \\
\hline $01: 20$ & El infierno de la Primera Guerra Mundial \\
\hline $02: 10$ & El infierno de la Primera Guerra Mundial \\
\hline $03: 00$ & Macabro, pero cierto \\
\hline $03: 45$ & La historia del Universo \\
\hline $04: 30$ & La historia del Universo \\
\hline $05: 15$ & Piscinas insólitas \\
\hline $06: 00$ & ¿Cómo lo hacen? \\
\hline $06: 25$ & Te lo dije \\
\hline $07: 10$ & Monstruos de río \\
\hline $08: 00$ & Aventura en pelotas \\
\hline $08: 45$ & El último superviviente \\
\hline $09: 35$ & El último superviviente \\
\hline $10: 20$ & Dúo de supervivientes \\
\hline $11: 10$ & Monstruos de río \\
\hline $12: 00$ & Wild Frank \\
\hline $12: 55$ & Trato hecho \\
\hline $13: 20$ & Trato hecho \\
\hline $13: 50$ & Pareja a la puja \\
\hline $14: 15$ & Pareja a la puja \\
\hline $14: 45$ & Cazasubastas \\
\hline $15: 15$ & Cazasubastas \\
\hline $15: 45$ & Caballeros medievales \\
\hline $16: 40$ & Asedio al castillo con Dan Snow \\
\hline $17: 40$ & Cazasubastas \\
\hline $18: 05$ & Cazasubastas \\
\hline $18: 35$ & Pareja a la puja \\
\hline $19: 05$ & Pareja a la puja \\
\hline $19: 35$ & Fast n’loud \\
\hline $20: 30$ & Joyas sobre ruedas \\
\hline $21: 30$ & ¿Cómo lo hacen? \\
\hline $22: 00$ & ¿Cómo lo hacen? \\
\hline $22: 30$ & Caballeros medievales \\
\hline & Mitos y leyendas \\
\hline
\end{tabular}

Sábado 28 de marzo de 2015

\begin{tabular}{ll} 
00:25 & Mitos y leyendas \\
\hline $01: 20$ & Mitos y leyendas \\
\hline 02:10 & Asesinos en serie \\
\hline 03:00 & Perfil de un psicópata \\
\hline 03:45 & Desaparecidos \\
\hline $04: 30$ & Desaparecidos \\
\hline $05: 15$ & El asesino de al lado \\
\hline $06: 00$ & Maestros de la restauración \\
\hline $06: 45$ & Maestros de la restauración
\end{tabular}




\begin{tabular}{|c|c|}
\hline $07: 35$ & El mago pop \\
\hline $08: 25$ & Pareja a la puja \\
\hline 08:50 & Pareja a la puja \\
\hline $09: 15$ & Pareja a la puja \\
\hline 09:40 & Pareja a la puja \\
\hline $10: 05$ & Pareja a la puja \\
\hline $10: 30$ & Pareja a la puja \\
\hline $10: 55$ & Pareja a la puja \\
\hline $11: 20$ & Pareja a la puja \\
\hline $11: 45$ & Cazasubastas \\
\hline $12: 10$ & Cazasubastas \\
\hline $12: 35$ & Cazasubastas \\
\hline 13:00 & Cazasubastas \\
\hline $13: 30$ & Cazasubastas \\
\hline $13: 55$ & Cazasubastas \\
\hline $14: 25$ & Cazasubastas \\
\hline $14: 55$ & Cazasubastas \\
\hline $15: 25$ & La segunda guerra mundial en color \\
\hline $16: 20$ & La segunda guerra mundial en color \\
\hline $17: 15$ & Mitos y leyendas \\
\hline $18: 10$ & Mi casa en un árbol \\
\hline 19:05 & Acuarios XXL \\
\hline 20:00 & Acuarios XXL \\
\hline $21: 00$ & Sobrevivir a un tiburón \\
\hline $22: 00$ & Aventura en pelotas \\
\hline $23: 00$ & Aventura en pelotas \\
\hline
\end{tabular}

Domingo 29 de marzo de 2015

\begin{tabular}{ll}
\hline $00: 00$ & Aventura en pelotas \\
\hline $01: 00$ & Aventura en pelotas \\
\hline $02: 00$ & Perfil de un psicópata \\
\hline $02: 45$ & Perfil de un psicópata \\
\hline $03: 30$ & Desaparecidos \\
\hline $04: 15$ & El asesino de al lado \\
\hline $05: 00$ & Maestros de la restauración \\
\hline $06: 35$ & Maestros de la restauración \\
\hline $07: 25$ & Dynamo: el mago \\
\hline $08: 15$ & Supervivencia en pareja \\
\hline $09: 05$ & Supervivencia en pareja \\
\hline $09: 55$ & El último superviviente \\
\hline $10: 45$ & El último superviviente \\
\hline $11: 35$ & Aventura en pelotas \\
\hline $12: 30$ & Aventura en pelotas \\
\hline $13: 25$ & Monstruos de río \\
\hline $14: 25$ & Monstruos de río \\
\hline $15: 20$ & Vida en Marte \\
\hline $15: 45$ & Alienígenas: caso abierto \\
\hline $16: 15$ & Alienígenas: caso abierto \\
\hline $16: 45$ & Container wars \\
\hline
\end{tabular}




\begin{tabular}{ll}
\hline $17: 05$ & ¡Me lo quedo! \\
\hline $18: 35$ & ¡Me lo quedo! \\
\hline $19: 00$ & ¡Me lo quedo! \\
\hline $19: 30$ & ¡Me lo quedo! \\
\hline $20: 00$ & ¡Me lo quedo! \\
\hline $20: 35$ & ¡Me lo quedo! \\
\hline $21: 00$ & Cómo funciona la ciudad \\
\hline $22: 00$ & Nueva York, zona cero \\
\hline $22: 55$ & Control de aduanas, Canadá \\
\hline $23: 20$ & Control de aduanas, Canadá \\
\hline $23: 50$ & Control de aduanas
\end{tabular}

\section{JUNIO 2015 - DISCOVERY MAX}

Lunes 22 de junio de 2015

\begin{tabular}{ll}
\hline $00: 25$ & Fieras indomables \\
\hline $01: 20$ & Fieras indomables \\
\hline $02: 10$ & Esquivando la muerte \\
\hline $03: 00$ & Asesinos en serie \\
\hline $03: 45$ & El asesino de al lado \\
\hline $04: 30$ & La evidencia perdida \\
\hline $05: 15$ & La evidencia perdida \\
\hline $06: 00$ & ¿Cómo lo hacen? \\
\hline $06: 25$ & ¿Cómo lo hacen? \\
\hline $06: 50$ & Madrid ink \\
\hline $07: 35$ & Monstruos de río \\
\hline $08: 20$ & Supervivencia en pareja \\
\hline $09: 10$ & El último superviviente \\
\hline $10: 00$ & El último superviviente \\
\hline $10: 45$ & Aventura en pelotas \\
\hline $11: 35$ & Pesca radical \\
\hline $12: 25$ & Monstruos de río \\
\hline $13: 15$ & Container wars \\
\hline $13: 40$ & Container wars \\
\hline $14: 05$ & Pareja a la puja \\
\hline $14: 30$ & Pareja a la puja \\
\hline $15: 00$ & Cazasubastas \\
\hline $15: 25$ & Cazasubastas \\
\hline $15: 55$ & Mitos y leyendas \\
\hline $16: 50$ & Mitos y leyendas \\
\hline $17: 45$ & Pareja a la puja \\
\hline $18: 10$ & Pareja a la puja \\
\hline $18: 40$ & Perdido, vendido \\
\hline $19: 10$ & Perdido, vendido \\
\hline $19: 40$ & Fast n'loud \\
\hline $20: 35$ & Joyas sobre ruedas \\
\hline $21: 30$ & ¿Cómo lo hacen? \\
\hline & ¿Cómo lo hacen? \\
\hline
\end{tabular}


Martes 23 de junio de 2015

\begin{tabular}{ll}
\hline $00: 25$ & Fast n'loud \\
\hline $01: 20$ & Fast n'loud \\
\hline $02: 10$ & El último superviviente \\
\hline $03: 00$ & El último superviviente \\
\hline $03: 45$ & Buscando bichos con Dominic Monaghan \\
\hline $04: 30$ & Car to the limit \\
\hline $05: 15$ & Car to the limit \\
\hline $06: 00$ & ¿Cómo lo hacen? \\
\hline $06: 25$ & ¿Cómo lo hacen? \\
\hline $06: 50$ & Madrid ink \\
\hline $07: 35$ & Monstruos de río \\
\hline $08: 20$ & Supervivencia en pareja \\
\hline $09: 10$ & El último superviviente \\
\hline $10: 00$ & El último superviviente \\
\hline $10: 45$ & Aventura en pelotas \\
\hline $11: 35$ & Pesca radical \\
\hline $12: 25$ & Monstruos de río: Guarida de gigantes \\
\hline $13: 15$ & Container wars \\
\hline $13: 40$ & Container wars \\
\hline $14: 05$ & Pareja a la puja \\
\hline $14: 30$ & Pareja a la puja \\
\hline $15: 00$ & Cazasubastas \\
\hline $15: 25$ & Cazasubastas \\
\hline $15: 55$ & Mitos y leyendas \\
\hline $16: 50$ & Mitos y leyendas \\
\hline $17: 45$ & Pareja a la puja \\
\hline $18: 10$ & Pareja a la puja \\
\hline $18: 40$ & Perdido, vendido \\
\hline $19: 10$ & Perdido, vendido \\
\hline $19: 40$ & Fast n'loud \\
\hline $20: 35$ & Joyas sobre ruedas \\
\hline $21: 30$ & ¿Cómo lo hacen? \\
\hline $22: 00$ & ¿Cómo lo hacen? \\
\hline $23: 25$ & La fiebre del oro \\
\hline & La fiebre del oro \\
\hline
\end{tabular}

Miércoles 24 de junio de 2015

\begin{tabular}{ll}
$00: 25$ & La fiebre del oro \\
\hline $01: 20$ & La fiebre del oro \\
\hline $02: 10$ & ¿Que no cunda el pánico! \\
\hline 03:00 & ¿Que no cunda el pánico! \\
\hline 03:45 & Mundo hacker \\
\hline $04: 30$ & Grandes misiones de la NASA \\
\hline 05:15 & Grandes misiones de la NASA \\
\hline $06: 00$ & ¿Cómo lo hacen?
\end{tabular}


06:25

06:50

07:35

08:20

09:10

10:00

$10: 45$

11:35

$12: 25$

$13: 15$

$13: 40$

14:05

$14: 30$

15:00

$15: 25$

$15: 55$

$16: 50$

$17: 45$

$18: 10$

18:40

19:10

19:40

20:35

21:30

22:00

22:30

23:25

¿Cómo lo hacen?

Madrid ink

Monstruos de río: Guarida de gigantes

Supervivencia en pareja

El último superviviente

El último superviviente

Aventura en pelotas

Pesca radical

Monstruos de río: Guarida de gigantes

Container Wars

Container Wars

Pareja a la puja

Pareja a la puja

Cazasubastas

Cazasubastas

Mitos y leyendas

Mitos y leyendas

Pareja a la puja

Pareja a la puja

Perdido, vendido

Perdido, vendido

Fast n'loud

Joyas sobre ruedas

¿Cómo lo hacen?

¿Cómo lo hacen?

Tesoros al descubierto

Tesoros al descubierto

Jueves 25 de junio de 2015

00:25 Alienígenas: caso abierto

00:50 Alienígenas: caso abierto

01:20 Alienígenas: caso abierto

01:45 Alienígenas: caso abierto

02:10 Desmontando el cosmos

03:00 Desmontando el cosmos

03:45 Descubriendo el mañana con Stephen Hawking

04:30 Corwin: aventura salvaje

05:15 Corwin: aventura salvaje

06:00 ¿Cómo lo hacen?

06:25 ¿Cómo lo hacen?

06:50 Madrid ink

07:35 Monstruos de río: Guarida de gigantes

08:20 Supervivencia en pareja

09:10 El último superviviente

10:00 El último superviviente

10:45 Aventura en pelotas

11:35 Pesca radical

12:25 Monstruos de río

13:15 Container Wars

13:40 Container Wars 
Pareja a la puja

$14: 30$

Pareja a la puja

15:00 Cazasubastas

15:25 Cazasubastas

15:55 Mitos y leyendas

16:50 Mitos y leyendas

17:45 Pareja a la puja

18:10 Pareja a la puja

18:40 Perdido, vendido

19:10 Perdido, vendido

19:40 Fast n'loud

20:35 Joyas sobre ruedas

21:30 ¿Cómo lo hacen?

22:00 ¿Cómo lo hacen?

22:30 La segunda guerra mundial en color

23:25 La segunda guerra mundial en color

Viernes 26 de junio de 2015

00:25 La segunda guerra mundial en color

01:20 La segunda guerra mundial en color

02:10 Mercenarios

03:00 Supermotos

03:45 Supermotos

04:30 Megatraslados

05:15 Megatraslados

06:00 ¿Cómo lo hacen?

06:25 ¿Cómo lo hacen?

06:50 Madrid ink

07:35 Monstruos de río

08:20 Supervivencia en pareja

09:10 El último superviviente

10:00 El último superviviente

10:45 Aventura en pelotas

11:35 Pesca radical

12:25 Monstruos de río

13:15 Container wars

13:40 Container wars

14:05 Pareja a la puja

14:30 Pareja a la puja

15:00 Cazasubastas

15:25 Cazasubastas

15:55 Mitos y leyendas

16:50 Mitos y leyendas

17:45 Pareja a la puja

18:10 Pareja a la puja

18:40 Pareja a la puja

19:10 Fast n'loud

20:05 Joyas sobre ruedas

21:00 ¿Cómo lo hacen?

21:30 ¿Cómo lo hacen? 
24 kilates

22:55

Piscinas insólitas

23:55

Piscinas insólitas

Sábado 27 de junio de 2015

\begin{tabular}{ll} 
00:50 & Superpiscinas \\
\hline $01: 40$ & Un porche con vistas \\
\hline $02: 10$ & Perfil de un psicópata \\
\hline $03: 00$ & Perfil de un psicópata \\
\hline $03: 45$ & El asesino de al lado \\
\hline $04: 30$ & Esquivando la muerte \\
\hline $05: 15$ & Desde la celda \\
\hline $06: 00$ & Si fallas estás muerto \\
\hline $06: 25$ & Te lo dije \\
\hline $07: 10$ & Maestros de la restauración \\
\hline $08: 55$ & Maestros de la restauración \\
\hline $09: 05$ & ¡Me lo quedo! \\
\hline $09: 30$ & ¡Me lo quedo! \\
\hline $09: 55$ & ¡Me lo quedo! \\
\hline $10: 20$ & ¡Me lo quedo! \\
\hline $10: 45$ & Pareja a la puja \\
\hline $11: 10$ & Pareja a la puja \\
\hline $11: 35$ & Pareja a la puja puja \\
\hline $12: 00$ & Pareja a la puja \\
\hline $12: 25$ & Pareja a la puja \\
\hline $12: 50$ & Cazasubastas \\
\hline $13: 15$ & Cazasubastas \\
\hline $13: 40$ & Cazasubastas \\
\hline $14: 05$ & Cazasubastas \\
\hline $14: 30$ & Cazasubastas \\
\hline $15: 00$ & Cazasubastas \\
\hline $15: 25$ & Tesoros al descubierto \\
\hline $16: 20$ & Tesoros al descubierto \\
\hline $17: 15$ & Mitos y leyendas \\
\hline $19: 10$ & Maestros de la madera \\
\hline $20: 05$ & Maestros de la madera \\
\hline $22: 00$ & Tiburón zombie \\
\hline
\end{tabular}

Domingo 28 de junio de 2015

\begin{tabular}{ll} 
00:50 & Aventura en pelotas \\
\hline $01: 40$ & Redrum (murder) \\
\hline $02: 10$ & Esquivando la muerte \\
\hline 03:00 & Asesinos en serie \\
\hline $03: 45$ & Perfil de un psicópata
\end{tabular}




\begin{tabular}{ll}
\hline $04: 30$ & Desaparecidos \\
\hline $05: 15$ & Desaparecidos \\
\hline $06: 00$ & Si fallas estás muerto \\
\hline $06: 25$ & ¿Qué pasó después? \\
\hline $06: 55$ & Te lo dije \\
\hline $08: 40$ & Maestros de la restauración \\
\hline $09: 10$ & Maestros de la restauración \\
\hline $10: 00$ & Car to the limit \\
\hline $10: 50$ & Mundos perdidos \\
\hline $11: 40$ & El último superviviente \\
\hline $12: 30$ & El último superviviente \\
\hline $13: 20$ & Dúo de supervivientes \\
\hline $14: 10$ & Dúo de supervivientes \\
\hline $15: 00$ & Monstruos de río \\
\hline $15: 55$ & Monstruos de río \\
\hline $16: 50$ & Los enigmas de Jesucristo \\
\hline $17: 45$ & Los enigmas de Jesucristo \\
\hline $18: 40$ & Los enigmas de Jesucristo \\
\hline $19: 40$ & Exodus: ¿podría pasar hoy? \\
\hline $20: 35$ & Wild Frank \\
\hline $21: 35$ & Wild Frank \\
\hline $23: 30$ & Wild Frank \\
\hline
\end{tabular}

\section{SEPTIEMBRE 2015 - DISCOVERY MAX}

Lunes 21 de septiembre de 2015

\begin{tabular}{ll}
$00: 25$ & El rey de la manada \\
\hline $02: 10$ & Perfil de un psicópata \\
\hline $03: 00$ & El asesino de al lado \\
\hline $03: 45$ & El asesino de al lado \\
\hline $04: 30$ & Expediente ovni \\
\hline $05: 15$ & Expediente ovni \\
\hline $06: 00$ & Te lo dije \\
\hline $06: 45$ & Monstruos de río \\
\hline $07: 30$ & ¿Cómo lo hacen? \\
\hline $08: 55$ & ¿Cómo lo hacen? \\
\hline $09: 10$ & El último superviviente \\
\hline $10: 00$ & El último superviviente \\
\hline $10: 55$ & El último superviviente \\
\hline $11: 50$ & Pesca radical \\
\hline $12: 50$ & Pesca radical \\
\hline $13: 50$ & Maestros de la madera \\
\hline $14: 45$ & Mi casa en un árbol \\
\hline $15: 40$ & La fiebre del oro \\
\hline $16: 40$ & La fiebre del oro \\
\hline $17: 40$ & Black ops de la antigüedad \\
\hline $18: 35$ & Black ops de la antigüedad \\
\hline
\end{tabular}


Fast n'loud

21:30 Joyas sobre ruedas

¿Cómo lo hacen?

22:30 Cuba car club

23:25

Cuba car club

Martes 22 de septiembre de 2015

\begin{tabular}{ll}
$00: 25$ & Fast n'loud \\
\hline $01: 20$ & Misfit garage \\
\hline $02: 10$ & Coches con historia \\
\hline $03: 00$ & Coches con historia \\
\hline $03: 45$ & Joyas sobre ruedas \\
\hline $04: 30$ & Joyas sobre ruedas \\
\hline $05: 15$ & Joyas sobre ruedas \\
\hline $06: 00$ & Te lo dije \\
\hline $06: 45$ & Monstruos de río \\
\hline $07: 30$ & ¿Cómo lo hacen? \\
\hline $07: 55$ & ¿Cómo lo hacen? \\
\hline $08: 20$ & Food factory \\
\hline $08: 45$ & Food factory \\
\hline $09: 10$ & El último superviviente \\
\hline $10: 00$ & Food factory \\
\hline $10: 55$ & Pesca radical \\
\hline $12: 50$ & Pesca radical \\
\hline $13: 50$ & Mi casa en un árbol \\
\hline $14: 45$ & Mi casa en un árbol \\
\hline $15: 40$ & La fiebre del oro \\
\hline $16: 40$ & La fiebre del oro \\
\hline $17: 40$ & Black ops de la antigüedad \\
\hline $18: 35$ & Black ops de la antigüedad \\
\hline $19: 35$ & Fast n'loud \\
\hline $20: 35$ & Fast n'loud \\
\hline $21: 30$ & Joyas sobre ruedas \\
\hline $22: 00$ & ¿Cómo lo hacen? \\
\hline $22: 30$ & ¿Cómo lo hacen? \\
\hline $23: 25$ & Expedientes misterio de la antigüedad \\
\hline
\end{tabular}

Miércoles 23 de septiembre de 2015

\begin{tabular}{ll}
$00: 25$ & Contacto alienígena \\
\hline $00: 50$ & Contacto alienígena \\
\hline $01: 20$ & Alienígenas: caso abierto \\
\hline $01: 45$ & Alienígenas: caso abierto \\
\hline $02: 10$ & Titanes mecánicos \\
\hline $03: 00$ & Titanes mecánicos \\
\hline $03: 45$ & Titanes mecánicos \\
\hline $04: 30$ & Car to the limit \\
\hline $05: 15$ & Car to the limit
\end{tabular}




\begin{tabular}{ll}
$06: 00$ & Te lo dije \\
\hline $06: 45$ & Monstruos de río \\
\hline $07: 30$ & ¿Cómo lo hacen? \\
\hline $07: 55$ & ¿Cómo lo hacen? \\
\hline $08: 20$ & Food factory \\
\hline $08: 45$ & Food factory \\
\hline $09: 10$ & El último superviviente \\
\hline $10: 00$ & El último superviviente \\
\hline $11: 50$ & Pesca radical \\
\hline $12: 50$ & Pesca radical \\
\hline $13: 50$ & Mi casa en un árbol \\
\hline $14: 45$ & Mi casa en un árbol \\
\hline $15: 40$ & La fiebre del oro \\
\hline $16: 40$ & La fiebre del oro \\
\hline $17: 40$ & Leyendas del salvaje oeste \\
\hline $18: 35$ & Leyendas del salvaje oeste \\
\hline $19: 35$ & Fast n'loud \\
\hline $20: 35$ & Fast n'loud \\
\hline $21: 30$ & Joyas sobre ruedas \\
\hline $22: 00$ & ¿Cómo lo hacen? \\
\hline $22: 30$ & ¿Cómo lo hacen? \\
\hline $23: 25$ & La vida en llamas \\
\hline
\end{tabular}

Jueves 24 de septiembre de 2015

\begin{tabular}{ll}
\hline $01: 20$ & Norte América \\
\hline $02: 10$ & Grandes misiones de la NASA \\
\hline $03: 00$ & Desmontando el cosmos \\
\hline $03: 45$ & Desmontando el cosmos \\
\hline $04: 30$ & Macabro, pero cierto \\
\hline $05: 15$ & Macabro, pero cierto \\
\hline $06: 45$ & Te lo dije \\
\hline $07: 30$ & Monstruos de río \\
\hline $07: 55$ & ¿Cómo lo hacen? \\
\hline $08: 20$ & ¿Cómo lo hacen? \\
\hline $08: 45$ & Food factory \\
\hline $09: 10$ & Food factory \\
\hline $10: 00$ & El último superviviente \\
\hline $10: 55$ & El último superviviente \\
\hline $11: 50$ & Pesca radical \\
\hline $12: 50$ & Pesca radical \\
\hline $13: 50$ & Mi casa en un árbol \\
\hline $14: 45$ & Mi casa en un árbol \\
\hline $15: 40$ & La fiebre del oro \\
\hline $16: 40$ & La fiebre del oro \\
\hline $17: 40$ & Leyendas del salvaje oeste \\
\hline $18: 35$ & Leyendas del salvaje oeste \\
\hline $20: 35$ & Fast n'loud \\
\hline & Fast n'loud \\
\hline Joyas sobre ruedas \\
\hline 0
\end{tabular}


Viernes 25 de septiembre de 2015

\begin{tabular}{|c|c|}
\hline $00: 25$ & La segunda guerra mundial en color \\
\hline 01:20 & La segunda guerra mundial en color \\
\hline $02: 10$ & Sociedades secretas \\
\hline 03:00 & Mitos y leyendas \\
\hline 03:45 & Mitos y leyendas \\
\hline $04: 30$ & Titanes mecánicos \\
\hline $05: 15$ & Titanes mecánicos \\
\hline 06:00 & Te lo dije \\
\hline $06: 45$ & Monstruos de río \\
\hline $07: 30$ & ¿Cómo lo hacen? \\
\hline $07: 55$ & ¿Cómo lo hacen? \\
\hline $08: 20$ & Food factory \\
\hline $08: 45$ & Food factory \\
\hline $09: 10$ & El último superviviente \\
\hline $10: 00$ & El último superviviente \\
\hline $10: 55$ & Pesca radical \\
\hline $11: 50$ & Monstruos de río \\
\hline $12: 50$ & Mi casa en un árbol \\
\hline $13: 50$ & Mi casa en un árbol \\
\hline $14: 45$ & La fiebre del oro \\
\hline $15: 40$ & La fiebre del oro \\
\hline $16: 40$ & Leyendas del salvaje oeste \\
\hline $17: 40$ & Este coche es para mí \\
\hline $18: 05$ & Fast n'loud \\
\hline 19:05 & Fast n'loud \\
\hline $20: 05$ & Joyas sobre ruedas \\
\hline $21: 00$ & Así se hace: coches alucinantes \\
\hline $21: 30$ & Así se hace: coches alucinantes \\
\hline $22: 00$ & Grandes fracasos de la ingeniería \\
\hline $22: 55$ & Grandes fracasos de la ingeniería \\
\hline $23: 55$ & Control de aduanas, Canadá \\
\hline
\end{tabular}

Sábado 26 de septiembre de 2015

00:20 Control de aduanas, Canadá

00:50 Control de aduanas, Canadá

01:15 Control de aduanas, Canadá

01:40 Vivos de milagro

02:10 Creencias mortales

03:00 Creencias mortales

03:45 Asesinos en serie

04:30 Desaparecidos

05:15 Desaparecidos

06:00 Vivos de milagro 


\begin{tabular}{|c|c|}
\hline $06: 25$ & Vivos de milagro \\
\hline $06: 50$ & Maestros de la restauración \\
\hline $07: 45$ & Un pringao por el mundo \\
\hline $08: 35$ & Negocios de familia \\
\hline 09:00 & Negocios de familia \\
\hline 09:30 & Pareja a la puja \\
\hline $09: 55$ & Pareja a la puja \\
\hline $10: 25$ & Pareja a la puja \\
\hline $10: 50$ & Pareja a la puja \\
\hline $11: 15$ & Container wars \\
\hline $11: 40$ & Container wars \\
\hline $12: 10$ & Container wars \\
\hline $12: 40$ & Container wars \\
\hline $13: 05$ & Cazasubastas \\
\hline $13: 35$ & Cazasubastas \\
\hline $14: 05$ & Cazasubastas \\
\hline $14: 35$ & Cazasubastas \\
\hline $15: 05$ & Cazasubastas \\
\hline $15: 35$ & La fiebre del oro \\
\hline $16: 30$ & La fiebre del oro \\
\hline $17: 25$ & La fiebre del oro \\
\hline $18: 20$ & El rey de espadas \\
\hline 19:15 & Maestros de la madera \\
\hline $20: 10$ & Maestros de la madera \\
\hline $21: 05$ & Aventura en pelotas \\
\hline $22: 00$ & Aventura en pelotas XL \\
\hline $22: 55$ & Aventura en pelotas XL \\
\hline $23: 55$ & Aventura en pelotas \\
\hline
\end{tabular}

Domingo 27 de septiembre de 2015

\begin{tabular}{ll}
$23: 55$ & Aventura en pelotas \\
\hline $00: 50$ & Aventura en pelotas \\
\hline $01: 40$ & Redrum (murder) \\
\hline $02: 10$ & Perfil de un psicópata \\
\hline $03: 00$ & La prueba del crimen \\
\hline $03: 45$ & La prueba del crimen \\
\hline $04: 30$ & Desaparecidos \\
\hline $05: 15$ & Desaparecidos \\
\hline $06: 00$ & Si fallas estás muerto \\
\hline $06: 25$ & Si fallas estás muerto \\
\hline $06: 50$ & Maestros de la restauración \\
\hline $07: 45$ & Un pringao por el mundo \\
\hline $09: 35$ & Buscando bichos con Dominic Monaghan \\
\hline $10: 25$ & Buscando bichos con Dominic Monaghan \\
\hline $11: 15$ & El último superviviente \\
\hline $12: 10$ & El último superviviente \\
\hline $13: 05$ & Dúo de supervivientes \\
\hline $14: 05$ & Dúo de supervivientes \\
\hline $15: 00$ & Aventura en pelotas \\
\hline
\end{tabular}


$15: 55$

$16: 50$

$17: 45$

$18: 10$

$18: 40$

$19: 10$

$19: 40$

20:05

$20: 35$

21:05

$21: 35$

22:00

22:30

$23: 25$

Aventura en pelotas XL

Aventura en pelotas XL

Control de aduanas

Control de aduanas

Control de aduanas, Canadá

Control de aduanas, Canadá

Control de aduanas, Canadá

Control de aduanas, Canadá

Control de aduanas, Canadá

Control de aduanas, Canadá

Control de aduanas, Canadá

Control de aduanas, Canadá

Avispas asesinas

Devorahombres: supercocodrilo

\section{DICIEMBRE 2015 - DISCOVERY MAX}

Lunes 21 de diciembre de 2015

00:25 En lo desconocido con Ed Stanfford

01:20 El misterio de las islas perdida

02:10 Desaparecidos

03:00 Desaparecidos

03:45 Desaparecidos

04:30 Grandes misiones de la NASA

05:15 Grandes misiones de la NASA

06:00 Pesca extrema con Robson Green

06:45 Monstruos de río

07:30 ¿Cómo lo hacen?

07:55 ¿Cómo lo hacen?

08:20 El último superviviente

09:10 El último superviviente

10:05 El último superviviente

11:00 El último superviviente

12:00 Pesca radical

12:55 Pesca radical

13:55 Aventura en pelotas

14:50 Aventura en pelotas

15:50 La fiebre del oro

16:45 La fiebre del oro

17:45 Fast n'loud

18:40 Fast n'loud

19:40 Wild Frank

20:35 Wild Frank

21:30 Dynamo: el mago

22:30 Chapa y pintura

23:25 Chapa y pintura

Martes 22 de diciembre de 2015

$00: 25$

Fast n'loud 


\begin{tabular}{ll}
\hline $01: 20$ & Fast n'loud \\
\hline $02: 10$ & Coches con historia \\
\hline $03: 00$ & Coches con historia \\
\hline $03: 45$ & Los rescatacoches \\
\hline $04: 30$ & Te lo dije \\
\hline $05: 15$ & Te lo dije \\
\hline $06: 00$ & Pesca extrema con Robson Green \\
\hline $07: 45$ & Monstruos de río \\
\hline $07: 30$ & ¿Cómo lo hacen? \\
\hline $08: 20$ & ¿Cómo lo hacen? \\
\hline $08: 45$ & Food Factory \\
\hline $09: 10$ & Food Factory \\
\hline $10: 05$ & Wild Frank \\
\hline $11: 00$ & El último superviviente \\
\hline $12: 00$ & El último superviviente \\
\hline $12: 55$ & Pesca radical \\
\hline $13: 55$ & Pesca radical \\
\hline $14: 50$ & Aventura en pelotas \\
\hline $15: 50$ & Aventura en pelotas \\
\hline $16: 45$ & La fiebre del oro \\
\hline $17: 45$ & La fiebre del oro \\
\hline $18: 40$ & Fast n'loud \\
\hline $20: 40$ & Fast n'loud \\
\hline $21: 35$ & Wild Frank \\
\hline $22: 30$ & Wild Frank \\
\hline $23: 25$ & Dynamo: el mago \\
\hline
\end{tabular}

Miércoles 23 de diciembre de 2015

\begin{tabular}{ll}
$00: 25$ & Los enigmas de Jesucristo \\
\hline $01: 20$ & Los secretos de la Biblia \\
\hline $02: 10$ & Mitos y leyendas \\
\hline $03: 00$ & Macabro, pero cierto \\
\hline $03: 45$ & Macabro, pero cierto \\
\hline $04: 30$ & Black ops de la antigüedad \\
\hline $05: 15$ & Black ops de la antigüedad \\
\hline $06: 00$ & Pesca extrema con Robson Green \\
\hline $06: 45$ & Monstruos de río \\
\hline $07: 30$ & ¿Cómo lo hacen? \\
\hline $07: 55$ & ¿Cómo lo hacen? \\
\hline $08: 20$ & Food Factory \\
\hline $08: 45$ & Food Factory \\
\hline $09: 10$ & Wild Frank \\
\hline $10: 05$ & El último superviviente \\
\hline $11: 00$ & El último superviviente \\
\hline $12: 00$ & Pesca radical \\
\hline $12: 55$ & Pesca radical \\
\hline $13: 55$ & Aventura en pelotas \\
\hline $14: 50$ & Aventura en pelotas
\end{tabular}




\begin{tabular}{ll}
$15: 50$ & La fiebre del oro \\
\hline $16: 45$ & La fiebre del oro \\
\hline $17: 45$ & Fast n'loud \\
\hline $18: 40$ & Fast n'loud \\
\hline $19: 40$ & Wild Frank \\
\hline $20: 35$ & Wild Frank \\
\hline $21: 30$ & Dynamo: el mago \\
\hline $22: 30$ & Vice \\
\hline $23: 25$ & La pesca del oro
\end{tabular}

Jueves 24 de diciembre de 2015

\begin{tabular}{|c|c|}
\hline $00: 25$ & La pesca del oro \\
\hline $01: 20$ & La pesca del oro \\
\hline 02:10 & Monstruos de río \\
\hline 03:00 & Expediente no resuelto \\
\hline $03: 45$ & Expediente no resuelto \\
\hline $04: 30$ & El universo según Stephen Hawking \\
\hline $05: 15$ & El universo según Stephen Hawking \\
\hline 06:00 & Pesca extrema con Robson Green \\
\hline $06: 45$ & Monstruos de río \\
\hline $07: 30$ & ¿Cómo lo hacen? \\
\hline $07: 55$ & ¿Cómo lo hacen? \\
\hline $08: 20$ & Food Factory \\
\hline $08: 45$ & Food Factory \\
\hline $09: 10$ & Wild Frank \\
\hline $10: 05$ & El último superviviente \\
\hline $11: 00$ & El último superviviente \\
\hline $12: 00$ & Pesca radical \\
\hline $12: 55$ & Pesca radical \\
\hline $13: 55$ & Aventura en pelotas \\
\hline $14: 50$ & Aventura en pelotas \\
\hline $15: 50$ & La fiebre del oro \\
\hline $16: 45$ & La fiebre del oro \\
\hline $17: 45$ & Fast n'loud \\
\hline $18: 40$ & Fast n'loud \\
\hline $19: 40$ & Wild Frank \\
\hline $20: 35$ & Wild Frank \\
\hline $21: 30$ & Dynamo: el mago \\
\hline $22: 30$ & El mago pop \\
\hline $23: 25$ & El mago pop \\
\hline
\end{tabular}

Viernes 25 de diciembre de 2015

\begin{tabular}{ll}
$01: 20$ & El mago pop \\
\hline $00: 25$ & El mago pop \\
\hline $02: 10$ & Ben Earl: el ilusionista \\
\hline $03: 00$ & Ben Earl: el ilusionista \\
\hline $03: 45$ & Ben Earl: el ilusionista \\
\hline $04: 30$ & Ben Earl: el ilusionista \\
\hline $05: 15$ & Derren Brown al descubierto
\end{tabular}




\begin{tabular}{|c|c|}
\hline 06:00 & Buscando bichos con Dominic Monaghan \\
\hline $06: 45$ & Monstruos de río \\
\hline 07:30 & ¿Cómo lo hacen? \\
\hline 07:55 & ¿Cómo lo hacen? \\
\hline 08:20 & Food Factory \\
\hline 08:45 & Food Factory \\
\hline 09:10 & ¡Me lo quedo! \\
\hline $09: 35$ & ¡Me lo quedo! \\
\hline $10: 05$ & ¡Me lo quedo! \\
\hline $10: 30$ & ¡Me lo quedo! \\
\hline $11: 00$ & ¡Me lo quedo! \\
\hline $11: 30$ & ¡Me lo quedo! \\
\hline $12: 00$ & ¡Me lo quedo! \\
\hline $12: 25$ & Cazasubastas \\
\hline $12: 55$ & Cazasubastas \\
\hline $13: 25$ & Cazasubastas \\
\hline $13: 55$ & Cazasubastas \\
\hline $14: 20$ & Cazasubastas \\
\hline $14: 50$ & Cazasubastas \\
\hline $15: 20$ & Cazasubastas \\
\hline $15: 50$ & Maestros de la madera \\
\hline $16: 45$ & Maestros de la madera \\
\hline $17: 45$ & La invasión de las luces navideñas 2 \\
\hline $18: 40$ & Árboles de navidad XXL \\
\hline $19: 40$ & Wild Frank \\
\hline $20: 35$ & Wild Frank \\
\hline $21: 30$ & El mago pop, 48 horas con... \\
\hline $22: 30$ & ADN Max \\
\hline
\end{tabular}

Sábado 26 de diciembre de 2015

\begin{tabular}{ll}
$00: 25$ & Dynamo: el mago \\
\hline $01: 20$ & Dynamo: el mago \\
\hline $02: 10$ & Dynamo: el mago \\
\hline $03: 00$ & Dynamo: el mago \\
\hline $03: 45$ & Dynamo: el mago \\
\hline $04: 30$ & Dynamo: el mago \\
\hline $05: 15$ & Dynamo: el mago \\
\hline $06: 00$ & Te lo dije \\
\hline $06: 45$ & Te lo dije \\
\hline $07: 30$ & Maestros de la restauración \\
\hline $08: 15$ & Maestros de la restauración \\
\hline $09: 00$ & ¿Qué esconde esta caja? \\
\hline $09: 25$ & ¿Qué esconde esta caja? \\
\hline $09: 50$ & Container wars \\
\hline $10: 15$ & Container wars \\
\hline $10: 45$ & Container wars \\
\hline $11: 10$ & Container wars \\
\hline $11: 40$ & Cazasubastas \\
\hline $12: 05$ & Cazasubastas \\
\hline $12: 35$ & Cazasubastas \\
\hline
\end{tabular}


13:30 iMe lo quedo!

13:55 ¡Me lo quedo!

14:25 ¡Me lo quedo!

14:50 iMe lo quedo!

15:20 iMe lo quedo!

15:50 Killing Jesus

18:15 Los enigmas de Jesucristo

19:10 Control de aduanas, Canadá

19:40 Control de aduanas, Canadá

20:05 Control de aduanas, Canadá

20:35 Control de aduanas, Canadá

21:05 Control de aduanas, Canadá

21:35 Control de aduanas, Canadá

22:00 Devorahombres: supercalamar

22:55 Devorahombres: superlobos

23:55 Devorahombres: felinos zombis

Domingo 27 de diciembre de 2015

00:50 Devorahombres: supercocodrilo

\begin{tabular}{ll}
\hline $01: 40$ & Perfil de un psicópata \\
\hline $02: 30$ & Perfil de un psicópata \\
\hline $03: 15$ & El asesino de al lado \\
\hline $04: 00$ & El asesino de al lado \\
\hline $04: 45$ & Asesinos en serie \\
\hline $05: 30$ & Vivos de milagro \\
\hline $06: 00$ & Detrás de la magia \\
\hline $06: 25$ & Detrás de la magia \\
\hline $06: 50$ & Te lo dije \\
\hline $07: 40$ & Te lo dije \\
\hline $08: 25$ & Chef rubio \\
\hline $09: 10$ & Chef rubio \\
\hline $10: 05$ & Comida salvaje \\
\hline $11: 00$ & El último superviviente \\
\hline $12: 00$ & Dúo de supervivientes \\
\hline $13: 55$ & Dúo de supervivientes \\
\hline $14: 50$ & Wild Frank \\
\hline $15: 50$ & Wild Frank \\
\hline $16: 45$ & Los enigmas de Jesucristo \\
\hline $17: 45$ & Los enigmas de Jesucristo \\
\hline $18: 40$ & Los enigmas de Jesucristo \\
\hline $19: 40$ & Los enigmas de Jesucristo \\
\hline $20: 05$ & Control de aduanas, Canadá \\
\hline $20: 35$ & Control de aduanas, Canadá \\
\hline $21: 05$ & Control de aduanas, Canadá \\
\hline $21: 35$ & Control de aduanas, Canadá \\
\hline $22: 00$ & Control de aduanas, Canadá \\
\hline $22: 55$ & Y el mundo cambió \\
\hline $23: 55$ & Y el mundo cambió \\
\hline
\end{tabular}


